\title{
BASELINE ECOLOGICAL RISK ASSESSMENT SALMON SITE LAMAR COUNTY, MISSISSIPPI
}

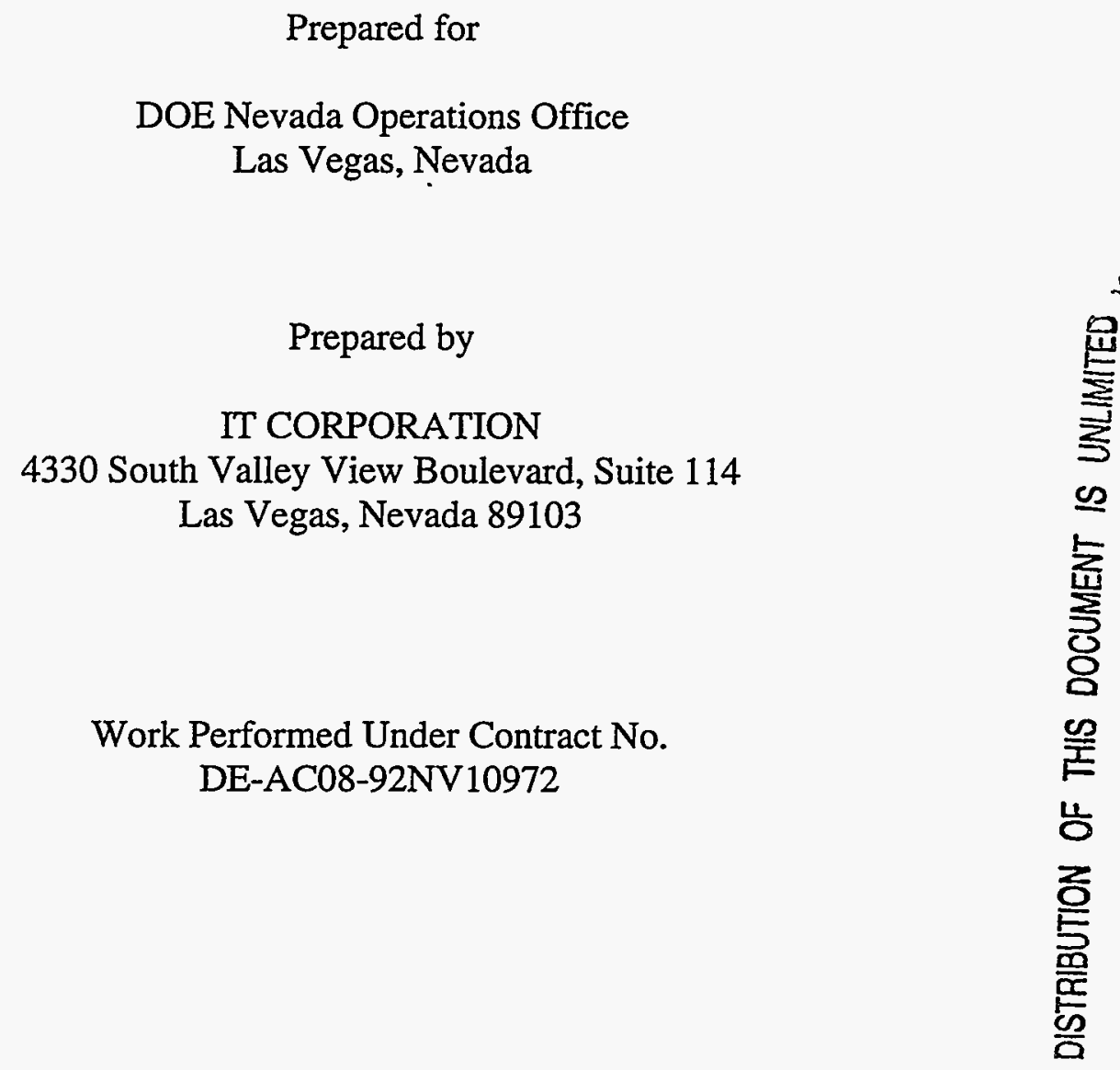

April 1995

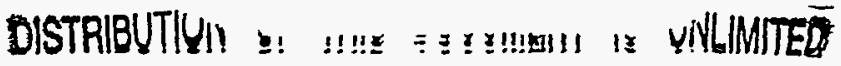




\section{DISCLAIMER}

This report was prepared as an account of work sponsored by the United States Government. Neither the United States nor the United States Department of Energy, nor any of their employees, makes a warranty, express or implied, or assumes any legal liability or responsibility for the accuracy, completeness or usefulness of any information, apparatus, product or process disclosed, or represents that its use would not infringe privately owned rights. Reference herein to any specific commercial products, process, or service by trade name. mark, manufacturer, or otherwise, does not necessarily constitute or imply its endorsement, recommendation, or favoring by the United States Government or any agency thereof. The views and opinions of authors expressed herein do not necessarily state or reflect those of the United States Government or any agency thereof. 


\section{DISCLAIMER}

Portions of this document may be illegible in electronic image products. Images are produced from the best available original document. 


\section{Table of Contents}

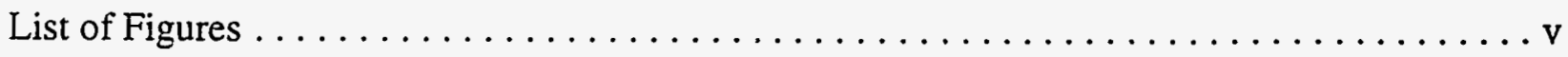

List of Tables $\ldots \ldots \ldots \ldots \ldots \ldots \ldots \ldots \ldots \ldots \ldots \ldots \ldots \ldots \ldots \ldots \ldots$

List of Acronyms and Abbreviations $\ldots \ldots \ldots \ldots \ldots \ldots \ldots \ldots \ldots \ldots \ldots$

Executive Summary $\ldots \ldots \ldots \ldots \ldots \ldots \ldots \ldots \ldots \ldots \ldots \ldots \ldots \ldots \ldots \ldots$

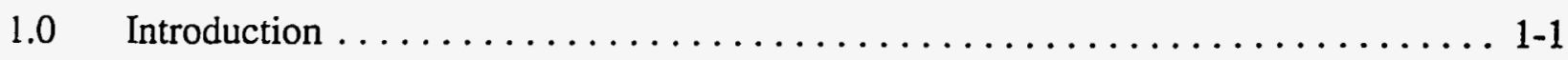

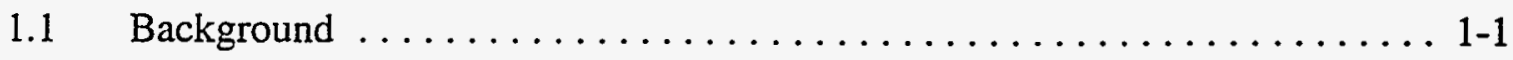

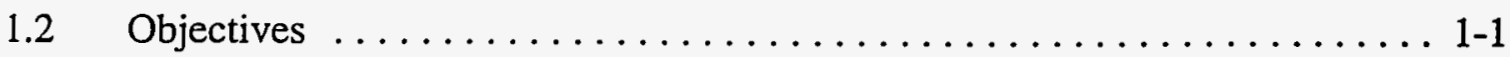

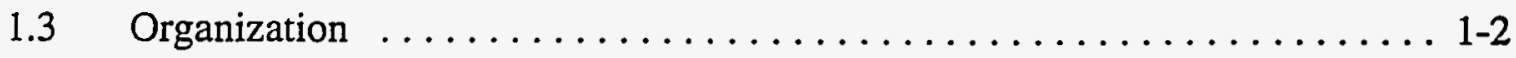

$2.0 \quad$ Area Description $\ldots \ldots \ldots \ldots \ldots \ldots \ldots \ldots \ldots \ldots \ldots \ldots \ldots \ldots \ldots \ldots \ldots$

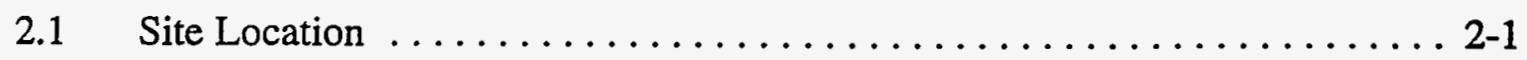

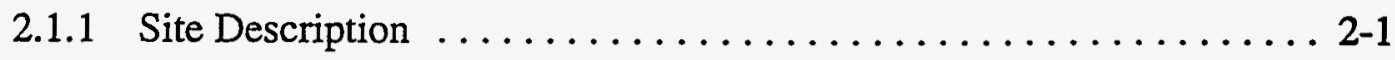

2.1 .2 Site Maps .......................... 2-1

2.2 Sources of Site Historical Data .................... 2-1

2.2.1 Site Operational History and Current Status . . . . . . . . . . 2-11

2.2.2 Hazardous Substance and Waste Management ... . . . . . . . . 2-14

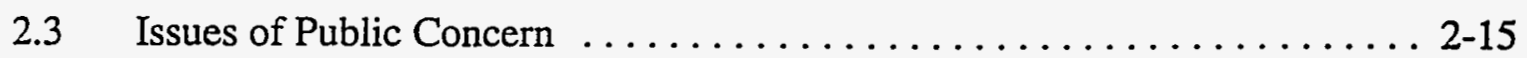

3.0 Problem Formulation $\ldots \ldots \ldots \ldots \ldots \ldots \ldots \ldots \ldots \ldots \ldots \ldots \ldots \ldots \ldots$

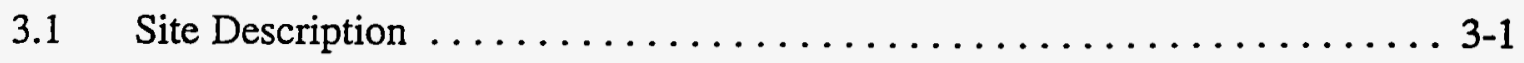

3.1 .1 Physical Features $\ldots \ldots \ldots \ldots \ldots \ldots \ldots \ldots \ldots \ldots \ldots . \ldots \ldots \ldots$

3.1.2 Biological Features . . . . . . . . . . . . . . . . . . 3-2

3.1.3 Species of Special Concern . . . . . . . . . . . . . . . . 3-11

3.2 Constituents of Potential Concern Selection ............... 3-11

3.2.1 Data Collection ......................... 3-12

3.2.1.1 Reference Samples ................... 3-12

3.2.1.2 Sediment and Surface Water .............. 3-12

3.2.1.3 Surficial Soil . . . . . . . . . . . . . . . . 3-16

3.2.2 Data Evaluation $\ldots \ldots \ldots \ldots \ldots \ldots \ldots \ldots \ldots \ldots \ldots \ldots \ldots . \ldots \ldots$ 
3.2.2.1 Analytical Methods . . . . . . . . . . . . . . . . . . . 3-16

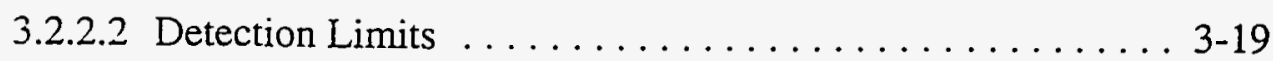

3.2.2.3 Qualified Data ..................... 3-20

3.2.2.4 Blanks ........................... 3-22

3.2.2.5 Frequency of Detection .................. 3-22

3.2.2.6 Essential Nutrients . . . . . . . . . . . . . . . . . . 3-23

3.2.2.7 Water Chemistry ...................... 3-24

3.2.2.8 Physiochemical Properties and Bioaccumulation

Potential ............ . . . . . . . . . . . . . . 3-24

3.2.2.9 Reference Data . . . . . . . . . . . . . . 3-25

3.2.3 Analytical Results ....................... 3-26

3.2.3.1 Sediment .......................... 3-26

3.2.3.2 Surface Water . . . . . . . . . . . . . . . . . . . . . 3-39

3.2.3.3 Surficial Soil ....................... 3-39

3.2.4 Constituents of Potential Concern . . . . . . . . . . . . . 3-41

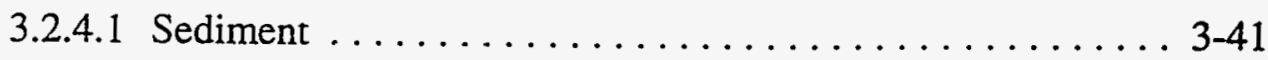

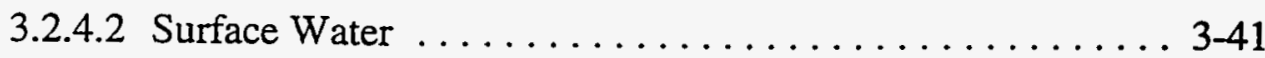

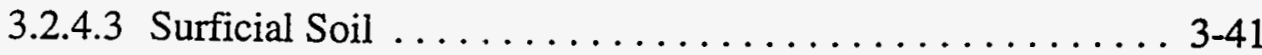

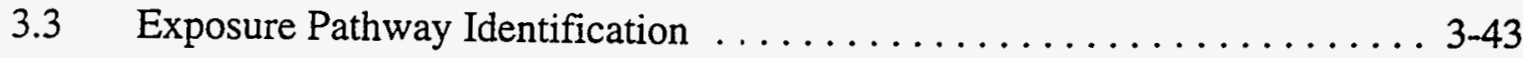

3.3.1 Animal Exposure Routes . . . . . . . . . . . . . . . . . . . . . . 3-46

3.3.2 Plant Exposure Routes . . . . . . . . . . . . . . . . . . . . . . . . 3-48

3.4 Ecological Receptor Identification . . . . . . . . . . . . . . . . . . 3-49

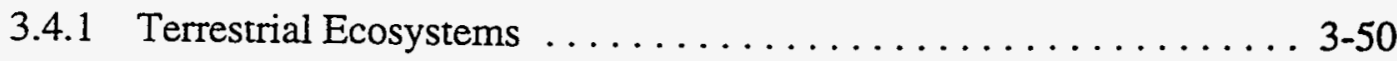

3.4.1.1 Vegetation .......................... 3-50

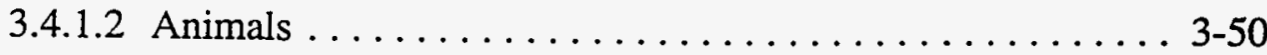

3.4.2 Aquatic Ecosystems ......................... 3-50 . . . . . . . .

3.4.2.1 Macrobenthos ........................ 3-50

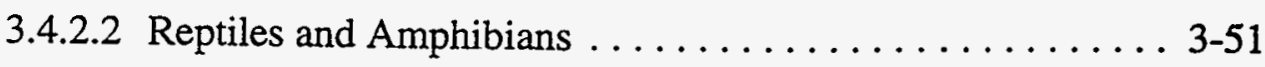

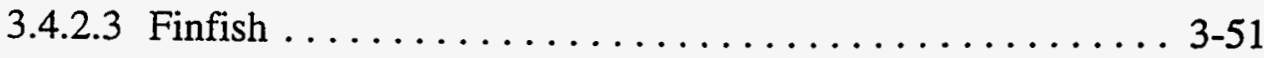

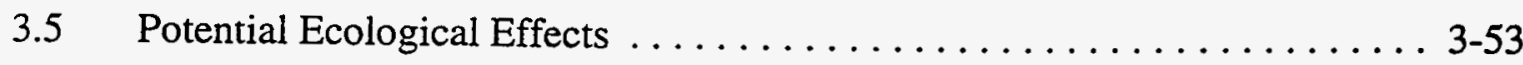

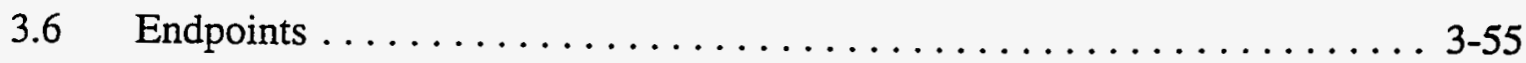

3.6.1 Aquatic Ecosystems ......................... 3-55

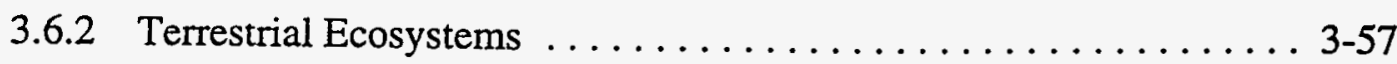




\section{Table of Contents (Continued)}

3.7 Problem Formulation Summary $\ldots \ldots \ldots \ldots \ldots \ldots \ldots \ldots \ldots \ldots \ldots \ldots$

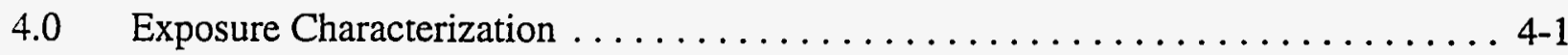

4.1 Transport and Fate Estimation $\ldots \ldots \ldots \ldots \ldots \ldots \ldots \ldots \ldots \ldots, 4-1$

$4.2 \quad$ Ecological Receptors $\ldots \ldots \ldots \ldots \ldots \ldots \ldots \ldots \ldots \ldots \ldots \ldots . \ldots .1$

4.3 Estimated Receptor Exposures . ..................... 4-5

4.3.1 Aquatic Biota Tissue Analysis $\ldots \ldots \ldots \ldots \ldots \ldots \ldots \ldots .4 .6 \ldots$

4.3.2 Terrestrial Vegetation Tissue Analysis . . . . . . . . . . . 4-8

4.3.3 Terrestrial Wildlife Tissue Analysis $\ldots \ldots \ldots \ldots \ldots \ldots \ldots \ldots .4 .9$

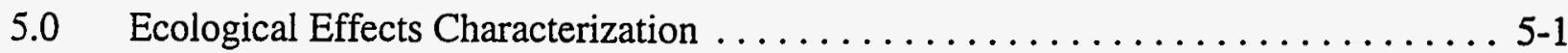

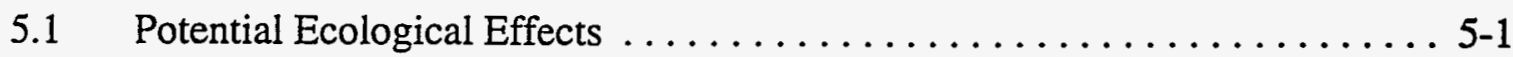

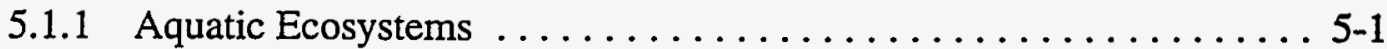

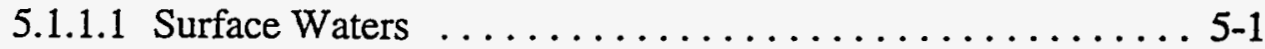

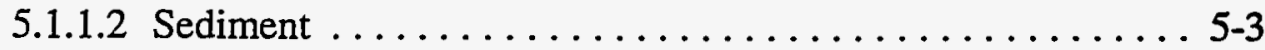

5.1.1.3 Potential Aquatic Ecosystem Effects Summary ........ 5-6

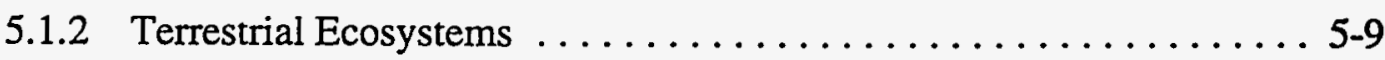

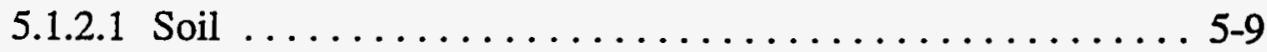

5.1.2.2 Potential Terrestrial Ecosystem Effects Summary ...... 5-18

5.1 .3 Laboratory Studies . ..................... 5-18

5.1.3.1 Aquatic Toxicity Tests .................... 5-18

5.1.3.2 Terrestrial Toxicity Tests . . . . . . . . . . . . . . 5-19

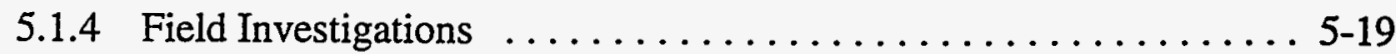

5.1.4.1 Benthic Ecology Investigations

(Rapid Bioassessment Protocol I) .............. 5-19

5.1.4.2 Benthic Ecology Investigations

(Rapid Bioassessment Protocol III) .............. 5-21

5.1.4.3 Aquatic Field Observations ................. 5-24

5.1.4.4 Terrestrial Field Observations ................ 5-24

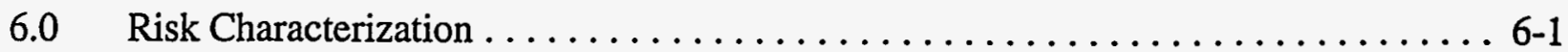

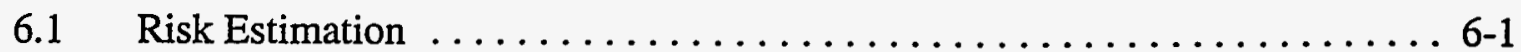

6.2 Risk Description ............................... 6-1 


\section{Table of Contents (Continued)}

6.2.1 Aquatic Ecosystem ....................... 6-2

6.2 .1 .1 Water Pathway .................... 6-2

6.2.1.2 Sediment Pathway .................. 6-2

6.2.2 Terrestrial Ecosystems $\ldots \ldots \ldots \ldots \ldots \ldots \ldots \ldots \ldots \ldots .6 \ldots$

6.2.2.1 Soil Pathway . . . . . . . . . . . . . . . .

6.2 .2 .2 Air Pathway . . . . . . . . . . . . . . . . 6-3

6.3 Uncertainty Analysis $\ldots \ldots \ldots \ldots \ldots \ldots \ldots \ldots \ldots \ldots . \ldots \ldots$

6.4 Conclusions and Recommendations $\ldots \ldots \ldots \ldots \ldots \ldots \ldots \ldots \ldots \ldots$

$7.0 \quad$ References $\ldots \ldots \ldots \ldots \ldots \ldots \ldots \ldots \ldots \ldots \ldots \ldots \ldots \ldots \ldots \ldots \ldots$

Appendix A - Analytical Data . . . . . . . . . . . . . . . . . . A-1 


\section{List of Figures}

Number

Title

Page

2-1 General Location Map of the Salmon Site $\ldots \ldots \ldots \ldots \ldots \ldots \ldots \ldots . \ldots .2-2$

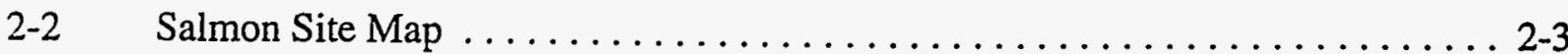

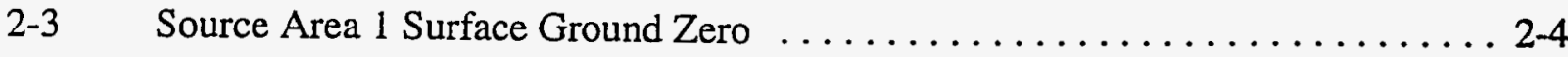

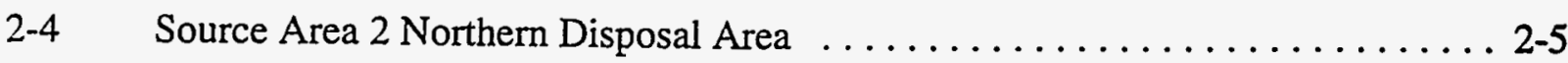

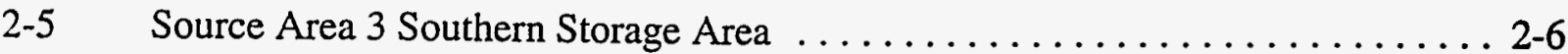

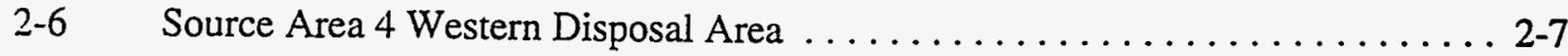

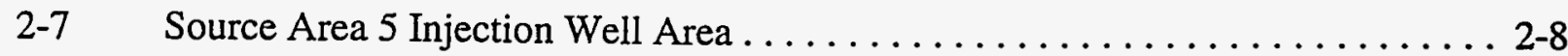

2-8 Source Area 6 Helicopter Pad and Storage Area $\ldots \ldots \ldots \ldots \ldots \ldots . \ldots . . \ldots$

3-1 Salmon Site Surface-Water and Sediment Sampling Locations $\ldots \ldots \ldots \ldots$ 3-3

3-2 Salmon Site Soil- and Vegetation-Sampling Locations $\ldots \ldots \ldots \ldots \ldots$ 3-13

3-3 Screening Criteria for Selection of Constituents of Potential Concern $\ldots \ldots \ldots 3-42$

3-4 Conceptual Site Model, Salmon Site $\ldots \ldots \ldots \ldots \ldots \ldots \ldots \ldots . \ldots \ldots .44$

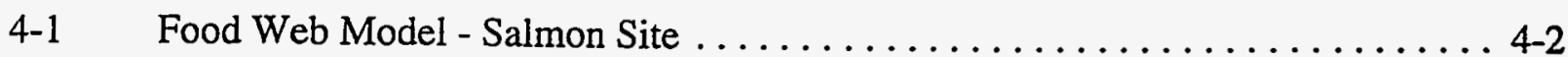

4-2 Salmon Site Location of Traplines $\ldots \ldots \ldots \ldots \ldots \ldots \ldots \ldots \ldots \ldots .4 .20$ 


\section{List of Tables}

Number

Title

Page

2-1 Sites within each Source Area. Salmon Site . . . . . . . . . . . . . . . 2-10

3-1 Species List - Vegetation Survey, July 13 to 19,1992 , Salmon Site . . . . . . . 3-4

3-2 Species List - Avian Survey, July 13 to 19 , 1992, Salmon Site . . . . . . . . 3-7

3-3 Species List - Reptiles and Amphibian Survey, July 13 to 19, 1992 ,

Salmon Site . . . . . . . . . . . . . . . . . . . . . . 3-8

3-4 Species List - Mammalian Survey, July 13 to 19, 1992, Salmon Site . . . . . . 3-9

3-5 Species Collected, February 22 to 28,1993 , Salmon Site . . . . . . . . . . 3-9

3-6 Fish Biosurvey Results, July 13 to 19,1992 , Salmon Site . . . . . . . . . . 3-10

3-7 Surface Water and Sediment Sample Locations for the Aquatic Ecosystem Investigation, Salmon Site . . . . . . . . . . . . . . . . . 3-14

3-8 Summary of Samples Collected for the Aquatic Ecosystem Investigation, Salmon Site . . . . . . . . . . . . . . . . . . . . . . . . 3-15

3-9 Sample Locations for the Terrestrial Ecosystem Investigation, Salmon Site . . . 3-17

3-10 Summary of Samples Collected for the Terrestrial Ecosystem Investigation, Salmon Site . . . . . . . . . . . . . . . . . . . . . . . . . . . 3-18

3-11 Summary of Inorganic Concentrations in Sediment, Salmon Site . . . . . . . . 3-27

3-12 Summary of Semivolatile and Volatile Organic Concentrations in Sediment, Salmon Site . . . . . . . . . . . . . . . . . . . . . . . . . . . 3-28

3-13 Summary of Radionuclide Activity in Sediment, Salmon Site . . . . . . . . . 3-29

3-14 Grain-Size Analysis, Salmon Site . . . . . . . . . . . . . . . . 3-30

3-15 Summary of Inorganic Concentrations in Surface Water, Salmon Site . . . . . 3-31

3-16 Summary of Radionuclide Activity in Surface Water, Salmon Site . . . . . . 3-32

3-17 Summary of Inorganic Concentrations in Surficial Soil, Salmon Site . . . . . . 3-33 


\section{List of Tables (Continued)}

3-18 Summary of Pesticide and PCB Concentrations in Surficial Soil.

Salmon Site .................................. 3-35

3-19 Summary of Semivolatile and Volatile Organic Concentrations in

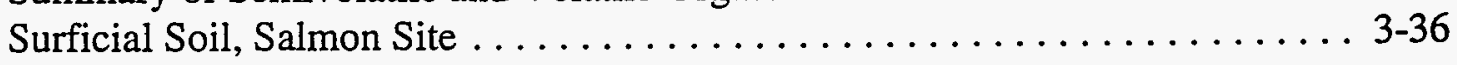

3-20 Summary of Radionuclide Activity in Surficial Soil, Salmon Site . . . . . . 3-37

3-21 Macrobenthos Qualitative Field Data, Salmon Site $\ldots \ldots \ldots \ldots \ldots \ldots . . \ldots .52$

3-22 Assessment and Measurement Endpoints for Aquatic Ecosystems,

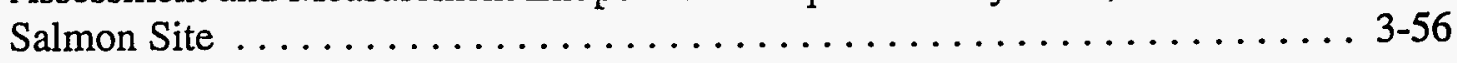

3-23 Assessment and Measurement Endpoints for Terrestrial Ecosystems,

Salmon Site . . . . . . . . . . . . . . . . . . . . . . . . . . . . . . .

4-1 Summary of Constituent Concentrations in Fish Tissue, Salmon Site . . . . . 4-6

4-2 Summary of Constituent Concentrations in Vegetation, Salmon Site . . . . . 4-10

4-3 Summary of Constituent Concentrations in Large Mammal Tissues,

Salmon Site . . . . . . . . . . . . . . . . . . . . . .

4-4 Summary of Constituent Concentrations in Small Mammal Tissues,

Salmon Site . . . . . . . . . . . . . . . . .

5-1 Final Selection of Constituents of Concern in Surface Water, Salmon Site ... 5-1

5-2 Final Selection of Constituents of Concern in Sediment, Salmon Site $\ldots \ldots \ldots$ 5-4

5-3 Total Dose due to Sediments, Surface Water, and Soil Pathways,

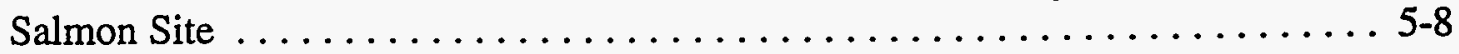

5-4 Selected Radionuclides of Importance and Their Half-Lives, Salmon Site . . . . 5-8

5-5 Final Selection of Constituents of Concern in Soil, Salmon Site $\ldots \ldots \ldots \ldots$ 5-9

5-6 Comparison of Copper Concentrations in Mammal Tissues to Literature Reference Values, Salmon Site $\ldots \ldots \ldots \ldots \ldots \ldots \ldots \ldots \ldots \ldots . \ldots \ldots . \ldots \ldots$ 


\section{List of Tables (Continued)}

5-7 Comparison of Lead Concentrations in Mammal Tissues to Literature Reference Values. Salmon Site ........................ 5-14

5-8 Benthic Ecology RBP III Metric Results, Salmon Site $\ldots \ldots \ldots \ldots \ldots \ldots$. $5-23$ 


\section{List of Acronyms and Abbreviations}

\begin{tabular}{|c|c|}
\hline AEC & U.S. Atomic Energy Commission \\
\hline AWQC & ambient water quality criteria \\
\hline BERA & Baseline Ecological Risk Assessment \\
\hline BOD & biochemical oxygen-demand \\
\hline $\begin{array}{l}\text { CERCLA } \\
\mathrm{cm}\end{array}$ & $\begin{array}{l}\text { Comprehensive Environmental Response, Compensation, and Liability Act } \\
\text { centimeter }\end{array}$ \\
\hline CRDL & Contract Required Detection Limit \\
\hline $\mathrm{COC}$ & constituent of concern \\
\hline COPC & constituent of potential concern \\
\hline CPOM & Coarse Particulate Organic Matter \\
\hline CPT & cone penetrometer \\
\hline CSM & Conceptual Site Model \\
\hline DOE & U.S. Department of Energy \\
\hline DNA & deoxyribonucleic acid \\
\hline $\mathrm{DRH}$ & Division of Radiological Health \\
\hline EEW & Environmental Evaluation Work Plan \\
\hline EPA & U.S. Environmental Protection Agency \\
\hline EPC & exposure point concentration \\
\hline $\mathrm{EPC}_{\mathrm{aq}}$ & aquatic exposure point concentration \\
\hline $\mathrm{EPC}_{\text {sed }}$ & sediment exposure point concentration \\
\hline ER-L & Effects Range - Low \\
\hline $\mathrm{ft}$ & foot \\
\hline g & gram \\
\hline g/day & gram per day \\
\hline GI & gastrointestinal \\
\hline GPR & ground penetrating radar \\
\hline IAEA & International Atomic Energy Agency \\
\hline IDW & investigation-derived waste \\
\hline in. & inch \\
\hline ITAS & International Technology Analytical Services \\
\hline $\mathrm{K}_{\mathrm{d}}$ & soil/water partition coefficient \\
\hline $\mathrm{kg}$ & kilogram \\
\hline $\mathrm{kg} / \mathrm{d}$ & kilogram per day \\
\hline
\end{tabular}




\section{List of Acronyms and Abbreviations (Continued)}

\begin{tabular}{ll}
$\mathrm{K}_{\mathrm{ow}}$ & octanol/water partition coefficient \\
$\mathrm{kt}$ & kiloton \\
$\mathrm{m}$ & meter \\
$\mathrm{mg} / \mathrm{l}$ & milligram per liter \\
$\mathrm{MDA}$ & Minimum Detectable Activity \\
$\mathrm{mg} / \mathrm{kg}$ & milligram per kilogram \\
$\mathrm{mg} / \mathrm{kg} / \mathrm{d}$ & milligram per kilogram per day \\
$\mathrm{MSDEQ}$ & Mississippi Department of Environmental Quality \\
$\mathrm{MTL}$ & maximum tolerance level \\
$\mathrm{NPL}$ & National Priorities List \\
$\mathrm{NTS}$ & Nevada Test Site \\
$\mathrm{pCi} / \mathrm{g}$ & picocurie per gram \\
$\mathrm{pC} / \mathrm{m} \ell$ & picocurie per milliliter \\
$\mathrm{PCB}$ & polychlorinated biphenyls \\
$\mathrm{RI} / \mathrm{FS}$ & Remedial Investigation and Feasibility Study \\
$\mathrm{RBP}$ & Rapid Bioassessment Protocols \\
$\mathrm{SA}$ & Source Area \\
$\mathrm{SGZ}$ & surface ground zero \\
$\mathrm{SS}$ & Salmon Site \\
$\mathrm{TIC}$ & Tentatively Identified Compound \\
$\mathrm{UCL}$ & upper confidence limit \\
$\mu \mathrm{g} / \mathrm{kg}$ & microgram per kilogram \\
$\mu \mathrm{g} / \ell$ & microgram per liter \\
$\mu \mathrm{Ci}$ & microcurie \\
& \\
\hline &
\end{tabular}




\section{Executive Summary}

The Salmon Site (SS), formerly the Tatum Dome Test Site, is located in Lamar County, Mississippi, southwest of the city of Hattiesburg and near the communities of Purvis and Baxterville. It was the site of two nuclear and two gas explosion tests conducted between 1964 and 1970 as part of the U.S. Atomic Energy Commission's (now U.S. Department of Energy [DOE]) Vela Uniform Program to improve the United States capability to detect, identify, and locate underground nuclear detonations. The SS is managed by the DOE Nevada Operations Office.

In October 1964, the U.S. Atomic Energy Commission initiated testing activities at the SS with the detonation of a 5.3 kiloton (kt) nuclear device within the Tatum Salt Dome. This first test, designated the Salmon Event, was conducted at a depth of 826 meters (2,710 feet). The test resulted in the formation of a cavity within the salt dome. A second nuclear test, Sterling $(0.38 \mathrm{kt})$, was detonated in the cavity in December 1968. Two methane/oxygen gas detonations were also conducted in the cavity formed by the Salmon Event. Diode Tube and Humid Water, both equivalent to $0.32 \mathrm{kt}$, were detonated in April 1970.

A consequence of these testing activities is that radionuclides generated during the testing were released into the salt dome, where they are presently contained. During reentry drilling and other site activities, incidental liquid and solid wastes that contained radioactivity were generated. These wastes resulted in some soil, groundwater, and equipment contamination at the SS. During the 1972 decommissioning of the site, most of the contaminated soil and water were collected and disposed either in the cavity left by the tests or in an injection well. The equipment was decontaminated and transported to the Nevada Test Site for disposal. Nonradioactive wastes were disposed in pits at the site; these pits were subsequently backfilled with clean soil and graded.

The DOE is conducting investigations at the SS as part of a Remedial Investigation and Feasibility Study (RI/FS). The RI/FS is the methodology under the Comprehensive Environmental Response, Compensation and Liability Act (CERCLA) for evaluating hazardous waste sites on the National Priorities List (NPL). The SS is not on the NPL, but DOE has voluntarily elected to conduct the evaluation of the SS in accordance with CERCLA. 
As a part of the remedial investigation effort, a Baseline Ecological Risk Assessment (BERA) was conducted at the SS. The purpose of this assessment is to gauge ecological and other environmental impacts attributable to past activities at the former test facility. This assessment was designed to be facility-specific so that all stakeholders could participate effectively.

The purpose of the SS BERA was to

- Describe the observed or potential magnitude of adverse ecological effect(s) at the SS and the primary cause(s) of the effect(s)

- Characterize the ecological consequences of the "no further action" remedial alternative.

Abiotic (soil, sediment, and surface water) and biotic (vegetation and mammalian tissues) media were sampled and analyzed. The site was surveyed and the various species utilizing the aquatic and terrestrial habitats recorded. Sensitive species identified on site were the gopher tortoise and Bachman's sparrow.

Data gathered in the field were used in the problem formulation process to select constituents of potential concern (COPC) and identify ecological receptors. The concerns identified for surface waters were aluminum, arsenic, and radiation sources; for sediments, arsenic, barium, cadmium, lead, manganese, zinc, and radiation sources; and for surficial soils, copper, lead, and radiation sources. Potential radiation sources included tritium and radionuclides detected by gamma spectroscopy (alpha, beta, and gamma omitters) and were taken as COPC in terms of total radiation dose received by an ecological receptor. Potential exposure routes and effects of the COPC to the SS receptors were also identified.

Exposure of ecological receptors was characterized by analyzing the transport and fate of COPC through calculations of exposure point concentrations (EPC) for the various media. The 95-percent upper confidence limit of the mean constituent concentrations for all samples, soil/water partition coefficients $\left(\mathrm{K}_{\mathrm{d}}\right)$, and bioconcentration factors were considered. Biological tissues analyzed included fish, loblolly pine, a crop plant sample, small mammals, a raccoon, an opossum, and several white-tailed deer. Sampled species were selected as ecological receptors, representing producers and various trophic levels. Species not sampled were also selected, including the sensitive species, and all top consumers represented by the red-tailed hawk and the great blue heron. 
Effects to these receptors were characterized by comparison of EPC and tissue concentrations to established criteria, benchmarks, and literature-derived toxicity values. Radiation dose modeled for the mouse, fish, and great blue heron did not exceed established protective criteria. Inorganic $\mathrm{COPC}$ in the aquatic ecosystems were eliminated when EPC did not exceed established criteria for the protection of aquatic life. Aluminum exceeded the criteria for surface water in the site samples, and in the reference samples. This is believed to be indicative of high natural levels at the SS. The calculated aquatic EPC for barium and manganese did not exceed values estimated to have adverse effects in freshwater systems; however, residue levels in fish tissue samples were found to exceed reference concentrations. No data were available to determine if these tissue levels were toxic. No acute toxicity was observed in toxicity testing, and most communities appeared unimpaired according to Rapid Bioassessment Protocol metrics.

Terrestrial biota tissue results were compared with values reported in the literature, and it was determined that no adverse effects would be expected due to copper or lead. Calculations made to determine the dose of copper and lead to the red-tailed hawk yielded results well below literature-derived No Observable Adverse Effects Levels. Based on residue concentrations in field collected animals, it was concluded that no adverse effects would be expected for sensitive species or game birds at the SS.

Risk was characterized from these exposure and effects data in the context of uncertainty analysis and potential data gaps. Potential data gaps include the lack of toxicity data for barium and manganese and the lack of game bird and reference-site tissue data. Although localized areas of elevated contamination exist at the site, there is enough evidence to conclude that the assessment endpoints were met in being protective of communities and populations at the SS. The no action alternative would be acceptable unless the desire is to be protective of individual organisms. In that case, removal of isolated areas of elevated contamination should be considered. 


\subsection{Introduction}

\subsection{Background}

The overall objective of the Salmon Site (SS) Project is to conduct an investigation in accordance with the U.S. Environmental Protection Agency (EPA); Comprehensive Environmental Response, Compensation, and Liability Act (CERCLA); U.S. Department of Energy (DOE) Orders; and Mississippi Department of Environmental Quality guidelines. Although the SS is not listed on the National Priorities List, the DOE has voluntarily elected to conduct the evaluation in accordance with CERCLA. This Baseline Ecological Risk Assessment (BERA) was prepared as part of the CERCLA methodology for characterizing the nature and extent of risks posed by uncontrolled hazardous waste sites. The BERA provides the basis to determine whether remedial actions are necessary and, if so, the justification for performing them at the SS.

\subsection{Objectives}

The primary objective of this BERA is to determine if the constituents present in environmental media at the SS have caused, or could cause, an adverse ecological impact. Specific objectives of this assessment were to

- Review existing site-related ecological data and, if necessary, perform additional field surveys to identify natural resources and terrestrial and aquatic ecological receptors on and near the site.

- Summarize these data into a description of ecological conditions at the site.

- Develop a conceptual model to identify reasonable site-specific exposure pathways and potential terrestrial and aquatic ecological receptors.

- Select constituents of potential concern (COPC) based on results of chemical analysis of abiotic media samples, using physicochemical and ecologically relevant criteria.

- Perform an ecotoxicological assessment (that includes field measurements and laboratory bioassays) to determine the potential for COPC to induce adverse ecological effects in identified terrestrial and aquatic ecological receptors, then identify constituents of concern (COC) and their potential for inducing adverse effects on ecological conditions at the site. 
- Prepare a baseline assessment report that documents the analyses and interpretation of results obtained from the field surveys, laboratory investigations, and ecotoxicological analyses. When adverse impacts are suggested but not quantifiable with available data, identify critical data gaps. define additional data requirements, and make recommendations for additional investigations.

These objectives were met through three phases of investigation that were tailored to the specific circumstances and conditions for the SS. Phase I included a general field survey of the flora and fauna associated with the site, placing particular emphasis on identifying sensitive ecosystems, endangered species and their critical habitats, and species possibly consumed by humans or found in human food chains. Sensitive ecosystems include wetlands, floodplains, wildlife breeding areas, and wildlife refuges. This work was described in reports submitted to the DOE Nevada Operations Office (IT, 1992a and 1993). Phase II investigations included collection of biological tissue and site-related media samples, as well as field monitoring and/or observation, bioassay, and analytical investigations. Phase III involved comparison and evaluation of field data, analytical findings, and bioassay data to relevant criteria and other applicable standards, as available, and culminated in the submission of this BERA report.

\subsection{Organization}

This report is organized in the following manner, which is consistent with the organization suggested in the Framework for Ecological Risk Assessment (EPA, 1992):

Section 1.0 Introduction: Outlines objectives and scope for this assessment and provides general information on the facility being investigated.

Section 2.0 Area Description: Gives a broad-based discussion of ecological and ecologicallyrelated resources and features in the region.

Section 3.0 Problem Formulation: Reviews available information in order to provide an understanding of the current extent of potential problems at the site. Information presented includes available environmental sampling data and identified ecological receptors for each trophic level.

Section 4.0 Exposure Characterization: Characterizes contaminant transport and fate phenomena, identifies specific ecological receptors, and quantifies exposure point concentrations from both primary and secondary exposure pathways.

Section 5.0 Ecological Effects Characterization: Discusses quantitative links between contaminant concentrations and effects in receptors. Literature reviews are the primary source of such dose-response information. 
Section 6.0 Risk Characterization: Estimates and describes potential risks to ecological receptors, populations, communities, and ecosystems of interest. An uncertainty analysis is also included in this section.

Section 7.0 References: Contains bibliographic information for Sections 1.0 through 6.0 . 


\subsection{Area Description}

\subsection{Site Location}

The SS is located in Lamar County, Mississippi, near the communities of Baxterville and Purvis. The site is comprised of approximately 595 hectares (1,470 acres) of land in Sections 11, 12, 13, and 14 of the Township 2 North, Range 16 West, St. Stephens Meridian. The test site is rectangular with boundaries that run north-south and east-west. Access to within 1.6 kilometers (one mile) of the site is by way of the Columbia-Purvis County road from Purvis. A network of gravel and sand roads provides access to various locations within the site. A general location map of the area is presented in Figure 2-1.

\subsubsection{Site Description}

The SS was leased by the government and contractor-operated as part of the U.S. Atomic Energy Commission's (AEC) nuclear weapons testing program. The land is currently owned by the DOE, which also holds the exclusive rights to all subsurface activity at the dome. The test site was decommissioned by the DOE in June of 1972. A granite monument (latitude $31^{\circ} 08^{\prime}$ $32^{\prime \prime}$ north, longitude $89^{\circ} 34^{\prime} 12^{\prime \prime}$ west) marks the location of surface ground zero (SGZ), which is the ground surface point directly above the nuclear test activities. In 1988, the DOE submitted a Preliminary Assessment of the site to the EPA. This assessment concluded that the residual levels of radioactivity in the vicinity of SGZ were not sufficiently high to warrant listing the former facility as a Superfund site.

\subsubsection{Site Maps}

Aerial photographs taken at different times during the life of the project were used to assist in locating and defining areas of past DOE activity. The photographs were also used to interpret and evaluate site conditions and activities over time.

From the aerial photographs, archived construction maps, and on-site field work, base maps for the SS were prepared (Figure 2-2). For planning the remedial investigation, the sites on the SS were organized into Source Areas (SA) based on the nature of the activities, geographic proximity, and physical setting. Six SAs have been established at the SS (Figures 2-3 through 2-8) each containing from one to nine individual sites (Table 2-1).

\subsection{Sources of Site Historical Data}

The SS has been extensively investigated as a part of the DOE activities at the site and monitoring by federal and state agencies. An extensive data base of information on the 


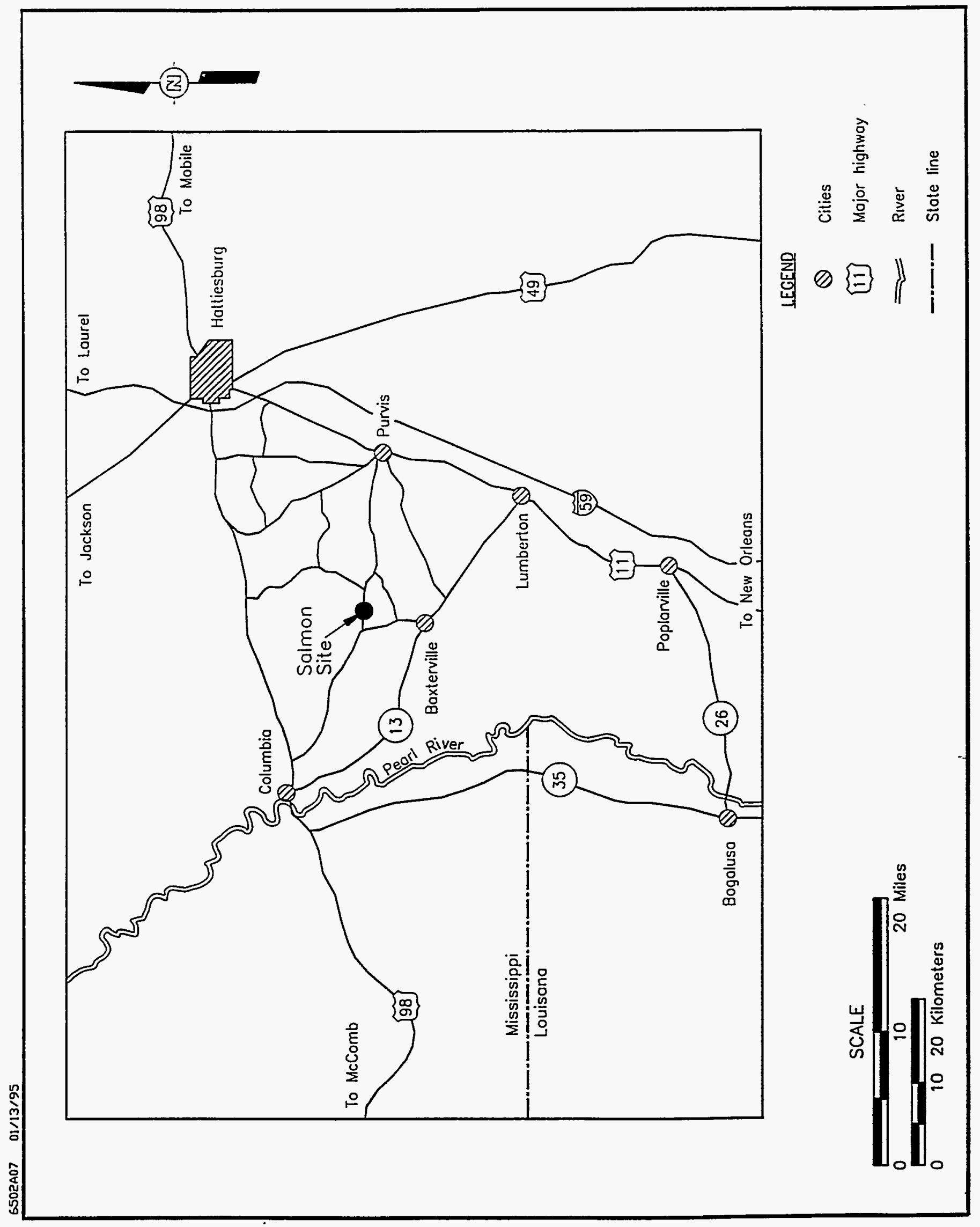

Figure 2-1

General Location Map of the Salmon Site 


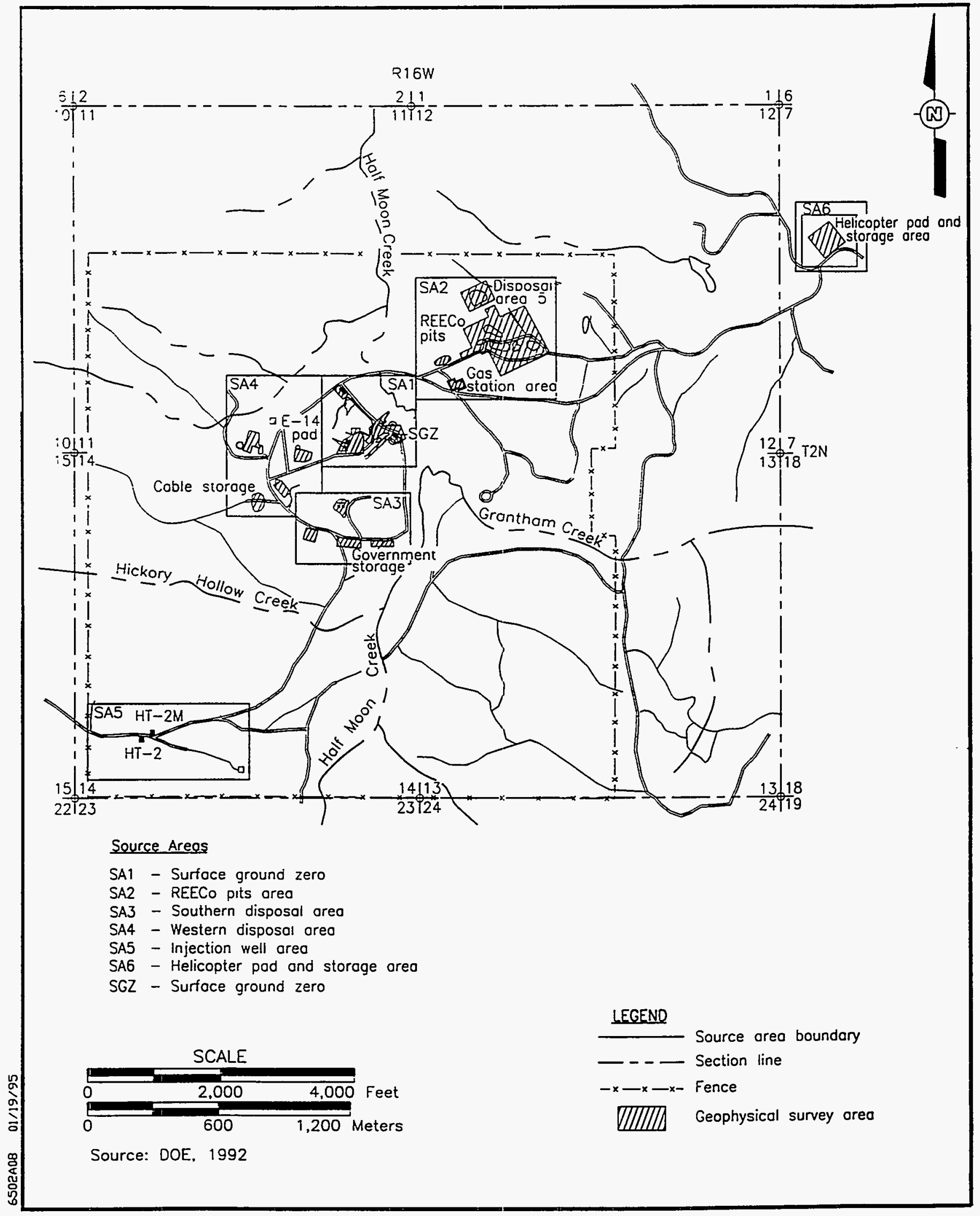

Figure 2-2

Salmon Site Map 

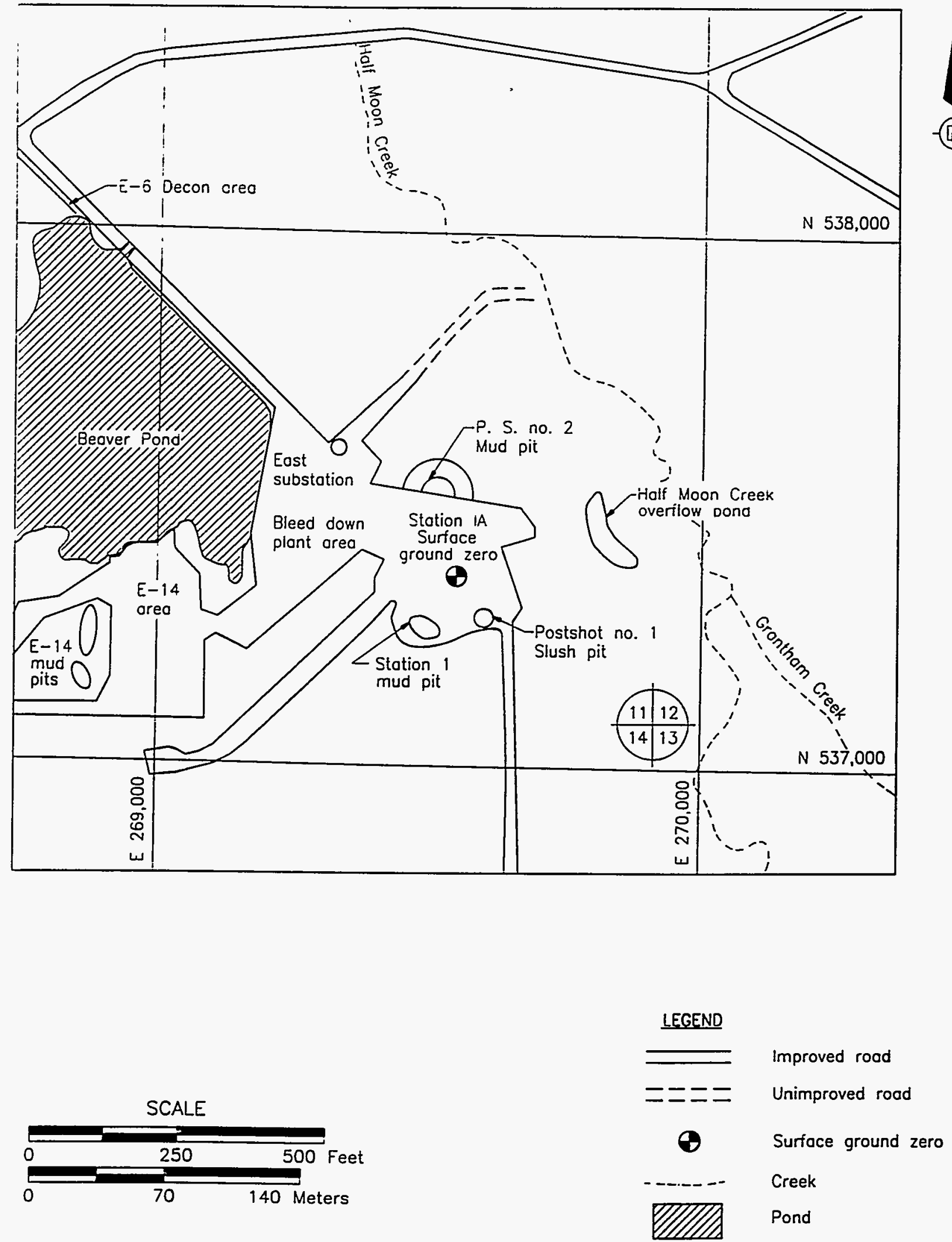

Figure 2-3

Source Area 1

Surface Ground Zero 


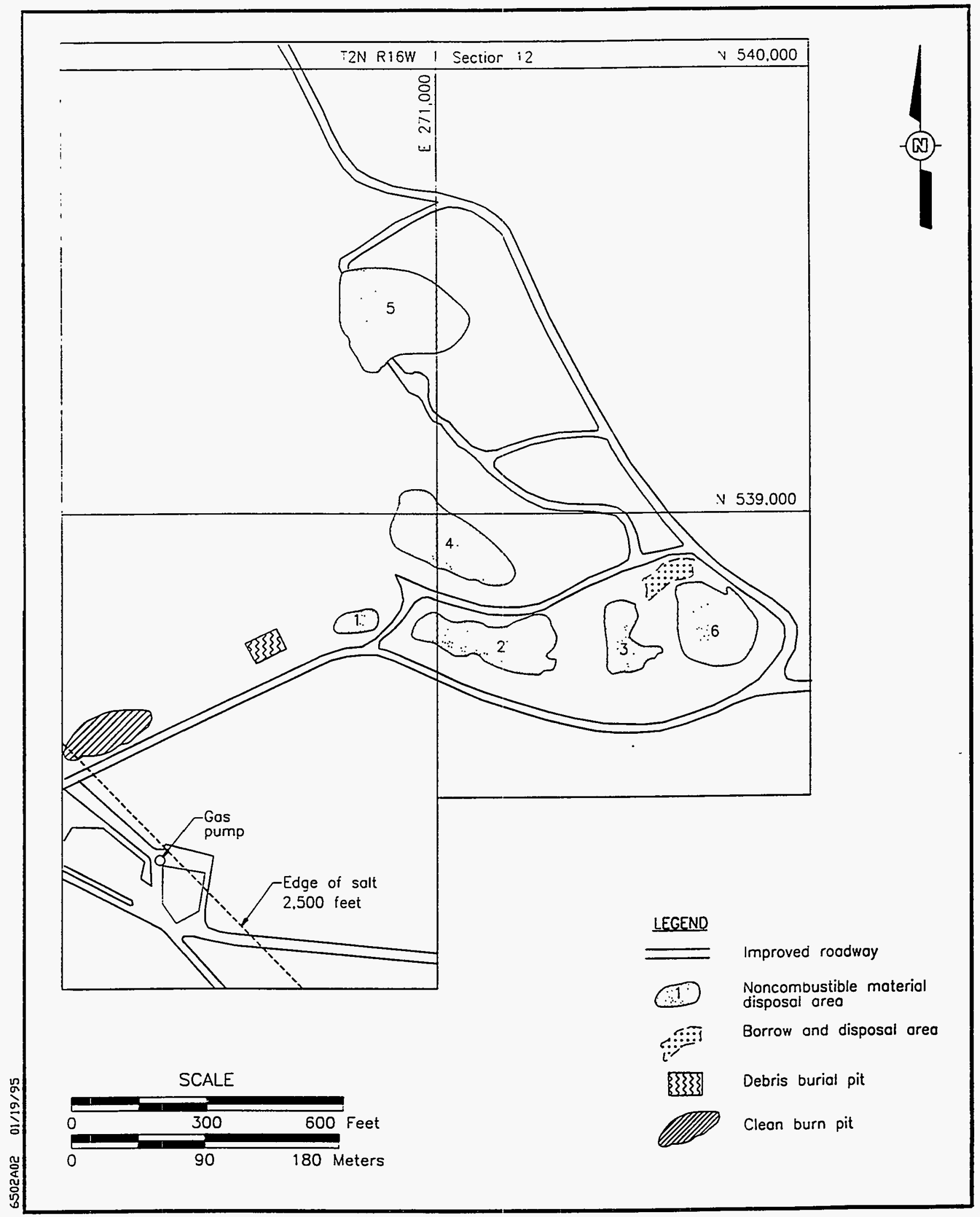

Figure 2-4

Source Area 2

Northern Disposal Area 


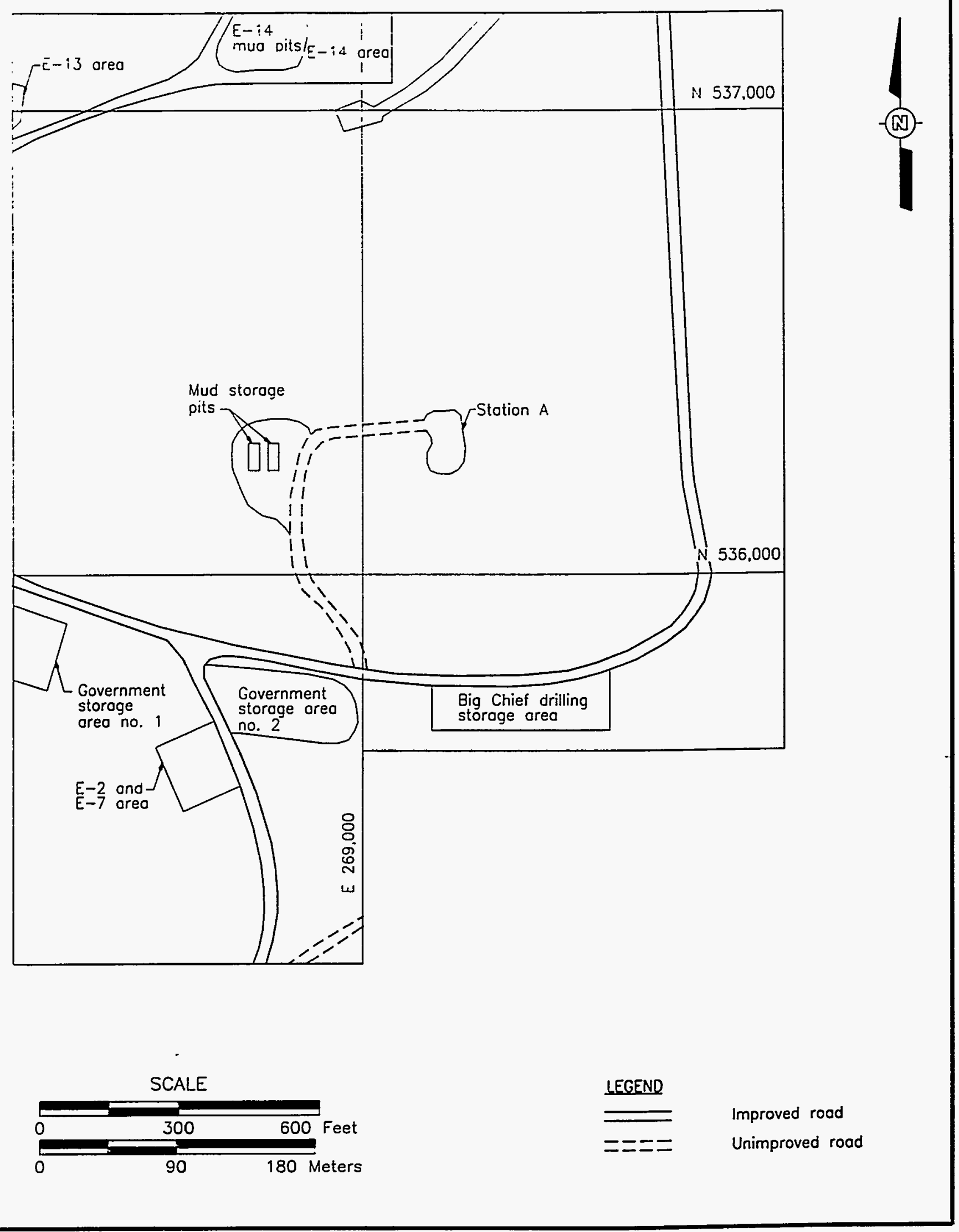

Figure 2-5

Source Area 3

Southern Storage Area 


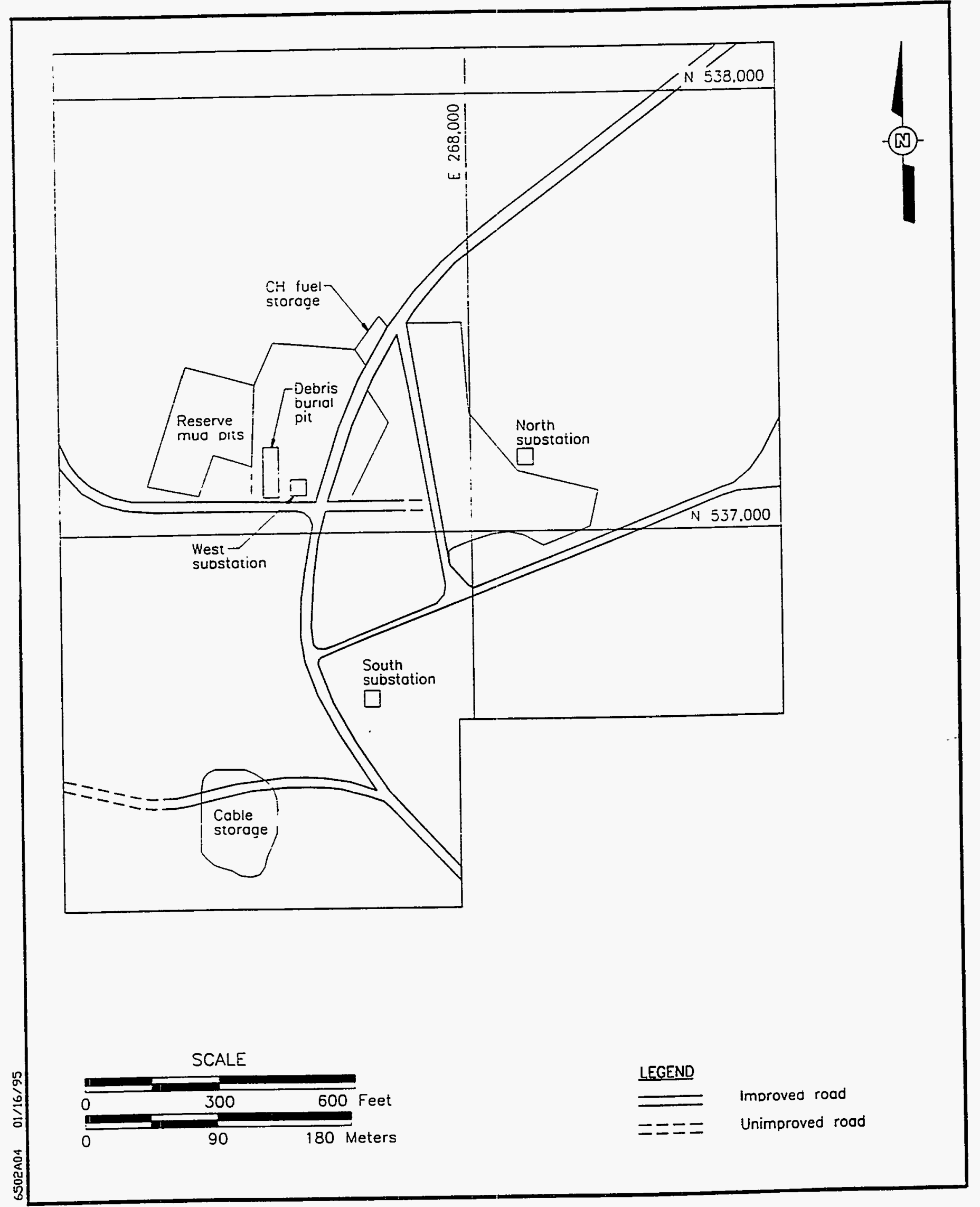

Figure 2-6

Source Area 4

Western Disposal Area 


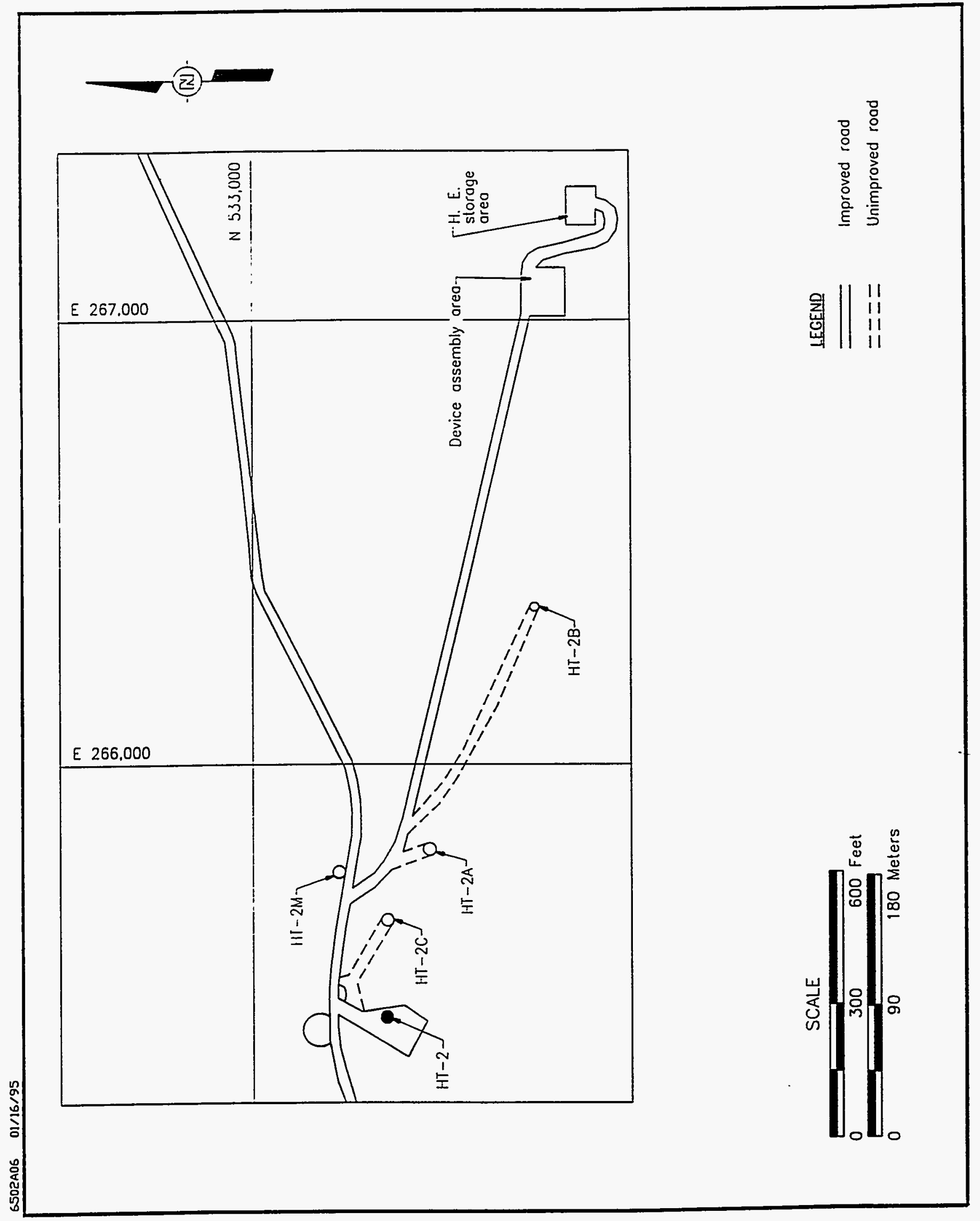

Figure 2-7

Source Area 5

Injection Well Area 


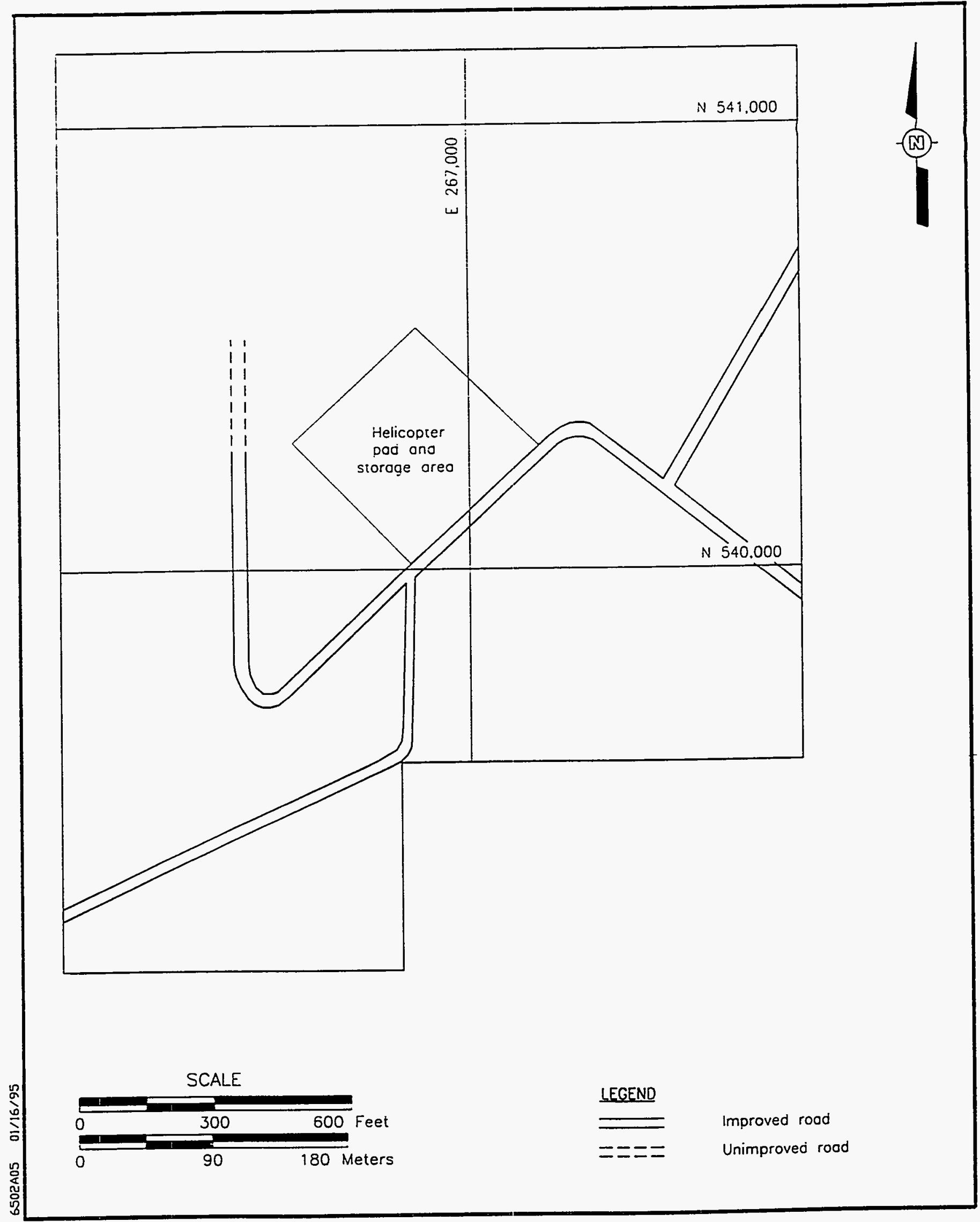

Figure 2-8

Source Area 6

Helicopter Pad and Storage Area 
Table 2-1

Sites within each Source Area,

Salmon Site

\begin{tabular}{|c|c|}
\hline \multicolumn{2}{|r|}{ Source Area (SA) 1 - Surface Ground Zero } \\
\hline $\begin{array}{l}1-A \\
1-B \\
1-C \\
1-D \\
1-E \\
1-F \\
1-G \\
1-H \\
1-1\end{array}$ & $\begin{array}{l}\text { Shot Cavity, Surface Ground Zero } \\
\text { Beaver Pond } \\
\text { Half Moon Creek Overflow Pond } \\
\text { Postshot No. } 1 \text { Slush Pit \& Mouse Hole } \\
\text { Bleed-Down Plant Area } \\
\text { East Substation } \\
\text { E-14 Pad and Mud Pits } \\
\text { E-6 Decontamination Pad } \\
\text { Postshot No. } 2 \text { Mud Pit }\end{array}$ \\
\hline \multicolumn{2}{|r|}{ SA-2 - Northern Disposal Area } \\
\hline $\begin{array}{l}2-A \\
2-B \\
2-C \\
2-D\end{array}$ & $\begin{array}{l}\text { Reynolds Electrical \& Engineering Co., Inc., Disposal Pits } \\
\text { Clean Burn Pit } \\
\text { Clean Burn Pit } \\
\text { Gas Pump }\end{array}$ \\
\hline \multicolumn{2}{|r|}{ SA-3 - Southern Disposal Area } \\
\hline $\begin{array}{l}3-A \\
3-B \\
3-C \\
3-D \\
3-E\end{array}$ & $\begin{array}{l}\text { Mud Storage Pits/South Borrow Pit } \\
\text { Big Chief Drilling Storage Area } \\
\text { Site E-2 and E-7 } \\
\text { Government Storage Area } 1 \text { (Drilling Storage Yard) } \\
\text { Government Storage Area } 2\end{array}$ \\
\hline \multicolumn{2}{|r|}{ SA-4 - Western Disposal Area } \\
\hline $\begin{array}{l}4-A \\
4-B \\
4-C \\
4-D \\
4-E \\
4-F \\
4-G\end{array}$ & $\begin{array}{l}\text { Reserve Mud Pits } \\
\text { Debris Burial Pit } \\
\text { West Substation } \\
\text { CH Fuel Storage } \\
\text { Cable Storage } \\
\text { South Substation } \\
\text { North Substation }\end{array}$ \\
\hline \multicolumn{2}{|r|}{ SA-5 - Injection Well Area } \\
\hline $\begin{array}{l}5-A \\
5-B\end{array}$ & $\begin{array}{l}\text { HT-2 Well Area } \\
\text { HT-2M Well Area }\end{array}$ \\
\hline & SA-6 - Helicopter Pad and Storage Area \\
\hline $6-A$ & Helicopter Pad and Storage Area \\
\hline
\end{tabular}


operation, waste generation, disposal activities, and physical setting of the site is available. Historical environmental data collected from the early 1970s through 1990 on the SS are chronicled in the following reports:

- Cleanup Summary Report, Tatum Dome Test Site. Mississippi, June 1972 (NVO-129) (DOE. 1972)

- Long-Term Radiological Surveillance Program, Tatum Dome Test Site, Revised March 1975 (NVO-143) (DOE, 1975)

- Special Study: Tatum Dome Test Site Lamar County, Mississippi, Final Report, October 1978 (NVO-200) (DOE, 1978)

- Animal Investigation Program, Mississippi Results (EPA, 1974)

- The Tatum Dome Project, Lamar County, Mississippi (NVO-225) (DOE, 1980)

- Onsite and Offsite Environmental Monitoring Report: Radiation Monitoring Around Tatum Salt Dome, Lamar County, Mississippi (EPA, 1990)

- Tatum Salt Dome Radiological Monitoring, Annual Report, March 1990 (MDOH, 1990).

\subsubsection{Site Operational History and Current Status}

In 1961, the AEC (now the DOE) conducted exploratory drilling, surveying, and road construction at a site located on the Tatum Salt Dome in Lamar County, Mississippi (AEC, 1972). The Tatum Salt Dome was selected as the site of the AEC's Vela Uniform Program designed to determine if a salt dome could be used to mask the seismic signature of underground nuclear tests. Construction for the Salmon test started in early 1963 with the boring of an emplacement shaft into the salt dome. In October 1964, the Salmon device was detonated at a depth of 828 meters $(\mathrm{m})(2,716$ feet [ft]). The Salmon event had a reported yield of 5.3 kilotons $(\mathrm{kt})$ and resulted in the formation of a cavity with a radius of approximately $33 \mathrm{~m}$ (108 ft) within the salt dome (AEC, 1972). Following the event, the point of detonation was investigated by drilling back into the cavity and sampling the contents. To reduce the risk of radioactivity being released from the cavity to the environment during the re-entry drilling, a bleed-down plant was constructed. Gases released during the re-entry boring were routed to the bleed-down plant where they were filtered to reduce the radioactivity to regulatory standards prior to release to the atmosphere.

A second nuclear event, Sterling (0.38 kt), was detonated in December 1966 in the cavity formed by the Salmon Event. Both events were fully contained so there was no uncontrolled 
venting of gases or particulates to the surface. There was a minor release of gaseous, radioactive materials during cable cutting and sealing of the holes for the Sterling event (DOE, 1971). It is expected that any such releases would have been quickly dissipated to the atmosphere.

Two methane/oxygen gas detonations were also performed in the cavity left by the Salmon Event. The two tests, Diode Tube and Humid Water, were part of the Miracle Play Series events, both had yields of $0.32 \mathrm{kt}$, and were detonated in February 1969 and April 1970, respectively.

Following the Humid Water event the DOE began clean-up, restoration, and decommissioning activities at the site.

As a consequence of the testing activities, radionuclides were released into the salt dome where they are presently contained. During re-entry drilling and other site activities, incidental liquid and solid wastes were generated that contained radioactivity. These wastes resulted in some soil, groundwater, and equipment contamination at the site. Most of these wastes and contaminated soil and water were cleaned up and disposed of, either in the shot cavity or in an injection well. The equipment was decontaminated and transported to the Nevada Test Site (NTS) for disposal. Nonradioactive wastes were disposed in pits at the site, which were backfilled with clean soil and graded. The DOE plugged 34 of the 39 exploratory and monitoring wells that were constructed between 1961 and 1972. The site was officially decommissioned on June 30, 1972:

Environmental monitoring at the SS was initiated in 1964 by the Public Health Service and continued until May 1970. Long-term hydrologic monitoring was initiated in 1972 by the EPA and continues to the present. As a part of this monitoring, all potable aquifers, many individual water wells, public water supplies, and some surface waters have been and are currently sampled annually in the vicinity of the SS. The MSDEQ, Division of Radiological Health (DRH), also conducts a quarterly monitoring program.

In addition to the monitoring program maintained by the EPA, the DOE is currently conducting a Remedial Investigation and Feasibility Study (RI/FS) (IT, 1992b) that includes this BERA. Preliminary activities started in July 1992, but the major intrusive tasks could not be conducted until DOE owned the land. The following outlines activities that have been conducted on site since July 1992: 
July 1992 Initiation of surveys and RI/FS Work Plan:

Floodplain and Wetland Investigation

- Wetlands delineation

National Environmental Policy Act Surveys

- Avian

- Mammalian

- Reptile/amphibian (gopher tortoise identified on site)

- Vegetation

- Historical/archaeological

Aquatic Surveys

- Rapid Bioassessment Protocols

- Established surface water/sediment sampling stations

Initial Geophysical Investigation

- Established grids and collection of magnetometer data

October $1992 \quad$ Gopher Tortoise Survey

- Located burrows and habitat evaluation

Continuation of Geophysical Survey

- Cleared survey grids

- Ground penetrating radar (GPR)

- Magnetometer

February 1993

Sample Collection

- Surface water

- Sediment

- Biota

- Fish, mammals, aquatic invertebrates

- Expanded geophysical survey

- Line cutting, GPR, magnetometer

April 1993

Soil/Vegetation Sampling

- Sampled SAs for soil and vegetation

- Continued geophysical survey

- Line cutting, GPR, magnetometer

August 1993

Continuation of RI/FS Work Plan

- Expanded geophysical investigation by 100 percent

- Clearing lines, GPR, magnetometer

- Clearing/grubbing of areas to be used for investigation-derived waste (IDW) Storage and Decontamination Pad 


$\begin{array}{ll}\text { September } 1993 & \text { - Construction of new bridge/bypass on Half Moon Creek } \\ & \text { - Repaired and widened site roads } \\ & \text { - Continued geophysical survey } \\ & \text { - Installed fence around decontamination pad }\end{array}$

October 1993 - Completed geophysical surveys

- Flagged well and cone penetrometer (CPT) locations

November $1993 \quad-$ CPT

- Cleared 18 sites

- Stratigraphy logs

- Sampled groundwater and soil with the CPT rig

- Installed 2 wastewater tanks at the decontamination pad

December 1993

- Trench Excavations

- Dug 17 trenches in Reynolds Electrical \& Engineering Co., Inc., pits to locate the magnetic anomalies identified through geophysical surveys

- Soil sampled from around buried anomalies

- Trench Closure

- Cleared and prepped two drill pads at SGZ

January 1994

- Site Closure

- Moved waste/drums off site

- Moved all equipment to office compound

- Sampled wastewater tank

- Closed office trailer and demobilized IT Corporation personnel as of January 21

\subsubsection{Hazardous Substance and Waste Management}

Both radioactive and hazardous wastes were generated as part of the normal operations at the SS. During operation, more than 100 people worked at the SS requiring fuel, electricity, sanitation, waste disposal, and the storage and use of hazardous materials. In addition, following each of the test events, reentry holes were drilled into the shot cavity to determine the subsurface effects of the explosion. These drilling operations generated the largest volume of residual waste materials, primarily contaminated drill cuttings and fluids.

Many of the individual sites within the SAs were investigated during site decommissioning, and contaminated soils and equipment were consolidated and disposed. Radioactively-contaminated equipment was decontaminated and shipped to the NTS for disposal. Radioactivelycontaminated soil and drilling fluids were transported to the SGZ area and injected into the shot cavity. Radioactively-contaminated water was also injected into the deep brine aquifer used for 
the disposal of oil field brines. Nonradioactively-contaminated wastes were primarily disposed by landfilling them on site.

The initial activities completed under the RI/FS at the SS produced some IDW. These are stored on site pending completion of the land acquisition. Construction debris, such as concrete, steel landing mat, and old culverts from the Half Moon Creek bridge bypass construction was piled to either side of the new bridge. These materials have been surveyed for gross radiological contamination, and samples were analyzed at a laboratory for radiation with negative results. All trees that were removed in the process of building the IDW storage area were piled to the east of the main road near the decontamination pad. These trees are creating a potential biological hazard because they are infested with bark beetles that may attack the live trees along the edges of the IDW storage area. Within the decon-pad compound there are approximately 4.500 gallons of stored waste water from decontamination of the CPT equipment. Laboratory analyses indicate no radiological or hazardous COCs in the water.

\subsection{Issues of Public Concern}

At the present time, members of the surrounding community are concerned that past activities at the salt dome may pose a risk to the environment and public health. Concerns to the BERA include the following:

- Is radionuclide contamination present in the on-site environmental media?

- Is nonradionuclide contamination present in the on-site environmental media?

- If present, what is the nature and extent of contamination?

Several long-term monitoring programs have been funded by DOE and conducted by EPA and MSDEQ/DRH. In the 18 plus years since these programs were initiated, no radioactivity above naturally occurring background levels has been detected in any of the off-site water supplies. Studies conducted by the MSDEQ/DRH and EPA have found no unusually high incidence of cancer in humans within Lamar County. 


\subsection{Problem Formulation}

Problem formulation is the first step of the ecological risk assessment process. Problem formulation can be defined as a systematic planning step that identifies the major factors to be considered in a particular assessment (EPA, 1992). It establishes the goals, breadth, and focus of the assessment and is linked to the regulatory drivers and policy context of the assessment. The process begins with the initial characterization of the exposure and ecological effects, including evaluating the stressor characteristics, the ecosystem potentially at risk, and the ecological effects expected or observed. Problem formulation describes the relationships among assessment and measurement endpoints, data required, and methodologies that will be used to analyze the data.

\subsection{Site Description}

This section describes and discusses the physical and biological characteristics of the SS. These characteristics (i.e., geology, water resources, climate, existing use, and biota) provide the building blocks from which the conceptual model of the site was developed.

Overall, the SS has largely returned to a natural state and, except for the monument erected by the DOE at SGZ, there is little indication of the past activities at the site. The areas where soils were excavated have been back filled and seeded and now have a well established cover of vegetation. Numerous species of flora and fauna are abundant at the former test site, and the area is currently used for timber production and hunting.

\subsubsection{Physical Features}

The SS is situated in the low hills of the pine woods area of the Gulf Coast region. This area is characterized by narrow, flat-topped ridges and intervening valleys that trend predominantly in a south-southeast direction toward the Gulf of Mexico. The maximum relief on site is approximately $30 \mathrm{~m}$ ( $100 \mathrm{ft}$ ) with elevations ranging from 75 to $110 \mathrm{~m}$ ( 246 to $360 \mathrm{ft}$ ) above mean sea level. Surface ground zero lies east of Half Moon Creek, the principal drainage from the site.

The SS is situated on the northern edge of the Mississippi Salt Basin. The geologic strata deposited in the basin are typically interbedded, discontinuous sandstones and shales with local marls, evaporites, and limestones. Regionally the sediments dip gently to the south and southeast. Locally, the dip may be modified by the intrusion of salt domes. 
The SS is located in the Atlantic and Gulf Coastal Plain Groundwater Region. Groundwater occurs throughout the region in a vertical series of aquifers, with the surficial aquifer generally located less than $30 \mathrm{~m}$ (100 ft) below surface. On a regional scale, groundwater flow is primarily in a southerly or southeasterly direction. However, the hydrogeologic conditions on the local, near-dome scale, are very complex because of the effect of the dome. At SGZ, the alluvial aquifer extends from near ground surface to a depth of about $12 \mathrm{~m}$ (39 ft) below the land surface.

Surface drainage at the SS is through three creeks: Hickory Hollow, Grantham, and Half Moon Creeks. These creeks receive groundwater discharge in the dry season from the alluvial aquifer, which may transport contamination along with it. Tritium and trace levels of organic constituents have been detected in groundwater from the alluvial aquifer near SGZ. Ponds located on the SS also represent important hydrologic elements. The ponds of most concern with regard to contaminated groundwater discharge are the Beaver Pond and Half Moon Creek Overflow Pond (Figure 3-1).

\subsubsection{Biological Features}

The SS is located within a belt of pine forest that extends along the coastal plains of the South Atlantic and Gulf States. The pine forest is a seral stage of the temperate deciduous forest. These forests can be classified into either one of two major types: loblolly/short leaf and slash/long leaf pine. The continued dominance of the pine species is dependent upon periodic fires and cutting, without which the pines would be replaced by hardwoods, such as oaks (Quercus sp.), hickory (Carya sp.), and magnolia (Magnolia sp.). Most of the SS is open, long-leaf pine forest with a shrub understory.

The diversity of vegetation and perennially available water provide suitable habitat for whitetailed deer (Odocoileus virginianus); armadillo (Dasypus novemcinctus); eastern cottontail rabbit (Sylvilagus floridanus); coyote (Canis latrans); raccoon (Procyon lotor); opossum (Didelphis marsupialis); beaver (Castor canadensis); squirrel (Tamiasciurus hudsonicus and Sciurus carolinensis); several species of small rodents; and numerous bird, reptile, and amphibian species. The small creeks and ponds on site provide limited habitat for large fish species, but do support populations of minnows, which provide forage for egrets, herons, and other piscivorous species. A complete listing of all flora and fauna observed on site is presented in Tables 3-1 through 3-6. 


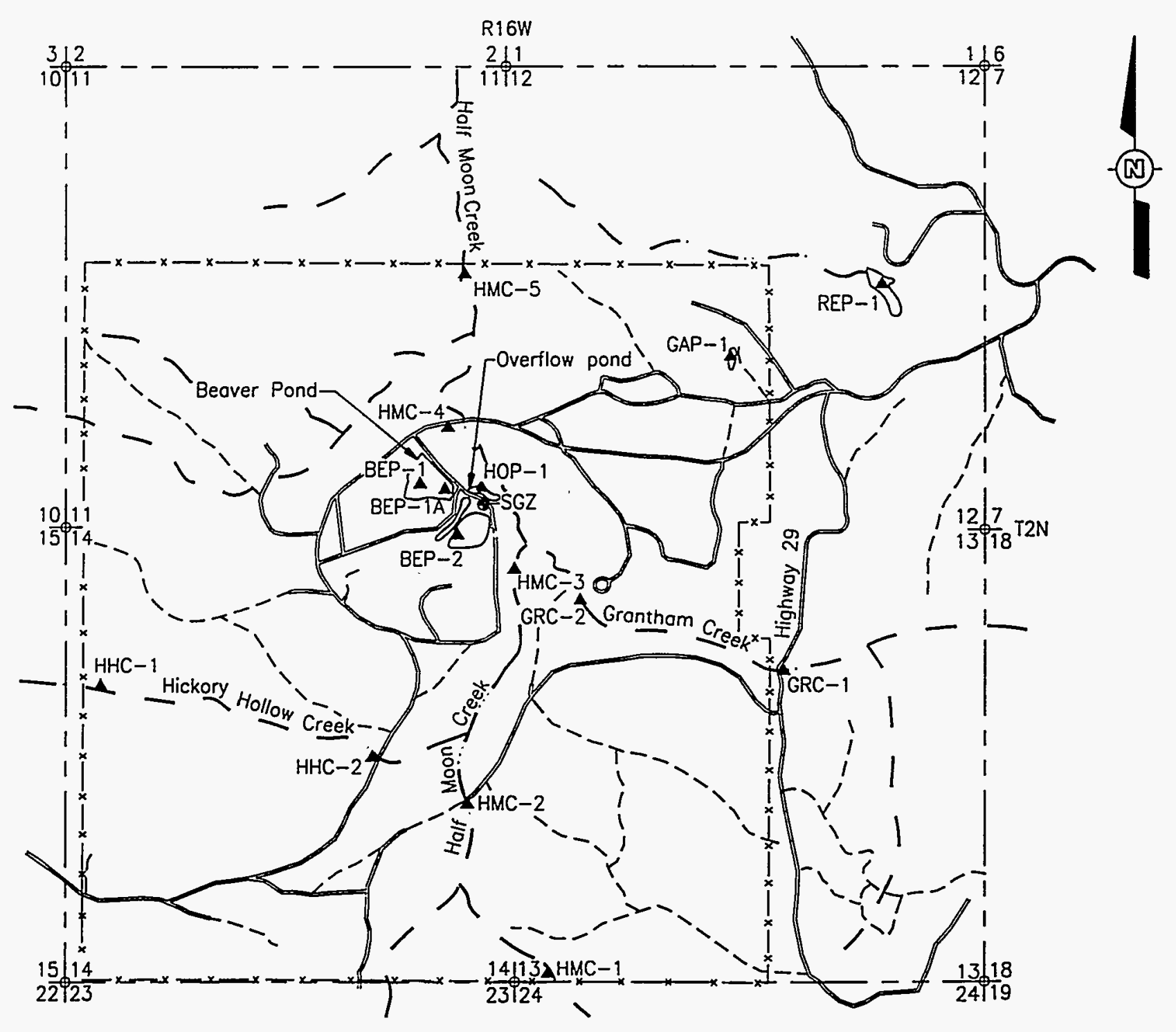

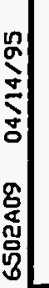
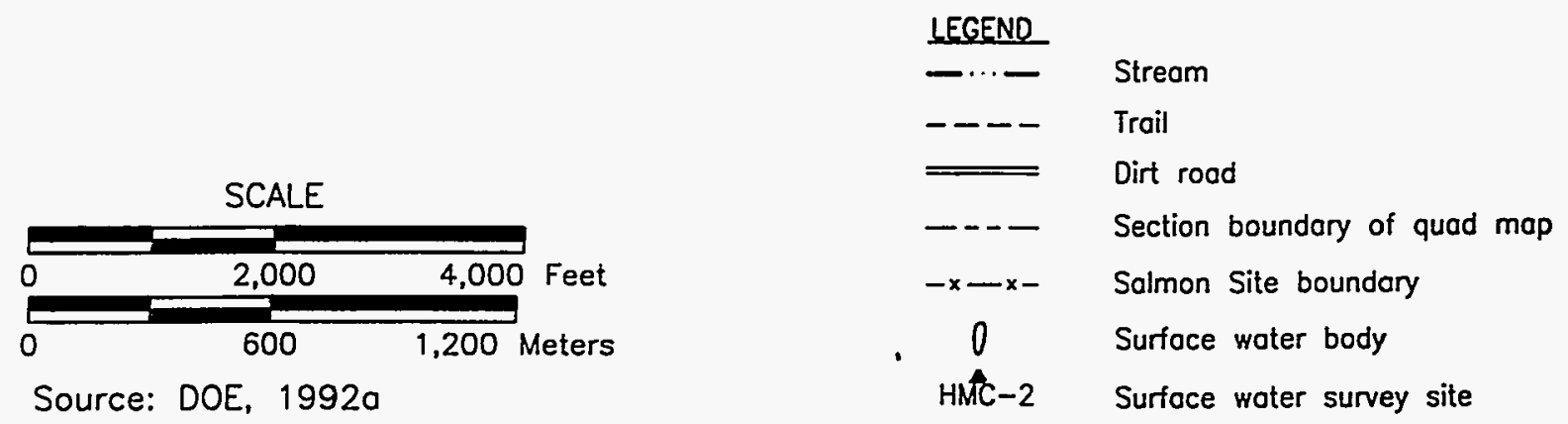

Figure 3-1

Salmon Site Surface-Water and Sediment Sampling Locations 
Table 3-1

Species List - Vegetation Survey, July 13 to 19,1992 ,

Salmon Site

(Page 1 of 3 )

\begin{tabular}{|c|c|}
\hline Common Name & Scientific Name \\
\hline Sensitive Fern & $\begin{array}{l}\text { Polypodiaceae } \\
\text { Onoclea sensibilis }\end{array}$ \\
\hline $\begin{array}{l}\text { Green Bristlegrass } \\
\text { Bristlegrass } \\
\text { Foxtail } \\
\text { Grasses } \\
\text { Cord Grass }\end{array}$ & $\begin{array}{l}\text { Gramineae } \\
\text { Setaria viridis } \\
\text { Setaria sp. } \\
\text { Alopecurus sp. } \\
\text { Gramineae sp. } \\
\text { Spartina pectinata }\end{array}$ \\
\hline $\begin{array}{l}\text { Bladder Sedge } \\
\text { Umbrella Sedge }\end{array}$ & $\begin{array}{l}\text { Cyperaceae } \\
\text { Carex intumescens } \\
\text { Cyperus strigosus }\end{array}$ \\
\hline $\begin{array}{l}\text { Canada Rush } \\
\text { Toad Rush }\end{array}$ & $\begin{array}{l}\text { Juncaceae } \\
\text { Juncus canadensis } \\
\text { Juncus bufonius }\end{array}$ \\
\hline Fragrant Water Lily & $\begin{array}{l}\text { Nymphacaceae } \\
\text { Nymphaea odorata }\end{array}$ \\
\hline $\begin{array}{l}\text { Common Greenbriar } \\
\text { Long-Stalk Greenbriar } \\
\text { Indian Cucumber Root }\end{array}$ & $\begin{array}{l}\text { Lillaceae } \\
\text { Smilax rotundifolia } \\
\text { Smilax pseudochina } \\
\text { Medeola virginiana }\end{array}$ \\
\hline Bitternut Hickory & $\begin{array}{l}\text { Jugiandaceae } \\
\text { Carya cordiformis }\end{array}$ \\
\hline $\begin{array}{l}\text { Blackjack Oak } \\
\text { Willow Oak } \\
\text { Water Oak } \\
\text { Laurel Oak }\end{array}$ & $\begin{array}{l}\text { Fagaceae } \\
\text { Quercus marilandica } \\
\text { Quercus phellos } \\
\text { Quercus nigra } \\
\text { Quercus laurifolia }\end{array}$ \\
\hline Sassafras & $\begin{array}{l}\text { Lauraceae } \\
\text { Sassafras albidum }\end{array}$ \\
\hline Sweetgum & $\begin{array}{l}\text { Hamamelidaceae } \\
\quad \text { Liquidambar styraciflua }\end{array}$ \\
\hline $\begin{array}{l}\text { Blackberry } \\
\text { Blackcherry }\end{array}$ & $\begin{array}{l}\text { Rosaceae } \\
\quad \text { Rubus allegheniensis } \\
\text { Prunus serotina }\end{array}$ \\
\hline $\begin{array}{l}\text { Poison Ivy } \\
\text { Winged Sumac }\end{array}$ & $\begin{array}{l}\text { Anacardiaceae } \\
\text { Toxicodendron radicans } \\
\text { Toxicodendron copallinum }\end{array}$ \\
\hline
\end{tabular}


Table 3-1

Species List - Vegetation Survey,

July 13 to 19,1992 ,

Salmon Site

(Page 2 of 3 )

\begin{tabular}{|c|c|}
\hline Common Name & Scientific Name \\
\hline Red Maple & $\begin{array}{l}\text { Aceraceae } \\
\text { Acer rubrum }\end{array}$ \\
\hline $\begin{array}{l}\text { Water Tupelo } \\
\text { Black Gum } \\
\text { Flowering Dogwood }\end{array}$ & $\begin{array}{l}\text { Cornaceae } \\
\text { Nyssa aquatica } \\
\text { Nyssa sylvatica } \\
\text { Cornus florida }\end{array}$ \\
\hline White Ash & $\begin{array}{l}\text { Oleaceae } \\
\text { Fraxinus americana }\end{array}$ \\
\hline $\begin{array}{l}\text { Boneset } \\
\text { Tickseed Sunflower } \\
\text { Ragweed } \\
\text { Goldenrod } \\
\text { Bearded Tickseed }\end{array}$ & $\begin{array}{l}\text { Compositae } \\
\text { Eupatorium perfoliatum } \\
\text { Bidens sp. } \\
\text { Ambrosia artemisiifolia } \\
\text { Solidago sp. } \\
\text { Bidens aristosa } \\
\end{array}$ \\
\hline Buttonbush & $\begin{array}{l}\text { Rubiaceae } \\
\text { Cephalanthus occidentalis }\end{array}$ \\
\hline Pawpaw & $\begin{array}{l}\text { Annonaceae } \\
\text { Asimina triloba }\end{array}$ \\
\hline Baldcypress & $\begin{array}{l}\text { Taxodiaceae } \\
\text { Taxodium distichum }\end{array}$ \\
\hline Saw Palmetto & $\begin{array}{l}\text { Palmae } \\
\text { Serenoa repens }\end{array}$ \\
\hline Common Persimmon & $\begin{array}{l}\text { Ebenaceae } \\
\text { Diospyros virginiana }\end{array}$ \\
\hline $\begin{array}{l}\text { Yellow Poplar } \\
\text { Southern Magnolia }\end{array}$ & $\begin{array}{l}\text { Magnoliaceae } \\
\text { Liriodendron tulipifera } \\
\text { Magnolia grandiflora }\end{array}$ \\
\hline Southern Bayberry & $\begin{array}{l}\text { Myricaceae } \\
\text { Myrica cerifera }\end{array}$ \\
\hline American Holly & $\begin{array}{l}\text { Aquifoliaceae } \\
\text { Ilex opaca }\end{array}$ \\
\hline $\begin{array}{l}\text { Loblolly Pine } \\
\text { Longleaf Pine } \\
\text { Shortleaf Pine }\end{array}$ & $\begin{array}{l}\text { Pinaceae } \\
\text { Pinus taeda } \\
\text { Pinus palustris } \\
\text { Pinus echinata }\end{array}$ \\
\hline Hooded Pitcher-Plant & $\begin{array}{l}\text { Ericaceae } \\
\quad \text { Sarracenia minor } \\
\end{array}$ \\
\hline
\end{tabular}


Table 3-1

Species List - Vegetation Survey, July 13 to 19,1992 ,

Salmon Site

(Page 3 of 3 )

\begin{tabular}{|c|c|}
\hline Common Name & Scientific Name \\
\hline Common Cattail & $\begin{array}{l}\text { Typhaceae } \\
\text { Typha latifolia }\end{array}$ \\
\hline Common Pipewort & $\begin{array}{l}\text { Eriocaulaceae } \\
\text { Eriocaulon septangulare }\end{array}$ \\
\hline $\begin{array}{l}\text { Arrow-Arum } \\
\text { Jack-in-the-Pulpit }\end{array}$ & $\begin{array}{l}\text { Alaceae } \\
\text { Peltandra virginica } \\
\text { Arisaema triphyllum }\end{array}$ \\
\hline Snowy White Orchid & $\begin{array}{l}\text { Orchidaceae } \\
\text { Habenaria nivea }\end{array}$ \\
\hline $\begin{array}{l}\text { Rattlebox } \\
\text { Partridge Pea }\end{array}$ & $\begin{array}{l}\text { Leguminosae } \\
\text { Crotalaria sagittalis } \\
\text { Cassia fasciculata }\end{array}$ \\
\hline Box Huckleberry & $\begin{array}{l}\text { Elicacea } \\
\text { Gaylussacia brachvcera }\end{array}$ \\
\hline Marsh Pink & $\begin{array}{l}\text { Gentianaceae } \\
\text { Sabatia stellaris }\end{array}$ \\
\hline Japanese Honeysuckle & $\begin{array}{l}\text { Caprifoliaceae } \\
\text { Lonicera japonica }\end{array}$ \\
\hline Common St. Johnswort & $\begin{array}{l}\text { Guttiferae } \\
\text { Hypericum perforatum }\end{array}$ \\
\hline Old Field Toadflax & $\begin{array}{l}\text { Sorophulariaceae } \\
\text { Linaria canadensis }\end{array}$ \\
\hline White Baneberry & $\begin{array}{l}\text { Ranunculaceae } \\
\text { Actaea pachypoda }\end{array}$ \\
\hline Green Amaranth & $\begin{array}{l}\text { Amaranthaceae } \\
\text { Amaranthus retroflexus }\end{array}$ \\
\hline
\end{tabular}


Table 3-2

Species List - Avian Survey, July 13 to 19,1992 , Salmon Site (Page 1 of 2)

\begin{tabular}{|c|c|}
\hline Common Name & Scientific Name \\
\hline Wood Duck & Aix sponsa \\
\hline $\begin{array}{l}\text { White Ibis } \\
\text { Cattle Egret } \\
\text { Green Heron }\end{array}$ & $\begin{array}{l}\text { Eudocimus albus } \\
\text { Bubulcus ibis } \\
\text { Butorides striatus }\end{array}$ \\
\hline $\begin{array}{l}\text { Broad-Winged Hawk } \\
\text { Red-Tailed Hawk } \\
\text { Mississippi Kite } \\
\text { Barred Owl } \\
\text { Black Vulture }\end{array}$ & $\begin{array}{l}\text { Buteo platypterus } \\
\text { Buteo jamaicensis } \\
\text { Ictinia mississippiensis } \\
\text { Strix varia } \\
\text { Coragypes atratus }\end{array}$ \\
\hline $\begin{array}{l}\text { Northern Bobwhite } \\
\text { Wild Turkey }\end{array}$ & $\begin{array}{l}\text { Colinus virginianus } \\
\text { Meleagris gallopavo }\end{array}$ \\
\hline $\begin{array}{l}\text { Common Flicker } \\
\text { Red-Bellied Woodpecker } \\
\text { Downy Woodpecker }\end{array}$ & $\begin{array}{l}\text { Colaptes auratus } \\
\text { Melanerpes carolinus } \\
\text { Picoides pubescens }\end{array}$ \\
\hline $\begin{array}{l}\text { Great Crested Flycatcher } \\
\text { Eastern Wood Pewee }\end{array}$ & $\begin{array}{l}\text { Myiarchus crinitus } \\
\text { Contopus virens }\end{array}$ \\
\hline $\begin{array}{l}\text { Northern Rough-Winged Swallow } \\
\text { Chimney Swift } \\
\text { Common Nighthawk }\end{array}$ & $\begin{array}{l}\text { Stelgidopteryx serripennis } \\
\text { Chaetura pelagica } \\
\text { Chordeiles minor }\end{array}$ \\
\hline $\begin{array}{l}\text { Bluejay } \\
\text { American Crow }\end{array}$ & $\begin{array}{l}\text { Cyanocitta cristata } \\
\text { Corvus brachyrhynchos }\end{array}$ \\
\hline $\begin{array}{l}\text { Carolina Chickadee } \\
\text { Tufted Titmouse } \\
\text { Carolina Wren }\end{array}$ & $\begin{array}{l}\text { Parus carolinensis } \\
\text { Parus bicolor } \\
\text { Thryothorus ludovicianus }\end{array}$ \\
\hline $\begin{array}{l}\text { Northern Mockingbird } \\
\text { Brown Thrasher } \\
\text { American Robin } \\
\text { Wood Thrush }\end{array}$ & $\begin{array}{l}\text { Mimus polyglottos } \\
\text { Toxostoma rufum } \\
\text { Turdus migratorius } \\
\text { Hylocichla mustelina }\end{array}$ \\
\hline Blue-Gray Gnatcather & Polioptila caerulea \\
\hline $\begin{array}{l}\text { Pine Warbler } \\
\text { Common Yellow-Throat } \\
\text { Hooded Warbler } \\
\text { Swainson's Warbler } \\
\text { Prairie Warbler }\end{array}$ & $\begin{array}{l}\text { Dendroica pinus } \\
\text { Geothlypis trichas } \\
\text { Wilsonia citrina } \\
\text { Limnothlypis swainsonii } \\
\text { Dendroica discolor }\end{array}$ \\
\hline
\end{tabular}


Table 3-2

Species List - Avian Survey,

July $13-19,1992$,

Salmon Site

(Page 2 of 2)

\begin{tabular}{||l|l||}
\hline \multicolumn{1}{|c|}{ Common Name } & \multicolumn{1}{|c|}{ Scientific Name } \\
\hline \hline Scarlet Tanager & Piranga olivacea \\
Summer Tanager & Piranga rubra \\
\hline Northern Cardinal & Cardinalis cardinalis \\
Blue Grosbeak & Guiraca caerulea \\
Indigo Bunting & Passerina cyanea \\
House Finch & Carpodacus mexicanus \\
Rufous-Sided Towhee & Pipilo erythrophthalmus \\
\hline Bachman's Sparrow & Aimophila aestivalis \\
\hline
\end{tabular}

Table 3-3

Species List - Reptiles and Amphibian Survey,

July 13 to 19,1992 ,

Salmon Site

\begin{tabular}{||l|l||}
\hline \multicolumn{1}{|c|}{ Common Name } & \multicolumn{1}{|c|}{ Scientific Name } \\
\hline \hline Amphibians & \\
Eastern Narrow-Mouthed Toad & \\
Squirrel Treefrog & Gastrophyrne carolinensis \\
Slimy Salamander & Hyla squirella \\
Alabama Waterdog & Plethodon glutinosus \\
Bronze Frog & Necturus alabamensis \\
River Frog & Rana clamitans clamitans \\
Southern Dusky Salamander & Rana heckscheri \\
Southern Cricket Frog & Desmognathus auriculatus \\
Four-Toed Salamander & Acris gryllus gryllus \\
Reptiles & Hemidactylium scutatum \\
Southeastern Five-Lined Skink & \\
Gopher Tortoise & \\
Green Anole & Eumeces inexpectatus \\
Ground Skink & Gopherus polyphemus \\
Fence Lizard & Anolis carolinensis \\
Eastern Box Turtle & Scincella laterale \\
Northern Brown Snake & Sceloporus undulatus \\
Water Snake (unidentified) & Terrapene carolina carolina \\
Western Cottonmouth & Storeria dekayi dekayi \\
Southern Toad & Nerodea sp. \\
\hline
\end{tabular}

Table 3-4

Species List - Mammalian Survey, 
Table 3-4

Species List - Mammalian Survey, July 13 to 19,1992 , Salmon Site

\begin{tabular}{||l|l|}
\hline \multicolumn{1}{|c|}{ Common Name } & \multicolumn{1}{|c|}{ Scientific Name } \\
\hline \hline Armadillo $^{\text {abc }}$ & Dasypus novemcinctus \\
Big Brown Bat $^{\mathrm{a}}$ & Eptesicus fuscus \\
Myotis $^{\mathrm{a}}$ & Myotis sp. \\
\hline Eastern Cottontail $^{\text {abc }}$ & Sylvilagus floridanus \\
Squirrel $^{\text {ad }}$ (Grey or Fox $)_{\text {Coyote }^{\mathrm{b}}}$ & Sciurus sp. \\
Domestic Dog $^{\mathrm{b}}$ & Canis latrans \\
Domestic Cat $^{\mathrm{b}}$ & Canis familiaris \\
White-Tailed Deer $^{\text {abc }}$ & Felis catus \\
\hline
\end{tabular}

Identified by sighting

Identified by tracks

$c_{\text {Identified by scat }}$

Identified by sound

Table 3-5

Species Collected, February 22 to 28, 1993,

Salmon Site

\begin{tabular}{|c|c|}
\hline Common Name & Scientific Name \\
\hline $\begin{array}{l}\text { White-Tailed Deer } \\
\text { Raccoon } \\
\text { Opossum } \\
\text { Eastern Cottontail } \\
\text { Marsh Rabbit } \\
\text { Pine Vole } \\
\text { Short-Tailed Shrew } \\
\text { Eastern Woodrat } \\
\text { Mice }\end{array}$ & $\begin{array}{l}\text { Odocoileus virginianus } \\
\text { Procyon lotor } \\
\text { Didelphis marsupialis } \\
\text { Sylviagus floridanus } \\
\text { Sylviagus palustris } \\
\text { Pitymus pinetorum } \\
\text { Blarina brevicauda } \\
\text { Neotoma floridana } \\
\text { Peromyscus sp. }\end{array}$ \\
\hline
\end{tabular}


Table 3-6

Fish Biosurvey Results,

July 13 to 19,1992 ,

Salmon Site

\begin{tabular}{|c|c|c|c|c|c|c|c|c|c|c|c|c|c|c|}
\hline \multirow{2}{*}{ Common Name } & \multirow{2}{*}{ Genus Species } & \multicolumn{13}{|c|}{ Aquatic Survey Stations } \\
\hline & & BeP-1 & BeP-2 & GRC-1 & GRC-2 & HHC- 1 & HHC-2 & HOP-1 & GiP-1 & HMC-1 & HMC-2 & HMC-3 & HMC-4 & HMC-5 \\
\hline Bass & Family: Centrarchidae & $x$ & & & & & & & & & & & & \\
\hline Black Banded Darter & Percina nigrofasciata & & & $x$ & & & & & & & & & & \\
\hline $\begin{array}{l}\text { Blackstripe } \\
\text { Topminnow }\end{array}$ & Fundulus notatus & & & & & & $x^{a}$ & & & & & & & \\
\hline Blacktail Shiner & Notropis venusta & & & & & & & & & & & & $x$ & \\
\hline Bluegill & Lepomis macrochirus & & & $x$ & & & & $x^{a}$ & & & & & & \\
\hline $\begin{array}{l}\text { Broadstripe } \\
\text { Topminnow }\end{array}$ & Fundulus euryzonus & & & & & & & & & & & & $x$ & \\
\hline Brown Bullhead & Ameiurus nebulosus & & & $x$ & & & & & & & & $x$ & & \\
\hline Cherryfin Shiner & Lythrurus roseipinnis & & & $x^{a}$ & $x^{a}$ & & $x$ & & & & $x^{a}$ & $x^{a}$ & $x^{a}$ & $x^{a}$ \\
\hline Chesinut Lamprey & $\begin{array}{l}\text { Ichithyomyzon } \\
\text { castaneus }\end{array}$ & & & & x & & & & & & & & $x$ & $x$ \\
\hline Flagfin Shiner & Notropis signipinnis & & & $x$ & & & & & & $x^{a}$ & $x$ & $x$ & & \\
\hline Gulf Darter & Etheostoma swaini & & & & & & & & & & & $x$ & & \\
\hline Mosquito Fish & Gambusia affinis & $x^{a}$ & $x$ & & & & & & & & & & & \\
\hline Silverstripe Shiner & Notropis stilbuis & $x$ & & & & & & & & & & & $x$ & \\
\hline $\begin{array}{l}\text { Starhead } \\
\text { Topminnow }\end{array}$ & Fundulus notti & $x$ & $x^{a}$ & & & & & & & & & & $x$ & \\
\hline Yellow Bullhead & Ameiurus natalis & & & & & & & & & & & & $x$ & \\
\hline Alabama Waterdog & Necturus alabamensis & & & & & & & & & & & & $x$ & \\
\hline Lesser Siren & Siren intermedia & & & & & & & & & & & $x$ & & \\
\hline
\end{tabular}

indicates dominant specles at that station 


\subsubsection{Species of Special Concern}

Only two species listed as either threatened, endangered, or sensitive are known to inhabit the SS. These are the gopher tortoise (Gopherus polyphemus), (federally-listed threatened and statelisted endangered) and Bachman's sparrow (federal Category 2, information insufficient to list). However, the habitat supporting these species on the SS is not unique in any way, but is part of an expanse of similar pine forest that is common throughout the southeastern part of the state. A complete listing of the survey methods and results for threatened and/or endangered species is presented in the Results of a Preliminary Survey for Threatened and Endangered Species and Floodplains/Wetlands at the Tatum Dome Test Site Lamar County, Mississippi (IT, 1992a).

\subsection{Constituents of Potential Concern Selection}

A multistep method was used to identify COPC for the site because of the large quantity of analytical data available for both chemical and radiological constituents.

The first step involved identifying a set of reported concentrations that were of acceptable quality for use in the environmental evaluation. This was accomplished through (a) evaluations of analytical methods, (b) evaluations of the quality of the data with respect to detection limits, and (c) laboratory and validation qualifiers and blanks.

The second step was to reduce the data set to those constituents that frequently had higher concentrations in the on-site samples than were found in the reference sample. This is an indication that these constituents are present due to site-related activities.

The third step involved identifying COPC within the soil, sediment, and surface water, which were of greatest concern with respect to bioaccumulation in ecological receptors based on the octanol/water partition coefficient $\left(\mathrm{K}_{\mathrm{ow}}\right)$.

The list of COPC was further reduced, on the basis of water or sediment quality criteria and detection in biota tissue samples, to a final list of contaminants of concern. A COC was selected if water or sediment quality criteria, which are developed to be protective of all aquatic life, were exceeded, or if the constiuent was detected in tissues. If no aquatic criteria existed for water or sediment COPC, but the constituent was present in fish tissue, it was considered a COC. Since no mandated soil quality criteria exist, and COPC were detected in animal and plant tissues, these were carried through as COC. This list of COC was then used to assess contaminant-related risk at the SS. 


\subsubsection{Data Collection}

\subsubsection{Reference Samples}

Reference sites for surface water and sediment were established on Half Moon Creek (HMC-1), located at the southern boundary; Grantham Creek ( $\mathrm{GrC}-1$ ), located at the eastern boundary; and Hickory Hollow Creek (HHC-1), locared at the western boundary of the SS. An unnamed catfish pond located off site (ReP-1) was used as the source of the northern reference sample. Figure 3-1 shows the locations of the surface-water sampling stations. The field adjacent to the catfish pond was used as the reference location for surficial soils. Figure 3-2 shows the location of the soil sampling stations at the SS. Reference sampling was conducted concurrently with the on-site sampling events.

\subsubsection{Sediment and Surface Water}

Sediment samples were collected during the period of February 22 to 28. 1993. Only 15 of the 22 stations originally identified in the Environmental Evaluation Work Plan (EEW) were sampled during the investigation (Table 3-7). During the initial site reconnaissance, it was determined that the ponds in SA-2 and SA-4 no longer existed. Swamps identified in previous investigations were also absent or were now part of the Beaver Pond. The large size of the Beaver Pond required that three sampling stations be used instead of one. Station BeP-1 was located on the northern end of the pond near the E-6 Decontamination Pad; station BeP-1a at the southeastern end near the Bleed Down Plant Area and E-14 Pad; and station BeP-2 was located in a small pond connected to the main pond by a galvanized steel culvert beneath Half Moon Circle Road. This portion of the Beaver Pond is located near the E-14 Pad and Mud Pits. Sediment samples were analyzed for organic, inorganic, and radiological constituents. In addition, grain size and total organic carbon were measured. Figure 3-1 shows the location of these sampling stations.

Surface water samples were analyzed for organic, inorganic, and radiological constituents, as well as general water-quality chemistry parameters. The biochemical oxygen-demand (BOD) analyses were conducted after holding time had expired. The original BOD data were supplemented with five additional samples collected on April 28, 1993. These five samples were collected from HMC-4, HOP-1, HHC-2, HMC-2, and GrC-1. Figure 3-1 shows the locations of these sampling stations. A summary of the types of samples collected for the aquatic investigation is provided in Table 3-8. 


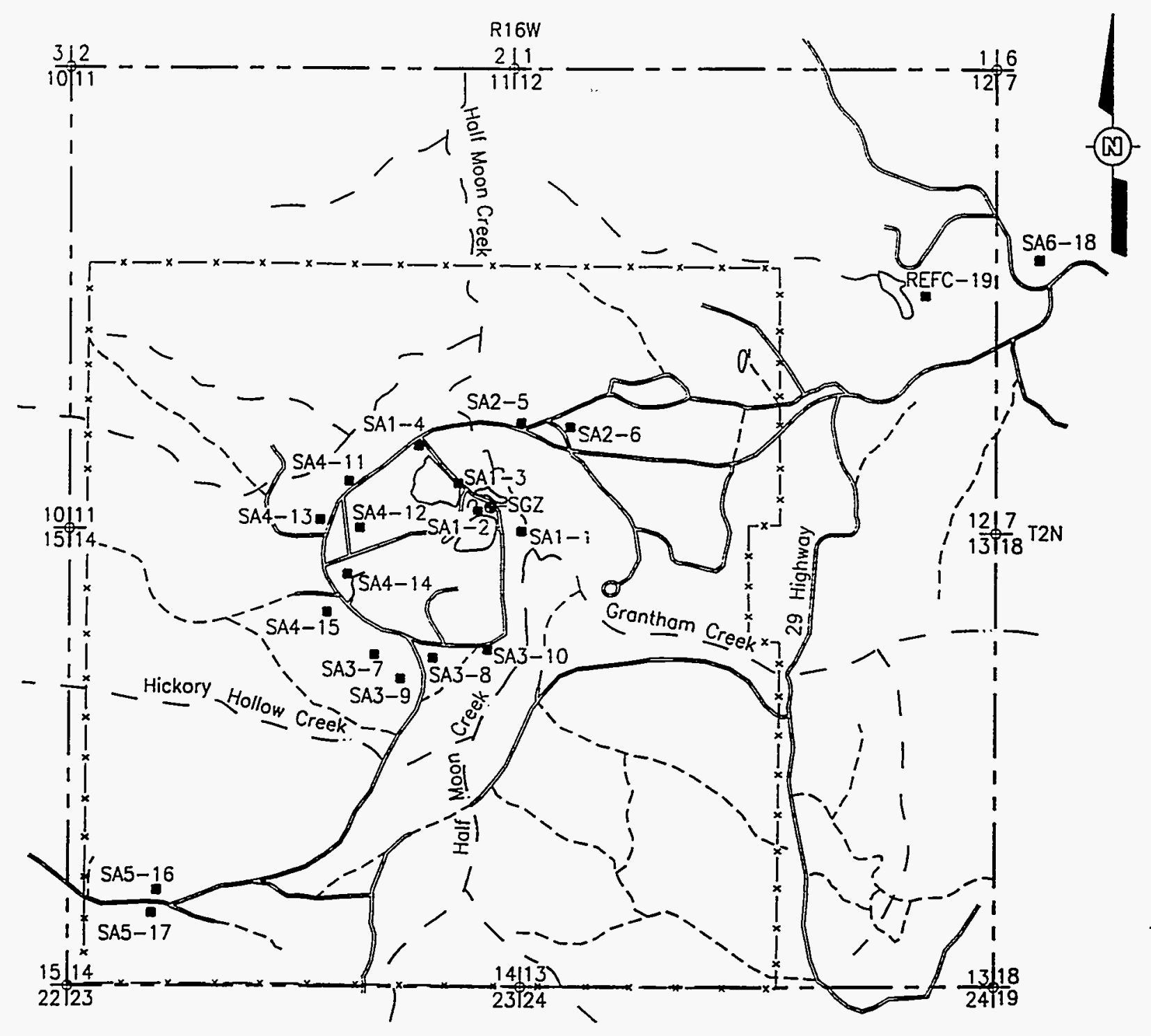

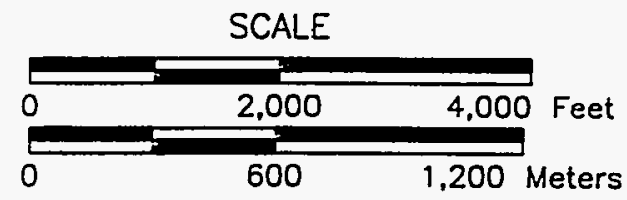

Source: DOE, 19920
LEGEND

$\begin{array}{ll}-\cdots- & \text { Stream } \\ ---- & \text { Trail } \\ --- & \text { Dirt rood } \\ 0 & \text { Section boundary of quad mop } \\ -x-x- & \text { Surface water body } \\ \text { SA5-17 } & \text { Soil and vegetation sampling sites }\end{array}$

Figure 3-2

Salmon Site Soil- and Vegetation-Sampling Locations 
Table 3.7

\section{Surface Water and Sediment Sampie Locations for the Aquatic Ecosystem Investigation, Salmon Site}

\begin{tabular}{|c|c|}
\hline HMC-1 & Half Moon Creek just within the southern boundary of the Salmon Site (SS) (Reference). \\
\hline HMC-2 & $\begin{array}{l}\text { Half Moon Creek approximately } 1 / 2 \text { mile upstream of the confluence of Hickory Hollow } \\
\text { Creek and Half Moon Creek. This station is downstream of surficial groundwater flow from } \\
\text { Source Area (SA)-5. }\end{array}$ \\
\hline HMC-3 & $\begin{array}{l}\text { Half Moon Creek approximately } 1 / 8 \text { mile upstream of the confluence of Grantham Creek } \\
\text { and Half Moon Creek. This station is in an area of surficial groundwater flow from SA-5. }\end{array}$ \\
\hline HMC-4 & $\begin{array}{l}\text { Half Moon Creek approximately } 1 / 2 \text { mile downstream of the confluence of Grantham Creek } \\
\text { and Half Moon Creek at the bridge where the Main Road crosses Half Moon Creek. This } \\
\text { station is in an area just downstream of surficial groundwater flow from SA-1. }\end{array}$ \\
\hline HMC-5 & Half Moon Creek just within the northern boundary of SS. \\
\hline $\mathrm{HHC}-1$ & Hickory Hollow Creek just within the western boundary of SS (Reference). \\
\hline HHC-2 & $\begin{array}{l}\text { Hickory Hollow Creek approximately } 1 / 2 \text { mile upstream of the confluence of Hickory Hollow } \\
\text { Creek and Half Moon Creek. This station is downstream of surficial groundwater flow from } \\
\text { SA-5. }\end{array}$ \\
\hline GrC-1 & Grantham Creek just within the eastern boundary of SS (Reference). \\
\hline GrC-2 & $\begin{array}{l}\text { Grantham Creek approximately } 1 / 8 \text { mile upstream of the confluence of Grantham Creek } \\
\text { and Half Moon Creek. This station is an area of surficial groundwater flow from SA-2. }\end{array}$ \\
\hline BeP-1 & $\begin{array}{l}\text { Beaver Pond } 1 \text { on the northern end of the Pond. This pond receives runoff and } \\
\text { groundwater discharge from potential "hot spots" within SA-1 and SA-2. }\end{array}$ \\
\hline BeP-1a & Beaver Pond location 2 on the southern end of the Pond. \\
\hline BeP-2 & Beaver Pond location 3 on the small pond connected to the Beaver Pond. \\
\hline HOP-1 & $\begin{array}{l}\text { Half Moon Creek Overflow Pond. This pond has received runoff and groundwater } \\
\text { discharge that was contaminated with tritium from surface ground zero. }\end{array}$ \\
\hline $\operatorname{ReP}-1$ & $\begin{array}{l}\text { Reference Pond. This privately-owned pond is located off the northeast corner of the SS } \\
\text { (Reference). }\end{array}$ \\
\hline
\end{tabular}


Table 3-8

Summary of Samples Collected

for the Aquatic Ecosystem Investigation, Salmon Site

\begin{tabular}{|c|c|c|c|c|c|c|}
\hline $\begin{array}{l}\text { Salmon Site } \\
\text { Surface Water } \\
\text { Station }\end{array}$ & $\begin{array}{c}\text { Water } \\
\text { Quality } \\
\text { Parameters }\end{array}$ & $\begin{array}{l}\text { Analytical } \\
\text { Samples }\end{array}$ & $\begin{array}{l}\text { Grain } \\
\text { Size and } \\
\text { Sediment } \\
\text { Analysis }\end{array}$ & $\begin{array}{l}\text { Benthic } \\
\text { Ecology } \\
\text { Analysis }\end{array}$ & $\begin{array}{c}\text { Fish } \\
\text { Tissue } \\
\text { Analysis }\end{array}$ & $\begin{array}{c}\text { Toxicity } \\
\text { Tests }\end{array}$ \\
\hline HMC-1 & $x^{a}$ & $x$ & $x$ & $x$ & $x^{b}$ & $x$ \\
\hline HMC-2 & $x$ & $x$ & $x$ & $x$ & $x^{b}$ & $x$ \\
\hline HMC-3 & $x$ & $x$ & $x$ & $x$ & $x^{b}$ & $x$ \\
\hline HMC-4 & $x$ & $x$ & $x$ & $x$ & $x^{b}$ & $x$ \\
\hline HMC-5 & $x$ & $x$ & $x$ & $x$ & $x^{b}$ & $x$ \\
\hline $\mathrm{HHC}-1$ & $x$ & $x$ & $x$ & $x$ & $N A^{c}$ & $x$ \\
\hline HHC-2 & $x$ & $x$ & $x$ & $x$ & NA & $x$ \\
\hline GrC-1 & $x$ & $x$ & $x$ & $x$ & $x^{b}$ & $x$ \\
\hline GrC-2 & $x$ & $x$ & $x$ & $x$ & $x^{b}$ & $x$ \\
\hline BeP-1 & $x$ & $x$ & $x$ & $x$ & $x$ & $x$ \\
\hline$B e P-1 A$ & $x$ & $x$ & $x$ & $x$ & $x$ & $x$ \\
\hline BeP-2 & $x$ & $x$ & $x$ & $x$ & $x$ & $x$ \\
\hline GtP-1 & $x$ & $x$ & $x$ & $x$ & NA & $x$ \\
\hline HOP-1 & $x$ & $x$ & $x$ & $x$ & NA & $x$ \\
\hline Ref. Pond & $x$ & $x$ & $x$ & $x$ & $x$ & $x$ \\
\hline
\end{tabular}

\footnotetext{
Sample collected

${ }^{b}$ Fish tissue sample represents a composite sample of the organisms collected for that creek or pond system.

'No sample was obtained from the collection effort.
} 


\subsubsection{Surficial Soil}

Surficial soil samples were collected during the period of April 26 to 30, 1993, and analyzed for chemical and radiological constituents. All 18 sites (excluding ponds, mud pits, and waste burial pits) located on site were sampled individually and not composited as originally planned. The reference site was also sampled. The 19 soil sample stations are listed in Table 3-9.

Five soil samples were collected at each site: one at the approximate center of site activity and one each $30 \mathrm{~m}$ ( $100 \mathrm{ft}$ ) from the center to the north, south, east, and west. The sample designator $\mathrm{A}$ was given to the north sample, $\mathrm{B}$ to the west sample, $\mathrm{C}$ to the center sample, $D$ to the east sample, and $E$ to the south sample.

Soil samples were collected from the top 10 centimeters (cm) (4 inch [in.]) of soil, excluding vegetation and leaf litter. At each location. the leaf litter was removed by gently pushing it aside. After an area of approximately 10-cm diameter had been cleared, a stainless-steel shovel was used to excavate a 10-cm-deep hole. This hole was then tested with an organic vapor analyzer before sampling. After being deemed safe from organic vapors in the breathing zone, sections of the undisturbed wall were removed and placed in the sample containers. Samples were then shipped on ice to the International Technology Analytical Services (ITAS) Laboratory for analysis. Table 3-10 summarizes the data collected for the terrestrial investigation.

\subsubsection{Data Evaluation}

\subsubsection{Analytical Methods}

The data sets used in the quantitative evaluations have been developed according to a standard set of sensitive, chemical-specific methods. The standard methods apply both to the collection of samples and the analyses thereof. Due to the lack of information on the methods used to collect and analyze the earlier samples, only the most recent data were used in the quantitative evaluations. The data from earlier studies were only used to guide the development of the EEW.

Analytical results that are not specific for a particular compound or that are the result of insensitive analytical methods are useful for qualitative assessments but are generally not appropriate for quantitative evaluations. Likewise, results of analytical methods associated 
Table 3-9

Sample Locations for the

Terrestrial Ecosystem Investigation,

Salmon Site

\begin{tabular}{|c|c|}
\hline \multicolumn{2}{|r|}{ Source Area (SA)-1 - Surface Ground Zero } \\
\hline $\begin{array}{l}\text { SA-1-1 } \\
\text { SA-1-2 } \\
\text { SA-1-3 } \\
\text { SA-1-4 }\end{array}$ & $\begin{array}{l}\text { Station } 1 \text { A Surface Ground Zero } \\
\text { Bleed Down Plant Area } \\
\text { East Substation } \\
\text { E-6 Decon Area }\end{array}$ \\
\hline \multicolumn{2}{|r|}{ SA-2 - Northern Disposal Area } \\
\hline $\begin{array}{l}\text { SA-2-5 } \\
\text { SA-2-6 }\end{array}$ & $\begin{array}{l}\text { Clean Burn Pit } \\
\text { Gas Pump }\end{array}$ \\
\hline \multicolumn{2}{|r|}{ SA-3 - Southern Disposal Area } \\
\hline $\begin{array}{l}\text { SA-3-7 } \\
\text { SA-3-8 } \\
\text { SA-3-9 } \\
\text { SA-3-10 }\end{array}$ & $\begin{array}{l}\text { Big Chief Drilling Storage } \\
\text { Site E-2 and E-7 } \\
\text { Government Storage Area } 2 \text { (Drilling Storage Yard) } \\
\text { Government Storage Area } 3\end{array}$ \\
\hline \multicolumn{2}{|r|}{ SA-4 - Western Disposal Area } \\
\hline $\begin{array}{l}\text { SA-4-11 } \\
\text { SA-4-12 } \\
\text { SA-4-13 } \\
\text { SA-4-14 } \\
\text { SA-4-15 }\end{array}$ & $\begin{array}{l}\text { CH Fuel Storage } \\
\text { Cable Storage } \\
\text { North Substation } \\
\text { South Substation } \\
\text { West Substation }\end{array}$ \\
\hline \multicolumn{2}{|r|}{ SA-5 - Injection Well Area } \\
\hline $\begin{array}{l}S A-5-16 \\
S A-5-17\end{array}$ & $\begin{array}{l}\text { HT-2 Well Area } \\
\text { HT-2M Well Area }\end{array}$ \\
\hline \multicolumn{2}{|r|}{ SA-6 - Helicopter Pad and Storage Area } \\
\hline SA-6-18 & Helicopter Pad and Storage Area \\
\hline \multicolumn{2}{|r|}{ Reference Area } \\
\hline Ref-19 & Reference Station \\
\hline
\end{tabular}


Table 3-10

Summary of Sampies Collected

for the Terrestrial Ecosystem Investigation,

Salmon Site

\begin{tabular}{|c|c|c|c|c|c|}
\hline $\begin{array}{l}\text { Salmon } \\
\text { Site }\end{array}$ & $\begin{array}{c}\text { Soil } \\
\text { Analyses }\end{array}$ & $\begin{array}{l}\text { Field Biota } \\
\text { Observations }\end{array}$ & $\begin{array}{c}\text { Vegetation } \\
\text { Tissue } \\
\text { Analyses }\end{array}$ & $\begin{array}{c}\text { Mammalian } \\
\text { Tissue } \\
\text { Analyses }\end{array}$ & $\begin{array}{c}\text { Toxicity } \\
\text { Tests }\end{array}$ \\
\hline $\begin{array}{l}\text { Source Area } \\
\text { (SA) } 1-1\end{array}$ & $x^{a}$ & $x$ & $x$ & $x^{b}$ & $x^{a}$ \\
\hline$S A-1-2$ & $x^{a}$ & $x$ & $x$ & $x^{b}$ & $x^{a}$ \\
\hline$S A-1-3$ & $x^{a}$ & $x$ & $x$ & $x^{b}$ & $x^{a}$ \\
\hline$S A-1-4$ & $x^{a}$ & $x$ & $x$ & $x^{b}$ & $x^{a}$ \\
\hline SA-2-5 & $x^{a}$ & $x$ & $x$ & $x^{b}$ & $x^{a}$ \\
\hline SA-2-6 & $x^{a}$ & $x$ & $x$ & $x^{b}$ & $x^{a}$ \\
\hline SA-3-7 & $x^{a}$ & $x$ & $x$ & $x^{b}$ & $x^{a}$ \\
\hline SA-3-8 & $x^{a}$ & $x$ & $x$ & $x^{b}$ & $x^{a}$ \\
\hline SA-3-9 & $x^{a}$ & $x$ & $x$ & $x^{b}$ & $x^{a}$ \\
\hline SA-3-10 & $x^{a}$ & $x$ & $x$ & $x^{b}$ & $x^{a}$ \\
\hline$S A-4-11$ & $x^{a}$ & $x$ & $x$ & $x^{b}$ & $x^{a}$ \\
\hline SA-4-12 & $x^{a}$ & $x$ & $x$ & $x^{b}$ & $x^{a}$ \\
\hline$S A-4-13$ & $x^{a}$ & $x$ & $x$ & $x^{b}$ & $x^{a}$ \\
\hline$S A-4-14$ & $x^{a}$ & $X$ & $x$ & $x^{b}$ & $x^{a}$ \\
\hline$S A-4-15$ & $x^{a}$ & $x$ & $x$ & $x^{b}$ & $x^{a}$ \\
\hline$S A-5-16$ & $x^{a}$ & $x$ & $x$ & $x^{b}$ & $x^{a}$ \\
\hline$S A-5-17$ & $x^{a}$ & $x$ & $x$ & $x^{b}$ & $x^{a}$ \\
\hline SA-6-18 & $x^{a}$ & $x$ & $x$ & $x^{b}$ & $x^{a}$ \\
\hline Ref-19 & $x^{2}$ & $x$ & $x$ & $x^{b}$ & $x^{a}$ \\
\hline
\end{tabular}

${ }^{a}$ Analyses or tests conducted on five replicates from the site.

Collected as site-wide samples. 
with unknown, few, or no Quality Assurance/Quality Control procedures were eliminated from quantitative consideration.

\subsubsection{Detection Limits}

All analyzed chemicals were evaluated with respect to their quantitation or detection limits. This evaluation was either conducted by the laboratory or later during data validation.

Constituents that were analyzed for, but not detected, were eliminated from the COPC list; however, before eliminating the constituents from further evaluation, several points were considered. Sample quantitation limits of known site-related constituents may be greater than corresponding standards, criteria, or other levels of concern. Therefore, these constituents may be present at concentrations greater than the corresponding reference concentrations. A samplespecific detection limit may be significantly higher than positively detected values in other samples in a data set. In other words, only a limited number of samples may test positive for a particular constituent.

When determining exposure concentrations at the SS, positively detected results were considered together with nondetected results. If there was reason to believe that the constituent was present in a sample at a concentration below the detection limit, then half the detection limit was used as the estimated concentration for that sample (EPA, 1989a). This method assumes that constituent concentrations are uniformally distributed in the range of concentrations below the detection limit. Therefore, half the detection limit is the arithmetic average of all such concentrations and is also the maximum likelihood estimator.

If the site-specific information indicated that a constituent was not likely to be present in a sample, a value of zero may have been used as the estimated concentration. In cases when the constituents were anthropogenic in nature and site-specific information indicated localized usage and limited transport from areas of use, the use of zero as the estimated concentration would be considered acceptable in areas of no known usage of these constituents.

Those constituents that were not detected in any samples of a particular medium were eliminated from further consideration in the quantitative evaluations. The outcome of these steps was a data set that contained only constituents which were detected in at least one sample from each medium. 


\subsubsection{Qualified Data}

Qualifiers may be attached to the analytical results by the laboratory conducting the analyses or by persons performing the data validation. These qualifiers generally indicate questions concerning constituent identity, concentration, or both.

Because the data validation process assesses the effect of quality control issues on data usability, validation data qualifiers supersede the laboratory qualifiers. When an analytical result has laboratory and validation qualifiers that appear contradictory, only the validation qualifier is considered. Laboratory qualifiers are valid unless they have been superseded during data validation.

The qualifiers used in the SS data sets are presented in the following paragraphs. Organic, inorganic, and radiochemical qualifiers are presented separately since some of the qualifiers have different meanings for different data sets.

The organic qualifiers are as follows:

- B - indicates that the constituent was found in an associated blank, as well as in the sample. Use of these data is discussed in the next subsection.

- E - indicates that the concentration exceeded the calibration range of the Gas Chromatograph/Multispectral Scanner. The use of this qualifier implies uncertainty in concentration but not in identity. These concentrations were treated as positive detections.

- $\mathrm{J}$ - indicates that the reported results were quantitatively estimated. These concentrations were treated as positive detections.

- NJ - indicates that there was presumptive evidence that a Tentatively Identified Compound (TIC) was present at an estimated concentration. The use of this data is discussed in a subsequent subsection.

- NP - indicates that data validation was not performed. Laboratory qualifiers were valid for these data.

- $\mathrm{R}$ - indicates that the data were rejected. These data were unusable and could not be used in the quantitative evaluations.

- U - indicates that the constituent was analyzed for but not detected. The use of these data was discussed in the previous subsection.

- UJ - indicates that the reported quantitation limit was quantitatively estimated. These data were treated as not detected and were used as indicated in the previous subsection. 
- $5 \mathrm{U}$ or $10 \mathrm{U}$ - indicates that the 5-times and 10-times rule (EPA, 1989a) was applied due to blank contamination. Use of these data is discussed in the following subsection.

The inorganic qualifiers are as follows:

- B - indicates that the reported value was below the Contract Required Detection Limit (CRDL), but above the Instrument Detection Limit. The use of this qualifier indicated uncertainty in concentration but not in identity. These data were treated as positive detections.

- E - indicates that the Inductively Coupled Plasma dilution (\%D) was out of control limits. This qualifier indicated uncertainty in the reported concentration. These data were treated as positive detections.

- $\mathrm{J}$ - indicates that the reported result was qualitatively estimated. These data were treated as positive detections.

- $\mathrm{N}$ - indicates that the spiked sample recovery was not within control limits. This qualifier indicated uncertainty in the reported concentration. These data were treated as positive detections.

- $\mathrm{NJ}$ - indicates that there was presumptive evidence that a TIC was present at an estimated concentration.

- NP - indicates that data validation was not performed. Laboratory qualifiers were valid for these data.

- $\mathrm{R}$ - indicates that the data were rejected. These data were unusable and could not be used in the quantitative evaluations.

- $S$ - indicates that the reported value was determined by the Method of Standard Addition. No uncertainty in either concentration or identity was implied by the use of this qualifier. Data were treated as positively detected.

- $\mathrm{U}$ - indicates that the constituent was analyzed for but not detected.

- UJ - indicates that the reported quantitation limit was quantitatively estimated. These data were treated as not detected and were used as indicated in the previous subsection.

- $5 \mathrm{U}$ or $10 \mathrm{U}$ - indicates that the 5-times and 10-times rule was applied due to blank contamination. Use of these data is discussed in the following subsection.

- W - indicates that the postdigestion spike for furnace atomic absorption analysis was out of control limits. This qualifier indicated uncertainty in the reported concentration. These data were treated as positive detections. 
The radiochemical constituent qualifiers are as follows:

- $\mathrm{J}$ - indicates that the reported result was qualitatively estimated. These data were treated as positive detects.

- ND - indicates that the constituent was not detected since the result was below the Minimum Detectable Activity (MDA). Such data were treated as not detected. Appropriate estimated concentrations were used as discussed in the previous subsection.

- NP - indicates that data validation was not performed. Laboratory qualifiers were valid for these data.

- $\mathrm{U}$ - indicates that the compound was not detected at the specified detection limit. Appropriate estimated concentrations were used as discussed in the previous subsection.

- UJ - indicates that the reported quantitation limit was quantitatively estimated. These data were treated as not detected and were used as indicated in the previous subsection.

\subsubsection{Blanks}

Blank samples provide a means to check for contamination that may have been introduced into a sample in the field while the samples were being collected and transported or while in the laboratory during sample preparation or analysis. The concentrations of constituents detected in blanks must be compared with the concentrations of the same constituents detected in site samples in order to prevent the inclusion of nonsite-related constituents into the quantitative evaluation of COPC.

As part of the data validation process, an analyte was not considered further if the maximum sample concentration did not exceed 10 times the highest blank for all common laboratory contaminants (acetone, 2-butanone, methylene chloride, toluene, and phthalates) or 5 times the highest blank for other chemicals (EPA, 1989a).

\subsubsection{Frequency of Detection}

Constituents that are infrequently detected may be artifacts in the data due to sampling or analytical procedures or from other means of contamination. Chemicals that were detected in 5 percent or less of the on-site samples for a particular medium were eliminated as COPC. Less than 20 surface water or sediment samples were taken and analyzed. In these cases, a constituent was considered a COPC unless the detected concentration, when averaged with half the detection limit for nondetected samples, produced a 95-percent upper confidence limit (UCL) that was within the reference range or less than the actual detection limit for the reference samples or that could be eliminated on another basis as discussed below. 


\subsubsection{Essential Nutrients}

Calcium, sodium, potassium, iron, and magnesium aré generally eliminated as constituents of potential ecological concern because they are essential elements for animal and plant life and are only toxic at very high concentrations, as supported by EPA (1989a). However, these may be products of site activities, specifically abandoned mud pits from rotary drilling. Further examination of these elements indicates that calcium was the only analyte among the five mentioned above for which the 95-percent upper confidence limit of the mean for site samples in surficial soils exceeded concentrations in soil samples collected from reference locations.

Limited data exist on the toxicity of calcium. As indicated by the National Research Council (1980), toxicity of calcium is dependent on the level of dietary potassium, and on the age and reproductive status of the animal. Maximum tolerance levels (MTL) for calcium are 2 percent of the diet for cattle, sheep, horse, and rabbits; 4 percent for swine; and 1 percent of the diet for poultry (National Research Council. 1980). If a value of 2 percent is used for the white-tailed deer (body weight of 90.72 kilogram [kg]) (Harestad and Bunnel, 1979); estimated ingestion rate of 2,319 grams per day (g/day) (EPA, 1993) and 1 percent for the red-tailed hawk (body weight of $1.126 \mathrm{~kg}$ [Dunning, 1994]; ingestion rate of $58.9 \mathrm{~g} /$ day [EPA, 1993]), the MTLs for these receptorsare estimated to be 46.4 grams $(\mathrm{g})$ of calcium per day and $0.707 \mathrm{~g}$ of calcium per day for the deer and hawk, respectively. Further, assuming that the entire diet of the deer consists of plant matter and using a soil-to-plant transfer factor of 3.5 (Baes et al., 1984), the deer would be exposed to $6.54 \mathrm{~g}$ of calcium per day. Calcium is, therefore, not expected to be toxic to this herbivorous mammal. If it assumed that the hawk consumes only herbivorous mice from the site (Peromyscus maniculatus, body weight of $21 \mathrm{~g}$ [Millar, 1989 as cited in EPA, 1993]; ingestion rate of $3.46 \mathrm{~g} /$ day [EPA, 1993]; absorption coefficient of 0.80 assumed [Ganong, 1979]), the hawk would be exposed to $0.022 \mathrm{~g}$ of calcium per day. As with the deer, calcium at the site is not expected to be toxic to the top avian receptor. This provides quantitative support to the original contention that essential nutrients be eliminated as COPC because they are generally toxic only at very high concentrations.

With reference to sediments, calcium, magnesium and sodium, 95-percent UCL of the mean of site samples exceeded reference ranges. For surface water, site iron, calcium, magnesium and sodium exceeded the reference ranges. Potassium was not detected at the CRDL in water or sediment. No federally mandated Ambient Water Quality Criteria (AWQC) or sediment quality criteria exist for calcium, sodium or magnesium. In general, these elements are not considered toxic to aquatic life, a contention supported by the fact that no toxicity benchmarks have been established or mandated by EPA. One location had particularly high levels of calcium, sodium 
and magnesium in surface water (Half Moon Creek overflow pond), and another (Beaver Pond) also had some high values in surface water and sediments. These two areas are likely to have received materials from nearby rotary drilling mud pits. Since evaluation of toxicity of calcium, sodium and magnesium in aquatic environments has not been promulgated by EPA, it will be assumed that in general, the aquatic environments at the SS do not have sufficiently high concentrations to cause toxicity, and will not be carried through as COPC. The Beaver Pond and Half Moon Creek overflow pond, however, should be held under consideration as "hot spots" for these constituents.

An AWQC of 1,000 ug/l does, however, exist for the chronic exposure of freshwater biota to iron. The 95-percent UCL of the mean for site surface water samples exceeded the reference range and the AWQC, and iron was therefore carried through the assessment as a COPC in surface water.

\subsubsection{Water Chemistry}

General water chemistry parameters, such as sulfates, carbonate, bicarbonate, chloride, dissolved solids, and fluoride, are also generally toxic only at very high levels. Measurements of these are useful in determining the nature of a water body being studied, but are not considered COPCs for the SS.

\subsubsection{Physiochemical Properties and Bioaccumulation Potential}

The $\mathrm{K}_{\text {ow }}$ provides a useful screening tool for organic compounds on the basis of the bioaccumulation potential. In general, a higher $\mathrm{K}_{\mathrm{ow}}$ relates to a higher bioaccumulation potential (i.e., a tendency to occur in biota at higher concentrations than the surrounding environment). Garten and Trabalka (1983) state that compounds with $\log \mathrm{K}_{\mathrm{ow}}$ values of less than 3.5 generally do not bioaccumulate in the fat tissues of mammals and birds by a factor of greater than 0.3. In addition, according to Thomann (1989), bioaccumulation in aquatic food chains is not significant for compounds with $\log \mathrm{K}_{\text {ow }}$ values of up to 5. Finally, EPA (1993) has correlated food chain multipliers with $\log \mathrm{K}_{\mathrm{ow}}$ values and trophic level in an aquatic system. Compounds with $\log K_{o w}$ values of less than or equal to 3.9 are given food chain multipliers of 1 or less for each of the three trophic levels, which include zooplankton in level 2, small fish in level 3, and piscivorous fish in level 4 . It is also recommended that trophic levels 3 and 4 be used for wildlife, depending on the specific bird or mammal in question. For these reasons, the conservative $\log \mathrm{K}_{\mathrm{ow}}$ value of 3.5 was used to blanket all potential bioaccumulation pathways. Constituents with a log $\mathrm{K}_{\mathrm{ow}}$ less than 3.5 were not therefore, considered as COPC via bioaccumulation pathways. 


\subsubsection{Reference Data}

Reference data were gathered during the BERA investigation using methods and procedures identical to those used for gathering site samples. Reference data were collected from areas not influenced by the site. They are collected from each medium of concern (soil, sediment, and surface water) from areas that could not have received contamination from the site, but that do have the same basic characteristics as the medium of concern on site.

Reference soil samples were collected from an area off site and upgradient of the site. Reference surface water and sediment samples were collected from each of the three on-site creeks (Hickory Hollow Creek, Half-Moon Creek, and Grantham Creek) at points where the creeks enter the site and from a reference pond located off site and upgradient of the site.

Site data were evaluated with respect to reference data by comparing the calculated exposure point concentration (EPC) for each constituent to the range of reference and background concentrations for that constituent. The EPC is a conservative estimate of the most probable concentration in a particular media to which biota may be exposed. It is calculated as the 95-percent UCL on the arithmetic mean of the positive detections and half the detection limit for samples in which the analyte was not detected, using the following equation:

$\mathrm{EPC}=95$-percent $\mathrm{UCL}$ of the mean $=$

$$
\text { mean }+\left[t_{0.05(2)(n-1)}(s / \sqrt{(n)}]\right.
$$

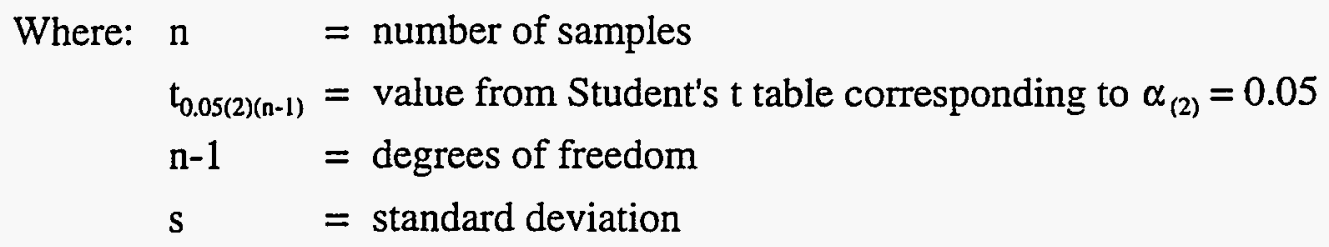

If the EPC is within the range of background or reference data, the constituent's presence is considered to be ambient and not site-related. The constituent is then removed from the quantitative evaluation.

A summary of the detected constituents in sediment, surface water, and surficial soil are presented in Tables 3-11 through 3-14, 3-15 through 3-16, and 3-17 through 3-20, respectively. The EPC and reference ranges are included for data evaluation comparisons. Those constituents present on site at levels greater than ambient are considered potentially site-related constituents. 


\subsubsection{Analytical Results}

Analyte concentrations were measured in sediment, surface water, surficial soil, vegetation, and wildlife tissues. All data are presented in Appendix A of this report and summarized below. The summary tables presented in this section use the data evaluation and data estimation procedures for nondetected concentrations discussed in the preceding sections.

\subsubsection{Sediment}

Sediment data are presented in Appendix A. Tables A-3.1 through A-3.9 present the inorganic, pesticide and polychlorinated biphenyls (PCB), volatile, semivolatile, gross alpha and beta, gamma spectroscopy, tritium, grain size, and wet chemistry data sets, respectively.

The majority of inorganic constituents detected in sediments are naturally occurring soil constituents and were found at reference concentrations. Cadmium was found at the Beaver Pond in concentrations above background. Concentrations in the Beaver Pond sediments ranged from 1.7 to 9.0 milligrams per kilogram ( $\mathrm{mg} / \mathrm{kg}$ ) cadmium. Cadmium was not detected in the Reference Pond sediments. The Beaver Pond sediments had the highest levels of many of the inorganic constituents: aluminum (13,000 mg/kg), arsenic $(7.7 \mathrm{mg} / \mathrm{kg})$, barium $(181 \mathrm{mg} / \mathrm{kg})$, calcium $(5,630 \mathrm{mg} / \mathrm{kg})$, lead $(20.2 \mathrm{mg} / \mathrm{kg})$, magnesium (1,380 mg/kg), manganese $(583 \mathrm{mg} / \mathrm{kg})$, sodium $(1,230 \mathrm{mg} / \mathrm{kg})$ and zinc $(111 \mathrm{mg} / \mathrm{kg})$. Chromium was highest in the Half Moon Creek Overflow Pond sediment $(14.8 \mathrm{mg} / \mathrm{kg})$. Concentrations of inorganics in sediments on the SS are summarized in Table 3-10.

No pesticides or PCBs were detected in sediments on the SS. However, 3 organic compounds were detected in the Beaver Pond sediment samples: 2-butanone (170 micrograms per kilogram $[\mu \mathrm{g} / \mathrm{kg}])$, toluene $(220 \mu \mathrm{g} / \mathrm{kg})$ and benzoic acid $(550 \mu \mathrm{g} / \mathrm{kg}$, estimated concentration below the detection limit). Sediment volatile and semivolatile organic compound concentrations are summarized in Table 3-11.

Gross alpha levels above the MDA were found in sediments of the Beaver Pond (17.21 picocuries per gram [pCi/g]) and Gator Pond (22.48 pCi/g). Gross beta levels above the MDA were detected at all sediment stations ( $8.84 \mathrm{pCi} / \mathrm{g}$ to $23.69 \mathrm{pCi} / \mathrm{g})$; the highest levels were found in the Gator Pond (23.69 pCi/g) and Beaver Pond (18.6 pCi/g) sediments. 
Table 3-11

Summary of Inorganic Concentrations in Sediment, Salmon Site

\begin{tabular}{|c|c|c|c|c|c|c|c|c|}
\hline Analyte & $\begin{array}{c}\text { Frequency of } \\
\text { Detection }\end{array}$ & $\begin{array}{c}\text { Minimum } \\
\text { Detection } \\
\text { Limit }^{\mathbf{a}}(\mathrm{mg} / \mathrm{kg})^{\mathrm{b}}\end{array}$ & $\begin{array}{l}\text { Range of Detected } \\
\text { Concentrations } \\
(\mathrm{mg} / \mathrm{kg})\end{array}$ & $\begin{array}{c}\text { Reference Range } \\
\text { (mg/kg) }\end{array}$ & $\begin{array}{l}\text { Average } \\
\text { Concentration } \\
\text { (mg/kg) }\end{array}$ & $\begin{array}{l}\text { Standard } \\
\text { Deviation }\end{array}$ & $\begin{array}{l}95 \% \text { Upper Confidence } \\
\text { Limit of the Mean } \\
(\mathrm{mg} / \mathrm{kg})\end{array}$ & $\begin{array}{l}\text { Constituent of } \\
\text { Potential } \\
\text { Concern }\end{array}$ \\
\hline Aluminum & $12 / 12$ & -- & $84.40-13,000$ & $195-6480$ & 3,218 & 3,973 & 5,742 & $\mathrm{No}^{\mathrm{e}}$ \\
\hline Arsenic & $7 / 12$ & 0.30 & $0.30 \cdot 7.70$ & $0.0007(N D)^{f}-2.10$ & 1.54 & 2.27 & 2.98 & Yes \\
\hline Barium & $12 / 12$ & -- & $2.40-181$ & $1.4(N D)-19.90$ & 42.71 & 54.82 & 77.54 & Yes \\
\hline Cadmium & $2 / 12$ & 0.25 & $1.70 \cdot 9.00$ & $0.37(N D)-0.48(N D)$ & 1.43 & 2.44 & 2.98 & Yes \\
\hline Calcium & $12 / 12$ & - & $179-5,630$ & $190-451$ & 1,195 & 1,682 & 2,264 & $\mathrm{No}^{\mathrm{g}}$ \\
\hline Chromium & $9 / 12$ & 0.90 & $1.20-14.80$ & $0.45(N D)-9.30$ & 4.88 & 5.13 & 814 & $\mathrm{No}^{\mathrm{e}}$ \\
\hline Iron & $12 / 12$ & -- & $125-13,000$ & $102-19,300$ & 3,564 & 4,692 & 6,545 & No ${ }^{d, g}$ \\
\hline Lead & $12 / 12$ & - & $0.61 \cdot 20.20$ & $0.0034-5.00$ & 6.23 & 6.38 & 10.23 & Yes \\
\hline Magnesium & $12 / 12$ & -- & $39.80-1,380$ & $47.20-152$ & 273 & 378 & 514 & $\mathrm{No}^{\mathrm{g}}$ \\
\hline Manganese & $12 / 12$ & -- & $6.30-583$ & $0.80(N D)-85.10$ & 109 & 161 & 211 & Yes \\
\hline Sodium & $11 / 12$ & 60.7 & $59.80-1,230$ & $55.40-80.80$ & 238 & 8347 & 459 & $\mathrm{No}^{\mathrm{g}}$ \\
\hline Vanadium & $8 / 12$ & 0.40 & $1.40-27.70$ & $0.48(N D)-43.00$ & 5.98 & 8.17 & 11.17 & $\mathrm{No}^{\circ}$ \\
\hline Zinc & $4 / 12$ & 2.20 & $1.60-111$ & $1.1(N D)-2.60$ & 15.93 & 31.21 & 35.76 & Yes \\
\hline
\end{tabular}

${ }_{b}^{a}$ Minimum detection limit was selected from those samples in which the analyte was not delected.

Milligram per kilogram

Reference range consists of samples GrC-1, HHC-1, HMC-1, and Rep-1.

Half the detection limit was used for those samples in which the analyte was not detected at the detection limit.

Within reference range

Not detected; value represents half the detectlon limit.

Essential nutrient 
Table 3-12

Summary of Semivolatile and Volatile Organic

Concentrations in Sediment,

Salmon Site

\begin{tabular}{|c|c|c|c|c|c|c|c|c|}
\hline Analyte & $\begin{array}{l}\text { Frequency of } \\
\text { Detection }\end{array}$ & $\begin{array}{l}\text { Minimum } \\
\text { Detection Limita } \\
(\mathrm{mg} / \mathrm{kg})^{\mathrm{b}}\end{array}$ & $\begin{array}{l}\text { Range of Detected } \\
\text { Concentrations } \\
(\mathrm{mg} / \mathrm{kg})\end{array}$ & $\begin{array}{l}\text { Reference Range }{ }^{c, d} \\
(\mathrm{mg} / \mathrm{kg})\end{array}$ & $\begin{array}{l}\text { Average } \\
\text { Concentration } \\
\text { (mg/kg) }\end{array}$ & $\begin{array}{l}\text { Standard } \\
\text { Deviation }\end{array}$ & $\begin{array}{l}95 \% \text { Upper Confidence } \\
\text { Limit of the Mean } \\
\text { ( } \mathrm{mg} / \mathrm{kg})\end{array}$ & $\begin{array}{l}\text { Constituent of } \\
\text { Potential } \\
\text { Concern }\end{array}$ \\
\hline Toluene & $2 / 15$ & 6.00 & $11.00-220$ & $3.50(N D)^{e}-4.50(N D)$ & 20.03 & 55.44 & 50.73 & No d, \\
\hline 2-Butanone & $2 / 15$ & 13.00 & $5.00-170$ & $6.5(N D)-9.00(N D)$ & 20.87 & & & $\mathrm{No}^{\mathrm{e}}$ \\
\hline Benzoic Acid & $1 / 12$ & 2,100 & 550 & $1,000(N D)-1,150(N D)$ & 2,300 & 2,684 & 2,858 & $\mathrm{No}^{\mathrm{d}}$ \\
\hline
\end{tabular}

${ }_{b}^{a}$ Minimum detection limit was selected from those samples in which the analyte was not detected.

Milligram per kilogram

Reference concentration range consists of samples GrC-1, HMC-1, HHC-1, and ReP-1.

Half the detection limit was used for those samples in which the analyte was not detected at the detection limit.

Half the detection limit was used for those samples in whi
eNot detected; value represents half the delection limit.

Log octanol/water partition coefificient $\left(K_{\text {ow }}\right)$ less than 3.5 , unilikely io bioaccumuiale (Garien and Trabalika, 1963).

${ }^{9}$ Common laboratory contaminant 
Table 3-13

Summary of Radionuclide Activity in Sediment, Salmon Site

\begin{tabular}{|c|c|c|c|c|c|c|c|c|}
\hline Radionuclide & $\begin{array}{c}\text { Frequency of } \\
\text { Detection }\end{array}$ & $\begin{array}{c}\text { Minimum } \\
\text { Detection Limit }^{\mathrm{a}}\end{array}$ & $\begin{array}{l}\text { Range of Detected } \\
\text { Concentrations } \\
(\mathrm{pCl} / \mathrm{g})^{\mathbf{b}}\end{array}$ & $\begin{array}{l}\text { Reference Range }{ }^{c, d} \\
(\mathrm{pCi} / \mathrm{g})\end{array}$ & $\begin{array}{c}\text { Average } \\
\text { Concentration }^{d} \\
(\mathrm{pCi} / \mathrm{g})\end{array}$ & $\begin{array}{l}\text { Standard } \\
\text { Deviation }\end{array}$ & $\begin{array}{l}95 \% \text { Upper Confidence } \\
\text { Limit of the Mean } \\
\text { (pCi/g) }\end{array}$ & $\begin{array}{c}\text { Exceeds } \\
\text { Reference } \\
\text { Range? }\end{array}$ \\
\hline Gross Alpha & $2 / 12$ & 7.47 & $17.21-22.4$ & $5.58(N D)^{e}-7.53(N D)$ & 9.14 & 5.26 & 12.48 & Yes \\
\hline Gross Beta & $12 / 12$ & -- & $8.84-23.69$ & $4.3-12.61$ & 12.69 & 5.26 & 16.03 & Yes \\
\hline Beryllium-7 & $1 / 1$ & - & 2.40 & $N A^{f}$ & NA & NA & NA & $\mathrm{No}^{\mathrm{g}}$ \\
\hline Bismuth-212 & $1 / 1$ & - & 0.09 & 0.11 & NA & NA & NA & $\mathrm{No}^{\mathrm{g}}$ \\
\hline Bismulh-214 & $1 / 1$ & $\because$ & 0.43 & NA & NA & NA & NA & No \\
\hline Cadmium-109 & $1 / 2$ & 1.10 & 0.70 & $1.00(N D)-0.74$ & 0.61 & 0.08 & 1.33 & $\mathrm{No}^{\mathrm{g}}$ \\
\hline Cerium-144 & $1 / 1$ & - & 0.30 & $0.4(\mathrm{ND})$ & NA & NA & NA & $\mathrm{No}^{\mathrm{g}}$ \\
\hline Cesium-137 & $6 / 12$ & 0.01 & $0.07-1.09$ & $0.01(N D)-0.11(N D)$ & 0.19 & 0.33 & 0.40 & Yes \\
\hline Lead-210 & $6 / 7$ & 1.41 & $0.20-9.60$ & $0.20-0.99$ & 2.10 & 3.35 & 5.19 & $\begin{array}{ll}\cdots & \\
& \text { Yes } \\
\end{array}$ \\
\hline Lead-212 & $4 / 10$ & 0.02 & $0.43-1.05$ & $0.01(N D)-1.42$ & 0.80 & 0.26 & 1.00 & $\mathrm{No}^{\mathrm{g}}$ \\
\hline Radium-224 & $3 / 11$ & 0.17 & $0.68-4.14$ & $0.065(N D)-1.26$ & 0.87 & 1.17 & 1.66 & Yes \\
\hline Radlum-226 & $1 / 13$ & 0.02 & 0.36 & $0.005(N D)-0.15(N D)$ & 0.03 & NA & NA & Yes \\
\hline Radium-228 & $2 / 11$ & 0.03 & 0.80 & $0.015(N D)-1.16$ & 0.81 & NA & NA & $\mathrm{No}^{\mathrm{g}}$ \\
\hline Thallium-208 & $6 / 6$ & $-\cdot$ & $0.04 \cdot 0.13$ & 0.008 (ND) -0.39 & 0.09 & 0.04 & 0.13 & $\mathrm{No}^{\mathrm{g}}$ \\
\hline Tritium & $1 / 12$ & 0.06 & 0.40 & $0.02(N D)-0.035(N D)$ & NA & NA & NA & Yes \\
\hline
\end{tabular}

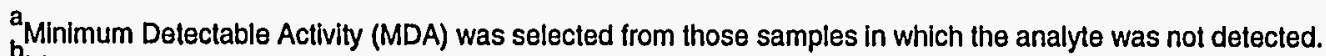

Picocurle per gram

dReference range consists of samples GrC-1, HMC-1, HHC-1, and ReP-1.

Half the MDA was used for those samples in which the analyte was not detected at the MDA.

Not detected; value represents half the MDA.

Not applicable

$\mathbf{g}_{\text {Maximum detected sample concentration was less than or equal to reference. }}$ 
Table 3-14

Grain-Size Analysis,

Salmon Site

\begin{tabular}{|c|c|c|c|c|}
\hline Sample & Percent Moisture & $\begin{array}{l}\text { Percent Sand } \\
\left(>0.0625 \mathrm{~mm}^{\mathrm{a}}\right)\end{array}$ & $\begin{array}{c}\text { Percent Silt } \\
(0.062 \mathrm{~mm} \text { to } 0.0039 \mathrm{~mm})\end{array}$ & $\begin{array}{l}\text { Percent Clay } \\
(<0.0039 \mathrm{~mm})\end{array}$ \\
\hline BEP-1 & 66.5 & 11.1 & 65.7 & 23.2 \\
\hline BEP-1A & 25.0 & 40.8 & 34.5 & 24.7 \\
\hline BEP-2 & 27.0 & 86.5 & 7.6 & 5.9 \\
\hline$A P-1$ & 79.1 & 42.6 & 33.9 & 23.5 \\
\hline GRC-1 & 20.6 & 100.0 & 0.0 & 0.0 \\
\hline GRC-2 & 23.4 & 100.0 & 0.0 & 0.0 \\
\hline $\mathrm{HHC}-1$ & 30.6 & 100.0 & 0.0 & 0.0 \\
\hline HHC-2 & 18.7 & 96.3 & 1.8 & 1.9 \\
\hline HMC-1 & 21.7 & 95.2 & 2.0 & 2.8 \\
\hline HMC-2 & 29.3 & 93.2 & 3.8 & 3.0 \\
\hline HMC-3 & 24.3 & 98.2 & 0.7 & 1.1 \\
\hline HMC-4 & 21.6 & 100.0 & 0.0 & 0.0 \\
\hline HMC-4D & 22.7 & 100.0 & 0.0 & 0.0 \\
\hline HMC-5 & 33.6 & 96.3 & 1.8 & 1.9 \\
\hline HOP-1 & 26.2 & 91.6 & 4.9 & 3.6 \\
\hline REP-1 & 28.2 & 70.9 & 7.0 & 22.2 \\
\hline
\end{tabular}

${ }^{\mathrm{a}}$ Millimeter 
Table 3-15

Summary of Inorganic Concentrations in Surface Water, Salmon Site

\begin{tabular}{|c|c|c|c|c|c|c|c|c|}
\hline Analyte & $\begin{array}{c}\text { Frequency of } \\
\text { Detection }\end{array}$ & $\begin{array}{c}\text { Minimum } \\
\text { Detection Limit }^{\mathrm{a}} \\
(\mu \mathrm{g} / \mathrm{l})^{\mathrm{b}}\end{array}$ & $\begin{array}{c}\text { Range of Detected } \\
\text { Concentrations } \\
(\mu \mathrm{g} / \mathrm{\ell})\end{array}$ & $\begin{array}{c}\text { Reference } \\
\text { Range }{ }^{c, d} \\
(\mu g / l) \\
\end{array}$ & $\begin{array}{c}\text { Average } \\
\text { Concentration } \\
(\mu g / l) \\
\end{array}$ & $\begin{array}{l}\text { Standard } \\
\text { Deviation }\end{array}$ & $\begin{array}{c}\text { 95\% Upper Confidence } \\
\text { Limit of the Meand } \\
(\mu g / l)\end{array}$ & $\begin{array}{c}\text { Constituent of } \\
\text { Potential } \\
\text { Concern } \\
\end{array}$ \\
\hline Aluminum & $12 / 12$ & $-\cdot$ & $87.80-416$ & $164-201$ & 201 & 108 & 269 & Yes \\
\hline Arsenic & $1 / 12$ & 1.00 & 2.20 & $0.50(N D)^{e}$ & 0.64 & 0.49 & 0.95 & Yes \\
\hline Barium & $12 / 12$ & - & $18.80-76.70$ & $19.90-90.40$ & 29.83 & 16.07 & 40.04 & No ${ }^{f}$ \\
\hline Cadmium & $2 / 12$ & 2.70 & $1.35-3.20$ & $1.35(\mathrm{ND})-3.80$ & 1.64 & 0.68 & 2.07 & $\mathrm{No}^{\prime}$ \\
\hline Calcium & $12 / 12$ & - & $569-24,600$ & $573-3,070$ & 3,454 & 6,767 & 7,754 & $\mathrm{No}^{\mathrm{g}}$ \\
\hline Cobalt & $1 / 12$ & 6.00 & 9.10 & $3.00(N D)-10.10$ & 3.76 & 1.89 & 4.96 & No' \\
\hline Iron & $12 / 12$ & - & $118-4,190$ & $111-677$ & 1,012 & 1,261 & 1,813 & $\mathrm{No}^{\mathrm{g}}$ \\
\hline Lead & $2 / 12$ & 1.00 & $1.10-1.20$ & $0.50(N D)-1.20$ & 0.61 & 0.25 & 0.77 & $\mathrm{No}^{\prime}$ \\
\hline Magneslum & $12 / 12$ & - & $405-2,220$ & $363-812$ & 729 & 496 & 1,044 & $\mathrm{No}^{\mathrm{g}}$ \\
\hline Manganese & $12 / 12$ & 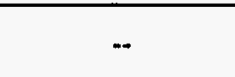 & $21.50-576$ & $34.40-213$ & 113 & 153 & 210 & No' \\
\hline Mercury & $1 / 12$ & 0.10 & 0.20 & $0.05(N D)-0.15$ & 0.06 & 0.03 & 0.08 & No' \\
\hline Silver & $2 / 12$ & 3.50 & $3.50-5.30$ & $1.75-14.60$ & 2.19 & 1.10 & 2.89 & $\mathrm{No}^{f}$ \\
\hline Sodlum & $12 / 12$ & - & $1,640-56,400$ & $1,220-2,160$ & 8,011 & 15,926 & 18,130 & $\mathrm{NO}^{\mathrm{g}}$ \\
\hline Zinc & $3 / 12$ & 3.00 & $3.30-7.20$ & $2.15(N D)-13.80$ & 3.78 & 1.98 & 5.04 & No ${ }^{\prime}$ \\
\hline
\end{tabular}

${ }_{b}^{a}$ Minimum detection limit was selected from those samples which the analyte was not detected.

Microgram per liter

Reference range consists of samples GrC-1, HHC-1, HMC-1, and ReP-1.

Half the detection limit was used for those samples in which the analyte was not detected at the detection limit.

Not detected; value represents half the detection limit.

Essential nutrient 
Table 3-16

Summary of Radionuclide Activity in Surface Water, Salmon Site

\begin{tabular}{|c|c|c|c|c|c|c|c|c|}
\hline Radionuclide & $\begin{array}{c}\text { Frequency of } \\
\text { Detection }\end{array}$ & $\begin{array}{c}\text { Minimum } \\
\text { Detectable Activity }^{\mathrm{a}} \\
{\text { (pcl/l) })^{\mathrm{b}}}\end{array}$ & $\begin{array}{l}\text { Range of Detected } \\
\text { Concentrations } \\
\text { (pCi/l) }\end{array}$ & $\begin{array}{l}\text { Reference Range } e^{c, d} \\
\text { (pCi/l) }\end{array}$ & $\begin{array}{l}\text { Average } \\
\text { Concentration }^{d} \\
\text { (pci/e) }\end{array}$ & $\begin{array}{l}\text { Standard } \\
\text { Deviation }\end{array}$ & $\begin{array}{l}\text { 95\% Upper Confidence } \\
\text { Limit of the Mean } \\
\text { (pCi/l) }\end{array}$ & $\begin{array}{c}\text { Exceeds } \\
\text { Reference } \\
\text { Range? }\end{array}$ \\
\hline $\operatorname{Tin}-113$ & $1 / 7$ & 7.10 & 8.70 & $3.90(N D)^{e}-5.50(N D)$ & 6.02 & 1.86 & 7.74 & $\mathrm{No}^{\prime}$ \\
\hline Tritium & $5 / 12$ & 0.19 & $0.20-0.70$ & $0.10-0.20$ & 0.22 & 0.19 & 0.34 & Yes \\
\hline
\end{tabular}

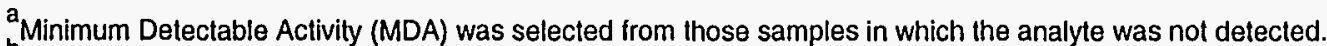

Picocurie per gram

Reference range consists of samples GrC-1, HHC-1, HMC-1, and ReP-1.

Half the MDA was used for those samples in which the analyte was not detected at the MDA.

Nol detected; values represent half the MDA.

The only detection was lower than the actual MDA for several of the reference samples. 
Table 3-17

Summary of Inorganic Concentrations in Surficial Soil, Salmon Site

(Page 1 of 2)

\begin{tabular}{|c|c|c|c|c|c|c|c|c|}
\hline Analyte & $\begin{array}{l}\text { Frequency of } \\
\text { Detection }\end{array}$ & $\begin{array}{c}\text { Minimum } \\
\text { Detection Limit } \\
\text { (mg/kg) }^{\mathbf{b}}\end{array}$ & $\begin{array}{l}\text { Range of } \\
\text { Detections } \\
(\mathrm{mg} / \mathrm{kg})\end{array}$ & $\begin{array}{l}\text { Reference Range } e^{c, d} \\
(\mathrm{mg} / \mathrm{kg})\end{array}$ & $\begin{array}{l}\text { Average } \\
\text { Concentration } \\
\text { (mg/kg) }\end{array}$ & $\begin{array}{l}\text { Standard } \\
\text { Deviation }\end{array}$ & $\begin{array}{c}95 \% \text { Upper Confidence } \\
\text { Limit of the Mean } \\
\text { (mg/kg) }\end{array}$ & $\begin{array}{c}\text { Constituent of } \\
\text { Potential Concern }\end{array}$ \\
\hline Aluminum & $108 / 108$ & -- & $719.00-18,800$ & $1,980-14,600$ & 4,694 & 2,883 & 5244.47 & $\mathrm{No}^{\mathrm{e}}$ \\
\hline Antimony & $1 / 90$ & 12.10 & 23.60 & $6.05(N D)^{f}-8.10(N D)$ & 6.88 & 2.23 & 7.34 & $\mathrm{No}^{\mathrm{c}, \mathrm{g}}$ \\
\hline Arsenic & $106 / 108$ & 0.54 & $0.49-11.90$ & $0.66-2.70$ & 1.88 & 1.44 & 2.15 & $\mathrm{No}^{\mathrm{e}}$ \\
\hline Beryllium & $18 / 108$ & 0.06 & $0.07-0.29$ & $0.03(N D) \cdot 0.33$ & 0.09 & 0.09 & 0.11 & $\mathrm{No}^{\mathrm{e}}$ \\
\hline Cadmium & $7 / 108$ & 0.64 & $0.72 \cdot 1.40$ & $0.32(N D)-0.45(N D)$ & 0.39 & 0.17 & 0.42 & $\mathrm{No}^{\mathrm{e}}$ \\
\hline Calcium & $108 / 108$ & -- & $144-9,480$ & $273-671$ & 805.47 & 1,201 & 1,035 & $\mathrm{No}^{n}$ \\
\hline Chromium & $108 / 108$ & -- & $1.50-44.00$ & $0.48(N D)-10.40$ & 7.74 & 5.90 & 8.89 & $\mathrm{No}^{\mathrm{e}}$ \\
\hline Cobalt & $60 / 108$ & 0.87 & $1.00-10.60$ & $0.45(\mathrm{ND})-5.60$ & 2.58 & 2.11 & 2.98 & $\mathrm{No}^{\mathrm{e}}$ \\
\hline Copper & $34 / 108$ & 0.55 & $1.20-9,950$ & $0.27(N D)-10.70$ & 97.20 & 957 & 280 & Yes \\
\hline Iron & $108 / 108$ & - & $1,170-19,700$ & $1,780-11,200$ & 6,390 & 3,721 & 7,100 & $\mathrm{No}^{\mathrm{e}, \mathrm{h}}$ \\
\hline Lead & $105 / 108$ & 5.20 & $1.40-120.00$ & $1.80-12.60$ & 14.09 & 16.92 & 17.32 & Yes \\
\hline Magnesium & $107 / 108$ & 161 & $49.80-1,500$ & $120-582$ & 241 & 230 & 285 & No ${ }^{e, h}$ \\
\hline Manganese & $108 / 108$ & 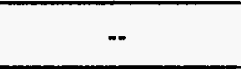 & $6.50-1,150$ & $60.50-385$ & 200 & 274 & 253 & $\mathrm{No}^{\mathrm{e}}$ \\
\hline Mercury & $18 / 108$ & 0.05 & $0.06-0.29$ & $0.03(N D)-0.04(N D)$ & 0.04 & 0.04 & 0.05 & $\mathrm{No}^{\mathrm{i}}$ \\
\hline Nickel & $10 / 108$ & 4.30 & $4.70 \cdot 19.10$ & $2.11(N D) \cdot 7.80$ & 2.90 & 2.23 & 3.33 & $\mathrm{No}^{\circ}$ \\
\hline Potassium & $7 / 108$ & 6.50 & $725-878$ & $308(N D)-656$ & 393 & 307 & 453 & $\mathrm{No}^{\mathrm{e}, \mathrm{h}}$ \\
\hline Selenlum & $6 / 104$ & 0.21 & $0.24-0.69$ & $0.11(N D)-0.21(N D)$ & 0.15 & 0.10 & 0.17 & $\mathrm{No}^{\mathrm{e}}$ \\
\hline Sodium & $16 / 108$ & 11.30 & $16.4 \cdot 154$ & 24.55 (ND) - 57.43 & 22.68 & 23.37 & 27.13 & $\mathrm{No}^{\mathrm{e}, \mathrm{h}}$ \\
\hline
\end{tabular}

Refer to footnotes at end of table. 
Table 3-17

Summary of Inorganic Concentrations in Surficial Soil, Salmon Site

(Page 2 of 2)

\begin{tabular}{|c|c|c|c|c|c|c|c|c|}
\hline Analyte & $\begin{array}{c}\text { Frequency of } \\
\text { Detection }\end{array}$ & $\begin{array}{l}\text { Minimum } \\
\text { Detection Limit } \\
(\mathrm{mg} / \mathrm{kg})^{\mathbf{b}}\end{array}$ & $\begin{array}{c}\text { Range of } \\
\text { Detections } \\
\text { (mg/kg) }\end{array}$ & $\begin{array}{l}\text { Reference Range }{ }^{\mathrm{c}, \mathrm{d}} \\
(\mathrm{mg} / \mathrm{kg})\end{array}$ & $\begin{array}{c}\text { Average } \\
\text { Concentration }^{d} \\
(\mathrm{mg} / \mathrm{kg})\end{array}$ & $\begin{array}{l}\text { Standard } \\
\text { Deviation }\end{array}$ & $\begin{array}{l}95 \% \text { Upper Confidence } \\
\text { Limit of the Mean } \\
\text { (mg/kg) }\end{array}$ & $\begin{array}{c}\text { Constituent of } \\
\text { Potential Concern }\end{array}$ \\
\hline Thallium & $3 / 108$ & 0.21 & $0.26 \cdot 0.28$ & $0.11(N D)-0.14(N D)$ & 0.12 & 0.03 & 0.13 & $\mathrm{No}^{\mathrm{g}}$ \\
\hline Vanadium & $104 / 108$ & 2.50 & $5.40 \cdot 34.00$ & $4.10-25.60$ & 8.27 & 7.93 & 9.78 & $\mathrm{No}^{\mathrm{e}}$ \\
\hline Zinc & $88 / 108$ & 2.10 & $2.40-278$ & $3.60(N D)-24.40$ & 14.14 & 27.78 & 19.44 & $\mathrm{No}^{\mathrm{e}}$ \\
\hline Cyanide & $18 / 108$ & 0.13 & $0.13 \cdot 0.68$ & $0.07(N D)-0.27$ & 0.11 & 0.10 & 0.13 & $\mathrm{No}^{\ominus}$ \\
\hline
\end{tabular}

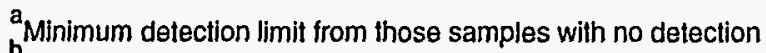

Milligram per kilogram

CReference range consists of samples Ref-19A, Ref-19B, Ref-19C, Ref-19D, and Ref-19E

$d_{H a l f}$ the detection limit was used for those samples in which the analyte was not detected at the detection limit.

95-percent upper confidence limit of the mean was within reference concentration range.

Not detected; value represents half the detection limit.

9 Detected in less than 5 percent of samples

$h_{\text {Essential nutrient }}$

95-percent upper confidence limit of the mean did not exceed the actual reference detection limits. 
Table 3-18

Summary of Pesticide and PCB Concentrations in Surficial Soil,

Salmon Site

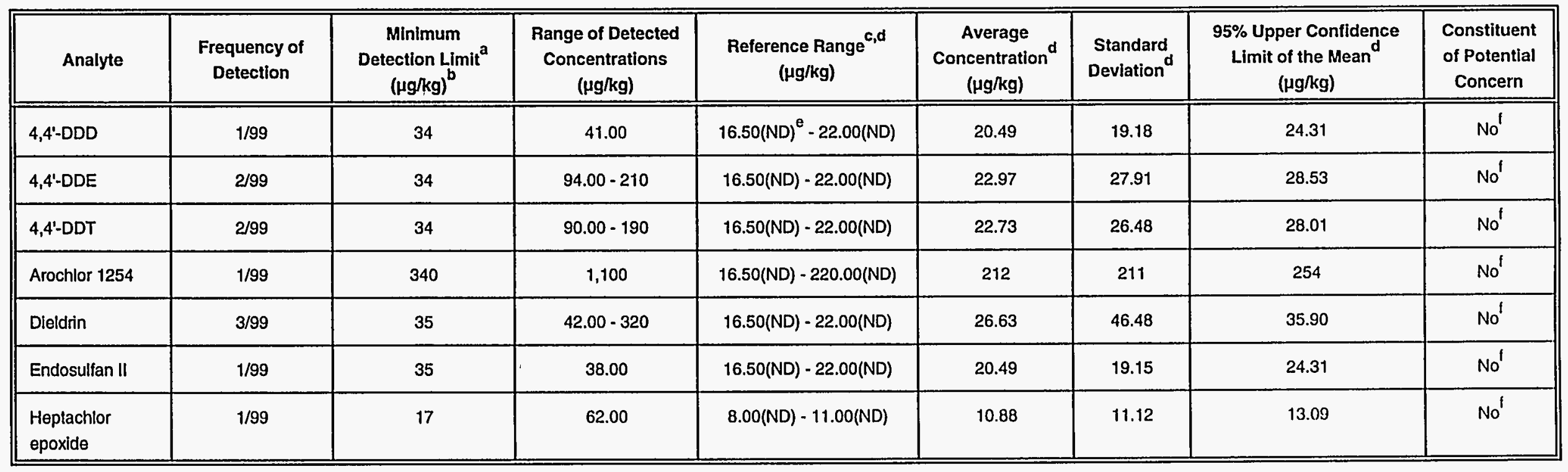

ainimum detection limit from those samples with no detection

Microgram per killogram

Reference range consists of samples Ref-19A, Ref-19B, Ref-19C, Ref-19D, and Ref-19E.

Half the detection limit was used for those samples in which the analytes were not detected at the detection limit.

Not detected; value represents half the detection limit.

Detected in less than 5 percent of samples 
Table 3-19

Summary of Semivolatile and Volatile Organic

Concentrations in Surficial Soil,

Salmon Site

\begin{tabular}{|c|c|c|c|c|c|c|c|c|}
\hline Analyte & $\begin{array}{c}\text { Frequency of } \\
\text { Detection }\end{array}$ & $\begin{array}{c}\text { Minimum } \\
\text { Detection Limit } \\
(\mu g / \mathrm{kg})^{b}\end{array}$ & $\begin{array}{c}\text { Range of Detected } \\
\text { Concentrations } \\
(\mu \mathrm{g} / \mathrm{kg})\end{array}$ & $\begin{array}{c}\text { Reference Range }{ }^{c, d} \\
(\mu \mathrm{g} / \mathrm{kg})\end{array}$ & $\begin{array}{c}\text { Average } \\
\text { Concentration } \\
(\mu \mathrm{g} / \mathrm{kg})\end{array}$ & $\begin{array}{l}\text { Standard } \\
\text { Deviation }\end{array}$ & $\begin{array}{c}95 \% \text { Upper Confidence } \\
\text { Limit of the Mean } \\
(\mu \mathrm{g} / \mathrm{kg})\end{array}$ & $\begin{array}{c}\text { Constituent of } \\
\text { Potential } \\
\text { Concern }\end{array}$ \\
\hline Acenaphthylene & $1 / 103$ & 340 & 110 & $170(N D)^{\theta}-225(N D)$ & 225.55 & 81.15 & 241.41 & $\mathrm{No}^{\prime}$ \\
\hline Acetone & $6 / 106$ & 10.00 & $24.00 \cdot 97.00$ & $5.50(N D)-8.50(N D)$ & 21.42 & 18.32 & 24.95 & $\mathrm{No}^{\mathrm{g}, \mathrm{h}}$ \\
\hline Benzoic Acid & $51 / 103$ & 1,600 & $39.00 \cdot 870$ & $99.00 \cdot 570$ & 690.14 & 578.05 & 803.14 & $\mathrm{No}^{\mathrm{g}}$ \\
\hline $\begin{array}{l}\text { Bis(2- } \\
\text { ethylhexyl)phthalate }\end{array}$ & $55 / 103$ & 340 & $38.00-1,700$ & $170(N D)-225(N D)$ & 217.82 & 241.75 & 265.08 & $\mathrm{No}^{h}$ \\
\hline Chloroform & $6 / 96$ & 2.00 & $4.00-7.00$ & $2.50(N D)-3.50(N D)$ & 2.93 & 0.92 & 3.12 & $\mathrm{No}^{\mathrm{g}}$ \\
\hline Ethylbenzene & $4 / 96$ & 5.00 & $1.00-2.00$ & $2.50(N D)-3.50(N D)$ & 2.75 & 0.36 & 2.82 & $\mathrm{No}^{\mathrm{f}, \mathrm{g}, \mathrm{i}}$ \\
\hline Methylene Chloride & $9 / 105$ & 5.00 & $1.00-10.00$ & $2.50(\mathrm{ND})-3.50(\mathrm{ND})$ & 4.30 & 3.01 & 4.88 & $\mathrm{No}^{\mathrm{g}, \mathrm{h}}$ \\
\hline Phenol & $2 / 103$ & 340 & $48.00-130$ & $170(N D)-225(N D)$ & 229.06 & 83.23 & 245.33 & No ${ }^{\prime}$ \\
\hline Styrene & $1 / 97$ & 5.00 & 25.00 & $2.50(\mathrm{ND})-3.50(\mathrm{ND})$ & 3.98 & 2.58 & 4.50 & No ${ }^{f, g, i}$ \\
\hline Toluene & $25 / 101$ & 5.00 & $1.00-9.00$ & $2.50(N D)-3.50(N D)$ & 2.67 & 0.88 & 2.84 & $\mathrm{No}^{\mathrm{h}}$ \\
\hline Xylene (total) & $13 / 96$ & 5.00 & $2.00 \cdot 13.00$ & $2.50(N D) \cdot 3.50(N D)$ & 4.01 & 1.85 & 4.39 & $\mathrm{No}^{9}$ \\
\hline
\end{tabular}

${ }^{a}$ Minimum detection limit was selected from those with no detections.

${ }_{c}^{b}$ Microgram per kilogram

Reference range consists of samples Ref-19A, Ref-19B, Ref-19C, Ref-19D, and Ref-19E.

Half the detection limit was used for those samples in which the analyte was not detected at the detection limit.

Not detected; value represents half the detection limit.

Detected in less than 5 percent of samples

${ }_{\text {Log }} \mathrm{K}_{\text {ow }}$ less than 3.5, unlikely to bioaccumulate (Garten and Trabalka, 1983)

Common laboratory contaminant

Within reference concentration range 
Table 3-20

Summary of Radionuclide Activity in Surficial Soil,

Salmon Site

(Page 1 of 2)

\begin{tabular}{|c|c|c|c|c|c|c|c|c|}
\hline Radionuclide & $\begin{array}{c}\text { Frequency of } \\
\text { Detection }\end{array}$ & $\begin{array}{c}\text { Minimum Detectable } \\
\text { Activity }^{\mathrm{a}} \\
\text { (pci/g) }\end{array}$ & $\begin{array}{c}\text { Range of Detected } \\
\text { Concentrations } \\
\text { (pCi/g) }\end{array}$ & $\begin{array}{l}\text { Reference Range } \\
\text { (pCi/g) }\end{array}$ & $\begin{array}{l}\text { Average } \\
\text { Concentration } \\
\text { (pCi/g) }\end{array}$ & $\begin{array}{l}\text { Standard } \\
\text { Deviation }\end{array}$ & $\begin{array}{l}\text { 95\% Upper Confidence } \\
\text { Limit of the Mean }{ }^{d} \\
\text { (pCi/g) }\end{array}$ & $\begin{array}{c}\text { Exceeds } \\
\text { Reference } \\
\text { Range? }\end{array}$ \\
\hline Gross Alpha & $74 / 97$ & 5.86 & $5.52 \cdot 37.90$ & $4.24-12.20$ & 10.60 & 5.95 & 11.80 & $\mathrm{No}^{\mathrm{e}}$ \\
\hline Gross Beta & $97 / 97$ & -- & $6.78-31.20$ & $9.65-15.60$ & 14.24 & 4.04 & 15.05 & $\mathrm{No}^{\mathrm{C}}$ \\
\hline Bismuth-212 & $45 / 75$ & 0.09 & $0.16-1.01$ & $0.06-0.46$ & 0.29 & 0.21 & 0.34 & $\mathrm{No}^{\mathrm{e}}$ \\
\hline Cesium-137 & $86 / 98$ & 0.02 & $0.02-0.92$ & $0.01(N D)^{9}-0.38$ & 0.19 & 0.20 & 0.23 & $\mathrm{No}^{\mathrm{C}}$ \\
\hline Lead-210 & $46 / 66$ & 0.28 & $0.04-2.04$ & 0.20 (ND) - 2.05 & 0.95 & 0.44 & 1.06 & $\mathrm{No}^{\mathrm{e}}$ \\
\hline Lead-212 & $63 / 86$ & 0.02 & $0.20-1.86$ & $0.01-0.53$ & 0.47 & 0.41 & 0.56 & Yes \\
\hline Mercury-203 & $1 / 1$ & -. & 0.03 & NA & NA & NA & NA & NA \\
\hline Potasslum-40 & $84 / 87$ & 0.49 & $0.25-7.16$ & $1.27 \cdot 5.39$ & 2.10 & 1.53 & 2.42 & No ${ }^{\mathrm{e}}$ \\
\hline Proaclinium-231 & $5 / 5$ & -- & $0.61-0.96$ & NA & 0.75 & 0.14 & 0.92 & NA \\
\hline Protactinium-234 & $1 / 1$ & - & 2.96 & NA & NA & NA & NA & NA \\
\hline Radium-223 & $14 / 14$ & -- & $0.09-0.42$ & 0.16 & 0.21 & 0.10 & 0.27 & Yes \\
\hline Radium-224 & $22 / 65$ & 0.18 & $0.29-1.46$ & $0.08-0.59$ & 0.34 & 0.29 & 0.41 & $\mathrm{No}^{\mathrm{e}}$ \\
\hline Radium-226 & $79 / 87$ & 0.03 & $0.19-1.29$ & $0.41-0.73$ & 0.47 & 0.27 & 0.53 & $\mathrm{No}^{e}$ \\
\hline Radium-228 & $76 / 87$ & 0.06 & $0.18-1.76$ & $0.42-0.72$ & 0.47 & $0.33 \ldots$ & 0.54 & $\mathrm{No}^{\mathrm{e}}$ \\
\hline Tin-113 & $2 / 2$ & -- & $0.02-0.03$ & NA & 0.03 & 0.01 & 0.09 & NA \\
\hline
\end{tabular}

Refer to footnotes at end of table. 
Table 3-20

Summary of Radionuclide Activity in Surficial Soil, Salmon Site

(Page 2 of 2)

\begin{tabular}{|c|c|c|c|c|c|c|c|c|}
\hline Radionuclide & $\begin{array}{c}\text { Frequency of } \\
\text { Detection }\end{array}$ & $\begin{array}{c}\text { Minimum Detectable } \\
\text { Activity }^{\mathrm{a}} \\
\text { (pci/g) }^{\mathrm{b}}\end{array}$ & $\begin{array}{c}\text { Range of Detected } \\
\text { Concentrations } \\
\text { (pCi/g) }\end{array}$ & $\begin{array}{l}\text { Reference Range } e^{c, d} \\
\qquad(\mathrm{pCi} / \mathrm{g})\end{array}$ & $\begin{array}{c}\text { Average } \\
\text { Concentration }^{d} \\
(\mathrm{pCl} / \mathrm{g}) \\
\end{array}$ & $\begin{array}{l}\text { Standard } \\
\text { Deviation }^{d}\end{array}$ & $\begin{array}{c}95 \% \text { Upper Confidence } \\
\text { Limit of the Mean }{ }^{d} \\
(\mathrm{pCi} / \mathrm{g})\end{array}$ & $\begin{array}{c}\text { Exceeds } \\
\text { Reference } \\
\text { Range? } \\
\end{array}$ \\
\hline Thallium-208 & $53 / 80$ & 0.01 & $0.07-0.53$ & $0.11-0.15$ & 0.13 & 0.12 & 0.16 & Yes \\
\hline Thorium-228 & $11 / 11$ & -- & $0.83-11.61$ & $0.38(N D)$ & 3.00 & 3.09 & 5.08 & Yes \\
\hline Uranium-234 & $2 / 2$ & -- & $3.19 \cdot 10.40$ & NA & 6.80 & 5.10 & 52.62 & NA \\
\hline Uranium-235 & $1 / 1$ & -- & 0.09 & NA & NA & NA & NA & NA \\
\hline Uranium-238 & $64 / 87$ & 0.17 & $0.21-1.80$ & $0.52-0.88$ & 0.60 & 0.38 & 0.68 & $\mathrm{No}^{\mathrm{e}}$ \\
\hline
\end{tabular}

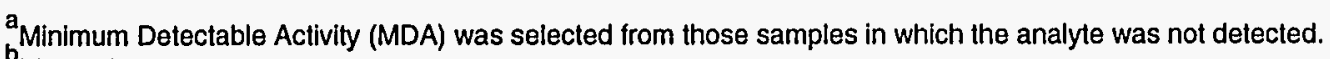

Picocurie per gram

CReference range consists of samples GrC-1, HMC-1, HHC-1, and ReP-1.

iHalf the MDA was used for those samples in which the analyte was not detected at the MDA.

Maximum detected sample concentration was less than or equal to reference.

Not applicable

${ }^{9}$ Not detected; value represents half the MDA. 
Gamma spectroscopic analysis of sediment samples denoted several detectable levels of radionuclides. Although most radionuclides were detẻcted infrequently and at reference concentrations, cesium-137 and lead-210 were found elevated in the Gator Pond and Beaver Pond sediments. In these ponds, potassium- 40 was detected at $5.21 \mathrm{pCi} / \mathrm{g}$ and $2.38 \mathrm{pCi} / \mathrm{g}$, cesium-137 at $0.61 \mathrm{pCi} / \mathrm{g}$ and $1.09 \mathrm{pCi} / \mathrm{g}$, respectively, and lead-210 at $9.6 \mathrm{pCi} / \mathrm{g}$ in the Beaver Pond.

Tritium was detected in one sediment sample on the SS. This sample was from the Beaver Pond at a concentration of $0.48 \mathrm{pCi} / \mathrm{g}$. Radioactive constituent data are summarized in Table 3-12.

Grain-size distribution data show the creek sediments to be at least 90-percent sand. Though the pond stations had smaller particle sizes, the majority was either sand or silt. Total organic carbon content ranged from less than 0.1 percent in Grantham Creek to over 19 percent in the Beaver Pond. Ammonia at the Beaver Pond station was extremely high ( $195 \mu \mathrm{g} / \mathrm{kg})$; ammonia at other areas ranged from below detection to $3.43 \mu \mathrm{g} / \mathrm{kg}$. These data are presented in Table 3-13.

\subsubsection{Surface Water}

Surface water data are presented in Appendix A. Tables A-4.1 through A-4.9 present the inorganic, pesticide and PCBs, volatile, semivolatile, gross alpha and beta, gamma spectroscopy, tritium, wet chemistry, and BOD data sets, respectively.

The majority of inorganic constituents detected in surface water are naturally occurring soil constituents. Many are essential macronutrients and necessary components of surface water bodies. Trace elements, such as cobalt, arsenic, and mercury, were detected once each in the three ponds on site: cobalt at 9.1 micrograms per liter $(\mu \mathrm{g} / \ell)$ in the Half Moon Creek Overflow Pond, arsenic at $2.2 \mu \mathrm{g} / \mathrm{l}$ in the Beaver Pond, and mercury at $0.17 \mu \mathrm{g} / \mathrm{l}$ in the Gator Pond. A summary of the inorganic constituents in surface water on the SS are presented in Table 3-14.

The only radioactive constituents detected in surface water were tin-113 and tritium (Table 3-15).

\subsubsection{Surficial Soil}

Soil data are presented in Appendix A. Tables A-5.1 through A-5.7 present the inorganic, pesticide and PCBs, volatile, semivolatile, gross alpha and beta, and gamma spectroscopy data sets, respectively. 
Many of the inorganic constituents detected are naturally occurring soil constituents and were found at reference levels. One copper concentration of almost $10,000 \mathrm{mg} / \mathrm{kg}$ was found in surficial soils at the West Substation although most other samples were comparable to reference (ND - $10.70 \mathrm{mg} / \mathrm{kg}$ ) and background concentrations (ND - $700 \mathrm{mg} / \mathrm{kg}$ ). Concentrations of inorganics in surficial soils on the SS are summarized in Table 3-17.

Several pesticides were detected in soils on site at isolated locations. The Big Chief Drilling Storage Area in SA-3 contained detectable concentrations of heptachlor epoxide ( $62 \mu \mathrm{g} / \mathrm{kg})$, dieldrin (42 and $320 \mu \mathrm{g} / \mathrm{kg}$ ), and endosulfan II (38 $\mu \mathrm{g} / \mathrm{kg})$. Dieldrin was also detected at the North Substation in SA-4 (320 $\mu \mathrm{g} / \mathrm{kg})$. Both 4,4'-DDE and 4,4'-DDD were found at the East Substation in SA-1 (210 and $41 \mu \mathrm{g} / \mathrm{kg}$, respectively) and the HT-2 Well Area in SA-5 (94 and $90 \mu \mathrm{g} / \mathrm{kg}$, respectively). In addition, 4,4'-DDT was found at the East Substation (190 $\mu \mathrm{g} / \mathrm{kg})$.

One detection of PCBs was found in surficial soils. The East Substation had a detectable level of Aroclor- $1254(1,100 \mu \mathrm{g} / \mathrm{kg})$. Concentrations of pesticides and PCBs in surficial soils in the SS are summarized in Table 3-18.

Volatile organic compounds detected in surficial soils included toluene, xylene, and styrene. Detected concentrations of toluene ranged from $1 \mu \mathrm{g} / \mathrm{kg}$ to $9 \mu \mathrm{g} / \mathrm{kg}$, and detected concentrations of xylene ranged from $2 \mu \mathrm{g} / \mathrm{kg}$ to $13 \mathrm{mg} / \mathrm{kg}$. The majority of detected concentrations were found at Station 1A, Big Chief Drilling Storage Area, Sites E-2 and E-7 in SA-3, and the CH Fuel Storage Area in SA-4.

Four semivolatile organic compounds were detected in surficial soils. Benzoic acid and bis(2-ethylhexyl)phthalate were detected in approximately half of the samples. Concentrations ranged from nondetectable to $1,900 \mu \mathrm{g} / \mathrm{kg}$ for benzoic acid and from nondetectable to $1,700 \mu \mathrm{g} / \mathrm{kg}$ for bis(2-ethylhexyl)phthalate. Phenol and acenaphthylene were detected twice and once, respectively. Concentrations of volatile and semivolatile organics in surficial soils in the SS are summarized in Table 3-19.

Gross alpha and beta and gamma spectroscopic data for surficial soils are summarized in Table 3-20. Although most sample concentrations were within reference ranges, elevated concentrations existed on site. Maximum on-site concentrations were $37.9 \mathrm{pCi} / \mathrm{g}$ and $31.2 \mathrm{pCi} / \mathrm{g}$, respectively. 


\subsubsection{Constituents of Potential Concern}

Constituents of potential concern are site related, have reported quantities of reliable quality, and are of greatest potential concern for ecological receptors given their physiochemical, toxicological. and bioaccumalative properties. A summary of the screening criteria is presented in Figure 3-3. It is this list of COPC for which stress was characterized at the SS.

\subsubsection{Sediment}

In sediment, six inorganic constituents, arsenic, barium, cadmium, lead, manganese, and zinc, were considered to be COPC. No organic constituents were considered COPC in sediment. Alpha and beta emissions are considered COPC in all media. Likewise, all radionuclides detected with sufficient quantity and quality are considered potentially site related and COPC. Tritium is considered a COPC because of past site activities. Three radionuclides were detected by gamma spectroscopy at levels above reference. These are cesium-137, lead-210, and radium-224.

\subsubsection{Surface Water}

In surface water, two inorganics are considered COPC: aluminum and arsenic. Aluminum was not considered a COPC in other media; however, arsenic was considered a COPC in sediment. No organic constituents were considered COPC in surface water.

Alpha and beta emissions were not detected in surface water samples. Tritium was detected in five samples. The highest levels were in the Beaver Pond and Half Moon Creek Overflow Pond. The only radionuclide detected by gamma spectroscopy in surface water samples was tin-113 in Grantham Creek just above the detection limit.

\subsubsection{Surficial Soil}

In soil, only two inorganic constituents are considered COPC. These are copper and lead. The majority of inorganic constituents detected were within site-specific reference ranges. Antimony, selenium, and thallium were detected in less than 5 percent of the surficial soil samples. None of these is attributable to past site activities. 
ALL CONSTITUENTS

Evaluation of Methods

Evaluation of Detection Limits

Evaluation oí Qualifiers

Evaluation of Blanks

Evaluation of Tentatively Identified Compounds

POSITIVELY DETECTED CONSTITUENTS OF ACCEPTABLE DATA QUALITY

Comparison to Reference

POSITIVELY SITE-RELATED POSITIVELY DETECTED CONSTITUENTS OF ACCEPTABLE DATA QUALITY

Low Frequency of Detections

Essential macronutrients

General water chemistry parameters

Low bioaccumulation potential

CONSTITUENTS OF POTENTIAL CONCERN

Figure 3-3

Screening Criteria for Selection of Constituents of Potential Concern 
No organic constituents are considered COPC in soil. Phenol, acenaphthylene, ethylbenzene, and styrene were detected in less than 5 percent of the samples. Bis(2-ethylhexyl)phthalate is a common laboratory contaminant with no site-related history. Benzoic acid is a naturally occurring constituent found in both flora and vertebrate excretions and, along with toluene and xylene, have $\log \mathrm{K}_{\mathrm{ow}}$ values of less than 3.5 .

Alpha and beta emissions are considered COPC in all media. Likewise, all radionuclides detected with sufficient quantity and quality through gamma spectroscopy are considered potentially site-related and COPC.

\subsection{Exposure Pathway Identification}

This pathway assessment analyzes potential exposure pathways for terrestrial and aquatic flora and fauna at the SS, using existing site conditions, coupled with additional information on the life histories of biota using the site. A Conceptual Site Model (CSM) (Figure 3-4) was used to describe suspected sources and types of constituents present, constituent release and transport mechanisms, rate of constituent release and transport (where possible), affected media, known and potential routes of migration, and known and potential environmental receptors.

Complete exposure pathways must exist for exposures to occur. A complete exposure pathway requires (1) a source and mechanism for contaminant release, (2) a transport medium, (3) a point of environmental contact, and (4) an exposure route at the exposure point (EPA, 1989b). If any of these four components is absent, a pathway is generally considered incomplete. However, the transport medium may be missing, and the pathway may still be complete if the contact point is directly at the contaminant release point.

Contaminants at the SS may migrate from their source to other environmental compartments via six major pathways: (1) volatilization to the air and transport by wind, (2) leaching to the saturated zone and transport with groundwater, (3) adsorption onto surface soil particles and transport by wind as fugitive dust, (4) erosion and transport with surface water runoff, (5) discharge of groundwater to surface water, and (6) exchanges between surface water and sediment. 


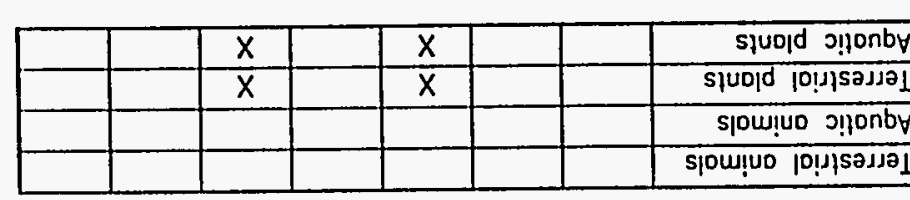

\begin{tabular}{|c|c|c|c|c|c|}
\hline$x$ & $x$ & $x$ & & & sjuojd ग!lonby \\
\hline & & & & & squopd \\
\hline$x$ & & $x$ & $\bar{x}$ & $\bar{x}$ & șou!uo ग!ןonby \\
\hline $\bar{x}$ & & $x$ & $\bar{x}$ & $\bar{x}$ & s|ow!̣u $|0 ! j| s a j s a \mid$ \\
\hline
\end{tabular}

\begin{tabular}{|c|c|c|c|c|c|}
\hline $\bar{x}$ & $\bar{x}$ & $\bar{x}$ & & & şudid ग!jonby \\
\hline & & & & & spuopd $10 ! 1\}$ sedsal \\
\hline $\bar{x}$ & & $\bar{x}$ & $x$ & $x$ & spou!uo s!jonby \\
\hline$x$ & & $x$ & $x$ & $x$ & 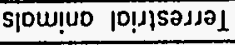 \\
\hline
\end{tabular}

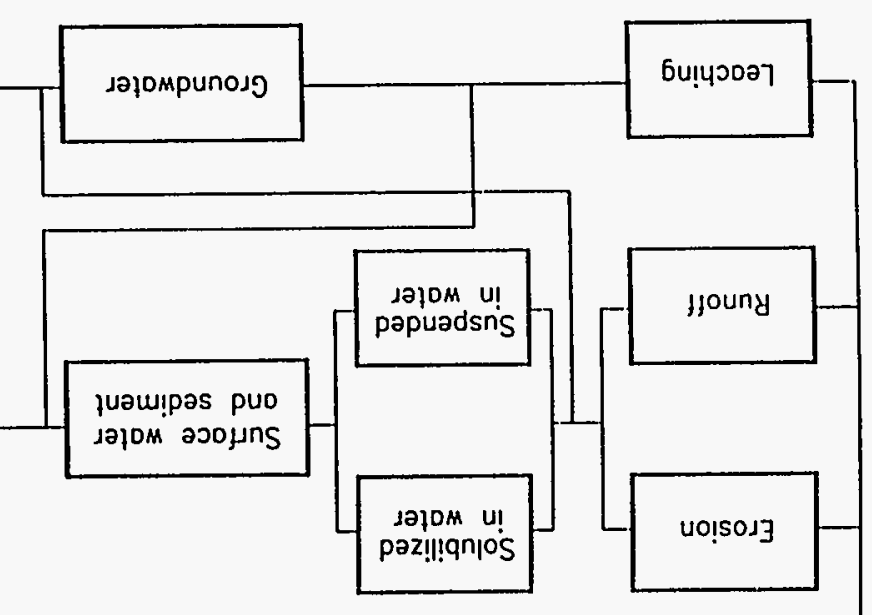

\begin{tabular}{|c|c|c|c|c|c|c|}
\hline $\bar{x}$ & $\bar{x}$ & $\bar{x}$ & $\bar{x}$ & & & s\}uold s!jonby \\
\hline $\bar{x}$ & $\bar{x}$ & $\bar{x}$ & $\bar{x}$ & & & sjuold |0!j]sadsal \\
\hline $\bar{x}$ & & $\bar{x}$ & $\bar{x}$ & & & s|ow!uo J!lonby \\
\hline $\bar{x}$ & & $x$ & $\bar{x}$ & $\bar{x}$ & $x$ & S|Duinu |D!jisajal \\
\hline
\end{tabular}

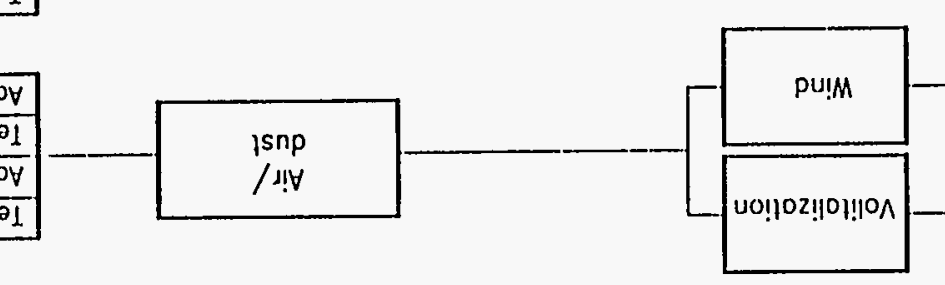

\begin{tabular}{|c|c|c|c|c|c|c|c|c|}
\hline$x$ & $x$ & & $\bar{x}$ & & & słuopd ग!lonby & \multirow{4}{*}{$\begin{array}{c}\text { PDIUOOS } \\
\text { l!OS }\end{array}$} & \multirow{3}{*}{$\begin{array}{l}\text { 100juos } \\
\text { 102. }\end{array}$} \\
\hline$x$ & $x$ & $x$ & $x$ & & & sfuold $10 ! 1\}$ sastal & & \\
\hline$x$ & & & $x$ & & & slowinu ग!onby & & \\
\hline$x$ & & & $\bar{x}$ & $\bar{x}$ & $\bar{x}$ & spouivio jo!jisanal & & \\
\hline
\end{tabular}

pod เәңdoग!|әH s!|әM Uo!joalu suompisqns $12 \mathrm{MO}$ a6osols janf ว60Jols puo 6u!l!! ן!jnq $5 ! j q \partial 0$ pOYs jSa\} JOäOnN sa!!!n!!’ 2!!S

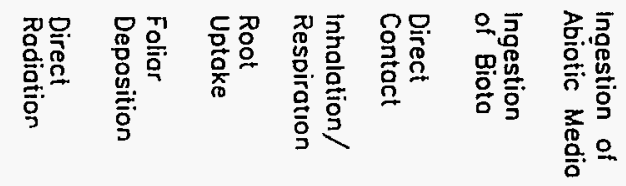

\begin{tabular}{|c|c|c|c|c|}
\hline sąnoy asnsodx 3 & $\begin{array}{l}\text { soldaray } \\
\text { 10!!uatod }\end{array}$ & $\begin{array}{c}\text { D!paW } \\
\text { pəiวə|l }\end{array}$ & $\begin{array}{l}\text { wsiuduoaw } \\
\text { jodsud } \\
\text { /asoajay }\end{array}$ & $\begin{array}{l}\text { כosnos } \\
\text { juou!mofuoj }\end{array}$ \\
\hline
\end{tabular}


Nonadsorptive water-soluble contaminants present in soils may migrate into groundwater or become dissolved in stormwater runoff from the site. Contaminants that leach into the groundwater may be transported to surface waters via seeps and/or springs. Contaminants with strong affinity for soils may be transported off site as sediment load in surface water or as wind-generated particulates. Nonvolatile contaminants with a lesser affinity for soils may also be transported off site by wind.

Ecological receptors may be exposed to water-borne contaminants via dermal contact, consumption of water, or inhalation of organic vapors. Terrestrial organisms may come into contact with water-borne contaminants as a result of wading or swimming in contaminated waters. Terrestrial organisms may also ingest water-borne contaminants if wildlife use impacted waters as a source of drinking water. Aquatic organisms inhabiting contaminated waters would be in constant contact with contaminants. Terrestrial organisms may be exposed to organic vapors that result from the volatilization of organics in surface waters; however, significant exposure via this route would be limited to terrestrial organisms that spend most of their time near or in the water (e.g., waterfowl and turtles).

Contaminants present in sediment may result from erosion or adsorption of water-borne contaminants onto sediment particles. If sediments are present in an area that is periodically inundated with water, previous exposure pathways for soils would be applicable during dry periods. Water overlying sediments would prevent contaminants from either volatilizing or being carried by wind erosion. Exposure via dermal contact may occur especially for benthic organisms. Some aquatic organisms consume sediment and ingest organic matter from the sediment. Inadvertent ingestion of sediments may occur as the result of feeding on benthic organisms and plants.

While contaminants in soils may leach into groundwater, environmental receptors generally will not come in contact with these contaminants unless groundwater is discharged to the surface. However, root contact with, and uptake of. contaminants in groundwater is a potential pathway.

Potential primary exposure pathways for terrestrial receptors include (1) dermal contact with contaminated soil, sediment, and surface water; (2) ingestion of contaminated soil, sediment, and surface water; (3) inhalation of organic vapors and/or contaminated particulates; (4) uptake through roots in contact with soil, sediment, surface water, or groundwater; and (5) direct radiation from contaminated soil, sediment, or surface water. 
Potential primary exposure pathways for aquatic receptors include (1) dermal contact with contaminated sediments or surface water, (2) ingestion of contaminated sediment or surface water, (3) uptake through roots and leaves in contact with surface water or sediment, and (4) direct radiation from contaminated surface water or sediment.

Secondary exposure pathways involve contaminants that are transferred through the food chain. This pathway may include contaminants bioaccumulated from soil or sediment into plant tissues, which are subsequently ingested by terrestrial or aquatic herbivores. Benthic invertebrates may bioaccumulate contaminants from the surface water and/or sediments and then become prey for bottom feeding fish. which subsequently become prey for piscivorous avian species.

The potential sources of contamination and routes of migration are summarized in the site-wide CSM for the SS (Figure 3-4).

\subsubsection{Animal Exposure Routes}

There are five major exposures routes by which terrestrial and aquatic animals might be exposed to contaminants at the SS: (1) direct ingestion of contaminated abiotic media, (2) the consumption of contaminated animal or plant tissue (food web interactions), (3) inhalation, (4) direct contact (e.g., absorption through skin or gill surfaces), and (5) direct radiation.

\section{Direct Ingestion of Contaminated Abiotic Media}

Direct ingestion of contaminated soil or sediment could occur while animals grub for food, feed on plant matter covered with contaminated soil, filter feed in areas where sediments have been resuspended in the water column, or preen or groom themselves. Soil ingestion may inadvertently occur while grooming; burrowing; or consuming plants, insects, or invertebrates resident in the soil. Aquatic deposit feeders directly ingest large quantities of bulk sediment in order to obtain the energy-rich organic fraction; these organisms would likely have a significant exposure from this pathway. Terrestrial species would also ingest potentially contaminated surface water from the streams, ponds, and wetland areas at the SS.

\section{Ingestion of Contaminated Tissues}

Predatory organisms (secondary and tertiary consumers) may be exposed when feeding upon prey that contains elevated levels of contaminants. The ability of contaminants to be passed from lower to higher trophic levels is dependent upon their fate inside the prey animals. If the contaminant is solely ingested and excreted by the prey without absorption from the gastrointestinal (GI) tract and storage in its tissues, the exposure of higher trophic levels is 
minimized. The dose received by the predator is dependent upon the contaminant concentration in the prey, its ingestion rate, and the amount of contaminated matter consumed.

The risk of exposure for predatory organisms is greater if the prey assimilates the ingested contaminants or directly bioaccumulates contaminants present in the media into its tissues. The risk of exposure to predators in this case would then be dependent upon the concentration of contaminants in the particular tissues consumed and the rate of food consumption. The actual concentration within the predator would also depend upon the rate of assimilation from the GI tract of the contaminants during ingestion, the rate of metabolism, and the depuration rate.

\section{Inhalation}

Volatile organic compounds and, to a lesser extent, lower-molecular-weight polycyclic aromatic hydrocarbons tend to volatilize from surface soils or surface water. In vapor form, these compounds may become bioavailable to organisms during respiration and pose an important exposure route. However, organic compounds were not detected in high concentrations in environmental media, and this exposure route is probably minimal at the SS.

Exposure via inhalation of fugitive dust would be limited to contaminants present in surface soils at an area that was devoid of either vegetation or landscaping that would prevent the erosion of soil particles. Exposure via inhalation is most important to organisms that burrow in contaminated soils, especially those that bear their young in below-ground burrows (e.g., gopher tortoises). However, intake via this mechanism is considered minimal relative to other pathways.

\section{Direct Contact}

Direct exposure to soils, sediments, and surface water are other pathways important to some species. This could result from direct dermal contact with the soils, sediments, or surface water on unprotected surfaces (e.g., gill membranes, exposed skin, or exposed mucosal membranes). Significant exposure via dermal contact would be limited to organic contaminants that are lipophilic and can penetrate epidermal barriers. Mammals and birds are less susceptible to exposure via dermal contact with soils because their fur and feathers prevent skin from coming into full contact with soil.

Dermal exposure may be most important to aquatic organisms, such as benthic invertebrates, and bottom dwelling fish. Direct exposure is likely to have far less impact on terrestrial organisms than other routes such as ingestion of contaminated media or tissues. 


\section{Direct Radiation}

Unlike chemicals, radionuclides can have deleterious effects on animals without being taken or brought into contact with the body. This is because high-energy beta particles from radionuclides in contaminated air. water, or soil can travel long distances with only minimum attenuation in these media before depositing their energy in animal tissues. Gamma and $\mathrm{x}$-rays are the most penetrating of the emitted radiations and comprise the primary contribution to the radiation dose from external exposures. Alpha particles are not sufficiently energetic to penetrate the outer layer of skin and do not contribute significantly to the external dose. External exposure to beta particles primarily imparts a dose to the outer layer skin cells, although high-energy beta radiation can penetrate into animal bodies.

\subsubsection{Plant Exposure Routes}

There are four major routes by which plants might be exposed to contaminants at the SS:

(1) incorporation of organic vapors through gas exchange, (2) root uptake. (3) foliar deposition or direct contact for aquatic plants, and (4) direct radiation.

\section{Respiration of Organic Vapors}

Organic vapors resulting from the volatilization of contaminants in soil and/or surface water may be incorporated into vascular plants via gas exchange and respiration. Because the SS did not have high media levels of organics, exposure via this pathway is probably minimal.

\section{Root Uptake}

Both aquatic and terrestrial plants may be exposed to site-related contaminants in soil, sediment, and/or surface water by root uptake. This pathway is the most important exposure route for plant uptake of contaminants.

Plant uptake of chemicals and radionuclides from soils is affected by numerous processes. Because of the multiplicity of factors, soil-to-plant concentration ratios may exhibit considerable variability. Among the more important factors that affect root uptake are (1) the physicochemical form of the chemical or radionuclide, (2) soil characteristics, (3) fertilizers and agricultural chemicals, (4) chelating agents in the soil, (5) distribution of chemicals and radionuclides in the soil, and (6) plant species and internal translocation within the plant.

\section{Foliar Deposition}

Plants on and around the SS may be exposed to site-related contaminants adhering to particulates that have been eroded by the wind. Wet and/or dry deposition of air-associated contaminants 
onto leaf surfaces would make them available for uptake by the plants either directly through the epidermal tissues or through the stomates. Uptake of contaminants may also occur through direct contact of aquatic plants with contaminated surface waters.

\section{Direct Radiation}

High-energy beta particles from radionuclides in contaminated air, water, or soil can travel long distances with only minimal attenuation in these media before depositing their energy in plant tissues. Gamma and x-rays are the most penetrating of the emitted radiations and comprise the primary contribution to the radiation dose from external exposures. Alpha particles are not sufficiently energetic to penetrate the outer layer of plant tissue and do not contribute significantly to the external dose. External exposure to beta particles primarily imparts a dose to the outer layer of plant tissue although high-energy beta radiation can penetrate further into plant tissues.

The buildup of radionuclides on vegetation as a result of deposition of airborne radioactive materials may be an important process in several exposure pathways. It is a major source of radionuclide contamination of terrestrial food products such as vegetables and forage for terrestrial animals. Deposited beta- and gamma-emitting radionuclides contribute to exposure from external radiation.

\subsection{Ecological Receptor Identification}

An ecosystem is the combination of the abiotic (nonliving) physiochemical environment and the assemblage of biotic (living) organisms that combine together to form an interrelated and interdependent system.

There are two basic environments existing at SS that provide a natural classification of chemical and/or radiation exposure pathways: terrestrial and aquatic (freshwater) ecosystems. For the SS ecosystems, the areal extent of investigation has been defined as the former test site bounded by the fence. However, it should be noted that the habitats present on site (e.g., forest, field, and wetlands) extend off-site beyond the area of investigation.

The loss of valued native species or the establishment of unwanted exotic species would be viewed as a major ecosystem degradation. Closely tied to this view is the concept and measure of species' diversity. Diversity has been shown to generally decline in response to disturbance for a variety of different stressors and ecosystems. 


\subsubsection{Terresirial Ecosystems}

\subsubsection{Vegetation}

The SS site is dominated by open long-leaf pine forest (Pinus taeda and Pinus palustris) with a shrub understory. Some areas have been replaced uy oaks (Quercus sp.), hickory (Carya sp.), and magnolia (Magnolia sp.).

Along the drainages and in the vicinity of the ponds on the site, bottomland hardwood forest with bald cypress (Taxodium distichum), water tupelo (Nyssa aquatica), red maple (Acer rubrum), black willow (Salix nigra), and other obligate and facultative wetland tree species comprise the canopy and understory. Emergent wetland vegetation exists around open ponded areas and is composed of water lily (Nymphaea odorata), common cattail (Typha latifolia), buttonbush (Cephalanthus occidentalis), marsh elder (Iva frutescens), and arrow arum (Peltandra virginica) among other species.

\subsubsection{Animals}

Primary consumers at the site include large mammals (white-tailed deer [Odocoileus virginianus]) and small mammals (mice [Peromyscus sp.], short-tailed shrews [Blarina brevicauda], pine vole [Pitymus pinetorum], and eastern cottontail [Sylvilagus floridanus]). Secondary consumers include omnivorous raccoons (Procyon lotor), opossums (Didelphis marsupialis, and carnivorous coyotes[Canis latrans]).

Birds identified at SS are mostly passerines including the Bachman's sparrow (Aimophila aestivalis), whicri: is on the threatened species list, and the northern bobwhite (Colinus virginianus), which is a common game bird. A number of avian predators were also identified, including the red-tailed hawk (Buteo jamaicensis).

Reptiles and amphibians can be found in both aquatic and terrestrial habitats. Most of these animals at the site were observed in aquatic environments. However, a terrestrial sensitive species, the gopher tortoise (Gopherus polyphemus), was observed at the site.

\subsubsection{Aquatic Ecosystems}

\subsubsection{Macrobenthos}

The qualitative macrobenthos field data are summarized in Table 3-21. Ten taxa were observed at the various creek stations. Taxa identification and confirmation were performed using 
Peckarsky et al., 1990. The most prevalent taxa found throughout the site were Plecoptera, Coleoptera, Anisoptera, Decapoda, and Tabanidae. Station HHC-2 was the lowest in overall taxa richness, but was abundant in Chironomidae, which are generally a stress- tolerant species. This was probably more attributable to the station's creek topography than external sources of stress. Station HMC-3 had a large submerged root mass present that was found to support a diverse macroinvertebrate population. Grass shrimp and gastropods, taxa usually indicative of a healthy macrobenthos population, were unique to that station, which is located in close proximity to SGZ.

Stations HMC-2, HMC-5, and GRC-2 shared a common overall abundance and taxa richness, with three different taxa present. Station HHC-2 had two taxa that were abundant ( $>10$ individual organisms) and three taxa that were rare ( $<3$ individuals). Stations HHC-1, GRC-1, HMC-1, HMC-3, and HMC-4 shared a common overall abundance and taxa richness, with four to seven different taxa occurring at those stations. Crayfish, lampreys, salamanders, tadpoles, Anisoptera, Coleoptera, and Plecoptera were found commonly throughout the creek areas. The presence of these taxa indicates that a relatively high-quality habitat is present throughout the creek systems, with no observable site-related influence.

\subsubsection{Reptiles and Amphibians}

Salamanders are commonly found in or near creeks, springs, or seeps and were found at Half Moon Creek on the site. They are usually absent from large streams where predatory fish live. They are most common along the edges of small woodland streams where stones, chunks of wood, and miscellaneous debris provide ample shelter and food. Salamanders feed on a number of aquatic insects and other aquatic macroinvertebrates. They are in turn fed upon by larger salamanders, fish, birds, and mammals. Aquatic amphibians are good indicators of the health of aquatic systems. These animals are especially sensitive to pollution and loss of aquatic habitat. Snakes, including a water snake (Nerodea sp.), were observed along with lizards; turtles; skinks; toads; and frogs, including the river frog (Rana heckscheri).

\subsubsection{Finfish}

Fifteen finfish species were found on the site. The greatest diversity and abundance occurred at station HMC-4. No fish species were observed or collected at stations HHC-1 or GtP-1. The only abnormalities observed were external parasites on a bluegill (Lepomis macrochirus) found at station GRC-1. 
Table 3-21

Macrobenthos Qualitative Field Data, Salmon Site

\begin{tabular}{|c|c|c|c|c|c|c|c|c|c|}
\hline \multirow{2}{*}{ Taxon } & \multicolumn{9}{|c|}{ Salmon Site Station Locations } \\
\hline & HMC-1 & HMC-2 & HMC-3 & HMC-4 & HMC-5 & GRC-1 & GRC-2 & HHC-1 & HHC-2 \\
\hline Oligochaeta & $\begin{array}{l}a \\
\end{array}$ & & & & & & & & \\
\hline \multicolumn{10}{|l|}{ Isopoda } \\
\hline \multicolumn{10}{|l|}{ Amphipoda } \\
\hline \multicolumn{10}{|l|}{ Decapodaa } \\
\hline Insecta & $c^{b}$ & $\mathrm{C}$ & C & $\mathrm{R}^{\mathrm{c}}$ & & & & C & $R$ \\
\hline Anisoptera & C & C & C & $R$ & $\mathrm{C}$ & $\mathrm{C}$ & $\mathrm{C}$ & $\mathrm{C}$ & $A^{d}$ \\
\hline Zygoptera & C & & $\mathrm{C}$ & & & & & & \\
\hline \multicolumn{10}{|l|}{ Hemiptera } \\
\hline Coleoptera & C & & C & & C & A & $A$ & $A$ & $R$ \\
\hline \multicolumn{10}{|l|}{ Diptera } \\
\hline \multicolumn{10}{|l|}{ Tipulidae } \\
\hline Tabanidae & $R$ & & & $\mathrm{C}$ & & $R$ & & C & \\
\hline Culicidae & & & & & & C & & & $R$ \\
\hline Chironomidae & C & & C & $A$ & $\mathrm{C}$ & c & C & & \\
\hline Plecoptera & C & C & & & & & & & \\
\hline \multicolumn{10}{|l|}{ Ephemeroptera } \\
\hline \multicolumn{10}{|l|}{ Tricoptera } \\
\hline Gastropoda & & & C & & & & & & \\
\hline
\end{tabular}

${ }^{\text {B }}$ Blank = Not Observed

${ }^{b}$ Common 3-9 indlviduals

Rare $<3$ individuals

Abundant $>10$ individuals 
The cherryfin shiner (Lythrurus roseipinnis) was found at all three creeks and was the dominant species on the site. It was dominant at creek stations GRC-1, GRC-2, HMC-2, HMC-3, HMC-4, and HMC-5 and was also found at creek stations GRC-1, HMC-2, and HMC-3. The two other shiner species found on the site were the silverstripe shiner (Notropis stilbuis) at pond station BeP-1 and creek station HMC-4 and the blacktail shiner (Notropis venusta) found only at creek station HMC-4. Two darter species were found on the site: the blackbanded darter (Percina nigrofasciata) at creek station GRC-1 and the gulf darter (Etheostoma swaini) at the creek station HMC-3.

Additional fish species found on the site were the starhead top minnow (Fundulus notti), which was found at pond stations BeP-1 and BeP-2 and creek station HMC-4. This species was dominant at BeP-2. The chestnut lamprey (Ichthyomyzon castaneus) was found at three creek stations: GRC-2, HMC-4, and HMC-5. The bluegill (Lepomis macrochirus) was dominant at pond station HOP-1 and was also found at creek station GRC-1. The mosquitofish (Gambusia affinis) was dominant at pond station BeP-1 and was also found at pond station BeP-2.

\subsection{Potential Ecological Effects}

Chemical and radiological contaminants are the primary stressors at the SS. Other anthropogenic, physical, or naturally-occurring stressors are discussed in this assessment where appropriate; however, potential impacts to ecological receptors at the SS from significant off-site (non-SS) stressor sources were not investigated for this BERA.

For a given set of environmental conditions, species have characteristic attributes, such as birth rates, age and sex distributions, migration patterns, and mortality rates. A species' habitat preferences, food preferences, and other behavioral characteristics (e.g., nesting, foraging, and rearing young) also may determine population size and distribution in an area and may also significantly affect the potential for exposure.

A contaminant entering the environment will cause adverse effects if

- It exists in a form and concentration sufficient to cause harm

- It comes in contact with organisms or environmental media with which it can interact

- The interaction that takes place is detrimental to life functions.

Adverse effects may also occur if a contaminant interacts with other chemicals already present in a synergistic manner that could raise the overall toxicity of the contaminated environment. The likelihood of ecological harm is thus a combined function of chemical, physical, and biological 
factors, depending on the nature of the contaminant and the environment into which it is released.

Ecological effects from a single or occasional release are likely to be considerably different than those associated with a continuous release. Contaminants may enter the environment or move among environmental compartments on several possible time scales, such as the following:

- Single event (e.g., from an accidental spill)

- Intermittently (e.g., from storms transporting surficial soil runoff)

- Seasonally (e.g., from heavy rainfall during the spring)

- Continuously (e.g., from groundwater discharge).

Some of these release scenarios may be occurring at the SS, and each type of release may produce a different level of stress on a given ecosystem. Since the AEC's testing program at the SS ceased in 1970 , the only contaminant releases to the SS environment potentially occurring are chronic in nature (e.g., groundwater discharge) or the result of intermittent episodes (e.g., heavy rainfall events). The assessment endpoints and measurement endpoints that have been selected for this assessment will address these different time spans and exposure durations, as well as the synergistic or antagonistic effects of different combinations of contaminants.

As stated above, the potential exposures to SS-related contaminants are expected to be chronic in nature. Chronic toxicity due to exogenous chemicals in an ecosystem can greatly increase the mortality rate of component populations or can change the organisms' ability to survive and reproduce in less direct ways, such as the following:

- Altering developmental rates, metabolic processes, physiologic function, or behavior patterns

- Increasing susceptibility to disease, parasitism, or predation

- Disrupting reproductive functions

- Causing mutations or otherwise reducing the viability of offspring.

Ecological effects are most easily expressed as some impairment of a biological function or condition. There are two basic approaches to expressing ecological effects: (1) observed effects or a statement of contaminant-related effects observed on site and an interpretation of associated ecological implications in relation to appropriate endpoints or (2) comparison of on-site measured concentrations to established benchmarks for the environmental media of concern. Both of these approaches, observed effects and comparison to benchmarks, were used in the ecological assessment of the various ecosystems at the SS. 
Contaminants may cause or induce changes in the composition and structure of a biotic community as a secondary effect of the changes in the size of particular populations. These species may be a major source of food or shelter for the rest of the community. Others may be crucial in maintaining a balance of species in a habitat.

\subsection{Endpoints}

An assessment endpoint is an expression of the environmental value that is to be protected while the measurement endpoint is a measurable ecological characteristic that is related to the characteristic chosen as the assessment endpoint (Suter, 1993). The quality of the terrestrial and aquatic ecosystems at the SS and their vitality as habitat is the primary assessment endpoint for this study.

\subsubsection{Aquatic Ecosystems}

The aquatic ecosystems at the SS were assessed using two assessment endpoints as presented in Table 3-22: (1) Benthic macroinvertebrate community viability and (2) Probability of subacute affects in pelagic organisms. The quality and suitability as habitat of the streams and ponds that make up the aquatic ecosystems at the SS, namely Half Moon Creek, Grantham Creek, Hickory Hollow Creek, Beaver Pond 1-A, Beaver Pond 2, Gator Pond, and Half Moon Creek Overflow Pond, can be measured through an analysis of the benthic invertebrate community and the application of specific community metrics, as employed by RBP III (EPA, 1989c). Biological communities reflect overall ecological integrity, integrating chemical, physical, and biological influences, as well as the effects of different ecological stressors. Communities provide a holistic measure of the aggregate impact of these stressors over time and fluctuating environmental conditions.

Benthic invertebrates comprise a heterogenous assemblage of animal taxa that inhabit the sediment or live on or in other bottom substrates in the aquatic environment and are common in most aquatic habitats. The macroinvertebrate communities are good indicators of localized conditions because many invertebrates have limited migration patterns or sessile modes of life and are, therefore, well suited for assessing site-specific impacts. The macroinvertebrate communities also integrate the effects of short-term environmental variations. 
Table 3-22

Assessment and Measurement Endpoints

for Aquatic Ecosystems,

Salmon Site

\begin{tabular}{||c|cc||}
\hline Assessment Endpoint & Measurement Endpoint \\
\hline $\begin{array}{c}\text { Benthic Macroinvertebrate } \\
\text { Community Viability }\end{array}$ & (1) & $\begin{array}{l}\text { Rapid Bioassessment Protocol III Metrics. } \\
\text { (2) }\end{array}$ \\
\begin{tabular}{c|cl||} 
Calculation of Estimated Aquatic Exposure Point \\
Concentrations for Contaminants and Comparison to \\
Literature-Derived Sediment or Water Quality Criteria.
\end{tabular} \\
\hline $\begin{array}{c}\text { Probability of Chronic Effects } \\
\text { in Pelagic Organisms }\end{array}$ & (1) & $\begin{array}{l}\text { Fish Species Survey and Determination of Tissue } \\
\text { Contaminant Burdens Relative to Literature-Derived } \\
\text { Reference Levels. }\end{array}$ \\
\hline
\end{tabular}

The measured community metrics from the streams and ponds associated with contaminant source areas at the SS are compared with the benthic macroinvertebrate community metrics of the reference locations to determine if site-related contaminants are impacting the ponds and streams at the SS and to determine the current overall biotic quality of the aquatic ecosystems.

In order to characterize the risk to the benthic macroinvertebrate communities, the estimated interstitial water concentrations of the $\mathrm{COC}$ were compared to ambient water quality criteria or standards for the protection of aquatic life or. when criteria were not available, threshold values as determined from the scientific literature.

The toxicity and kinetics of inorganics in sediment are not as well understood as for organics. For this reason, characterizing the risk to benthic organisms from metals in sediments will be accomplished by comparing the measured sediment concentration of the metals of concern to threshold concentrations as determined in the literature. The primary source of the biologically effective sediment concentrations is Long and Morgan (1990). Long and Morgan have compiled data from existing studies that link concentrations of contaminants with predicted or observed biological effects. From these data, concentrations were selected that represent the lower tenth percentile of the data. This concentration is the Effects Range - Low and is used as the benchmark value in the risk characterization for metals in sediments. 
The second assessment endpoint was the probability of chronic effects in pelagic organisms in the ponds and streams at the SS. Chronic exposure to site COPC may induce deoxyribonucleic acid (DNA) damage, cancer, reproductive failure, or other effects. Fish populations were surveyed and characterized in the ponds and streams at the SS. Tissues were analyzed from several species of fish collected at the site. These body burdens can be compared with literaturederived effect levels to address the probability effects associated with chronic exposure. Surface water concentrations of $\mathrm{COC}$ were also measured in the ponds and streams at the SS, and comparisons were made with ambient water-quality criteria or standards for the protection of aquatic life. When these criteria were unavailable, comparisons were made with threshold values as determined from the scientific literature.

Comparisons were also made between fish tissue samples collected at reference locations that were not directly impacted by the SS and fish tissue samples collected from areas of suspected or known contamination.

\subsubsection{Terrestrial Ecosystems}

The quality and suitability as habitat of the terrestrial ecosystems at the SS were assessed using two assessment endpoints as presented in Table 3-23: (1) change in floral community diversity and (2) probability of chronic effects in faunal community.

The maintenance of diversity of a rich floral community is the first assessment endpoint to be considered for terrestrial systems at the SS. The floral communities throughout the SS were surveyed in order to identify individual species and communities present and their relative abundance. Visual evidence of stress or vitality was also noted during this survey. Information collected during these field surveys was used to characterize the vegetative communities and to determine whether they exhibited characteristics of either stressed or healthy communities.

Sampling and analysis of plant tissues from reference sites and source areas were also conducted at the SS. The analytical results from this sampling yields information regarding the potential plant uptake of site-related contaminants and their potential adverse effects on individual plants and communities. The concentrations of contaminants detected in samples from reference areas were compared to samples collected in suspected source areas to determine whether there were any significant differences in plant tissue concentrations. Literature-derived toxicity data are used to determine whether the increased tissue concentrations could cause detrimental effects to individual plants and/or communities. 
The second assessment endpoint to be considered is the probability of chronic effects in the faunal communities at the SS. Chronic exposure to site COPC may induce DNA damage, cancer. reproductive failure. or other effects. The measurement endpoints will yield speciesspecific data that can be related to the entire SS. Avian species were surveyed in order to enumerate the different species using the site for nesting, breeding, feeding, or other activities.

Table 3.23

\section{Assessment and Measurement Endpoints for Terrestrial Ecosystems, Salmon Site}

\begin{tabular}{||c|c|c||}
\hline Assessment Endpoint & \multicolumn{1}{|c|}{ Measurement Endpoint } \\
\hline \hline Change in Flora Community Diversity & (1) & $\begin{array}{l}\text { Qualitative Evidence of Vegetative Stress or } \\
\text { Vitality. }\end{array}$ \\
\hline $\begin{array}{c}\text { Probability of Chronic Effects } \\
\text { in Fauna Community }\end{array}$ & (2) & $\begin{array}{l}\text { Vegetation Species Survey and Determination of } \\
\text { Tissue Contaminant Burdens Relative to } \\
\text { Literature-Derived Effects Levels. }\end{array}$ \\
\hline & (1) $\begin{array}{l}\text { Small Mammal Species Survey and Determination } \\
\text { of Tissue Contaminant Burdens Relative to } \\
\text { Literature-Derived Reference Levels. }\end{array}$ \\
(2) & $\begin{array}{l}\text { Large Mammal Species Survey and } \\
\text { Determination of Tissue Contaminant Burdens } \\
\text { Relative to Literature-Derived Reference Levels. } \\
\text { Calculation of Estimated Exposure to Species Not } \\
\text { Sampled (including Predators and Sensitive } \\
\text { Species) and Comparison with Literature-Derived } \\
\text { Effects Levels. } \\
\text { Terrestrial Toxicity Tests. }\end{array}$ \\
\hline \hline
\end{tabular}

Small and large mammal surveys and tissue sampling were also used to aid in estimating the probability of adverse effects in these populations. These mammal surveys identified and enumerated the specific mammalian species utilizing the SS for feeding, breeding, hunting, and other activities. The analytical results of the mamrnalian tissues collected from the SS were used to identify whether site-related contaminants are bioaccumulating in mammals that frequent the site, and if so, in what specific tissue has the bioaccumulation taken place and to what extent. 


\subsection{Problem Formulation Summary}

The SS can be segregated by ecosystem type into teriestrial and aquatic. Both ecosystems have COPC, receptors, and complete pathways. There is abundant habitat, and diverse plant and animal communities were observed in both ecosystems, but the potential exists for acute or chronic toxic effects from exposure to contaminants in soils, surface water, and sediments.

There are larger questions relative to the assessment goals for the SS: Are the COPC from previous site activities present in sufficient bioavailable concentrations, and are the COPC capable of bioaccumulation in SS flora and fauna to a level that might pose a risk to these organisms and these ecosystems? These questions were addressed via the analysis of the assessment and measurement endpoints through the processes of exposure effects and risk characterization in the following sections. 


\subsection{Exposure Characterization}

Exposure characterization involves the quantification of the magnitude or type of actual and/or potential exposures of ecological receptors to site-specific COPC. This part of the assessment includes quantification of stressor release, transport and fate. ecological receptor characterization, and determination (either by measurement or modeling) of EPCs.

\subsection{Transport and Fate Estimation}

The EPC in sediment, surface water. and surficial soil samples are represented by the 95-percent UCL of measured concentrations of constituents that passed the screening process outlined in Figure 3-3, calculated as shown in Section 3.2.2.9. Additionally, soil/water partition coefficients $\left(\mathrm{K}_{\mathrm{d}}\right)$, when available for inorganic COPC, were used to calculate aquatic EPC $\left(\mathrm{EPC}_{\mathrm{aq}}\right)$ to estimate the concentration of COPC in interstitial waters as that portion of the bulk sediment concentration that was bioavailable. This was calculated by the following equation:

$$
\mathrm{EPC}_{\mathrm{aq}}=\mathrm{EPC}_{\mathrm{sed}} / \mathrm{K}_{\mathrm{d}}
$$

The bioconcentration factor is another measure of fate, as it reflects the chemical-specific degree of uptake by organisms from water, osmotic exchange, and equilibrium. Bioconcentration factor values and $K_{d}$ values for inorganic COPC were obtained from the literature (EPA, 1986 and Baes et al., 1984).

\subsection{Ecological Receptors}

Evaluating risks posed by COPC to each and every species or population present is not feasible, and thus an assessment must focus on a limited number of receptors. This subset of potential ecological receptors may include organisms that are (1) chronically exposed to site-related COPC, (2) endangered, threatened, special concern, or protected species, (3) of relevance to assessment endpoints, or (4) chronically exposed via a pathway that is different from previously considered organisms.

Following is a discussion of selected receptors and the feeding habits and characteristics used to place them in the site-specific food web (Figure 4-1). These organisms were chosen based on their presence or suspected presence at the site, their trophic level, and their occupation of 


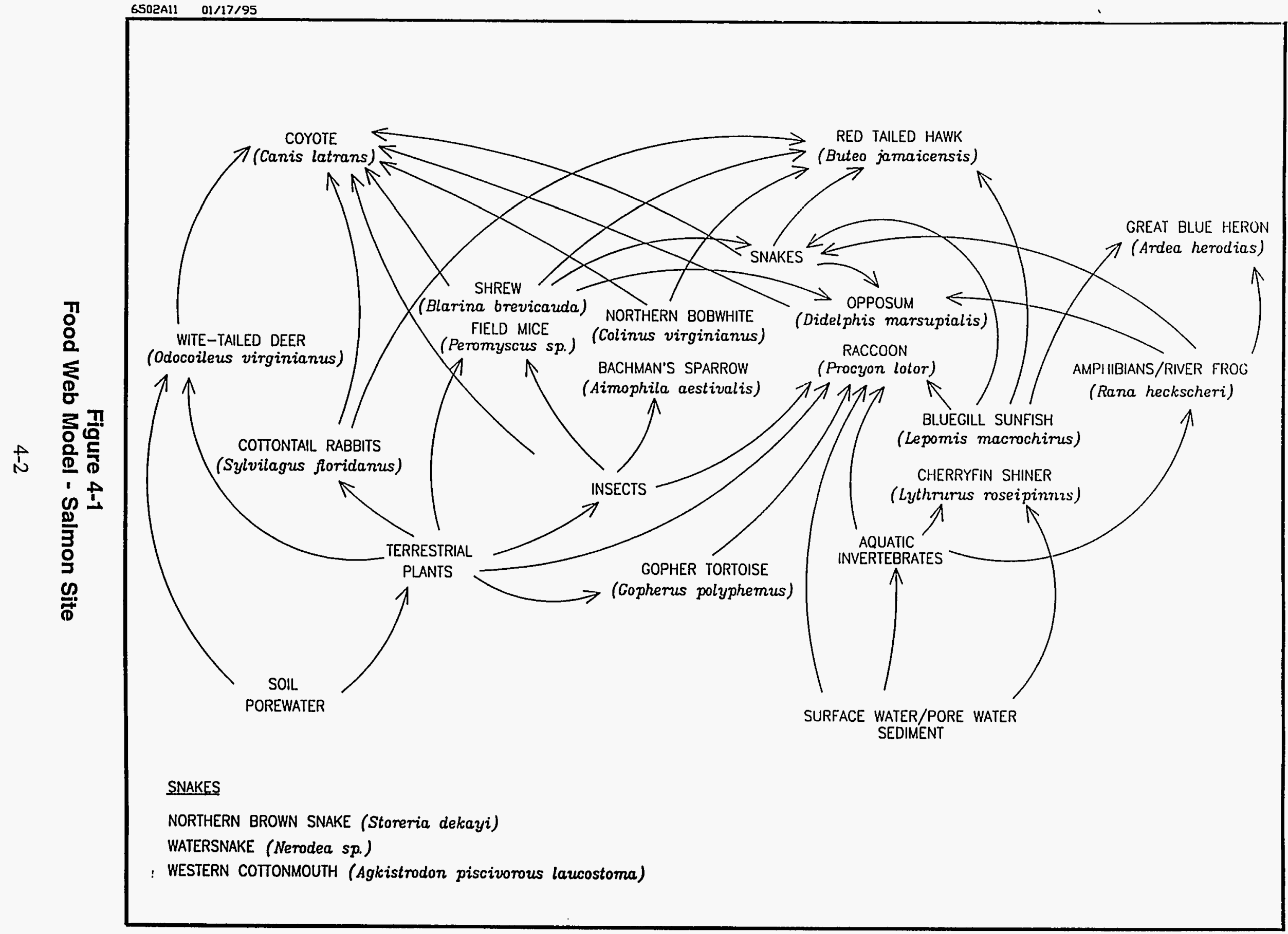


a specific niche not filled by another species. The chosen organisms included those sampled at the SS site.

\section{Raccoon (Procyon lotor)}

The raccoon is the most abundant and widespread medium-size omnivore in North America, except at the higher elevations of the Rocky Mountains and into southern Canada. Racoons are found near practically every aquatic habitat, particularly swamps, mangroves, floodplain forests. and freshwater and saltwater marshes. They are also common in suburban residential areas and abandoned farmlands. The raccoon is an omnivorous, primarily nocturnal feeder, eating fleshy fruits, nuts, acorns and corn. but also grains, insects, frogs, crayfish, eggs, and virtually any animal and vegetable matter (EPA, 1993). In residential areas, raccoons tip over or climb into garbage cans (Whitaker, 1993). The size of a raccoon's home range depends on its sex and age, food sources. and the season. Home ranges of a few hundred hectares appear to be most common, seasonally ranging from 5 to 5,000 hectares ( 2 to 2,024 acres) (EPA, 1993).

\section{Gopher Tortoise (Gopherus polyphemus)}

The gopher tortoise is a sensitive species and is the "gopher" of the Deep South. It is an

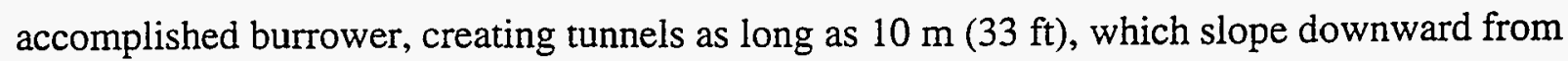
the surface, leveling off underground. The tortoise emerges daily in warm weather, usually in the cooler morning hours to forage on grass, leaves, wild fruits, and berries (Conant and Collins, 1991). No information was available on body weight, but a similar species, the Eastern Box Turtle, has a mean body weight of approximately 370 to 400 grams (EPA, 1993).

\section{White-Tailed Deer (Odocoileus virginianus)}

Once nearly exterminated in much of the Northeast and Midwest, white-tail deer are now the most plentiful game animal in eastern North America. They are found in farmland, brushy areas, and woods in most of the United States, except for a few western locations. White-tails graze on green plants and aquatic plants in the summer, and acorns, beechnuts and other nuts and corn in the fall, and feed on woody vegetation, including the twigs and buds of viburnum, birch, maple, and many conifers in the winter. Bucks and doe herd separately most of the year, but in winter gather together or "herd up" (Whitaker, 1993).

\section{Red-Tailed Hawk (Buteo jamaicensis)}

This is one of the most common and widespread members of the genus Buteo in the continental United States and Canada (Brown and Amadon, 1968). Red-tailed hawks live in a variety of habitats, such as farmland, woodlands, mountains, and deserts, as long as there is open country 
interspersed with woods, bluffs, or streamside trees. Small mammals, including mice, shrews, voles, rabbits, and squirrels are important prey, particúlarly during winter. Red-tails also eat birds, lizards, snakes, and large insects, depending on availability (EPA, 1993). Home range has been reported as approximately 165 hectares (66.8 acres) (Janes. 1984). Body weights average 1,126 grams (Dunning, 1993).

\section{Bachman's Sparrow (Aimophila aestivalis)}

Bachman's sparrow is considered a sensitive species in the United States. It dwells in open stretches of pines with grass and scattered shrubs for ground cover. Like many other sparrows, it feeds on insects, such as crickets and beetles, and on seeds of grasses and sedges. It spends most of its time feeding on the ground (Whitaker, 1993). Body weights average 19.7 grams (Dunning, 1993).

\section{Mice (Peromyscus sp.)}

Mice of the genus Peromyscus (deer [P. maniculatus] or white-footed mice [P. leucopus]) have adapted to every possible North American habitat where they are often the most abundant mammals present (Whitaker, 1993). The habitat for mice includes all types of dry-land habitats within their range, including coniferous and deciduous forest and grasslands, as well as deserts and alpine tundra. Deer mice are omnivorous and highly opportunistic, which leads to substantial regional and seasonal variation in their diet. They eat principally seeds, arthropods, some green vegetation, roots, fruits, and fungi, as available. The nonseed plant materials provide a significant portion of the mouse's daily water requirements. Body weights of deer mice range from 15 to 35 grams, averaging 21 grams. Home range sizes vary seasonally and regionally from 0.014 to 0.128 hectares (0.006 to 0.05 acres) (EPA, 1993).

\section{Great Blue Heron (Ardea herodias)}

Although not observed at the site at the time of the species survey, this bird is likely to use the aquatic habitat at the SS and would represent a top consumer in the aquatic food chain. The heron feeds primarily on aquatic animals, preferring fish, but will also consume amphibians, reptiles, and crustaceans. Its feeding territory changes seasonally from 0.6 to 8.4 hectares (0.24 to 20.7 acres). Body weight averages 2,229 grams (EPA, 1993). 


\subsection{Estimated Receptor Exposures}

\subsubsection{Aquatic Biota Tissue Analysis}

From February 26 to 28, 1993, fish tissues were collected from surface water bodies on the SS and the Reference Pond site. Sample collection was attempted at all 15 surface water stations. Although several attempts were made. no fish were obtained from Hickory Hollow Creek, Gator Pond, or Half Moon Creek Overflow Pond. Six fish samples were collected for analysis from the remaining stations. The following five species of fish were collected for whole body analysis: channel catfish (Ictalurus punctatus), bluegill (Lepomis macrochirus), starhead topminnow (Fundulus notti), golden shiner (Notropis sp.), and cherryfin shiner (Lythrurus roseipinnis).

Fish collection methods included dip-netting, baited hooks on trap lines, and baited killi-pots. Bait included raccoon meat, sardines, and crawfish. Due to the minimal volume of fish collected at Half Moon and Grantham Creeks, a composite sample of the species collected throughout those creeks was analyzed. An insufficient amount of fish tissue was obtained at Grantham Creek (GrC-composite), Beaver Pond-1A (BeP-1A), and Beaver Pond-2 (BeP-2) for the following analyses: alpha-total, beta-total, pesticides, and metals. However, there were sufficient fish tissues for the gamma spectrometry analysis to be performed. No analyses were carried out for cyanide or volatile or semivolatile organics.

Tissue analysis data are presented in Appendix A of this report (Tables A-2.1 through A-2.5) for inorganic, pesticide/PCBs, gross alpha, gross beta, gamma spectroscopy, and tritium analyses. All concentrations are reported on a wet weight basis.

Of the COPC for water and sediment, aluminum, barium, manganese, and zinc were found in all fish tissue samples (Reference Pond, Beaver Pond, and Half Moon Creek). Lead was found in a site sample and the reference sample at estimated concentrations below the CRDL.

No pesticides or PCBs were detected in fish samples. Gross alpha was not detected while gross beta was detected in all samples. On-site fish samples had concentrations of 0.6 and $0.9 \mathrm{pCi} / \mathrm{g}$, and reference samples had $1.3 \mathrm{pCi} / \mathrm{g}$. Tritium was detected in Grantham Creek, Half Moon Creek, and the Beaver Pond samples at levels ranging from $0.24 \mathrm{pCi} / \mathrm{g}$ to $0.55 \mathrm{pCi} / \mathrm{g}$. Tritium was not detected in the Reference Pond sample. Of the other radionuclides, only potassium- 40 was detected once in the Beaver Pond (7.2 pCi/g) and in the Reference Pond (2.8 pCi/g). Fish tissue detected concentrations are summarized in Table 4-1. 
Table 4-1

Summary of Constituent Concentrations in Fish Tissue,

Salmon Site

(Page 1 of 2)

\begin{tabular}{|c|c|c|c|c|c|c|}
\hline \multirow[b]{2}{*}{ Parameter } & \multirow[b]{2}{*}{$\begin{array}{c}\text { Reference } \\
\text { Station } \\
\end{array}$} & \multicolumn{5}{|c|}{ Salmon Site Stations } \\
\hline & & $\begin{array}{l}\text { Number of } \\
\text { Samples }\end{array}$ & $\begin{array}{l}\text { Number of } \\
\text { Detections }\end{array}$ & $\begin{array}{c}\text { Average } \\
\text { Concentration }^{\mathrm{a}} \\
\end{array}$ & Minimum & Maximum \\
\hline $\begin{array}{l}\text { METALS (mg/kg) } \\
\text { Aluminum }\end{array}$ & 13.4 & 2 & 2 & 3.80 & $2.3 \mathrm{BJ}$ & $5.3 B^{c} J^{d}$ \\
\hline Barium & $2.2 \mathrm{BJ}$ & 2 & 2 & 36.15 & $6.1 \mathrm{BJ}$ & 66.2 \\
\hline Calcium & 3690.0 & 2 & 2 & $21,310.00$ & $8,020.0$ & $34,600.0$ \\
\hline Chromium & $0.35 \mathrm{BJ}$ & 2 & 2 & 0.32 & $0.25 \mathrm{BJ}$ & $0.38 \mathrm{BJ}$ \\
\hline Copper & $N D^{e}$ & 2 & 2 & 2.50 & 1.4 & 3.6 \\
\hline Iron & 41.6 & 2 & 2 & 18.65 & 13.0 & 24.3 \\
\hline Lead & $0.08 \mathrm{BW} \mathrm{f}$ & 2 & 1 & 0.12 & $0.12 \mathrm{BJ}$ & $0.12 \mathrm{BJ}$ \\
\hline Magnesium & 291.0 & 2 & 2 & 516.00 & 351.0 & 681.0 \\
\hline Manganese & 13.4 & 2 & 2 & 28.65 & 28.2 & 29.1 \\
\hline Mercury & ND & 2 & 1 & 0.43 & 0.43 & 0.43 \\
\hline Potassium & 2910.0 & 2 & 2 & $2,960.00$ & $2,790.0$ & $3,130.0$ \\
\hline Selenium & ND & 2 & 1 & 0.34 & 0.345 & 0.345 \\
\hline Sodium & 750.0 & 2 & 2 & $1,096.00$ & 942.0 & $1,250.0$ \\
\hline Thallium & ND & 2 & 1 & 0.05 & $0.05 \mathrm{BWJ}$ & $0.05 \mathrm{BWJ}$ \\
\hline Zinc & 17.6 & 2 & 2 & 17.35 & 15.1 & 19.6 \\
\hline
\end{tabular}

Refer to footnotes at end of table. 
Table 4-1

Summary of Constituent Concentrations in Fish Tissue,

Salmon Site

(Page 2 of 2)

\begin{tabular}{|c|c|c|c|c|c|c|}
\hline \multirow[b]{2}{*}{ Parameter } & \multirow[b]{2}{*}{$\begin{array}{c}\text { Reference } \\
\text { Station }\end{array}$} & \multicolumn{5}{|c|}{ Salmon Site Stations } \\
\hline & & $\begin{array}{c}\text { Number of } \\
\text { Samples }\end{array}$ & $\begin{array}{l}\text { Number of } \\
\text { Detections }\end{array}$ & $\begin{array}{c}\text { Average } \\
\text { Concentration }^{\mathrm{a}}\end{array}$ & Minimum & Maximum \\
\hline$\frac{\text { GROSS BETA }(p C i / g)^{9} \text { Wet weight basis }}{\text { Beta }}$ & 1.3 & 2 & 2 & 0.75 & 0.6 & 0.9 \\
\hline$\frac{\text { TRITIUM (pCi/g) }}{\text { Tritium }}$ & ND & 5 & 3 & 0.43 & 0.24 & 0.55 \\
\hline$\frac{\text { GAMMA SPECTROSCOPY }}{\text { Potassium-40 }}(\mathrm{pCi} / \mathrm{g})$ & 2.8 & 5 & 1 & 7.20 & 7.2 & 7.2 \\
\hline
\end{tabular}

${ }_{b}^{a}$ Average concentration was calculated from detected concentrations only.

Milligram per kllogram

The reported value is below the Contract Required Delection Limit, but above the Instrument Detection Limit.

Reported result is quantitatively estimated.

Not detected

Postdigestion spike for furnace atomic absorption analysis is out of control limit.

Picocurie per gram 


\subsubsection{Terrestrial Vegetation Tissue Analysis}

In conjunction with the April 26 to 30, 1993, soil sampling event, samples of terrestrial vegetation were collected for chemical and radiological analyses. The two most abundant species of pine encountered at the SS were longleaf (Pinus palustris) and loblolly (Pinus taeda), and the samples for the most part consisted of these two species. Trees sampled were on average greater than 20 years of age. The field adjacent to the catfish pond was utilized as the reference location for vegetation samples.

Vegetation samples were taken from each of the individual sites identified in Table 3-8 and Figure 3-2. Nineteen samples were taken: 18 sites plus 1 reference site. The reference sample was collected off site in the vicinity of the reference pond. Each tree sampled was cored using a $1 / 4$-in.-increment corer in order to determine the age of the specimen. This core was then used as part of the sample. The remainder of the sample mass consisted of branch segments cut into small pieces using a hand saw and pruning shears. Each of the samples was a composite formed from cores and tree branch segments taken from at least 10 trees per site. The trees sampled were no further than $60 \mathrm{~m}(200 \mathrm{ft})$ from the center of the site. Cores and clipped-branch segments were packaged in sealable plastic bags and glass jars, immediately placed on ice in coolers, and shipped to the ITAS Laboratory for analysis. Vegetation samples submitted to the laboratory were analyzed for inorganics, pesticides/PCBs, and radionuclides. These samples were not analyzed for tritium or cyanide.

The only sample that was not comprised of pine tree wood was taken from SA-6, the Helicopter Pad. No trees were within $60 \mathrm{~m}$ ( $200 \mathrm{ft}$ ) of the center of the sampling site; therefore, the vegetation sampled consisted of hay and a low vine that was growing in the open pasture. This sample was packaged and handled in the same fashion as the other vegetation samples.

Plant tissue analysis data are presented in Appendix A of this report. Tables A-6.1 through A-6.5 present the inorganics, pesticides and PCBs, semivolatiles, gross alpha and beta, and gamma spectroscopy data sets, respectively. The majority of inorganic constituents detected in vegetation are naturally occurring soil constituents. Many are essential nutrients.

Concentrations of inorganics in vegetation on the SS were, for the most part, similar to those from the reference area. Of the COPC for soil, copper was only detected in plants from the Clean Burn Pit in SA-2 and the Helicopter Pad in SA-6 (6.70 and $6.30 \mathrm{mg} / \mathrm{kg}$, respectively) and at the reference area $(3.20 \mathrm{mg} / \mathrm{kg})$. Lead was detected in samples from all source areas, but not in the sample from the reference area. The highest average concentration was at SA-3 (10.07 mg/kg). 
Gross alpha was not detected in the reference area vegetation. but was detected in some samples from all SAs (0.26 to $3.89 \mathrm{pCi} / \mathrm{g}$ ). Levels were particularly high at the helicopter landing pad in SA-6 (2.06 pCi $/ \mathrm{g})$ and at the South Substation in SA-4 (3.89 pCi $/ \mathrm{g})$. Gross beta was higher in vegetation from the reference area $(1.00 \mathrm{pCi} / \mathrm{g})$ than all other areas $(0.3$ to $0.9 \mathrm{pCi} / \mathrm{g})$ except SA-6 ( $2.6 \mathrm{pCi} / \mathrm{g})$. Several radionuclides were detected in the plant tissues. Cesium- 137 was detected in one SA-5 sample $(0.21 \mathrm{pCi} / \mathrm{g})$ and lead-212, bismuth-214, and cerium-139 were detected only in the SA-6 sample. Tin-113 was detected only in the reference sample. Potassium-40, beryllium- 7 , and lead- 210 were detected in samples from several locations. Table 4-2 summarizes the detected levels of constituents in vegetation on the SS and at the reference area.

\subsubsection{Terrestrial Wildlife Tissue Analysis}

The active collection of avian species was attempted during February 1993 using mist-netting near the junction of Main Road and Toxie Road where doves had been observed. The mistnetting was stretched across an open field in likely flight paths for 48 hours. The net was checked periodically, but the attempts proved unsuccessful. The same area was then flushed three to four times at dawn and dusk each day in hopes of being able to shoot game bird species. However, because of the time of year, game birds were scarce, and none was collected.

During the February 1993 investigation, large and small mammals were collected for metals and radionuclide tissue analysis. White-tailed deer (Odocoileus virginianus), cottontail rabbits (Sylvilagus floridanus), and marsh rabbits (Sylvilagus palustris) were collected with firearms under the supervision of the Mississippi Department of Game, Fish, and Wildlife. These collection activities took place on the nights of February 25 and 26, 1993. In all, seven whitetail deer and seven rabbits were collected during the two nights. Specific tissues analyzed from these specimens included fat, muscle, bone, and liver. Tissues were harvested as close to the time of death as possible, packed in appropriate containers on ice in coolers, and shipped to the ITAS Laboratory for analysis. 
Table 4-2

Summary of Constituent Concentrations in Vegetation,

Salmon Site

(Page 1 of 9 )

\begin{tabular}{|c|c|c|c|c|c|c|}
\hline Parameter & Type & $\begin{array}{l}\text { Number of } \\
\text { Samples }\end{array}$ & $\begin{array}{l}\text { Number of } \\
\text { Detections }\end{array}$ & $\begin{array}{c}\text { Average } \\
\text { Concentration }^{a}\end{array}$ & Minimum & Maximum \\
\hline $\begin{array}{l}\text { METALS }(\mathrm{mg} / \mathrm{kg})^{\mathrm{b}} \text { Wet weight basis } \\
\text { Aluminum }\end{array}$ & $\begin{array}{c}\text { Reference } \\
\text { SA-1 } \\
\text { SA-2 } \\
\text { SA-3 } \\
\text { SA-4 } \\
\text { SA-5 } \\
\text { SA-6 } \\
\text { Sitewide }\end{array}$ & $\begin{array}{c}1 \\
4 \\
2 \\
4 \\
5 \\
2 \\
1 \\
18\end{array}$ & $\begin{array}{c}1 \\
4 \\
2 \\
4 \\
5 \\
2 \\
1 \\
18\end{array}$ & $\begin{array}{l}207.00 \\
107.63 \\
147.00 \\
100.05 \\
100.12 \\
201.50 \\
238.00 \\
126.12\end{array}$ & $\begin{array}{c}207.0 \\
61.6 \\
115.0 \\
87.6 \\
47.6 \\
159.0 \\
238.0 \\
126.12\end{array}$ & $\begin{array}{l}207.0 \\
159.0 \\
183.0 \\
115.0 \\
131.0 \\
244.0 \\
238.0 \\
244.0\end{array}$ \\
\hline Barium & $\begin{array}{c}\text { Reference } \\
\text { SA-1 } \\
\text { SA-2 } \\
\text { SA-3 } \\
\text { SA-4 } \\
\text { SA-5 } \\
\text { SA-6 } \\
\text { Sitewide }\end{array}$ & $\begin{array}{c}1 \\
4 \\
2 \\
4 \\
5 \\
2 \\
1 \\
18\end{array}$ & $\begin{array}{c}1 \\
4 \\
2 \\
4 \\
5 \\
2 \\
1 \\
18\end{array}$ & $\begin{array}{c}8.00 \\
11.20 \\
6.75 \\
7.00 \\
5.64 \\
12.60 \\
169.00 \\
17.15\end{array}$ & $\begin{array}{c}8.0 \mathrm{~B}^{\mathrm{c} J} \mathrm{~d} \\
2.8 \mathrm{BJ} \\
6.4 \mathrm{BJ} \\
6.2 \mathrm{BJ} \\
3.4 \mathrm{BJ} \\
8.0 \mathrm{BJ} \\
169.0 \\
2.8 \mathrm{BJ}\end{array}$ & $\begin{array}{c}8.0 \mathrm{BJ} \\
16.5 \mathrm{BJ} \\
7.1 \mathrm{BJ} \\
7.6 \mathrm{BJ} \\
9.0 \mathrm{BJ} \\
17.2 \mathrm{BJ} \\
169.0 \\
169.0\end{array}$ \\
\hline Calcium & $\begin{array}{c}\text { Reference } \\
\text { SA-1 } \\
\text { SA-2 } \\
\text { SA-3 } \\
\text { SA-4 } \\
\text { SA-5 } \\
\text { SA-6 } \\
\text { Sitewide }\end{array}$ & $\begin{array}{c}1 \\
4 \\
2 \\
4 \\
5 \\
2 \\
1 \\
18\end{array}$ & $\begin{array}{c}1 \\
4 \\
2 \\
4 \\
5 \\
2 \\
1 \\
18\end{array}$ & $\begin{array}{l}1,650.00 \\
2,002.90 \\
1,591.50 \\
1,755.00 \\
2,150.00 \\
2,515.00 \\
4,840.00 \\
2,157.39\end{array}$ & $\begin{array}{c}1,650.0 \\
1,610.0 \\
923.0 \mathrm{BJ} \\
1,260.0 \\
1,470.0 \\
2,330.0 \\
4,840.0 \\
923.0 \mathrm{BJ}\end{array}$ & $\begin{array}{l}1,650.0 \\
2,430.0 \\
2,260.0 \\
2,270.0 \\
3,280.0 \\
2,700.0 \\
4,840.0 \\
4,840.0\end{array}$ \\
\hline
\end{tabular}

Refer to footnotes at end of table. 
Table 4-2

Summary of Constituent Concentrations in Vegetation, Salmon Site

(Page 2 of 9)

\begin{tabular}{|c|c|c|c|c|c|c|}
\hline Parameter & Type & $\begin{array}{c}\text { Number of } \\
\text { Samples }\end{array}$ & $\begin{array}{l}\text { Number of } \\
\text { Detections }\end{array}$ & $\begin{array}{c}\text { Average } \\
\text { Concentration }^{a}\end{array}$ & Minimum & Maximum \\
\hline Chromium & $\begin{array}{c}\text { Reference } \\
\text { SA-1 } \\
\text { SA-2 } \\
\text { SA-3 } \\
\text { SA-4 } \\
\text { SA-5 } \\
\text { SA-6 } \\
\text { Sitewide }\end{array}$ & $\begin{array}{c}1 \\
4 \\
2 \\
4 \\
5 \\
2 \\
1 \\
18\end{array}$ & $\begin{array}{l}0 \\
0 \\
1 \\
0 \\
0 \\
0 \\
1 \\
2\end{array}$ & $\begin{array}{l}N D^{e} \\
N D \\
5.90 \\
N D \\
N D \\
N D \\
0.99 \\
3.45\end{array}$ & $\begin{array}{l}\text { ND } \\
\text { ND } \\
5.90 \\
\text { ND } \\
\text { ND } \\
\text { ND } \\
0.99 \mathrm{BJ} \\
0.99 \mathrm{BJ}\end{array}$ & $\begin{array}{c}\text { ND } \\
\text { ND } \\
5.90 \\
\text { ND } \\
\text { ND } \\
\text { ND } \\
0.99 \text { BJ } \\
5.90\end{array}$ \\
\hline Copper & $\begin{array}{c}\text { Reference } \\
\text { SA-1 } \\
\text { SA-2 } \\
\text { SA-3 } \\
\text { SA-4 } \\
\text { SA-5 } \\
\text { SA-6 } \\
\text { Sitewide }\end{array}$ & $\begin{array}{c}1 \\
4 \\
2 \\
4 \\
5 \\
2 \\
1 \\
18\end{array}$ & $\begin{array}{l}1 \\
0 \\
1 \\
0 \\
0 \\
0 \\
1 \\
2\end{array}$ & $\begin{array}{l}3.20 \\
N D \\
6.70 \\
N D \\
N D \\
N D \\
6.30 \\
6.50\end{array}$ & $\begin{array}{c}3.2 \mathrm{BJ} \\
\text { ND } \\
6.7 \\
\text { ND } \\
\text { ND } \\
\text { ND } \\
6.3 \\
6.3\end{array}$ & $\begin{array}{c}3.2 \mathrm{BJ} \\
\text { ND } \\
6.7 \\
\text { ND } \\
\text { ND } \\
\text { ND } \\
6.3 \\
6.7\end{array}$ \\
\hline Iron & $\begin{array}{c}\text { Reference } \\
\text { SA-1 } \\
\text { SA-2 } \\
\text { SA-3 } \\
\text { SA-4 } \\
\text { SA-5 } \\
\text { SA-6 } \\
\text { Sitewide }\end{array}$ & $\begin{array}{c}1 \\
4 \\
2 \\
4 \\
5 \\
2 \\
1 \\
18\end{array}$ & $\begin{array}{c}1 \\
4 \\
2 \\
4 \\
5 \\
2 \\
1 \\
18\end{array}$ & $\begin{array}{c}28.90 \\
25.68 \\
31.30 \\
21.65 \\
20.24 \\
24.40 \\
165.00 \\
31.49\end{array}$ & $\begin{array}{c}28.9 \\
16.0 \mathrm{BJ} \\
13.9 \mathrm{BJ} \\
16.3 \mathrm{BJ} \\
13.2 \mathrm{BJ} \\
20.7 \\
165.0 \\
13.2 \mathrm{BJ}\end{array}$ & $\begin{array}{c}28.9 \\
37.3 \\
48.7 \\
25.8 \\
29.8 \\
28.1 \\
165.0 \\
165.0\end{array}$ \\
\hline
\end{tabular}

Refer to footnotes at end of table. 
Table 4-2

Summary of Constituent Concentrations in Vegetation, Salmon Site

(Page 3 of 9)

\begin{tabular}{|c|c|c|c|c|c|c|}
\hline Parameter & Type & $\begin{array}{c}\text { Number of } \\
\text { Samples }\end{array}$ & $\begin{array}{l}\text { Number of } \\
\text { Detections }\end{array}$ & $\begin{array}{c}\text { Average } \\
\text { Concentration }^{\mathrm{a}} \\
\end{array}$ & Minimum & Maximum \\
\hline Lead & $\begin{array}{c}\text { Reference } \\
\text { SA-1 } \\
\text { SA-2 } \\
\text { SA-3 } \\
\text { SA-4 } \\
\text { SA-5 } \\
\text { SA-6 } \\
\text { Sitewide }\end{array}$ & $\begin{array}{c}1 \\
4 \\
2 \\
4 \\
5 \\
2 \\
1 \\
18\end{array}$ & $\begin{array}{c}0 \\
4 \\
2 \\
4 \\
1 \\
1 \\
1 \\
13\end{array}$ & $\begin{array}{c}\text { ND } \\
2.40 \\
2.45 \\
10.07 \\
4.30 \\
1.90 \\
2.70 \\
4.25\end{array}$ & $\begin{array}{c}\text { ND } \\
1.30 \\
1.60 \\
1.60 \\
4.30 \mathrm{~S} \\
1.90 \\
2.70 \\
1.30\end{array}$ & $\begin{array}{c}N D \\
3.70 \mathrm{~S}^{f} \\
3.30 \\
14.30 \\
4.30 \mathrm{~S} \\
1.90 \\
2.70 \\
14.30\end{array}$ \\
\hline Magnesium & $\begin{array}{c}\text { Reference } \\
\text { SA-1 } \\
\text { SA-2 } \\
\text { SA-3 } \\
\text { SA-4 } \\
\text { SA-5 } \\
\text { SA-6 } \\
\text { Sitewide }\end{array}$ & $\begin{array}{c}1 \\
4 \\
2 \\
4 \\
5 \\
2 \\
1 \\
18\end{array}$ & $\begin{array}{c}1 \\
4 \\
2 \\
4 \\
5 \\
2 \\
1 \\
18\end{array}$ & $\begin{array}{l}289.00 \\
312.50 \\
311.50 \\
249.25 \\
264.20 \\
373.00 \\
770.00 \\
317.06\end{array}$ & $\begin{array}{l}289.0 \mathrm{BJ} \\
294.0 \mathrm{BJ} \\
238.0 \mathrm{BJ} \\
225.0 \mathrm{BJ} \\
217.0 \mathrm{BJ} \\
352.0 \mathrm{BJ} \\
770.0 \mathrm{BJ} \\
217.0 \mathrm{BJ}\end{array}$ & $\begin{array}{l}289.0 \mathrm{BJ} \\
328.0 \mathrm{BJ} \\
385.0 \mathrm{BJ} \\
281.0 \mathrm{BJ} \\
341.0 \mathrm{BJ} \\
394.0 \mathrm{BJ} \\
770.0 \mathrm{BJ} \\
770.0 \mathrm{BJ}\end{array}$ \\
\hline Manganese & $\begin{array}{c}\text { Reference } \\
\text { SA-1 } \\
\text { SA-2 } \\
\text { SA-3 } \\
\text { SA-4 } \\
\text { SA-5 } \\
\text { SA-6 } \\
\text { Sitewide }\end{array}$ & $\begin{array}{c}1 \\
4 \\
2 \\
4 \\
5 \\
2 \\
1 \\
18\end{array}$ & $\begin{array}{c}1 \\
4 \\
2 \\
4 \\
5 \\
2 \\
1 \\
18\end{array}$ & $\begin{array}{c}58.90 \\
125.93 \\
205.50 \\
131.98 \\
93.30 \\
140.00 \\
300.00 \\
138.28\end{array}$ & $\begin{array}{r}58.9 \\
63.7 \\
194.0 \\
87.9 \\
33.4 \\
102.0 \\
300.0 \\
33.4\end{array}$ & $\begin{array}{r}58.9 \\
155.0 \\
217.0 \\
168.0 \\
115.0 \\
178.0 \\
300.0 \\
300.0\end{array}$ \\
\hline
\end{tabular}

Refer to footnotes at end of table. 
Table 4-2

Summary of Constituent Concentrations in Vegetation,

Salmon Site

(Page 4 of 9)

\begin{tabular}{|c|c|c|c|c|c|c|}
\hline Parameter & Type & $\begin{array}{c}\text { Number of } \\
\text { Samples }\end{array}$ & $\begin{array}{l}\text { Number of } \\
\text { Detections }\end{array}$ & $\begin{array}{c}\text { Average } \\
\text { Concentration }^{\mathrm{a}}\end{array}$ & Minimum & Maximum \\
\hline Potassium & $\begin{array}{c}\text { Reference } \\
\text { SA-1 } \\
\text { SA-2 } \\
\text { SA-3 } \\
\text { SA-4 } \\
\text { SA-5 } \\
\text { SA-6 } \\
\text { Sitewide }\end{array}$ & $\begin{array}{c}1 \\
4 \\
2 \\
4 \\
5 \\
2 \\
1 \\
18\end{array}$ & $\begin{array}{c}1 \\
3 \\
2 \\
2 \\
5 \\
2 \\
1 \\
15\end{array}$ & $\begin{array}{c}1,010.00 \\
842.67 \\
778.50 \\
680.00 \\
769.40 \\
760.50 \\
623.00 \\
762.40\end{array}$ & $\begin{array}{c}1,010.0 \\
676.0 \mathrm{BJ} \\
647.0 \mathrm{BJ} \\
606.0 \mathrm{BJ} \\
623.0 \mathrm{BJ} \\
701.0 \mathrm{BJ} \\
623.0 \mathrm{BJ} \\
606.0 \mathrm{BJ}\end{array}$ & $\begin{array}{c}1,010.0 \\
1,090.0 \\
910.0 \mathrm{BJ} \\
754.0 \mathrm{BJ} \\
1,000.0 \mathrm{BJ} \\
820.0 \mathrm{BJ} \\
623.0 \mathrm{BJ} \\
1,090.0 \mathrm{BJ}\end{array}$ \\
\hline Sodium & $\begin{array}{c}\text { Reference } \\
\text { SA-1 } \\
\text { SA-2 } \\
\text { SA-3 } \\
\text { SA-4 } \\
\text { SA-5 } \\
\text { SA-6 } \\
\text { Sitewide }\end{array}$ & $\begin{array}{c}1 \\
4 \\
2 \\
4 \\
5 \\
2 \\
1 \\
18\end{array}$ & $\begin{array}{c}1 \\
4 \\
2 \\
4 \\
5 \\
2 \\
1 \\
18\end{array}$ & $\begin{array}{l}38.20 \\
50.56 \\
45.00 \\
52.90 \\
53.60 \\
50.70 \\
52.50 \\
51.43\end{array}$ & $\begin{array}{l}38.2 \mathrm{BJ} \\
42.7 \mathrm{BJ} \\
41.6 \mathrm{BJ} \\
37.1 \mathrm{BJ} \\
36.1 \mathrm{BJ} \\
48.5 \mathrm{BJ} \\
52.5 \mathrm{BJ} \\
36.1 \mathrm{BJ}\end{array}$ & $\begin{array}{l}38.2 \mathrm{BJ} \\
65.1 \mathrm{BJ} \\
48.4 \mathrm{BJ} \\
63.3 \mathrm{BJ} \\
64.2 \mathrm{BJ} \\
52.9 \mathrm{BJ} \\
52.5 \mathrm{BJ} \\
65.1 \mathrm{BJ}\end{array}$ \\
\hline Zinc & $\begin{array}{c}\text { Reference } \\
\text { SA-1 } \\
\text { SA-2 } \\
\text { SA-3 } \\
\text { SA-4 } \\
\text { SA-5 } \\
\text { SA-6 } \\
\text { Sitewide }\end{array}$ & $\begin{array}{c}1 \\
4 \\
2 \\
4 \\
5 \\
2 \\
1 \\
18\end{array}$ & $\begin{array}{c}1 \\
4 \\
2 \\
4 \\
5 \\
2 \\
1 \\
18\end{array}$ & $\begin{array}{l}12.20 \\
21.35 \\
23.30 \\
12.20 \\
39.12 \\
56.50 \\
43.50 \\
29.58 \\
\end{array}$ & $\begin{array}{c}12.2 \mathrm{E}^{\mathrm{g} J} \\
13.2 \mathrm{EJ} \\
19.5 \mathrm{EJ} \\
8.4 \mathrm{EJ} \\
8.6 \mathrm{EJ} \\
11.0 \mathrm{EJ} \\
43.5 \mathrm{EJ} \\
8.4 \mathrm{EJ}\end{array}$ & $\begin{array}{c}12.2 \mathrm{EJ} \\
29.5 \mathrm{EJ} \\
27.1 \mathrm{EJ} \\
16.5 \mathrm{EJ} \\
115.0 \mathrm{EJ} \\
102.0 \mathrm{EJ} \\
43.5 \mathrm{EJ} \\
115.0 \mathrm{EJ}\end{array}$ \\
\hline
\end{tabular}

Refer to footnotes at end of table. 
Table 4-2

Summary of Constituent Concentrations in Vegetation, Salmon Site

(Page 5 of 9)

\begin{tabular}{|c|c|c|c|c|c|c|}
\hline Parameter & Type & $\begin{array}{c}\text { Number of } \\
\text { Samples }\end{array}$ & $\begin{array}{l}\text { Number of } \\
\text { Detections }\end{array}$ & $\begin{array}{c}\text { Average } \\
\text { Concentration }^{a}\end{array}$ & Minimum & Maximum \\
\hline $\begin{array}{l}\text { PESTICIDES/PCBs }(\mu \mathrm{g} / \mathrm{kg})^{h} \\
\text { Wet weight basis } \\
\text { Beta-BHC }\end{array}$ & $\begin{array}{c}\text { Reference } \\
\text { SA-1 } \\
\text { SA-2 } \\
\text { SA-3 } \\
\text { SA-4 } \\
\text { SA-5 } \\
\text { SA-6 } \\
\text { Sitewide }\end{array}$ & $\begin{array}{c}1 \\
4 \\
2 \\
4 \\
5 \\
2 \\
1 \\
18\end{array}$ & $\begin{array}{l}0 \\
0 \\
0 \\
0 \\
1 \\
0 \\
0 \\
1\end{array}$ & $\begin{array}{c}\text { ND } \\
\text { ND } \\
\text { ND } \\
\text { ND } \\
27.00 \\
\text { ND } \\
\text { ND } \\
27.00\end{array}$ & $\begin{array}{c}\text { ND } \\
\text { ND } \\
\text { ND } \\
\text { ND } \\
27.0 \mathrm{~J} \\
\text { ND } \\
\text { ND } \\
27.0 \mathrm{~J}\end{array}$ & $\begin{array}{c}N D \\
N D \\
N D \\
N D \\
27.0 \mathrm{~J} \\
N D \\
N D \\
27.0 \mathrm{~J}\end{array}$ \\
\hline $4^{\prime}, 4-\mathrm{DDD}$ & $\begin{array}{c}\text { Reference } \\
\text { SA-1 } \\
\text { SA-2 } \\
\text { SA-3 } \\
\text { SA-4 } \\
\text { SA-5 } \\
\text { SA-6 } \\
\text { Sitewide }\end{array}$ & $\begin{array}{c}1 \\
4 \\
2 \\
4 \\
5 \\
2 \\
1 \\
18\end{array}$ & $\begin{array}{l}0 \\
1 \\
0 \\
0 \\
0 \\
1 \\
0 \\
2\end{array}$ & $\begin{array}{c}\text { ND } \\
50.00 \\
\text { ND } \\
\text { ND } \\
\text { ND } \\
88.0 \\
\text { ND } \\
69.00\end{array}$ & $\begin{array}{c}\text { ND } \\
50.0 \times H J \\
\text { ND } \\
\text { ND } \\
\text { ND } \\
88.0 \times J \\
\text { ND } \\
50.0 \times J\end{array}$ & $\begin{array}{c}\text { ND } \\
50.0 \times J \\
N D \\
\text { ND } \\
\text { ND } \\
88.0 \times J \\
\text { ND } \\
88.0 \times J\end{array}$ \\
\hline Endrin & $\begin{array}{c}\text { Reference } \\
\text { SA-1 } \\
\text { SA-2 } \\
\text { SA-3 } \\
\text { SA-4 } \\
\text { SA-5 } \\
\text { SA-6 } \\
\text { Sitewide }\end{array}$ & $\begin{array}{c}1 \\
4 \\
2 \\
4 \\
5 \\
2 \\
1 \\
18\end{array}$ & $\begin{array}{l}0 \\
0 \\
0 \\
0 \\
2 \\
1 \\
0 \\
3\end{array}$ & $\begin{array}{c}\text { ND } \\
\text { ND } \\
\text { ND } \\
\text { ND } \\
46.00 \\
42.00 \\
\text { ND } \\
46.00\end{array}$ & $\begin{array}{c}N D \\
N D \\
N D \\
N D \\
40.0 \mathrm{~J} \\
42.0 \mathrm{~J} \\
N D \\
40.0 \mathrm{~J}\end{array}$ & $\begin{array}{c}N D \\
N D \\
N D \\
N D \\
52.0 \mathrm{~J} \\
42.0 \mathrm{~J} \\
N D \\
52.0 \mathrm{~J}\end{array}$ \\
\hline
\end{tabular}

Refer to footnotes at end of table. 
Table 4-2

Summary of Constituent Concentrations in Vegetation, Salmon Site

(Page 6 of 9)

\begin{tabular}{|c|c|c|c|c|c|c|}
\hline Parameter & Type & $\begin{array}{c}\text { Number of } \\
\text { Samples }\end{array}$ & $\begin{array}{l}\text { Number of } \\
\text { Detections }\end{array}$ & $\begin{array}{c}\text { Average } \\
\text { Concentration }^{a}\end{array}$ & Minimum & Maximum \\
\hline Endosulfan Sulfate & $\begin{array}{c}\text { Reference } \\
\text { SA-1 } \\
\text { SA-2 } \\
\text { SA-3 } \\
\text { SA-4 } \\
\text { SA-5 } \\
\text { SA-6 } \\
\text { Sitewide }\end{array}$ & $\begin{array}{c}1 \\
4 \\
2 \\
4 \\
5 \\
2 \\
1 \\
18\end{array}$ & $\begin{array}{l}0 \\
0 \\
1 \\
3 \\
3 \\
1 \\
0 \\
8\end{array}$ & $\begin{array}{c}\text { ND } \\
\text { ND } \\
42.00 \\
38.67 \\
51.67 \\
49.00 \\
\text { ND } \\
45.25\end{array}$ & $\begin{array}{c}N D \\
N D \\
42.0 \mathrm{~J} \\
35.0 \mathrm{~J} \\
39.0 \mathrm{~J} \\
49.0 \mathrm{~J} \\
\mathrm{ND} \\
35.0 \mathrm{~J}\end{array}$ & $\begin{array}{c}N D \\
N D \\
42.0 \mathrm{~J} \\
42.0 \mathrm{~J} \\
71.0 \mathrm{~J} \\
49.0 \mathrm{~J} \\
N D \\
71.0 \mathrm{~J}\end{array}$ \\
\hline Endrin Ketone & $\begin{array}{c}\text { Reference } \\
\text { SA-1 } \\
\text { SA-2 } \\
\text { SA-3 } \\
\text { SA-4 } \\
\text { SA-5 } \\
\text { SA-6 } \\
\text { Sitewide }\end{array}$ & $\begin{array}{c}1 \\
4 \\
2 \\
4 \\
5 \\
2 \\
1 \\
18\end{array}$ & $\begin{array}{l}0 \\
0 \\
0 \\
0 \\
4 \\
1 \\
0 \\
5\end{array}$ & $\begin{array}{c}\text { ND } \\
\text { ND } \\
\text { ND } \\
\text { ND } \\
89.50 \\
87.00 \\
\text { ND } \\
89.00\end{array}$ & $\begin{array}{c}\text { ND } \\
N D \\
N D \\
N D \\
70.0 \mathrm{~J} \\
870 \mathrm{~J} \\
N D \\
70.0 \mathrm{~J}\end{array}$ & $\begin{array}{c}N D \\
N D \\
N D \\
N D \\
130.0 \mathrm{~J} \\
87.0 \mathrm{~J} \\
N D \\
130.0 \mathrm{~J}\end{array}$ \\
\hline $\begin{array}{l}\frac{\text { GROSS ALPHA/BETA }}{\text { Wet weight basis }}(\mathrm{pi} / \mathrm{g})^{\prime} \\
\text { Alpha }\end{array}$ & $\begin{array}{c}\text { Reference } \\
\text { SA-1 } \\
\text { SA-2 } \\
\text { SA-3 } \\
\text { SA-4 } \\
\text { SA-5 } \\
\text { SA-6 } \\
\text { Sitewide }\end{array}$ & $\begin{array}{c}1 \\
4 \\
2 \\
4 \\
5 \\
2 \\
1 \\
18\end{array}$ & $\begin{array}{c}0 \\
3 \\
2 \\
4 \\
3 \\
1 \\
1 \\
14\end{array}$ & $\begin{array}{l}\text { ND } \\
0.35 \\
0.33 \\
0.34 \\
1.55 \\
0.36 \\
2.06 \\
0.72\end{array}$ & $\begin{array}{l}\text { ND } \\
0.29 \\
0.26 \\
0.28 \\
0.39 \\
0.36 \\
2.06 \\
0.26\end{array}$ & $\begin{array}{l}\text { ND } \\
0.42 \\
0.40 \\
0.42 \\
3.89 \\
0.36 \\
2.06 \\
3.89\end{array}$ \\
\hline
\end{tabular}

Refer to footnotes at end of table. 
Table 4-2

Summary of Constituent Concentrations in Vegetation, Salmon Site

(Page 7 of 9)

\begin{tabular}{|c|c|c|c|c|c|c|}
\hline Parameter & Type & $\begin{array}{c}\text { Number of } \\
\text { Samples }\end{array}$ & $\begin{array}{l}\text { Number of } \\
\text { Detections }\end{array}$ & $\begin{array}{c}\text { Average } \\
\text { Concentration }^{a}\end{array}$ & Minimum & Maximum \\
\hline Beta & $\begin{array}{c}\text { Relerence } \\
\text { SA-1 } \\
\text { SA-2 } \\
\text { SA-3 } \\
\text { SA-4 } \\
\text { SA-5 } \\
\text { SA-6 } \\
\text { Sitewide }\end{array}$ & $\begin{array}{c}1 \\
4 \\
2 \\
4 \\
5 \\
2 \\
1 \\
18\end{array}$ & $\begin{array}{c}1 \\
4 \\
2 \\
3 \\
4 \\
2 \\
1 \\
16\end{array}$ & $\begin{array}{l}1.00 \\
0.43 \\
0.40 \\
0.47 \\
0.63 \\
0.40 \\
2.60 \\
0.49\end{array}$ & $\begin{array}{l}1.0 \\
0.3 \\
0.3 \\
0.4 \\
0.4 \\
0.3 \\
2.6 \\
0.3\end{array}$ & $\begin{array}{l}1.0 \\
0.5 \\
0.5 \\
0.6 \\
0.9 \\
0.5 \\
2.6 \\
2.6\end{array}$ \\
\hline $\begin{array}{l}\text { GAMMA SPECTROSCOPY (pCi/g) } \\
\text { Wet weight basis } \\
\text { Cesium- } 137\end{array}$ & $\begin{array}{c}\text { Reference } \\
\text { SA-1 } \\
\text { SA-2 } \\
\text { SA-3 } \\
\text { SA-4 } \\
\text { SA-5 } \\
\text { SA-6 } \\
\text { Sitewide }\end{array}$ & $\begin{array}{c}1 \\
4 \\
2 \\
4 \\
5 \\
2 \\
1 \\
18\end{array}$ & $\begin{array}{l}0 \\
0 \\
0 \\
0 \\
0 \\
1 \\
0 \\
1\end{array}$ & $\begin{array}{l}\text { ND } \\
\text { ND } \\
N D \\
N D \\
N D \\
0.21 \\
N D \\
0.21\end{array}$ & $\begin{array}{l}\text { ND } \\
N D \\
N D \\
N D \\
N D \\
0.21 \\
N D \\
0.21\end{array}$ & $\begin{array}{l}\text { ND } \\
\text { ND } \\
\text { ND } \\
\text { ND } \\
\text { ND } \\
0.21 \\
\text { ND } \\
0.21\end{array}$ \\
\hline Potassium-40 & $\begin{array}{c}\text { Reference } \\
\text { SA-1 } \\
\text { SA-2 } \\
\text { SA-3 } \\
\text { SA-4 } \\
\text { SA-5 } \\
\text { SA-6 } \\
\text { Sitewide } \\
\end{array}$ & $\begin{array}{c}1 \\
4 \\
2 \\
4 \\
5 \\
2 \\
1 \\
18 \\
\end{array}$ & $\begin{array}{l}0 \\
2 \\
1 \\
0 \\
1 \\
0 \\
0 \\
4\end{array}$ & $\begin{array}{c}\text { ND } \\
6.35 \\
8.60 \\
N D \\
21.30 \\
N D \\
N D \\
10.65\end{array}$ & $\begin{array}{l}\text { ND } \\
6.3 \\
8.6 \\
\text { ND } \\
21.3 \\
\text { ND } \\
\text { ND } \\
6.3 \\
\end{array}$ & $\begin{array}{l}\text { ND } \\
6.4 \\
8.6 \\
\text { ND } \\
21.3 \\
\text { ND } \\
\text { ND } \\
21.3\end{array}$ \\
\hline
\end{tabular}

Refer to footnotes at end of table. 
Table 4-2

Summary of Constituent Concentrations in Vegetation,

Salmon Site

(Page 8 of 9)

\begin{tabular}{|c|c|c|c|c|c|c|}
\hline Parameter & Type & $\begin{array}{c}\text { Number of } \\
\text { Samples }\end{array}$ & $\begin{array}{l}\text { Number of } \\
\text { Detections }\end{array}$ & $\begin{array}{c}\text { Average } \\
\text { Concentration }^{a}\end{array}$ & Minimum & Maximum \\
\hline Lead-212 & $\begin{array}{c}\text { Reference } \\
\text { SA-1 } \\
\text { SA-2 } \\
\text { SA-3 } \\
\text { SA-4 } \\
\text { SA-5 } \\
\text { SA-6 } \\
\text { Sitewide }\end{array}$ & $\begin{array}{c}1 \\
4 \\
2 \\
4 \\
5 \\
2 \\
1 \\
18\end{array}$ & $\begin{array}{l}0 \\
0 \\
0 \\
0 \\
0 \\
0 \\
1 \\
1\end{array}$ & $\begin{array}{l}\text { ND } \\
\text { ND } \\
\text { ND } \\
\text { ND } \\
\text { ND } \\
\text { ND } \\
0.50 \\
0.50\end{array}$ & $\begin{array}{l}\text { ND } \\
\text { ND } \\
\text { ND } \\
\text { ND } \\
\text { ND } \\
\text { ND } \\
0.5 \\
0.5\end{array}$ & $\begin{array}{l}\text { ND } \\
\text { ND } \\
\text { ND } \\
\text { ND } \\
\text { ND } \\
\text { ND } \\
0.5 \\
0.5\end{array}$ \\
\hline Beryllium-7 & $\begin{array}{c}\text { Reference } \\
\text { SA-1 } \\
\text { SA-2 } \\
\text { SA-3 } \\
\text { SA-4 } \\
\text { SA-5 } \\
\text { SA-6 } \\
\text { Sitewide }\end{array}$ & $\begin{array}{c}1 \\
4 \\
2 \\
4 \\
5 \\
2 \\
1 \\
18\end{array}$ & $\begin{array}{l}0 \\
3 \\
1 \\
1 \\
1 \\
2 \\
1 \\
9\end{array}$ & $\begin{array}{c}\text { ND } \\
3.23 \\
2.40 \\
1.90 \\
5.80 \\
3.20 \\
25.50 \\
5.74\end{array}$ & $\begin{array}{c}\text { ND } \\
3.0 \\
2.4 \\
1.9 \\
5.8 \\
2.8 \\
25.5 \\
1.9\end{array}$ & $\begin{array}{c}\text { ND } \\
3.5 \\
2.4 \\
1.9 \\
5.8 \\
3.6 \\
25.5 \\
25.5\end{array}$ \\
\hline Bismuth-214 & $\begin{array}{c}\text { Reference } \\
\text { SA-1 } \\
\text { SA-2 } \\
\text { SA-3 } \\
\text { SA-4 } \\
\text { SA-5 } \\
\text { SA-6 } \\
\text { Sitewide }\end{array}$ & $\begin{array}{c}1 \\
4 \\
2 \\
4 \\
5 \\
2 \\
1 \\
18\end{array}$ & $\begin{array}{l}0 \\
0 \\
0 \\
0 \\
0 \\
0 \\
1 \\
1\end{array}$ & $\begin{array}{l}\text { ND } \\
\text { ND } \\
\text { ND } \\
\text { ND } \\
\text { ND } \\
\text { ND } \\
0.68 \\
0.68\end{array}$ & $\begin{array}{l}\text { ND } \\
\text { ND } \\
N D \\
N D \\
N D \\
N D \\
0.68 \\
0.68\end{array}$ & $\begin{array}{l}\text { ND } \\
N D \\
N D \\
N D \\
N D \\
N D \\
0.68 \\
0.68\end{array}$ \\
\hline
\end{tabular}

Refer to footnotes at end of table. 
Table 4-2

Summary of Constituent Concentrations in Vegetation, Salmon Site

(Page 9 of 9)

\begin{tabular}{|c|c|c|c|c|c|c|}
\hline Parameter & Type & $\begin{array}{l}\text { Number of } \\
\text { Samples }\end{array}$ & $\begin{array}{l}\text { Number of } \\
\text { Detections }\end{array}$ & $\begin{array}{c}\text { Average } \\
\text { Concentration }^{a}\end{array}$ & Minimum & Maximum \\
\hline Cerium-139 & $\begin{array}{c}\text { Reference } \\
\text { SA-1 } \\
\text { SA-2 } \\
\text { SA-3 } \\
\text { SA-4 } \\
\text { SA-5 } \\
\text { SA-6 } \\
\text { Sitewide }\end{array}$ & $\begin{array}{c}1 \\
4 \\
2 \\
4 \\
5 \\
2 \\
1 \\
18\end{array}$ & $\begin{array}{l}0 \\
0 \\
0 \\
0 \\
0 \\
0 \\
1 \\
1\end{array}$ & $\begin{array}{l}\text { ND } \\
\text { ND } \\
\text { ND } \\
\text { ND } \\
\text { ND } \\
\text { ND } \\
0.15 \\
0.15\end{array}$ & $\begin{array}{l}\text { ND } \\
\text { ND } \\
\text { ND } \\
\text { ND } \\
\text { ND } \\
\text { ND } \\
0.15 \\
0.15\end{array}$ & $\begin{array}{l}\text { ND } \\
\text { ND } \\
\text { ND } \\
\text { ND } \\
\text { ND } \\
\text { ND } \\
0.15 \\
0.15\end{array}$ \\
\hline Tin-113 & $\begin{array}{c}\text { Reference } \\
\text { SA-1 } \\
\text { SA-2 } \\
\text { SA-3 } \\
\text { SA-4 } \\
\text { SA-5 } \\
\text { SA-6 } \\
\text { Sitewide }\end{array}$ & $\begin{array}{c}1 \\
4 \\
2 \\
4 \\
5 \\
2 \\
1 \\
18\end{array}$ & $\begin{array}{l}1 \\
0 \\
0 \\
0 \\
0 \\
0 \\
0 \\
1\end{array}$ & $\begin{array}{l}0.20 \\
N D \\
N D \\
N D \\
N D \\
N D \\
N D \\
0.20\end{array}$ & $\begin{array}{l}0.2 \\
\text { ND } \\
\text { ND } \\
\text { ND } \\
\text { ND } \\
\text { ND } \\
\text { ND } \\
0.2\end{array}$ & $\begin{array}{l}0.2 \\
\text { ND } \\
\text { ND } \\
\text { ND } \\
\text { ND } \\
\text { ND } \\
\text { ND } \\
0.2\end{array}$ \\
\hline Lead-210 & $\begin{array}{c}\text { Reference } \\
\text { SA-1 } \\
\text { SA-2 } \\
\text { SA-3 } \\
\text { SA-4 } \\
\text { SA-5 } \\
\text { SA-6 } \\
\text { Sitewide } \\
\end{array}$ & $\begin{array}{c}1 \\
4 \\
2 \\
4 \\
5 \\
2 \\
1 \\
18 \\
\end{array}$ & $\begin{array}{l}1 \\
2 \\
0 \\
0 \\
2 \\
1 \\
1 \\
6\end{array}$ & $\begin{array}{l}2.33 \\
2.91 \\
\text { ND } \\
\text { ND } \\
3.18 \\
2.10 \\
7.61 \\
3.65 \\
\end{array}$ & $\begin{array}{l}2.33 \\
2.29 \\
\text { ND } \\
\text { ND } \\
2.21 \\
2.10 \\
7.61 \\
2.10 \\
\end{array}$ & $\begin{array}{l}2.33 \\
3.52 \\
N D \\
N D \\
4.15 \\
2.10 \\
7.61 \\
7.61 \\
\end{array}$ \\
\hline
\end{tabular}

${ }^{a}$ Average concentration was calculated from detected concentrations only. Milligram per kilogram

The reported value is below the Contract Required Detection Limit, but above Instrument Detection Limit.

Reported result is quantitatively estimated.

Not detected
'The reported value was determined by Method of Standard Addition. ${ }^{9}$ Inductively-coupled plasma dilution (\%D) is out of control limits.

Microgram per kilogram

Data entered manually.

Picocurie per gram 
Field mice, raccoon, and opossum were collected between February 22 and 28. 1993. Traps utilized for raccoons and opossum were Conibear ${ }^{\circledR}$ Models 110 and 210. These traps were set on low tree branches or stumps and baited. Traps were set and checked three times a day. Museum Special ${ }^{\circledR}$ snap traps were used to collect field mice and other members of the rodent family. One raccoon, one Virginia opossum, one pine vole, two shorttail shrews, one Eastern wood rat. and nine field mice were collected and shipped to the laboratory for analyses. Specific tissues analyzed from the raccoon and opossum specimens included fat, muscle, bone, and liver. Large mammal tissues analyzed also included bone. liver, fat, and muscle. Whole bodies of the field mice specimens were analyzed. All small mammals collected were shipped to the ITAS Laboratory for analysis. However, of the rodent samples submitted, only one mouse sample, the woodrat, and a shrew/vole composite sample were analyzed. Trapline locations are shown in Figure 4-2.

Mammal tissue analysis data are presented in Appendix A of this report. The Appendix includes data for inorganic, pesticide/PCBs, gross alpha, gross beta, gamma spectroscopy, and tritium. Tables A-7.1 through A-7.5 present small mammal data. Tables A-8.1 through A-8.5 present large mammal data.

Many inorganic constituents were found within the mammalian tissues. Copper was detected in most tissues, but primarily in liver. Copper was only detected in bones of small mammals. Lead was detected in all tissue types in large mammals, most frequently in bone, but with the highest concentrations in fat. Similar lead results were found for small mammal tissues, with the highest concentrations in bone. The composite samples had an average concentration of $0.24 \mathrm{mg} / \mathrm{kg}$ wet weight, with a maximum of $0.36 \mathrm{mg} / \mathrm{kg}$.

Gross alpha was detected in some large and small mammals, mostly in bone (7.29 to $7.80 \mathrm{pCi} / \mathrm{g}$ ). Gross beta was detected in more samples with the highest levels in bone (21.05 to $37.43 \mathrm{pCi} / \mathrm{g}$ ). Tritium was detected in some large and small mammals. Highest levels were in fat $(84.59 \mathrm{pCi} / \mathrm{g})$ and liver $(6.60 \mathrm{pCi} / \mathrm{g})$. Other radionuclides were detected sporadically in some tissues of some samples. No pesticides or PCBs were detected in mammalian tissues. The detected constituent concentrations are summarized in Table 4-3 and Table 4-4. All concentrations are presented on a wet weight basis. 


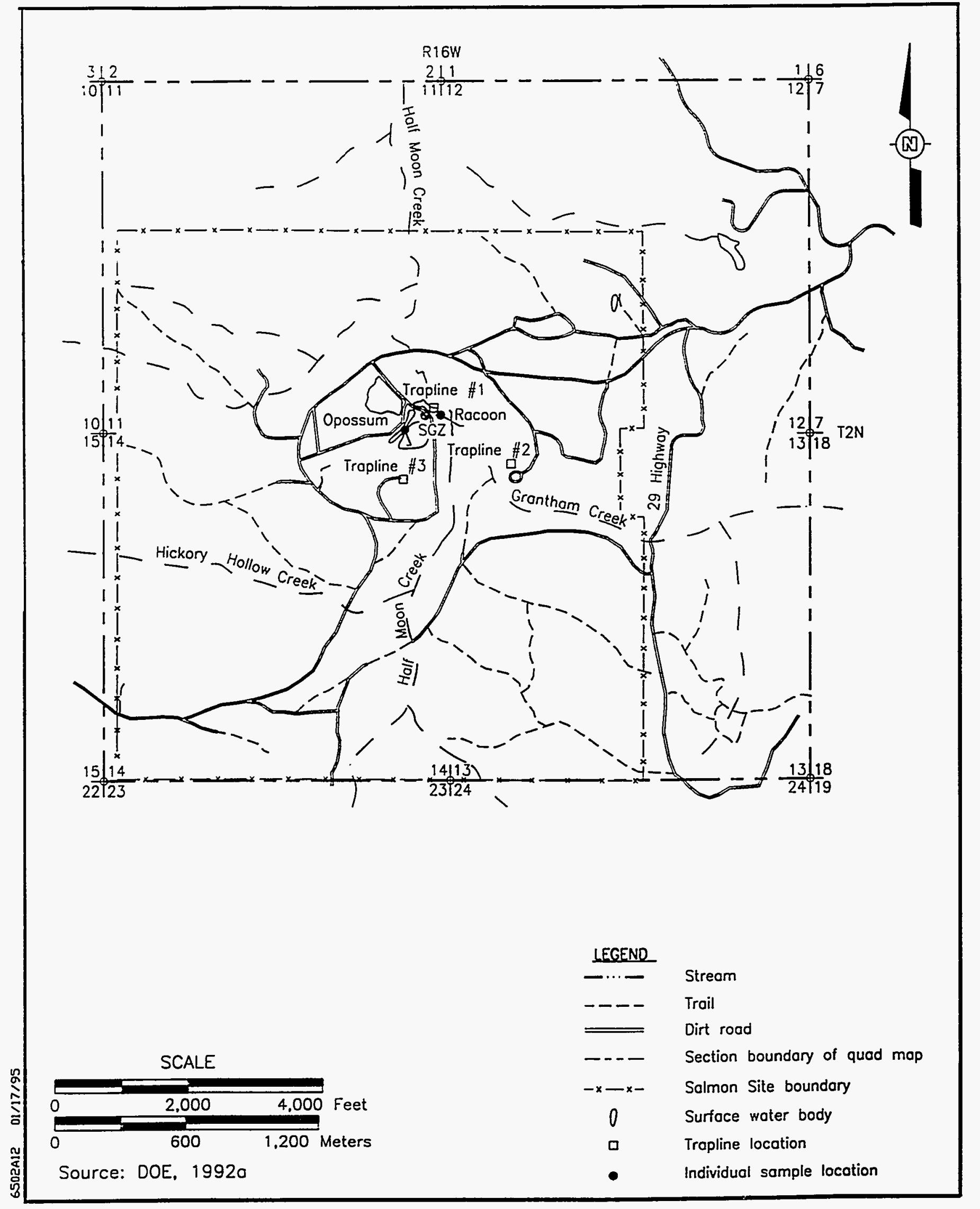

Figure 4-2

Salmon Site Location of Traplines 
Table 4-3

Summary of Constituent Concentrations in Large Mammal Tissues,

Salmon Site

(Page 1 of 5)

\begin{tabular}{|c|c|c|c|c|c|c|}
\hline Parameter & Type & $\begin{array}{c}\text { Number of } \\
\text { Samples }\end{array}$ & $\begin{array}{l}\text { Number of } \\
\text { Detects }\end{array}$ & $\begin{array}{c}\text { Average } \\
\text { Concentration }^{a}\end{array}$ & Minimum & Maximum \\
\hline$\frac{\text { METALS }(\mathrm{mg} / \mathrm{kg})^{\mathrm{b}} \text { Wet weight basis }}{\text { Aluminum }}$ & $\begin{array}{l}\text { Bone } \\
\text { Liver } \\
\text { Fat } \\
\text { Muscle }\end{array}$ & $\begin{array}{l}7 \\
7 \\
6 \\
7\end{array}$ & $\begin{array}{l}4 \\
2 \\
2 \\
3\end{array}$ & $\begin{array}{l}6.25 \\
1.50 \\
5.55 \\
1.30\end{array}$ & $\begin{array}{c}5.5 \mathrm{~B}^{\mathrm{C} J} \\
1.5 \mathrm{BJ} \\
4.3 \mathrm{BJ} \\
1.1 \mathrm{BJ}\end{array}$ & $\begin{array}{l}7.4 \mathrm{BJ} \\
1.5 \mathrm{BJ} \\
6.8 \mathrm{BJ} \\
1.4 \mathrm{BJ}\end{array}$ \\
\hline Antimony & $\begin{array}{c}\text { Bone } \\
\text { Liver } \\
\text { Fat } \\
\text { Muscle }\end{array}$ & $\begin{array}{l}7 \\
7 \\
6 \\
7\end{array}$ & $\begin{array}{l}1 \\
0 \\
0 \\
2\end{array}$ & $\begin{array}{l}3.30 \\
N D^{e} \\
N D \\
1.25\end{array}$ & $\begin{array}{c}3.3 \\
\text { ND } \\
\text { ND } \\
1.1 \mathrm{BJ}\end{array}$ & $\begin{array}{c}3.3 \\
\mathrm{ND} \\
\mathrm{ND} \\
1.4 \mathrm{BJ}\end{array}$ \\
\hline Arsenic & $\begin{array}{c}\text { Bone } \\
\text { Liver } \\
\text { Fat } \\
\text { Muscle }\end{array}$ & $\begin{array}{l}7 \\
7 \\
6 \\
7\end{array}$ & $\begin{array}{l}2 \\
0 \\
0 \\
0\end{array}$ & $\begin{array}{l}1.01 \\
\text { ND } \\
\text { ND } \\
\text { ND }\end{array}$ & $\begin{array}{c}0.62 \mathrm{~J} \\
\text { ND } \\
\text { ND } \\
\text { ND }\end{array}$ & $\begin{array}{l}1.40 \mathrm{~J} \\
\text { ND } \\
\text { ND } \\
\text { ND }\end{array}$ \\
\hline Barium & $\begin{array}{l}\text { Bone } \\
\text { Liver } \\
\text { Fat } \\
\text { Muscle }\end{array}$ & $\begin{array}{l}7 \\
7 \\
6 \\
7\end{array}$ & $\begin{array}{l}7 \\
7 \\
5 \\
7\end{array}$ & $\begin{array}{c}472.86 \\
0.46 \\
0.86 \\
0.38\end{array}$ & $\begin{array}{c}345.00 \\
0.12 \\
0.52 \mathrm{BJ} \\
0.21 \mathrm{BJ}\end{array}$ & $\begin{array}{c}565.00 \\
0.94 \\
1.80 \mathrm{BJ} \\
0.72 \mathrm{BJ}\end{array}$ \\
\hline Beryllium & $\begin{array}{c}\text { Bone } \\
\text { Liver } \\
\text { Fat } \\
\text { Muscle }\end{array}$ & $\begin{array}{l}7 \\
7 \\
6 \\
7\end{array}$ & $\begin{array}{l}2 \\
0 \\
1 \\
0\end{array}$ & $\begin{array}{l}0.06 \\
N D \\
0.22 \\
N D\end{array}$ & $\begin{array}{c}0.05 \mathrm{BJ} \\
\mathrm{ND} \\
0.22 \mathrm{~B} \\
\mathrm{ND}\end{array}$ & $\begin{array}{c}0.06 \mathrm{BJ} \\
\mathrm{ND} \\
0.22 \mathrm{~B} \\
\mathrm{ND}\end{array}$ \\
\hline Cadmium & $\begin{array}{c}\text { Bone } \\
\text { Liver } \\
\text { Fat } \\
\text { Muscle }\end{array}$ & $\begin{array}{l}7 \\
7 \\
6 \\
7\end{array}$ & $\begin{array}{l}1 \\
1 \\
0 \\
0\end{array}$ & $\begin{array}{l}0.15 \\
0.39 \\
N D \\
N D\end{array}$ & $\begin{array}{c}0.15 \mathrm{BJ} \\
0.39 \\
\text { ND } \\
\text { ND }\end{array}$ & $\begin{array}{c}0.15 \mathrm{BJ} \\
0.39 \\
\text { ND } \\
\text { ND }\end{array}$ \\
\hline Calcium & $\begin{array}{c}\text { Bone } \\
\text { Liver } \\
\text { Fat } \\
\text { Muscle }\end{array}$ & $\begin{array}{l}7 \\
7 \\
6 \\
7\end{array}$ & $\begin{array}{l}7 \\
7 \\
6 \\
7\end{array}$ & $\begin{array}{c}212,857 \\
238.79 \\
363.67 \\
203.86\end{array}$ & $\begin{array}{c}199,000.0 \\
96.5 \mathrm{BJ} \\
174.0 \mathrm{~B} \\
133.0 \mathrm{BJ}\end{array}$ & $\begin{array}{c}227,000 \\
440 \\
665 \\
336\end{array}$ \\
\hline
\end{tabular}

Refer to footnotes at end of table. 
Table 4-3

Summary of Constituent Concentrations in Large Mammal Tissues,

Salmon Site

(Page 2 of 5)

\begin{tabular}{|c|c|c|c|c|c|c|}
\hline Parameter & Type & $\begin{array}{c}\text { Number of } \\
\text { Samples }\end{array}$ & $\begin{array}{c}\text { Number of } \\
\text { Detects }\end{array}$ & $\begin{array}{c}\text { Average } \\
\text { Concentration }^{\mathrm{a}} \\
\end{array}$ & Minimum & Maximum \\
\hline Chromium & $\begin{array}{c}\text { Bone } \\
\text { Liver } \\
\text { Fat } \\
\text { Muscle }\end{array}$ & $\begin{array}{l}7 \\
7 \\
6 \\
7\end{array}$ & $\begin{array}{l}7 \\
6 \\
5 \\
6\end{array}$ & $\begin{array}{l}3.31 \\
0.42 \\
0.47 \\
0.35\end{array}$ & $\begin{array}{c}2.90 \\
0.16 \mathrm{BJ} \\
0.26 \mathrm{BJ} \\
0.16\end{array}$ & $\begin{array}{c}3.60 \\
0.77 \mathrm{BJ} \\
0.71 \mathrm{BJ} \\
0.55\end{array}$ \\
\hline Cobalt & $\begin{array}{c}\text { Bone } \\
\text { Liver } \\
\text { Fat } \\
\text { Muscle }\end{array}$ & $\begin{array}{l}7 \\
7 \\
6 \\
7\end{array}$ & $\begin{array}{l}1 \\
1 \\
0 \\
0\end{array}$ & $\begin{array}{l}0.29 \\
0.59 \\
N D \\
N D\end{array}$ & $\begin{array}{c}0.29 \mathrm{BJ} \\
0.59 \mathrm{BJ} \\
\mathrm{ND} \\
\mathrm{ND}\end{array}$ & $\begin{array}{c}0.29 \mathrm{BJ} \\
0.59 \mathrm{BJ} \\
\mathrm{ND} \\
\mathrm{ND}\end{array}$ \\
\hline Copper & $\begin{array}{c}\text { Bone } \\
\text { Liver } \\
\text { Fat } \\
\text { Muscle }\end{array}$ & $\begin{array}{l}7 \\
7 \\
6 \\
7\end{array}$ & $\begin{array}{l}0 \\
7 \\
5 \\
7\end{array}$ & $\begin{array}{l}\text { ND } \\
51.21 \\
2.88 \\
1.79\end{array}$ & $\begin{array}{c}\text { ND } \\
33.50 \\
0.28 \\
1.50\end{array}$ & $\begin{array}{c}\text { ND } \\
64.80 \\
5.10 \\
2.20\end{array}$ \\
\hline Iron & $\begin{array}{c}\text { Bone } \\
\text { Liver } \\
\text { Fat } \\
\text { Muscle }\end{array}$ & $\begin{array}{l}7 \\
7 \\
6 \\
7\end{array}$ & $\begin{array}{l}6 \\
7 \\
4 \\
5\end{array}$ & $\begin{array}{c}4.87 \\
195.71 \\
18.33 \\
29.82\end{array}$ & $\begin{array}{c}2.8 \mathrm{BJ} \\
137 \\
4.0 \mathrm{BJ} \\
24.0\end{array}$ & $\begin{array}{c}10.4 \\
258.0 \\
35.8 \\
35.9\end{array}$ \\
\hline Lead & $\begin{array}{c}\text { Bone } \\
\text { Liver } \\
\text { Fat } \\
\text { Muscle }\end{array}$ & $\begin{array}{l}7 \\
7 \\
6 \\
7\end{array}$ & $\begin{array}{l}6 \\
2 \\
3 \\
2\end{array}$ & $\begin{array}{c}2.98 \\
3.38 \\
29.62 \\
0.095\end{array}$ & $\begin{array}{c}0.32 \\
0.05 \mathrm{BJ} \\
0.27 \\
0.09 \mathrm{BJ}\end{array}$ & $\begin{array}{c}13.90 \\
6.70 \mathrm{~s}^{\mathrm{f}} \\
88.20 \\
0.10 \mathrm{BW}^{\mathrm{g} J}\end{array}$ \\
\hline Magnesium & $\begin{array}{c}\text { Bone } \\
\text { Liver } \\
\text { Fat } \\
\text { Muscle }\end{array}$ & $\begin{array}{l}7 \\
7 \\
6 \\
7\end{array}$ & $\begin{array}{l}7 \\
7 \\
6 \\
7\end{array}$ & $\begin{array}{c}3,191.43 \\
182.71 \\
63.27 \\
263.14\end{array}$ & $\begin{array}{c}3,050.00 \\
162.0 \mathrm{BJ} \\
25.4 \mathrm{BJ} \\
237.0\end{array}$ & $\begin{array}{c}3,350.00 \\
204.0 \mathrm{BJ} \\
91.9 \mathrm{BJ} \\
283.0\end{array}$ \\
\hline Manganese & $\begin{array}{c}\text { Bone } \\
\text { Liver } \\
\text { Fat } \\
\text { Muscle }\end{array}$ & $\begin{array}{l}7 \\
7 \\
6 \\
7\end{array}$ & $\begin{array}{l}7 \\
7 \\
4 \\
7\end{array}$ & $\begin{array}{l}1.37 \\
5.19 \\
1.66 \\
1.29\end{array}$ & $\begin{array}{c}1.10 \\
4.00 \\
0.09 \mathrm{BJ} \\
0.17 \mathrm{BJ}\end{array}$ & $\begin{array}{l}1.60 \\
6.30 \\
3.20 \\
4.20\end{array}$ \\
\hline
\end{tabular}

Refer to footnotes at end of table. 
Table 4-3

Summary of Constituent Concentrations in Large Mammal Tissues, Salmon Site

(Page 3 of 5)

\begin{tabular}{|c|c|c|c|c|c|c|}
\hline Parameter & Type & $\begin{array}{c}\text { Number of } \\
\text { Samples }\end{array}$ & $\begin{array}{c}\text { Number of } \\
\text { Detects }\end{array}$ & $\begin{array}{c}\text { Average } \\
\text { Concentration }^{a} \\
\end{array}$ & Minimum & Maximum \\
\hline Mercury & $\begin{array}{c}\text { Bone } \\
\text { Liver } \\
\text { Fat } \\
\text { Muscle }\end{array}$ & $\begin{array}{l}7 \\
7 \\
6 \\
7\end{array}$ & $\begin{array}{l}0 \\
5 \\
0 \\
2\end{array}$ & $\begin{array}{l}\text { ND } \\
0.08 \\
\text { ND } \\
0.13\end{array}$ & $\begin{array}{c}\text { ND } \\
0.04 \mathrm{BJ} \\
\text { ND } \\
0.07\end{array}$ & $\begin{array}{c}\text { ND } \\
0.19 \\
\text { ND } \\
0.19\end{array}$ \\
\hline Potassium & $\begin{array}{c}\text { Bone } \\
\text { Liver } \\
\text { Fat } \\
\text { Muscle }\end{array}$ & $\begin{array}{l}7 \\
7 \\
6 \\
7\end{array}$ & $\begin{array}{l}2 \\
7 \\
3 \\
7\end{array}$ & $\begin{array}{c}350.50 \\
2,672.86 \\
757.33 \\
3,342.86\end{array}$ & $\begin{array}{c}316.0 \\
2,380.0 \\
581.0 \mathrm{BJ} \\
2,880.0\end{array}$ & $\begin{array}{c}385.0 \\
3,200.0 \\
870.0 \mathrm{BJ} \\
3,710.0\end{array}$ \\
\hline Selenium & $\begin{array}{c}\text { Bone } \\
\text { Liver } \\
\text { Fat } \\
\text { Muscle }\end{array}$ & $\begin{array}{l}7 \\
7 \\
6 \\
7\end{array}$ & $\begin{array}{l}2 \\
3 \\
0 \\
0\end{array}$ & $\begin{array}{l}0.62 \\
0.56 \\
\text { ND } \\
\text { ND }\end{array}$ & $\begin{array}{c}0.57 \mathrm{BWJ} \\
0.42 \mathrm{BWJ} \\
\mathrm{ND} \\
\mathrm{ND}\end{array}$ & $\begin{array}{c}0.66 \mathrm{BE}^{\mathrm{h}} \mathrm{J} \\
0.77 \mathrm{BJ} \\
\mathrm{ND} \\
\mathrm{ND}\end{array}$ \\
\hline Sodium & $\begin{array}{c}\text { Bone } \\
\text { Liver } \\
\text { Fat } \\
\text { Muscle }\end{array}$ & $\begin{array}{l}7 \\
7 \\
6 \\
7\end{array}$ & $\begin{array}{l}7 \\
7 \\
6 \\
4\end{array}$ & $\begin{array}{c}5,344.29 \\
970.29 \\
510.17 \\
596.40\end{array}$ & $\begin{array}{c}5,190.0 \\
807.0 \\
161.0 \mathrm{BJ} \\
507.0\end{array}$ & $\begin{array}{c}5,720.0 \\
1,260.0 \\
1,050.0 \\
735.0\end{array}$ \\
\hline Zinc & $\begin{array}{c}\text { Bone } \\
\text { Liver } \\
\text { Fat } \\
\text { Muscle }\end{array}$ & $\begin{array}{l}7 \\
7 \\
6 \\
7\end{array}$ & $\begin{array}{l}7 \\
7 \\
6 \\
7\end{array}$ & $\begin{array}{c}68.53 \\
38.29 \\
4.92 \\
35.26 \\
\end{array}$ & $\begin{array}{c}50.7 \\
31.9 \\
2.4 \\
30.3\end{array}$ & $\begin{array}{c}99.1 \\
47.7 \\
7.6 \\
43.7\end{array}$ \\
\hline $\begin{array}{l}\text { GROSS ALPHA/BETA }(\mathrm{pCi} / \mathrm{g})^{\mathrm{i}} \\
\text { Wet weight basis } \\
\text { Alpha }\end{array}$ & $\begin{array}{c}\text { Bone } \\
\text { Liver } \\
\text { Fat } \\
\text { Muscle }\end{array}$ & $\begin{array}{l}7 \\
7 \\
6 \\
7\end{array}$ & $\begin{array}{l}2 \\
6 \\
2 \\
2\end{array}$ & $\begin{array}{l}7.55 \\
0.32 \\
0.35 \\
0.25\end{array}$ & $\begin{array}{l}7.29 \\
0.22 \mathrm{~J} \\
0.11 \\
0.24 \mathrm{~J} \\
\end{array}$ & $\begin{array}{l}7.80 \mathrm{~J} \\
0.40 \mathrm{~J} \\
0.58 \mathrm{~J} \\
0.26 \mathrm{~J} \\
\end{array}$ \\
\hline Beta & $\begin{array}{l}\text { Bone } \\
\text { Liver } \\
\text { Fat } \\
\text { Muscle }\end{array}$ & $\begin{array}{l}7 \\
7 \\
6 \\
7\end{array}$ & $\begin{array}{l}7 \\
7 \\
5 \\
7\end{array}$ & $\begin{array}{l}30.84 \\
2.61 \\
0.23 \\
2.42\end{array}$ & $\begin{array}{l}21.05 \\
2.27 \\
0.11 \\
2.02\end{array}$ & $\begin{array}{l}37.43 \\
3.06 \\
0.41 \\
3.07\end{array}$ \\
\hline
\end{tabular}


Table 4-3

Summary of Constituent Concentrations in Large Mammal Tissues,

Salmon Site

(Page 4 of 5)

\begin{tabular}{|c|c|c|c|c|c|c|}
\hline Parameter & Type & $\begin{array}{c}\text { Number of } \\
\text { Samples }\end{array}$ & $\begin{array}{c}\text { Number of } \\
\text { Detects }\end{array}$ & $\begin{array}{c}\text { Average } \\
\text { Concentration }^{a}\end{array}$ & Minimum & Maximum \\
\hline $\begin{array}{l}\text { TRITIUM (pCi/g) } \\
\text { Wet weight basis } \\
\text { Tritium }\end{array}$ & $\begin{array}{l}\text { Bone } \\
\text { Liver } \\
\text { Fat } \\
\text { Muscle }\end{array}$ & $\begin{array}{l}7 \\
7 \\
7 \\
7\end{array}$ & $\begin{array}{l}0 \\
2 \\
4 \\
1\end{array}$ & $\begin{array}{c}\text { ND } \\
3.36 \\
31.51 \\
0.36\end{array}$ & $\begin{array}{l}\text { ND } \\
0.11 \\
0.14 \\
0.36\end{array}$ & $\begin{array}{l}\text { ND } \\
6.60 \\
84.59 \\
0.36\end{array}$ \\
\hline $\begin{array}{l}\text { GAMMA SPECTROSCOPY }(\mathrm{pCi} / \mathrm{g}) \\
\text { Wet weight basis } \\
\text { Cesium }-137\end{array}$ & $\begin{array}{l}\text { Bone } \\
\text { Liver } \\
\text { Fat } \\
\text { Muscle }\end{array}$ & $\begin{array}{l}7 \\
7 \\
7 \\
7\end{array}$ & $\begin{array}{l}0 \\
4 \\
0 \\
4\end{array}$ & $\begin{array}{l}\text { ND } \\
0.20 \\
N D \\
0.46\end{array}$ & $\begin{array}{l}\text { ND } \\
0.14 \\
N D \\
0.32\end{array}$ & $\begin{array}{l}\text { ND } \\
0.24 \\
N D \\
0.77\end{array}$ \\
\hline Potassium-40 & $\begin{array}{l}\text { Bone } \\
\text { Liver } \\
\text { Fat } \\
\text { Muscle }\end{array}$ & $\begin{array}{l}7 \\
7 \\
7 \\
7\end{array}$ & $\begin{array}{l}0 \\
2 \\
0 \\
4\end{array}$ & $\begin{array}{l}\text { ND } \\
6.7 \\
\text { ND } \\
3.6\end{array}$ & $\begin{array}{l}\text { ND } \\
3.2 \\
\text { ND } \\
2.7\end{array}$ & $\begin{array}{l}\text { ND } \\
10.2 \\
N D \\
4.1\end{array}$ \\
\hline Lead-212 & $\begin{array}{c}\text { Bone } \\
\text { Liver } \\
\text { Fat } \\
\text { Muscle }\end{array}$ & $\begin{array}{l}7 \\
7 \\
7 \\
7\end{array}$ & $\begin{array}{l}4 \\
0 \\
0 \\
0\end{array}$ & $\begin{array}{l}0.28 \\
N D \\
N D \\
N D\end{array}$ & $\begin{array}{l}0.00 \\
N D \\
N D \\
N D\end{array}$ & $\begin{array}{l}1.00 \\
\text { ND } \\
\text { ND } \\
\text { ND }\end{array}$ \\
\hline Radium-226 & $\begin{array}{c}\text { Bone } \\
\text { Liver } \\
\text { Fat } \\
\text { Muscle }\end{array}$ & $\begin{array}{l}7 \\
7 \\
7 \\
7\end{array}$ & $\begin{array}{l}1 \\
0 \\
0 \\
0\end{array}$ & $\begin{array}{l}0.3 \\
\text { ND } \\
\text { ND } \\
\text { ND }\end{array}$ & $\begin{array}{l}0.3 \\
\text { ND } \\
\text { ND } \\
\text { ND }\end{array}$ & $\begin{array}{l}0.3 \\
\text { ND } \\
\text { ND } \\
\text { ND }\end{array}$ \\
\hline Bismuth-214 & $\begin{array}{c}\text { Bone } \\
\text { Liver } \\
\text { Fat } \\
\text { Muscle }\end{array}$ & $\begin{array}{l}7 \\
7 \\
7 \\
7\end{array}$ & $\begin{array}{l}1 \\
0 \\
0 \\
0\end{array}$ & $\begin{array}{l}0.4 \\
\text { ND } \\
\text { ND } \\
\text { ND }\end{array}$ & $\begin{array}{l}0.4 \\
N D \\
N D \\
N D\end{array}$ & $\begin{array}{l}0.4 \\
\text { ND } \\
\text { ND } \\
\text { ND }\end{array}$ \\
\hline Radium-228 & $\begin{array}{c}\text { Bone } \\
\text { Liver } \\
\text { Fat } \\
\text { Muscle }\end{array}$ & $\begin{array}{l}7 \\
7 \\
7 \\
7\end{array}$ & $\begin{array}{l}1 \\
0 \\
0 \\
0\end{array}$ & $\begin{array}{l}1.40 \\
\text { ND } \\
\text { ND } \\
\text { ND }\end{array}$ & $\begin{array}{l}1.40 \\
N D \\
N D \\
N D\end{array}$ & $\begin{array}{l}1.40 \\
\text { ND } \\
\text { ND } \\
\text { ND }\end{array}$ \\
\hline
\end{tabular}

Refer to footnotes al end of table. 
Table 4-3

Summary of Constituent Concentrations in Large Mammal Tissues,

Salmon Site

(Page 5 of 5 )

\begin{tabular}{|c|c|c|c|c|c|c|}
\hline Parameter & Type & $\begin{array}{c}\text { Number of } \\
\text { Samples }\end{array}$ & $\begin{array}{c}\text { Number of } \\
\text { Detects }\end{array}$ & $\begin{array}{c}\text { Average } \\
\text { Concentration }^{a}\end{array}$ & Minimum & Maximum \\
\hline Titanium-208 & $\begin{array}{c}\text { Bone } \\
\text { Liver } \\
\text { Fat } \\
\text { Muscle }\end{array}$ & $\begin{array}{l}7 \\
7 \\
7 \\
7\end{array}$ & $\begin{array}{l}0 \\
0 \\
1 \\
0\end{array}$ & $\begin{array}{l}\text { NA } \\
\text { NA } \\
0.30 \\
\text { ND }\end{array}$ & $\begin{array}{l}\text { ND } \\
\text { ND } \\
0.30 \\
\text { ND }\end{array}$ & $\begin{array}{l}\text { ND } \\
\text { ND } \\
0.30 \\
\text { ND }\end{array}$ \\
\hline
\end{tabular}

${ }^{a}$ Average concentration was calculated from detected concentrations only.

Milligram per kilogram

The reported value is below the Contract Required Detection Limit, but above Instrument Detection Limit.

Reported value is quantitatively estimated.

Not detected

The reported value was determined by Method of Standard Addition.

9 postdigestion spike for furnace atomic absorption analysis is out of control limit.

Inductively-coupled plasma dilution (\%D) is out of control limits.

Picocurie per gram 
Table 4-4

Summary of Constituent Concentrations in Small Mammal Tissues, Salmon Site

(Page 1 of 5)

\begin{tabular}{|c|c|c|c|c|c|c|}
\hline Parameter & Type & $\begin{array}{l}\text { Number of } \\
\text { Samples }\end{array}$ & $\begin{array}{l}\text { Number of } \\
\text { Detections }\end{array}$ & $\begin{array}{c}\text { Average } \\
\text { Concentration }^{\text {a }}\end{array}$ & Minimum & Maximum \\
\hline $\begin{array}{l}\text { METALS (mg/kg) }{ }^{b} \text { Wet weight basis } \\
\text { Aluminum }\end{array}$ & $\begin{array}{c}\text { Bone } \\
\text { Liver } \\
\text { Fat } \\
\text { Muscle } \\
\text { Composite }\end{array}$ & $\begin{array}{l}9 \\
1 \\
1 \\
9 \\
3\end{array}$ & $\begin{array}{l}9 \\
1 \\
1 \\
8 \\
3\end{array}$ & $\begin{array}{c}4.54 \\
1.00 \\
5.10 \\
1.91 \\
10.87\end{array}$ & $\begin{array}{c}2.80 \mathrm{~B}^{\mathrm{c} J} \mathrm{~d} \\
1.00 \mathrm{BJ} \\
5.10 \mathrm{BJ} \\
1.30 \mathrm{BJ} \\
4.00 \mathrm{BJ}\end{array}$ & $\begin{array}{l}8.00 \mathrm{BJ} \\
1.00 \mathrm{BJ} \\
5.10 \mathrm{BJ} \\
2.80 \mathrm{BJ} \\
17.90\end{array}$ \\
\hline Arsenic & $\begin{array}{c}\text { Bone } \\
\text { Liver } \\
\text { Fat } \\
\text { Muscle } \\
\text { Composite }\end{array}$ & $\begin{array}{l}9 \\
1 \\
1 \\
9 \\
3\end{array}$ & $\begin{array}{l}1 \\
0 \\
0 \\
0 \\
0\end{array}$ & $\begin{array}{l}0.75 \\
\text { ND } \\
\text { ND } \\
\text { ND } \\
\text { ND }\end{array}$ & $\begin{array}{c}0.75 \mathrm{BW}^{\mathrm{e}} \mathrm{J} \\
\mathrm{ND} \\
\mathrm{ND} \\
\mathrm{ND} \\
\mathrm{ND}\end{array}$ & $\begin{array}{c}0.75 \text { BWJ } \\
\text { ND } \\
\text { ND } \\
\text { ND } \\
\text { ND }\end{array}$ \\
\hline Barium & $\begin{array}{c}\text { Bone } \\
\text { Liver } \\
\text { Fat } \\
\text { Muscle } \\
\text { Composite }\end{array}$ & $\begin{array}{l}9 \\
1 \\
1 \\
9 \\
3\end{array}$ & $\begin{array}{l}9 \\
0 \\
0 \\
5 \\
2\end{array}$ & $\begin{array}{c}116.39 \\
\text { ND } \\
\text { ND } \\
0.32 \\
5.19\end{array}$ & $\begin{array}{c}32.10 \\
N D \\
\text { ND } \\
0.16 \mathrm{BJ} \\
0.97 \mathrm{BJ}\end{array}$ & $\begin{array}{c}262.00 \\
N D \\
N D \\
0.47 \mathrm{~B} \\
9.40 \mathrm{BJ}\end{array}$ \\
\hline Calcium & $\begin{array}{c}\text { Bone } \\
\text { Liver } \\
\text { Fat } \\
\text { Muscle } \\
\text { Composite }\end{array}$ & $\begin{array}{l}9 \\
1 \\
1 \\
9 \\
3\end{array}$ & $\begin{array}{l}9 \\
1 \\
1 \\
9 \\
3\end{array}$ & $\begin{array}{c}57,044.44 \\
139.00 \\
251.00 \\
198.00 \\
6,730.00\end{array}$ & $\begin{array}{c}22,500.0 \\
139.00 \mathrm{BJ} \\
251.0 \\
158.0 \mathrm{BJ} \\
2,860.0\end{array}$ & $\begin{array}{c}98,500.0 \\
139.00 \mathrm{BJ} \\
251.0 \\
291.0 \\
8,290.0\end{array}$ \\
\hline Chromium & $\begin{array}{c}\text { Bone } \\
\text { Liver } \\
\text { Fat } \\
\text { Muscle } \\
\text { Composite }\end{array}$ & $\begin{array}{l}9 \\
1 \\
1 \\
9 \\
3\end{array}$ & $\begin{array}{l}9 \\
0 \\
0 \\
9 \\
3\end{array}$ & $\begin{array}{l}1.63 \\
\text { ND } \\
\text { ND } \\
0.25 \\
\text { ND }\end{array}$ & $\begin{array}{l}0.33 \mathrm{BJ} \\
\text { ND } \\
\text { ND } \\
0.18 \mathrm{BJ} \\
\text { ND }\end{array}$ & $\begin{array}{l}5.10 \\
\text { ND } \\
\text { ND } \\
0.36 \mathrm{BJ} \\
\text { ND }\end{array}$ \\
\hline Copper & $\begin{array}{c}\text { Bone } \\
\text { Liver } \\
\text { Fat } \\
\text { Muscle } \\
\text { Composite }\end{array}$ & $\begin{array}{l}9 \\
1 \\
1 \\
9 \\
3\end{array}$ & $\begin{array}{l}7 \\
1 \\
1 \\
9 \\
3\end{array}$ & $\begin{array}{l}4.69 \\
6.80 \\
5.30 \\
1.61 \\
3.40\end{array}$ & $\begin{array}{c}1.20 \mathrm{BJ} \\
6.80 \\
5.30 \\
1.10 \mathrm{BJ} \\
1.50\end{array}$ & $\begin{array}{l}11.10 \\
6.80 \\
5.30 \\
2.20 \\
5.20\end{array}$ \\
\hline
\end{tabular}

Refer to footnotes at end of table. 
Table 4-4

Summary of Constituent Concentrations in Small Mammal Tissues, Salmon Site

(Page 2 of 5)

\begin{tabular}{|c|c|c|c|c|c|c|}
\hline Parameter & Type & $\begin{array}{c}\text { Number of } \\
\text { Samples }\end{array}$ & $\begin{array}{l}\text { Number of } \\
\text { Detections }\end{array}$ & $\begin{array}{c}\text { Average } \\
\text { Concentration }^{a}\end{array}$ & Minimum & Maximum \\
\hline Iron & $\begin{array}{c}\text { Bone } \\
\text { Liver } \\
\text { Fat } \\
\text { Muscle } \\
\text { Composite }\end{array}$ & $\begin{array}{l}9 \\
1 \\
1 \\
9 \\
3\end{array}$ & $\begin{array}{l}9 \\
1 \\
1 \\
9 \\
3\end{array}$ & $\begin{array}{c}73.27 \\
579.00 \\
30.80 \\
24.89 \\
57.47\end{array}$ & $\begin{array}{c}43.1 \mathrm{E}^{9} \mathrm{~J} \\
579.0 \mathrm{EJ} \\
30.8 \mathrm{EJ} \\
14.2 \\
43.1 \mathrm{EJ}\end{array}$ & $\begin{array}{c}67.5 \text { EJ } \\
579.0 \text { EJ } \\
30.8 \text { EJ } \\
55.2 \\
67.5 \text { EJ }\end{array}$ \\
\hline Lead & $\begin{array}{c}\text { Bone } \\
\text { Liver } \\
\text { Fat } \\
\text { Muscle } \\
\text { Composite }\end{array}$ & $\begin{array}{l}9 \\
1 \\
1 \\
9 \\
3\end{array}$ & $\begin{array}{l}9 \\
1 \\
1 \\
8 \\
3\end{array}$ & $\begin{array}{l}54.67 \\
0.11 \\
0.10 \\
2.65 \\
0.24\end{array}$ & $\begin{array}{c}0.26 \mathrm{WJ} \\
0.11 \mathrm{BJ} \\
0.10 \mathrm{BJ} \\
0.08 \mathrm{BWJ} \\
0.07 \mathrm{BWJ}\end{array}$ & $\begin{array}{c}391.00 \\
0.11 \mathrm{BJ} \\
010 \mathrm{BJ} \\
19.30 \\
0.36\end{array}$ \\
\hline Magnesium & $\begin{array}{c}\text { Bone } \\
\text { Liver } \\
\text { Fat } \\
\text { Muscle } \\
\text { Composite }\end{array}$ & $\begin{array}{l}9 \\
1 \\
1 \\
9 \\
3\end{array}$ & $\begin{array}{l}9 \\
1 \\
1 \\
9 \\
3\end{array}$ & $\begin{array}{c}1,079.11 \\
162.00 \\
57.30 \\
291.33 \\
316.00\end{array}$ & $\begin{array}{c}673.0 \\
162.0 \mathrm{BJ} \\
57.3 \mathrm{BJ} \\
250.0 \\
218.0\end{array}$ & $\begin{array}{c}1,530.0 \\
162.0 \mathrm{BJ} \\
57.3 \mathrm{BJ} \\
319.0 \\
375.0\end{array}$ \\
\hline Manganese & $\begin{array}{c}\text { Bone } \\
\text { Liver } \\
\text { Fat } \\
\text { Muscle } \\
\text { Composite }\end{array}$ & $\begin{array}{l}9 \\
1 \\
1 \\
9 \\
3\end{array}$ & $\begin{array}{l}9 \\
1 \\
1 \\
8 \\
3\end{array}$ & $\begin{array}{c}2.18 \\
2.70 \\
0.23 \\
0.53 \\
18.40\end{array}$ & $\begin{array}{l}0.38 \mathrm{BJ} \\
2.70 \\
0.23 \mathrm{BJ} \\
0.21 \mathrm{BJ} \\
2.50\end{array}$ & $\begin{array}{c}4.60 \\
2.70 \\
0.23 \mathrm{BJ} \\
2.00 \\
27.30\end{array}$ \\
\hline Mercury & $\begin{array}{c}\text { Bone } \\
\text { Liver } \\
\text { Fat } \\
\text { Muscle } \\
\text { Composite }\end{array}$ & $\begin{array}{l}9 \\
1 \\
1 \\
9 \\
3\end{array}$ & $\begin{array}{l}0 \\
1 \\
0 \\
0 \\
0\end{array}$ & $\begin{array}{l}\text { ND } \\
0.64 \\
\text { ND } \\
\text { ND } \\
\text { ND }\end{array}$ & $\begin{array}{l}\text { ND } \\
0.64 \\
\text { ND } \\
\text { ND } \\
\text { ND }\end{array}$ & $\begin{array}{l}\text { ND } \\
0.64 \\
\text { ND } \\
\text { ND } \\
\text { ND }\end{array}$ \\
\hline Nickel & $\begin{array}{c}\text { Bone } \\
\text { Liver } \\
\text { Fat } \\
\text { Muscle } \\
\text { Composite }\end{array}$ & $\begin{array}{l}9 \\
1 \\
1 \\
9 \\
3\end{array}$ & $\begin{array}{l}2 \\
0 \\
0 \\
0 \\
0\end{array}$ & $\begin{array}{l}5.30 \\
\text { ND } \\
\text { ND } \\
\text { ND } \\
\text { ND }\end{array}$ & $\begin{array}{l}2.40 \\
\text { ND } \\
\text { ND } \\
\text { ND } \\
\text { ND }\end{array}$ & $\begin{array}{l}8.20 \\
\text { ND } \\
\text { ND } \\
\text { ND } \\
\text { ND }\end{array}$ \\
\hline
\end{tabular}


Table 4-4

Summary of Constituent Concentrations in Small Mammal Tissues,

Salmon Site

(Page 3 of 5)

\begin{tabular}{|c|c|c|c|c|c|c|}
\hline Parameter & Type & $\begin{array}{c}\text { Number of } \\
\text { Samples }\end{array}$ & $\begin{array}{l}\text { Number of } \\
\text { Detections }\end{array}$ & $\begin{array}{c}\text { Average } \\
\text { Concentration }^{a}\end{array}$ & Minimum & Maximum \\
\hline Potassium & $\begin{array}{c}\text { Bone } \\
\text { Liver } \\
\text { Fat } \\
\text { Muscle } \\
\text { Composite }\end{array}$ & $\begin{array}{l}9 \\
1 \\
1 \\
9 \\
3\end{array}$ & $\begin{array}{l}9 \\
1 \\
1 \\
9 \\
3\end{array}$ & $\begin{array}{c}2,251.11 \\
1,780.00 \\
352.00 \\
3,640.00 \\
2,596.67\end{array}$ & $\begin{array}{c}1,340.0 \\
1,780.0 \\
352.0 \\
3,210.0 \\
2,260.0\end{array}$ & $\begin{array}{c}2,870.0 \\
1,780.0 \\
352.0 \\
3,980.0 \\
3,060.0\end{array}$ \\
\hline Selenium & $\begin{array}{c}\text { Bone } \\
\text { Liver } \\
\text { Fat } \\
\text { Muscle } \\
\text { Composite }\end{array}$ & $\begin{array}{l}9 \\
1 \\
1 \\
9 \\
3\end{array}$ & $\begin{array}{l}1 \\
0 \\
0 \\
0 \\
0\end{array}$ & $\begin{array}{l}0.07 \\
\text { ND } \\
\text { ND } \\
\text { ND } \\
\text { ND }\end{array}$ & $\begin{array}{l}0.07 \text { BWJ } \\
\text { ND } \\
\text { ND } \\
\text { ND } \\
\text { ND }\end{array}$ & $\begin{array}{l}0.07 \text { BWJ } \\
\text { ND } \\
\text { ND } \\
\text { ND } \\
\text { ND }\end{array}$ \\
\hline Sodium & $\begin{array}{c}\text { Bone } \\
\text { Liver } \\
\text { Fat } \\
\text { Muscle } \\
\text { Composite }\end{array}$ & $\begin{array}{l}9 \\
1 \\
1 \\
9 \\
3\end{array}$ & $\begin{array}{l}9 \\
1 \\
1 \\
9 \\
3\end{array}$ & $\begin{array}{c}1,693.33 \\
1,500.00 \\
759.00 \\
488.11 \\
1,096.33\end{array}$ & $\begin{array}{c}1,060.0 \\
1,500.0 \\
759.0 \\
363.0 \\
869.0\end{array}$ & $\begin{array}{c}3,080.0 \\
1,500.0 \\
759.0 \\
680.0 \\
1,270.0\end{array}$ \\
\hline Vanadium & $\begin{array}{c}\text { Bone } \\
\text { Liver } \\
\text { Fat } \\
\text { Muscle } \\
\text { Composite }\end{array}$ & $\begin{array}{l}9 \\
1 \\
1 \\
9 \\
3\end{array}$ & $\begin{array}{l}0 \\
1 \\
0 \\
0 \\
0\end{array}$ & $\begin{array}{l}\text { ND } \\
0.28 \\
\text { ND } \\
\text { ND } \\
\text { ND }\end{array}$ & $\begin{array}{l}\text { ND } \\
0.28 \mathrm{~B} \\
\text { ND } \\
\text { ND } \\
\text { ND }\end{array}$ & $\begin{array}{l}\text { ND } \\
0.28 \mathrm{~B} \\
\text { ND } \\
\text { ND } \\
\text { ND }\end{array}$ \\
\hline Zinc & $\begin{array}{c}\text { Bone } \\
\text { Liver } \\
\text { Fat } \\
\text { Muscle } \\
\text { Composite }\end{array}$ & $\begin{array}{l}9 \\
1 \\
1 \\
9 \\
3\end{array}$ & $\begin{array}{l}9 \\
1 \\
1 \\
8 \\
3\end{array}$ & $\begin{array}{c}58.10 \\
25.10 \\
5.10 \\
27.16 \\
22.63\end{array}$ & $\begin{array}{c}38.9 \text { EJ } \\
25.1 \\
5.1 \\
11.1 \text { EJ } \\
18.8\end{array}$ & $\begin{array}{c}94.0 \mathrm{EJ} \\
25.1 \\
5.1 \\
67.0 \mathrm{EJ} \\
25.7\end{array}$ \\
\hline $\begin{array}{l}\text { GROSS ALPHA/BETA }(\mathrm{pCi} / \mathrm{g})^{\mathrm{h}} \\
\text { Wet weight basis } \\
\text { Alpha }\end{array}$ & $\begin{array}{c}\text { Bone } \\
\text { Liver } \\
\text { Fat } \\
\text { Muscle } \\
\text { Composite }\end{array}$ & $\begin{array}{l}9 \\
1 \\
1 \\
9 \\
3\end{array}$ & $\begin{array}{l}1 \\
0 \\
0 \\
3 \\
0\end{array}$ & $\begin{array}{l}12.55 \\
\text { ND } \\
\text { ND } \\
2.86 \\
\text { ND }\end{array}$ & $\begin{array}{c}12.55 \mathrm{~J} \\
\text { ND } \\
\text { ND } \\
0.19 \\
\text { ND }\end{array}$ & $\begin{array}{c}12.55 \mathrm{~J} \\
\text { ND } \\
\text { ND } \\
6.44 \\
\text { ND }\end{array}$ \\
\hline
\end{tabular}

Refer to footnotes at end of table. 
Table 4-4

Summary of Constituent Concentrations in Small Mammal Tissues,

Salmon Site

(Page 4 of 5)

\begin{tabular}{|c|c|c|c|c|c|c|}
\hline Parameter & Type & $\begin{array}{c}\text { Number of } \\
\text { Samples }\end{array}$ & $\begin{array}{l}\text { Number of } \\
\text { Detections }\end{array}$ & $\begin{array}{c}\text { Average } \\
\text { Concentration }^{\mathrm{a}}\end{array}$ & Minimum & Maximum \\
\hline Beta & $\begin{array}{c}\text { Bone } \\
\text { Liver } \\
\text { Fat } \\
\text { Muscle } \\
\text { Composite }\end{array}$ & $\begin{array}{l}9 \\
1 \\
1 \\
9 \\
3\end{array}$ & $\begin{array}{l}8 \\
1 \\
0 \\
3 \\
3\end{array}$ & $\begin{array}{c}59.04 \\
1.57 \\
\text { ND } \\
2.69 \\
0.77\end{array}$ & $\begin{array}{l}18.90 \\
1.57 \\
\text { ND } \\
1.80 \\
0.61\end{array}$ & $\begin{array}{c}107.27 \\
1.57 \\
\text { ND } \\
3.14 \\
0.89\end{array}$ \\
\hline $\begin{array}{l}\text { TRITIUM (pCi/g) } \\
\text { Wet weight basis } \\
\text { Tritium }\end{array}$ & $\begin{array}{c}\text { Bone } \\
\text { Liver } \\
\text { Fat } \\
\text { Muscle } \\
\text { Composite }\end{array}$ & $\begin{array}{c}9 \\
9 \\
1 \\
9 \\
13\end{array}$ & $\begin{array}{c}4 \\
2 \\
1 \\
2 \\
12\end{array}$ & $\begin{array}{c}3.42 \\
10.66 \\
0.10 \\
8.88 \\
4.05\end{array}$ & $\begin{array}{l}0.25 \\
1.14 \\
0.10 \\
6.37 \\
0.08\end{array}$ & $\begin{array}{c}12.70 \\
20.17 \\
0.10 \\
11.38 \\
39.77\end{array}$ \\
\hline $\begin{array}{l}\text { GAMMA SPECTROSCOPY }(\mathrm{pCi} / \mathrm{g}) \\
\text { Wet weight basis } \\
\text { Cesium- } 137\end{array}$ & $\begin{array}{c}\text { Bone } \\
\text { Liver } \\
\text { Fat } \\
\text { Muscle } \\
\text { Composite }\end{array}$ & $\begin{array}{c}9 \\
9 \\
1 \\
9 \\
13\end{array}$ & $\begin{array}{l}2 \\
3 \\
0 \\
1 \\
6\end{array}$ & $\begin{array}{l}0.21 \\
0.50 \\
\text { ND } \\
0.63 \\
0.85\end{array}$ & $\begin{array}{l}0.14 \\
0.31 \\
\text { ND } \\
0.63 \\
0.18\end{array}$ & $\begin{array}{l}0.28 \\
0.60 \\
N D \\
0.63 \\
3.50\end{array}$ \\
\hline Potassium-40 & $\begin{array}{c}\text { Bone } \\
\text { Liver } \\
\text { Fat } \\
\text { Muscle } \\
\text { Composite }\end{array}$ & $\begin{array}{c}9 \\
9 \\
1 \\
9 \\
13\end{array}$ & $\begin{array}{l}1 \\
4 \\
0 \\
5 \\
5\end{array}$ & $\begin{array}{l}2.70 \\
6.60 \\
\text { ND } \\
3.34 \\
4.26\end{array}$ & $\begin{array}{l}2.70 \\
1.90 \\
N D \\
2.50 \\
2.80\end{array}$ & $\begin{array}{l}2.70 \\
9.80 \\
\text { ND } \\
4.20 \\
5.60\end{array}$ \\
\hline Lead-212 & $\begin{array}{c}\text { Bone } \\
\text { Liver } \\
\text { Fat } \\
\text { Muscle } \\
\text { Composite }\end{array}$ & $\begin{array}{c}9 \\
9 \\
1 \\
9 \\
13\end{array}$ & $\begin{array}{l}1 \\
1 \\
0 \\
0 \\
1\end{array}$ & $\begin{array}{l}0.54 \\
0.80 \\
\text { ND } \\
\text { ND } \\
0.40\end{array}$ & $\begin{array}{l}0.54 \\
0.80 \\
\text { ND } \\
\text { ND } \\
0.40\end{array}$ & $\begin{array}{l}0.54 \\
0.80 \\
\text { ND } \\
\text { ND } \\
0.40\end{array}$ \\
\hline Uranium-238 & $\begin{array}{c}\text { Bone } \\
\text { Liver } \\
\text { Fat } \\
\text { Muscle } \\
\text { Composite }\end{array}$ & $\begin{array}{c}9 \\
9 \\
1 \\
9 \\
13\end{array}$ & $\begin{array}{l}0 \\
0 \\
0 \\
0 \\
1\end{array}$ & $\begin{array}{l}\text { ND } \\
\text { ND } \\
\text { ND } \\
\text { ND } \\
1.90\end{array}$ & $\begin{array}{l}\text { ND } \\
\text { ND } \\
\text { ND } \\
\text { ND } \\
1.90\end{array}$ & $\begin{array}{l}\text { ND } \\
\text { ND } \\
\text { ND } \\
\text { ND } \\
1.90\end{array}$ \\
\hline
\end{tabular}


Table 4-4

Summary of Constituent Concentrations in Small Mammal Tissues, Salmon Site

(Page 5 of 5)

\begin{tabular}{|c|c|c|c|c|c|c|}
\hline Parameter & Type & $\begin{array}{c}\text { Number of } \\
\text { Samples }\end{array}$ & $\begin{array}{l}\text { Number of } \\
\text { Detections }\end{array}$ & $\begin{array}{c}\text { Average } \\
\text { Concentration }^{a}\end{array}$ & Minimum & Maximum \\
\hline Thallium-208 & $\begin{array}{c}\text { Bone } \\
\text { Liver } \\
\text { Fat } \\
\text { Muscle } \\
\text { Composite }\end{array}$ & $\begin{array}{c}9 \\
9 \\
1 \\
9 \\
13\end{array}$ & $\begin{array}{l}0 \\
2 \\
0 \\
0 \\
0\end{array}$ & $\begin{array}{l}\text { ND } \\
0.14 \\
\text { ND } \\
\text { ND } \\
\text { ND }\end{array}$ & $\begin{array}{l}\text { ND } \\
0.13 \\
\text { ND } \\
\text { ND } \\
\text { ND }\end{array}$ & $\begin{array}{l}\text { ND } \\
0.14 \\
\text { ND } \\
\text { ND } \\
\text { ND }\end{array}$ \\
\hline Lead-210 & $\begin{array}{c}\text { Bone } \\
\text { Liver } \\
\text { Fat } \\
\text { Muscle } \\
\text { Composite }\end{array}$ & $\begin{array}{c}9 \\
9 \\
1 \\
9 \\
13\end{array}$ & $\begin{array}{l}0 \\
0 \\
0 \\
0 \\
1\end{array}$ & $\begin{array}{l}\text { ND } \\
\text { ND } \\
\text { ND } \\
\text { ND } \\
1.70\end{array}$ & $\begin{array}{l}\text { ND } \\
\text { ND } \\
\text { ND } \\
\text { ND } \\
1.70\end{array}$ & $\begin{array}{l}\text { ND } \\
\text { ND } \\
\text { ND } \\
\text { ND } \\
1.70\end{array}$ \\
\hline Thorium-230 & $\begin{array}{c}\text { Bone } \\
\text { Liver } \\
\text { Fat } \\
\text { Muscle } \\
\text { Composite }\end{array}$ & $\begin{array}{c}9 \\
9 \\
1 \\
9 \\
13\end{array}$ & $\begin{array}{l}0 \\
1 \\
0 \\
0 \\
0\end{array}$ & $\begin{array}{c}\text { ND } \\
22.80 \\
\text { ND } \\
\text { ND } \\
\text { ND }\end{array}$ & $\begin{array}{l}\text { ND } \\
22.80 \\
\text { ND } \\
\text { ND } \\
\text { ND }\end{array}$ & $\begin{array}{l}\text { ND } \\
22.80 \\
\text { ND } \\
\text { ND } \\
\text { ND }\end{array}$ \\
\hline
\end{tabular}

${ }_{b}^{a}$ Average concentration was calculated from detected concentrations only.

Milligram per kilogram

The reported value is below the Contract Required Detection Limit, but above the Instrument Detection Limit.

Reported value is quantitatively estimated.

Postdigestion spike for furnace atomic absorption analysis is out of control limit.

Not detected

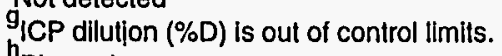

Picocurie per gram 


\subsection{Ecological Effects Characterization}

\subsection{Potential Ecological Effects}

\subsubsection{Aquatic Ecosystems}

\subsubsection{Surface Waters}

In order to characterize surface water COPC impacts to aquatic life, comparisons were made to the ambient water quality criteria (AWQC) for the protection of aquatic life or, when these were unavailable, to threshold values as determined from the scientific literature. The federal ambient water criteria and standards that have been established to protect the aquatic environment are the primary benchmark for comparisons. The potential for impacts to viability or propagation of aquatic life in the surface water bodies on the SS was investigated through the use of surface water concentrations for: aluminum, arsenic, and tritium (Table 5-1).

\section{Table 5-1}

Final Selection of Constituents of Concern in Surface Water,

\section{Salmon Site}

\begin{tabular}{|c|c|c|c|c|c|}
\hline $\begin{array}{l}\text { Constituent of } \\
\text { Potential } \\
\text { Concern }\end{array}$ & $B C F^{a}$ & $\begin{array}{c}\text { Surface Water } \\
\text { Concentration (95\% Upper } \\
\text { Confidence Limit of the } \\
\text { Mean }[\mu g / l])^{b}\end{array}$ & $\begin{array}{c}\text { Chronic AWQC } \\
(\mu g / \ell)\end{array}$ & $\begin{array}{l}\text { Detected in } \\
\text { Fish Tissue? }\end{array}$ & $\begin{array}{l}\text { Constituent of } \\
\text { Concern? }\end{array}$ \\
\hline Aluminum & $N D^{d}$ & 269.40 & 87 & Yes $^{e}$ & Yes \\
\hline Arsenic & 44 & 0.95 & $\begin{array}{c}48 \text { (pentavalent) } \\
190 \text { (trivalent) }\end{array}$ & No & No \\
\hline Iron & ND & 1,813 & 1,000 & Yes $^{e}$ & Yes \\
\hline \multicolumn{6}{|c|}{ Radionuclides Exceeding Reference Surface Water Concentrations } \\
\hline Tritium & $N A^{\prime}$ & $0.34 \mathrm{pCi/2}{ }^{g}$ & NA & Yes & Yes $^{h}$ \\
\hline
\end{tabular}

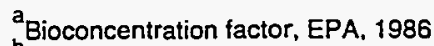

Microgram per liter

Ambient Water Quality Criteria

No data available

Detected at concentrations below the detection limit and lower than the concentrations in the reference sample. Iron was detected at concentrations above the detection limit, but lower than that of the reference sample.

Not applicable

${ }^{9}$ Picocurie per liter

hAll radiation sources are considered together as a constituent of concern in terms of total radiation dose. 


\section{Aluminum}

Studies conducted regarding aluminum suggest that. when the $\mathrm{pH}$ is between 6.5 and 9.0 , freshwater aquatic organisms should not be adversely affected by chronic exposure to less than $87 \mu \mathrm{g} / \mathrm{l}$ of aluminum or by acute exposure to less than $750 \mu \mathrm{g} / \mathrm{l}$ (EPA, 1988). Acute criteria were not exceeded in any surface water body investigated throughout the SS. However, exposure to constituents should be considered a continuous and, therefore, chronic exposure. All measured aluminum concentrations, including those from the reference pond, exceeded the chronic criteria. Therefore, it should be noted that aluminum in the surface waters at the SS are probably indicative of naturally occurring minerals in the soils and headwaters of these water bodies. Levels exceeding those from the reference pond were found at the Beaver Pond and Half Moon Creek Overflow Pond and at the furthest downstream section of Half Moon Creek. However, although aluminum was detected in fish tissue, it was at concentrations below the detection limit and lower than the concentration in the reference sample. Although unlikely, the potential for chronic toxicity to sensitive organisms exists. and aluminum is, therefore, considered a COC for freshwater systems at the SS.

\section{Arsenic}

The EPC for arsenic in surface water was $0.95 \mu \mathrm{g} / \mathrm{l}$, which is well below the chronic AWQC of either pentavalent $(48 \mu \mathrm{g} / \ell)$ or trivalent $(190 \mu \mathrm{g} / \mathrm{l})$ arsenic. No arsenic was detected in fish tissue. Therefore, arsenic was eliminated from further considerations as a COC.

\section{Iron}

Although the 95-percent UCL of the mean for site surface water samples exceeded the reference range and the AWQC, the AWQC value was exceeded only at the Beaver Pond and Half Moon Creek overflow pond locations. However, fish-tissue samples from the Beaver Pond and Half Moon Creek had lower iron concentrations than fish from the off-site reference pond.

\section{Radiation/Radionuclides}

Tritium was the only radioactive constituent that exceeded reference concentrations in surface water. Both the Beaver Pond and Half Moon Creek Overflow Pond had tritium concentrations above the range detected at reference stations.

No apparent bioaccumulation or bioconcentration effect for tritium has been found in either aquatic or terrestrial food chains. Dilution is in fact more likely (NCRP, 1979). A major concern in tritium toxicity is undesirable genetic or cellular effects resulting from its incorporation into DNA (NCRP, 1979). However, data on levels at which these effects occur 
due to tritium exposure in aquatic organisms were not available. Tritium was detected in three of five fish tissue samples. but not in the reference sample. Tritium is taken as part of the radiation dose received by aquatic organisms.

Gross beta radiation was detected in the fish tissue. but at a higher concentration in the reference than in the site samples. Alpha radiation was not detected in fish tissue. The only radionuclide detected in fish tissue was naturally-occurring potassium-40. General radiation effects are discussed in Section 5.1.2.1.

\subsubsection{Sediment}

The potential for biological effects to benthic organisms was based on COPC sediment concentrations. The assessment of effects through sediment contamination was accomplished through comparison of sediment concentrations with benchmarks.

The toxicity and kinetics of inorganics in sediment are not well understood. For this reason, risk to benthic organisms from toxic metals in sediments was characterized by comparing the measured sediment concentrations to sediment threshold values as determined from the literature. Long and Morgan (1990) have compiled data from existing studies that link concentrations of contaminants with predicted or observed biological effects. Concentrations were then selected that represent the lower tenth percentile of the screened data. This concentration is the ER-L and is used as the benchmark value in the stress characterization for metals in sediments.

COPC identified in sediment were arsenic, barium, cadmium, lead, manganese, zinc, and radiation sources, including total alpha and beta activity, tritium, and gamma spectroscopydetected radionuclides (Table 5-2).

\section{Arsenic}

The sediment criterion derived for arsenic is $33 \mathrm{mg} / \mathrm{kg}$ (Long and Morgan, 1990). The EPC for sediment (95-percent UCL of the mean, $2.98 \mathrm{mg} / \mathrm{kg}$ ) does not exceed this concentration, and arsenic would, therefore, not be expected to adversely affect aquatic life. Additionally, the calculated $\mathrm{EPC}_{\mathrm{aq}}$ as an estimate of the bioavailable concentration in interstitial waters would not exceed the AWQC levels, and arsenic was not detected in fish tissues. Therefore, arsenic was eliminated from further consideration as a $\mathrm{COC}$ in sediment. 
Table 5-2

Finai Selection of Constituents of Concern in Sediment, Salmon Site

\begin{tabular}{|c|c|c|c|c|c|c|c|}
\hline $\begin{array}{c}\text { Constituents } \\
\text { of Potential } \\
\text { Concern }\end{array}$ & $K_{d}^{a}$ & $\mathrm{BCF}^{\mathrm{b}}$ & $\begin{array}{l}\mathrm{EPC}_{\mathrm{aq}}{ }^{\mathrm{C}} \\
(\mathrm{mg} / \mathrm{l})_{\mathrm{d}}\end{array}$ & $\begin{array}{c}\text { EPC }_{\text {sed }}{ }^{\mathrm{e}} \\
(95 \% \text { Upper } \\
\text { Confidence Limit of } \\
\text { the Mean }[\mathrm{mg} / \mathrm{kg}])^{\mathrm{f}}\end{array}$ & $\begin{array}{l}\text { Sediment } \\
\text { Criteria } \\
\text { (mg/kg) }\end{array}$ & $\begin{array}{l}\text { Detected in } \\
\text { Fish Tissue? }\end{array}$ & $\begin{array}{c}\text { Constituent of } \\
\text { Concern? }\end{array}$ \\
\hline Arsenic & 200 & 44 & 0.0149 & 2.98 & 33 & No & No \\
\hline Barium & 60 & $N^{h}$ & 1.2923 & 77.54 & ND & Yes & Yes \\
\hline Cadmium & ND & ND & ND & 2.98 & 5 & No & No \\
\hline Lead & 900 & 49 & 0.0114 & 10.23 & 35 & Yes $^{\mathrm{i}}$ & No \\
\hline Manganese & 65 & ND & 3.2435 & 210.83 & ND & Yes & Yes \\
\hline Zinc & 40 & 47 & 0.894 & 35.76 & 120 & Yes & No \\
\hline \multicolumn{8}{|c|}{ Radionuclides Exceeding Reference Sediment Concentrations } \\
\hline Gross Alpha & $\mathrm{NA}^{\mathrm{k}}$ & NA & NA & $12.41 \mathrm{pCi} / \mathrm{g}^{\prime}$ & NA & No & Yes ${ }^{j \cdot m}$ \\
\hline Gross Beta & NA & NA & NA & $16.03 \mathrm{pCi} / \mathrm{g}$ & NA & Yes & Yes $^{\mathrm{j}, \mathrm{m}}$ \\
\hline Cesium-137 & NA & NA & NA & $0.40 \mathrm{pCi} / \mathrm{g}$ & NA & No & Yes $s^{\mathrm{j} m}$ \\
\hline Lead-210 & NA & NA & NA & $5.19 \mathrm{pCi} / \mathrm{g}$ & NA & No & Yes ${ }^{j, m}$ \\
\hline Radium-224 & NA & NA & NA & $1.66 \mathrm{pCi} / \mathrm{g}$ & NA & No & Yes ${ }^{j, m}$ \\
\hline Trillum & NA & NA & NA & $0.16 \mathrm{pCi} / \mathrm{g}$ & NA & Yes & Yes, \\
\hline
\end{tabular}

${ }^{a}$ Soil/water partition coefficient from Baes et al., 1984

Bioconcentration factor, EPA, 1986

Aquatic Exposure Point Concentration. $E \mathrm{CC}_{\mathrm{aq}}=\mathrm{EPC}_{\mathrm{sed}} / \mathrm{K}_{\mathrm{d}}$

Milligram per liter

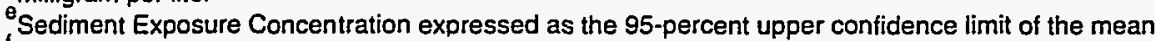

Milligram per kilogram

gLong and Morgan, 1990

$h_{\text {No data available }}$

'Analyte was detected below the Contract Required Detection Limit at estimated concentration.

Average concentration did not exceed reference concentration.

kot applicable

'Picocune per gram

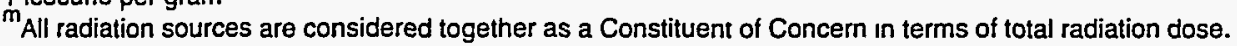

\section{Barium}

No sediment criterion was available for barium. The EPA $\mathrm{aq}_{\mathrm{aq}}$ was calculated to be 1.2923 milligrams per liter $(\mathrm{mg} / \mathrm{l})$. Although barium ions are thought to be rapidly removed from solution by precipitation and other processes, concentrations in drinking water in some midwestern and western states have been known to range as high as $3 \mathrm{mg} / \mathrm{l}$ (EPA, 1986). A restrictive criterion for barium does not appear warranted since barium is unlikely to exist in the toxic soluble form under usual fresh water conditions and soluble barium would have to exceed 
$50 \mathrm{mg} / \mathrm{l}$ before toxicity to aquatic life would be expected (EPA, 1986). However, barium was detected at an elevated concentration $(66.2 \mathrm{mg} / \mathrm{kg})$ in one fish tissue sample and, therefore, warrants further consideration as a COC in sediment.

\section{Cadmium}

The ER-L for cadmium is estimated at $5.0 \mathrm{mg} / \mathrm{kg}$ (Long and Morgan, 1990). Cadmium was detected in two samples from the SS. A sample from Half Moon Creek contained $1.70 \mathrm{mg} / \mathrm{kg}$ of cadmium. One sample from the Beaver Pond (BeP-1) contained $9.00 \mathrm{mg} / \mathrm{kg}$ of cadmium. While BeP-1 exceeded the ER-L, it was found to be equal to the reported Effects Range-Median (Long and Morgan, 1990), and it is that concentration above which effects are expected to occur. Additionally, cadmium was not detected in fish tissue. Therefore, cadmium is not considered further as a COC for sediment.

\section{Lead}

The sediment criterion derived for lead is $35 \mathrm{mg} / \mathrm{kg}$ (Long and Morgan, 1990). The EPC for sediment does not exceed this concentration, and lead would, therefore, not be expected to adversely affect aquatic life at the SS. Lead was detected in one fish tissue sample, but at an estimated concentration below the CRDL. Lead is, therefore, eliminated from further consideration as a COC in sediment.

\section{Manganese}

Manganese is a micronutrient required by both plants and animals. Manganese is not considered to be a problem in fresh waters since tolerance values for aquatic life range from 1.5 to over $1,000 \mathrm{mg} / \mathrm{l}(\mathrm{EPA}, 1986)$. The calculated $\mathrm{EPC}_{\mathrm{aq}}$ for manganese in SS sediments was $3.2435 \mathrm{mg} / \mathrm{l}$, at the lower end of this range. However, since the two fish-tissue samples from the site contained approximately twice as much manganese as the reference sample, manganese should be considered further as a COC in sediment.

\section{Zinc}

Zinc is a necessary micronutrient. The sediment criterion derived for zinc is $120 \mathrm{mg} / \mathrm{kg}$ (Long and Morgan, 1990). The EPC for zinc in SS sediment does not exceed this concentration and would, therefore, not be expected to adversely affect aquatic life. Zinc was detected in all fish samples, but the average concentration did not exceed the reference concentration. Zinc is, therefore, eliminated from further consideration as a COC in SS sediments. 


\section{Radiation/Radionuclides}

The potential for effects exists in areas of elevated concentrations. such as the Beaver Pond and Gator Pond. Gross alpha activity in the Beaver Pond and Gator Pond were as high as

$17.21 \mathrm{pCi} / \mathrm{g}$ and $22.48 \mathrm{pCi} / \mathrm{g}$, respectively, whereas gross beta activity was as high as $18.6 \mathrm{pCi} / \mathrm{g}$ and $23.69 \mathrm{pCi} / \mathrm{g}$. Cesium-137 was highest in the Beaver Pond $(0.61 \mathrm{pCi} / \mathrm{g})$ and the Gator Pond $(1.09 \mathrm{pCi} / \mathrm{g})$, but also occurred in the Half Moon Creek Overflow Pond, Half Moon Creek at HMC-4, and Hickory Hollow Creek at HHC-2 in levels above background. Lead-210 was elevated in the Beaver Pond as was radium-224, which was also detected at HMC-4. Tritium was only detected at the Beaver Pond. Total radiation dose was considered as a $\mathrm{COC}$ for sediment. See Section 5.1.2.1 for a discussion of general radiation effects.

\subsubsection{Potential Aquatic Ecosystem Effects Summary}

The final COC selected for risk characterization in the preceding sections for aquatic ecosystems at the SS include aluminum, barium, manganese, iron, and radiation sources.

The potential for chronic toxicity to sensitive organisms due to aluminum in surface waters was discussed above. Although aluminum was detected in all fish samples, the concentration was higher at the reference station than in the site samples. which were detected below the CRDL. It is likely that the aluminum concentrations in these waters are natural and that the organisms in these systems are tolerant of these concentrations. No data were available for toxicity comparisons to the fish tissue concentrations. No toxicity data were available either for manganese or barium, but it is apparent from water-quality criteria information that these elements would not be considered to be at toxic levels in SS aquatic environments. The water quality criterion for iron was exceeded in surface waters at the site, but only by the samples from the Beaver Pond and Half Moon Creek overflow pond. Fish tissue concentrations were higher in the reference pond samples than in the site samples. It is unlikely that toxicity to these organisms is occurring due to iron.

Due to the interconnected nature of the food web and the fact the terrestrial animals probably consume surface water on the site, exposure of terrestrial organisms to the aquatic contaminants should be considered. For aluminum, however, only one sample (a small mammal composite) had a concentration above the $\mathrm{CRDL}$, considering all large and small mammal samples. Barium and manganese were detected in most animal tissue samples. Barium is relatively abundant in nature and tends to accumulate in the skeleton (Amdur et al., 1991). The highest concentrations at the SS were found in bone samples, and the only tissues with concentrations above the detection limit were liver samples $(0.95 \mathrm{mg} / \mathrm{kg}$ wet weight) from large mammals, which may 
range off site. Manganese, an essential micronutrient is present in all living organisms (Amdur et al., 1991). Manganese concentrates in the liver in the normal processing of this nutrient (Amdur et al., 1991) and was found in highest concentrations in the liver samples from the SS. These results are. therefore, likely to represent naturally-occurring concentrations. Iron is an essential nutrient also found in highest concentration in the liver samples from the SS. This element, an essential component of the oxygen-carrying molecule hemoglobin, also likely represents naturally-occurring concentrations.

Tritium, the heaviest and only radioactive isotope of hydrogen, has been a ubiquitous contaminant produced by the atomic energy programs (NCRP, 1979). However, natural tritium also exists due to cosmic ray interactions in the atmosphere (NCRP, 1979).

When tritium is introduced into an aquatic environment. the tissue water of all invertebrates and most vertebrate organisms present in that water body will approach equilibrium with the tritium concentration in the water after a period of several weeks. Fish (mosquito fish and top minnows) raised in tritiated water had tritium concentrations in their tissues approximately .31 to .56 percent of the water concentration. The tissue concentrations of tritium in fish that were fed brine shrimp, which were also raised in tritiated water, were .73 percent of the water concentration (NCRP, 1979). This was essentially the case at the SS, with a mean water concentration of 0.22 picocuries per milliliter $(\mathrm{pCi} / \mathrm{m} \ell)$ and a mean tissue concentration of $0.43 \mathrm{pCi} / \mathrm{g}$.

The radiological doses to aquatic receptors, the great blue heron and general fish species, were calculated according to the method of Baker and Soldat (1992) using the reported radionuclide concentrations in surface water and sediment. The results are shown in Table 5-3. The external dose to fish was greater than the internal dose by two orders of magnitude due primarily to the presence of cesium-137, cadmium-109, and radium-224. The internal dose was due to tritium. Tin-113 was excluded from the dose calculation due to its short half-life (115 days, Table 5-4). The heron's internal dose arises from the assumption of a 600 -gram per day consumption rate of fish. The total dose for each of these receptors was well below the National Council on Radiation Protection criterion for protecting populations of aquatic organisms at $1 \mathrm{rad}$ per day (NCRP, 1991) or International Atomic Energy Agency rate for terrestrial populations at $0.1 \mathrm{rad} /$ day (IAEA, 1991). 
Table 5-3

Total Dose due to Sediments, Surface Water, and Soil Pathways, Salmon Site

\begin{tabular}{|c|c|c|c||}
\hline Receptor & $\begin{array}{c}\text { Internal Dose } \\
\text { (Rad/day) }\end{array}$ & $\begin{array}{c}\text { External Dose } \\
\text { (Rad/day) }\end{array}$ & $\begin{array}{c}\text { Total Dose } \\
\text { (Rad/day) }\end{array}$ \\
\hline \hline Mouse (Peromyscus) & $6 \times 10^{-8}$ & $6 \times 10^{-4}$ & $6 \times 10^{-4}$ \\
\hline $\begin{array}{c}\text { Heron (Ardea } \\
\text { herodias) }\end{array}$ & $2 \times 10^{-4 \mathrm{a}}$ & $2 \times 10^{-4 \mathrm{~b}}$ & $4 \times 10^{-4}$ \\
\hline Fish & $1 \times 10^{-7 \mathrm{a}}$ & $1 \times 10^{-5 \mathrm{~b}}$ & $1 \times 10^{-5}$ \\
\hline
\end{tabular}

${ }^{\mathrm{a}}$ Dose due to tritium only. Dose associated with other radionuclides was not estimated due to the absence of data on the effective absorbed energy rate for the specific radionuclides from the reference document (Baker and Soldat, 1992).

${ }^{b}$ Greater than 50 percent of the external dose is due to cesium-137

\section{Assumptions}

1. Tin-113 was not considered when calculating dose due to the short half-life.

2. A biological half-life of one day was used when data were not available from DOE, 1994.

3. It was conservatively assumed that the probability of a gamma emission per disintegration was one in all cases. This could result in an overestimate of the external dose by approximately one order of magnitude.

Table 5-4

Selected Radionuclides of Importance and Their Half-Lives, Salmon Site

\begin{tabular}{||c|c|}
\hline Radionuclide & Half-Life \\
\hline \hline Uranium-238 & $4,500,000,000$ years \\
\hline Plutonium-239 & 24,300 years \\
\hline Carbon-14 & 5,800 years \\
\hline Radium-226 & 1,620 years \\
\hline Cesium-137 & 30 years \\
\hline Strontium-90 & 28 years \\
\hline Tritium & 12.3 years \\
\hline Krypton-85 & 10.9 years \\
\hline Tin-113 & 115 days \\
\hline lodine-131 & 8 days \\
\hline Xenon-133 & 5.2 days \\
\hline lodine-132 & 2.4 hours \\
\hline
\end{tabular}




\subsubsection{Terrestrial Ecosystems}

\subsubsection{Soil}

The assessment of potential effects to terrestrial biota. based on soil concentrations of COPC, is not as simply defined as that for surface water or sediment. For the COPC identified in soil, applied daily doses reported in the literature to cause effects were compared to soil concentrations. The COPC identified in soil are copper, lead, and radiation (Table 5-5).

Table Ei-5

Final Selection of Constituents of Concern in Soil, Salmon Site

\begin{tabular}{|c|c|c|c|c|}
\hline $\begin{array}{l}\text { Constituents of } \\
\text { Potential Concern }\end{array}$ & $\begin{array}{c}\text { Soil Concentration } \\
\text { (95\% Upper Confidence } \\
\text { Limit of the Mean } \\
[\mu g / \mathrm{kg}])^{\mathrm{a}}\end{array}$ & $\begin{array}{l}\text { Detected in } \\
\text { Vegetation? }\end{array}$ & $\begin{array}{l}\text { Detected in } \\
\text { Animal } \\
\text { Tissues? }\end{array}$ & $\begin{array}{c}\text { Constituent of } \\
\text { Concern? }\end{array}$ \\
\hline Copper & 279.82 & Yes & Yes & Yes \\
\hline Lead & 17.32 & Yes & Yes & Yes \\
\hline \multicolumn{5}{|c|}{ Radionuclides Exceeding Reference Soil Concentrations } \\
\hline Lead-212 & $0.56 \mathrm{pCi} / \mathrm{g}^{\mathrm{b}}$ & Yes & Yes & Yes $^{c}$ \\
\hline Radium-223 & $0.27 \mathrm{pCi} / \mathrm{g}$ & No & No & Yes $^{c}$ \\
\hline Thallium-208 & $0.16 \mathrm{pCi} / \mathrm{g}$ & No & Yes & Yes $^{c}$ \\
\hline Thorium-228 & $5.08 \mathrm{pCi} / \mathrm{g}$ & No & No & Yes $^{c}$ \\
\hline
\end{tabular}

${ }_{\text {Microgram per kilogram }}$

Picocurie per gram

${ }^{c}$ All radiation sources are considered together as a constituent of concern in terms of total radiation dose.

\section{Copper}

Copper was detected in 34 of the 108 samples taken from the SS. The majority of the detected concentrations were within the reference range (ND $-10.70 \mathrm{mg} / \mathrm{kg}$ ). One sample from Site E-2 and E-7 in SA-3 and two samples from the CH Fuel Storage Area in SA-4 had levels slightly higher than the reference area. However, all soil samples from the West Substation in SA-4 had the highest levels of copper with the minimum concentration of $25.23 \mathrm{mg} / \mathrm{kg}$. The soil sample obtained from the center of the site activity was reported as $9,950 \mathrm{mg} / \mathrm{kg}$, over 100 times greater than any other value. Evidence of localized copper contamination at this site is apparent. The presence of soil COPC in vegetation tissue at concentrations above background is evidence of bioavailability and possible uptake. Copper was detected in one vegetation sample from SA-2 
and one from SA-6. Copper was not detected in the vegetation samples related to the West Substation where the soil concentrations were highest.

Copper toxicity to plants may occur at very high concentrations, but it is more likely under field conditions like those at the SS that plants would become tolerant to elevated copper concentrations in soil. Copper tolerance in plants has been widely documented (Shaw, 1989).

Copper was detected in small and large mammal tissue, with highest concentrations in the liver samples. Since no reference mammal tissues were collected in conjunction with SS samples, the SS results were compared with naturally occurring reference tissue concentrations in the published literature (Table 5-6). Copper concentrations in small mammal composites were slightly above the average control area concentrations for shrew and vole species, but within the range for deer mice from one study. With only one raccoon sample and little published data, comparisons should be made with caution. The raccoon- liver copper concentration was slightly elevated compared with other omnivorous and herbivorous species. No data were available for large mammals. It is likely that these levels, being within or near reference levels, are below levels that would be expected to have an adverse effect. The tissue concentrations of copper in Bachman's sparrows and game birds are likely to be similar to that of the small mammal composite because of similar diets and possibly lower since the sparrow would have less contact with soils. The burrowing, herbivorous gopher tortoise may also have similar copper concentrations in its tissues. Copper is likely to be less toxic to the tortoise due to its slower metabolic rate.

Copper is an essential element required for enzyme processes and hemoglobin synthesis. Little information is available on chronic effects of elevated copper in biota, but may result in hemolytic anemia in humans. To determine whether bioaccumulation to higher trophic levels was a concern, copper intake was calculated for the red-tailed hawk, assuming a diet of small mammals using the following equation:

$$
\left(I_{v}=\frac{\left(C_{v}\right)\left(Q_{v}\right)(F I)}{B W}\right)
$$


Table 5-6

Comparison of Copper Concentrations in Mammal Tissues

to Literature Reference Values,

Salmon Site

\begin{tabular}{|c|c|c|c|c|c|c|c|}
\hline $\begin{array}{l}\text { Salmon Site } \\
\text { Species }\end{array}$ & Tissue Type & $\begin{array}{c}\text { Water } \\
\text { Content }^{a}\end{array}$ & $\begin{array}{c}\text { Maximum } \\
\text { Concentration } \\
\text { (mg/kgc dry weight) }\end{array}$ & $\begin{array}{l}\text { Literature } \\
\text { Test Species }\end{array}$ & Tissue Type & Location & $\begin{array}{c}\text { Concentration } \\
\text { Range } \\
\text { (mg/kg dry } \\
\text { weight) } \\
\end{array}$ \\
\hline \multirow[t]{3}{*}{$\begin{array}{l}\text { Small Mammal } \\
\text { Composite }\end{array}$} & \multirow[t]{3}{*}{ Whole Body } & \multirow[t]{3}{*}{$68 \%$} & \multirow[t]{3}{*}{16.25} & $\begin{array}{l}\text { Short-tailed shrew } \\
\text { (Blarina brevicauda) }\end{array}$ & Whole Body & $\begin{array}{l}\text { Not stated } \\
\text { (U.S.) }\end{array}$ & $9-11^{d}$ \\
\hline & & & & $\begin{array}{l}\text { Meadow vole } \\
\text { (Microtus pennsylvanicus) }\end{array}$ & Whole Body & $\begin{array}{l}\text { Not stated } \\
\text { (U.S.) }\end{array}$ & $11.9^{d}$ \\
\hline & & & & $\begin{array}{l}\text { Deer mouse } \\
\text { Long-tailed field mouse } \\
\text { (Peromyscus maniculatus) }\end{array}$ & $\begin{array}{l}\text { Whole Body } \\
\text { Whole Body }\end{array}$ & $\begin{array}{l}\text { Not stated } \\
\text { (U.S.) }\end{array}$ & $\begin{array}{l}10-13.4^{d} \\
8.8-17.2^{e}\end{array}$ \\
\hline \multirow[t]{5}{*}{$\begin{array}{l}\text { Raccoon } \\
\text { (Procyon lotor) }\end{array}$} & Bone & $\begin{array}{c}90 \% \text { ash } \\
\text { (estimated) }\end{array}$ & 12.33 & $\begin{array}{l}\text { Raccoon } \\
\text { (Procyon lotor) }\end{array}$ & Baculum bone & Illinois & $0.13-1.7^{e, f}$ \\
\hline & \multirow[t]{4}{*}{$\begin{array}{l}\text { Liver (one } \\
\text { sample) }\end{array}$} & \multirow[t]{4}{*}{$\begin{array}{c}75 \% \\
\text { (estimated) }\end{array}$} & \multirow[t]{4}{*}{27.2} & $\begin{array}{l}\text { Rat } \\
\text { (Rattus rattus) }\end{array}$ & Liver & Vermont & $10.7^{f}$ \\
\hline & & & & $\begin{array}{l}\text { Rock squirrel } \\
\text { (Spermophilus variegatus) }\end{array}$ & Liver & Utah & $12.1-24.1^{f}$ \\
\hline & & & & $\begin{array}{l}\text { Goat } \\
\text { (Capra hirsus) }\end{array}$ & Liver & Germany & $11.3^{f}$ \\
\hline & & & & & Liver & Germany & $63.3^{t}$ \\
\hline
\end{tabular}

${ }_{b}^{a} E P A, 1993$

Salmon Site tissue concentrations are reported on wet weight basis. Values shown here are converted to a dry weight basis for comparison to literature values.

Milligram per kilogram

Talmage and Walton, 1991

$\theta$ Weight on ashed basis

EPA, 1980 
where

$I_{v} \quad=$ intake of chemical by predator (milligrams per kilograms per day $[\mathrm{mg} / \mathrm{kg} / \mathrm{d}]$ )

$\mathrm{C}_{\mathrm{v}}=$ concentration in $\operatorname{diet}(\mathrm{mg} / \mathrm{kg})$

$=97.2 \% \times 5.2 \mathrm{mg} / \mathrm{kg}$ (small mammal composite) $+2.8 \% \times 279.82 \mathrm{mg} / \mathrm{kg}$ (soil)

$\mathrm{Q}_{\mathrm{v}}=$ ingestion rate (kilograms per day $[\mathrm{kg} / \mathrm{d}]$ )

$=0.124 \mathrm{~kg} / \mathrm{d}$ wet weight $($ EPA, 1993)

FI = fraction ingested from the site. Since the hawk's foraging area is approximately 165 hectares ( 67 acres), and the site is 595 hectares (241 acres), the calculation was made for a hawk that forages only on the SS.

$$
=1
$$

$\mathrm{BW}=$ Body weight of hawk, $\mathrm{kg}$

$=1.126 \mathrm{~kg}$ average for males and females, wet weight (Dunning, 1993).

$$
I_{v}=\frac{12.89 \mathrm{mg} / \mathrm{kg} \text { copper diet }(0.124 \mathrm{~kg} / \mathrm{d})(1)}{1.126 \mathrm{~kg}}=1.42 \mathrm{mg} / \mathrm{kg} / \mathrm{d}
$$

It was also assumed that soil consumption would be approximately 2.8 percent using figures for the red fox (EPA, 1993), which has similar feeding habits and probably more contact with soils. An extrapolated No Observed Adverse Effect Level for copper carbonate has been calculated at $27.89 \mathrm{mg} / \mathrm{kg} / \mathrm{d}$ and for copper oxide at $22.49 \mathrm{mg} / \mathrm{kg} / \mathrm{d}$ for the red-tailed hawk (Opresko et al., 1993). Therefore, it is not expected that adverse effects will occur at tertiary consumer levels at SS due to copper.

\section{Lead}

Lead was detected in 105 of the 108 SS samples, ranging from 1.4 to $120 \mathrm{mg} / \mathrm{kg}$ with the 95-percent UCL of the mean being $17.32 \mathrm{mg} / \mathrm{kg}$.

Lead was not detected in the reference area plant samples, but was detected in plants from all source areas. The highest concentration was found in a sample from SA-3 at $14.3 \mathrm{mg} / \mathrm{kg}$. The average concentration of the detected samples sitewide was $4.25 \mathrm{mg} / \mathrm{kg}$. Rolfe and Bazzaz (1975) saw significant uptake of lead when applying soluble lead to soil as lead chloride. Loblolly-pine and autumn-olive photosynthesis was inhibited by 11 and 17 percent, respectively, at foliar lead concentrations of 60 and $72 \mathrm{mg} / \mathrm{kg}$ dry weight, respectively. Below these concentrations, no effect was evident. Seiler and Paganelli (1987) found that red-spruce net photosynthesis was significantly lower than the control at a foliar lead concentration of only $3.2 \mathrm{mg} / \mathrm{kg}$ dry weight, but no effect was seen in loblolly pine at $2.2 \mathrm{mg} / \mathrm{kg}$. 
It is likely that foliar concentrations would be lower than or equal to the woody tissue concentrations measured at the SS. Lead tolerance in plants has also been documented and may be a factor in assessing effects to these plants. It is unlikely that lead levels seen in these plants would result in adverse effects.

Lead was detected in small mammal tissues above the CRDL in bone, muscle, and composite samples and in large mammals in bone and fat. The highest concentration was observed in a small mammal bone sample at $391 \mathrm{mg} / \mathrm{kg}$. The SS results were compared with naturally occurring reference tissue concentrations in published literature (Table 5-7). These comparisons showed that lead concentrations in small mammals, raccoon, and deer tissues were within normal ranges and would not be expected to cause adverse effects. Again, extrapolating from these results, lead levels in the Bachman's sparrow and gopher tortoise, as well as game birds, would be expected to be in normal ranges. A calculation was made for the dose to the red-tailed hawk, using the same equation as for copper:

$$
I_{v}=\frac{0.8349 \mathrm{mg} \text { copper } / \mathrm{kg} \operatorname{diet}(0.124 \mathrm{~kg} / \mathrm{d})(1)}{1.126 \mathrm{~kg}}=0.092 \mathrm{mg} / \mathrm{kg} / \mathrm{d}
$$

$\mathrm{C}_{\mathrm{v}}=$ Soil lead EPC of $17.32 \mathrm{mg} / \mathrm{kg} \times 2.8 \%$ of diet $+0.36 \mathrm{mg} / \mathrm{kg}$ wet weight small mammal x $97.2 \%$

Depression of the enzyme, aminolevulinic acid dehydratase, which is involved in hemoglobin production (and chlorophyll production in plants), occurred in all tissues of American Kestrels (Falco sparverius) at $25 \mathrm{mg} / \mathrm{kg} / \mathrm{d}$. No measurable effects were seen at $10 \mathrm{mg} / \mathrm{kg} / \mathrm{d}$

(Eisler, 1988). The dose received here by the hawk is well below these levels, and, therefore, lead would not pose a threat of adverse effects to top consumers at the SS.

\section{Radiation/Radionuclides}

Although the 95-percent UCL of the media did not exceed the reference range, both alpha and beta activity were found above reference area levels at various sites throughout the SS. Gross alpha radiation was found at elevated levels particularly at the Clean Burn Pit and Gas Pump in SA-2, Sites E-2 and E-7 and the Government Storage Area 2 in SA-3, the Cable Storage Area and West Substation in SA-4, and the HT-2 Well Area in SA-5. Gross beta activity was found at elevated levels at many of these same sites: the Clean Burn Pit in SA-2; the CH Fuel Storage Area, Cable Storage Area, and West Substation in SA-4; and the HT-2 and HT-2M Well Areas in SA-5. Biota at these sites may be potentially affected by low levels of radioactivity, and thus radiation should be considered as a $\mathrm{COC}$ for soil. All radionuclides detected in site soils are 
Table 5-7

Comparison of Lead Concentrations in Mammal Tissues

to Literature Reference Values,

Salmon Site

\begin{tabular}{|c|c|c|c|c|c|c|c|}
\hline $\begin{array}{l}\text { Salmon Site } \\
\text { Species }\end{array}$ & Tissue Type & $\begin{array}{l}\text { Water } \\
\text { Content }\end{array}$ & $\begin{array}{c}\text { Maximum } \\
\text { Concentration }{ }^{a} \\
\text { (mg/kg dry weight) }^{b}\end{array}$ & Literature Species & Tissue Type & Location & $\begin{array}{c}\text { Concentration } \\
\text { Range } \\
\text { (mg/kg dry weight) }\end{array}$ \\
\hline \multirow[t]{4}{*}{$\begin{array}{l}\text { Small Mammal } \\
\text { Composite }\end{array}$} & \multirow[t]{4}{*}{ Whole body } & \multirow[t]{4}{*}{$68 \%^{c}$} & \multirow[t]{4}{*}{1.125} & $\begin{array}{l}\text { Field mouse } \\
\text { (Apodemus sylvaticus) }\end{array}$ & Whole body & Not stated & $1^{d}$ \\
\hline & & & & $\begin{array}{l}\text { Short-tailed shrew } \\
\text { (Blarina brevicauda) }\end{array}$ & Whole body & Not stated & $6^{d}$ \\
\hline & & & & $\begin{array}{l}\text { White- footed mouse } \\
\text { (Peramyscus leucopus) }\end{array}$ & Whole body & Not stated & $7^{d}$ \\
\hline & & & & $\begin{array}{l}\text { Deer mouse } \\
\text { (Peramyscus maniculatus) }\end{array}$ & Whole body & Not stated & $2.2^{d}$ \\
\hline $\begin{array}{l}\text { Raccoon } \\
\text { (Procyon lotor) }\end{array}$ & $\begin{array}{c}\text { Liver } \\
\text { (one sample) }\end{array}$ & $\begin{array}{c}75 \% \\
\text { (estimated) }\end{array}$ & $0.44^{\theta}$ & $\begin{array}{l}\text { Raccoon } \\
\text { (Procyon lotor) }\end{array}$ & Liver, kidney & Not stated & $>140^{\mathrm{d}, \mathrm{f}}$ \\
\hline \multirow{2}{*}{$\begin{array}{l}\text { White-Tailed Deer } \\
\text { (Odocoileus } \\
\text { virginianus) }\end{array}$} & Bone & $\begin{array}{c}10 \% \\
\text { (estimated) }\end{array}$ & 15.44 & \multirow[t]{2}{*}{$\begin{array}{l}\text { White-tailed Deer } \\
\text { (Odocoileus virginianus) }\end{array}$} & Bone & Not stated & $3-11^{d}$ \\
\hline & Liver & $\begin{array}{c}75 \% \\
\text { (estimated) }\end{array}$ & $\begin{array}{l}26 . .^{g} \\
0.2^{\mathrm{h}}\end{array}$ & & Liver & Not stated & $<0.4^{d}$ \\
\hline
\end{tabular}

${ }^{a}$ Salmon Site tissue concentrations are reported on wet weight basis. Values shown here are converted to a dry weight basis for comparison to literature values.

Milligram per kilogram

\section{EPA, 1993}

Elsler, 1988. Concentrations are means unless a range is given.

Based on estimated concentration below the detection limit

Lead-intoxicated animal

${ }^{9}$ Only detection above Contract Required Detection Limit of seven samples, arrived at by Standard Addition Method

Detected below detection limit at estimated concentration 
considered site related and require further consideration. as discussed below. Those for which the 95-percent UCL exceeded the reference range of concentrations included lead-210, thallium-208, and thorium-228.

Vegetation in SA-6 had the highest gross alpha and beta measurements. Vegetation from SA-6 was entirely crop plants. and the samples are not directly comparable since all other samples were composed of pine. Excluding SA-6, gross beta was higher in reference area vegetation than onsite vegetation. Gross alpha was similar on site to reference areas except for SA-4. Of the COPC identified for soils, copper, alpha and beta radiation. and the radionuclides cesium-137, potassium40 , lead-212, beryllium-7, bismuth-214, cerium-139, tin-113, and lead-210 were detected in vegetation. Most radionuclides were detected in only 1 of the 18 samples, except lead-210 (in 6 samples) and the naturally occurring beryllium-7 (in 9 samples) and potassium-40 (in 4 samples). No tritium analyses were conducted for either plants or soils. Gross alpha and beta radiation and several radionuclides were detected in small and large mammal tissues. Radionuclides detected in more than 1 sample include cesium-137, potassium-40, lead-212, and thallium-208 (detected in 2 small mammals and 1 large mammal). A general discussion of radionuclide effects is as follows.

Radioactive atoms, which represent unstable forms of an element, undergo spontaneous nuclear transformations. Charged particles and electromagnetic waves are given off in the form of radiation. Excess energy released in this way is termed ionizing radiation. Such transformations are referred to as radioactive decay. A fundamental and unique characteristic of each radionuclide is its radioactive half-life. The half-life of a radionuclide is the time required for the number of atoms present to decrease (decay) by one-haif. Half-lives range from fractions of a second to millions of years. Selected radionuclides of potential importance for the SS and their half-lives are listed in Table 5-4.

The absorption of the energy of ionizing radiation in cells involves ionization of atoms and the production of ions within the cells. Although the exact mechanism of action of ionizing radiation is not known, radiation injury is considered to be related in some way to the transfer of energy into a cell and the production of ions within the cell. Ionizing radiation can cause deleterious effects on biological tissues only when the energy released during radioactive decay is absorbed by the tissue. The dose delivered to tissues from radiations external to the body occurs only while the radiation field is present. However, the dose delivered to body tissues due to radiations from systemically incorporated radionuclides may continue long after intake of the nuclide has ceased. 
Alpha particles originate in the nuclei of radioactive heavy elements. Because of their double positive charge, these particles have great ionizing power, but their large size results in very little penetrating power. Alpha particles typically travel only about $4 \mathrm{~cm}$ (1.6 in.) through air and cannot penetrate a sheet of paper or a single layer of skin. However, alpha-emitting radionuclides are considered internal radiation hazards and are dangerous if inhaled or ingested.

Beta particles are emitted from within the nuclei of atoms undergoing a radioactive decay process. Many of the common isotopes used in biological research, such as tritium, carbon-14, phosphorus-32, sulfur-35, and calcium-45, emit beta particles. The ability of beta particles to penetrate a material is dependent upon the energy of the particle. Radionuclides that emit beta particles are considered both external and internal radiation hazards. The probability and severity of risk from beta emitters is related to the kinetic energy of the beta particle, the physical half-life of the radionuclide, and the biological half-life of the radioisotope. Beta particles from tritium do not have enough energy to penetrate a single layer of dead skin cells (Shapiro, 1981).

Gamma rays originate from unstable atomic nuclei releasing energy to gain stability. They have definite energies, characteristic of the nuclide from which they are emitted. Gamma rays ionize materials largely indirectly through a variety of mechanisms that involve ejection of high-speed electrons from the atoms by which they are absorbed. Because of their high penetration ability, gamma rays are of most concern as external hazards.

The sources for exposure of plants and animals to ionizing radiation can be broken down into four major groups: (1) natural sources of irradiation, both external and internal; (2) medical sources and radiopharmaceuticals; (3) nuclear reactions, such as nuclear power reactors and nuclear weapons: and (4) other miscellaneous sources. Exposure to natural sources of irradiation are unavoidable for the most part, but the degree of exposure to man-made sources is subject to change, depending upon usage of such sources.

The debris from nuclear detonations predominantly emit gamma and beta radiation. Some of the more common radionuclides involved in a nuclear explosion are uranium-238, plutonium-239, carbon-14, radium-226, cesium-137, strontium-90, tritium, krypton-85, iodine-131, xenon-133, and iodine- 132 .

The principal exposure and primary dose from nonfallout radiation include the buildup of deposited radionuclides in soil and vegetation, transfer of radioactive materials from soil to plants, and incorporation of radioactive materials in animals, both prey and predatory species. Currently, 
the projected annual average whole-body dose rate from global atmospheric weapons testing is projected to be 4 to 5 millirems per year through the year 2000 for the United States population (BEIR, 1980). No estimates are given for wildlife, but one could assume them to be equal to, or slightly higher than, those given for humans.

Although different radionuclides have different properties and energies, alpha. beta and gamma radiation are all sources of ionizing radiation and, since they occur together at the site, would all contribute to the total dose. Dosages are measured in rads or grays. One hundred rads are equal to one gray.

Radionuclide levels in tissues can change with dietary composition (e.g., different levels may occur in different types of vegetation; an animal may shift from vegetation to insects at different times of the year). Therefore, the radiation dose was calculated to the mouse as a terrestrial ecological receptor that is assumed to spend all of its time on site. The radiological dose to the mouse was calculated using radionuclide soil concentrations and a modification of the methodology outlined in the Hanford Site Risk Assessment Methodology (DOE, 1994). Yu et al. (1993) was also consulted.

The external dose to the mouse was about four orders of magnitude greater than the internal dose. The primary contributors to the external dose were cesium-137 and thorium-228. For the external exposure calculation, it was conservatively assumed that, for each radionuclide that is a gamma emitter, the probability of a gamma emission is one. This means that the mega-electron volts per disintegration used in the calculation was not multiplied by the probability of gamma being the mode of decay. The resulting external dose was less than $1 \mathrm{rad}$ per day. Therefore, this conservatism is permissible. The total dose to the mouse was $6 \times 10^{-4}$ rad per day (Table 5-3), well below the IAEA (1991) rate of $0.1 \mathrm{rad}$ per day for terrestrial population protection. The Bachman's sparrow is expected to have a similar internal dose due to diet similarities between this sensitive species and the mouse. However, the external dose would probably be lower since the sparrow does not burrow and would spend less time in contact with the soil. The dose to the tortoise is expected to be as low as the mouse, or lower, since the external dose would be reduced by the shielding effect of the shell (Cosgrove, 1971).

Woodwell and Rebuck (1967) studied chronic gamma irradiation of an oak-pine forest. Pines were the most sensitive species, followed by shrubs, herbacious plants, and lichens. A reduction 
in species diversity was observed at 100 rad per day ( 1 gray per day) (Woodwell and Rebuck. 1967). Measurable changes in diversity in a grassland plant community require a dose rate of about $400 \mathrm{rad} / \mathrm{day}$, and a calculation using effective decay energy for Pu-239 was devised to determine the concentration required to achieve this dose rate (Whicker, 1980). It was determined that $1.5 \times 10^{-2}$ microcuries $(\mu \mathrm{Ci}) \mathrm{Pu}-239 / \mathrm{g}$ plant tissue or $150 \mu \mathrm{Ci} \mathrm{Pu}-239 / \mathrm{g}$ soil were required to achieve this dosage (Whicker, 1980). The dose to the SS plants is well below these levels.

\subsubsection{Potential Terrestrial Ecosystem Effects Summary}

Levels of lead and copper in plant and animal tissues at the SS were found to be generally within reference ranges found in the published literature and would, therefore, be below levels that would be expected to cause adverse effects. Calculations of the intake of these elements by the top predator observed at the site. the red-tailed hawk, also gave results for which adverse effects would not be expected. The radiation dose calculated for the mouse was well below established criteria for radiation exposure effects to terrestrial populations. No adverse effects to the plant and animal populations at the SS are expected due to copper, lead, or radiation sources.

\subsubsection{Laboratory Studies}

\subsubsection{Aquatic Toxicity Tests}

Toxicity tests were used to assess the potential for gross effects from contaminated media on selected test species. The toxicity tests integrate the acute effects of all constituents with the bioavailability of those constituents in the contaminated media.

Surface water samples used in toxicity testing were collected on April 25, 1993, from the fifteen stations indicated in Table 3-6 and 3-7. All samples were collected as composited, mid-depth samples from random points at each station. Samples were immediately packed on ice and shipped for testing as outlined in the EEW Standard Operating Procedures. Ceriodaphnid and fathead minnow tests screened surface waters for acute toxicity. The assessment of toxicity is made by comparing the response, either survival or germination, in the on-site media to the response in the reference area media.

The results of toxicity tests are presented in Tables A-4.10 and A-4.11 in Appendix A of this report. Survival of fathead minnows in surface waters of the SS was at least 95 percent in all site samples, references, and controls. Survival of ceriodaphnids in test waters was lower. The lowest survival was seen in the ponds and Hickory Hollow Creek. Survival in on-site ponds 
ranged from 60 to 72 percent, but was only 80 percent in the reference pond. On-site Hickory Hollow Creek survival was 64 percent; upstream survival was only 60 percent. Grantham Creek survival ranged from 80 percent on site to 88 percent upstream. Half Moon Creek survival ranged from 88 to 100 percent on site as compared to 88 percent upstream. No significant differences were found between any on-site location and the applicable reference with respect to acute toxicity.

\subsubsection{Terrestrial Toxicity Tests}

Soil samples used in toxicity tests were collected as aliquots of samples collected for chemical and radionuclide analyses. These samples were collected from April 26 to 30, 1993. Samples were immediately packed on ice in a cooler and shipped for testing as outlined previously. Samples were not composited, but tested as individual replicates for each station. The lettuce seed germination test was used to screen surficial soils for acute toxicity. The assessment of toxicity is made by comparing the response, either survival or germination, in the on-site media to the response in the reference area media. Testing was conducted from May 4 to 9, 1993, in the ITEdison Bioassay Laboratory. Average seed germination per site soil sample ranged from 64

percent to 72 percent. Reference area germination was 66 percent and laboratory control was 64 percent.

\subsubsection{Field Investigations}

\subsubsection{Benthic Ecology Investigations (Rapid Bioassessment Protocol I)}

During the period July 13 to 19,1992 , each of the nine creek stations underwent benthic macroinvertebrate analysis using RBP I (EPA, 1989c). The six pond stations were surveyed to support general macrobenthos quality comparisons.

Benthic macroinvertebrate samples were collected using a kick-net technique at all lotic system (running water) stations and with an Ekman grab sampler at all lentic-system stations. Data collected from the samples were relative abundance of macroinvertebrate families or orders, as well as quality measurements (e.g., dissolved oxygen and $\mathrm{pH}$ ) and habitat characteristics (e.g., substrate, flow, and cover) for general habitat assessment.

The benthic-community habitat-assessment data for the ponds and creeks of the SS are presented in Appendix A. Table A-9.1 is the habitat assessment for RBP I and Table A-9.2 is the RBP I level macrobenthos data. 
The RBP I habitat assessment found all creek habitats to be comparable to the reference station or of a higher quality, except for station HHC-2. This station was evaluated as capable of supporting a habitat similar to its reference station (station HHC-1).

The macrobenthos qualitative field data from the RBP I investigation are summarized in Appendix Table A-9.2. Ten taxa were observed at the various creek stations. Taxa identification and confirmation was performed using Peckarsky et al.. 1990. A description of the ecological requirements and importance of the taxa found at the SS was presented in the Results of a Preliminary Survey for Threatened and Endangered Species and Floodplains and Wetlands at the TDTS (IT, 1992a). The most prevalent taxa found throughout the site were Plecoptera, Coleoptera, Anisoptera, Decapoda, and Tabanidae. Station HHC-2 was the lowest in taxa richness and was abundant in Chironomidae, which are generally a stress-tolerant species. This was probably more artributable to the station's creek topography than external sources of stress, due to the abundance of pollution intolerant Anisoptera that were also found at that station. Station HMC-3 had a large submerged root mass present that was found to support a diverse macroinvertebrate population. Grass shrimp and Gastropods were unique to that station, which is located closest in proximity to SGZ.

The SS aquatic ecosystem was evaluated using the Habitat Assessment/Impairment technique associated with the RBP (EPA, 1989c). The data for the RBP I are presented in Appendix Table A-9.1. The RBP Habitat Assessment compares the ratio of the score for the station of interest to the score of the appropriate reference station. The result of this comparison indicates whether the habitat across the site is capable of supporting an adequate aquatic community. The results for the RBP I habitat assessment found that $\mathrm{HHC}-2$ had the lowest percent comparability to its reference station, yet it is still classified as supporting adequate biota. This may be attributed to the fact that Hickory Hollow Creek is an intermittent stream that was reduced to standing pools in the area of $\mathrm{HHC}-2$ during the study period. However, the sitewide RBP I results, as presented in Appendix Table A-9.1, reflect habitat conditions and parameters that are predominantly in the good to excellent category for supporting a biological community.

The RBP I qualitative evaluation showed that stations HMC-2, HMC-5, and GrC-2 shared a common overall abundance and taxa richness, with three different taxa present. Station HHC-2, had two taxa that were abundant ( $>10$ individuals) and three taxa that were rare ( $<3$ individuals). Stations HHC-2, GRC-1, HMC-1, HCM-3, and HMC-4 shared a common overall abundance and 
taxa richness, with four to seven different taxa occurring at those stations. Crayfish. lampreys, salamanders, tadpoles, Anisoptera, Coleoptera, and Plecoptera were found commonly throughout the creek areas. The presence of these taxa is normally indicative of an uncontaminated habitat.

\subsubsection{Benthic Ecology Investigations (Rapid Bioassessment Protocol III)}

The RBP III was used for a more quantitative benthic ecology survey and was conducted during the second phase of the investigation between February 22 and 28, 1993. The 15 stations sampled previously using RBP I were resampled using RBP III. A kick net was again employed for collecting both riffle/run and pool samples. In addition, a Coarse Particulate Organic Matter (CPOM) sample was collected from each station for functional feeding group analysis. Appendix Table A-9.3 is the habitat assessment for RBP III, Appendix Table A-9.4 is the RBP III level macrobenthos data, and Appendix Table A-9.5 is the CPOM data..

The RBP III habitat assessment found Half Moon Creek stations to be comparable to the reference station or of a higher quality. Both Grantham Creek and Hickory Hollow Creek were found to be capable of supporting a habitat similar to their respective reference stations (station HHC- 1 and $\mathrm{GrC}-1$ ).

The macrobenthos field results for the RBP III investigation are summarized in Appendix Table A-9.4. Sixty-seven taxa were collected in the riffle/run samples. The only taxa that were identified in the RBP III investigation that were not found in the RBP I investigation were Hirudinea (leeches), Turbellaria (flatworms), and Megaloptera (alderflies). All taxa were identified at the IT Aquatic Sciences Laboratory in Edison, New Jersey, to the lowest practical taxa. The most prevalent taxa found throughout the site were Plecoptera, Tricoptera, Ephemeroptera, and Diptera. The biological integrity of each creek station was evaluated by performing the analysis for the eight metrics that are associated with the RBP III.

The SS aquatic ecosystem was evaluated using the Habitat Assessment/Impairment technique associated with the RBP (EPA, 1989c). The data for the RBP III are presented in Appendix Table A-9.3. The RBP Habitat Assessment compares the ratio of the score for the station of interest to the score of the appropriate reference station. The result of this comparison indicates whether the habitat across the site is capable of supporting an adequate aquatic community. The results for the RBP III habitat assessment found that both HHC-2 and GrC-2 were capable of supporting a similar biological community as compared to their respective reference stations and that all HMC stations were comparable or of a higher quality than the reference station. The conditions at HHC-2 may be attributed to the intermittent nature of that creek, as discussed 
previously. The conditions at $\mathrm{GrC}-2$ are capable of supporting a biological community that is similar to the reference station as demonstrated by the results of the benthic macroinvertebrate investigation (as presented in Appendix Table A-9.5). The data demonstrate that $\mathrm{GrC}-2$ had 20 organisms present, representing 11 different species. as compared to 4 organisms present that represented 4 different species at station $\mathrm{GrC}-1$. The overall RBP III Habitat Assessment results, as presented in Appendix Table A-9.3, reflect habitat conditions and parameters that are predominantly in the good to excellent category for supporting a biological community.

The RBP III is a more rigorous bioassessment technique than the RBP I, involving systematic field collection and subsequent lab analysis in order to detect more subtle degrees of impairment. The RBP III macrobenthos data are summarized in Table A-9.4. The final analysis of the RBP III is a summation of biological scores from eight different metrics that evaluate the biological integrity at each creek station as compared to its respective reference station. Using the raw benthic data (see Appendix Table A-9.4), a numeric value is calculated for each metric.

Calculated values are then compared to values derived from either an unimpaired reference site within the same region or a suitable control station on the same stream. The scores for the eight metrics are then totaled and compared to the total metric score for the reference station. The first seven metrics evaluate the riffle/run macrobenthos and metric \#8 evaluates the functional feeding groups present in the CPOM sample. The percent comparison between the total scores provides a final evaluation of relative biological condition.

The results of the RBP III analysis are presented in Table 5-8. The range of biological scores for the reference stations ranged from 48 at $\mathrm{HMC}-1$ to 42 at $\mathrm{GrC}-1$. The lowest biological score of 14 of all the test stations occurred at station HMC-5 and the highest biological score of 42 occurred at station HMC-4. The percent comparability to the reference station indicated that HMC-2 and HMC-3 as being slightly impaired due to the community structure being less than expected.

Station HMC-5 was found to be moderately impaired as compared to the reference, due to a reduction in the Ephemeroptera, Plecoptera, Trichoptera index and the presence of tolerant types of species. The habitat assessment for the Half Moon Creek system was found to be comparable to the reference area, and good finfish diversity was found throughout the entire creek system. The grain-size distribution across the site and within the Half Moon Creek System was found to be uniform and to be approximately 90 -percent sand. The grain-size data were further discussed in Section 3.2.1.2. 
Table 5-8

Benthic Ecology RBP III Metric Results, Salmon Site

\begin{tabular}{|c|c|c|c|c|c|c|c|c|c|}
\hline \multirow{3}{*}{$\begin{array}{l}\text { Station } \\
\text { Location }\end{array}$} & \multicolumn{8}{|c|}{ Biological Score } & \multirow{3}{*}{ Total } \\
\hline & \multicolumn{8}{|c|}{ Metı'ic \# } & \\
\hline & 1 & 2 & 3 & 4 & 5 & 6 & 7 & 8 & \\
\hline $\mathrm{GrC}-1^{\mathrm{a}}$ & 6 & 6 & 6 & 6 & $-b$ & 6 & 6 & 6 & 42 \\
\hline GrC-2 & 6 & 6 & - & - & 0 & 6 & 6 & 6 & 30 \\
\hline $\mathrm{HHC}-1^{2}$ & 6 & 6 & 6 & 6 & 4 & 6 & 6 & 6 & 46 \\
\hline $\mathrm{HHC}-2$ & 6 & 6 & - & 2 & 6 & 6 & 6 & 6 & 38 \\
\hline $\mathrm{HMC}-1^{\mathrm{a}}$ & 6 & 6 & 6 & 6 & 6 & 6 & 6 & 6 & 48 \\
\hline HMC-2 & 6 & 6 & - & 2 & 6 & 6 & 4 & 6 & 36 \\
\hline HMC-3 & 6 & 6 & 6 & 2 & 4 & 2 & 4 & 2 & 32 \\
\hline HMC-4 & 6 & 6 & 6 & 4 & 6 & 6 & 6 & 2 & 42 \\
\hline HMC-5 & 2 & 6 & - & 2 & 0 & 0 & 2 & 2 & 14 \\
\hline
\end{tabular}

\begin{tabular}{|c|c|c|c|c|c|c|c|c|c|c|}
\hline \multirow{3}{*}{$\begin{array}{l}\text { Station } \\
\text { Location }\end{array}$} & \multicolumn{8}{|c|}{$\%$ Comparability } & \multirow{3}{*}{$\begin{array}{c}\% \text { Comparability } \\
\text { to Reference }\end{array}$} & \multirow{3}{*}{$\begin{array}{l}\text { Biological } \\
\text { Condition } \\
\text { Category }\end{array}$} \\
\hline & \multicolumn{8}{|c|}{ Metric \# } & & \\
\hline & 1 & 2 & 3 & 4 & 5 & 6 & 7 & 8 & & \\
\hline $\mathrm{GrC}-1^{\mathrm{a}}$ & 100 & 100 & 100 & - & - & 100 & - & 100 & 100 & Nonimpaired \\
\hline GrC-2 & 155 & 90 & 0 & - & 0 & 133 & - & 171 & 92 & Nonimpaired \\
\hline $\mathrm{HHC}-1^{a}$ & 100 & 100 & 100 & 100 & 4 & 100 & - & 100 & 104 & Nonimpaired \\
\hline HHC-2 & 151 & 115 & 200 & 40 & 6 & 200 & - & 55 & 133 & Nonimpaired \\
\hline$H M C-1^{2}$ & 100 & 100 & 100 & 100 & 6 & 100 & - & 100 & 106 & Nonimpaired \\
\hline HMC-2 & 130 & 95 & 0 & 25 & 6 & 100 & - & 80 & 78 & Slightly \\
\hline HMC-3 & 93 & 82 & 100 & 25 & 4 & 75 & - & 85 & 72 & Slightly \\
\hline HMC-4 & 128 & 114 & 200 & 70 & 6 & 150 & - & 20 & 120 & Nonimpaired \\
\hline HMC-5 & 43 & 101 & 0 & 25 & 0 & 25 & - & 22 & 36 & Moderately \\
\hline
\end{tabular}

a Reference station

Indicates that the metric value could not to be calculated 


\subsubsection{Aquatic Field Observations}

The RBP habitat assessment technique is appropriate for streams and rivers only; therefore the ponds on site were not evaluated using this technique. The pond habitats had a predominantly muck-mud or organic-detritus substrate, including coarse and fine particulate organic matter. The inorganic substrate consisted predominantly of sand mixed with silt or clay. The canopy is open at the Beaver Pond and the Reference Pond (ReP-1), and a partly shaded canopy exists for the Gator Pond (GaP-1) and Half Moon Creek Overflow Pond (HOP-1). All ponds except for HOP- 1 and ReP-1 had water lilies present on approximately 75 to 80 percent of their surface area. The pond habitats that were observed are typical for the site topography and drainage basin area.

In support of the aquatic field observations. a finfish survey was conducted during the threatened and endangered species survey (IT, 1992a). The finfish biosurvey results indicated a diverse and abundant population present for both the creek and pond stations at the SS. Sufficient food sources and suitable habitat exist for the species found across the site, which appears to further indicate a healthy aquatic ecosystem.

The SS pond stations were not evaluated using the RBP because this method is not applicable to nonlotic systems. The pond stations had similar numbers of taxa except for the Beaver Pond where a great number of diptera species were found. At station BeP-1, 291 of the 298 organisms that were found were diptera species. At station BeP-1a and BeP-2 approximately 50 percent of the organisms found were diptera species. The diptera or chironomidae species tend to be present in greater numbers in stressed aquatic systems, due to the chironomidae being generally a pollutant-tolerant species. Therefore, some biological alteration was found at the Beaver Pond as compared to the reference pond site.

\subsubsection{Terrestrial Field Observations}

Field observations of the SS terrestrial ecosystem occurred during July 13 to 19, 1992. The results of the vegetation, wetland/floodplain, avian, herpetological, and mammalian surveys conducted were presented in detail in the Results of a Preliminary Survey for Threatened and Endangered Species and Floodplains/Wetlands at the SS (IT, 1992a). The Phase II investigation, which occurred in February and April 1993, involved additional field observations made during the collection of soil, vegetation, and large and small mammal samples. The terrestrial ecosystem of the SS was found to have good diversity, as well as no observed abnormalities associated with the vegetation, soil, or biota. 


\subsection{Risk Characterization}

\subsection{Risk Estimation}

For the assessment at the SS. the following assumptions were made:

- COC and their respective concentrations in on-site media were appropriate indicators of overall contamination.

- Bioassay tests performed with media collected from the site were appropriate indicators of gross biological effect.

- Field observations made on a qualitative basis were indicative of overall community and individual stress.

- The reference sites selected were similar to the study areas with regard to environmental characteristics. but were relatively unaffected by site-related activities and contamination.

- Only those constituents with site concentrations greater than reference area concentrations (for organics and inorganics) were considered further as possible COC.

Risks posed by COC concentrations within the surface water, sediment, soil, and biological tissues were assessed through comparisons with benchmarks. These benchmarks were criteria or standards gathered through review of the scientific literature. Contaminant concentrations exceeding benchmarks are indicative of potentially stressful conditions.

Toxicity test response data from the on-site samples and reference sample were compared and any on-site sample showing statistically significant adverse responses relative to the reference sample was considered to show measurable toxicity.

Comparisons between on-site community conditions and reference conditions or expected conditions were made using biological data gathered from benthic macroinvertebrate analyses or terrestrial site observations. In addition, chemical concentrations within biotic tissue could offer evidence of exposure, which may be detrimental or lead to food chain transfers.

\subsection{Risk Description}

Section 3.3 of this report described the exposure pathways and the factors relating to them. Five pathways were described that have the potential to expose biota to COCs: water, sediment, soil, air, and biota via food chain transfers. The following sections describe the potential risk to ecological receptors posed by each pathway, within the aquatic and terrestrial ecosystems. 


\subsubsection{Aquatic Ecosystem}

\subsubsection{Water Pathway}

Some impairment of benthic communities according to RBP III metrics was detected at stations HMC-2, HMC-3, HMC-5, BeP-1, BeP-1a, and BeP-2. Impairment of benthic communities was also detected at stations HMC-5. BeP-1, BeP-1a, and BeP-2, as well as stations HMC-4, HOP-1, and GaP-1. This impairment could be due to elevated contaminant concentrations or to habitat factors. Impairment based on acute toxicity testing was not observed at any stations.

There is strong evidence for absence of constituent-induced risk at both $\mathrm{GrC}-2$ and $\mathrm{HHC}-2$ since impairment was not detected according to analytical data, bioassay tests, or field observations. The slight impairment at HMC-2 and HMC-3 is probably not due to constituents because the $\mathrm{COC}$ concentrations were not elevated with respect to the reference areas. The measured constituents in the Half Moon Creek Overflow Pond, the Gator Pond, and HMC-4, though elevated, may not be bioavailable to organisms because no impairment was found. HMC-5 had a high concentration of aluminum $(235 \mu \mathrm{g} / \mathrm{l})$. This exceeds the chronic criteria of $87 \mu \mathrm{g} / \mathrm{l}$ by a factor of almost three. Although no acute toxicity was found in these surface waters, elevated aluminum may be causing chronic risk to organisms and, thus, may be the cause of the slight impairment in benthic macroinvertebrate communities there, according to RBP III metric interpretation. Risk to the fish population due to aluminum or iron would appear to be negligible because the site tissue samples had lower concentrations than the reference sample.

Tritium contributed the entire internal dose to fish, but the total dose, including that received from sediments, was still well below the protective criterion for aquatic populations. The dose to the great blue heron was also extremely low and within protective dose rates. Radiation thus poses no risk to aquatic biota through the water pathway.

\subsubsection{Sediment Pathway}

The Beaver Pond had high levels of many constituents. Although surface waters were not found to be acutely toxic, the benthic macroinvertebrate community appeared stressed relative to the reference area. The elevated levels of $\mathrm{COC}$ in the sediments may be causing chronic effects on aquatic biota in the Beaver Pond.

On an over-all basis, the only apparent potential for risk would be related to the presence of elevated levels of barium and manganese. However, although site fish tissues had elevated concentrations of these elements compared to the reference sample, adverse effects would not be 
expected in the aquatic life on the site because neither barium nor manganese exists in high soluble (bioavailable) concentrations in fresh water. Neither chemical was considered a COPC in surface water. Because these two metals are widely found in nature and manganese is a micronutrient, it is likely that the concentrations in the fish are within normal ranges and do not represent a sitewide risk. The lack of effects data for manganese and barium in fish tissue, however. could be considered a data gap.

Radiation. as discussed above, was calculated as a total dose to fish and herons from water and sediment sources and poses no risk to aquatic biota.

\subsubsection{Terrestrial Ecosystems}

\subsubsection{Soil Pathway}

Comparison of SS tissue results for lead and copper to literature reference values and calculations of dose to a top predator led to the conclusion that no adverse effects would be expected for terrestrial receptors on a sitewide basis. The same is true for radiation sources, for which calculated dose to the mouse was well below the protective criterion for terrestrial populations. It is reasonable to extrapolate these results to the Bachman's sparrow, game birds, and gopher tortoise because of the similarity in their diets. The birds wouid have less contact with soils than the mouse, and although the gopher tortoise may have more soil contact, its shell is an effective shield against radiation (Cosgrove, 1971).

There were no observed signs of stress at any of the sites except for the physical alterations due to DOE-related activities. Also, based on laboratory toxicity tests, there was no evidence of acute toxicity to flora in the surficial soils. However, COC were present at a few sites. The Clean Burn Pit in SA-2 and the HT-2 Well Area in SA-5 had high levels of both alpha and beta activity and some radionuclides. The West Substation in SA-4 also had high measurements of gross alpha and beta activity and radionuclides and also had high levels of copper. Although the potential for risk to terrestrial receptor populations site-wide is negligible, there may be risk of chronic effects to individuals in these localized areas.

\subsubsection{Air Pathway}

There is no ecological risk expected related to the air pathway. The only release mechanism to air for lead and copper would be through adsorption to soil-particles and mobilization to air as fugitive dust. A similar mechanism is also possible for radionuclides, and minor levels of noble gases, such as krypton and argon, may have been emitted during reentry drilling operations. 
However, as discussed in Section 3.3.1, intake via this mechanism is probably minimal relative to other pathways. Also, COC absorbed by this pathway would have been accounted for in the tissue analyses from which it was concluded that risk is negligible.

\subsection{Uncertainty Analysis}

The assumption used for this assessment was that all site receptors were exposed to all site contaminants within an ecosystem, i.e., habitat was not delineated by source area. The following are uncertainties that may affect the outcome of risk characterization:

- Impacts to individual organisms on a site-wide basis are considered in this assessment as a predictor of impacts to populations. Generally, except for threatened and endangered species, assessments need only evaluate population effects. Evaluating risks to individual organisms tends to overestimate risks to populations.

- In estimating effects to red-tailed hawks from lead and copper. a conservative calculation was used, and no depuration losses were assumed.

- Applicability of literature-derived data depends on types of results presented and methods used to arrive at these results. Test endpoints produced by laboratory and field tests may be reported as formally defined toxicological endpoints or as less stringently defined measures of mortality or sublethal effect; variations in format introduce a source of error when subsumed into a single acceptable level value. Thus, seemingly equivalent values may in fact be significantly different due to differences in test protocols, test conditions, or responses of individual organisms.

- Regulatory standards, criteria, and/or toxicological data were not available for every COC (i.e., barium and manganese), and thus they could not be evaluated for potential impacts. These data gaps may cause an underestimate of risk because unevaluated COC could be unrecognized sources of risk.

- Tissue concentrations may only represent one animal or two or more animals of different species and may lead to either over- or underestimations of exposure to a population. No samples representative of avian tissue $\mathrm{COC}$ concentrations were sampled, and extrapolation from mammalian values were used. Also, no reference sources were sampled, and comparisons had to be made to literature-derived values.

- Synergistic, additive, and antagonistic interactions between chemicals were not explored.

\subsection{Conclusions and Recommendations}

The overall objective of this investigation was to conduct a BERA in accordance with federal and state guidance, which, when implemented, would allow for the selection of a cost-effective plan of action that ensured the protection of the public health and the environment. This 
assessment determined the $\mathrm{COC}$ to ecological receptors and gave estimates as to the relative toxicity of the $\mathrm{COC}$ to both aquatic and terrestrial ecosystems present at the SS. This assessment sought to

- Describe the observed or potential magnitude of adverse ecological effect(s) at the SS and the primary cause(s) of the effect(s)

- Characterize the ecological consequences of the "no further action" remedial alternative.

The intrusive field activities conducted ensured that data gaps were identified and the necessary information collected to support these goals.

This BERA found localized areas with potentially elevated risks. These areas include the following:

- Station HMC-5 on Half Moon Creek may have a slightly impaired benthic community. This may be attributable to the chronic effects of aluminum in surface water and sediment $\mathrm{COC}$ or to natural conditions.

- The Beaver Pond, Half Moon Creek Overflow Pond, SA-2 (Clean Burn Area), SA-5 (HT-2 Well Area), and SA-6 (West Substation) had locally elevated concentrations of COC.

The assessment endpoints are meant to be protective of communities or populations. Therefore, the risk to individuals that spend all their time in the most highly contaminated areas is not considered in meeting the assessment endpoints. According to the toxicity test results, benchmarks, criteria, and calculations presented in this BERA, risks to the aquatic and terrestrial populations at the SS are negligible, and, therefore, the assessment endpoints and goals have been met. No action would be an acceptable alternative unless the desire is to be protective of individual organisms. It that case, removal of isolated areas of high contamination should be considered. 


\subsection{References}

AEC - See U.S. Atomic Energy Commission.

Amdur, M., J. Doull, and C. Klaassen, 1991, Casarett and Doull's Toxicology: The Basic Science of Poisons, Fourth Ed., Pergamon Press, Inc., Elmsford, NY.

Baes, C.F., R.D. Sharp, A.L. Sjoreen, and R.W. Shor, Oak Ridge National Laboratory, 1984, A Review and Analysis of Parameters for Assessing Transport of Environmentally Released Radionuclides through Agriculture, ORNL-5786, Oak Ridge, TN.

Baker, D.A. and J.K. Soldat, Pacific Northwest Laboratory, 1992, Methods for Estimating Doses to Organisms from Radioactive Materials Released into the Aquatic Environment, PNL-8150, Richland, WA.

BEIR Committee, 1980, The Effects of Populations on Exposure to Low Levels of Ionizing Radiation, National Academy Press, Washington, DC.

Brown, L. and D. Amadon, 1968, Eagles, Hawks and Falcons of the World, Vol.1, McGraw-Hill Book Company, NY.

Conant, R. and J.T. Collins, 1991, A Field Guide to Reptiles and Amphibians, Eastern and Central North America, Houghton-Mifflin, NY.

Cosgrove, G.E., 1971, "Reptilian Radiobiology," Journal of the American Veterinary Medical Association, Vol. 159, No. 11, pp. 1678-84.

DOE - See U.S. Department of Energy.

Dunning, J.B., Jr., 1993, CRC Handbook of Avian Body Masses, CRC Press, Boca Raton, FL.

Eisler, R., U.S Fish and Wildlife Service, 1988, Lead Hazards to Fish Wildlife and Invertebrates: A Synoptic Review, Biological Report 85 (1.14), Laurel, MD.

EPA - See U.S. Environmental Protection Agency.

Ganong, W.F., 1979, Review of Medical Physiology, 9th edition, Lange Medical Publications, Los Altos, CA.

Garten, C.T., Jr. and J.R. Trabalka, 1983, “Evaluation of Models for Predicting Terrestrial Food Chain Behavior of Xenobiotics," Environmental Science and Technology, Vol. 17, No. 10, pp. 590-595.

Harestad, A.S. and F.L. Bunnel, 1979, "Home Range and Body Weight - A Reevaluation," Ecology, Vol. 60, pp. 389-402. 
International Atomic Energy Agency, 1991, Effects of Ionizing Radiation on Plants and Animals at Levels Implied by Current Radiation Protection Standards, Technical Report Ser., Vienna. Austria.

IT Corporation. May 1993, Status Report of the Ecological Investigations Conducted at the Former U.S. DOE Tatum Dome Test Site, Las Vegas, NV.

IT Corporation. October 1992a, Results of a Preliminary Survey for Threatened and Endangered Species and Floodplains/Wetlands at the Tatum Dome Test Site Lamar County, Mississippi, Las Vegas, NV.

IT Corporation, June 1992b, Remedial Investigation and Feasibility Study of the Tatum Dome Test Site Lamar County, Mississippi, Draft Final Work Plan, Las Vegas, NV.

Janes, S.W., 1984, "Fidelity to breeding territory in a population of red-tailed hawks," Condor, Vol. 86.

Long, E.R. and L.G. Morgan, 1990, The Potential for Biological Effects of Sediment-Sorbed Contaminants Tested in the National Status and Trends Program, NOAA Technical Memorandum Nos. OMA 52, Seattle, WA.

Millar, J.S., 1989, "Reproduction and Development," in G.L. Kirkland and J.N. Lane, eds., Advances in the Study of Peromyscus (Rodentia), Texas Tech University Press, Lubbock, TX.

Mississippi Department of Health, 1990, Tatum Salt Dome Radiological Monitoring, Annual Report, Jackson. MS.

National Council on Radiation Protection and Measurements (NCRP), 1991, Effects of Ionizing Radiation on Aquatic Organisms, NCRP Report No. 109, Bethesda, MD.

National Council on Radiation Protection and Measurements (NCRP), 1979, Tritium in the Environment, NCRP Report No. 62, Bethesda, MD, pp. 45-58.

National Research Council, 1980, Mineral Tolerance of Domestic Animals, National Academy of Sciences, Washington, DC.

Opresko, D.M, B.E. Sample, and G.W. Suter, Oak Ridge National Laboratory, 1993, Toxicological Benchmarks for Wildlife, Oak Ridge, TN, ES/ER/TM-86.

Peckarsky, B.L., P.R. Fraissinet, M.A. Penton, and D.J. Conklin, Jr., 1990, Freshwater Macroinvertebrates of Northeastern North America, Cornell University Press, Ithaca, NY.

Seiler, J.R. and D.J. Paganelli, 1987, "Photosynthesis and Growth Response of Red Spruce and Loblolly Pine to Soil Applied Lead and Simulated Acid Rain," Forest Science, 33:668-675. 
Shapiro, J., 1981, Radiation Protection: A Guide for Scientists and Physicians, 2nd Ed. Harvard College, Boston, MA.

Shaw, A.J., 1989, Heavy Metal Tolerance in Plants: Evolutionary Aspects, CRC Press, Boca Raton, FL.

Suter, G.W. II, 1993, Ecological Risk Assessment, Lewis Publishers, Boca Raton, FL.

Talmage, S.S and B.T. Walton, 1991, "Small Mammals as Monitors of Environmental Contaminants," Review of Environmental Contamination and Toxicology, Vol. 119.

U.S. Atomic Energy Commission, Nevada Operations Office, 1972, Cleanup Summary Report, Tatum Dome Test Site, Mississippi, NVO-129, Las Vegas, NV.

U.S. Department of Energy, 1994, Hanford Site Risk Assessment Methodology, DOE/RL-91-46, Rev. 3, Review Draft, Richland, WA.

U.S. Department of Energy, Nevada Operations Office, 1980, The Tatum Dome Project, Lamar County, Mississippi, NVO-225, Las Vegas, NV.

U.S. Department of Energy, Nevada Operations Office, 1978, Special Study: Tatum Dome Test Site, Lamar County, Mississippi, NVO-200, Las Vegas, NV.

U.S. Department of Energy, Nevada Operations Office, 1975, Long-Term Radiological Surveillance Program, Tatum Dome Test Site, NVO-143, Las Vegas, NV.

U.S. Department of Energy, Nevada Operations Office, 1972, Cleanup Summary Report Tatum Dome Test Site, Mississippi, NVO-129, Las Vegas, NV.

U.S. Environmental Protection Agency, 1993, Wildlife Exposure Factors Handbook, Office of Research and Development, EPAI600IR-93\187a, Washington DC.

U.S. Environmental Protection Agency, 1992, Framework for Ecological Risk Assessment, Risk Assessment Forum, EPA/630/R-92/001, Washington, DC.

U.S. Environmental Protection Agency, 1990, Onsite and Offsite Environmental Monitoring Report: Radiation Monitoring Around Tatum Salt Dome, Lamar County, Mississippi, EPA/600/4-91/005, Las Vegas, NV.

U.S. Environmental Protection Agency, 1989a, Risk Assessment Guidance for Superfund, Volume I: Human Health Evaluation Manual (Part A), EPA/540/1-89/002, Washington, DC.

U.S. Environmental Protection Agency, 1989b, Risk Assessment Guidance for Superfund, Volume II: Environmental Evaluation Manual, EPA/540/1-89/001, Washington, DC. 
U.S. Environmental Protection Agency, 1989c, Rapid Bioassessment Protocols for Use in Streams and Rivers: Benthic Macroinvertebrates and Fish, EPA/444/4-89/001, Washington, DC.

U.S. Environmental Protection Agency, 1988. Ambient Water Quality Criteria for Aluminum, Office of Water Regulations and Standards. EPA/440/5-86-008, Washington, DC.

U.S. Environmental Protection Agency, 1986. Quality Criteria for Water. Office of Water Regulations and Standards, EPA/440/5/86/001. Washington, DC.

U.S. Environmental Protection Agency, 1980, Biological Monitoring of Toxic Trace Metals: Volume I, Biological Monitoring and Surveillance. EPA-600/300-80-089, Las Vegas, NV.

U.S. Environmental Protection Agency, 1974, Animal Investigation Program. Mississippi Results.

Whicker. F.W.. 1980, "Ecological Effects of Transuranics in the Terrestrial Environment," Transuranics in the Environment. Summary of Environmental Research on Transuranium Radionuclides Funded by the U.S. Department of Energy Through Calendar Year 1979, Technical Information Center/U.S. Department of Energy, DOE/TIC-22800, Washington, DC.

Whitaker Jr., J.O, 1993, The Audubon Society Field Guide to North American Mammals, Alfred A. Knopf, NY.

Woodwell, G.M. and A.L. Rebuck, 1967, "Effects of Chronic Gamma Radiation on the Structure and Diversity of an Oak-Pine Forest," Ecological Monographs. 37:53-69.

Yu, C.A., A.J. Zielen, J.-J. Cheng, Y.C. Yuan, L.G. Jones, D.J. LePoire, Y.Y. Wang, C.O. Loureiro, E. Gnanapragasam, E. Faillace, A.Wallo III, W.A. Williams and H. Peterson, 1993. Argonne National Laboratory, Manual for Implementing Residual Radioactive Material Guidelines Using RESRAD, Version 5.0," ANL/EAD/LD-2, Argonne, IL. 
Appendix A

Analytical Data 


\section{SALMON SITE}

\section{Appendix A:}

Analytical Data

\section{Table of Contents}

Matrix

Insitu Water Quality Parameters

Fish Biota Data

Sediment Data

Surface Water Data

Soil Data

Vegetation Data

Small Mammal Biota Data

Large Mammal Biota Data

Rapid Bioassessment Protocol (RBP) Data
Table Number

A-1

A-2

A-3

A-4

A-5

A-6

A-7

A-8

A-9
Page Number

1

3

9

46

83

244

271

301

332 


\begin{tabular}{|c|c|c|c|c|c|c|c|c|c|c|c|}
\hline \multirow[b]{2}{*}{ Parameter } & \multicolumn{11}{|c|}{ Table A-1 Insitu Water Quality Parameters } \\
\hline & 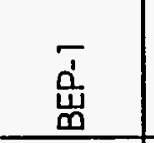 & 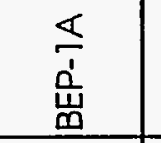 & $\begin{array}{l}\text { N } \\
\text { 岀 } \\
\text { a }\end{array}$ & $\frac{1}{d}$ & 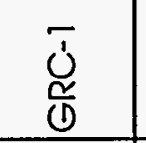 & $\begin{array}{l}\text { N } \\
\text { Uั } \\
\text { (1) }\end{array}$ & 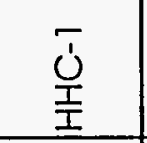 & 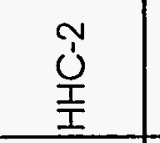 & 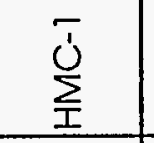 & 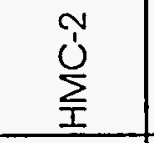 & 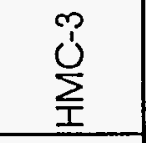 \\
\hline $\mathrm{pH}$ & 5.99 & 5.03 & 4.50 & 5.56 & 3.90 & 5.12 & 4.70 & 5.56 & 5.15 & 5.54 & 4.30 \\
\hline Dissolved Oxygen (mg/L) & 5.30 & 3.78 & 2.74 & 6.25 & 8.70 & 7.80 & 5.01 & 8.40 & 7.78 & 7.76 & 8.02 \\
\hline Oxidation Reduction Potential ( $\mathrm{mV}$ ) & 109 & 106 & 131 & 135 & 107 & 125 & -232 & 180 & 175 & 156 & 148 \\
\hline Conductivity (ms/cm) & 0.057 & 0.046 & 0.043 & 0.142 & 0.015 & 0.015 & 0.033 & 0.015 & 0.020 & 0.027 & 0.02 \\
\hline Temperature $\left({ }^{\circ} \mathrm{C}\right)$ & 17.5 & 19.6 & 12.6 & 14.9 & 14.2 & 12.0 & 10.6 & 12.2 & 11.6 & 12.0 & 11.0 \\
\hline Turbidity (ntu) & 5 & 16 & 10 & 0.70 & -10 & 2 & 1 & 10 & -10 & -10 & 1 \\
\hline Depth (m) & 0.50 & 0.50 & 0.25 & 0.10 & 0.76 & 0.76 & 0.076 & 0.11 & 0.38 & 0.91 & 0.53 \\
\hline Width $(\mathrm{m})$ & $\ldots 1$ & --1 & $\ldots 1$ & $N R^{*}$ & 4.6 & 6.1 & 0.91 & 1.1 & 1.4 & 5.5 & 5.5 \\
\hline Velocity $(\mathrm{m} / \mathrm{s})$ & 0 & 의 & 의 & 요 & 0.372 & $0.24^{2}$ & 0.15 & 0.55 & 0.12 & 0.18 & 0.373 \\
\hline Date & $2 / 22 / 93$ & $2 / 22 / 93$ & $2 / 23 / 93$ & $2 / 25 / 93$ & $2 / 23 / 93$ & $2 / 24 / 93$ & $2 / 27 / 93$ & $2 / 24 / 93$ & $2 / 25 / 93$ & $2 / 25 / 93$ & $2 / 24 / 93$ \\
\hline
\end{tabular}

$N R^{*}=$ Not Recorded.

1 Pond dimensions are estimated at $260 \mathrm{~m} \times 240 \mathrm{~m}$.

2 At a depth of $0.76 \mathrm{~m}$.

3 At a depth of $0.53 \mathrm{~m}$. 


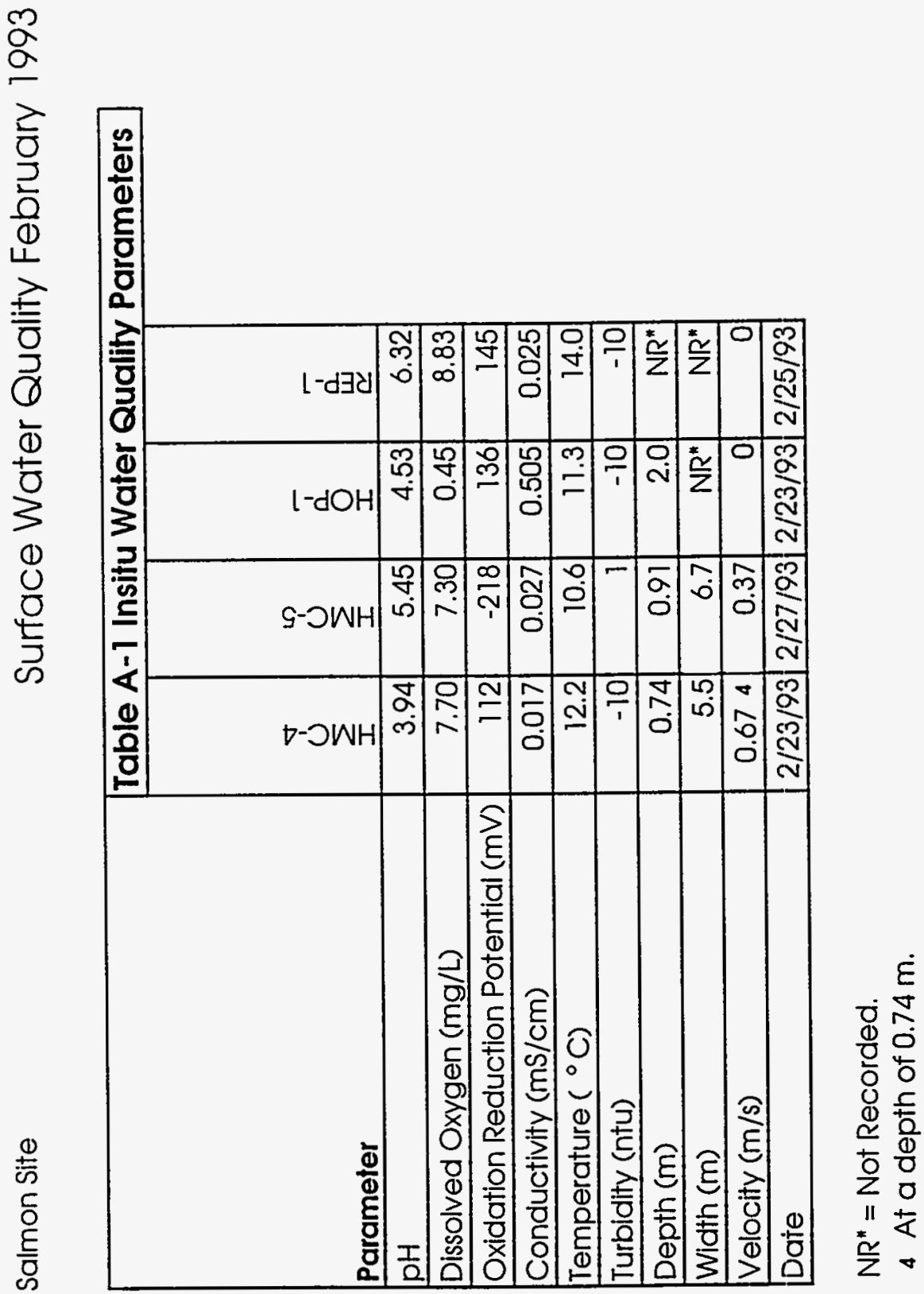




\begin{tabular}{|c|c|c|c|c|c|c|c|c|c|}
\hline \multirow[b]{2}{*}{ Compound $(\mathrm{mg} / \mathrm{Kg})$} & \multicolumn{9}{|c|}{ Table A-2.1 Metals } \\
\hline & $\begin{array}{l}\bar{u} \\
\dot{4} \\
\frac{1}{1} \\
\text { 岁 } \\
0\end{array}$ & & $\stackrel{*}{2}$ & 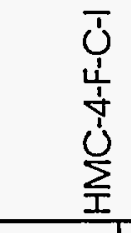 & & $\stackrel{*}{2}$ & 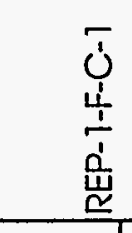 & & $\stackrel{*}{*}$ \\
\hline Aluminum & 2.3 & $\mathrm{~B}$ & $\mathrm{~J}$ & 5.3 & $\mathrm{~B}$ & $\mathrm{~J}$ & 13.4 & & - \\
\hline Antimony & 2.6 & 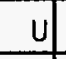 & $-\infty$ & 2.6 & 4 & $-\infty$ & 2.6 & U) & - \\
\hline Arsenic & 0.49 & 4 & - & 0.45 & 4 & - & 0.44 & uW & $\mathrm{UJ}$ \\
\hline Barlum & 6.1 & $\mathrm{~B}$ & J & 66.2 & & - & 2.2 & $\mathrm{~B}$ & $\mathrm{~J}$ \\
\hline Beryllium & 0.04 & $u$ & $-\infty$ & 0.05 & $\mathrm{~B}$ & $\mathrm{U}$ & 0.04 & 4 & -- \\
\hline Cadmium & 0.13 & 4 & -- & 0.13 & 4 & - & 0.13 & 4 & -- \\
\hline Calcium & 8020 & & \begin{tabular}{|l|}
- \\
\end{tabular} & 34600 & & - & 3690 & & - \\
\hline Chromium & 0.25 & B & J & 0.38 & B & J & 0.35 & 8 & $\mathrm{~J}$ \\
\hline Cobalt & 0.28 & $\mathrm{U}$ & $\ldots$ & 0.28 & 4 & $\ldots$ & 0.28 & $\mathrm{U}$ & $\ldots$ \\
\hline Copper & 3.6 & & - & 1.4 & & $\ldots$ & 1.1 & B & $\mathrm{U}$ \\
\hline Iron & 24.3 & & \begin{tabular}{|l|}
- \\
\end{tabular} & 13.0 & & - & 41.6 & & $-\cdots$ \\
\hline Lead & 0.05 & 4 & $-\ldots$ & 0.12 & B & $\mathrm{J}$ & 0.08 & $\mathrm{BW}$ & $\mathrm{J}$ \\
\hline Magnesium & 351.0 & & $\ldots$ & 681.0 & & $\ldots$ & 291.0 & & - \\
\hline Manganese & 28.2 & & $\ldots$ & 29.1 & & $\ldots$ & 13.4 & & - \\
\hline Mercury & 0.15 & & 4 & 0.43 & & -- & 0.04 & 4 & -- \\
\hline Nickel & 0.95 & 4 & -- & 0.93 & $\mathrm{U}$ & $\ldots$ & 0.95 & $\mathrm{U}$ & $\ldots$ \\
\hline Potassium & 3130 & & $\ldots$ & 2790 & & - & 2910 & & - \\
\hline Selenium & 0.25 & UW & UJ & 0.34 & $s$ & $-\ldots$ & 0.22 & UW & UJ \\
\hline Silver & 0.17 & 4 & - & 0.16 & 4 & - & 0.17 & 4 & - \\
\hline Sodium & 942.0 & & - & 1250.0 & & - & 750.0 & & - \\
\hline Thallium & 0.05 & $\mathrm{BW}$ & $\mathrm{J}$ & 0.05 & uW & UJ & 0.04 & UW & UJ \\
\hline Vanadium & 0.17 & $\underline{U}$ & - & 0.17 & $\mathrm{U}$ & - & 0.17 & 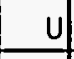 & - \\
\hline Zinc & 15.1 & & - & 19.6 & & - & 17.6 & & $1-$ \\
\hline
\end{tabular}




\begin{tabular}{|c|c|c|c|c|c|c|c|c|c|}
\hline \multirow[b]{2}{*}{ Compound (ug/Kg) } & \multicolumn{9}{|c|}{ Table A-2.2 Pesticides/PCB's } \\
\hline & 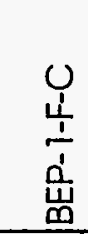 & $\stackrel{*}{\square}$ & & 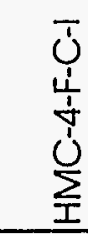 & $\stackrel{*}{\varnothing}$ & $\stackrel{3}{0}^{*}$ & $\begin{array}{l}\bar{U} \\
\stackrel{1}{1} \\
\dot{1} \\
\dot{u} \\
\underline{\underline{\alpha}}\end{array}$ & ¿ & $\stackrel{2}{0}^{*}$ \\
\hline Alpha-BHC & 46 & $\mathrm{u}$ & - & 48 & $\mathrm{U}$ & -- & 48 & $u$ & $\ldots$ \\
\hline Beta-BHC & 46 & $u$ & - & 48 & $\mathrm{U}$ & $\ldots$ & 48 & $u$ & $\ldots$ \\
\hline Delta-BHC & 46 & $u$ & $\ldots$ & 48 & $u$ & $\ldots$ & 48 & $U$ & $\ldots$ \\
\hline Gamma-BHC & 46 & $\mathrm{u}$ & - & 48 & $u$ & -- & 48 & $\mathrm{u}$ & - \\
\hline Heptachlor & 46 & $\mathrm{u}$ & - & 48 & $U$ & -- & 48 & $\mathrm{U}$ & $\ldots$ \\
\hline Aldrin & 46 & $u$ & - & 48 & $U$ & - & 48 & 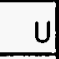 & - \\
\hline Heptachlor epoxide & 46 & $\mathrm{u}$ & - & 48 & $\mathrm{U}$ & - & 48 & $\mathrm{U}$ & $\ldots$ \\
\hline Endosulfan I & 46 & $\mathrm{U}$ & - & 48 & $\mathrm{U}$ & -- & 48 & 4 & $-\cdots$ \\
\hline Dieldrin & 92 & $u$ & - & 96 & $u$ & $\cdots$ & 95 & $U$ & - \\
\hline 4,4'-DDE & 92 & $u$ & - & 96 & $u$ & - & 95 & $u$ & $\ldots$ \\
\hline Endrin & 92 & $U$ & - & 96 & $\mathrm{U}$ & - & 95 & $U$ & - \\
\hline Endosuifan II & 92 & $\mathrm{u}$ & $\ldots$ & 96 & $U$ & $\ldots$ & 95 & $\mathrm{U}$ & - \\
\hline 4,4'-DDD & 92 & $u$ & - & 96 & $u$ & - & 95 & $u$ & - \\
\hline Endosulfan sulfate & 92 & $u$ & - & 96 & $U$ & $\ldots$ & 95 & $U$ & - \\
\hline 4,4'-DDT & 92 & $\mathrm{U}$ & $\ldots$ & 96 & $\underline{U}$ & $\cdots$ & 95 & $\mathrm{U}$ & $-\ldots$ \\
\hline Methoxychlor & 460 & $u$ & - & 480 & $\mathrm{U}$ & - & 480 & $\mathrm{U}$ & - \\
\hline Endrin ketone & 92 & $u$ & - & 96 & $U$ & - & 95 & $u$ &.- \\
\hline Alpha-chlordane & 460 & $\mathrm{u}$ & $\ldots$ & 480 & $\mathrm{U}$ & $=$ & 480 & $\mathrm{U}$ & $-\ldots$ \\
\hline Gamma-chlordane & 460 & $\mathrm{u}$ & - & 480 & $\mathrm{u}$ & $\ldots$ & 480 & $\mathrm{U}$ & $\ldots$ \\
\hline Toxaphene & 920 & $u$ & $\ldots$ & 960 & $\mathrm{u}$ & $\ldots$ & 950 & $\mathrm{U}$ & $\ldots$ \\
\hline Aroclor-1016 & 460 & $\mathrm{U}$ & - & 480 & $\mathrm{U}$ & - & 480 & $u$ & - \\
\hline Aroclor-1221 & 460 & 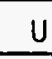 & $\ldots$ & 480 & $U$ & - & 480 & $\mathrm{U}$ & - \\
\hline Aroclor-1232 & 460 & $\mathrm{U}$ & $\ldots$ & 480 & $u$ & - & 480 & $\mathrm{U}$ & - \\
\hline Aroclor-1242 & 460 & $u$ & - & 480 & $\mathrm{U}$ & - & 480 & $u$ & - \\
\hline
\end{tabular}




\begin{tabular}{|c|c|c|c|c|c|c|}
\hline \multirow[b]{2}{*}{ Compound (ug/Kg) } & \multicolumn{6}{|c|}{ Table A-2.2 Pesticides/PCB's } \\
\hline & $\begin{array}{l}\frac{1}{4} \\
\frac{1}{1} \\
\begin{array}{l}1 \\
\mathbf{M}\end{array}\end{array}$ & $\stackrel{*}{0}$ & 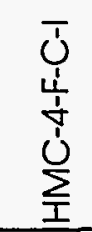 & ${ }^{*}{ }^{*}{ }^{*}{ }^{*}$ & 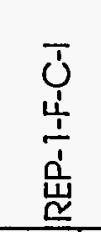 & $\stackrel{\circ}{\circ}$ \\
\hline Aroclor- 1248 & 460 & $\begin{array}{lll} & \ldots \\
\end{array}$ & 480 & U. & 480 & 0. \\
\hline Aroclor-1254 & 920 & 4) $-=$ & 960 & $u \mid-$ & 950 & \begin{tabular}{l|l}
4 & --1 \\
\end{tabular} \\
\hline Aroclor-1260 & 920 & \begin{tabular}{l|l|} 
& $-\ldots$ \\
\end{tabular} & 960 & U. & 950 & u| \\
\hline
\end{tabular}




\begin{tabular}{|c|c|c|c|c|c|c|}
\hline \multirow[b]{2}{*}{ Parameter $(\mathrm{pCi} / \mathrm{g})$} & \multicolumn{6}{|c|}{ Table A-2.3 Gross Alpha/Beta } \\
\hline & $\begin{array}{l}\bar{u} \\
\dot{1} \\
\dot{1} \\
\dot{1} \\
\text { 岗 } \\
\end{array}$ & ${ }_{0}^{*}$ & $\begin{array}{l}\bar{U} \\
\dot{1} \\
\dot{1} \\
\dot{1} \\
\dot{J} \\
\dot{I}\end{array}$ & $\stackrel{*}{2}$ & 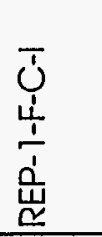 & 兌 \\
\hline Alpha & 0.05 & -- & 0.20 & -- & ND & --- \\
\hline Sigma Error $+1-$ & 0.07 & -- & 0.14 & - & - & $\ldots$ \\
\hline $\mathrm{MDA}^{*}$ & 0.12 & $\mathrm{U}$ & 0.21 & $\underline{U}$ & 0.16 & $\underline{U}$ \\
\hline Beta & 0.57 & -- & 0.94 & -- & 1.29 & $\cdots$ \\
\hline Sigma Error $+1-$ & 0.08 & $-\cdots$ & 0.11 & --- & 0.13 & --- \\
\hline $\mathrm{MDA}^{*}$ & 0.09 & --- & 0.12 & --- & 0.12 & -- \\
\hline
\end{tabular}




\begin{tabular}{|c|c|c|c|c|c|c|c|c|c|c|c|c|}
\hline \multirow[b]{2}{*}{ Nuclide (pCi/g) } & \multicolumn{12}{|c|}{ Table A-2.4 Gamma Spectroscopy } \\
\hline & 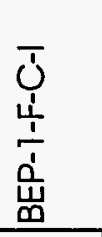 & ${ }_{2}^{*}$ & 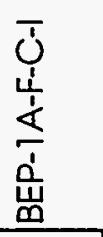 & $\stackrel{3}{0}^{*}$ & 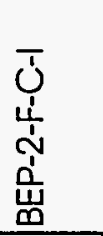 & ${ }_{0}^{*}$ & $\begin{array}{l}\overline{0} \\
\dot{1} \\
\frac{1}{1} \\
\dot{1} \\
\frac{1}{0} \\
1\end{array}$ & $\stackrel{3}{0}^{*}$ & 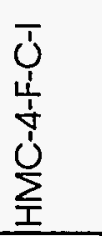 & $\stackrel{0}{2}$ & $\begin{array}{l}\bar{U} \\
\frac{1}{1} \\
\frac{1}{i} \\
\underline{\underline{u}} \\
\underline{\underline{L}}\end{array}$ & $\stackrel{*}{2}$ \\
\hline Cesium 137 & ND & $\ldots$ & ND & $-\cdots$ & ND & $\cdots$ & ND & $-\cdots$ & ND & $-\cdots$ & ND & $-\cdots$ \\
\hline Sigma Error +1- & - & - & - & -- & - & -- & - & -- & - & -- & - & -- \\
\hline MDA* & 0.20 & $\mathrm{U}$ & 0.30 & $\mathrm{U}$ & 0.10 & $U$ & 0.20 & $\mathrm{U}$ & 0.10 & $\mathrm{U}$ & 0.10 & $U$ \\
\hline Potassium 40 & 7.20 & -- & ND & $-\ldots$ & ND & $-\ldots$ & ND & $-\cdots$ & ND & $\ldots$ & 2.80 & $\cdots$ \\
\hline Sigma Error $+1-$ & 0.80 & -- & 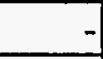 & $-\cdots$ & - & -- & - & $-\cdots$ & - & $-\cdots$ & 0.40 & $-\cdots$ \\
\hline MDA* & 7.20 & $-\cdots$ & 5.50 & $U$ & 4.90 & $\mathrm{U}$ & 3.50 & $U$ & 3.10 & $\mathrm{U}$ & 0.24 & $-\cdots$ \\
\hline Lead 212 & ND & $\ldots$ & ND & $-{ }_{-1}$ & ND & - & ND & $-{ }_{-1}$ & ND & \begin{tabular}{|l|}
-- \\
\end{tabular} & ND & - \\
\hline Sigma Error +/- & & $-\infty$ & & $-\cdots$ & - & $\cdots$ & - & $-\cdots$ & -1 & $-\cdots$ & - & - \\
\hline MDA" & 0.30 & $\mathrm{U}$ & 0.40 & $U$ & 0.20 & $\mathrm{U}$ & 0.30 & $U$ & 0.20 & U & 0.20 & U \\
\hline
\end{tabular}


$\frac{\square}{\frac{D}{d}}$

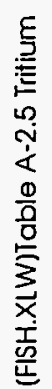

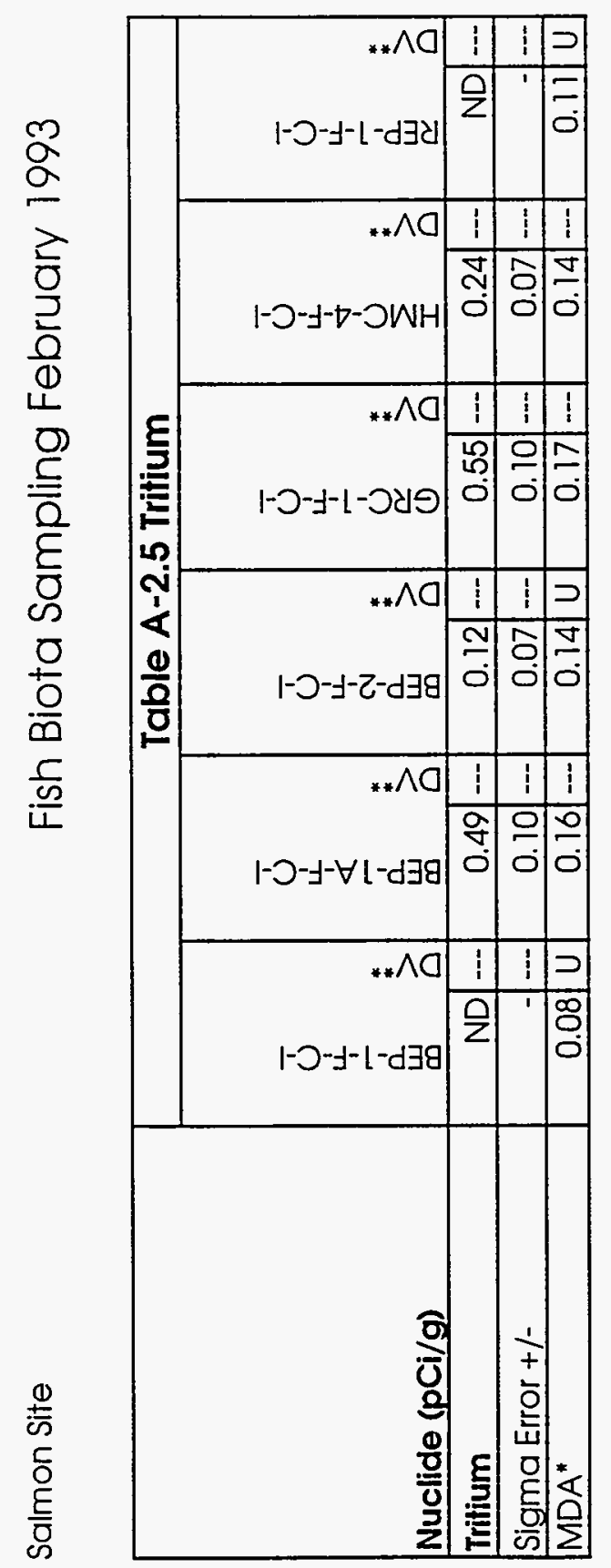

$\infty$
0
0
0
0

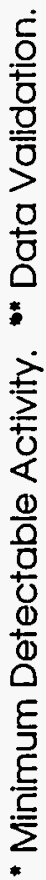




\begin{tabular}{|c|c|c|c|c|}
\hline \multirow[b]{2}{*}{ Sample Number } & \multicolumn{4}{|c|}{ Table A-3.1 Grain Size Analysis } \\
\hline & $\%$ Moisture & $\begin{array}{c}\% \text { Sand } \\
(>0.0625 \mathrm{~mm})\end{array}$ & $\begin{array}{c}\% \text { Silt } \\
(0.0625 \mathrm{~mm} \text { to } \\
0.0039 \mathrm{~mm})\end{array}$ & $\begin{array}{c}\% \text { Clay } \\
(<0.0039 \mathrm{~mm})\end{array}$ \\
\hline BEP-1-GS-G-I & 66.5 & 11.1 & 65.7 & 23.2 \\
\hline BEP-IA-GS-G-I & 25.0 & 40.8 & 34.5 & 24.7 \\
\hline BEP-2-GS-G-I & 27.0 & 86.5 & 7.6 & 5.9 \\
\hline GAP-1-GS-G-1 & 79.1 & 42.6 & 33.9 & 23.5 \\
\hline GRC-1-GS-G-1 & 20.6 & 100.0 & 0.0 & 0.0 \\
\hline GRC-2-GS-G-I & 23.4 & 100.0 & 0.0 & 0.0 \\
\hline HHC-1-GS-G-I & 30.6 & 100.0 & 0.0 & 0.0 \\
\hline HHC-2-GS-G-I & 18.7 & 96.3 & 1.8 & 1.9 \\
\hline HMC-1-GS-G-I & 21.7 & 95.2 & 2.0 & 2.8 \\
\hline HMC-2-GS-G-I & 29.3 & 93.2 & 3.8 & 3.0 \\
\hline HMC-3-GS-G-I & 24.3 & 98.2 & 0.7 & 1.1 \\
\hline HMC-4-GS-G-I & 21.6 & 100.0 & 0.0 & 0.0 \\
\hline HMC-4-GS-G-I-D & 22.7 & 100.0 & 0.0 & 0.0 \\
\hline HMC-5-GS-G-I & 33.6 & 96.3 & 1.8 & 1.9 \\
\hline HOP-1-GS-G-I & 26.2 & 91.6 & 4.9 & 3.6 \\
\hline REP-1-GS-G-1 & 28.2 & 70.9 & 7.0 & 22.2 \\
\hline
\end{tabular}




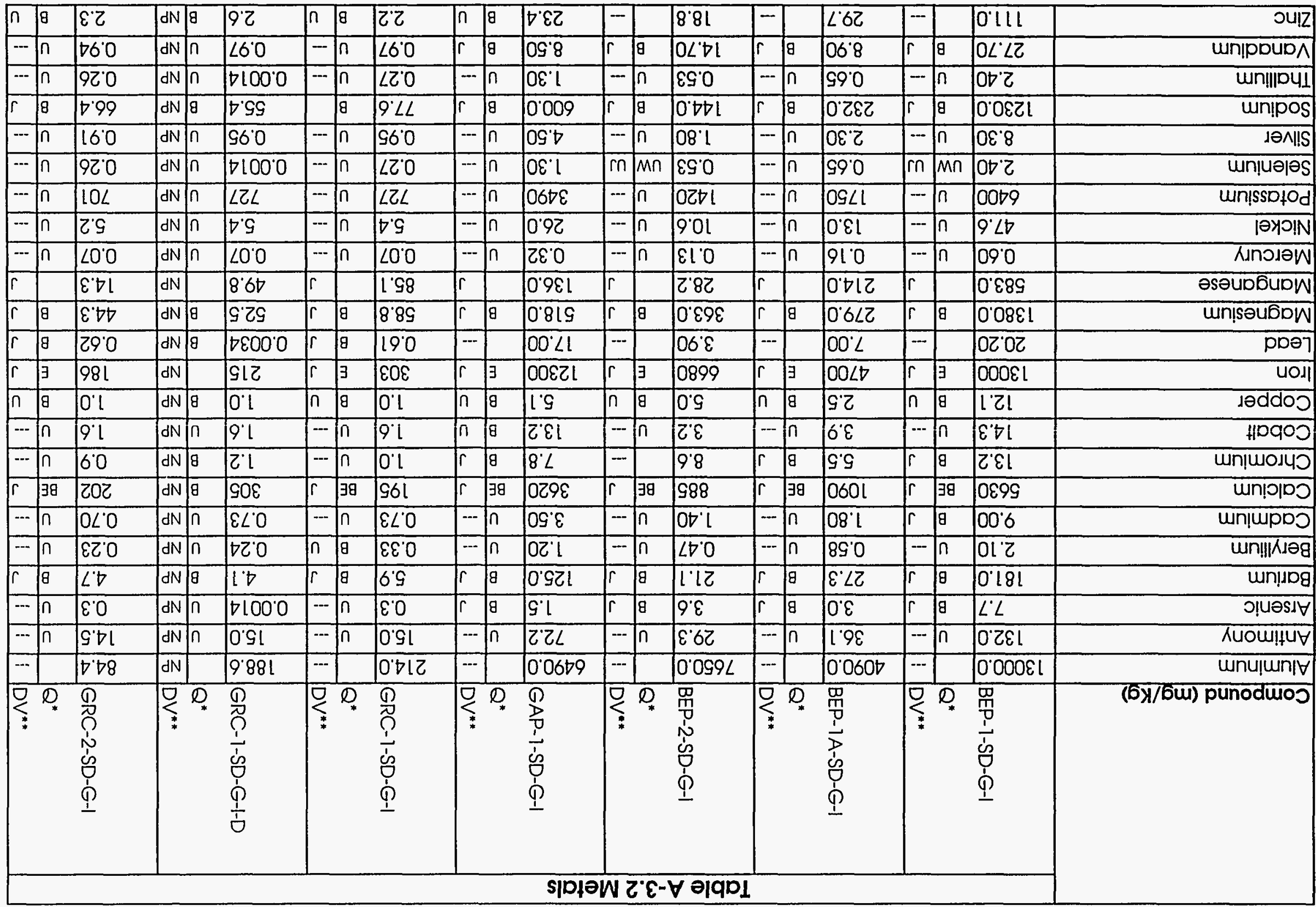




\begin{tabular}{|c|c|c|c|c|c|c|c|c|c|c|c|c|c|c|c|c|c|c|}
\hline n & 0.01 & \begin{tabular}{|l|l}
$n$ & 8 \\
\end{tabular} & & $Z^{\prime} Z$ & \begin{tabular}{|l|} 
\\
\end{tabular} & & $g^{\prime} \varepsilon$ & \begin{tabular}{|l|l}
$n$ & 8 \\
\end{tabular} & $g^{\prime} b$ & 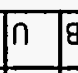 & & $0^{\prime} L$ & \begin{tabular}{|l|l}
$n$ & 日 \\
\end{tabular} & & $\varepsilon^{\prime} \varepsilon$ & \begin{tabular}{|l|l}
$d N$ & $\theta$ \\
\end{tabular} & 9.1 & ou!: \\
\hline$\Gamma$ & $08^{\circ} \mathrm{L}$ & $-m$ & & $66^{\circ} 0$ & -- & n & $01 \% \mathrm{~L}$ & \begin{tabular}{|c|c|}
$-\cdots$ & $n$ \\
\end{tabular} & 960 & \begin{tabular}{l|l}
$\Gamma$ & $\theta$ \\
$\Gamma$
\end{tabular} & & $09^{\circ} \varepsilon$ & $-\pi n$ & & $O \varepsilon^{\prime} \mid$ & \begin{tabular}{|l|l|}
$d N$ & $n$ \\
\end{tabular} & $06^{\circ} 0$ & wn!pDuo $\wedge$ \\
\hline-- & \begin{tabular}{l|l|}
$n$ & $80^{\circ} 0$ \\
\end{tabular} & $-\cdots n$ & & $8 Z^{\prime} 0$ & $\cdots$ & & Zद'0 & $\begin{array}{ll}-\cdots & n \\
\end{array}$ & $\angle Z^{\prime} O$ & $-n$ & & $8 \varepsilon^{\prime} 0$ & $--n$ & & $9 \varepsilon^{\prime} 0$ & \begin{tabular}{|l|l|}
$d N$ & $n$ \\
\end{tabular} & $92^{\prime} 0$ & 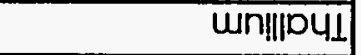 \\
\hline$r$ & 0.821 & \begin{tabular}{|l|l}
$n$ & 0 \\
\end{tabular} & 日 & $\angle ' 09$ & r & a & $Z^{\prime} \varepsilon L$ & $\begin{aligned} & \theta \\
&\end{aligned}$ & $\varepsilon^{\prime} O L$ & $r$ & & 8.96 & \begin{tabular}{|l|l} 
& 8 \\
\end{tabular} & & $0 ' 8 L$ & \begin{tabular}{|l|l|l|l|l}
$d N$ & $\theta$
\end{tabular} & 8.69 & wn!pos \\
\hline-- & \begin{tabular}{l|l}
$n$ & $0 L 1$ \\
\end{tabular} & $-x^{n}$ & & $\angle 6^{\circ} 0$ & $\cdots$ & n & 01.1 & $--n$ & $86^{\circ} 0$ & --1 & 1 & $0 \varepsilon^{\prime} L$ & $-\cdots$ & & $O Z 1$ & \begin{tabular}{|l|l|}
$d N$ & $n$ \\
\end{tabular} & $16^{\prime} 0$ & JəAIIS \\
\hline-- & \begin{tabular}{l|l}
$n$ & $80^{\circ} 0$ \\
\end{tabular} & $\cdots n$ & & $8 Z^{\prime} 0$ & $\cdots$ & $n$ & $2 \varepsilon^{\prime} 0$ & $--n$ & $\angle 2 \circ$ & 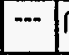 & $i$ & $8 \varepsilon^{\prime} 0$ & $\cdots n$ & & 980 & \begin{tabular}{|l|l|}
$d N$ & $n$ \\
\end{tabular} & $92^{\prime} 0$ & un!uə|əs \\
\hline-- & \begin{tabular}{|l|l|}
$n$ & 0621 \\
\end{tabular} & $-\cdots n$ & & $\varepsilon \nabla L$ & $\cdots$ & $n$ & $\angle 98$ & $-\cdots$ & $D I L$ & $-a-1$ & T & OZOL & $-n$ & & 276 & $\mathrm{dN} / \mathrm{n}$ & $10 L$ & wn!ssD $\downarrow \circ d$ \\
\hline$\cdots$ & \begin{tabular}{|l|l|}
$n$ & $9^{\prime} 6$ \\
\end{tabular} & $-n$ & & $g^{\prime} G$ & $\cdots$ & $\bar{n}$ & $\bar{\nabla} 9$ & $\cdots \mid$ & E' & $-\cdots$ & i & $9 \cdot \mathrm{L}$ & $\cdots n$ & & $O^{\prime} \mathrm{L}$ & $d N \mid n$ & 29 & |िхगाN \\
\hline$\cdots$ & \begin{tabular}{|l|l|}
$n$ & $21^{\prime} 0$ \\
\end{tabular} & $-\pi$ & & $\angle 0^{\prime} 0$ & -- & $n$ & $80^{\circ} 0$ & $-\cdots$ & $\angle 0^{\circ} 0^{\circ}$ & $-a$ & 5 & $60^{\circ} 0$ & \begin{tabular}{l|l}
$r$ & $\theta$ \\
\end{tabular} & & 11.0 & dN & $90^{\circ} 0$ & KมnOנəW \\
\hline$r$ & $9^{\prime} \forall 8$ & r & & 587 & $r$ & & $1 \cdot \angle t$ & $\ln \sqrt{8}$ & 9.1 & $r$ & & $\bar{Z}^{\prime} Z \varepsilon$ & r & & $\bar{G}^{\prime} 9 \varepsilon$ & $\mathrm{dN}$ & $\bar{\varepsilon} 9$ & 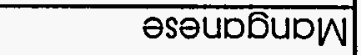 \\
\hline$r$ & 0.991 & \begin{tabular}{l|l}
$r$ & 0 \\
\end{tabular} & 8 & 9.97 & r & $\overline{8}$ & $6 . \angle L$ & \begin{tabular}{l|l}
$r$ & $a$ \\
\end{tabular} & $Z \angle t$ & \begin{tabular}{|r|r}
$r$ \\
\end{tabular} & 5 & $00 \angle 1$ & \begin{tabular}{l|l}
$r$ & 0 \\
\end{tabular} & & $8.6 L$ & $\begin{array}{l}\mathrm{d} N \mathrm{~g} \\
\end{array}$ & $8^{\prime} 6 \varepsilon$ & un!̣səub̂" \\
\hline$\cdots$ & $00^{\prime} \mathrm{S}$ & --1 & & $O Z^{\prime} Z$ & $-\cdots$ & & $00^{\circ} \mathrm{Z}$ & $\cdots$ & 01.1 & $\cdots$ & & $00^{\prime} 2$ & \begin{tabular}{l|l}
$r$ & 0 \\
\end{tabular} & & $06^{\circ} 0$ & dN & $\angle 0^{\prime} \mathrm{L}$ & pDə7| \\
\hline r & 0701 & r $\mathbf{r}^{\prime}$ & 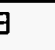 & 692 & I & 9 & $61 \varepsilon$ & \begin{tabular}{l|l} 
& 1
\end{tabular} & 201 & \begin{tabular}{|l|l|l|l|l}
$r$ &
\end{tabular} & 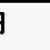 & 0861 & \begin{tabular}{r|l}
$r$ & 3 \\
\end{tabular} & & $\varepsilon \nabla L$ & $\mathrm{dN}$ & SzL & UO1 \\
\hline$n$ & $g^{\prime} Z$ & $\begin{array}{ll}n & 8 \\
\end{array}$ & a & 1.1 & -- & ก & 21 & $\cdots \mid n$ & 0.1 & --1 & 1 & $D^{\prime} \mathrm{L}$ & $\pi \mid$ & & D. & dN & 0.1 & 1əddo0 \\
\hline$\cdots$ & 62 & $-\infty n$ & & $\angle ' L$ & -- & n & 6.1 & 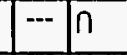 & 9.1 & $-\cdots$ & T & $\varepsilon^{\prime} Z$ & $-n$ & & 122 & dN $\mathrm{n}$. & 9.1 & HDq00 \\
\hline$r$ & $9^{\prime} \mathrm{Z}$ & ---1 & & 0.1 & r & 8 & $S^{\prime} 1$ & $\cdots n$ & 60 & r & 3 & $D^{\prime} Z$ & \begin{tabular}{r|r} 
& $a$ \\
\end{tabular} & & 27 & \begin{tabular}{|l|l|}
$d N$ & $n$ \\
\end{tabular} & $60^{\circ} 0$ & un!wody \\
\hline$r$ & \begin{tabular}{l|l}
38 & $6 \angle 9$ \\
\end{tabular} & 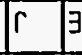 & 㫜 & $88 \mathrm{~L}$ & I & ⿶凵 & $68 \varepsilon$ & Ir $\quad 98$ & 061 & r & 百 & $E I L$ & $\begin{array}{rl}\Gamma_{1} & 3 \\
\end{array}$ & 8 & 196 & $\mathrm{dN} / \mathrm{g}$ & $6 \angle L$ & wn!lo \\
\hline$\cdots$ & \begin{tabular}{l|l}
$n$ & $0 \varepsilon^{\prime} L$ \\
\end{tabular} & 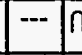 & & SL'O & -- & & $0 L^{\circ} \mathrm{L}$ & $--\infty$ & $2 L^{\prime} 0$ & -1 & $i$ & $00^{\circ} \mathrm{L}$ & $-\cdots n$ & n & 96.0 & \begin{tabular}{|l|l|}
$d N$ & $n$ \\
\end{tabular} & $0 \angle ' 0$ & un!wpDo \\
\hline-- & $E D^{\prime} 0$ & \begin{tabular}{|l|l|}
$-\cdots$ \\
\end{tabular} & & $9 Z^{\prime} 0$ & $-\infty$ & $\bar{n}$ & 620 & $\cdots / n$ & $\Delta Z 0$ & $\cdots+1$ & 5 & $\nabla \varepsilon^{\prime} 0$ & $-\cdots n$ & & $2 \varepsilon^{\prime} 0$ & \begin{tabular}{l|l}
$\mathrm{dN}$ & $\mathrm{n}$ \\
\end{tabular} & $\varepsilon Z^{\circ} 0$ & un!||人<eg \\
\hline$r$ & $\angle ' 19$ & $r^{2} 8$ & & $E L$ & $r$ & g & $\angle Z Z$ & \begin{tabular}{l|l}
$n$ & 8 \\
\end{tabular} & 87 & $r$ & 5 & $\varepsilon^{\prime} \nabla \varepsilon$ & \begin{tabular}{l|l}
$r$ & $a$ \\
\end{tabular} & $\bar{\theta}$ & 0.91 & $\mathrm{dN} / \mathrm{g}$ & $\bar{\nabla} Z$ & un!̣.log \\
\hline$r$ & $\angle 0$ & $\cdots n$ & & 80 & -- & & $8^{\circ} 0$ & In $M n$ & 80 & $m$ & $\mathrm{Mn}$ & 70 & $\ln \sqrt{n}$ & $\overline{M n}$ & 70 & $\begin{array}{l}\mathrm{dN} \\
\mathrm{n}\end{array}$ & 80 & 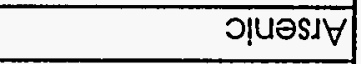 \\
\hline$-\cdot$ & \begin{tabular}{l|l|l|l}
$n$ & $\angle 92$ \\
\end{tabular} & \begin{tabular}{|l|l|} 
\\
\end{tabular} & & D'SI & - & & $\angle \angle L$ & $\cdots n$ & $80 \mathrm{~L}$ & $\cdots$ & i & 0.12 & $-\cdots$ & & 961 & \begin{tabular}{|l|l|} 
dN & $n$ \\
\end{tabular} & $g^{\prime} \nabla 1$ & Kuow!tu \\
\hline-- & D.OSGl & --1 & & 0.112 & -- & & 0.679 & $\cdots$ & $10^{\circ} 961$ & -- & & $0^{\circ} 0812$ & -- & & 0.099 & dN & $\angle L^{\prime} \varepsilon 6$ & 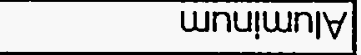 \\
\hline \% & 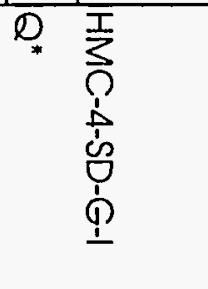 & $\overbrace{\sharp}^{g}$ & & 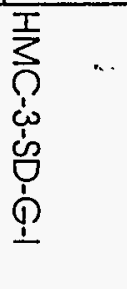 & $\underset{\$}{\bar{\sigma}}$ & & 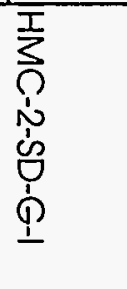 & $\overbrace{\sharp}$ & 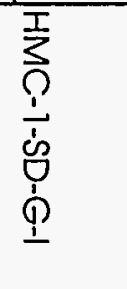 & & & 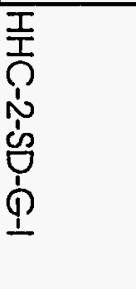 & $\bar{F}^{\ell}$ & & 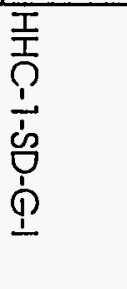 & $\overbrace{\sharp}^{Q_{*}}$ & 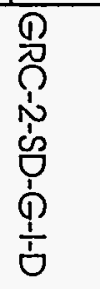 & (Бत//6u) punoduios \\
\hline
\end{tabular}




\begin{tabular}{|c|c|c|c|c|c|c|c|c|c|}
\hline \multirow[b]{2}{*}{ Compound $(\mathrm{mg} / \mathrm{Kg})$} & \multicolumn{9}{|c|}{ Table A-3.2 Metals } \\
\hline & $\begin{array}{l}\overline{0} \\
\dot{1} \\
01 \\
0 \\
0 \\
0 \\
\text { Ḋ }\end{array}$ & & $\stackrel{*}{2}$ & 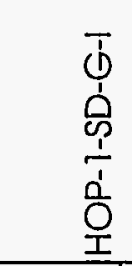 & & $\stackrel{*}{\text { ¿ }}$ & 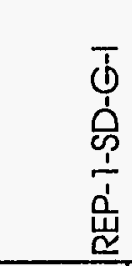 & & \\
\hline Aluminum & 836.0 & & $-\ldots$ & 1780.0 & & - & 6480.0 & & -- \\
\hline Antimony & 17.8 & $u$ & - & 16.1 & $\mathrm{u}$ & - & 16.2 & $u$ & -- \\
\hline Arsenic & 0.3 & BW & J & 0.9 & $\mathrm{~B}$ & J & 2.1 & $B$ & $\mathrm{~J}$ \\
\hline Barium & 34.0 & $B$ & $\mathrm{~J}$ & 11.0 & $B$ & J & 19.9 & $B$ & $\mathrm{~J}$ \\
\hline Beryllium & 0.29 & 4 & $-\infty$ & 0.29 & 8 & $\underline{U}$ & 0.26 & $\mathrm{U}$ & $\ldots$ \\
\hline Cadmium & 0.87 & 4 & $-{ }_{-1}$ & 0.78 & $u$ & - & 0.79 & $\underline{U}$ & - \\
\hline Calcium & 454 & $\mathrm{BE}$ & $\mathrm{J}$ & 417 & $\mathrm{BE}$ & J & 369 & $\overline{\mathrm{BE}}$ & $\mathrm{J}$ \\
\hline Chromium & 1.2 & 8 & $\mathrm{~J}$ & 14.8 & & - & 9.3 & & - \\
\hline Cobalt & 3.7 & B & $\mathrm{U}$ & 1.7 & 4 & $\ldots$ & 2.9 & $\underline{B}$ & $\mathrm{U}$ \\
\hline Copper & 1.2 & 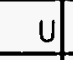 & $\ldots$ & 2.8 & $B$ & $\underline{u}$ & 4.1 & $B$ & $u$ \\
\hline Iron & 942 & $\mathrm{E}$ & $\mathrm{J}$ & 1280 & $E$ & J & 19300 & $E$ & 1 \\
\hline Lead & 3.40 & & $\ldots$ & 10.00 & & - & 5.00 & & - \\
\hline Magnesium & 85.9 & B & $\mathrm{J}$ & 106.0 & B & J & 152.0 & B & 5 \\
\hline Manganese & 90.8 & & $\mathrm{~J}$ & 17.5 & & J & 45.8 & & J \\
\hline Mercury & 0.12 & 8 & $\mathrm{~J}$ & 0.07 & 4 & - & 0.07 & $u$ & $\ldots$ \\
\hline Nickel & 6.4 & 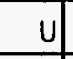 & $-{ }_{-1}$ & 5.8 & U & - & 5.8 & $\underline{u}$ &.- \\
\hline Potassium & 862 & 4 & $\cdots$ & 777 & $u$ & $\ldots$ & 784 & $\bar{u}$ & -.. \\
\hline Selenium & 0.32 & $u$ & -- & 0.29 & uW & $u_{J}$ & 0.29 & UW & u \\
\hline Silver & 1.10 & U & -- & 1.00 & 4 & - & 1.00 & $u$ & --. \\
\hline Sodium & 83.6 & $\mathrm{~B}$ & $\mathrm{~J}$ & 112.0 & $\mathrm{~B}$ & 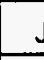 & 80.8 & B & 5 \\
\hline Thallium & 0.32 & 4 & - & 0.29 & 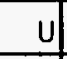 & - & 0.29 & $\underline{u}$ & - \\
\hline Vanadium & 1.40 & $B$ & $\mathrm{~J}$ & 3.20 & $B$ & 5 & 43.00 & & - \\
\hline Zinc & 6.1 & $B$ & $u$ & 5.5 & B & $u$ & 4.6 & B & 4 \\
\hline
\end{tabular}




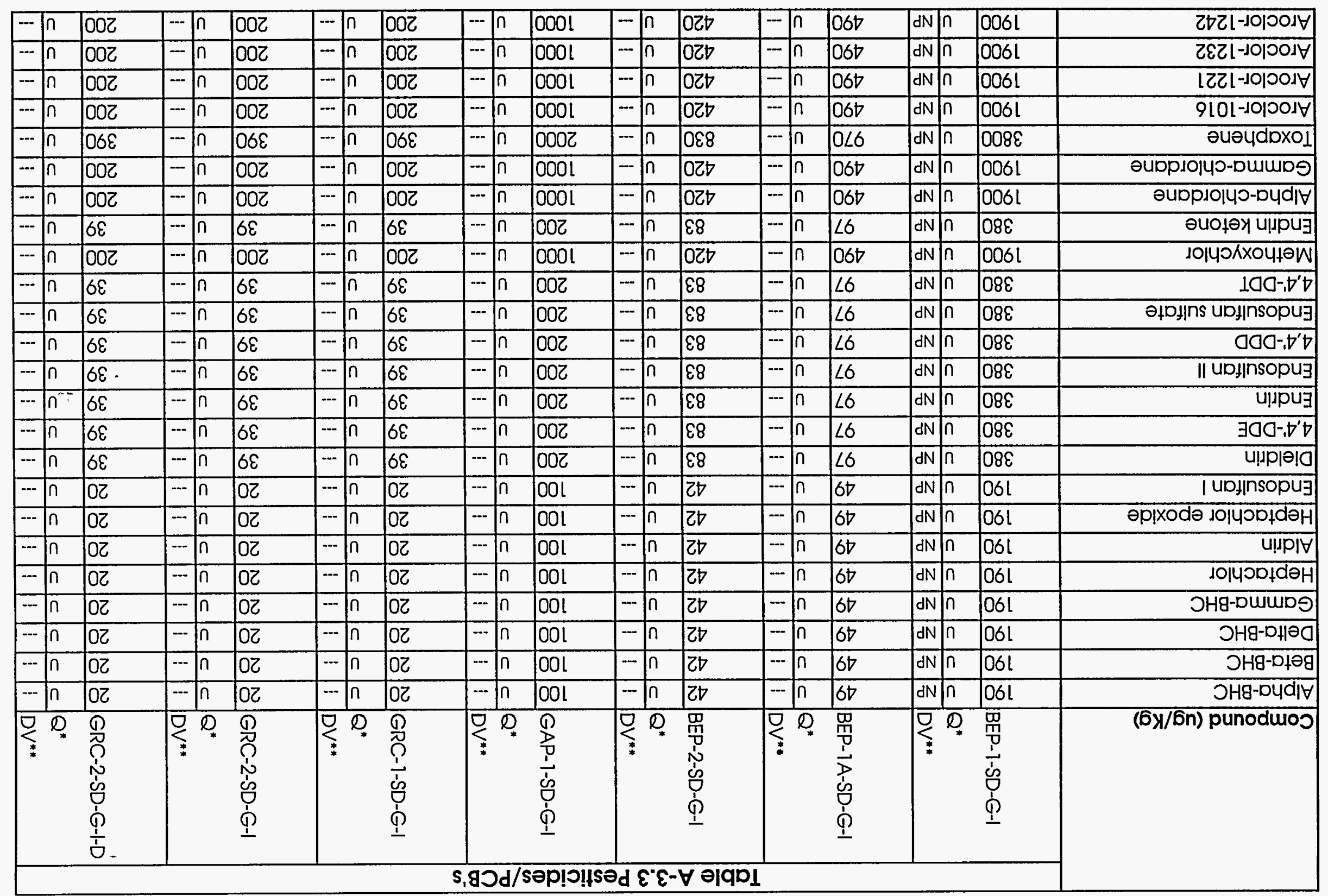




\begin{tabular}{|c|c|c|c|c|c|c|c|c|c|c|c|c|c|c|}
\hline \multirow[b]{2}{*}{ Compound (ug/ $/ \mathrm{Kg}$ ) } & \multicolumn{14}{|c|}{ Table A-3.3 Pesticides/PCB's } \\
\hline & 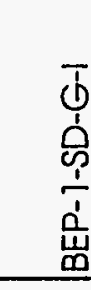 & ¿ & 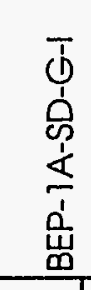 & $\stackrel{*}{*}$ & 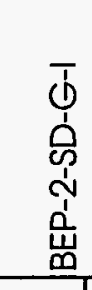 & ${ }^{*} \stackrel{*}{*}$ & $\begin{array}{l}\overline{0} \\
1 \\
0 \\
1 \\
1 \\
1 \\
\frac{1}{1} \\
\mathbb{1}\end{array}$ & $\stackrel{*}{0}$ & 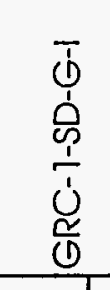 & $\stackrel{*}{\sigma}$ & 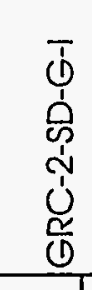 & $\stackrel{*}{*}{ }_{0}^{*}$ & 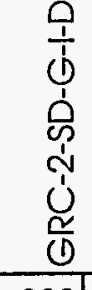 & $\stackrel{*}{\sigma} \overbrace{}^{*}$ \\
\hline Aroclor-1248 & 1900 & U/NP & 490 & \begin{tabular}{l|l}
4 & $\ldots$ \\
\end{tabular} & 420 & $4 \ldots$ & 1000 & $4 \mid-\ldots$ & 200 & 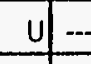 & 200 & 4. - - & 200 & \begin{tabular}{c|c}
4 & $\ldots$ \\
4
\end{tabular} \\
\hline Aroclor-1254 & 3800 & UNP & 970 & \begin{tabular}{l|l} 
& $-\ldots$ \\
\end{tabular} & 830 & v) $=$ & 2000 & $4:-$ & 390 & 0 & 390 & $4 \ldots$ & 390 & $\begin{array}{ll}4 & -- \\
\end{array}$ \\
\hline Aroclor-1260 & 3800 & U/NP & 970 & \begin{tabular}{l|l} 
& $-\ldots$ \\
\end{tabular} & 830 & u $] \ldots$ & 2000 & v & 390 & $\mathrm{u} \mid \ldots$ & 390 & $0 \mid \ldots$ & 390 & \begin{tabular}{l|l} 
& $\ldots$ \\
\end{tabular} \\
\hline
\end{tabular}




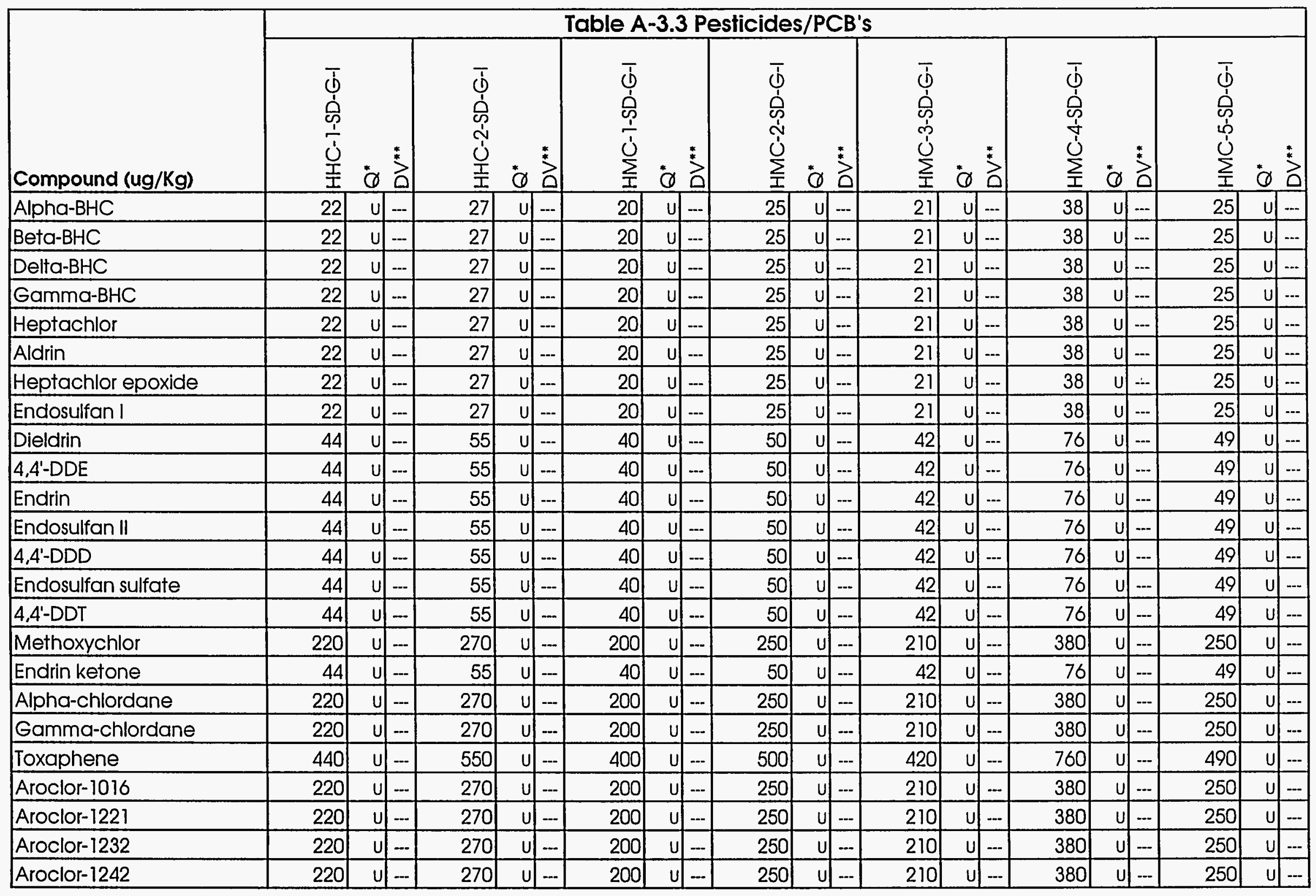




\begin{tabular}{|c|c|c|c|c|c|c|c|c|c|c|c|c|c|c|}
\hline \multirow[b]{2}{*}{ Compound $(\mathrm{ug} / \mathrm{Kg})$} & \multicolumn{14}{|c|}{ Table A-3.3 Pesticides/PCB's } \\
\hline & 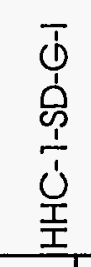 & $\stackrel{*}{*} \stackrel{*}{2}$ & 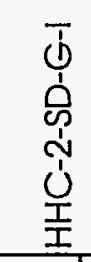 & $\dot{0}^{*} \stackrel{*}{0}$ & 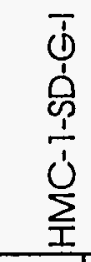 & ${ }^{*}{ }^{*}{ }^{*}$ & 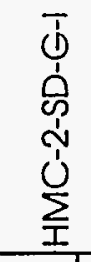 & $\stackrel{0}{\circ}$ & 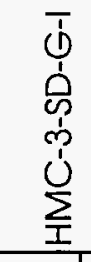 & $\stackrel{*}{\underline{Q}} \stackrel{*}{*}$ & 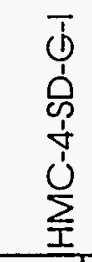 & ${ }^{*}{ }^{*}{ }^{*}$ & 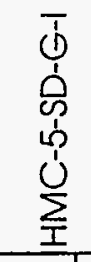 & ${ }^{*}{ }^{*}{ }^{*}$ \\
\hline Aroclor-1248 & 220 & U. & 270 & \begin{tabular}{ll|}
$4 \ldots$ \\
\end{tabular} & 200 & $\begin{array}{lll}4 & -\ldots \\
\end{array}$ & 250 & $4 \ldots$ & 210 & 4. & 380 & \begin{tabular}{l|l|l|}
0 & $\ldots$ \\
\end{tabular} & 250 & \begin{tabular}{l|l|} 
& $\ldots$ \\
\end{tabular} \\
\hline Aroclor-1254 & 440 & \begin{tabular}{l|l}
$U$ & $-\ldots$
\end{tabular} & 550 & \begin{tabular}{l|l|}
4 & $-\ldots$ \\
\end{tabular} & 400 & 0 & 500 & U & 420 & \begin{tabular}{l|l}
4 & $\ldots$ \\
\end{tabular} & 760 & \begin{tabular}{l|l|} 
& $\ldots$ \\
\end{tabular} & 490 & 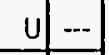 \\
\hline Aroclor-1260 & 440 & U. & 550 & \begin{tabular}{l|l|}
0 & $-\ldots$ \\
\end{tabular} & 400 & v & 500 & $\begin{array}{lll} & \ldots & -. . \\
\end{array}$ & 420 & 4. & 760 & \begin{tabular}{l|l|} 
& $\ldots$ \\
\end{tabular} & 490 & \begin{tabular}{l|l|}
0 & $\ldots$ \\
\end{tabular} \\
\hline
\end{tabular}




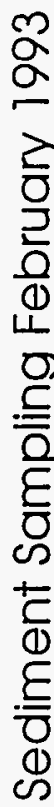

$\frac{1}{0}$

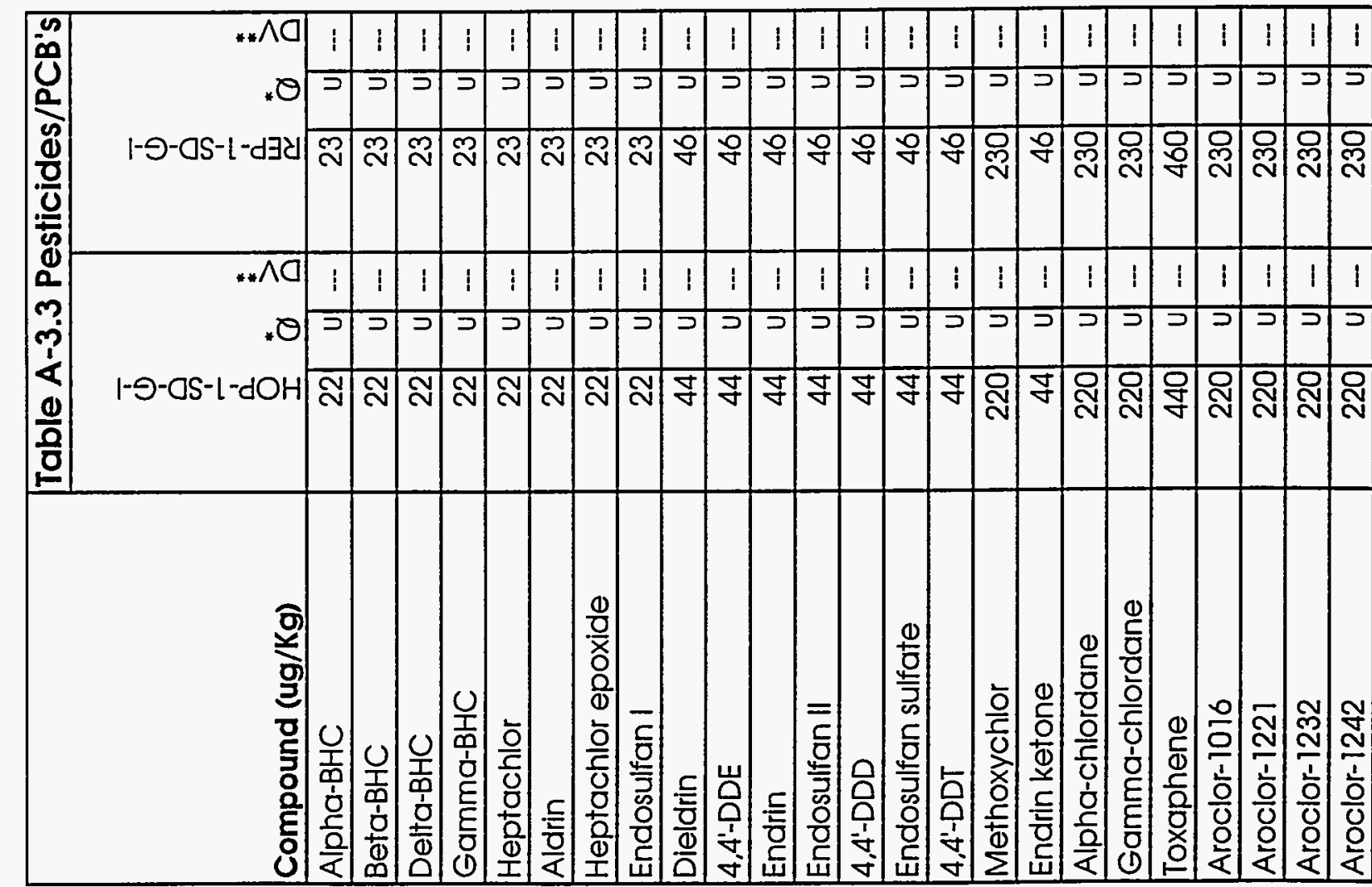




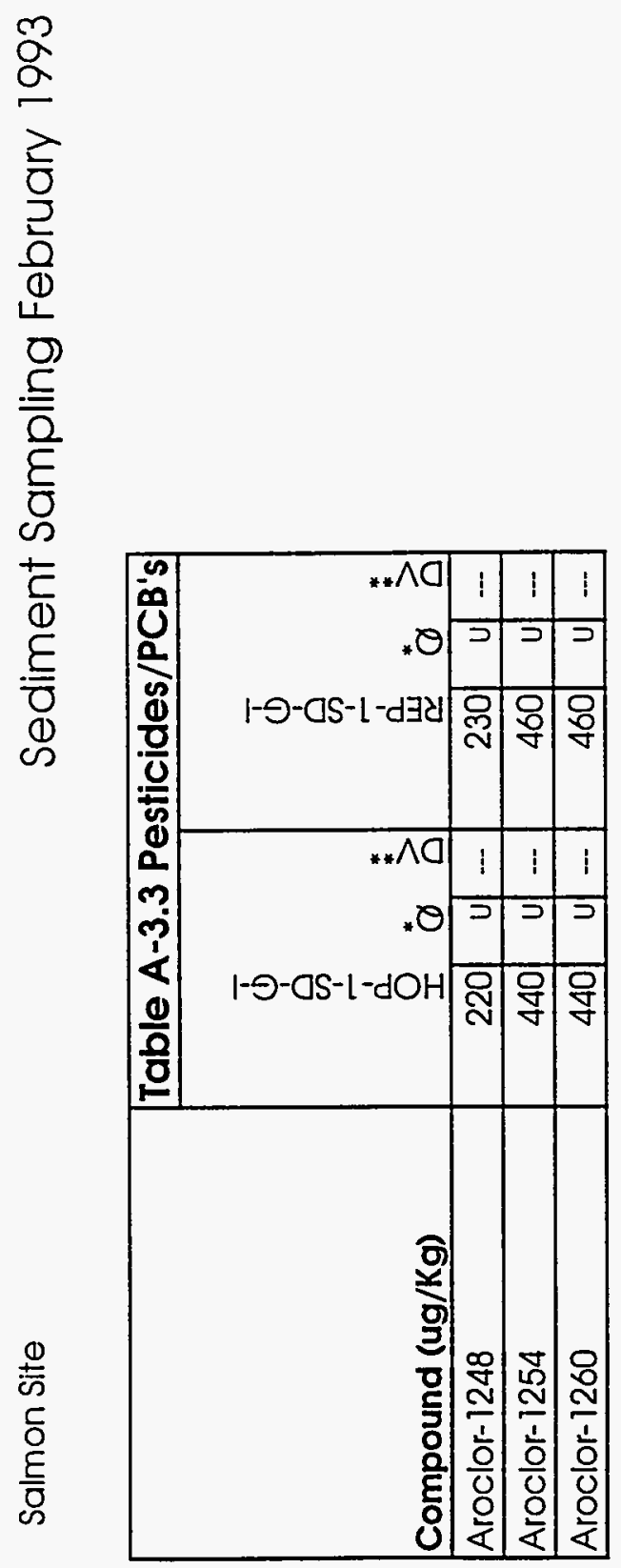

$\infty$
0
0
0
0 


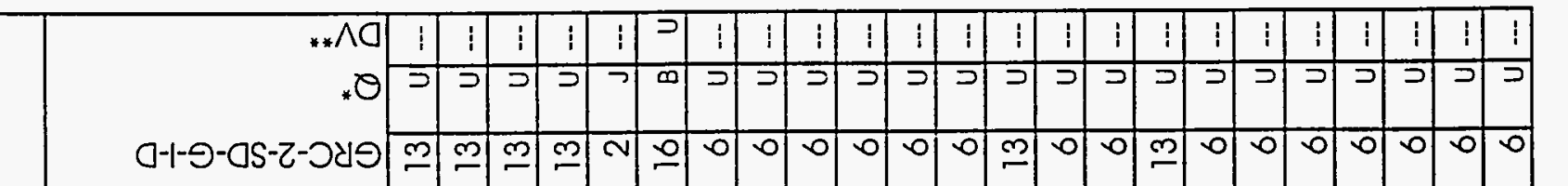

\%

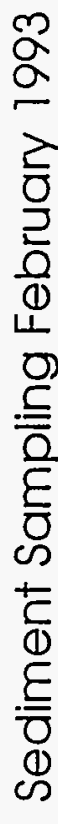

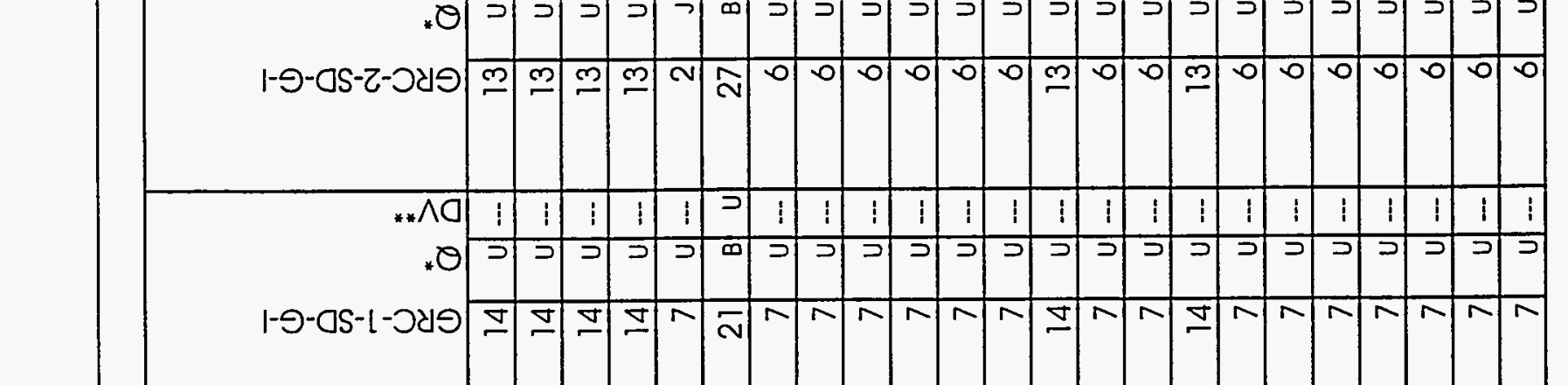

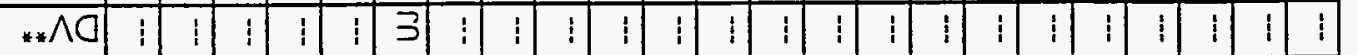

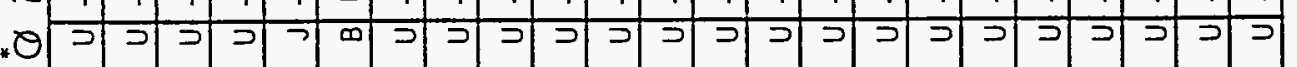

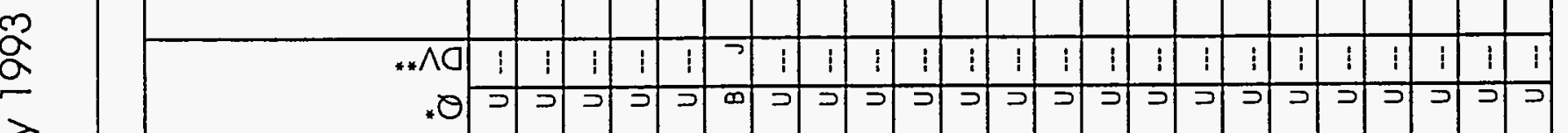

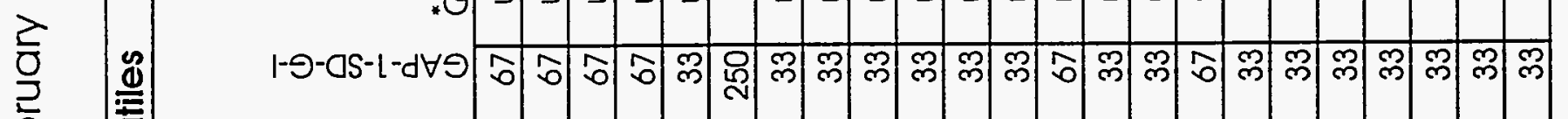

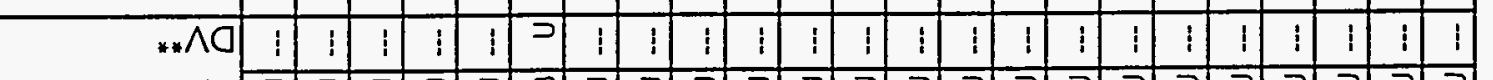

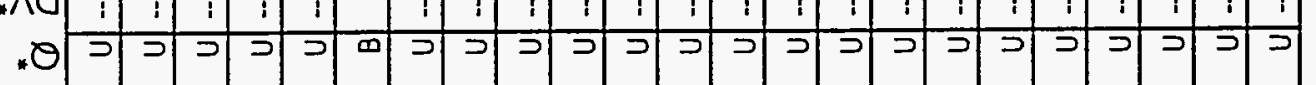

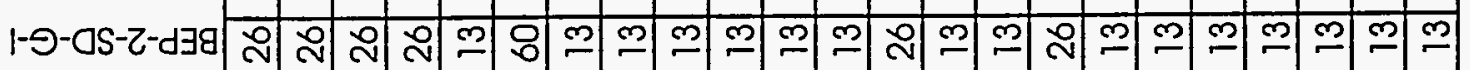
0
0
0
0
0

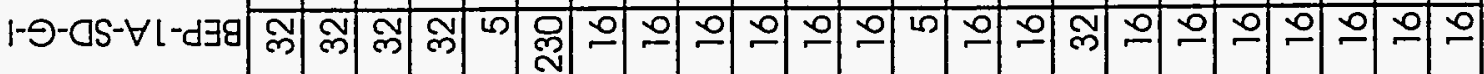

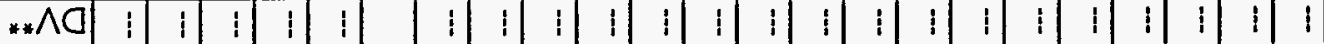
* l-9-CS-L-dヨg (

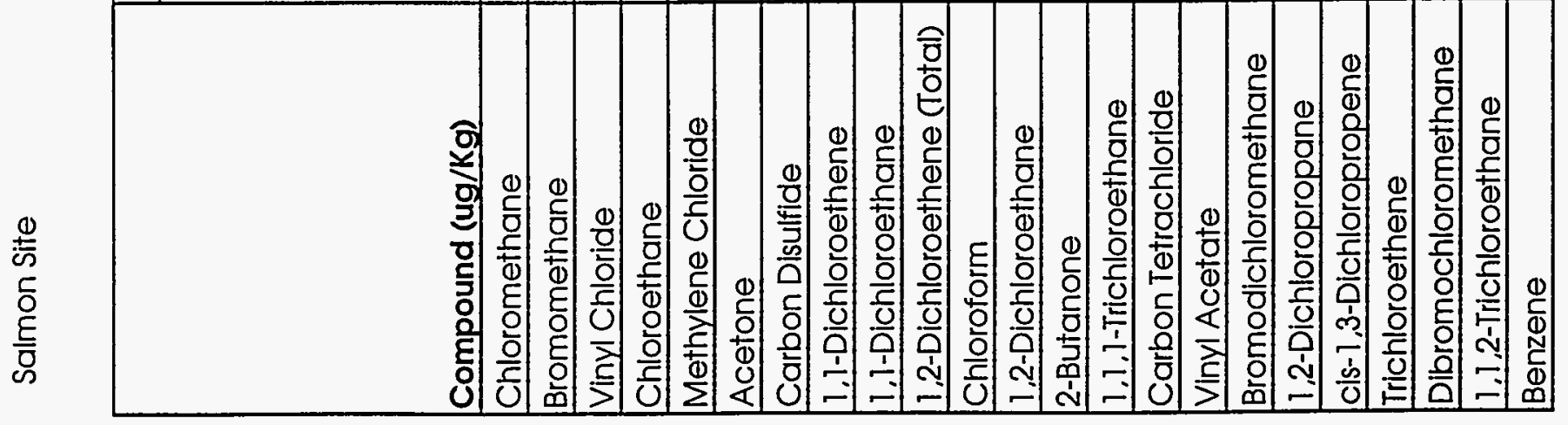




\begin{tabular}{|c|c|c|c|c|c|c|c|c|c|c|c|c|c|c|c|c|c|c|c|c|}
\hline--1 & $n$ & 9 & $-\infty$ & $n$ & 9 & $-\cdots \mid$ & $\bar{n}$ & $L$ & -- & & $\varepsilon \varepsilon$ & \begin{tabular}{|l|l|}
$-\cdots$ & $n$ \\
\end{tabular} & $\varepsilon \mathrm{El}$ & - & Tn & 91 & $-\infty$ & $n$ & 29 & (|D+OD әUә|KX \\
\hline$-\infty$ & $n$ & 9 & $--\mid$ & $n$ & 9 & $\cdots$ & $\bar{n}$ & $L$ & $\cdots$ & $n$ & $\overline{\varepsilon \varepsilon}$ & \begin{tabular}{|l|l|}
-- & $n$ \\
\end{tabular} & $\varepsilon l$ & -- & $n$ & 91 & -- & $n$ & 29 & ӘUӘार 4 S \\
\hline$\cdots$ & $n$ & 9 & $\cdots$ & $n$ & 9 & $\cdots$ & $n$ & $L$ & $\cdots$ & $n$ & $\varepsilon \varepsilon$ & $---n$ & $\varepsilon$ & -- & Tn & 91 & -- & $n$ & 29 & 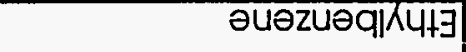 \\
\hline \begin{tabular}{|l|}
-- \\
\end{tabular} & $n$ & 9 & -- & $n$ & 9 & $\cdots$ & $n$ & $L$ & $-\cdots$ & $n$ & $\varepsilon \varepsilon$ & \begin{tabular}{l|l|}
$-\cdots$ & $n$ \\
\end{tabular} & $\varepsilon l$ & $\cdots$ & n & 91 & -- & $n$ & 29 & әบәZuəq010|4ว \\
\hline$-\infty$ & $n$ & 9 & $\cdots$ & $n$ & 9 & 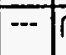 & $n$ & L & $\cdots$ & $n$ & $\overline{\varepsilon \varepsilon}$ & 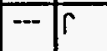 & II & -- & $\bar{n}$ & 91 & - & & 022 & วนəก|O1 \\
\hline$\cdots$ & $n$ & 9 & $\cdots$ & $n$ & 9 & $\cdots$ & $n$ & $L$ & $\cdots$ & $n$ & $\varepsilon \varepsilon$ & \begin{tabular}{|l|l|}
$\cdots$ & $n$ \\
\end{tabular} & $\varepsilon$ & $-\cdots$ & n & 91 & $\cdots$ & $n$ & 29 & 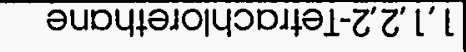 \\
\hline$-\cdots$ & $n$ & 9 & $\cdots$ & $n$ & 9 & --- & $n$ & $\bar{L}$ & $-\cdots$ & $n$ & $\varepsilon \varepsilon$ & \begin{tabular}{|l|l|}
-- & $n$ \\
\end{tabular} & $\varepsilon \mathrm{El}$ & --- & $\pi$ & 91 & --- & $n$ & 29 & 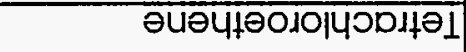 \\
\hline$\cdots$ & $n$ & $\varepsilon \mathrm{E}$ & $-\cdots$ & ก & $\varepsilon$ & -- & $n$ & $\nabla L$ & $\cdots$ & $n$ & $\angle 9$ & \begin{tabular}{|l|l|}
-- & $n$ \\
\end{tabular} & 92 & --- & n & $\overline{Z \varepsilon}$ & $\cdots$ & $n$ & $\overline{0 Z L}$ & әUOUDXəH-Z \\
\hline-- & n & $E l$ & $\cdots$ & $n$ & $\varepsilon !$ & -- & $n$ & $\nabla L$ & $-\cdots$ & $n$ & $\angle 9$ & \begin{tabular}{|l|l|}
-- & $n$ \\
\end{tabular} & 92 & $\cdots$ & $\pi$ & $2 \varepsilon$ & $-\cdots$ & $n$ & OZL & 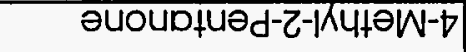 \\
\hline \begin{tabular}{|l|l|}
$---\mid$ & 1
\end{tabular} & $n$ & $\overline{9}$ & -- & $n$ & 9 & -1 & $n$ & $L$ & -- & $n$ & $\varepsilon \varepsilon$ & \begin{tabular}{|l|l|}
$\cdots$ & $n$ \\
\end{tabular} & $\varepsilon l$ & $\cdots$ & $n$ & 91 & -- & $n$ & 29 & wojowosg \\
\hline \begin{tabular}{|l|}
--- \\
\end{tabular} & $n$ & 9 & -- & $n$ & 9 & $-\cdots$ & $n$ & $L$ & $-\cdots$ & $n$ & $\varepsilon \varepsilon$ & \begin{tabular}{|l|l|}
$\cdots$ & $n$ \\
\end{tabular} & $\varepsilon l$ & $\cdots$ & $n$ & 91 & & $n$ & 29 & 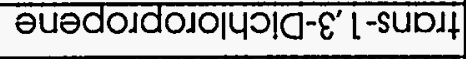 \\
\hline 官 & D & 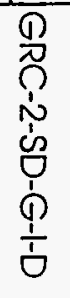 & $\sum_{*}^{\sigma}$ & D & 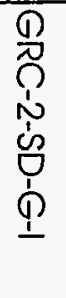 & 安 & $D_{*}$ & 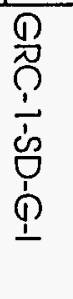 & $\overbrace{*}^{\sigma}$ & D & 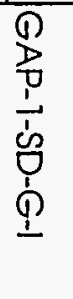 & $\sum_{*} D_{*}$ & 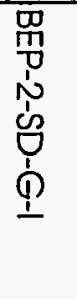 & $\sum_{*}^{\bar{\sigma}}$ & $D_{*}$ & 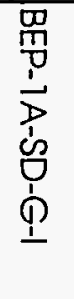 & $\underset{7}{\square}$ & $D_{*}$ & 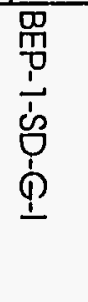 & (6त्र/6n) punoduos \\
\hline
\end{tabular}


1-の-এS-๖-つWH

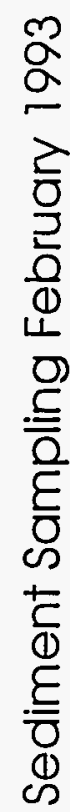

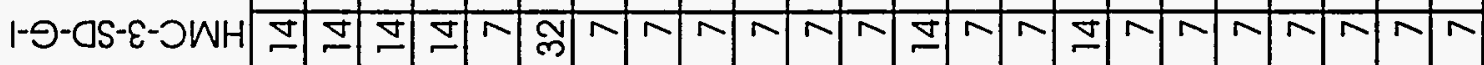

I-๑-ロS-乙-つWH

*^0 * 


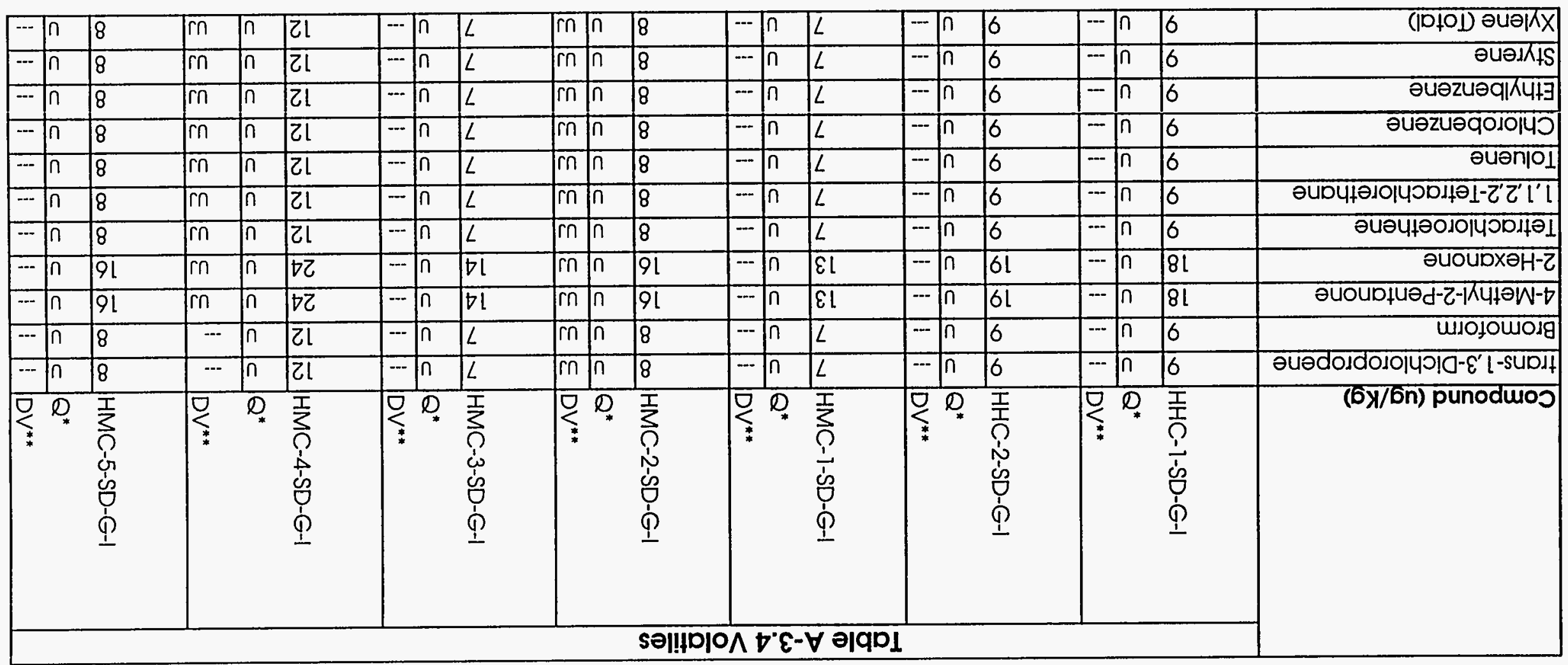




\begin{tabular}{|c|c|c|c|c|c|c|}
\hline \multirow[b]{2}{*}{ Compound (ug $/ \mathrm{Kg}$ ) } & \multicolumn{6}{|c|}{ Table A-3.4 Volatiles } \\
\hline & 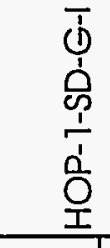 & & $\stackrel{*}{2}$ & 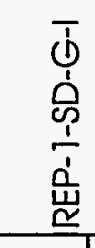 & & $\stackrel{*}{*}$ \\
\hline Chloromethane & 14 & 4 & $\ldots$ & 14 & $u$ & $\ldots$ \\
\hline Bromomethane & 14 & $u$ & $\ldots$ & 14 & $u$ & $-\ldots$ \\
\hline Vinyl Chloride & 14 & $u$ & - & 14 & 4 & - \\
\hline Chloroethane & 14 & 4 & -- & 14 & $u$ & $\ldots$ \\
\hline Methylene Chloride & 2 & BJ & 70 & 2 & J & -- \\
\hline Acetone & 36 & B) & 4 & 32 & B & $\mathrm{U}$ \\
\hline Carbon Disulfide & 7 & 4 & $\ldots$ & 7 & $\mathrm{u}$ & $\ldots$ \\
\hline 1,1-Dichloroethene & 7 & 4 & -- & 7 & $u$ & - \\
\hline 1,1-Dichloroethane & 7 & $u$ & $\ldots$ & 7 & $u$ & -- \\
\hline 1.2-Dichloroethene (Total) & 7 & u) &.- & 7 & $\mathrm{u}$ & $\ldots$ \\
\hline Chloroform & 7 & 4 & $\ldots$ & 7 & $u$ &.- \\
\hline 1,2-Dichloroethane & 7 & $u$ & $\ldots$ & 7 & $u$ & $\ldots$ \\
\hline 2-Butanone & 14 & $u$ & $\ldots$ & 14 & $u$ & -- \\
\hline 1,1,1-Trichloroethane & 7 & $u$ & Uu & 7 & $\mathrm{u}$ & $\ldots$ \\
\hline Carbon Tetrachloride & 7 & $u$ & UJ & 7 & $\underline{4}$ & $\ldots$ \\
\hline Vinyl Acetate & 14 & U & UJ & 14 & $u$ & -- \\
\hline Bromodichloromethane & 7 & $u$ & UJ & 7 & $u$ & - \\
\hline 1,2-Dichloropropane & 7 & 4 & $\mathrm{UJ}$ & 7 & $u$ & $\ldots$ \\
\hline cis-1,3-Dichloropropene & 7 & 4 & UJ & 7 & 4 & $-\cdots$ \\
\hline Trichloroethene & 7 & 4 & UJ & 7 & $u$ & - \\
\hline Dibromochloromethane & 7 & 4 & UJ & 7 & $u$ & $\ldots$ \\
\hline 1,1,2-Trichloroethane & 7 & 4 & UJ & 7 & $u$ & - \\
\hline Benzene & 7 & u) & $\mathrm{UJ}$ & 7 & & $\ldots$ \\
\hline
\end{tabular}


$\frac{\sqrt[J]{d}}{\frac{0}{\sigma}}$

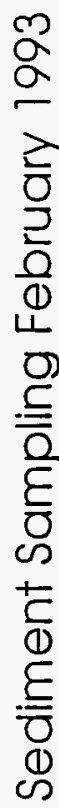

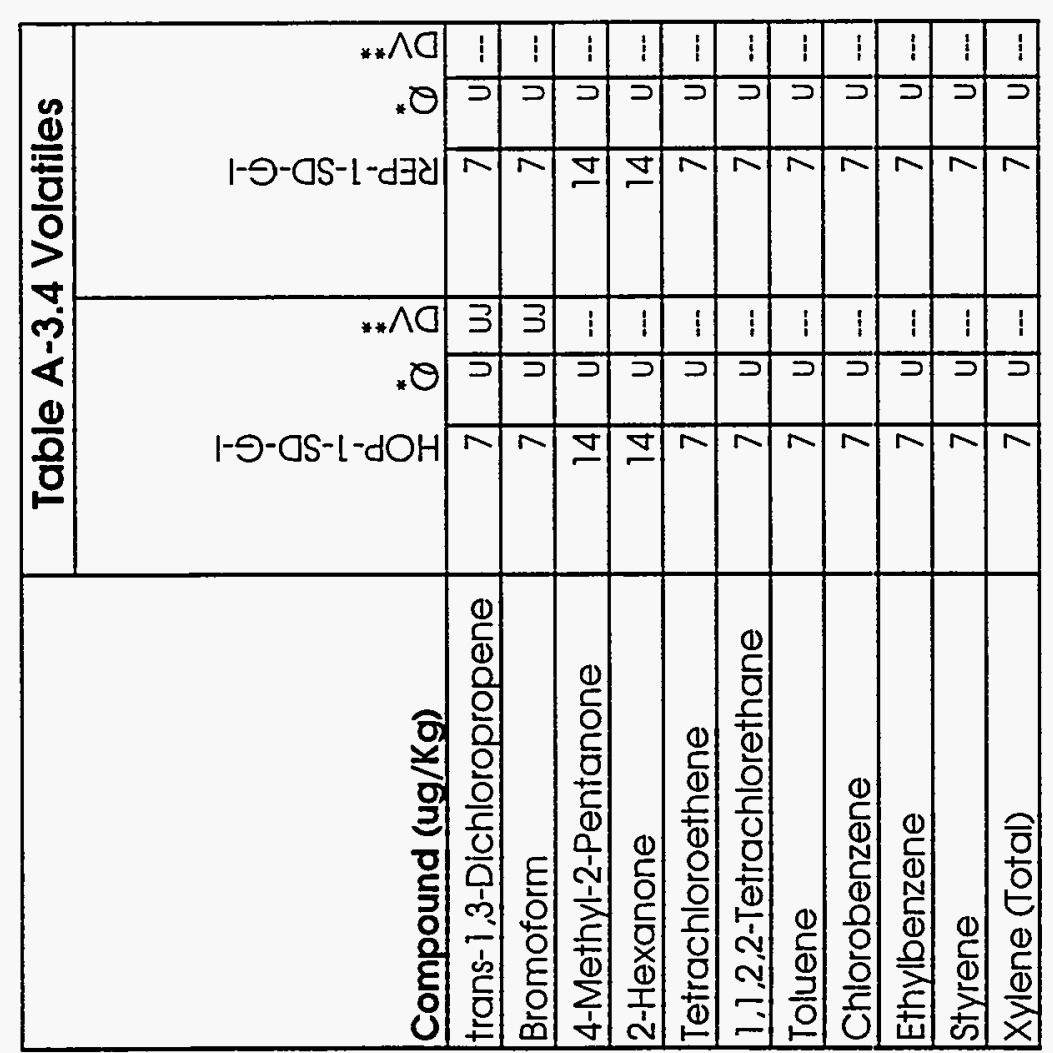

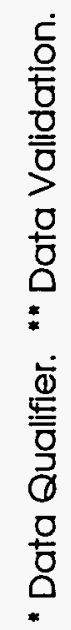




\begin{tabular}{|c|c|c|c|c|c|c|c|c|c|c|c|c|c|c|c|c|c|c|}
\hline \multirow[b]{2}{*}{ Compound (ug/Kg) } & \multicolumn{18}{|c|}{ Table A-3.5 Semi-Volatiles } \\
\hline & $\begin{array}{l}\bar{j} \\
\dot{1} \\
\dot{1} \\
\dot{1} \\
\dot{1} \\
\dot{1} \\
\dot{u} \\
\end{array}$ & & & 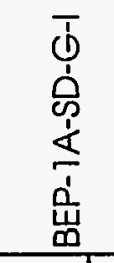 & $\stackrel{*}{0}$ & $3^{*}$ & 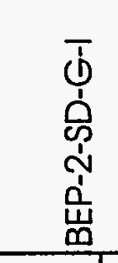 & $\stackrel{*}{Q}$ & $\stackrel{2}{0}$ & 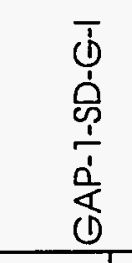 & $\ddot{\sigma}$ & 号 & 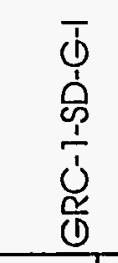 & $\stackrel{*}{\sigma}$ & $\stackrel{2}{0}^{*}$ & 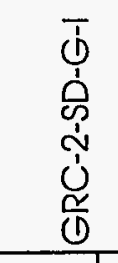 & ${ }^{*}$ & $\stackrel{2}{0}^{*}$ \\
\hline Phenol & 4100 & $u$ & -- & 990 & 4 & -- & 870 & 4 & -- & 2100 & 4 & -- & 410 & $u$ & --- & 410 & 4 & -- \\
\hline bis (2-Cloroethyl)Ether & 4100 & 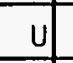 & - & 990 & 4 & -- & 870 & $u$ & $\ldots$ & 2100 & $\mathrm{u}$ & - & 410 & 4 & -- & 410 & $\mathrm{u}$ & $-\ldots$ \\
\hline 2-Chlorophenol & 4100 & 4 & --- & 990 & 4 & - & 870 & 4 & $\ldots$ & 2100 & $u$ & $\ldots$ & 410 & 4 & - & 410 & $u$ & $\ldots$ \\
\hline 1,3-Dichlorobenzene & 4100 & 4 & - & 990 & 4 & -- & 870 & $u$ & $\ldots$ & 2100 & $\mathrm{u}$ & - & 410 & $u$ & $\ldots$ & 410 & $u$ & $\ldots$ \\
\hline 1,4-Dichlorobenzene & 4100 & 4 & -- & 990 & $U$ & $\ldots$ & 870 & 4 & -- & 2100 & $\mathrm{U}$ & - & 410 & $u$ & $\ldots$ & 410 & 4 & $\ldots$ \\
\hline Benzyl Alcohol & 4100 & 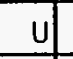 & -- & 990 & $u$ & $\ldots$ & 870 & $\mathrm{u}$ & - & 2100 & $u$ & - & 410 & 4 & $\ldots$ & 410 & $U$ & $-\ldots$ \\
\hline 1,2-Dichlorobenzene & 4100 & 4 & -- & 990 & 4 & -- & 870 & $u$ & $\ldots$ & 2100 & 4 & $-\ldots$ & 410 & 4 & $\ldots$ & 410 & 4 & $\ldots$ \\
\hline 2-Methylphenol & 4100 & 4 & - & 990 & 4 & --- & 870 & 0 & $\ldots$ & 2100 & $\mathrm{u}$ & -- & 410 & 4 & $\ldots$ & 410 & 4 & $\ldots$ \\
\hline bis (2-Chloroisopropyl)Ether & 4100 & $u$ & $\ldots$ & 990 & 4 & $\ldots$ & 870 & 4 & - & 2100 & 4 & -- & 410 & 4 & -- & 410 & $u$ & $\ldots$ \\
\hline 4-Methylphenol & 2200 & J & - & 990 & 4 & --- & 870 & 4 & $\ldots$ & 2100 & 4 & $\ldots$ & 410 & 4 & - & 410 & 4 & -- \\
\hline N-Nitroso-Di-n-Propylamine & 4100 & 4 & - & 990 & $u$ & -- & 870 & 4 & - & 2100 & 4 & $\ldots$ & 410 & 4 & $\cdots$ & 410 & $u$ & - \\
\hline Hexachloroethane & 4100 & 4 & - & 990 & 4 & -- & 870 & $u$ & - & 2100 & 4 & - & 410 & 4 & -- & 410 & 4 & $\ldots$ \\
\hline \begin{tabular}{|l} 
Nitrobenzene \\
\end{tabular} & 4100 & 4 & - & 990 & 4 & - & 870 & 4 & -- & 2100 & 4 & -- & 410 & 4 & -- & 410 & 4 & -- \\
\hline Isophorone & 4100 & 4 & - & 990 & 4 & -- & 870 & 4 & $\ldots$ & 2100 & $\mathrm{U}$ & - & 410 & 4 & $\ldots$ & 410 & 4 & $\ldots$ \\
\hline 2-Nitrophenol & 4100 & $u$ & $\ldots$ & 990 & $\mathrm{U}$ & - & 870 & $\mathrm{u}$ & -- & 2100 & $U$ & -- & 410 & 4 & -- & 410 & 4 & -- \\
\hline 2,4-Dimethylphenol & 4100 & 4 & - & 990 & 4 & - & 870 & $\mathrm{U}$ & -- & 2100 & $u$ & - & 410 & 4 & $\ldots$ & 410 & 4 & -- \\
\hline Benzoic Acid & 20000 & 4 & -- & 550 & $\mathrm{~J}$ & J & 4200 & 4 & -- & 10000 & $\mathrm{u}$ & -- & 2000 & 4 & -- & 2000 & 4 & -- \\
\hline bis (2-Chloroethoxy)Methane & 4100 & 4 & $\cdots$ & 990 & 4 & $\ldots$ & 870 & $u$ & - & 2100 & 4 & $\ldots$ & 410 & 4 & -- & 410 & 4 & -- \\
\hline 2,4-Dichlorophenol & 4100 & $u$ & - & 990 & 4 & - & 870 & 4 & -- & 2100 & 4 & - & 410 & 4 & $\ldots$ & 410 & 4 & $\ldots$ \\
\hline 1,2,4-Trichlorobenzene & 4100 & 4 & $\ldots$ & 990 & $u$ & -- & 870 & $u$ & $\ldots$ & 2100 & 4 & -- & 410 & U & $\ldots$ & 410 & 4 &.- \\
\hline Naphthalene & 4100 & 4 & $\ldots$ & 990 & Uf & $\ldots$ & 870 & 4 & $\cdots$ & 2100 & 4 & - & 410 & u & - & 410 & $u$ & $\ldots$ \\
\hline 4-Chloroaniline & 4100 & 4 & - & 990 & U & - & 870 & 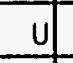 & - & 2100 & 4 & - & 410 & 4 & $\ldots$ & 410 & U & - \\
\hline Hexachlorobutadiene & 4100 & $\mathrm{u}$ & - & 990 & u & $\ldots$ & 870 & 4 & $\ldots$ & 2100 & $u$ & - & 410 & u & $\ldots$ & 410 & U & -- \\
\hline 4-Chloro-3-Methylphenol & 4100 & u & - & 990 & U] & - & 870 & $U$ & - & 2100 & $u$ & - & 410 & U] & - & 410 & U] & - \\
\hline
\end{tabular}




\begin{tabular}{|c|c|c|c|c|c|c|c|c|c|c|c|c|c|c|c|c|c|c|}
\hline \multirow[b]{2}{*}{ Compound (ug/Kg) } & \multicolumn{18}{|c|}{ Table A-3.5 Semi-Volatiles } \\
\hline & 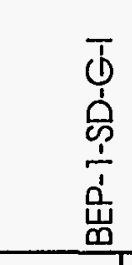 & $\stackrel{*}{0}$ & $\stackrel{3}{0}^{*}$ & 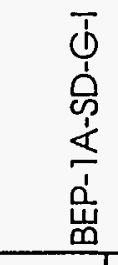 & 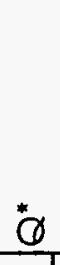 & $\sum_{0}^{*}$ & 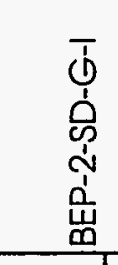 & $\stackrel{*}{\varnothing}$ & $\sum^{*}$ & 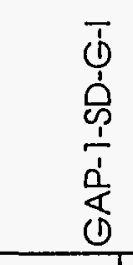 & $\stackrel{*}{0}$ & $\stackrel{2}{0}^{*}$ & 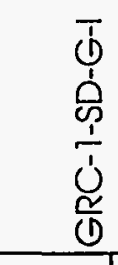 & $\stackrel{*}{Q}$ & $\stackrel{*}{2}$ & 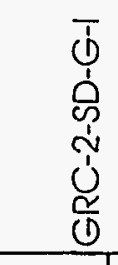 & $\stackrel{*}{Q}$ & $\stackrel{2}{0}^{*}$ \\
\hline 2-Methylnaphthalene & 4100 & $u$ & $\ldots$ & 990 & $\mathrm{u}$ & $\ldots$ & 870 & U) & $\overline{--}$ & 2100 & $u$ & $\ldots$ & 410 & $\mathrm{u}$ & $\ldots$ & 410 & U & $\ldots$ \\
\hline Hexachlorocyclopentadiene & 4100 & $u$ & $\ldots$ & 990 & $u$ & $\ldots$ & 870 & $u$ & $\ldots$ & 2100 & $u$ & $\ldots$ & 410 & $u$ & $\ldots$ & 410 & U & $\ldots$ \\
\hline 2,4.6-Trichlorophenol & 4100 & $u$ & $-{ }_{-1}$ & 990 & $u$ & $\ldots$ & 870 & U & $\ldots$ & 2100 & $\mathrm{u}$ & $\ldots$ & 410 & $u$ & $\ldots$ & 410 & U & -- \\
\hline 2,4,5-Trichlorophenol & 20000 & $\mathrm{u}$ & -- & 4800 & $u$ & -- & 4200 & $u$ & -- & 10000 & 4 & -- & 2000 & $u$ & $-\cdots$ & 2000 & u & -- \\
\hline 2-Chloronaphthalene & 4100 & $u$ & - & 990 & $\mathrm{U}$ & $\ldots$ & 870 & u & -- & 2100 & $\mathrm{U}$ & $\ldots$ & 410 & 4 & $\ldots$ & 410 & 4 & $\ldots$ \\
\hline 2-Nitroaniline & 20000 & $u$ & - & 4800 & 4 & $\cdots$ & 4200 & $u$ & $\ldots$ & 10000 & $\mathrm{U}$ & -- & 2000 & 4 & $\ldots$ & 2000 & $\mathrm{U}$ & $\cdots$ \\
\hline Dimethyl Phthalate & 4100 & 4 & -- & 990 & 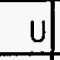 & $\cdots$ & 870 & U & - & 2100 & U & - & 410 & 4 & - & 410 & U & $-\ldots$ \\
\hline Acenaphthylene & 4100 & $\mathrm{U}$ & - & 990 & 4 & -- & 870 & U) & - & 2100 & $\mathrm{U}$ & -- & 410 & 4 & $--\cdot$ & 410 & 4 & -- \\
\hline 2,6-Dinitrotoluene & 4100 & 4 & - & 990 & $u$ & $\ldots$ & 870 & $\mathrm{u}$ & - & 2100 & 4 & - & 410 & 0 & $\ldots$ & 410 & $\mathrm{U}$ & $\ldots$ \\
\hline 3-Nitroaniline & 20000 & 4 & -1 & 4800 & 4 & -- & 4200 & 4 & - & 10000 & 4 & -- & 2000 & $u$ & $\ldots$ & 2000 & $4]^{5}$ & -.. \\
\hline Acenaphthene & 4100 & 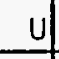 & - & 990 & U) & $\ldots$ & 870 & $u$ & - & 2100 & $\mathrm{U}$ & -- & 410 & 4 & -- & 410 & U & -- \\
\hline 2,4-Dinitrophenol & 20000 & $u$ & - & 4800 & $\mathrm{U}$ & -- & 4200 & $u$ & -- & 10000 & U & - & 2000 & 4 & -- & 2000 & 4 & $\ldots$ \\
\hline 4-Nitrophenol & 20000 & $u$ & - & 4800 & $\mathrm{u}$ & $\cdots$ & 4200 & $u$ & $\ldots$ & 10000 & $u$ & $\ldots$ & 2000 & 4 & $\ldots$ & 2000 & 4 & $\ldots$ \\
\hline Dibenzofuran & 4100 & $u$ & - & 990 & $u$ & $\cdots$ & 870 & $u$ & -- & 2100 & U & -- & 410 & 4 & -- & 410 & $u$ & -- \\
\hline 2,4-Dinitrotoluene & 4100 & $\mathrm{U}$ & - & 990 & 4 & -- & 870 & 4 & -- & 2100 & $\mathrm{U}$ & $\cdots$ & 410 & 4 & - & 410 & 4 & -- \\
\hline Diethylphthalate & 4100 & $u$ & - & 990 & $u$ & $\cdots$ & 870 & 4 & $\cdots$ & 2100 & $\mathrm{U}$ & - & 410 & $u$ & -- & 410 & 4 & - \\
\hline 4-Chlorophenyl-phenylether & 4100 & 4 & - & 990 & $u$ & $\cdots$ & 870 & $\mathrm{u}$ & $\ldots$ & 2100 & $\mathrm{u}$ & -- & 410 & $\mathrm{U}$ & $\ldots$ & 410 & 4 & $\cdots$ \\
\hline Fluorene & 4100 & $\mathrm{U}$ & - & 990 & 4 & -- & 870 & $u$ & $\cdots$ & 2100 & $u$ & -- & 410 & $u$ & - & 410 & $u$ & -- \\
\hline 4-Nitroaniline & 20000 & $\mathrm{u}$ & $\ldots$ & 4800 & 4 & -- & 4200 & $u$ & $\ldots$ & 10000 & $\mathrm{U}$ & -- & 2000 & 4 & -- & 2000 & $u$ &.- \\
\hline 4,6-Dinitro-2-Methylphenol & 20000 & 4 & - & 4800 & 4 & - & 4200 & 4 & $\cdots$ & 10000 & $\mathrm{U}$ & -- & 2000 & 4 & -- & 2000 & 4 & -- \\
\hline N-Nitrosodiphenylamine (1) & 4100 & 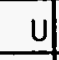 & - & 990 & $u$ & -- & 870 & 4 & $\cdots$ & 2100 & $u$ & $\ldots$ & 410 & $u$ & -- & 410 & $u$ & - \\
\hline 4-Bromophenyl-phenylether & 4100 & 4 & - & 990 & $\mathrm{U}$ & - & 870 & 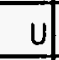 & -- & 2100 & $u$ & -- & 410 & $u$ & - & 410 & $u$ & - \\
\hline Hexachlorobenzene & 4100 & $u$ & - & 990 & 4 & - & 870 & 4 & $\ldots$ & 2100 & $\mathrm{U}$ & -- & 410 & $u$ & - & 410 & 4 & - \\
\hline Pentachlorophenol & 20000 & $\mathrm{U}$ & - & 4800 & $u$ & - & 4200 & $u$ & - & 10000 & $u$ & - & 2000 & $\mathrm{u}$ & - & 2000 & 0 & - \\
\hline
\end{tabular}




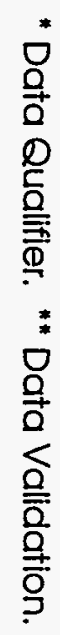

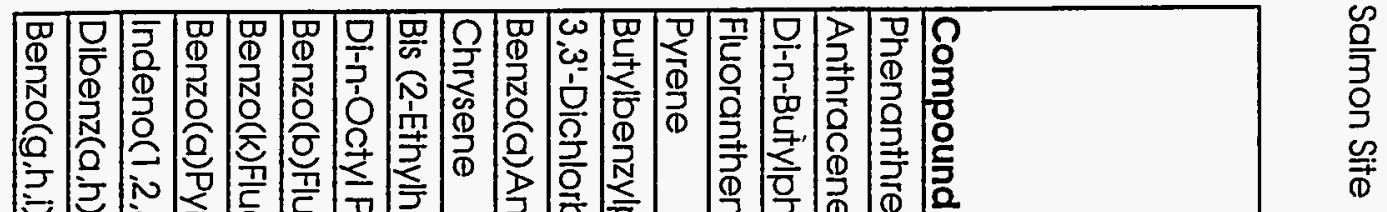

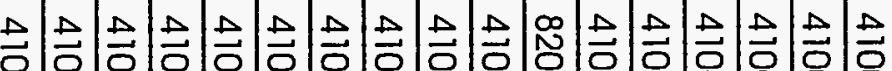

50

c $c \subset c e c c e c c c c c c c c c Q^{*}$

$\begin{array}{llllllllllllllllllllll}1 & 1 & 1 & 1 & 1 & 1 & 1 & 1 & 1 & 1 & 1 & 1 & 1 & 1 & 1 & 1 & 1 & \text { DV** }\end{array}$

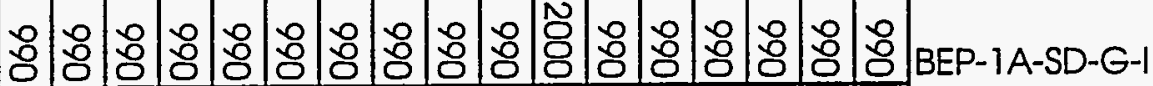

c e c e c e c e c c c c c c c c c Q $^{*}$

$\begin{array}{llllllllllllllllllllllll}1 & 1 & 1 & 1 & 1 & 1 & 1 & 1 & 1 & 1 & 1 & 1 & 1 & 1 & 1 & 1 & 1 & D V^{* *}\end{array}$

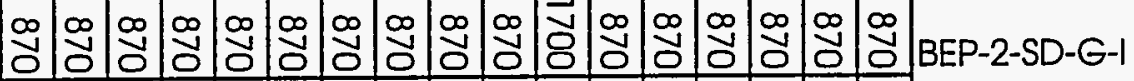

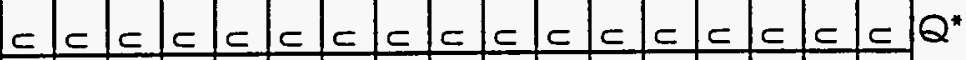

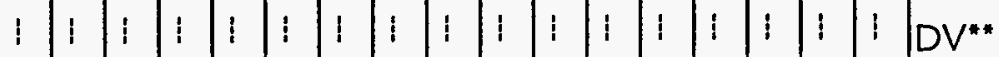

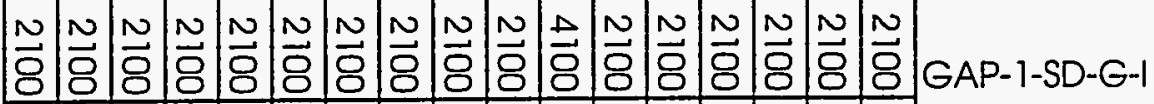

$c \subset c e c c c c c c c c c c c c c c \mid$

$\frac{\overrightarrow{0}}{\frac{0}{0}} \stackrel{\bar{\partial}}{\overline{0}}$

\begin{tabular}{l} 
D \\
을 \\
$\frac{1}{2}$ \\
\hline
\end{tabular}

옥

$\frac{\text { D }}{\frac{0}{2}}$

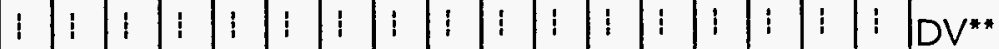

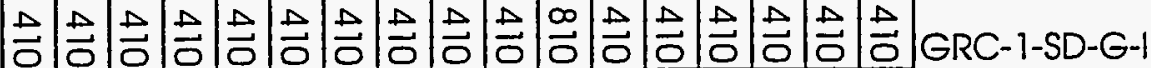

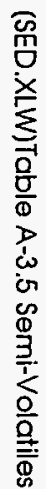

c c e e e e e e e e c e c c e c e l $Q^{*}$

$\begin{array}{lllllllllllllllllllllll}1 & 1 & 1 & 1 & 1 & 1 & 1 & 1 & 1 & 1 & 1 & 1 & 1 & 1 & 1 & 1 & 1 & D^{* *}\end{array}$

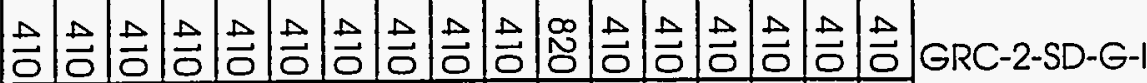

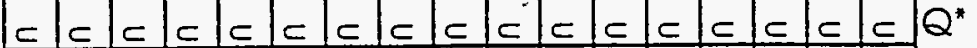

\begin{tabular}{llllllllllllllllllll}
\hline & 1 & 1 & 1 & 1 & 1 & 1 & 1 & 1 & 1 & 1 & 1 & 1 & 1 & 1 & 1 & 1 & $D V^{* *}$
\end{tabular} 
Table A-3.5 Semi-Volatiles

\begin{tabular}{|c|c|c|c|c|c|c|c|c|c|c|c|c|c|c|c|c|c|c|}
\hline \multirow[b]{2}{*}{ Compound (ug/Kg) } & \multicolumn{18}{|c|}{ Table A-3.5 Semi-Volatiles } \\
\hline & 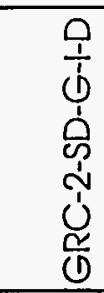 & $\stackrel{*}{\varnothing}$ & $3_{0}^{*}$ & 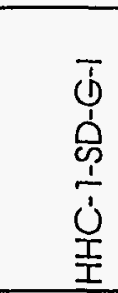 & $\stackrel{0}{0}$ & $\stackrel{3}{0}^{*}$ & 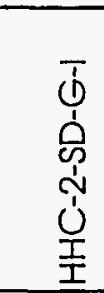 & $\stackrel{*}{\varnothing}$ & $\stackrel{3}{0}^{*}$ & 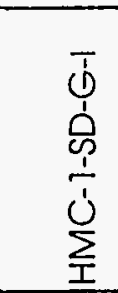 & ¿ & $\stackrel{*}{*}$ & 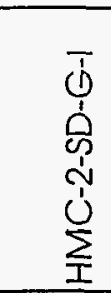 & " & $\stackrel{2}{0}^{*}$ & 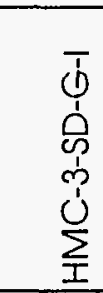 & $\stackrel{*}{Q}$ & $\stackrel{3}{0}^{*}$ \\
\hline Phenol & 410 & U) & -- & 450 & u & $\ldots$ & 570 & $u$ & $\ldots$ & 420 & U & $\ldots$ & 510 & 0 & $\ldots$ & 430 & 4 & $\ldots$ \\
\hline bis (2-Cloroethyl)Ether & 410 & 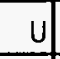 & $\ldots$ & 450 & $u$ & $-\cdots$ & 570 & $\mathrm{U}$ & $-\ldots$ & 420 & $u$ & $\ldots$ & 510 & $u$ & $\ldots$ & 430 & 4 & $\ldots$ \\
\hline 2-Chlorophenol & 410 & 4 & - & 450 & 4 & $\ldots$ & 570 & 4 & $\ldots$ & 420 & $u$ & -- & 510 & 4 & - & 430 & 4 & -- \\
\hline 1,3-Dichlorobenzene & 410 & 4 & $\ldots$ & 450 & 4 & $\ldots$ & 570 & $\mathrm{u}$ & $\ldots$ & 420 & $u$ & $\ldots$ & 510 & $u$ & $\ldots$ & 430 & 4 & $\ldots$ \\
\hline 1,4-Dichlorobenzene & 410 & $u$ & -- & 450 & 4 & $\ldots$ & 570 & 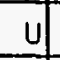 & $\ldots$ & 420 & $u$ & $\ldots$ & 510 & 4 & $\ldots$ & 430 & U & $\ldots$ \\
\hline Benzyl Alcohol & 410 & 4 & -- & 450 & 4 & $\cdots$ & 570 & U & --- & 420 & 4 & $\ldots$ & 510 & 4 & $\cdots$ & 430 & 4 & $\ldots$ \\
\hline 1.2-Dichlorobenzene & 410 & 4 & -- & 450 & 4 & $-\cdots$ & 570 & U & --- & 420 & $u$ & $\ldots$ & 510 & 4 & $\ldots$ & 430 & U) & $\cdots$ \\
\hline 2-Methylphenol & 410 & $u$ & $\ldots$ & 450 & 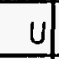 & $\ldots$ & 570 & 4 & $\ldots$ & 420 & $u$ & $-\ldots$ & 510 & 4 & $\ldots$ & 430 & 4 & $\cdots$ \\
\hline bis (2-Chloroisopropyl)Ether & 410 & $u$ & -- & 450 & 4 & $\cdots$ & 570 & U & $\ldots$ & 420 & $u$ & -- & 510 & 4 & $\ldots$ & 430 & 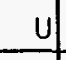 & -- \\
\hline 4-Methylphenol & 410 & U) & -- & 450 & 4 & $\cdots$ & 570 & U & $\ldots$ & 420 & u & -- & 510 & u & $\ldots$ & 430 & 4 & -.- \\
\hline N-Nitroso-Di-n-Propylamine & 410 & 4 & -- & 450 & 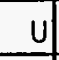 & -- & 570 & $u$ & --- & 420 & 4 & $\ldots$ & 510 & 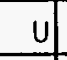 & $\ldots$ & 430 & 4 & $\cdots$ \\
\hline Hexachloroethane & 410 & 4 & -- & 450 & 4 & $\cdots$ & 570 & $\mathrm{U}$ & -- & 420 & 4 & - & 510 & 4 & -- & 430 & $\mathrm{U}$ & $\cdots$ \\
\hline Nitrobenzene & 410 & 4 & -- & 450 & $\mathrm{U}$ & - & 570 & 4 & -- & 420 & 4 & $\ldots$ & 510 & 4 & -- & 430 & 4 & $\cdots$ \\
\hline Isophorone & 410 & U) & -- & 450 & 4 & $\ldots$ & 570 & $\mathrm{u}$ & $\ldots$ & 420 & $u$ & $\ldots$ & 510 & 4 & --- & 430 & 4 & $\ldots$ \\
\hline 2-Nitrophenol & 410 & 4 & $\ldots$ & 450 & u & -- & 570 & u & -- & 420 & 4 & $-\infty$ & 510 & 4 & -- & 430 & 4 & $\cdots$ \\
\hline 2,4-Dimethylphenol & 410 & 4 & $\cdots$ & 450 & 4 & $\cdots$ & 570 & U & $\cdots$ & 420 & $U$ & $\ldots$ & 510 & ut & $\ldots$ & 430 & 4 & $\cdots$ \\
\hline Benzolc Acid & 2000 & 4 & -- & 2200 & $\mathrm{u}$ & - & 2800 & U) & $\cdots$ & 2000 & 4 & -- & 2500 & 4 & -- & 2100 & $u$ & $\ldots$ \\
\hline bis (2-Chloroethoxy)Methane & 410 & u & -- & 450 & $u$ & -- & 570 & $u$ & $\ldots$ & 420 & $u$ & -- & 510 & $u$ & 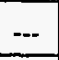 & 430 & 4 & 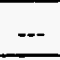 \\
\hline 2,4-Dichlorophenol & 410 & $u$ & $\cdots$ & 450 & $\mathrm{U}$ & - & 570 & u) &.- & 420 & 4 & - & 510 & 4 & -- & 430 & 4 & -- \\
\hline 1,2,4-Trichlorobenzene & 410 & 4 & -- & 450 & $u$ & - & 570 & U] & -- & 420 & U & -- & 510 & U) & $\ldots$ & 430 & $\mathrm{U}$ & $\ldots$ \\
\hline Naphthalene & 410 & $\mathrm{U}$ & -- & 450 & $u$ & -- & 570 & u & $\ldots$ & 420 & $\mathrm{u}$ & - & 510 & $u$ & $\ldots$ & 430 & $u$ & $\ldots$ \\
\hline 4-Chloroaniline & 410 & 4 & - & 450 & $\mathrm{u}$ & - & 570 & U) & - & 420 & $u$ & $\ldots$ & 510 & 4 & - & 430 & 4 & -- \\
\hline Hexachlorobutadiene & 410 & U & - & 450 & $u$ & - & 570 & U & -- & 420 & 4 & - & 510 & 4 & $\ldots$ & 430 & 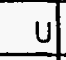 & $\ldots$ \\
\hline 4-Chloro-3-Methylphenol & 410 & 0 & - & 450 & $\mathrm{u}$ & - & 570 & 4 & - & 420 & 4 & - & 510 & $u$ & $\cdots$ & 430 & 4 & - \\
\hline
\end{tabular}

- Data Qualifier. " Data Validation. 


\begin{tabular}{|c|c|c|c|c|c|c|c|c|c|c|c|c|c|c|c|c|c|c|}
\hline \multirow[b]{2}{*}{ Compound (ug/Kg) } & \multicolumn{18}{|c|}{ Table A-3.5 Semi-Volatiles } \\
\hline & 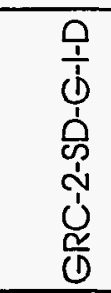 & & $\stackrel{2}{0}^{*}$ & 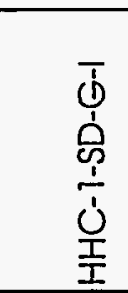 & $\stackrel{*}{\emptyset}$ & $\stackrel{*}{0}^{*}$ & 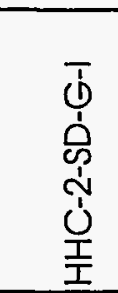 & $\stackrel{*}{\emptyset}$ & $\stackrel{0}{0}^{*}$ & 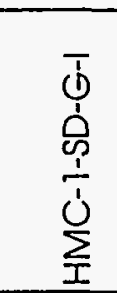 & ஜ & $3_{0}^{*}$ & 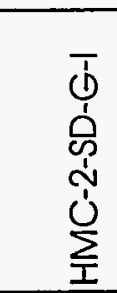 & ๑ & $\stackrel{2}{0}^{*}$ & 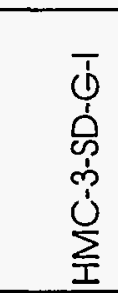 & $\ddot{\theta}$ & $\stackrel{*}{2}$ \\
\hline 2-Methylnaphthalene & 410 & $\mathrm{u}$ & - & 450 & $u$ & $\ldots$ & 570 & $\mathrm{u}$ & $\ldots$ & 420 & $\mathrm{u}$ & $\ldots$ & 510 & U) & --- & 430 & U) & $\ldots$ \\
\hline Hexachlorocyclopentadiene & 410 & $u$ & - & 450 & $\mathrm{u}$ & -- & 570 & $u$ & $\ldots$ & 420 & $\mathrm{u}$ & $\ldots$ & 510 & $u$ & --- & 430 & $u$ & $-\cdots$ \\
\hline 2,4,6-Trichlorophenol & 410 & $u$ & $\ldots$ & 450 & $u$ & $\cdots$ & 570 & 4 & $\ldots$ & 420 & $\mathrm{u}$ & $\ldots$ & 510 & u) & $\cdots$ & 430 & $\mathrm{u}$ & -- \\
\hline 2,4,5-Trichlorophenol & 2000 & $\mathrm{u}$ & -- & 2200 & $\mathrm{u}$ & $\ldots$ & 2800 & $\mathrm{u}$ & - & 2000 & $u$ & $\ldots$ & 2500 & $u$ & $\ldots$ & 2100 & $\mathrm{u}$ & $-\cdots$ \\
\hline 2-Chloronaphthalene & 410 & $\mathrm{u}$ & - & 450 & $u$ & - & 570 & U & $\ldots$ & 420 & $u$ & --- & 510 & $\mathrm{U}$ & --- & 430 & 4 & - \\
\hline 2-Nitroaniline & 2000 & $u$ & -- & 2200 & $u$ & -- & 2800 & $\mathrm{U}$ & $\cdots$ & 2000 & $u$ & --- & 2500 & u) & -- & 2100 & $\mathrm{u}$ & $\ldots$ \\
\hline Dimethyl Phthalate & 410 & $\mathrm{u}$ & -- & 450 & $\mathrm{u}$ & $\ldots$ & 570 & $u$ & -- & 420 & $u$ & $\ldots$ & 510 & u & $\ldots$ & 430 & 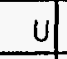 & - \\
\hline Acenaphthylene & 410 & $\mathrm{u}$ & - & 450 & $u$ & -- & 570 & U & - & 420 & $u$ & $-\cdots$ & 510 & $\mathrm{u}$ & --- & 430 & 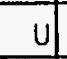 & - \\
\hline 2,6-Dinitrotoluene & 410 & $\mathrm{U}$ & - & 450 & U & $\ldots$ & 570 & $\mathrm{U}$ & - & 420 & $u$ & $\cdots$ & 510 & 4 & -- & 430 & 4 & - \\
\hline 3-Nitroaniline & 2000 & 4 & - & 2200 & 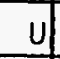 & - & 2800 & 4 & -- & 2000 & $u$ & -- & 2500 & $u$ & -- & 2100 & $u$ & $\ldots$ \\
\hline Acenaphthene & 410 & $\mathrm{u}$ & - & 450 & $\mathrm{u}$ & $\ldots$ & 570 & $\mathrm{u}$ & -- & 420 & $u$ & $-\ldots$ & 510 & $\mathrm{U}$ & -- & 430 & $u$ & 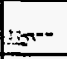 \\
\hline 2,4-Dinitrophenol & 2000 & $\mathrm{U}$ & - & 2200 & $\mathrm{U}$ & - & 2800 & $\mathrm{u}$ & $\ldots$ & 2000 & $\mathrm{u}$ & -- & 2500 & $\mathrm{U}$ & -- & 2100 & $u$ & - \\
\hline 4-Nitrophenol & 2000 & 4 & -- & 2200 & U & - & 2800 & u & $\ldots$ & 2000 & $\mathrm{u}$ & $\ldots$ & 2500 & $u$ & - & 2100 & $u$ & - \\
\hline Dibenzofuran & 410 & $\mathrm{U}$ & - & 450 & 4 & - & 570 & $\mathrm{U}$ & -- & 420 & 4 & -- & 510 & $\mathrm{u}$ & -- & 430 & 4 & -- \\
\hline 2,4-Dinitrotoluene & 410 & $\mathrm{U}$ & - & 450 & $\mathrm{u}$ & - & 570 & $\mathrm{u}$ & - & 420 & $u$ & -- & 510 & $\mathrm{u}$ & -- & 430 & $u$ & -- \\
\hline Diethylphthalate & 410 & $\mathrm{U}$ & - & 450 & $U$ & $\ldots$ & 570 & $\mathrm{u}$ & - & 420 & $u$ & - & 510 & $u$ & $\ldots$ & 430 & U & $\ldots$ \\
\hline 4-Chlorophenyl-phenylether & 410 & $\mathrm{U}$ & -- & 450 & $\mathrm{u}$ & -- & 570 & $\mathrm{u}$ & $\cdots$ & 420 & $\mathrm{u}$ & $\ldots$ & 510 & 4 & -- & 430 & $u$ & $\ldots$ \\
\hline Fluorene & 410 & 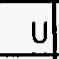 & $\ldots$ & 450 & $u$ & $\ldots$ & 570 & $\mathrm{u}$ & $\ldots$ & 420 & $\mathrm{u}$ & $\ldots$ & 510 & $u$ & $\ldots$ & 430 & 4 & $\ldots$ \\
\hline 4-Nitroaniline & 2000 & $\mathrm{U}$ & -- & 2200 & 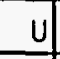 & -- & 2800 & $u$ & - & 2000 & $\mathrm{U}$ & -- & 2500 & 4 & -- & 2100 & $u$ & --- \\
\hline 4,6-Dinitro-2-Methyiphenol & 2000 & 4 & -- & 2200 & 4 & -- & 2800 & U & - & 2000 & 4 & - & 2500 & 4 & - & 2100 & 4 & - \\
\hline N-Nitrosodiphenylamine (1) & 410 & $\mathrm{U}$ & -- & 450 & $u$ & - & 570 & $\mathrm{u}$ & - & 420 & $\mathrm{u}$ & -- & 510 & $\mathrm{u}$ & $\ldots$ & 430 & $u$ & $\ldots$ \\
\hline 4-Bromophenyl-phenylether & 410 & $\mathrm{U}$ & - & 450 & $\mathrm{U}$ & -- & 570 & $\mathrm{U}$ & - & 420 & $\mathrm{U}$ & - & 510 & 4 & --- & 430 & 4 & $\ldots$ \\
\hline Hexachlorobenzene & 410 & $\mathrm{U}$ & - & 450 & $\mathrm{U}$ & - & 570 & 4 & - & 420 & 4 & - & 510 & 4 & - & 430 & 4 & - \\
\hline Pentachlorophenol & 2000 & $u$ & - & 2200 & $u$ & - & 2800 & $\mathrm{U}$ & - & 2000 & $\mathrm{U}$ & - & 2500 & u & -- & 2100 & U) & $\ldots$ \\
\hline
\end{tabular}

" Data Qualifier. " "Data Validation. 


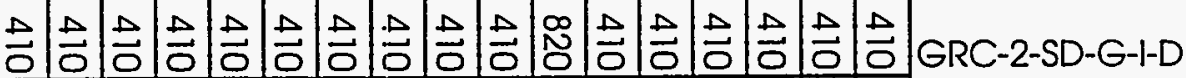

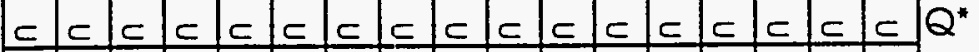
$\begin{array}{lllllllllllllllllllll}1 & 1 & 1 & 1 & 1 & 1 & 1 & 1 & 1 & 1 & 1 & 1 & 1 & 1 & 1 & 1 & 1 & D V^{*}\end{array}$

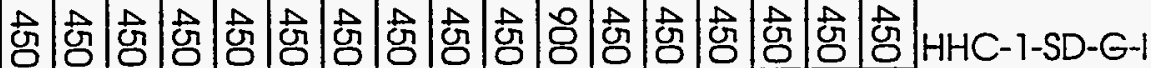

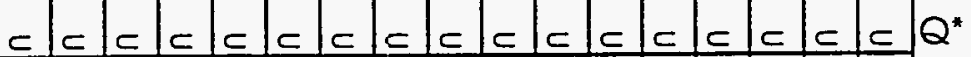

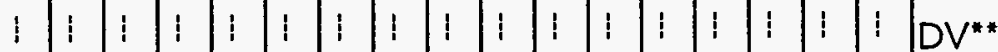

ปூ

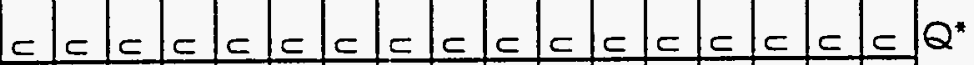

$\begin{array}{lllllllllllllllllllllll}1 & 1 & 1 & 1 & 1 & 1 & 1 & 1 & 1 & 1 & 1 & 1 & 1 & 1 & 1 & 1 & 1 & D^{* *}\end{array}$

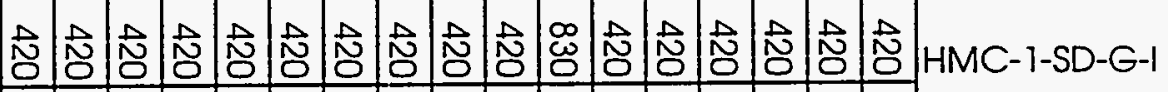

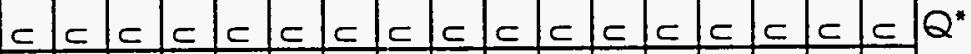

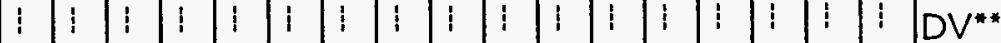

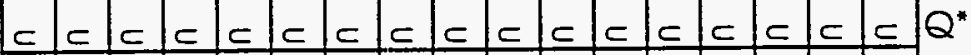

$\begin{array}{lllllllllllllllllllllll}1 & 1 & 1 & 1 & 1 & 1 & 1 & 1 & 1 & 1 & 1 & 1 & 1 & 1 & 1 & 1 & 1 & D^{* *}\end{array}$

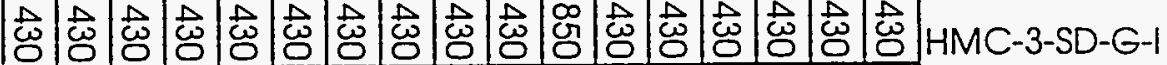

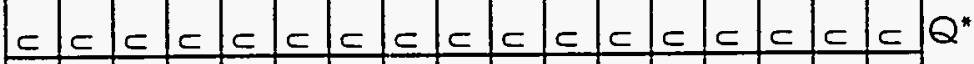

$\begin{array}{llllllllllllllllllllllll}1 & 1 & 1 & 1 & 1 & 1 & 1 & 1 & 1 & 1 & 1 & 1 & 1 & 1 & 1 & 1 & 1 & \text { DV** }\end{array}$ 


\begin{tabular}{|c|c|c|c|c|c|c|c|c|c|c|c|c|}
\hline \multirow[b]{2}{*}{ Compound (ug/Kg) } & \multicolumn{12}{|c|}{ Table A-3.5 Semi-Volatiles } \\
\hline & 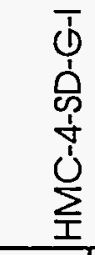 & & $\stackrel{3}{0}^{*}$ & 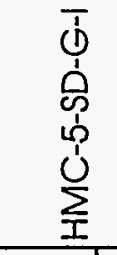 & $\stackrel{*}{\emptyset}$ & $\stackrel{*}{*}$ & 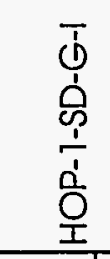 & 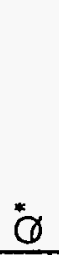 & $\stackrel{\partial}{0}^{*}$ & 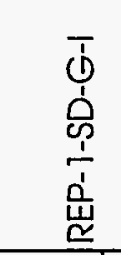 & ๑ & 草 \\
\hline Phenol & 780 & U & $\ldots$ & 510 & $\mathrm{U}$ & -- & 460 & $\mathrm{U}$ & $\ldots$ & 480 & $u$ & $\ldots$ \\
\hline bis (2-Cloroethyl)Ether & 780 & 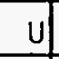 & - & 510 & $\mathrm{u}$ & -- & 460 & $\mathrm{U}$ & $\ldots$ & 480 & $u$ & $\ldots$ \\
\hline 2-Chlorophenol & 780 & $u$ & - & 510 & $\mathrm{U}$ & -- & 460 & $\mathrm{u}$ & $\cdots$ & 480 & $u$ &.- \\
\hline 1,3-Dichlorobenzene & 780 & $u$ & - & 510 & $\mathrm{U}$ & - & 460 & $u$ & -- & 480 & $u$ & - \\
\hline 1,4-Dichlorobenzene & 780 & $u$ & $\ldots$ & 510 & 4 & -- & 460 & u & $\ldots$ & 480 & $u$ & -- \\
\hline Benzyl Alcohol & 780 & $\mathrm{u}$ & $\ldots$ & 510 & $u$ & -- & 460 & $\mathrm{u}$ & $\ldots$ & 480 & u) & -- \\
\hline 1,2-Dichlorobenzene & 780 & 4 & -- & 510 & 4 & $\cdots$ & 460 & U & -- & 480 & 4 & -- \\
\hline 2-Methylphenol & 780 & 4 & $\ldots$ & 510 & 4 & -- & 460 & u & $\ldots$ & 480 & 4 & -- \\
\hline bis (2-Chloroisopropyl)Ether & 780 & $u$ & $\ldots$ & 510 & $u$ & -- & 460 & $u$ & $\ldots$ & 480 & $\mathrm{u}$ & $\ldots$ \\
\hline 4-Methylphenol & 780 & $\mathrm{U}$ & $\cdots$ & 510 & 4 & -- & 460 & 4 & -- & 480 & $u$ & -- \\
\hline N-Nitroso-Di-n-Propylamine & 780 & 4 & $\cdots$ & 510 & 4 & -- & 460 & 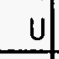 & - & 480 & $u$ & $\ldots$ \\
\hline Hexachloroethane & 780 & 4 & -- & 510 & 4 & -- & 460 & $\mathrm{U}$ & $\cdots$ & 480 & $u$ & $\ldots$ \\
\hline Nitrobenzene & 780 & $\mathrm{U}$ & - & 510 & $\mathrm{U}$ & -- & 460 & 4 & - & 480 & 4 & $\cdots$ \\
\hline Isophorone & 780 & 4 & -- & 510 & 4 & $\ldots$ & 460 & 4 & - & 480 & $u$ & $\ldots$ \\
\hline 2-Nitrophenol & 780 & 4 & - & 510 & 4 & $\ldots$ & 460 & 4 & -- & 480 & 4 & $\ldots$ \\
\hline 2,4-Dimethylphenol & 780 & $\mathrm{U}$ & -- & 510 & $u$ & -- & 460 & $u$ & $\ldots$ & 480 & $u$ & -- \\
\hline Benzoic Acid & 3800 & $\mathrm{U}$ & -- & 2500 & 4 & -- & 2200 & 4 & $\ldots$ & 2300 & 4 & -- \\
\hline bis (2-Chioroethoxy)Methane & 780 & 4 & -- & 510 & $\mathrm{u}$ & -- & 460 & 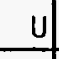 & -- & 480 & 4 & $\cdots$ \\
\hline 2,4-Dichlorophenol & 780 & $u$ & $\ldots$ & 510 & $\mathrm{U}$ & $\ldots$ & 460 & $u$ & $\cdots$ & 480 & $u$ & $\ldots$ \\
\hline 1,2,4-Trichlorobenzene & 780 & u & - & 510 & $\underline{u}$ & -- & 460 & $\underline{u}$ & $\ldots$ & 480 & 4 & -- \\
\hline Naphthalene & 780 & $\mathrm{u}$ & $\ldots$ & 510 & $u$ & $\cdots$ & 460 & $\mathrm{U}$ & $\cdots$ & 480 & $\mathrm{U}$ & $\ldots$ \\
\hline 4-Chloroaniline & 780 & $\mathrm{u}$ & -- & 510 & $\mathrm{u}$ & -- & 460 & $\mathrm{U}$ & -- & 480 & $u$ & -- \\
\hline Hexachlorobutadiene & 780 & 4 & - & 510 & $\mathrm{u}$ & $-\cdots$ & 460 & $u$ & -- & 480 & $u$ & $\cdots$ \\
\hline 4-Chloro-3-Methylphenol & 780 & $\mathrm{u}$ & - & 510 & $\mathrm{U}$ & - & 460 & 4 & -- & 480 & $u$ & -- \\
\hline
\end{tabular}


$\frac{d}{\frac{\gamma}{\alpha}}$

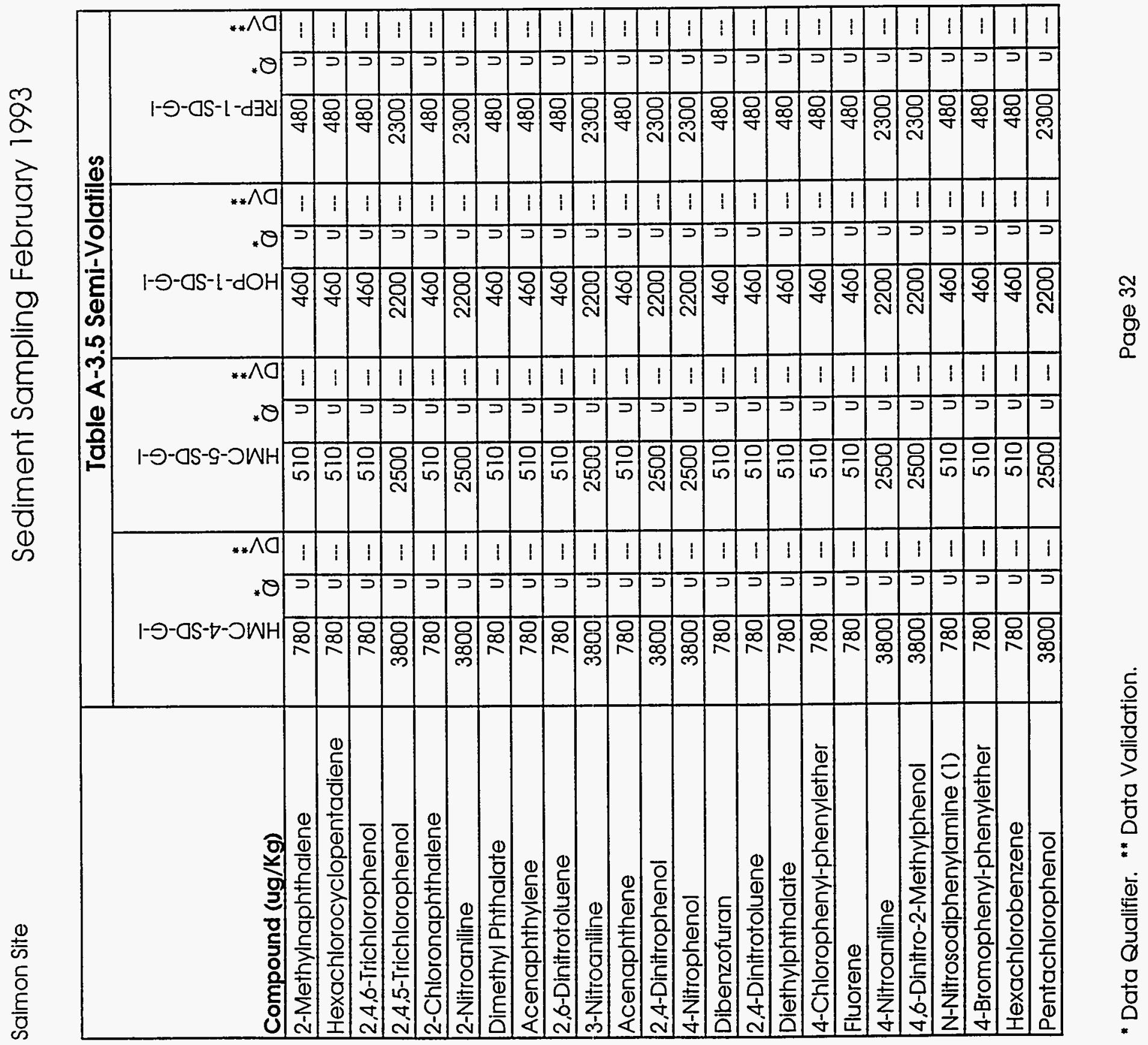




\begin{tabular}{|c|c|c|c|c|c|c|c|c|c|c|c|c|}
\hline \multirow[b]{2}{*}{ Compound (ug/Kg) } & \multicolumn{12}{|c|}{ Table A-3.5 Semi-Volatiles } \\
\hline & $\begin{array}{l}\bar{j} \\
\dot{1} \\
0 \\
\dot{j} \\
\dot{j} \\
\sum_{i}\end{array}$ & $\ddot{\varnothing}$ & $\sum_{0}^{*}$ & 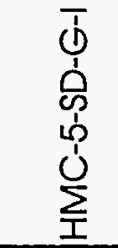 & $\stackrel{*}{6}$ & 方 $^{*}$ & 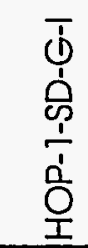 & $\stackrel{0}{0}$ & $\stackrel{3}{0}^{*}$ & 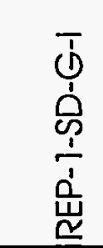 & $\stackrel{*}{0}$ & $\sum_{0}^{*}$ \\
\hline Phenanthrene & 780 & $u$ & - & 510 & U & $\ldots$ & 460 & $u$ & $\ldots$ & 480 & $\mathrm{u}$ & -- \\
\hline Anthracene & 780 & $u$ & $-\cdots$ & 510 & $u$ & - & 460 & $u$ & $\ldots$ & 480 & $\mathrm{u}$ & $\ldots$ \\
\hline Di-n-Butylphthalate & 780 & U & -- & 510 & 4 & $\ldots$ & 460 & $u$ & $\ldots$ & 480 & $\mathrm{U}$ & - \\
\hline Fluoranthene & 780 & $\mathrm{u}$ & - & 510 & $u$ & $\ldots$ & 460 & $u$ & $\ldots$ & 480 & 4 & $\ldots$ \\
\hline Pyrene & 780 & $u$ & - & 510 & u) & $\ldots$ & 460 & $u$ & -- & 480 & $\mathrm{u}$ & -- \\
\hline Butylbenzylphthalate & 780 & 4 & -- & 510 & 4 & -- & 460 & 4 & - & 480 & $u$ & -- \\
\hline 3,3'-Dichlorbenzidine & 1600 & $u$ & $\cdots$ & 1000 & 4 & -- & 910 & 4 & -- & 960 & $\mathrm{U}$ & -- \\
\hline Benzo(a)Anthracene & 780 & $u$ & $\cdots$ & 510 & $u$ & $\ldots$ & 460 & 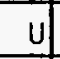 & -- & 480 & $\mathrm{U}$ & $\ldots$ \\
\hline Chrysene & 780 & 4 & -- & 510 & 4 & $--\cdot$ & 460 & 4 & $\ldots$ & 480 & $u$ & --- \\
\hline Bis (2-Ethylhexyl)Phthalate & 780 & $\mathrm{u}$ & -- & 510 & $\mathrm{U}$ & $\ldots$ & 460 & $\mathrm{U}$ & -- & 480 & $\mathrm{U}$ & $\ldots$ \\
\hline Di-n-Octyl Phthalate & 780 & $u$ & -- & 510 & $u$ & $\ldots$ & 460 & $\mathrm{u}$ & $\ldots$ & 480 & 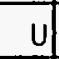 & $\ldots$ \\
\hline Benzo(b)Fluoranthene & 780 & 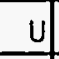 & $\ldots$ & 510 & U & - & 460 & $u$ & $\ldots$ & 480 & U & -- \\
\hline Benzo(k)Fluoranthene & 780 & $\mathrm{u}$ & $\ldots$ & 510 & 4 & - & 460 & 4 & $\ldots$ & 480 & 4 & --- \\
\hline Benzo(a)Pyrene & 780 & $u$ & $\ldots$ & 510 & $u$ & -- & 460 & $u$ & -- & 480 & $U$ & -- \\
\hline Indeno(1,2,3-cd)Pyrene & 780 & $\mathrm{U}$ & $\ldots$ & 510 & $\mathrm{u}$ & $-\ldots$ & 460 & $\mathrm{U}$ & $-\ldots$ & 480 & $\mathrm{U}$ & -- \\
\hline Dibenz(a,h)Anthracene & 780 & $u$ & - & 510 & 4 & -- & 460 & 4 & $\cdots$ & 480 & 4 & -- \\
\hline Benzo(g,h,i)Perylene & 780 & $\mathrm{U}$ & - & 510 & $u$ & $\ldots$ & 460 & $\mathrm{U}$ & $\ldots$ & 480 & $U$ & $\cdots$ \\
\hline
\end{tabular}




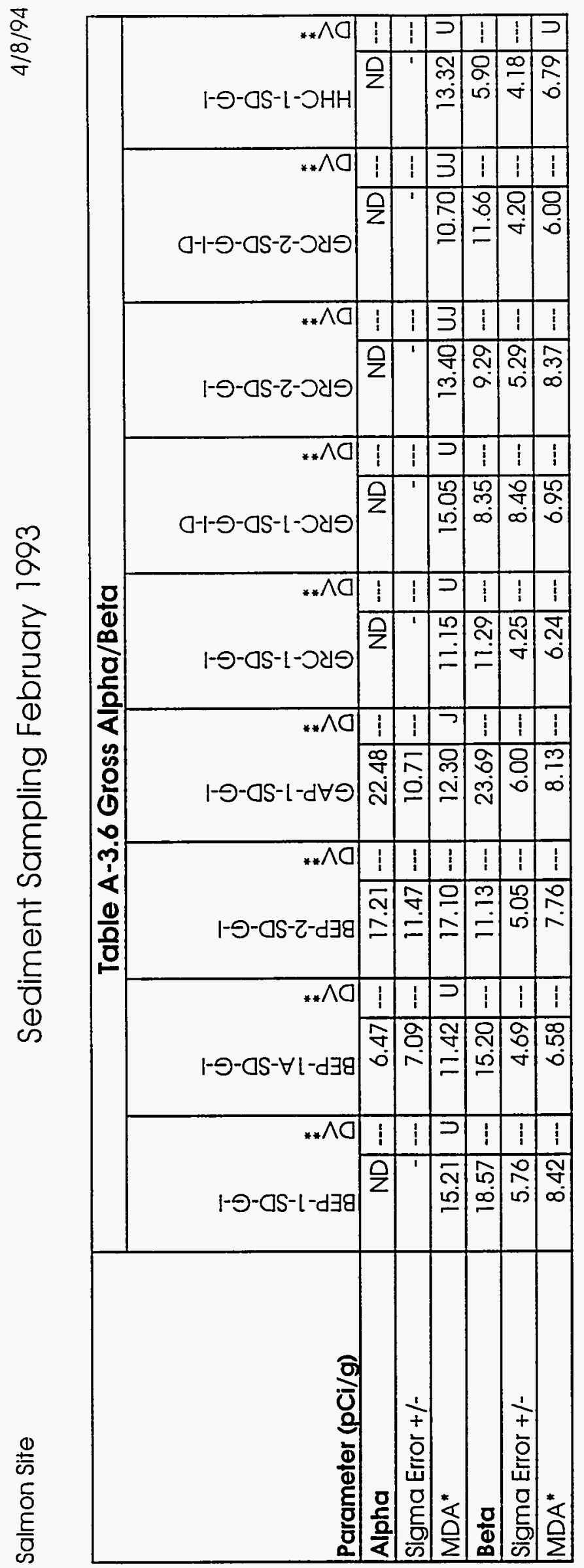




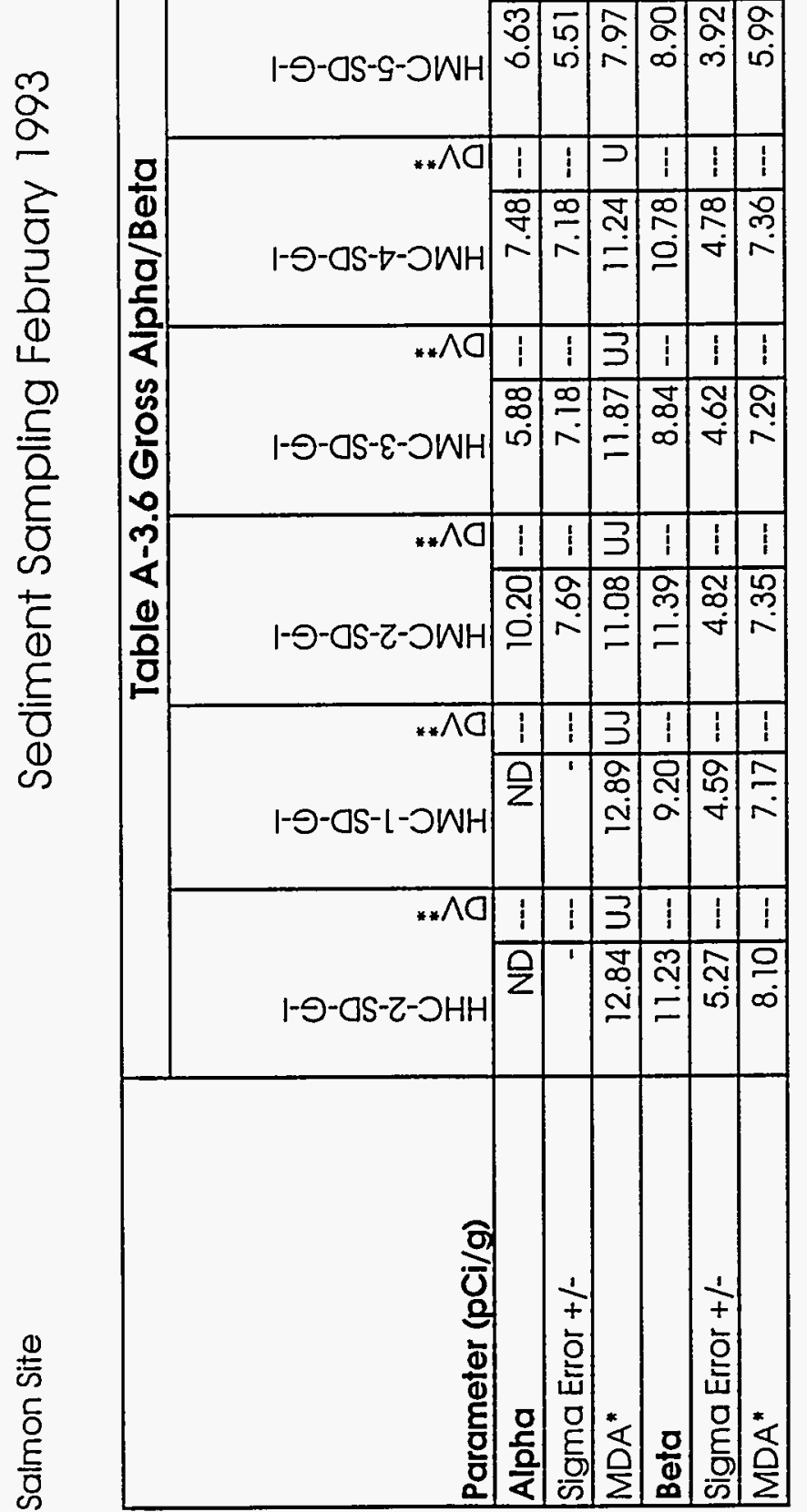

$n$
0
0
0
0
0 


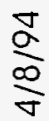

I-๑-OS-L-つHH

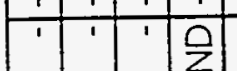

옹

을

色

$* * \wedge$

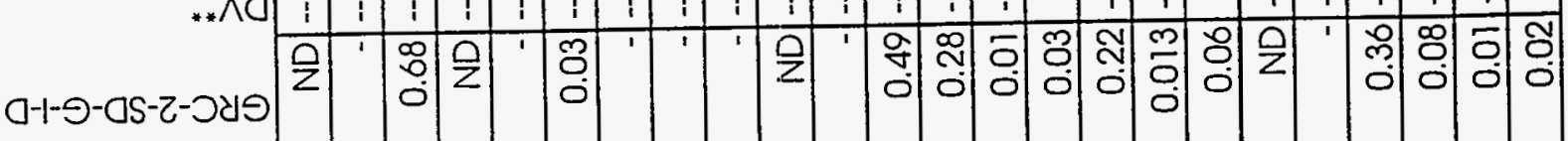

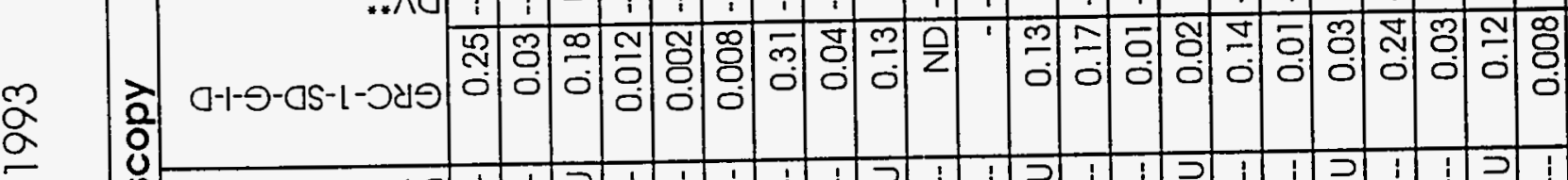

1-э-as-z-วयง

$\frac{\gtrsim}{\frac{2}{2}}$

4

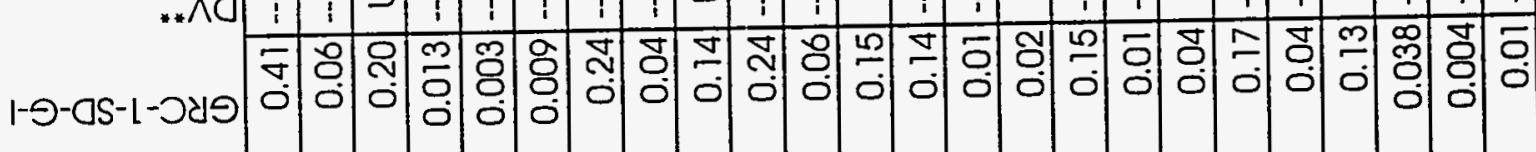
$* * \wedge$

$1-2-a s-1-972$

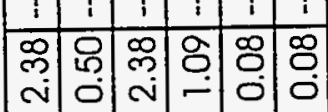

\begin{tabular}{cccc}
\hline & & 1 & 1 \\
\hline & 0 & 0 & 0 \\
0 & 0 & 2
\end{tabular}

志

ปั

요

o)

으

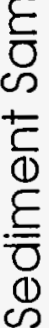

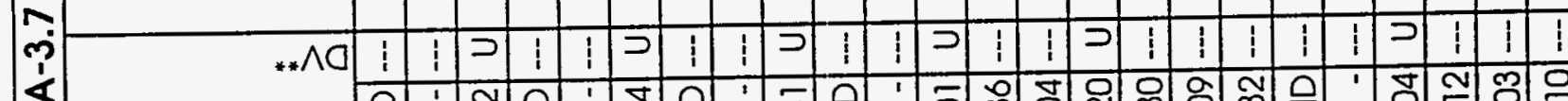
$1-9-a S-\tau-d \exists g$

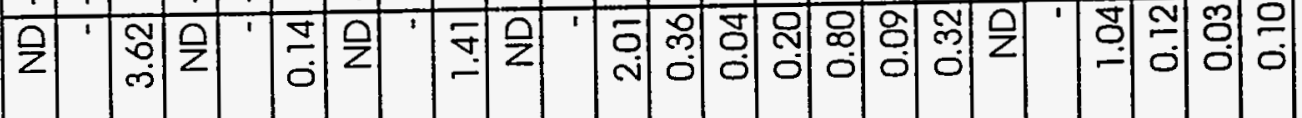

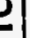

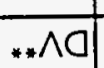

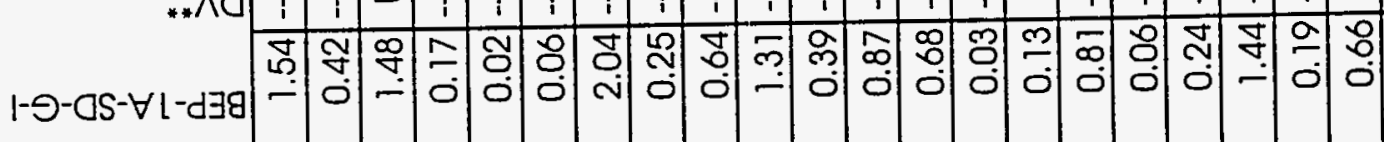

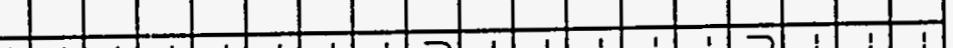

$\frac{\dot{0}}{\overline{0}}$
$\frac{0}{0}$
$\frac{0}{0}$
$\frac{0}{0}$
$\frac{0}{0}$

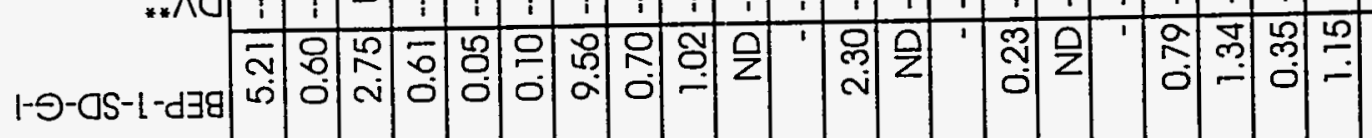




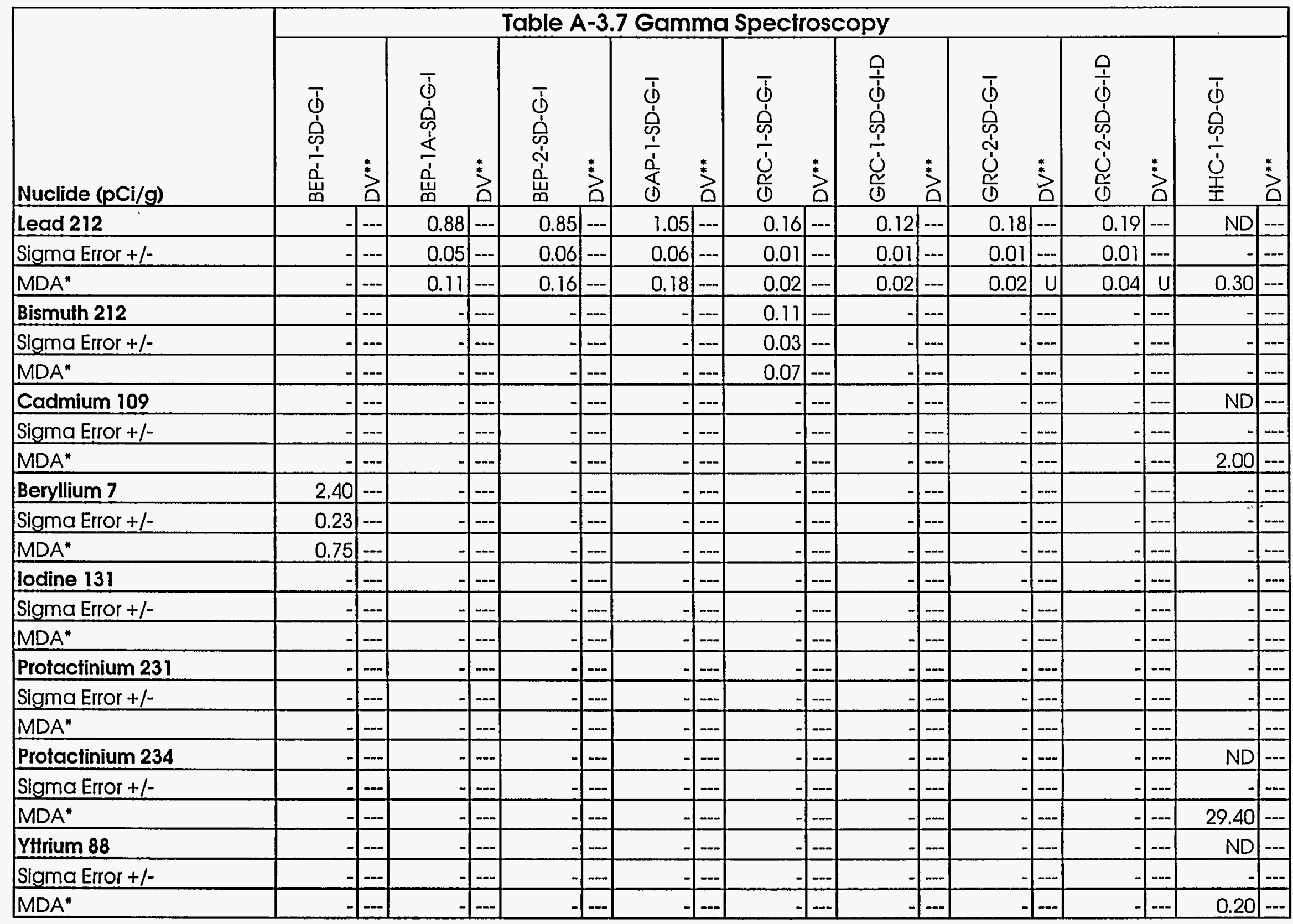

"Minimum Detectable Activity. " "Data Validation. 


\begin{tabular}{|c|c|c|c|c|c|c|c|c|c|c|c|c|c|c|c|c|c|c|}
\hline \multirow[b]{2}{*}{ Nuclide (pCi/g) } & \multicolumn{18}{|c|}{ Table A-3.7 Gamma Spectroscopy } \\
\hline & 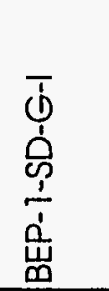 & $3^{*}$ & 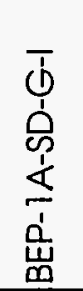 & $3_{0}^{*}$ & 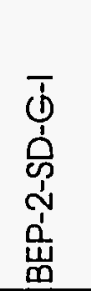 & 3 & $\begin{array}{l}\bar{d} \\
\dot{1} \\
\frac{0}{1} \\
\frac{1}{1} \\
\frac{1}{\alpha} \\
0\end{array}$ & $\stackrel{2}{0}^{*}$ & $\begin{array}{l}\overline{0} \\
1 \\
01 \\
\frac{1}{0} \\
\bar{j} \\
\mathbb{N}\end{array}$ & 艾 & $\begin{array}{l}0 \\
\frac{1}{1} \\
1 \\
1 \\
0 \\
\frac{1}{1} \\
\frac{0}{10} \\
0\end{array}$ & 莒 & 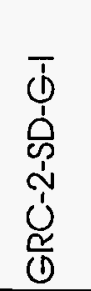 & $\stackrel{2}{0}^{*}$ & 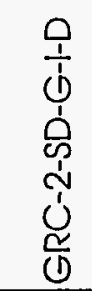 & $\stackrel{3}{0}^{*}$ & 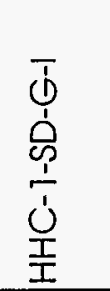 & $\stackrel{2}{0}^{*}$ \\
\hline Cerium 144 & & $-\infty$ & & $-1-\ldots$ & & $-\cdots$ & & J..- & & -2 & & -... & & $-7-\ldots$ & & $-\ldots$ & ND & J--- \\
\hline Sigma Error $+1-$ & & $-\infty$ & & $-\cdots$ & & - & & - & & $+\ldots$ & & $-\infty$ & & - & & $-\ldots$ & & - \\
\hline $\mathrm{MDA}^{*}$ & & $-\infty$ & & - & & $-\ldots$ & & $-\ldots$ & & $-\ldots$ & & $-\ldots$ & & - & & $-\ldots$ & 0.80 & D-- \\
\hline Thorium 230 & & $-\infty$ & & 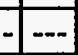 & & $-\cdots$ & & .... & & $\ldots$ & & $\ldots$ & & $-\ldots$ & & $-\ldots$ & ND & {$[-\ldots$} \\
\hline Sigma Error $+1-$ & & $-\infty$ & & $-\infty$ & & $-\infty$ & & - & & \begin{tabular}{|c|}
$-\ldots$ \\
$-\ldots$
\end{tabular} & & - & & $-\ldots$ & & $-\ldots$ & & $-\cdots$ \\
\hline $\mathrm{MDA}^{*}$ & & $\ldots$ & & 4 & & - & & $\ldots$ & & $+\ldots$ & & $-\infty$ & & - & & $-\ldots$ & 18.90 & D- \\
\hline Bismuth 214 & 0.43 & $-\infty$ & & $-\cdots$ & & - & & - & & $+\infty$ & & $-\infty$ & & $-\ldots$ & & \begin{tabular}{c|c}
-- \\
\end{tabular} & & - \\
\hline Sigma Error $+1-$ & 0.06 & $-\ldots$ & & - & & -.. & & $\overline{-\ldots}$ & & \begin{tabular}{|l|}
$-\ldots$ \\
$-\ldots$
\end{tabular} & & $-\infty$ & & --.- & & \begin{tabular}{|c|}
$-\ldots$ \\
\end{tabular} & & -.- \\
\hline $\mathrm{MDA}^{*}$ & 0.27 & $\mid-\ldots$ & & $-\ldots$ & & $\ldots$ & & -.- & & \begin{tabular}{|l|}
$-\ldots$ \\
\end{tabular} & & $-\ldots$ & & $-\ldots$ & & $-1--$ & & $-\ldots$ \\
\hline
\end{tabular}




\begin{tabular}{|c|c|c|c|c|c|c|c|c|c|c|c|c|c|c|c|c|}
\hline \multirow[b]{2}{*}{ Nuclide (pCi/g) } & \multicolumn{16}{|c|}{ Table A-3.7 Gamma Spectroscopy } \\
\hline & 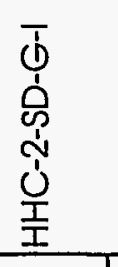 & 莒 & 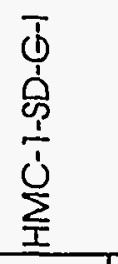 & 莒 & 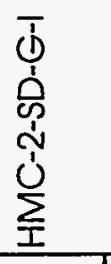 & 袁 & 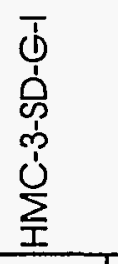 & 兌 & 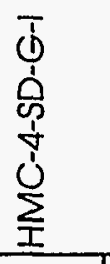 & 莡 & 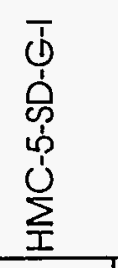 & $\stackrel{*}{2}$ & 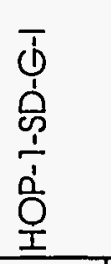 & $\stackrel{*}{*}$ & 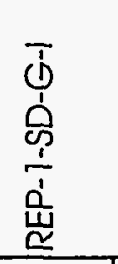 & $\stackrel{*}{2}$ \\
\hline Polassium 40 & 0.94 & $-\cdots$ & 0.57 & -- & 0.26 & $-\cdots$ & 0.39 & $-\cdots$ & 0.90 & -- & -1 & $-\cdots$ & 1.42 & -- & 1.50 & -- \\
\hline Sigma Error $+/-$ & 0.12 & -- & 0.07 & -- & 0.03 & $-\cdots$ & 0.05 & $-\cdots$ & 0.09 & -- & - & -- & 0.30 & $\cdots$ & 0.18 & -- \\
\hline $\mathrm{MDA}^{*}$ & 0.75 & $\mathrm{U}$ & 0.27 & $\mathrm{U}$ & 0.07 & $\mathrm{U}$ & 0.19 & $\mathrm{U}$ & 0.37 & $\mathrm{U}$ & ـ & $-\cdots$ & 0.10 & $\mathrm{U}$ & 0.31 & U \\
\hline Cesium 137 & 0.07 & $-\cdots$ & ND & -- & ND & -- & ND & $\cdots$ & 0.08 & -- & ND & $\cdots$ & 0.16 & -- & ND & -- \\
\hline Sigma Error +1- & 0.01 & $\cdots$ & & -- & - & -- & & -- & 0.01 & -- & & $\cdots$ & 0.04 & -- & & -- \\
\hline$M D A^{*}$ & 0.02 & -- & 0.21 & -- & 0.01 & $\cdots$ & 0.01 & $-\cdots$ & 0.02 & -- & 0.10 & -- & 0.03 & -- & 0.03 & $\ldots$ \\
\hline Lead 210 & & $\ldots$ & 0.41 & --- & - & -- & 0.26 & -- & 1.15 &.-- & -1 & -- & 0.88 & --- & 0.99 & $-\cdots$ \\
\hline Sigma Error +1- & & $\ldots$ & 0.06 & $-\cdots$ & - & -- & 0.05 & $\cdots$ & 0.10 & -- & - & $\cdots$ & 0.08 & $\cdots$ & 0.10 & -- \\
\hline MDA* & & $\ldots$ & 0.19 & U & 1 & -- & 0.16 & $U$ & 0.23 & U & - & $\cdots$ & 0.36 & U & 0.260 & U \\
\hline Radium 224 & ND & $\cdots$ & 0.30 & -- & ND & -- & ND & -- & 0.68 & -- & - & $\cdots$ & ND & -- & 1.26 & $-\cdots$ \\
\hline Sigma Error +1- & & $-\ldots$ & 0.11 & -- & & -- & - & -- & 0.17 & - & - & $\ldots$ & - & -- & 0.36 & $\cdots$ \\
\hline MDA* & 0.61 & -- & 0.20 & U. & 0.17 & -- & 0.22 & -- & 0.22 & -- & & - & 0.77 & $U$ & 0.24 & $=$ \\
\hline Radium 226 & 0.46 & -- & 0.31 & -- & ND & $\cdots$ & 0.18 & $\cdots$ & 0.40 & - & 0.36 & $\ldots$ & ND & - & 0.76 & - \\
\hline Sigma Error +/- & 0.02 & -- & 0.01 & -- & & -- & 0.01 & --- & 0.02 & -- & 0.03 & -- & & -- & 0.03 & $-\cdots$ \\
\hline MDA* & 0.04 & 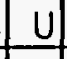 & 0.03 & U & 0.02 & -- & 0.02 & $\mathrm{U}$ & 0.03 & U & 0.17 & -- & 0.08 & U & 0.03 & U \\
\hline Radium 228 & 0.30 & $\ldots$ & 0.27 & $-\cdots$ & ND & $-\cdots$ & 0.15 & $\cdots$ & 0.37 & - & - & -- & ND & $-\ldots$ & 1.16 & $-\cdots$ \\
\hline Sigma Error +1- & 0.020 &.- & 0.02 & -- & & $-\cdots$ & 0.010 & -- & 0.02 & -- & & -- & & -- & 0.04 & -- \\
\hline $\mathrm{MDA}^{*}$ & 0.07 & 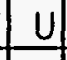 & 0.05 & 4 & 0.03 & $-\cdots$ & 0.03 & 4 & 0.05 & $U$ & & -- & 0.16 & U & 0.04 & - \\
\hline Uranium 238 & ND & $-\cdots$ & 0.36 & -- & 0.27 & $-\cdots$ & 0.17 & $-\cdots$ & 0.33 & $\cdots$ & -1 & - & 0.67 & -- & 1.21 & $-\cdots$ \\
\hline Sigma Error +/- & & $\ldots$ & 0.05 & $-\cdots$ & 0.03 & $-\cdots$ & 0.06 & -- & 0.06 & - & & $\ldots$ & 0.14 & $\ldots$ & 0.11 & $\ldots$ \\
\hline $\mathrm{MDA}^{*}$ & 0.41 & -- & 0.18 & 4 & 0.12 & u & 0.13 & $u$ & 0.21 & U & & -- & 0.39 & $U$ & 0.25 & $U$ \\
\hline Thallium 208 & 0.13 & - & & -- & - & -- & 0.043 & -- & & -- & & -- & 0.11 & -- & 0.39 & $-\cdots$ \\
\hline Sigma Error +1- & 0.01 & $\ldots$ & & $-\cdots$ & & $\ldots$ & 0.004 & - & & $-\cdots$ & - & $\cdots$ & 0.01 & - & 0.02 & -- \\
\hline $\mathrm{MDA}^{*}$ & 0.020 & -- & & $\ldots$ & & --- & 0.010 & $\mid u$ & & $\ldots$ & & -- & 0.04 & $U$ & 0.02 & $-\cdots$ \\
\hline
\end{tabular}

"Minimum Detectable Activity. " Data Validation. 


\begin{tabular}{|c|c|c|c|c|c|c|c|c|c|c|c|c|c|c|c|c|}
\hline \multirow[b]{2}{*}{ Nuclide (pCi/g) } & \multicolumn{16}{|c|}{ Table A-3.7 Gamma Spectroscopy } \\
\hline & 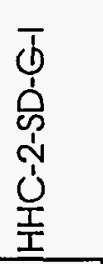 & $\stackrel{3}{0}^{*}$ & 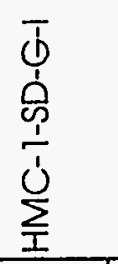 & $\stackrel{2}{0}^{*}$ & 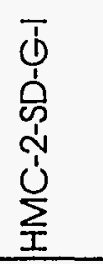 & 莡 & 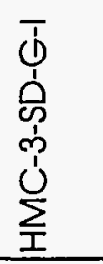 & $\stackrel{*}{3}$ & 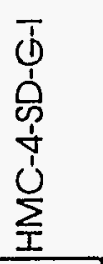 & $\stackrel{2}{2}$ & 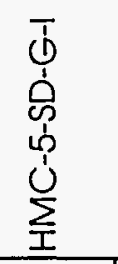 & $\stackrel{*}{3}$ & $\begin{array}{l}\bar{\Phi} \\
1 \\
0 \\
1 \\
1 \\
0 \\
0 \\
0\end{array}$ & $\stackrel{2}{0}^{*}$ & $\begin{array}{l}\bar{T} \\
\dot{0} \\
0 \\
\frac{1}{1} \\
\stackrel{1}{\simeq} \\
\end{array}$ & $\stackrel{*}{2}$ \\
\hline Lead 212 & 0.39 & $-\ldots$ & ND & -- & ND & -- & 0.19 & -- & & $-\cdots$ & 0.43 & $-\ldots$ & 0.34 & -- & 1.42 & - \\
\hline Sigma Error +/- & 0.02 & -- & & -- & - & -- & 0.01 & - & - & -- & 0.07 & $\ldots$ & 0.03 & $\cdots$ & 0.06 & - \\
\hline MDA" & 0.04 & $\mathrm{U}$ & 0.02 & $\ldots$ & 0.02 & $\ldots$ & 0.02 & $\mathrm{U}$ & & -- & 0.14 & $-\ldots$ & 0.07 & $U$ & 0.03 & - \\
\hline Bismuth 212 & & $\ldots$ & -1 & -- & $=$ & $\ldots$ & 0.09 & -- & & --- & - & -- & -1 & -- & -1 & --- \\
\hline Sigma Error $+1-$ & & $-\cdots$ & & -- & & -- & 0.02 & - & & -- & - & -- & - & -- & - & - \\
\hline MDA* & & -- & & -- & _ & $-\cdots$ & 0.07 & -- & - & -- & - & -- & J & - & - & - \\
\hline Cadmium 109 & & $\ldots$ & 0.74 & -- & - & $\ldots$ & & -- & 0.67 & -- & $\mathrm{ND}$ & $-\ldots$ & -1 & $\ldots$ & -1 & - \\
\hline Sigma Error $+/$ - & & $-\cdots$ & 0.14 & $\ldots$ & & $\ldots$ & & -- & 0.13 & $\ldots$ & - & $-\cdots$ & - & -- & - & $\cdots$ \\
\hline MDA* & & $-\cdots$ & 0.20 & $-\infty$ & - & -- & & -- & 0.29 & $\mathrm{U}$ & 1.10 & -- & - & -- & 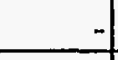 & - \\
\hline Beryllium 7 & & -- & & $\ldots$ & & - & & -- & & -- & - & -- & -1 & -- & - & - \\
\hline Sigma Error $+/-$ & & -- & -1 & $\cdots$ & $=$ & -- & & $-\cdots$ & & $\ldots$ & - & -- & - & -- & -1 & - \\
\hline $\mathrm{MDA}^{*}$ & & $\cdots$ & & $\ldots$ & & $-\ldots$ & & -- & & -- & - & -- & - & -- & & $-\cdots$ \\
\hline lodine 131 & & $-\cdots$ & & -- & & $\ldots$ & & -- & & -- & - & $-\cdots$ & -7 & $-\cdots$ & 0.10 & - \\
\hline Sigma Error $+1-$ & & -- & - & $-\infty$ & & -- & & -- & & $\cdots$ & - & $\ldots$ & - & -- & 0.04 & - \\
\hline $\mathrm{MDA}^{*}$ & & -- & & $\ldots$ & & $\ldots$ & & -- & & -- & & -- & & -- & 0.01 & - \\
\hline Profactinium 231 & & -- & & $-\cdots$ & & $-\cdots$ & & -- & & -- & - & -- & - & -- & 1.11 & - \\
\hline Sigma Error $+1-$ & & $\cdots$ & & - & & $\ldots$ & & $-\cdots$ & & $-\ldots$ & - & - & - & $\cdots$ & 0.22 & $-\cdots$ \\
\hline MDA* & & $\cdots$ & & $\cdots$ & & $\ldots$ & & -- & & $\cdots$ & & -- & - & -- & 0.47 & - \\
\hline Protactinium 234 & & $-\cdots$ & & - & & - & & -- & & - & ND & $\ldots$ & & $-\cdots$ & 3.89 & - \\
\hline Sigma Error + /- & & -- & & -- & & $\cdots$ & &.- & & $-\ldots$ & & -- & - & -- & 0.66 & $-\cdots$ \\
\hline $\mathrm{MDA}^{*}$ & & $-\cdots$ & & $\cdots$ & & $\ldots$ & & $\ldots$ & & -- & 20.50 & -- & -1 & $\cdots$ & 2.96 & - \\
\hline YHrium 88 & & -- & & -- & & $-\ldots$ & & $-\cdots$ & &.- & ND & -- & &.- & & -- \\
\hline Sigma Error +/- & & -- & & -- & & -- & & -- & & - & & - & & -- & - & -- \\
\hline MDA* & & $\ldots$ & & $\cdots$ & & $-\cdots$ & & $-\cdots$ & & $\ldots$ & 0.12 & $-\cdots$ & & $\ldots$ & & $\ldots$ \\
\hline
\end{tabular}




\begin{tabular}{|c|c|c|c|c|c|c|c|c|c|c|c|c|c|c|c|c|}
\hline \multirow[b]{2}{*}{ Nuclide (pCi/g) } & \multicolumn{16}{|c|}{ Table A-3.7 Gamma Spectroscopy } \\
\hline & 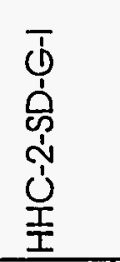 & 莒 & 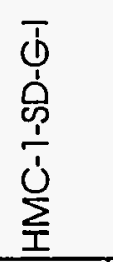 & 莒 & 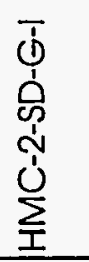 & 3 & 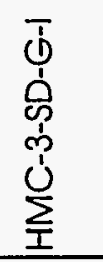 & 茥 & 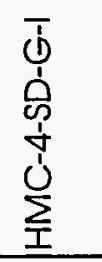 & 莒 & 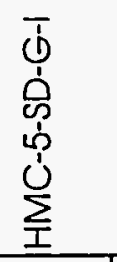 & 兌 & 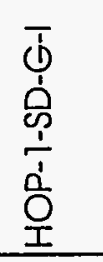 & $3^{*}$ & $\begin{array}{l}\bar{\phi} \\
\dot{0} \\
0 \\
1 \\
1 \\
\dot{1} \\
\underline{u}\end{array}$ & $\stackrel{2}{0}^{*}$ \\
\hline Cerium 144 & & -- & - & -- & & $-\cdots$ & & $-\cdots$ & & $-\cdots$ & 0.30 & -- & & $-\cdots$ & & - \\
\hline Sigma Error $+/-$ & & -- & & $\cdots$ & & $-\cdots$ & & $-\cdots$ & & --- & 0.10 & -- & & $-\cdots$ & & --- \\
\hline $\mathrm{MDA}^{*}$ & & $-\cdots$ & - & $-\cdots$ & & $-\cdots$ & & $-\cdots$ & & -- & 0.30 & - & & -- & & $-\cdots$ \\
\hline Thorium 230 & & - & & -- & & -- & & -- & & - & ND & --- & & $-\cdots$ & & - \\
\hline Sigma Error + /- & & $-\cdots$ & & --- & & $-\cdots$ & & $-\cdots$ & & $-\cdots$ & & -- & & $-\ldots$ & & $-\cdots$ \\
\hline $\mathrm{MDA}^{*}$ & & - & & $-\cdots$ & & $-\cdots$ & & $-\cdots$ & & - & 11.10 & $-\cdots$ & & $-\cdots$ & & -- \\
\hline Bismulh 214 & & $-\cdots$ & & -- & & -- & & $-\cdots$ & & - & - & $\cdots$ & & $-\cdots$ & & $-\cdots$ \\
\hline Sigma Error $+1-$ & & $-\cdots$ & & - & & $-\infty$ & & $-\infty$ & & - & & -- & & $-\ldots$ & & - \\
\hline $\mathrm{MDA}^{*}$ & & $\ldots$ & & $-\cdots$ & & $-\cdots$ & & $-\cdots$ & & $-\cdots$ & & -- & & $-\ldots$ & & - \\
\hline
\end{tabular}




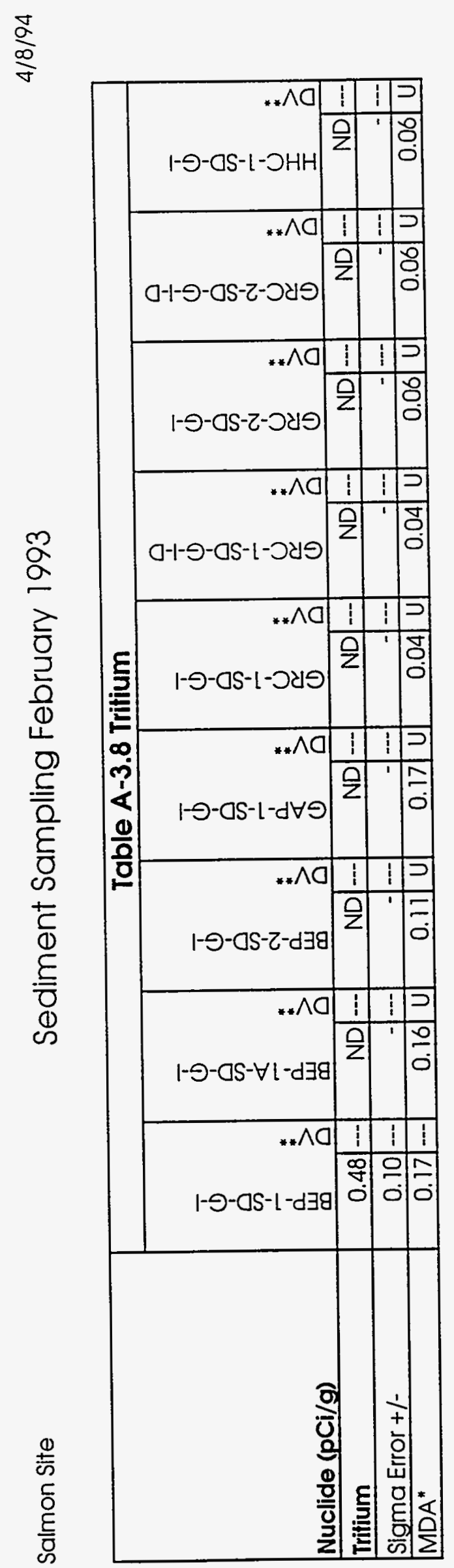

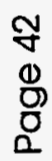

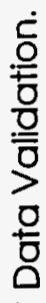

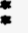

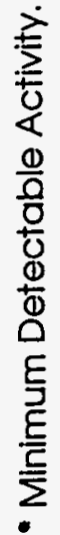




\begin{tabular}{|c|c|c|c|c|c|c|c|c|c|c|c|c|c|c|c|c|}
\hline \multirow[b]{2}{*}{ Nuclide (pCi/g) } & \multicolumn{16}{|c|}{ Table A-3.8 Tritium } \\
\hline & 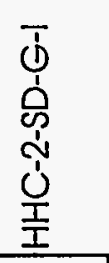 & 莒 & 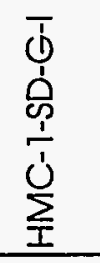 & 艾 & 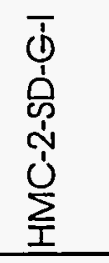 & 莒 & 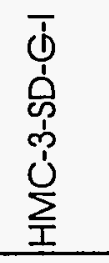 & 莡 & 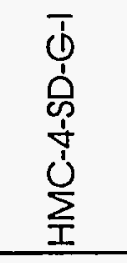 & 莡 & 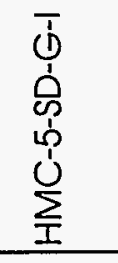 & 艾 & 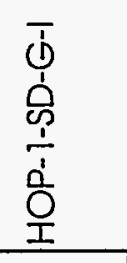 & $\begin{array}{l}* \\
\vdots \\
\end{array}$ & $\begin{array}{l}\bar{\phi} \\
\dot{1} \\
\stackrel{0}{0} \\
\stackrel{1}{1} \\
\underline{\underline{u}} \\
\underline{\underline{u}}\end{array}$ & 常 \\
\hline Tritium & $\mathrm{ND}$ & -.. & 0.03 & -.- & $\mathrm{ND}$ & -... & $\mathrm{ND}$ & D.- & $N D$ & D.- & 0.04 & 4.-- & ND & $\ldots$ & & $-\ldots$ \\
\hline Sigma Error +/- & & -.. & 0.03 & $\ldots$ & & -... & & $\ldots$ & & $\ldots$ & 0.04 & $4 \mid-\ldots$ & & $\ldots$ & & $\ldots$ \\
\hline $\mathrm{MDA}^{*}$ & $\overline{0.06}$ & & 0.06 & & 0.08 & 0 & 0.06 & 4 & 0.13 & 3 & 0.08 & 3 & 0.10 & $\mathrm{U}$ & 0.07 & 0 \\
\hline
\end{tabular}




\begin{tabular}{|c|c|c|c|c|c|c|c|c|c|c|c|c|c|c|c|c|c|c|}
\hline \multirow[b]{2}{*}{ Parameter (ug/g) } & \multicolumn{18}{|c|}{ Table A-3.9 Ammonia and Total Organic Carbon } \\
\hline & 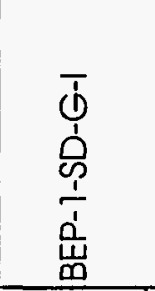 & 3 & 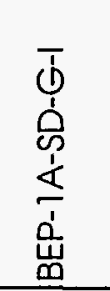 & $\dot{2}^{*}$ & 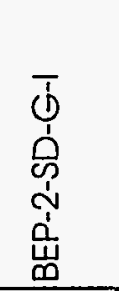 & 莒 & 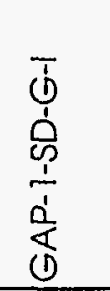 & $3^{*}$ & 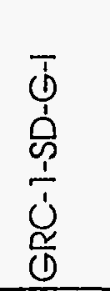 & 莒 & 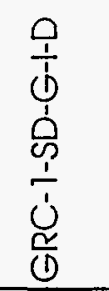 & ${ }_{0}^{*}$ & 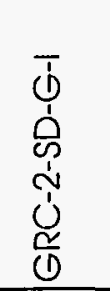 & 艾 & 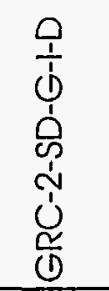 & $3^{*}$ & 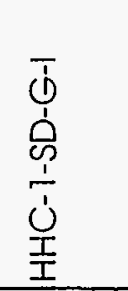 & 己े \\
\hline Ammonia & 195 & $\ldots$ & 10.2 & (-.. & 2.99 & $\ldots$ & 2.61 & -- & ND & -- & ND & $\ldots$ & 0.760 & $\ldots$ & 0.764 & a. & 2.49 & -- \\
\hline Detection Limit & 17.7 & - & 0.971 & -. & 0.789 & -- & 1.94 & $-\ldots$ & 0.404 & $\ldots$ & 0.404 & $-\infty$ & 0.389 & $\ldots$ & 0.389 & $-\cdots$ & 0.521 & \\
\hline Total Organic Carbon (TOC) & 190000 & J & 46700 & 1 & 27400 & $\sqrt{1}$ & 63800 & & 674 & J & 585 & $\mathrm{~J}$ & 365 & $\mathrm{~J}$ & 397 & $\mathrm{~J}$ & 18600 & \\
\hline Detection Limit & 295 & -.. & 80.9 & $-\ldots$ & 65.7 & $-\infty$ & 161 & - & 33.6 & - & 33.6 & $\ldots$ & 32.4 & -.. & 32.4 & $-\ldots$ & 43.6 & \\
\hline
\end{tabular}




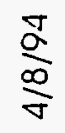

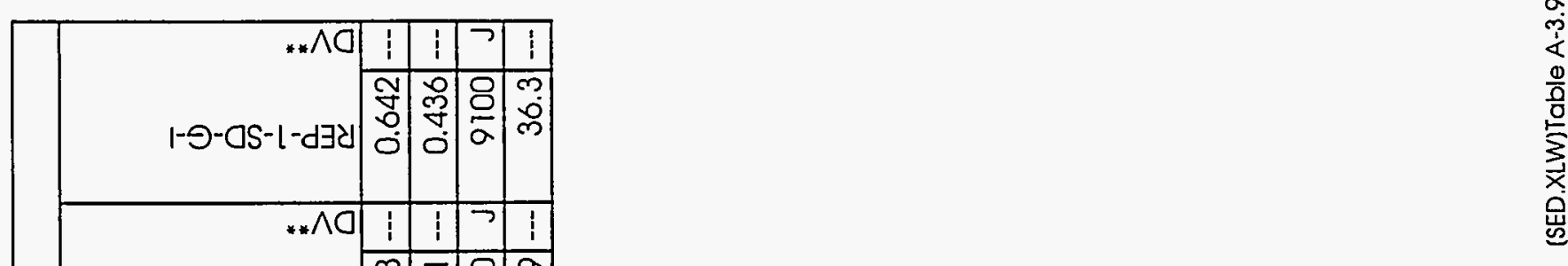

0
0
0
0
0 


\begin{tabular}{|c|c|c|c|c|c|c|c|c|c|c|c|c|c|c|c|c|c|c|c|c|c|}
\hline \multirow[b]{2}{*}{ Compound (ug/L) } & \multicolumn{21}{|c|}{ Table A-4.1 Metals } \\
\hline & 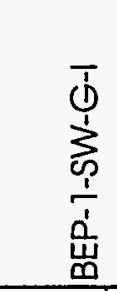 & $\stackrel{*}{\varnothing}$ & & 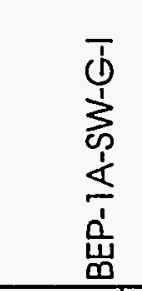 & & $\stackrel{*}{\mathbf{D}^{\prime}}$ & 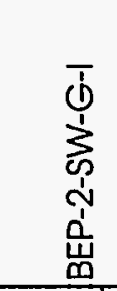 & & 艾 & $\begin{array}{l}\overline{1} \\
\frac{1}{1} \\
\frac{1}{1} \\
\frac{1}{1} \\
\frac{1}{1} \\
0 \\
0\end{array}$ & $\stackrel{*}{\theta}$ & & 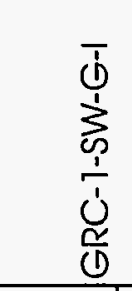 & & $\stackrel{*}{2}$ & 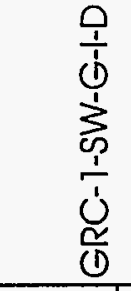 & & 艾 & 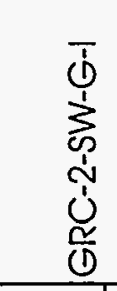 & $\stackrel{*}{\square}$ & 莡 \\
\hline Aluminum & 261.0 & & $-\ldots$ & 228.0 & & $\ldots$ & 416.0 & & $\ldots$ & 110.0 & $B$ & $\mathrm{~J}$ & 179.0 & $B$ & $\mathrm{~J}$ & 164.8 & $\mathrm{~B}$ & $\mathrm{NP}$ & 87.8 & $B$ & $\mathrm{~s}$ \\
\hline Antimony & 55.6 & $u$ & $\ldots$ & 55.6 & $u$ & -- & 55.6 & $\mathrm{u}$ & --- & 55.6 & $\mathrm{U}$ & $\ldots$ & 55.6 & $u$. & $\ldots$ & 55.6 & 4 & $\mathrm{NP}$ & 55.6 & $\mathrm{U}$ & -- \\
\hline Arsenic & 1.0 & uW & UJ & 1.0 & UW & UJ & 2.2 & $\mathrm{BW}$ & $\mathrm{J}$ & 1.0 & $u$ & $-\cdots$ & 1.0 & uW & UJ & 1.0 & 4 & $\mathrm{NP}$ & 1.0 & $u$ & -- \\
\hline Barium & 31.3 & B & J & 26.2 & $\mathrm{~B}$ & J) & 18.9 & $\mathrm{~B}$ & $\mathrm{~J}$ & 32.6 & $\mathrm{~B}$ & $\mathrm{~J}$ & 25.6 & $\mathrm{~B}$ & $\mathrm{~J}$ & 25.1 & B) & $\mathrm{NP}$ & 19.9 & $\mathrm{~B}$ & J \\
\hline Beryllium & 0.9 & U & -- & 0.9 & u & -- & 0.9 & $\mathrm{u}$ & $\ldots$ & 0.9 & 4 &.- & 0.9 & $u$. & -- & 0.9 & 4 & $\mathrm{NP}$ & 0.9 & $\mathrm{U}$ & -- \\
\hline Cadmium & 2.7 & U) & - & 2.7 & $u$ & -- & 2.7 & 4 & -- & 2.7 & 4 & -- & 2.7 & U. & $\ldots$ & 3.8 & $\mathrm{~B}$ & NP & 2.7 & 4 & $\cdots$ \\
\hline Calcium & 2450 & $B$ & $\mathrm{~J}$ & 2460 & $B$ & J) & 3660 & $B$ & $\mathrm{~J}$ & 3630 & $B$ & $J$ & 3070 & $\mathrm{~B}$ & $\mathrm{~J}$ & 2975 & $\mathrm{~B}$ & $\mathrm{NP}$ & 594 & $B$ & 5 \\
\hline Chromium & 3.5 & $U$ & -- & 3.5 & $u$ & - & 3.5 & $u$. & $\ldots$ & 3.5 & 4 & $\ldots$ & 3.5 & $u$. & -- & 3.5 & 4 & $\mathrm{NP}$ & 3.5 & 4 & $\cdots$ \\
\hline Cobalt & 6.0 & $U$ & -- & 6.0 & U & -- & 6.0 & 4. & $\ldots$ & 6.0 & 4 & -- & 10.1 & $B$ & $\mathrm{~J}$ & 6.0 & U. & $\mathrm{NP}$ & 6.0 & 4 & -- \\
\hline Copper & 3.7 & $U$ & -- & 3.7 & u) & -- & 3.7 & 4. & $\cdots$ & 3.7 & 4 & -- & 3.7 & 4. & - & 3.7 & $u$ & $\mathrm{NP}$ & 3.7 & $u$ & $\cdots$ \\
\hline Iron & 1440 & $E$ & $\mathrm{~J}$ & 1450 & E & $\mathrm{J}$ & 2690 & $E$ & $\mathrm{~J}$ & 252 & $E$ & $\mathrm{~J}$ & 654 & E & $\mathrm{J}$ & 591 & & NP & 417 & $E$ & 5 \\
\hline Lead & 1.0 & $u$ & - & 1.0 & uW & UJ & 1.2 & $\mathrm{~B}$ & $\mathrm{~J}$ & 1.0 & $u$ & -- & 1.2 & $\mathrm{~B}$ & $\mathrm{~J}$ & 1.1 & 8 & NP & 1.0 & 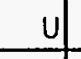 & $\ldots$ \\
\hline Magnesium & 584 & $B$ & $\mathrm{~J}$ & 560 & $B$ & -- & 568 & $B$ & J & 1040 & $\mathrm{~B}$ & $\mathrm{~J}$ & 812 & $\mathrm{~B}$ & $\mathrm{~J}$ & 785 & $\mathrm{~B}$ & $\mathrm{NP}$ & 474 & B & s \\
\hline Manganese & 155.0 & & - & 120.0 & & - & 150.0 & & -- & 84.2 & & $\ldots$ & 116.0 & & -- & 121.5 & & $\mathrm{NP}$ & 56.3 & & $\ldots$ \\
\hline Mercury & 0.1 & u & -- & 0.1 & 4 & -- & 0.1 & $\mathrm{U}$ & $\ldots$ & 0.2 & $\mathrm{~B}$ & $\mathrm{~J}$ & 0.1 & $u$ & -- & 0.1 & 4 & NP & 0.1 & $U$ & -- \\
\hline Nickel & 20.0 & 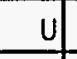 & $\ldots$ & 20.0 & 4 & $\ldots$ & 20.0 & 4. & $\ldots$ & 20.0 & 4 & -- & 20.0 & $u$ & $\ldots$ & 20.0 & 4 & $\mathrm{NP}$ & 20.0 & $\mathrm{U}$ & $\ldots$ \\
\hline Potassium & 2690 & $\mathrm{u}$ & $\ldots$ & 2690 & $\mathrm{u}$ & $\ldots$ & 2690 & 4 & $\ldots$ & 2690 & $u$ & $-\cdots$ & 2690 & $u$ & $\ldots$ & 2690 & U & NP & 2690 & U & - \\
\hline Selenium & 1.0 & $\mathrm{u}$ & $\ldots$ & 1.0 & U) & -- & 1.0 & $u$ & $\ldots$ & 1.0 & uW & UJ & 1.0 & $u$ & -- & 1.0 & U & $\mathrm{NP}$ & 1.0 & uW & U. \\
\hline Silver & 3.5 & 4 & $\ldots$ & 3.5 & 4 & -- & 3.5 & $u$ & $\ldots$ & 3.5 & $u$ & $\ldots$ & 3.5 & $U$ & -- & 3.5 & 4 & NP & 3.5 & $u$ & - \\
\hline Sodium & 2910 & $B$ & $\mathrm{~J}$ & 2700 & B & $\mathrm{J}$ & 2440 & B & $\mathrm{J}$ & 18200 & & -- & 2160 & $\mathrm{~B}$ & $\mathrm{~J}$ & 2094 & $B$ & $\mathrm{NP}$ & 1740 & $\mathrm{~B}$ & . \\
\hline Thallium & 1.0 & U) & $\ldots$ & 1.0 & $\mathrm{u}$ & $-\ldots$ & 1.0 & $u$ & $\ldots$ & 1.0 & $u$ & -- & 1.0 & $u$ & - & 1.0 & U & NP & 1.0 & $u$ & - \\
\hline Vanadium & 3.6 & 4 & -- & 3.6 & 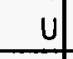 & - & 3.6 & U & - & 3.6 & 4 & $\ldots$ & 3.6 & 4 & -- & 3.6 & U & NP & 3.6 & u & $=$ \\
\hline Zinc & 4.8 & B & U & 7.0 & $B$ & U & 6.8 & $\mathrm{~B}$ & $\mathrm{u}$ & 3.8 & $\mathrm{~B}$ & u & 13.1 & $\mathrm{~B}$ & U & 13.8 & $B$ & NP & 3.6 & $\mathrm{~B}$ & 4 \\
\hline
\end{tabular}




\begin{tabular}{|c|c|c|c|c|c|c|c|c|c|c|c|c|c|c|c|c|c|c|c|c|c|}
\hline \multirow[b]{2}{*}{ Compound (ug/L) } & \multicolumn{21}{|c|}{ Table A-4.1 Metals } \\
\hline & 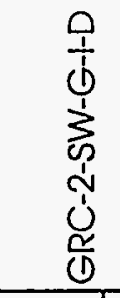 & \% & $\stackrel{*}{2}$ & 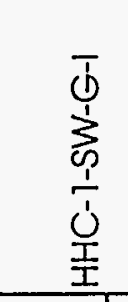 & $\ddot{\theta}$ & 艾 & 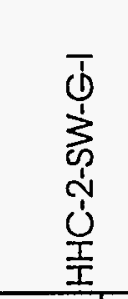 & $\stackrel{*}{\varnothing}$ & & 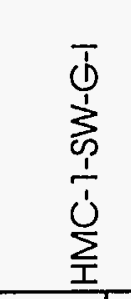 & & $\stackrel{*}{2}$ & 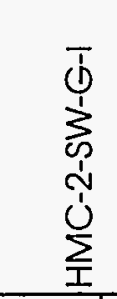 & & ${ }^{*}$ & 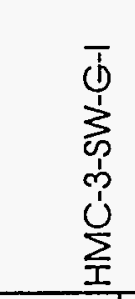 & & $\stackrel{2}{*}$ & 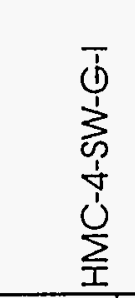 & $\stackrel{*}{Q}$ & $\stackrel{2}{*}^{*}$ \\
\hline Aluminum & 117.0 & $\mathrm{~B}$ & $\mathrm{NP}$ & 201.0 & & -- & 165.0 & $\mathrm{~B}$ & $\mathrm{~J}$ & 190.0 & $B$ & $\mathrm{~J}$ & 151.0 & $B$ & $\mathrm{~J}$ & 113.0 & 8 & $\mathrm{~J}$ & 141.0 & $B$ & $\mathrm{~J}$ \\
\hline Antimony & 55.6 & & $\mathrm{NP}$ & 55.6 & 4. & -- & 55.6 & $u$. & -- & 55.6 & 4 & $\ldots$ & 55.6 & U. & $\ldots$ & 55.6 & U) & $\ldots$ & 55.6 & 4. & $\cdots$ \\
\hline Arsenic & 1.0 & 4 & $\mathrm{NP}$ & 1.0 & 4. & - & 1.0 & 4. & $\cdots$ & 1.0 & 4 & -- & 1.0 & 4. & $\ldots$ & 1.0 & $u$ & $\ldots$ & 1.0 & uW & UJ \\
\hline Barium & 18.8 & $B$ & $\mathrm{NP}$ & 90.4 & $B$ & $\mathrm{~J}$ & 29.0 & 8 & $\mathrm{~J}$ & 29.8 & $\mathrm{~B}$ & $\mathrm{~J}$ & 27.9 & $\mathrm{~B}$ & $\mathrm{~J}$ & 25.4 & $\mathrm{~B}$ & $J$ & 22.3 & $\mathrm{~B}$ & $\mathrm{~J}$ \\
\hline Beryllium & 0.9 & $u$ & $\mathrm{NP}$ & 0.9 & 4. & - & 0.9 & 4. & -- & 0.9 & 4 & -- & 0.9 & u. & $\ldots$ & 0.9 & 4 & -- & 0.9 & 4. & $\cdots$ \\
\hline Cadmium & 3.2 & 8 & $\mathrm{NP}$ & 2.7 & 4. & -- & 2.7 & U. & $\ldots$ & 2.7 & 4 & $\ldots$ & 2.7 & u. & - & 2.7 & 4 & - & 2.7 & 4. & $\ldots$ \\
\hline Calcium & 569 & $\mathrm{~B}$ & $\mathrm{NP}$ & 827 & B & $\mathrm{J}$ & 615 & $\mathrm{~B}$ & J & 573 & B & $\mathrm{J}$ & 747 & B & $\mathrm{J}$ & 694 & $B$ & $\mathrm{~J}$ & 634 & $\mathrm{~B}$ & $\mathrm{~J}$ \\
\hline Chromium & 3.5 & 4 & $\mathrm{NP}$ & 3.5 & $u$ & - & 3.5 & 4. & -- & 3.5 & 4 & $\ldots$ & 3.5 & uf & -- & 3.5 & u & -- & 3.5 & 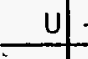 & -- \\
\hline Cobalt & 6.0 & 4 & NP & 6.0 & 4 & $\ldots$ & 6.0 & 4 & $\ldots$ & 6.0 & 4 & $\ldots$ & 6.0 & 4 & - & 6.0 & U & $\ldots$ & 6.0 & II) & $\ldots$ \\
\hline Copper & 3.7 & 4 & $N P$ & 3.7 & $u$ & - & 3.7 & 4. & - & 3.7 & 4 & $\ldots$ & 3.7 & 4 & - & 3.7 & 4 & -- & 3.7 & 4. & -- \\
\hline Iron & 424 & & $\mathrm{NP}$ & 206 & $\mathrm{E}$ & $J$ & 118 & E & J & 111 & E & $\mathrm{J}$ & 208 & E & $\mathrm{J}$ & 204 & E & $\mathrm{J}$ & 329 & $E$ & $\mathrm{~J}$ \\
\hline Lead & 1.0 & $u$ & $\mathrm{NP}$ & 1.0 & uW & UJ & 1.1 & $\mathrm{~B}$ & $\mathrm{~J}$ & 1.0 & 4 & $\ldots$ & 1.0 & 0 & $\ldots$ & 1.0 & 4 & - & 1.0 & 4. & -- \\
\hline Magnesium & 464 & $\mathrm{~B}$ & $\mathrm{NP}$ & 531 & $B$ & $\mathrm{~J}$ & 405 & B & $\mathrm{J}$ & 363 & B & $\mathrm{J}$ & 677 & B & $\mathrm{J}$ & 639 & B & 3 & 534 & B & J \\
\hline Manganese & 55.8 & & $N P$ & 79.2 & & $\ldots$ & 26.9 & & - & 34.4 & & -- & 22.6 & & $\ldots$ & 21.5 & & -- & 35.3 & & - \\
\hline Mercury & 0.1 & $\mathrm{u}$ & $\mathrm{NP}$ & 0.1 & 4 & $\ldots$ & 0.1 & 4 & $-\ldots$ & 0.1 & U & -- & 0.1 & 4 & - & 0.1 & 4 & $\ldots$ & 0.1 & 0. & $\ldots$ \\
\hline Nickel & 20.0 & $\mathrm{U}$ & $\mathrm{NP}$ & 20.0 & 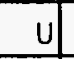 & -- & 20.0 & $U$ & $\ldots$ & 20.0 & 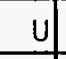 & -- & 20.0 & 4 & $\ldots$ & 20.0 & 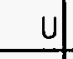 & -- & 20.0 & 4. & $\ldots$ \\
\hline Potassium & 2690 & 4 & $\mathrm{NP}$ & 2690 & 4 & - & 2690 & $U$ & $\ldots$ & 2690 & 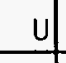 & -- & 2690 & ㄴ) & $\ldots$ & 2690 & 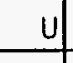 & -- & 2690 & 4. & -- \\
\hline Selenium & 1.0 & 4 & $\mathrm{NP}$ & 1.0 & UW & us & 1.0 & uW & UJ & 1.0 & uW & UJ & 1.0 & uw & $\underline{U}$ & 1.0 & uW & UJ & 1.0 & UW & UJ \\
\hline Silver & 3.5 & $u$ & $\mathrm{NP}$ & 3.5 & 4 & -- & 3.5 & 4 & $\ldots$ & 3.5 & 4 & $\ldots$ & 5.3 & B & $\mathrm{J}$ & 3.5 & U & -- & 3.5 & 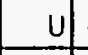 & -- \\
\hline Sodium & 1866 & $B$ & $\mathrm{NP}$ & 1680 & B & $\mathrm{J}$ & 1640 & $B$ & $\mathrm{~J}$ & 1610 & 8 & J & 2110 & B & $\mathrm{J}$ & 2050 & $\mathrm{~B}$ & $J$ & 1950 & B) & $\mathrm{J}$ \\
\hline Thallium & 1.0 & $u$ & $\mathrm{NP}$ & 1.0 & 4 & $\cdots$ & 1.0 & 4 & - & 1.0 & 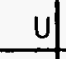 & - & 1.0 & 4 & - & 1.0 & 4 & - & 1.0 & $u$ & -- \\
\hline Vanadium & 3.8 & 4 & $\mathrm{NP}$ & 3.6 & 4 & - & 3.6 & 4 & -- & 3.6 & 4 & - & 3.6 & U. & - & 3.6 & 4 & - & 3.6 & 4 & - \\
\hline Zinc & 3.3 & $B$ & $\mathrm{NP}$ & 5.8 & B & $\mathrm{u}$ & 5.1 & B & JI & 4.3 & B & $\mathrm{U}$ & 5.2 & $\mathrm{~B}$ & $\mathrm{~J}$ & 4.3 & B & U & 3.0 & B & $\mathrm{U}$ \\
\hline
\end{tabular}




\begin{tabular}{|c|c|c|c|c|c|c|c|c|c|}
\hline \multirow[b]{2}{*}{ Compound (ug/L) } & \multicolumn{9}{|c|}{ Table A-4.1 Metals } \\
\hline & \multicolumn{3}{|c|}{ ¿ } & \multicolumn{3}{|c|}{ 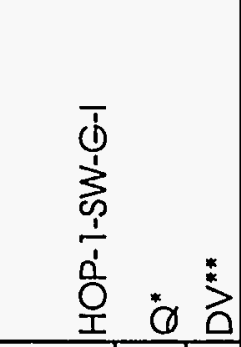 } & \multicolumn{3}{|l|}{ 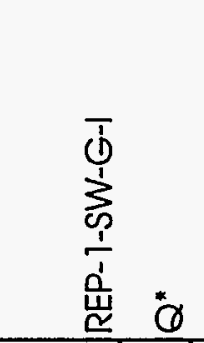 } \\
\hline Aluminum & 235.0 & & -- & 384.0 & & - & 180.0 & $B$ & 3 \\
\hline Antimony & 55.6 & $\mathrm{U}$ & $\ldots$ & 55.6 & $\mathrm{u}$ & -- & 55.6 & $\mathrm{u}$ & $\ldots$ \\
\hline Arsenic & 1.0 & u & $-\ldots$ & 1.0 & UW & $\mathrm{UJ}$ & 1.0 & $u$ & $\ldots$ \\
\hline Barium & 27.0 & $B$ & $\mathrm{~J}$ & 78.7 & $\mathrm{~B}$ & $\mathrm{~J}$ & 19.9 & $B$ & . \\
\hline Beryllium & 0.9 & U. & -- & 0.9 & $u$ & -- & 0.9 & $\mathrm{U}$ & - \\
\hline Cadmium & 2.7 & $u$ & - & 3.0 & $\mathrm{~B}$ & $\mathrm{~J}$ & 2.7 & $u$ & $\ldots$ \\
\hline Calcium & 798 & $\mathrm{~B}$ & $\mathrm{~J}$ & 24600 & & -- & 1620 & $B$ & . \\
\hline Chromium & 3.5 & 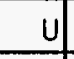 & - & 3.5 & $\mathrm{u}$ & - & 3.5 & $u$ & J... \\
\hline Cobalt & 6.0 & $\mathrm{U}$ & -- & 9.1 & 8 & $\mathrm{~J}$ & 6.0 & $\mathrm{U}$ & J... \\
\hline Copper & 3.7 & 4 & $-\cdots$ & 3.7 & $\mathrm{U}$ & $\ldots$ & 3.7 & $\mathrm{U}$ & - \\
\hline Iron & 421 & E & $\mathrm{J}$ & 4190 & $E$ & $\mathrm{~J}$ & 677 & $E$ & 1. \\
\hline Lead & 1.0 & uW & uJ & 1.0 & 4 & -- & 1.0 & $U$ & J \\
\hline Magnesium & 581 & $B$ & $\mathrm{~J}$ & 2220 & $B$ & $\mathrm{~J}$ & 566 & $B$ & 3. \\
\hline Manganese & 52.5 & & $-\ldots$ & 576.0 & & $\ldots$ & 213.0 & & - \\
\hline Mercury & 0.1 & 4 & - & 0.1 & 4 & $\cdots$ & 0.2 & $\mathrm{~B}$ & 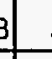 \\
\hline Nickel & 20.0 & U & $\ldots$ & 20.0 & $u$ & -- & 20.0 & $U$ & J... \\
\hline Potassium & 2690 & $\mathrm{U}$ & -- & 2690 & $u$ & $\ldots$ & 2690 & $\mathrm{u}$ & J. \\
\hline Selenium & 1.0 & uW & UJ & 1.0 & UW & $\mathrm{UJ}$ & 1.0 & $\mathrm{U}$ & 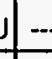 \\
\hline Silver & 3.5 & B & J) & 3.5 & U & $\ldots$ & 14.6 & & $\ldots$ \\
\hline Sodium & 2120 & $\mathrm{~B}$ & $\mathrm{~J}$ & 56400 & & - & 1220 & $B$ & 3 \\
\hline Thallium & 1.0 & U & $\ldots$ & 1.0 & uW & $\mathrm{UJ}$ & 1.0 & $\mathrm{U}$ & . \\
\hline Vanadium & 3.6 & U & - & 3.6 & 4 & $\ldots$ & 3.6 & $U$ & J... \\
\hline Zinc & 4.5 & $\mathrm{~B}$ & $u$ & 7.5 & $B$ & $u$ & 5.9 & $B$ & 31 \\
\hline
\end{tabular}

"Data Qualifier. " "Data Validation. 


\begin{tabular}{|c|c|c|c|c|c|c|c|c|c|c|c|c|c|c|c|c|c|c|c|c|c|}
\hline-- & $n$ & $80^{\prime} 0$ & -- & $n$ & $80^{\circ} 0$ & - & $n$ & $80^{\circ} 0$ & - & $n$ & $60^{\prime} 0$ & - & $n$ & $8 \nabla^{\prime} 0$ & -1 & $n$ & $80^{\prime} 0$ & - & $n$ & $80^{\circ} 0$ & 乙६ट!-10100ग \\
\hline-- & $n$ & $80^{\circ} 0$ & - & $n$ & $86^{\circ} 0$ & $-\infty$ & $n$ & $80^{\circ} 0$ & -- & $n$ & $60^{\circ} 0$ & - & $n$ & $80^{\prime} 0$ & - & $n$ & $80^{\circ} 0$ & - & $n$ & $80^{\prime} 0$ & ІZZL-」O|ত০। \\
\hline$\cdots$ & $n$ & $80^{\circ} 0$ & -- & $n$ & $80^{\circ} 0$ & -- & n & $80^{\circ} 0$ & $\cdots$ & $n$ & $60^{\circ} 0$ & -- & $n$ & $86^{\prime} 0$ & $-\infty$ & $\bar{n}$ & $8 b^{\prime} 0$ & - & $n$ & $80^{\circ} 0$ & 910L-J01001 \\
\hline$\cdots$ & $n$ & $\angle 6^{\circ} 0$ & - & $n$ & 960 & \begin{tabular}{|l|}
$-\cdots$ \\
\end{tabular} & $n$ & $960^{\circ}$ & $-\cdots$ & $n$ & $86^{\circ} 0$ & $-\infty$ & $n$ & 960 & $\cdots$ & $n$ & 96.0 & - & $n$ & $96^{\circ} 0$ & әuәपdDX01 \\
\hline-- & $n$ & $80^{\circ} 0$ & --- & $n$ & $80^{\prime} 0$ & \begin{tabular}{|l|}
-- \\
\end{tabular} & $n$ & $80^{\circ} 0$ & $\cdots$ & $n$ & $60^{\circ} 0$ & -- & $n$ & $80^{\circ} 0$ & $-\infty$ & $n$ & $80^{\circ} 0$ & - & $n$ & $8 \nabla^{\prime} 0$ & әuDpIo|4ว-Duسng \\
\hline-- & $n$ & $80^{\circ} 0$ & -- & $n$ & $80^{\circ} 0$ & \begin{tabular}{|l|}
-- \\
\end{tabular} & $n$ & $80^{\prime} 0$ & $\cdots$ & $n$ & $66^{\circ} 0$ & -- & $n$ & $80^{\prime} 0$ & - & $n$ & $80^{\circ} 0$ & - & $n$ & $80^{\circ} 0$ & 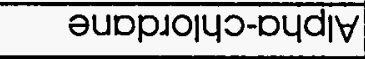 \\
\hline$\cdots$ & $n$ & $01^{\circ} 0$ & -- & $n$ & $0 L^{\prime} 0$ & $-\cdots$ & $n$ & $01^{\prime} 0$ & $-\cdots$ & $n$ & $01^{\circ} 0$ & - & n & $01^{\prime} 0$ & -- & $n$ & $0 L^{\circ} 0$ & -- & $n$ & $010^{\prime} 0$ & 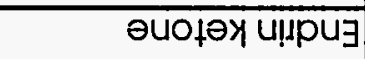 \\
\hline$-\cdots$ & n & $80^{\circ} 0$ & --- & $n$ & $80^{\prime} 0$ & $\cdots$ & $n$ & $80^{\circ} 0$ & -- & $n$ & $60^{\circ} 0$ & $\cdots$ & ก & $80^{\circ} 0$ & -- & $n$ & $80^{\circ} 0$ & - & n & $80^{\circ} 0$ & 10140KxOप12W \\
\hline$\cdots$ & $n$ & 010 & -- & $n$ & 010 & --- & $n$ & 01.0 & $-\cdots$ & $n$ & $0 L^{\prime} 0$ & $\cdots$ & n & $01^{\circ} 0$ & -- & $n$ & 01.0 & -- & $n$ & $01^{\circ} 0$ & $100-\phi^{\prime} t$ \\
\hline--- & n & $01^{\circ} 0$ & -- & $n$ & $01^{\prime} 0$ & $--\cdot$ & $n$ & 01.0 & --- & $n$ & $011^{\circ}$ & $-\cdots$ & $n$ & $01^{\circ} 0$ & $-\cdots$ & $n$ & $01 \%$ & $\cdots$ & $n$ & 010 & EfDflns uDf|nsopu \\
\hline$\cdots$ & $n$ & $01^{\prime} 0$ & -- & $n$ & $01^{\prime} 0$ & $\cdots$ & $n$ & $0 l^{\circ} 0$ & $\cdots$ & $n$ & $0 L^{\prime} 0$ & $-\cdots$ & n & 010 & $-\cdots$ & $n$ & $0 \mathrm{l}^{\prime} 0$ & -- & $\pi$ & 01.0 & $000-\nabla^{\prime} t$ \\
\hline$\cdots$ & n & 01.0 & --- & $n$ & 010 & -- & $n$ & $01{ }^{\prime} 0$ & $-\cdots$ & $n$ & $0 L^{\prime} 0$ & -- & n & $01^{\circ} 0$ & -- & $n$ & 010 & -- & $n$ & $01^{\prime} 0$ & II UDf|nsopu \\
\hline$-\cdots$ & $\pi$ & 010 & -- & $n$ & 010 & $-\cdots$ & $n$ & $01^{\circ} 0$ & $\cdots$ & $n$ & $01^{\circ} 0$ & $\cdots$ & $n$ & $01{ }^{\prime} 0$ & -- & $n$ & 010 & $\cdots$ & $n$ & $01 \%$ & u!ıpuヨ \\
\hline-- & $n$ & 010 & - & $n$ & $01{ }^{\prime} 0$ & -- & n & $01^{\circ} 0$ & $\cdots$ & $n$ & 010 & -- & n & $01 \%$ & $\cdots$ & $n$ & $01 \%$ & -- & $n$ & 01.0 & $\exists 00-\nabla^{\prime} t$ \\
\hline-- & $n$ & $01^{\prime} 0$ & $-\cdots$ & $n$ & $01^{\prime} 0$ & $\cdots$ & $n$ & $0 !^{\circ} 0$ & $\cdots$ & $n$ & $0 ! \cdot 0$ & $-\cdots$ & n & 010 & $-\infty$ & $n$ & $0 ! 0$ & -- & $\pi$ & $0 !$ & u!̣p!ə!ם \\
\hline-- & $n$ & $90^{\circ} 0$ & $\because-$ & $n$ & $90^{\circ} 0$ & -- & $n$ & $90^{\prime} 0$ & $-\cdots$ & $n$ & 900 & -- & $n$ & 900 & -- & $n$ & 900 & - & $n$ & $90^{\circ} 0$ & I UD,finsopu \\
\hline--- & $n$ & $90^{\circ}$ & -- & $n$ & $90^{\circ} 0$ & 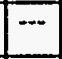 & n & $90^{\circ} 0$ & -- & $n$ & $90^{\circ} 0$ & $\cdots$ & $n$ & $90^{\circ} 0$ & -- & $n$ & 900 & -- & $n$ & $90^{\circ} 0$ & әp!̣xode 10|บODłdəH \\
\hline-- & n & $90^{\circ} 0$ & -- & $n$ & $90^{\circ} 0$ & -- & $n$ & 900 & $\cdots$ & n & $90^{\prime} 0$ & -- & $n$ & $90^{\circ} 0$ & - & $n$ & $90^{\circ} 0$ & -- & $n$ & $90^{\circ} 0$ & U!ाp| \\
\hline-- & $n$ & $90^{\circ} 0$ & -- & $n$ & $90^{\circ} 0$ & $\cdots$ & $n$ & $90^{\circ} 0$ & $\cdots$ & $n$ & 900 & -- & $n$ & $90^{\prime} 0$ & $\cdots$ & $n$ & $90^{\circ} 0$ & -- & $n$ & $90^{\prime} 0$ & गOापOD।dəH \\
\hline-- & $\pi$ & $90^{\prime} 0$ & -- & $n$ & $90^{\circ} 0$ & -- & $n$ & $90^{\circ}$ & $-\cdots$ & $n$ & $90^{\circ} 0$ & -- & $n$ & $90 \%$ & -- & $n$ & $90^{\circ} 0$ & - & $n$ & $90 ' 0$ & วHg-DUwDS \\
\hline-- & $n$ & $90^{\prime} 0$ & -- & $n$ & $90^{\circ} 0$ & -- & $n$ & $90^{\prime} 0$ & $-\cdots$ & $n$ & $90^{\circ} 0$ & - & $n$ & 900 & -- & $n$ & $90^{\prime} 0$ & - & $n$ & $90^{\circ} 0$ & $\mathrm{OHg}-\mathrm{DH}$ \\
\hline-- & n & $90^{\prime} 0$ & -- & $n$ & $90^{\circ} 0$ & $\cdots$ & $n$ & 900 & $\cdots$ & $n$ & $50^{\circ} 0$ & $-\cdots$ & $n$ & $90^{\circ} 0$ & -- & $n$ & $90^{\circ} 0$ & -- & $n$ & $90^{\circ} 0$ & כHब-Dłəg \\
\hline$\cdots$ & $n$ & $90 ' 0$ & -- & $n$ & $90^{\circ} 0$ & -- & $n$ & $90^{\circ} 0$ & $-\cdots$ & $n$ & $90^{\circ} 0$ & -- & $n$ & $90^{\circ} 0$ & - & $n$ & 900 & -- & $n$ & $90^{\circ} 0$ & OHg-Dud/ \\
\hline$\underset{*}{\nabla}$ & $D_{*}$ & 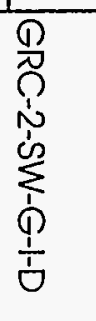 & $\underset{*}{\nabla}$ & & 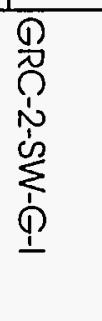 & $\bar{\gamma}_{*}^{\bar{\sigma}}$ & $\mathbb{D}_{*}$ & 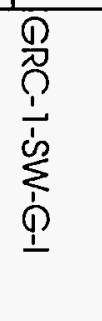 & $\overbrace{*}^{\frac{\sigma}{<}}$ & $D_{*}$ & 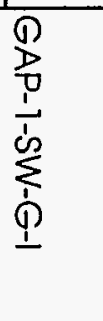 & $\sum_{*}^{g}$ & $\mathbb{D}_{*}$ & 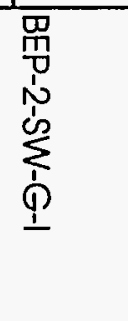 & $\underset{*}{\nabla}$ & $\mathscr{O}_{*}$ & 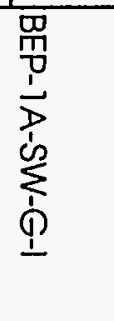 & $\underset{*}{\underset{*}{\sigma}}$ & $\mathbb{Q}_{*}$ & 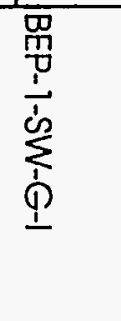 & (7/6n) punoduros \\
\hline \multicolumn{21}{|c|}{ 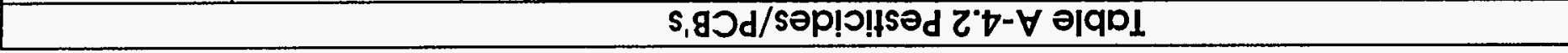 } & \\
\hline
\end{tabular}




\begin{tabular}{|c|c|c|c|c|c|c|c|c|c|c|c|c|c|c|}
\hline \multirow[b]{2}{*}{ Compound (ug/L) } & \multicolumn{14}{|c|}{ Table A-4.2 Pesticides/PCB's } \\
\hline & 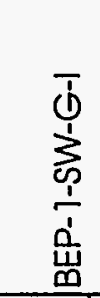 & $\stackrel{*}{\circ}$ & 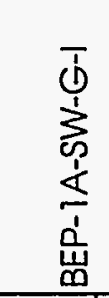 & $\stackrel{*}{*}$ & 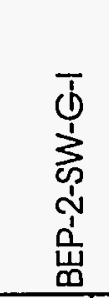 & $\stackrel{*}{*} \stackrel{*}{\circ}$ & 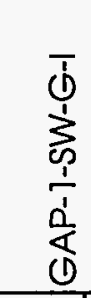 & $\stackrel{\circ}{\circ}$ & 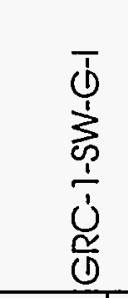 & 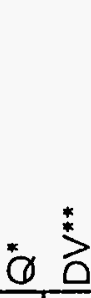 & 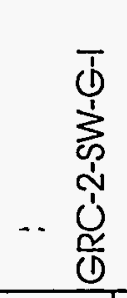 & 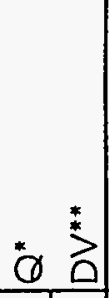 & 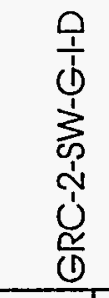 & ${ }^{*}{ }^{*}{ }^{*}$ \\
\hline Aroclor-1242 & 0.48 & u. & 0.48 & 0. & 0.48 & U. & 0.49 & $0 \mid-\ldots$ & 0.48 & $4-$ & 0.48 & 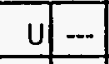 & 0.48 & 0. \\
\hline Aroclor-1248 & 0.48 & u|... & 0.48 & U. - & 0.48 & $u \mid \ldots$ & 0.49 & v|... & 0.48 & \begin{tabular}{c|c} 
& -
\end{tabular} & 0.48 & \begin{tabular}{l|l|}
0 & - \\
\end{tabular} & 0.48 & 0 \\
\hline Aroclor-1254 & 0.95 & U. & 0.95 & $u-$ & 0.95 & $\bar{u} \mid \ldots$ & 0.98 & U) ... & 0.95 & 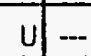 & 0.95 & v & 0.97 & U. \\
\hline Aroclor-1260 & 0.95 & 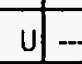 & 0.95 & v. - & 0.95 & 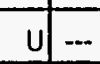 & 0.98 & U] $\ldots$ & 0.95 & U. & 0.95 & U. & 0.97 & \begin{tabular}{ll|}
0 & - \\
\end{tabular} \\
\hline
\end{tabular}


$\frac{\check{D}}{\stackrel{\partial}{\partial}}$

1-O-MS-s-JWH Lั

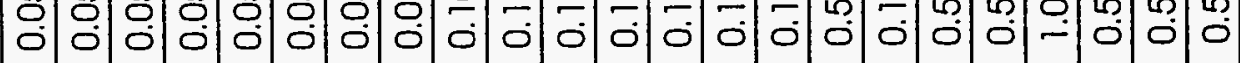

*... 0

$* \theta$

1-S-MS- $-5 W H$ 뉴

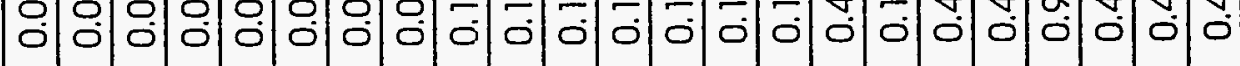

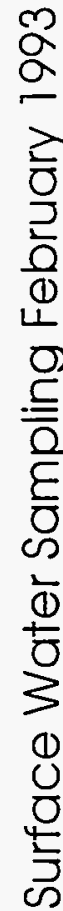

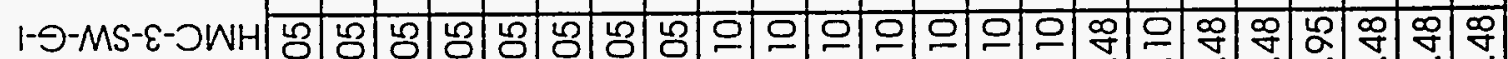

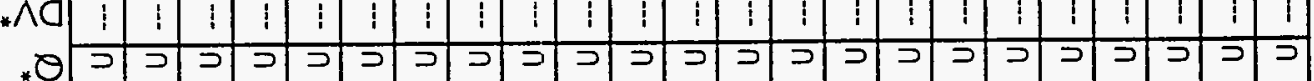
O-

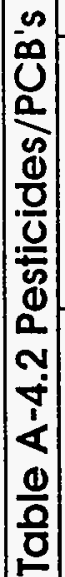

$* \wedge 0$

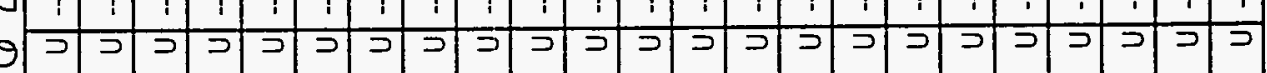

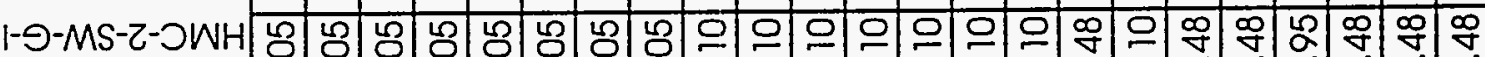

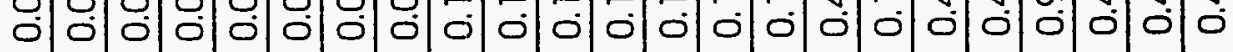

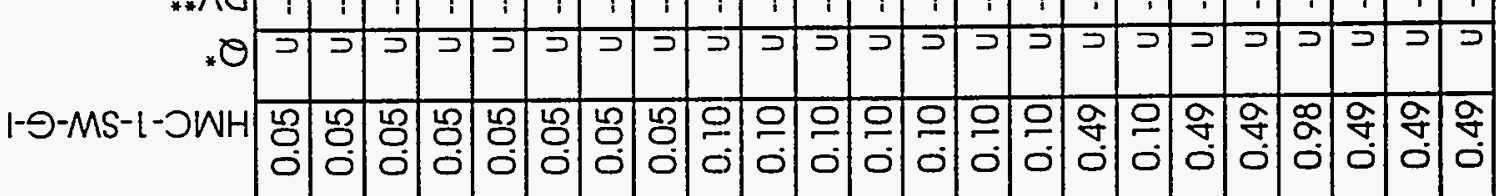

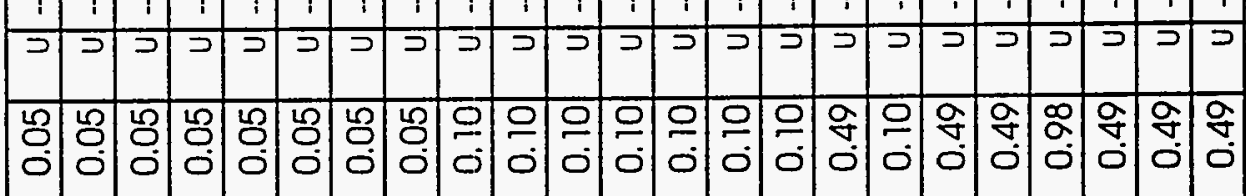

$* \wedge \mathrm{O}$

$* \theta$

a

$* \theta$

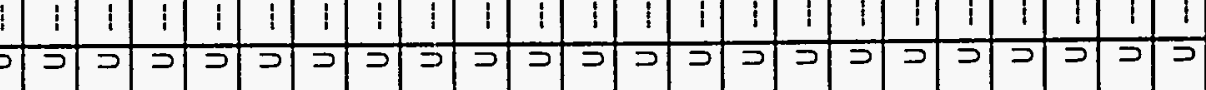

1-MS-乙-כHH \& ○ 00 O

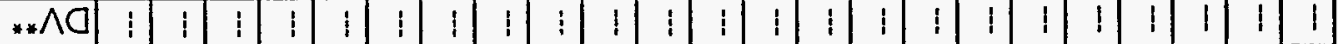

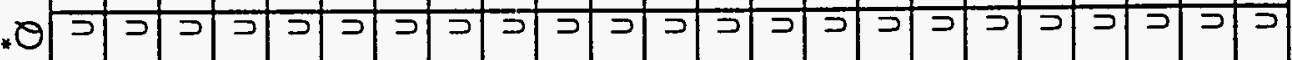

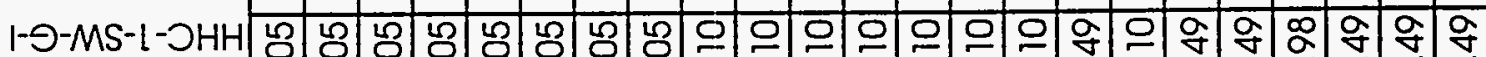

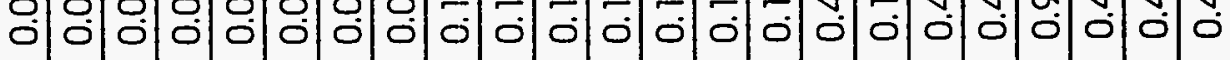

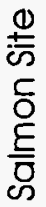

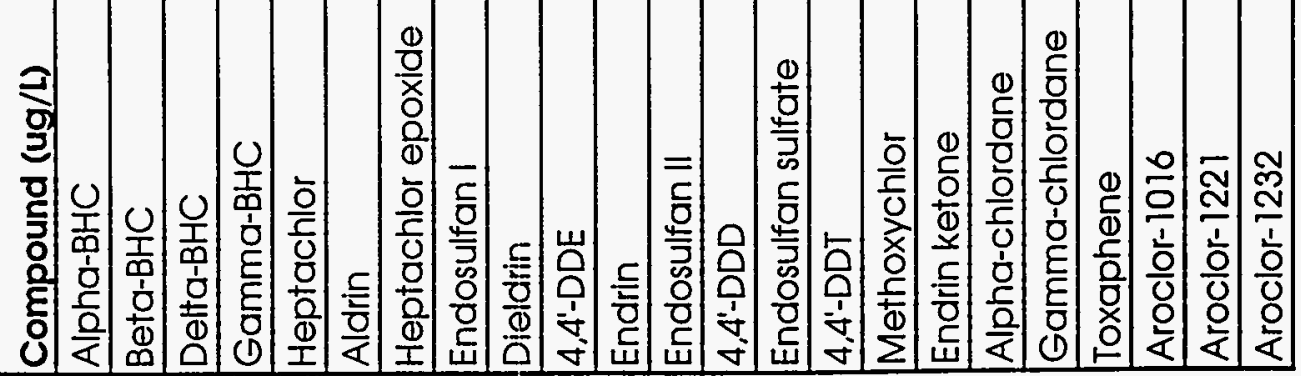




\begin{tabular}{|c|c|c|c|c|c|c|c|c|c|c|c|c|c|c|c|c|c|c|c|c|c|}
\hline \multirow[b]{2}{*}{ Compound (ug/L) } & \multicolumn{21}{|c|}{ Table A-4.2 Pesticides/PCB's } \\
\hline & 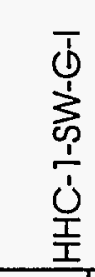 & & & 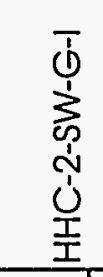 & & ${ }_{2}^{*}$ & 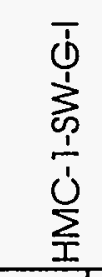 & & 艺 & 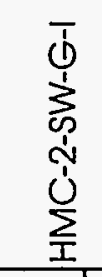 & & $\stackrel{*}{2}$ & $\begin{array}{l}\overrightarrow{0} \\
\sum_{\infty}^{1} \\
0 \\
0 \\
0 \\
\vdots\end{array}$ & & $\stackrel{*}{2}$ & $\sum_{\substack{1 \\
j}}^{\substack{1 \\
j}}$ & & $\stackrel{*}{2}$ & 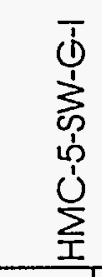 & $\stackrel{*}{0}$ & $\stackrel{*}{2}$ \\
\hline Aroclor- 1242 & 0.49 & $u$ & $\ldots$ & 0.48 & 4 & - & 0.49 & 4 & $\ldots$ & 0.48 & $u$ & $\ldots$ & 0.48 & u. & -- & 0.48 & $u$ & $\ldots$ & 0.52 & $\mathrm{u}$ & -- \\
\hline Aroclor-1248 & 0.49 & $\mathrm{u}$ & -- & 0.48 & $\mathrm{U}$ & -- & 0.49 & $u$ & $\ldots$ & 0.48 & 4 & -- & 0.48 & U. & $-\ldots$ & 0.48 & $u$ & -- & 0.52 & 4 & --- \\
\hline Aroclor-1254 & 0.98 & $u$ & - & 0.95 & U & -- & 0.98 & $u$ & $\ldots$ & 0.95 & 4 & $-\ldots$ & 0.95 & $u$ & -- & 0.95 & $u$ & -- & 1.00 & 4 & -- \\
\hline Aroclor- 1260 & 0.98 & & $-\ldots$ & 0.95 & 4 & -- & 0.98 & $u$ & $\ldots$ & 0.95 & & $\ldots$ & 0.95 & u. & $-\ldots$ & 0.95 & $\mathrm{u}$ & $-\ldots$ & 1.00 & & $\ldots$ \\
\hline
\end{tabular}




\begin{tabular}{|c|c|c|c|c|c|c|}
\hline \multirow[b]{2}{*}{ Compound (ug/L) } & \multicolumn{6}{|c|}{ Table A-4.2 Pesticides/PCB's } \\
\hline & 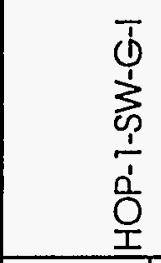 & $\stackrel{*}{0}$ & ${ }^{*}$ & 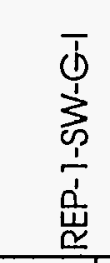 & ๑ & $\stackrel{3}{0}^{*}$ \\
\hline Alpha-BHC & 0.05 & $u$ & -- & 0.05 & $\mathrm{u}$ & $\ldots$ \\
\hline Beta-BHC & 0.05 & 4 & $\cdots$ & 0.05 & 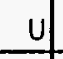 & $\ldots$ \\
\hline Delta-BHC & 0.05 & $u$ & - & 0.05 & $u$ & $\ldots$ \\
\hline Gamma-BHC & 0.05 & $u$ & - & 0.05 & $u$ & $\ldots$ \\
\hline Heptachlor & 0.05 & $u$ & - & 0.05 & 4 & $\ldots$ \\
\hline Aldrin & 0.05 & 4 & - & 0.05 & 4 & - \\
\hline Heptachlor epoxide & 0.05 & $u$ & -- & 0.05 & $u$ & - \\
\hline Endosulfan I & 0.05 & $u$ & - & 0.05 & 4 & - \\
\hline Dieldrin & 0.10 & 4 & $\ldots$ & 0.10 & 4 & $\ldots$ \\
\hline 4.4'-DDE & 0.10 & 4 & $\ldots$ & 0.10 & 4 & $-\ldots$ \\
\hline Endrin & 0.10 & 4 & -- & 0.10 & 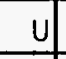 & $\ldots$ \\
\hline Endosulfan II & 0.10 & 4 & -- & 0.10 & $u$ & -- \\
\hline 4,4'-DDD & 0.10 & 4 & -- & 0.10 & 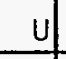 & $\ldots$ \\
\hline Endosulfan sulfate & 0.10 & $u$ & -- & 0.10 & 4 &.- \\
\hline 4,4'-DDT & 0.10 & 4 & $\ldots$ & 0.10 & 4 & $\ldots$ \\
\hline Methoxychlor & 0.48 & $\mathrm{U}$ & -- & 0.48 & 4 & -- \\
\hline Endrin ketone & 0.10 & $u$ & $-\ldots$ & 0.10 & $u$ & $\ldots$ \\
\hline Alpha-chlordane & 0.48 & $u$ & - & 0.48 & $\mathrm{U}$ & -- \\
\hline Gamma-chlordane & 0.48 & 4 & - & 0.48 & $\mathrm{U}$ & - \\
\hline Toxaphene & 0.95 & 4 & - & 0.95 & 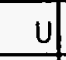 & $\ldots$ \\
\hline Aroclor-1016 & 0.48 & U) & -- & 0.48 & 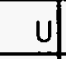 & - \\
\hline Aroclor-1221 & 0.48 & U) & - & 0.48 & 4 & - \\
\hline Aroclor- 1232 & 0.48 & U) & - & 0.48 & $\mathrm{U}$ & - \\
\hline
\end{tabular}




\begin{tabular}{|c|c|c|c|c|}
\hline \multirow[b]{2}{*}{ Compound (ug/L) } & \multicolumn{4}{|c|}{ Table A-4.2 Pesticides/PCB' } \\
\hline & 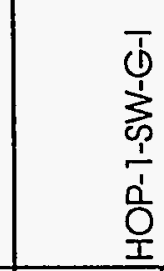 & $\ddot{0}$ & 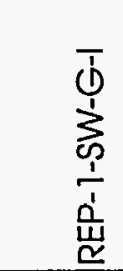 & \\
\hline Aroclor-1242 & 0.48 & U & 0.48 & \begin{tabular}{l|l} 
& $\ldots$ \\
\end{tabular} \\
\hline Aroclor-1248 & 0.48 & \begin{tabular}{l|l}
$U$ & $\ldots$
\end{tabular} & 0.48 & $\mathrm{u} \mid \ldots$ \\
\hline Aroclor- 1254 & 0.95 & $4 \mid$ & 0.95 & $\mathrm{u}[\ldots$ \\
\hline Aroclor-1260 & 0.95 & u| & 0.95 & $u$ \\
\hline
\end{tabular}




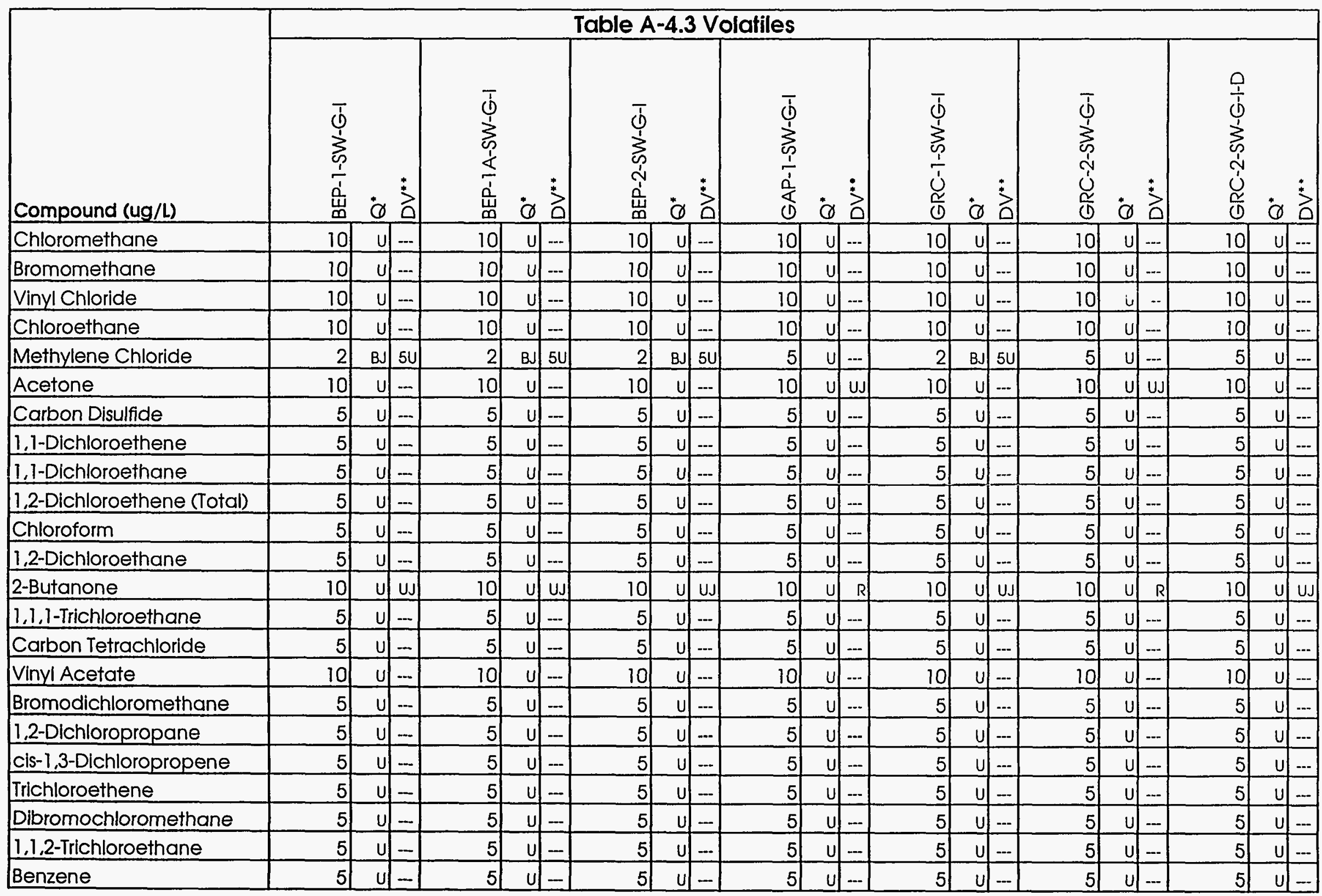




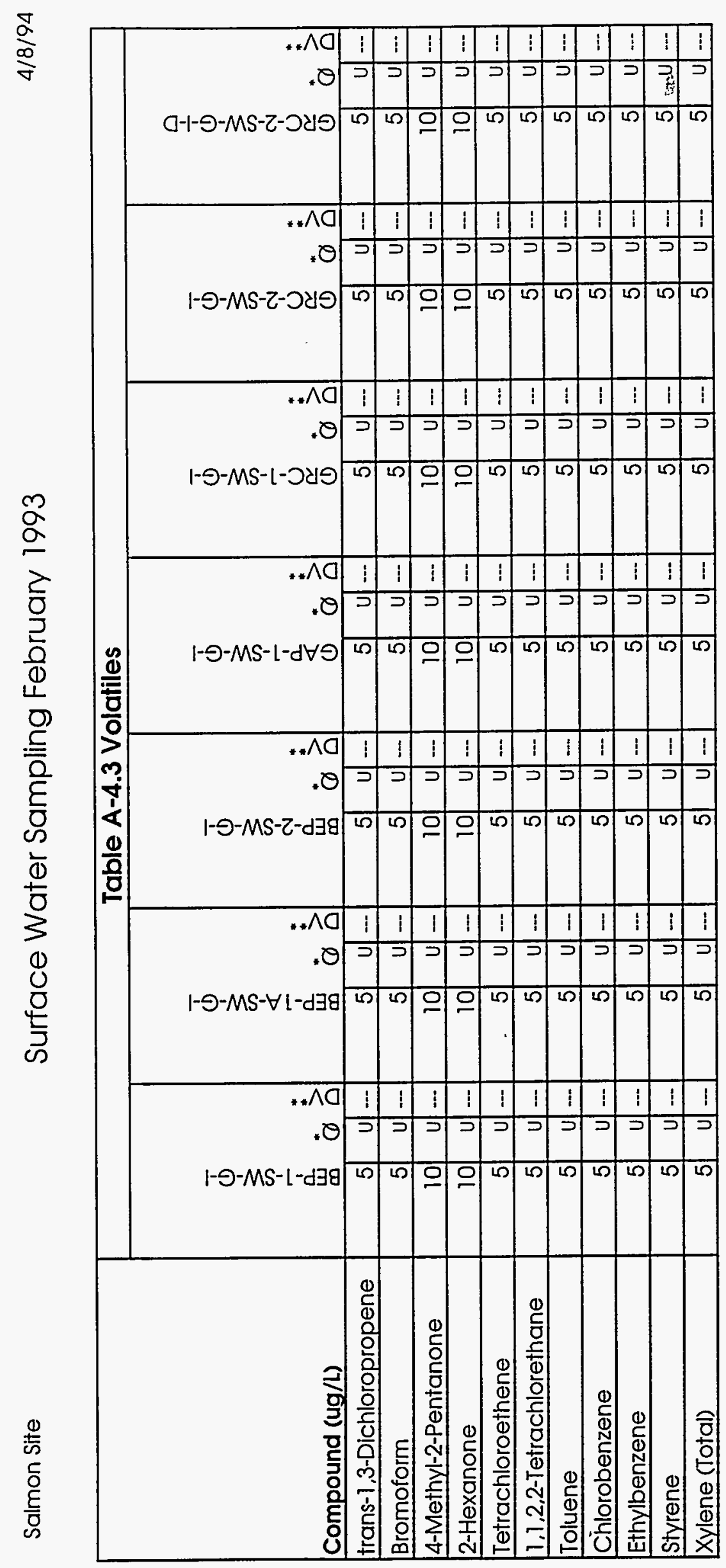




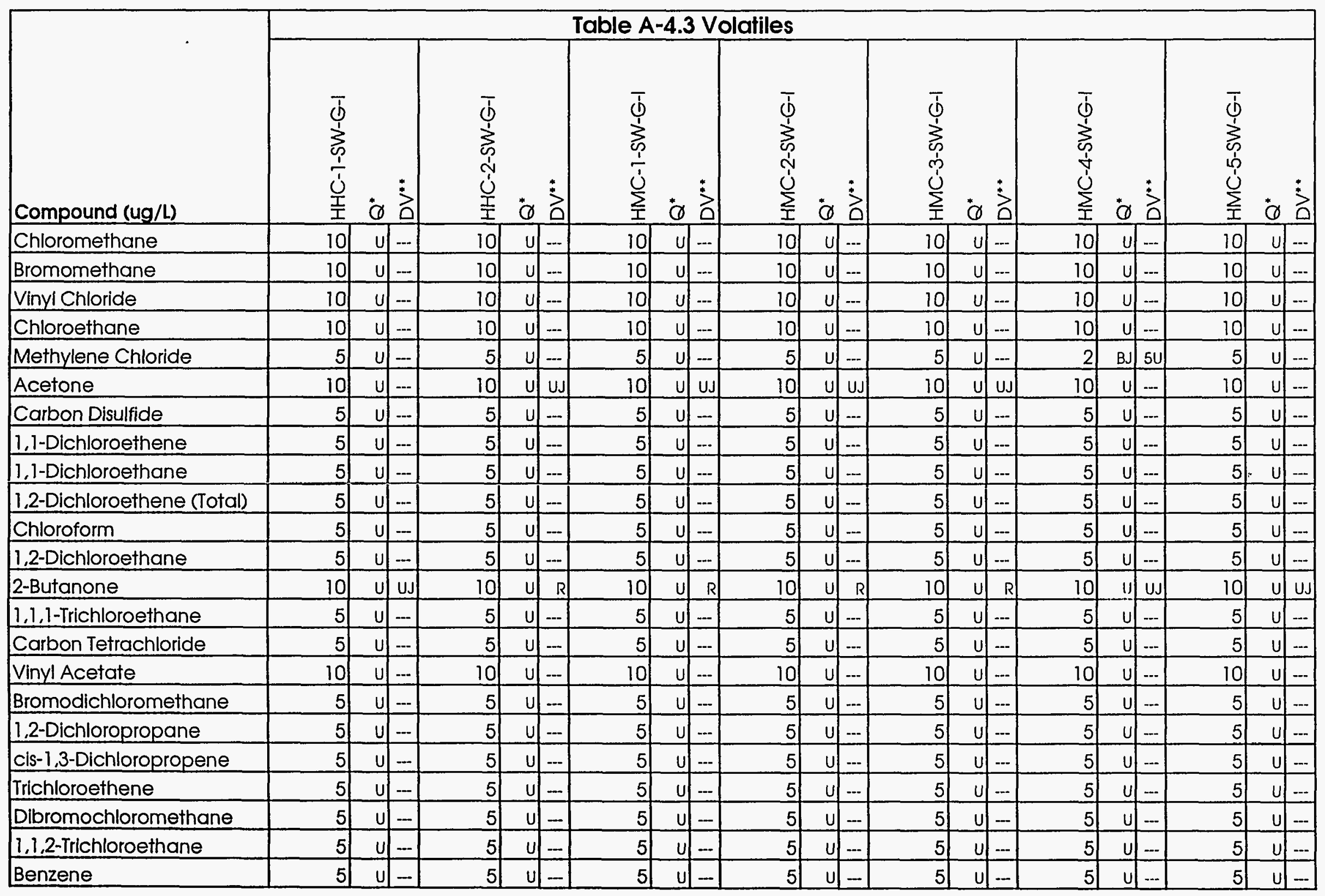




\begin{tabular}{|c|c|c|c|c|c|c|c|c|c|c|c|c|c|c|c|c|c|c|c|c|c|}
\hline \multirow[b]{2}{*}{ Compound (ug/L) } & \multicolumn{21}{|c|}{ Table A-4.3 Volatiles } \\
\hline & $\begin{array}{l}\bar{j} \\
\frac{1}{3} \\
\frac{1}{1} \\
\frac{j}{1} \\
\frac{1}{I}\end{array}$ & & & 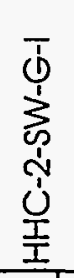 & (ृ) & ${ }^{*}$ & 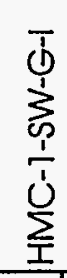 & & $3^{*}$ & 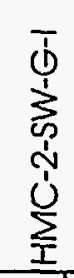 & & 方 & 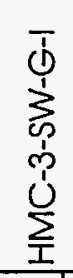 & & 方 & 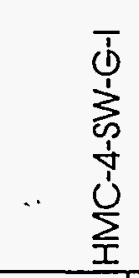 & & $\dot{a}^{*}$ & 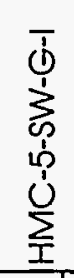 & $\ddot{0}$ & 完 \\
\hline trans-1,3-Dichloropropene & 5 & 4 & $\ldots$ & 5 & $\underline{u}$ &.- & 5 & 4 & $-\ldots$ & 5 & $u$ & $\ldots$ & 5 & $\underline{u}$ & -- & 5 & 4 & $\ldots$ & 5 & $u$ & $\ldots$ \\
\hline Bromoform & 5 & $u$ & - & 5 & $u$ & $-\ldots$ & 5 & 4 & $-{ }_{-1}$ & 5 & $u$ & $\ldots$ & 5 & $\underline{u}$ & -- & 5 & $u$ & $\ldots$ & 5 & $u$ & $\ldots$ \\
\hline 4-Methyl-2-Pentanone & 10 & $u$ & - & 10 & $\underline{u}$ & - & 10 & $u$ & $\ldots$ & 10 & $u$ & - & 10 & u & - & 10 & 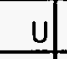 & $\ldots$ & 10 & $\mathrm{u}$ & $\ldots$ \\
\hline 2-Hexanone & 10 & U) & $\ldots$ & 10 & $u$ & $-{ }_{-1}$ & 10 & $u$ & $\ldots$ & 10 & $u$ & $\ldots$ & 10 & $u$ & $\ldots$ & 10 & $u$ & $\ldots$ & 10 & $\mathrm{U}$ & $\ldots$ \\
\hline Tetrachloroethene & 5 & $u$ & $\ldots$ & 5 & $u$ & -- & 5 & $u$ & $\ldots$ & 5 & $u$ & $\ldots$ & 5 & $\mathrm{u}$ & --- & 5 & $u$ & $\ldots$ & 5 & $\mathrm{u}$ & $\ldots$ \\
\hline 1,1,2,2-Tetrachlorethane & 5 & 4 & -- & 5 & 4 & - & 5 & 4 & $\ldots$ & 5 & 4 & $\ldots$ & 5 & 4 & $\ldots$ & 5 & 4 & $\cdots$ & 5 & 4 & --- \\
\hline Toluene & 5 & 4 & - & 5 & $u$ & -- & 5 & 4 &.-- & 5 & 4 & $\ldots$ & 5 & uf & - & 5 & $\underline{u}$ & $\ldots$ & 5 & 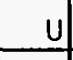 &.- \\
\hline Chlorobenzene & 5 & 4 & - & 5 & $u$ & - & 5 & 4 & - & 5 & $u$ & $\ldots$ & 5 & $\mathrm{U}$ & -- & 5 & 4 & $\ldots$ & 5 & 4 & $\ldots$ \\
\hline Ethylbenzene & 5 & 4 & $\ldots$ & 5 & 4 & $\cdots$ & 5 & 4 & -- & 5 & 4 & $\ldots$ & 5 & 4 & $\ldots$ & 5 & 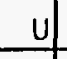 & $\ldots$ & 5 & $\mathrm{U}$ & $\ldots$ \\
\hline Styrene & 5 & 4 & $\ldots$ & 5 & 4 & - & 5 & 4 & $\ldots$ & 5 & 4 & -- & 5 & $\underline{U}$ & -- & 5 & 4 & $\ldots$ & 5 . & $U$ & $\ldots$ \\
\hline Xylene (Total) & 5 & U] & -1 & 5 & u & $\ldots$ & 5 & U] & - & 5 & $\mathrm{U}$ & $\ldots$ & 5 & U] & $\ldots$ & 5 & u & $\ldots$ & 5 & $\mathrm{U}$ &.- \\
\hline
\end{tabular}




\begin{tabular}{|c|c|c|c|c|c|c|c|c|c|c|c|c|c|c|c|c|c|c|}
\hline \multirow[b]{2}{*}{ Compound (ug/L) } & \multicolumn{18}{|c|}{ Table A-4.3 Volatiles } \\
\hline & $\begin{array}{l}\bar{\phi} \\
1 \\
3 \\
01 \\
1 \\
01 \\
0 \\
\underline{1}\end{array}$ & & & 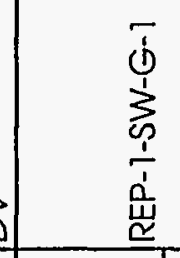 & Q & & $\begin{array}{l}\bar{y} \\
\bar{E} \\
\overline{0} \\
0 \\
\text { 을 }\end{array}$ & $\ddot{Q}$ & $\stackrel{2}{0}^{*}$ & 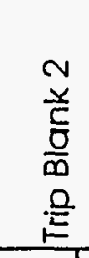 & & $\begin{array}{l}\vdots \\
0\end{array}$ & 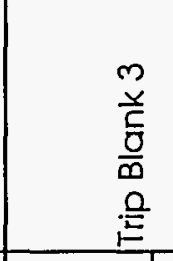 & & $\stackrel{3}{0}^{*}$ & 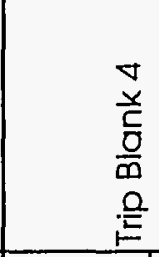 & $\ddot{\theta}$ & $\stackrel{*}{3}$ \\
\hline Chloromethane & 10 & 4 & $\ldots$ & 10 & $\mathrm{U}$ & $-\ldots$ & 10 & U & $\ldots$ & 10 & 4 & $\ldots$ & 10 & U & $\ldots$ & 10 & U & - \\
\hline Bromomethane & 10 & $\mathrm{u}$ & $\ldots$ & 10 & $u$ & $\ldots$ & 10 & 4 & $\ldots$ & 10 & 4 & $\ldots$ & 10 & $\mathrm{u}$. & $\ldots$ & 10 & 4 & $\ldots$ \\
\hline Vinyl Chloride & 10 & $u$ & $\ldots$ & 10 & $\mathrm{U}$ & $-\ldots$ & 10 & 4 & $\ldots$ & 10 & 4 & $\ldots$ & 10 & $\mathrm{u}$ & $\ldots$ & 10 & U) & $\ldots$ \\
\hline Chloroethane & 10 & 4 & $\ldots$ & 10 & $u$ & -- & 10 & 4 & -- & 10 & 4 & $-{ }_{-1}$ & 10 & 4 & -- & 10 & 4 &.-- \\
\hline Methylene Chloride & 2 & BJ & 50 & 5 & $u$ & $\ldots$ & 2 & $\mathrm{BJ}$ & 50 & 2 & Bs & 50 & 2 & 4 & $\ldots$ & 5 & u) & -- \\
\hline Acetone & 10 & $u$ & $\ldots$ & 10 & 4 & UJ & 15 & & $\mathrm{U}$ & 10 & 4 &.- & 10 & 4 & U.J & 10 & 4 & -- \\
\hline Carbon Disulfide & 5 & 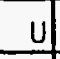 & $\ldots$ & 5 & $u$ & -- & 5 & U & $\ldots$ & 5 & 4 & - & 5 & 4 & $\ldots$ & 5 & 4 & - \\
\hline 1,1-Dichloroethene & 5 & $\mathrm{U}$ & $\ldots$ & 5 & $\mathrm{U}$ & - & 5 & 4 & $\ldots$ & 5 & 4 & $\ldots$ & 5 & 4 & - & 5 & u) & $\ldots$ \\
\hline 1,1-Dichloroethane & 5 & $\mathrm{u}$ & $\ldots$ & 5 & $\mathrm{U}$ & $\ldots$ & 5 & u & $\ldots$ & 5 & $u$ & $\ldots$ & 5 & 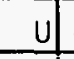 & $\ldots$ & 5 & U) & - \\
\hline 1,2-Dichloroethene (Total) & 5 & $u$ & $\ldots$ & 5 & $u$ & $\ldots$ & 5 & 4 & $\ldots$ & 5 & ut & $\ldots$ & 5 & U) & -1 & 5 & u) & - \\
\hline Chloroform & 5 & 4 & $\ldots$ & 5 & $\mathrm{u}$ & $\ldots$ & 5 & 4 & $\ldots$ & 5 & 4 & $\ldots$ & 5 & U. & - & 5 & 4 & -- \\
\hline 1,2-Dichloroethane & 5 & $u$ & $\ldots$ & 5 & $\mathrm{u}$ & -- & 5 & U) & -- & 5 & $u$ & -- & 5 & 4 & -- & 5 & $u$ & -- \\
\hline 2-Butanone & 10 & 4 & UJ & 10 & 4 & $R$ & 10 & 4 & UJ & 10 & 4 & $\mathrm{Uu}$ & 10 & 4 & $\mathrm{R}$ & 10 & $u$ & UJ \\
\hline 1,1,1-Trichloroethane & 5 & $\mathrm{u}$ & -- & 5 & $\mathrm{u}$ & -- & 5 & 4 & - & 5 & 4 &.- & 5 & 4 & - & 5 & 4 & $\ldots$ \\
\hline Carbon Tetrachloride & 5 & 4 & - & 5 & $\mathrm{U}$ & - & 5 & U) & $\ldots$ & 5 & 4 & $\ldots$ & 5 & $u$ & - & 5 & 4 & $\ldots$ \\
\hline Vinyl Acetate & 10 & 4 & -- & 10 & $u$ & $\ldots$ & 10 & 4 & - & 10 & 4 & $\ldots$ & 10 & 4 & - & 10 & $u$ & $\ldots$ \\
\hline Bromodichloromethane & 5 & $u$ & $\ldots$ & 5 & $\mathrm{u}$ & $-\ldots$ & 5 & $u$ & -- & 5 & $\mathrm{U}$ & $\ldots$ & 5 & 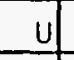 & $\ldots$ & 5 & $u$ & -- \\
\hline 1,2-Dichloropropane & 5 & 4 &.- & 5 & $\mathrm{U}$ & $\ldots$ & 5 & u) & - & 5 & 4 & $\ldots$ & 5 & u & - & 5 & $u$ & $\ldots$ \\
\hline cis-1,3-Dichloropropene & 5 & $u$ & - & 5 & $\mathrm{u}$ & -- & 5 & 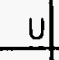 & $\ldots$ & 5 & 4 & $\ldots$ & 5 & 4 & - & 5 & $u$ & $\ldots$ \\
\hline Trichloroethene & 5 & U & $\ldots$ & 5 & $\mathrm{U}$ & - & 5 & 4 & - & 5 & $u$ & $\ldots$ & 5 & $u$ & - & 5 & $u$ & $\ldots$ \\
\hline Dibromochloromethane & 5 & $u$ & - & 5 & $\mathrm{U}$ & - & 5 & 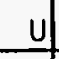 & - & 5 & 4 & $-\ldots$ & 5 & 4 & - & 5 & $u$ & $\ldots$ \\
\hline 1,1,2-Trichloroethane & 5 & U & - & 5 & $u$ & - & 5 & $\mathrm{u}$ & - & 5 & $u$ & - & 5 & $u$ & - & 5 & 4 & - \\
\hline Benzene & 5 & & - & 5 & $\mathrm{U}$ & - & 5 & U) & - & 5 & & - & 5 & & -1 & 5 & & $\ldots$ \\
\hline
\end{tabular}




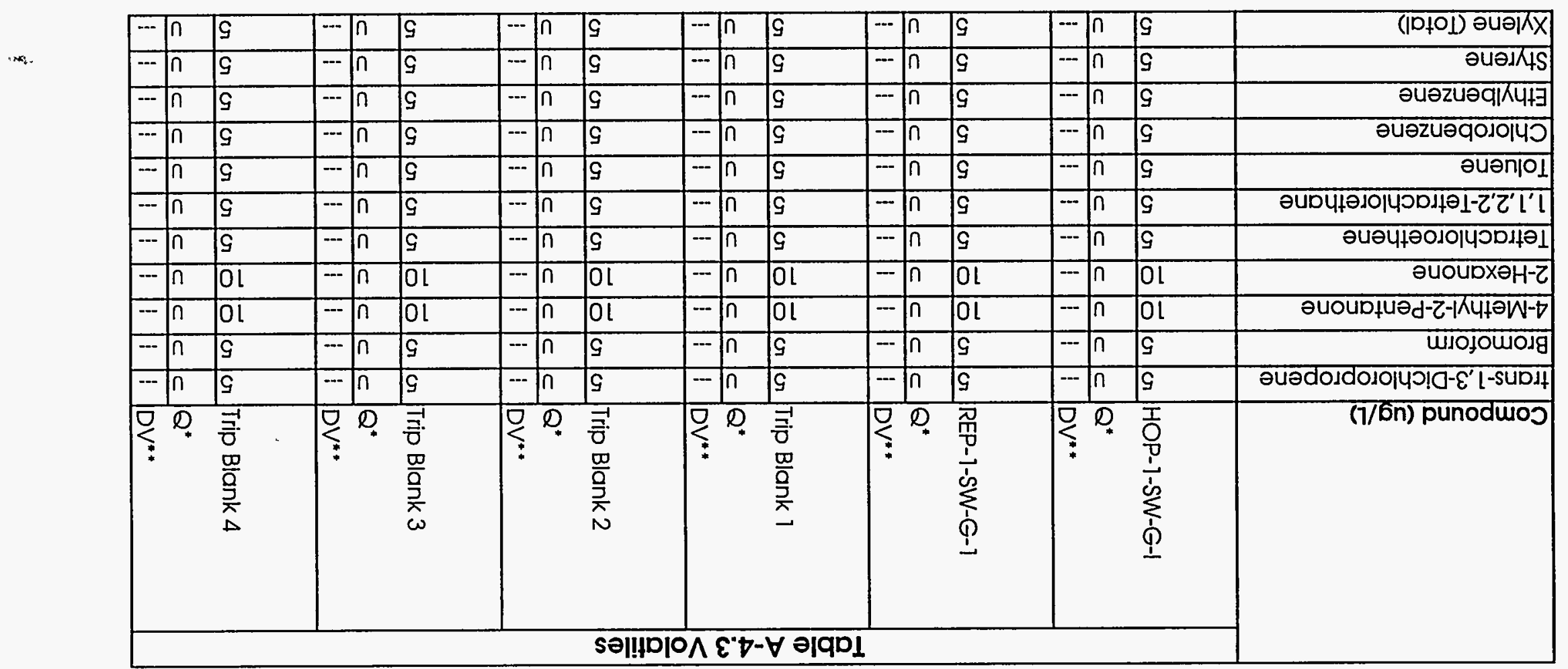




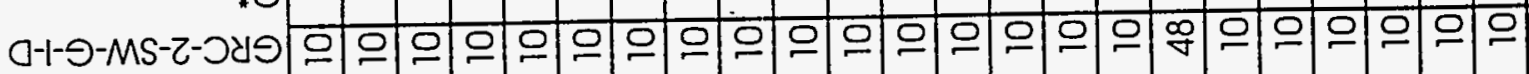

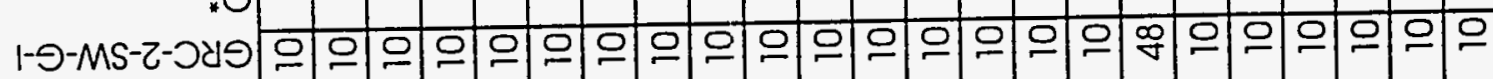

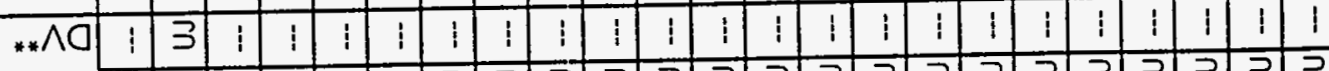

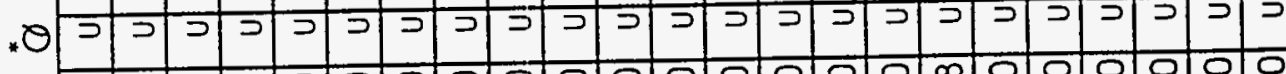

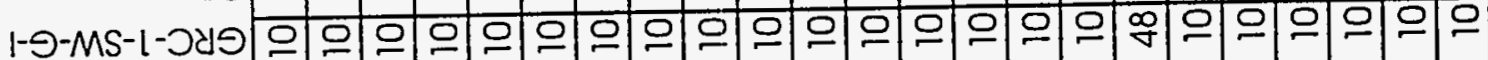

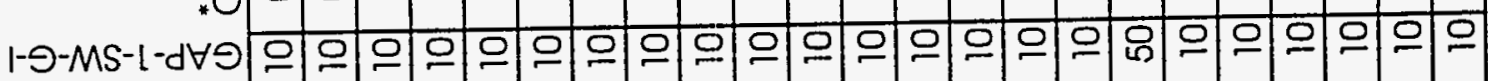

**व $1: \begin{array}{llllllllllllllllllllllllllll} & 1 & 3 & 1 & 1 & 1 & 1 & 1 & 1 & 1 & 1 & 1 & 1 & 1 & 1 & 1 & 1 & 1 & 1 & 1 & 1 & 1 & 1 & 1\end{array}$

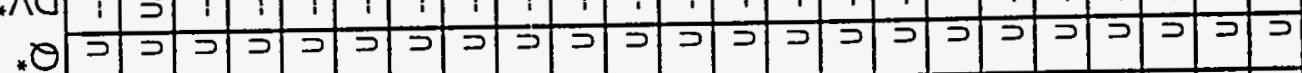

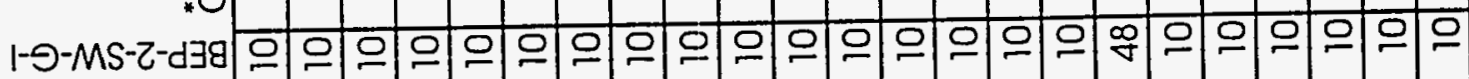

$* \wedge$ औ

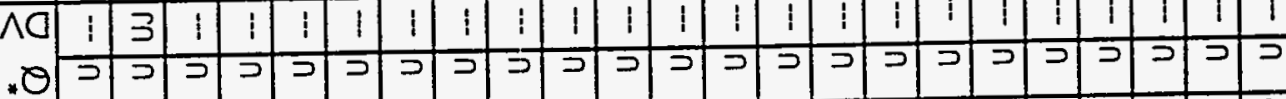

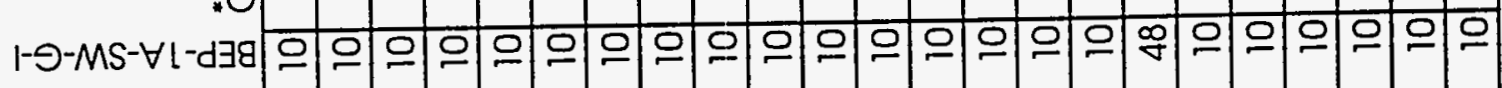

\section{$* \wedge 0$}

$\theta$

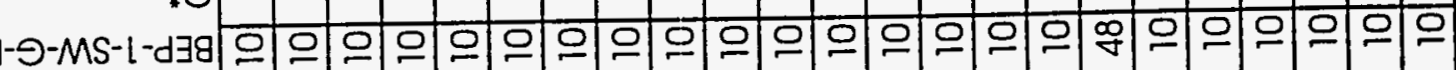

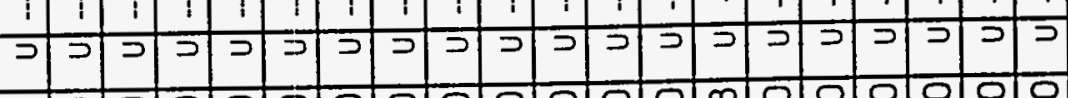




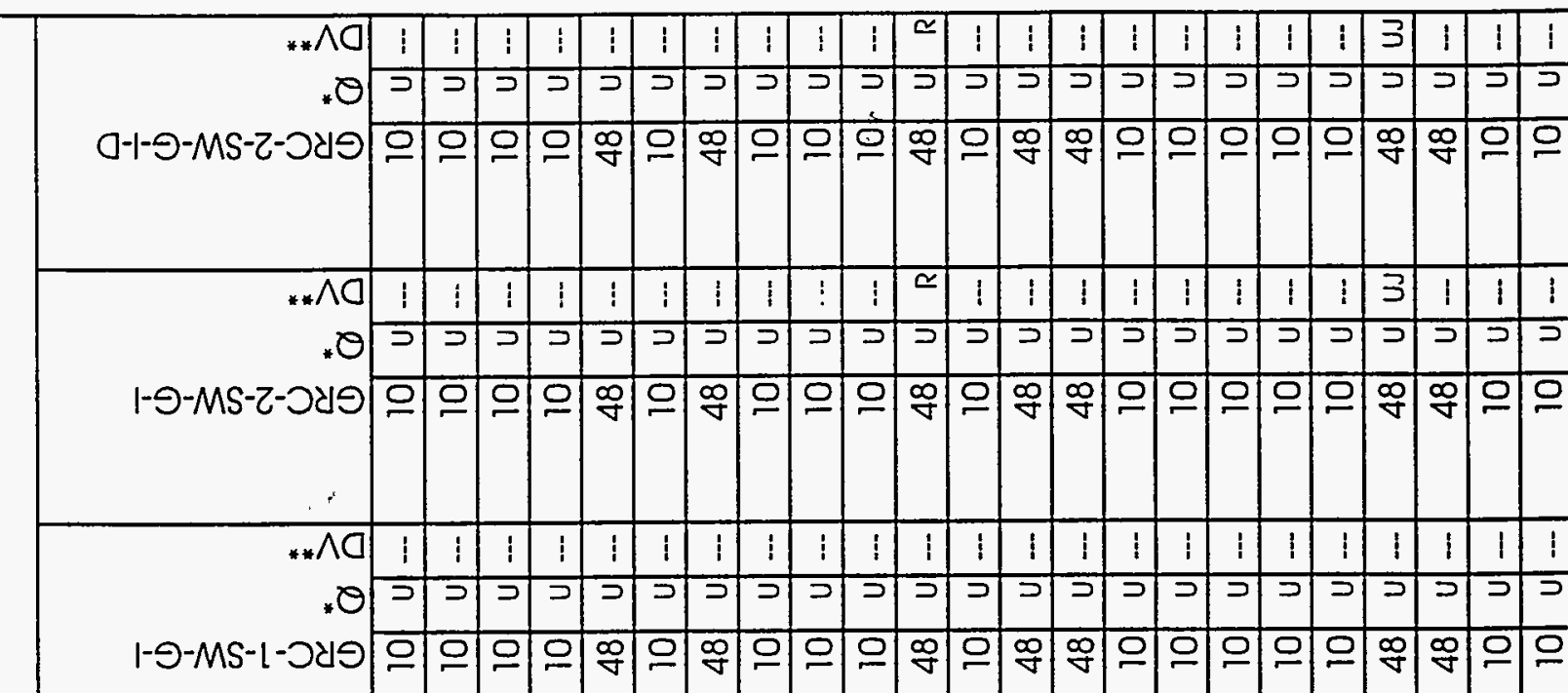

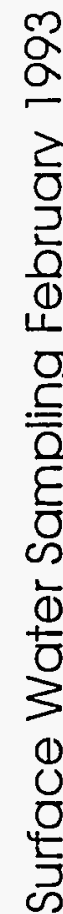

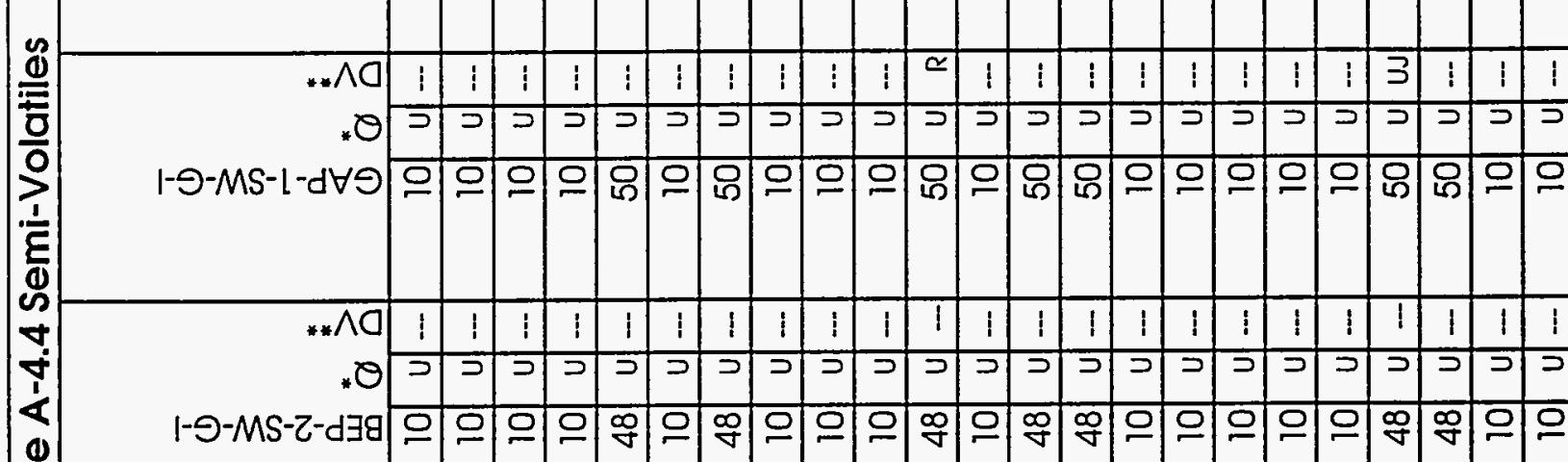

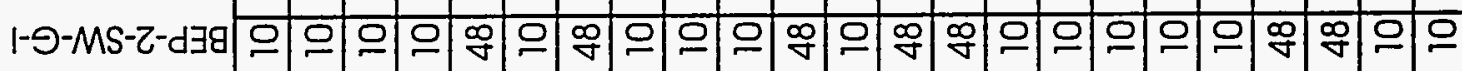

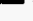

${ }_{*} \wedge$ व

.0 ᄀ J

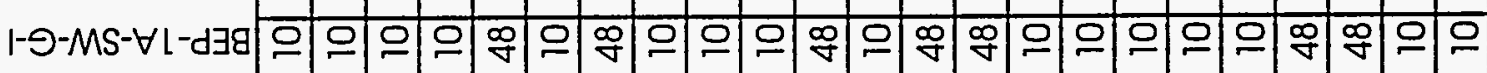

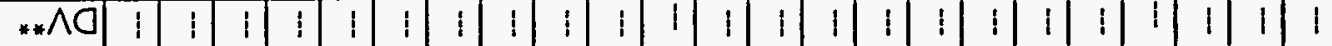

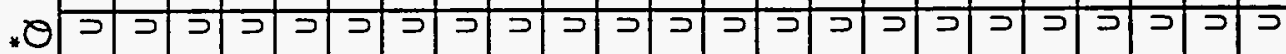

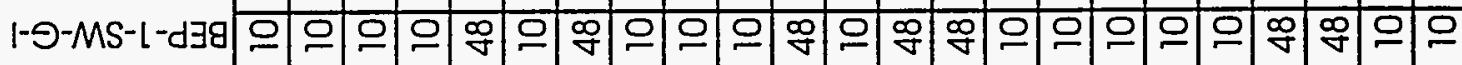




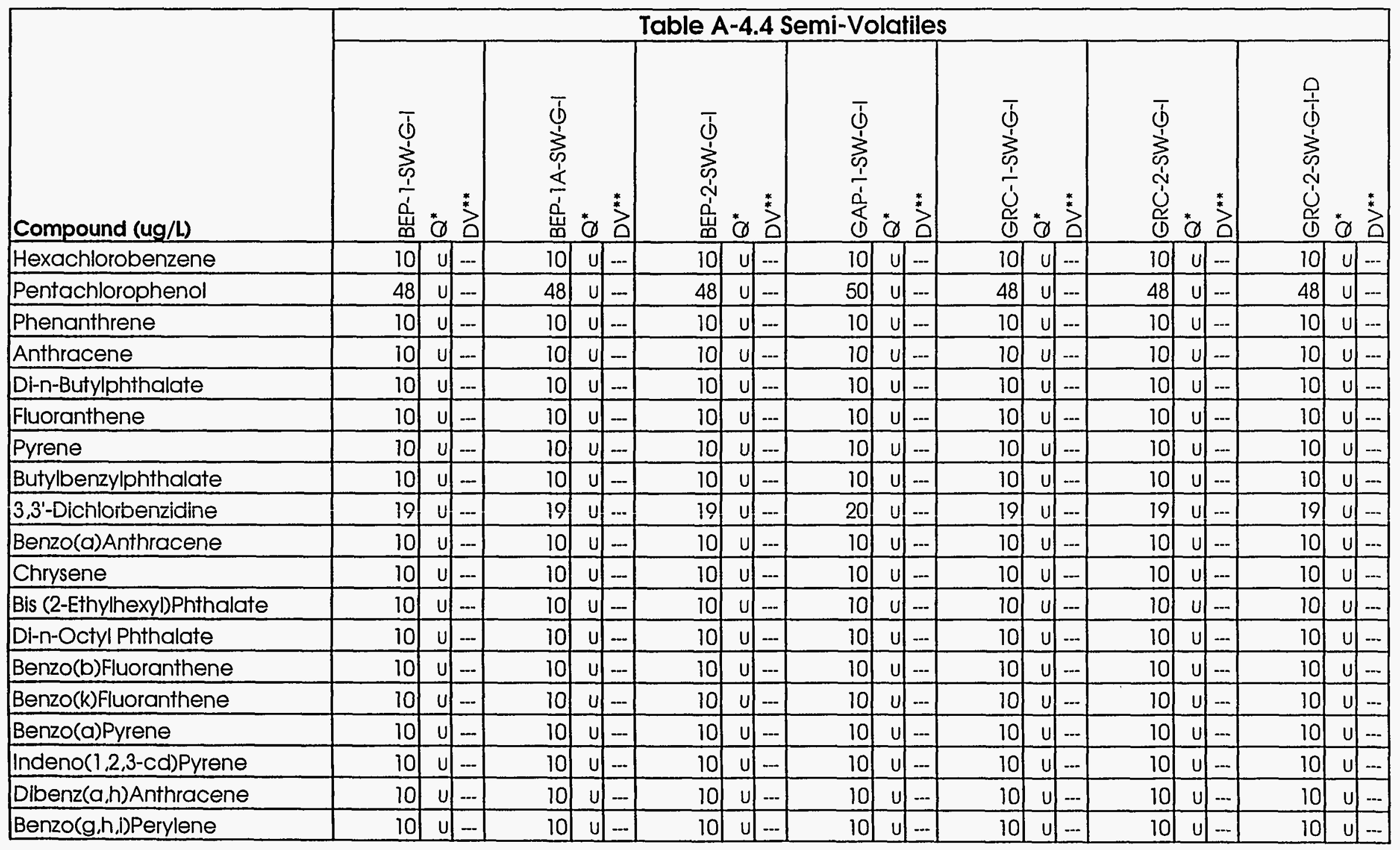




\begin{tabular}{|c|c|c|c|c|c|c|c|c|c|c|c|c|c|c|c|c|c|c|c|c|c|c|}
\hline \multirow[b]{2}{*}{ Compound (ug/L) } & \multicolumn{22}{|c|}{ Table A-4.4 Semi-Volatiles } \\
\hline & & & & 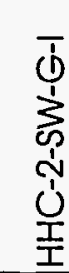 & & & 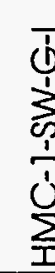 & $\gamma$ & & 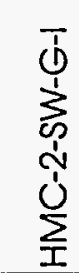 & 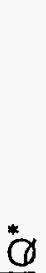 & & 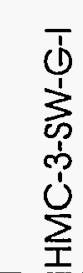 & & & 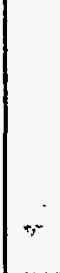 & 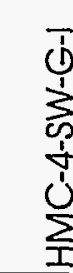 & & $x^{*}$ & 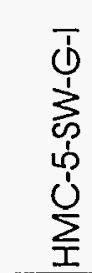 & & $\left.\gamma^{*}\right)^{*}$ \\
\hline Phenol & & u. & & 10 & $\bar{u}$ & $\ldots$ & 10 & $u$ & $\ldots$ & 10 & & $\ldots$ & 10 & & $\ldots$ & & 10 & & J.- & 10 & & J.-. \\
\hline bis (2-Cloroethyl)Ether & 10 & u. & -1 & 10 & $u$ & - & 10 & 1 & - & 10 & & $\ldots$ & 10 & & $\ldots$ & & 10 & & $\mathrm{uJ}$ & 10 & & J.- \\
\hline 2-Chlorophenol & 10 & u. & - & 10 & $u$ & - & 10 & & - & 10 & 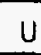 & $\ldots$ & 10 & & $\ldots$ & & 10 & $u$ & J.- & 10 & $\mathrm{u}$ & J... \\
\hline 1,3-Dichlorobenzene & 10 & u. & 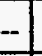 & 10 & $u$ & $\ldots$ & 10 & $u$ & - & 10 & & $\ldots$ & 10 & & - & & 10 & & J. & 10 & & $1-$ \\
\hline 1,4-Dichlorobenzene & 10 & 0. & - & 10 & & - & 10 & & - & 10 & $\mathrm{u}$ & $\ldots$ & 10 & & - & & 10 & $u$ & J... & 10 & & $\mathrm{~J} \ldots$ \\
\hline Benzyl Alcohol & 10 & u. & -1 & 10 & $\mathrm{u}$ & - & 10 & & - & 10 & 1 & $\ldots$ & 10 & $\mathrm{u}$ & -.. & & 10 & 0 & |... & 10 & & J.-. \\
\hline 1,2-Dichlorobenzene & 10 & u. & - & 10 & $u$ & $\ldots$ & 10 & & - & 10 & 1 & -- & 10 & 1 & $\ldots$ & & 10 & $u$ & J-- & 10 & $\mathrm{u}$ & J--. \\
\hline 2-Methylphenol & 10 & u. & - & 10 & $\bar{u}$ & - & 10 & & $\ldots$ & 10 & $u$ & -- & 10 & $u$ & $\ldots$ & & 10 & $u$ & J)... & 10 & $u$ & J) \\
\hline bis (2-Chloroisopropyl)Ether & 10 & 0. & -1 & 10 & & $\ldots$ & 10 & & $\ldots$ & 10 & $u$ & $\ldots$ & 10 & $u$ & $\ldots$ & & 10 & $u$ & (... & 10 & $\mathrm{u}$ & J)... \\
\hline 4-Methyiphenol & 10 & u. & - & 10 & $u$ & $\ldots$ & 10 & & $\ldots$ & 10 & & $\ldots$ & 10 & & $\ldots$ & & 10 & $u$ & J... & 10 & & נ).- \\
\hline N-Nitroso-Di-n-Propylamine & 10 & u. & 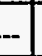 & 10 & $u$ & -.- & 10 & & - & 10 & 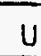 & $\ldots$ & 10 & & $\ldots$ & & 10 & $u$ & j]... & 10 & & J.-. \\
\hline Hexachloroethane & 10 & u. & -1 & 10 & $u$ & - & 10 & & - & 10 & & $\ldots$ & 10 & $u$ & $\ldots$ & & 10 & $u$ & J.-- & 10 & & J.- \\
\hline Nitrobenzene & 10 & uf & - & 10 & $u$ & $=$ & 10 & & - & 10 & 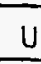 & - & 10 & & - & & 10 & 0 & ... & 10 & & J- \\
\hline Isophorone & 10 & 4 & 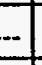 & 10 & $\mathrm{u}$ & $\ldots$ & 10 & & $\ldots$ & 10 & & - & 10 & & $\ldots$ & & 10 & $u$ & -.. & 10 & & J... \\
\hline 2-Nitrophenol & 10 & u. & 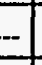 & 10 & $\mathrm{U}$ & - & 10 & & - & 10 & & $\ldots$ & 10 & & $\ldots$ & & 10 & 0 & - & 10 & & .... \\
\hline 2,4-Dimethylphenol & 10 & of. & a & 10 & $\underline{u}$ & $=$ & 10 & & $=$ & 10 & & 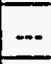 & 10 & & - & & 10 & $u$ & $+\ldots$ & 10 & & 5 \\
\hline Benzoic Acid & 48 & u & uJ & 48 & & UJ & 49 & & $U_{S}$ & 48 & & UJ & 48 & & UJ & & 48 & $u$ & $1 .$. & 49 & & us \\
\hline bis (2-Chloroethoxy)Methane & 10 & of & at & 10 & & - & 10 & & - & 10 & & $\ldots$ & 10 & & $\ldots$ & & 10 & $u$ & -.- & 10 & & J... \\
\hline 2,4-Dichlorophenol & 10 & 4. & 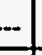 & 10 & $\Xi$ & $=$ & 10 & & $-\ldots$ & 10 & & - & 10 & & $\ldots$ & & 10 & $u$ & o- & 10 & & $\mathrm{~J}$ \\
\hline 1,2,4-Trichlorobenzene & 10 & 4 & - & 10 & - & - & 10 & & $\ldots$ & 10 & & $\ldots$ & 10 & & - & & 10 & $u$ & -.. & 10 & & o. \\
\hline Naphthalene & 10 & ㄴ. & - & 10 & & $=$ & 10 & & - & 10 & & -- & 10 & & $-\ldots$ & & 10 & $u$ & |- - - & 10 & & - \\
\hline 4-Chloroanilline & 10 & v. & - & $\pi$ & & - & 10 & & $\ldots$ & 10 & & - & 10 & $u$ & $\ldots$ & & 10 & $u$ & -.- & 10 & & $J \ldots$ \\
\hline Hexachlorobutadlene & 10 & 4 & & 10 & u & - & 10 & & $\ldots$ & 10 & & $\ldots$ & 10 & & $\ldots$ & & 10 & $u$ & $-\ldots$ & 10 & & 0 \\
\hline
\end{tabular}

"Data Qualifier. " Data Validation. 


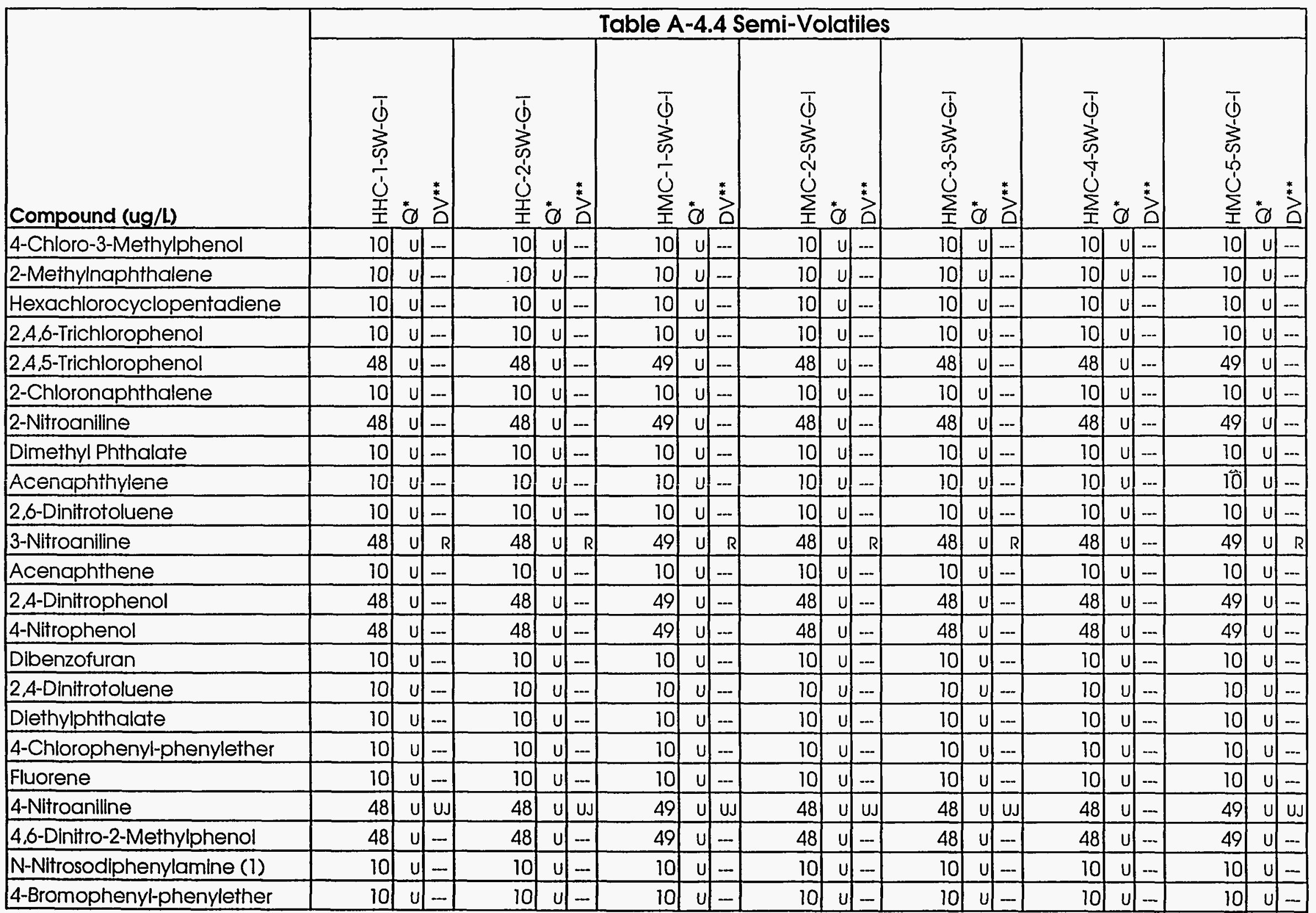




\begin{tabular}{|c|c|c|c|c|c|c|c|c|c|c|c|c|c|c|c|c|c|c|c|c|c|}
\hline \multirow[b]{2}{*}{ Compound (ug/L) } & \multicolumn{21}{|c|}{ Table A-4.4 Semi-Volatiles } \\
\hline & \multicolumn{3}{|c|}{ 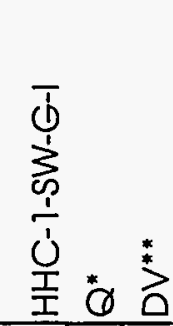 } & \multicolumn{3}{|c|}{ 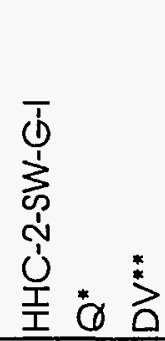 } & \multicolumn{3}{|c|}{ 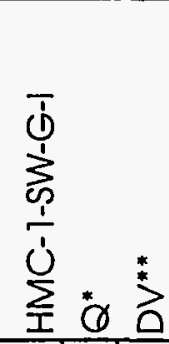 } & \multicolumn{3}{|c|}{ 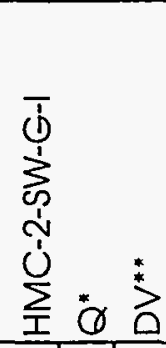 } & \multicolumn{3}{|c|}{ 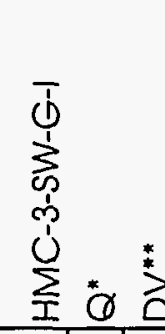 } & \multicolumn{3}{|c|}{ 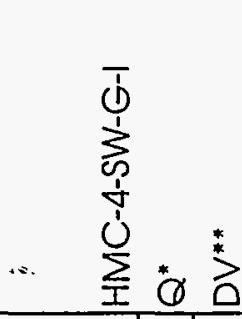 } & \multicolumn{3}{|c|}{$\begin{array}{l}\bar{j} \\
0 \\
\sum_{0}^{1} \\
0 \\
0 \\
\sum^{1} \\
0\end{array}$} \\
\hline Phenanthrene & 10 & $\mathrm{U}$. & $\ldots$ & 10 & 4. & -- & 10 & $\mathrm{U}$ & $\ldots$ & 10 & U & -- & 10 & $u$ & -- & 10 & U & $\ldots$ & 10 & U & J.- \\
\hline Anthracene & 10 & $u$. & $\ldots$ & 10 & $U$. & -- & 10 & $\mathrm{u}$ & - & 10 & $u$ & $\ldots$ & 10 & $\mathrm{u}$ & $\ldots$ & 10 & u & -- & 10 & $\mathrm{U}$ & J.-. \\
\hline Di-n-Butylphthalate & 10 & $\mathrm{u}$ & $\ldots$ & 10 & $u$. & -1 & 10 & $u$ & $\ldots$ & 10 & $u$ & $\ldots$ & 10 & $\mathrm{U}$ & $\ldots$ & 10 & 4 & $\ldots$ & 10 & U & j... \\
\hline Fluoranthene & 10 & $\mathrm{U}$. & - & 10 & $u$. & -- & 10 & U & - & 10 & 4 & - & 10 & U & -- & 10 & U & $\ldots$ & 10 & $u$ & J.- \\
\hline Pyrene & 10 & 4. & $\ldots$ & 10 & $\mathrm{u}$. & -- & 10 & $\mathrm{U}$ & $\ldots$ & 10 & $\mathrm{u}$ & $\ldots$ & 10 & $\mathrm{u}$ & $-\ldots$ & 10 & 4 &.- & 10 & 4 & J... \\
\hline Chrysene & 10 & $\mathrm{U}$. & $\ldots$ & 10 & $\mathrm{u}$. & $\ldots$ & 10 & $\mathrm{U}$ & -- & 10 & $\mathrm{u}$ & -- & 10 & $u$ & -- & 10 & 4 & -- & 10 & $\mathrm{U}$ & J. $\ldots$ \\
\hline Bis (2-Ethylhexyl)Phthalate & 10 & $u$ & - & 10 & $u$. & $\ldots$ & 10 & $\mathrm{U}$ & - & 10 & $\mathrm{u}$ & -- & 10 & $u$ & -- & 10 & U & -- & 10 & 4 & U... \\
\hline Di-n-Octyl Phthalate & 10 & $U$. & -- & 10 & $u$ & $\ldots+$ & 10 & $u$ & - & 10 & $u$ & $\ldots$ & 10 & U & $\ldots$ & 10 & $U$ & $\ldots$ & 10 & 4 & v... \\
\hline Benzo(b)Fluoranthene & 10 & $\mathrm{u}$ & - & 10 & $\mathrm{u}$. & - & 10 & $\mathrm{U}$ & - & 10 & 4 & $\ldots$ & 10 & U & $\ldots$ & 10 & $\mathrm{u}$ & $\ldots$ & 10 & $\mathrm{u}$ & u... \\
\hline Benzo(k)Fluoranthene & 10 & $\mathrm{u}$. & -- & 10 & 4. & -- & 10 & $u$ & - & 10 & $\mathrm{u}$ &.- & 10 & $\mathrm{U}$ & $-\ldots$ & 10 & $\mathrm{u}$ & -- & 10 & $\mathrm{U}$ & 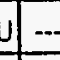 \\
\hline Benzo(a)Pyrene & 10 & $\mathrm{u}$ & -- & 10 & $\mathrm{u}$. & $\ldots$ & 10 & $u$ & $\ldots$ & 10 & 4 & $\ldots$ & 10 & $\mathrm{U}$ & $\ldots$ & 10 & $\mathrm{U}$ & $\ldots$ & 10 & $U$ & i... \\
\hline Indeno( $1,2,3-c d)$ Pyrene & 10 & $\mathrm{u}$ & - & 10 & $\mathrm{u}$ & $\ldots$ & 10 & $\mathrm{u}$ & - & 10 & $\mathrm{u}$ & $\ldots$ & 10 & $\mathrm{u}$ & $\ldots$ & 10 & $\mathrm{u}$ & $\ldots$ & 10 & $\mathrm{U}$ & U... \\
\hline Dibenz(a,h)Anthracene & 10 & 4 & - & 10 & 4 & $-\ldots$ & 10 & $\mathrm{U}$ & -- & 10 & 4 &.- & 10 & $\mathrm{u}$ & -- & 10 & $u$ & $\ldots$ & 10 & 4 & U... \\
\hline Benzo(g,h.i)Perylene & 10 & & $\ldots$ & 10 & $u$ & $\ldots$ & 10 & $\mathrm{U}$ & - & 10 & $\mathrm{u}$ & $\ldots$ & 10 & $\mathrm{u}$ & -- & 10 & $u$ & $-\cdots$ & 10 & $u$ & U. \\
\hline
\end{tabular}


3
8
2
2
0
$\frac{2}{2}$
$\frac{1}{0}$
4
0
$=\frac{1}{0}$
ह
0
0
$\frac{1}{1}$
$\frac{1}{0}$
3
0
0
0
4
5
0

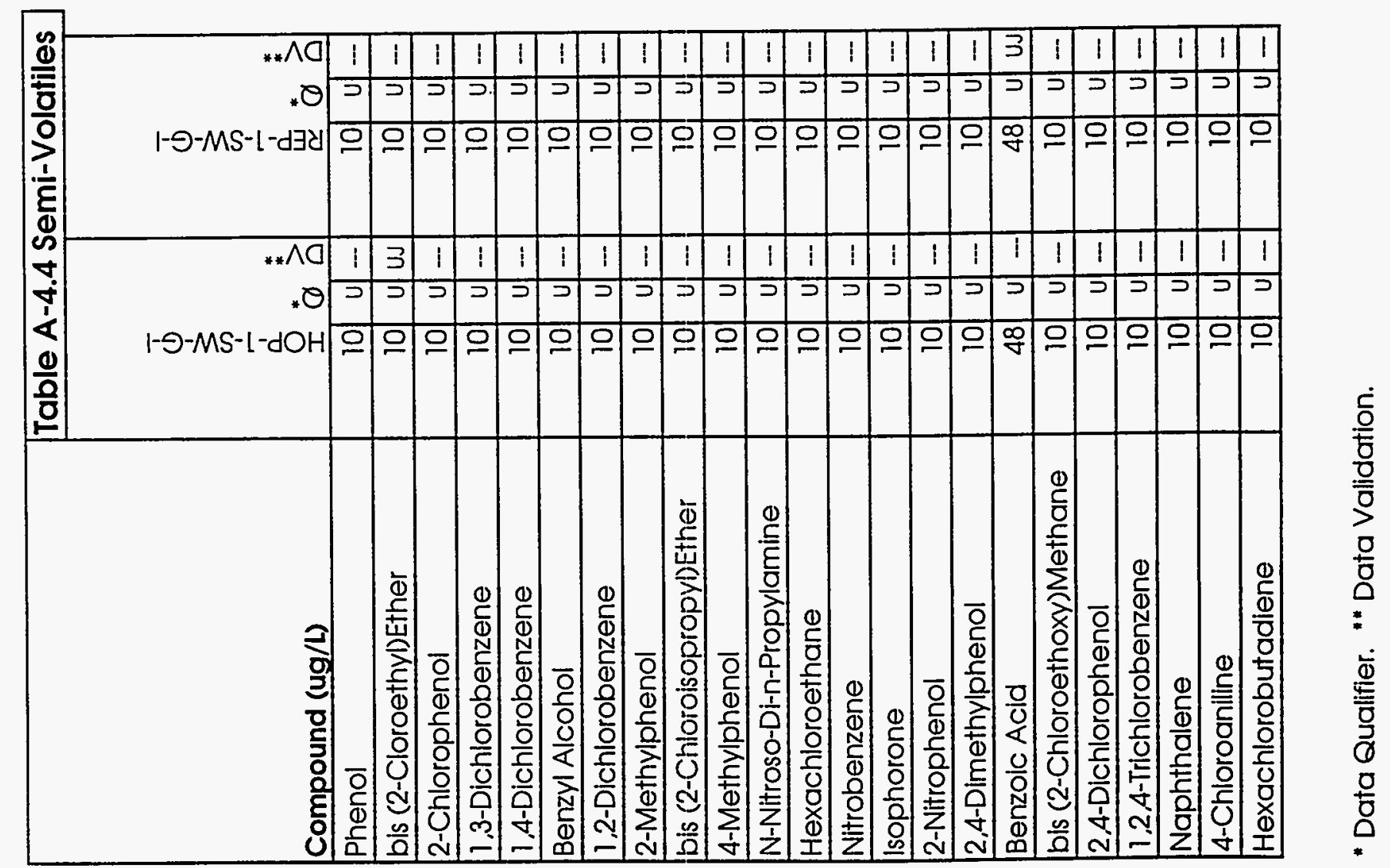




\begin{tabular}{|c|c|c|c|c|c|c|}
\hline \multirow[b]{2}{*}{ Compound (ug/L) } & \multicolumn{6}{|c|}{ Table A-4.4 Semi-Volatiles } \\
\hline & $\begin{array}{l}\overline{1} \\
1 \\
\vdots \\
1 \\
1 \\
1 \\
0 \\
0 \\
0\end{array}$ & & & 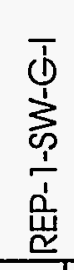 & $\stackrel{*}{Q}$ & ${ }^{*}$ \\
\hline 4-Chloro-3-Methylphenol & 10 & $\mathrm{U}$ & -- & 10 & $u$ & $\ldots$ \\
\hline 2-Methylnaphthalene & 10 & U & - & 10 & $\mathrm{U}$ & -- \\
\hline Hexachlorocyclopentadiene & 10 & $u$ & --- & 10 & $u$ & $\ldots$ \\
\hline 2,4,6-Trichlorophenol & 10 & $\mathrm{u}$ & -- & 10 & $\mathrm{u}$ & $\ldots$ \\
\hline 2,4,5-Trichlorophenol & 48 & $\mathrm{U}$ & -- & 48 & $\mathrm{U}$ & - \\
\hline 2-Chloronaphthalene & 10 & $u$ & -- & 10 & $\mathrm{U}$ & $-\ldots$ \\
\hline 2-Nitroaniline & 48 & $u$ & -- & 48 & $\mathrm{u}$ & - \\
\hline Dimethyl Phthalate & 10 & $u$ & - & 10 & U & - \\
\hline Acenaphthylene & 10 & $\mathrm{U}$ & -- & 10 & U & - \\
\hline 2,6-Dinitrotoluene & 10 & U & $\ldots$ & 10 & $\mathrm{U}$ & - \\
\hline 3-Nitroaniline & 48 & $u$ & - & 48 & $\mathrm{U}$ & $\mathrm{R}$ \\
\hline Acenaphthene & 10 & u & $\ldots$ & 10 & $\mathrm{U}$ & - \\
\hline 2,4-Dinitrophenol & 48 & $\mathrm{u}$ & $\ldots$ & 48 & $u$ & -- \\
\hline 4-Nitrophenol & 48 & $u$ & - & 48 & U & -- \\
\hline Dibenzofuran & 10 & $\mathrm{U}$ & $\cdots$ & 10 & U & -- \\
\hline 2,4-Dinitrotoluene & 10 & $\mathrm{U}$ & - & 10 & $\mathrm{U}$ & - \\
\hline Diethylphthalate & 10 & $\mathrm{U}$ & -- & 10 & $\mathrm{U}$ & $\ldots$ \\
\hline 4-Chlorophenyl-phenyiether & 10 & $\mathrm{U}$ & $\ldots$ & 10 & $\mathrm{U}$ & -- \\
\hline Fluorene & 10 & $\underline{u}$ & -- & 10 & $\mathrm{U}$ & -- \\
\hline 4-Nitroaniline & 48 & 4 & - & 48 & 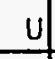 & UJ \\
\hline 4,6-Dinitro-2-Methylphenol & 48 & $\mathrm{U}$ & - & 48 & $\mathrm{u}$ & - \\
\hline N-Nitrosodiphenylamine (1) & 10 & $u$ & - & 10 & $u$ & - \\
\hline 4-Bromophenyl-phenylether & 10 & & -- & 10 & $\mathrm{U}$ & - \\
\hline
\end{tabular}

"Data Qualifier. " " Data Validation. 


\begin{tabular}{|c|c|c|c|c|c|c|}
\hline \multirow[b]{2}{*}{ Compound (ug/L) } & \multicolumn{6}{|c|}{ Table A-4.4 Semi-Volatiles } \\
\hline & $\begin{array}{l}\overline{0} \\
0 \\
\sum_{0}^{\prime} \\
\frac{1}{1} \\
\dot{1} \\
0 \\
0 \\
\end{array}$ & & & 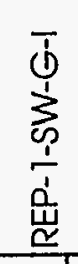 & $\stackrel{*}{0}$ & $\stackrel{*}{2}$ \\
\hline Hexachlorobenzene & 10 & U) & -- & 10 & $\mathrm{U}$ & -- \\
\hline Pentachlorophenol & 48 & $u$ & -- & 48 & $\mathrm{u}$ & -- \\
\hline Phenanthrene & 10 & u & $\ldots$ & 10 & $\mathrm{u}$ & - \\
\hline Anthracene & 10 & $u$ & -- & 10 & $u$ & - \\
\hline Di-n-Butylphthalate & 10 & U & $\ldots$ & 10 & $\mathrm{u}$ & -- \\
\hline Fluoranthene & 10 & $\mathrm{U}$ &.- & 10 & $\mathrm{u}$ & $\ldots$ \\
\hline Pyrene & 10 & 4 &.- & 10 & $\mathrm{U}$ & -- \\
\hline Butylbenzylphthalate & 10 & 4 & -- & 10 & $\mathrm{u}$ & --- \\
\hline 3,3'-Dichloibenzidine & 19 & 4 & $\ldots$ & 19 & $\mathrm{U}$ & UU \\
\hline Benzo(a)Anthracene & 10 & U) & -- & 10 & $\mathrm{U}$ & -- \\
\hline Chrysene & 10 & 4 & - & 10 & $\mathrm{u}$ & --- \\
\hline Bis (2-Ethylhexyl)Phthalate & 10 & $u$ & - & 10 & $\mathrm{U}$ & $\ldots$ \\
\hline Dl-n-Octyl Phthalate & 10 & 4 & -- & 10 & u & -- \\
\hline Benzo(b)Fluoranthene & 10 & 4 & - & 10 & $\mathrm{U}$ & -- \\
\hline Benzo(k)Fluoranthene & 10 & 4 & - & 10 & U & -- \\
\hline Benzo(a)Pyrene & 10 & $u$ & - & 10 & u & $\ldots$ \\
\hline Indeno(1,2,3-cd)Pyrene & 10 & 4 & - & 10 & U & - \\
\hline Dibenz(a,h)Anthracene & 10 & 4 & -- & 10 & $\underline{u}$ & -- \\
\hline Benzo(g,h,l)Perylene & 10 & $u$ & -- & 10 & & -- \\
\hline
\end{tabular}




\begin{tabular}{|c|c|c|c|c|c|c|c|c|c|c|c|c|c|c|c|c|c|c|c|c|}
\hline \multirow[b]{2}{*}{ Parameter $(\mathrm{pCi} / \mathrm{L})$} & \multicolumn{20}{|c|}{ Table A-4.5 Gross Alpha/Beta } \\
\hline & 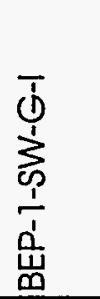 & $\stackrel{*}{*}$ & 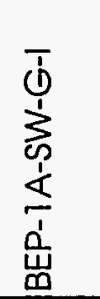 & $\stackrel{*}{*}$ & 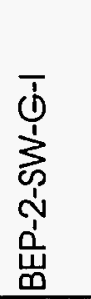 & ة & $\begin{array}{l}\overline{0} \\
\sum_{0}^{1} \\
\frac{1}{1} \\
\frac{1}{1} \\
0\end{array}$ & 茄 & 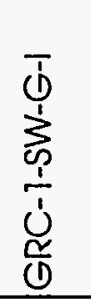 & 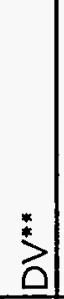 & 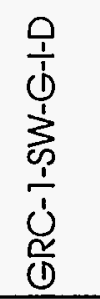 & 艾 & 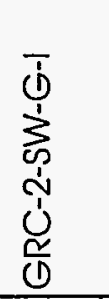 & 艾 & 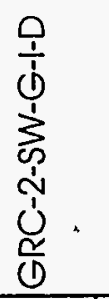 & 菅 & 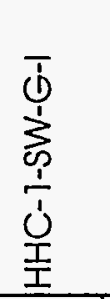 & 茥 & 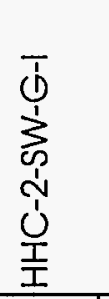 & 艾 \\
\hline Alpha & $\mathrm{ND}$ & - & ND & - & $\overline{N D}$ & - & $\mathrm{ND}$ & - & $\mathrm{ND}$ & $\ldots$ & ND & $-\infty$ & $\mathrm{ND}$ & $-\ldots$ & 0.87 & $-\infty$ & 1.63 & $\ldots$ & $\mathrm{ND}$ & $-\cdots$ \\
\hline Sigma Error $+/-$ & & $\ldots$ & & - & & $\ldots$ & & $\ldots$ & & $-{ }_{-}^{--}$ & & $-\mathrm{A}_{-1}$ & & --- & 0.90 & $-\infty$ & 1.46 & 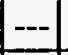 & & -- \\
\hline MDA* & 2.50 & UU & 3.51 & UJ & 2.61 & UJ & 4.44 & UJ & 2.41 & Uu & 2.46 & UJ & 2.51 & $u J$ & 1.35 & UJ & 2.17 & UJ & 2.32 & $\underline{U U}$ \\
\hline Beta & $\mathrm{ND}$ & $\ldots$ & ND & - & ND & --- & ND & - & $\mathrm{ND}$ & -- & ND & -- & 3.58 & -- & $\mathrm{ND}$ & $-\ldots$ & $\mathrm{ND}$ & -- & $\mathrm{ND}$ & - \\
\hline Sigma Error $+/-$ & & -- & & -- & & -- & & -- & & -- & & -- & 3.59 & --- & & $-\infty$ & & $-\infty$ & & -- \\
\hline MDA* & 5.63 & $\mathrm{u}$ & 6.67 & U & 5.16 & $\mathrm{U}$ & 6.23 & U & 4.63 & $u$ & 4.96 & $u$ & 4.94 & u & 4.98 & 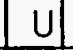 & 5.78 & $u$ & 4.89 & $\mathrm{U}$ \\
\hline
\end{tabular}


$\frac{\sqrt[\square]{\sigma}}{\frac{\pi}{\sigma}}$

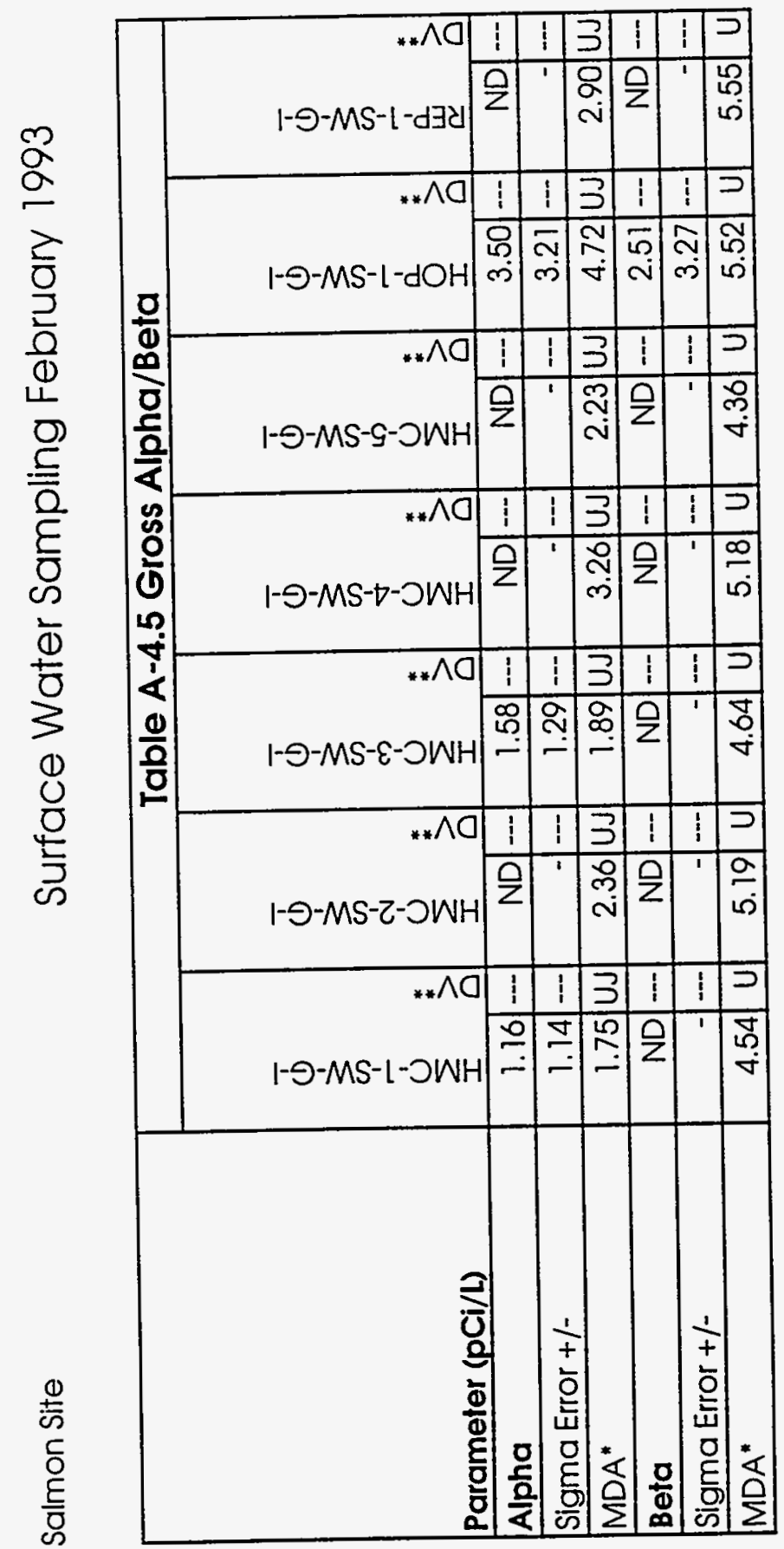




\begin{tabular}{|c|c|c|c|c|c|c|c|c|c|c|c|c|c|c|c|c|c|c|}
\hline \multirow[b]{2}{*}{ Nuclide (pCi/L) } & \multicolumn{18}{|c|}{ Table A-4.6 Gamma Spectroscopy } \\
\hline & $\begin{array}{l}\overline{0} \\
\frac{1}{3} \\
\frac{1}{1} \\
\frac{1}{1} \\
\text { 㟧 }\end{array}$ & 艾 & 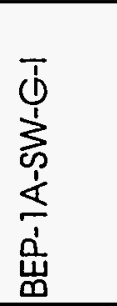 & $\stackrel{2}{3}$ & 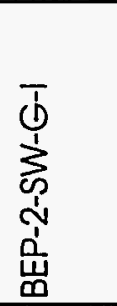 & ${ }^{*}$ & $\begin{array}{l}\bar{d} \\
\frac{1}{1} \\
\sum_{0}^{1} \\
\frac{1}{1} \\
\frac{1}{0} \\
0\end{array}$ & $\stackrel{2}{2^{*}}$ & $\begin{array}{l}\overline{1} \\
\text { 1 } \\
\sum_{0}^{1} \\
\frac{1}{1} \\
\dot{1} \\
\frac{1}{10}\end{array}$ & $\stackrel{*}{3}$ & 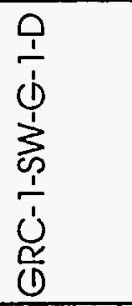 & ${ }^{*}$ & 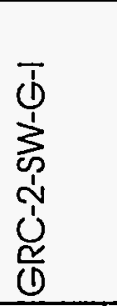 & $\stackrel{2}{*}^{*}$ & 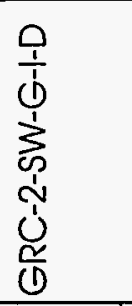 & 艾 & 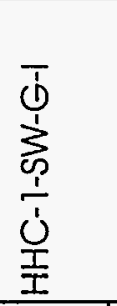 & $\stackrel{*}{*}$ \\
\hline $\operatorname{Tin} 113$ & & -- & & $\cdots$ & & -- & ND & -- & & -- & & - & 8.70 & $\cdots$ & ND & $\cdots$ & ND & -- \\
\hline Sigma Error +/- & & -- & & --- & & -- & 7 & $\cdots$ & & -- & & - & 2.10 & -- & +1 & --- & -7 & -- \\
\hline $\mathrm{MDA}^{*}$ & & -- & & -- & -1 & $\ldots-$ & 13.80 & U & & -- & 4 & -- & & -- & 15.40 & $\mathrm{U}$ & 11.00 & $\mathrm{U}$ \\
\hline Cesium 137 & ND & -- & ND & -- & ND & -- & ND & -- & ND & $\cdots$ & ND & -- & ND & -- & ND & -- & ND & -- \\
\hline Sigma Error + /- & & -- & - & $-\cdots$ & - & $-\cdots$ & - & -- & - & - & & -- & 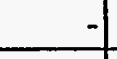 & $\cdots$ & -1 & -- & - & $-\cdots$ \\
\hline $\mathrm{MDA}^{*}$ & 13.05 & $\mathrm{U}$ & 10.97 & $U$ & 9.14 & $\mathrm{U}$ & 11.40 & $\mathrm{U}$ & 14.81 & $U$ & 13.43 & $\mathrm{U}$ & 8.20 & $U$ & 13.60 & $\mathrm{U}$ & 11.00 & $U$ \\
\hline
\end{tabular}




\begin{tabular}{|c|c|c|c|c|c|c|c|c|c|c|c|c|c|c|c|c|}
\hline \multirow[b]{2}{*}{ Nuclide (pCi/L) } & \multicolumn{16}{|c|}{ Table A-4.6 Gamma Spectroscopy } \\
\hline & 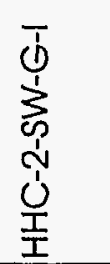 & 莡 & $\begin{array}{l}\bar{\Phi} \\
\sum_{0} \\
\vdots \\
\vdots \\
\vdots \\
\vdots\end{array}$ & $3^{*}$ & 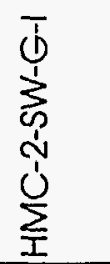 & 艾 & 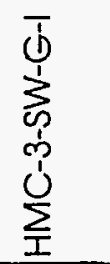 & $\stackrel{*}{*}$ & 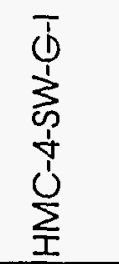 & 3 & 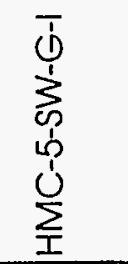 & ว & 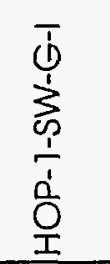 & 3 & 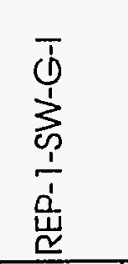 & $\overbrace{0}^{*}$ \\
\hline $\operatorname{Tin} 113$ & $\mathrm{ND}$ & -- & ND & --- & $\mathrm{ND}$ & $-\cdots$ & ND & $-\cdots$ & & $\ldots$ & ND & $-\ldots$ & & $-\cdots$ & $\mathrm{ND}$ & - \\
\hline Sigma Error +/- & & |- & & -- & & $-\ldots$ & & $\ldots$ & & $-\infty$ & & $\ldots$ & & $-\infty$ & & $-\ldots$ \\
\hline $\mathrm{MDA}^{*}$ & 8.50 & $u$ & 7.80 & $U$ & 11.90 & $\mathrm{U}$ & 7.10 & U & & - & 10.20 & U & & $-\cdots$ & 9.30 & 0 \\
\hline Cesium 137 & $\mathrm{ND}$ & $-\ldots$ & ND & $\ldots$ & $N D$ & $-{ }_{-}$ & ND & - & ND & --. & $\mathrm{ND}$ & $-{ }_{-}$ & $\mathrm{ND}$ & $-\ldots$ & $\mathrm{ND}$ & $-\infty$ \\
\hline Sigma Error +/- & & - & & - & & $-\ldots$ & & $\ldots$ & & - & & $-\infty$ & & $\ldots$ & & $\ldots$ \\
\hline$\overline{M D A^{*}}$ & 5.90 & $\mid \mathrm{u}$ & 6.90 & $u$ & 10.30 & $u$ & 7.30 & $u$ & 13.79 & $u$ & 10.40 & U & 10.00 & u & 7.50 & 0 \\
\hline
\end{tabular}




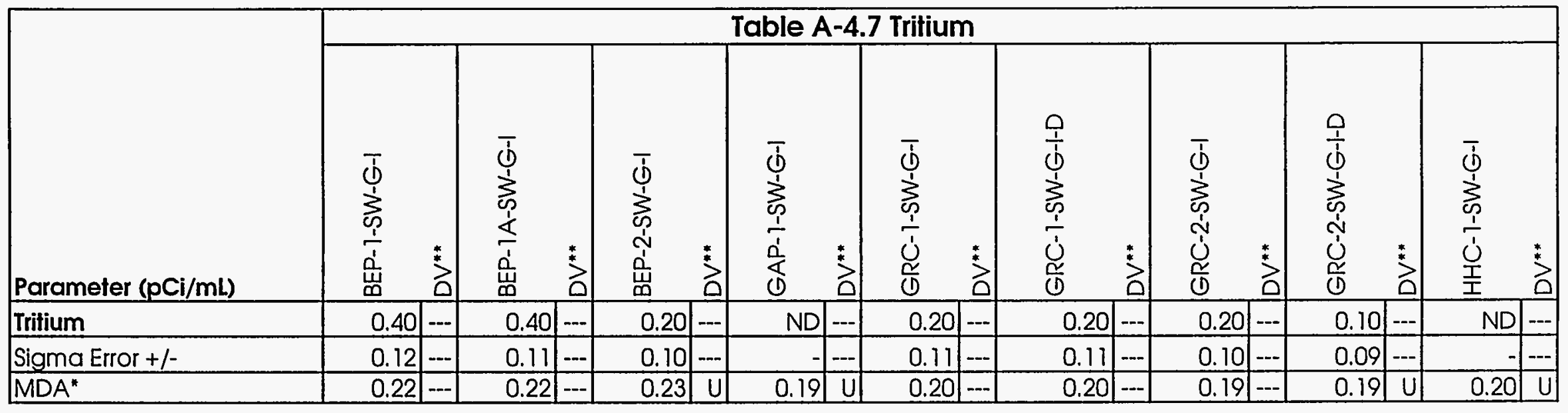


$\frac{\nabla}{\frac{\nabla}{\nabla}}$

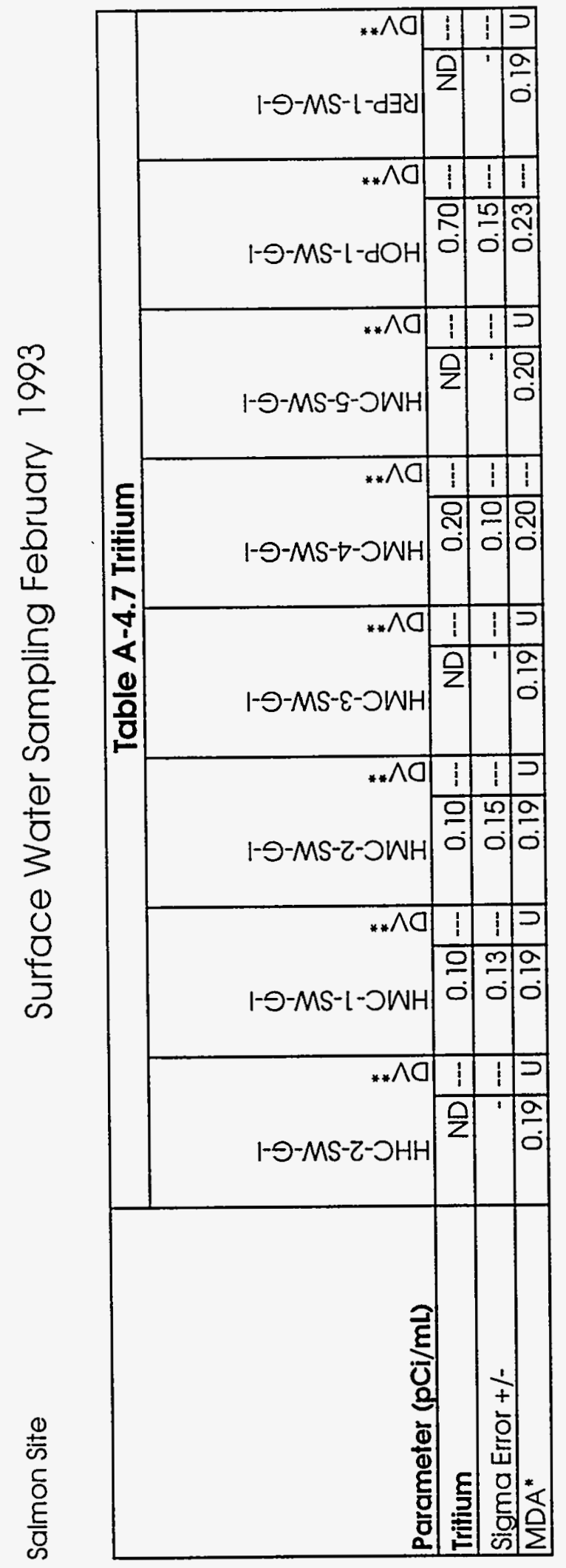

0
0
0
0
0

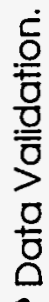




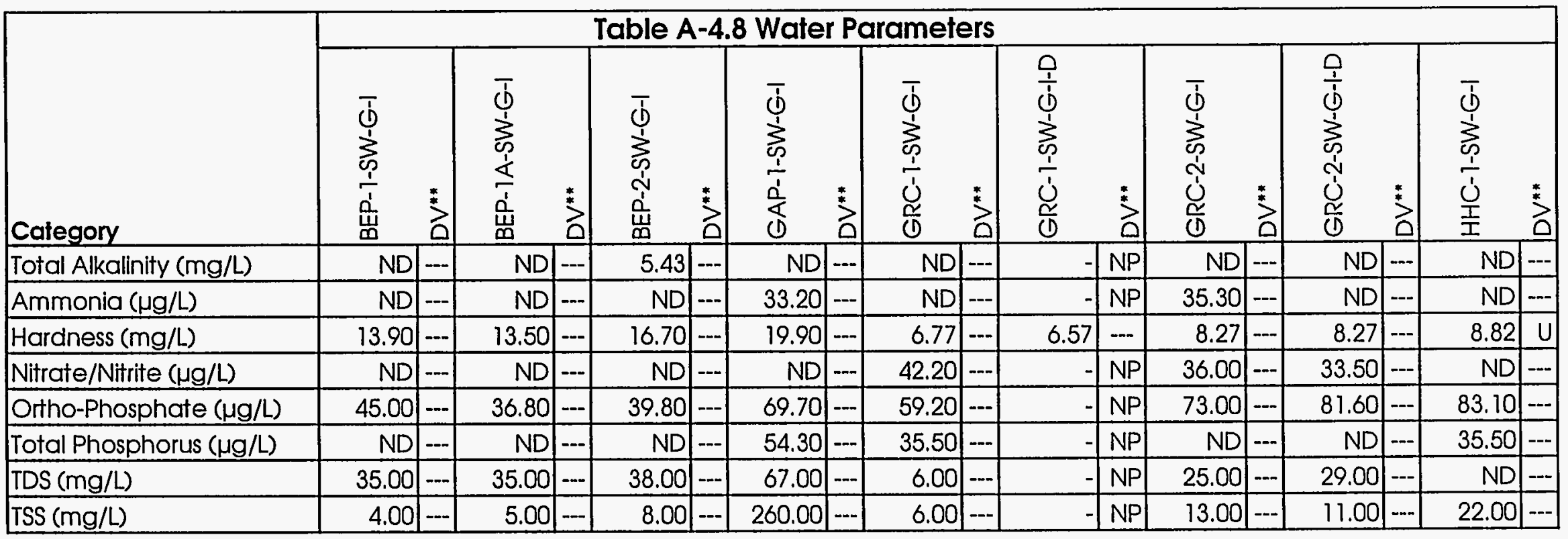




\begin{tabular}{|c|c|c|c|c|c|c|c|c|c|c|c|c|c|c|c|c|}
\hline \multirow[b]{2}{*}{ Category } & \multicolumn{16}{|c|}{ Table A-4.8 Wet Chemistry } \\
\hline & 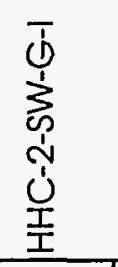 & 方 & 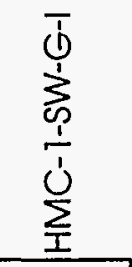 & $\stackrel{*}{0}$ & 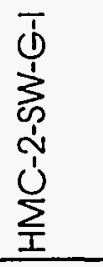 & $2^{*}$ & 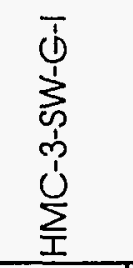 & $\stackrel{2}{0}^{*}$ & 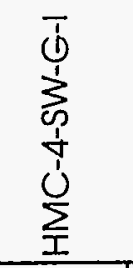 & $\stackrel{*}{2}$ & 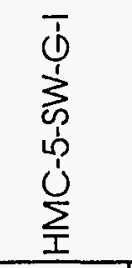 & $2^{*}$ & 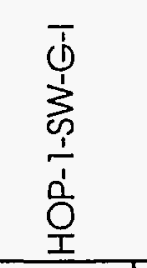 & $\stackrel{*}{*}$ & 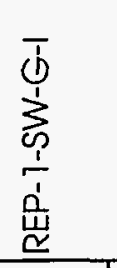 & 莒 \\
\hline Total Alkalinity (mg/L) & ND & -- & ND & -- & ND & $-\cdots$ & ND & $\ldots$ & ND & $-\infty$ & ND & --- & 5.33 & -- & ND & $-\cdots$ \\
\hline Ammonia $(\mu \mathrm{g} / \mathrm{L})$ & ND & -- & ND & -- & ND & $-\cdots$ & ND & -- & 34.70 & -- & ND & $-\cdots$ & 94.40 & -- & 76.90 & -- \\
\hline Hardness (mg/L) & 7.88 & -- & 9.65 & -- & 10.20 & -- & 10.20 & -- & 7.76 & -- & 11.80 & $\mathrm{U}$ & 78.40 & --- & 13.60 & -- \\
\hline Nitrate/Nitrite $(\mu \mathrm{g} / \mathrm{L})$ & ND & -- & 216.00 & --- & ND & -- & 198.00 & -- & 113.00 & --- & 112.00 & $-\cdots$ & ND & $\cdots$ & 21.10 & -- \\
\hline Ortho-Phosphate $(\mu \mathrm{g} / \mathrm{L})$ & 83.90 & -- & 93.60 & -- & 72.70 & $-\cdots$ & 65.20 & $\ldots$ & 60.00 & $-\ldots$ & 63.30 & -- & 47.30 & -- & 42.10 & $-\cdots$ \\
\hline Total Phosphorus $(\mu \mathrm{g} / \mathrm{L})$ & ND & -- & ND & -- & ND & -- & $\mathrm{ND}$ & -- & ND & -- & ND & -- & ND & -- & ND & -- \\
\hline TDS (mg/L) & 43.00 & -- & 14.00 & -- & 34.00 & -- & 23.00 & -- & 22.00 & -- & 36.00 & $-\cdots$ & 310.00 & -- & 18.00 & -- \\
\hline $\mathrm{TSS}(\mathrm{mg} / \mathrm{L})$ & 9.00 & -- & 3.00 & - & 6.00 & $-\ldots$ & 3.00 & $\ldots$ & 4.00 & $\ldots$ & 10.00 & -- & 18.00 & -- & 7.00 & $-\cdots$ \\
\hline
\end{tabular}




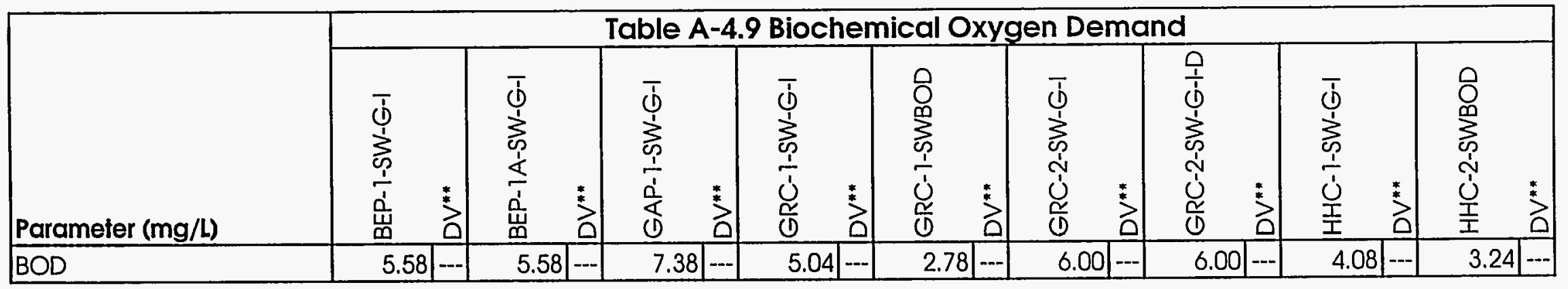




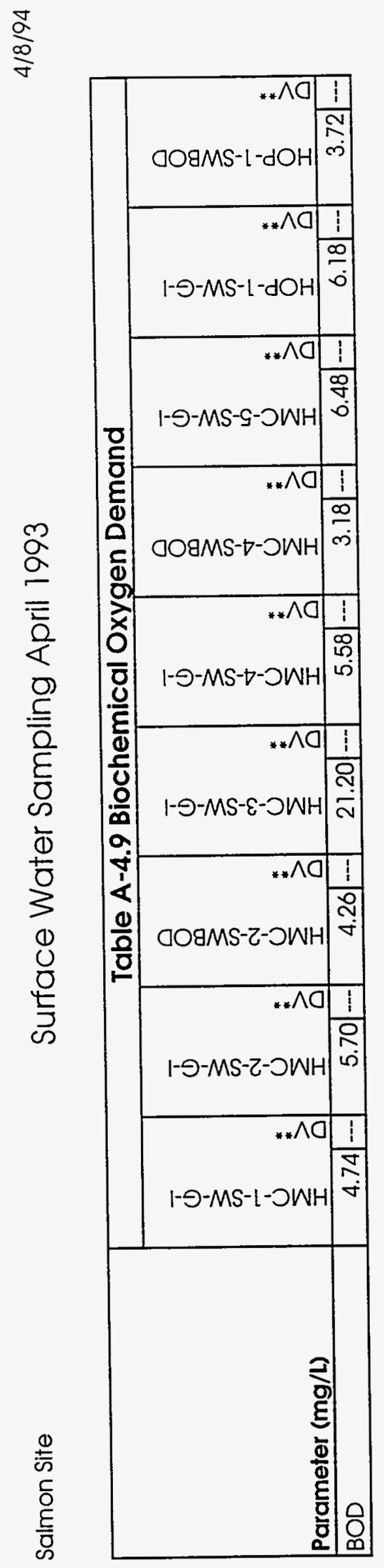

0
0
0
0
0 
$\frac{d}{d}$

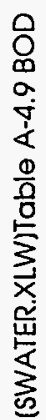

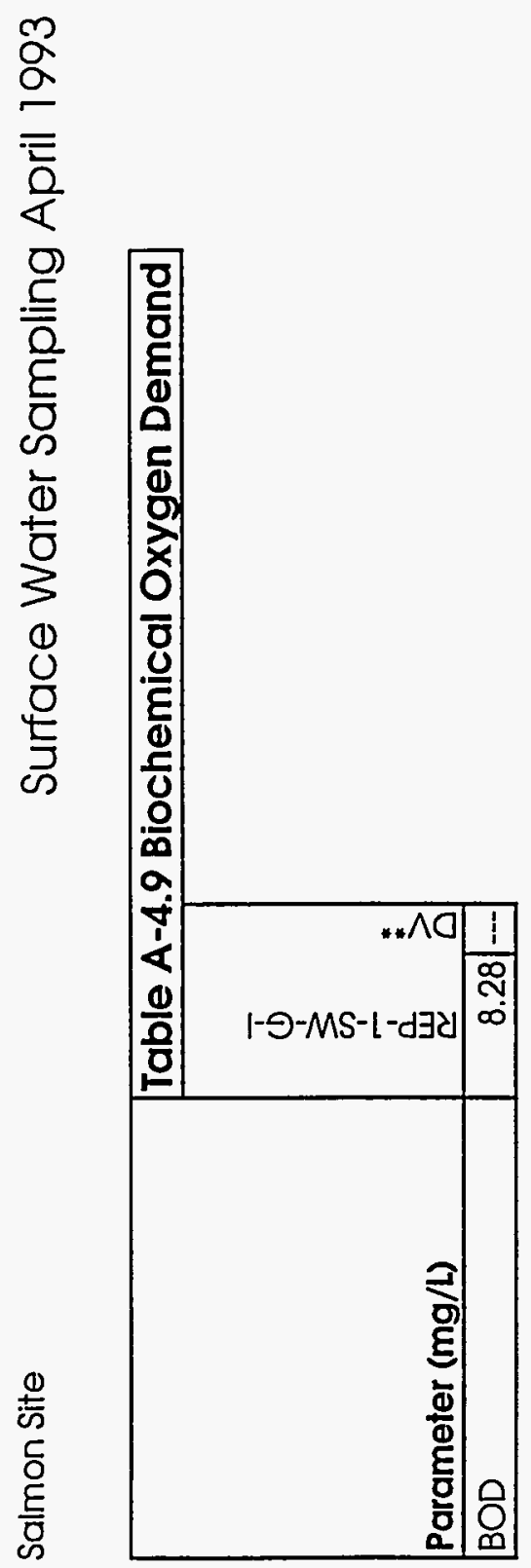


Table A-4. 10

Summary of 48-Hour Ceriodaphnid Acute Toxicity Tests

Conducted April 27 - 29, 1993

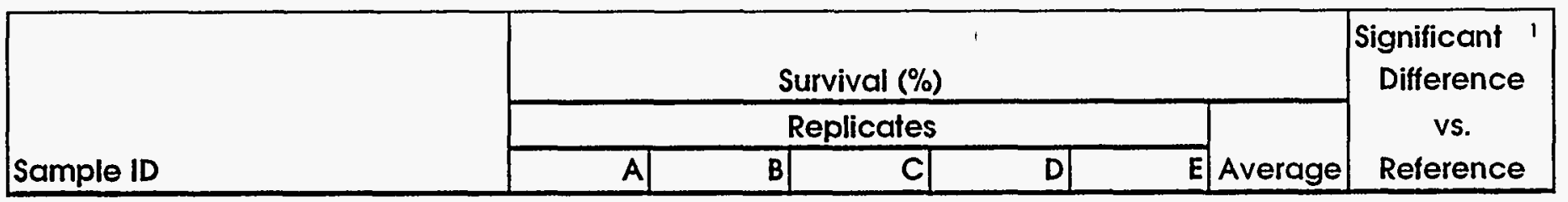

\begin{tabular}{|l|r|r|r|r|r|r|r|r|}
\hline CONTROL (laboratory) & 80 & 100 & 100 & 100 & 100 & 96 & NA \\
\hline Half Moon Creek Stations & 80 & 100 & 100 & 100 & 60 & 88 & NA \\
\hline HMC-1 (reference) & 100 & 100 & 100 & 100 & 100 & 100 & --- \\
\hline HMC-2 & 40 & 100 & 100 & 100 & 100 & 88 & $-\cdots$ \\
\hline HMC-3 & 80 & 100 & 100 & 100 & 80 & 92 & $\cdots$ \\
\hline HMC-4 & 100 & 80 & 100 & 100 & 80 & 92 & $\cdots$ \\
\hline HMC-5 &
\end{tabular}

Grantham Creek Stations

\begin{tabular}{|l|r|r|r|r|r|r|r|}
\hline GRC-1 (reference) & 100 & 40 & 100 & 100 & 100 & 88 & NA \\
\hline GRC-2 & 100 & 60 & 80 & 80 & 80 & 80 & $\ldots$ \\
\hline
\end{tabular}

Hickory Hollow Creek Stations

\begin{tabular}{|l|r|r|r|r|r|r|r|}
\hline$H H C-1$ (reference) & 80 & 40 & 60 & 60 & 60 & 60 & NA \\
\hline$H H C-2$ & 100 & 40 & 80 & 60 & 40 & 64 & -- \\
\hline
\end{tabular}

\section{Pond Stations}

REP-1 (reference)

BEP-1

BEP-IA

BEP-2

GAP-1

HOP-1

\begin{tabular}{|c|r|r|r|r|r|l|}
\hline 80 & 60 & 100 & 80 & 80 & 80 & NA \\
\hline 40 & 80 & 100 & 80 & 60 & 72 & $\cdots$ \\
\hline 40 & 60 & 60 & 80 & 60 & 60 & $\cdots$ \\
\hline 40 & 60 & 40 & 100 & 60 & 60 & $\cdots$ \\
\hline 80 & 60 & 80 & 40 & 40 & 60 & $\cdots$ \\
\hline 40 & 60 & 40 & 80 & 80 & 60 & $\cdots$ \\
\hline
\end{tabular}

1 An asterisk (") indicates sample survival is significantly less than respective reference survival at the $95 \%$ confidence level.

A dash (-) indicates no difference. 
Table A-4.11

Summary of 48-Hour Fathead Minnow Acute Toxicity Tests

Conducted April 27 - 29, 1993

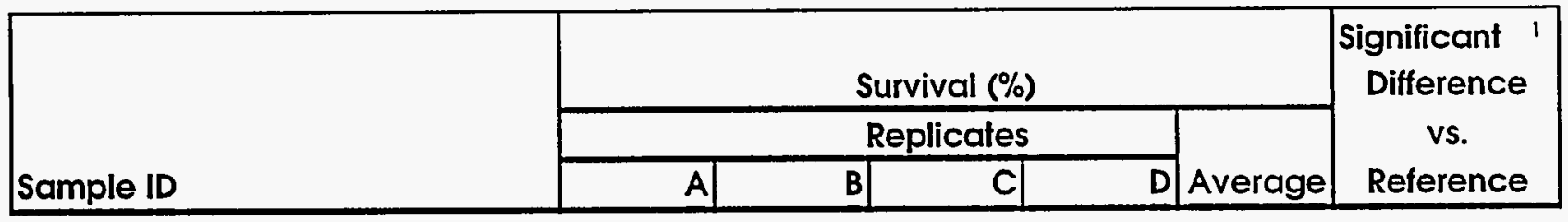

\begin{tabular}{|l|r|r|r|r|r|r|r|}
\hline CONTROL (laboratory) & 100 & 100 & 100 & 100 & 100 & NA \\
\hline Half Moon Creek Stations & 100 & 100 & 100 & 100 & 100 & NA \\
\hline HMC-1 (reference) & 100 & 100 & 100 & 100 & 100 & $\ldots$ \\
\hline HMC-2 & 100 & 80 & 100 & 100 & 95 & $\ldots$ \\
\hline HMC-3 & 100 & 100 & 100 & 100 & 100 & $\ldots$ \\
\hline HMC-4 & 100 & 100 & 100 & 100 & 100 & $\ldots$ \\
\hline HMC-5 &
\end{tabular}

Grantham Creek Stations

\begin{tabular}{|l|r|r|r|r|r|c|}
\hline GRC-1 (reference) & 100 & 100 & 80 & 100 & 95 & NA \\
\hline GRC-2 & 100 & 100 & 100 & 100 & 100 & -- \\
\hline
\end{tabular}

Hickory Hollow Creek Stations

\begin{tabular}{|l|r|r|r|r|r|c|}
\hline HHC-1 (reference) & 100 & 100 & 100 & 100 & 100 & NA \\
\hline HHC-2 & 100 & 100 & 100 & 100 & 100 & -- \\
\hline
\end{tabular}

\section{Pond Stations}

\begin{tabular}{|l|r|r|r|r|r|c|}
\hline REP-1 (reference) & 100 & 100 & 100 & 100 & 100 & NA \\
\hline BEP-1 & 100 & 100 & 100 & 100 & 100 & -- \\
\hline BEP-1A & 100 & 100 & 100 & 100 & 100 & $\cdots$ \\
\hline BEP-2 & 100 & 100 & 100 & 100 & 100 & $\cdots$ \\
\hline GAP-1 & 100 & 100 & 100 & 100 & 100 & $\cdots$ \\
\hline HOP-1 & 100 & 100 & 100 & 100 & 100 & $\cdots$ \\
\hline
\end{tabular}

1 An asterisk (") indicates sample survival is significantly less than respective reference survival at the $95 \%$ confidence level.

A dash (-) indicates no difference. 


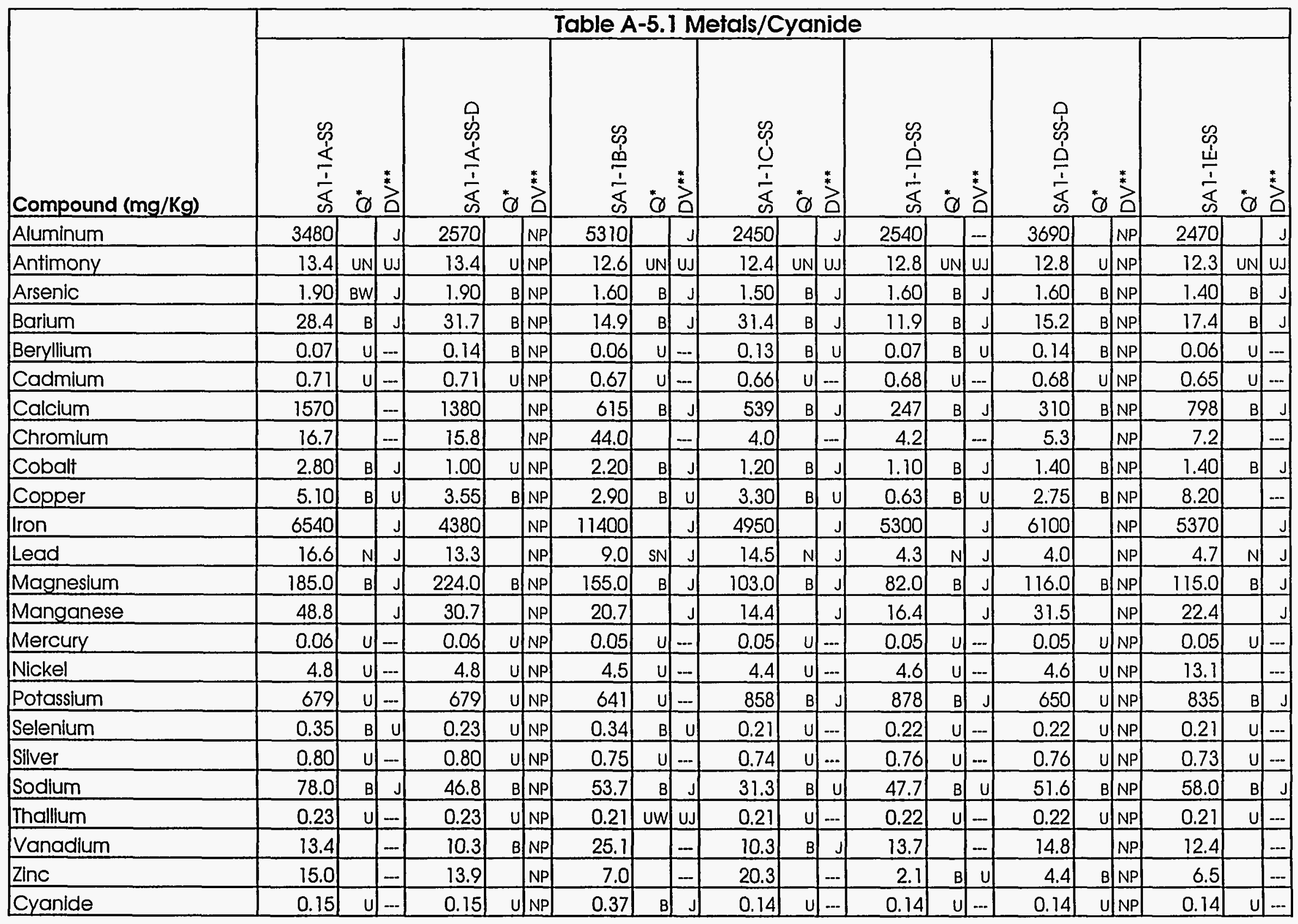

" Data Qualifier. " "Data Validation. 


\begin{tabular}{|c|c|c|c|c|c|c|c|c|c|c|c|c|c|c|c|c|c|c|c|c|c|}
\hline Compound (mg/Kg) & \multicolumn{21}{|c|}{ Table A-5.1 Metals/Cyanide } \\
\hline Arsenic & 1.80 & $B$ & $\sqrt{ }$ & 2.00 & $\mathrm{~B}$ & J & 2.10 & $B$ & J & 3.20 & & $\ldots$ & 11.90 & & $\ldots$ & 1.80 & $\mathrm{~B}$ & $\mathrm{~J}$ & 1.80 & $\mathrm{~B}$ & $\mathrm{~J}$ \\
\hline Barium & 6.1 & $\mathrm{~B}$ & $\mathrm{~J}$ & 7.8 & $\mathrm{~B}$ & J & 7.7 & $\mathrm{~B}$ & J & 14.0 & $\mathrm{~B}$ & J & 16.9 & $\mathrm{~B}$ & J & 19.8 & B & $\mathrm{J}$ & 10.7 & B) & $\mathrm{J}$ \\
\hline Beryllium & 0.07 & u. & -- & 0.07 & 4 & -- & 0.06 & $\underline{4}$ & - & 0.07 & $u$ &.- & 0.14 & B) & $u$ & 0.08 & U & $\ldots$ & 0.13 & $\mathrm{~B}$ & $u$ \\
\hline Cadmium & 0.68 & 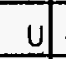 & $-\ldots$ & 0.72 & 4 & $\ldots$ & 0.67 & U & $-\ldots$ & 0.73 & 4 & $\ldots$ & 0.71 & u. & $\ldots-$ & 0.79 & 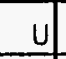 & $\ldots$ & 0.67 & u. & $\ldots$ \\
\hline Calcium & 162 & $B$ & J & 172 & $B$ & $\mathrm{~J}$ & 230 & 8 & J & 249 & 8 & J & 667 & $\mathrm{~B}$ & $\mathrm{~J}$ & 184 & $B$ & $\mathrm{~J}$ & 182 & B & $\mathrm{J}$ \\
\hline Iron & 6400 & & $\mathrm{~J}$ & 6610 & & J & 5130 & & $J$ & 5260 & & $\mathrm{~J}$ & 6960 & & J & 4530 & & $\mathrm{~J}$ & 9080 & & $\mathrm{~J}$ \\
\hline Lead & 2.8 & $N$ & $\mathrm{~J}$ & 5.2 & $N$ & J & 3.5 & $\mathrm{~N}$ & $\mathrm{~J}$ & 16.7 & $\mathrm{~N}$ & J & 5.9 & $\mathrm{~N}$ & uJ & 9.7 & $N$ & $\mathrm{~J}$ & 5.2 & $\mathrm{~N}$ & UJ \\
\hline Magnesium & 83.1 & $\mathrm{~B}$ & $\mathrm{~J}$ & 97.2 & 8 & J & 106.0 & $B$ & J & 109.0 & $B$ & $\mathrm{~J}$ & 190.0 & $\mathrm{~B}$ & $\mathrm{~J}$ & 97.9 & $B$ & $\mathrm{~J}$ & 138.0 & 8 & $\mathrm{~J}$ \\
\hline Manganese & 9.1 & & J & 13.2 & & $\mathrm{~J}$ & 14.9 & & $\mathrm{~J}$ & 23.1 & & $\mathrm{~J}$ & 47.3 & & J & 10.5 & & $\mathrm{~J}$ & 26.5 & & 1 \\
\hline Mercury & 0.05 & $u$ & - & 0.06 & 4 & $\ldots$ & 0.05 & $u$ & $\ldots$ & 0.06 & 4 & $\ldots$ & 0.29 & & $\ldots$ & 0.06 & U & $\ldots$ & 0.05 & $u$ & $=$ \\
\hline Nickel & 4.6 & $u$ & - & 4.8 & 4 & $\ldots$ & 4.5 & u & $\ldots$ & 4.9 & $u$ & $\ldots$ & 4.8 & $\mathrm{u}$ &.- & 5.3 & $u$ & $\ldots$ & 4.5 & $\mathrm{u}$ & $\ldots$ \\
\hline Potassium & 654 & $u$ & -- & 689 & U &.-- & 644 & 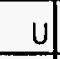 &.- & 702 & 4 & $\ldots$ & 687 & u. & $\ldots$ & 761 & U & $\ldots$ & 641 & $u$ & - \\
\hline Selenium & 0.22 & 4 & -- & 0.23 & 4 & -- & 0.22 & $u$ & - & 0.24 & U & $\ldots$ & 0.23 & 4 & $\ldots$ & 0.26 & uW & UJ & 0.21 & $u$ & $\ldots$ \\
\hline Silver & 0.77 & 4 & $-\ldots$ & 0.81 & $u$ & $\ldots$ & 0.76 & $u$ & $\ldots$ & 0.82 & $u$ & $\ldots$ & 0.81 & 4. & $\ldots$ & 0.89 & $u$ & $\ldots$ & 0.75 & 4 & - \\
\hline Sodium & 37.4 & $B$ & $\mathrm{u}$ & 33.2 & B & $\mathrm{u}$ & 45.4 & B & $\mathrm{U}$ & 41.1 & B & $u$ & 49.5 & 8 & $U$ & 45.7 & B & $\mathrm{u}$ & 30.4 & 8 & $\mathrm{u}$ \\
\hline Thallium & 0.22 & $u$ & - & 0.23 & 4 & - & 0.22 & $u$ & - & 0.24 & 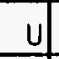 & $\ldots$ & 0.23 & u. & - & 0.26 & $u$ & $\ldots$ & 0.21 & $u$ & $=$ \\
\hline
\end{tabular}


Table A-5.1 Metals/Cyanide

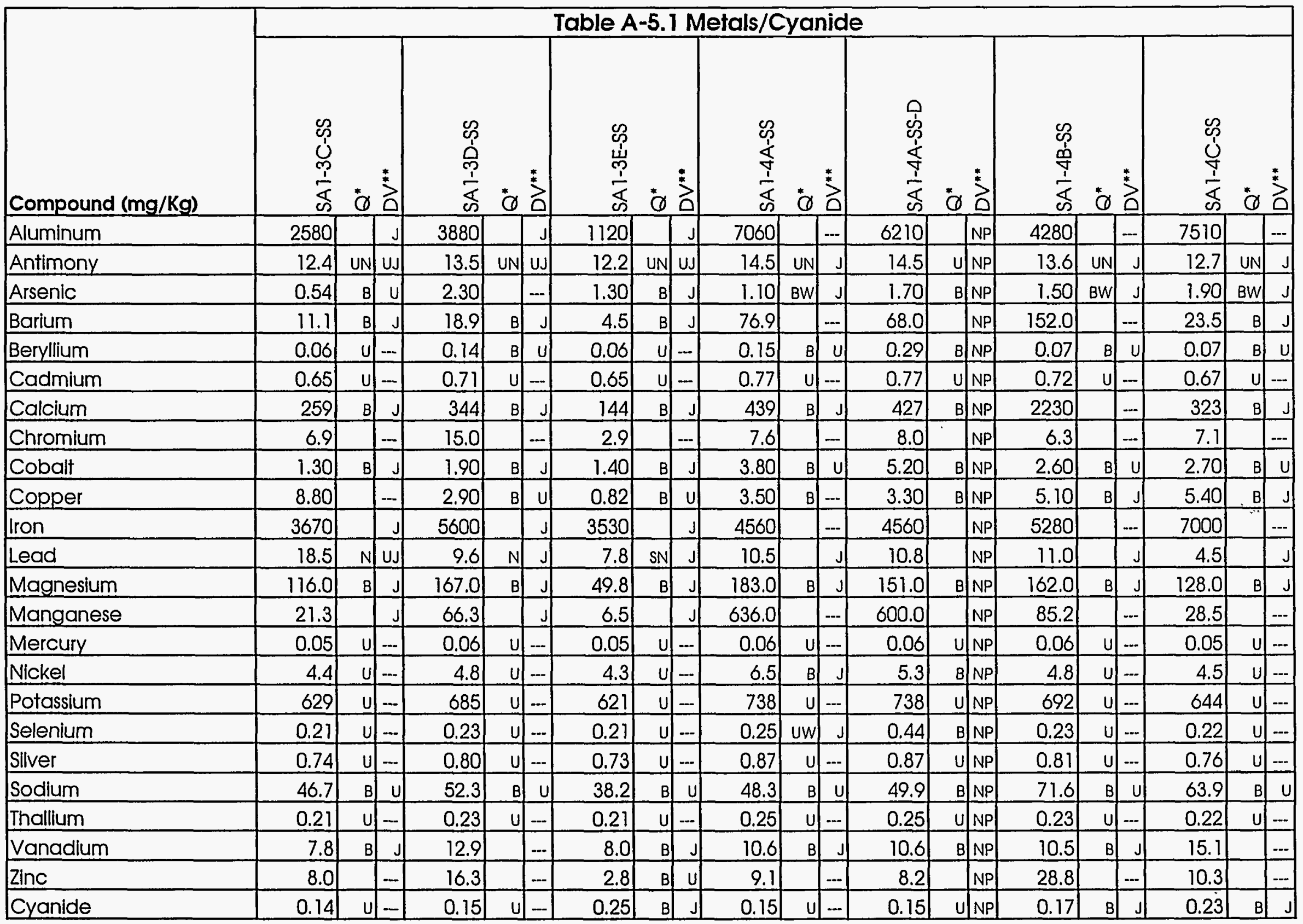




\begin{tabular}{|c|c|c|c|c|c|c|c|c|c|c|c|c|c|c|c|c|c|c|c|c|c|}
\hline \multirow[b]{2}{*}{ Compound (mg/Kg) } & \multicolumn{21}{|c|}{ Table A-5.1 Metals/Cyanide } \\
\hline & 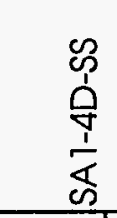 & & & 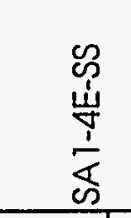 & $\stackrel{*}{Q}$ & & 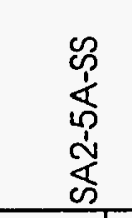 & $\stackrel{*}{Q}$ & & 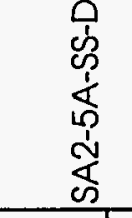 & & & 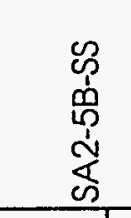 & ${ }^{*}$ & $\stackrel{*}{*}$ & 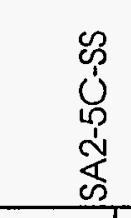 & & $\begin{array}{l}{ }^{*} \\
\mathrm{D}\end{array}$ & 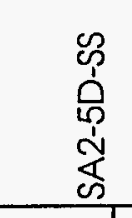 & & \\
\hline Aluminum & 4710 & & $\ldots$ & 6900 & & $\ldots$ & 4670 & & $\ldots$ & 4440 & & $\mathrm{NP}$ & 4190 & & $\ldots$ & 9210 & & $-\ldots$ & 3430 & & $\ldots$ \\
\hline Antimony & 13.7 & UN & J & 14.6 & $\mathrm{UN}$ & $\mathrm{J}$ & 13.8 & UN & UJ & 13.8 & $U N$ & $\mathrm{NP}$ & 13.6 & UN & UJ & 14.0 & UN & UJ & 12.9 & UN & uJ \\
\hline Arsenic & 1.20 & $\mathrm{BW}$ & $\mathrm{J}$ & 2.60 & s & -- & 1.30 & $8 W$ & $\mathrm{~J}$ & 1.40 & & $\mathrm{NP}$ & 2.20 & $\mathrm{BW}$ & $\mathrm{J}$ & 4.00 & s. & $\ldots$ & 1.40 & BW & $\mathrm{s}$ \\
\hline Barium & 27.2 & $\mathrm{~B}$ & $\mathrm{~J}$ & 208.0 & & - & 43.8 & $B$ & $\mathrm{~J}$ & 42.4 & & $N P$ & 38.4 & $B$ & $J$ & 22.4 & $\mathrm{~B}$ & $\mathrm{~J}$ & 19.6 & $B$ & 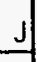 \\
\hline Beryllium & 0.07 & 4 & - & 0.07 & $\mathrm{~B}$ & $\mathrm{~J}$ & 0.27 & $B$ & $\mathrm{~J}$ & 0.27 & $B N$ & $\mathrm{NP}$ & 0.27 & B & $J$ & 0.28 & 8 & J & 0.07 & 4 & 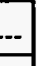 \\
\hline Cadmium & 0.72 & $u$ & $\ldots$ & 0.77 & $u$ & $\ldots$ & 0.73 & $u$ & $\ldots$ & 0.73 & $\cup N$ & $\mathrm{NP}$ & 0.72 & $u$ & -- & 0.74 & $u$. & $\ldots$ & 0.68 & $u$ & - \\
\hline Calcium & 250 & $B$ & $\mathrm{~J}$ & 1350 & & - & 814 & $\mathrm{BE}$ & $\mathrm{J}$ & 785 & $B N$ & $\mathrm{NP}$ & 1790 & E & $\mathrm{J}$ & 676 & $\mathrm{BE}$ & J & 406 & $\mathrm{BE}$ & J \\
\hline Chromium & 6.9 & & $\ldots$ & 13.8 & & $\ldots$ & 6.9 & & $\ldots$ & 5.0 & & $\mathrm{NP}$ & 6.6 & & $-\infty$ & 7.7 & & - & 3.9 & & - \\
\hline Cobalt & 3.60 & $B$ & $\mathrm{U}$ & 5.90 & $B$ & 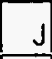 & 7.10 & 8 & 1 & 8.80 & $B N$ & $\mathrm{NP}$ & 4.10 & $\mathrm{~B}$ & $u$ & 3.70 & B & $u$ & 3.50 & B & $u$ \\
\hline Copper & 2.70 & $B$ & $\mathrm{u}$ & 8.80 & & - & 0.61 & UN & $\ldots$ & 0.61 & $U N$ & $\mathrm{NP}$ & 1.20 & $\mathrm{BN}$ & $\mathrm{J}$ & 0.62 & UN & $\ldots$ & 0.57 & UN & - \\
\hline Iron & 4640 & & $\ldots$ & 6110 & & $\ldots$ & 4750 & & $\ldots$ & 4730 & & $\mathrm{NP}$ & 7810 & & $\ldots$ & 11500 & & $\ldots$ & 4270 & & $\ldots$ \\
\hline Lead & 5.9 & & $\mathrm{~J}$ & 16.0 & & J & 10.2 & & $-\ldots$ & 10.9 & & $\mathrm{NP}$ & 18.4 & & $\ldots$ & 10.0 & & $\ldots$ & 7.3 & & $\ldots$ \\
\hline Magnesium & 122.0 & $B$ & J & 156.0 & $\mathrm{~B}$ & J & 252.0 & B & J & 228.0 & $B$ & $\mathrm{NP}$ & 351.0 & B & $J$ & 615.0 & B & J & 183.0 & $B$ & $\mathrm{~J}$ \\
\hline Manganese & 247.0 & & $\ldots$ & 581.0 & & - & 956.0 & & $-\infty$ & 994.0 & & $N P$ & 482.0 & & $\ldots$ & 31.1 & & $\ldots$ & 274.0 & & $\ldots$ \\
\hline Mercury & 0.08 & $B$ & $u$ & 0.06 & $u$ & - & 0.11 & $B$ & $J$ & 0.12 & & $N P$ & 0.07 & B & $J$ & 0.06 & 4 & $\ldots$ & 0.06 & 4 & $\cdots$ \\
\hline Nickel & 5.8 & $B$ & $\ldots$ & 5.2 & $u$ & - & 4.9 & $u$ & -- & 4.9 & 41 & $\mathrm{NP}$ & 4.8 & $u$ & $\ldots$ & 5.0 & 4 & $\ldots$ & 4.6 & u & -- \\
\hline Potassium & 696 & 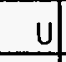 & $\ldots$ & 765 & B & J & 699 & $\mathrm{u}$ & - & 699 & $U 1$ & $\mathrm{NP}$ & 690 & $u$ & $\ldots$ & 710 & 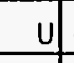 & $\ldots$ & 657 & 4 & $\ldots$ \\
\hline Selenium & 0.23 & 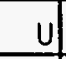 & - & 0.25 & $\mathrm{U}$ & -- & 0.26 & $B$ & $u$ & 0.23 & Ui & $N P$ & 0.23 & $u$ & - & 0.24 & $u$ & $\ldots$ & 0.22 & U & - \\
\hline Silver & 0.82 & $u$ & $\ldots$ & 0.87 & $\mathrm{U}$ & -- & 0.82 & 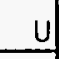 & - & 0.82 & 41 & $\mathrm{NP}$ & 0.81 & $u$ & -- & 0.83 & 4 & $-\ldots$ & 0.77 & $u$ & -- \\
\hline Sodium & 40.0 & $\mathrm{~B}$ & $U$ & 154.0 & $B$ & $\mathrm{~J}$ & 71.2 & $\mathrm{~B}$ & $u$ & 53.5 & $B \perp$ & NP & 46.9 & B & $u$ & 70.3 & 8 & $u$ & 70.5 & B & $\mathrm{U}$ \\
\hline Thallium & 0.23 & $u$ & - & 0.25 & $\mathrm{U}$ & $=$ & 0.23 & $u$ & $-\infty$ & 0.23 & 41 & $\mathrm{NP}$ & 0.23 & 4 & -- & 0.27 & $\mathrm{~B}$ & J & 0.22 & UW & UJ \\
\hline Vanadium & 9.9 & $\mathrm{~B}$ & $\mathrm{~J}$ & 11.4 & $B$ & $\mathrm{~J}$ & 9.2 & $\mathrm{~B}$ & $\mathrm{~J}$ & 9.4 & $B$ & NP & 11.0 & $B$ & $\mathrm{~J}$ & 17.3 & & $\ldots$ & 8.5 & B & 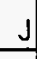 \\
\hline Zinc & 8.5 & & - & 31.8 & & - & 7.3 & $N$ & $\mathrm{~J}$ & 19.5 & & $\mathrm{NP}$ & 11.9 & $\mathrm{~N}$ & J & 9.1 & $N$ & $\mathrm{uJ}_{\mathrm{J}}$ & 8.5 & $\mathrm{~N}$ & - \\
\hline Cyanide & 0.13 & $B$ & - & 0.14 & $\mathrm{u}$ & - & 0.15 & $u$ & - & 0.15 & uा & $\mathrm{NP}$ & 0.18 & $B$ & $\mathrm{~J}$ & 0.15 & & $\ldots$ & 0.14 & & $\ldots$ \\
\hline
\end{tabular}




\begin{tabular}{|c|c|c|c|c|c|c|c|c|c|c|c|c|c|c|c|c|c|c|c|c|c|}
\hline \multirow[b]{2}{*}{ Compound $(\mathrm{mg} / \mathrm{Kg})$} & \multicolumn{21}{|c|}{ Table A-5.1 Metals/Cyanide } \\
\hline & 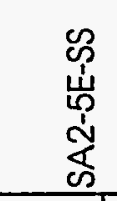 & ¿ & & 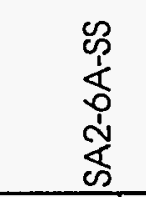 & & & 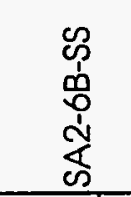 & & 莡 & 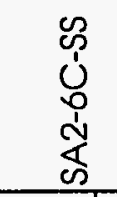 & $\stackrel{*}{\emptyset}$ & & 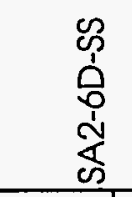 & & 艾 & 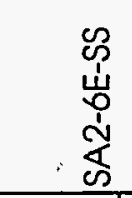 & & 艾 & \multicolumn{3}{|c|}{ 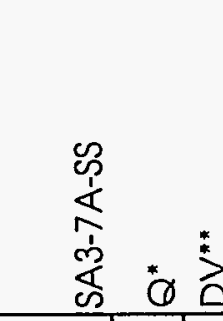 } \\
\hline Aluminum & 6360 & & $-\ldots$ & 3730 & & $\ldots$ & 2950 & & -- & 1610 & & - & 2890 & & -- & 1910 & & -- & 5050 & & - \\
\hline Antimony & 13.6 & UN & UJ & 13.6 & UN & UJ & 12.6 & UN & $\mathrm{R}$ & 12.2 & UN & $R$ & 12.7 & UN & $R$ & 12.9 & UN & $\mathrm{R}$ & 13.7 & $u-$ & $\ldots$ \\
\hline Arsenic & 2.20 & BW & J & 0.75 & $B$ & $\mathrm{~J}$ & 0.82 & $B$ & $\mathrm{~J}$ & 1.60 & 8 & J & 0.78 & $\mathrm{~B}$ & J & 2.20 & $\mathrm{~B}$ & $\mathrm{~J}$ & 2.50 & & - \\
\hline Barium & 26.3 & $B$ & $\mathrm{~J}$ & 26.6 & $\mathrm{~B}$ & $\mathrm{~J}$ & 7.5 & $B$ & $\mathrm{~J}$ & 4.2 & $\mathrm{~B}$ & J & 6.1 & $\mathrm{~B}$ & $\mathrm{~J}$ & 14.2 & 8 & $\mathrm{~J}$ & 41.6 & $\mathrm{~B}$ & J \\
\hline Beryllium & 0.27 & $B$ & $\mathrm{~J}$ & 0.07 & $u$ & $\ldots$ & 0.06 & u. & $\ldots$ & 0.06 & $u$ & $\ldots$ & 0.07 & U. & -- & 0.07 & $u$ & - & 0.37 & $B$ & $\mathrm{U}$ \\
\hline Cadmium & 0.72 & $U$ & $\ldots$ & 0.72 & $u$ & - & 1.40 & & $\ldots$ & 0.64 & $u$ & $\ldots$ & 0.67 & $u$ & $\ldots$ & 0.68 & $u$ & - & 0.72 & $\mathrm{U}$. & $\ldots$ \\
\hline Calcium & 409 & $\mathrm{BE}$ & J & 484 & $B$ & J & 299 & 8 & J & 204 & $B$ & $\mathrm{~J}$ & 150 & $B$ & 1 & 255 & $B$ & $\mathrm{~J}$ & 572 & $B$ & 1 \\
\hline Chromium & 6.9 & & $-\ldots$ & 6.4 & & - & 4.5 & & $\ldots$ & 3.8 & & $\ldots$ & 4.7 & &.- & 2.2 & $B$ & 3 & 12.4 & & $\ldots$ \\
\hline Cobalt & 9.30 & B & $\mathrm{J}$ & 6.00 & $B$ & J & 1.10 & 8 & J & 2.30 & $B$ & 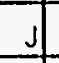 & 1.60 & 8 & 1 & 2.30 & $B$ & J & 7.20 & $\mathrm{~B}$ & $\mathrm{~J}$ \\
\hline Copper & 0.60 & UN & - & 1.40 & $B$ & $\mathrm{~J}$ & 1.50 & $B$ & $u$ & 1.30 & $\mathrm{~B}$ & $\mathrm{u}$ & 1.80 & $\mathrm{~B}$ & $u$ & 0.57 & $u$ & $\ldots$ & 4.70 & BE 1 & UJ \\
\hline Iron & 9260 & & $-\ldots$ & 5130 & & $\ldots$ & 4890 & & $\ldots$ & 3720 & & - & 5270 & & $-\ldots$ & 3940 & & -- & 6700 & & - \\
\hline Lead & 12.1 & & -- & 8.1 & & $\ldots$ & 4.6 & & $-\ldots$ & 18.4 & & - & 12.3 & & - & 8.5 & & $\ldots$ & 14.5 & & -- \\
\hline Magnesium & 286.0 & 8 & J & 190.0 & $B$ & $\mathrm{~J}$ & 94.9 & $B$ & J & 68.7 & 8 & J & 83.4 & $B$ & $\mathrm{~J}$ & 84.2 & B & J & 248.0 & 8 & $\mathrm{~J}$ \\
\hline Manganese & 202.0 & & -- & 564.0 & & -- & 41.6 & & $\ldots$ & 21.1 & & - & 18.7 & & - & 278.0 & & $\ldots$ & 696.0 & & J \\
\hline Mercury & 0.06 & $u$ & $-\ldots$ & 0.06 & $u$ & $\ldots$ & 0.05 & $u$ & $\ldots$ & 0.05 & $u$ & $\ldots$ & 0.05 & $u$ & - & 0.05 & $u$ & $\ldots$ & 0.06 & $\mathrm{U}$ & $\ldots$ \\
\hline Nickel & 4.8 & 4 & $-\ldots$ & 4.8 & $U$ & -- & 4.5 & 4 & $\ldots$ & 4.3 & $u$ & $\ldots$ & 4.5 & $u$ & $\ldots$ & 4.6 & 4 & $-\infty$ & 4.9 & $u$. & $\ldots$ \\
\hline Potassium & 691 & $\mathrm{u}$ & $\ldots$ & 690 & $u$ & $\ldots$ & 641 & 4 & $\ldots$ & 620 & $u$ & $\ldots$ & 646 & $\mathrm{U}$ & $\ldots$ & 653 & $u$ & - & 697 & $u$ & $\ldots$ \\
\hline Selenium & 0.23 & $\mathrm{u}$ & $\ldots$ & 0.56 & $\mathrm{BN}$ & UJ & 0.21 & UN & $\mathrm{UJ}$ & 0.21 & UN & UJ & 0.22 & UN & UJ & 0.23 & $\mathrm{BN}$ & UJ & 0.23 & UWN & UJ \\
\hline Silver & 0.81 & $u$ & $\ldots$ & 0.81 & U & $-\ldots$ & 0.75 & $u$ & $\ldots$ & 0.73 & $u$ & $\ldots$ & 0.76 & $u$ &.- & 0.77 & $u$ & $\ldots$ & 0.82 & $u$ & $-\ldots$ \\
\hline Sodium & 44.1 & $\mathrm{~B}$ & $\mathrm{u}$ & 49.0 & $\mathrm{~B}$ & $\mathrm{u}$ & 44.0 & B & $\mathrm{u}$ & 38.7 & B & $u$ & 47.4 & $B$ & $U$ & 25.8 & B & $u$ & 44.1 & $\mathrm{~B}$ & U \\
\hline Thallium & 0.26 & $B W$ & $\mathrm{~J}$ & 0.23 & U & - & 0.21 & 4 & $\ldots$ & 0.21 & 4 & -- & 0.22 & 4 & $\ldots$ & 0.22 & 4 & $\ldots$ & 0.23 & $u$. & --- \\
\hline Vanadium & 17.4 & & - & 10.6 & $B$ & $\mathrm{~J}$ & 10.5 & $B$ & $\mathrm{~J}$ & 8.0 & $\mathrm{~B}$ & 1 & 10.6 & $\mathrm{~B}$ & $\mathrm{~J}$ & 8.4 & 8 & $\mathrm{~J}$ & 14.1 & & $-\cdots$ \\
\hline Zinc & 5.9 & $N$ & Uu & 4.2 & $B$ & $\mathrm{~J}$ & 5.2 & & - & 4.1 & B & J & 3.8 & B & $u$ & 2.7 & $B$ & 4 & 5.3 & & U \\
\hline Cyanide & 0.15 & $\mathrm{U}$ & $\ldots$ & 0.15 & $u$ & $\ldots$ & 0.14 & $u$ & $\ldots$ & 0.14 & $\mathrm{~B}$ & $\mathrm{~J}$ & 0.14 & 0 & - & 0.14 & u) & $\ldots$ & 0.13 & $\mathrm{u}$ & - \\
\hline
\end{tabular}




\begin{tabular}{|c|c|c|c|c|c|c|c|c|c|c|c|c|c|c|c|c|c|c|c|c|c|}
\hline \multirow[b]{2}{*}{ Compound (mg/Kg) } & \multicolumn{21}{|c|}{ Table A-5.1 Metals/Cyanide } \\
\hline & 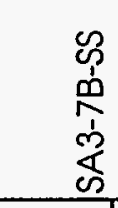 & $\stackrel{*}{\varnothing}$ & 莒 & 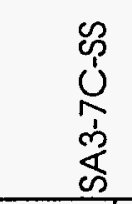 & $\stackrel{*}{\varnothing}$ & & 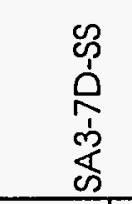 & $\stackrel{*}{\square}$ & 䓪 & 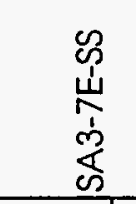 & & & 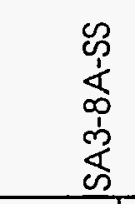 & & 茥 & 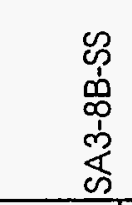 & & $\stackrel{*}{2}$ & 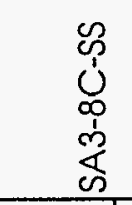 & & $\stackrel{*}{2}$ \\
\hline Aluminum & 4830 & & $\ldots$ & 2080 & & $\ldots$ & 2950 & & $\ldots$ & 2450 & & $\ldots$ & 5470 & & $\ldots$ & 2770 & & $\ldots$ & 1300 & & $\ldots$ \\
\hline Antimony & 14.2 & U & $\ldots$ & 12.8 & 4 & $\ldots+$ & 13.0 & $u$ & $\ldots$ & 12.4 & u & $\ldots$ & 14.2 & $u$ & $\ldots+$ & 12.5 & $u$ & $\ldots$ & 12.1 & u. - &.- \\
\hline Arsenic & 2.80 & & $\ldots$ & 1.50 & $\mathrm{~B}$ & $\mathrm{~J}$ & 4.60 & & -- & 6.10 & & $\ldots$ & 2.50 & & - & 1.50 & 8 & J & 0.49 & $\mathrm{~B}$ & J \\
\hline Barium & 42.4 & $B$ & $J$ & 12.7 & B) & $\mathrm{J}$ & 29.2 & $B$ & $\mathrm{~J}$ & 12.7 & $B$ & J & 74.0 & & -- & 23.2 & B & 3 & 7.0 & B & $\mathrm{J}$ \\
\hline Beryllium & 0.30 & $\mathrm{~B}$ & $\mathrm{U}$ & 0.07 & B) & $\mathrm{u}$ & 0.08 & $B$ & $\mathrm{u}$ & 0.07 & $B$ & $\mathrm{~J}$ & 0.67 & B & $u$ & 0.06 & 4 & -- & 0.07 & $\mathrm{~B}$ & $U$ \\
\hline Cadmium & 0.75 & 4 & $\ldots$ & 0.67 & 4 & $\ldots$ & 0.68 & 4 & $\ldots$ & 0.66 & 4 & $\ldots$ & 0.75 & 4 & - & 0.66 & $u$ & $\ldots$ & 0.64 & $u=$ & -- \\
\hline Calcium & 544 & $\mathrm{~B}$ & $\mathrm{~J}$ & 232 & B & $\mathrm{J}$ & 1230 & & $\ldots$ & 215 & B & $\mathrm{J}$ & 686 & B & $\mathrm{J}$ & 3370 & & $\ldots$ & 247 & $\mathrm{~B}$ & J \\
\hline Chromium & 11.5 & & $\ldots$ & 5.3 & & $\ldots$ & 16.4 & & $-\ldots$ & 5.9 & & $\ldots$ & 7.7 & & -- & 5.1 & & $\ldots$ & 2.1 & & - \\
\hline Cobalt & 8.50 & $B$ & J & 2.30 & B & $u$ & 5.00 & B & $u$ & 3.30 & $\mathrm{~B}$ & $u$ & 10.60 & B & J & 3.10 & B & U & 1.40 & $\mathrm{~B}$ & $U$ \\
\hline Copper & 20.50 & E & us & 12.00 & E & UJ & 9.70 & E & UJ & 5.70 & E & UJ & 5.60 & $\mathrm{BE}$ & UJ & 16.40 & E & (u.) & 3.50 & $B E$ & U.J. \\
\hline Iron & 10100 & & $\ldots$ & 4660 & & - & 15400 & & $\ldots$ & 4480 & & $\ldots$ & 5300 & & - & 7340 & & $\ldots$ & 2740 & & - \\
\hline Lead & 26.6 & & $\ldots$ & 24.4 & $w$ & J & 85.2 & s & $\ldots$ & 40.3 & & $\ldots$ & 20.1 & & - & 12.5 & & $\ldots$ & 5.6 & & -- \\
\hline Magnesium & 261.0 & $\mathrm{~B}$ & J & 102.0 & $\mathrm{~B}$ & $\mathrm{~J}$ & 219.0 & B & $J$ & 110.0 & B & $\mathrm{J}$ & 365.0 & B & $\mathrm{J}$ & 174.0 & 8 & J & 77.9 & B & $\mathrm{J}$ \\
\hline Manganese & 746.0 & & 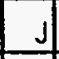 & 109.0 & & $\mathrm{~J}$ & 865.0 & & J & 183.0 & & $\mathrm{~J}$ & 977.0 & & $\mathrm{~J}$ & 118.0 & & $\mathrm{~J}$ & 33.7 & & $\mathrm{~J}$ \\
\hline Mercury & 0.06 & U & $\ldots$ & 0.05 & 4 & $\ldots$ & 0.06 & $u$ & $\ldots$ & 0.05 & $\mathrm{u}$ & $\ldots$ & 0.07 & B & $\mathrm{J}$ & 0.05 & $u$ & $\ldots$ & 0.05 & 4. & -- \\
\hline Nickel & 5.0 & $u$ & - & 4.5 & 4 & $\ldots$ & 5.9 & $\mathrm{~B}$ & $\mathrm{~J}$ & 4.4 & 4 & $-\ldots$ & 5.0 & $u$ & $\ldots$ & 4.4 & 4 & $\ldots$ & 4.3 & $u$. & $\ldots$ \\
\hline Potassium & 720 & U & - & 648 & $u$ & $\ldots$ & 658 & 4 & - & 631 & U) & $\ldots$ & 720 & 4 & $\ldots$ & 633 & 4 & $\ldots$ & 615 & $u$. & $\ldots$ \\
\hline Selenium & 0.24 & UN & Uu & 0.22 & UN & UJ & 0.22 & UN & UJ & $0.21 \mathrm{u}$ & UWN & $U_{J}$ & 0.24 & UN & UJ & 0.21 & UWN & UJ & 0.21 & UN & UJ \\
\hline Silver & 0.84 & $u$ & - & 0.76 & 4 & $\ldots$ & 0.77 & $u$ & - & 0.74 & U) & -- & 0.84 & 4 & $\ldots$ & 0.74 & 4 & $\ldots$ & 0.72 & 4 & $\ldots$ \\
\hline Sodium & 61.5 & 8 & $\mathrm{U}$ & 43.9 & $B$ & 4 & 47.5 & $\mathrm{~B}$ & $u$ & 51.1 & B & $\mathrm{u}$ & 61.5 & $\mathrm{~B}$ & 4 & 49.4 & $\mathrm{~B}$ & $u$ & 41.7 & B & $\mathrm{U}$ \\
\hline Thallium & 0.24 & uW & US & 0.22 & 4 & - & 0.22 & 4 & - & 0.21 & 4 & - & 0.24 & uW & US & 0.21 & 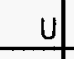 & $\ldots$ & 0.21 & 4 & - \\
\hline Vanadium & 16.6 & & - & 8.5 & $B$ & J & 13.0 & & - & 9.7 & B & $\mathrm{J}$ & 11.2 & $\mathrm{~B}$ & J & 10.4 & $\mathrm{~B}$ & $\mathrm{~J}$ & 6.1 & $\mathrm{~B}$ & $\mathrm{~J}$ \\
\hline Zinc & 54.3 & & - & 17.5 & & - & 278.0 & & - & 76.4 & & $\ldots$ & 8.0 & & - & 12.2 & & - & 3.5 & B & $\mathrm{U}$ \\
\hline Cyanide & 0.14 & u & - & 0.13 & $u$ & - & 0.15 & 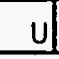 & - & 0.13 & U & - & 0.16 & & - & 0.13 & & $1-$ & 0.12 & & - \\
\hline
\end{tabular}




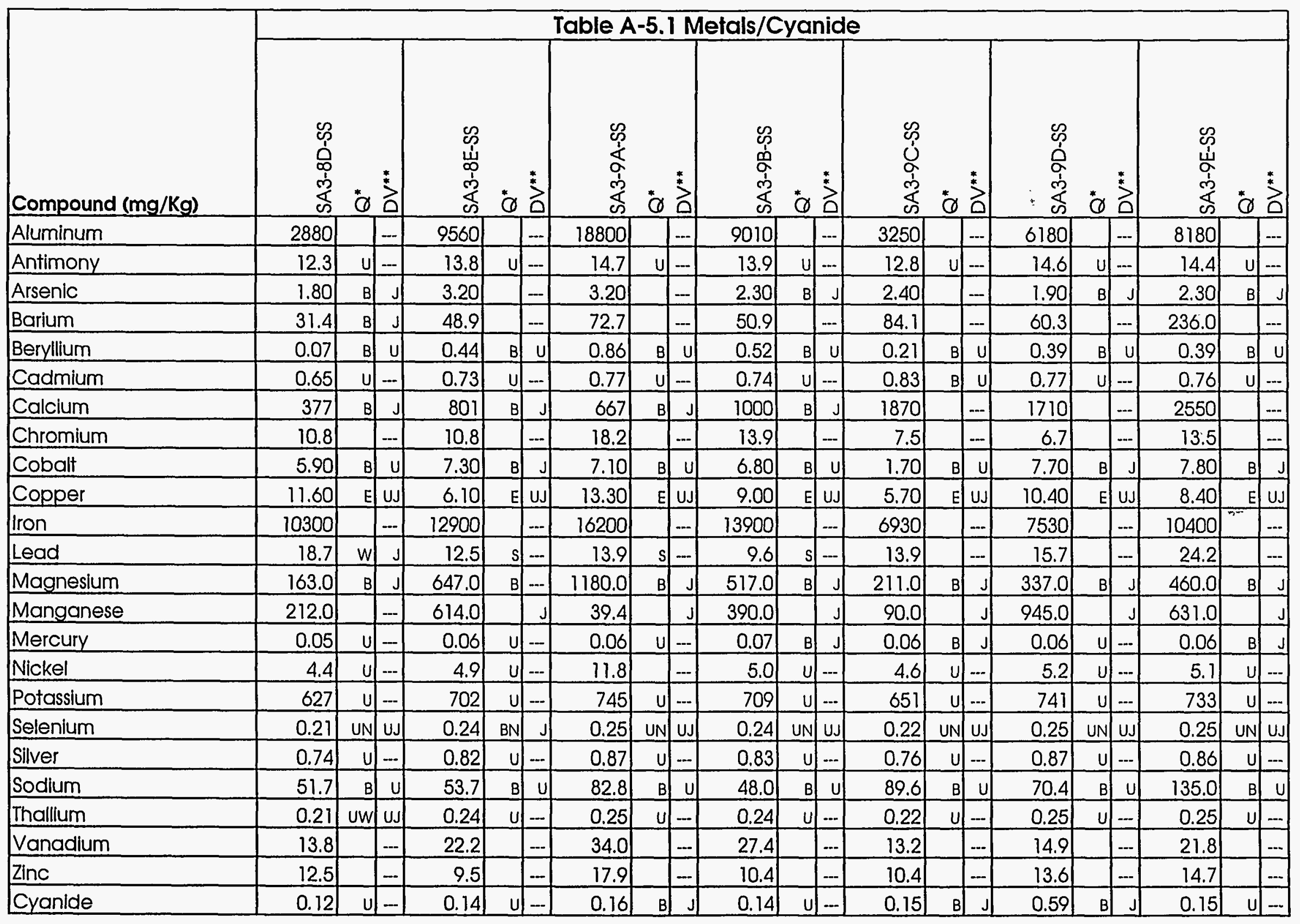


$\frac{\sqrt[J]{d}}{\frac{d}{d}}$

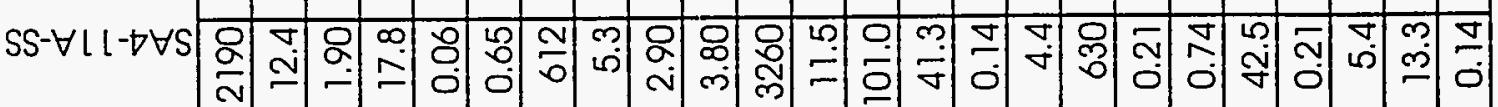

$* \wedge 0$

$* \theta$

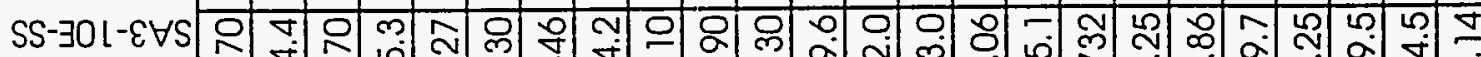

भे

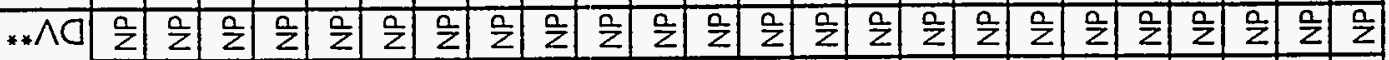

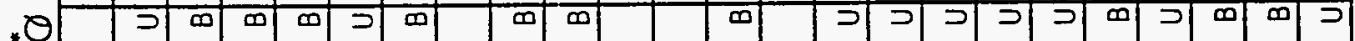

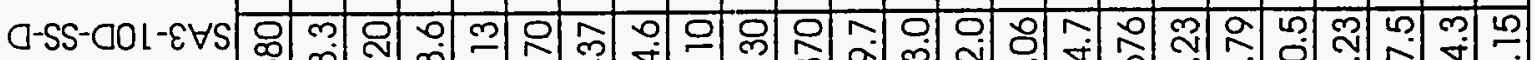

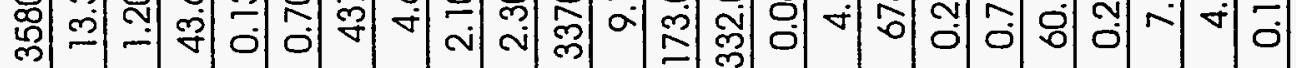

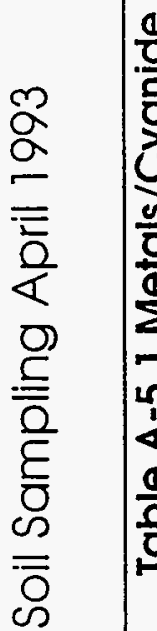

吾

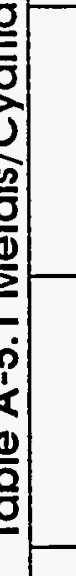

SSm m N

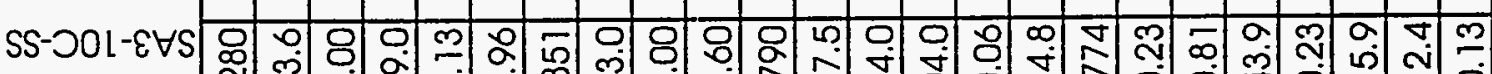
令

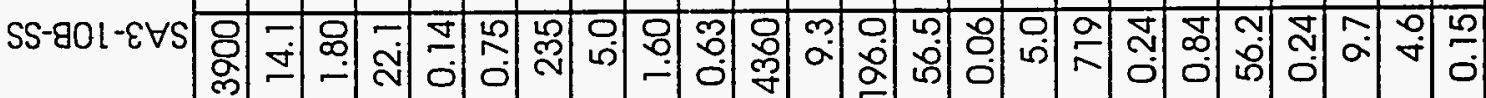

* $\wedge$ (

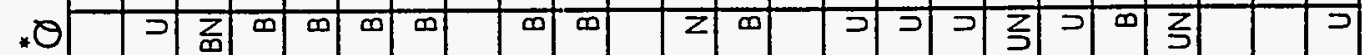

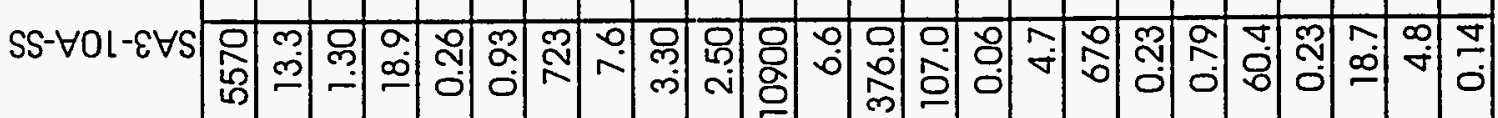




\begin{tabular}{|c|c|c|c|c|c|c|c|c|c|c|c|c|c|c|c|c|c|c|c|c|c|}
\hline \multirow[b]{2}{*}{ Compound (mg/Kg) } & \multicolumn{21}{|c|}{ Table A-5.1 Metals/Cyanide } \\
\hline & 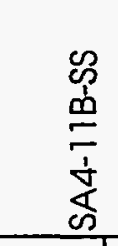 & $\stackrel{*}{0}$ & & 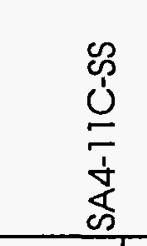 & & & 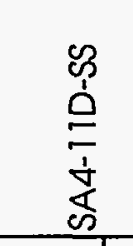 & & & 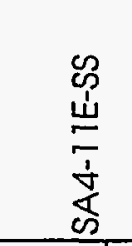 & & & 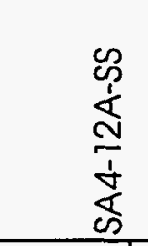 & & ${ }^{*}$ & 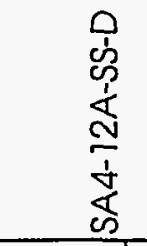 & $\stackrel{*}{Q}$ & ${ }^{*}$ & 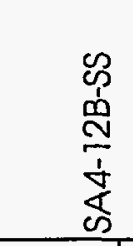 & & $\stackrel{2}{*}^{*}$ \\
\hline Aluminum & 3380 & & $\ldots$ & 3810 & & $\ldots$ & 4350 & & $\ldots$ & 3070 & & $\ldots$ & 14200 & & $\ldots$ & 17000 & & $\mathrm{NP}$ & 7840 & & $\ldots$ \\
\hline Antimony & 12.8 & UN & $\mathrm{J}$ & 12.4 & UN & $\mathrm{J}$ & 13.3 & UN & $\mathrm{J}$ & 12.5 & UN & J & 14.8 & $N$ & $R$ & 14.1 & $\mathrm{u}$ & $\mathrm{NP}$ & 13.2 & $\mathrm{BN}$ & $R$ \\
\hline Arsenic & 1.80 & $\mathrm{~B}$ & $\mathrm{~J}$ & 1.90 & $\mathrm{BW}$ & $\mathrm{J}$ & 4.00 & & - & 1.70 & $\mathrm{~B}$ & $\mathrm{~J}$ & 1.60 & $\mathrm{~B}$ & $\mathrm{~J}$ & 2.20 & $\mathrm{~B}$ & $\mathrm{NP}$ & 2.20 & & - \\
\hline Barium & 32.9 & $\mathrm{~B}$ & $\mathrm{~J}$ & 48.2 & & $\ldots$ & 39.2 & $B$ & $\mathrm{~J}$ & 15.8 & B & $\mathrm{J}$ & 22.7 & $B$ & $J$ & 24.6 & $B$ & $\mathrm{NP}$ & 49.3 & & $=$ \\
\hline Beryllium & 0.07 & 4 & - & 0.13 & B & $\mathrm{J}$ & 0.07 & 4 & $\ldots$ & 0.06 & 4. & $\ldots$ & 0.23 & B & $\mathrm{J}$ & 0.15 & $B$ & $\mathrm{NP}$ & 0.07 & 4 & -- \\
\hline Cadmium & 0.67 & $u$ & - & 0.66 & $U$ & - & 0.70 & $u$ & $\ldots$ & 0.66 & $u$. & $\ldots$ & 0.90 & B & 1 & 0.75 & 41 & $\mathrm{NP}$ & 0.69 & $u$ & -- \\
\hline Calcium & 712 & $B$ & 1 & 2150 & & $\ldots$ & 1490 & & $\ldots$ & 709 & $\mathrm{~B}$ & $\mathrm{~J}$ & 1170 & $\mathrm{~B}$ & $J$ & 1170 & $B$ & $\mathrm{NP}$ & 576 & $\mathrm{~B}$ & J \\
\hline Chromium & 6.6 & & $\ldots$ & 15.9 & & - & 5.3 & & - & 6.6 & & $\ldots$ & 14.8 & & -- & 17.0 & & $\mathrm{NP}$ & 7.9 & & $\ldots$ \\
\hline Cobalt & 2.50 & $\mathrm{~B}$ & $\mathrm{u}$ & 3.60 & $B$ & $\mathrm{u}$ & 3.80 & B & $\mathrm{u}$ & 1.80 & B & $\mathrm{u}$ & 4.90 & 8 & $\mathrm{~J}$ & 3.40 & 8 & $\mathrm{NP}$ & 3.80 & $\mathrm{~B}$ & $J$ \\
\hline Copper & 4.80 & B & $\mathrm{J}$ & 11.10 & & -- & 17.70 & & $\ldots$ & 4.90 & B & J & 5.40 & B & $\mathrm{J}$ & 3.70 & $\mathrm{~B}$ & $\mathrm{NP}$ & 4.50 & $\mathrm{~B}$ & J \\
\hline Iron & 4220 & & $\ldots$ & 10600 & & $\ldots$ & 7280 & & $\ldots$ & 4540 & & $\ldots$ & 19700 & & - & 17500 & & $\mathrm{NP}$ & 12300 & & $-\ldots$ \\
\hline Lead & 8.8 & & $\mathrm{~J}$ & 54.3 & & $\mathrm{~J}$ & 22.9 & & $\mathrm{~J}$ & 6.6 & & $\mathrm{~J}$ & 6.9 & & -- & 7.8 & & $\mathrm{NP}$ & 9.1 & &.- \\
\hline Magnesium & 171.0 & $\mathrm{~B}$ & $\mathrm{~J}$ & 190.0 & 旦 & 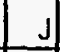 & 251.0 & $\mathrm{~B}$ & $J$ & 161.0 & $\mathrm{~B}$ & U] & 1300.0 & & $\ldots$ & 1500.0 & & $\mathrm{NP}$ & 773.0 & B & $\mathrm{J}$ \\
\hline Manganese & 40.9 & & $\ldots$ & 94.9 & & - & 104.0 & & $-\cdots$ & 26.4 & & - & 24.8 & & $\ldots$ & 28.9 & & $\mathrm{NP}$ & 16.1 & & $\ldots$ \\
\hline Mercury & 0.21 & & - & 0.05 & $u$ & - & 0.07 & - B & $\mathrm{U}$ & 0.06 & $B$ & $u$ & 0.06 & U & $\ldots$ & 0.06 & $u$ & $\mathrm{NP}$ & 0.06 & 4 & $\ldots$ \\
\hline Nickel & 4.8 & $\mathrm{~B}$ & $\mathrm{~J}$ & 4.4 & 4 & - & 4.7 & $u$ & - & 4.4 & 4. & $-\infty$ & 5.0 & uf & $\ldots$ & 5.0 & 4 & $\mathrm{NP}$ & 4.7 & 4 & $\ldots$ \\
\hline Potassium & 648 & 4 & $\ldots$ & 633 & $u$ & -- & 676 & $u$ & $\ldots$ & 633 & 4. & $\ldots$ & 717 & 4 & $\ldots$ & 717 & U. & $\mathrm{NP}$ & 667 & 4 & $\ldots$ \\
\hline Selenium & 0.22 & $u$ & - & 0.21 & $\mathrm{U}$ & $\ldots$ & 0.23 & $\mathrm{U}$ & -- & 0.21 & $U$ & -- & 0.69 & $\mathrm{BN}$ & $\mathrm{J}$ & 0.34 & B & $\mathrm{NP}$ & 0.22 & UN & US \\
\hline Silver & 0.76 & $\mathrm{u}$ & - & 0.74 & U & -- & 0.79 & $u$ & - & 0.74 & U. & $\ldots$ & 0.84 & u & $\ldots$ & 0.84 & u & $\mathrm{NP}$ & 0.78 & $u$ & $=$ \\
\hline Sodium & 47.5 & $\mathrm{~B}$ & U & 48.2 & B & 4 & 69.9 & $B$ & $U$ & 50.1 & B & $u$ & 56.6 & 8 & J & 67.4 & B & $\mathrm{NP}$ & 44.7 & B & J \\
\hline Thallium & 0.22 & 4 & $\ldots$ & 0.21 & 4 & -- & 0.23 & $\mathrm{U}$ & $\ldots$ & 0.21 & $U$ & $\ldots$ & 0.24 & u) & $\ldots$ & 0.24 & 4 & $\mathrm{NP}$ & 0.22 & U & - \\
\hline Vanadlum & 7.0 & $B$ & $\mathrm{~J}$ & 9.7 & $B$ & $\mathrm{~J}$ & 10.3 & $B$ & $\mathrm{~J}$ & 9.5 & B & J & 29.1 & & $\ldots$ & 26.5 & & $N P$ & 17.2 & & $=$ \\
\hline Zinc & 33.1 & & $\ldots$ & 29.3 & & - & 50.9 & & - & 6.7 & & - & 13.5 & & - & 16.8 & & $N P$ & 10.2 & & $\ldots$ \\
\hline Cyanide & 0.14 & $\mathrm{U}$ & $\ldots$ & 0.14 & U) & $\ldots$ & 0.15 & $u$ & $\ldots$ & 0.49 & B & $\mathrm{J}$ & 0.19 & B) & J & 0.16 & 0 & NP & 0.15 & & $\ldots$ \\
\hline
\end{tabular}




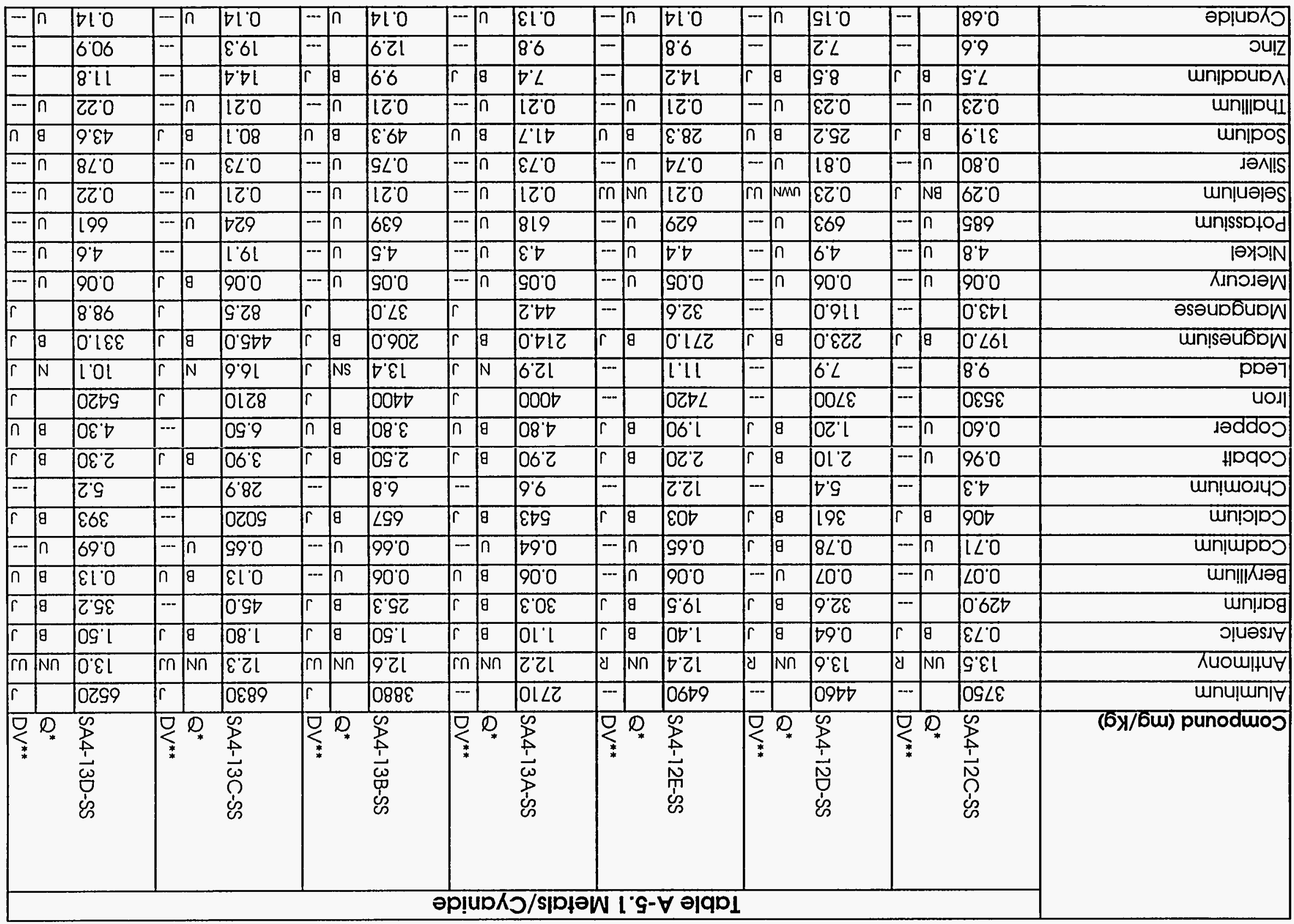




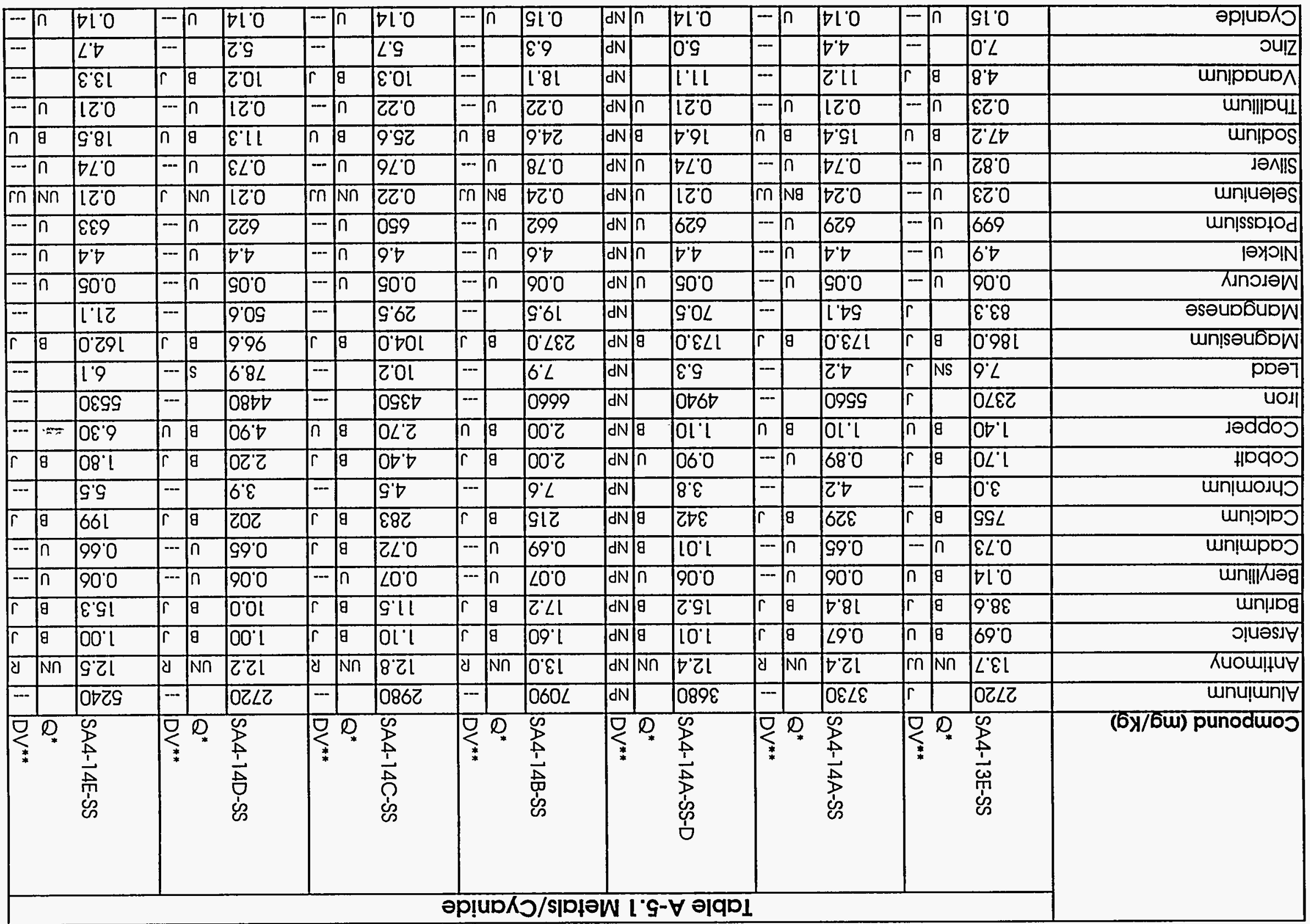




\begin{tabular}{|c|c|c|c|c|c|c|c|c|c|c|c|c|c|c|c|c|c|c|c|c|}
\hline$\cdots$ & & $91^{\circ} 0$ & r & 8 & 220 & -- & ก & Si'0 & $T$ & 8 & $61^{\circ} 0$ & -1 & ก & $91: 0$ & $\mathrm{dN} T$ & $6 L^{\prime} 0$ & - & $n$ & $\nabla 10$ & әp! \\
\hline$r n$ & $N$ & $8 \cdot 8$ & $\cdots$ & & $8 \cdot 81$ & $-\cdots$ & & 0.011 & $\cdots$ & & $0^{\prime}\lfloor\varepsilon l$ & - & & कीll & $\mathrm{dN}$ & 199 & - & & 0.8 & गu!Z \\
\hline$r$ & 8 & $\overline{6.6}$ & $-\cdots$ & & 9 & -- & & $\nabla^{\prime} 9 L$ & --- & & $\angle \angle L$ & - & & {$\left[{ }^{\prime} \varepsilon \mid\right.$} & dN & $\overline{\varepsilon^{\prime} 0 L}$ & -- & & $\overline{9} 2 !$ & யn!pDuD \\
\hline$-\cdots$ & $n$ & 220 & $\cdots$ & $n$ & $\varepsilon Z^{\prime} 0$ & --- & ก & $8 Z^{\circ} 0$ & $\cdots$ & $\bar{n}$ & 220 & -7 & n & $\overline{\nabla 2} 0$ & dN & 120 & - & $n$ & 120 & யn!||Dप1 \\
\hline$\cdots$ & $n$ & $\angle L^{\prime} O$ & $\cdots$ & $n$ & $28^{\circ} 0$ & \begin{tabular}{|l|}
-- \\
\end{tabular} & ก & 180 & $\cdots$ & n & $\angle L^{\prime} O$ & $-\cdots$ & n & $88^{\prime} 0$ & $\overline{d N}$ & $\overline{\varepsilon L{ }^{\circ} 0}$ & -- & $\vec{n}$ & $\varepsilon \angle L^{\prime} O$ & $\overline{\text { IəA\|IS }}$ \\
\hline$\cdots$ & $n$ & 220 & rn & $\overline{N n}$ & हृ'0 & m & $\overline{N n}$ & $\varepsilon Z^{\prime} 0$ & m & $\mathrm{N} \cap$ & 220 & $m \pi$ & $\overline{\mathrm{N} n}$ & $\nabla 20$ & $\mathrm{dN} \pi$ & $12^{\prime} 0$ & $m$ & $\overline{\mathrm{Nn}}$ & 120 & யuṇuəjəS \\
\hline r & g & $80^{\circ} 0$ & $r$ & 日 & $90^{\circ} 0$ & $\cdots$ & ก & $90^{\circ} 0$ & -- & $\bar{n}$ & $90^{\prime} 0$ & $r$ & 8 & $\angle 0^{\circ} 0$ & $\mathrm{dN} / \mathrm{T}$ & $90^{\prime} 0$ & --- & $n$ & $90^{\circ} 0$ & KinojəW \\
\hline-- & & 0.890 & $r$ & & 6.80 & r & & $\overline{0^{\circ} L Z L}$ & $r$ & & $0^{\prime} 12$ & $r$ & & 0.861 & dN & $\overline{0.02}$ & $r$ & & 1.00 & วsəuD6uDW \\
\hline$r$ & 8 & 0.692 & r & 8 & $0.16 \varepsilon$ & $r$ & 8 & $0.00 \varepsilon$ & r & 8 & 0.129 & $r$ & $\theta$ & $0^{\circ} \varepsilon \angle Z$ & dN $\bar{E}$ & 0.602 & $r$ & 8 & $0^{\prime} 9 \nabla 2$ & wn!səubow \\
\hline-- & & 8.9 & -- & $s$ & 1.01 & $-\cdots$ & $s$ & $8^{\circ} 91$ & -- & & $0.02 \mathrm{~L}$ & $\cdots$ & & Q'॰ & $\mathrm{dN}$ & 69 & $\cdots$ & $s$ & $\bar{G}$ & $\overline{\mathrm{pD} 91}$ \\
\hline$\cdots$ & & $\overline{0209}$ & -- & & 00021 & -- & & $00 \angle \angle L$ & $\cdots$ & & 0226 & $\cdots$ & & 0169 & $\mathrm{dN}$ & 0880 & -- & & 0069 & पOग \\
\hline$\cdots$ & $n$ & $69^{\circ} 0$ & -- & $n$ & $2 \angle 0$ & $-\cdots$ & ก & $2 \angle 0$ & --- & $n$ & $69^{\circ} 0$ & $-\cdots$ & n & $\nabla L^{\prime} 0$ & dN & $99^{\circ} 0$ & -- & $n$ & $99^{\circ} 0$ & யn!̣upDJ \\
\hline$\cdots$ & $n$ & $\angle 0^{\circ} O$ & $n$ & 日 & 190 & $n$ & $\theta$ & $9 \varepsilon^{\prime} 0$ & n & $\theta$ & $80^{\circ} 0$ & $n$ & $\theta$ & $\varepsilon Z^{\prime} 0$ & dNE & $\angle O^{\prime} O$ & $n$ & 8 & $\varepsilon L^{\circ} 0$ & un!!|Kıəg \\
\hline$\cdots$ & & $\varepsilon^{\prime} 80$ & r & 8 & 9.82 & $-\cdots$ & & $8.9 L$ & $r$ & 9 & 9.62 & $r$ & 8 & $\varepsilon^{\prime} \varepsilon \varepsilon$ & $d N \mid \bar{E}$ & $1.8 \mathrm{~L}$ & $r$ & $\bar{\theta}$ & 1.61 & யก!ा.J口g \\
\hline$r$ & $M 8$ & $66^{\circ} 0$ & -- & & Ot' $\varepsilon$ & $-\infty$ & & $00 \cdot 9$ & $-\cdots$ & & $\overline{O L} Z$ & -- & & $\overline{08^{\prime} \varepsilon}$ & $\mathrm{dN} / \varepsilon$ & $00^{\prime} Z$ & $r$ & 8 & $O S^{\prime} l$ & 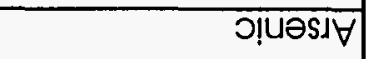 \\
\hline mi & Nn & 0.81 & --- & $n$ & $\angle \cdot E L$ & $-\cdots$ & & $9 \cdot \varepsilon l$ & $-\cdots$ & & $\overline{9 \cdot \varepsilon z}$ & $-x-1$ & ก & 001 & $\mathrm{dN}$ tr & 272 & -- & $n$ & $2 \cdot 21$ & Kuou!!u \\
\hline$\cdots$ & & 0299 & $\cdots$ & & $\overline{O D Z L}$ & $-\cdots$ & & OSZS & $\cdots$ & & $\overline{O \nabla \varepsilon L}$ & $-\cdots$ & & 10200 & $\mathrm{dN}$ & OEDD & $-\cdots$ & & Dध90 & unu!̣un| \\
\hline$\sum_{*}^{g}$ & $D_{*}$ & 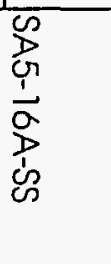 & & D & 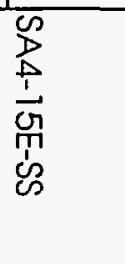 & $\sum_{*}^{Q}$ & $\bar{Q}$ & 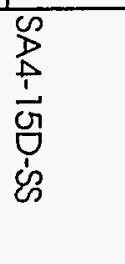 & $\underset{*}{\stackrel{\sigma}{\sigma}}$ & $Q_{*}$ & 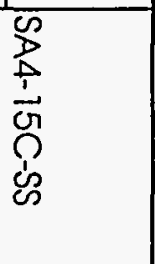 & $\underset{\nabla}{\nabla}$ & & 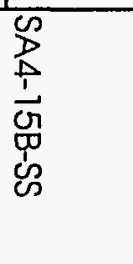 & $\overbrace{*}$ & 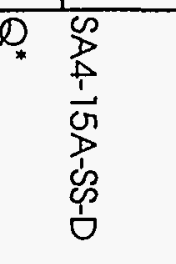 & & $\oslash_{*}$ & 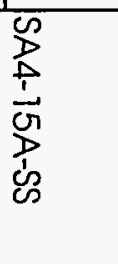 & (6)्र/6u) punodwo5 \\
\hline
\end{tabular}


Table A-5.1 Metals/Cyanide

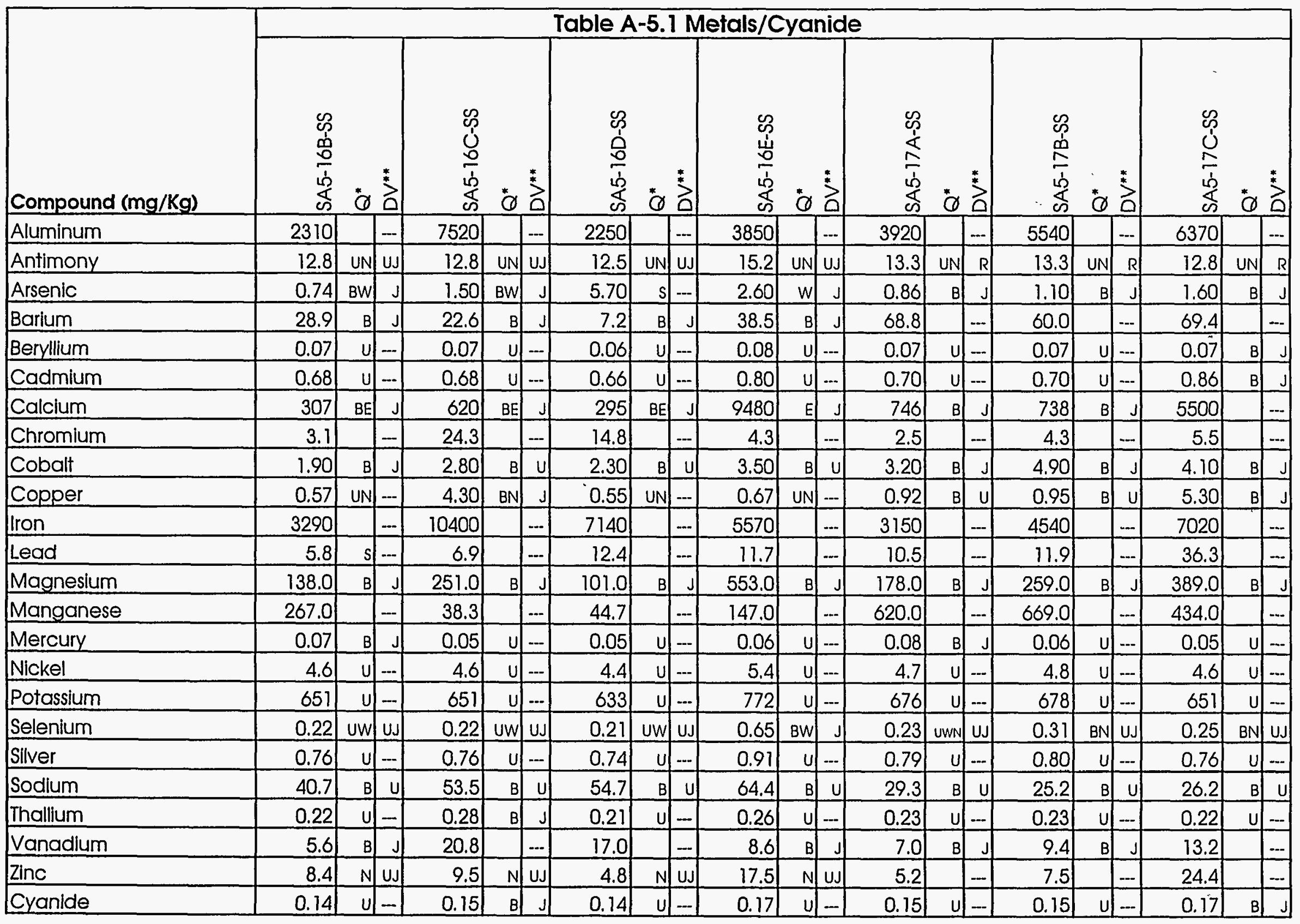




\begin{tabular}{|c|c|c|c|c|c|c|c|c|c|c|c|c|c|c|c|c|c|c|c|c|c|}
\hline \multirow[b]{2}{*}{ Compound $(\mathrm{mg} / \mathrm{Kg})$} & \multicolumn{21}{|c|}{ Table A-5.1 Metals/Cyanide } \\
\hline & 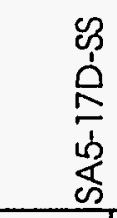 & $\stackrel{*}{0}$ & 光 & 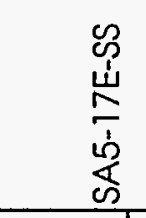 & & & 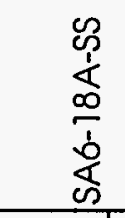 & & & 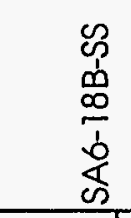 & & & 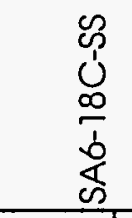 & $\stackrel{*}{\square}$ & 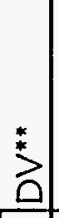 & 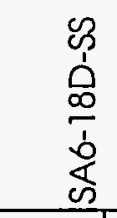 & & 草 & \multicolumn{3}{|c|}{ 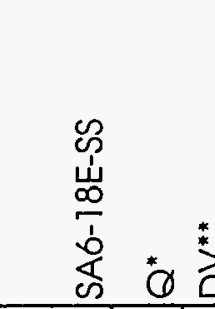 } \\
\hline Aluminum & 6930 & & $\ldots$ & 6660 & & $\ldots$ & 3130 & & $\ldots$ & 4600 & & $\ldots$ & 2630 & & $\ldots$ & 2750 & & $\ldots$ & 4450 & & -- \\
\hline Antimony & 13.7 & UN & $R$ & 13.4 & UN & $R$ & 13.3 & UN & UJ & 13.2 & UN & UJ & 13.1 & UN & U. & 12.9 & UN & Uu & 13.1 & UN & UJ \\
\hline Arsenic & 1.20 & B & $\mathrm{J}$ & 0.93 & B & J & 1.10 & $\mathrm{BW}$ & - & 1.40 & $\mathrm{BW}$ & $\mathrm{s}$ & 0.94 & $\mathrm{BW}$ & J & 0.91 & $\mathrm{BW}$ & 1 & 1.30 & $\mathrm{BW}$ & $\mathrm{J}$ \\
\hline Barium & 76.7 & & $\ldots$ & 107.0 & & -- & 22.4 & $\mathrm{~B}$ & $\mathrm{~J}$ & 19.9 & B & $\mathrm{J}$ & 13.5 & $B$ & $\mathrm{~J}$ & 19.7 & $B$ & $\mathrm{~J}$ & 26.2 & $B$ & $\mathrm{~J}$ \\
\hline Beryllium & 0.07 & $u$ & -- & 0.27 & $\mathrm{~B}$ & $\mathrm{~J}$ & 0.07 & $\mathrm{U}$ & $\ldots$ & 0.07 & U & $\ldots$ & 0.07 & 4 & $\ldots$ & 0.07 & 4 & $\ldots$ & 0.07 & $u$ & $\ldots$ \\
\hline Cadmium & 0.72 & 4 & $-\ldots$ & 0.71 & $u$ & $\ldots$ & 0.70 & $u$ & $\ldots$ & 0.70 & $u$ & $\ldots$ & 0.69 & $u$ & $\ldots$ & 0.68 & 4 & $\ldots$ & 0.69 & $u$ & $\ldots$ \\
\hline Calcium & 842 & $\mathrm{~B}$ & J & 775 & $B$ & $\mathrm{~J}$ & 263 & $\mathrm{BE}$ & 3 & 301 & $\mathrm{BE}$ & $\mathrm{J}$ & 235 & $\mathrm{BE}$ & $J$ & 287 & $\mathrm{BE}$ & $\mathrm{J}$ & 287 & $\mathrm{BE}$ & $\mathrm{J}$ \\
\hline Chromium & 4.9 & & $\ldots$ & 5.2 & & - & 6.9 & & $-\ldots$ & 5.2 & & $\ldots$ & 3.8 & & $\ldots$ & 2.6 & & $\ldots$ & 4.0 & & $\ldots$ \\
\hline Cobalt & 4.00 & $\mathrm{~B}$ & $\mathrm{~J}$ & 5.20 & B & J & 2.50 & B & $u$ & 1.70 & B & 4 & 0.94 & 4 & $\ldots$ & 2.50 & $\mathrm{~B}$ & 4 & 2.10 & B & $\mathrm{U}$ \\
\hline Copper & 0.61 & 4 & -- & 1.20 & B & $\mathrm{U}$ & 0.59 & UN & $\ldots$ & 0.59 & UN & $\ldots$ & 0.58 & UN & $\ldots$ & 0.57 & UN & $\ldots$ & 0.58 & UN &.- \\
\hline Iron & 4740 & & $\ldots$ & 4880 & & - & 3430 & & - & 4520 & & $\ldots$ & 3210 & & $-\ldots$ & 2500 & & $\ldots$ & 3880 & & $\ldots$ \\
\hline Lead & 9.2 & & $\ldots$ & 63.6 & & - & 19.7 & & $-\ldots$ & 16.1 & & $\ldots$ & 23.1 & & $\ldots$ & 6.4 & & $\ldots$ & 6.7 & & $\ldots$ \\
\hline Magnesium & 343.0 & $\mathrm{~B}$ & J & 307.0 & B & $\mathrm{J}$ & 151.0 & $\mathrm{~B}$ & J & 209.0 & B & J & 133.0 & B & 3 & 140.0 & B & J & 170.0 & B & $\mathrm{J}$ \\
\hline Manganese & 754.0 & & -- & 1150.0 & & - & 207.0 & & $-\infty$ & 72.5 & & -- & 43.8 & & $\ldots$ & 144.0 & & $-\ldots$ & 157.0 & & $\ldots$ \\
\hline Mercury & 0.06 & $B$ & 3 & 0.06 & $\mathrm{U}$ & - & 0.06 & $\mathrm{~B}$ & $\mathrm{~J}$ & 0.06 & 4 & $\ldots$ & 0.06 & $\mathrm{U}$ & $\ldots$ & 0.05 & 4 & - & 0.07 & B & $\mathrm{J}$ \\
\hline Nickel & 4.9 & 4 & $\ldots$ & 4.8 & $u$ & -- & 4.7 & $\underline{U}$ & $\ldots$ & 4.7 & 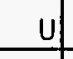 & -- & 4.7 & 4 & $\ldots$ & 4.6 & 4 & $\ldots$ & 4.6 & 4 & $\ldots$ \\
\hline Potassium & 696 & $u$ & $-\ldots$ & 681 & 4 & - & 674 & $\mathrm{U}$ & $\ldots$ & 726 & 8 & 3 & 665 & 4 &.- & 653 & 4 & $\ldots$ & 725 & B & $\mathrm{I}$ \\
\hline Selenium & 0.37 & $\mathrm{BN}$ & UJ & 0.44 & $\mathrm{BN}$ & UJ & 0.23 & UW & UJ & 0.23 & UW & UJ & 0.22 & 4 & $\ldots$ & 0.22 & UW & UJ & 0.22 & uW & UJ \\
\hline Silver & 0.82 & 4 & $\ldots$ & 0.80 & $\mathrm{U}$ & $\ldots$ & 0.79 & $\mathrm{U}$ & - & 0.79 & 4 & $\ldots$ & 0.78 & $\mathrm{u}$ & $\ldots$ & 0.77 & U) & $\ldots$ & 0.78 & 4 & $\ldots$ \\
\hline Sodium & 28.0 & B & $u$ & 25.3 & $\mathrm{~B}$ & U & 57.2 & $\mathrm{~B}$ & $U$ & 50.0 & B & 4 & 41.5 & $\mathrm{~B}$ & $u$ & 52.7 & B & u & 50.7 & B & $u$ \\
\hline Thallium & 0.23 & uf & - & 0.23 & $\mathrm{U}$ & - & 0.23 & UW & UJ & 0.23 & uW & $\mathrm{uJ}_{\mathrm{J}}$ & 0.22 & UW & uJ & 0.22 & 4 & $\ldots$ & 0.22 & $u$ & - \\
\hline Vanadium & 10.9 & $\mathrm{~B}$ & $\mathrm{~J}$ & 10.5 & $\mathrm{~B}$ & $\mathrm{~J}$ & 6.7 & $B$ & $J$ & 8.6 & $B$ & J & 5.3 & $\mathrm{~B}$ & $\mathrm{~J}$ & 5.5 & $\mathrm{~B}$ & 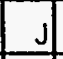 & 8.9 & $B$ & $\mathrm{~J}$ \\
\hline Zinc & 8.5 & & - & 9.1 & & - & 7.6 & $\mathrm{~N}$ & $\mathrm{uJ}$ & 8.2 & $\mathrm{~N}$ & uJ & 10.6 & $\mathrm{~N}$ & UJ & 4.8 & $N$ & us & 6.9 & $\mathrm{~N}$ & UJ \\
\hline Cyanide & 0.15 & UI & - & 0.15 & $U$ & - & 0.15 & $U$ & - & 0.15 & U & -1 & 0.15 & U] & -1 & 0.14 & u) & - & 0.15 & & - \\
\hline
\end{tabular}




\begin{tabular}{|c|c|c|c|c|c|c|c|c|c|c|c|c|c|c|c|}
\hline \multirow[b]{2}{*}{ Compound (mg/Kg) } & \multicolumn{15}{|c|}{ Table A-5.1 Metals/Cyanide } \\
\hline & 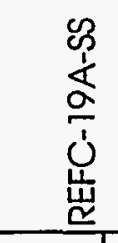 & & & 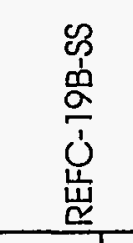 & & & 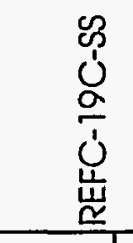 & $\stackrel{*}{\sigma}$ & 艾 & 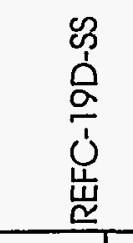 & & 草 & 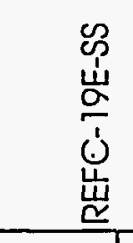 & & 莡 \\
\hline Aluminum & 3490 & & - & 5010 & & -1 & 14600 & & $-\ldots$ & 1980 & & $\ldots$ & 3820 & & $\ldots$ \\
\hline Antimony & 12.6 & UN & UJ & 13.5 & UN & UJ & 16.2 & UN & UJ & 12.1 & UN & UJ & 12.5 & UN & UJ \\
\hline Arsenic & 1.20 & $\mathrm{BW}$ & J & 2.00 & BW & $\mathrm{J}$ & 2.70 & B & J & 0.66 & $B W$ & J & 1.10 & $\mathrm{BW}$ & $\mathrm{J}$ \\
\hline Barium & 21.5 & B & $\mathrm{J}$ & 36.4 & $\mathrm{~B}$ & $\mathrm{~J}$ & 80.6 & & - & 9.6 & $\mathrm{~B}$ & J & 40.0 & $B$ & $\mathrm{~J}$ \\
\hline Beryllium & 0.06 & U) & - & 0.07 & U. & -- & 0.33 & $\mathrm{~B}$ & $\mathrm{~J}$ & 0.06 & $u$. & $\ldots$ & 0.06 & $u$ &.- \\
\hline Cadmium & 0.67 & u) & $\ldots$ & 0.71 & $\mathrm{U}$ & $\ldots$ & 0.85 & u] & - & 0.64 & $\mathrm{U}$. & $\ldots$ & 0.66 & $u$ & - \\
\hline Calcium & 306 & $\mathrm{BE}$ & $\mathrm{J}$ & 519 & $\mathrm{BE}$ & $\mathrm{J}$ & 671 & $\mathrm{BE}$ & $\mathrm{J}$ & 273 & $\mathrm{BE}$ & $\mathrm{J}$ & 539 & BE & $\mathrm{J}$ \\
\hline Chromium & 2.4 & & - & 4.4 & & - & 10.4 & & $\ldots$ & 0.95 & $u$. & - & 2.2 & & - \\
\hline Cobalt & 0.90 & $u$ & $\ldots$ & 2.00 & $\mathrm{~B}$ & $\mathrm{u}$ & 5.60 & $B$ & $\mathrm{~J}$ & 1.10 & $\mathrm{~B}$ & $\mathrm{~J}$ & 2.10 & $B$ & $\mathrm{~J}$ \\
\hline Copper & 10.70 & $N$ & J & 0.60 & UN & - & 0.72 & UN & $\ldots$ & 0.54 & UN & $\ldots$ & 0.55 & UN &.- \\
\hline Iron & 3540 & & - & 6700 & & - & 11700 & & $\ldots$ & 1780 & & $\ldots$ & 3340 & & $\ldots$ \\
\hline Lead & 4.6 & & -- & 7.7 & & -1 & 12.6 & & $\ldots$ & 1.8 & & - & 5.6 & & $\ldots$ \\
\hline Magnesium & 186.0 & $B$ & J & 210.0 & B & J & 582.0 & $\mathrm{~B}$ & J & 120.0 & $\mathrm{~B}$ & $\mathrm{~J}$ & 218.0 & $B$ & 3 \\
\hline Manganese & 74.8 & & -- & 211.0 & & - & 385.0 & & $\ldots$ & 60.5 & & $\ldots$ & 241.0 & & $\ldots$ \\
\hline Mercury & 0.05 & $u$ & -- & 0.06 & u & -- & 0.07 & $u$ & $\ldots$ & 0.05 & $\mathrm{U}$ & - & 0.05 & $U$ & -.. \\
\hline Nickel & 4.5 & U) & -- & 4.8 & 4 & $\ldots$ & 7.8 & B & $\mathrm{J}$ & 4.3 & $u$ & $\ldots$ & 4.5 & 4 & $\ldots$ \\
\hline Potassium & 641 & $u$ & $\ldots$ & 687 & $u$ & $\ldots$ & 822 & $u$ & $\ldots$ & 617 & $u$ & $\ldots$ & 656 & $B$ & $\mathrm{~J}$ \\
\hline Selenium & 0.22 & uW & UJ & 0.231 & uW & $\mathrm{uJ}$ & 0.28 & uW & UJ & 0.21 & $u$ & $\ldots$ & 0.21 & $\mathrm{U}$ & $\ldots$ \\
\hline Silver & 0.75 & $u$ & $\ldots$ & 0.81 & U) & $\ldots$ & 0.96 & $\mathrm{u}$ & $\ldots$ & 0.72 & U & $\ldots$ & 0.75 & $\mathrm{U}$ & ... \\
\hline Sodium & 49.1 & $\mathrm{~B}$ & $u$ & 52.6 & $\mathrm{~B}$ & $\mathrm{u}$ & 62.8 & $B$ & $u$ & 87.9 & $B$ & $u$ & 117.0 & $B$ & $\mathrm{~J}$ \\
\hline Thallium & 0.22 & 4 & $-\ldots$ & 0.23 & u & $\ldots$ & 0.28 & 4 & $\ldots$ & 0.21 & 4 & $\ldots$ & 0.21 & 4 & ... \\
\hline Vanadium & 7.7 & $\mathrm{~B}$ & $\mathrm{~J}$ & 14.6 & & $\ldots$ & 25.6 & & $\ldots$ & 4.1 & B & $\mathrm{J}$ & 6.9 & $B$ & 3 \\
\hline Zinc & 7.2 & & $\mathrm{UJ}$ & 16.7 & $\mathrm{~N}$ & UJ & 24.4 & $\mathrm{~N}$ & $\mathrm{~J}$ & 4.7 & $\mathrm{~N}$ & J & 7.4 & $\mathrm{~N}$ & $\mathrm{~J}$ \\
\hline Cyanide & 0.14 & $u$ & $\ldots$ & 0.15 & U) & $\ldots$ & 0.27 & $\mathrm{~B}$ & $\begin{array}{ll}\mathrm{J} \\
\mathrm{n}\end{array}$ & 0.16 & B & $\mathrm{J}$ & 0.17 & B & $\begin{array}{l}3 \\
\end{array}$ \\
\hline
\end{tabular}

" Data Qualifier. "* Data Validation. 
Table A-5.2 Pesticides/PCB's

\begin{tabular}{|c|c|c|c|c|c|c|c|c|c|c|c|c|c|c|c|c|c|c|c|c|c|}
\hline \multirow[b]{2}{*}{ Compound (ug/Kg) } & \multicolumn{21}{|c|}{ Table A-5.2 Pesticides/PCB's } \\
\hline & $\begin{array}{l}\infty \\
\frac{1}{1} \\
\frac{1}{5} \\
\frac{1}{6} \\
\text { con }\end{array}$ & & & $\begin{array}{l}\mathscr{c} \\
0 \\
0 \\
\frac{1}{1} \\
\frac{1}{6} \\
0\end{array}$ & 0 & & 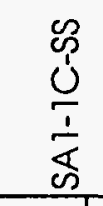 & & $\stackrel{2}{0}^{*}$ & 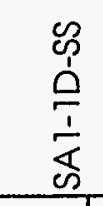 & & $\stackrel{2}{*}^{*}$ & 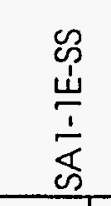 & & $\stackrel{*}{0}$ & 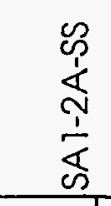 & & 莒 & 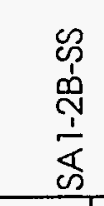 & & $\stackrel{*}{*}$ \\
\hline Alpha-BHC & 18 & $u$ & $\ldots$ & 17 & $\mathrm{U}$ & -- & 17 & U & -- & 17 & U & $\ldots$ & 17 & u. & $-\ldots$ & 18 & 4 & $\ldots$ & 18 & 4 & $\ldots$ \\
\hline Beta-BHC & 18 & $u$ & $\ldots$ & 17 & $\mathrm{U}$ & - & 17 & U & $\ldots$ & 17 & U. & $\ldots$ & 17 & $\mathrm{U}$ & $\ldots$ & 18 & $\mathrm{u}$ & $\ldots$ & 18 & & - \\
\hline Delta-BHC & 18) & $u$ & $\ldots$ & 17 & 4 & $\ldots$ & 17 & 4 & - & 17 & U & $\ldots$ & 17 & $\mathrm{u}$ & $\ldots$ & 18 & $\mathrm{U}$ & $\ldots$ & 18 & & $\ldots$ \\
\hline Gamma-BHC & 18 & $\mathrm{U}$ & -- & 17 & $u$ & $\ldots$ & 17 & $\mathrm{u}$ & $\ldots$ & 17 & U & $\ldots$ & 17 & $u$ & - & 18 & $\mathrm{u}$ & $-\ldots$ & 18 & $u$ & $\ldots$ \\
\hline Heptachlor & 18 & U & $\ldots$ & 17 & 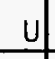 & $\ldots$ & 17 & $\mathrm{U}$ & -- & 17 & $\mathrm{u}$ & - & 17 & u. & -- & 18 & $u$ & $\ldots$ & 18 & & $\ldots$ \\
\hline Aldrin & 18 & $u$ & $\ldots$ & 17 & u & - & 17 & $u$ & $\ldots$ & 17 & $u$ & - & 17 & 4. & $\ldots$ & 18 & $u$ & $\ldots$ & 18 & & $\ldots$ \\
\hline Heptachlor epoxide & 18 & $\mathrm{U}$ & $-\ldots$ & 17 & $u$ & $\ldots$ & 17 & $\mathrm{u}$ & -- & 17 & $u$ & $\ldots$ & 17 & $u$ & $-\ldots$ & 18 & $u$ & $\ldots$ & 18 & $\mathrm{u}$ & $\ldots$ \\
\hline Endosulfan ! & 18 & u & $\ldots$ & 17 & $u$ & $\ldots$ & 17 & $\mathrm{u}$ & $\ldots$ & 17 & $u$ & - & 17 & $U$. & $\ldots$ & 18 & 4 & $\ldots$ & 18 & $u$ & $\ldots$ \\
\hline Dieldrin & 36 & 4 & $\ldots$ & 34 & 4 & $\ldots$ & 34 & 4 & -- & 35 & 4 & $\ldots$ & 34 & 4 & $\ldots$ & 35 & 4 & -- & 37) & & $\ldots$ \\
\hline 4,4'-DDE & 36 & $\mathrm{U}$ & $\ldots$ & 34 & $\mathrm{U}$ & $\ldots$ & 34 & 4 & - & 35 & $\mathrm{u}$ & - & 34 & $u$. & $\ldots$ & 35 & $u$ & $\ldots$ & 37 & $u$ & $\ldots$ \\
\hline Endrin & 36 & U & -- & 34 & U & $\ldots$ & 34 & $\mathrm{u}$ & $\ldots$ & 35 & $\mathrm{U}$ & $\ldots$ & 34 & $u$ & $\ldots$ & 35 & $\mathrm{u}$ & $\ldots$ & 37 & $u$ & $\ldots$ \\
\hline Endosulfan II & 36 & $u$ & -- & 34 & 4 & $\ldots$ & 34 & $u$ & $\ldots$ & 35 & $u$ & $\ldots$ & 34 & $u$ & $\ldots$ & 35 & $u$ & -- & 37 & $u$ & -- \\
\hline 4,4'-DDD & 36 & u & -- & 34 & 4 & - & 34 & $\mathrm{u}$ & $\ldots$ & 35 & $\mathrm{u}$ & $\ldots$ & 34 & 0 & $\ldots$ & 35 & $u$ & $\ldots$ & 37 & 4 & $\ldots$ \\
\hline Endosulfan sulfate & 36 & $\mathrm{U}$ & - & 34 & U & $\ldots$ & 34 & 4 & -- & 35 & $\mathrm{u}$ & $\ldots$ & 34 & $\mathrm{u}$ & $\ldots$ & 35 & 4 & $\ldots$ & 37 & $\mathrm{U}$ & $\ldots$ \\
\hline $4,4^{\prime}-\mathrm{DDT}$ & 36 & $\mathrm{u}$ & -- & 34 & U & - & 34 & 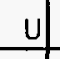 & -- & 35 & 4 & -1 & 34 & $u$ & - & 35 & $\mathrm{u}$ & $\ldots$ & 37 & $\underline{4}$ & $\ldots$ \\
\hline Methoxychlor & 180 & $u$ & -- & 170 & $u$ & $\ldots$ & 170 & $u$ & - & 170 & $\mathrm{u}$ & $\ldots$ & 170 & $u$ & $\ldots$ & 180 & $\mathrm{U}$ & $\ldots$ & 180 & $u$ & $\ldots$ \\
\hline Endrin ketone & 36 & U & $\ldots$ & 34 & U & $\ldots$ & 34 & $\mathrm{u}$ &.--1 & 35 & $\mathrm{U}$ & $\ldots$ & 34 & $\mathrm{u}$ & $\ldots$ & 35 & $\mathrm{u}$ & $\ldots$ & 37 & $\mathrm{U}$ & $\ldots$ \\
\hline Alpha-chlordane & 180 & $\mathrm{U}$ & -- & 170 & $\mathrm{U}$ & -- & 170 & ut & - & 170 & 4 & $\ldots$ & 170 & $\mathrm{u}$ & -- & 180 & $\mathrm{u}$ & - & 180 & $\mathrm{U}$ & $\ldots$ \\
\hline Gamma-chlordane & 180 & $u$ & $\ldots$ & 170 & $u$ & --- & 170 & $U$ & - & 170 & $u$ & - & 170 & $u$ & -- & 180 & $\mathrm{u}$ & $\ldots$ & 180 & 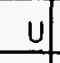 & $-\ldots$ \\
\hline Toxaphene & 360 & $\mathrm{U}$ & $\ldots$ & 340 & 4 & -- & 340 & $\mathrm{u}$ & - & 350 & $\mathrm{u}$ & $\ldots$ & 340 & 0 & $\ldots$ & 350 & $\mathrm{U}$ & $\ldots$ & 370 & 4 & $\ldots$ \\
\hline Aroclor-1016 & 180 & U & - & 170 & 4 & - & 170 & $\mathrm{U}$ & - & 170 & $\mathrm{u}$ & $\ldots$ & 170 & $u$ & $\ldots$ & 180 & $\mathrm{u}$ & $\ldots$ & 180 & & $\ldots$ \\
\hline Aroclor-1221 & 180 & 4 & - & 170 & U & - & 170 & 4 & - & 170 & $u$ & - & 170 & $u$ & $\ldots$ & 180 & 4 & $\ldots$ & 180 & & $\ldots$ \\
\hline Aroclor-1232 & 180 & 4 & -1 & 170 & u & - & 170 & $\mathrm{u}$ & - & 170 & $\mathrm{u}$ & $\ldots$ & 170 & $u$ & - & 180 & $u$ &.-- & 180 & & - \\
\hline Aroclor-1242 & 180 & U & -1 & 170 & u & $\ldots$ & 170 & U) & - & 170 & & -1 & 170 & u & - & 180 & & - & 180 & & $\ldots$ \\
\hline
\end{tabular}




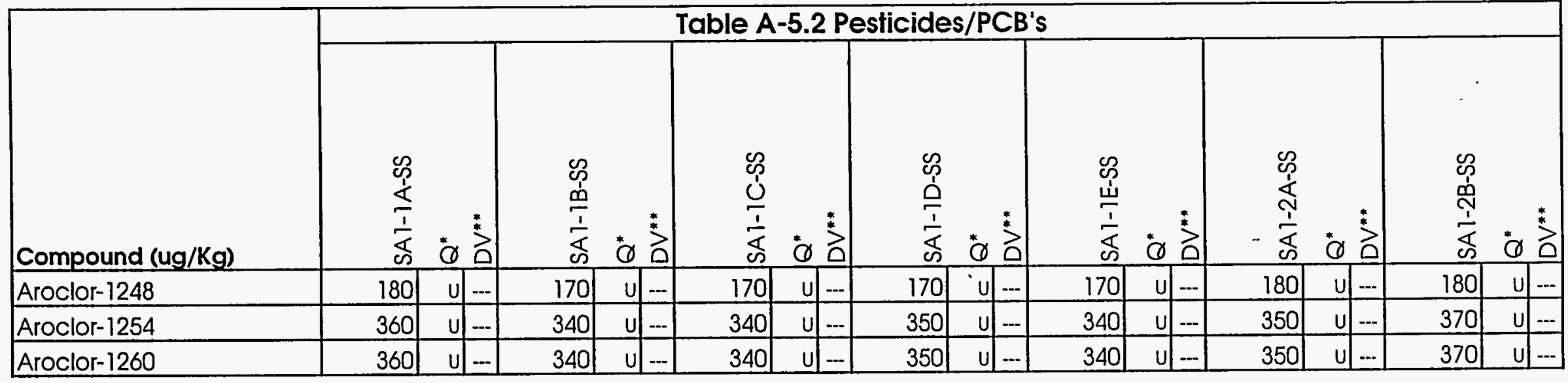




\begin{tabular}{|c|c|c|c|c|c|c|c|c|c|c|c|c|c|c|c|c|c|c|c|c|c|}
\hline \multirow[b]{2}{*}{ Compound (ug/Kg) } & \multicolumn{21}{|c|}{ Table A-5.2 Pesticides/PCB's } \\
\hline & 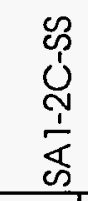 & $\stackrel{*}{\varnothing}$ & & $\begin{array}{l}\tilde{p} \\
\stackrel{p}{p} \\
\frac{1}{1} \\
\frac{1}{c}\end{array}$ & "ृ & $\stackrel{*}{*}$ & 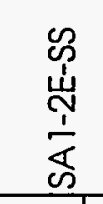 & & 艾 & 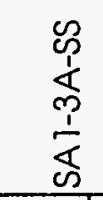 & & ${ }^{*}$ & $\begin{array}{l}\mathscr{n} \\
\infty \\
\infty \\
0 \\
\frac{1}{4} \\
心\end{array}$ & & $\stackrel{*}{2}$ & 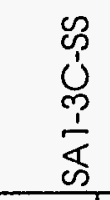 & & $\stackrel{*}{*}$ & 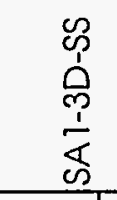 & & $\stackrel{2}{0}^{*}$ \\
\hline Alpha-BHC & 17 & $U$ & - & 19 & $u$ & -- & 18 & $u$ & $\ldots$ & 20 & 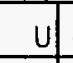 & $\ldots$ & 17 & $\mathrm{u}$ & - & 17 & $u$ & $\ldots$ & 17 & U & $\ldots$ \\
\hline Beta-BHC & 17 & $\mathrm{u}$ & $\ldots$ & 19 & $u$ & $\ldots$ & 18 & u) & $-\ldots$ & 20 & 4 & $\ldots$ & 17 & $\mathrm{u}$ & $\ldots$ & 17 & $u$ & $\ldots$ & 17 & & $\ldots$ \\
\hline Delta-BHC & 17 & $u$ & $\ldots$ & 19 & $\mathrm{U}$ & $\ldots$ & 18 & 4 & $\ldots$ & 20 & $u$ & $\ldots$ & 17 & $u$ & -- & 17 & $u$ & $\ldots$ & 17 & 4 & $\ldots$ \\
\hline Gamma-BHC & 17 & $\mathrm{u}$ & $\ldots$ & 19 & $\mathrm{U}$ &.-- & 18 & U & $\ldots$ & 20 & $u$ & $\ldots$ & 17 & $\mathrm{U}$ & - & 17 & $u$ & $\ldots$ & 17 & 4 & $\ldots$ \\
\hline Heptachlor & 17 & $u$ & $\ldots$ & 19 & $\mathrm{U}$ & $\ldots$ & 18 & $\mathrm{U}$ &.- & 20 & $\mathrm{U}$ & $\ldots$ & 17 & $\mathrm{u}$ & $\ldots$ & 17 & $u$ & $\ldots$ & 17 & & $\ldots$ \\
\hline Aldrin & 17 & $\mathrm{U}$ & $\ldots$ & 19 & $\mathrm{U}$ & $\ldots$ & 18 & $u$ & $\ldots$ & 20 & $u$ & -- & 17 & 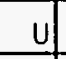 & $\ldots$ & 17 & $u$ & $\ldots$ & 17 & $\mathrm{U}$ &.- \\
\hline Heptachlor epoxide & 17 & $\mathrm{u}$ & $\ldots$ & 19 & $\mathrm{U}$ & $\ldots$ & 18 & $u$ & - & 20 & $u$ & $\ldots$ & 17 & $u$ & - & 17 & U & $-\ldots$ & 17 & 4 & - \\
\hline Endosulfan I & 17 & $u$ & $\ldots$ & 19 & $\mathrm{u}$ & $\ldots$ & 18 & $\mathrm{U}$ & $\ldots$ & 20 & $u$ & $\ldots$ & 17 & $\mathrm{u}$ & -- & 17 & $u$ & $\ldots$ & 17 & $u$ & $\ldots$ \\
\hline Dieldrin & 34 & $u$ & $\ldots$ & 38 & $\mathrm{U}$ & $\ldots$ & 37 & $u$ & $\ldots$ & 41 & 4 & $\ldots$ & 34 & 4 & $\ldots$ & 34 & 4 & $\ldots$ & 35 & $u$ & $\ldots$ \\
\hline 4,4'-DDE & 34 & $u$ & $\ldots$ & 38 & $\mathrm{U}$ & $\ldots$ & 37 & $u$ & $\ldots$ & 210 & & $\ldots$ & 34 & $\mathrm{U}$ &.-- & 34 & $\mathrm{u}$ & $\ldots$ & 35 & $\mathrm{u}$ & $\ldots$ \\
\hline Endrin & 34 & $u$ & $\ldots$ & 38 & $\mathrm{U}$ & $\ldots$ & 37 & U &.-- & 41 & $u$ & $\ldots$ & 34 & $U$ & $\ldots$ & 34 & $u$ & $\ldots$ & 35 & $\mathrm{U}$ & - \\
\hline Endosulfan II & 34 & $u$ & $\ldots$ & 38 & $u$ & $\ldots$ & 37 & $u$ & - & 41) & $u$ & $-\ldots$ & 34 & 4 & -- & 34 & 4 & $\ldots$ & 35 & 4 & - \\
\hline $4,4^{\prime}-\mathrm{DDD}$ & 34 & $U$ & $\ldots$ & 38 & $\mathrm{U}$ & $\ldots$ & 37 & $u$ &.- & 41 & & $\ldots$ & 34 & $u$ & $\ldots$ & 34 & $u$ & $\ldots$ & 35 & $\mathrm{u}$ & $\ldots$ \\
\hline Endosulfan sulfate & 34 & $u$ & $\ldots$ & 38 & $\mathrm{U}$ &.-- & 37 & $u$ & - & 41 & $\mathrm{U}$ & $\ldots$ & 34 & 4 & -- & 34 & U & -- & 35 & $u$ & - \\
\hline 4,4'-DDT & 34 & $\mathrm{U}$ & $\ldots$ & 38 & $\mathrm{U}$ & $\ldots$ & 37 & $\mathrm{u}$ & -- & 190 & & $\ldots$ & 34 & $u$ & $\ldots$ & 34 & $u$ & $\ldots$ & 35 & $u$ & - \\
\hline Methoxychlor & 170 & $u$ &.- & 190 & $\mathrm{U}$ & $\ldots$ & 180 & $u$ & - & 200 & uf & - & 170 & $u$ & $\ldots$ & 170 & u & $\ldots$ & 170 & $\mathrm{U}$ & - \\
\hline Endrin ketone & 34 & $u$ & $\ldots$ & 38 & $\mathrm{u}$ & - & 37 & $u$ & $\ldots$ & 41 & $u$ & $\ldots$ & 34 & $\mathrm{U}$ & -- & 34 & 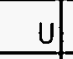 & -- & 35 & $\mathrm{u}$ & $-\ldots$ \\
\hline Alpha-chlordane & 170 & $\mathrm{u}$ & - & 190 & $\mathrm{u}$ & - & 180 & $u$ & - & 200 & 4 & $\ldots$ & 170 & $u$ & $\ldots$ & 170 & $u$ & $\ldots$ & 170 & $\mathrm{u}$ & $\ldots$ \\
\hline Gamma-chlordane & 170 & $\mathrm{U}$ & - & 190 & $\underline{U}$ & $=$ & 180 & $u$ & - & 200 & u & $\ldots$ & 170 & $u$ & - & 170 & 4 & $\ldots$ & 170 & 4 & - \\
\hline Toxaphene & 340 & $\mathrm{U}$ & - & 380 & $u$ & - & 370 & 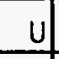 & - & 410 & U & $\ldots$ & 340 & 4 & - & 340 & 4 & -- & 350 & $\mathrm{U}$ & $-\ldots$ \\
\hline Aroclor-1016 & 170 & $\mathrm{U}$ & - & 190 & $U$ & $\ldots$ & 180 & $\mathrm{U}$ & - & 200 & $u$ & $\ldots$ & 170 & $u$ & - & 170 & u) & $\ldots$ & 170 & $\mathrm{U}$ & $\ldots$ \\
\hline Aroclor-1221 & 170 & $\mathrm{u}$ & - & 190 & $\mathrm{U}$ & - & 180 & $\mathrm{u}$ & - & 200 & $u$ & -- & 170 & $\mathrm{U}$ & - & 170 & U & -- & 170 & $u$ & ... \\
\hline Aroclor- 1232 & 170 & $\mathrm{u}$ & - & 190 & $\mathrm{U}$ & - & 180 & 4 & - & 200 & 4 & - & 170 & $u$ & - & 170 & $u$ & $\ldots$ & 170 & $u$ & ... \\
\hline Aroclor- 1242 & 170 & $\mathrm{U}$ & - & 190 & $\mathrm{U}$ & - & 180 & $\mathrm{U}$ & - & 200 & U] & $\ldots$ & 170 & $u$ & - & 170 & $\mathrm{u}$ & $\ldots$ & 170 & & J... \\
\hline
\end{tabular}




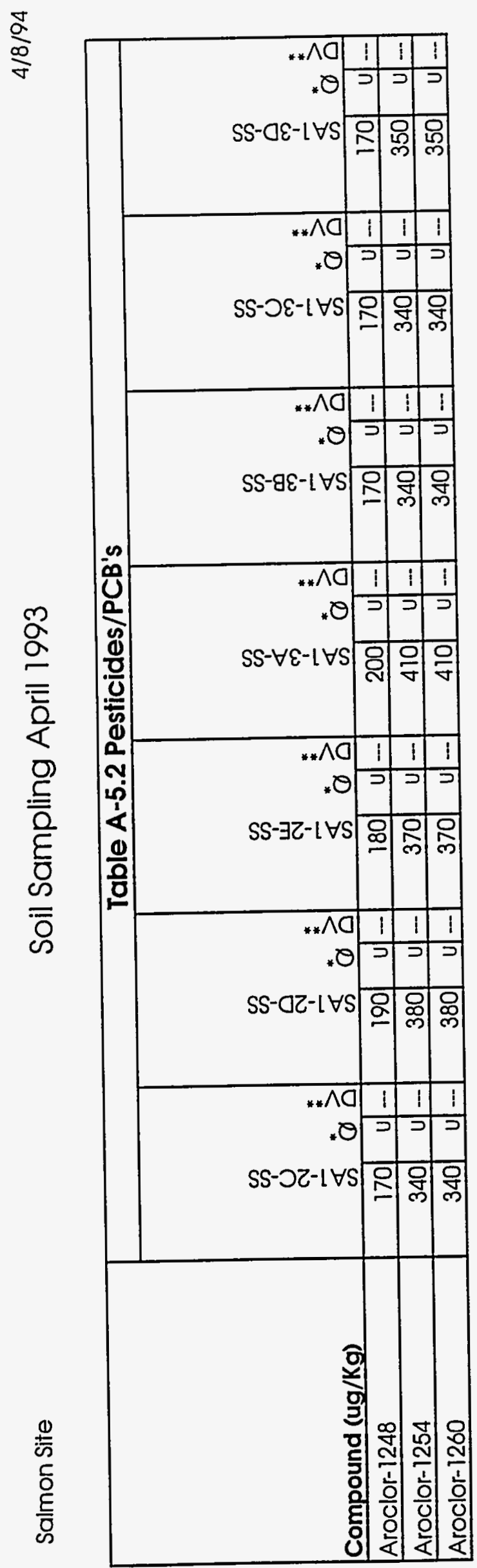

$\overline{0}$
0
0
0

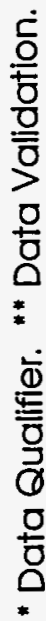




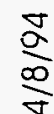

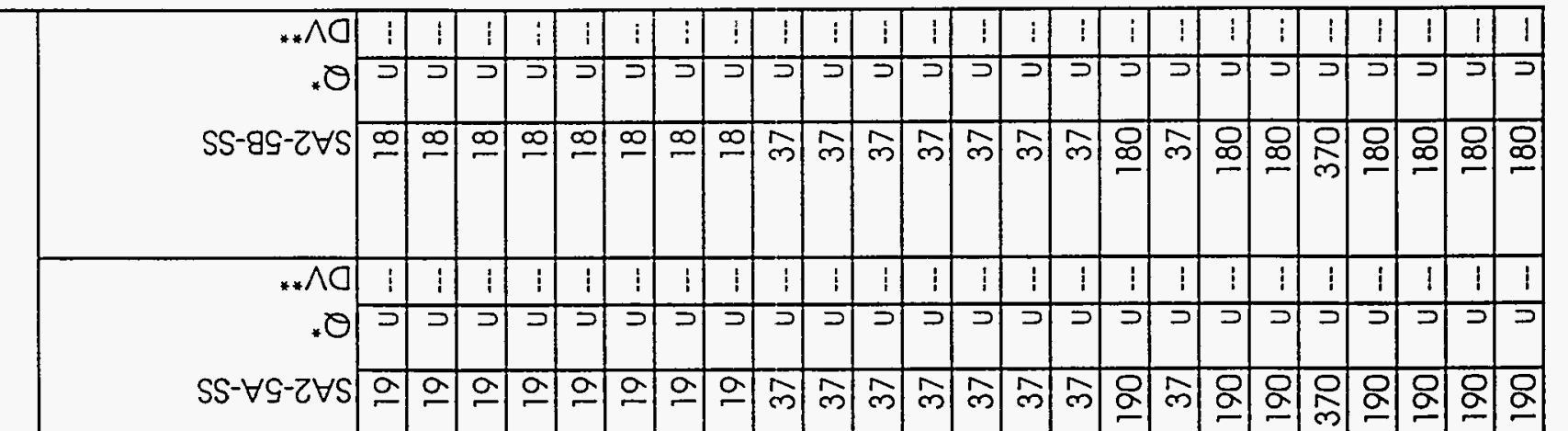

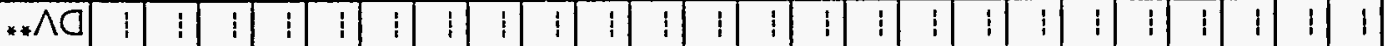
.$\theta$ Э

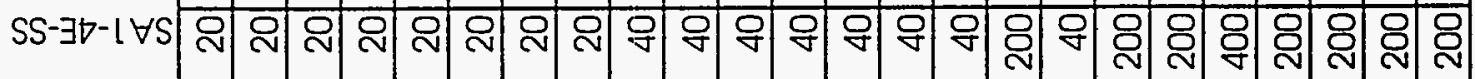

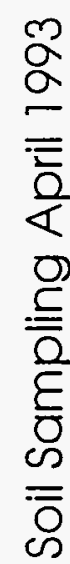

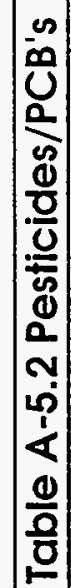

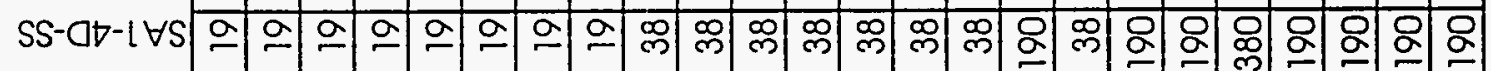

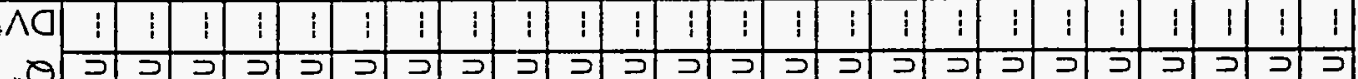




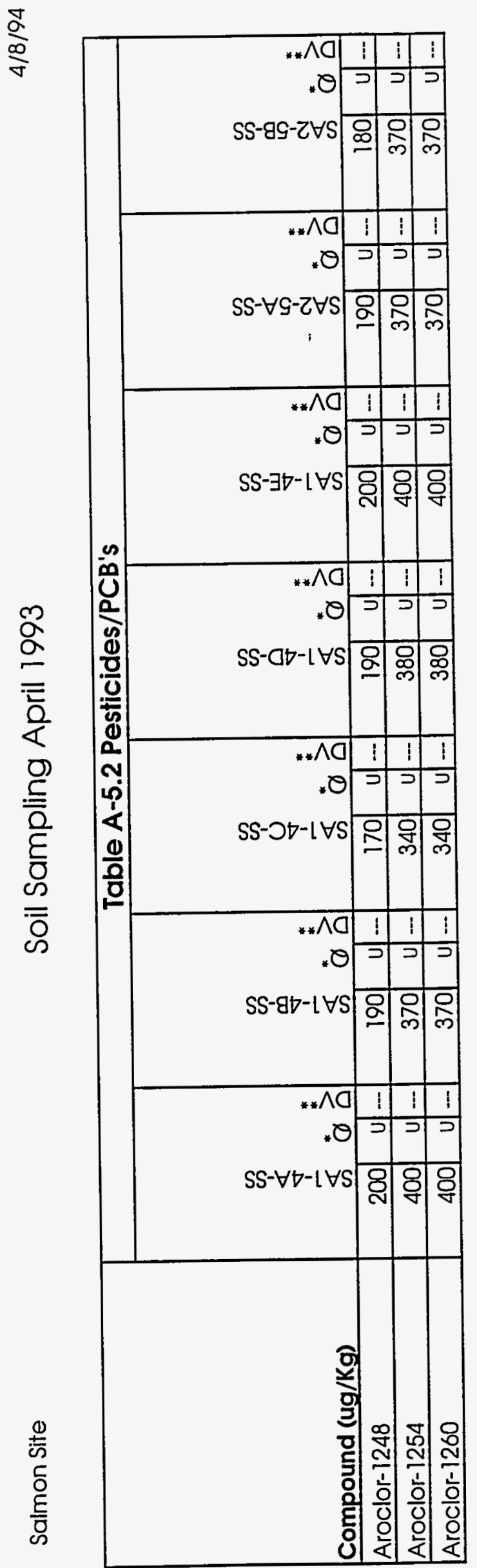

0
0
0
0
0
0

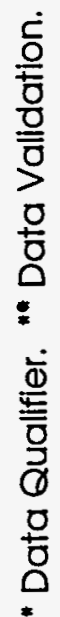


$\frac{\square}{\sqrt{\sigma}}$

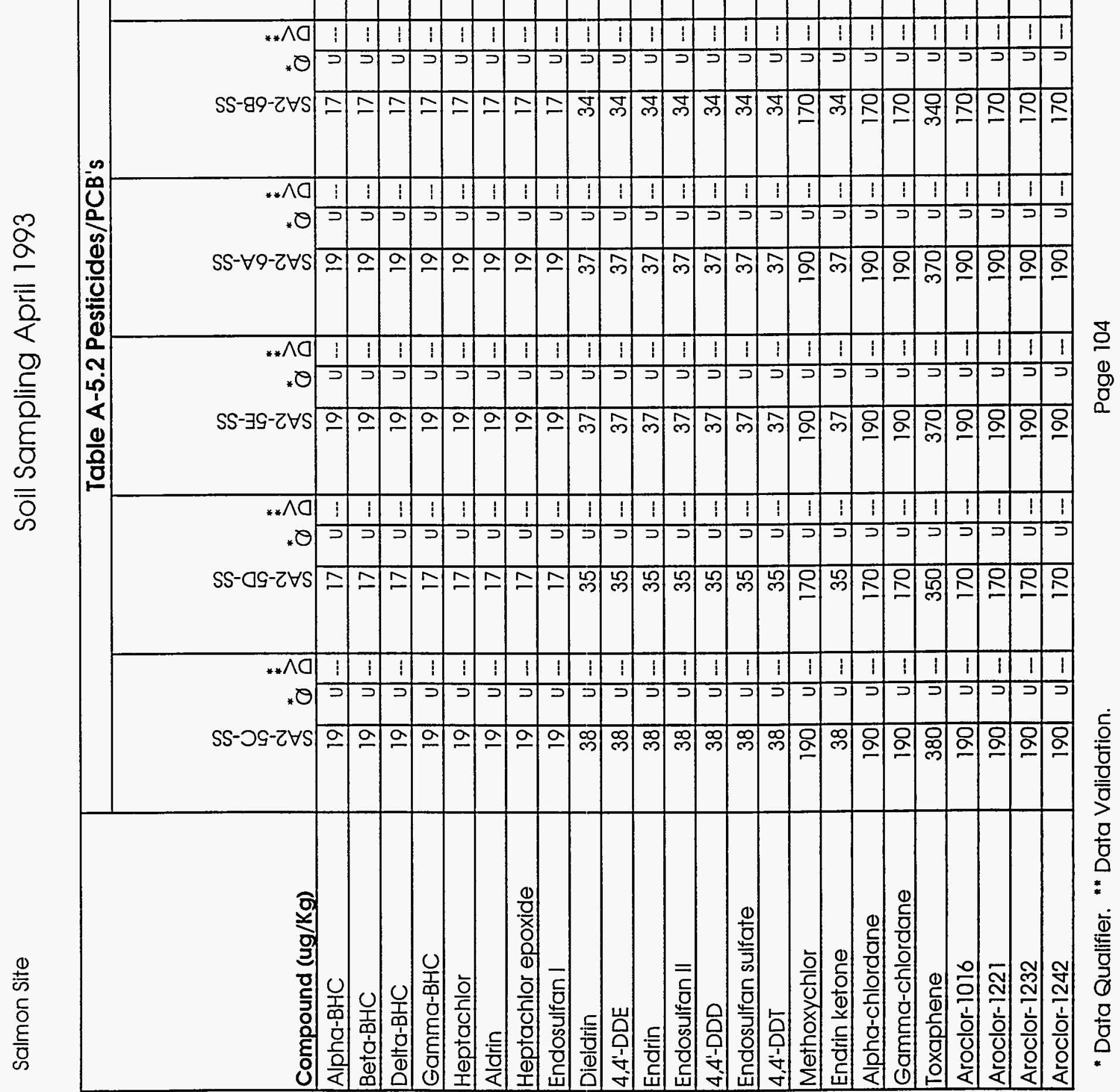

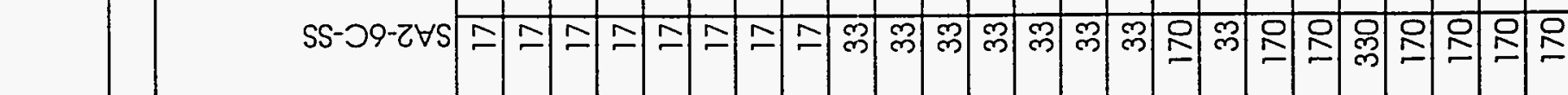

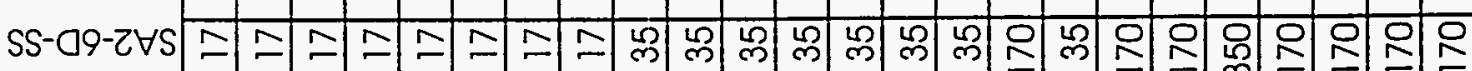

$* * \wedge 0 \quad 1 \quad\left[\begin{array}{llllllllllllllllllllllllll}* & 1 & 1 & 1 & 1 & 1 & 1 & 1 & 1 & 1 & 1 & 1 & 1 & 1 & 1 & 1 & 1 & 1 & 1 & 1 & 1 & 1 & 1\end{array}\right.$

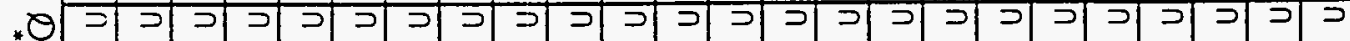




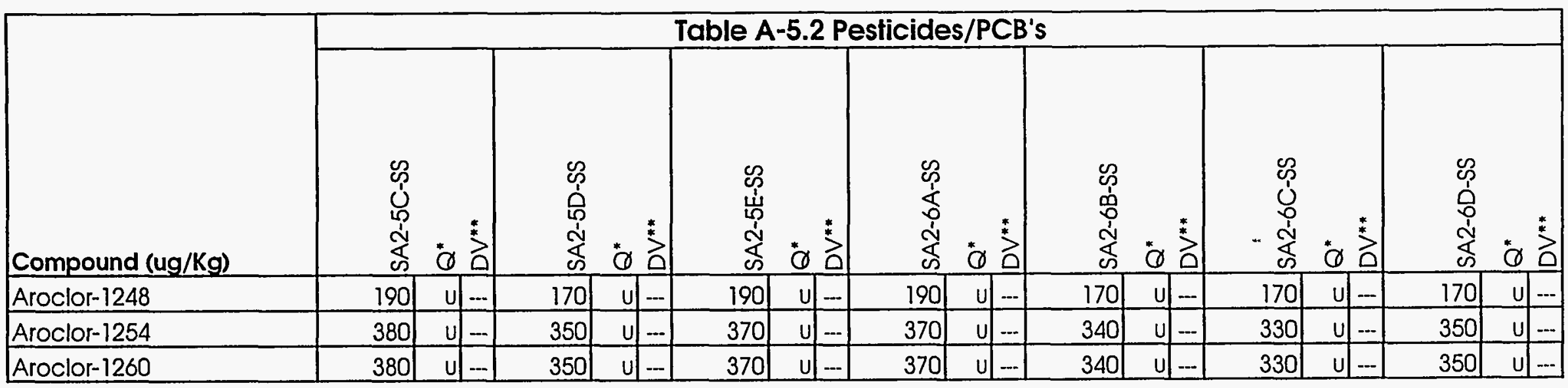


$\frac{\sqrt[J]{d}}{\frac{d}{d}}$
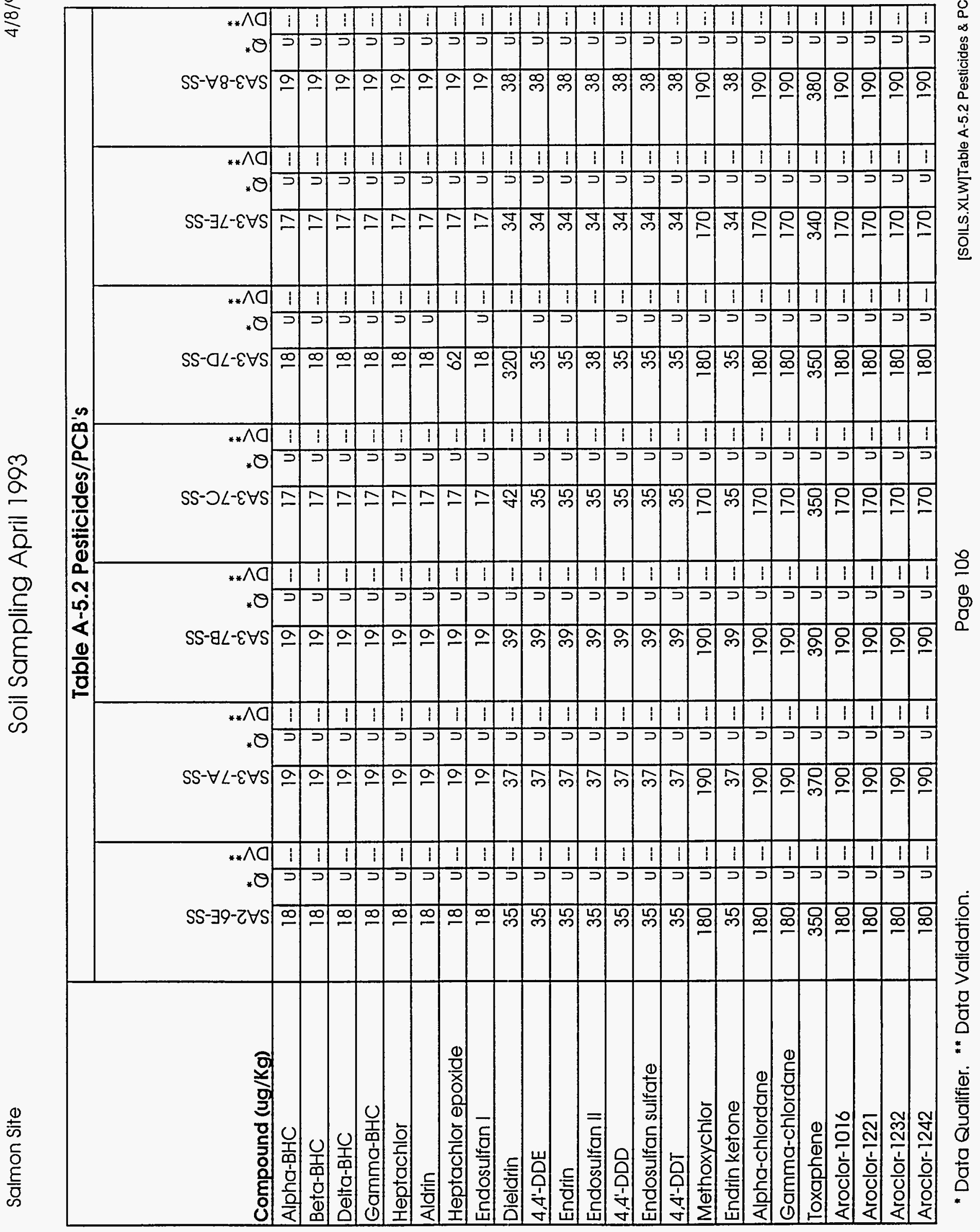


\begin{tabular}{|c|c|c|c|c|c|c|c|c|}
\hline \multirow[b]{2}{*}{ Compound (ug/Kg) } & \multicolumn{8}{|c|}{ Table A-5.2 Pesticides/PCB's } \\
\hline & 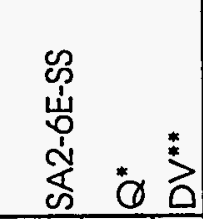 & 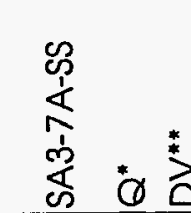 & 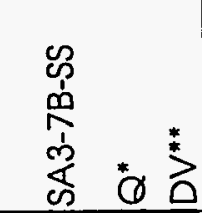 & 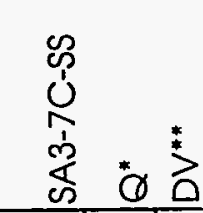 & & & 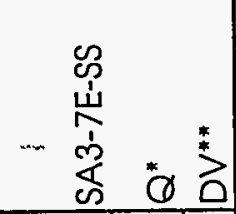 & 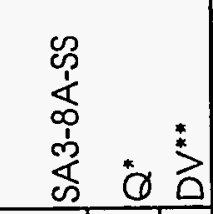 \\
\hline \begin{tabular}{|l|l|} 
Aroclor-1248 \\
\end{tabular} & \begin{tabular}{l|l|l|}
180 & 0 & $-\ldots$ \\
\end{tabular} & $190 \mid$ U & 190 o & \begin{tabular}{l|l|l|}
$170 \mid$ & $0 \mid-$
\end{tabular} & 180 & $4=$ & \begin{tabular}{l|l|l|}
170 & U \\
\end{tabular} & \begin{tabular}{l|l|}
190 & प \\
\end{tabular} \\
\hline Aroclor-1254 & \begin{tabular}{l|l|l|}
350 & u & - \\
\end{tabular} & \begin{tabular}{l|l}
370 & u_- \\
\end{tabular} & \begin{tabular}{l|l}
390 & u
\end{tabular} & \begin{tabular}{l|l|l}
350 & U. & $=$
\end{tabular} & 350 & $4=$ & \begin{tabular}{l|ll}
340 & 0 & $\ldots$ \\
\end{tabular} & $380 \mid$ U \\
\hline Aroclor-1260 & \begin{tabular}{l|l|l|}
350 & u \\
\end{tabular} & \begin{tabular}{l|l}
370 & u
\end{tabular} & \begin{tabular}{l|l|}
390 & U \\
$-\ldots$
\end{tabular} & \begin{tabular}{ll|l|}
350 & $\mathrm{u}$ & - \\
\end{tabular} & & $v \mid-$ & 340 & 380 \\
\hline
\end{tabular}


Table A-5.2 Pesticides/PCB's

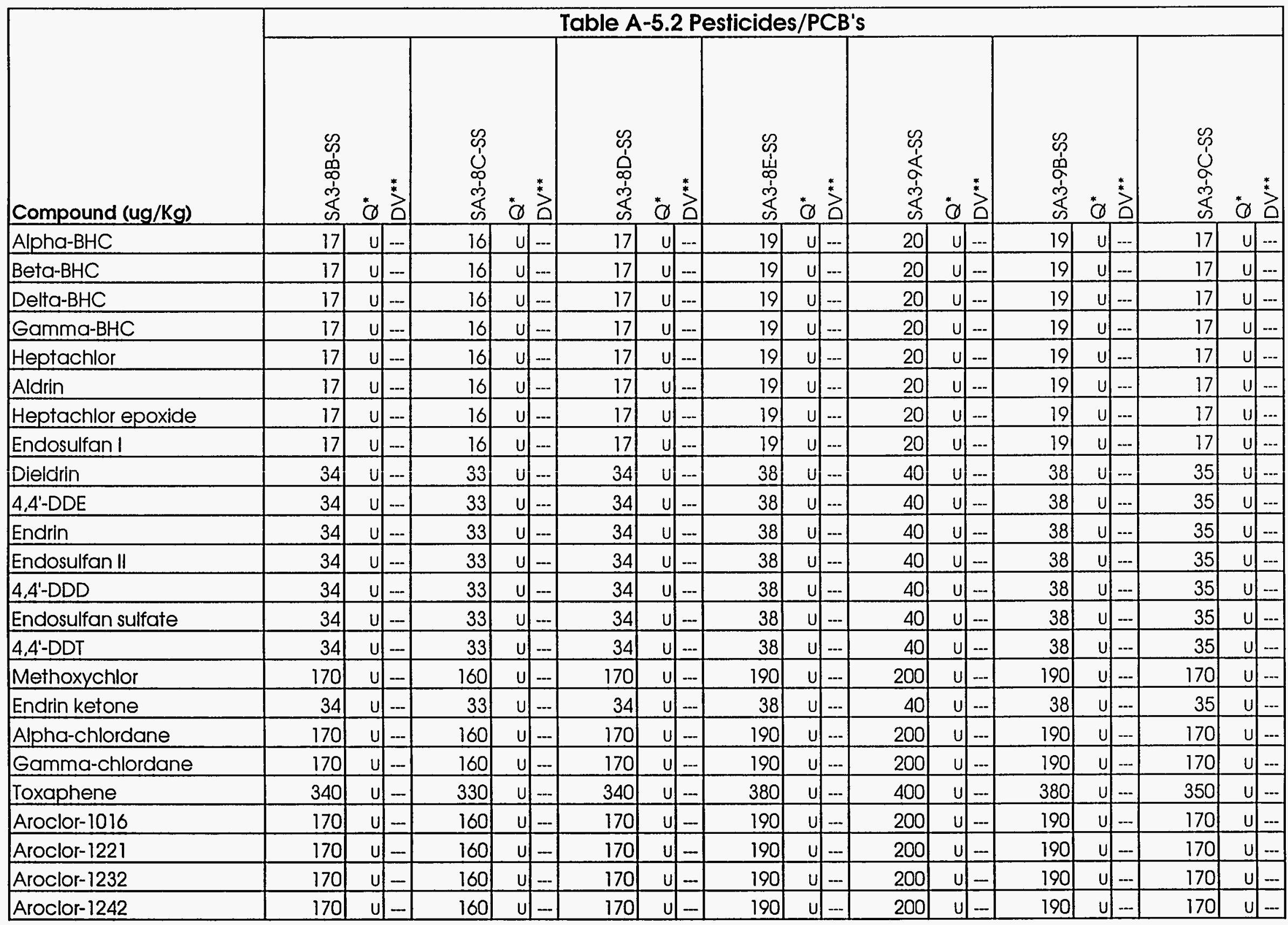




\begin{tabular}{|c|c|c|c|c|c|c|c|c|c|c|c|c|c|c|}
\hline \multirow[b]{2}{*}{ Compound (ug/ $/ \mathrm{Kg}$ ) } & \multicolumn{14}{|c|}{ Table A-5.2 Pesticides/PCB's } \\
\hline & 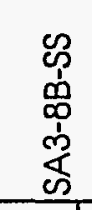 & ${ }^{\circ} \stackrel{\circ}{\circ}$ & 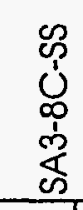 & $\dot{\theta}^{*} \stackrel{*}{2}$ & 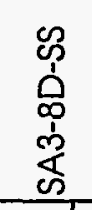 & $\stackrel{*}{*}$ & 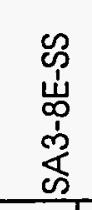 & $\stackrel{\circ}{\circ} \stackrel{*}{\square}$ & 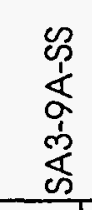 & ${ }^{\circ} \stackrel{*}{*}$ & 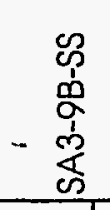 & * & 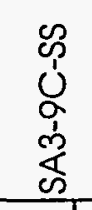 & 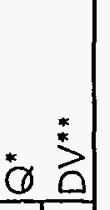 \\
\hline Aroclor-1248 & 170 & u| & 160 & \begin{tabular}{c|c}
$-\ldots$ \\
-
\end{tabular} & 170 & \begin{tabular}{l|l|}
4 & - \\
\end{tabular} & 190 & \begin{tabular}{l|l} 
& $\ldots$ \\
\end{tabular} & 200 & 0. & 190 & \begin{tabular}{l|l|}
4 & -1 \\
\end{tabular} & 170 & 0. \\
\hline Aroclor-1254 & 340 & $u[-$ & 330 & 4. & 340 & $\mathrm{u}]$ & 380 & $u$ & 400 & 0 & 380 & u) ... & 350 & $-\ldots$ \\
\hline Aroclor -1260 & 340 & u $[-$ & 330 & $0 . \ldots$ & 340 & U. & 380 & u $]$ & 400 & $u[-$ & 380 & U $[\ldots$ & 350 & \\
\hline
\end{tabular}




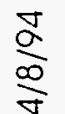

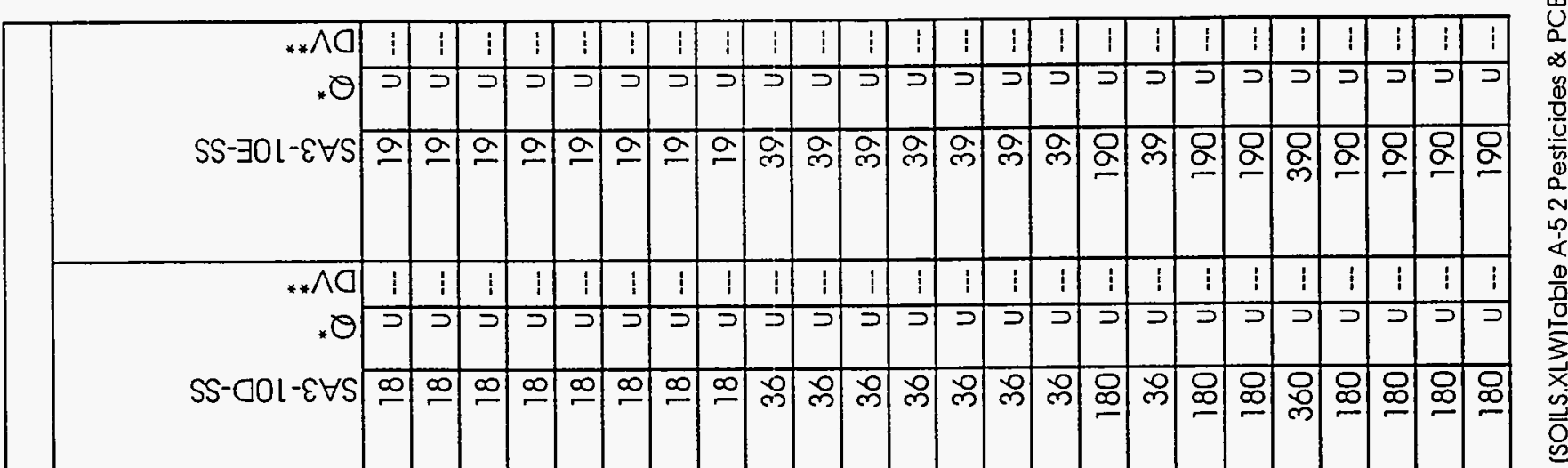

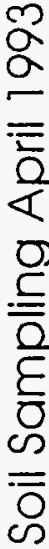

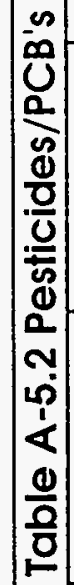
$\theta$

** $\wedge$

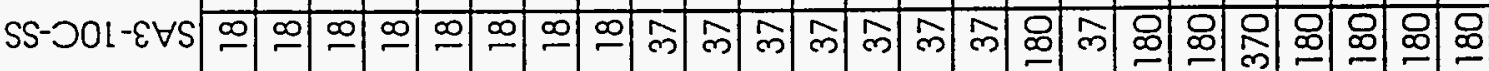

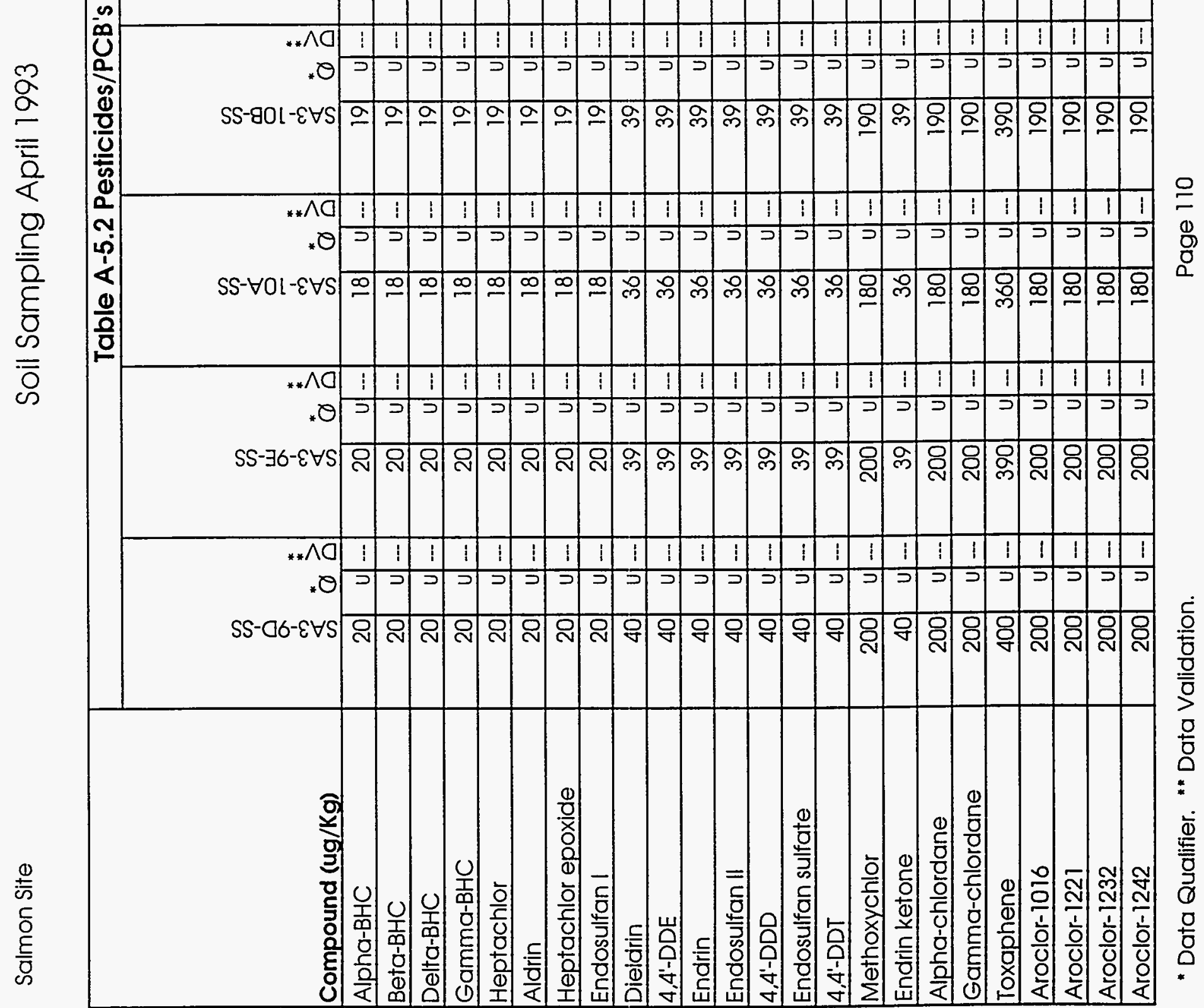




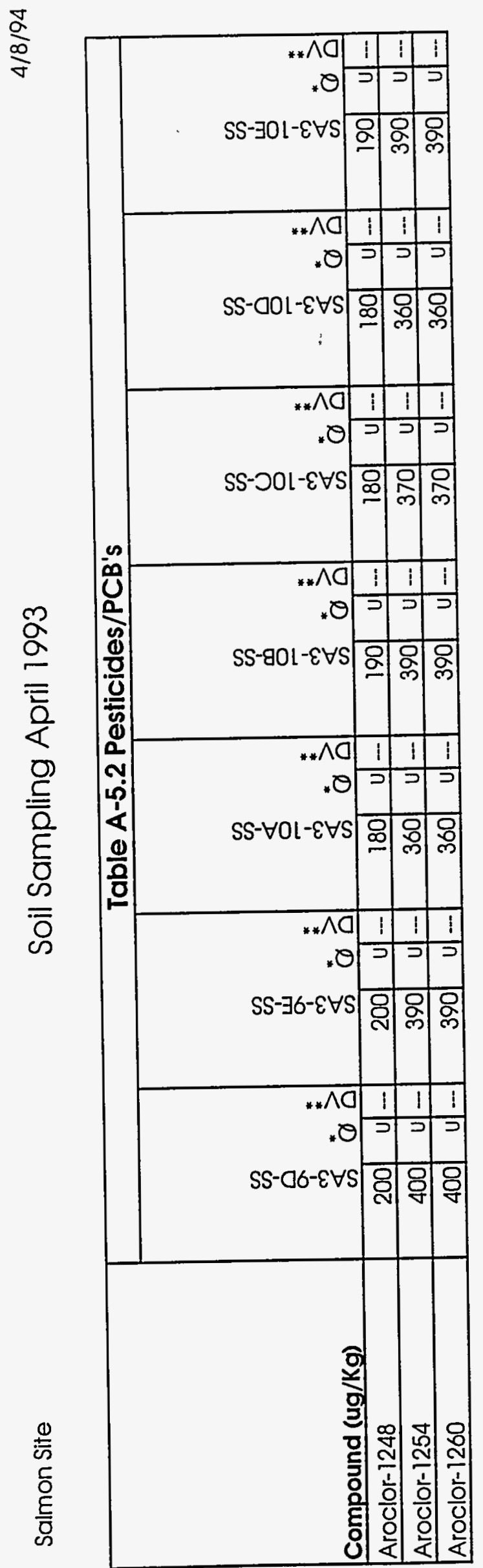




\begin{tabular}{|c|c|c|c|c|c|c|c|c|c|c|c|c|c|c|c|c|c|c|c|c|c|}
\hline \multirow[b]{2}{*}{ Compound (ug/Kg) } & \multicolumn{21}{|c|}{ Table A-5.2 Pesticides/PCB's } \\
\hline & 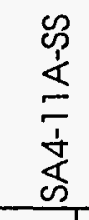 & & $\stackrel{*}{2}$ & 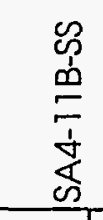 & & & 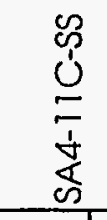 & & & 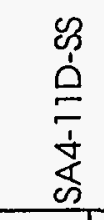 & & & 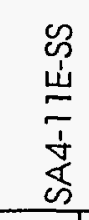 & & $\stackrel{2}{0}^{*}$ & 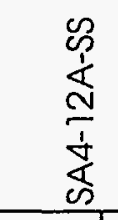 & & $\stackrel{*}{*}$ & 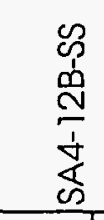 & & 늠 \\
\hline Alpha-BHC & 16 & 4 & -- & 16 & $u$ & $\ldots$ & 16 & $u$ & $-\ldots$ & 17 & $u$ & $\ldots$ & 16 & $u$ & $\ldots$ & 19 & $\mathrm{u}$. & $\ldots$ & 18 & $u$ & $\ldots$ \\
\hline Beta-BHC & 16 & u) & $\ldots$ & 16 & 4 & $\ldots$ & 16 & u & $\ldots$ & 17 & 4 & $\ldots$ & 16 & $\mathrm{u}$ & -- & 19 & $u$. & $\ldots$ & 18 & $\mathrm{u}$ & $\ldots$ \\
\hline Delta-BHC & 16 & u & $\ldots$ & 16 & U) & $\ldots$ & 16 & $u$ & $\ldots$ & 17 & U & $\ldots$ & 16 & $u$ & $\ldots$ & 19 & 4 & $\ldots$ & 18 & $\mathrm{u}$ & $\ldots$ \\
\hline Gamma-BHC & 16 & 4 & $\ldots$ & 16 & $u$ & $\ldots$ & 16 & u & $\ldots$ & 17 & 4 & $\ldots$ & 16 & $u$ & $\ldots$ & 19 & $\mathrm{u}$ & $\ldots$ & 18 & $u$ & $\ldots$ \\
\hline Heptachlor & 16 & u & $\ldots$ & 16 & 4 & -- & 16 & $\mathrm{U}$ & $\ldots$ & 17 & 4 & $\ldots$ & 16 & $u$ & $\ldots$ & 19 & $u$. & $\ldots$ & 18 & $u$ & $\ldots$ \\
\hline Aldrin & 16 & 4 & $\ldots$ & 16 & u & $\ldots$ & 16 & u) & $\ldots$ & 17 & 4 & $\ldots$ & 16 & $U$ & - & 19 & $u$ & $\ldots-$ & 18 & 4 & - \\
\hline Heptachlor epoxide & 16 & U) & $\ldots$ & 16 & u & $\ldots$ & 16 & u) & $\ldots$ & 17 & U & $\ldots$ & 16 & $U$ & $\ldots$ & 19 & $u$. & $\ldots$ & 18 & u & $\ldots$ \\
\hline Endosulfan I & 16 & 4 & -- & 16 & 4 & $\ldots$ & 16 & $u$ & -- & 17 & U) & - & 16 & $u$ & $\ldots$ & 19 & $u$ & $\ldots$ & 18 & U & - \\
\hline Dieldrin & 33 & u) & $\ldots$ & 32 & U) & $\ldots$ & 32 & u) & $\ldots$ & 34 & u) & $\ldots$ & 32 & U & $\ldots$ & 38 & U. & $\ldots$ & 35 & (1) & $\ldots$ \\
\hline 4., $4^{\prime}-D D E$ & 33 & 4 & $\ldots$ & 32 & u) & $\ldots$ & 32 & 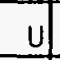 & $\ldots$ & 34 & 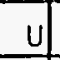 & $\ldots$ & 32 & $\mathrm{U}$ & $\ldots$ & 38 & $u$ & $\ldots$ & 35 & $\vec{u}$ & $\ldots$ \\
\hline Endrin & 33 & $u$ & $\ldots$ & 32 & 4 & $\ldots$ & 32 & U & $\ldots$ & 34 & 4 & $\ldots$ & 32 & 4 & $\ldots$ & 38 & 4. & $\ldots$ & 35 & 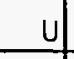 & $\ldots$ \\
\hline Endosulfan II & 33 & 4 & -- & 32 & 4 & $\ldots$ & 32 & 4 & -- & 34 & 4 & -- & 32 & 4 & $\ldots$ & 38 & 4. & $\ldots$ & 35 & 4 & $-\cdots$ \\
\hline 4,4'-DDD & 33 & $u$ & - & 32 & u) & $\ldots$ & 32 & $u$ & $\ldots$ & 34 & $u$ & $\ldots$ & 32 & $\mathrm{u}$ & -- & 38 & $u$ & $\ldots+$ & 35 & $u$ & $\ldots$ \\
\hline Endosulfan sulfate & 33 & 4 & - & 32 & $u$ & -- & 32 & 4 & $\ldots$ & 34 & 4 & $\ldots$ & 32 & 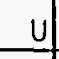 & -- & 38 & $\underline{u}$ & $\cdots$ & 35 & $u$ & $\ldots$ \\
\hline 4,4'-DDT & 33 & u & - & 32 & 4 & -- & 32 & 4 & $\ldots$ & 34 & 4 & - & 32 & $\mathrm{u}$ & $\ldots$ & 38 & $u$. & $\ldots$ & 35 & $u$ & $\ldots$ \\
\hline Methoxychlor & 160 & 4 & $=$ & 160 & 4 & $\ldots$ & 160 & 4 & -- & 170 & 4 & -- & 160 & 4 & $\ldots$ & 190 & 4. & $\ldots$ & 180 & U & - \\
\hline Endrin ketone & 33 & 4 & $\ldots$ & 32 & $u$ & $\ldots$ & 32 & 4 & -- & 34 & 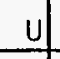 & -- & 32 & $u$ & - & 38 & 4. & $\ldots-$ & 35 & 4 & - \\
\hline Alpha-chlordane & 160 & Uf & - & 160 & $u$ & $\ldots$ & 160 & $u$ & - & 170 & 4 & $\ldots$ & 160 & 4 & -- & 190 & 4 & $\ldots$ & 180 & u & $\ldots$ \\
\hline Gamma-chlordane & 160 & 4 & - & 160 & 4 & $\ldots$ & 160 & 4 & - & 170 & U & -- & 160 & $\mathrm{u}$ & -- & 190 & U & $\ldots$ & 180 & u & - \\
\hline Toxaphene & 330 & $u$ & - & 320 & 4 & - & 320 & 4 & $\ldots$ & 340 & U & - & 320 & $u$ & - & 380 & 4 & $\ldots$ & 350 & U & - \\
\hline Aroclor-1016 & 160 & U & - & 160 & u & - & 160 & 4 & - & 170 & 4 & $\ldots$ & 160 & $\underline{U}$ & - & 190 & $u$ & - & 180 & $u$ & - \\
\hline Aroclor-1221 & 160 & u & - & 160 & 4 & - & 160 & 4 & - & 170 & 4 & $=$ & 160 & 4 & - & 190 & 4 & $\ldots$ & 180 & 4 & - \\
\hline Aroclor-1232 & 160 & $\mathrm{u}$ & - & 160 & U & $\ldots$ & 160 & U) & - & 170 & $\mathrm{u}$ & - & 160 & $\mathrm{U}$ & - & 190 & U & $\ldots$ & 180 & $u$ & - \\
\hline Aroclor- 1242 & 160 & U] & -1 & 160 & U) & $\ldots$ & 160 & U) & -1 & 170 & U] & --1 & 160 & U & - & 190 & U] & - & 180 & U] & $\ldots$ \\
\hline
\end{tabular}

- Data Qualifier. " Data Validation. 


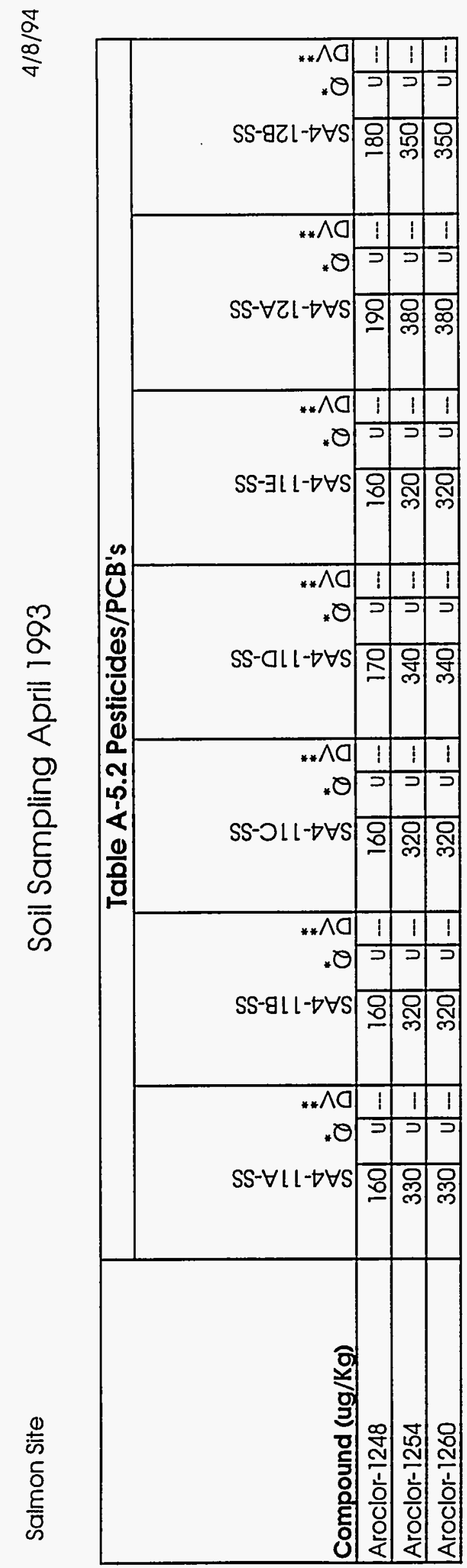

$\frac{m}{\stackrel{0}{0}}$

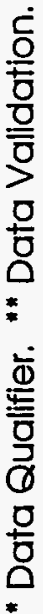


$\frac{\square}{\infty}$

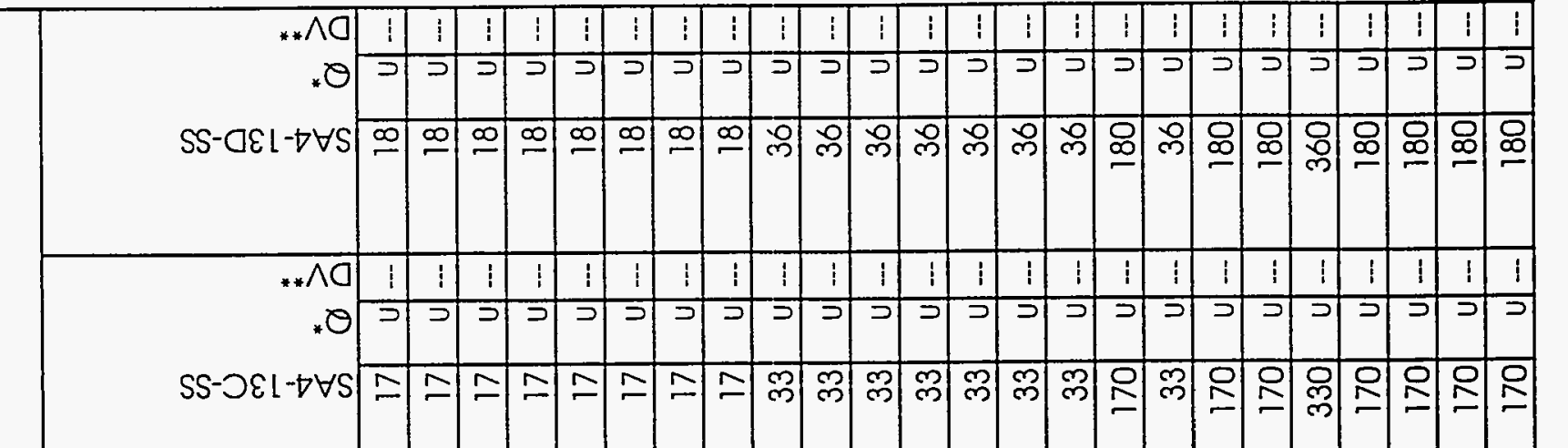

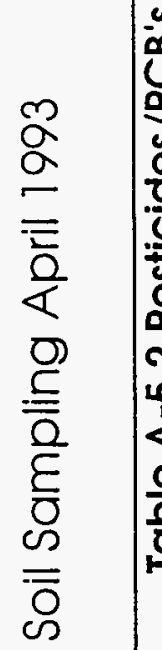<smiles>[CH]1CCCC1</smiles>

$\infty$

Uి

$* \wedge \mathrm{\wedge}$

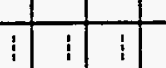

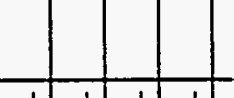

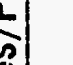

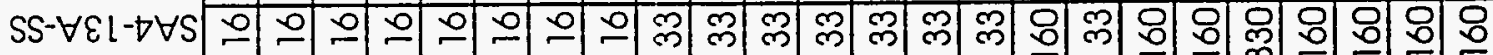

0
0
0
0
0
0
0

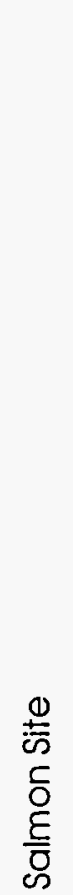

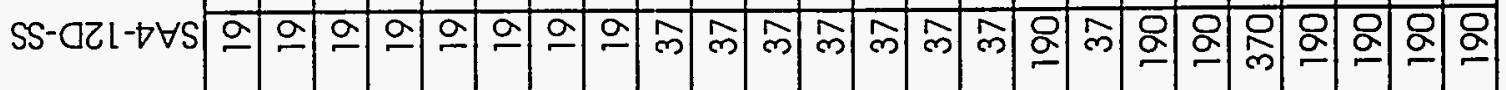

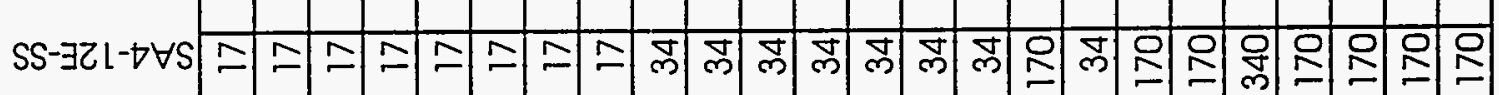

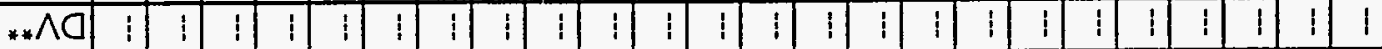
.$\theta$ د ग د

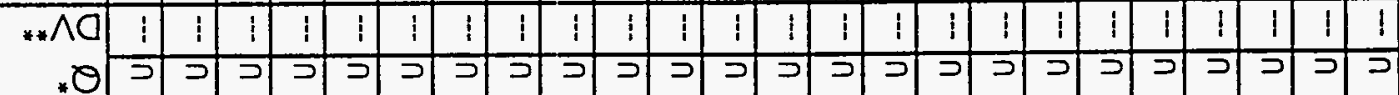

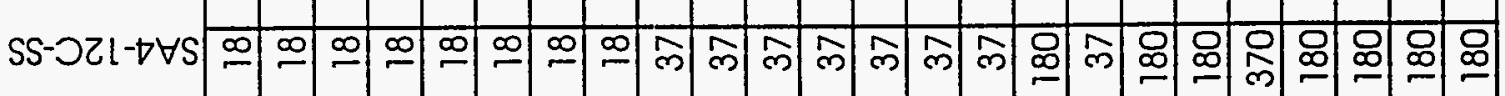




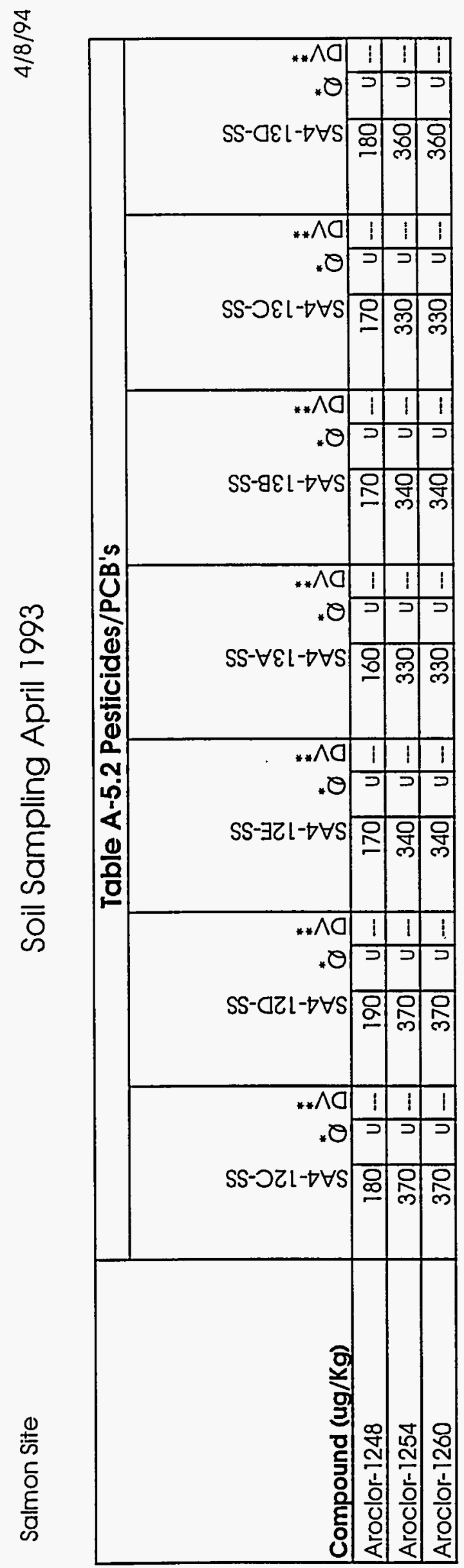

$\frac{1}{1}$
0
0
0 


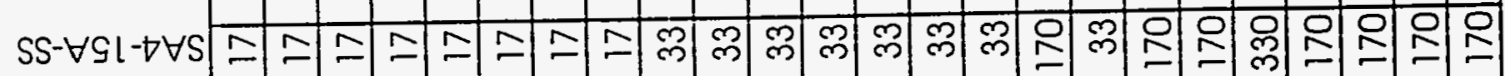

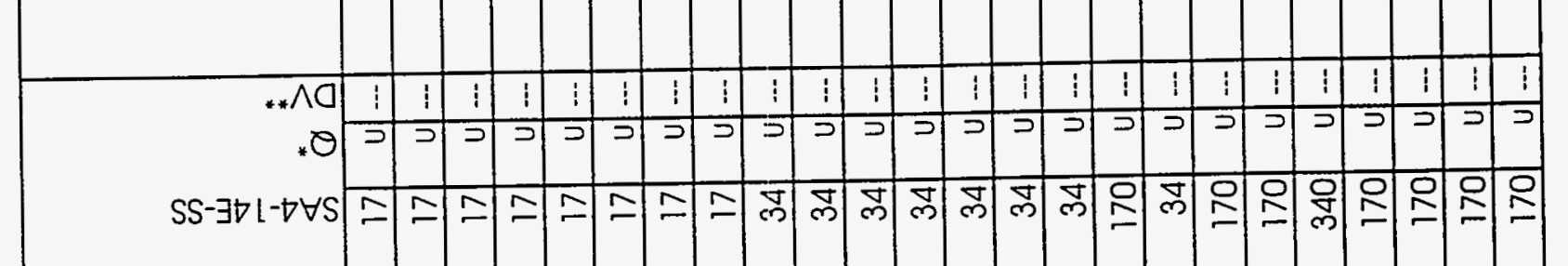

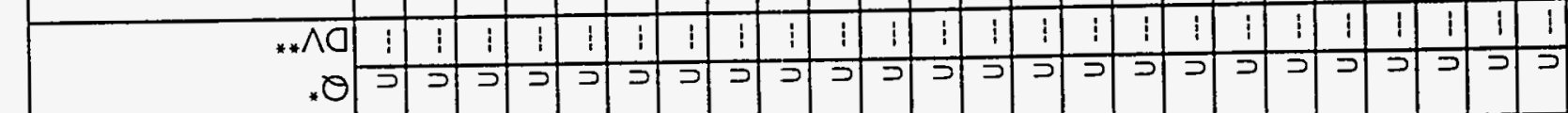

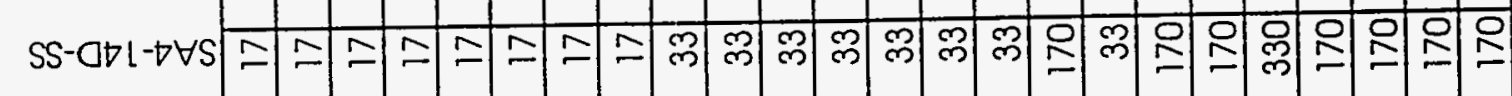

is Uి

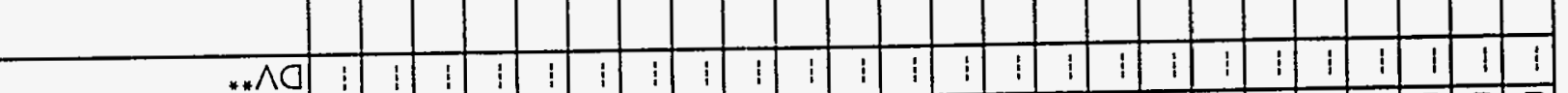

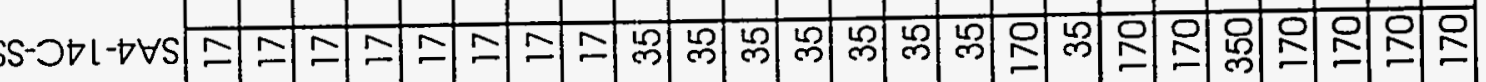




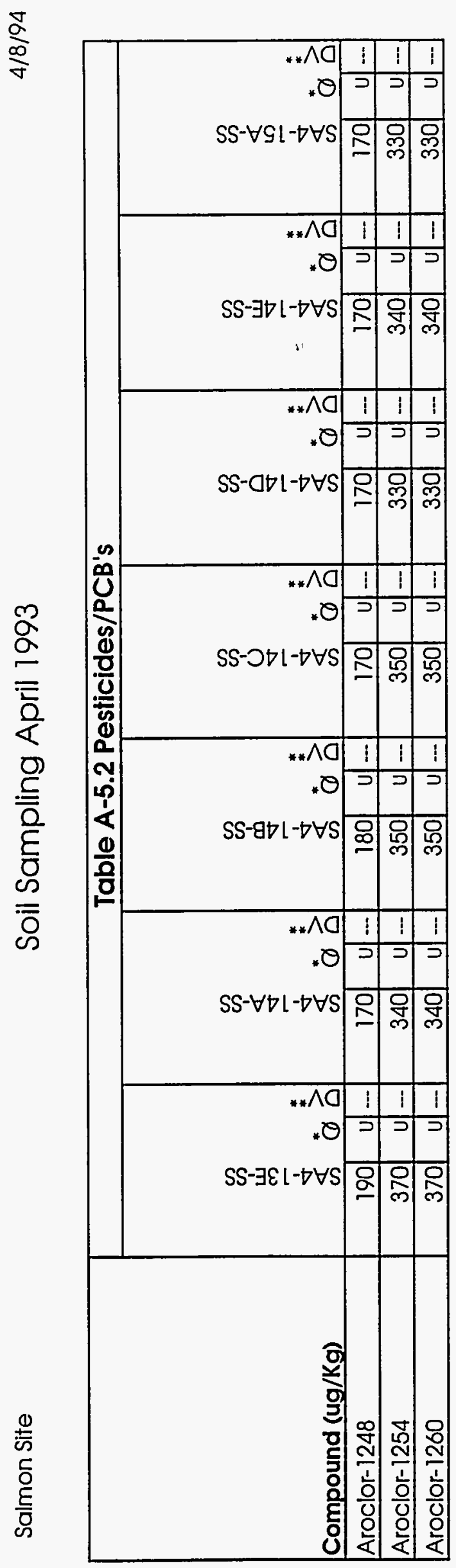


$\frac{\sigma}{\frac{\sigma}{\sigma}}$
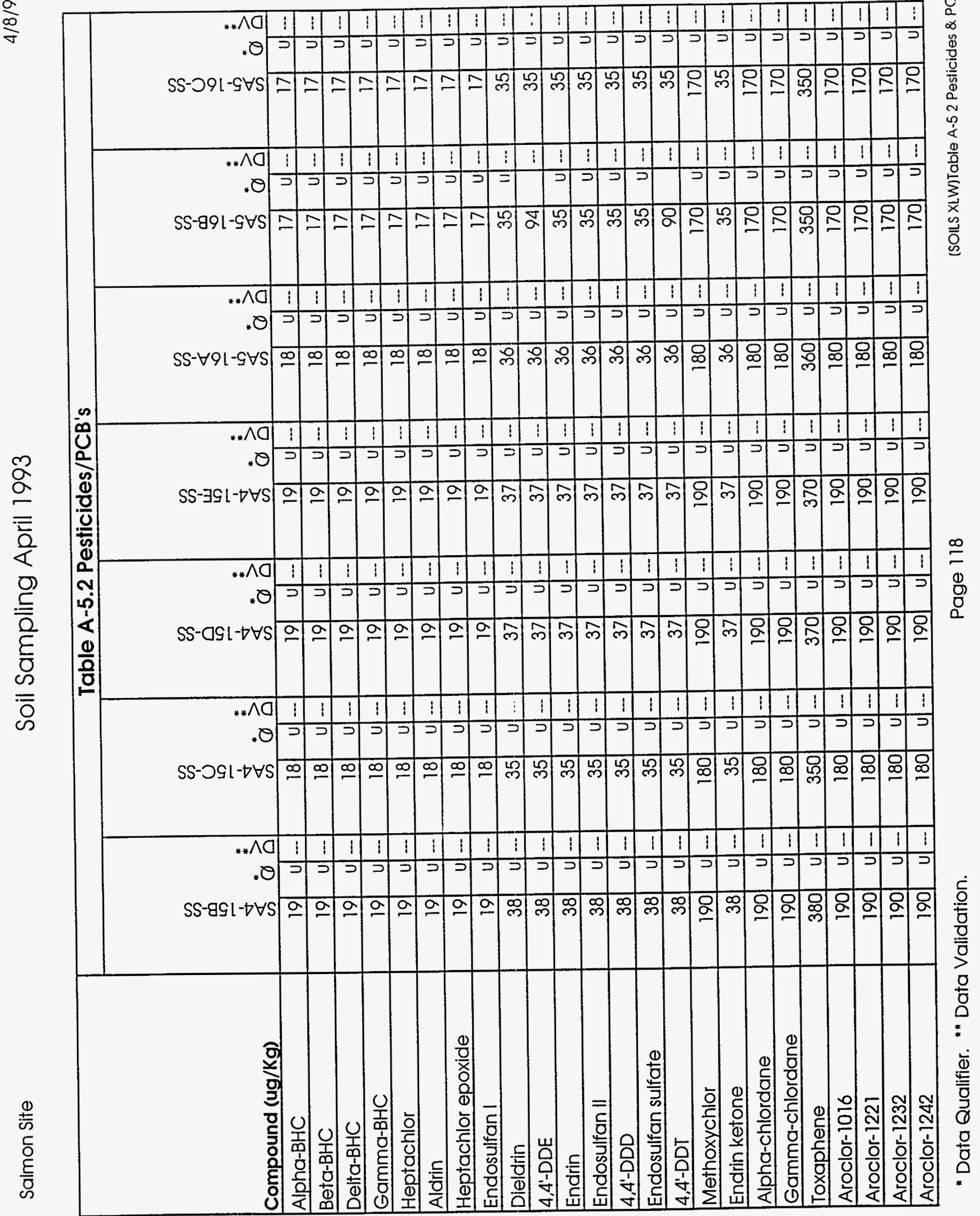


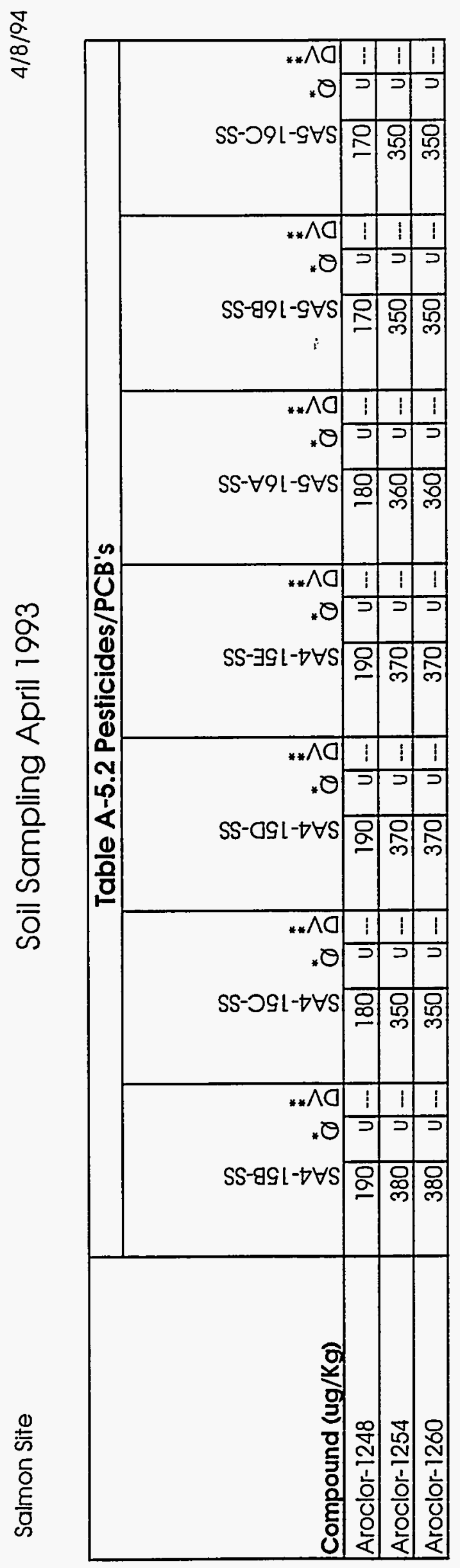




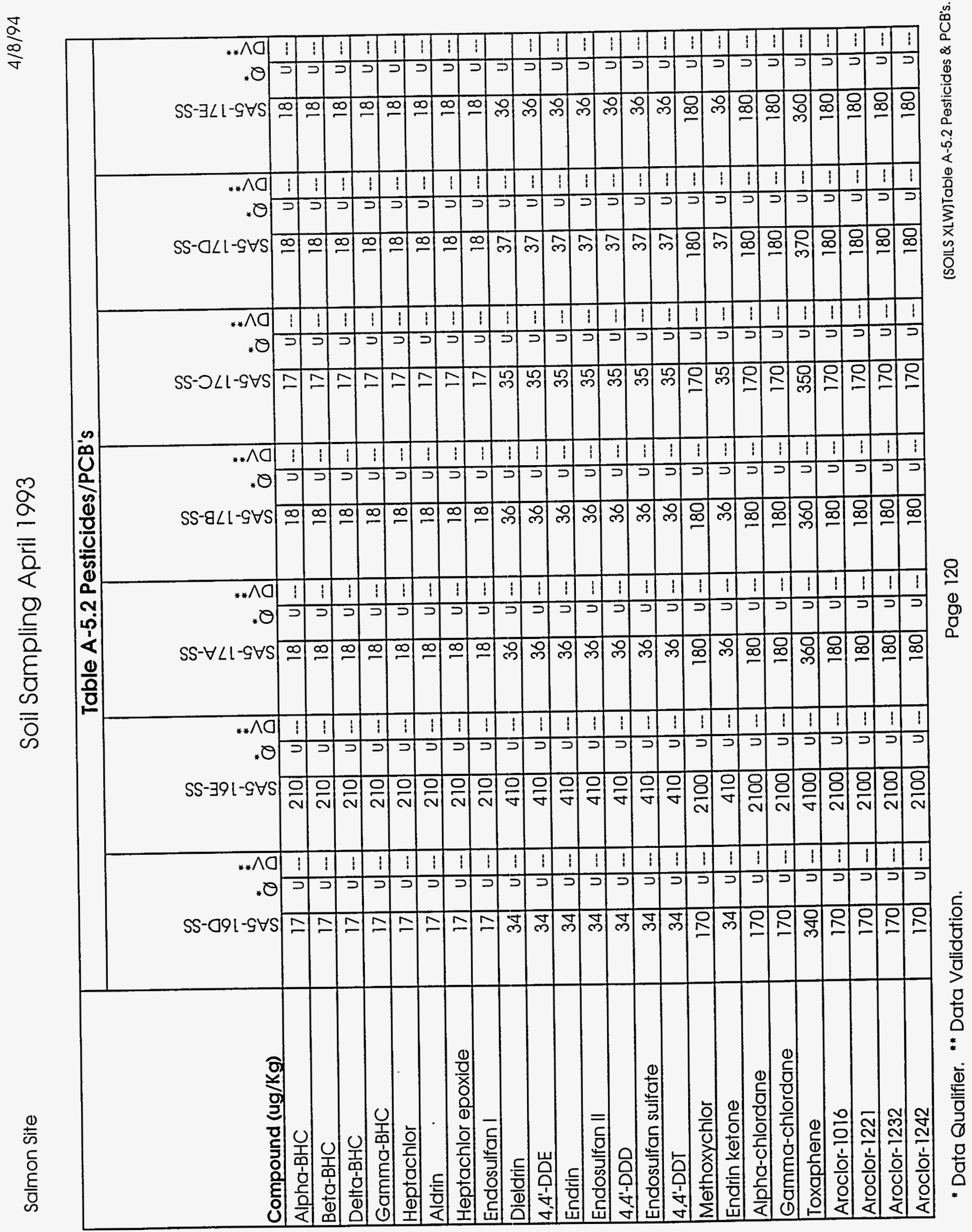




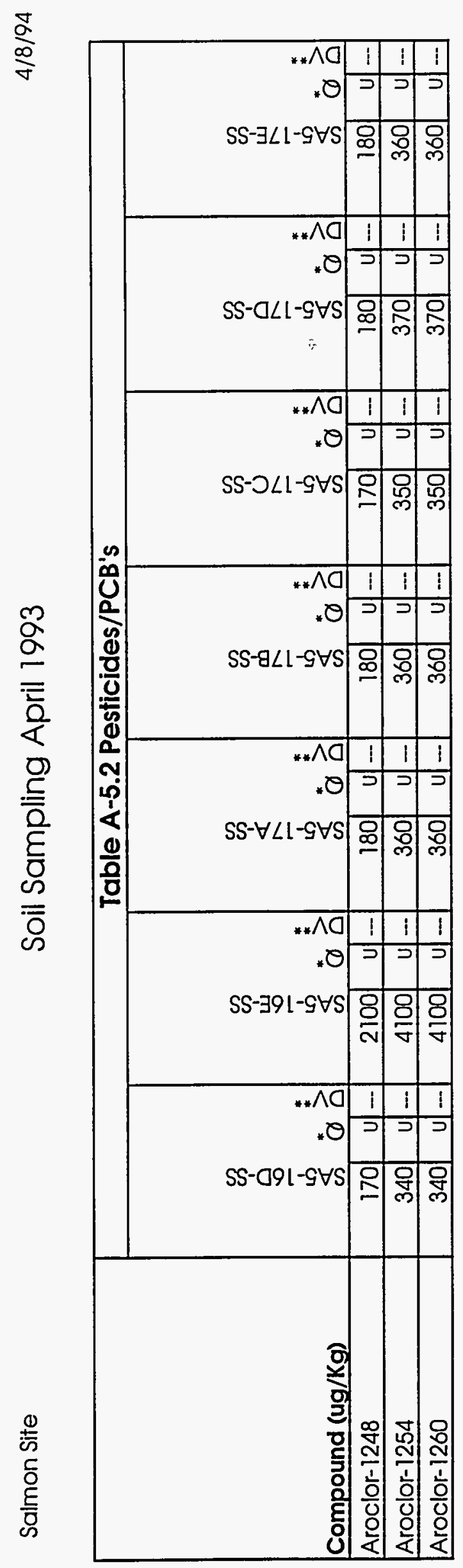

$\bar{N}$
$\overline{0}$
$\square$
$\square$

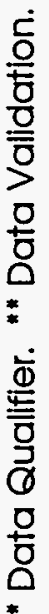


Table A-5.2 Pesticides/PCB's

\begin{tabular}{|c|c|c|c|c|c|c|c|c|c|c|c|c|c|c|c|c|c|c|c|c|c|}
\hline \multirow[b]{2}{*}{ Compound (ug/Kg) } & \multicolumn{21}{|c|}{ Table A-5.2 Pesticides/PCB's } \\
\hline & 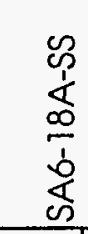 & & & 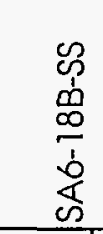 & & & $\begin{array}{l}\infty \\
0 \\
0 \\
\infty \\
0 \\
\vdots \\
\delta\end{array}$ & $\stackrel{*}{\oslash}$ & $\stackrel{2}{*}$ & 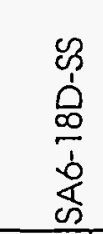 & $\stackrel{*}{Q}$ & $\stackrel{3}{0}^{*}$ & 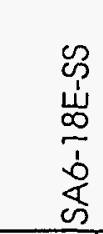 & & $\stackrel{*}{*}$ & 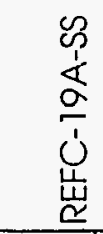 & & $\stackrel{*}{2}$ & 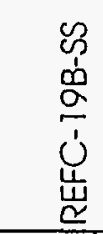 & & $\stackrel{3}{0}^{*}$ \\
\hline Alpha-BHC & 18 & $u$ & - & 18 & $\mathrm{U}$ & $-\ldots$ & 18 & $u$ & $\ldots$ & 18 & $U$ & $\ldots$ & 18 & $u$ & $\ldots$ & 17 & $u$ & $\ldots$ & 18 & U & $\ldots$ \\
\hline Beta-BHC & 18 & $u$ & $\ldots$ & 18 & $u$ & -- & 18 & 4 & $\ldots$ & 18 & $u$ & $\ldots$ & 18 & $u$ & $\ldots$ & 17 & $u$ & $-\ldots$ & 18 & $u$ & $\ldots$ \\
\hline Delta-BHC & 18 & $\mathrm{u}$ & $\ldots$ & 18 & $\mathrm{u}$ & -- & 18 & $u$ & $\ldots$ & 18 & $\mathrm{u}$ & $\ldots$ & 18 & $u$ & $\ldots$ & 17 & $u$ & $\ldots$ & 18 & $u$ & $\ldots$ \\
\hline Gamma-BHC & 18 & $u$ & $\ldots$ & 18 & $\mathrm{U}$ & $\ldots$ & 18 & u & $\ldots$ & 18 & $u$ & $\ldots$ & 18 & 4 & $\ldots$ & 17 & $u$ &..- & 18 & $u$ & - \\
\hline Heptachlor & 18 & 4 & $\ldots$ & 18 & $u$ & - & 18 & $u$ & $\ldots$ & 18 & $u$ & - & 18 & $u$ & $\ldots$ & 17 & $\mathrm{U}$ &.- & 18 & 4 & $\ldots$ \\
\hline Aldrin & 18 & $\mathrm{U}$ & $\ldots$ & 18 & $\mathrm{U}$ & -- & 18 & $u$ & $\ldots$ & 18 & $u$ & $\ldots$ & 18 & 4 & -- & 17 & $u$ & $\ldots$ & 18 & 4 & $\ldots$ \\
\hline Heptachlor epoxide & 18 & $\mathrm{U}$ & $\ldots$ & 18 & $\mathrm{U}$ & $\ldots$ & 18 & $u$ & $\ldots$ & 18 & $\mathrm{u}$ & $\ldots$ & 18 & $U$ & $\ldots$ & 17 & $u$ & --- & 18 & $u$ & $\ldots$ \\
\hline Endosulfan I & 18 & $u$ & $\ldots$ & 18 & $\mathrm{U}$ & $-\ldots$ & 18 & $u$ & $\ldots$ & 18 & $u$ & $\ldots$ & 18 & u & $\ldots$ & 17 & $u$ & $\ldots$ & 18 & U & $\ldots$ \\
\hline Dieldrin & 36 & $u$ & $\ldots$ & 35 & $\mathrm{U}$ & - & 35 & $u$ & $\cdots$ & 35 & $u$ & $\ldots$ & 35 & $\mathrm{u}$ & $\ldots$ & 34 & $u$ & $\ldots$ & 37 & 11 & $\ldots$ \\
\hline 4,4'-DDE & 36 & $u$ & $\ldots$ & 35 & $\mathrm{U}$ & - & 35 & $\mathrm{U}$ & $\ldots$ & 35 & $\mathrm{u}$ & - & 35 & $u$ & $\ldots$ & 34 & U & $\ldots$ & 37 & $u$ & $\ldots$ \\
\hline Endrin & 36 & $u$ & $\ldots$ & 35 & $\mathrm{U}$ & $-\cdots$ & 35 & $\mathrm{U}$ & $\cdots$ & 35 & $\mathrm{u}$ & -- & 35 & 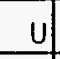 & $\ldots$ & 34 & $U$ & $\ldots$ & 37 & 4 & $\ldots$ \\
\hline Endosulfan II & 36 & $\mathrm{U}$ & $\ldots$ & 35 & $U$ & - & 35 & $u$ & $\ldots$ & 35 & $\mathrm{u}$ & $\ldots$ & 35 & $u$ & $\ldots$ & 34 & $u$ & $\ldots$ & 37 & 1) & $\ldots$ \\
\hline 4,4'-DDD & 36 & U. & $\ldots$ & 35 & $\mathrm{U}$ & $\ldots$ & 35 & $u$ & $\ldots$ & 35 & $\mathrm{U}$ & - & 35 & $u$ & $\ldots$ & 34 & $u$ & - & 37 & $u$ & $\ldots$ \\
\hline Endosulfan sulfate & 36 & $u$ & $\ldots$ & 35 & $\mathrm{U}$ & $\ldots$ & 35 & $\mathrm{U}$ & $\ldots$ & 35 & $\mathrm{u}$ & - & 35 & $u$ & $\ldots$ & 34 & $u$ &.-- & 37 & $u$ & $\ldots$ \\
\hline 4,4'-DDT & 36 & $u$ & $\ldots$ & 35 & $\mathrm{U}$ & - & 35 & 4 & $\ldots$ & 35 & $\mathrm{u}$ & -- & 35 & 4 & $\ldots$ & 34 & $u$ & $\ldots$ & 37 & $\mathrm{U}$ & $\ldots$ \\
\hline Methoxychlor & 180 & $u$ & $\ldots$ & 180 & $\mathrm{u}$ & - & 180 & $u$ & $-\ldots$ & 180 & $\mathrm{U}$ & $\ldots$ & 180 & $u$ & $\ldots$ & 170 & $u$ & $\ldots$ & 180 & $u$ & $\ldots$ \\
\hline Endrin ketone & 36 & $u$ & $\ldots$ & 35 & $\mathrm{U}$ & $\ldots$ & 35 & $u$ & $\ldots$ & 35 & $\mathrm{u}$ & $\ldots$ & 35 & $u$ & $-{ }_{-1}$ & 34 & $\mathrm{u}$ &.-- & 37 & 4 & $\ldots$ \\
\hline Alpha-chlordane & 180 & 4 & $\ldots$ & 180 & $u$ & - & 180 & 4 & $\ldots$ & 180 & $u$ & - & 180 & 4 & $\ldots$ & 170 & $u$ & $\ldots$ & 180 & $u$ & $\ldots$ \\
\hline Gamma-chlordane & 180 & $u$ & $\ldots$ & 180 & $\mathrm{U}$ & -- & 180 & $u$ &.- & 180 & $u$ & $\ldots$ & 180 & $\mathrm{u}$ & $-\ldots$ & 170 & $\mathrm{U}$ & $\ldots$ & 180 & $u$ & $\ldots$ \\
\hline Toxaphene & 360 & u & $\ldots$ & 350 & $u$ & - & 350 & $u$ & $\ldots$ & 350 & $\mathrm{u}$ & $\ldots$ & 350 & $u$ & $\ldots$ & 340 & $\mathrm{U}$ & $\ldots$ & 370 & 4 & $\ldots$ \\
\hline Aroclor-1016 & 180 & 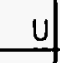 & $\ldots$ & 180 & $\mathrm{U}$ & - & 180 & $u$ & $\ldots$ & 180 & $u$ & $\ldots$ & 180 & 4 &.-- & 170 & $u$ & $\ldots$ & 180 & $u$ & $\ldots$ \\
\hline Aroclor-1221 & 180 & $\mathrm{U}$ & $\ldots$ & 180 & $u$ & $\ldots$ & 180 & u & -- & 180 & $\mathrm{U}$ & $\ldots$ & 180 & $u$ & $\ldots$ & 170 & $u$ & $\ldots$ & 180 & $u$ & $\ldots$ \\
\hline Aroclor- 1232 & 180 & $u$ & $\ldots$ & 180 & $\mathrm{U}$ & - & 180 & $u$ & -- & 180 & $u$ & -- & 180 & $u$ & $\ldots$ & 170 & $\mathrm{u}$ & $\ldots$ & 180 & $u$ & $\ldots$ \\
\hline Aroclor-1242 & 180 & U & $\ldots$ & 180 & $u$ & - & 180 & ul & - & 180 & $\mathrm{U}$ & -- & 180 & u & $\ldots$ & 170 & & $\ldots$ & 180 & & $\ldots$ \\
\hline
\end{tabular}




\begin{tabular}{|c|c|c|c|c|c|c|c|c|c|c|c|c|c|c|c|c|c|c|c|c|c|}
\hline \multirow[b]{2}{*}{ Compound (ug/Kg) } & \multicolumn{21}{|c|}{ Table A-5.2 Pesticides/PCB's } \\
\hline & 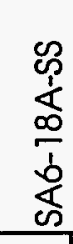 & & & 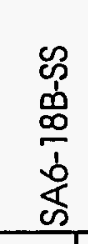 & ๑ & & 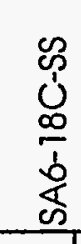 & & ${ }^{*}$ & 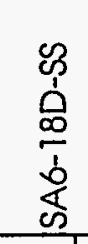 & & ${ }^{*}$ & 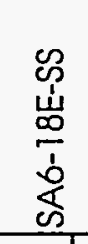 & & 으 & 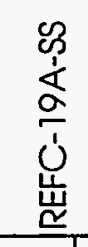 & & $\stackrel{2}{0}^{*}$ & 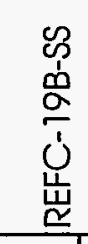 & & $\stackrel{2}{0}^{*}$ \\
\hline Aroclor-1248 & 180 & u. & $\ldots$ & 180 & & -- & 180 & 4 & - & 180 & & -- & 180 & 4 & $\cdots$ & 170 & $u$ & $\ldots$ & 180 & & $\ldots$ \\
\hline Aroclor- 1254 & 360 & & $\ldots$ & 350 & & $\ldots$ & 350 & u & -- & 350 & & - & 350 & $u$ & $\ldots$ & 340 & $u$ &.- & 370 & & $\cdots$ \\
\hline Aroclor- 1260 & 360 & & $-\ldots$ & 350 & $u$ - & $\ldots$ & 350 & & - & 350 & & $\ldots$ & 350 & & $-\ldots$ & 340 & & $\ldots$ & 370 & & $\ldots$ \\
\hline
\end{tabular}




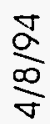

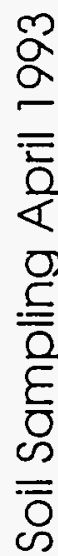

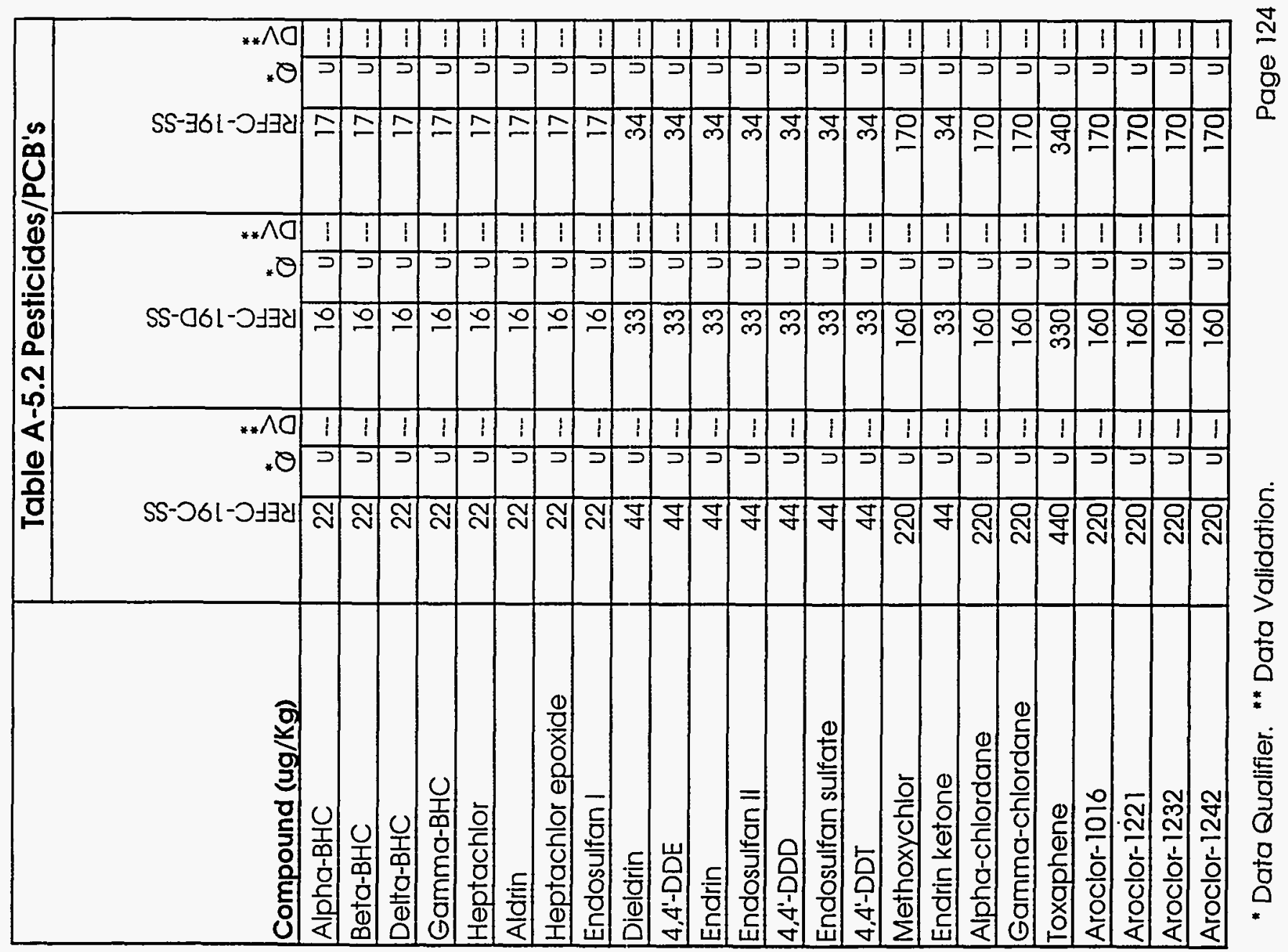




\begin{tabular}{|c|c|c|c|}
\hline \multirow[b]{2}{*}{ Compound $(\mathrm{ug} / \mathrm{kg})$} & \multicolumn{3}{|c|}{ Table A-5.2 Pesticides/PCB's } \\
\hline & 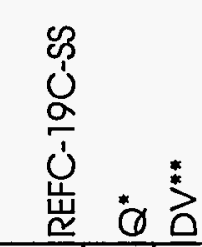 & 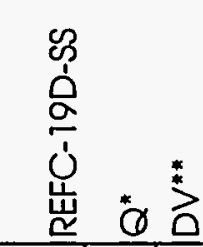 & 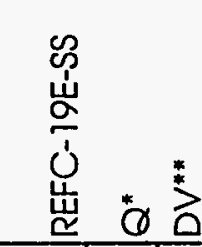 \\
\hline Aroclor-1248 & \begin{tabular}{l|l|}
220 & 4 \\
2
\end{tabular} & $160|0|=$ & \begin{tabular}{l|l|l}
170 & 0 \\
\end{tabular} \\
\hline Aroclor-1254 & \begin{tabular}{l|l}
440 & y.-
\end{tabular} & \begin{tabular}{l|l|}
330 & U
\end{tabular} & \begin{tabular}{l|l|}
340 & $4=$
\end{tabular} \\
\hline Aroclor- 1260 & \begin{tabular}{l|l|}
440 & U
\end{tabular} & \begin{tabular}{l|l|}
330 & U
\end{tabular} & 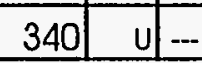 \\
\hline
\end{tabular}




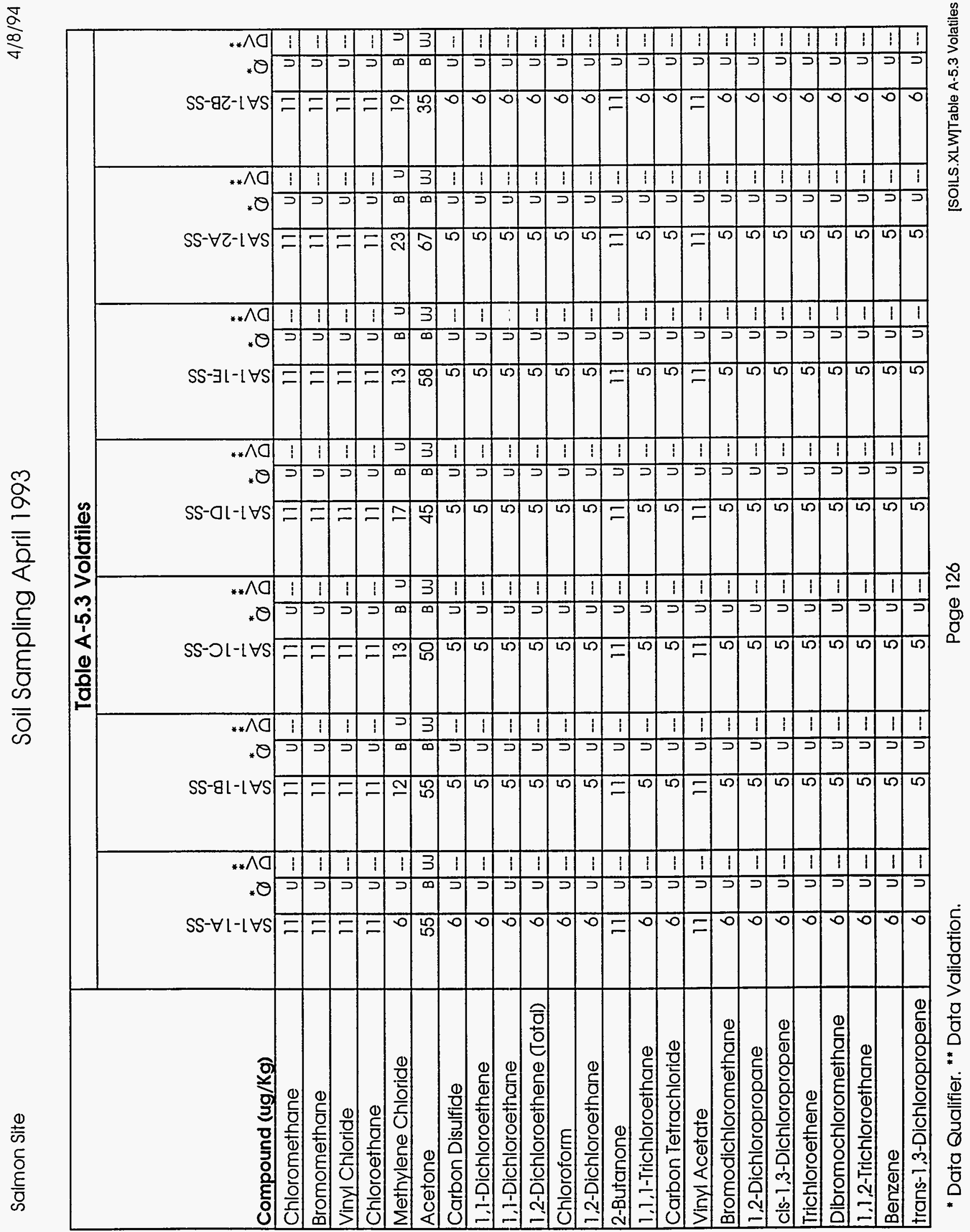




\begin{tabular}{|c|c|c|c|c|c|c|c|c|c|c|c|c|c|c|c|c|c|c|c|c|c|}
\hline \multirow[b]{2}{*}{ Compound (ug/Kg) } & \multicolumn{21}{|c|}{ Table A-5.3 Volatiles } \\
\hline & $\begin{array}{l}c \\
c \\
\frac{1}{4} \\
\frac{1}{4} \\
\frac{1}{6}\end{array}$ & & & 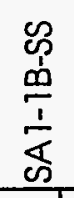 & & & $\begin{array}{l}\mathscr{c} \\
0 \\
0 \\
\frac{1}{4} \\
\mathbb{c}\end{array}$ & & ${ }_{2}^{*}$ & 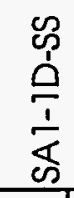 & & $3^{*}$ & 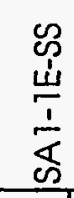 & & $3^{*}$ & $\begin{array}{r}\infty \\
\frac{1}{\alpha} \\
-\quad \frac{1}{\alpha} \\
-\frac{1}{5} \\
\end{array}$ & & ${ }^{*}$ & 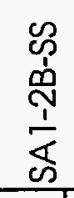 & * & ¿ $^{*}$ \\
\hline Bromoform & 6 & $u$ & - & 5 & $\mathrm{U}$ & - & 5 & $u$ & $\ldots$ & 5 & $u$ & $\ldots$ & 5 & $u$ & - & 5 & $u$ & $\ldots$ & 6 & $u$ & $\ldots$ \\
\hline 4-Methyl-2-Pentanone & 11 & ut & - & 11 & $u$ & - & 11 & u & $\ldots$ & 11 & 4 & $\ldots$ & 11 & $u$ & - & 11 & U) & -- & 11 & $u$ & - \\
\hline 2-Hexanone & 11 & Ut & - & 11 & $u$ & - & 11 & ut & - & 11 & ut & $\ldots$ & 11 & $u$ & - & 11 & $u$ & - & 11 & $u$ & - \\
\hline Tetrachloroethene & 6 & u & -- & 5 & $u$ & - & 5) & $u$ & $\ldots$ & 5 & u) & - & 5 & $u$ & - & 5 & $u$ & $\ldots$ & 6 & $u$ & - \\
\hline 1,1,2,2-Tetrachlorethane & 6 & 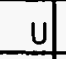 & - & 5 & 4 & - & 5 & $u$ &.- & 5 & u &.- & 5 & $u$ & - & 5 & $u$ & $-\ldots$ & 6 & $u$ & $\ldots$ \\
\hline Toluene & 1 & J) & - & 3 & J) & $\ldots$ & 4 & J) & $\ldots$ & 5 & U & $\ldots$ & 2 & J & $=$ & 5 & 4 & $\ldots$ & 6 & 4 & $\ldots$ \\
\hline Chlorobenzene & 6 & uf & $\ldots$ & 5 & 4 & $\ldots$ & 5 & u & $\ldots$ & 5 & u) & $\ldots$ & 5 & $u$ & - & 5 & U. & $\ldots$ & 6 & $\mathrm{U}$ & - \\
\hline Ethylbenzene & 6 & u) & $-\ldots$ & 2 & $\mathrm{~J}$ & $\ldots$ & 5 & U & -- & 5 & U) & $\ldots$ & 5 & $u$ & $\ldots$ & 5 & 4 & $\ldots$ & 6 & $\mathrm{U}$ & $\ldots$ \\
\hline Styrene & 6 & ut & - & 5 & 4 & $\ldots$ & 5 & 4 & $\ldots$ & 5 & u & -- & 5 & 4 & - & 5 & 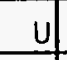 & $\ldots$ & 6 & 4 &.- \\
\hline Xylene (Total) & 2 & J] & $\ldots$ & 5 & & $\ldots$ & 13 & & $\ldots$ & 2 & & $\ldots$ & 4 & J & $\ldots$ & 5 & & $\ldots$ & 3 & -1 & $\ldots$ \\
\hline
\end{tabular}




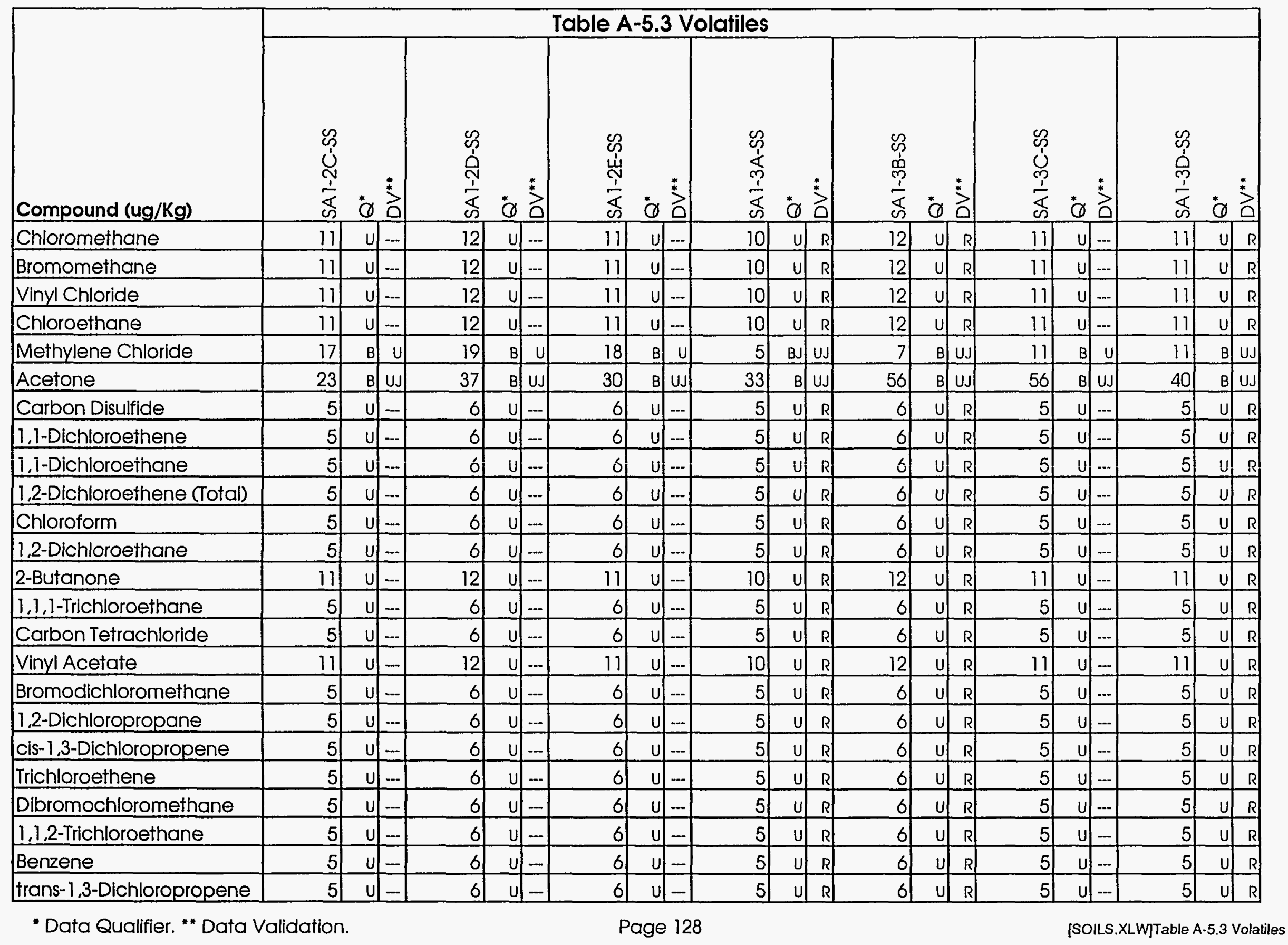




\begin{tabular}{|c|c|c|c|c|c|c|c|c|c|c|c|c|c|c|c|c|c|c|c|c|}
\hline \multirow[b]{2}{*}{ Compound (ug/Kg) } & \multicolumn{20}{|c|}{ Table A-5.3 Volatiles } \\
\hline & 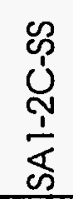 & $\stackrel{*}{\theta}$ & & 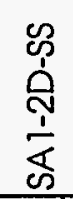 & & 䓠 & 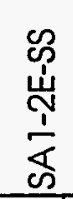 & & & $\begin{array}{l}\mathscr{p} \\
\frac{1}{\alpha} \\
\frac{1}{1} \\
\frac{1}{4}\end{array}$ & & & $\begin{array}{l}\text { cp } \\
\text { p. } \\
p \\
\frac{1}{\alpha} \\
\omega\end{array}$ & & 莒 & $\begin{array}{l}\infty \\
0 \\
0 \\
0 \\
\mathbb{p} \\
\mathbb{4} \\
\infty\end{array}$ & $\ddot{\theta}$ & 草 & 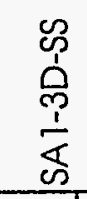 & $0^{\circ}$ \\
\hline Bromoform & 5 & u & $\ldots$ & 6 & & $\approx$ & 6 & & - & 5 & u & $R$ & 6 & $u$ & $\mathrm{R}$ & 5 & & - & 5 & U $1 \mathrm{P}$ \\
\hline 4-Methyl-2-Pentanone & 11 & $u$ & -1 & 12 & & - & 17 & & - & 10 & $u$ & $R$ & 12 & $u$ & $\mathrm{R}$ & 11 & & -1 & 11 & $4 \mathrm{~B}$ \\
\hline 2-Hexanone & 11 & $u$ & - & 12 & & -1 & 11 & & - & 10 & $u$ & $R$ & 12 & $u$ & $\mathrm{R}$ & 11 & & $\ldots$ & 11 & $0[\mathrm{r}$ \\
\hline Tetrachloroethene & 5 & & - & 6 & & - & 6 & & - & 5 & $u$ & $R$ & 6 & $\mathrm{u}$ & $R$ & 5 & & - & 5 & 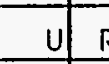 \\
\hline 1,1,2,2-Tetrachlorethane & 5 & & - & 6 & & -1 & 6 & & - & 5 & $u$ & $R$ & 6 & $u$ & $R$ & 5 & & - & 5 & $\mathrm{u}[\mathrm{B}$ \\
\hline Toluene & 5 & & -1 & 6 & & -1 & 6 & & - & 5 & $u$ & $R$ & 6 & $u$ & $R$ & 5 & & $\ldots$ & 5 & 0 \\
\hline Chlorobenzene & 5 & & - & 6 & & -1 & 6 & & - & 5 & $\mathrm{u}$ & $R$ & 6 & $u$ & $R$ & 5 & & $\ldots$ & 5 & 4 \\
\hline Ethylbenzene & 5 & & - & 6 & & - & 6 & & - & 5 & $u$ & $R$ & 6 & $u$ & $R$ & 5 & & $\ldots$ & 5 & 0 \\
\hline Styrene & 5 & & - & 6 & & $-\ldots$ & 6 & & - & 5 & $u$ & $R$ & 6 & $u$ & $R$ & 5 & & $\ldots$ & 5 & 0 \\
\hline Xylene (Total) & 5 & u & $\ldots$ & 2 & & ... & 6 & & $\ldots$ & 5 & $\mathrm{u}$ & $R$ & 6 & & $R$ & 5 & & $\ldots$ & 5 & $u[1$ \\
\hline
\end{tabular}


Table A-5.3 Volatiles

\begin{tabular}{|c|c|c|c|c|c|c|c|c|c|c|c|c|c|c|c|c|c|c|c|c|c|}
\hline \multirow[b]{2}{*}{ Compound (ug/Kg) } & \multicolumn{21}{|c|}{ Table A-5.3 Volatiles } \\
\hline & 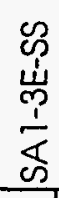 & $\stackrel{*}{0}$ & & $\begin{array}{l}\mathscr{N} \\
\frac{1}{\delta} \\
\frac{1}{1} \\
\frac{1}{\alpha} \\
\infty\end{array}$ & ${ }^{*}$ & 靣 & 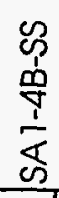 & & & 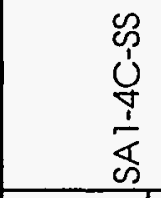 & ¿ & $3^{*}$ & 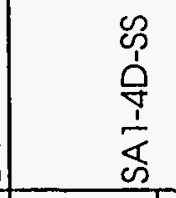 & $\stackrel{*}{\emptyset}$ & 艾 & 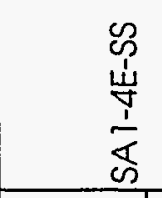 & $\stackrel{*}{Q}$ & $\stackrel{2}{0}^{*}$ & 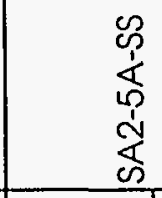 & ¿ & $\stackrel{*}{2}$ \\
\hline Chloromethane & 14 & $u$ & $R$ & 12 & $\mathrm{U}$ & UJ & 12 & $\mathrm{U}$ & $R$ & 11 & $u$ & $\ldots$ & 12 & U & --- & 12 & $u$ & $\ldots$ & 6 & $u$ & $\ldots$ \\
\hline Bromomethane & 14 & $u$ & $\mathrm{R}$ & 12 & $\mathrm{U}$ & $\mathrm{UJ}$ & 12 & $\mathrm{u}$ & $\mathrm{R}$ & 11 & $\mathrm{U}$ & $-\ldots$ & 12 & 4 & -- & 12 & $u$ & $\ldots$ & 6 & 4 & $\ldots$ \\
\hline Vinyl Chloride & 14 & $\mathrm{U}$ & $R$ & 12 & $\underline{U}$ & UJ & 12 & $\underline{u}$ & $\mathrm{R}$ & 11 & 4 & $-\ldots$ & 12 & $\mathrm{U}$ & - & 12 & $\underline{4}$ & $\ldots$ & 6 & $\mathrm{u}$ & $\ldots$ \\
\hline Chloroethane & 14 & $\mathrm{u}$ & $R$ & 12 & $U$ & $\mathrm{UJ}$ & 12 & $u$ & $R$ & 11 & $U$ & $-\ldots$ & 12 & 4 & $\ldots$ & 12 & $U$ & $\ldots$ & 6 & $u$ & $\ldots$ \\
\hline Methylene Chloride & 8 & $\mathrm{~B}$ & UJ & 6 & $\mathrm{U}$ & U. & 5 & BJ & UJ & 5 & 4 & $\ldots$ & 6 & $u$ & - & 6 & $u$ & $\ldots$ & 6 & 4 & $\ldots$ \\
\hline Acetone & 45 & B & UJ & 41 & $B$ & U. & 59 & $B$ & UJ & 24 & $B$ & U.J & 25 & B & UJ & 30 & $\mathrm{~B}$ & $\mathrm{UJ}$ & 12 & 4 & $\ldots$ \\
\hline Carbon Disulfide & 7 & $u$ & $R$ & 6 & $\mathrm{U}$ & $\mathrm{UJ}$ & 6 & $u$ & $R$ & 5 & $\mathrm{U}$ & $\ldots$ & 6 & 4 & \begin{tabular}{|l|}
- \\
--
\end{tabular} & 6 & $\mathrm{u}$ & $\ldots$ & 12 & $u$ & $\ldots$ \\
\hline 1,1-Dichloroethene & 7 & 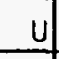 & $R$ & 6 & $\mathrm{U}$ & UJ & 6 & $u$ & $R$ & 5 & $\mathrm{U}$ & -- & 6 & $\mathrm{U}$ & -- & 6 & $\mathrm{U}$ & $\ldots$ & 6 & 4 & -- \\
\hline i,i-Dichioroethane & 7 & 4 & $R$ & ó & $u$ & US & 6 & 4 & R & 5 & 4 & $\ldots$ & 6 & 4 & - & 6 & 4 & $\ldots$ & 의 & 4 & $\ldots$ \\
\hline 1,2-Dichloroethene (Total) & 7 & $\mathrm{u}$ & $R$ & 6 & $\mathrm{U}$ & $\mathrm{UJ}$ & 6 & $\mathrm{U}$ & $\mathrm{R}$ & 5 & $\mathrm{U}$ & $\ldots$ & 6 & $\mathrm{u}$ & $\ldots$ & 6 & 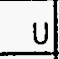 & $\ldots$ & 6 & $u$ & $\ldots$ \\
\hline Chloroform & 7 & $u$ & $R$ & 6 & $\mathrm{U}$ & Uu & 6 & $u$ & $\mathrm{R}$ & 5 & $\mathrm{U}$ & -- & 6 & u & $-\ldots$ & 6 & $u$ & -- & 6 & U) & - \\
\hline 1.2-Dichloroethane & 7 & $u$ & $R$ & 6 & $u$ & $\mathrm{uJ}$ & 6 & $u$ & $\mathrm{R}$ & 5 & $u$ & $-\ldots$ & 6 & $u$ & -- & 6 & $u$ & $\ldots$ & 6 & 4 & -- \\
\hline 2-Butanone & 14 & $u$ & $\mathrm{R}$ & 12 & $u$ & US & 12 & $u$ & $R$ & 11) & $U$ & $\ldots$ & 12 & 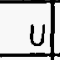 & $\ldots$ & 12 & $u$ & $\ldots$ & 12 & u) & $R$ \\
\hline 1,1,1-Trichloroethane & 7 & 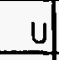 & $R$ & 6 & $\mathrm{u}$ & $\mathrm{UJ}$ & 6 & 4 & $R$ & 5 & $\mathrm{U}$ &.- & 6 & $u$ & $\ldots$ & 6 & $u$ & $\ldots$ & 6 & $u$ & $\ldots$ \\
\hline Carbon Tetrachloride & 7 & 4 & $R$ & 6 & $u$ & Wu & 6 & $u$ & $R$ & 5 & 4 & $\ldots$ & 6 & $u$ & $-\mathrm{Al}_{-1}$ & 6 & 4 & $\ldots$ & 6 & 4 &.-- \\
\hline Vinyl Acetate & 14 & $u$ & $R$ & 12 & $\mathrm{U}$ & $\mathrm{Uu}$ & 12 & $u$ & $\mathrm{R}$ & 11 & $\mathrm{U}$ & $\ldots$ & 12 & 4 & -- & 12 & $\mathrm{U}$ & $-\ldots$ & 12 & U) & $\ldots$ \\
\hline Bromodichloromethane & 7 & $u$ & $R$ & 6 & $\underline{U}$ & UJ & 6 & $u$ & $R$ & 5 & $u$ & $\ldots$ & 6 & 4 & $\ldots$ & 6 & $u$ & $\ldots$ & 6 & U) & $\ldots$ \\
\hline 1,2-Dichloropropane & 7 & $u$ & $R$ & 6 & $\underline{U}$ & UJ & 6 & 4 & $R$ & 5 & $u$ & $\ldots$ & 6 & $u$ & -- & 6 & $u$ & $\ldots$ & 6 & 4 & $\ldots$ \\
\hline cis-1,3-Dichloropropene & 7 & $\mathrm{U}$ & $R$ & 6 & $\mathrm{U}$ & $\mathrm{UJ}$ & 6 & $u$ & $R$ & 5 & 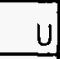 & $\ldots$ & 6 & 4 & $\ldots$ & 6 & $U$ & $\ldots$ & 6 & 4 & $\ldots$ \\
\hline Trichloroethene & 7 & $\mathrm{U}$ & $R$ & 6 & $\underline{u}$ & UJ & 6 & $\mathrm{u}$ & $R$ & 5 & $u$ & $\ldots$ & 6 & $u$ & -- & 6 & $\mathrm{u}$ & $\ldots$ & 6 & 4 & $\ldots$ \\
\hline Dibromochloromethane & 7 & $\mathrm{U}$ & $\mathrm{R}$ & 6 & $u$ & $\mathrm{UJ}$ & 6 & 4 & $\mathrm{R}$ & 5 & $\mathrm{U}$ & - & 6 & $\mathrm{U}$ & - & 6 & $u$ & - & 6 & $u$ & - \\
\hline 1,1,2-Trichloroethane & 7 & $u$ & $R$ & 6 & $U$ & UJ & 6 & $u$ & $\mathrm{R}$ & 5 & $\mathrm{U}$ & - & 6 & $u$ & - & 6 & $u$ & -- & 6 & $\mathrm{ut}$ & - \\
\hline Benzene & 7 & $\mathrm{U}$ & $R$ & 6 & $\mathrm{U}$ & $\mathrm{UJ}$ & 6 & $\mathrm{u}$ & $R$ & 5 & 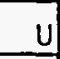 & - & 6 & $u$ & - & 6 & $u$ & - & 6 & u & - \\
\hline trans-1,3-Dichloropropene & 7 & $u$ & $R$ & 6 & $\mathrm{U}$ & $\mathrm{UJ}$ & 6 & $u$ & $\mathrm{R}$ & 5 & $\underline{u}$ & - & 6 & $u$ & - & 6 & $u$ & $\ldots$ & 6 & $u$ & $\ldots$ \\
\hline
\end{tabular}

" Data Qualifier. " " Data Validation. 


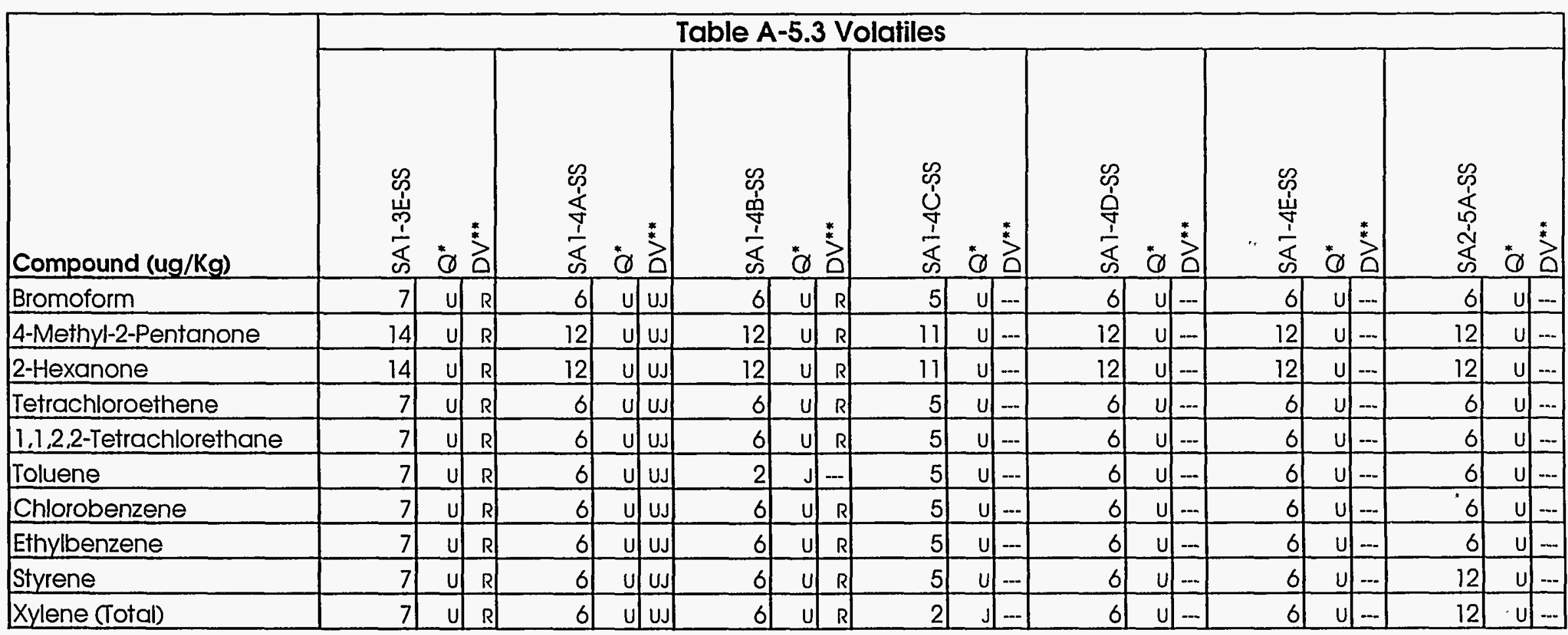




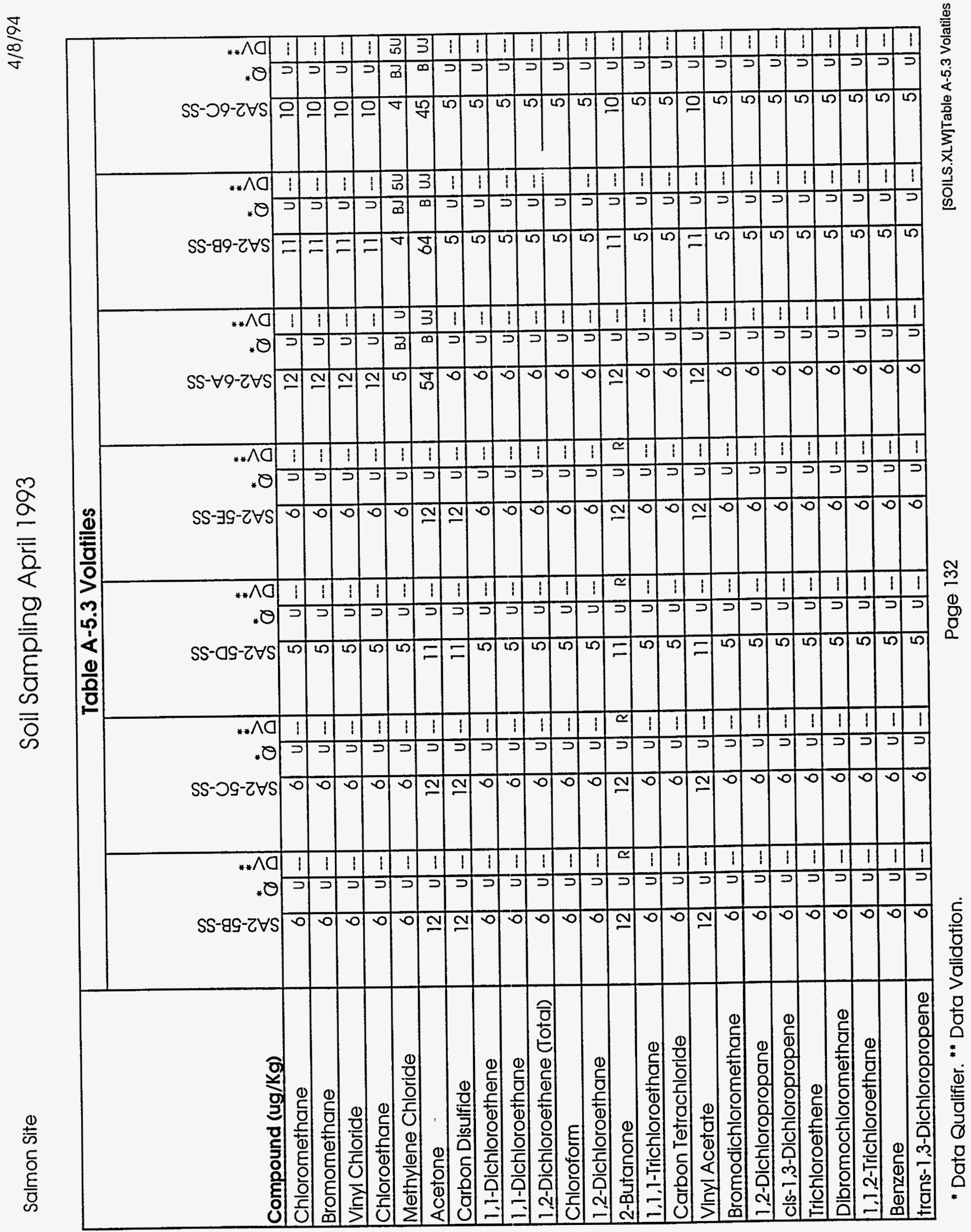




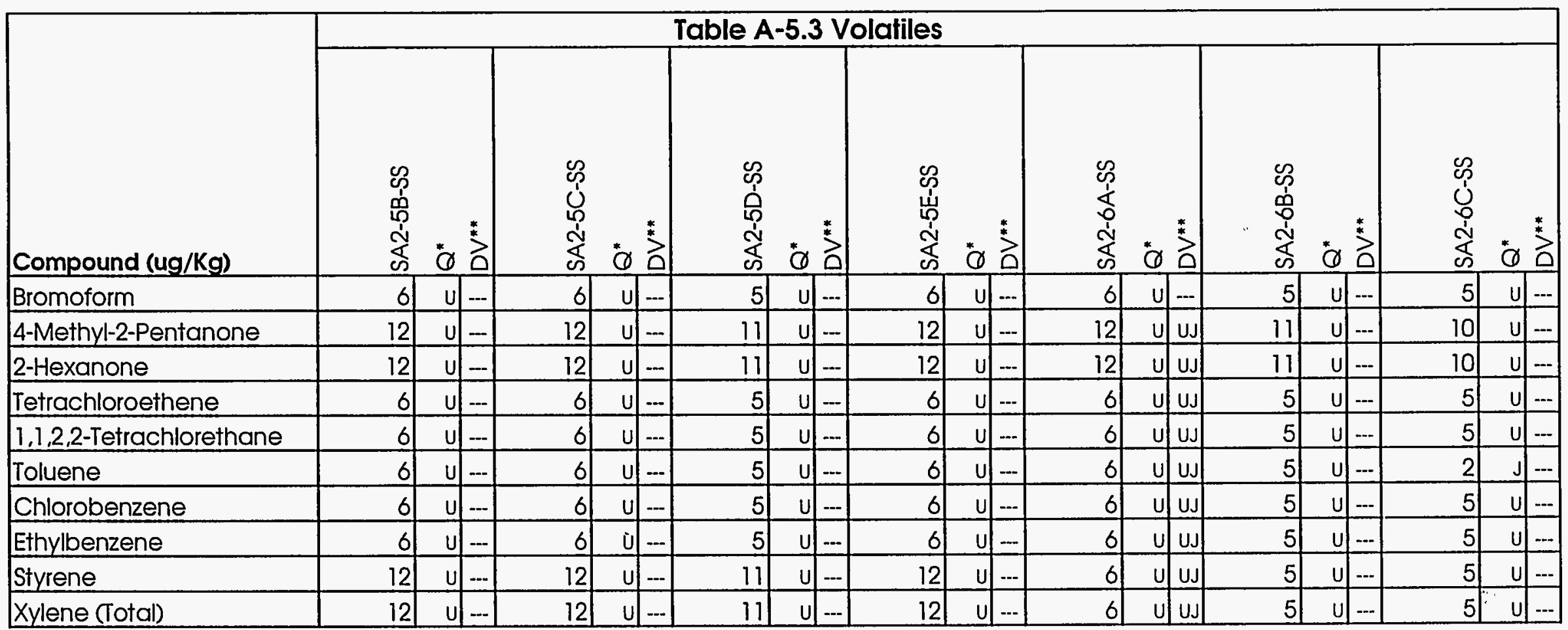




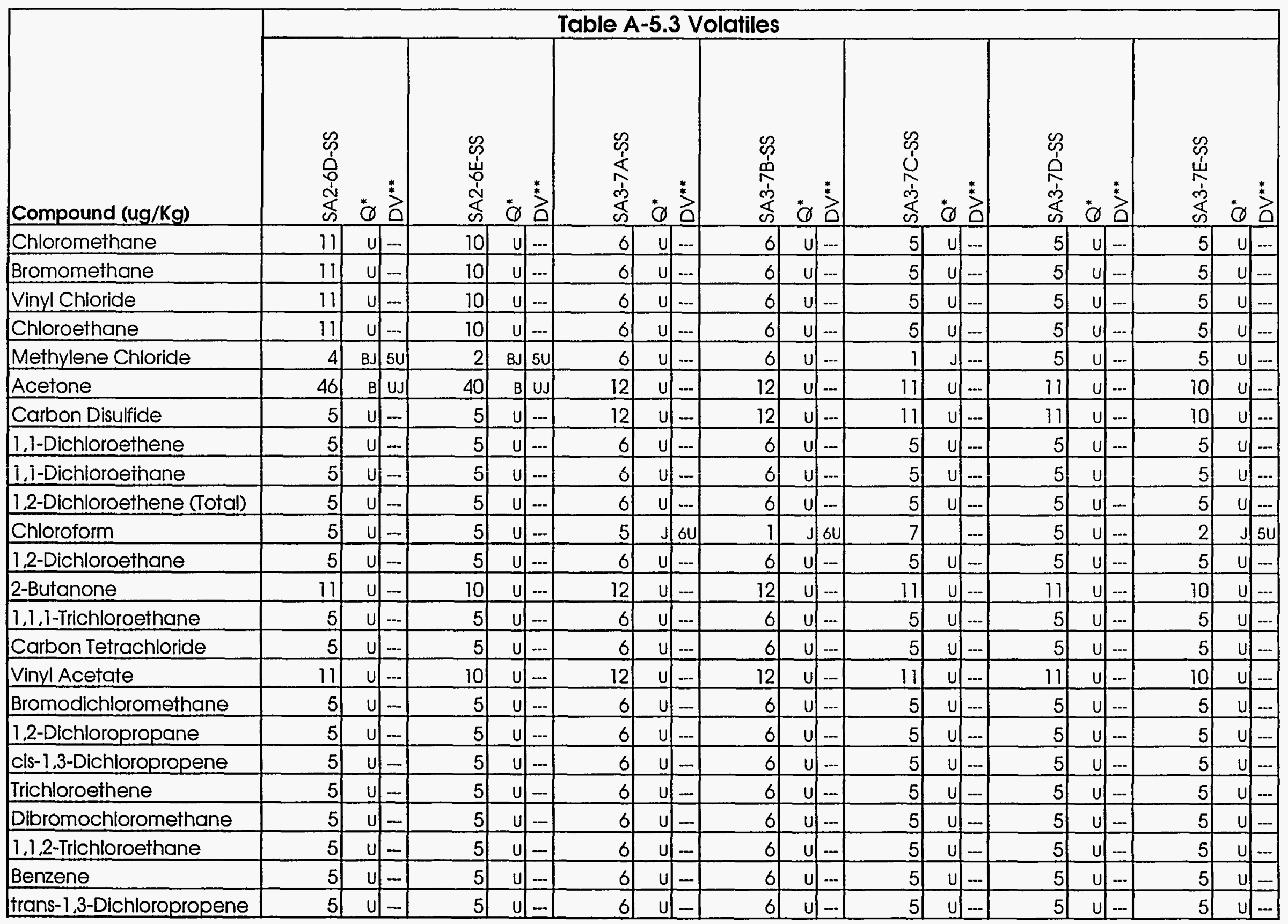

"Data Qualifier. "* Data Validation. 


\begin{tabular}{|c|c|c|c|c|c|c|c|c|c|c|c|c|c|c|c|c|c|c|c|c|c|}
\hline \multirow[b]{2}{*}{ Compound (ug/Kg) } & \multicolumn{21}{|c|}{ Table A-5.3 Volatiles } \\
\hline & 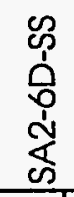 & & & 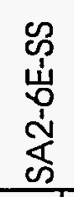 & $\stackrel{*}{\emptyset}$ & $\stackrel{*}{*}$ & 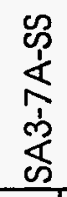 & & 莒 & 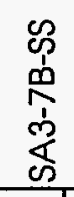 & & $\overbrace{}^{*}$ & 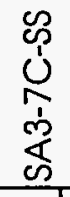 & $\stackrel{*}{0}$ & $\stackrel{2}{0}^{*}$ & 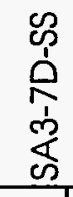 & & $\stackrel{2}{0}^{*}$ & 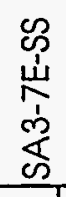 & & 己 \\
\hline Bromoform & 5 & $\mathrm{U}$ & - & 5 & $\mathrm{u}$ & - & 6 & $\mathrm{u}$ & - & 6 & $u$ & $\ldots$ & 5 & $\mathrm{u}$ & - & 5 & $u$ & - & 5 & $\mathrm{U}$ & -- \\
\hline 4-Methyl-2-Pentanone & 11 & & - & 10 & $u$ & - & 12 & 4 & $\ldots$ & 12 & $\mathrm{U}$ & - & 11 & $u$ & - & 11 & $u$ & $\ldots$ & 10 & $u$ & - \\
\hline 2-Hexanone & 11 & & $\ldots$ & 10 & $\mathrm{U}$ & -- & 12 & $\mathrm{u}$ & -- & 12 & $\mathrm{U}$ & - & 11 & $\mathrm{U}$ & -- & 11 & $u$ & -- & 10 & $\mathrm{U}$ & $\ldots$ \\
\hline Tetrachloroethene & 5 & $u$ & - & 5 & $\mathrm{U}$ & - & 6 & $\mathrm{u}$ & $\ldots$ & 6 & $\mathrm{u}$ & $\ldots$ & 5 & $\mathrm{u}$ & $\ldots$ & 5 & 4 & -- & 5 & $\mathrm{U}$ & $\ldots$ \\
\hline 1,1,2,2-Tetrachlorethane & 5 & $u$ & - & 5 & $\mathrm{U}$ & - & 6 & $\mathrm{u}$ & - & 6 & $\mathrm{u}$ & - & 5 & $\mathrm{U}$ & - & 5 & $u$ & - & 5 & $\mathrm{u}$ & - \\
\hline Toluene & 2 & J & $\ldots$ & 5 & $\mathrm{U}$ & -- & 6 & $\mathrm{U}$ & - & 6 & $\mathrm{U}$ & - & 5 & $\mathrm{U}$ & -- & 5 & $\mathrm{u}$ & $-\ldots$ & 5 & 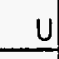 & - \\
\hline Chlorobenzene & 5 & $u$ & - & 5 & $U$ & $\ldots$ & 6 & $u$ & - & 6 & $\mathrm{U}$ & $\ldots$ & 5 & $\mathrm{U}$ & $\ldots$ & 5 & $\mathrm{U}$ & - & 5 & $U$ & $\ldots$ \\
\hline Ethylbenzene & 5 & 4 & - & 5 & $\mathrm{U}$ & $\ldots$ & 6 & $\mathrm{u}$ & $\ldots$ & 6 & $\mathrm{u}$ & $\ldots$ & 5 & $\underline{u}$ & - & 5 & $u$ & $\ldots$ & 5 & $u$ & - \\
\hline Styrene & 5 & 4 & - & 5 & $\mathrm{U}$ & $\ldots$ & 12 & $u$ & $\ldots$ & 12 & $\mathrm{U}$ & $\ldots$ & 11 & $u$ & $\ldots$ & 11 & $\mathrm{U}$ & - & 10 & $U$ & $\ldots$ \\
\hline Xylene (Total) & 5 & & - & 5 & $\mathrm{U}$ & -- & 12 & $u$ & $\ldots$ & 12 & $u$ & - & 11 & $\mathrm{U}$ & $\ldots$ & 11 & $\mathrm{U}$ & $\ldots$ & 10 & & - \\
\hline
\end{tabular}




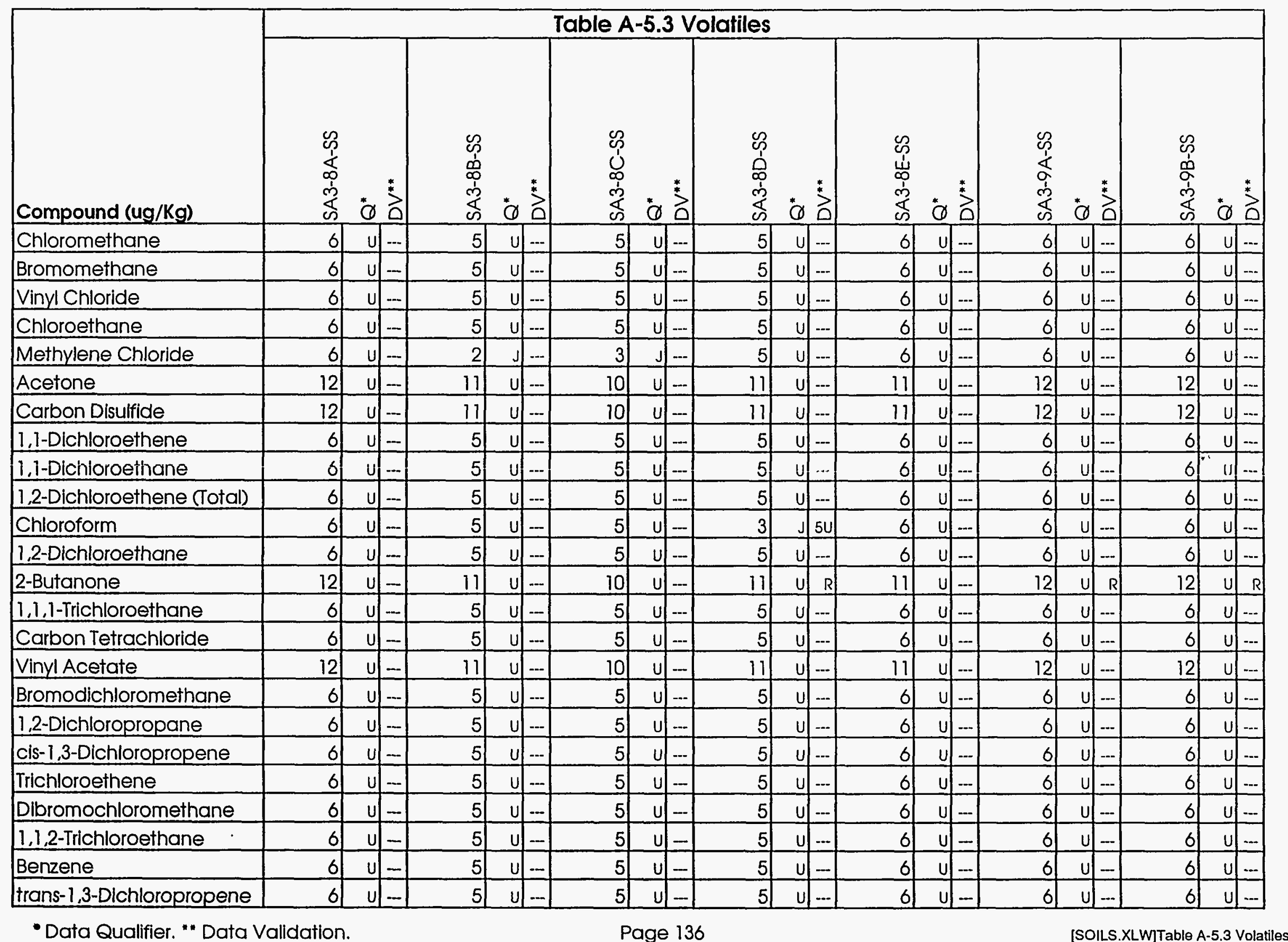




\begin{tabular}{|c|c|c|c|c|c|c|c|c|c|c|c|c|c|c|c|c|c|c|c|c|c|}
\hline \multirow[b]{2}{*}{ Compound (ug/Kg) } & \multicolumn{18}{|c|}{ Table A-5.3 Volatiles } & \multirow[b]{2}{*}{ 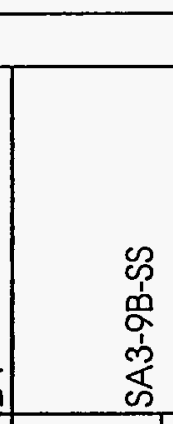 } & \multirow{2}{*}{\multicolumn{2}{|c|}{$\stackrel{*}{\emptyset}$}} \\
\hline & 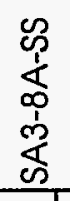 & $\stackrel{*}{\square}$ & & 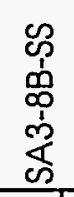 & & & 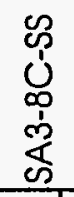 & & ${ }^{*}$ & 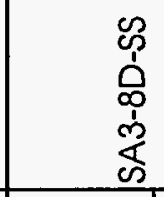 & & $\stackrel{2}{0}^{*}$ & 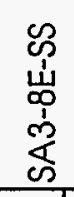 & & ${ }^{*}$ & 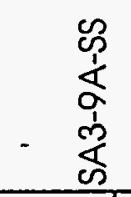 & & $\stackrel{\text { 莒 }}{2}$ & & & \\
\hline Bromoform & 6 & $u$ & $-\ldots$ & 5 & $u$ & -- & 5 & $\mathrm{u}$ & $\ldots$ & 5 & $u$ & -- & 6 & & -- & 6 & $u$ & $\ldots$ & 6 & & -- \\
\hline 4-Methyl-2-Pentanone & 12 & 4 & $-\ldots$ & 11 & $u$ & - & 10 & $u$ & $\ldots$ & 11 & $u$ & $-a_{-1}$ & 11 & & $-\ldots$ & 12 & $u$ & $\ldots$ & 12 & $u$ & $\ldots$ \\
\hline 2-Hexanone & 12 & $u$ & -- & 11 & $u$ & -- & 10 & $\mathrm{U}$ & $\ldots$ & 11 & $u$ & -- & 11 & u. - & -- & 12 & 4 & $\ldots$ & 12 & 4 & -- \\
\hline Tetrachloroethene & 6 & $\mathrm{U}$ & $\ldots$ & 5 & U & -- & 5 & $\mathrm{U}$ & - & 5 & $u$ & $\ldots$ & 6 & & $-\infty$ & 6 & $u$ & $\ldots$ & 6 & 4 & - \\
\hline 1,1,2,2-Tetrachlorethane & 6 & $u$ & $\ldots$ & 5 & $u$ & $\ldots$ & 5 & $u$ & $\ldots$ & 5 & $u$ & $\ldots$ & 6 & $\mathrm{u}$. & -- & 6 & $u$ & $\ldots$ & 6 & $u$ & -- \\
\hline Toluene & 6 & $u$ & $\ldots$ & 5 & $u$ & - & 5 & $U$ & $\ldots$ & 5 & $u$ & $\ldots$ & 6 & $u$. & $\ldots$ & 6 & $u$ & $\ldots$ & 6 & $\mathrm{u}$ & $\ldots$ \\
\hline Chlorobenzene & 6 & $u$ & $\ldots$ & 5 & $u$ &.- & 5 & 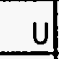 & $\ldots$ & 5 & 4 & -- & 6 & U. & -- & 6 & 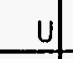 & - & 6 & $\mathrm{u}$ & $\ldots$ \\
\hline Ethylbenzene & 6 & 4 & $\ldots$ & 5 & 4 & $\ldots$ & 5 & 4 & - & 5 & $\mathrm{U}$ & $-\ldots$ & 6 & 4. & $\ldots$ & 6 & 4 & -- & 6 & 4 & $\ldots$ \\
\hline Styrene & 12 & 4 & $\ldots$ & 11 & $\mathrm{U}$ & $\ldots$ & 10 & $\mathrm{u}$ & $\ldots$ & 11 & U) & $\ldots$ & 11 & 4. & $\ldots$ & 12 & 4 & - & 12 & 4 & $\ldots$ \\
\hline Xylene (Total) & 12 & $\mathrm{U}$ & $\ldots$ & 11 & $U$ & -- & 10 & & $\ldots$ & 11 & U] & $-\ldots$ & 11 & & $\ldots$ & 12 & & - & 12 & & $\ldots$ \\
\hline
\end{tabular}




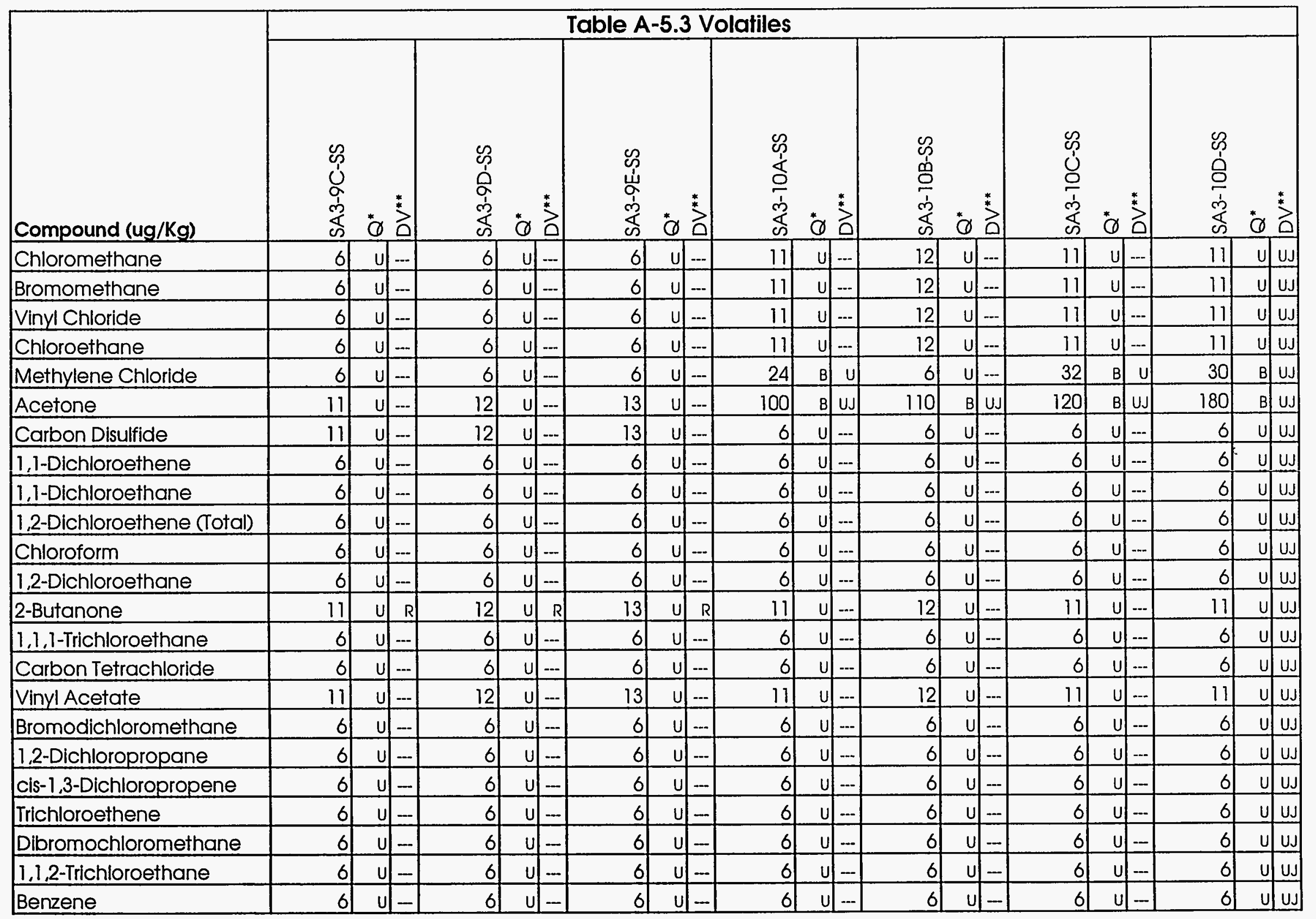




\begin{tabular}{|c|c|c|c|c|c|c|c|c|c|c|c|c|c|c|c|c|c|c|c|c|c|}
\hline \multirow[b]{2}{*}{ Compound (ug/Kg) } & \multicolumn{21}{|c|}{ Table A-5.3 Volatiles } \\
\hline & 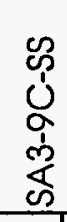 & & 艾 & $\begin{array}{l}\mathscr{p} \\
\dot{1} \\
\alpha \\
1 \\
m \\
\dot{c} \\
\infty\end{array}$ & & & 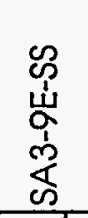 & $\stackrel{*}{0}$ & ${ }^{*}$ & 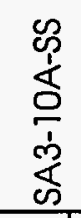 & & 艾 & 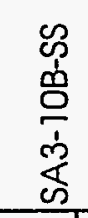 & & 号 & 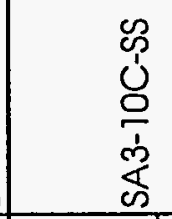 & & $\stackrel{*}{2}$ & 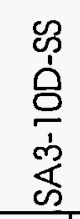 & & $\stackrel{3}{0}^{*}$ \\
\hline trans-1,3-Dichloropropene & 6 & 4. & $\ldots$ & 6 & $u$ & $\ldots$ & 6 & $\mathrm{U}$ & --- & 6 & $u$ & - & 6 & 4 & $\ldots$ & 6 & $\mathrm{u}$ & $\ldots$ & 6 & $u$ & UJ \\
\hline Bromoform & 6 & 4. & $\ldots$ & 6 & $u$ & $-a_{-1}^{-1}$ & 6 & $\mathrm{u}$ & - & 6 & 4. & $\ldots$ & 6 & & $\ldots$ & 6 & $\mathrm{u}$ & $-{ }_{-1}$ & 6 & $u$ & UJ \\
\hline 4-Methyl-2-Pentanone & 11 & 4. & $-\ldots$ & 12 & U. & $\ldots$ & 13 & $\mathrm{u}$ & $-\infty$ & 11 & 4 & $\ldots$ & 12 & $u$ & $\ldots$ & 11 & $u$ & $\ldots$ & 11 & $u$ & $\mathrm{UJ}$ \\
\hline 2-Hexanone & 11 & $u$. & $\ldots$ & 12 & $u$. & $\ldots$ & 13 & 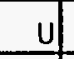 & $\ldots$ & 11 & $\mathrm{U}$ & $-\ldots$ & 12 & $\mathrm{u}$ & $\ldots$ & 11 & $u$ & - & 11 & $u$ & UJ \\
\hline Tetrachloroethene & 6 & $u$. & $\ldots$ & 6 & $U$ & $\ldots$ & 6 & 4 & -- & 6 & $\mathrm{u}$ & -- & 6 & $u$ & $\ldots$ & 6 & $u$ & $-\ldots$ & 6 & $u$ & $\mathrm{UJ}$ \\
\hline 1,1,2,2-Tetrachlorethane & 6 & $u$. & -1 & 6 & u. & -- & 6 & U & $\ldots$ & 6 & $\mathrm{u}$ & $\ldots$ & 6 & $u$ & $\ldots$ & 6 & 4 & $\ldots$ & 6 & $u$ & UJ \\
\hline Toluene & 6 & $\mathrm{u}$ & -1 & 6 & $\mathrm{U}$ & $\ldots$ & 6 & $u$ & - & 2 & J. & $-\ldots$ & 2 & & -- & 6 & 4 & $\ldots$ & 2 & $\mathrm{~J}$ & -- \\
\hline Chlorobenzene & 6 & $u$ & $\ldots$ & 6 & $\mathrm{U}$ & $\ldots$ & 6 & $U$ & -- & 6 & u) & $\ldots$ & 6 & 4. & $-\ldots$ & 6 & 4 & - & 6 & $\mathrm{U}$ & UJ \\
\hline Ethylbenzene & 6 & $u$ & $\ldots$ & 6 & $\mathrm{u}$. & $\ldots$ & 6 & U & -- & 6 & 4 & $\ldots$ & 6 & $u$. & $\ldots$ & 6 & $\mathrm{U}$ & $\ldots$ & 6 & $\mathrm{U}$ & UJ \\
\hline Styrene & 11 & $u$ & - & 12 & 4. & $\ldots$ & 13 & 4 & $\ldots$ & 6 & $\mathrm{u}$ & $\ldots$ & 6 & & $\ldots$ & 6 & $u$ & $-\infty$ & 6 & $u$ & UJ \\
\hline Xylene (Total) & 11 & $u$ & $\ldots$ & 12 & $\mathrm{u}$. & $\ldots$ & 13 & 4 & $\ldots$ & 6 & $u$ & 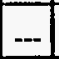 & 6 & & $\ldots$ & 6 & $\mathrm{u}$ & $-\infty$ & 6 & $u$ & $\mathrm{UJ}$ \\
\hline
\end{tabular}




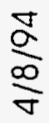

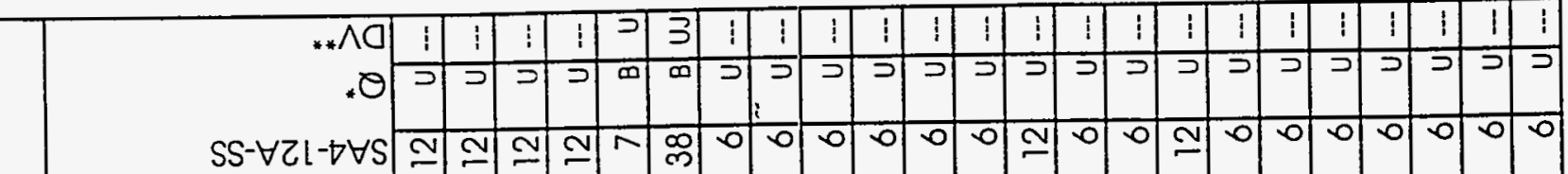

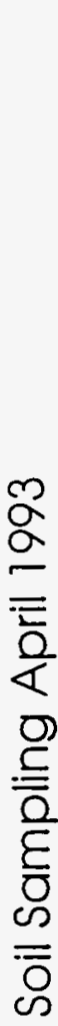

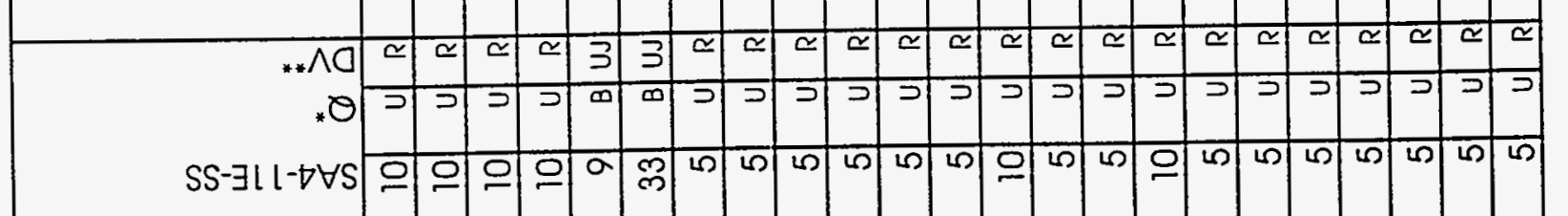

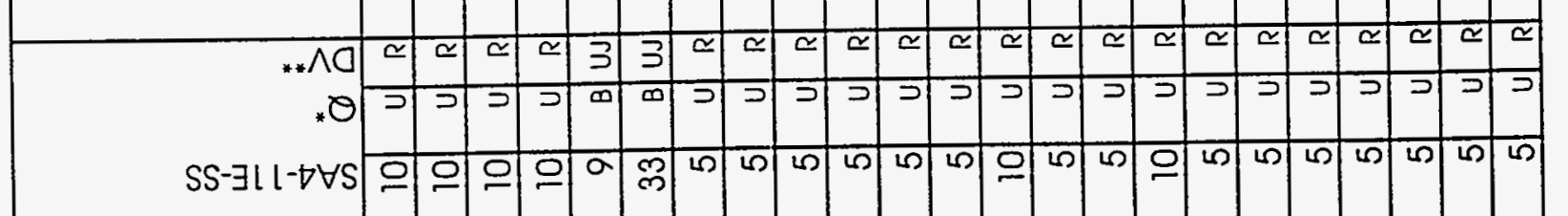

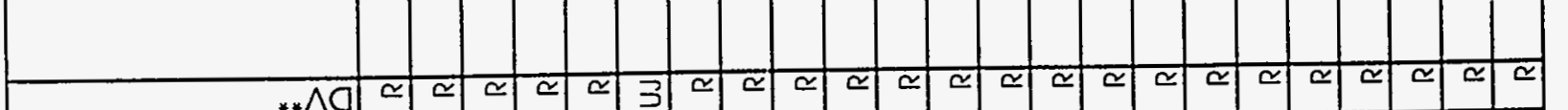

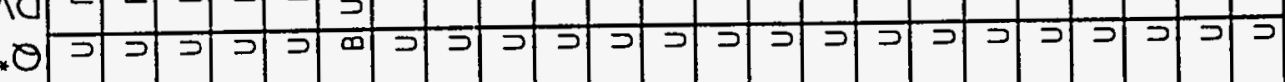

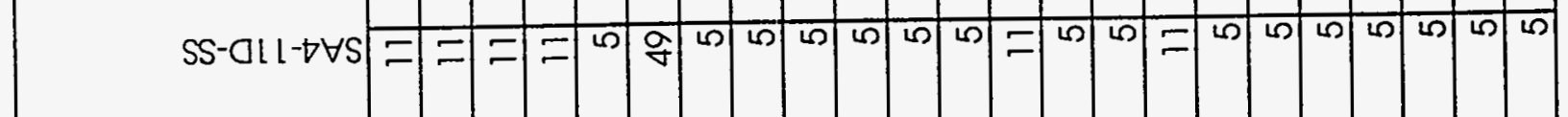

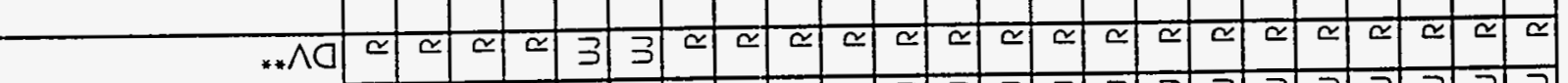

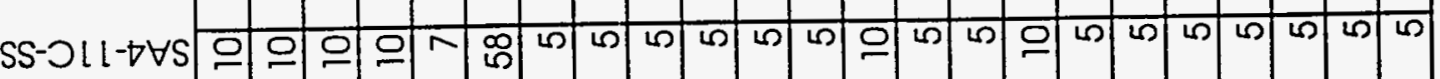

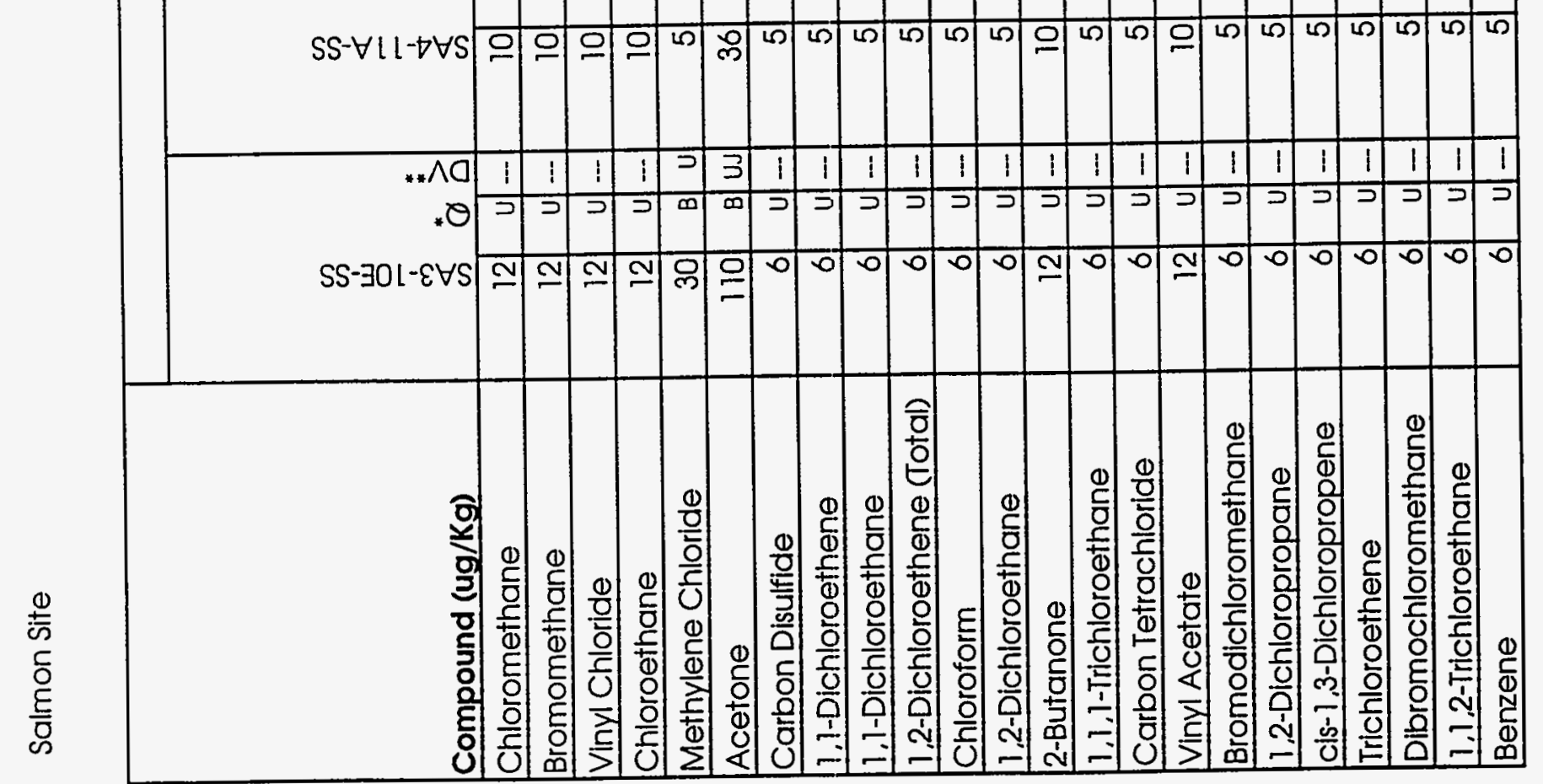




\begin{tabular}{|c|c|c|c|c|c|c|c|c|c|c|c|c|c|c|c|c|c|c|c|c|c|}
\hline \multirow[b]{2}{*}{ Compound (ug/Kg) } & \multicolumn{21}{|c|}{ Table A-5.3 Volatiles } \\
\hline & 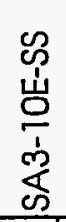 & & & 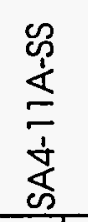 & & & $\begin{array}{l}\text { क } \\
\text { 占 } \\
\text { 字 } \\
\text { 安 }\end{array}$ & 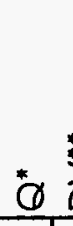 & 艾 & 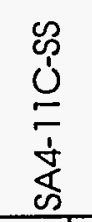 & & 草 & $\begin{array}{l}\mathscr{p} \\
\dot{1} \\
0 \\
\frac{1}{1} \\
\frac{1}{c} \\
\tilde{c}\end{array}$ & & & 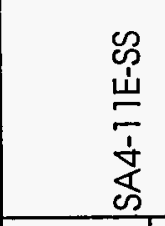 & $\stackrel{*}{Q}$ & $\mathrm{D}^{*}$ & 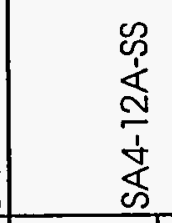 & $\stackrel{*}{\sigma}$ & $\stackrel{2}{0}^{*}$ \\
\hline trans-1,3-Dichloropropene & 6 & U. & $\ldots$ & 5 & $u$ & $R$ & 5 & u & $\mathrm{R}$ & 5 & $u$ & $\mathrm{R}$ & 5 & $u$ & $\mathrm{R}$ & 5 & $u$ & $R$ & 6 & & $\ldots$ \\
\hline Bromoform & 6 & u. & $\ldots$ & 5 & $\mathrm{u}$ & $\mathrm{R}$ & 5 & 0 & $R$ & 5 & 4 & $R$ & 5 & 4 & $\mathrm{R}$ & 5 & $u$ & $R$ & 6 & 4 & $\ldots$ \\
\hline 4-Methyl-2-Pentanone & 12 & 0. & - & 10 & $u$ & $\mathrm{R}$ & 10 & 4 & $R$ & 10 & $u$ & $R$ & 11 & $u$ & $\mathrm{R}$ & 10 & $u$ & $R$ & 12 & u & $-\ldots$ \\
\hline 2-Hexanone & 12 & $u=$ & -- & 10 & $\mathrm{u}$ & $R$ & 10 & 4 & $\mathrm{R}$ & 10 & $u$ & $R$ & 11 & $u$ & $R$ & 10 & 4 & $\mathrm{R}$ & 12 & 4 & $\ldots$ \\
\hline Tetrachloroethene & 6 & $u-$ & -- & 5 & $\mathrm{u}$ & $R$ & 5 & 4 & $R$ & 5 & $u$ & $\mathrm{R}$ & 5 & $\mathrm{u}$ & $R$ & 5 & U & R & 6 & $u$ &.- \\
\hline 1,1,2,2-Tetrachlorethane & 6 & $\mathrm{u}$. & $\ldots$ & 5 & 4 & $R$ & 5 & $u$ & $R$ & 5 & $\mathrm{u}$ & $R$ & 5 & $u$ & $R$ & 5 & U & $\mathrm{R}$ & 6 & $\mathrm{u}$ & - \\
\hline Toluene & 6 & $\mathrm{u}$. & - & 3 & J. & $\ldots$ & 1 & 5 & $\ldots$ & 5 & $u$ & $R$ & 9 & & $\mathrm{~J}$ & 2 & J. & $\ldots$ & 6 & 4 & - \\
\hline Chlorobenzene & 6 & $\mathrm{U}$. & $\ldots$ & 5 & 4 & $R$ & 5 & 4 & $R$ & 5 & $u$ & $R$ & 5 & $u$ & $R$ & 5 & $u$ & $\mathrm{R}$ & 6 & 4 & $\ldots$ \\
\hline Ethylbenzene & 6 & $\mathrm{u}$. & $\ldots$ & 5 & u & $R$ & 5 & 4 & $R$ & 5 & $u$ & $R$ & 5 & $u$ & $\mathrm{R}$ & 5 & $u$ & $\mathrm{R}$ & 6 & $u$ & $\ldots$ \\
\hline Styrene & 6 & U. & -1 & 5 & U & $R$ & 5 & $u$ & $R$ & 5 & $u$ & $\mathrm{R}$ & 25 & & $\mathrm{~J}$ & 5 & 4 & $R$ & 6 & $\mathrm{u}$ & - \\
\hline xylene (Total) & 6 & $u$. & 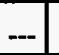 & 5 & $u$ & $\mathrm{R}$ & 5 & $u$ & $\mathrm{R}$ & 5 & $u$ & $R$ & 5 & $\mathrm{U}$ & $\mathrm{R}$ & 5 & $u$ & $R$ & 6 & $\mathrm{u}$ & $\ldots$ \\
\hline
\end{tabular}


$\frac{\sqrt[J]{\alpha}}{\frac{\infty}{\sigma}}$

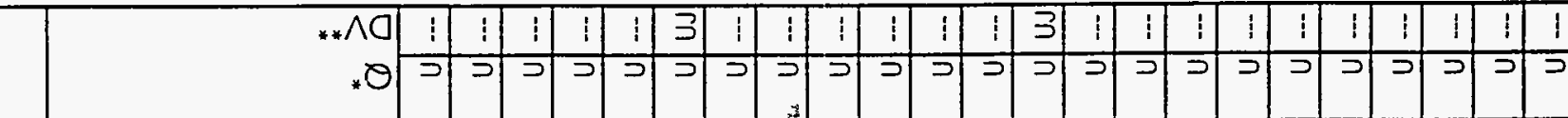

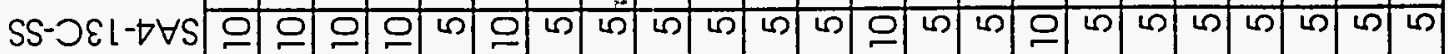

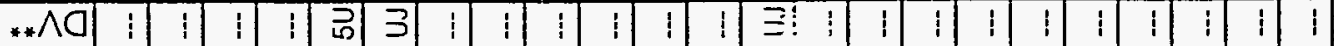

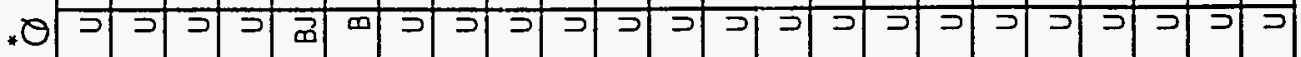

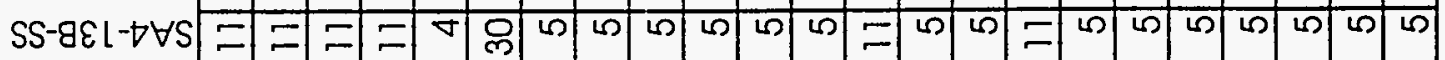

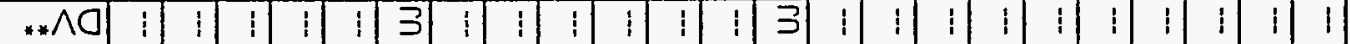

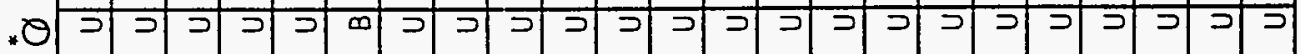

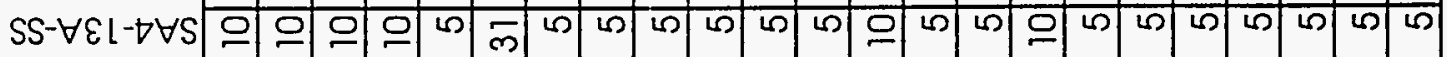

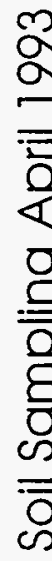

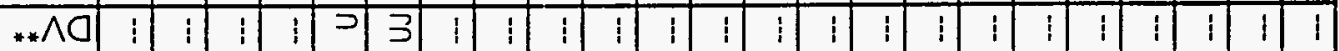

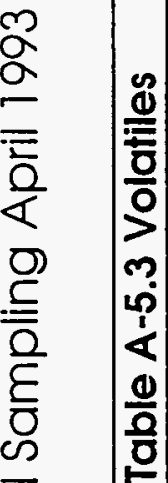

$* \theta$ Ј Ј

SS- $321-\nabla \forall S=E$ F

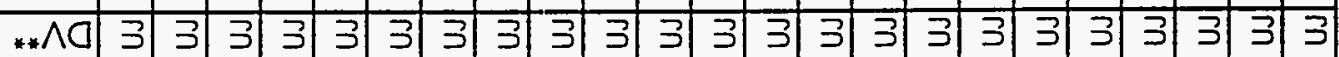

* ১

$S S-O Z L-\nabla \forall S$ N $N$ N $N$ N

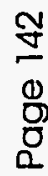

$S S-つ 乙 L-\nabla \forall S$ = $=$ E

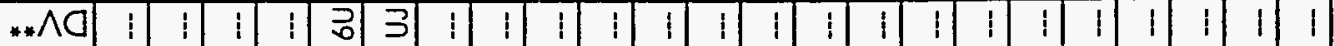

.8 د د د

SS-g己L- $\forall S$ 厈而 


\begin{tabular}{|c|c|c|c|c|c|c|c|c|c|c|c|c|c|c|c|c|c|c|c|c|c|}
\hline \multirow[b]{2}{*}{ Compound (ug/Kg) } & \multicolumn{21}{|c|}{ Table A-5.3 Volatiles } \\
\hline & 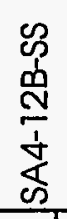 & * & & 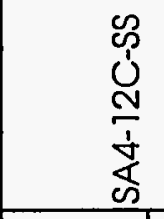 & $\stackrel{0}{0}$ & 它 & 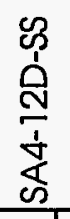 & & $\stackrel{\text { * }}{2}$ & 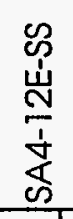 & & $\stackrel{2}{*}$ & 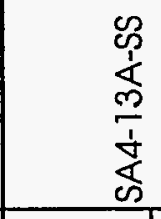 & $\stackrel{*}{\sigma}$ & 苛 & $\cdots \frac{c}{c}$ & $\stackrel{*}{\emptyset}$ & $\stackrel{2}{0}^{*}$ & $\begin{array}{l}\infty \\
0 \\
0 \\
m \\
\dot{0} \\
\dot{d} \\
\text { d }\end{array}$ & & $\stackrel{*}{0}$ \\
\hline trans-1,3-Dichloropropene & 6 & u & $\ldots$ & 6 & $u$ & - & 6 & u) & UJ & 5 & $u$ & $\ldots$ & 5 & $u$ & $\ldots$ & 5 & $u$ & $\ldots$ & 5 & $u$ & $\ldots$ \\
\hline Bromoform & 6 & U. & $-\ldots$ & 6 & $u$ & - & 6 & $u$ & $\mathrm{UJ}$ & 5 & $u$ & - & 5 & $u$ & $\ldots$ & 5 & u & $\ldots$ & 5 & $u$ & $\ldots$ \\
\hline 4-Methyl-2-Pentanone & 11 & $\mathrm{u}$ & $-\ldots$ & 11 & 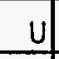 & -- & 12 & $u$ & UJ & 11 & 4 & -- & 10 & 4 & - & 11 & 4 & -- & 10 & 4 & -- \\
\hline 2-Hexanone & 11 & 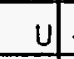 & -- & 11 & $u$ & $\ldots$ & 12 & $\mathrm{U}$ & UJ & 11 & $u$ & - & 10 & $u$ & - & 11 & $u$ & -- & 10 & u & - \\
\hline Tetrachloroethene & 6 & u & - & 6 & $\mathrm{u}$ & $\ldots$ & 6 & $u$ & UJ & 5 & 4 & $\ldots$ & 5 & $\mathrm{u}$ & - & 5 & $u$ & - & 5 & $u$ & -- \\
\hline 1,1,2,2-Tetrachlorethane & 6 & $\mathrm{u}$ & - & 6 & $u$ &.- & 6 & 4 & UJ & 5 & $u$ & - & 5 & $u$ & - & 5 & 4 & - & 5 & 4 & -- \\
\hline Toluene & 6 & $u$ & - & 6 & $u$ & $\ldots$ & 6 & $u$ & UJ & 5 & $u$ & $\ldots$ & 2 & $\mathrm{~J}$ & $\ldots$ & 5 & u) & $\ldots$ & 5 & 4 & - \\
\hline Chlorobenzene & 6 & $u$ & -- & 6 & $\mathrm{U}$ & $\ldots$ & 6 & $\mathrm{u}$ & UJ & 5 & $u$ & $\ldots$ & 5 & 4 & $\ldots$ & 5 & u) & $\ldots$ & 5 & 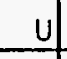 & -- \\
\hline Ethylbenzene & 6 & $\mathrm{u}$ & $\ldots$ & 6 & $\mathrm{u}$ & $=$ & 6 & $u$ & UJ & 5 & $\mathrm{u}$ &.- & 5 & $u$ & $\ldots$ & 5 & 4 & - & 5 & $\mathrm{u}$ & $\ldots$ \\
\hline Styrene & 6 & $\mathrm{u}$ & - & 6 & $\mathrm{u}$ & - & 6 & $\mathrm{u}$ & UJ & 5 & $u$ & -- & 5 & $\mathrm{U}$ & -- & 5 & $\mathrm{u}$ & $\ldots$ & 5 & $\mathrm{u}$ & - \\
\hline Xylene (Total) & 6 & $U$ & $\ldots$ & 6 & $\mathrm{U}$ & - & 6 & $u$ & UJ & 5 & & - & 5 & $u$ & $-\cdots$ & 5 & $u$ &.- & 5 & $u$ & $\ldots$ \\
\hline
\end{tabular}




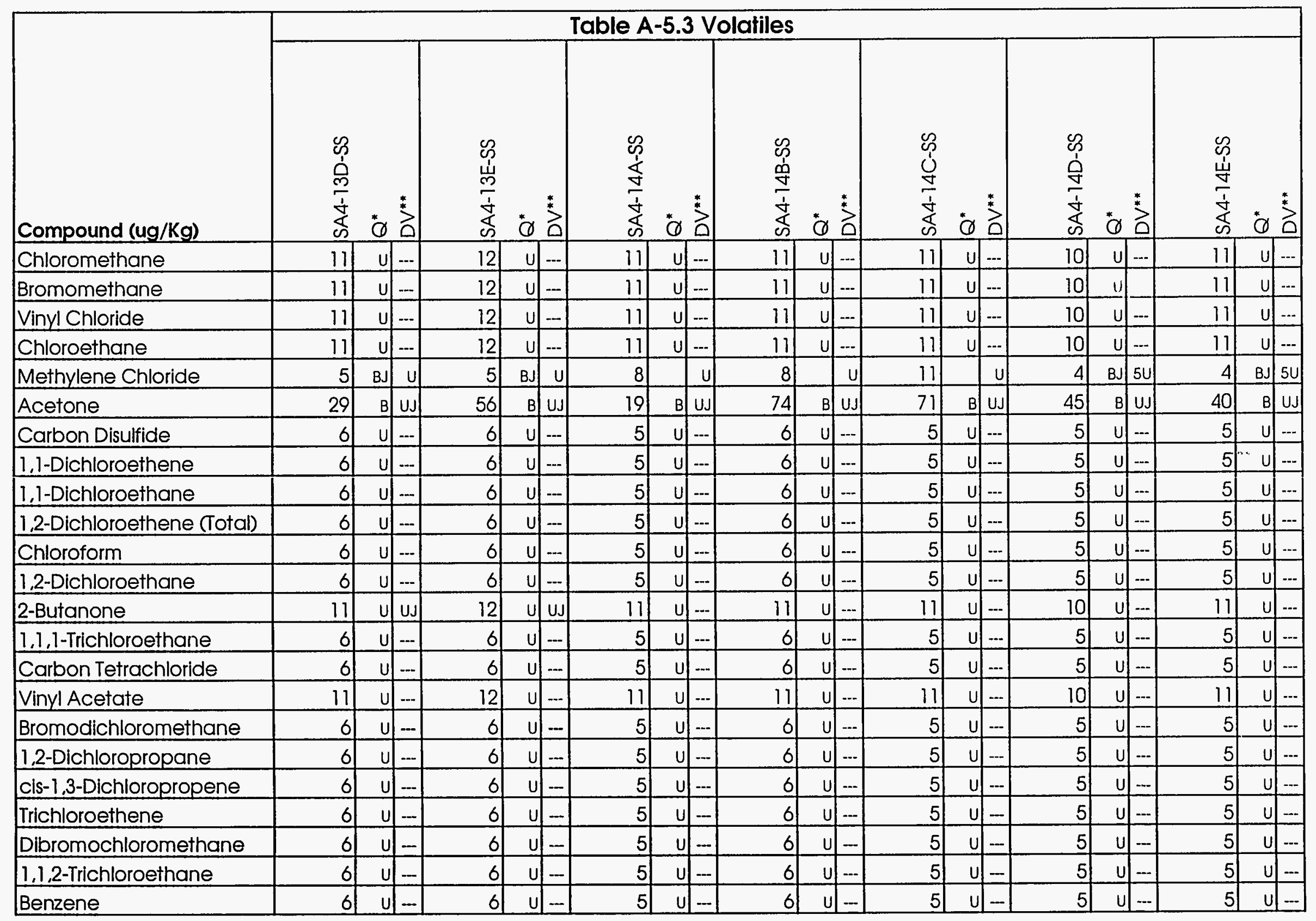




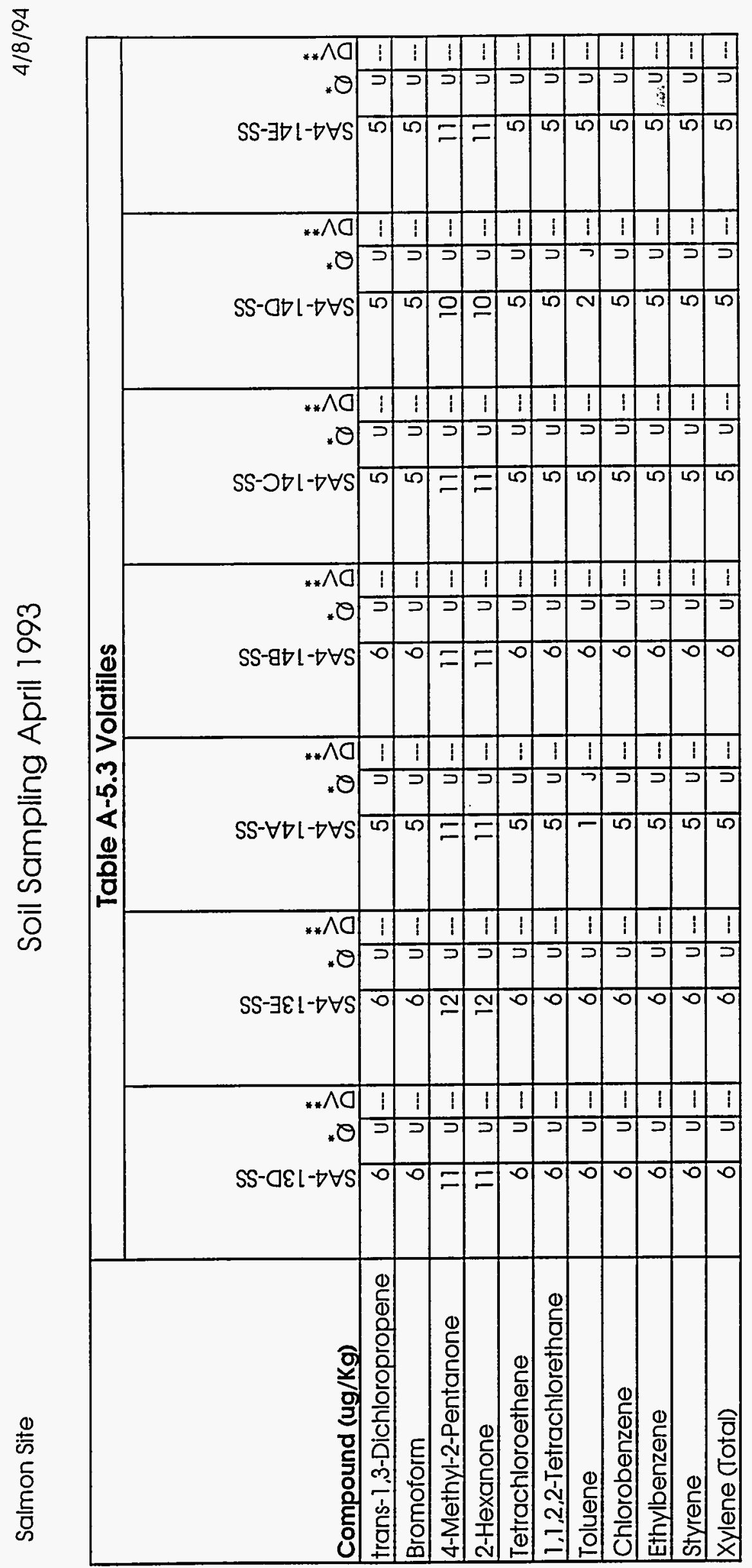

$\frac{1}{ \pm}$
0
0
0
0

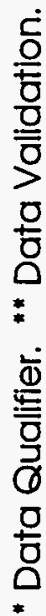




\begin{tabular}{|c|c|c|c|c|c|c|c|c|c|c|c|c|c|c|c|c|c|c|c|c|c|}
\hline \multirow[b]{2}{*}{ Compound (ug/Kg) } & \multicolumn{21}{|c|}{ Table A-5.3 Volatiles } \\
\hline & $\begin{array}{l}\mathscr{\infty} \\
\frac{1}{1} \\
\frac{6}{5} \\
\frac{1}{d} \\
\infty\end{array}$ & & & 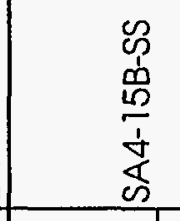 & 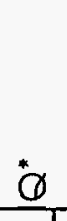 & ¿ & 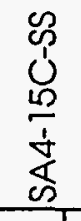 & & & 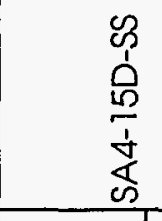 & $\stackrel{*}{Q}$ & & 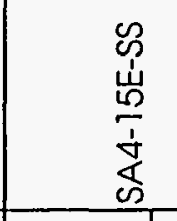 & & $\stackrel{*}{2}$ & 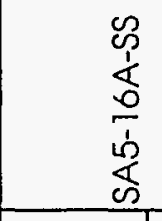 & $\stackrel{*}{Q}$ & $\stackrel{*}{3}$ & 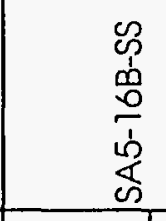 & $\ddot{\theta}$ & $\stackrel{*}{2}$ \\
\hline Chloromethane & 5 & $u$ & $-\ldots$ & 6 & $u$ & $\ldots$ & 5 & $u$ & $\ldots$ & 6 & $u$ & $\ldots$ & 6 & U. & $\ldots$ & 6 & u. & $\ldots$ & 5 & U. & $\ldots$ \\
\hline Bromomethane & 5 & 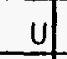 & $\ldots$ & 6 & U & $\ldots$ & 5 & 4 & $\ldots$ & 6 & $u$ & $\ldots$ & 6 & U. & $\ldots$ & 6 & u. & $\ldots$ & 5 & 4. & $\ldots$ \\
\hline Vinyl Chloride & 5 & 4 & $\ldots$ & 6 & U] & $\ldots$ & 5 & 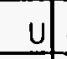 & $\ldots$ & 6 & $\mathrm{u}$ & $\ldots$ & 6 & $u$. & $\ldots$ & 6 & 4 & $\ldots$ & 5 & 4. & $\ldots$ \\
\hline Chloroethane & 5 & 4 & -- & 6 & 4 & $\ldots$ & 5 & 4 & $\ldots$ & 6 & 4 & $\ldots$ & 6 & U. & $\ldots$ & 6 & 4 & $\ldots$ & 5 & 4. & $\ldots$ \\
\hline Methylene Chloride & 5 & $u$ & $-\infty$ & 6 & 4 & $\ldots$ & 5 & $u$ & $\ldots$ & 6 & $u$ & $\ldots$ & 6 & $\mathrm{U}$. & $\ldots$ & 6 & U) & $\ldots$ & 5 & $\mathrm{u}$. & $\ldots$ \\
\hline Acetone & 10 & uf & $\ldots$ & 12 & U] & $\ldots$ & 11 & $\mathrm{u}$ & $\ldots$ & 12 & U & $\ldots$ & 12 & $\mathrm{U}$. & $\ldots$ & 11 & 4 & -- & 11 & $u$. & $\ldots$ \\
\hline Carbon Disulfide & 10 & 4 & - & 12 & U] & $\ldots$ & 11 & 4 & - & 12 & $\mathrm{u}$ & $\ldots$ & 12 & $u$. & $\ldots$ & 11 & U] & $\ldots$ & 11 & 4. & $-\ldots$ \\
\hline 1,1-Dichloroethene & 5 & $u$ & - & 6 & U] & $\ldots$ & 5 & $u$ & $\ldots$ & 6 & $u$ & $\ldots$ & 6 & U. & $\ldots$ & 6 & 4 & $\ldots$ & 5. & u. & $\ldots$ \\
\hline 1,1-Dichloroethane & 5 & 4 & $-\infty$ & 6 & 4 & $\ldots$ & 5 & 4 & $\ldots$ & 6 & $u$ & $\ldots$ & 6 & U. - & $\ldots$ & 6 & U) & $\ldots$ & 5 & u) & $\ldots$ \\
\hline 1,2-Dichloroethene (Total) & 5 & 4 & $-\infty$ & 6 & U & $\ldots$ & 5 & $\underline{u}$ & $\ldots$ & 6 & $\underline{u}$ & $\ldots$ & 6 & U. & $\ldots$ & 6 & u) & $\ldots$ & 5 & 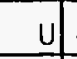 & $\ldots$ \\
\hline Chloroform & 5 & U. & $\ldots$ & 6 & U) & $\ldots$ & 5 & 4 & $\ldots$ & 9 & & $u$ & 6 & U. & $\ldots$ & 6 & 4 & $\ldots$ & 5 & 4 & -- \\
\hline 1,2-Dichloroethane & 5 & 4 & -- & 6 & $u$ & $\ldots-$ & 5 & $\mathrm{u}$ & $\ldots-$ & 6 & $u$ & $\ldots$ & 6 & 4. & $\ldots$ & 6 & $u$ & $\ldots$ & 5 & $u$ & $\ldots$ \\
\hline 2-Butanone & 10 & 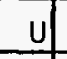 & $R$ & 12 & 4 & $\mathrm{R}$ & 11 & 4 & $R$ & 12 & U) & $R$ & 12 & $u$ & $\mathrm{R}$ & 11 & U) & $\mathrm{R}$ & 11 & 4 & $R$ \\
\hline 1,1,1-Trichloroethane & 5 & 4 & $\ldots$ & 6 & 4 & $\ldots$ & 5 & $u$ & $\ldots$ & 6 & $u$ & $\ldots$ & 6 & U. & $\ldots$ & 6 & $u$ &.. & 5 & 4 & $-\ldots$ \\
\hline Carbon Tetrachloride & 5 & $u$ & $-\infty$ & 6 & 4 & $\ldots$ & 5 & 4 & $\ldots-$ & 6 & $u$ & $\ldots$ & 6 & 4. & $\ldots$ & 6 & ut & $\ldots$ & 5 & u & $\ldots$ \\
\hline Vinyl Acetate & 10 & u. & - & 12 & $u$. & $\ldots$ & 11 & 4 & $\ldots$ & 12 & 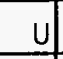 & $\ldots$ & 12 & U. & $\ldots$ & 11 & 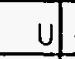 & $\ldots$ & 11 & $u$ & $-\ldots$ \\
\hline Bromodichloromethane & 5 & 4 & - & 6 & $u$ & $\ldots$ & 5 & $u$ & - & 6 & $\underline{4}$ & $\ldots$ & 6 & U. & $\ldots$ & 6 & U & $\ldots$ & 5 & u & $\ldots$ \\
\hline 1,2-Dichloropropane & 5 & 4 & -- & 6 & 4 & $\ldots$ & 5 & 4 & $\ldots$ & 6 & $u$ & $\ldots$ & 6 & 4. & $-\ldots$ & 6 & $u$ & -- & 5 & 4 & $\ldots$ \\
\hline cis-1,3-Dichloropropene & 5 & u & - & 6 & 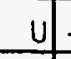 & - & 5 & 4 & -- & 6 & $U$ & $\ldots$ & 6 & $\mathrm{U}$ & $\ldots$ & 6 & U. & $\ldots$ & 5 & 4 & - \\
\hline Trichloroethene & 5 & 4 & - & 6 & u. & - & 5 & $u$. & - & 6 & U. & - & 6 & 4. & - & 6 & 11). & $\ldots$ & 5 & 4 & - \\
\hline Dibromochloromethane & 5 & 4 & - & 6 & U. & - & 5 & 4 & - & 6 & 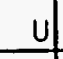 & - & 6 & U. & $-\ldots$ & 6 & u. & - & 5 & 4. & - \\
\hline 1,1,2-Trichloroethane & 5 & u & - & 6 & $u$. & -- & 5 & 4 & -- & 6 & $\mathrm{u}$ & $\ldots$ & 6 & u. & $-\ldots$ & 6 & U) & -- & 5 & u. & - \\
\hline Benzene & 5 & $u$ & -1 & 6 & u & -1 & 5 & 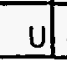 & -1 & 6 & $\mathrm{u}$ & - & 6 & $u-$ & -1 & 6 & 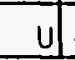 & -1 & 5 & $u$ & $\ldots$ \\
\hline
\end{tabular}




\begin{tabular}{|c|c|c|c|c|c|c|c|c|c|c|c|c|c|c|c|c|c|c|c|}
\hline \multirow[b]{2}{*}{ Compound (ug/Kg) } & \multicolumn{19}{|c|}{ Table A-5.3 Volatiles } \\
\hline & 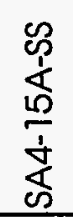 & Q & & 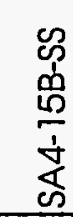 & & 艾 & 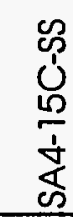 & & है। & 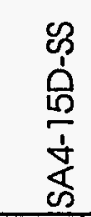 & \% & 3 & 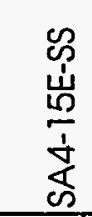 & $\sigma^{\circ}$ & & 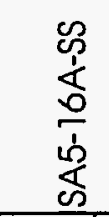 & $\sigma^{*}$ & 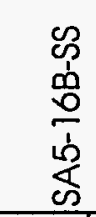 & $\stackrel{*}{*} \stackrel{3}{3}$ \\
\hline trans-1,3-Dichloropropene & 5 & u. & $=$ & 6 & & $\ldots$ & 5 & & $-\infty$ & 6 & & - & 6 & $u=$ & & 6 & $4-$ & 5 & $4 \ldots$ \\
\hline Bromoform & 5 & $u-$ & $=$ & 6 & $u$ & - & 5 & & - & 6 & & - & 6 & $u-$ & & 6 & $u=$ & 5 & $4 \ldots$ \\
\hline 4-Methyl-2-Pentanone & 10 & $u$ - & $=$ & 12 & & - & 11 & & - & 12 & & $\ldots$ & 12 & u] & & 11 & $u-$ & 11 & U) $=$ \\
\hline 2-Hexanone & 10 & $u$ - & $=$ & 12 & $u$ & - & 11 & & $\ldots$ & 12 & & $-\infty$ & 12 & $u \mid$ & & 11 & 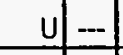 & 11 & u| - \\
\hline Tetrachloroethene & 5 & u. & $=$ & 6 & $u$ & - & 5 & & $-\ldots$ & 6 & & -- & 6 & $u \mid-$ & & 6 & $u=$ & 5 & $4=$ \\
\hline 1,1,2,2-Tetrachlorethane & 5 & u. $=$ & $=$ & 6 & $\mathrm{u}$ & 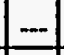 & 5 & & - & 6 & & - & 6 & $u$ & & 6 & u. & 5 & $u \mid=$ \\
\hline Toluene & 5 & $u$. & t & 6 & & $\ldots$ & 5 & & -1 & 6 & & -.. & 6 & $u$ & & 6 & $0 \ldots$ & 5 & $4=$ \\
\hline Chlorobenzene & 5 & u. & Et & 6 & $u$ & - & 5 & & - & 6 & & - & 6 & $\mathrm{u}-$ & & 6 & $4 \ldots$ & 5 & $0 \mid-$ \\
\hline Ethylbenzene & 5 & $u-$ & 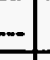 & 6 & $u$ & $\ldots$ & 5 & & - & 6 & & 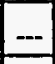 & 6 & $4 \mid$ & & 6 & $4 \mid \ldots$ & 5 & -0 \\
\hline Styrene & 10 & 4. & Et & 12 & $u$ & - & 11 & & - & 12 & & - & 12 & 4 & $=$ & 11 & U. & 11 & $4=$ \\
\hline Xylene (Total) & 10 & u. & & 12 & & - & 11 & & - & 12 & $u$ & $-{ }_{-}$ & 12 & $u \mid \ldots$ & - & 11 & u[ $[-\ldots$ & 11 & $u \mid \ldots$ \\
\hline
\end{tabular}




\begin{tabular}{|c|c|c|c|c|c|c|c|c|c|c|c|c|c|c|c|c|c|c|c|c|c|}
\hline \multirow[b]{2}{*}{ Compound (ug/Kg) } & \multicolumn{21}{|c|}{ Table A-5.3 Volatiles } \\
\hline & 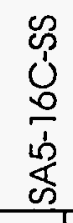 & & & 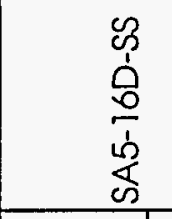 & & & 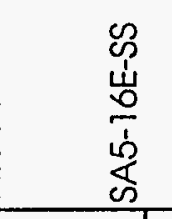 & & & 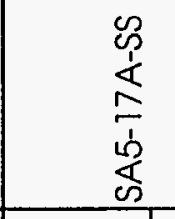 & & & 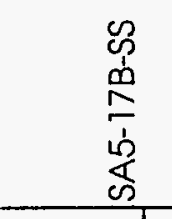 & & $\stackrel{*}{3}$ & 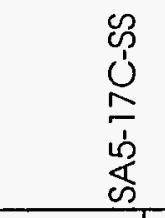 & & $\stackrel{*}{2}$ & 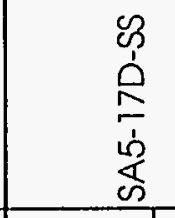 & $\stackrel{*}{Q}$ & $\stackrel{\text { * }}{\stackrel{0}{0}}$ \\
\hline Chloromethane & 5 & U & $\ldots$ & 5 & $u$ & $\ldots$ & 6 & U. & $\ldots$ & 11 & 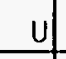 & $\ldots$ & 11 & $\mathrm{u}$. & $\ldots$ & 11 & 4 & -- & 12 & $u$ & $\mathrm{UJ}$ \\
\hline Bromomethane & 5 & 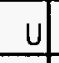 & $\ldots$ & 5 & U & $\ldots$ & 6 & u. & $\ldots+$ & 11 & u & $\ldots$ & 11 & $\mathrm{u}$. & - & 11 & U) & $\ldots$ & 12 & 4 & Uu \\
\hline Vinyl Chloride & 5 & $u$ & $\ldots$ & 5 & $U$ & $\ldots$ & 6 & $u$. & $\ldots$ & 11 & $u$ & $\ldots$ & 11 & $u$. & $\ldots$ & 11 & $u$ & -- & 12 & $u$ & UJ \\
\hline Chloroethane & 5 & U & - & 5 & $u$ & -- & 6 & $\mathrm{u}$. & $\ldots+$ & 11 & $u$ & $\ldots+$ & 11 & $u$. & $\ldots$ & 11 & u & -- & 12 & $\mathrm{u}$ & U. \\
\hline Methylene Chloride & 5 & $\mathrm{U}$ & - & 5 & 4 & -- & 6 & 4 & - & 7 & $\mathrm{~B}$ & $u$ & 7 & $\mathrm{~B}$ & U & 7 & B & 4 & 9) & B & $\mathrm{U}$ \\
\hline Acetone & 11 & 4 & $\ldots$ & 11 & $\mathrm{U}$ & $-\ldots$ & 13 & 4. & $\ldots$ & 45 & 8 & UJ & 58 & B & UJ & 73 & 8 & UJ & 50 & $\mathrm{~B}$ & $\mathrm{~J}$ \\
\hline Carbon Disulfide & 11 & 4 & $\ldots$ & 11 & $u$ & - & 13 & $\mathrm{u}$. & --- & 6 & 4 & $\ldots$ & 6 & 4. & -+ & 5 & 4 & $\ldots$ & 6 & 4 & UJ \\
\hline 1,1-Dichloroethene & 5 & 4 & - & 5 & u & - & 6 & $\mathrm{ut}$. & $-\ldots$ & 6 & U & $\ldots$ & 6 & 4. & $-\ldots$ & 5 & U & $\ldots$ & 6 & 4 & UJ \\
\hline 1,1-Dichloroethane & 5 & 4 & $\ldots$ & 5 & 4 & - & 6 & 4. & $\ldots$ & 6 & 4 & $-\ldots$ & 6 & 4. & - & 5 & $u$ & -- & 6 & 4 & Uu \\
\hline 1,2-Dichloroethene (Total) & 5 & $u$ & - & 5 & 4 & - & 6 & u. & $\ldots$ & 6 & ut & $\ldots$ & 6 & 4. & -- & 5 & 4 & -- & 6 & U & $\mathrm{UJ}$ \\
\hline Chloroform & 6 & & $\ldots$ & 5 & $\mathrm{~J}$ & $\ldots$ & 6 & $\mathrm{u}$. & $\ldots$ & 6 & 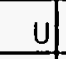 & $\ldots$ & 6 & 4. & -- & 5 & $u$ & $\ldots$ & 6 & 4 & UJ \\
\hline 1.2-Dichloroethane & 5 & u) & $\ldots$ & 5 & 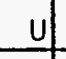 & $\ldots$ & 6 & $u$. & $\ldots$ & 6 & U & $\ldots$ & 6 & 4. & -- & 5 & ut & $\ldots$ & 6 & $u$ & UJ \\
\hline 2-Butanone & 11 & 4 & $R$ & 11 & 4 & $R$ & 13 & 4. & -- & 11 & $u$ & $\ldots$ & 11 & $u$. & $\ldots$ & 11 & ut & -- & 12 & 4 & Uu \\
\hline 1,1,1-Trichloroethane & 5 & $u$ & - & 5 & 4 & -- & 6 & $\mathrm{u}$ & - & 6 & $u$ & $-\ldots$ & 6 & 4. & $-\ldots$ & 5 & 4 & $\ldots$ & 6 & U & UJ \\
\hline Carbon Tetrachloride & 5 & 4 & $-\ldots$ & 5 & 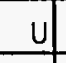 & $\ldots$ & 6 & $u$. & -- & 6 & 4 & $-\ldots$ & 6 & 4 & $-\infty$ & 5 & 4 & $\ldots$ & 6 & 4 & $\mathrm{uJ}$ \\
\hline Vinyl Acetate & 11 & 4 & - & 11 & $u$ & $\ldots$ & 13 & 4 & -- & 11 & 4 & -- & 11 & 4 & $\ldots$ & 11 & 4 &.- & 12 & 4 & $\mathrm{uJ}_{\mathrm{J}}$ \\
\hline Bromodichloromethane & 5 & 4 & $\ldots$ & 5 & 4 & -- & 6 & $u$. & $-\ldots$ & 6 & 4 & $\ldots$ & 6 & 4 & $\ldots$ & 5 & 4 & $-\ldots$ & 6 & 4 & UJ \\
\hline 1,2-Dichloropropane & 5 & $u$ & - & 5 & $u$ & -- & 6 & u & $\ldots$ & 6 & 4 & $-\ldots$ & 6 & $u$ & -- & 5 & 4 & $\ldots$ & 6 & $u$ & UJ \\
\hline cis-1,3-Dichloropropene & 5 & $u$ & $\ldots$ & 5 & $u$ & - & 6 & 4 & -- & 6 & 4 & $\cdots$ & 의 & 4 & -- & 5 & $u$ & - & 6 & $u$ & UJ \\
\hline Trichloroethene & 5 & $\mathrm{U}$ & - & 5 & $u$ & - & 6 & 4 & $\ldots$ & 6 & $u$ & $\ldots$ & 6 & 4 & -- & 5 & $u$ & -- & 6 & 4 & Uu \\
\hline Dibromochloromethane & 5 & 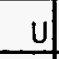 & - & 5 & 4 & -- & 6 & 4 & - & 6 & $\mathrm{U}$ & $\ldots$ & 6 & u & - & 5 & $u$ & $-\ldots$ & 6 & $u$ & UJ \\
\hline 1,1,2-Trichloroethane & 5 & $\mathrm{U}$ & $-\ldots$ & 5 & $u$ & - & 6 & $u$ & - & 6 & 4 & $-\infty$ & 6 & 4 & - & 5 & u & - & 6 & $u$ & UJ \\
\hline Benzene & 5 & $\mathrm{u}$ & - & 5 & $\mathrm{u}$ & - & 6 & $u$ & - & 6 & $\mathrm{u}$ & - & 6 & U] & $\ldots$ & 5 & $u$ & $4 \ldots$ & 6 & & $U \mathrm{UJ}$ \\
\hline
\end{tabular}




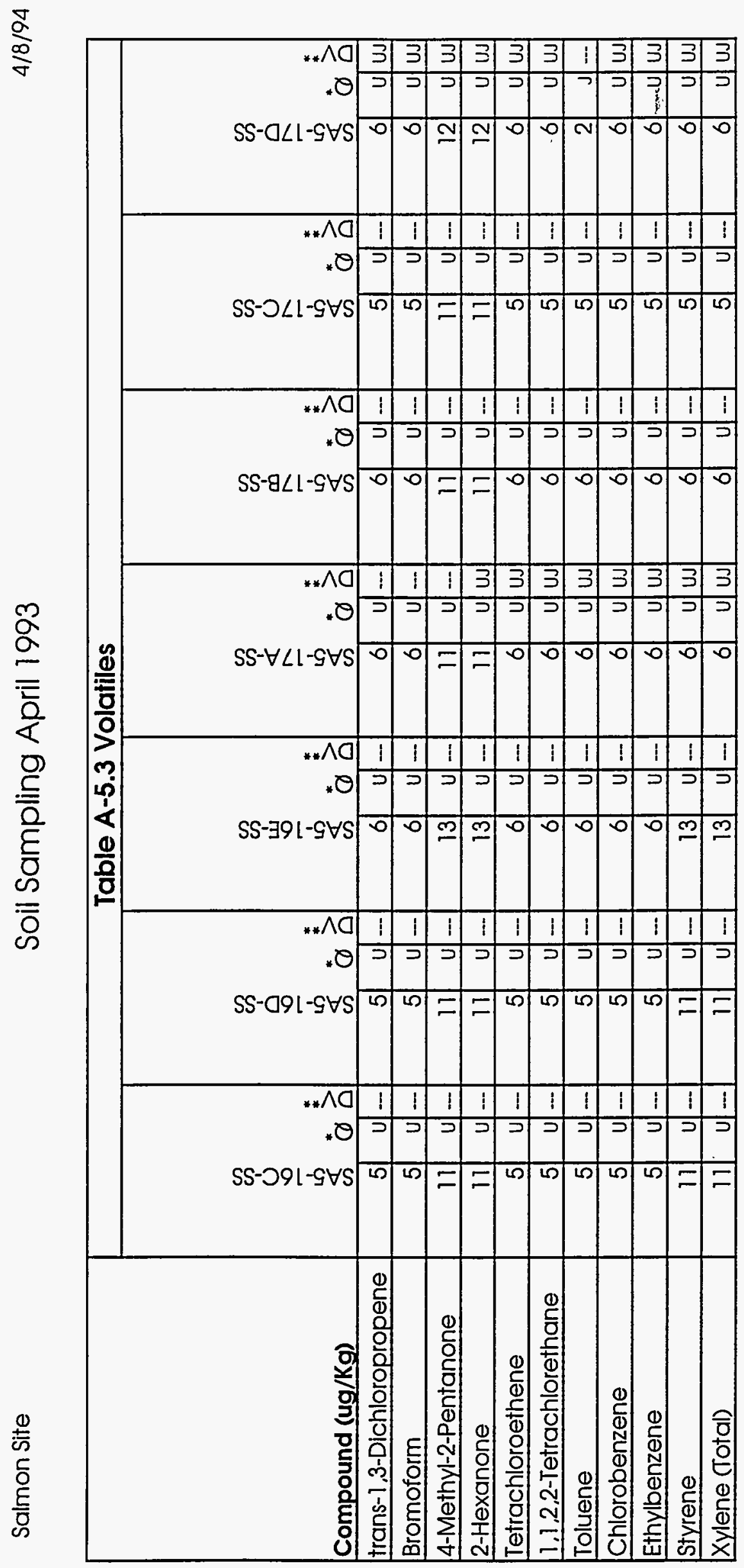

守
0
0
0
0
0

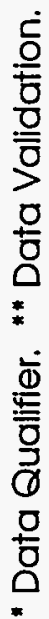




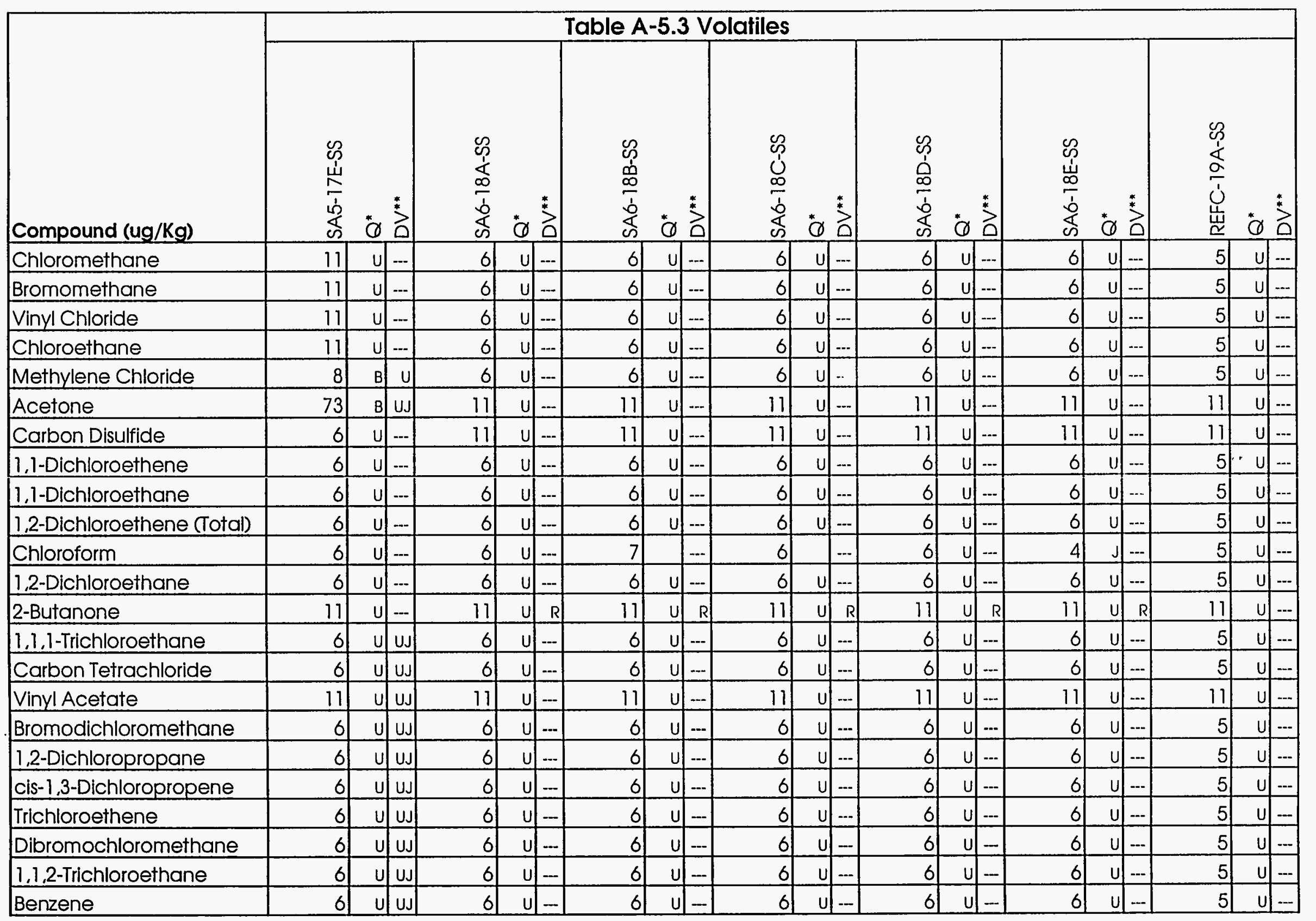




\begin{tabular}{|c|c|c|c|c|c|c|c|c|c|c|c|c|c|c|c|c|c|c|c|c|c|}
\hline \multirow[b]{2}{*}{ Compound (ug/Kg) } & \multicolumn{21}{|c|}{ Table A-5.3 Volatiles } \\
\hline & 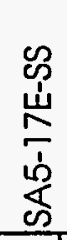 & & ${ }^{*}$ & 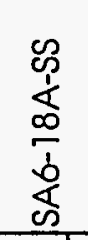 & & 莒 & 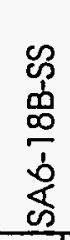 & & 方 & 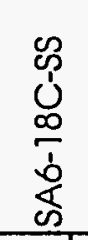 & & $\sum^{*}$ & 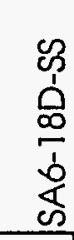 & & 总 & 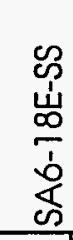 & $\stackrel{*}{0}$ & 号 & $\begin{array}{l}\mathscr{y} \\
\frac{1}{\alpha} \\
\alpha \\
\frac{1}{1} \\
\dot{u} \\
\underline{u} \\
\end{array}$ & & 艾 \\
\hline trans-1,3-Dichloropropene & 6 & 4 & UJ & 6 & $u$ & - & 6 & $u$ & - & 6 & U & - & 6 & 4 & -- & 6 & $\mathrm{u}$ & $\ldots$ & 5 & $\mathrm{U}$ & - \\
\hline Bromoform & 6 & $u$ & UJ & 6 & U & -- & 6 & 4 & -- & 6 & 4. & $\ldots$ & 6 & 4 & $\ldots$ & 6 & $u$ & $\ldots$ & 5 & $u$ &.- \\
\hline 4-Methyl-2-Pentanone & 11 & $u$ & UJ & 11 & U) & -- & 11 & $\mathrm{U}$ & -- & 11 & 4. & $\ldots$ & 11 & 4. & $\ldots$ & 11 & $\mathrm{u}$ & - & 11 & $u$ & $\ldots$ \\
\hline 2-Hexanone & 11 & $\mathrm{u}$ & uJ & 11 & $\mathrm{u}$ & $\ldots$ & 11 & $u$ & $\ldots$ & 11 & $u$. & $\ldots$ & 11 & $u$ & $\ldots$ & 11 & $\mathrm{u}$ & -- & 11 & $u$ & $\ldots$ \\
\hline Tetrachloroethene & 6 & $U$ & UJ & 6 & $u$ & $\ldots$ & 6 & 4 & $\ldots$ & 6 & 4. & $\ldots$ & 6 & 4. & $\ldots$ & 6 & 4 & -- & 5 & $\mathrm{U}$ &.- \\
\hline 1,1,2,2-Tetrachlorethane & 6 & 4 & UJ & 6 & $u$ & - & 6 & $u$ & -- & 6 & 4. & $\ldots$ & 6 & 4 & -- & 6 & $\mathrm{U}$ & - & 5 & 4 & 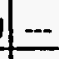 \\
\hline Toluene & 2 & J. & $\ldots$ & 6 & $\mathrm{u}$ & -- & 6 & $u$ & - & 6 & $u$. & $\ldots$ & 6 & U & $-\ldots$ & 6 & $\mathrm{u}$ & -- & 5 & $u$ & $\ldots$ \\
\hline Chlorobenzene & 6 & $U$ & UJ & 6 & $U$ & -- & 6 & $u$ & -- & 6 & $\mathrm{U}$ & $-\ldots$ & 6 & $U$ & $\ldots$ & 6 & $\mathrm{u}$ & $\ldots$ & 5 & $u$ & $\ldots$ \\
\hline Ethylbenzene & 6 & U) & UJ & 6 & 4 & - & 6 & $u$ & -- & 6 & $u$. & $\ldots$ & 6 & u. & $\ldots$ & 6 & $\mathrm{u}$ & - & 5 & 4 & 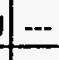 \\
\hline Styrene & 6 & $u$ & UJ & 11 & $u$ & - & 11 & $u$ & $\ldots$ & 11 & $\mathrm{u}$. & $\ldots$ & 11 & 4 & $\ldots$ & 11 & $\mathrm{u}$ & - & 11 & & 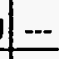 \\
\hline Xylene (Total) & 6 & $U$ & uJ & 111 & $u$ & - & 11 & U & $\ldots$ & 11 & $U$ & $\ldots$ & 11 & ul. & $-\ldots$ & 11 & U & $\ldots$ & 11 & U) & $1--$ \\
\hline
\end{tabular}




\begin{tabular}{|c|c|c|c|c|c|c|c|c|c|c|c|c|c|c|c|c|c|c|c|c|c|}
\hline \multirow[b]{2}{*}{ Compound (ug/Kg) } & \multicolumn{18}{|c|}{ Table A-5.3 Volatiles } & \multirow{2}{*}{\multicolumn{3}{|c|}{ 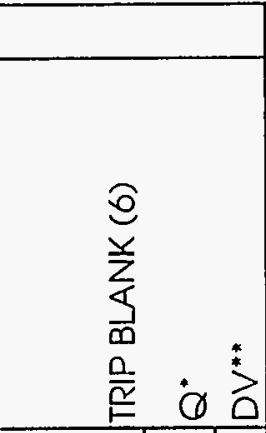 }} \\
\hline & 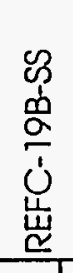 & & & 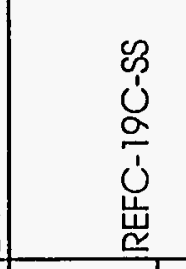 & & & 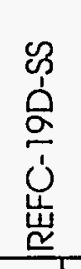 & $\stackrel{*}{0}$ & & 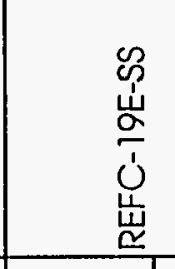 & & & 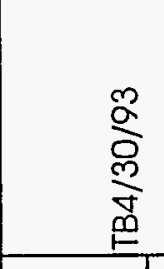 & $\ddot{Q}$ & $\stackrel{2}{*}^{*}$ & 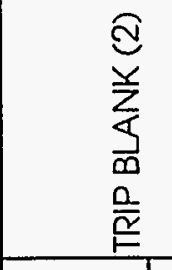 & & & & & \\
\hline Chloromethane & 6 & $\mathrm{u}$ & $\ldots$ & 7 & $\mathrm{U}$ & $-\infty$ & 5 & $u$ & $-\ldots$ & 5 & $u$ & \begin{tabular}{|l|l|}
$-\ldots$ & 0 \\
\end{tabular} & 5 & 4. & $\ldots$ & 10 & $u$ & $\ldots$ & 10 & 4 & $R$ \\
\hline Bromomethane & 6 & $u$ & $\ldots$ & 7 & $\mathrm{U}$ & $-\ldots$ & 5 & $u$ & $\ldots$ & 5 & $\mathrm{U}$ & \begin{tabular}{|l|}
$-\ldots$ \\
\end{tabular} & 5 & $\mathrm{U}$. & $\ldots$ & 10 & $u$. & $\ldots$ & 10 & 4 & $R$ \\
\hline Vinyl Chloride & 6 & $u$ & $-{ }_{-1}$ & 7 & 4 & -- & 5 & $u$ & - & 5 & $u$ & $\ldots$ & 5 & $u$. & -- & 10 & 4. & $\ldots$ & 10 & $U$ & $\mathrm{R}$ \\
\hline Chloroethane & 6 & 4 & -- & 7 & u & $-\infty$ & 5 & 4 & $-\ldots$ & 5 & 4 & $\ldots$ & 5 & 4. & - & 10 & 4. & $\ldots$ & 10 & $u$ & $\mathrm{R}$ \\
\hline Methylene Chloride & 6 & $\mathrm{u}$ & $-\ldots$ & 16 & & $\ldots$ & 9 & & -- & 5 & 4 & $-\ldots$ & 5 & 4. & --1 & 15 & $B$ & $u$ & 7 & B 1 & $\mathrm{uJ}$ \\
\hline Acetone & 12 & 4 & $\ldots$ & 13 & $\mathrm{U}$ & \begin{tabular}{|l|}
$-\ldots$ \\
\end{tabular} & 11 & 4 & $-\ldots$ & 11 & 4 & $\ldots$ & 10 & 4. & -- & 23 & $\mathrm{~B}$ & UJ & 10 & 4 & $R$ \\
\hline Carbon Disulfide & 12 & 4 & \begin{tabular}{|l|l|}
-- & -1 \\
\end{tabular} & 13 & $u$ & $\ldots$ & 11 & 4 & $\ldots$ & 11 & 4 & $\ldots$ & 10 & 4. &.-- & 5 & 4. & $\ldots$ & 5 & $U$ & $\mathrm{R}$ \\
\hline 1,1-Dichloroethene & 6 & $u$ & $-\infty$ & 7 & 4 & $-\ldots$ & 5 & 4 & $\ldots$ & 5 & 4 & -- & 5 & u. & $\ldots$ & 5 & 4. & $\ldots$ & 5 & $u$ & $R$ \\
\hline 1,1-Dichloroethane & 6 & 4 & -- & 7 & 4 & $-\ldots$ & 5 & U & $\ldots$ & 5 & 4 & -- & 5 & 4. & -- & 5 & 4 & $\ldots$ & 5 & $u$ & $\mathrm{R}$ \\
\hline 1,2-Dichloroethene (Total) & 6 & 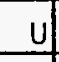 & $\ldots$ & 7 & 4 & \begin{tabular}{|l|l|}
-- & 0 \\
\end{tabular} & 5 & 4 & $\ldots$ & 5 & 4 & $\ldots$ & 5 & 4. & $\ldots$ & 5 & 4. & $\ldots$ & 5 & 4 & $\mathrm{R}$ \\
\hline Chloroform & 6 & $u$ & $-\ldots$ & 7 & 4 & $\ldots$ & 5 & 4 & -- & 5 & 4 & $\ldots$ & 2 & Bu & 50 & 5 & 4 &.- & 5 & $U$ & $\mathrm{R}$ \\
\hline 1,2-Dichloroethane & 6 & $u$ & $\ldots$ & 7 & 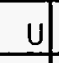 & $\ldots$ & 5 & 4 & $-\ldots$ & 5 & 4 & $\ldots$ & 5 & 4 & $\ldots$ & 5 & 4 & $\ldots$ & 5 & $u$ & $R$ \\
\hline 2-Butanone & 12 & 4 & $-{ }_{-1}$ & 13 & 4 & $\ldots$ & 11 & 4 & $\ldots$ & 11 & 4 & $R$ & 10 & 4 & $R$ & 10 & 4 & $R$ & 10 & 4 & $R$ \\
\hline 1,1,1-Trichloroethane & 6 & 4 & $\ldots$ & 7 & 4 & -- & 5 & 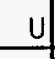 & $\ldots$ & 5 & 4 & $\ldots$ & 5 & 4 & $\ldots$ & 5 & $u$ & -- & 5 & $u$ & $R$ \\
\hline Carbon Tetrachloride & 6 & $\mathrm{u}$ & $\ldots$ & 7 & 4 & -- & 5 & $u$ & $\ldots$ & 5 & u. & $\ldots$ & 5 & $u$ & $\ldots$ & 5 & 4 & $\ldots$ & 5 & 4 & $R$ \\
\hline Vinyl Acetate & 12 & $u$ & $-\ldots$ & 13 & $u$ & $\ldots$ & 11 & $u$ & - & 11 & $u$ & $\ldots$ & 10 & $u$ & $\ldots$ & 10 & 4 & $\ldots$ & 10 & 4 & $\mathrm{R}$ \\
\hline Bromodichloromethane & 6 & $u$ & - & 7 & $u$ & -- & 5 & $\mathrm{U}$ & -- & 5 & $u$ & -- & 5 & $u$ & $\ldots$ & 5 & 13 & & 5 & U & $R$ \\
\hline 1,2-Dichloropropane & 6 & $u$ & $\ldots$ & 7 & $u$ & $\ldots$ & 5 & $\mathrm{U}$ & -- & 5 & u & -- & 5 & $u$ & $-\cdots$ & 5 & 4 & -- & 5 & 4 & $R$ \\
\hline cis-1,3-Dichloropropene & 6 & $\mathrm{U}$ & -- & 7 & $u$ &.-- & 5 & $\mathrm{U}$ & - & 5 & $u$ & -- & 5 & $u$ & -- & 5 & 4 & $\ldots$ & 5 & 4 & $R$ \\
\hline Trichloroethene & 6 & $\mathrm{u}$ & $\ldots$ & 7 & $u$ & - & 5 & $u$ & -- & 5 & U & - & 5 & $u$ & $\ldots$ & 5 & 4 &.-- & 5 & 4 & $R$ \\
\hline Dibromochloromethane & 6 & $u$ & - & 7 & $u$ & - & 5 & 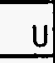 & - & 5 & 4 & -- & 5 & 4 & - & 5 & $u$ & $\ldots$ & 5 & 4 & $R$ \\
\hline 1,1,2-Trichloroethane & 6 & $\underline{U}$ & - & 7 & $u$ & - & 5 & $\mathrm{u}$ & - & 5 & 4 & $\ldots$ & 5 & 4 & $\ldots$ & 5 & $u$ & 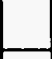 & 5 & $\mathrm{u}$ & $R$ \\
\hline Benzene & 6 & $u$ & - & 7 & $\mathrm{u}$ & - & 5 & U & - & 5 & U) & - & 5 & ul & -- & 5 & $\mathrm{U}$ & - & 5 & $u$ & $R$ \\
\hline
\end{tabular}

"Data Qualifier. "* Data Validation. 


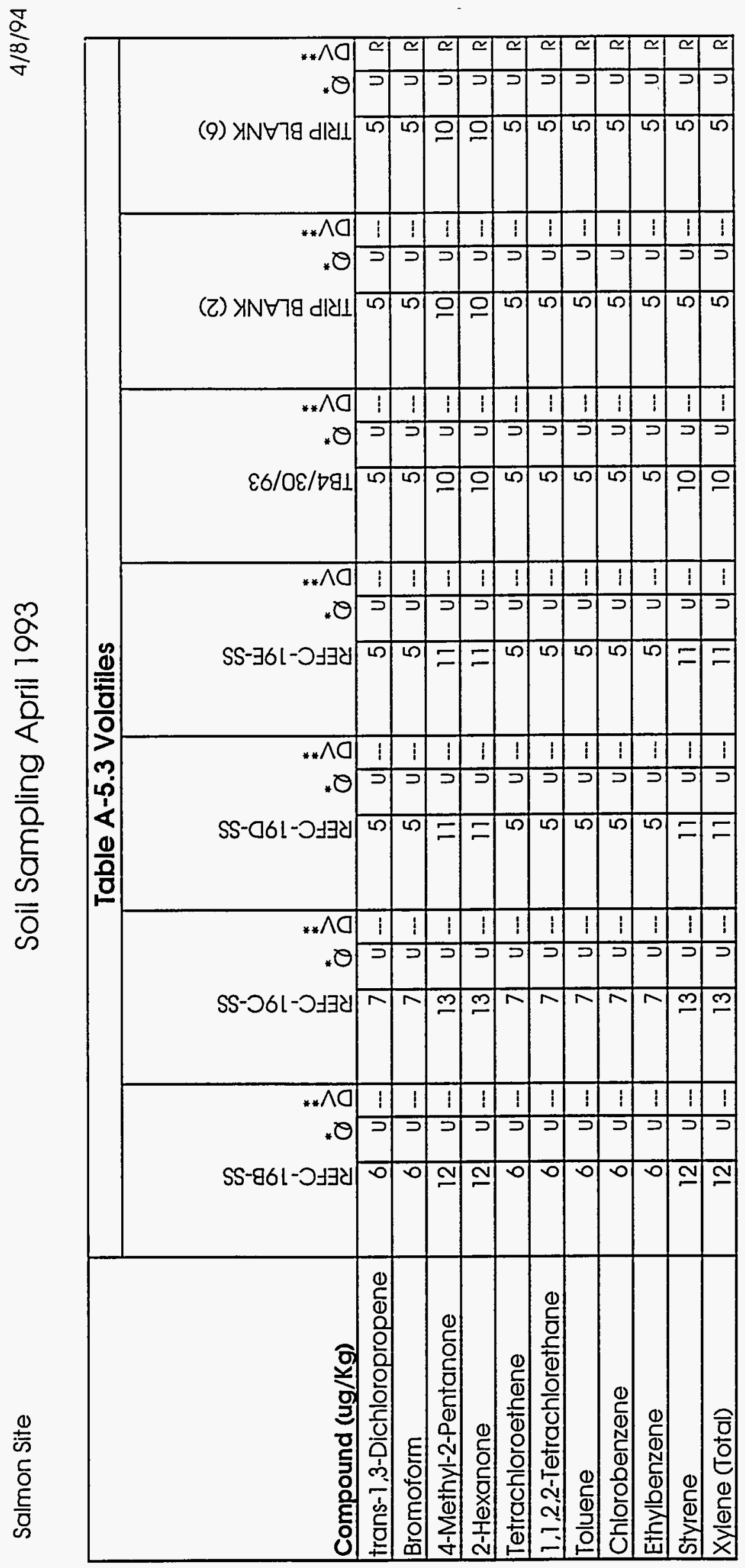

0
$\stackrel{0}{0}$
$\Phi$
0
0
0

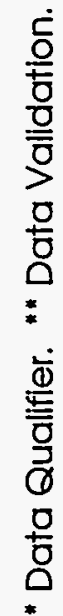




\begin{tabular}{|c|c|c|c|c|c|c|}
\hline \multirow[b]{2}{*}{ Compound (ug/Kg) } & \multicolumn{6}{|c|}{ Table A-5.3 Volatiles } \\
\hline & 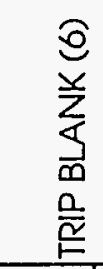 & $\stackrel{*}{6}$ & $\stackrel{2}{0}^{*}$ & 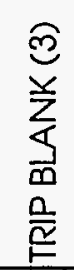 & $\stackrel{0}{\varnothing}$ & $\stackrel{2}{0}^{*}$ \\
\hline Chloromethane & 10 & $\underline{u}$ & -- & 10 & $\mathrm{U}$ & $N P$ \\
\hline Bromomethane & 10 & 4 & $\ldots$ & 10 & $u$ & $\mathrm{NP}$ \\
\hline Vinyl Chloride & 10 & $u$ & -- & 10 & 4 & $N P$ \\
\hline Chloroethane & 10 & $u$ & $\ldots$ & 10 & 4 & $\mathrm{NP}$ \\
\hline Methylene Chloride & 18 & B & $u$ & 7 & $\mathrm{~B}$ & $N P$ \\
\hline Acetone & 25 & 旦 & UJ & 10 & $u$ & NP \\
\hline Carbon Disulfide & 5 & $u$ & - & 5 & $u$ & $N P$ \\
\hline 1,1-Dichloroethene & 5 & $u$ & - & 5 & 4 & $\mathrm{NP}$ \\
\hline 1,1-Dichloroethane & 5 & 4 & - & 5 & $u$ & $\mathrm{NP}$ \\
\hline 1.2-Dichloroethene (Total) & 5 & $u$ & -- & 5 & $\underline{u}$ & $\mathrm{NP}$ \\
\hline Chloroform & 5 & $u$ & - & 5 & $u$ & $N P$ \\
\hline 1.2-Dichloroethane & 5 & $\mathrm{U}$ & - & 5 & $\underline{u}$ & $\mathrm{NP}$ \\
\hline 2-Butanone & 10 & $u$ & -- & 10 & 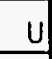 & $\mathrm{NP}$ \\
\hline 1.1.1-Trichloroethane & 5 & 4 & $\ldots$ & 5 & $u$ & $N P$ \\
\hline Carbon Tetrachloride & 5 & $\mathrm{U}$ & -- & 5 & 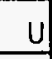 & $\mathrm{NP}$ \\
\hline Vinyl Acetate & 10 & 4 & - & 10 & $\underline{U}$ & $\mathrm{NP}$ \\
\hline Bromodichloromethane & 5 & 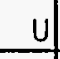 & -- & 5 & $\underline{u}$ & $\mathrm{NP}$ \\
\hline 1,2-Dichloropropane & 5 & 4 & $\ldots$ & 5 & $\underline{u}$ & $N P$ \\
\hline cis-1,3-Dichloropropene & 5 & $\mathrm{U}$ & - & 5 & $\underline{\mathrm{u}}$ & $\mathrm{NP}$ \\
\hline Trichloroethene & 5 & $u$ & - & 5 & $\underline{u}$ & NP \\
\hline Dibromochloromethane & 5 & $u$ & - & 5 & $u$ & $\mathrm{NP}$ \\
\hline 1,1,2-Trichloroethane & 5 & $u$ & $\ldots$ & 5 & $\underline{u}$ & $\mathrm{NP}$ \\
\hline Benzene & 5 & $u$ & $\ldots$ & 5 & & NP \\
\hline
\end{tabular}

"Data Qualifier. "* Data Validation. 
$\frac{d}{\frac{d}{2}}$

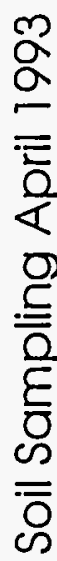

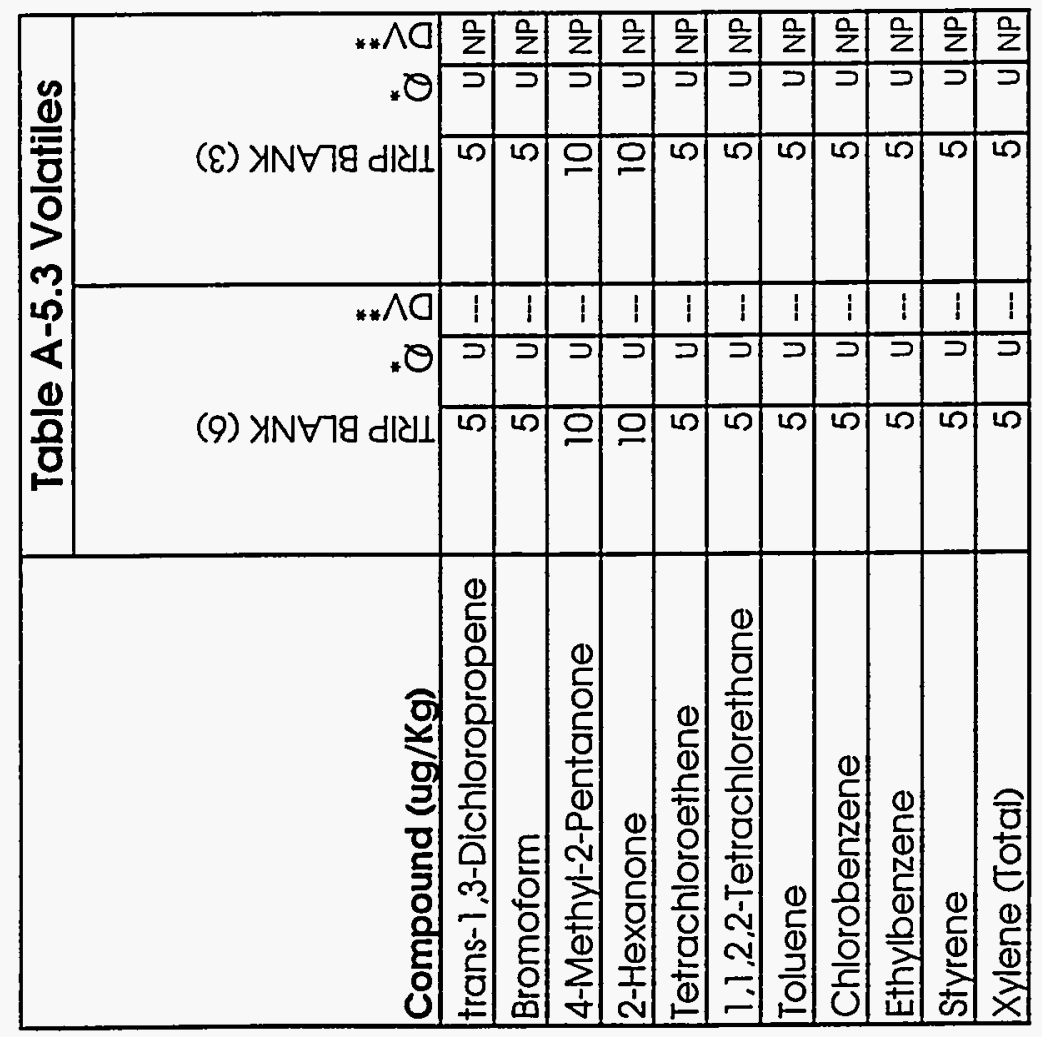

$\frac{6}{0}$
$\frac{0}{0}$
$\frac{0}{0}$ 


\begin{tabular}{|c|c|c|c|c|c|c|c|c|c|c|c|c|c|c|c|c|c|c|c|c|c|}
\hline \multirow[b]{2}{*}{ Compound (ug/Kg) } & \multicolumn{21}{|c|}{ Table A-5.4 Semi-Volatiles } \\
\hline & 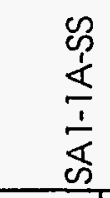 & & $\stackrel{2}{*}$ & 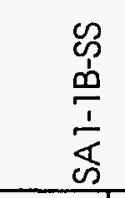 & & & 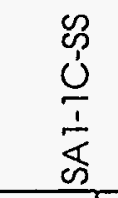 & & ${ }^{*}$ & $\begin{array}{l}\mathscr{c} \\
\stackrel{1}{0} \\
\frac{1}{5} \\
\frac{1}{5} \\
\text { c) }\end{array}$ & $\ddot{\theta}$ & ${ }^{*}$ & 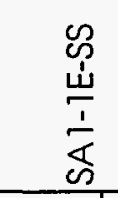 & & $\stackrel{3}{0}^{*}$ & 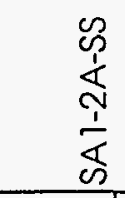 & & $\stackrel{*}{*}$ & 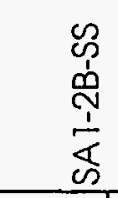 & & $\stackrel{*}{2}$ \\
\hline Phenol & 370 & $u$ & $-\ldots$ & 350 & u & $\ldots$ & 350 & $u$ & $\ldots$ & 360 & $\mathrm{u}$ & $\ldots$ & 340 & $u$. & $\ldots$ & 360 & $u$ & -- & 380 & & $N P$ \\
\hline bis (2-Cloroethyl)Ether & 370 & 4 & -- & 350 & U) & -- & 350 & 4 & -- & 360 & 4 & -- & 340 & $\mathrm{U}$. & -- & 360 & $u$. & -- & 380 & U & $N P$ \\
\hline 2-Chlorophenol & 370 & U & -- & 350 & U & $-\infty$ & 350 & 4 & $-\infty$ & 360 & 4 & $\ldots$ & 340 & $u$. & $\ldots$ & 360 & 4. & -- & 380 & $4 i$ & $N P$ \\
\hline 1,3-Dichlorobenzene & 370 & 4 & $-\cdots$ & 350 & 4 & $\ldots$ & 350 & 4 & - & 360 & 4 & $\ldots$ & 340 & $\mathrm{u}$ & $\ldots$ & 360 & $u$. & $\ldots$ & 380 & 4 & $N P$ \\
\hline 1.4-Dichlorobenzene & 370 & $u$ & $\ldots$ & 350 & $\mathrm{u}$ & 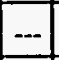 & 350 & $\mathrm{u}$ & $\ldots$ & 360 & 4 & $\ldots$ & 340 & $u$. & -- & 360 & $u$. &.- & 380 & $u i$ & $\mathrm{NP}$ \\
\hline Benzyl Alcohol & 370 & $\mathrm{U}$ & $\ldots$ & 350 & 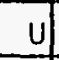 & $-\cdots$ & 350 & u & $-\ldots$ & 360 & 4 & $\ldots$ & 340 & $\mathrm{u}$. & -- & 360 & u. & -- & 380 & 0 & $\mathrm{NP}$ \\
\hline 1,2-Dichlorobenzene & 370 & 4 & -- & 350 & 4 & $\ldots$ & 350 & U) & $\ldots$ & 360 & U] & -- & 340 & $u$. & - & 360 & $u$ & $\cdots$ & 380 & $u$ & $\mathrm{NP}$ \\
\hline 2-Methylphenol & 370 & u) & $\ldots$ & 350 & u) & $\ldots$ & 350 & U) & $\ldots$ & 360 & U) & $\ldots$ & 340 & $u$. & $\ldots$ & 360 & 4. & $\ldots$ & 380 & 0 & $\mathrm{NP}$ \\
\hline bis (2-Chloroisopropyl)Ether & 370 & U) & $-\ldots$ & 350 & $\mathrm{u}$ & $\ldots$ & 350 & $\mathrm{u}$ & $\ldots$ & 360 & $u$ & $\ldots$ & 340 & $u$. & -- & 360 & $u$. & $\ldots$ & 380 & $u 1$ & $\mathrm{NP}$ \\
\hline 4-Methylphenol & 370 & 4 & - & 350 & $u$ & -- & 350 & 4 & -- & 360 & 4 &.-- & 340 & $u$. & - & 360 & $u$. & $-\cdots$ & 380 & 4 & $N P$ \\
\hline N-Nitroso-Di-n-Propylamine & 370 & 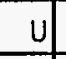 & $\ldots$ & 350 & 4 & $-{ }_{-1}$ & 350 & u & $\ldots$ & 360 & 4 & $-\infty$ & 340 & $u$. & -- & 360 & 0. & $\ldots$ & 380 & $U$ & $N P$ \\
\hline Hexachloroethane & 370 & 4 & -- & 350 & 4 & -- & 350 & 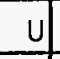 & $\ldots$ & 360 & U & $-\ldots$ & 340 & $u$. & $\ldots$ & 360 & $\mathrm{u}$ & $\ldots$ & 380 & 41 & $N P$ \\
\hline Nitrobenzene & 370 & 4 & -- & 350 & 4 & -- & 350 & 4 & -- & 360 & 4 & -- & 340 & 4. & -- & 360 & 4. & $\cdots$ & 380 & 0 & $\mathrm{NP}$ \\
\hline Isophorone & 370 & $\mathrm{U}$ & -- & 350 & 4 & -- & 350 & U & $\ldots$ & 360 & 4 & $\ldots$ & 340 & $u$. & $\ldots$ & 360 & $u$. & - & 380 & $\mathrm{u}$ & $N P$ \\
\hline 2-Nitrophenol & 370 & u & $\ldots$ & 350 & $u$ & $\ldots$ & 350 & $u$ & $\ldots$ & 360 & $u$ & $\ldots$ & 340 & 4. & $\ldots$ & 360 & $\mathrm{u}$ & $\ldots$ & 380 & $\mathrm{U} N$ & $\mathrm{NP}$ \\
\hline 2,4-Dimethylphenol & 370 & U) & -- & 350 & 4 & $\ldots$ & 350 & 4 & -- & 360 & 4 & $-\cdots$ & 340 & 4. & -- & 360 & 4. & -- & 380 & 41 & $N P$ \\
\hline Benzoic Acid & 1800 & 4 & $\ldots$ & 1700 & 4 & -- & 1700 & 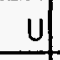 & $\ldots$ & 1700 & 4 & -- & 1700 & 4. & -- & 1800 & 0. & $\cdots$ & 1800 & 4 & NP \\
\hline bis (2-Chloroethoxy)Methane & 370 & 4 & $-\cdots$ & 350 & $u$ & $\ldots$ & 350 & $u$ & $\ldots$ & 360 & $u$ & -- & 340 & U. & $\ldots$ & 360 & $u$. & $\ldots$ & 380 & 41 & NP \\
\hline 2,4-Dichlorophenol & 370 & 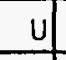 & -- & 350 & 4 & -- & 350 & 4 & - & 360 & u & $\ldots$ & 340 & $u$. & $\ldots$ & 360 & 4. & $\ldots$ & 380 & 4 & $\mathrm{NP}$ \\
\hline 1,2,4-Trichlorobenzene & 370 & 4 & $\cdots$ & 350 & U & -- & 350 & $u$ & $-\infty$ & 360 & 4 & -- & 340 & $u$. & $\ldots$ & 360 & 0. & $\ldots$ & 380 & 4 & $N P$ \\
\hline Naphthalene & 370 & 4 & - & 350 & 4 & -- & 350 & 4 & $-\ldots$ & 360 & 4 & $-\infty$ & 340 & $u$. & $-{ }_{-1}$ & 360 & 4. & $\ldots$ & 380 & $4 \pi$ & $N P$ \\
\hline 4-Chloroaniline & 370 & u & - & 350 & 4 & -- & 350 & $\mathrm{ut}$ & -- & 360 & & $-\ldots$ & 340 & $u$. & -- & 360 & $\mathrm{u}$. &.- & 380 & 4 & $\mathrm{NP}$ \\
\hline Hexachlorobutadiene & 370 & U) & -1 & 350 & $u$ & -1 & 350 & U) & - & 360 & 4 & - & 340 & 4. & $\ldots$ & 360 & 4 & - & 380 & & $N P$ \\
\hline
\end{tabular}




\begin{tabular}{|c|c|c|c|c|c|c|c|c|c|c|c|c|c|c|c|c|c|c|c|c|c|}
\hline \multirow[b]{2}{*}{ Compound (ug/Kg) } & \multicolumn{21}{|c|}{ Table A-5.4 Semi-Volatiles } \\
\hline & $\begin{array}{l}\infty \\
\frac{1}{1} \\
\frac{1}{1} \\
\frac{1}{4} \\
0\end{array}$ & 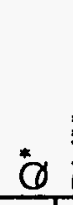 & & $\begin{array}{l}\infty \\
心 \\
\infty \\
\frac{1}{1} \\
\frac{1}{4} \\
\infty\end{array}$ & & & $\begin{array}{l}\infty \\
0 \\
0 \\
\frac{1}{1} \\
\frac{1}{4} \\
0\end{array}$ & & 责 & 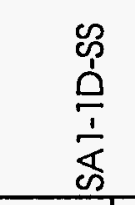 & & & 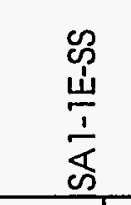 & & 草 & 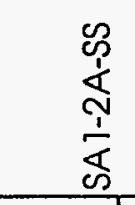 & & $\stackrel{3}{0}^{*}$ & 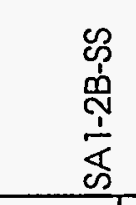 & & $\stackrel{3}{0}^{*}$ \\
\hline 4-Chloro-3-Methylphenol & 370 & $\mathrm{U}$ & -- & 350 & $u$ & 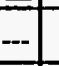 & 350 & $\mathrm{U}$ & - & 360 & $\mathrm{Ut}$ & $\ldots$ & 340 & $\mathrm{u}$. & $\ldots$ & 360 & $\mathrm{u}$ & $\ldots$ & 380 & & $\mathrm{NP}$ \\
\hline 2-Methylnaphthalene & 370 & 4. & - & 350 & & - & 350 & $\mathrm{u}$ & $\ldots$ & 360 & $\mathrm{U}-$ & -- & 340 & & - & 360 & 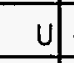 & -- & 380 & $\mathrm{u}$ & NP \\
\hline Hexachlorocyclopentadiene & 370 & $u$. & -1 & 350 & U. - & - & 350 & $\mathrm{U}$ & $-\infty$ & 360 & u. & --- & 340 & $\mathrm{u}$. & $\ldots$ & 360 & $\mathrm{U}$ & -- & 380 & $u$ & $N P$ \\
\hline 2,4,6-Trichlorophenol & 370 & $\mathrm{U}$ & -1 & 350 & U. & - & 350 & $\mathrm{u}$ & -+ & 360 & U. & $\ldots$ & 340 & $\mathrm{u}$. & -- & 360 & $\mathrm{U}$ & -- & 380 & $\mathrm{u}$ & $N P$ \\
\hline 2,4,5-Trichlorophenol & 1800 & $\mathrm{u}$ & -1 & 1700 & & - & 1700 & $u$ & $-\infty$ & 1700 & $\mathrm{U}-$ & - & 1700 & $\mathrm{U}$. & -- & 1800 & $\mathrm{U}$ & -- & 1800 & $u$ & $N P$ \\
\hline 2-Chloronaphthalene & 370 & $u$ & -1 & 350 & u. & - & 350 & $u$ & $-\infty$ & 360 & U. & --- & 340 & 4. & $-\ldots$ & 360 & U & $-\infty$ & 380 & $\mathrm{u}$ & $N P$ \\
\hline 2-Nitroaniline & 1800 & $\mathrm{u}$ & -- & 1700 & $u=$ & - & 1700 & $\mathrm{u}$ & -1 & 1700 & $\mathrm{u}-$ & $\ldots$ & 1700 & $\mathrm{u}$. & -- & 1800 & $\mathrm{u}$ & $\ldots$ & 1800 & $u$ & NP \\
\hline Dimethyl Phthalate & 370 & $u$. & - & 350 & v. & - & 350 & $\mathrm{u}$ & - & 360 & U. - & - & 340 & $\mathrm{u}$. & - & 360 & $\mathrm{U}$ & $\ldots$ & 380 & 4 & $N P$ \\
\hline Acenaphthylene & 370 & 4 & - & 350 & & - & 350 & $u$ & - & 360 & $\mathrm{u}$. & $\ldots$ & 340 & 4. & - & 360 & $u$ & -- & 380 & 4 & NP \\
\hline 2.6-Dinitrotoluene & 370 & $\mathrm{U}$ & - & 350 & $4=$ & - & 350 & $u$ & - & 360 & $\mathrm{u}-$ & -- & 340 & $\mathrm{U}$. & $\ldots$ & 360 & $u$ & $\ldots$ & 380 & 4 & NP \\
\hline 3-Nitroaniline & 1800 & $\mathrm{U}$ & - & 1700 & & - & 1700 & $\mathrm{u}$ & -- & 1700 & $u=$ & - & 1700 & u. & -- & 1800 & $u$ & -- & 1800 & 4 & NP \\
\hline Acenaphthene & 370 & $\mathrm{U}$ & - & 350 & $4=$ & $\ldots$ & 350 & 4 & - & 360 & $\mathrm{u}-$ & -- & 340 & $U$. & $\ldots$ & 360 & 4 & $\ldots$ & 380 & u & NP \\
\hline 2,4-Dinitrophenol & 1800 & $\mathrm{U}$ & - & 1700 & U. & - & 1700 & 4 & $-\ldots$ & 1700 & u. & -- & 1700 & U. & $\ldots$ & 1800 & $u$ & $\ldots$ & 1800 & 4 & $N P$ \\
\hline 4-Nitrophenol & 1800 & $\mathrm{U}$ & -- & 1700 & u. & - & 1700 & 4 & -- & 1700 & 4. & $\ldots$ & 1700 & $u$. & -- & 1800 & $\mathrm{U}$ & -- & 1800 & 4 & NP \\
\hline Dibenzofuran & 370 & u. & - & 350 & 4. & - & 350 & $u$ & $\ldots$ & 360 & u. & -- & 340 & $\mathrm{U}$. & $\ldots$ & 360 & u & $\ldots$ & 380 & 4 & $N P$ \\
\hline 2,4-Dinitrotoluene & 370 & $u$ & $\ldots$ & 350 & U. &.- & 350 & U) & -- & 360 & $\mathrm{U}-$ & --- & 340 & $u$. &.- & 360 & $u$ & $\ldots$ & 380 & 4 & NP \\
\hline Diethylphthalate & 370 & $u$ & $-\infty$ & 350 & 4. & $-\ldots$ & 350 & 4 & $\ldots$ & 360 & U. & - & 340 & 4. & $\ldots$ & 360 & 4 & $\ldots$ & 380 & $u$ & NP \\
\hline 4-Chlorophenyl-phenylether & 370 & U & -- & 350 & U. & $\cdots$ & 350 & $\mathrm{U}$ & $\ldots$ & 360 & U. & -- & 340 & U. & -- & 360 & 4 & $\ldots$ & 380 & $u$ & NP \\
\hline Fluorene & 370 & $\mathrm{u}$ & $-\infty$ & 350 & U. & - & 350 & u) & -- & 360 & $\mathrm{u}$. & $\ldots$ & 340 & $\mathrm{u}$. & $\ldots$ & 360 & $\mathrm{u}$ & - & 380 & $u$ & $\mathrm{NP}$ \\
\hline 4-Nitroaniline & 1800 & $u$ & - & 1700 & $u-$ & - & 1700 & & - & 1700 & 4. & - & 1700 & 4. & - & 1800 & 4 & -- & 1800 & 4 & $N P$ \\
\hline 4,6-Dinitro-2-Methylphenol & 1800 & $u$ & - & 1700 & U. & - & 1700 & & $\ldots$ & 1700 & 4. & -- & 1700 & 4. & - & 1800 & $u$ & -- & 1800 & $\mathrm{u}$ & NP \\
\hline N-Nitrosodiphenylamine (1) & 370 & $u$ & -1 & 350 & $u-$ & - & 350 & & - & 360 & $u$. & - & 340 & $\mathrm{u}$. & - & 360 & $u$ & - & 380 & 4 & $N P$ \\
\hline 4-Bromophenyl-phenylether & 370 & $\mathrm{u}$ & -- & 350 & $\mathrm{U}$. & - & 350 & & - & 360 & $u$ & -- & 340 & & - & 360 & & - & 380 & & $N P$ \\
\hline
\end{tabular}




\begin{tabular}{|c|c|c|c|c|c|c|c|c|c|c|c|c|c|c|c|c|c|c|c|c|c|}
\hline \multirow[b]{2}{*}{ Compound (ug/ $/ \mathrm{Kg}$ ) } & \multicolumn{18}{|c|}{ Table A-5.4 Semi-Volatiles } & \multirow[b]{2}{*}{ 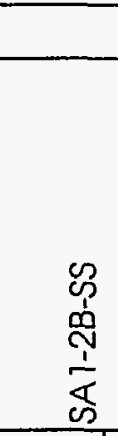 } & \multirow{2}{*}{\multicolumn{2}{|c|}{$\stackrel{*}{Q} \stackrel{*}{\underline{*}}$}} \\
\hline & 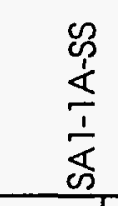 & & & 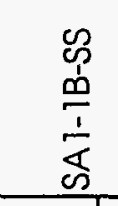 & & & $\begin{array}{l}\tilde{n} \\
\tilde{U} \\
\frac{1}{4} \\
\frac{1}{6}\end{array}$ & & $\stackrel{*}{2}$ & 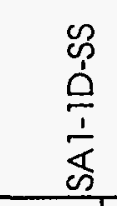 & & $\stackrel{0}{0}^{*}$ & 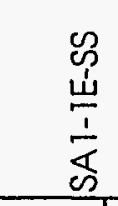 & & $\stackrel{3}{0}^{*}$ & 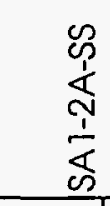 & & $\stackrel{*}{0}^{*}$ & & & \\
\hline Hexachlorobenzene & 370 & $\mathrm{u}$ & $-\infty$ & 350 & U & - & 350 & $u$ & -- & 360 & 4 & -- & 340 & $u$ & - & 360 & U & $-\cdots$ & 380 & & NP \\
\hline Pentachlorophenol & 1800 & 4 & $-\infty$ & 1700 & 4 & -- & 1700 & $\mathrm{U}$ & -- & 1700 & 4 & -- & 1700 & 4 & -- & 1800 & $\mathrm{U}$ & $\ldots$ & 1800 & & $N P$ \\
\hline Phenanthrene & 370 & $\mathrm{u}$ & - & 350 & $\mathrm{u}$ & - & 350 & $\mathrm{u}$ & - & 360 & $u$ & - & 340 & $\mathrm{U}$ &.-- & 360 & 4 & $\ldots$ & 380 & $u$ & NP \\
\hline Anthracene & 370 & $u$ & -- & 350 & $\mathrm{u}$ & - & 350 & $\mathrm{U}$ & - & 360 & $u$ & - & 340 & $\mathrm{u}$ & $\ldots$ & 360 & $u$ & $\ldots$ & 380 & $\mathrm{U}$ & NP \\
\hline Di-n-Butylphthalate & 370 & $\mathrm{u}$ & -- & 350 & $\mathrm{U}$ & $\ldots$ & 350 & $\mathrm{U}$ & $\ldots$ & 360 & 4 & - & 340 & $u$ & - & 360 & $U$ & $\ldots$ & 380 & $\mathrm{U}$ & $N P$ \\
\hline Fluoranthrene & 370 & $\mathrm{u}$ & - & 350 & $\mathrm{u}$ & -- & 350 & 4 & $\ldots$ & 360 & 4 & - & 340 & $u$ &.-- & 360 & 4 & $-\cdots$ & 380 & $u$ & $N P$ \\
\hline Pyrene & 370 & $u$ & -- & 350 & $\mathrm{u}$ & - & 350 & $u$ & -- & 360 & $\mathrm{U}$ & -- & 340 & $\mathrm{U}$ & -- & 360 & $\mathrm{U}$ & $\ldots$ & 380 & $U$ & NP \\
\hline Butylbenzylphthalate & 370 & $\mathrm{U}$ & $-\infty$ & 350 & $\mathrm{u}$ & - & 350 & $\mathrm{U}$ & -- & 360 & 4 &.- & 340 & $\mathrm{U}$ &.- & 360 & 4 & $\ldots$ & 380 & $u$ & $N P$ \\
\hline 3,3'-Dichlorbenzidine & 750 & $\mathrm{U}$ & -- & 710 & 4 & - & 690 & $u$ & - & 720 & 4 & -- & 690 & 4 & - & 720 & u & -- & 760 & $\mathrm{U}$ & $N P$ \\
\hline Benzo(a)Anthracene & 370 & $\mathrm{u}$ & $\ldots$ & 350 & $u$ & - & 350 & $\mathrm{U}$ & -- & 360 & $\mathrm{U}$ & - & 340 & $\mathrm{u}$ & $\ldots$ & 360 & $u$ & $\ldots$ & 380 & $u$ & $N P$ \\
\hline Chrysene & 370 & $\mathrm{U}$ & $\ldots$ & 350 & $u$ & - & 350 & $\mathrm{U}$ & -- & 360 & $\mathrm{U}$ & $\ldots$ & 340 & $u$ & $\ldots$ & 360 & 4 & $\ldots$ & 380 & 4 & $N P$ \\
\hline Bis (2-Ethylhexyl)Phthalate & 1700 & & -- & 730 & & - & 300 & 4 & $\ldots$ & 1300 & & - & 1200 & & -- & 180 & J) & $\ldots$ & 470 & & $N P$ \\
\hline Di-n-Octyl Phthalate & 370 & $\mathrm{u}$ & - & 350 & $u$ & - & 350 & $\mathrm{U}$ & $\mathrm{UJ}$ & 360 & $\mathrm{U}$ & $\ldots$ & 340 & $\mathrm{U}$ & - & 360 & $u$ & $\ldots$ & 380 & $u$ & $\mathrm{NP}$ \\
\hline Benzo(b)Fluoranthene & 370 & $\mathrm{U}$ & - & 350 & $\mathrm{U}$ & - & 350 & $\mathrm{U}$ & UJ & 360 & $\mathrm{U}$ & -- & 340 & $\mathrm{U}$ & $-\ldots$ & 360 & $u$ & $-\ldots$ & 380 & $u$ & $N P$ \\
\hline Benzo(k)Fluoranthene & 370 & $\mathrm{U}$ & - & 350 & 4 & - & 350 & $\mathrm{u}$ & UJ & 360 & 4 & - & 340 & $\mathrm{U}$ & - & 360 & $\mathrm{u}$ & $\ldots$ & 380 & $\mathrm{U}$ & $N P$ \\
\hline Benzo(a)Pyrene & 370 & $u$ & $\ldots$ & 350 & $u$ & $-\ldots$ & 350 & $\mathrm{u}$ & UJ & 360 & $\mathrm{U}$ & $\ldots$ & 340 & $\mathrm{u}$ & $\ldots$ & 360 & $u$ & $\ldots$ & 380 & $\mathrm{U}$ & NP \\
\hline Indeno(1,2,3-cd)Pyrene & 370 & $\mathrm{U}$ & -- & 350 & 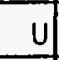 & -- & 350 & $\mathrm{u}$ & $\mathrm{UJ}$ & 360 & $u$ & - & 340 & $\mathrm{U}$ & -- & 360 & $u$ & $\ldots$ & 380 & $u$ & $N$ \\
\hline Dibenz(a,h)Anthracene & 370 & $\mathrm{U}$ & - & 350 & 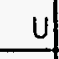 & -- & 350 & $\mathrm{U}$ & UJ & 360 & $u$ & - & 340 & $\mathrm{U}$ & -- & 360 & $u$ & $\ldots$ & 380 & $\mathrm{U}$ & $N P$ \\
\hline Benzo(g,h,i)Perylene & 370 & $u$ & UJ & 350 & $u$ & - & 350 & $u$ & $\mathrm{Uu}$ & 360 & $u$ & $\ldots$ & 340 & $U$ & $\ldots$ & 360 & 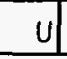 & $\ldots$ & 380 & & $N P$ \\
\hline
\end{tabular}




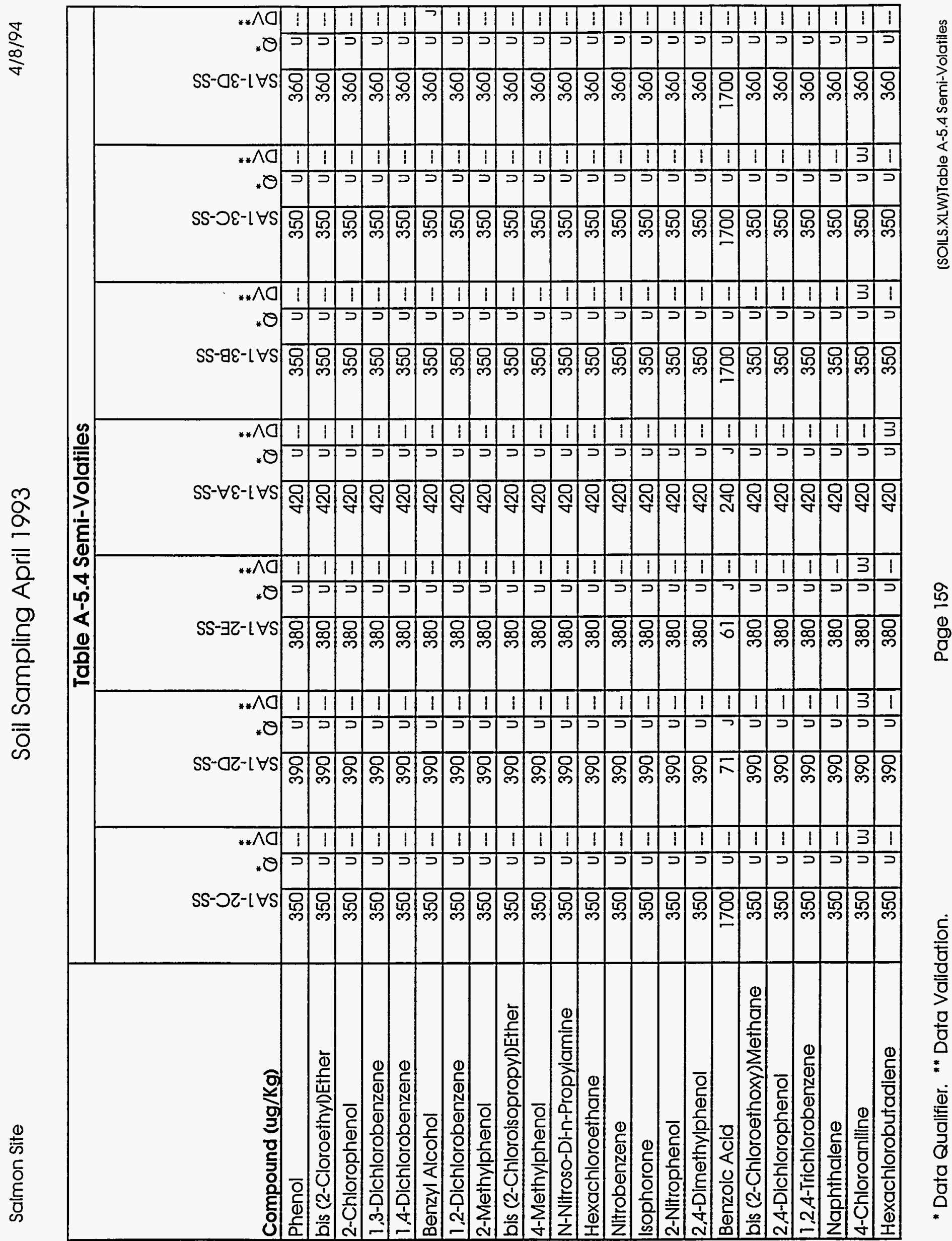




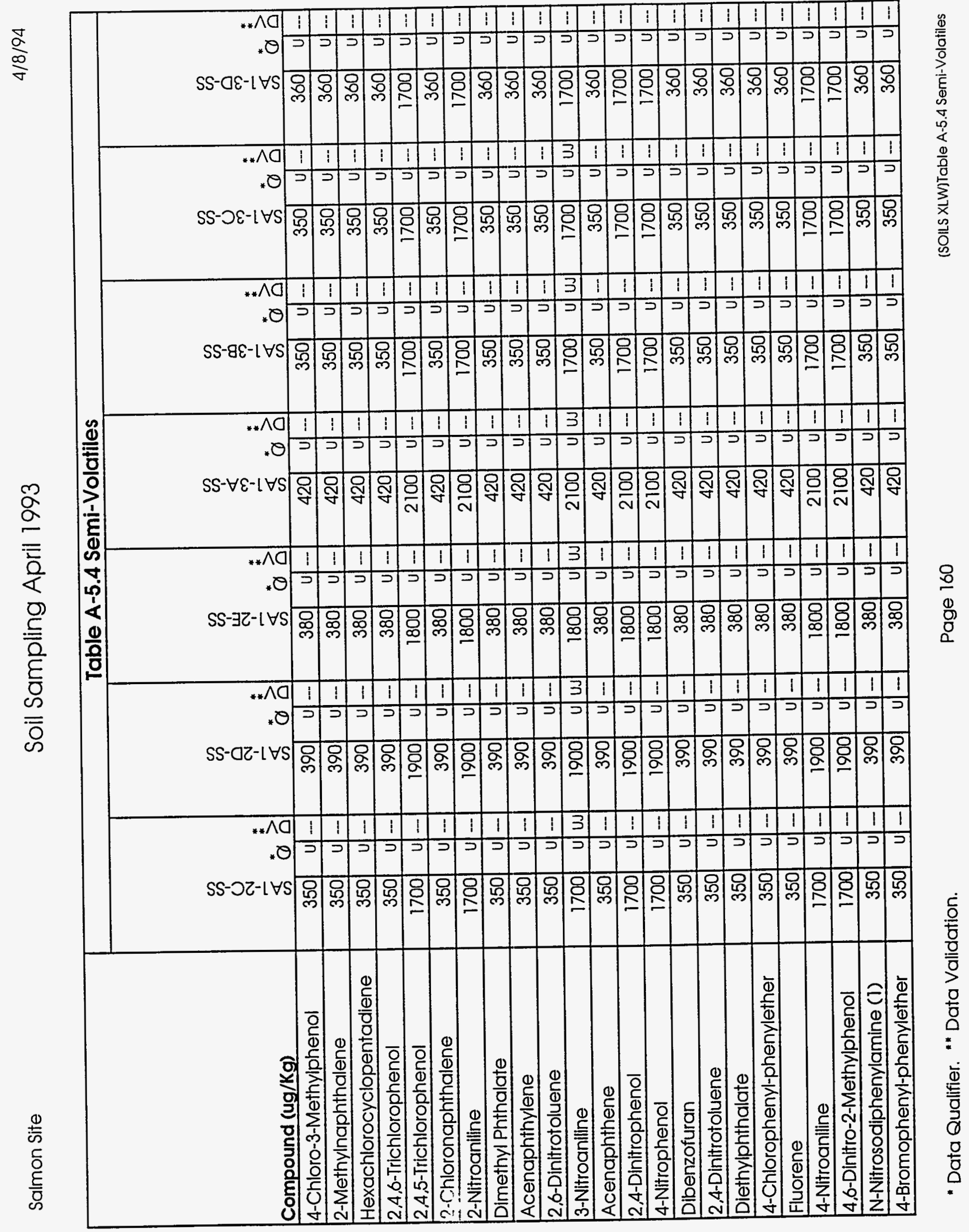




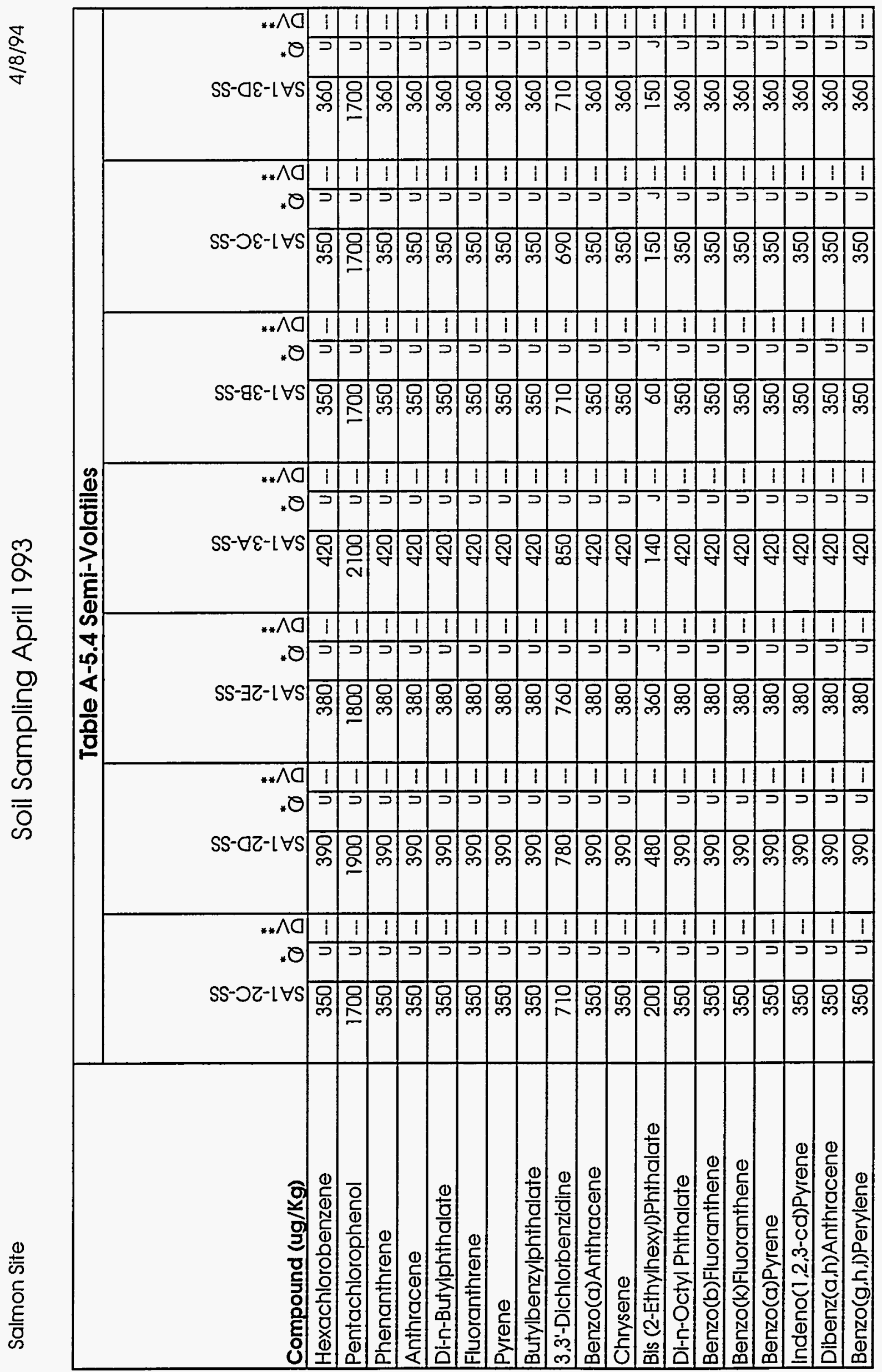




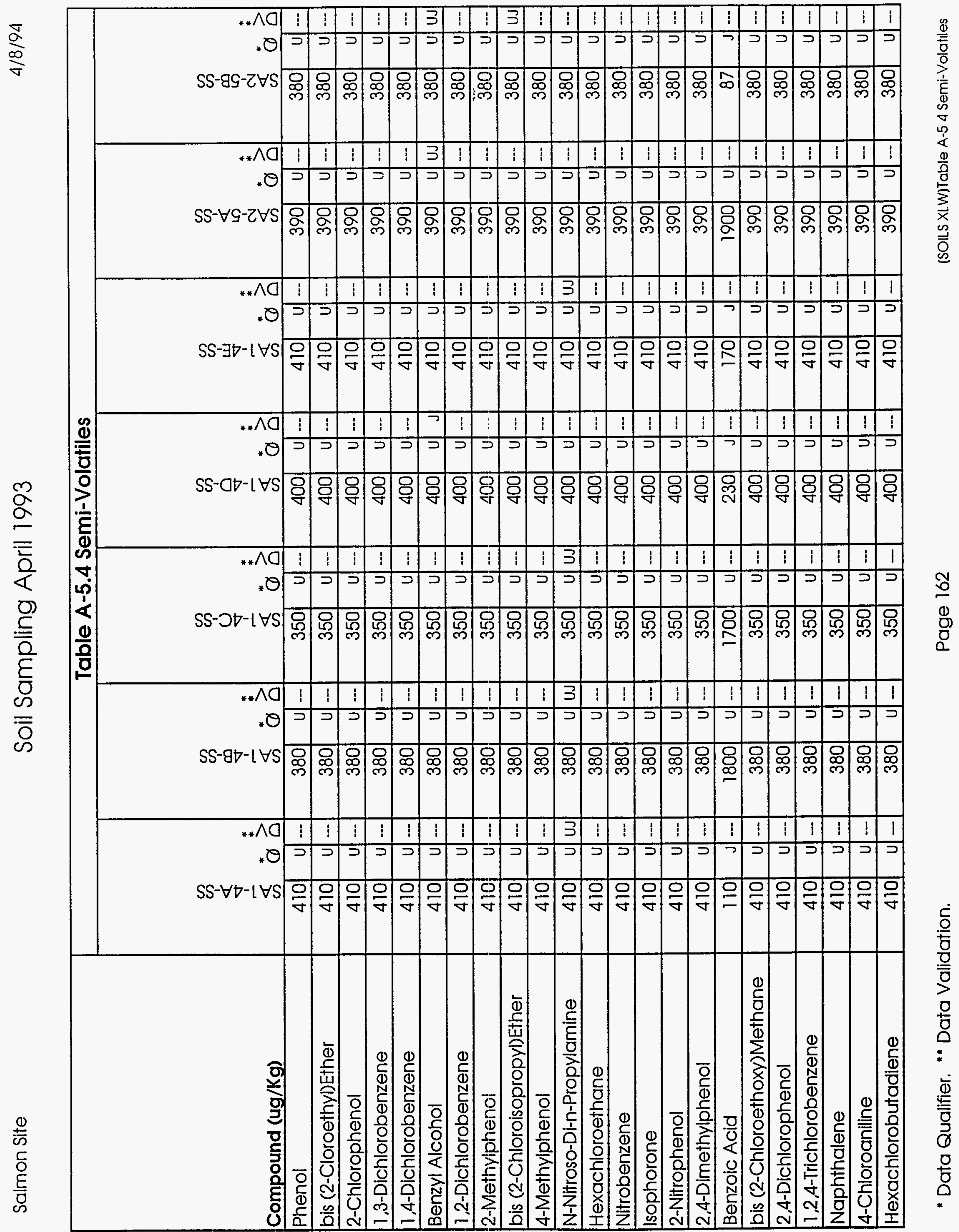




\begin{tabular}{|c|c|c|c|c|c|c|c|c|c|c|c|c|c|c|c|c|c|c|c|c|c|}
\hline \multirow[b]{2}{*}{ Compound $(u g / K g)$} & \multicolumn{21}{|c|}{ Table A-5.4 Semi-Volatiles } \\
\hline & 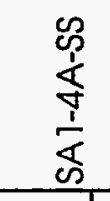 & & & 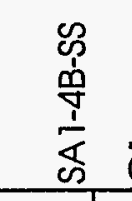 & & 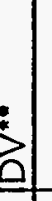 & 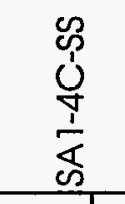 & $\stackrel{*}{\emptyset}$ & 草 & 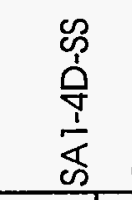 & & 艾 & 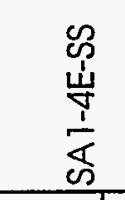 & & 綮 & 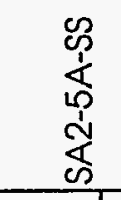 & & 草 & 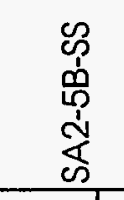 & & $\stackrel{*}{*}$ \\
\hline 4-Chloro-3-Methylphenol & 410 & $u$ & $\ldots$ & 380 & U. & - & 350 & & - & 400 & U. & $\ldots$ & 410 & U. & $\ldots$ & 390 & U. & $\ldots$ & 380 & & -- \\
\hline 2-Methyinaphthalene & 410 & 4 & $\ldots$ & 380 & 4. & - & 350 & U & - & 400 & $\mathrm{U}$. & $\ldots$ & 410 & U. & - & 390 & $\mathrm{U}$. & $\cdots$ & 380 & 0. & $\ldots$ \\
\hline Hexachlorocyclopentadiene & 410 & $\mathrm{U}$ & $R$ & 380 & 4 & $R$ & 350 & 4 & $R$ & 400 & 4 . & - & 410 & $\mathrm{u}$ & $R$ & 390 & U. & $\ldots$ & 380 & $\mathrm{u}-$ & $\ldots$ \\
\hline 2,4,6-Trichlorophenol & 410 & $u$ & - & 380 & $\mathrm{u}$. & -1 & 350 & $u$ & - & 400 & U. - & - & 410 & $\mathrm{U}-$ & - & 390 & U. & $\ldots$ & 380 & 4. & - \\
\hline 2,4,5-Trichlorophenol & 2000 & 4 & - & 1800 & $\mathrm{u}$. & 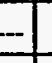 & 1700 & & 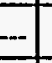 & 1900 & $\mathrm{u}$. & $\ldots$ & 2000 & 4. & - & 1900 & 4. & - & 1900 & $4=$ & - \\
\hline 2-Chloronaphthalene & 410 & $u$ & - & 380 & u. & - & 350 & $\mathrm{U}$ & -1 & 400 & $\mathrm{u}$. & $-\ldots$ & 410 & $\mathrm{U}$. & $\ldots$ & 390 & U. & $\ldots$ & 380 & 4. & $-\ldots$ \\
\hline 2-Nitroaniline & 2000 & 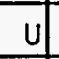 & - & 1800 & $u$. & $\ldots$ & 1700 & $\mathrm{U}$ & - & 1900 & U. & - & 2000 & U. & $\ldots$ & 1900 & U. - & $\ldots$ & 1900 & 4. &.- \\
\hline Dimethyl Phthalate & 410 & 4 & - & 380 & $\mathrm{u}$. & - & 350 & u & - & 400 & $\mathrm{u}$. & - & 410 & U. & $-\ldots$ & 390 & 4. & $\ldots$ & 380 & 0. & - \\
\hline Acenaphthylene & 410 & 4 & $\ldots$ & 380 & $\mathrm{U}$ & - & 350 & U. & $\cdots$ & 400 & U. & - & 410 & U. & -- & 390 & $\mathrm{u}=$ & $\cdots$ & 380 & $\mathrm{U}$ & $-\cdots$ \\
\hline 2,6-Dinitrotoluene & 410 & $\mathrm{U}$ & - & 380 & 4. & - & 350 & $\mathrm{U}$ & - & 400 & 4. & -- & 410 & 4. & $\ldots$ & 390 & u. - & - & 380 & 4 - & -- \\
\hline 3-Nitroaniline & 2000 & $\mathrm{U}$ & $\ldots$ & 1800 & $\mathrm{u}$. & - & 1700 & $\mathrm{u}-$ & $\ldots$ & 1900 & u. & - & 2000 & $u$. & $\ldots$ & 1900 & u. & $-\ldots$ & 1900 & $\mathrm{U}$ & 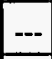 \\
\hline Acenaphthene & 410 & $u$ & $\ldots$ & 380 & $\mathrm{U}$ & - & 350 & u. & $\ldots$ & 400 & U. & - & 410 & $\mathrm{U}$ & $\ldots$ & 390 & $\mathrm{u}=$ & $\ldots$ & 380 & U. &.-- \\
\hline 2.4-Dinitrophenol & 2000 & 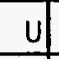 & - & 1800 & $\mathrm{U}$. & - & 1700 & U. & -- & 1900 & 4. & - & 2000 & U. & $\ldots$ & 1900 & 01 & UJ & 1900 & 4. & $\cdots$ \\
\hline 4-Nitrophenol & 2000 & $u$ & -- & 1800 & $\mathrm{u}$. & $\ldots$ & 1700 & 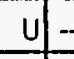 & -- & 1900 & 4 & -- & 2000 & 4. & -- & 1900 & $U-$ & -- & 1900 & 4. & -- \\
\hline Dibenzofuran & 410 & $u$ & $-\ldots$ & 380 & $u$ & - & 350 & $\mathrm{u}-$ & $\ldots$ & 400 & 4 & -- & 410 & u. & $\ldots$ & 390 & 4. & $\ldots$ & 380 & 4. & $\ldots$ \\
\hline 2,4-Dinitrotoluene & 410 & 4 & $\ldots$ & 380 & 4 & -1 & 350 & U. & -- & 400 & 4 & $\ldots$ & 410 & 4. & $\ldots$ & 390 & 4. & -- & 380 & U. & -- \\
\hline Diethylphthalate & 410 & 4 & - & 380 & $\mathrm{U}$ & - & 350 & U. & -- & 400 & $u$ & -- & 410 & u. & $\ldots$ & 390 & $\mathrm{u}$ & --- & 380 & U. & $\ldots$ \\
\hline 4-Chlorophenyl-phenylether & 410 & 4 & -- & 380 & $u$ & - & 350 & $\mathrm{U}$. &.- & 400 & 4 & -- & 410 & 4. & 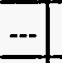 & 390 & 4. & --- & 380 & $u$. & $\ldots$ \\
\hline Fluorene & 410 & $u$ & - & 380 & 4 & -- & 350 & U. & -- & 400 & 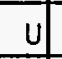 & -- & 410 & $u$. & -- & 390 & U. & --- & 380 & 4. & -- \\
\hline 4-Nitroaniline & 2000 & & - & 1800 & U & $\ldots$ & 1700 & $4=$ & $\ldots$ & 1900 & 0 & -- & 2000 & 4. & - & 1900 & $\mathrm{u}$. & -- & 1900 & 4 & -- \\
\hline 4.6-Dinitro-2-Methylphenol & 2000 & $\mathrm{U}$ & - & 1800 & $\mathrm{U}$ & $\ldots$ & 1700 & 4. & $\ldots$ & 1900 & 4 & - & 2000 & u. & - & 1900 & 4. & -- & 1900 & 4 & -- \\
\hline N-Nitrosodiphenylamine (1) & 410 & $\mathrm{U}$ & - & 380 & 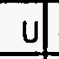 & - & 350 & $\mathrm{u}=$ & - & 400 & 4 & - & 410 & u. & -- & 390 & U. & $\ldots$ & 380 & $u$ & - \\
\hline 4-Bromophenyl-phenylether & 410 & & - & 380 & 4 & - & 350 & U) - & - & 400 & & -- & 410 & u. & -1 & 390 & 0. & -- & 380 & & - \\
\hline
\end{tabular}




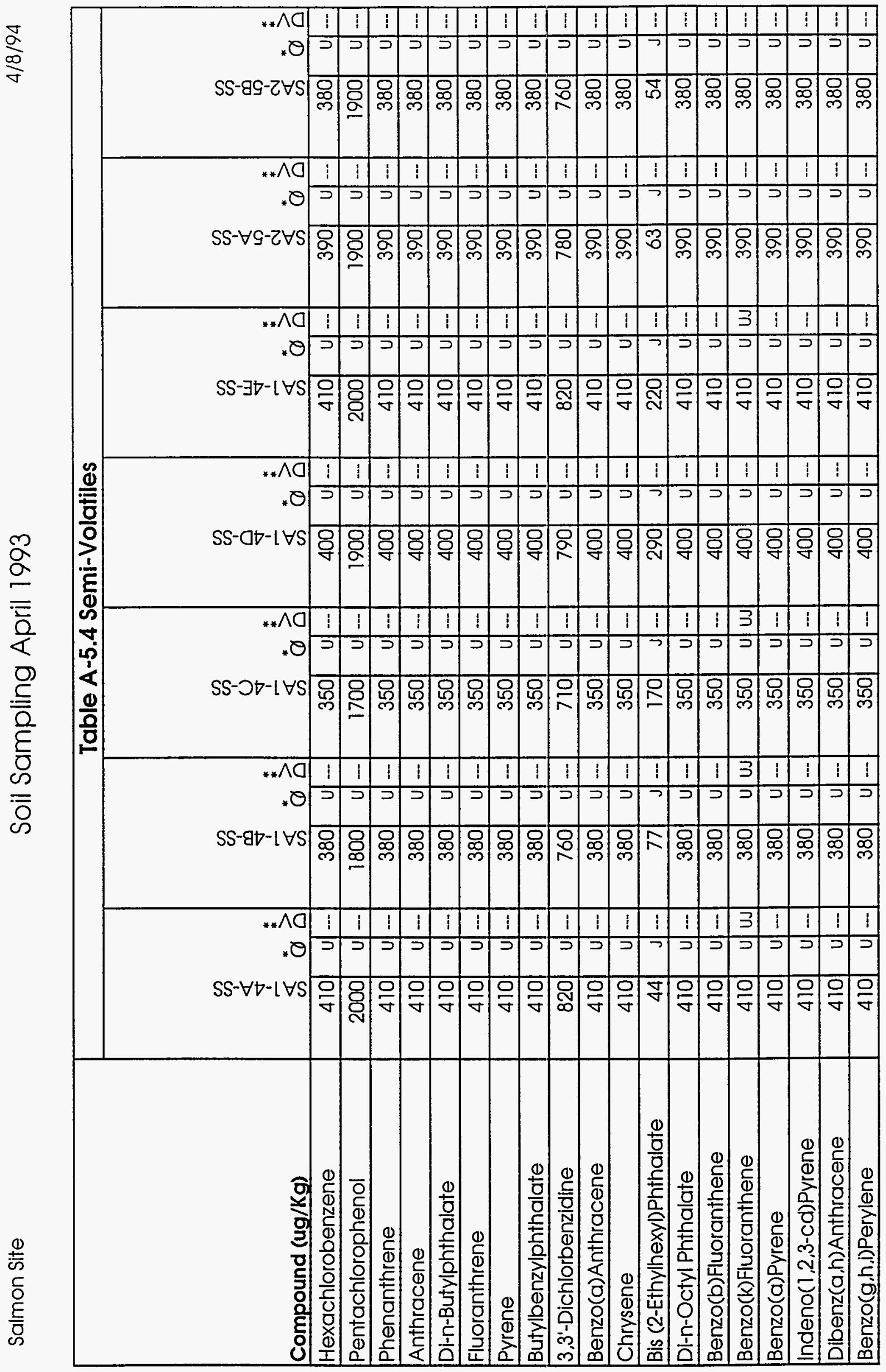

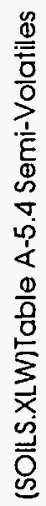

$\square$
$\frac{0}{0}$
0
0
0

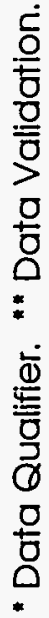




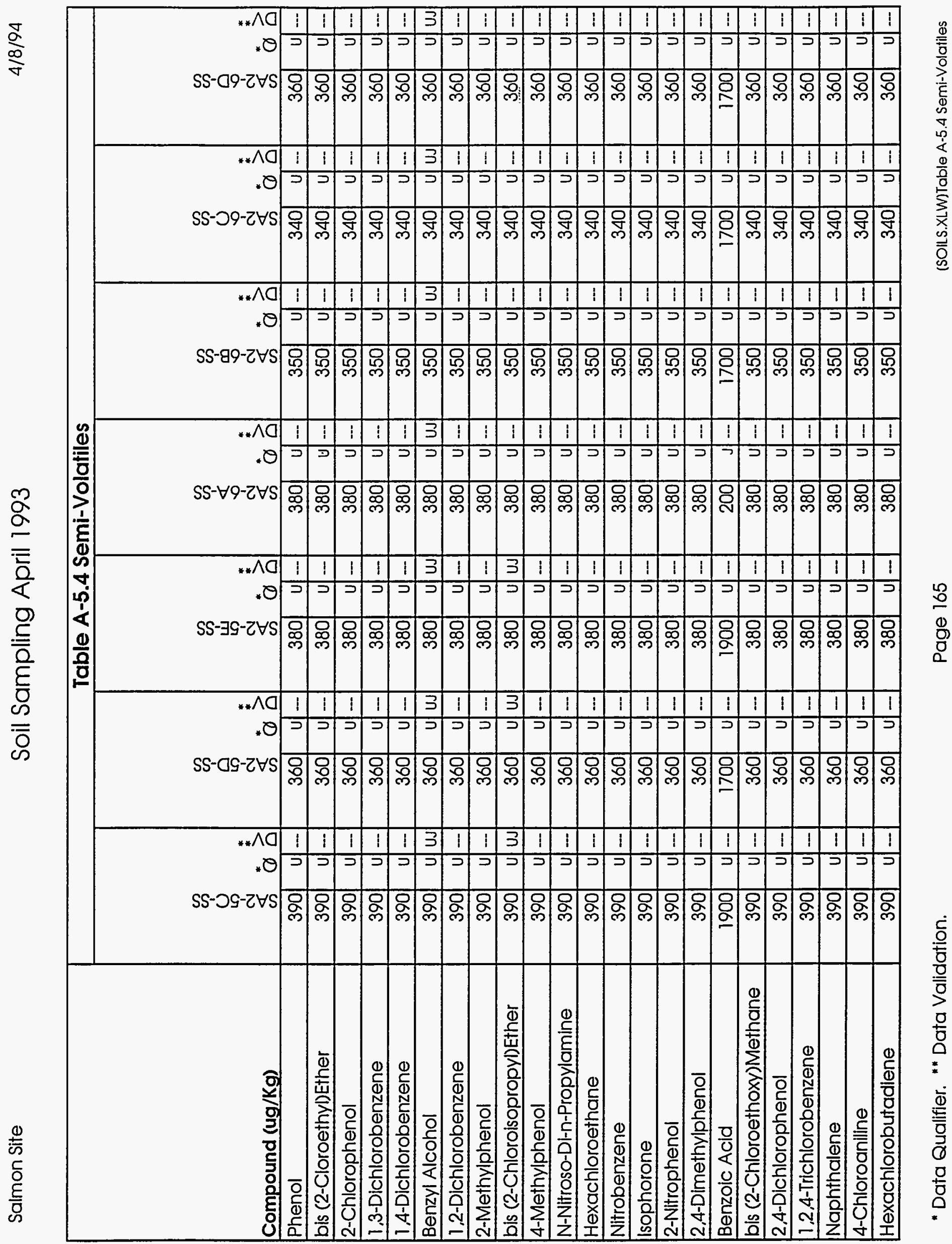




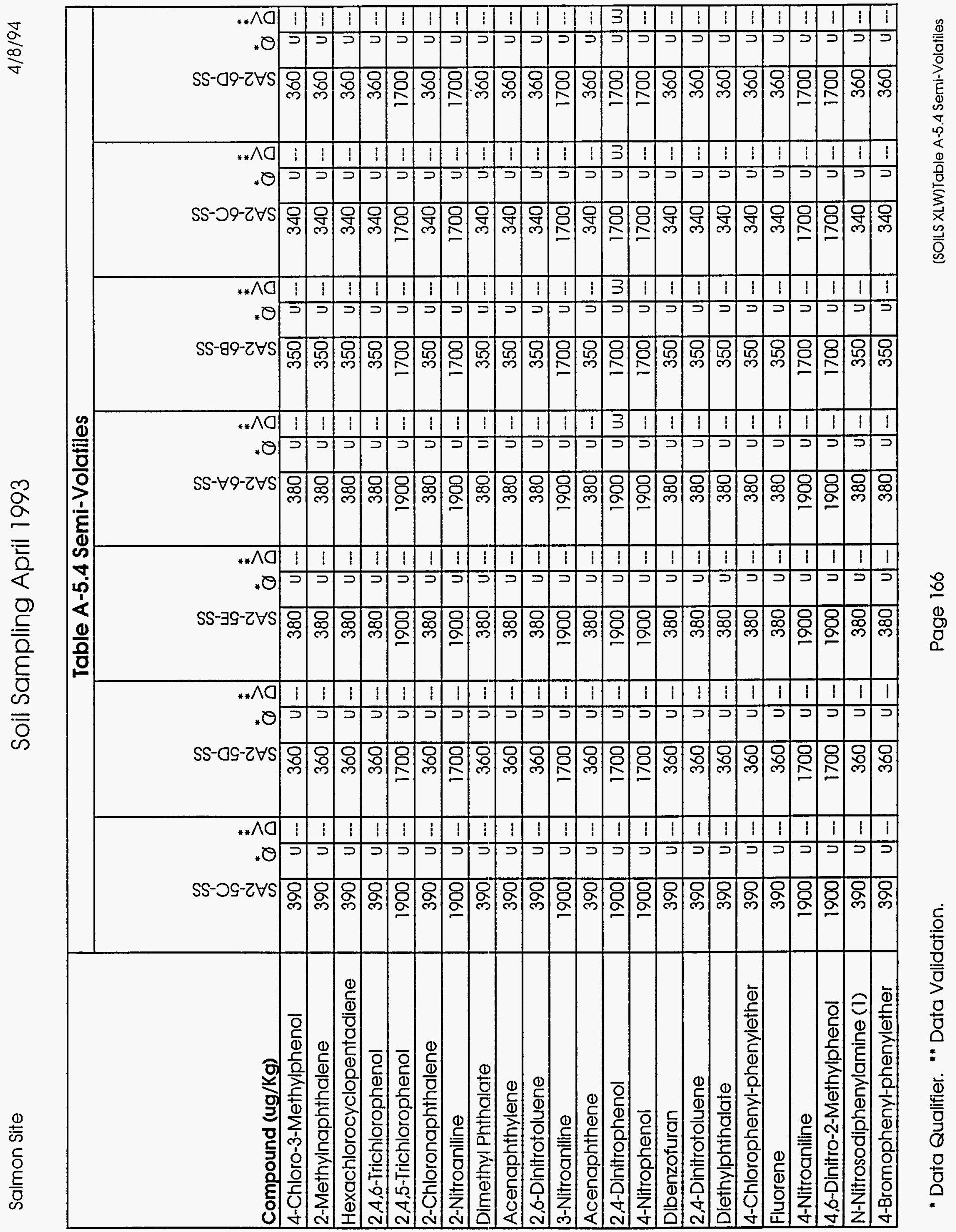




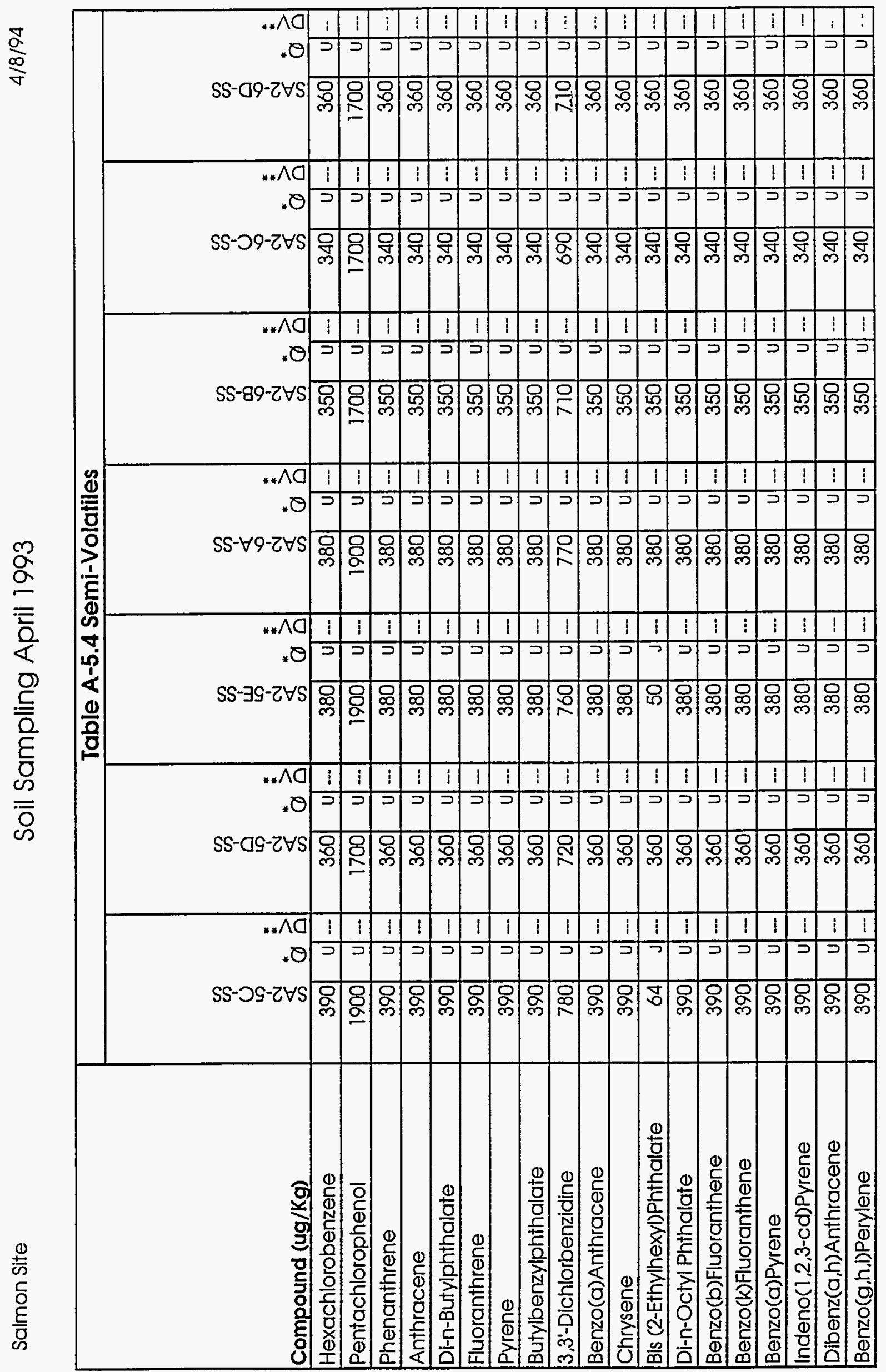




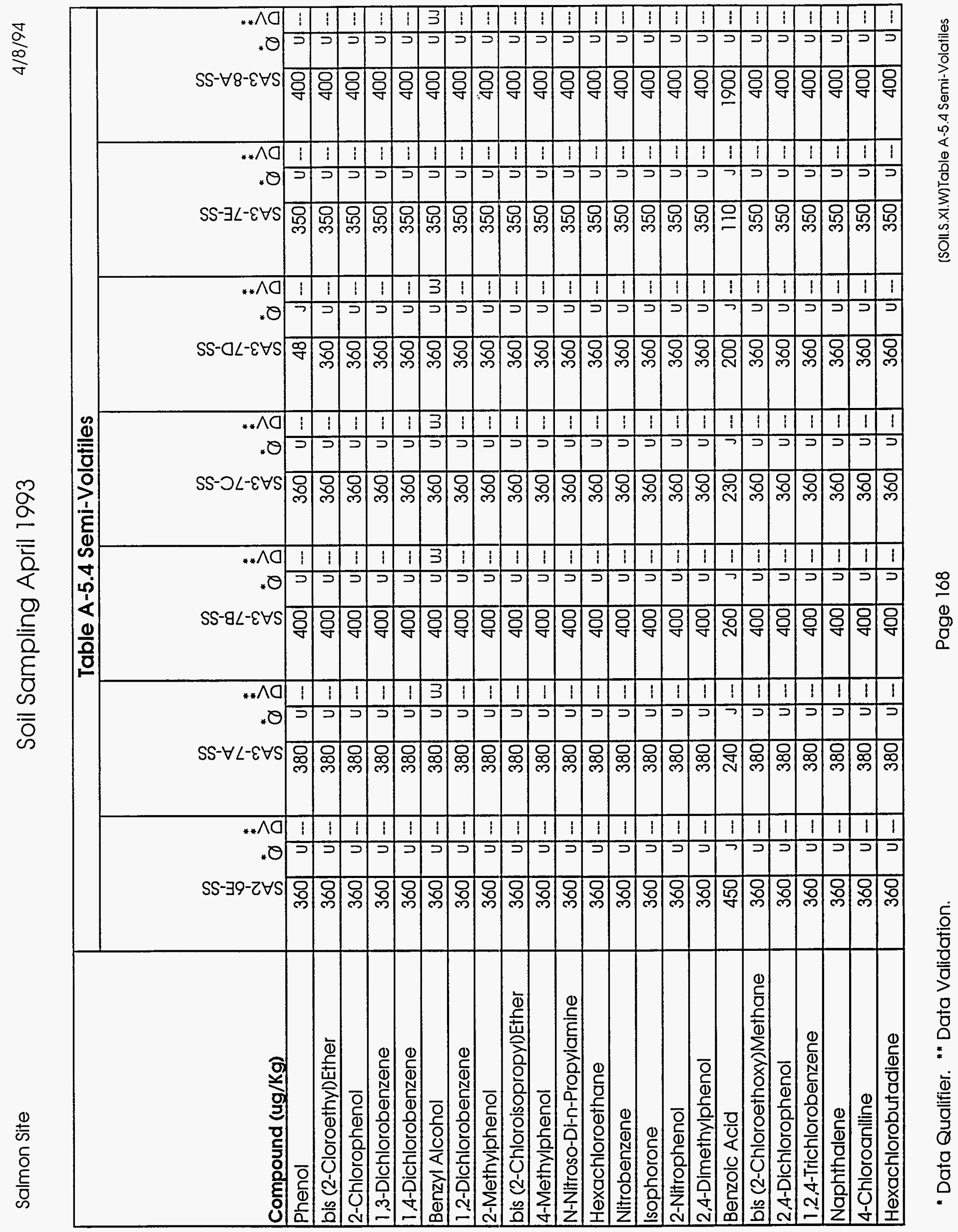




\begin{tabular}{|c|c|c|c|c|c|c|c|c|c|c|c|c|c|c|c|c|c|c|c|c|c|}
\hline \multirow[b]{2}{*}{ Compound (ug/Kg) } & \multicolumn{21}{|c|}{ Table A-5.4 Semi-Volatiles } \\
\hline & 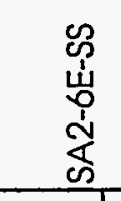 & & & 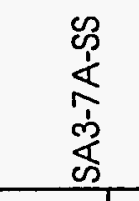 & $\stackrel{*}{0}$ & & 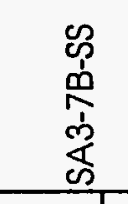 & & & 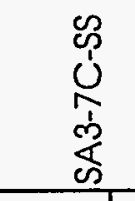 & & & 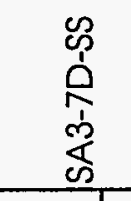 & & 兌 & 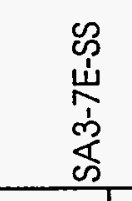 & 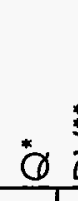 & $\stackrel{*}{3}$ & 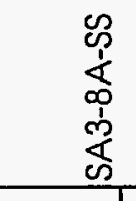 & $\stackrel{*}{0}$ & $\sum_{0}^{*}$ \\
\hline 4-Chloro-3-Methylphenol & 360 & $u$. & - & 380 & 4. & -- & 400 & $\mathrm{U}-$ & -- & 360 & U. & -- & 360 & & $\ldots$ & 350 & $\mathrm{u}-$ & -- & 400 & $\mathrm{u}$. & - \\
\hline 2-Methylnaphthalene & 360 & $u$. & - & 380 & $u-$ & - & 400 & U. & -- & 360 & U. - & -- & 360 & 4. & $\ldots$ & 350 & u. & -- & 400 & 4. & $\ldots$ \\
\hline Hexachlorocyclopentadiene & 360 & U. & - & 380 & 4. & - & 400 & $u-$ & - & 360 & 4. &.-- & 360 & U. - & $-\ldots$ & 350 & U. & -- & 400 & $U$. & $\ldots$ \\
\hline 2.4.6-Trichlorophenol & 360 & 4. & --- & 380 & $4-$ & - & 400 & 4. & - & 360 & 4. &.- & 360 & $4=$ & $-\infty$ & 350 & 4. & -- & 400 & 4. & - \\
\hline 2,4,5-Trichlorophenol & 1800 & $\mathrm{u}$. & - & 1900 & & $\ldots$ & 1900 & $\mathrm{U}$ & - & 1700 & 4. & $\ldots$ & 1800 & U. - & -- & 1700 & $\mathrm{U}$ & -- & 1900 & 4. & - \\
\hline 2-Chloronaphthalene & 360 & $u$ & - & 380 & $\mathrm{u}-$ & - & 400 & $u-$ & - & 360 & 4. & $-\cdots$ & 360 & 4. & $\ldots$ & 350 & 4 & -- & 400 & 4. & $\ldots$ \\
\hline 2-Nitroaniline & 1800 & $\mathrm{u}$ & - & 1900 & 4. & -- & 1900 & $\mathrm{U}$ & -- & 1700 & 4. & $\cdots$ & 1800 & 4. & $-{ }_{-1}$ & 1700 & 4. & -- & 1900 & 4. & $\ldots$ \\
\hline Dimethyl Phthalate & 360 & 4 & - & 380 & $4=$ & - & 400 & $u$ & - & 360 & $\mathrm{u}$ & $\ldots-$ & 360 & $\mathrm{u}$. & -- & 350 & $u$ & $\ldots$ & 400 & 4 & $\cdots$ \\
\hline Acenaphthylene & 360 & 4 & - & 380 & $\mathrm{U}$ & - & 400 & $\mathrm{u}$. & $\ldots$ & 360 & $\mathrm{U}$ & --- & 110 & $\mathrm{~J}$ & $-\infty$ & 350 & $\mathrm{u}$. & $\ldots$ & 400 & 4. & $\cdots$ \\
\hline 2,6-Dinitrotoluene & 360 & $\mathrm{u}$ & - & 380 & $4=$ & - & 400 & $\mathrm{U}=$ & - & 360 & $\mathrm{u}$ & - & 360 & 4. & -- & 350 & 4. & $\ldots$ & 400 & 4. & - \\
\hline 3-Nitroaniline & 1800 & $\mathrm{u}$ & -- & 1900 & 0. & $\ldots$ & 1900 & $u$. & - & 1700 & $\mathrm{u}$. & - & 1800 & u. & -- & 1700 & 4 & \begin{tabular}{|l|l|}
-- & 0 \\
\end{tabular} & 1900 & $u$ & $\cdots$ \\
\hline Acenaphthene & 360 & 4. & -- & 380 & 4. & - & 400 & 4. & - & 360 & 4. & -- & 360 & 4. & -- & 350 & 4. & $\ldots$ & 400 & 4 & - \\
\hline 2,4-Dinitrophenol & 1800 & $\mathrm{u}$ & - & 1900 & U. & -- & 1900 & U. & 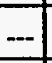 & 1700 & $u$. &.- & 1800 & 4. & $\ldots$ & 1700 & $\mathrm{u}$. & $\ldots$ & 1900 & 4 & - \\
\hline 4-Nitrophenol & 1800 & 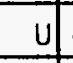 & -- & 1900 & 4. & -- & 1900 & 4. & $-\ldots$ & 1700 & 4 & $\ldots$ & 1800 & $u$. & $\ldots$ & 1700 & $u$. & $\cdots$ & 1900 & U) & $-\cdots$ \\
\hline \begin{tabular}{|l} 
Dibenzofuran \\
\end{tabular} & 360 & 4 & \begin{tabular}{|l|l|}
$-\infty$ & \\
\end{tabular} & 380 & 4. & - & 400 & 4. & $\ldots$ & 360 & 4. &.- & 360 & 4. & $\ldots$ & 350 & 4. & - & 400 & $U$ & $\cdots$ \\
\hline 2,4-Dinitrotoluene & 360 & $\mathrm{u}$. & \begin{tabular}{|l|}
$-\ldots$ \\
\end{tabular} & 380 & $u=$ & $\ldots$ & 400 & $\mathrm{u}$. & $\ldots$ & 360 & $\mathrm{U}$. & $\ldots$ & 360 & 4. & -- & 350 & 4. & -- & 400 & 4 & $\cdots$ \\
\hline Diethylphthalate & 360 & U. & -- & 380 & $0-$ & - & 400 & $\mathrm{u}$. & $\ldots$ & 360 & 4. & -- & 360 & $\mathrm{u}$. &.- & 350 & $u$. & $\ldots$ & 400 & u & -- \\
\hline 4-Chlorophenyl-phenylether & 360 & $\mathrm{U}$ & -- & 380 & $\mathrm{u}$ & - & 400 & $\mathrm{u}$. & $\ldots$ & 360 & $\mathrm{u}$. & $\ldots$ & 360 & 4 & -- & 350 & 4. & -- & 400 & 4 & - \\
\hline Fluorene & 360 & $\mathrm{u}$ & - & 380 & $\mathrm{u}$. & - & 400 & $\mathrm{U}$. & $\ldots$ & 360 & u. & --- & 360 & $\mathrm{U}$ & $\ldots$ & 350 & 4. & $\ldots$ & 400 & 4 & -- \\
\hline 4-Nitroaniline & 1800 & $u$. & - & 1900 & 4. & - & 1900 & 4. & -- & 1700 & 4 & -- & 1800 & $u$. & - & 1700 & 4. & $\ldots$ & 1900 & 4 & - \\
\hline 4,6-Dinitro-2-Methylphenol & 1800 & $u$ & $\ldots$ & 1900 & $u$. & -1 & 1900 & $u$ & - & 1700 & $u$. & $-\infty$ & 1800 & $u$. & - & 1700 & $\mathrm{U}$. & -- & 1900 & 4 & - \\
\hline N-Nitrosodiphenylamine (1) & 360 & $\mathrm{u}$ & - & 380 & 4. & - & 400 & $\mathrm{U}$. & - & 360 & $u$. & -- & 360 & 4 & - & 350 & $\mathrm{u}$ & $\ldots$ & 400 & 4 & $\ldots$ \\
\hline 4-Bromophenyl-phenylether & 360 & $U$ & - & 380 & U. & -1 & 400 & $u$. & - & 360 & $u$. & - & 360 & & - & 350 & & $\ldots$ & 400 & & - \\
\hline
\end{tabular}

" Data Qualifier. "* Data Validation. 


\begin{tabular}{|c|c|c|c|c|c|c|c|c|c|c|c|c|c|c|c|c|c|c|c|}
\hline$\cdots$ & & 000 & --- & $\bar{n}$ & OSE & $\cdots$ & $n$ & Tog & $-\cdots$ & & $09 \varepsilon$ & $\cdots$ & $n$ & $00 t$ & $--n$ & $08 \varepsilon$ & \begin{tabular}{|l|l|}
-- & $n$ \\
\end{tabular} & $09 \varepsilon$ & 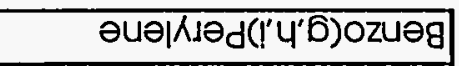 \\
\hline$--\mid$ & $n$ & 000 & --- & $n$ & $09 \varepsilon$ & $-\infty$ & $n$ & $09 \varepsilon$ & $\cdots$ & $n$ & $09 \varepsilon$ & -- & $n$ & 000 & $-\infty$ & $08 \varepsilon$ & \begin{tabular}{|l|l|}
-- & $n$ \\
\end{tabular} & $\overline{09 \varepsilon}$ & 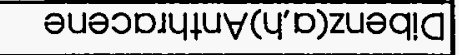 \\
\hline-- & $n$ & 000 & $-\cdots$ & $n$ & OSE & $-\cdots$ & $r$ & $0 \mathrm{Ol}$ & $-\cdots$ & $n$ & $09 \varepsilon$ & --- & $n$ & 000 & \begin{tabular}{|l|l|} 
& $n$ \\
\end{tabular} & $08 \varepsilon$ & \begin{tabular}{|l|l|}
$-\cdots$ \\
\end{tabular} & $09 \varepsilon$ & อuə $1 \Lambda_{d}\left(p 0-\varepsilon^{\prime} Z^{\prime}\right.$ l)ouəpu| \\
\hline$\cdots$ & $n$ & 000 & -- & $n$ & $09 \varepsilon$ & $-\cdots$ & & 029 & $-\cdots$ & $n$ & $09 \varepsilon$ & \begin{tabular}{|l|}
-- \\
\end{tabular} & $n$ & 000 & \begin{tabular}{|l|l|}
-- & $n$ \\
\end{tabular} & $08 \varepsilon$ & \begin{tabular}{l|l}
- & $n$ \\
\end{tabular} & $09 \varepsilon$ & əuə」ᄉd(D)Ozuəg \\
\hline-- & $n$ & 000 & $-\cdots$ & $n$ & $09 \varepsilon$ & -- & $r$ & $09 \varepsilon$ & -- & $n$ & $09 \varepsilon$ & $\cdots$ & $n$ & 000 & \begin{tabular}{|l|l}
$n$ \\
\end{tabular} & $08 \varepsilon$ & \begin{tabular}{|l|l|}
-- & $n$ \\
\end{tabular} & $09 \varepsilon$ & әuәutudion/f(x)Ozuәg \\
\hline-- & $n$ & 000 & -- & $n$ & $09 \varepsilon$ & -- & & 0091 & $\cdots$ & 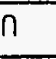 & $09 \varepsilon$ & -- & $n$ & 000 & $-n$ & $08 \varepsilon$ & \begin{tabular}{|l|l|}
$-\infty$ & $n$ \\
\end{tabular} & $09 \varepsilon$ & 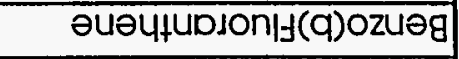 \\
\hline$\cdots$ & $n$ & $00 t$ & -- & $n$ & $09 \varepsilon$ & -- & $n$ & $09 \varepsilon$ & --- & $\bar{n}$ & 098 & -- & $n$ & 000 & \begin{tabular}{|l|l|}
-- & $n$ \\
\end{tabular} & $08 \varepsilon$ & $--\pi$ & $09 \varepsilon$ & 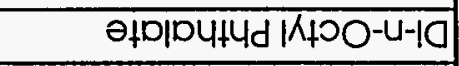 \\
\hline$\cdots$ & $n$ & 000 & $-\cdots$ & $r$ & 99 & -- & $n$ & $09 \varepsilon$ & $-\cdots$ & $n$ & $09 \varepsilon$ & -- & $n$ & 000 & \begin{tabular}{|l|l|}
$-\infty$ & $n$ \\
\end{tabular} & $08 \varepsilon$ & \begin{tabular}{|l|l}
$-\infty$ \\
\end{tabular} & $0 \varepsilon \mathrm{L}$ & 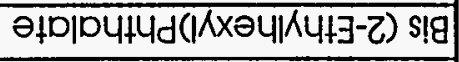 \\
\hline--- & $n$ & $00 t$ & $\cdots$ & $n$ & OSE & $r$ & & $008 \mathrm{~L}$ & -- & $n$ & $09 \varepsilon$ & - & $n$ & 000 & \begin{tabular}{|l|l|}
- & $n$ \\
\end{tabular} & $08 \varepsilon$ & $-1 n$ & $09 \varepsilon$ & วUәSК14ว \\
\hline$\cdots$ & $n$ & 000 & $\cdots$ & $n$ & $09 \varepsilon$ & $r$ & & $002 \mathrm{~L}$ & $\cdots$ & $n$ & $09 \varepsilon$ & - & $n$ & 000 & $\cdots$ & $08 \varepsilon$ & $\cdots$ & $09 \varepsilon$ & 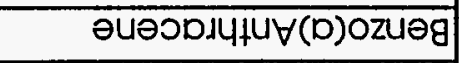 \\
\hline$-\cdots$ & $n$ & 008 & $\cdots$ & $n$ & 069 & $\cdots$ & $n$ & OZL & -- & $n$ & $02 L$ & -- & $n$ & $06 L$ & \begin{tabular}{|c|c|}
-- \\
\end{tabular} & $09 L$ & 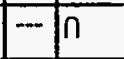 & OZL & 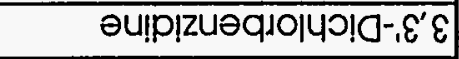 \\
\hline$\cdots$ & $n$ & 000 & $\cdots$ & $n$ & os $\varepsilon$ & $\cdots$ & $n$ & $09 \varepsilon$ & $-\cdots$ & $n$ & 098 & $-\infty$ & $n$ & 000 & $\cdots 1 n$ & $108 \varepsilon$ & \begin{tabular}{|l|l|} 
\\
\end{tabular} & $09 \varepsilon$ & 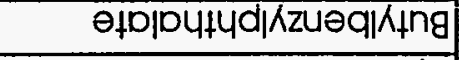 \\
\hline-- & $n$ & 000 & -- & $n$ & OSE & ro & a & $000 \varepsilon$ & $-\cdots$ & $n$ & $09 \varepsilon$ & -- & $n$ & 000 & \begin{tabular}{|l|l|}
-- & $n$ \\
\end{tabular} & $08 \varepsilon$ & $-z^{-} n$ & $09 \varepsilon$ & हuәमरd \\
\hline--- & $n$ & 000 & -- & $n$ & $09 \varepsilon$ & $\cdots$ & 0 & OOEZ & $\cdots$ & $n$ & $09 \varepsilon$ & $-\cdots$ & $n$ & 000 & \begin{tabular}{|l|l|}
-- & $n$ \\
\end{tabular} & $08 \varepsilon$ & $-\because n$ & $09 \varepsilon$ & 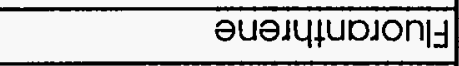 \\
\hline$-\cdots$ & $n$ & 000 & -- & $n$ & $09 \varepsilon$ & $\cdots$ & $n$ & $09 \varepsilon$ & $\cdots$ & $n$ & $09 \varepsilon$ & - & $n$ & $00 t$ & \begin{tabular}{|l|l|}
-- & $n$ \\
\end{tabular} & $08 \varepsilon$ & \begin{tabular}{|l|l|}
-- & $n$ \\
\end{tabular} & $09 \varepsilon$ & 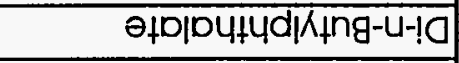 \\
\hline 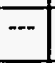 & $n$ & 000 & $-\cdots$ & $n$ & $09 \varepsilon$ & -- & $r$ & 091 & $\cdots$ & $n$ & $09 \varepsilon$ & - & $n$ & 000 & \begin{tabular}{|l|l|}
$-\cdots$ \\
\end{tabular} & $08 \varepsilon$ & \begin{tabular}{|l|l|}
-- & $n$ \\
\end{tabular} & $09 \varepsilon$ & 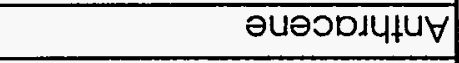 \\
\hline-- & $n$ & 000 & -- & $n$ & $0 s \varepsilon$ & -- & $r$ & 29 & $-\cdots$ & $n$ & $09 \varepsilon$ & $\cdots$ & $n$ & 000 & \begin{tabular}{|c|c|}
$n$ \\
\end{tabular} & $08 \varepsilon$ & $--n$ & $09 \varepsilon$ & 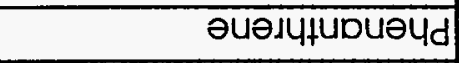 \\
\hline--- & $n$ & $006 \mathrm{~L}$ & $\cdots$ & & $00 \angle L$ & $-\cdots$ & $n$ & $008 \mathrm{~L}$ & $\cdots$ & $n$ & $00 \angle 1$ & $\cdots$ & $n$ & 0061 & $\cdots$ & $006 \mathrm{~L}$ & $\cdots n$ & $008 \mathrm{~L}$ & 10uәudosoluobfuəd \\
\hline$-\cdots$ & $n$ & 000 & $-\cdots$ & $n$ & $09 \varepsilon$ & $\cdots$ & $n$ & $09 \varepsilon$ & $-\cdots$ & $n$ & $09 \varepsilon$ & -- & $n$ & 000 & \begin{tabular}{|l|l|}
$-\cdots$ & $n$ \\
\end{tabular} & $08 \varepsilon$ & \begin{tabular}{|l|l|}
-- & $n$ \\
\end{tabular} & $09 \varepsilon$ & 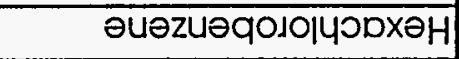 \\
\hline$\sum_{*}^{0}$ & & 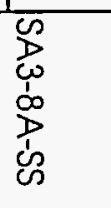 & $\overbrace{*}^{\nabla}$ & & 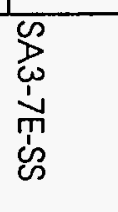 & $\underset{*}{\sigma}$ & $D_{*}$ & 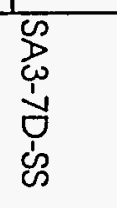 & $\underset{*}{\stackrel{\nabla}{*}}$ & & 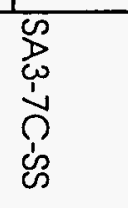 & 㝏 & $\mathscr{D}_{*}$ & 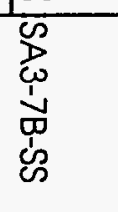 & $\underbrace{g}_{*} P_{*}^{\prime}$ & 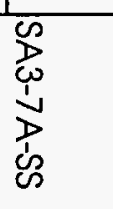 & $\underbrace{}_{*} \varrho_{*}$ & 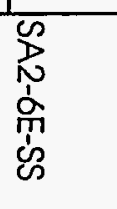 & (6)्र/6n) punoduos \\
\hline
\end{tabular}




\begin{tabular}{|c|c|c|c|c|c|c|c|c|c|c|c|c|c|c|c|c|c|c|c|c|c|}
\hline \multirow[b]{2}{*}{ Compound (ug/Kg) } & \multicolumn{21}{|c|}{ Table A-5.4 Semi-Volatiles } \\
\hline & 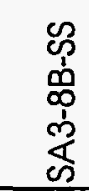 & $\stackrel{*}{\emptyset}$ & & 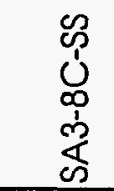 & & $\stackrel{\text { D }}{2}$ & 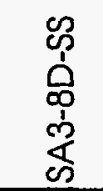 & & & 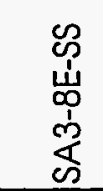 & & 苛 & 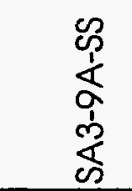 & $\stackrel{*}{\varnothing}$ & $\stackrel{*}{\stackrel{*}{\partial}}$ & 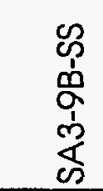 & & $\stackrel{*}{2}$ & 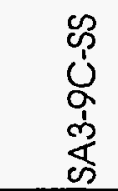 & & $\stackrel{*}{2}$ \\
\hline Phenol & 350 & $\mathrm{u}$ & - & 340 & $\mathrm{u}$ & -- & 350 & $\mathrm{u}$ & -- & 390 & $\mathrm{U}$ & $\ldots$ & 410 & 4 & -- & 390 & $u$ & -- & 360 & $u$. &.-- \\
\hline bis (2-Cloroethyl)Ether & 350 & 4. & - & 340 & $\mathrm{U}$ & $\ldots$ & 350 & $\mathrm{u}$ & - & 390 & $\mathrm{u}$ & $-\ldots$ & 410 & u & -- & 390 & $\mathrm{u}$ & $\ldots$ & 360 & $u$. & $\ldots$ \\
\hline 2-Chlorophenol & 350 & $u$ & - & 340 & U) & -- & 350 & 4 & - & 390 & $U$ & $\ldots$ & 410 & 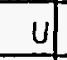 & $\ldots$ & 390 & 4 & $\ldots$ & 360 & $u$. & $\ldots$ \\
\hline 1,3-Dichlorobenzene & 350 & 4 & -- & 340 & $u$ & - & 350 & $u$ & - & 390 & $u$ & $\ldots$ & 410 & u & $\ldots$ & 390 & 4 & $\ldots$ & 360 & $u$ & - \\
\hline 1,4-Dichlorobenzene & 350 & U. & -- & 340 & 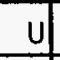 & - & 350 & $\mathrm{u}$ & - & 390 & $u$ & -- & 410 & 4 & -- & 390 & $u$ & $\ldots$ & 360 & $\mathrm{u}$. & $-\ldots$ \\
\hline Benzyl Alcohol & 350 & 4 & UJ & 340 & $\mathrm{U}$ & UJ & 350 & 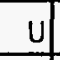 & UJ & 390 & 4 & UJ & 410 & 4 & UJ & 390 & 4 & UJ & 360 & 4 & UJ \\
\hline 1,2-Dichlorobenzene & 350 & $\mathrm{U}$ & - & 340 & $u$ & -- & 350 & $u$ & - & 390 & $\mathrm{u}$ & $\ldots$ & 410 & 4 & $\ldots$ & 390 & 4 & $\ldots$ & 360 & $u$ & - \\
\hline 2-Methylphenol & 350 & $\mathrm{u}$ & $-\infty$ & 340 & $\mathrm{U}$ & $\ldots$ & 350 & u & -- & 390 & $u$ & $\ldots$ & 410 & $u$ & $-\ldots$ & 390 & 4 & $\ldots$ & 360 & $u$ & $\ldots$ \\
\hline bis (2-Chloroisopropyl)Ether & 350 & $\mathrm{U}$ & -- & 340 & $u$ & - & 350 & $u$ & -- & 390 & $\mathrm{U}$ & - & 410 & U] & -- & 390 & U) & $\ldots$ & 360 & $u$. & - \\
\hline 4-Methylphenol & 350 & $\mathrm{u}$ & - & 340 & $\mathrm{u}$ & - & 350 & $\mathrm{u}$ & - & 390 & $u$ & - & 410 & U & $-\ldots$ & 390 & $u$ & $\ldots$ & 360 & 4 & - \\
\hline N-Nitroso-Di-n-Propylamine & 350 & $\mathrm{u}$ & -- & 340 & U & $-\ldots$ & 350 & $\mathrm{u}$ & - & 390 & $\mathrm{u}$ & - & 410 & 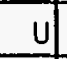 & -- & 390 & $u$ & $\ldots$ & 360 & U & -- \\
\hline Hexachloroethane & 350 & U. & - & 340 & $u$ & - & 350 & $u$ & - & 390 & $\mathrm{U}$ & - & 410 & $\mathrm{u}$ & -- & 390 & U & $\ldots$ & 360 & $u$ & -- \\
\hline Nitrobenzene & 350 & 4 & -- & 340 & 4 & $-\infty$ & 350 & $u$ & $\ldots$ & 390 & $\mathrm{u}$ & - & 410 & 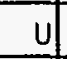 & -- & 390 & $u$ & $-\cdots$ & 360 & 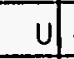 & $\ldots$ \\
\hline Isophorone & 350 & U) & - & 340 & $\mathrm{u}$ & $\ldots$ & 350 & 4 & - & 390 & $\mathrm{U}$ & $\ldots$ & 410 & u) & $\ldots$ & 390 & 4 & $\ldots$ & 360 & U & -- \\
\hline 2-Nitrophenol & 350 & 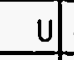 & $\ldots$ & 340 & 4 & $\ldots$ & 350 & $\mathrm{U}$ & $\ldots$ & 390 & $\mathrm{U}$ & $\ldots$ & 410 & $\mathrm{U}$ & $\ldots$ & 390 & $u$ & $\cdots$ & 360 & u & -- \\
\hline 2,4-Dimethylphenol & 350 & $u$ & $\ldots$ & 340 & 4 & - & 350 & $u$ & -- & 390 & $\mathrm{U}$ & $\ldots$ & 410 & $u$ & $\ldots$ & 390 & $u$ & -- & 360 & 4 & -- \\
\hline Benzolc Acid & 150 & $J$ & -- & 180 & $\mathrm{~J}$ & $-\infty$ & 170 & $\mathrm{~J}$ & $\ldots$ & 300 & $\mathrm{~J}$ & - & 2000 & 4 & -- & 260 & J) & -- & 1700 & 4 & - \\
\hline bis (2-Chloroethoxy)Methane & 350 & $\mathrm{u}$ & $\ldots$ & 340 & $\mathrm{u}$ & $\ldots$ & 350 & $u$ & - & 390 & $\mathrm{U}$ & $\ldots$ & 410 & $u$ & $\ldots$ & 390 & $u$ & \begin{tabular}{|l|l|}
-- & \\
\end{tabular} & 360 & $u$ & $\ldots$ \\
\hline 2.4-Dichlorophenol & 350 & 4 & - & 340 & & - & 350 & $\mathrm{u}$ & - & 390 & $u$ & - & 410 & $\mathrm{u}$ & $\ldots$ & 390 & $u$ & $-a_{1}$ & 360 & 4 & -- \\
\hline 1,2,4-Trichlorobenzene & 350 & u & - & 340 & 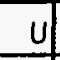 & - & 350 & 4 & - & 390 & $u$ & - & 410 & 4 & - & 390 & 4 & $-\infty$ & 360 & 4 & $\ldots$ \\
\hline Naphthalene & 350 & 4 & - & 340 & $\mathrm{U}$ & - & 350 & $u$ & - & 390 & $\mathrm{U}$ & - & 410 & $\mathrm{U}$ & $\ldots$ & 390 & u) & -- & 360 & u & -- \\
\hline 4-Chloroaniline & 350 & $u$ & - & 340 & & - & 350 & $u$ & - & 390 & $\mathrm{u}$ & - & 410 & $u$ & - & 390 & $u$ & - & 360 & $u$ & $\ldots$ \\
\hline Hexachlorobutadiene & 350 & U) & $-\infty$ & 340 & & $\ldots$ & 350 & 4 & $\ldots$ & 390 & & - & 410 & $u$ & $-\ldots$ & 390 & $u$ & -- & 360 & & - \\
\hline
\end{tabular}

"Data Qualifier. " Data Validation. 


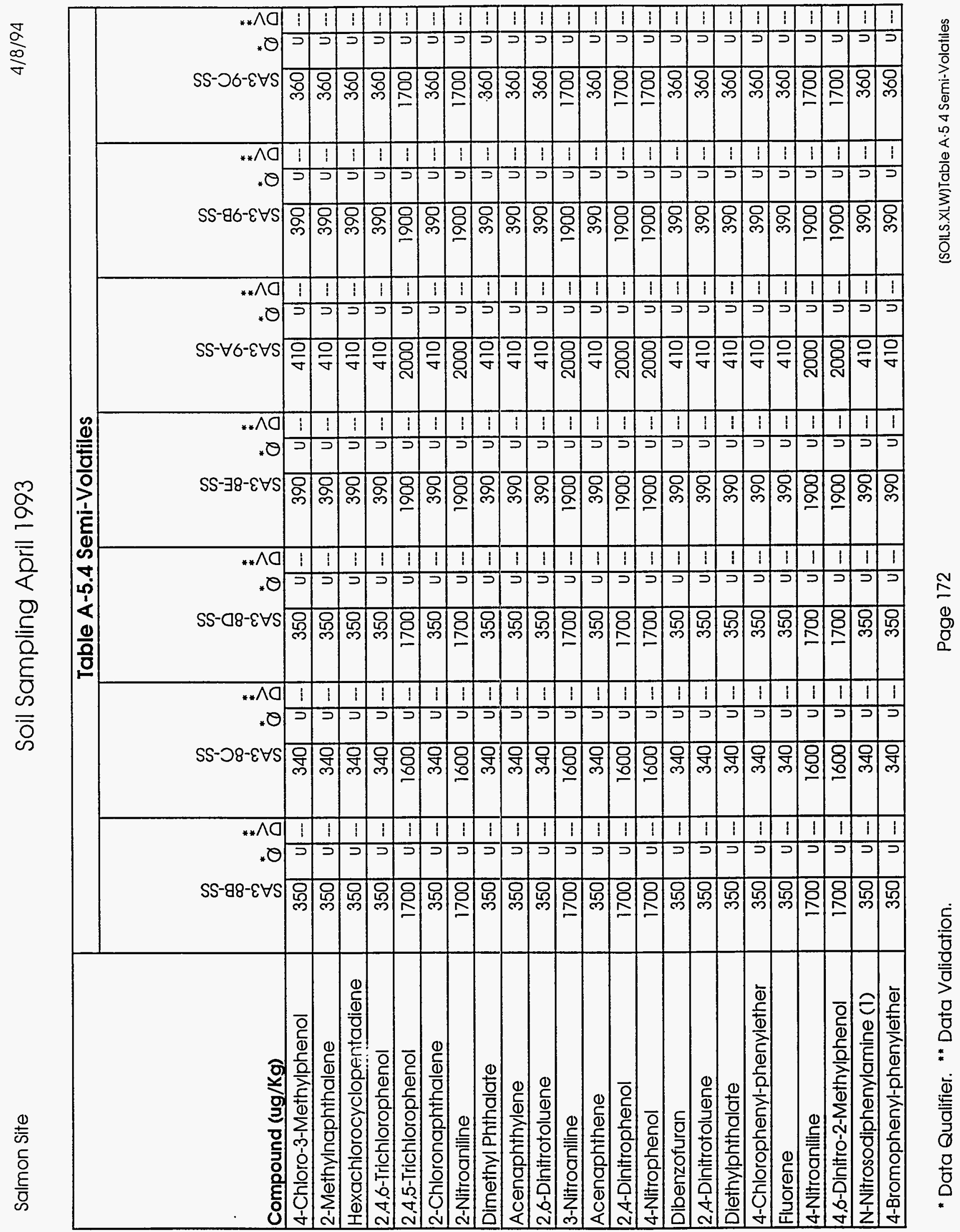




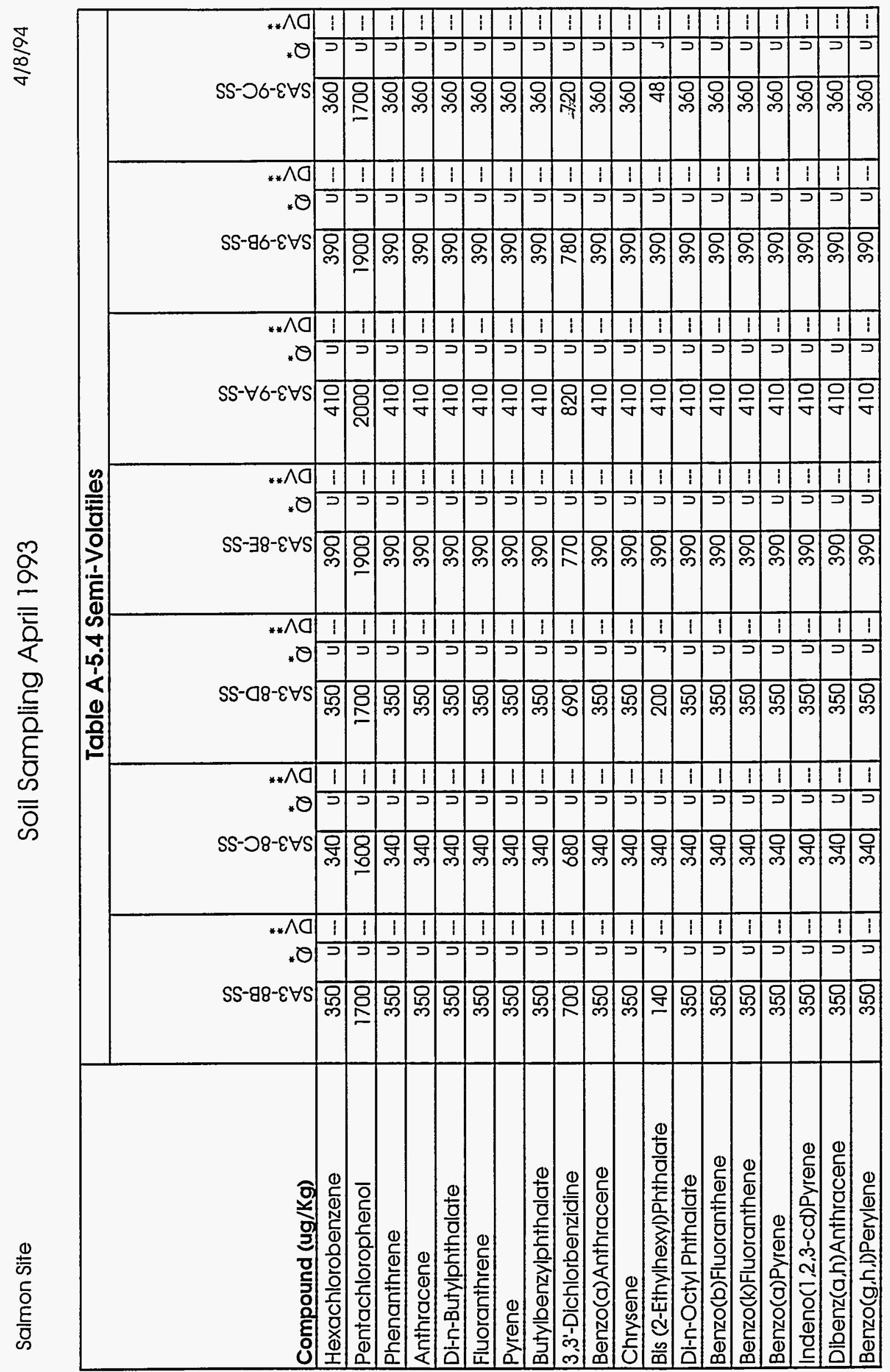




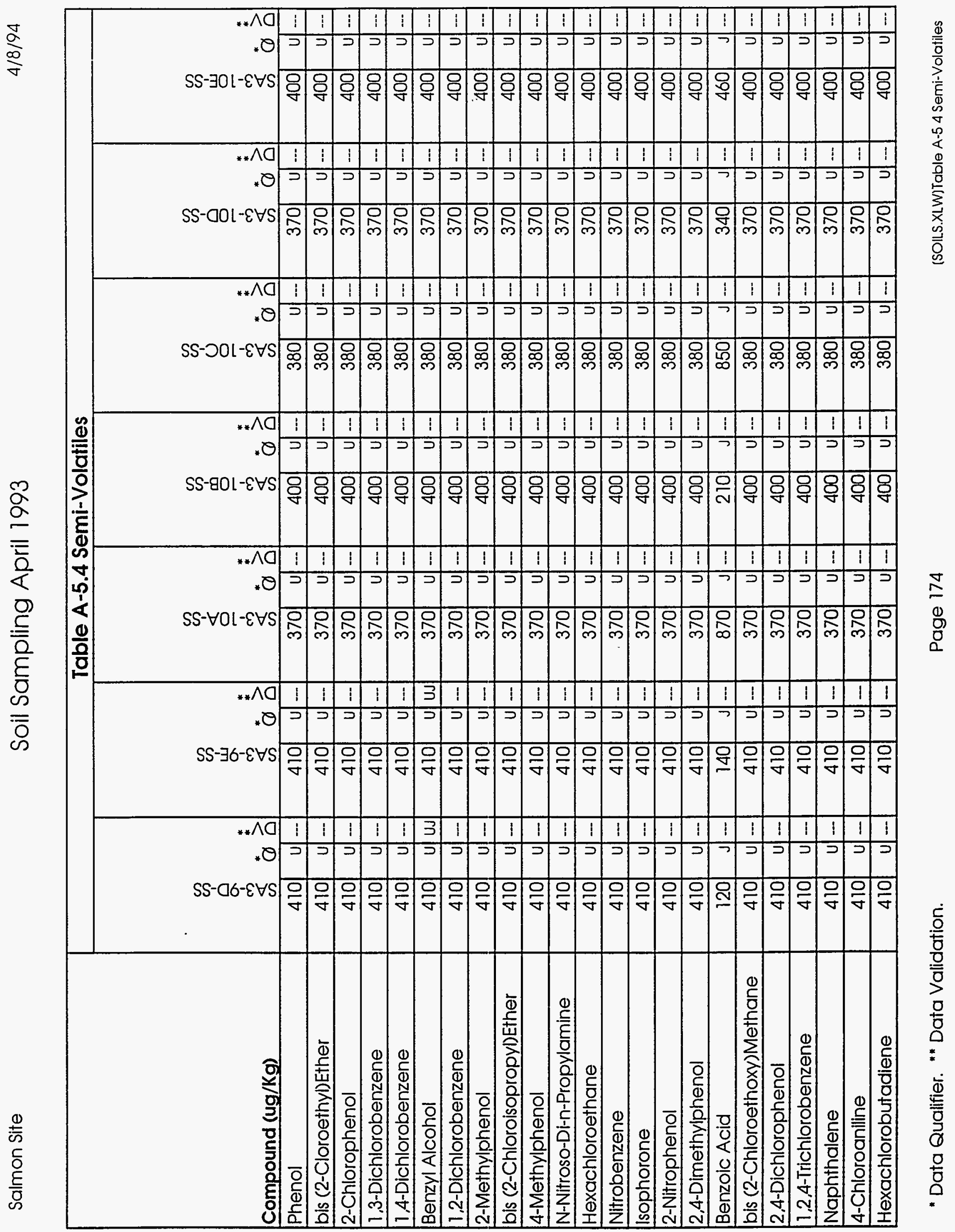




\begin{tabular}{|c|c|c|c|c|c|c|c|c|c|c|c|c|c|c|c|c|c|c|c|c|c|}
\hline \multirow[b]{2}{*}{ Compound (ug/Kg) } & \multicolumn{21}{|c|}{ Table A-5.4 Semi-Volatiles } \\
\hline & 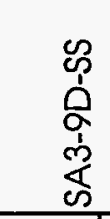 & & & 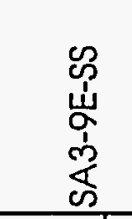 & & & 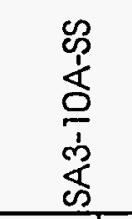 & & & 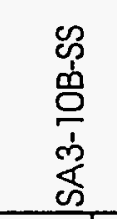 & & $\stackrel{*}{0}^{*}$ & 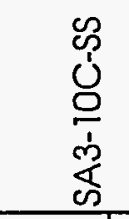 & & ¿ & 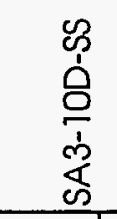 & & $\sum^{*}$ & 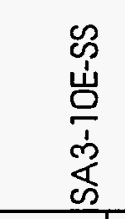 & $\stackrel{*}{Q}$ & $\stackrel{*}{\circ}$ \\
\hline 4-Chloro-3-Methylphenol & 410 & $u$. & - & 410 & $u$. & $-\ldots$ & 370 & $u$ & $\ldots$ & 400 & $u$ & $-\ldots$ & 380 & $\mathrm{u}$ & $\ldots$ & 370 & U. & -- & 400 & $\mathrm{u}$ & $\cdots$ \\
\hline 2-Methylnaphthalene & 410 & 0. & $\ldots$ & 410 & 0. & $-\infty$ & 370 & $u$ & $\ldots$ & 400 & u) & $-\ldots$ & 380 & $\mathrm{u}$ & -- & 370 & $u$ & $\ldots$ & 400 & $u$ & -- \\
\hline Hexachlorocyclopentadiene & 410 & $\mathrm{u}$. & $\ldots$ & 410 & U. & - & 370 & $u$ & - & 400 & $\mathrm{u}$ & $-\infty$ & 380 & $\mathrm{u}$ & - & 370 & $u$. & $\ldots$ & 400 & 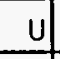 & $\cdots$ \\
\hline 2,4,6-Trichlorophenol & 410 & $\mathrm{u}$. & $\ldots$ & 410 & $u$. & $\ldots$ & 370 & $\mathrm{u}$ & - & 400 & $u$ & $-\ldots$ & 380 & 4 & - & 370 & 4. & $-\infty$ & 400 & $u$ & $\cdots$ \\
\hline 2,4,5-Trichlorophenol & 2000 & 0. & $\ldots$ & 2000 & 4. & $\ldots$ & 1800 & $\mathrm{U}$ & - & 1900 & $u$ & $\ldots$ & 1800 & u & - & 1800 & 4. & - & 2000 & 4 & -- \\
\hline 2-Chloronaphthalene & 410 & $u$. & - & 410 & $\mathrm{u}$. & $\ldots$ & 370 & $\mathrm{u}$ & - & 400 & $u$ & -- & 380 & $u$ & -- & 370 & 4 & $\ldots$ & 400 & 4 & -- \\
\hline 2-Nitroaniline & 2000 & $u$. & - & 2000 & 4. & $-\infty$ & 1800 & 4 & $\ldots$ & 1900 & 4 & $\ldots$ & 1800 & u & - & 1800 & U. & - & 2000 & $\mathrm{u}$ & $\ldots$ \\
\hline Dimethyl Phthalate & 410 & $\mathrm{u}$. & - & 410 & $\mathrm{U}$. & -- & 370 & $u$ & $\ldots$ & 400 & $u$ & -- & 380 & $\mathrm{u}$ & -- & 370 & $\mathrm{U}$ &.- & 400 & u & -- \\
\hline Acenaphthylene & 410 & $\mathrm{u}$. & -1 & 410 & $\mathrm{u}$. & - & 370 & $\mathrm{u}$ & - & 400 & 4 & --- & 380 & 4 & -- & 370 & $\mathrm{U}$. & -- & 400 & $\mathrm{U}$ & -- \\
\hline 2,6-Dinitrotoluene & 410 & $\mathrm{u}$. & - & 410 & 4. & - & 370 & $\mathrm{U}$ & - & 400 & $\mathrm{U}$ & - & 380 & 4 & - & 370 & 4. & -- & 400 & 4 & --- \\
\hline 3-Nitroaniline & 2000 & $\mathrm{u}$. & - & 2000 & 4. & - & 1800 & $\mathrm{U}$ & - & 1900 & $\mathrm{u}$ & - & 1800 & 4 & -- & 1800 & $\mathrm{U}$. & $\ldots$ & 2000 & 4 & -- \\
\hline Acenaphthene & 410 & $\mathrm{u}$. & - & 410 & 4. & - & 370 & $\mathrm{u}$ & - & 400 & 4 & -- & 380 & 4 & -- & 370 & 4. & -- & 400 & 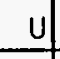 & $\ldots$ \\
\hline 2,4-Dinitrophenol & 2000 & u. & - & 2000 & $\mathrm{u}$ & - & 1800 & $\mathrm{U}$ & -- & 1900 & Uf & - & 1800 & 4 & $\cdots$ & 1800 & $\mathrm{u}$ & $\ldots$ & 2000 & $\mathrm{u}$ & $\ldots$ \\
\hline 4-Nitrophenol & 2000 & 4. & $\cdots$ & 2000 & $\mathrm{U}$. & $\ldots$ & 1800 & $\mathrm{U}$ & - & 1900 & 4 & - & 1800 & 4 & -- & 1800 & u. & -- & 2000 & $u$ & -- \\
\hline Dibenzofuran & 410 & u. & -- & 410 & $u$. & - & 370 & $u$ & -- & 400 & $u$ & -- & 380 & 4 & -- & 370 & $u$. & -- & 400 & 4 & -- \\
\hline 2,4-Dinitrotoluene & 410 & 4. & -- & 410 & 4. & - & 370 & $\mathrm{U}$ & -- & 400 & 0 & $\ldots$ & 380 & 4 & -- & 370 & $u$ & $\ldots$ & 400 & 4 & -- \\
\hline Diethylphthalate & 410 & U. & - & 410 & U. & -- & 370 & 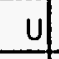 & $\ldots$ & 400 & 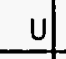 & - & 380 & 4 & $\ldots$ & 370 & $\mathrm{u}$. & $\ldots$ & 400 & $u$ & $\ldots$ \\
\hline 4-Chlorophenyl-phenylether & 410 & $\mathrm{U}$ & $\ldots$ & 410 & $\mathrm{U}$ & - & 370 & U & $\ldots$ & 400 & $u$ & -- & 380 & 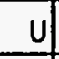 & $\ldots$ & 370 & $u$ & -- & 400 & 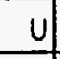 & - \\
\hline Fluorene & 410 & 4 & - & 410 & 4. & - & 370 & $u$ & $\ldots$ & 400 & $u$ & -- & 380 & 4 & - & 370 & 4. & -- & 400 & 4 & $\cdots$ \\
\hline 4-Nitroaniline & 2000 & 4 & - & 2000 & 4. & - & 1800 & 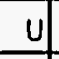 & $\ldots$ & 1900 & 4 & $-\cdots$ & 1800 & 4 & - & 1800 & $\mathrm{u}$. & - & 2000 & 4 & -- \\
\hline 4,6-Dinitro-2-Methylphenol & 2000 & 4 & - & 2000 & $u$. & - & 1800 & $u$ & - & 1900 & $u$ & -- & 1800 & & - & 1800 & 4. & -- & 2000 & 4 & - \\
\hline N-Nitrosodiphenylamine (1) & 410 & 4 & -- & 410 & 4. & - & 370 & $\mathrm{U}$ & - & 400 & U) & - & 380 & & -- & 370 & U. & -- & 400 & $u$ & --- \\
\hline 4-Bromophenyl-phenylether & 410 & $u$ & $\ldots$ & 410 & $u$ & $\ldots$ & 370 & $u$ & - & 400 & U) & -- & 380 & & - & 370 & & -1 & 400 & & - \\
\hline
\end{tabular}




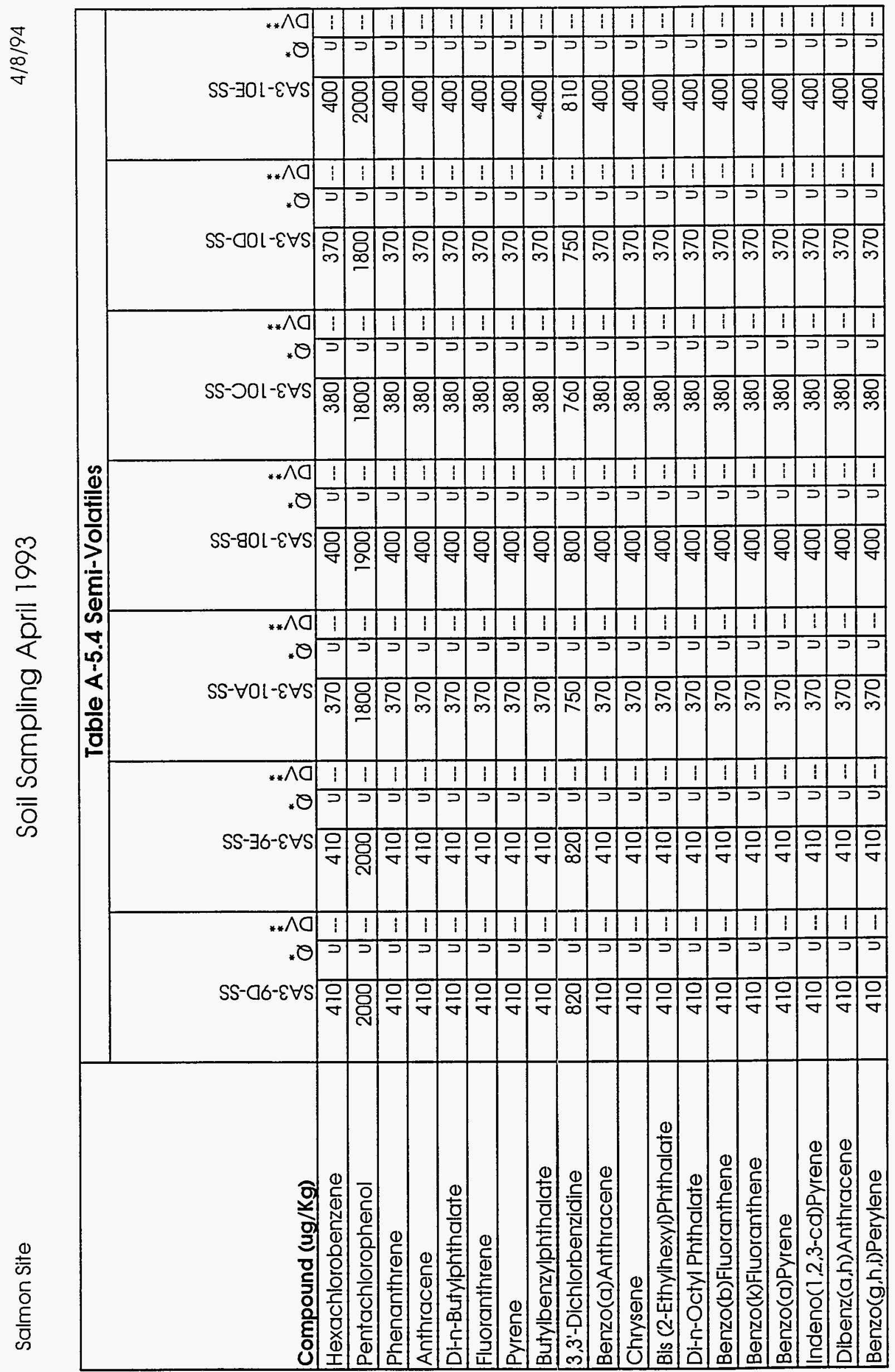




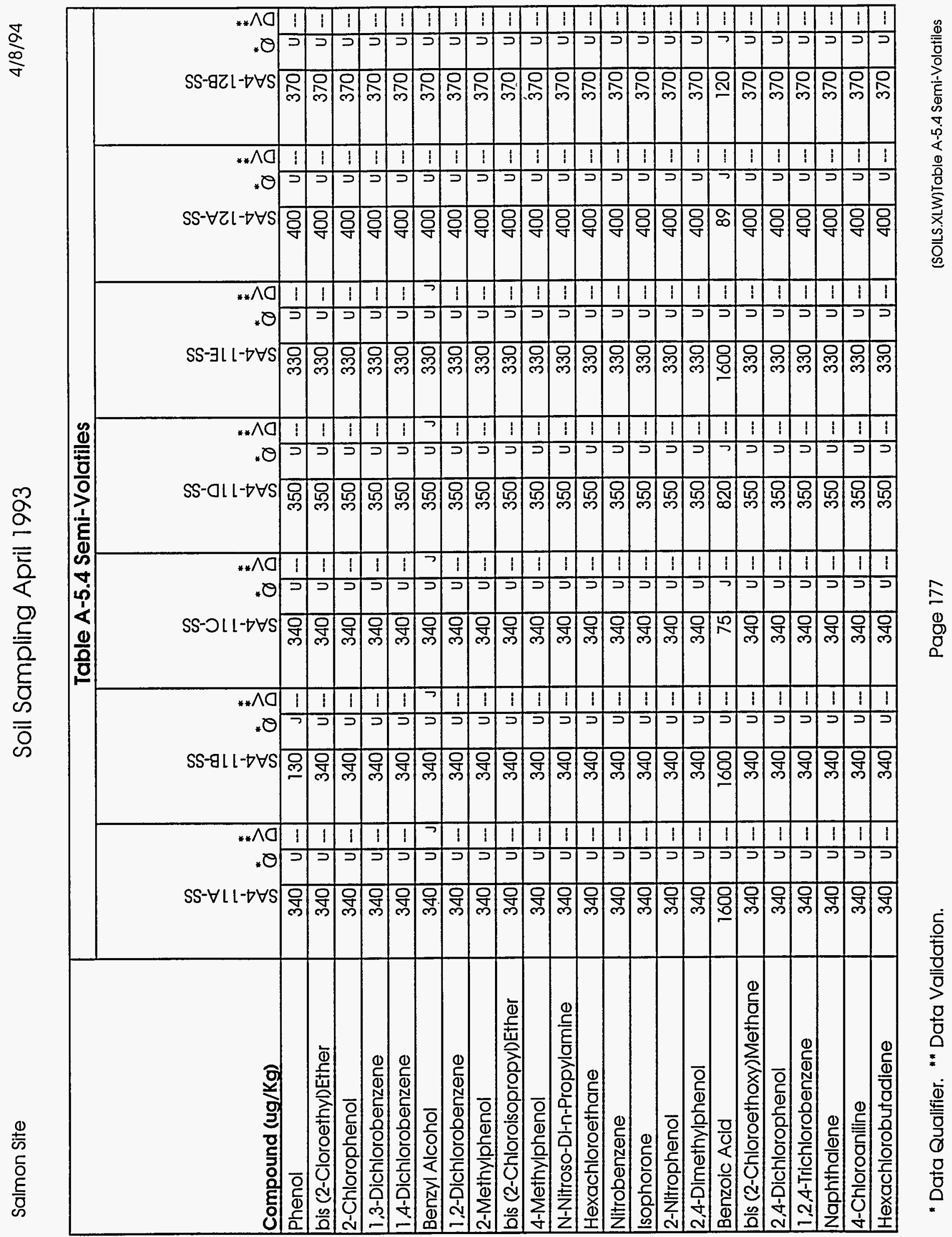




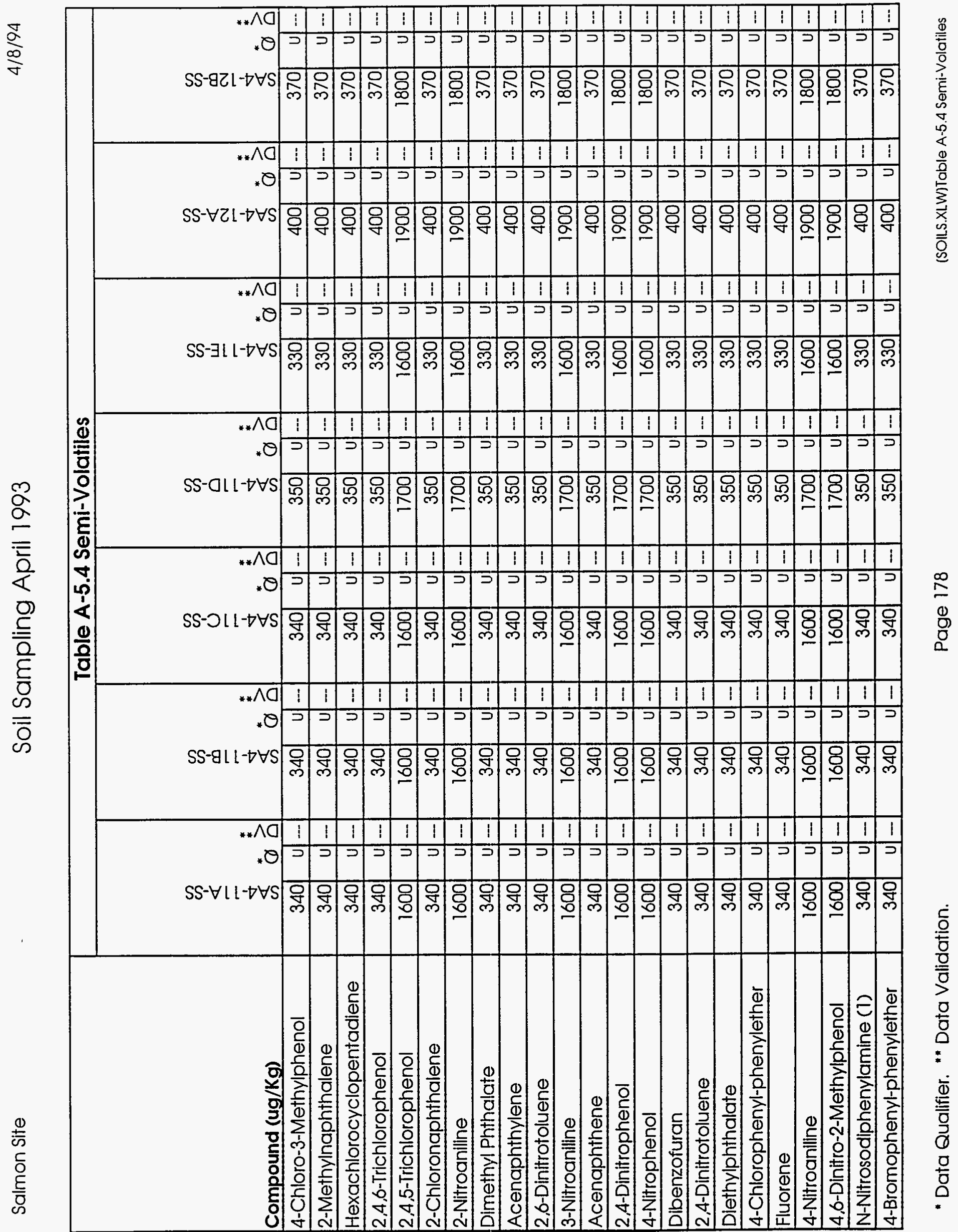




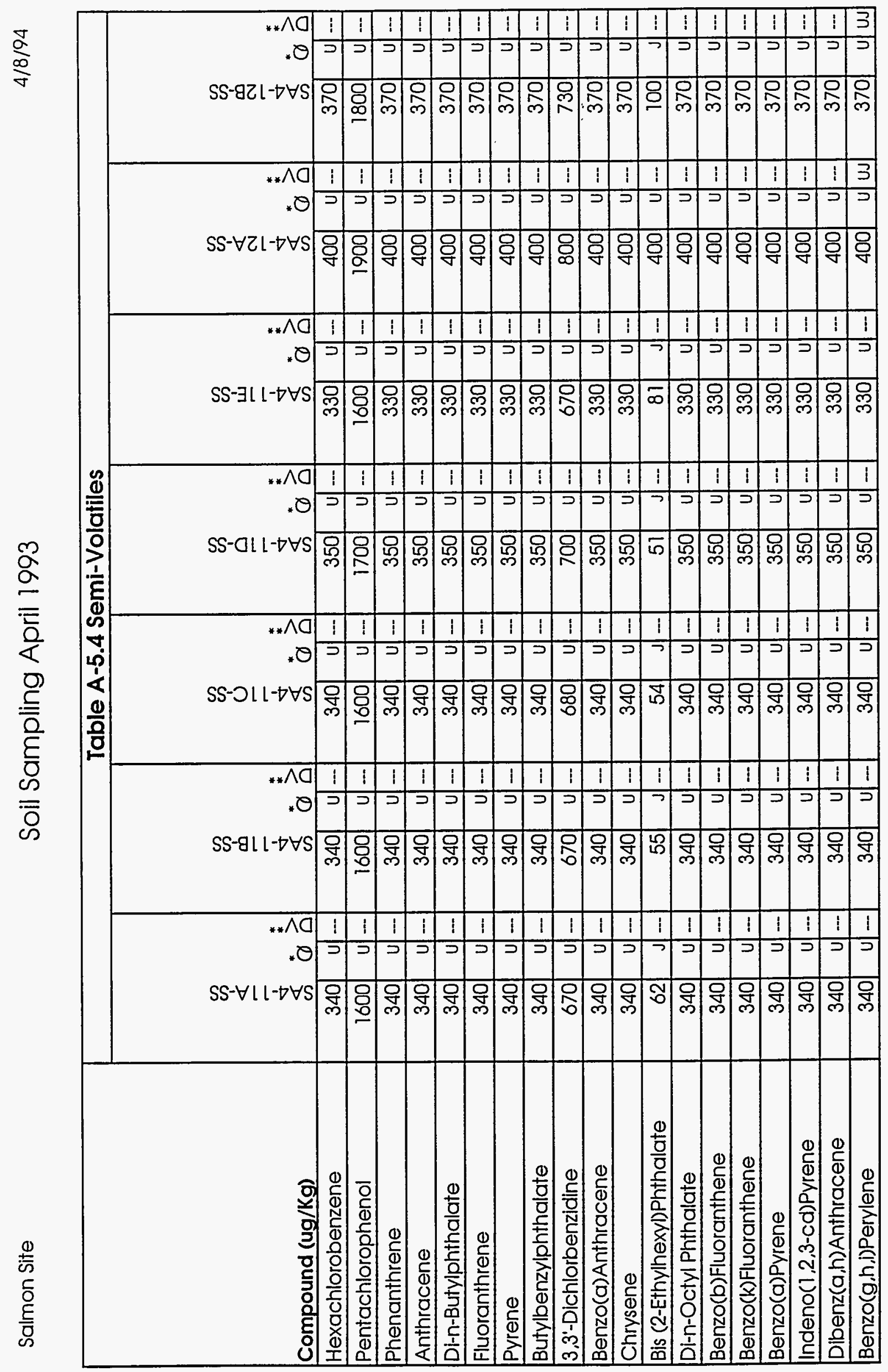

$\frac{2}{2}$

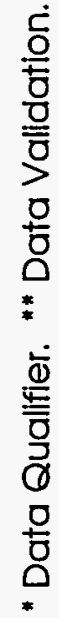




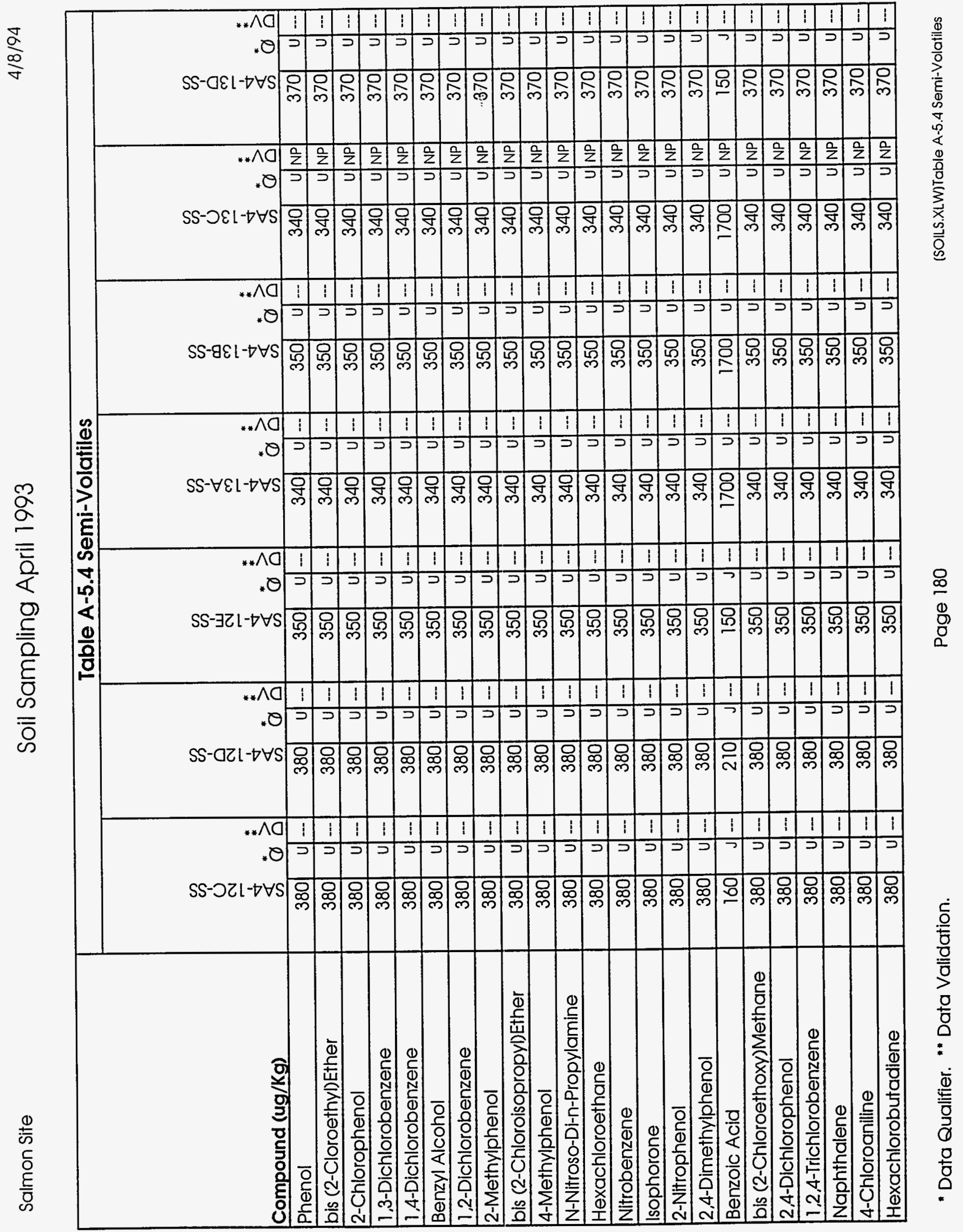




\begin{tabular}{|c|c|c|c|c|c|c|c|c|c|c|c|c|c|c|c|c|c|c|c|c|c|}
\hline \multirow[b]{2}{*}{ Compound (ug/Kg) } & \multicolumn{21}{|c|}{ Table A-5.4 Semi-Volatiles } \\
\hline & $\begin{array}{l}\mathscr{S} \\
\dot{d} \\
\mathbb{N} \\
\dot{d} \\
\dot{d}\end{array}$ & $\stackrel{*}{Q}$ & & 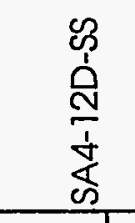 & & & 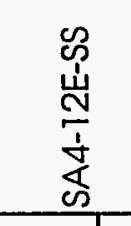 & & & 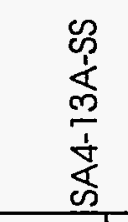 & & & 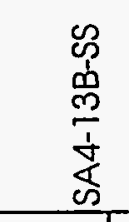 & & ${ }^{*}$ & 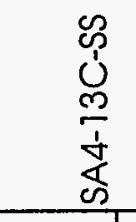 & $\stackrel{0}{0}$ & 草 & $\begin{array}{l}\text { c } \\
\dot{1} \\
0 \\
\frac{1}{1} \\
\dot{1} \\
\text { co }\end{array}$ & & $\stackrel{*}{2}$ \\
\hline 4-Chloro-3-Methylphenol & 380 & 4 & -- & 380 & U. & $\ldots$ & 350 & $u$ & - & 340 & $\mathrm{UL}$ & - & 350 & 0. & $\ldots$ & 340 & $4 /$ & $\mathrm{NP}$ & 370 & $u$ & $\ldots$ \\
\hline 2-Methylnaphthalene & 380 & 4. & $\ldots$ & 380 & u. & $\ldots$ & 350 & $u$ & -- & 340 & $\mathrm{u}$ & -- & 350 & 4 & $-\ldots$ & 340 & & $\mathrm{NP}$ & 370 & $u$ & $\ldots$ \\
\hline Hexachlorocyclopentadiene & 380 & $u$. & -- & 380 & 4. & - & 350 & $\mathrm{u}$ & $\ldots$ & 340 & $u-$ & - & 350 & u. & $-\cdots$ & 340 & $\mathrm{u}$ & $\mathrm{NP}$ & 370 & $\mathrm{u}$ & $\ldots$ \\
\hline 2,4,6-Trichlorophenol & 380 & $\mathrm{u}$. & -- & 380 & $u$. & -- & 350 & 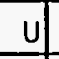 & $\cdots$ & 340 & 4 & $\cdots$ & 350 & 4 & $\ldots$ & 340 & 4 & $\mathrm{NP}$ & 370 & 4 & -- \\
\hline 2,4,5-Trichlorophenol & 1800 & $\mathrm{u}$. & $\ldots$ & 1800 & $\mathrm{U}$. & $-\ldots$ & 1700 & $u$ & -- & 1700 & U. & - & 1700 & $u$ & $-\ldots$ & 1700 & $4 i$ & $\mathrm{NP}$ & 1800 & $u$ & -- \\
\hline 2-Chloronaphthalene & 380 & 4. & $\ldots$ & 380 & 4. & - & 350 & $\mathrm{U}$ &.-- & 340 & U. & - & 350 & 4 & $-\ldots$ & 340 & $4 i$ & $\mathrm{NP}$ & 370 & $u$ & $\ldots$ \\
\hline 2-Nitroaniline & 1800 & $\mathrm{u}$. & - & 1800 & u. & -- & 1700 & $u$ & -- & 1700 & 4 & $\cdots$ & 1700 & u. & -- & 1700 & 4 & $\mathrm{NP}$ & 1800 & U & $-\cdots$ \\
\hline Dimethyl Phthalate & 380 & 4. & - & 380 & $\mathrm{u}=$ & - & 350 & $\mathrm{U}$ & - & 340 & U. & $\ldots$ & 350 & 4. & $-{ }_{-1}$ & 340 & 41 & $\mathrm{NP}$ & 370 & 4 & $\ldots$ \\
\hline Acenaphthylene & 380 & $\mathrm{u}$. & - & 380 & U. & - & 350 & $u$ & - & 340 & U. & $\ldots$ & 350 & 4 & $\ldots$ & 340 & 41 & $\mathrm{NP}$ & 370 & $\mathrm{u}$ & - \\
\hline 2,6-Dinitrotoluene & 380 & $\mathrm{u}$. & - & 380 & $u-$ & - & 350 & U & - & 340 & $\mathrm{U}$ & $\cdots$ & 350 & 4 & - & 340 & $u$ & $\mathrm{NP}$ & 370 & 4 & $\ldots$ \\
\hline 3-Nitroaniline & 1800 & 4. & - & 1800 & U. & - & 1700 & $\mathrm{U}$ & - & 1700 & 4. & $\cdots$ & 1700 & $u$ & -- & 1700 & 41 & $\mathrm{NP}$ & 1800 & $\mathrm{U}$ & - \\
\hline Acenaphthene & 380 & $\mathrm{u}$. & -- & 380 & U. & - & 350 & $\mathrm{U}$ & -- & 340 & $\mathrm{U}-$ & -- & 350 & U & $\ldots$ & 340 & 4 & $\mathrm{NP}$ & 370 & 4 &.- \\
\hline 2,4-Dinitrophenol & 1800 & $u$ & -- & 1800 & 4. & $\ldots$ & 1700 & $u$ & $\ldots$ & 1700 & $u-$ & - & 1700 & 4 & $-\infty$ & 1700 & 41 & $\mathrm{NP}$ & 1800 & 4 & - \\
\hline 4-Nitrophenol & 1800 & $u$ & $\ldots$ & 1800 & $\mathrm{U}$. & -- & 1700 & $\mathrm{U}$ & $\ldots$ & 1700 & 4. & -- & 1700 & 4 & --- & 1700 & 41 & $\mathrm{NP}$ & 1800 & $\mathrm{U}$ & $\ldots$ \\
\hline Dibenzofuran & 380 & 4 & $\ldots$ & 380 & $u$. & - & 350 & $U$ & -- & 340 & $u-$ & -- & 350 & 4 & $\ldots$ & 340 & 41 & $\mathrm{NP}$ & 370 & 4 & $\ldots$ \\
\hline 2,4-Dinitrotoluene & 380 & 4 & $\ldots$ & 380 & $\mathrm{U}$ & $-{ }_{-1}$ & 350 & $u$ & -- & 340 & u. & --- & 350 & $u$ & $\ldots$ & 340 & 41 & $\mathrm{NP}$ & 370 & $u$ & - \\
\hline Diethylphthalate & 380 & 4 & - & 380 & 4. & $-\cdots$ & 350 & $\mathrm{u}$ & $\ldots$ & 340 & 0. & $\ldots-$ & 350 & 4 & -- & 340 & 41 & $\mathrm{NP}$ & 370 & $\underline{u}$ & 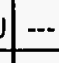 \\
\hline 4-Chlorophenyl-phenylether & 380 & $\mathrm{u}$ & $\ldots$ & 380 & $\mathrm{u}$ & $\ldots$ & 350 & $\mathrm{U}$ & -- & 340 & 4. & -- & 350 & $u$ & $\ldots$ & 340 & 4 & $\mathrm{NP}$ & 370 & $\mathrm{U}$ & -- \\
\hline Fluorene & 380 & $u$ & -- & 380 & $u$ & - & 350 & $u$ & -- & 340 & $\mathrm{u}$. & - & 350 & u & $-\ldots$ & 340 & 4 & $\mathrm{NP}$ & 370 & 4 & - \\
\hline 4-Nitroaniline & 1800 & U & -- & 1800 & $u$ & - & 1700 & $\mathrm{u}$ & - & 1700 & 4. & $\ldots$ & 1700 & U. &.- & 1700 & 4 & $\mathrm{NP}$ & 1800 & $\mathrm{u}$ & -- \\
\hline 4,6-Dinitro-2-Methylphenol & 1800 & 4 & - & 1800 & 4 & - & 1700 & 4 & - & 1700 & 4. & $\ldots$ & 1700 & $u$ & -- & 1700 & $u$ & $\mathrm{NP}$ & 1800 & $u$ & $=$ \\
\hline N-Nitrosodiphenylamine (1) & 380 & 4 & - & 380 & $\mathrm{u}$ & - & 350 & $\mathrm{u}$ & - & 340 & 4. & $\ldots$ & 350 & $u$ & - & 340 & $u$ & $\mathrm{NP}$ & 370 & $u$ & - \\
\hline 4-Bromophenyl-phenylether & 380 & 4 & -- & 380 & & - & 350 & & $\ldots$ & 340 & $u$. & -1 & 350 & & - & 340 & 4 & $\mathrm{NP}$ & 370 & & J... \\
\hline
\end{tabular}




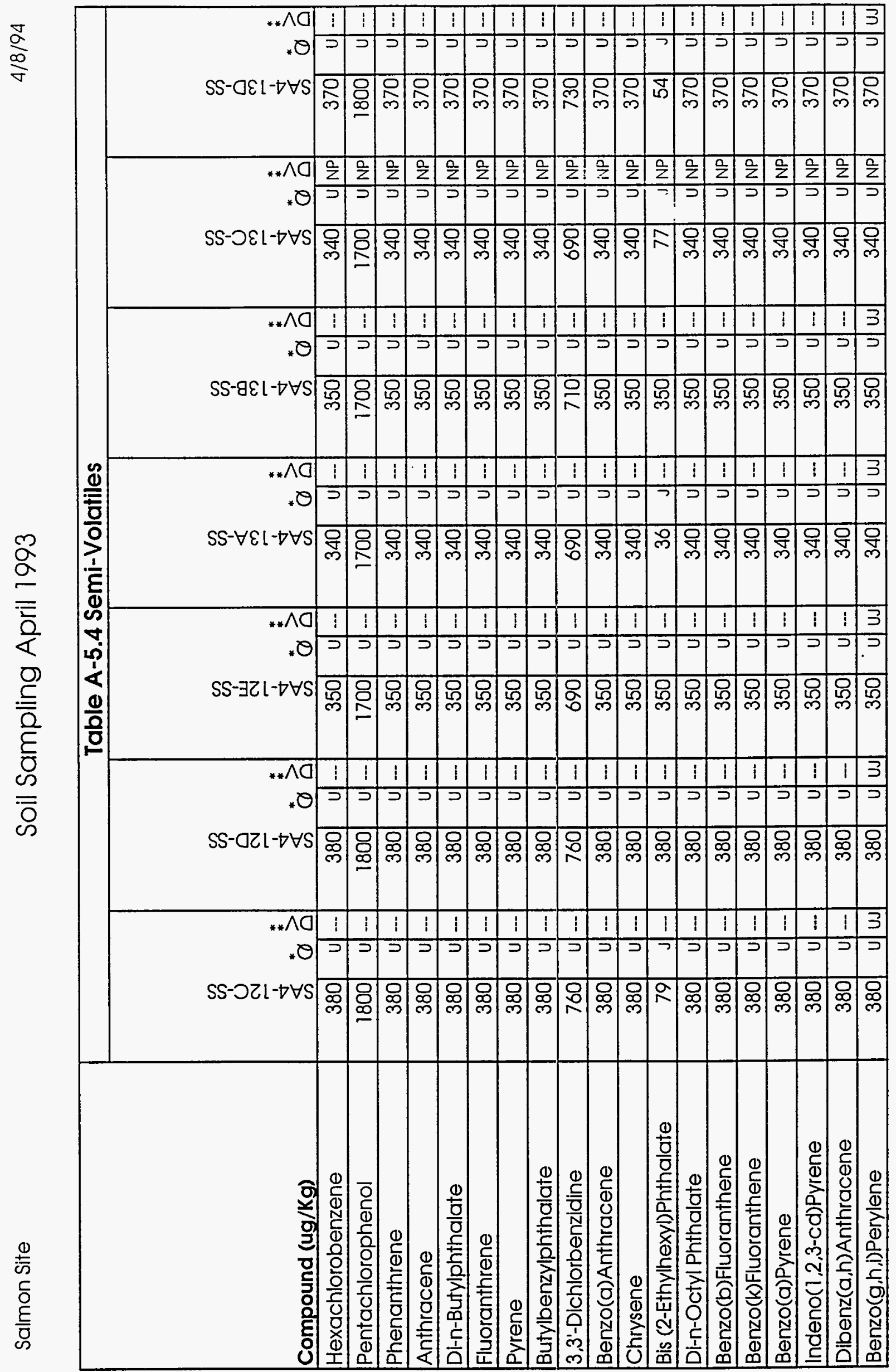




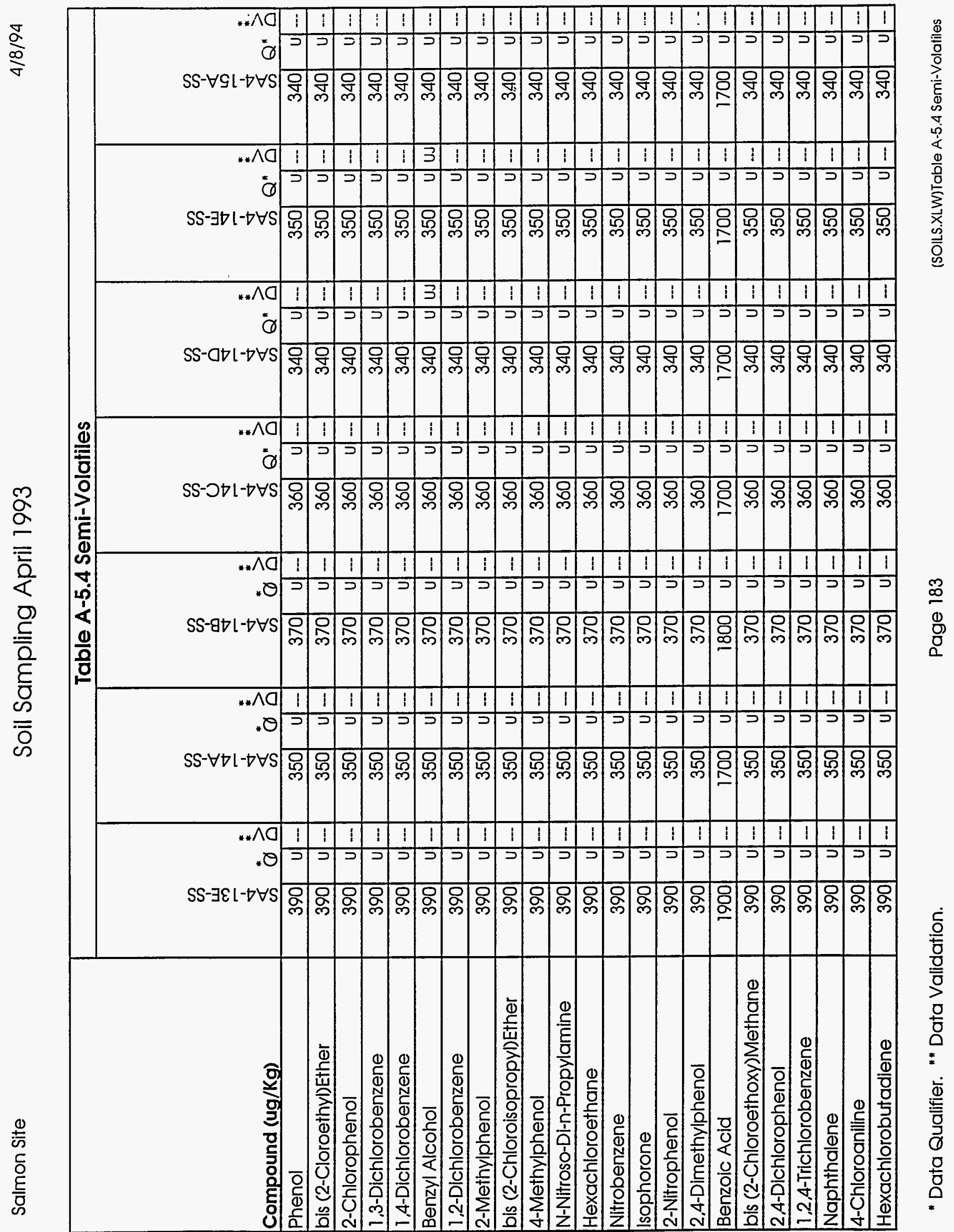




\begin{tabular}{|c|c|c|c|c|c|c|c|c|c|c|c|c|c|c|c|c|c|c|c|c|c|}
\hline \multirow[b]{2}{*}{ Compound (ug/Kg) } & \multicolumn{21}{|c|}{ Table A-5.4 Semi-Volatiles } \\
\hline & 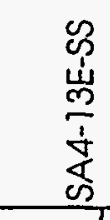 & & & 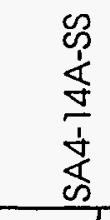 & $\stackrel{*}{Q}$ & & 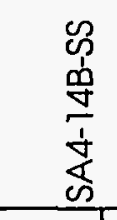 & & & 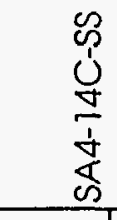 & $Q^{*}$ & $\sum_{0}^{*}$ & 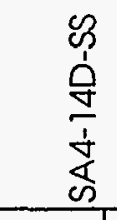 & $Q^{*}$ & $3^{*}$ & 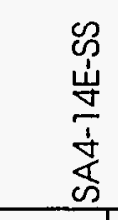 & $Q^{*}$ & $\stackrel{*}{2}$ & $\begin{array}{l}\mathscr{c} \\
0 \\
\frac{1}{4} \\
\frac{1}{1} \\
\dot{+} \\
\frac{1}{4} \\
0\end{array}$ & & $\stackrel{2}{0}^{*}$ \\
\hline 4-Chloro-3-Methylphenol & 390 & $\mathrm{u}$. & $\ldots$ & 350 & u & $\ldots$ & 370 & u) & $\ldots$ & 360 & U. & $\ldots$ & 340 & u. & $-\infty$ & 350 & $u$. & $\ldots$ & 340 & & $\ldots$ \\
\hline 2-Methylnaphthalene & 390 & $u$. & $\ldots$ & 350 & $u$ & $\ldots$ & 370 & $u$ & $\ldots$ & 360 & $u$. & $\ldots$ & 340 & $\mathrm{u}$ & $\ldots$ & 350 & $u$. & $\ldots$ & 340 & & $\ldots$ \\
\hline Hexachlorocyclopentadiene & 390 & $u$. & -- & 350 & U & - & 370 & u & $\ldots$ & 360 & 4. & $\ldots$ & 340 & $\mathrm{u}$ & -.. & 350 & $\mathrm{u}$. & $\ldots$ & 340 & $u$ & $\ldots$ \\
\hline 2,4,6-Trichlorophenol & 390 & U. & -- & 350 & U & -- & 370 & 4 & $\cdots$ & 360 & 4. & - & 340 & 4. & -- & 350 & 4. & $\ldots$ & 340 & 4 & -- \\
\hline 2,4,5-Trichlorophenol & 1900 & 4 & - & 1700 & 4 & $\ldots$ & 1800 & $\mathrm{U}$ & $\ldots$ & 1700 & U. & $\ldots$ & 1700 & 4. & $\ldots$ & 1700 & $u$. & $\ldots$ & 1700 & $u$ & $\ldots$ \\
\hline 2-Chloronaphthalene & 390 & $u$. & $-\ldots$ & 350 & u & $\ldots$ & 370 & u & $\ldots$ & 360 & 4. & $\ldots$ & 340 & $\mathrm{U}$ & $\ldots$ & 350 & $\mathrm{U}$. & $\ldots$ & 340 & $u$ & $\ldots$ \\
\hline 2-Nitroaniline & 1900 & 4. & $\ldots$ & 1700 & 4 & $\ldots$ & 1800 & u & -- & 1700 & $\mathrm{u}=$ & $\cdots$ & 1700 & u. & -- & 1700 & 4. & $\ldots$ & 1700 & $u$ & $\ldots$ \\
\hline Dimethyl Phthalate & 390 & 4. & $\ldots$ & 350 & $\mathrm{U}$ & $\ldots$ & 370 & $\mathrm{U}$ & $\cdots$ & 360 & 4. & $\cdots$ & 340 & U. & $-\infty$ & 350 & 4. & $\ldots$ & 340 & $\mathrm{u}$ & $\ldots$ \\
\hline Acenaphthylene & 390 & $\mathrm{u}$. & $\ldots$ & 350 & 4 & $\ldots$ & 370 & u & $\ldots$ & 360 & U. & $\ldots$ & 340 & u. & $\ldots$ & 350 & u. & $\ldots$ & 340 & $u$ & $\ldots$ \\
\hline 2.6-Dinitrotoluene & 390 & U. & $\ldots$ & 350 & 4 & $\ldots$ & 370 & 4 & -- & 360 & 4. & $\cdots$ & 340 & 4. & $-\infty$ & 350 & $\mathrm{U}$. & $\ldots$ & 340 & $\mathrm{U}$ & $\ldots$ \\
\hline 3-Nitroaniline & 1900 & 4. & $\ldots$ & 1700 & 4 & $\ldots$ & 1800 & U. & -- & 1700 & U. & $\cdots$ & 1700 & U. & $\ldots$ & 1700 & U. & $\ldots$ & 1700 & 4 & - \\
\hline Acenaphthene & 390 & 4. & $\ldots$ & 350 & U & $\ldots$ & 370 & 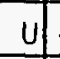 & $\ldots$ & 360 & 4. & $\ldots$ & 340 & $u$. & $\ldots$ & 350 & 4. & $\ldots$ & 340 & 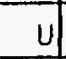 & $\ldots$ \\
\hline 2,4-Dinitrophenol & 1900 & 4. & $\ldots$ & 1700 & $u$ & - & 1800 & 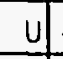 & $\ldots$ & 1700 & 0. & - & 1700 & $u$ & UJ & 1700 & u & UJ & 1700 & $\mathrm{U}$ & $\ldots$ \\
\hline 4-Nitrophenol & 1900 & 4. & - & 1700 & 4 & - & 1800 & $\mathrm{U}$ & - & 1700 & U. & $\cdots$ & 1700 & $u$. & -- & 1700 & $U$. & $\ldots$ & 1700 & 4 & $\ldots$ \\
\hline Dibenzofuran & 390 & 4. & -- & 350 & $u$ & - & 370 & $u$ & $-\ldots$ & 360 & 4. &.- & 340 & 4 & $\ldots$ & 350 & U. & $-\ldots$ & 340 & $u$ & $\ldots$ \\
\hline 2,4-Dinitrotoluene & 390 & $u$. & $\ldots$ & 350 & $\mathrm{U}$ & $\ldots$ & 370 & $u$ & - & 360 & U. & $\ldots$ & 340 & $u$ & -- & 350 & $u$ & $\ldots$ & 340 & $u$ & $\ldots$ \\
\hline Diethylphthalate & 390 & U. & $\ldots$ & 350 & $u$. & - & 370 & $\mathrm{U}$ & $\ldots$ & 360 & $\mathrm{Ut}$. & $\cdots$ & 340 & 4. & - & 350 & U. & $\ldots$ & 340 & $u$ & $\ldots$ \\
\hline 4-Chlorophenyl-phenylether & 390 & 4. & -- & 350 & $\mathrm{u}$ & -- & 370 & $u$ & $\ldots$ & 360 & 4. & $\ldots$ & 340 & $u$. & $\ldots$ & 350 & $u$. & $\ldots$ & 340 & $\mathrm{u}$ & $\ldots$ \\
\hline Fluorene & 390 & $\mathrm{u}$. & $\ldots$ & 350 & $\mathrm{u}$. & - & 370 & U & $\ldots$ & 360 & 0. & - & 340 & $u$. & -- & 350 & $\mathrm{u}$ & $\ldots$ & 340 & $\mathrm{U}$ & $\ldots$ \\
\hline 4-Nitroanilline & 1900 & $u$. & - & 1700 & 4. & - & 1800 & $u$ & - & 1700 & u. & - & 1700 & 4. & - & 1700 & $U$. & $\ldots$ & 1700 & $\mathrm{U}$ & $\ldots$ \\
\hline 4,6-Dinitro-2-Methylphenol & 1900 & U. & - & 1700 & 4. & - & 1800 & U & - & 1700 & 4. & - & 1700 & $u$. & - & 1700 & $u$. & $\ldots$ & 1700 & 4 & $\ldots$ \\
\hline N-Nitrosodiphenylamine (1) & 390 & $u$. & $\ldots$ & 350 & $u$ & - & 370 & $u$ & $\ldots$ & 360 & 4. & - & 340 & $u$ & - & 350 & $u$. & -- & 340 & 4 & $\ldots$ \\
\hline 4-Bromophenyl-phenylether & 390 & $\mathrm{u}$. & -1 & 350 & $\mathrm{u}$. & - & 370 & & -1 & 360 & u. & - & 340 & $\mathrm{U}$ & - & 350 & & $\ldots$ & 340 & & $\ldots$ \\
\hline
\end{tabular}




\begin{tabular}{|c|c|c|c|c|c|c|c|c|c|c|c|c|c|c|c|c|c|c|c|c|c|}
\hline \multirow[b]{2}{*}{ Compound (ug/Kg) } & \multicolumn{21}{|c|}{ Table A-5.4 Semi-Volatiles } \\
\hline & 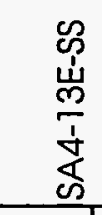 & & 艾 & 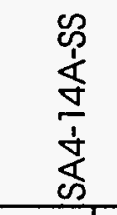 & $\stackrel{*}{0}$ & 苛 & 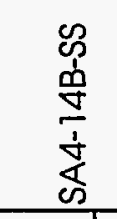 & & 莡 & 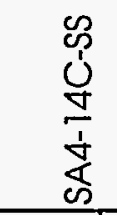 & $Q^{*}$ & 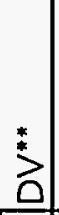 & 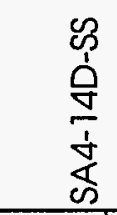 & $Q^{*}$ & $\stackrel{*}{2}$ & 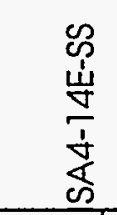 & $Q^{n}$ & $\stackrel{2}{2}$ & 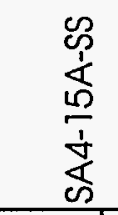 & $Q^{*}$ & 草 \\
\hline Hexachlorobenzene & 390 & $\mathrm{u}$ & $\ldots$ & 350 & $\mathrm{u}$ & $\ldots$ & 370 & $\mathrm{u}$ & -- & 360 & $\mathrm{u}$ & -- & 340 & $u$ & $\ldots$ & 350 & $u$ & $\ldots$ & 340 & $u$ & $\ldots$ \\
\hline Pentachlorophenol & 1900 & $u$ & - & 1700 & $\mathrm{u}$ & --1 & 1800 & $\mathrm{u}$ & $-\infty$ & 1700 & $\mathrm{U}$ & -- & 1700 & $\mathrm{U}$ & -- & 1700 & $u$ & $\ldots$ & 1700 & $u$ &.- \\
\hline Phenanthrene & 390 & $\mathrm{U}$ & $\ldots$ & 350 & $\mathrm{U}$ & $-\infty$ & 370 & $u$ & $\ldots$ & 360 & $\mathrm{U}$ & -- & 340 & U & $-\cdots$ & 350 & 4 & $-\cdots$ & 340 & $\mathrm{U}$ & $\ldots$ \\
\hline Anthracene & 390 & $\mathrm{u}$ & - & 350 & $\mathrm{u}$ & - & 370 & $u$ & -- & 360 & $\mathrm{u}$ & - & 340 & 4 & -- & 350 & 4 & $\ldots$ & 340 & 4 &.-- \\
\hline Di-n-Butylphthalate & 390 & $\mathrm{U}$ & -- & 350 & $\mathrm{U}$ & -- & 370 & $\mathrm{U}$ & $\ldots$ & 360 & $u$ & $\ldots$ & 340 & 4 & - & 350 & $u$ & $\cdots$ & 340 & U & -- \\
\hline Fluoranthrene & 390 & $u$ & -- & 350 & $u$ & - & 370 & $u$ & $\ldots$ & 360 & $u$ & $\ldots$ & 340 & $u$ & $-{ }_{-1}$ & 350 & $u$ & $\ldots$ & 340 & 4 & $\ldots$ \\
\hline Pyrene & 390 & $u$ & - & 350 & $\mathrm{U}$ & - & 370 & $\mathrm{U}$ & $-\ldots$ & 360 & $\mathrm{U}$ & $\ldots$ & 340 & 4 & -- & 350 & $u$ & $\ldots$ & 340 & 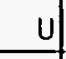 & $\ldots$ \\
\hline Butylbenzylphthalate & 390 & $\mathrm{U}$ & - & 350 & $\mathrm{u}$ & - & 370 & $\mathrm{u}$ & - & 360 & $\mathrm{u}$ & - & 340 & 4 & - & 350 & 4 & $\ldots$ & 340 & $\mathrm{U}$ & -- \\
\hline 3,3'-Dichlorbenzidine & 780 & $\mathrm{u}$ & - & 690 & $u$ & - & 730 & $\mathrm{u}$ & -- & 720 & $u$ & -- & 690 & $u$ & - & 700 & U & $\ldots$ & 690 & $\mathrm{U}$ & $\ldots$ \\
\hline Benzo(a)Anthracene & 390 & $u$ & $\ldots$ & 350 & $\mathrm{u}$ & $\ldots$ & 370 & $\mathrm{u}$ & - & 360 & $\mathrm{U}$ & $\ldots$ & 340 & 4 & -- & 350 & $u$ & $\ldots$ & 340 & $\mathrm{U}$ & -- \\
\hline Chrysene & 390 & 4 & $-\infty$ & 350 & $\mathrm{u}$ & $\ldots$ & 370 & $\mathrm{u}$ & -- & 360 & $\mathrm{u}$ & - & 340 & 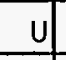 & - & 350 & 4 & $\ldots$ & 340 & $\mathrm{U}$ & $\ldots$ \\
\hline Bis (2-Ethylhexyl)Phthalate & 43 & $\mathrm{~J}$ & -- & 48 & $\mathrm{~J}$ & $-\infty$ & 68 & $\mathrm{~J}$ & $\ldots$ & 91 & $\mathrm{~J}$ & $-\ldots$ & 57 & J & $-\ldots$ & 54 & J) & -- & 340 & $u$ & $\ldots$ \\
\hline Di-n-Octyl Phthalate & 390 & $u$ & $\ldots$ & 350 & $u$ & -- & 370 & $\mathrm{U}$ & -- & 360 & $u$ & -- & 340 & $\mathrm{u}$ & $\ldots$ & 350 & 4 & $\ldots$ & 340 & 4 & -- \\
\hline Benzo(b)Fluoranthene & 390 & $u$ & $\ldots$ & 350 & $\mathrm{u}$ & - & 370 & $\mathrm{u}$ & - & 360 & $\mathrm{U}$ & - & 340 & $u$ & $\ldots$ & 350 & $u$ & $\ldots$ & 340 & 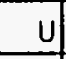 & -- \\
\hline Benzo(k)Fluoranthene & 390 & 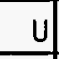 & - & 350 & $\mathrm{U}$ & -- & 370 & $u$ & $\ldots$ & 360 & 4 & $\ldots$ & 340 & 4 & -- & 350 & $u$ & -- & 340 & 4 & -- \\
\hline Benzo(a)Pyrene & 390 & $\mathrm{u}$ & $\ldots$ & 350 & $\mathrm{U}$ & -- & 370 & $u$ & -- & 360 & $\mathrm{U}$ & --- & 340 & $\mathrm{U}$ & -- & 350 & 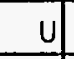 & $\ldots$ & 340 & $\mathrm{U}$ & $\ldots$ \\
\hline Indeno(1,2,3-cd)Pyrene & 390 & $u$ & -- & 350 & $\mathrm{U}$ & -- & 370 & $u$ & $\ldots$ & 360 & $\mathrm{u}$ & -- & 340 & $u$ & - & 350 & $u$ & -- & 340 & 4 & -- \\
\hline Dibenz $(a, h)$ Anthracene & 390 & $U$ & -- & 350 & $\mathrm{U}$ & -- & 370 & $\mathrm{U}$ & $\ldots$ & 360 & $\mathrm{u}$ & $\cdots$ & 340 & $u$ & $\ldots$ & 350 & 4 & -- & 340 & 4 & -- \\
\hline Benzo(g,h,i)Perylene & 390 & $u$ & UJ & 350 & $u$ & UJ & 370 & & $\mathrm{UJ}$ & 360 & $\mathrm{u}$ & UJ & 340 & $u$ & $\ldots$ & 350 & $u$ & $-\cdots$ & 340 & $\mathrm{U}$ & UJ \\
\hline
\end{tabular}




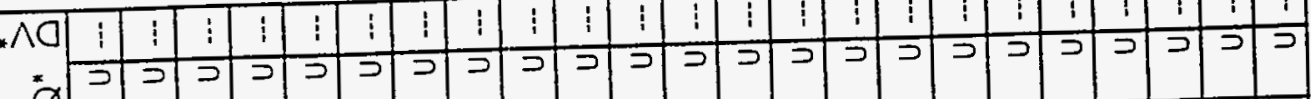
SS-J9L-SVS

\section{๑}

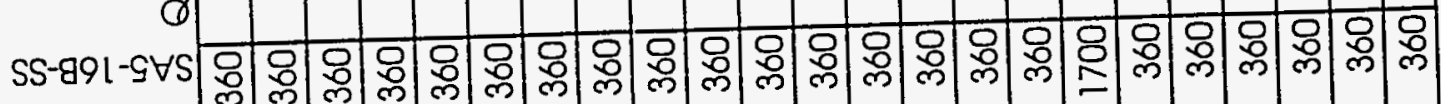
(20)

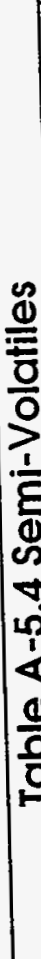

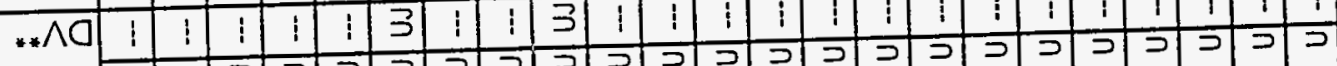

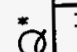

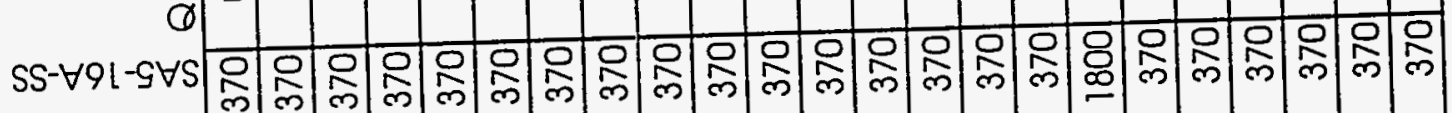

๑

SS- 9 I- $\forall$ S

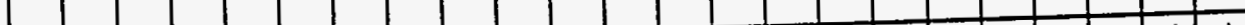

\begin{tabular}{llllllllllllllllllllllllllll} 
& 1 & 1 & 1 & 1 & 1 & 1 & 1 & 1 & 1 & 1 & 1 & 1 & 1 & 1 & 1 & 1 & 1 & 1 & 1 & 1 & 1 & 1 & 1 \\
\hline
\end{tabular} 


\begin{tabular}{|c|c|c|c|c|c|c|c|c|c|c|c|c|c|c|c|c|c|c|c|c|c|}
\hline \multirow[b]{2}{*}{ Compound (ug/Kg) } & \multicolumn{21}{|c|}{ Table A-5.4 Semi-Volatiles } \\
\hline & 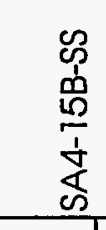 & & 光 & 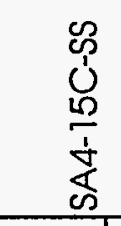 & $Q^{*}$ & & 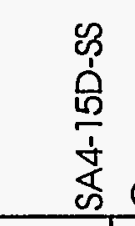 & $Q^{\prime \prime}$ & 苛 & 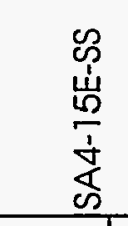 & $Q^{*}$ & $\stackrel{2}{0}^{*}$ & 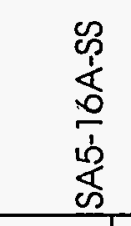 & $Q^{*}$ & 莒 & 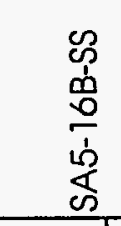 & $Q^{*}$ & 艾 & 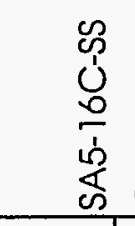 & $Q^{*}$ & 䓪 \\
\hline 4-Chloro-3-Methylphenol & 390 & U) & -- & 370 & 4 & -- & 380 & U. & -- & 380 & $u$ & $-\ldots$ & 370 & u & $-\ldots$ & 360 & $\mathrm{u}$ & $-\cdots$ & 360 & $\mathrm{u}$ & $\ldots$ \\
\hline 2-Methylnaphthalene & 390 & $\mathrm{u}$ & $-\cdots$ & 370 & $\mathrm{u}$ & $\ldots$ & 380 & $u$. & - & 380 & $u$ & - & 370 & $u$ & - & 360 & 4 & $\ldots$ & 360 & $\mathrm{u}$ &.- \\
\hline Hexachlorocyclopentadiene & 390 & $u$ & $\ldots$ & 370 & $u$ & $\ldots$ & 380 & 4. & -- & 380 & $u$ & $\ldots$ & 370 & 4 & - & 360 & 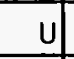 & $\ldots$ & 360 & 4 & -- \\
\hline 2,4,6-Trichlorophenol & 390 & 4 & $-\ldots$ & 370 & 4 & - & 380 & $\mathrm{u}$ & - & 380 & $\mathrm{U}$ & $\ldots$ & 370 & 4 & - & 360 & U & -- & 360 & $\mathrm{U}$ & $\ldots$ \\
\hline 2,4.5-Trichlorophenol & 1900 & 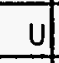 & - & 1800 & $u$ & - & 1900 & $\mathrm{u}$. & $\ldots$ & 1900 & $\mathrm{u}$ & $\ldots$ & 1800 & u & - & 1700 & $u$ & $\ldots$ & 1700 & $u$ & $\ldots$ \\
\hline 2-Chloronaphthalene & 390 & $u$ & - & 370 & $u$ & - & 380 & $u$. & $\ldots$ & 380 & $u$ & $\ldots$ & 370 & $u$ & $\ldots$ & 360 & U) & $\ldots$ & 360 & $\mathrm{u}$ & - \\
\hline 2-Nitroaniline & 1900 & 4 & -- & 1800 & 4 & - & 1900 & $\mathrm{U}$. & -- & 1900 & $u$ & $\ldots$ & 1800 & 4 & -- & 1700 & 4 & -- & 1700 & 4 & $\ldots$ \\
\hline Dimethyl Phthalate & 390 & $u$ & $\ldots$ & 370 & $\mathrm{U}$ & - & 380 & $u$. & -- & 380 & $\mathrm{u}$ & - & 370 & 4 & -- & 360 & 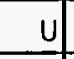 & $-\infty$ & 360 & $u$ & $\ldots$ \\
\hline Acenaphthylene & 390 & $u$ & $\ldots$ & 370 & $u$ & - & 380 & $u$. & $\ldots$ & 380 & u & -- & 370 & u & $-{ }_{-1}$ & 360 & $\mathrm{u}$ & $\ldots$ & 360 & $u$ & -- \\
\hline 2,6-Dinitrotoluene & 390 & $\mathrm{U}$ & -- & 370 & $\mathrm{u}$ & - & 380 & $u$. & -- & 380 & $\mathrm{U}$ & - & 370 & $u$ & -- & 360 & 4 & -- & 360 & $u$ & $\ldots$ \\
\hline 3-Nitroaniline & 1900 & 4 & $\ldots$ & 1800 & $\mathrm{u}$ & $\ldots$ & 1900 & U. & $\ldots$ & 1900 & $\mathrm{u}$ & -- & 1800 & $u$ & -- & 1700 & $u$ & $\ldots$ & 1700 & U & -- \\
\hline Acenaphthene & 390 & $u$ & $\ldots$ & 370 & $\mathrm{u}$ & - & 380 & 4 & - & 380 & $u$ & $\ldots$ & 370 & 4 & $=$ & 360 & 4 & - & 360 & 4 & $\ldots$ \\
\hline 2,4-Dinitrophenol & 1900 & $u$ & - & 1800 & $u$ & $\ldots$ & 1900 & $u$ & - & 1900 & $\mathrm{U}$ & -- & 1800 & U & $\ldots$ & 1700 & $\mathrm{U}$ & -- & 1700 & U. & $\cdots$ \\
\hline 4-Nitrophenol & 1900 & 4 & -- & 1800 & $\mathrm{U}$ &.- & 1900 & $\mathrm{u}$. & -- & 1900 & $u$ & - & 1800 & 4 & -- & 1700 & 4 & -- & 1700 & $u$ &.- \\
\hline Dibenzofuran & 390 & 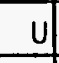 & $\ldots$ & 370 & $\mathrm{U}$ & - & 380 & $\mathrm{u}$ & $\ldots$ & 380 & $\mathrm{U}$ & - & 370 & u & $-\ldots$ & 360 & $\mathrm{U}$ & $\ldots$ & 360 & $u$ & - \\
\hline 2,4-Dinitrotoluene & 390 & $\mathrm{U}$ & - & 370 & $u$ & -- & 380 & $u$ & $-\ldots$ & 380 & 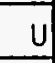 & - & 370 & 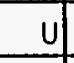 & -- & 360 & 4 & $\ldots$ & 360 & 4 & $\ldots$ \\
\hline Diethylphthalate & 390 & $u$ & -- & 370 & $\mathrm{U}$ & $\ldots$ & 380 & 4 & $-\ldots$ & 380 & $\underline{u}$ & - & 370 & 4 & - & 360 & $\mathrm{U}$ & -- & 360 & 4 & $\ldots$ \\
\hline 4-Chlorophenyl-phenylether & 390 & $u$ & $-\ldots$ & 370 & $\mathrm{U}$ & $-\cdots$ & 380 & $u$ & --- & 380 & $u$ & $\ldots$ & 370 & $u$ & $\ldots$ & 360 & 4 & $\ldots$ & 360 & 4 & -- \\
\hline Fluorene & 390 & $\mathrm{U}$ & - & 370 & $\underline{U}$ & - & 380 & 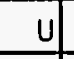 & - & 380 & $\mathrm{U}$ & $-\ldots$ & 370 & U & -- & 360 & 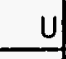 & -- & 360 & 4 & - \\
\hline 4-Nitroaniline & 1900 & $u$ & -- & 1800 & $\mathrm{u}$ & - & 1900 & $u$ & - & 1900 & $\underline{U}$ & - & 1800 & 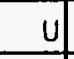 & $\ldots$ & 1700 & $\mathrm{U}$ & - & 1700 & 4 & - \\
\hline 4,6-Dinitro-2-Methylphenol & 1900 & $u$ & -- & 1800 & $\mathrm{U}$ & - & 1900 & U) & - & 1900 & $\underline{u}$ & -- & 1800 & 4 & -1 & 1700 & $u$ & $\ldots$ & 1700 & $u$ & -- \\
\hline N-Nitrosodiphenylamine (1) & 390 & $u$ & - & 370 & $u$ & $\ldots$ & 380 & $u$ & - & 380 & $\mathrm{u}$ & $\ldots$ & 370 & $u$ & $-\infty$ & 360 & 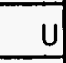 & $-\ldots$ & 360 & $\mathrm{u}$ & - \\
\hline 4-Bromophenyl-phenylether & 390 & $\mathrm{u}$ & - & 370 & $u$ & - & 380 & u & $-\infty$ & 380 & & - & 370 & $\mathrm{u}$ & - & 360 & $\mathrm{u}$ & - & 360 & & $\ldots$ \\
\hline
\end{tabular}




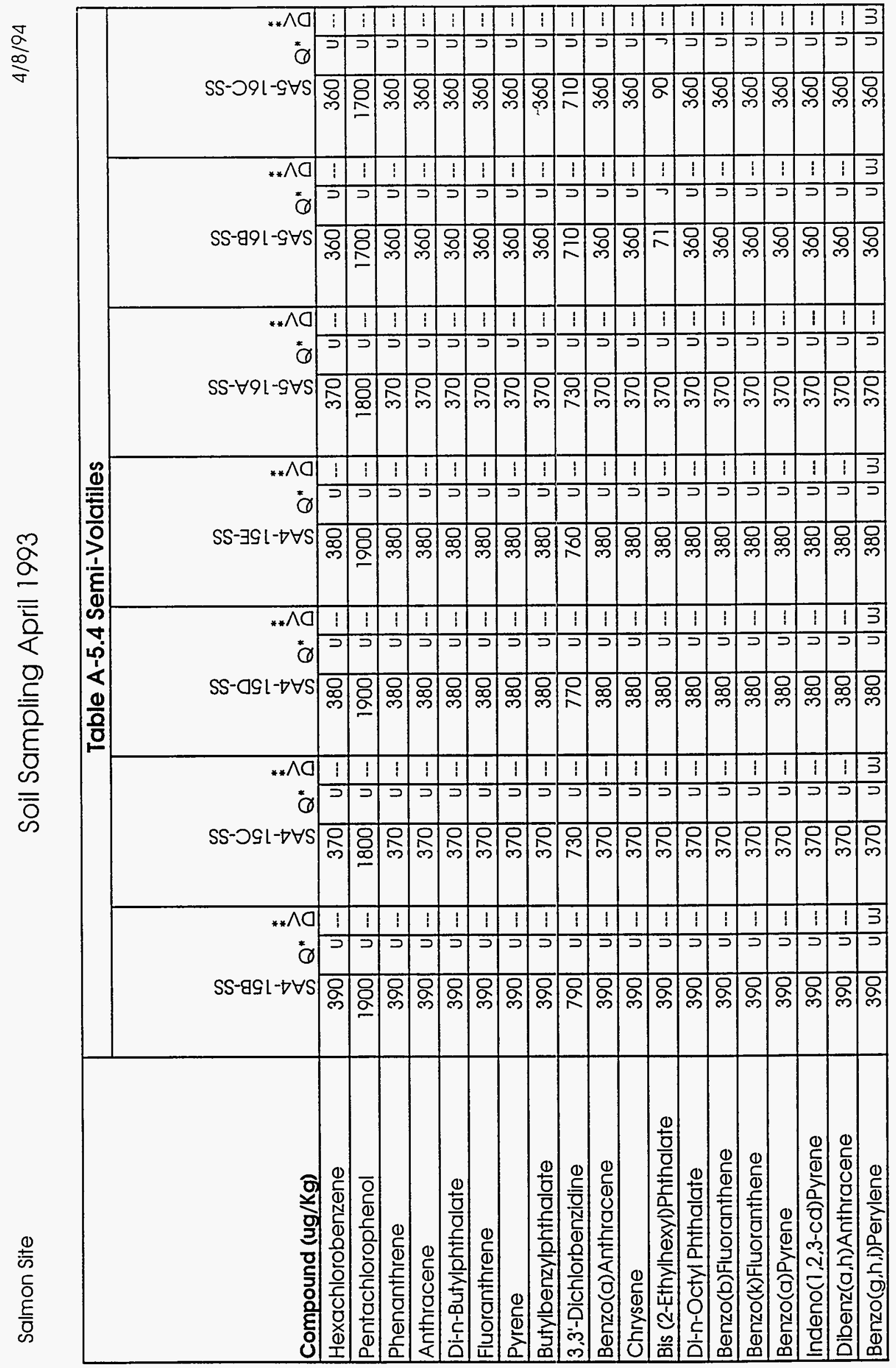




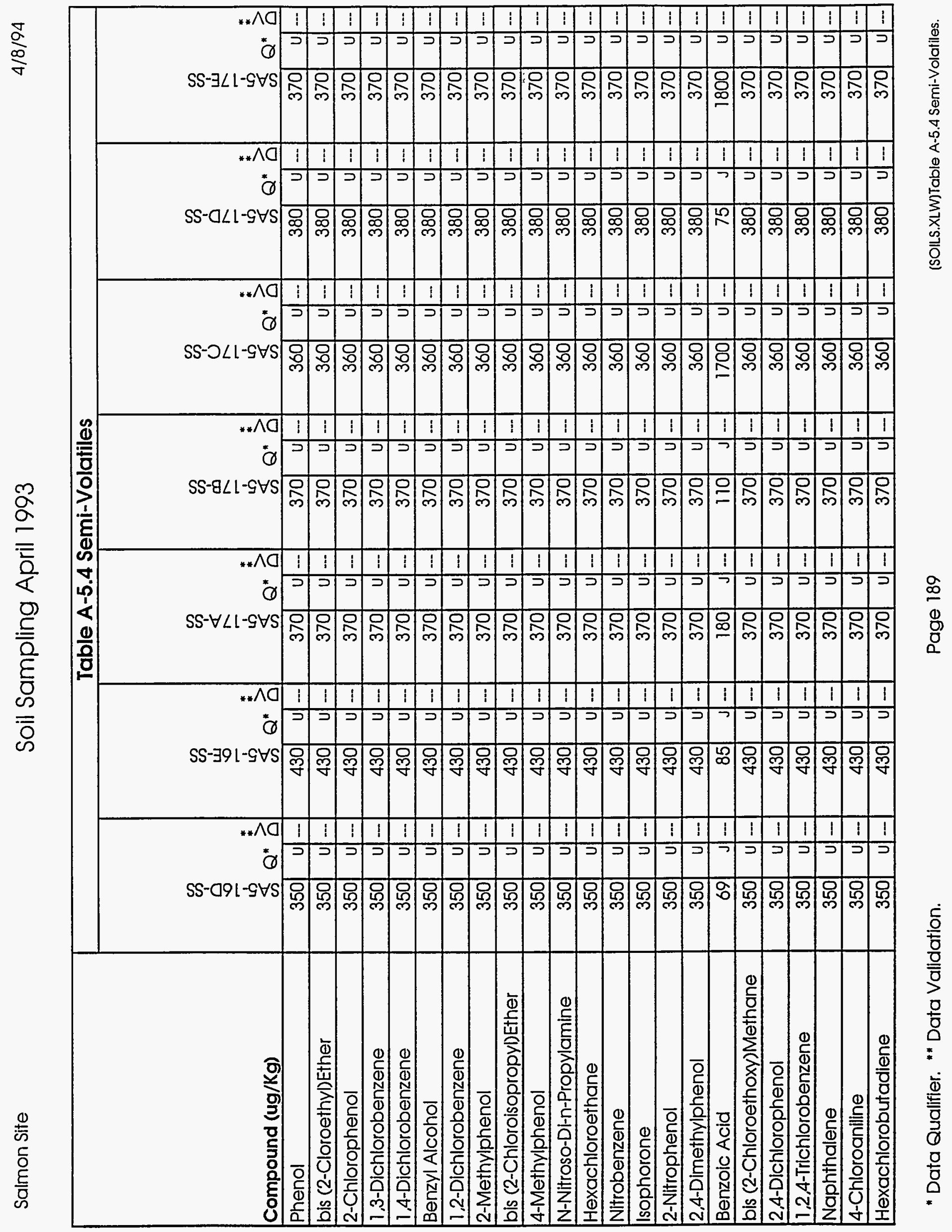




\begin{tabular}{|c|c|c|c|c|c|c|c|c|c|c|c|c|c|c|c|c|c|c|c|c|c|}
\hline \multirow[b]{2}{*}{ Compound (ug/Kg) } & \multicolumn{21}{|c|}{ Table A-5.4 Semi-Volatiles } \\
\hline & 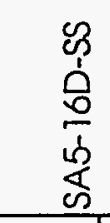 & & $\stackrel{*}{*}$ & 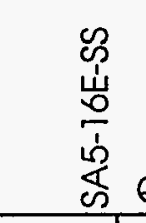 & & & 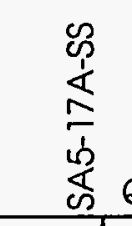 & & 艾 & 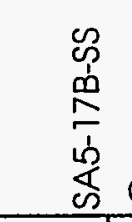 & $Q^{*}$ & ${ }^{*}$ & 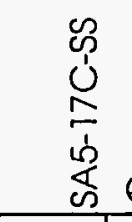 & & $\stackrel{*}{*}$ & 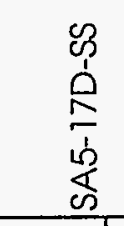 & $Q^{*}$ & 兌 & 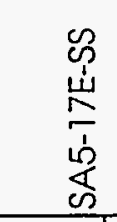 & & 草 \\
\hline 4-Chloro-3-Methylphenol & 350 & 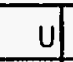 & -- & 430 & $u$ & $-\infty$ & 370 & u) & - & 370 & U & $\ldots$ & 360 & $u$. & $-\ldots$ & 380 & U & $-\infty$ & 370 & $\mathrm{u}$ & $-\ldots$ \\
\hline 2-Methylnaphthalene & 350 & 4 & - & 430 & 4 & $\ldots$ & 370 & $u$ & $\ldots$ & 370 & 4 & $\ldots$ & 360 & 4. & $\ldots$ & 380 & 4 & $-{ }_{-1}$ & 370 & 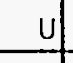 & - \\
\hline Hexachlorocyclopentadlene & 350 & 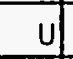 & - & 430 & U) & $\ldots$ & 370 & $\mathrm{U}$ & $-\ldots$ & 370 & $u$ & $\ldots+$ & 360 & 4. & $\ldots$ & 380 & 0 & $\ldots$ & 370 & U & $\ldots$ \\
\hline 2,4,6-Trichlorophenol & 350 & 4 & - & 430 & 4 & -- & 370 & $\mathrm{U}$ & $-\ldots$ & 370 & U & \begin{tabular}{|l|}
$-\ldots$ \\
\end{tabular} & 360 & 4. & $\ldots$ & 380 & 4 & $-\cdots$ & 370 & 4 & $-\infty$ \\
\hline 2,4,5-Trichlorophenol & 1700 & 4 & - & 2100 & 4 & -- & 1800 & $\mathrm{u}$ & $-\ldots$ & 1800 & $u$ & $\ldots$ & 1700 & 4. & $-\ldots$ & 1900 & 4 & $\ldots$ & 1800 & 4 & - \\
\hline 2-Chloronaphthalene & 350 & 4 & - & 430 & $u$ & -- & 370 & $\mathrm{u}$ & $\ldots$ & 370 & 4 & $-\ldots$ & 360 & 4 & \begin{tabular}{|l|l}
- & 0 \\
\end{tabular} & 380 & 4 & $\ldots$ & 370 & 4 & $\cdots$ \\
\hline 2-Nitroaniline & 1700 & 4 &.- & 2100 & $U$ & -- & 1800 & $u$ & -- & 1800 & 4 & $-\ldots$ & 1700 & 4. & $\ldots$ & 1900 & U & -- & 1800 & 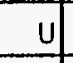 & -- \\
\hline Dimethyl Phthalate & 350 & 4 & $-\ldots$ & 430 & 4 & $\ldots$ & 370 & $u$ & $\ldots$ & 370 & $u$ & $\ldots$ & 360 & 4 & $-\ldots$ & 380 & 4 & $\ldots$ & 370 & 0 & $\ldots$ \\
\hline Acenaphthylene & 350 & 4 & -- & 430 & 4 & $-\cdots$ & 370 & 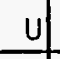 & -- & 370 & 4 & $\cdots$ & 360 & 4 & $\ldots$ & 380 & $u$ & - & 370 & u & $\ldots$ \\
\hline 2,6-Dinitrotoluene & 350 & $u$ & - & 430 & $u$ & - & 370 & $u$ & -- & 370 & U) & $-\cdots$ & 360 & U. & -- & 380 & $u$ & -- & 370 & $u$ & $\ldots$ \\
\hline 3-Nitroaniline & 1700 & 4 & -- & 2100 & 4 & $\ldots$ & 1800 & $\mathrm{U}$ & \begin{tabular}{|l|l}
-- & \\
\end{tabular} & 1800 & 4 & $\ldots$ & 1700 & 4 & $\ldots$ & 1900 & $! !$ & - & 1800 & $u$ & $\ldots$ \\
\hline Acenaphthene & 350 & 4 & -- & 430 & 4 & -- & 370 & $\mathrm{U}$ & $-\infty$ & 370 & $\mathrm{u}$ & $-\infty$ & 360 & 4 & $\ldots$ & 380 & $u$ & \begin{tabular}{|l|}
- \\
\end{tabular} & 370 & 4 & - \\
\hline 2,4-Dinitrophenol & 1700 & U) & $\ldots$ & 2100 & u) & $\ldots$ & 1800 & 4 & \begin{tabular}{|l|l|}
$-\infty$ & \\
\end{tabular} & 1800 & $u$ & - & 1700 & 4 & -- & 1900 & 4 & $\ldots$ & 1800 & 4 & $\ldots$ \\
\hline 4-Nitrophenol & 1700 & 4 & -- & 2100 & 4 & $\ldots$ & 1800 & $\mathrm{u}$ & -- & 1800 & 4 & $-{ }_{-1}$ & 1700 & 4 & $\ldots$ & 1900 & 4 & $\ldots$ & 1800 & 4 & $\ldots$ \\
\hline Dibenzofuran & 350 & 4 & - & 430 & $\mathrm{u}$ & - & 370 & 4 & $\ldots$ & 370 & $u$ & $-\infty$ & 360 & 4 & -- & 380 & 4 & $\ldots$ & 370 & 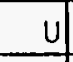 & -- \\
\hline 2,4-Dinitrotoluene & 350 & 4 & -- & 430 & 4 & -- & 370 & 4 & $\ldots$ & 370 & u. & $-\cdots$ & 360 & 4 & $\ldots$ & 380 & $\underline{4}$ & $-\cdots$ & 370 & 4 & -- \\
\hline Diethylphthalate & 350 & $u$ & -- & 430 & 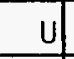 & $\ldots$ & 370 & U) & -- & 370 & $\mathrm{U}$ & $\ldots$ & 360 & 4 & -- & 380 & 4 & -- & 370 & $\mathrm{u}$ & -- \\
\hline 4-Chlorophenyl-phenylether & 350 & 4 & $\ldots$ & 430 & 4 & $\ldots$ & 370 & 4 & -- & 370 & 4 & $\ldots$ & 360 & 4 & -- & 380 & 4 & $\ldots$ & 370 & 4 & - \\
\hline Fluorene & 350 & 4 & -- & 430 & 4 & -- & 370 & $\mathrm{u}$ & -- & 370 & 4 & --- & 360 & 4 & - & 380 & $\mathrm{U}$ & $\ldots$ & 370 & 4 &.- \\
\hline 4-Nitroaniline & 1700 & 4 & - & 2100 & 4 & -- & 1800 & 4 & - & 1800 & 4 & -- & 1700 & 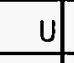 & $\ldots$ & 1900 & 4 & -- & 1800 & 4 & --- \\
\hline 4,6-Dinitro-2-Methylphenol & 1700 & 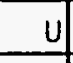 & - & 2100 & 4 & $\ldots$ & 1800 & 4 & - & 1800 & 4 & $\ldots$ & 1700 & U) & $\ldots$ & 1900 & $\mathrm{u}$ & -- & 1800 & $\mathrm{u}$ & $\ldots$ \\
\hline N-Nitrosodiphenylamine (1) & 350 & 4 & - & 430 & 4 & - & 370 & $u$ & - & 370 & $u$ & - & 360 & 4 & - & 380 & 4 & $\ldots$ & 370 & 4 &.- \\
\hline 4-Bromophenyl-phenylether & 350 & $\mathrm{u}$ & - & 430 & $u$ & - & 370 & & - & 370 & 4 & $\ldots$ & 360 & U) & - & 380 & $u$ & $\ldots$ & 370 & & -- \\
\hline
\end{tabular}




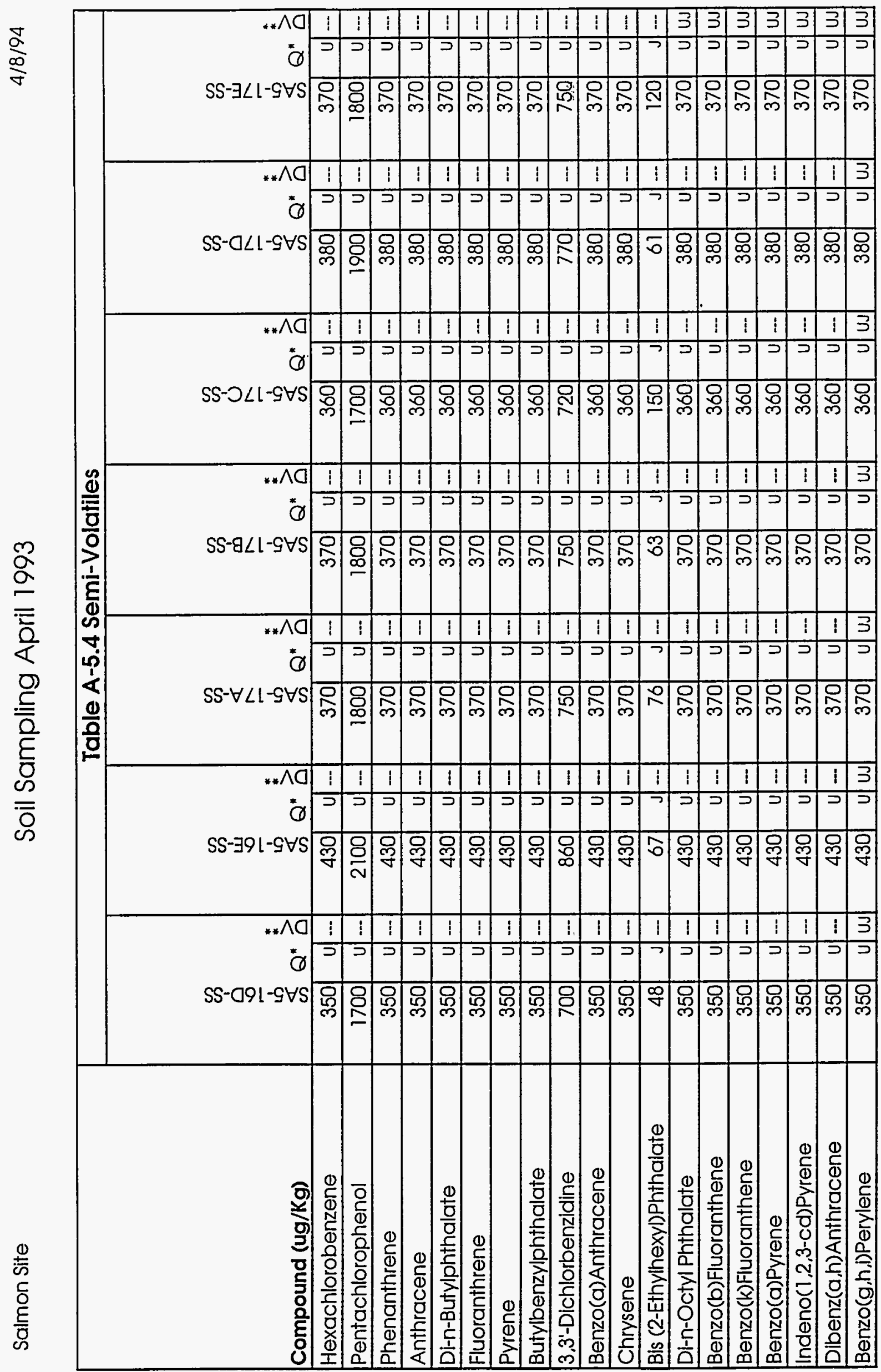


* $\wedge$ (

๑

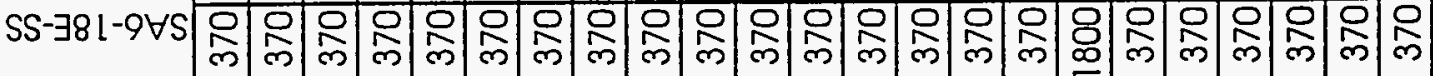

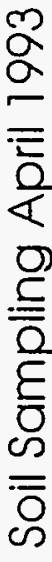

SS-08L-94S

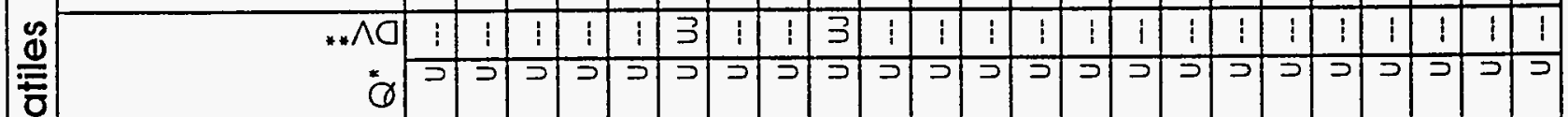

0
$\frac{1}{8}$
$\frac{8}{0}$
0
0
$\frac{1}{2}$
$\frac{1}{0}$
$\frac{0}{0}$

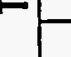

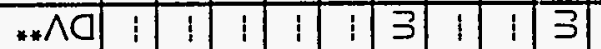

$\stackrel{*}{\varnothing}$

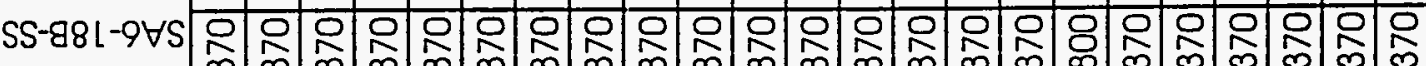

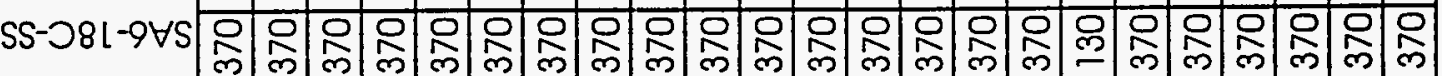

$\frac{\Omega}{2}$

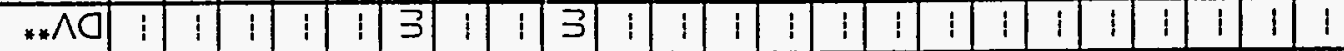

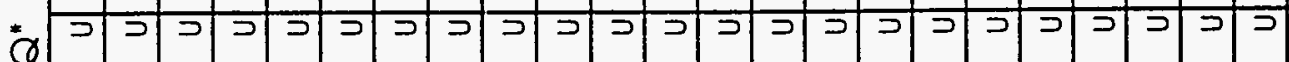

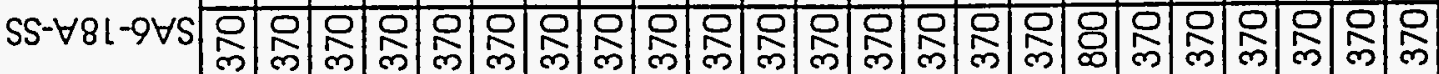




\begin{tabular}{|c|c|c|c|c|c|c|c|c|c|c|c|c|c|c|c|c|c|c|c|c|c|}
\hline \multirow[b]{2}{*}{ Compound (ug/Kg) } & \multicolumn{21}{|c|}{ Table A-5.4 Semi-Volatiles } \\
\hline & 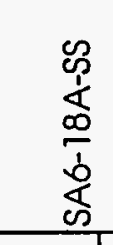 & & $\stackrel{3}{0}^{*}$ & 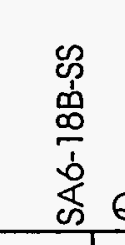 & & ${ }^{*}$ & 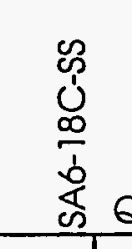 & & & 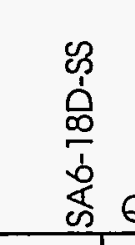 & & $\overbrace{}^{*}$ & 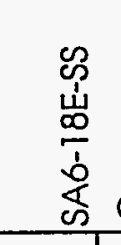 & & & 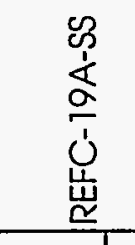 & & 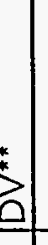 & 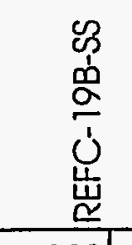 & & 莡 \\
\hline 4-Chloro-3-Methylphenol & 370 & $\mathrm{u}$ & - & 370 & U. & - & 370 & $u=$ & - & \begin{tabular}{l|l}
360 \\
\end{tabular} & $u$ & $-\ldots$ & 370 & $4=$ & - & 350 & & - & 380 & $u$ & $\ldots$ \\
\hline 2-Methylnaphthalene & 370 & 4. & - & 370 & 4. & $\ldots$ & 370 & 4. & $\ldots$ & 360 & $\mathrm{u}$. & $\ldots$ & 370 & U. & - & 350 & U. & 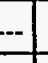 & 380 & 4 & $\ldots$ \\
\hline Hexachlorocyclopentadiene & 370 & 4. & - & 370 & $4=$ & - & 370 & 0. & - & 360 & 0. & - & 370 & $4=$ & $\ldots$ & 350 & U & $\ldots$ & 380 & 4 & $\ldots$ \\
\hline 2,4,6-Trichlorophenol & 370 & 0. & -- & 370 & $u$. & -- & 370 & 4. & - & 360 & 4. & $\ldots$ & 370 & 4. & $\cdots$ & 350 & & - & 380 & 4 & -- \\
\hline 2,4,5-Trichlorophenol & 1800 & 4. & -- & 1800 & $\mathrm{U}=$ & - & 1800 & $4=$ & -- & 1700 & $\mathrm{u}$. & - & 1800 & U. & - & 1700 & $\mathrm{u}-$ & - & 1800 & 4 & $\ldots$ \\
\hline 2-Chloronaphthalene & 370 & 4. & $\ldots$ & 370 & 4. & - & 370 & u. & -- & 360 & 4 & -- & 370 & $4=$ & $\ldots$ & 350 & $\mathrm{u}=$ & 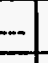 & 380 & 4 & $\ldots$ \\
\hline 2-Nitroaniline & 1800 & 4. & - & 1800 & 4. & $\ldots$ & 1800 & 4. & -- & 1700 & 4. & -- & 1800 & $4=$ & $\ldots$ & 1700 & u. $=$ & - & 1800 & u & $\cdots$ \\
\hline Dimethyl Phthalate & 370 & 4. & - & 370 & $4=$ & $\ldots$ & 370 & 4. & - & 360 & 4. & $\ldots$ & 370 & 4. & $\ldots$ & 350 & 4 & - & 380 & 4 & $\ldots$ \\
\hline Acenaphthylene & 370 & 4. & -- & 370 & $4-$ & - & 370 & 4. & -- & 360 & $u$. & $\ldots$ & 370 & U. & - & 350 & & -- & 380 & 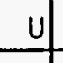 & --- \\
\hline 2.6-Dinitrotoluene & 370 & 4. & $\ldots$ & 370 & U. & - & 370 & 4. & - & 360 & 4. & - & 370 & 4. & -- & 350 & u. & - & 380 & $u$ & $\ldots$ \\
\hline 3-Nitroaniline & 1800 & 4. & - & 1800 & U. & $\ldots$ & 1800 & u. & $\ldots$ & 1700 & $u$. & -- & 1800 & 4. & $\cdots$ & 1700 & U. & $\cdots$ & 1800 & u) & -- \\
\hline Acenaphthene & 370 & 4 & $\ldots$ & 370 & 4. & $\ldots$ & 370 & $4=$ & $\cdots$ & 360 & $u$. & $\ldots$ & 370 & $\mathrm{u}=$ & -- & 350 & U. & $\ldots$ & 380 & $u$ & $\ldots$ \\
\hline 2,4-Dinitrophenol & 1800 & 4. & $\ldots$ & 1800 & $4=$ & $\ldots$ & 1800 & u. - & - & 1700 & 4. & - & 1800 & $4=$ & - & 1700 & U. & $\cdots$ & 1800 & u & - \\
\hline 4-Nitrophenol & 1800 & 4 & -- & 1800 & U. & $\ldots$ & 1800 & $u-$ & $\ldots$ & 1700 & $u$. & $\ldots$ & 1800 & U. & -- & 1700 & U. &.- & 1800 & $u$ & $\ldots$ \\
\hline Dibenzofuran & 370 & 4 & -- & 370 & 0. & - & 370 & 4. & $\cdots$ & 360 & 4. & $\ldots$ & 370 & 4. & - & 350 & U. & $\ldots$ & 380 & 4 & $=$ \\
\hline 2.4-Dinitrotoluene & 370 & 4. & - & 370 & 4. & -- & 370 & u. & $\ldots$ & 360 & 0 & -- & 370 & 4. & -- & 350 & 4. & $\ldots$ & 380 & 4 & -- \\
\hline Diethylphthalate & 370 & 4 & $\ldots$ & 370 & 4. & $\ldots$ & 370 & 4. & $\ldots$ & 360 & 4. & $\ldots$ & 370 & 4. & --- & 350 & 4 & -- & 380 & 4 & $\cdots$ \\
\hline 4-Chlorophenyl-phenylether & 370 & U. & -- & 370 & U. & -- & 370 & $u$ & -- & 360 & $u$. & -- & 370 & U. & -- & 350 & 4. & - & 380 & 4 & $\cdots$ \\
\hline Fluorene & 370 & 4 & - & 370 & 4. & $\ldots+$ & 370 & 4. & -- & 360 & 4 & -- & 370 & 4. & $\ldots$ & 350 & u. & $\ldots$ & 380 & U & $\ldots$ \\
\hline 4-Nitroanilline & 1800 & 4 & -- & 1800 & 4. & - & 1800 & ㄴ. & -- & 1700 & $u$ & $\ldots$ & 1800 & 4. & -- & 1700 & 4 & -- & 1800 & 4 & $-\cdots$ \\
\hline 4.6-Dinitro-2-Methylphenol & 1800 & 0 & $-\infty$ & 1800 & U. & - & 1800 & $u$. & - & 1700 & $u$ & $\ldots$ & 1800 & 4. & -- & 1700 & 4. & -- & 1800 & 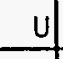 & -- \\
\hline N-Nitrosodiphenylamine (1) & 370 & 4 & - & 370 & $\mathrm{u}$. & -- & 370 & 4. & - & 360 & u & $\ldots$ & 370 & $\mathrm{u}$ & - & 350 & 4. & $\cdots$ & 380 & u & - \\
\hline 4-Bromophenyl-phenylether & 370 & u) & - & 370 & U. & -1 & 370 & u]. & - & 360 & & $\ldots$ & 370 & u. & -1 & 350| & & $\cdots$ & 380 & & $\leftarrow$ \\
\hline
\end{tabular}

"Data Qualifier. "* Data Validation.
Page 193 


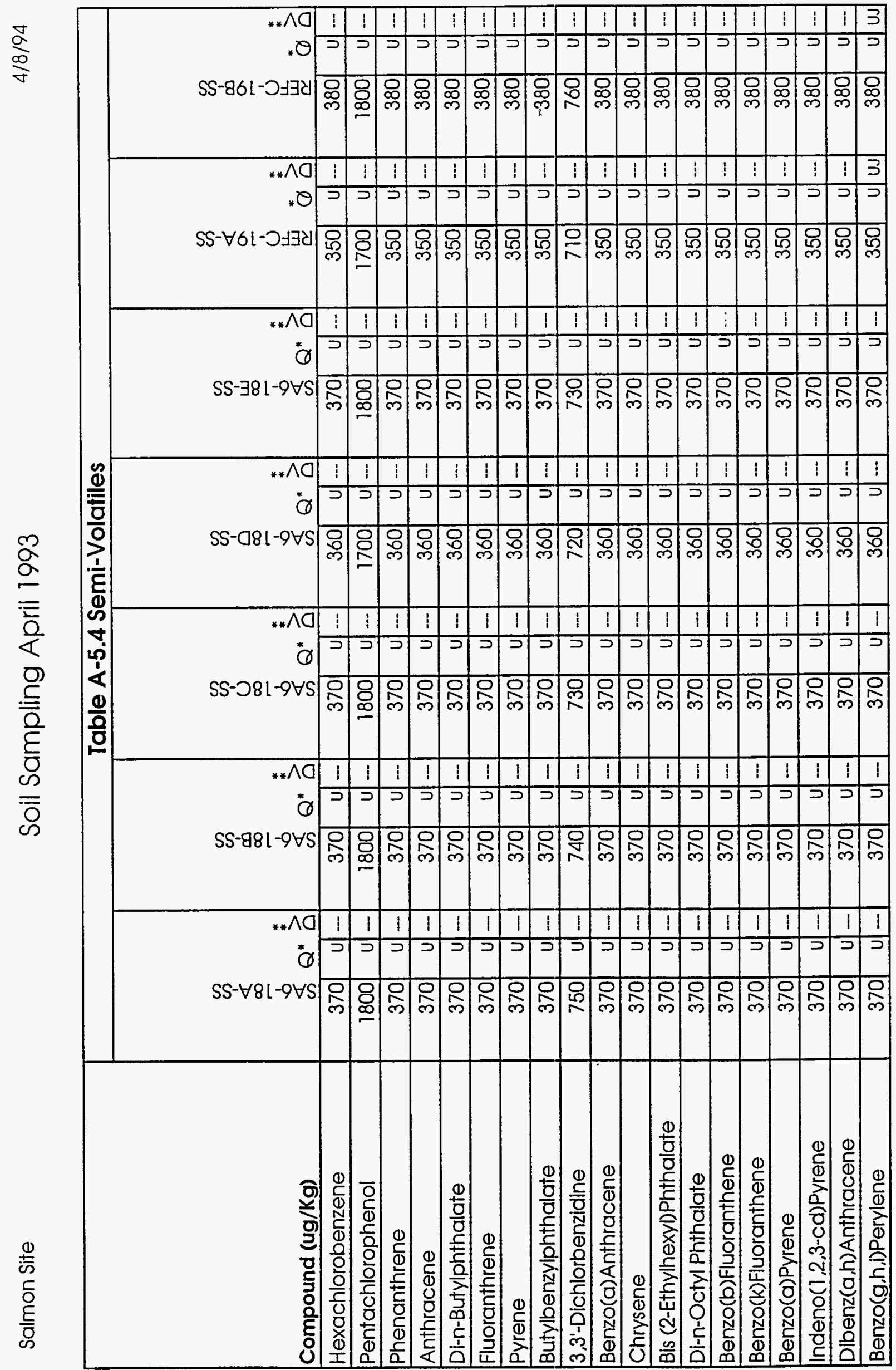

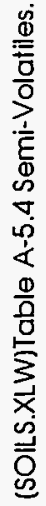

வ
$\frac{1}{0}$
0
0
0 


\begin{tabular}{|c|c|c|c|c|c|c|c|c|c|}
\hline \multirow[b]{2}{*}{ Compound (ug/Kg) } & \multicolumn{9}{|c|}{ Table A-5.4 Semi-Volatiles } \\
\hline & 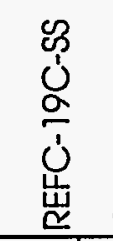 & & & 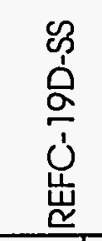 & & 艾 & 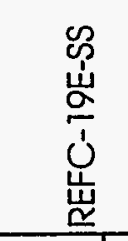 & $\stackrel{*}{\emptyset}$ & 草 \\
\hline Phenol & 450 & & - & 340 & $\mathrm{u}$ & - & 350 & $u$ & $\ldots$ \\
\hline bis (2-Cloroethyl)Ether & 450 & U & - & 340 & 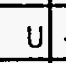 & $\ldots$ & 350 & $\mathrm{U}$ & -- \\
\hline 2-Chlorophenol & 450 & U. & $\ldots$ & 340 & $\mathrm{U}$ & -- & 350 & 4 & - \\
\hline 1,3-Dichlorobenzene & 450 & & - & 340 & u. & -- & 350 & U. & $\ldots$ \\
\hline 1.4-Dichlorobenzene & 450 & U) & - & 340 & 4 & $-\ldots$ & 350 & 4 & - \\
\hline Benzyl Alcohol & 450 & U.- & - & 340 & 4 & - & 350 & 4 & - \\
\hline 1,2-Dichlorobenzene & 450 & $\mathrm{u}$. & - & 340 & 4 & $\ldots$ & 350 & 4 & - \\
\hline 2-Methylphenol & 450 & $\mathrm{u}=$ & $\ldots$ & 340 & U. & - & 350 & u & -- \\
\hline bis (2-Chloroisopropyl)Ether & 450 & u. & - & 340 & $u$ & -- & 350 & $u$ & - \\
\hline 4-Methylphenol & 450 & $\mathrm{u}$ & - & 340 & 4. &.- & 350 & 0 & - \\
\hline N-Nitroso-DI-n-Propylamine & 450 & $\mathrm{u}$. & $\ldots$ & 340 & $\mathrm{u}$ & -- & 350 & 4 & - \\
\hline Hexachloroethane & 450 & U. & - & 340 & 4 & -- & 350 & $u$ & $\ldots$ \\
\hline Nitrobenzene & 450 & 4. & - & 340 & 4 & -- & 350 & 4 & $\ldots$ \\
\hline Isophorone & 450 & $\mathrm{U}$ & - & 340 & 4 &.- & 350 & 4 & $\ldots$ \\
\hline 2-Nitrophenol & 450 & 4. & - & 340 & ut & $\ldots$ & 350 & U) & -- \\
\hline 2,4-Dimethylphenol & 450 & $4-$ & - & 340 & 4 & $\ldots$ & 350 & 4 & - \\
\hline Benzolc Acid & 570 & J. & $\ldots$ & 99 & J) & $-\infty$ & 1700 & 4 & - \\
\hline bis (2-Chloroethoxy) Methane & 450 & U. & - & 340 & $u$ & $\ldots$ & 350 & 4 & -- \\
\hline 2,4-Dichlorophenol & 450 & $u$. & $\ldots$ & 340 & 4 & - & 350 & $u$ & - \\
\hline 1,2,4-Trichlorobenzene & 450 & $u$. & - & 340 & $u$ & - & 350 & $u$ & - \\
\hline Naphthalene & 450 & u. & - & 340 & U & - & 350 & $\mathrm{U}$ & $\ldots$ \\
\hline 4-Chloroaniline & 450 & $4=$ & - & 340 & u & - & 350 & $u$ & - \\
\hline Hexachlorobutadiene & 450 & U. & $\ldots$ & 340 & 4 & - & 350 & & - \\
\hline
\end{tabular}

"Data Qualifier. " Data Validation. 


\begin{tabular}{|c|c|c|c|c|c|c|c|c|c|}
\hline \multirow[b]{2}{*}{ Compound (ug/Kg) } & \multicolumn{9}{|c|}{ Table A-5.4 Semi-Volatiles } \\
\hline & 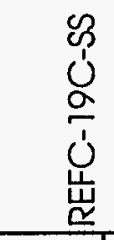 & & & 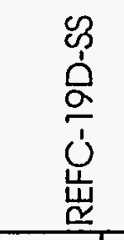 & & $\stackrel{2}{0}^{*}$ & 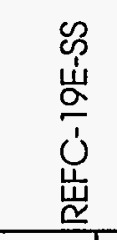 & $\stackrel{*}{\square}$ & 兌 \\
\hline 4-Chloro-3-Methylphenol & 450 & $u$ & -- & 340 & & - & 350 & 4 & - \\
\hline 2-Methylnaphthalene & 450 & 4 & - & 340 & $u$ & - & 350 & u & -- \\
\hline Hexachlorocyclopentadiene & 450 & $\mathrm{u}$ & -- & 340 & $\mathrm{u}$ & - & 350 & $u$ & - \\
\hline 2,4,6-Trichlorophenol & 450 & 4 & -- & 340 & $\mathrm{U}$ & - & 350 & 4 & - \\
\hline 2,4,5-Trichlorophenol & 2200 & 4 & - & 1600 & $\mathrm{U}$ & - & 1700 & $\mathrm{u}$ & $\ldots$ \\
\hline 2-Chloronaphthalene & 450 & $u$ & $\ldots$ & 340 & $u$ & $\ldots$ & 350 & 4 & -- \\
\hline 2-Nitroaniline & 2200 & U & -- & 1600 & 4 & -- & 1700 & 4 & -- \\
\hline Dimethyl Phthalate & 450 & 4 & -- & 340 & 4 & -- & 350 & 4 & $\ldots$ \\
\hline Acenaphthylene & 450 & 4 & -- & 340 & 4 & - & 350 & 4 & - \\
\hline 2.6-Dinitrotoluene & 450 & 4 & -- & 340 & $u$ & $\ldots$ & 350 & 4 & $\ldots$ \\
\hline 3-Nitroaniline & 2200 & 4 & $\ldots$ & 1600 & $u$ & - & 1700 & $u$ & -- \\
\hline Acenaphthene & 450 & 4 & - & 340 & 4 & $\ldots$ & 350 & 4 & - \\
\hline 2,4-Dinitrophenol & 2200 & U & $\ldots$ & 1600 & U & - & 1700 & $\mathrm{U}$ & $\ldots$ \\
\hline 4-Nitrophenol & 2200 & 4 & -- & 1600 & 4 & $\ldots$ & 1700 & 4 & - \\
\hline Dibenzofuran & 450 & 4 & -- & 340 & 4 & - & 350 & $\mathrm{U}$ & -- \\
\hline 2,4-Dinitrotoluene & 450 & 4 & -- & 340 & 4 & -- & 350 & 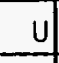 & - \\
\hline Diethylphthalate & 450 & 4 & $\ldots$ & 340 & $u$ & $\ldots$ & 350 & 4 & - \\
\hline 4-Chlorophenyl-phenylether & 450 & 4 & - & 340 & 4 & - & 350 & $u$ & $=$ \\
\hline Fluorene & 450 & 4 & - & 340 & 4 & $\ldots$ & 350 & $u$ & - \\
\hline 4-Nitroaniline & 2200 & ut & - & 1600 & 4 & - & 1700 & $\mathrm{U}$ & --- \\
\hline 4,6-Dinitro-2-Methylphenol & 2200 & 4 & $\ldots$ & 1600 & U) & - & 1700 & $\mathrm{u}$ & -- \\
\hline N-Nitrosodiphenylamine (1) & 450 & $u$ & 二 & 340 & $u$ & $\cdots$ & 350 & $u$ & - \\
\hline 4-Bromophenyl-phenylether & 450 & u) & - & 340 & & - & 350 & & - \\
\hline
\end{tabular}

" Data Qualifier. " " Data Validation. 


\begin{tabular}{|c|c|c|c|c|c|c|c|c|c|}
\hline \multirow[b]{2}{*}{ Compound (ug/Kg) } & \multicolumn{9}{|c|}{ Table A-5.4 Semi-Volatiles } \\
\hline & 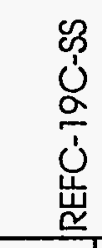 & & & 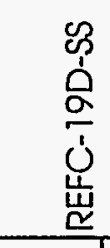 & 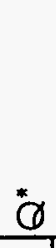 & 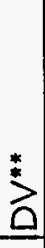 & 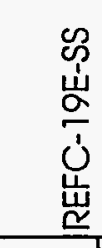 & & $\stackrel{3}{0}^{*}$ \\
\hline Hexachlorobenzene & 450 & 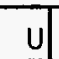 & $\ldots$ & 340 & $\mathrm{u}$ & - & 350 & $u$ & $-\ldots$ \\
\hline Pentachlorophenol & 2200 & $\mathrm{U}$ & -- & 1600 & $\mathrm{U}$ & $=$ & 1700 & $\mathrm{u}$ & - \\
\hline Phenanthrene & 450 & $\mathrm{u}$ & - & 340 & $u$ & - & 350 & $u$ & -- \\
\hline Anthracene & 450 & $u$ & $\ldots$ & 340 & $u$ & $\ldots$ & 350 & $\mathrm{U}$ & $-\ldots$ \\
\hline Di-n-Butylphthalate & 450 & $\mathrm{u}$ & - & 340 & $u$ & $\ldots$ & 350 & $\mathrm{u}$ & -- \\
\hline Fluoranthrene & 450 & $\mathrm{U}$ & -- & 340 & $u$ & $\ldots$ & 350 & $u$ & -- \\
\hline Pyrene & 450 & U) & - & 340 & $u$ & - & 350 & $u$ & -- \\
\hline Butylbenzylphthalate & 450 & 4 & $\ldots$ & 340 & $\mathrm{U}$ & -- & 350 & $u$ & $\ldots$ \\
\hline 3,3'-Dichlorbenzidine & 900 & 4 & - & 680 & $u$ & - & 700 & $u$ & -- \\
\hline Benzo(a)Anthracene & 450 & $\mathrm{u}$ & - & 340 & $u$ & -- & 350 & $\underline{U}$ & $\ldots$ \\
\hline Chrysene & 450 & $\mathrm{u}$ & $\ldots$ & 340 & $\mathrm{U}$ & - & 350 & 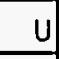 & $\ldots$ \\
\hline Bis (2-Ethylhexyl)Phthalate & 450 & $u$ & $\ldots$ & 340 & $\mathrm{U}$ & -- & 350 & $U$ & - \\
\hline Di-n-Octyl Phthalate & 450 & $u$ & - & 340 & $\mathrm{U}$ & $\cdots$ & 350 & $\mathrm{U}$ & - \\
\hline Benzo(b)Fluoranthene & 450 & 4 & $\ldots$ & 340 & $\mathrm{u}$ & - & 350 & $\mathrm{u}$ & $\ldots$ \\
\hline Benzo(k)Fluoranthene & 450 & $\mathrm{U}$ & - & 340 & $\underline{U}$ & - & 350 & $\mathrm{U}$ & - \\
\hline Benzo(a)Pyrene & 450 & 4 & $\ldots$ & 340 & $\underline{U}$ & - & 350 & $\mathrm{u}$ & - \\
\hline Indeno( $1,2,3$-cd)Pyrene & 450 & $\mathrm{U}$ & - & 340 & $\mathrm{U}$ & - & 350 & $\mathrm{U}$ & - \\
\hline Dibenz(a,h)Anthracene & 450 & U & $\ldots$ & 340 & $\mathrm{U}$ & - & 350 & $\mathrm{U}$ & - \\
\hline Benzo(g,h,i)Perylene & 450 & $\mathrm{U}$ & UJ & 340 & $u$ & UJ & 350 & $u$ & Us \\
\hline
\end{tabular}


$\frac{\bar{\sigma}}{\frac{\sigma}{\sigma}}$

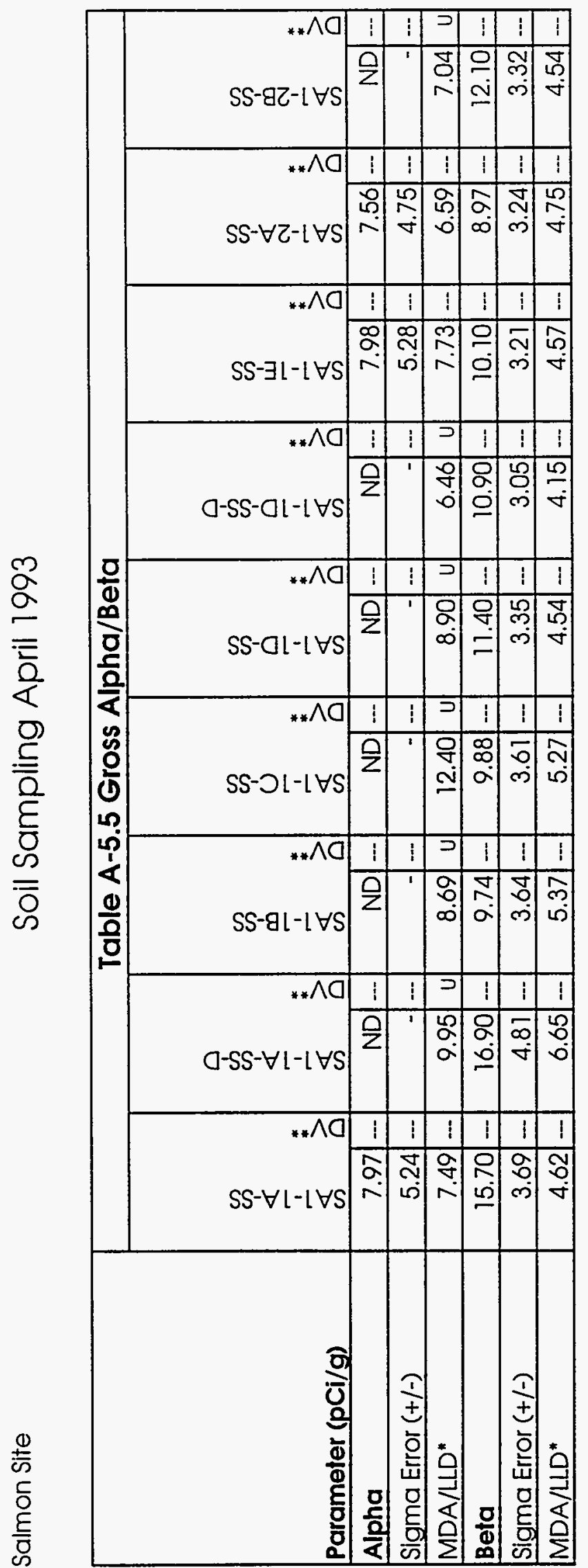

$\frac{\infty}{\stackrel{0}{0}}$

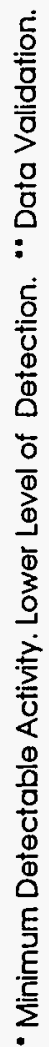




\begin{tabular}{|c|c|c|c|c|c|c|c|c|c|c|c|}
\hline$\cdots$ & $22 \cdot 6$ & $-\cdots$ & 99.9 & \begin{tabular}{l|l|l|}
$\cdots$ & $G L ' t$
\end{tabular} & $\cdots 96$ & $\cdots \longdiv { 8 2 9 }$ & $\begin{array}{ll}--0^{\circ} b \\
\end{array}$ & $\cdots \mid 29$ & $\cdots \mid z l^{\prime}$ & \begin{tabular}{|l|l|}
$-\cdots$ & $1 \varepsilon ' t$ \\
\end{tabular} & $.077 / \forall 0 W$ \\
\hline-- & $\varepsilon 9^{\circ} \varepsilon$ & $\cdots$ & $\overline{0 \varepsilon^{\prime}}$ & $\cdots 99^{\circ} \varepsilon$ & \begin{tabular}{|l|l|}
-- & $\varepsilon \nabla^{*} \varepsilon$
\end{tabular} & \begin{tabular}{l|l}
--7 \\
1
\end{tabular} & $\begin{array}{ll}-\cdots & 80^{\circ} \varepsilon\end{array}$ & $--\overline{O S}^{\circ} \varepsilon$ & \begin{tabular}{|l|l|}
$O^{\prime} \varepsilon$ \\
\end{tabular} & $\cdots \mid \overline{\varepsilon l^{\circ} \varepsilon}$ & $(-1+) 10113$ DW6!S \\
\hline$-\cdots$ & 00.81 & $\cdots$ & 78.6 & $\cdots$ & \begin{tabular}{|l|l|}
$-\cdots$ & $19^{\prime} 6$ \\
\end{tabular} & $\cdots 08^{\circ} 0 \mathrm{~L}$ & 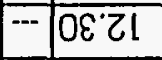 & $\Longrightarrow 0 L^{\circ} \varepsilon L$ & $---06^{\circ} 01$ & $\cdots \mid 0 \angle ' 01$ & Dाँ्g \\
\hline-- & $\overline{\angle G^{\prime} Q}$ & $n$ & $\overline{28.6}$ & \begin{tabular}{|l|l|}
$\cdots$ & $L L^{\prime} L$ \\
\end{tabular} & \begin{tabular}{|l|l|}
$-160^{\circ} 9$ \\
\end{tabular} & $\cdots \mid 00^{\prime} G$ & 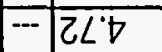 & $-\nabla 6^{\circ} 9$ & \begin{tabular}{|l|l|l|} 
& $\angle D^{\prime} G$ \\
\end{tabular} & \begin{tabular}{|l|l|}
$n$ & $6 L^{\prime} G$ \\
\end{tabular} & $.077 / \forall a W$ \\
\hline-- & $\nabla \varepsilon^{\prime} G$ & --- & - & \begin{tabular}{|l|l|}
-- & $\angle L^{\prime} G$ \\
\end{tabular} & 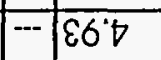 & 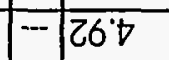 & \begin{tabular}{|l|l|}
$\cdots$ & $\angle \varepsilon^{\prime} t$ \\
\end{tabular} & $--\angle 6^{\circ} b$ & $--\overline{98^{\circ}} \varepsilon$ & $-1-$ & $(-1+) 10113$ DU6!S \\
\hline-- & $06 \div 1$ & -- & ON & \begin{tabular}{|l|l|}
-- & $0 \angle 01$ \\
\end{tabular} & \begin{tabular}{|l|l}
- & $90^{\circ} \mathrm{L}$ \\
\end{tabular} & -0601 & \begin{tabular}{|l|l|}
-- & $00^{\circ} 01$ \\
\end{tabular} & \begin{tabular}{l|l|l}
$C^{\circ} \mathrm{OL}$ \\
\end{tabular} & $\overline{29^{\circ} 9}$ & \begin{tabular}{|l|l|} 
& $\square N$ \\
\end{tabular} & Dudit \\
\hline$\sum_{*}^{Q}$ & $\frac{w}{\frac{D}{1}}$ & & 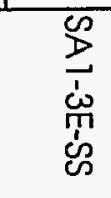 & 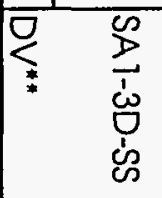 & 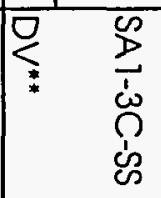 & 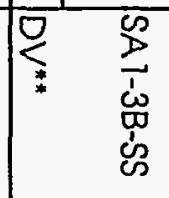 & 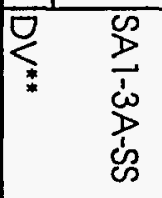 & 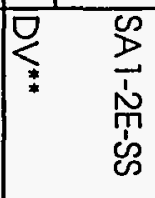 & 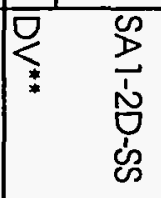 & 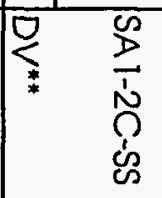 & 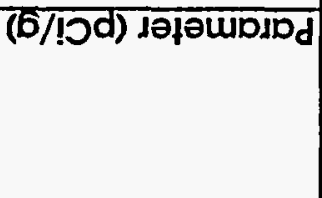 \\
\hline \multicolumn{11}{|c|}{ 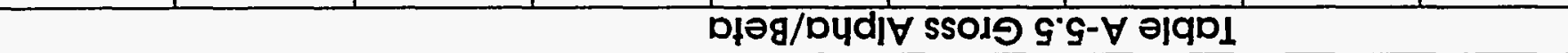 } & \\
\hline
\end{tabular}




\begin{tabular}{|c|c|c|c|c|c|c|c|c|c|c|c|c|c|c|c|c|c|c|}
\hline \multirow[b]{2}{*}{ Parameter (pCi/g) } & \multicolumn{18}{|c|}{ Table A-5.5 Gross Alpha/Beta } \\
\hline & 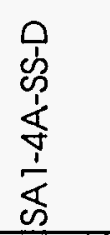 & ${ }^{*}$ & 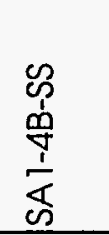 & ${ }^{*}$ & 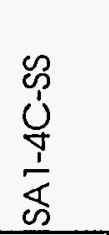 & 草 & 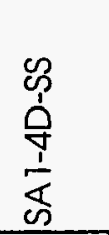 & $\stackrel{3}{0}^{*}$ & 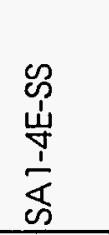 & $3^{*}$ & 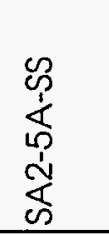 & 莒 & 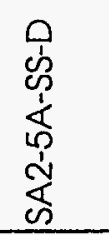 & $3^{*}$ & 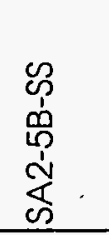 & 莡 & 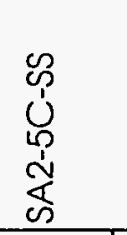 & 䓠 \\
\hline Alpha & 8.23 & -.. & 6.85 & $-\ldots$ & $\mathrm{ND}$ & ... & ND & $\ldots$ & 6.70 & $\ldots$ & 13.80 & $\ldots$ & 14.70 & $\ldots$ & 18.70 &.- & 19.90 & $\ldots$ \\
\hline Sigma Error $(+/-)$ & 5.45 & -.. & 4.30 & $-\ldots$ & & $\ldots$ & & $\ldots$ & 4.30 & $-\ldots$ & 5.72 & $\ldots$ & 5.94 & - & 7.10 & $\ldots$ & 7.35 & - \\
\hline MDA/LLD* & 7.97 & -.. & 5.96 & $-\ldots$ & 7.77 & $\ldots$ & 5.93 & $\ldots$ & 5.90 & $\ldots$ & 6.36 & $\ldots$ & 6.92 & $\ldots$ & 8.18 & - & 8.34 & $\ldots$ \\
\hline Beta & 18.40 & $\ldots$ & 13.90 & $\ldots$ & 9.21 & $\ldots$ & 11.90 & $\ldots$ & 13.50 & $\ldots$ & 19.20 & $\ldots$ & 16.70 & $\ldots$ & 20.20 & _. & 18.40 & $\ldots$ \\
\hline Sigma Error $(+/-)$ & 3.90 & $-\ldots$ & 3.35 & $\ldots$ & 3.39 & $\ldots$ & 3.27 & $\ldots$ & 3.33 & $\ldots$ & 3.82 & $\ldots$ & 3.49 & $\ldots$ & 4.41 & -.. & 4.03 & - \\
\hline MDA/LLD* & 4.72 & $\ldots$ & 4.30 & $\ldots$ & 5.01 & $\ldots$ & 4.41 & $\ldots$ & 4.45 & $\ldots$ & 4.31 & $\ldots$ & 4.08 & $\ldots$ & 5.47 & $\ldots$ & 4.92 & $\ldots$ \\
\hline
\end{tabular}




\begin{tabular}{|c|c|c|c|c|c|c|c|c|c|c|c|c|c|c|c|c|c|c|}
\hline \multirow[b]{2}{*}{ Parameter $(p C i / g)$} & \multicolumn{18}{|c|}{ Table A-5.5 Gross Alpha/Beta } \\
\hline & 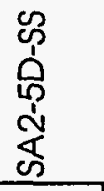 & 光 & 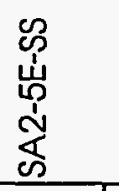 & ${ }^{*}$ & 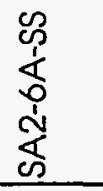 & ${ }_{0}^{*}$ & 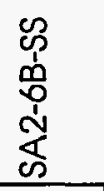 & 己 $^{*}$ & 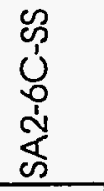 & ${ }^{*}$ & 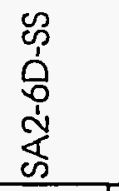 & $\stackrel{0}{3}$ & 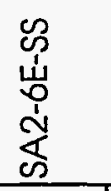 & ${ }_{2}^{*}$ & 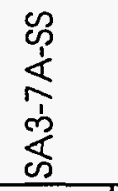 & ${ }^{*}$ & 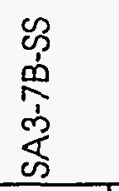 & ${ }^{*}$ \\
\hline Alpha & 17.80 & $-\ldots$ & 17.70 & $-\infty$ & 12.60 & - & 6.17 & $\ldots$ & 6.16 & $\ldots$ & 8.55 & $\ldots$ & 13.80 & $\ldots$ & 7.00 & $\ldots$ & 7.54 & - \\
\hline Sigma Error $(+/-)$ & 8.92 & $\ldots$ & 7.12 & - & 4.94 & - & 3.97 & $\ldots$ & 3.96 & - & 4.06 & - & 5.15 & $\ldots$ & 4.18 & $\ldots$ & 3.99 & $\ldots$ \\
\hline MDA/LLD* & 12.60 & -- & 8.46 & - & 5.27 & -- & 5.44 & - & 5.43 & $\ldots$ & 4.64 & $\ldots$ & 4.59 & $\ldots$ & 5.56 & $\ldots$ & 4.83 & $\ldots$ \\
\hline Beta & 20.40 & $\ldots$ & 18.00 & - & 17.00 & - & 10.50 & $\ldots$ & 11.80 & $\ldots$ & 9.98 & $\ldots$ & 8.73 & $\ldots$ & 13.00 & $\ldots$ & 11.20 & - \\
\hline Sigma Error ( $+/-)$ & 4.43 & $\ldots$ & 3.78 & -- & 3.31 & $\ldots$ & 2.99 & -- & 3.04 & $\ldots$ & 2.87 & $\ldots$ & 3.72 & $\ldots$ & 3.29 & $\ldots$ & 3.06 &.- \\
\hline MDA/LLD* & 5.34 & $\ldots$ & 4.37 & - & 3.74 & $-\ldots$ & 4.10 & $\ldots$ & 4.03 & $\ldots$ & 3.95 & $\ldots$ & 5.71 & $\ldots$ & 4.33 & $\ldots$ & 4.12 & - \\
\hline
\end{tabular}


$\frac{\square}{\frac{d}{d}}$

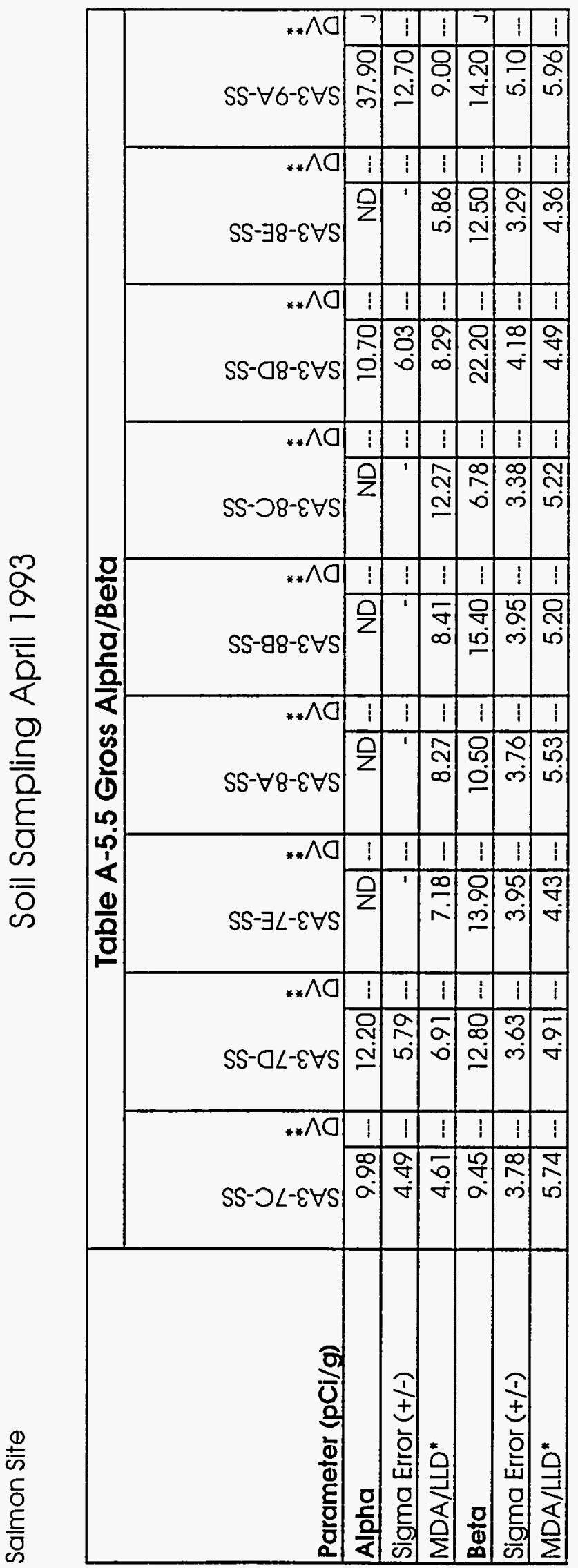

尺े
0
0
O
0.

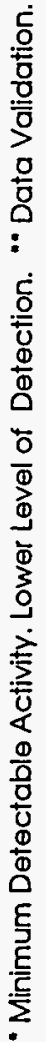




\begin{tabular}{|c|c|c|c|c|c|c|c|c|c|c|c|c|c|c|c|c|c|c|}
\hline \multirow[b]{2}{*}{ Parameter $(\mathrm{pCi} / \mathrm{g})$} & \multicolumn{18}{|c|}{ Table A-5.5 Gross Alpha/Beta } \\
\hline & 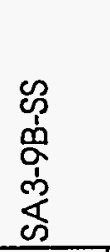 & ${ }^{*}$ & 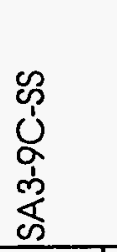 & $\stackrel{3}{0}^{*}$ & 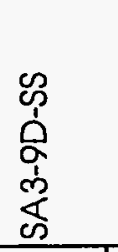 & $\stackrel{*}{0}$ & 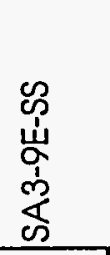 & 艺 & 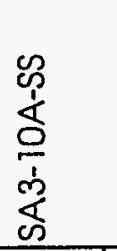 & $\mathrm{D}^{*}$ & 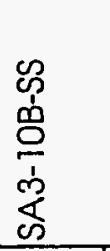 & ${ }^{*}$ & 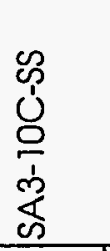 & ${ }^{*}$ & 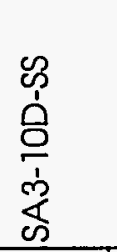 & $\stackrel{*}{*}$ & 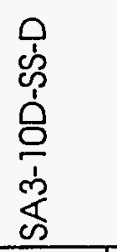 & $\stackrel{2}{0}^{*}$ \\
\hline Alpha & 17.50 & 5 & 12.30 & $\mathrm{~J}$ & 24.40 & $\mathrm{~J}$ & 13.00 & J & 22.50 & J & 16.80 & $\mathrm{~J}$ & 16.50 & $\mathrm{~J}$ & 16.40 & J) & 20.50 & $\mathrm{~J}$ \\
\hline Sigma Error (+/-) & 8.30 & $\ldots$ & 7.70 & $\ldots$ & 10.40 & $-\ldots$ & 7.80 & $\ldots$ & 9.80 & $\ldots$ & 8.30 & $\ldots$ & 8.50 & $\ldots$ & 8.00 & $\ldots$ & 9.30 & $-\ldots$ \\
\hline MDA/LLD* & 8.40 & $-\infty$ & 9.89 & - & 1.05 & - & 10.00 & $\ldots$ & 9.95 & -- & 9.18 & $\ldots$ & 9.62 & $\ldots$ & 8.15 & $\ldots$ & 9.45 & --- \\
\hline Beta & 17.80 & J & 13.00 & $\mathrm{~J}$ & 15.50 & $\mathrm{~J}$ & 14.60 & $\mathrm{~J}$ & 16.00 & $\mathrm{~J}$ & 11.70 & $\mathrm{~J}$ & 14.40 & $\mathrm{~J}$ & 9.70 & J & 10.10 & $\mathrm{~J}$ \\
\hline Sigma Error $(+/-)$ & 5.80 & $\ldots$ & 5.30 & $\ldots$ & 5.30 & - & 5.30 & $-\ldots$ & 5.20 & $\ldots$ & 4.50 & -- & 5.10 & $\ldots$ & 4.39 & $-\ldots$ & 4.60 & $\ldots$ \\
\hline MDA/LLL" & 6.21 & -- & 6.66 & $\ldots$ & 6.07 & $\ldots$ & 6.23 & $\ldots$ & 5.62 & $\ldots$ & 5.52 & $\ldots$ & 5.94 & $\ldots$ & 5.83 & $\ldots$ & 6.04 & -- \\
\hline
\end{tabular}




\begin{tabular}{|c|c|c|c|c|c|c|c|c|c|c|c|c|c|c|c|c|c|c|}
\hline \multirow[b]{2}{*}{ Parameter $(\mathrm{pCl} / \mathrm{g})$} & \multicolumn{17}{|c|}{ Table A-5.5 Gross Alpha/Beta } & \\
\hline & 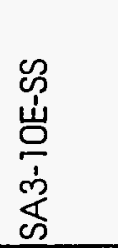 & 莡 & 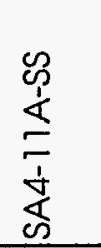 & ${ }_{3}^{*}$ & 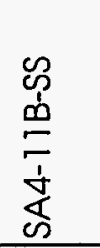 & s & 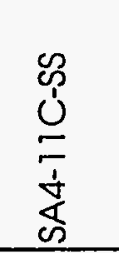 & 草 & 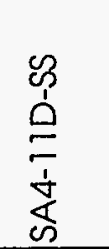 & 莒 & 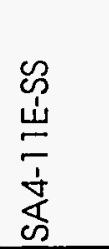 & 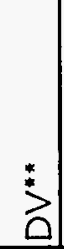 & 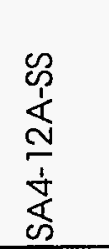 & ") & 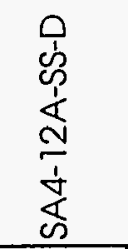 & 艾 & 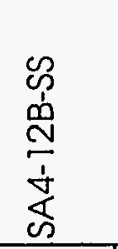 & \\
\hline Alpha & 15.80 & & 6.81 & $\ldots$ & 5.66 & $\ldots$ & 7.99 & $\ldots$ & 12.30 & $\ldots$ & 9.68 & $\ldots$ & 15.70 & $\ldots$ & 20.00 & $\ldots$ & 17.90 & $\ldots$ \\
\hline Sigma Error (+/-) & 8.50 & $\ldots$ & 4.37 & $\ldots$ & 3.96 & $\ldots$ & 3.99 &.- & 5.10 &.- & 5.40 & ... & 8.64 & $\ldots$ & 7.56 & $\ldots$ & 5.88 & $\ldots$ \\
\hline MDA/LLD* & 10.02 & - & 6.00 & $\ldots$ & 5.61 & $\ldots$ & 4.69 & ... & 4.93 & - & 6.98 & $\ldots$ & 12.30 & - & 8.45 & $\ldots$ & 4.68 & $\ldots$ \\
\hline Beta & 11.50 & 1 & 14.20 & ... & 11.20 & $\ldots$ & 11.80 & $\ldots$ & 16.40 & $\ldots$ & 13.60 & $\ldots$ & 26.20 & $=$ & 21.50 & $\ldots$ & 31.20 & $\ldots$ \\
\hline Sigma Error $(+/-)$ & 4.70 & $\ldots$ & 3.50 & -... & 3.18 & $\ldots$ & 3.04 & $\ldots$ & 4.44 & $\ldots$ & 3.72 & $\ldots$ & 4.85 & $\ldots$ & 4.07 & $\ldots$ & 5.25 & $\ldots$ \\
\hline MDA/LLD* & 6.01 & $\ldots$ & 4.52 & $2 \ldots$ & 4.37 & $\ldots$ & 3.99 & $\ldots$ & 0.14 & $\ldots$ & 4.96 & $\ldots$ & 5.24 & -.. & 4.37 & $\ldots$ & 5.56 & ... \\
\hline
\end{tabular}




\begin{tabular}{|c|c|c|c|c|c|c|c|c|c|c|c|c|c|c|c|c|c|c|}
\hline \multirow[b]{2}{*}{ Parameter $(\mathrm{pCi} / \mathrm{g})$} & \multicolumn{18}{|c|}{ Table A-5.5 Gross Alpha/Beta } \\
\hline & 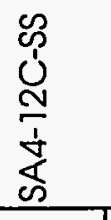 & $\stackrel{*}{*}$ & 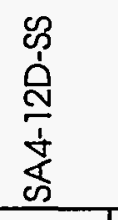 & ${ }^{*}$ & 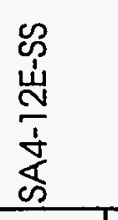 & $\stackrel{2}{*}^{*}$ & 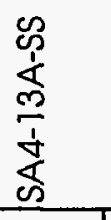 & $\stackrel{2}{0}^{*}$ & $\begin{array}{l}\text { p } \\
\text { m } \\
\text { m } \\
\frac{1}{4} \\
\text { d }\end{array}$ & ${ }^{*}$ & 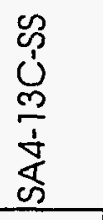 & $\stackrel{2}{0}^{*}$ & 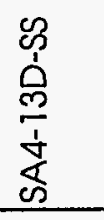 & ${ }_{2}^{*}$ & 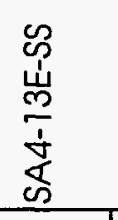 & $\stackrel{2}{*}^{*}$ & 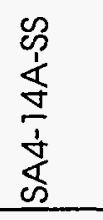 & $\stackrel{2}{0}^{*}$ \\
\hline Alpha & 11.70 & - & 14.90 & $-{ }_{-1}$ & ND & $\ldots$ & 8.63 & $-\ldots$ & 8.69 & $\ldots$ & 7.52 & $\ldots$ & ND & $\ldots$ & $\mathrm{ND}$ & $\ldots$ & 9.75 & $\ldots$ \\
\hline Sigma Error (+1-) & 5.32 & $\ldots$ & 6.03 & $\ldots$ & & $-\ldots$ & 4.30 & $\ldots$ & 4.85 & -- & 4.94 & $\ldots$ & & $\ldots$ & & $\ldots$ & 4.63 & $\ldots$ \\
\hline MDA/LLD* & 6.20 & -- & 7.02 & -- & 8.44 & $u$ & 4.71 & $\ldots$ & 6.26 & $\ldots$ & 7.07 & -- & 8.47 & $\mathrm{U}$ & 8.12 & $\mathrm{U}$ & 5.52 & $\ldots$ \\
\hline Beta & 14.50 & - & 14.80 & $\ldots$ & 12.80 & - & 13.00 & $\ldots$ & 13.40 & - & 11.60 &.- & 9.26 & - & 14.50 & -- & 11.60 & $\ldots$ \\
\hline Sigma Error $(+/-)$ & 3.49 & - & 3.36 &.- & 3.97 & $\ldots$ & 3.92 & $\ldots$ & 3.44 & -- & 3.14 & $\ldots$ & 3.61 & $\ldots$ & 3.78 & $\ldots$ & 3.18 & $-\ldots$ \\
\hline MDA/LLD* & 4.40 & - & 4.13 & $\ldots$ & 5.64 & $\ldots$ & 5.60 & $\ldots$ & 4.45 & - & 4.17 & $\ldots$ & 5.41 & $\ldots$ & 5.02 & $\ldots$ & 4.30 & $\ldots$ \\
\hline
\end{tabular}




\begin{tabular}{|c|c|c|c|c|c|c|c|c|c|c|c|c|c|c|c|c|c|c|}
\hline \multirow[b]{2}{*}{ Parameter $(\mathrm{pCi} / \mathrm{g})$} & \multicolumn{18}{|c|}{ Table A-5.5 Gross Alpha/Beta } \\
\hline & 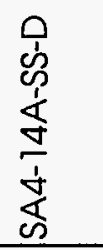 & $\stackrel{2}{0}^{*}$ & 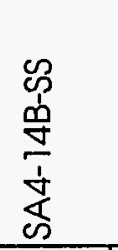 & $\stackrel{2}{0}^{*}$ & 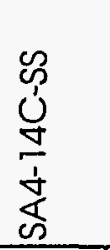 & $\stackrel{*}{2}$ & 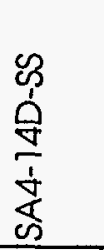 & $\sum_{0}^{*}$ & 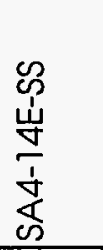 & $\stackrel{*}{*}$ & 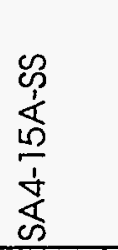 & ${ }_{0}^{*}$ & 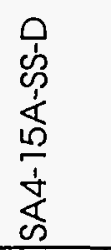 & $\stackrel{2}{0}^{*}$ & 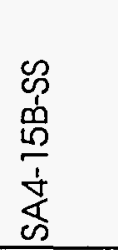 & $\stackrel{*}{{ }^{*}}$ & 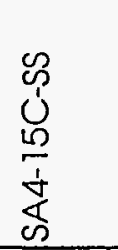 & $\stackrel{2}{0}^{*}$ \\
\hline Alpha & 8.03 & $\ldots$ & 10.40 & $\ldots$ & 12.10 & $-\ldots$ & ND & $\ldots$ & ND & $\ldots$ & 7.54 & $\ldots$ & 16.90 & $\ldots$ & 20.50 & $\ldots$ & 11.10 & $\ldots$ \\
\hline Sigma Error $(+/-)$ & 4.01 & - & 4.67 & $\ldots$ & 5.48 & $-{ }_{-1}$ & & $\ldots$ & - & $\ldots$ & 4.20 & $\ldots$ & 5.52 & $\ldots$ & 6.19 & $\ldots$ & 4.64 & $\ldots$ \\
\hline MDA/LLL" & 4.72 & $\ldots$ & 4.79 & $\ldots$ & 6.38 & - & 11.40 & $u$ & 8.35 & $u$ & 5.44 & $\ldots$ & 5.16 & $\ldots$ & 5.43 & $\ldots$ & 4.90 & $\ldots$ \\
\hline Beta & 11.00 & $\ldots$ & 13.70 & $\ldots$ & 11.00 & \begin{tabular}{|l|}
-- \\
\end{tabular} & 9.56 & $-\ldots$ & 12.20 & -.. & 15.70 & $\ldots$ & 13.90 & $\ldots$ & 17.70 & $\ldots$ & 13.90 & $\ldots$ \\
\hline Sigma Error $(+1-)$ & 2.98 & $\ldots$ & 4.30 & $\ldots$ & 3.18 & \begin{tabular}{|l|}
$\ldots$ \\
\end{tabular} & 3.63 & $\ldots$ & 3.29 & $\ldots$ & 3.27 & $\ldots$ & 3.14 & $-\ldots$ & 3.50 & $\ldots$ & 3.29 & $\ldots$ \\
\hline MDA/LLD* & 4.01 & $-\infty$ & 5.97 & $\ldots$ & 4.33 & \begin{tabular}{|l|}
-- \\
\end{tabular} & 4.86 & $\ldots$ & 4.31 & $\ldots$ & 3.86 & $\ldots$ & 3.89 & $\ldots$ & 4.04 & $-\ldots$ & 4.17 & $\ldots$ \\
\hline
\end{tabular}




\begin{tabular}{|c|c|c|c|c|c|c|c|c|c|c|c|c|c|c|c|c|c|c|}
\hline \multirow[b]{2}{*}{ Paramefer $(\mathrm{pCi} / \mathrm{g})$} & \multicolumn{18}{|c|}{ Table A-5.5 Gross Alpha/Beta } \\
\hline & 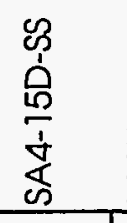 & 艾 & 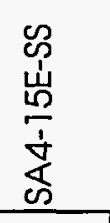 & 艾 & 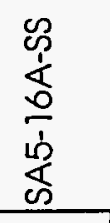 & 吾 & 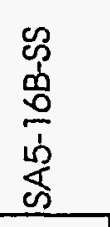 & 莒 & 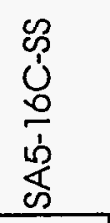 & 莡 & 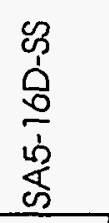 & 3 & 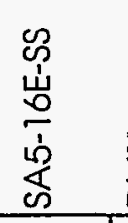 & 艾 & 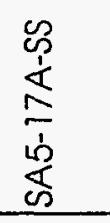 & 莡 & 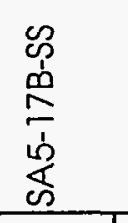 & 光 \\
\hline Alpha & 12.80 & $-\ldots$ & 16.80 & - & 18.10 & - & 11.00 & $\ldots$ & 12.20 & $\ldots$ & 9.11 & $-\cdots$ & 14.80 & $\ldots$ & ND & $\ldots$ & 18.80 & $\theta$ \\
\hline Sigma Error $(t /-)$ & 5.10 & $-\ldots$ & 6.18 & $\ldots$ & 6.92 & $=$ & 5.37 & -- & 6.19 & $\ldots$ & 5.87 & $\cdots$ & 8.04 & $\ldots$ & & $\ldots$ & 8.44 & - \\
\hline MDA/LLD* & 4.79 & $\ldots$ & 6.33 & - & 4.71 & $\ldots$ & 6.88 & - & 8.18 & $\ldots$ & 8.33 & $\ldots$ & 11.60 & $-{ }_{-1}$ & 8.17 & $u$ & 11.50 & $\ldots$ \\
\hline Beta & 23.10 & $\ldots$ & 17.10 & $\ldots$ & 23.80 & $\ldots$ & 16.10 & $\ldots$ & 16.50 & $\ldots$ & 13.30 & -... & 17.10 & $\ldots$ & 17.30 & -.. & 17.30 & $=$ \\
\hline Sigma Error $(+/-)$ & 4.82 & $-\ldots$ & 3.64 & - & 4.83 & - & 3.52 & - & 4.14 & $\ldots$ & 3.64 & $\ldots$ & 3.84 & $\ldots$ & 4.01 & $\ldots$ & 3.95 & $=$ \\
\hline MDA/LLD* & 5.97 & $\ldots$ & 4.29 & - & 5.87 & - & 4.24 & -... & 5.47 & -.. & 4.91 & -... & 4.71] & $\ldots$ & 5.05 & $\ldots$ & 4.89 & \\
\hline
\end{tabular}




\begin{tabular}{|c|c|c|c|c|c|c|c|c|c|c|c|c|c|c|c|c|c|c|}
\hline \multirow[b]{2}{*}{ Parameter $(\mathrm{pCi} / \mathrm{g})$} & \multicolumn{18}{|c|}{ Table A-5.5 Gross Alpha/Beta } \\
\hline & 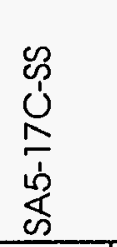 & 艾 & 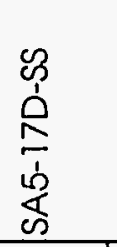 & $\stackrel{*}{*}$ & 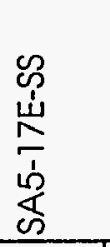 & 莡 & 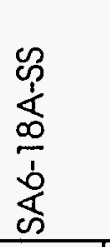 & 艾 & 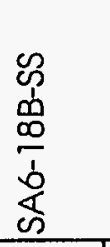 & ${ }^{*}$ & $\begin{array}{l}\mathscr{c} \\
0 \\
0 \\
\infty \\
\vdots \\
0 \\
0 \\
0\end{array}$ & 艾 & 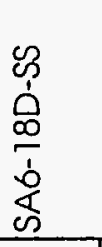 & $\stackrel{2}{0}^{*}$ & 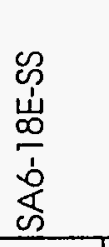 & $\stackrel{2}{0}^{*}$ & 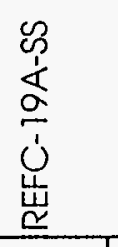 & $\stackrel{2}{0}^{*}$ \\
\hline Alpha & ND & $\ldots$ & 11.40 & $-\ldots$ & 9.82 & $\ldots$ & 9.77 & $\ldots$ & 8.37 & $\ldots$ & 12.90 & $\ldots$ & ND & $\ldots$ & 12.10 & $\ldots$ & 9.96 & $\ldots$ \\
\hline Sigma Error (+/-) & & -- & 4.76 & $-\ldots$ & 4.46 & $\ldots$ & 5.03 & $\ldots$ & 5.18 & $\ldots$ & 5.22 & $\ldots$ & & $\ldots$ & 4.90 & $\ldots$ & 5.95 &.- \\
\hline MDA/LLD* & 8.54 & $\mathrm{U}$ & 5.29 & $\ldots$ & 5.19 & $\ldots$ & 6.57 & $\ldots$ & 7.43 & $\ldots$ & 5.90 & $\ldots$ & 6.82 & u & 5.33 & $-\infty$ & 8.35 & - \\
\hline Beta & 15.20 & $\ldots$ & 16.80 & $\ldots$ & 18.00 & $\ldots$ & 16.80 & $\ldots$ & 15.10 & $\ldots$ & 12.70 & $\ldots$ & 13.90 & $\ldots$ & 14.10 & $\ldots$ & 14.80 & $\ldots$ \\
\hline Sigma Error $(+/-)$ & 3.58 & $\ldots$ & 3.39 & $-\ldots$ & 3.48 & $\ldots$ & 3.43 & $\ldots$ & 3.47 & \begin{tabular}{|l|}
$\ldots$ \\
\end{tabular} & 3.13 & \begin{tabular}{|l|}
$-\infty$ \\
\end{tabular} & 3.37 & $\ldots$ & 3.10 & $\ldots$ & 3.49 & $\ldots$ \\
\hline MDA/LLD* & 4.41 & - & 3.94 & $\ldots$ & 3.91 & $\ldots$ & 4.03 & $\ldots$ & 4.39 & $\ldots$ & 4.03 & $\ldots$ & 4.39 & $\ldots$ & 3.79 & $\ldots$ & 4.31 & - \\
\hline
\end{tabular}




\begin{tabular}{|c|c|c|c|c|c|c|c|c|}
\hline \multirow[b]{2}{*}{ Parameter $(p \mathrm{Ci} / g)$} & \multicolumn{8}{|c|}{ Table A-5.5 Gross Alpha/Beta } \\
\hline & 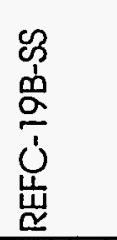 & ${ }^{*}$ & 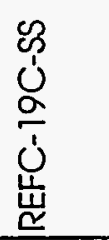 & $\stackrel{*}{2}$ & 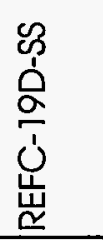 & \} ^ { * } $&{\text { 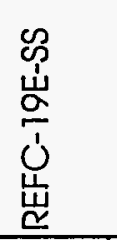 }} &{ } \\
{\hline \text { Alpha }} &{5.40} &{-\ldots} &{12.20} &{\ldots} &{4.24} &{\ldots} &{9.91} &{\ldots} \\
{\hline \text { Sigma Error }(+/-)} &{4.22} &{--} &{5.60} &{-} &{3.94} &{-} &{5.28} &{\ldots} \\
{\hline \text { MDA/LLD" }} &{6.35} &{u} &{7.21} &{\ldots} &{6.15} &{\mathrm{u}} &{7.12} &{-} \\
{\hline \text { Beta }} &{11.30} &{\ldots} &{15.60} &{\ldots} &{9.65} &{-} &{12.60} &{\ldots} \\
{\hline \text { Sigma Error }(+/-)} &{3.05} &{-} &{3.44} &{--} &{2.89} &{-} &{3.27} &{--} \\
{\hline \text { MDA/LLD* }} &{4.08} &{--} &{9.26} &{\ldots} &{4.03} &{-\ldots} &{4.38} &{\ldots} \\
$\hline
\end{tabular}




\begin{tabular}{|c|c|c|c|c|c|c|c|c|c|c|c|c|c|c|c|c|c|c|c|c|c|c|c|c|}
\hline$* \wedge 0$ & i) & 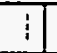 & 9 & 5 & i & 1 & $i$ & 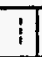 & ग & !) & 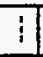 & T & $i$ & 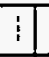 & 5 & $T$ & $T$ & & $i$ & & & & & \\
\hline$\partial z-\mid \forall S$ & 을 & & ') & $\begin{array}{l}M \\
0 \\
0 \\
0\end{array}$ & $\frac{\infty}{0}$ & वे & 은 & 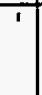 & पू & Q & 7 & $\begin{array}{l} \\
0 \\
0\end{array}$ & 穴 & $T$ & 음 & & & & Q & $T$ & $\begin{array}{l}\tilde{n} \\
0 \\
0 \\
0\end{array}$ & & & \\
\hline$* \wedge a$ & ! & $\pi$ & i & 3 & $\overline{1}$ & $\overline{1}$ & 5 & 1 & $\pi$ & 5 & $\pi$ & 1 & $i$ & $i$ & 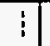 & $i$ & 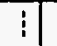 & 1 & 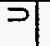 & ! & $i$ & $\bar{i}$ & $i$ & 7 \\
\hline$S S-g Z-I \forall S$ & $\begin{array}{l}0 \\
0 \\
0\end{array}$ & 웅 & 뭉 & $\begin{array}{l}8 \\
0 \\
0\end{array}$ & $\frac{\omega}{0}$ & $\begin{array}{l}8 \\
0 \\
0\end{array}$ & ? & $\begin{array}{l}\nabla \\
0 \\
0\end{array}$ & 8 & $\begin{array}{l}\infty \\
\text { N } \\
0\end{array}$ & $\begin{array}{l}\mathrm{s} \\
\mathrm{o} \\
\mathrm{0}\end{array}$ & of & $\begin{array}{l}\text { f̃ } \\
0\end{array}$ & $\begin{array}{l}\overline{0} \\
0\end{array}$ & రి & $\overline{0}$ & 뭉 & 응 & वे & $\frac{}{0}$ & $\frac{0}{0}$ & $\mathrm{Q}$ & ' & \\
\hline$* \wedge 0$ & $i$ & $i$ & 9 & $\overline{1}$ & $\bar{i}$ & 5 & 5 & $i$ & $\pi$ & 5 & 1 & iा & 1 & ! & 1 & 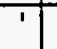 & & ' & ग & ! & $i$ & $!$ & 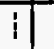 & 3 \\
\hline$S S-\forall Z-I \forall S$ & $\frac{9}{z}$ & 7 & 导 & 을 & $T$ & $\frac{a}{\square}$ & $\begin{array}{l}-1 \\
0 \\
0\end{array}$ & $\begin{array}{l}8 \\
0 \\
0\end{array}$ & தి & $\begin{array}{ll} & 0 \\
c 0 \\
0\end{array}$ & ల్ర & $\begin{array}{l} \\
\end{array}$ & 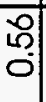 & $\begin{array}{l}0 \\
0 \\
0\end{array}$ & $\begin{array}{l}0 \\
0 \\
0\end{array}$ & & & 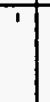 & 'ָ & $\frac{a}{0}$ & $\begin{array}{l}\vec{m} \\
0 \\
0\end{array}$ & 路 & & חై \\
\hline 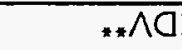 & : & $i$ & 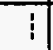 & 9 & 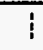 & 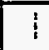 & 9 & 1 & $i$ & 5 & 1 & $i$ & 1 & 1 & 1 & T & & & $D$ & $!$ & $i$ & $!$ & $\vdots$ & 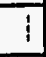 \\
\hline$S S-\exists L-1 \forall S$ & ơ & 이 & ర్ & م. & $\frac{a}{0}$ & ลิ & : & ? & $\begin{array}{l}\tilde{0} \\
0\end{array}$ & $\begin{array}{l}\mathscr{c} \\
\wp \\
0\end{array}$ & ס्. & ஜ: & $\begin{array}{l}\nabla \\
0\end{array}$ & 足 & 이 & & & & & O: & & & $=$ & సָ \\
\hline
\end{tabular}

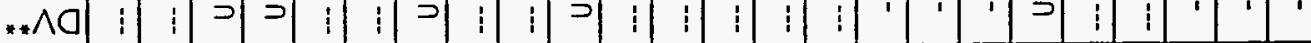

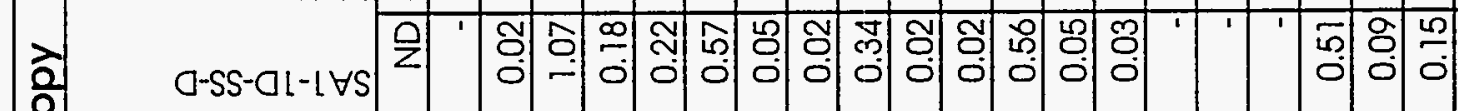

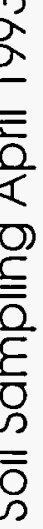

잉

은

$-2 S-I \forall S$

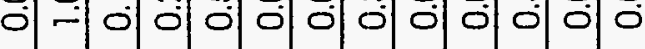

*^व

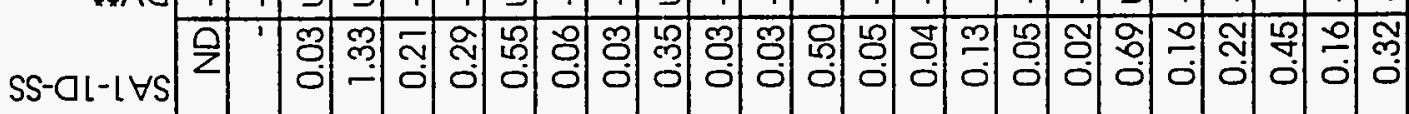

욤

-

SS-8L-I $\forall S$ S

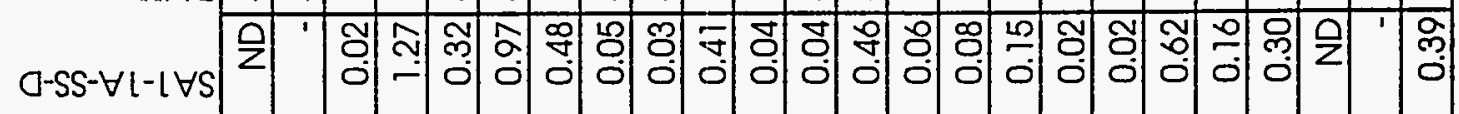




\begin{tabular}{|c|c|c|c|c|c|c|c|c|c|c|c|c|c|c|c|c|c|c|c|c|}
\hline \multirow[b]{2}{*}{ Nuclide $(p C i / g)$} & \multicolumn{20}{|c|}{ Table A-5.6 Gamma Spectroscopy } \\
\hline & $\begin{array}{l}\mathscr{D} \\
\frac{1}{\alpha} \\
\frac{1}{4} \\
\infty\end{array}$ & 莒 & 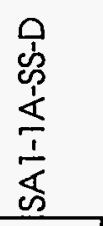 & 方 & 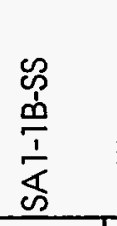 & 兌 & $\begin{array}{l}\mathscr{p} \\
0 \\
\frac{1}{1} \\
\frac{1}{4}\end{array}$ & $\stackrel{3}{2}^{*}$ & 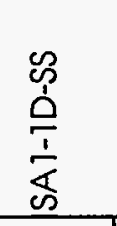 & ${ }_{2}^{*}$ & 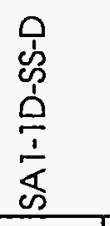 & 虽 & $\begin{array}{l}\mathscr{N} \\
\ddot{w} \\
\frac{1}{4} \\
\mathbb{N}\end{array}$ & ${ }^{*}$ & 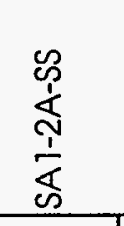 & 苛 & 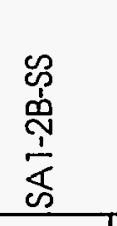 & 方 & 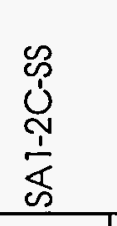 & $\stackrel{*}{*}$ \\
\hline Bismuth 212 & ND & $\ldots$ & ND & $-\ldots$ & 0.28 & -- & 0.28 & $\ldots$ & 0.29 & $R$ & 0.42 & $\ldots$ & ND & $-\ldots$ & ND &.-- & 0.29 & $\ldots$ & ND & - \\
\hline Sigma Error $(+/-)$ & & $\ldots$ & & $\ldots$ & 0.06 & $\ldots$ & 0.05 & $-\ldots$ & 0.09 & $\ldots$ & 0.07 & $\ldots$ & - & $\ldots$ & 1 & $-\ldots$ & 0.06 & $-\ldots$ & - & $-\cdots$ \\
\hline MDA* & 0.22 & $u$ & 0.12 & $u$ & 0.12 & $\ldots$ & 0.10 & $\ldots$ & 0.12 & $\ldots$ & 0.08 & $\ldots$ & 0.09 & $U$ & 0.18 & $u$ & 0.08 & $\ldots$ & 0.26 & u \\
\hline Radium 224 & $N D$ & $\ldots$ & $\mathrm{ND}$ & - & 0.43 & $\ldots$ & ND & $\ldots$ & ND & $\ldots$ & 0.52 & $\ldots$ & 0.30 & $\ldots$ & $\mathrm{ND}$ & $\ldots$ & ND & $\ldots$ & $\mathrm{ND}$ & -- \\
\hline Sigma Error $(+/-)$ & & $\ldots$ & & $\ldots$ & 0.21 & - & & $\ldots$ & & $\ldots$ & 0.29 & $\ldots$ & 0.35 & -- & & $\ldots$ & &.- & & - \\
\hline $\mathrm{MDA}^{*}$ & 0.54 & $u$ & 0.63 & 0 & 0.26 & $\ldots$ & 0.36 & $u$ & 0.49 & UR & 0.18 & $\ldots$ & 0.22 & $\ldots$ & 0.69 & $u$ & 0.18 & $\mathrm{u}$ & 0.71 & $\mathrm{U}$ \\
\hline Radium 223 & & - & - & - & & - & & - & & - & 0.17 & $-\ldots$ & -1 & $\ldots$ & - & -1 & - & - & & - \\
\hline Sigma Error $(+/-)$ & - & - & - & - & - & - & - & -1 & - & - & 0.04 & $\ldots$ & -1 & $\ldots$ & -1 & -1 & - & - & -1 & - \\
\hline $\mathrm{MDA}^{*}$ & - & - & - & - & -1 & - & -1 & - & -1 & - & 0.06 & $\ldots$ & & $\ldots$ & & -1 & -1 & - & -1 & - \\
\hline Thorium 228 & - & - & - & - & 1.83 & - & - & - & - & - & - & - & -1 & - & & -1 & & - & - & - \\
\hline Sigma Error $(+/-)$ & & - & - & - & 0.60 & $\ldots$ & - & -1 & - & - & - & -1 & - & - & - & - & & - & $x-$ & - \\
\hline $\mathrm{MDA}^{*}$ & - & - & - & - & 1.13 & $\ldots$ & & - & - & -1 & -1 & -1 & - & - & $\therefore$ & - & & - & 1 & - \\
\hline Protactinium 231 & & - & & - & & - & & - & & - & & -1 & - & - & - & -7 & 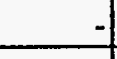 & - & & - \\
\hline Sigma Error $(+/-)$ & - & - & - & - & & - & & - & & - & & - & - & - & - & -1 & - & - & & - \\
\hline MDA* & & - & & - & & - & & - & & - & - & - & - & - & - & - & - & - & & - \\
\hline $\operatorname{Tin} 113$ & 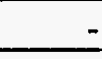 & - & & - & & - & & - & & - & 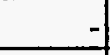 & - & 0.02 & $\ldots$ & - & - & -1 & - & & - \\
\hline Sigma Error (+/-) & & - & & - & & - & & - & & -1 & 1 & -1 & 0.01 & $\ldots$ & - & - & - & - & & $=$ \\
\hline MDA* $^{*}$ & - & - & - & - & - & - & - & - & 7 & -1 & - & - & 0.02 & $\ldots$ & - & -7 & - & - & -1 & - \\
\hline Mercury 203 & - & - & & - & & - & - & -1 & & -1 & & - & & - & - & - & - & - & 0.03 & $\ldots$ \\
\hline Sigma Error $(+/-)$ & - & - & & - & - & - & - & - & $\rightarrow$ & - & -1 & -1 & - & - & - & -1 & - & - & 0.01 & - \\
\hline MDA & - & - & & - & - & - & - & - & & - & 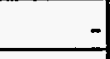 & - & - & - & - & -7 & - & - & 0.02 & $\ldots$ \\
\hline Uranium 234 & $=$ & - & & - & - & - & - & -1 & - & -1 & - & - & - & - & - & - & - & - & - & - \\
\hline Sigma Error $(+/-)$ & & - & & - & - & - & - & -1 & & -1 & & -1 & & - & - & - & - & - & - & - \\
\hline MDA* & $=$ & - & & - & -1 & - & -1 & $1-1$ & & -1 & & -1 & -1 & - & -1 & -1 & - & $1-$ & - & $1-$ \\
\hline
\end{tabular}




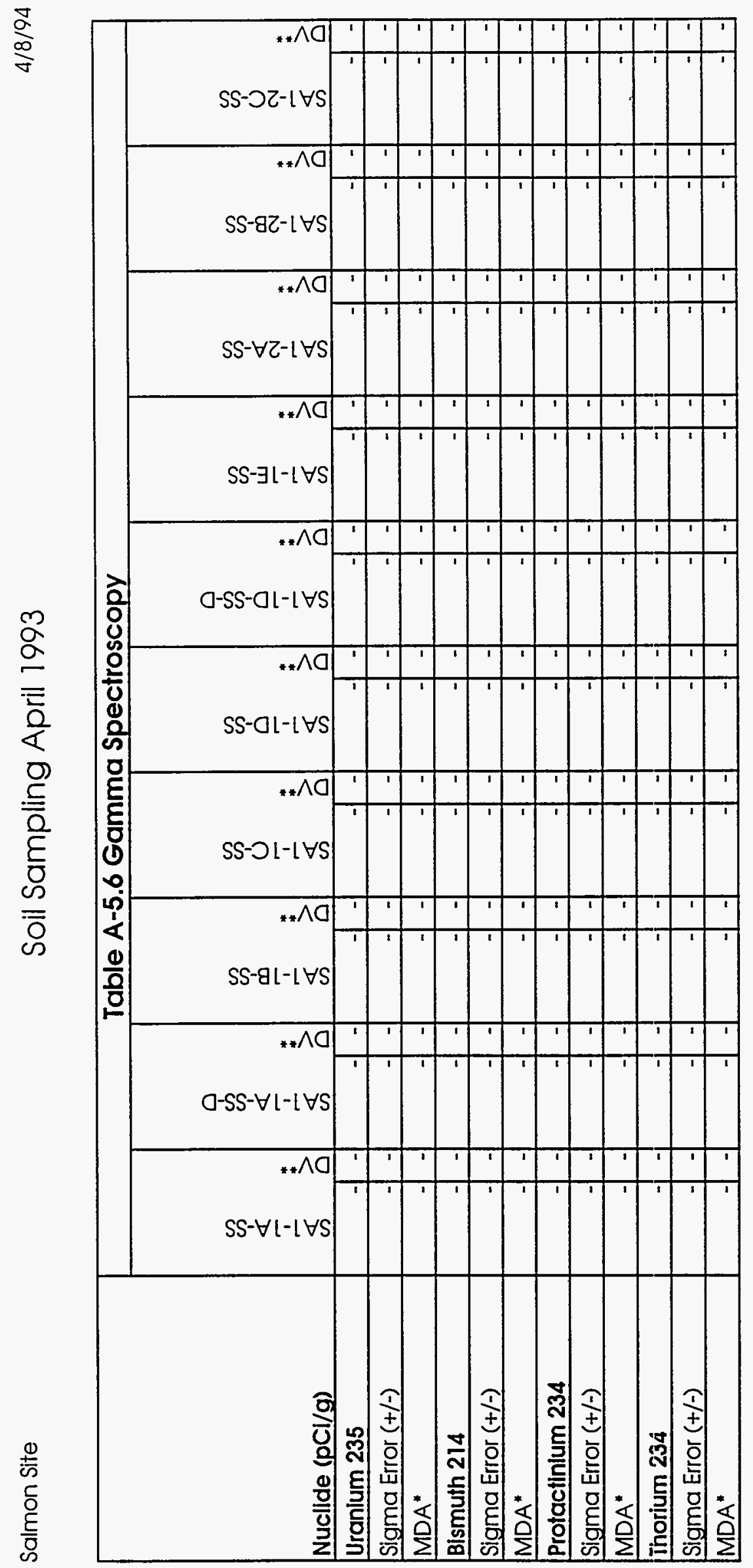




\begin{tabular}{|c|c|c|c|c|c|c|c|c|c|c|c|c|c|c|c|c|c|c|c|c|c|}
\hline \multirow[b]{2}{*}{ Nuclide (pCl/g) } & \multicolumn{21}{|c|}{ Table A-5.6 Gamma Spectroscopy } \\
\hline & 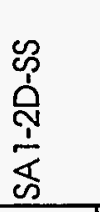 & 3 & 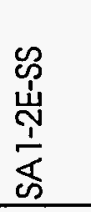 & 艺 & 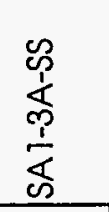 & 苛 & 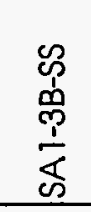 & & 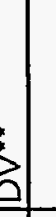 & 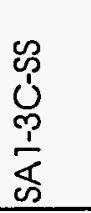 & 莡 & 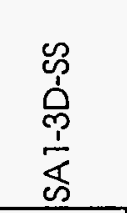 & 3 & 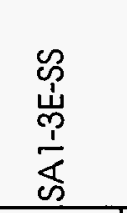 & 艾 & $\begin{array}{l}\text { po } \\
\frac{5}{5} \\
\frac{1}{4} \\
c\end{array}$ & 물 & 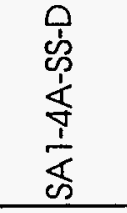 & 艾 & $\begin{array}{l}\tilde{p} \\
\hat{q} \\
\frac{1}{4} \\
\tilde{c}\end{array}$ & 을 \\
\hline Cesium 137 & 0.08 & $\ldots$ & 0.05 & $\ldots$ & 0.19 & $\ldots$ & & $\mathrm{ND}$ & 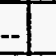 & 0.06 & $\ldots$ & 0.21 & $\ldots$ & 0.05 &.- & 0.35 & $\ldots$ & 0.31 & $-{ }_{-1}$ & 0.18 & - \\
\hline Sigma Error $(+/-)$ & 0.02 & $-\infty$ & 0.01 & $\ldots$ & 0.03 & - & & -1 & 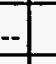 & 0.01 & - & 0.03 & $-\infty$ & 0.01 & - & 0.04 & $\ldots$ & 0.03 & $\ldots$ & 0.02 & $\ldots$ \\
\hline MDA* & 0.02 & $\ldots$ & 0.02 & $\ldots$ & 0.03 & $\ldots$ & 0.0 & & $\underline{u}$ & 0.01 & -.. & 0.03 & $-\ldots$ & 0.02 & - & 0.03 & $\ldots$ & 0.01 & $\ldots$ & 0.01 & $\ldots$ \\
\hline Potassium 40 & 0.51 & $u$ & 0.87 & $u$ & 1.08 & $u$ & 0.4 & 49 & $\underline{4}$ & 0.85 & $u$ & 1.33 & 0 & 0.60 & $u$ & 3.13 & $\ldots$ & 3.09 & $\ldots$ & 1.41 & $\ldots$ \\
\hline Sigma Error $(t /-)$ & 0.09 & $\ldots$ & 0.19 & $\ldots$ & 0.18 & -.. & 0.1 & 18. & 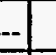 & 0.18 & - & 0.24 & $\ldots$ & 0.12 & $\ldots$ & 0.33 &..- & 0.18 & -..- & 0.19 & 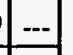 \\
\hline MDA* & 0.23 & $\ldots$ & 0.36 & - & 0.29 & $\ldots$ & 0.3 & 35 - & $\theta$ & 0.28 & $\ldots$ & 0.41 & - & 0.37 & - & 0.14 & $-\cdots$ & 0.19 & - & 0.19 & $\ldots$ \\
\hline Lead 212 & $N D$ & $\ldots$ & 0.50 & $u$ & 0.35 & $\mathrm{u}$ & 0.4 & 46 & $\underline{u}$ & 0.34 & $u$ & ND & $\ldots$ & $\mathrm{ND}$ & - & 0.69 & - & 0.70 & $\ldots$ & 0.43 & $-\cdots$ \\
\hline Sigma Error $(+/-)$ & & $\ldots$ & 0.05 & $\ldots$ & 0.04 & $\ldots$ & 0.0 & 04. & $\theta$ & 0.04 & $-\ldots$ & & $\ldots$ & & $\ldots$ & 0.06 & $\ldots$ & 0.04 & $\ldots$ & 0.04 & $\ldots$ \\
\hline $\mathrm{MDA}^{*}$ & 0.03 & 0 & 0.03 & $\ldots$ & 0.03 & $\ldots$ & 0.0 & 03 & $\theta$ & 0.02 & $\ldots$ & 0.05 & $u$ & 0.03 & $\mathrm{u}$ & 0.01 & $\ldots$ & 0.02 & $\ldots$ & 0.02 & $\ldots$ \\
\hline Radium 226 & $\mathrm{ND}$ & $\ldots$ & 0.37 & $u$ & 0.31 & $u$ & 0.3 & 30 & ut & 0.29 & $u$ & 0.37 & 4 & 0.29 & $\mathrm{u}$ & 0.63 & $u$ & 0.74 & $u$ & 0.42 & $u$ \\
\hline Sigma Error $(t /-)$ & & $\ldots$ & 0.03 & $\ldots$ & 0.03 & -.. & 0.6 & 03 . & 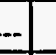 & 0.01 & $\ldots$ & 0.03 & $\ldots$ & 0.03 & - & 0.04 & - & 0.04 & -.. & 0.02 & 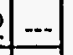 \\
\hline $\mathrm{MDA}^{*}$ & 0.03 & 0 & 0.03 & - & 0.04 & - & 0.0 & 03. & - & 0.02 & $\ldots$ & 0.05 & $\ldots$ & 0.03 & $\ldots$ & 0.02 & $=$ & 0.03 & $-\ldots$ & 0.03 & 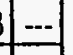 \\
\hline Radium 228 & 0.31 & $\ldots$ & 0.41 & - & 0.40 & -- & 0.4 & 42 . & 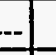 & 0.31 & $-\ldots$ & 0.37 & $\ldots$ & 0.33 & $\ldots$ & 0.69 & - & 0.61 & - & 0.47 & $\ldots$ \\
\hline Sigma Error $(+/-)$ & 0.01 & $\ldots$ & 0.05 & $\ldots$ & 0.04 & - & 0.6 & 05 . & $\ldots$ & 0.03 & $\ldots$ & 0.05 & - & 0.04 & $\ldots$ & 0.04 & -.. & 0.04 & - & 0.03 & - \\
\hline $\mathrm{MDA}^{*}$ & 0.05 & - & 0.06 & $\ldots$ & 0.05 & - & 0.6 & 09 - & $=$ & 0.06 & - & 0.08 & - & 0.07 & $\ldots$ & 0.03 & $\ldots$ & 0.04 & - & 0.05 & - \\
\hline Thallium 208 & & & 0.13 & $\ldots$ & 0.13 & $\ldots$ & 0. & 14 - & 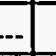 & 0.12 & $\ldots$ & & & & - & 0.21 & $\ldots$ & ND & $\ldots$ & $\mathrm{ND}$ & 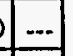 \\
\hline Sigma Error $(+1-)$ & & & 0.02 & - & 0.02 & $\ldots$ & 0.0 & $02-$ & - & 0.02 & - & & - & & - & 0.02 & $-\ldots$ & & -- & & $-\ldots$ \\
\hline $\mathrm{MDA}^{*}$ & & & 0.02 & 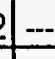 & 0.02 & $=$ & 0.0 & 02 - & + & 0.01 & $\ldots$ & & - & & & 0.01 & $\ldots$ & 0.01 & $u$ & 0.01 & \\
\hline Uranium 238 & ND & $\ldots$ & 0.73 & 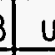 & ND & $\ldots$ & 0.5 & 56 & $u$ & 0.48 & $u$ & ND & .... & 0.55 & $u$ & 0.96 & $\ldots$ & 0.62 & $\ldots$ & 0.56 & 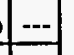 \\
\hline Sigma Error $(+/-)$ & & - & 0.19 & $-\ldots$ & & - & 0. & 14 - & - & 0.12 & $=$ & & $\cdots$ & 0.13 & $\ldots$ & 0.10 & $-\ldots$ & 0.09 &.-- & 0.10 & $\ldots$ \\
\hline MDA* & 0.30 & $\underline{u}$ & 0.25 & - & 0.35 & $u$ & 0.2 & 25 & -1 & 0.19 & $-=$ & 0.56 & 5 & 0.23 & $=$ & 0.12 & $2-$ & 0.17 & $-\ldots$ & 0.16 & 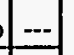 \\
\hline Lead 210 & & & 0.02 & A. & & - & 0. & 36 & 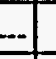 & 0.45 & - & & $\pi$ & & - & 1.53 & -.. & 1.14 & $\ldots$ & 0.75 & $\ldots$ \\
\hline Sigma Error $(+/-)$ & & - & 0.15 & $\ldots$ & & $=$ & 0. & 13. & $\ldots$ & 0.15 & -... & & - & & & 0.23 & 3 & 0.16 &.- & 0.11 & $\ldots$ \\
\hline $\mathrm{MDA}^{*}$ & & - & 0.32 & 4) & & - & 0. & 34 & $\ldots$ & 0.24 & $4]$ & & - & & & 0.12 & 4] - & 0.22 & - & 0.19 & 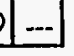 \\
\hline
\end{tabular}




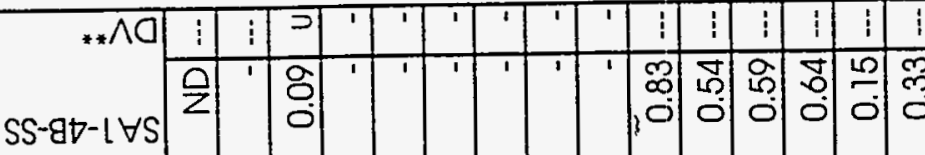

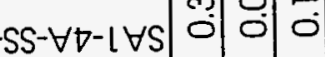

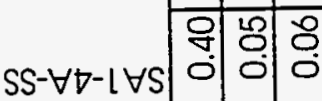
๓ 워

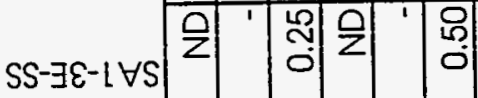

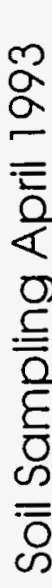

ฉ 


\begin{tabular}{|c|c|c|c|c|c|c|c|c|c|c|c|c|c|c|c|c|c|c|c|c|}
\hline \multirow[b]{2}{*}{ Nucllde $(\mathrm{pCl} / \mathrm{g})$} & \multicolumn{20}{|c|}{ Table A-5.6 Gamma Spectroscopy } \\
\hline & & & 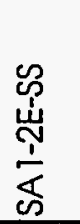 & 닌 & & & 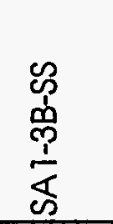 & לे & 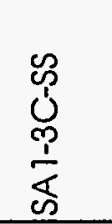 & לे & 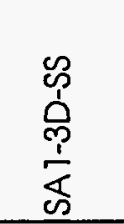 & $\vdots$ & 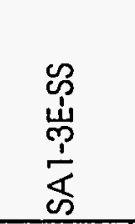 & 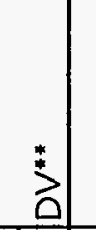 & 袋 & & 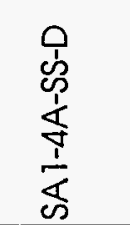 & & 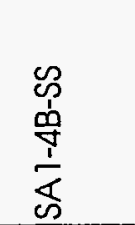 & \\
\hline \begin{tabular}{|l|} 
Uranlum 235 \\
\end{tabular} & & & & & & -1. & & $T$ & & -1 & & $-1-1$ & & -1 & & -1 & & 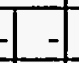 & & \\
\hline Sigma Error $(+/-)$ & & & & & & & & & & & & -1 & & - - & & - & & L & & \\
\hline MDA* & & & & & & & & - & & & & -1 & & -1. & & $T$ & & $1=-2 x+2$ & & \\
\hline Blsmuth 214 & & & & & & & & & & & & -1 & & - & & & & L. & & \\
\hline Sigma Error $(+/-)$ & & & & & & & & & & & & - & & -1. & & H. & & -1 & & \\
\hline MDA* & & & & & & & & & & & & -1 & & - & & -1. & & -1 & & \\
\hline Protactinlum 234 & & & & & & & & & & & & L & & L. & & & & & 2.96 & \\
\hline Sigma Error $(+/-)$ & & & & & & & & $-3+2+3$ & & & & $E$ & & 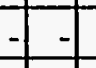 & & & & - & 0.96 & \\
\hline MDA* & & & & & & & & - & & -1 & & $-1-1$ & & -1 & & t & & + & 2.60 & \\
\hline Ihorium 234 & & & & & & & & -1 & & -1 & & -1 & & $\pm=$ & & - & & $1-1$ & & \\
\hline Sigma Error $(+/-)$ & & & & & & & & - & & 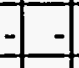 & & $1-1$ & & -1 & & -1 & & -1 & & \\
\hline MDA** & & $-7>$ & & & & & & -1 & & -1 & & T. & & -1. & & & & - & & L \\
\hline
\end{tabular}


SS-ZS-ZVS

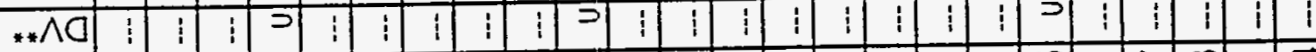

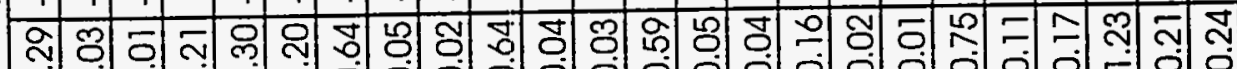

SS-वG-ZҰS

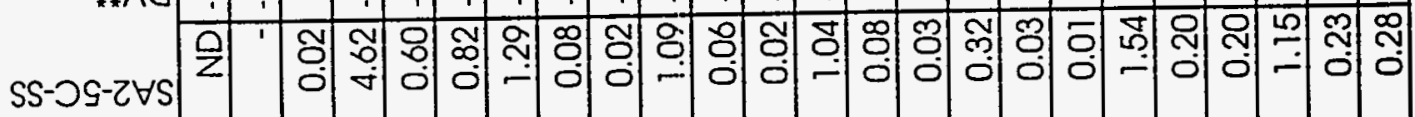

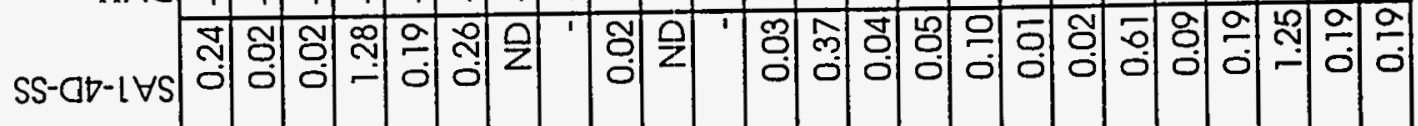

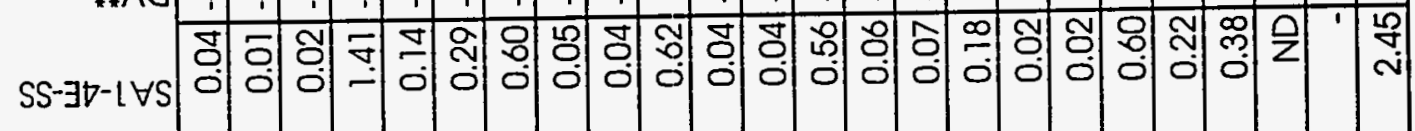




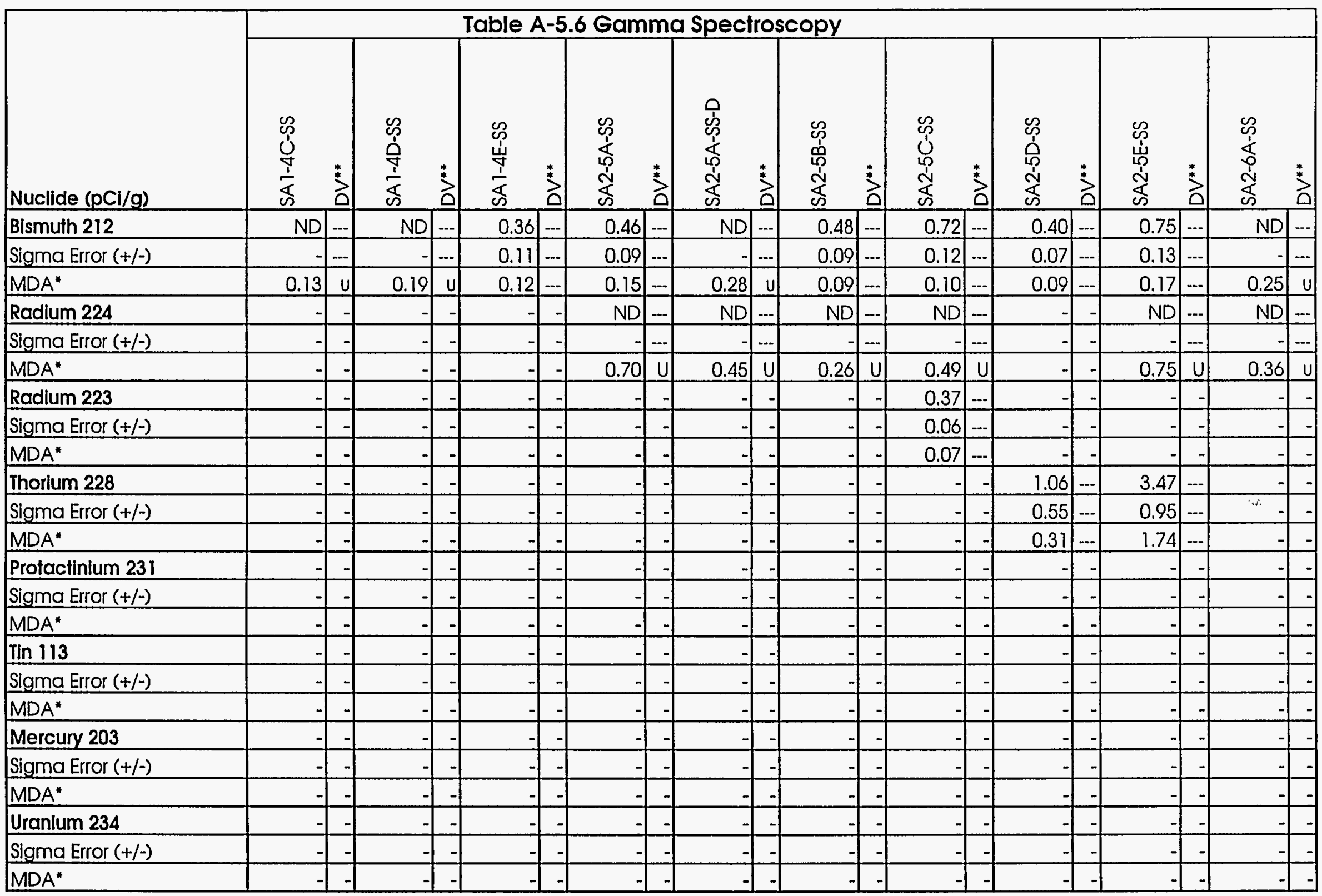




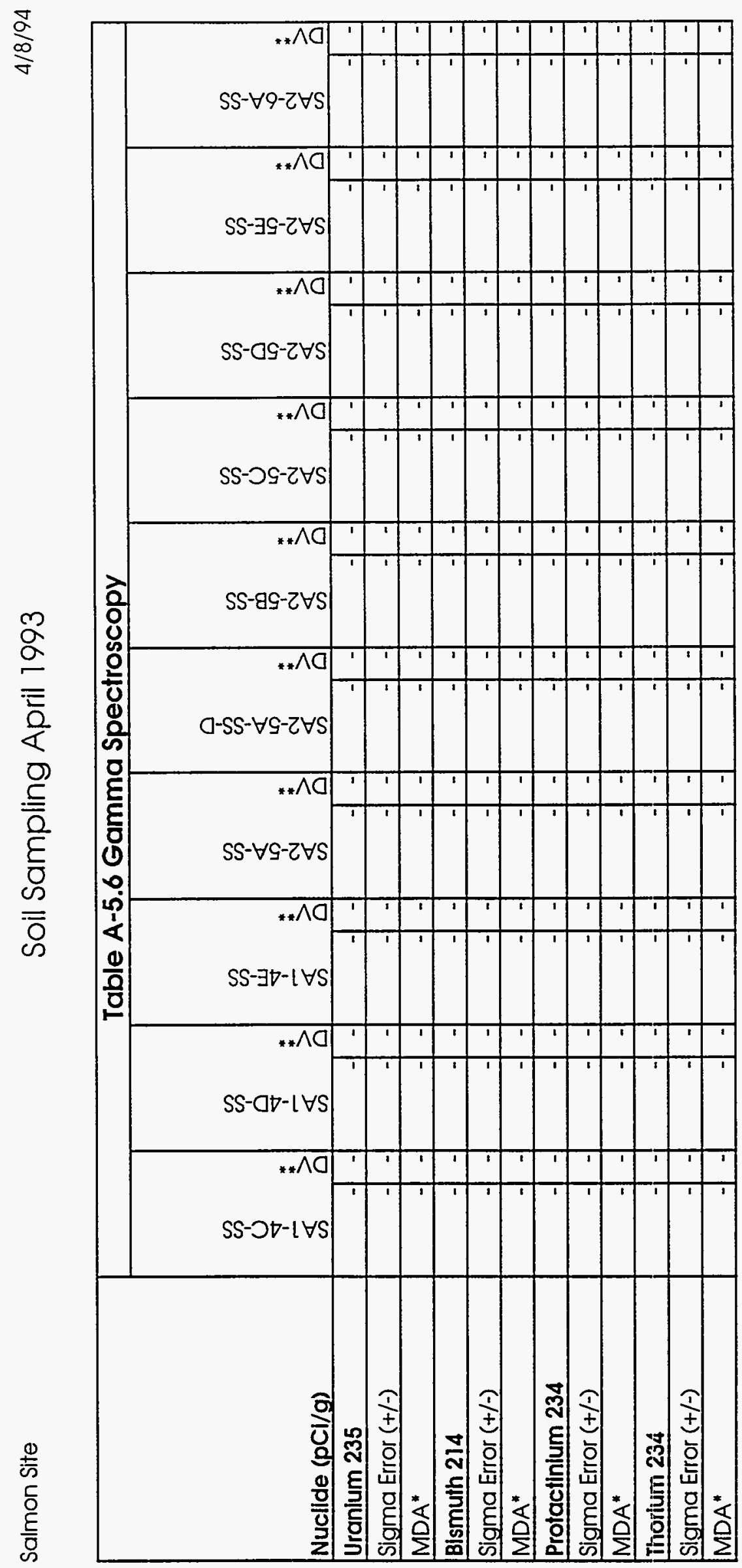

\begin{tabular}{l}
$\infty$ \\
\multirow{2}{0}{} \\
0 \\
0 \\
0 \\
0
\end{tabular}

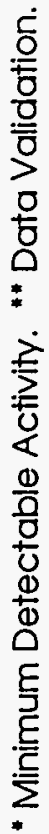




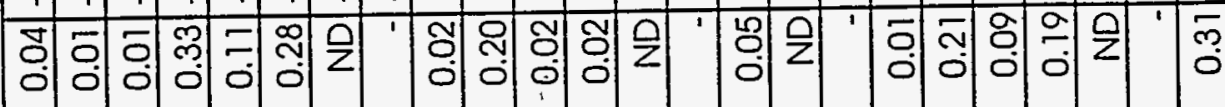

\section{$* \wedge \mathrm{\wedge O}$}

SS- $\angle-\varepsilon \forall S$

$=$ ㄱำ

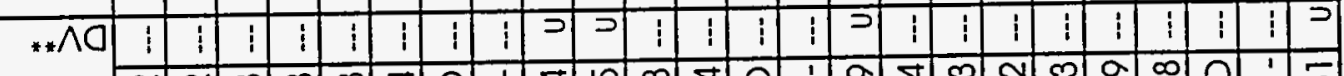

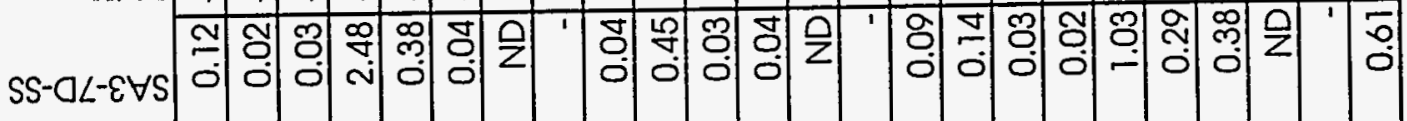

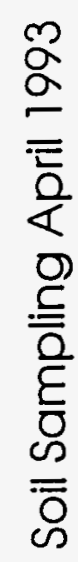

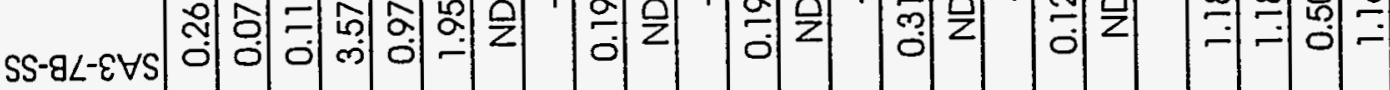

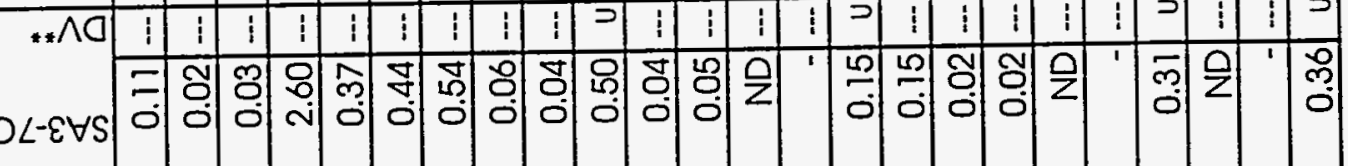
SS-O $\angle-\varepsilon \forall S$

* $\wedge$ 人

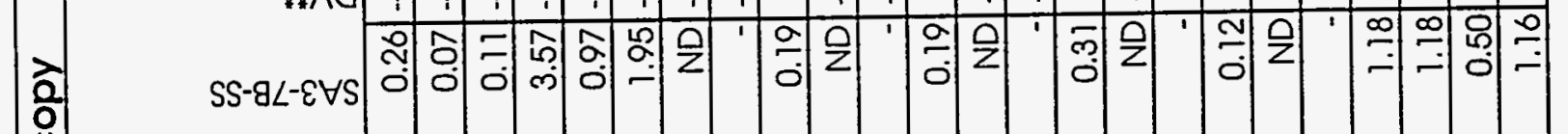

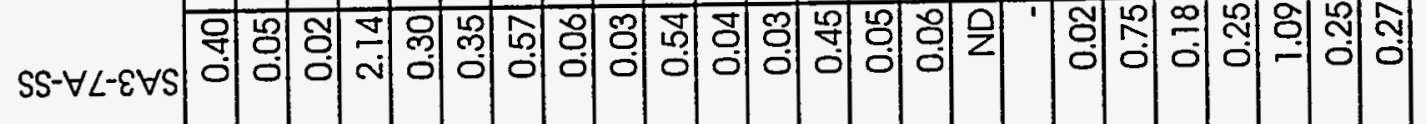

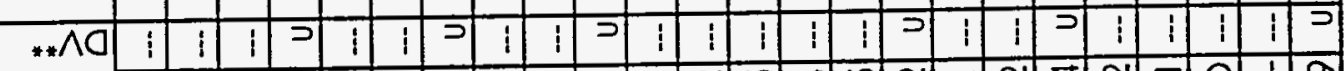

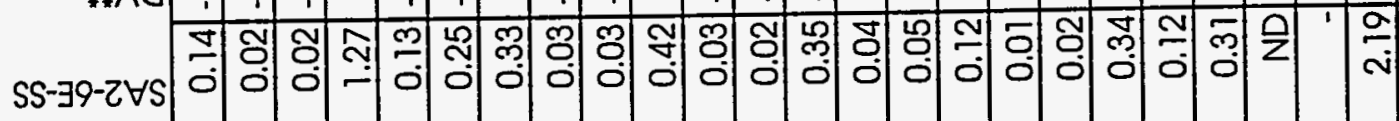

$\stackrel{0}{2}$

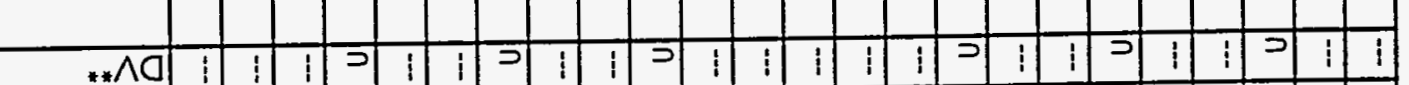

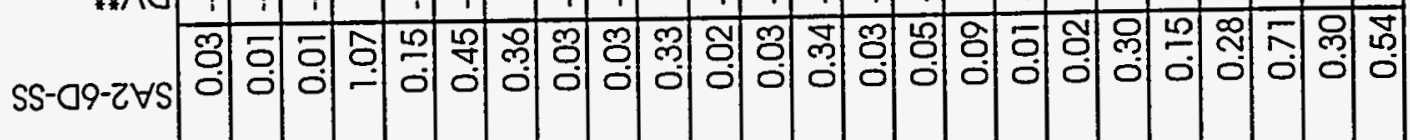

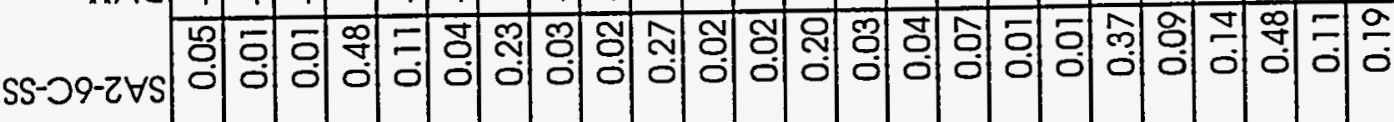

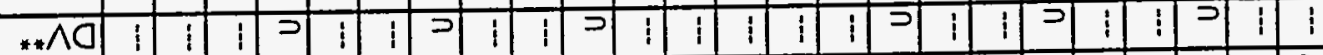

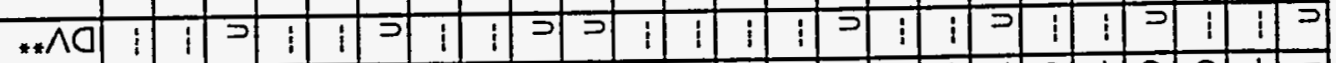

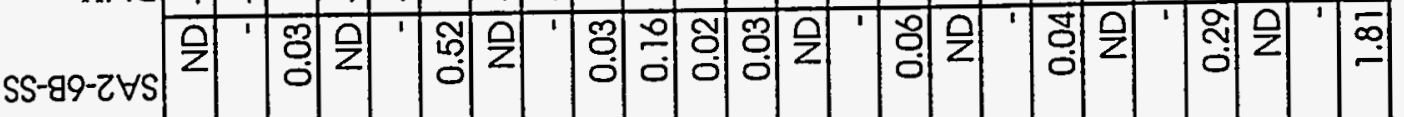




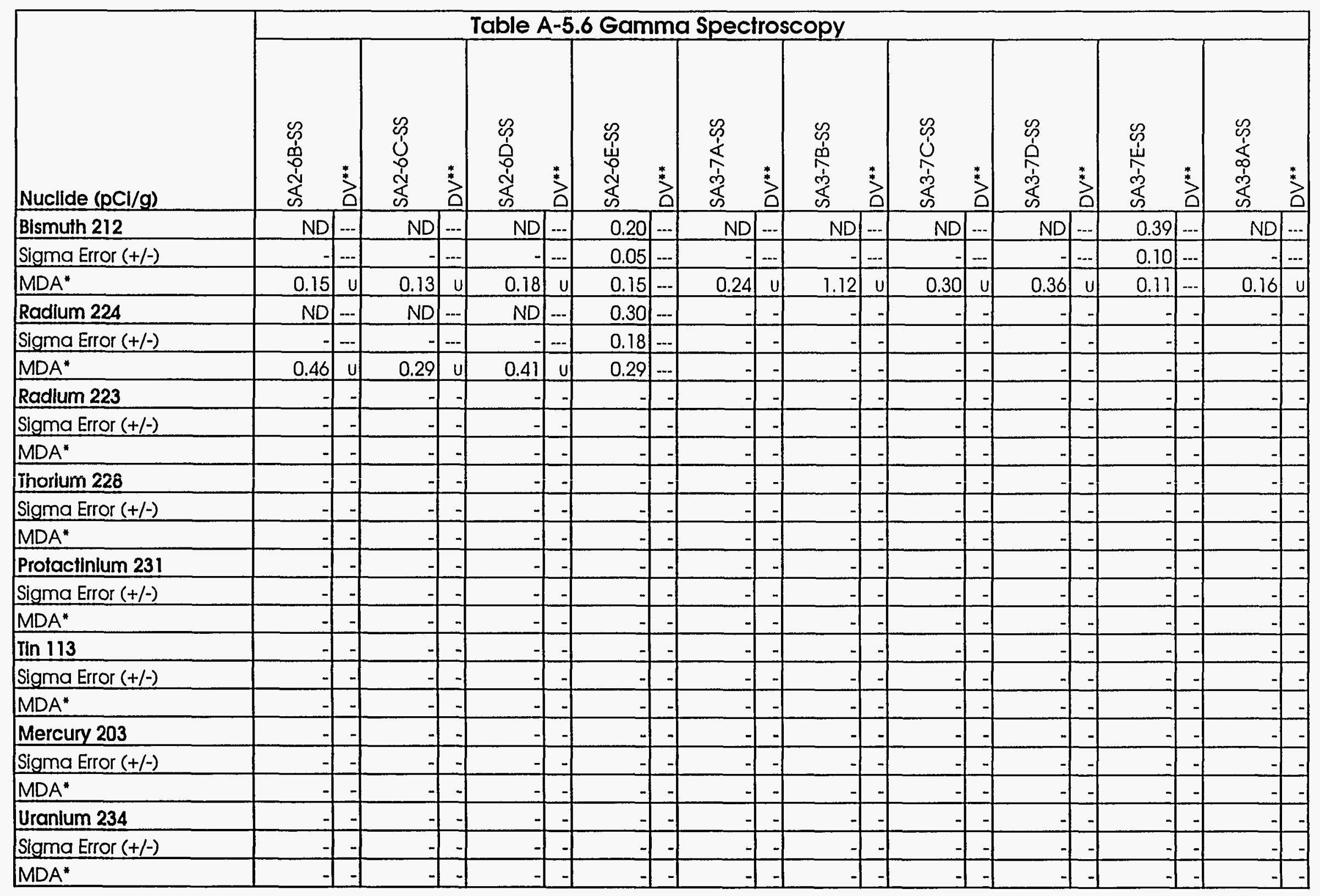




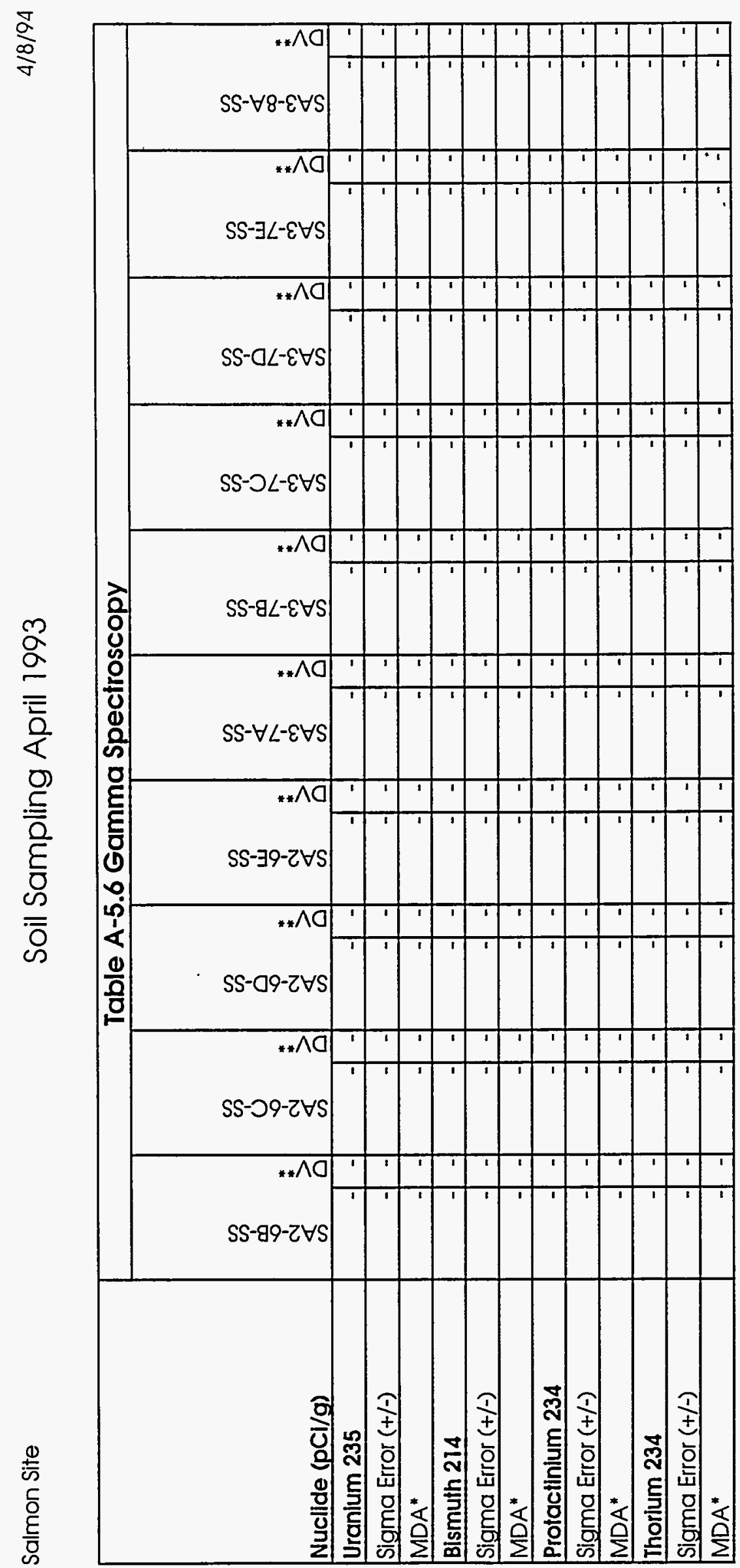

$\bar{N}$
D
ס

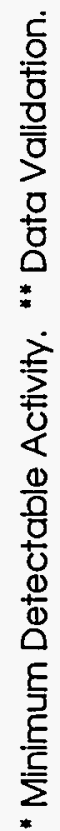




\begin{tabular}{|c|c|c|c|c|c|c|c|c|c|c|c|c|c|c|c|c|c|c|c|c|}
\hline & & & & & able & $4-5$ & Gan & $\mathrm{m}$ & Spec & tro & copy & & & & & & & & & \\
\hline Nuclide $(\mathrm{pcl} / \mathrm{g})$ & 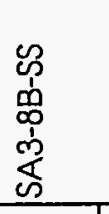 & 艾 & 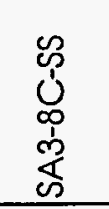 & 3 & 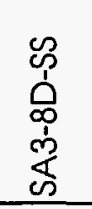 & 굼 & 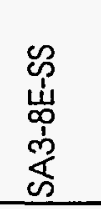 & 莒 & 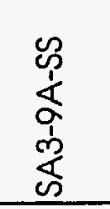 & 莒 & 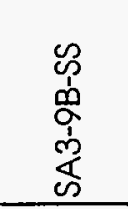 & 乼 & 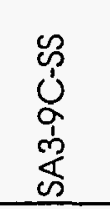 & 艾 & 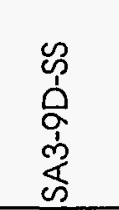 & 范 & 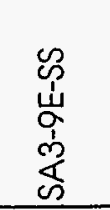 & 3 & 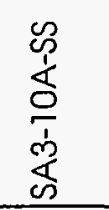 & $\stackrel{*}{*}$ \\
\hline Cesium 137 & 0.09 & $\ldots$ & 0.06 & 5 & 0.1 & $\ldots$ & 0.14 & $\ldots$ & $<.09$ & $u$ & 0.27 & $\ldots$ & 0.24 & $\ldots$ & 0.40 & $\ldots$ & 0.56 & $\ldots$ & 0.61 & $\ldots$ \\
\hline Sigma Error $(+/-)$ & 0.01 & $-\ldots$ & 0.01 & $1 \ldots$ & 0.0 & $\ldots$ & 0.02 & $\ldots$ & & - & 0.10 & $\ldots$ & 0.07 & - & 0.11 & $\ldots$ & 0.13 & $\ldots$ & 0.13 & $\ldots$ \\
\hline $\mathrm{MDA}^{*}$ & 0.03 & $\ldots$ & 0.02 & $2 \ldots$ & 0.0 & $\ldots$ & 0.01 & $\ldots$ & NR & - & $N R$ & - & $N R$ & -1 & $\mathrm{NR}$ & -1 & NR & - -1 & $\mathrm{NR}$ & \\
\hline Potassium 40 & 1.60 & $\ldots$ & 0.35 & - & 5.1 & ... & 1.13 & $\ldots$ & 5.87 & $\ldots$ & 5.19 &.- & 3.19 & $\ldots$ & 6.08 & ... & 4.36 & $\ldots$ & 3.16 & \\
\hline Sigma Error $(+/-)$ & 0.22 & $\ldots$ & 0.12 & $2 \ldots$ & 0.6 & - & 0.20 & $\ldots$ & 1.78 & $\ldots$ & 1.84 & -.. & 1.02 & $-\ldots$ & 1.52 & $\ldots$ & 1.55 & $\ldots$ & 1.33 & $\ldots$ \\
\hline MDA* & 0.33 & $-\infty$ & 0.37 & - & 0.3 & - & 0.23 & $\ldots$ & NR & $=$ & NR & $1-$ & NR & - & $N R$ & & NF & $21-$ & NR & \\
\hline Lead 212 & 0.32 & - & 0.20 & $u$ & $\overline{N L}$ & $\ldots$ & 0.71 & $\ldots$ & & - & J & - & & -1 & 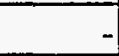 & - & -1 & - & & \\
\hline Sigma Error $(+/-)$ & 0.03 & $\ldots$ & 0.03 & (... & & $\ldots$ & 0.06 & $\ldots$ & & - & - & - & & -1 & & - & & - & & 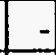 \\
\hline $\mathrm{MDA}^{*}$ & 0.03 & $-\ldots$ & 0.04 & I.- & 0.0 & $u$ & 0.02 & $\ldots$ & & - & & - & & -1 & & -1 & & - & & -1 \\
\hline Racilum 220 & ND & $\ldots$ & 0.19 & 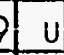 & 0.9 & -- & 0.42 & $\underline{u}$ & 1.12 & $\ldots$ & 1.22 & $\ldots$ & 0.74 & ב-ב & 0.96 & $\ldots$ & 0.97 & $\ldots$ & 0.76 & $\ldots$ \\
\hline Sigma Error $(+/-)$ & & $\ldots$ & 0.02 & 2 & 0.0 & $\ldots$ & 0.03 & $\ldots$ & 0.17 & $\ldots$ & 0.18 & $\ldots$ & 0.12 & 2... & 0.17 & $\ldots$ & 0.16 & $\ldots$ & 0.16 & $\ldots$ \\
\hline MDA* & 0.04 & 0 & 0.04 & 4 & 0.0 & - & 0.02 & $\ldots$ & NR & - & NR & $1-1$ & $\mathrm{NR}$ & $8-1$ & $N R$ & & NR & $4-$ & NR & \\
\hline Radium 228 & 0.32 & $\ldots$ & ND & 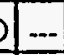 & 1.0 & - & 0.61 & $\ldots$ & 1.46 & $\ldots$ & 1.24 &.- & 0.97 & 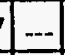 & 1.09 & $\ldots$ & 1.34 & $\ldots$ & 0.91 & $\ldots$ \\
\hline Sigma Error $(+/-)$ & 0.02 & $-\ldots$ & & $\ldots$ & 0.0 & $\ldots$ & 0.06 & $\ldots$ & 0.28 & $\ldots$ & 0.26 & $\ldots$ & 0.20 & ... & 0.25 & $\ldots$ & 0.26 & $\ldots$ & 0.23 & $\ldots$ \\
\hline $\mathrm{MDA}^{*}$ & 0.08 & - & 0.05 & 5 & 0.0 & $=$ & 0.03 & $\ldots$ & $\mathrm{NR}$ & $=$ & $N R$ & & $\mathrm{NR}$ & 2- & $\mathrm{NR}$ & & $N B$ & & $\mathrm{NR}$ & \\
\hline Thallium 208 & $N D$ & $\ldots$ & 0.07 & -..- & 0.3 & $\ldots$ & 0.21 & $\ldots$ & & - & & & & -1. & & & & . & & \\
\hline Sigma Error $(t /-)$ & & - & 0.01 & $1]$ & 0.0 & $\ldots$ & 0.02 & $\ldots$ & & - & & & & 1 & & & & . & & \\
\hline MDA* & 0.02 & $\mathrm{u}$ & 0.02 & \begin{tabular}{l|l}
2 & $\ldots$ \\
2
\end{tabular} & 0.0 & $\ldots$ & 0.01 & $\ldots$ & & - & & & & 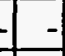 & & - & & 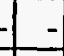 & & \\
\hline Uranium 238 & $\mathrm{ND}$ & $\ldots$ & $\mathrm{ND}$ & 2. & 1.3 & $\ldots$ & $\mathrm{ND}$ & $\ldots$ & & - & & & & 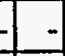 & & & & & & \\
\hline Sigma Error $(+/-)$ & & - & & $-\ldots$ & 0.1 & $\ldots$ & & $\cdots$ & & - & & t & & -1 & & & & & & \\
\hline MDA* & 0.38 & $\mathrm{u}$ & 0.33 & $\begin{array}{lll}3 & 0 \\
\end{array}$ & 0.2 & $\ldots$ & 0.17 & $\underline{u}$ & & & & & & & & & & & & \\
\hline Lead 210 & $\mathrm{ND}$ & -1 & ND & DI... & 2.0 & $\ldots$ & 0.51 & ב- & & & & & & & & & & 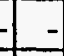 & & \\
\hline Sigma Error $(t /-)$ & & - & & - & 0.4 & -- & 0.11 & $=$ & & & & & & & & & & & & \\
\hline $\mathrm{MDA}^{*}$ & 2.46 & $u$ & 2.33 & $\begin{array}{ll}3 & 0 \\
3\end{array}$ & 0.3 & - & 0.02 & t? & & & & & & & & & & . & & - \\
\hline
\end{tabular}




\begin{tabular}{|c|c|c|c|c|c|c|c|c|c|c|c|c|c|c|c|c|c|c|c|c|}
\hline & & & & & able A & $4-5$ & $6 \mathrm{Gam}$ & $\mathrm{ams}$ & Spec & tros & copy & & & & & & & & & \\
\hline Nuclide $(\mathrm{pCl} / \mathrm{g})$ & 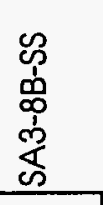 & $\sum_{0}^{*}$ & 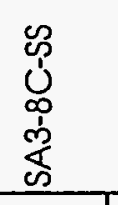 & ${ }^{*}$ & 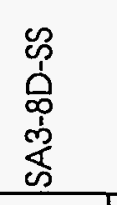 & 草 & 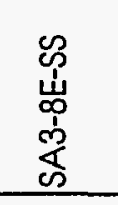 & $\stackrel{*}{3}$ & 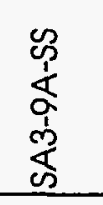 & $\stackrel{0}{3}$ & 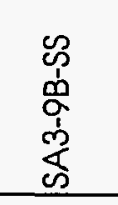 & $3^{*}$ & 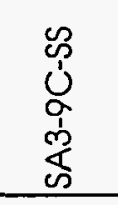 & $\stackrel{2}{0}^{*}$ & 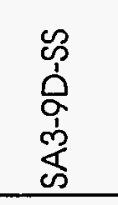 & 艺 & 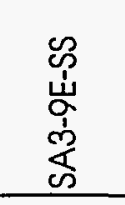 & 草 & $\begin{array}{l}\mathscr{p} \\
\frac{1}{\delta} \\
\frac{0}{1} \\
\dot{\infty} \\
\stackrel{\infty}{\infty}\end{array}$ & $\stackrel{1}{0}^{*}$ \\
\hline Bismuth 212 & $\mathrm{ND}$ & $\ldots$ & ND & $\ldots$ & 0.61 & -- & 0.37 & $\ldots$ & & - & & - & & - & - &. & & -1 & - & 5 \\
\hline Sigma Error $(+/-)$ & & $\ldots$ & -1 & $\ldots$ & 0.16 & $-\ldots$ & 0.10 & $\ldots$ & . & -1 & & - & & -1 & - & - & & -1 & & - \\
\hline MDA* & 0.29 & $\underline{u}$ & 0.23 & u) & 0.15 & $\ldots$ & 0.01 & $\ldots$ & & -1 & & - & & - & 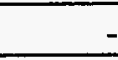 & - & & - & - & - \\
\hline Radium 224 & 0.97 & -- & - & - & 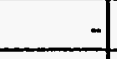 & - & & -1 & - & -1 & & - & & - & $=$ & - & & - & & - \\
\hline Sigma Error $(+/-)$ & 0.19 & $\ldots$ & -1 & - & - & - & & - & . & -1 & & - & & - & - & - & & -1 & & - \\
\hline MDA* & 0.35 & $\ldots$ & - & - & - & - & $=$ & - & - & -1 & & - & & -1 & - & - & & - & & - \\
\hline Radium 223 & & - & - & -1 & & - & - & - & - & -1 & 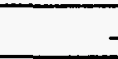 & - & & -1 & - & - & & - & & - \\
\hline Sigma Error $(+/-)$ & & - & - & -1 & & - & - & - & 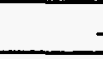 & -1 & 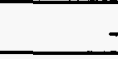 & - & & -1 & - & -1 & & $\therefore$ & & $=$ \\
\hline MDA" & & - & -1 & -1 & & - & - & - & 7 & -1 & - & - & & -1 & - & - & & - & - & - \\
\hline Thorium 228 & & - & -1 & - & & -1 & $=$ & - & s. & -1 & - & - & & -1 & $=$ & - & & - & & - \\
\hline Sigma Error $(+/-)$ &. & $=$ & - & -1 & - & - & - & - &. & -1 & - & - & & -1 & - & - & & - & - & - \\
\hline MDA* & & - & -1 & -1 & 7 & -1 & - & - & - & -1 & - & - & & -1 & - & - & & -1 & & - \\
\hline Protactinium 231 & & . & - & - & -1 & - & - & - & 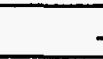 & -1 & & - & & -1 & - & - & & - & & - \\
\hline Sigma Error $(+/-)$ & -1 & - & - & -1 & -1 & - & $=$ & - & & -1 & & - & & - & - & -1 & & - & & - \\
\hline MDA" & & - & - & -1 & - & - & - & - & - & -1 & & - & & 71 & - & - & & - & - & - \\
\hline Tin 113 & -1 & -1 & - & -1 & $\rightarrow$ & - & - & -1 & - & -1 & 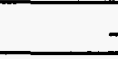 & - & & -1 & 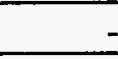 & - & & - & - & - \\
\hline Sigma Error $(+/-)$ & 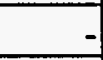 & - & -1 & -1 & & - & - & - & 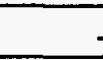 & -1 & . & - & & 91 & - & - & & - & - & - \\
\hline MDA* & - & - & - & -1 & & - & - & - & - & $-1-1$ & 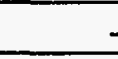 & - & & -1 & - & - & & - & - & - \\
\hline Mercury 203 & & - & - & -1 & & - & - & - & 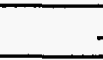 & -1 & - & - & & -1 & - & - & & -1 & - & . \\
\hline Sigma Error $(+/-)$ & - & - & - & - & & - & - & - & 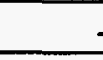 & -1 & $=$ & - & - & -1 & 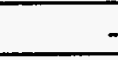 & - & - & - & - & - \\
\hline MDA* & & $=$ & & - & & - & - & 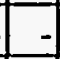 & 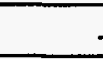 & -1 & s. & - & & -1 & - & - & & - & - & - \\
\hline Uranium 234 & -1 & - & -1 & - & & - & $=$ & 4 & - & -1 & - & - & 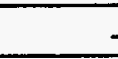 & -1 & $=$ & -1 & 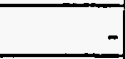 & -1 & - & - \\
\hline Sigma Error $(+1-)$ & - & $=$ & - & - & & - & & -1 & - & -1 & - & - & & --1 & 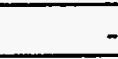 & - & - & - & - & - \\
\hline MDA* & 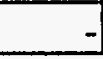 & - & -1 & - & - & - & - & - & . & 7 & 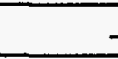 & - & & -1 & - & -1 & - & 5 & - & - \\
\hline
\end{tabular}




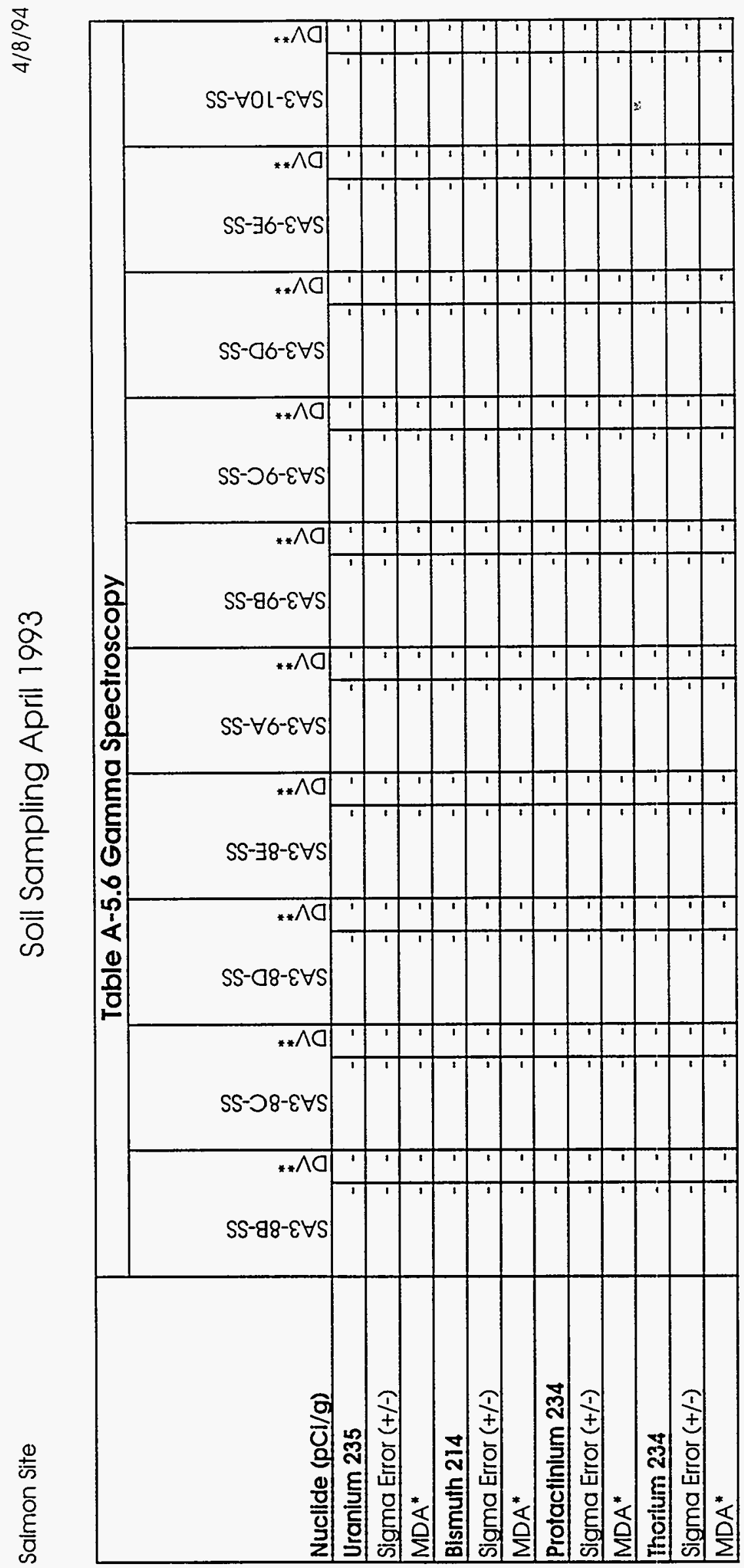

ส
0
0
0
0

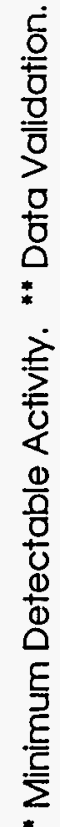




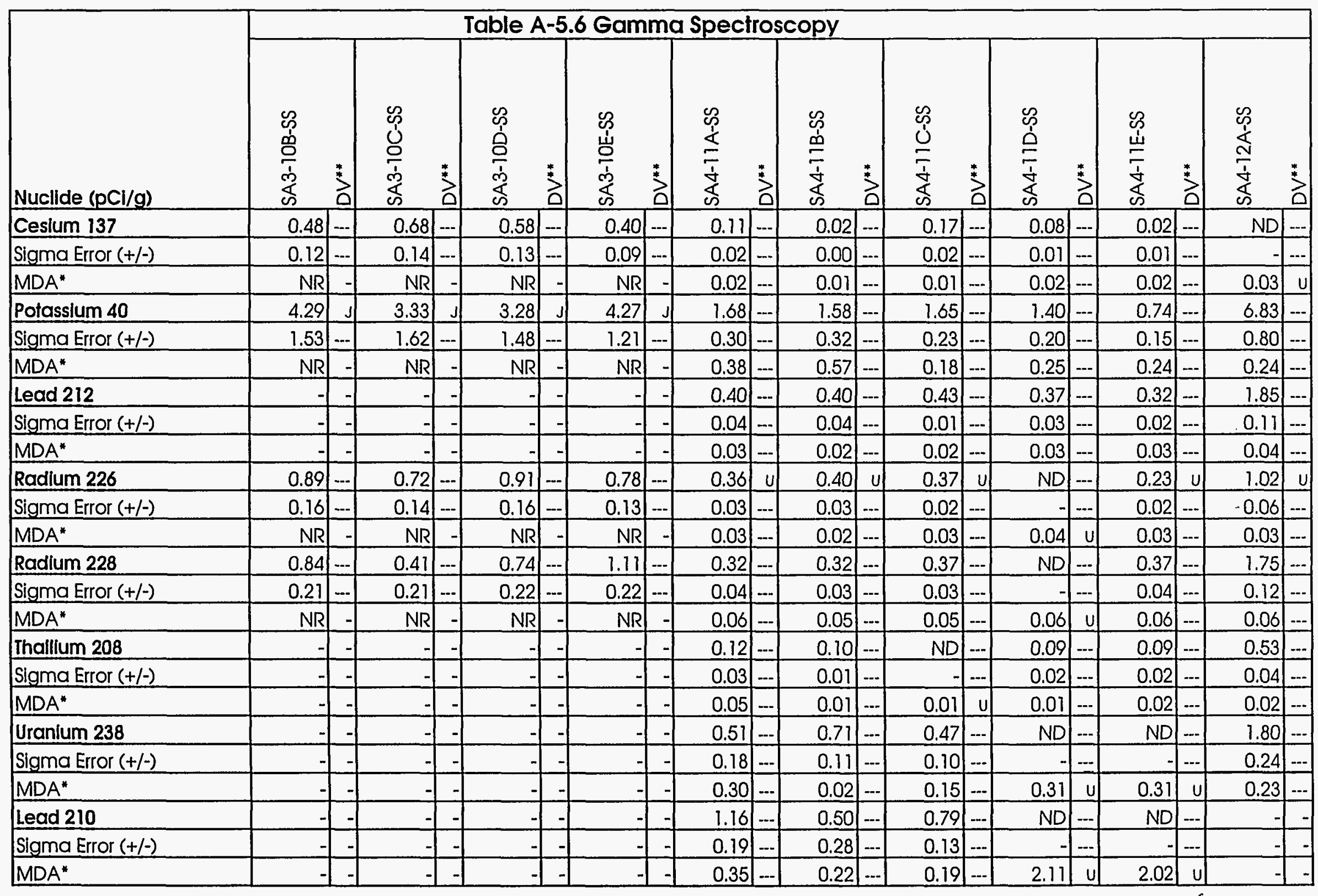

- Minimum Detectable Activity. " " Data Validation. 


\begin{tabular}{|c|c|c|c|c|c|c|c|c|c|c|c|c|c|c|c|c|c|c|c|c|}
\hline \multirow[b]{2}{*}{ Nuclide $(\mathrm{pCl} / \mathrm{g})$} & \multicolumn{20}{|c|}{ Table A-5.6 Gamma Spectroscopy } \\
\hline & 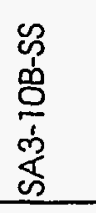 & 草 & 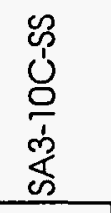 & 艾 & 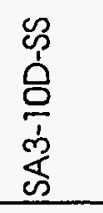 & 草 & 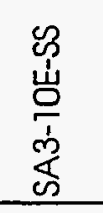 & $3^{*}$ & 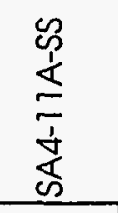 & $\stackrel{3}{0}^{*}$ & 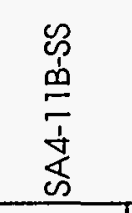 & 苛 & 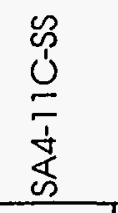 & 莡 & 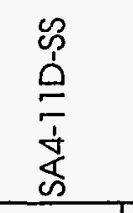 & 莡 & 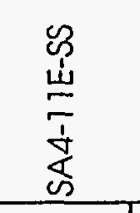 & 草 & 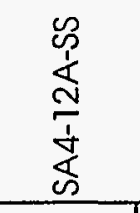 & $\stackrel{*}{2}$ \\
\hline Bismuth 212 & - & $\rightarrow$ & - & -1 & & -1 & & -1 & ND & $\ldots$ & 0.23 & $-\cdots$ & ND & $\ldots$ & ND & $\ldots$ & $\mathrm{ND}$ & $\ldots$ & & $2-1$ \\
\hline Sigma Error $(+/-)$ & - & - & - & -1 & & - & . & -1 & - & $\ldots$ & 0.06 & $\ldots$ & & $\ldots$ & -1 & $\ldots$ & -1 & $\ldots$ & - & - \\
\hline MDA* & - & - & - & -7 & & - & 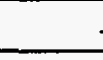 & -1 & 0.25 & $u$ & 0.09 & $\ldots$ & 0.15 & $\mathrm{U}$ & 0.21 & $U$ & 0.22 & $\mathrm{u}$ & - & - \\
\hline Radium 224 & $=$ & - & - & - & & - & . & -1 & 0.40 & $\ldots$ & & - & 0.29 & $\ldots$ & 0.80 & $\ldots$ & - & - & 1.23 & $\ldots$ \\
\hline Sigma Error (t/-) & - & - & - & -7 & & - & 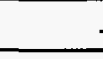 & -1 & 0.33 & $\ldots$ & & - & 0.19 & -- & 0.18 & $\ldots$ & & - & 0.48 & $\ldots$ \\
\hline MDA" & $=$ & - & - & -1 & & - & 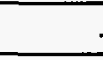 & -1 & 0.28 & $\ldots$ & & - & 0.19 & $\ldots$ & 0.03 & $\ldots$ & - & - & 0.41 & $\ldots$ \\
\hline Radium 223 & - & - & - & - & & - & 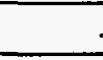 & -1 & - & -1 & -1 & - & & - & - & - & - & - & -1 & - \\
\hline Sigma Error $(+/-)$ & $=$ & - & - & -1 & & - & 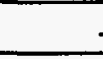 & -1 & - & - & - & - & & - & -1 & - & -1 & -1 & -1 & - \\
\hline$M D A^{*}$ & & - & - & -1 & - & - & 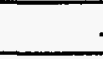 & -1 & - & -1 & -1 & - & -1 & - & -1 & - & -1 & - & - & - \\
\hline Thorium 228 & - & -1 & - & -1 & - & - & 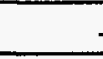 & $-1-1$ & - & -1 & -1 & - & & - & -1 & - & -1 & -1 & 4.35 & $\ldots$ \\
\hline Sigma Error $(+/-)$ & - & -1 & - & - & & - & - & -1 & $=$ & -1 & - & - & & -1 & - & - & - & -7 & 1.20 & $\ldots$ \\
\hline MDA* & - & - & - & -1 & & - & & -1 & - & -1 & & - & & - & -1 & - & -1 & -1 & 1.77 & $\ldots$ \\
\hline Protactinium 231 & - & -1 & - & -1 & - & - & 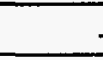 & -1 & - & - & - & - & & - & -7 & - & -1 & - & 0.96 & $\ldots$ \\
\hline Sigma Error (+/-) & - & - & - & -1 & - & - & 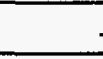 & -1 & - & - & & - & & - & -1 & - & - & - & 0.42 & $\ldots$ \\
\hline MDA* & 二 & -1 & - & - & - & - & 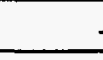 & -1 & - & - & - & - & -4 & - & - & - & - & - & 0.69 & $\ldots$ \\
\hline $\operatorname{Tin} 113$ & - & -1 & - & -1 & & - & - & -1 & 0.03 & $\ldots$ & & - & & - & - & - & - & - & - & - \\
\hline Sigma Error (+/-) & $=$ & -1 & - & -1 & - & - & 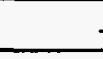 & -5 & 0.01 & $\ldots$ & & - & & - & - & - & - & - & - & - \\
\hline MDA* & - & - & - & - & - & -1 & - & -1 & 0.03 & $\ldots$ & & - & & - & -1 & -1 & - & - & - & - \\
\hline Mercury 203 & E & -1 & - & - & & - & 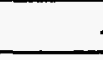 & -1 & & - & & - & & - & - & - & - & - & - & - \\
\hline Sigma Error $(+/-)$ & & -1 & - & - & & 1 & & -1 & & - & & - & & - & -1 & - & - & - & - & - \\
\hline MDA* & & -1 & - & -1 & & - & & 4.7 & & - & & - & & - & & - & & - & & - \\
\hline Uranium 234 & & -1 & - & -1 & & & & -1 & & - & & -1 & & - & & - & & - & - & - \\
\hline Sigma Error $(+/-)$ & & $\rightarrow$ & & - & & -7 & & $=1-7$ & & -7 & & - & & - & & - & & . & & - \\
\hline MDA* & & 7 & - & - & & - & & -I & & - & & - & & - & & - & & & -1 & - \\
\hline
\end{tabular}




\begin{tabular}{|c|c|c|c|c|c|c|c|c|c|c|c|c|c|c|c|c|c|c|c|c|c|}
\hline \multirow[b]{2}{*}{ Nuclide $(\mathrm{pCl} / \mathrm{g})$} & \multicolumn{21}{|c|}{ Table A-5.6 Gamma Spectroscopy } \\
\hline & 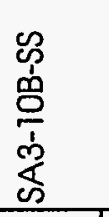 & 를 & 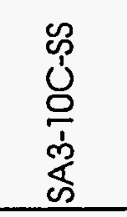 & 莒 & 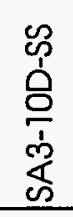 & 茨 & & 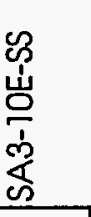 & 呈 & 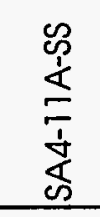 & 艾 & 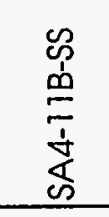 & 艾 & 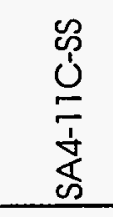 & 草 & 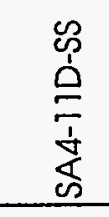 & 盗 & 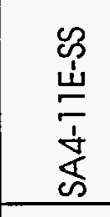 & 3 & 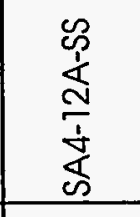 & 辛 \\
\hline \multicolumn{22}{|l|}{ Uranium 235} \\
\hline \multicolumn{22}{|l|}{ Sigma Error $(t /-)$} \\
\hline \multicolumn{22}{|l|}{ MDA* } \\
\hline \multicolumn{22}{|l|}{ Bismuth 214} \\
\hline \multicolumn{22}{|l|}{ Sigma Error $(+/-)$} \\
\hline \multicolumn{22}{|l|}{$\mathrm{MDA}^{*}$} \\
\hline \multirow{2}{*}{\multicolumn{22}{|c|}{ Protactinium 234}} \\
\hline \multirow{2}{*}{\multicolumn{22}{|c|}{$\begin{array}{l}\text { Sigma Error }(+/-) \\
M^{*}\end{array}$}} \\
\hline & & & & & & & & & & & & & & & & & & & & & \\
\hline \multicolumn{22}{|l|}{ Thorlum 234} \\
\hline Sigma Error $(+/-)$ & 1.03 & $\ldots$ & 0.99 & $\ldots$ & & 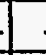 & & 0.92 & - & & - & & - & & -1 & & & & -1 & & $-1-$ \\
\hline $\mathrm{MDA}^{*}$ & $N R$ & 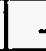 & NR & - & & . & & $N R$ & . & & -1 & & I & & -1 & & - & & $-1-1$ & & $-1-1$ \\
\hline
\end{tabular}




\begin{tabular}{|c|c|c|c|c|c|c|c|c|c|c|c|c|c|c|c|c|c|c|c|c|}
\hline \multirow[b]{2}{*}{ Nucllde (pCi/g) } & \multicolumn{20}{|c|}{ Table A-5.6 Gamma Spectroscopy } \\
\hline & 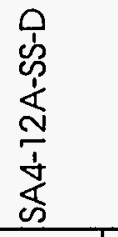 & ${ }^{*}$ & 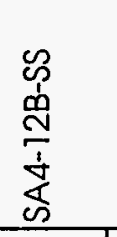 & $\stackrel{2}{*}^{*}$ & 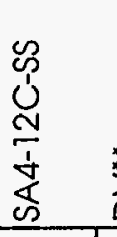 & 艾 & 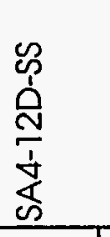 & ¿ & 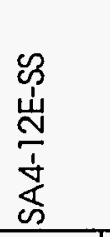 & 苛 & 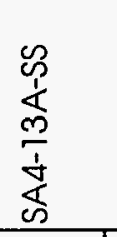 & 艾 & 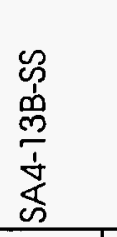 & $\stackrel{*}{*}$ & 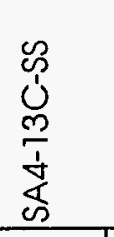 & ${ }^{*}$ & 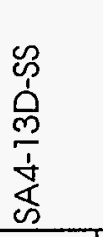 & $\stackrel{*}{*}$ & 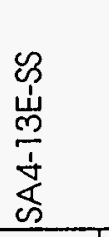 & $\stackrel{2}{0}^{*}$ \\
\hline Cesium 137 & ND & $\ldots$ & 0.04 & $\ldots$ & 0.51 & $-\ldots$ & 0.53 & $\ldots$ & 0.04 & $\ldots$ & 0.05 & $\ldots$ & 0.07 & \begin{tabular}{|l|}
$\ldots$ \\
\end{tabular} & 0.08 & \begin{tabular}{|l|}
$-\ldots$ \\
\end{tabular} & 0.26 & $\ldots$ & 0.19 & $\ldots$ \\
\hline Sigma Error (+/-) & & $\ldots$ & 0.01 & \begin{tabular}{|l|}
$-\ldots$ \\
\end{tabular} & 0.05 & $\ldots$ & 0.05 & $\ldots$ & 0.01 & $\ldots$ & 0.01 & $\ldots$ & 0.01 & $\ldots$ & 0.01 & $\ldots$ & 0.03 & $\ldots$ & 0.02 & $\ldots$ \\
\hline $\mathrm{MDA}^{*}$ & 0.03 & $u$ & 0.02 & $\ldots$ & 0.01 & $-\ldots$ & 0.02 & $\ldots$ & 0.01 & \begin{tabular}{|l|}
$\ldots$ \\
\end{tabular} & 0.02 & $\ldots$ & 0.02 & $\ldots$ & 0.02 & $\ldots$ & 0.01 & $\ldots$ & 0.02 & $\ldots$ \\
\hline Potassium 40 & 7.16 & $\ldots$ & 5.92 & $\ldots$ & 1.45 & $u$ & 2.12 & $\ldots$ & 1.65 & $u$ & 0.98 & $u$ & 1.22 & $u$ & 1.21 & $u$ & 2.79 & \begin{tabular}{|l|}
- \\
\end{tabular} & 2.50 & $\ldots$ \\
\hline Sigma Error $(+/-)$ & 1.03 & -- & 0.73 & $\ldots$ & 0.19 . & -1 & 0.31 & $\ldots$ & 0.22 & $\ldots$ & 0.19 & $\ldots$ & 0.20 & $\ldots$ & 0.15 & $-\infty$ & 0.36 & $\ldots$ & 0.32 & $\ldots$ \\
\hline MDA* & 1.15 & $-\ldots$ & 0.10 & $\ldots$ & 0.17 &.- & 0.26 & $\ldots$ & 0.21 & $\ldots$ & 0.23 & $\ldots$ & 0.26 & $\ldots$ & 0.23 & $\ldots$ & 0.22 & $\ldots$ & 0.24 & $\ldots$ \\
\hline Lead 212 & 1.86 & $\ldots$ & 1.46 & $\ldots$ & 0.54 & -1 & ND & $\ldots$ & 0.58 & $\ldots$ & ND & $\ldots$ & $\mathrm{ND}$ & \begin{tabular}{|l|}
- \\
\end{tabular} & ND & $\ldots$ & 0.56 & \begin{tabular}{|l|}
$-\ldots$ \\
\end{tabular} & ND & $\ldots$ \\
\hline Sigma Error $(+/-)$ & 0.11 & $\ldots$ & 0.08 & $\ldots$ & 0.04 & --1 & & $\ldots$ & 0.05 & $\ldots$ & & $\ldots$ & & \begin{tabular}{|l|l|}
$-\ldots$ \\
\end{tabular} & & $\ldots$ & 0.04 & $\ldots$ & 0.03 & $\ldots$ \\
\hline $\mathrm{MDA}^{*}$ & 0.04 & $\ldots$ & 0.04 & 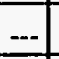 & 0.02 & $\ldots$ & 0.03 & $u$ & 0.02 & $\ldots-$ & 0.03 & $u$ & 0.02 & u & 0.02 & $u$ & 0.03 & $\ldots$ & .0 .03 & $\mathrm{U}$ \\
\hline Radlum 226 & 1.00 & u & 0.86 & u & 0.54 & 4 & 0.50 & 4 & 0.44 & $u$ & 0.28 & 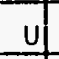 & 0.30 & 4 & 0.31 & U & 0.52 & u & 0.82 & $u$ \\
\hline Sigma Error $(+/-)$ & 0.05 & $\ldots$ & 0.05 & - & 0.03 & $\ldots$ & 0.03 & $-\ldots$ & 0.03 & $\ldots$ & 0.02 & $\ldots$ & 0.02 & -- & 0.02 & $\ldots$ & 0.03 & $\ldots$ & 0.04 & $\ldots$ \\
\hline MDA* & 0.04 & $\ldots$ & 0.04 & \begin{tabular}{|l|}
- \\
\end{tabular} & 0.02 & $\ldots$ & 0.04 & $\ldots$ & 0.02 & \begin{tabular}{|l|}
- \\
\end{tabular} & 0.03 & -- & 0.03 & $\ldots$ & 0.03 & $\ldots$ & 0.03 & $\ldots$ & 0.03 & $\ldots$ \\
\hline Radlum 228 & 1.76 & $\ldots$ & 1.34 & $\ldots$ & 0.49 & $\ldots$ & 0.38 & $\ldots$ & 0.49 & \begin{tabular}{|l|}
- \\
\end{tabular} & 0.23 & $\ldots$ & 0.25 & $\ldots$ & 0.29 & $\ldots$ & 0.47 & $\ldots$ & 0.54 & $\ldots$ \\
\hline Sigma Error $(+/-)$ & 0.11 & $\ldots$ & 0.09 & -- & 0.04 & $\ldots$ & 0.04 & $\ldots$ & 0.04 & $\ldots$ & 0.03 & $\ldots$ & 0.03 & $\ldots$ & 0.03 & $\ldots$ & 0.04 & $\ldots$ & 0.05 & $\ldots$ \\
\hline MDA* & 0.07 & $\ldots$ & 0.03 & $-\ldots$ & 0.05 & $\ldots$ & 0.07 & $-\ldots$ & 0.03 & $\ldots$ & 0.01 & $\ldots$ & 0.04 & 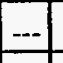 & 0.05 & $\ldots$ & 0.04 & $\ldots$ & 0.05 & $\ldots$ \\
\hline Thallium 208 & 0.52 & $\ldots$ & 0.43 & $\ldots$ & ND. & $\ldots$ & ND & $\cdots$ & 0.15 & $\ldots$ & 0.08 & U & ND & $\ldots$ & 0.10 & $u$ & 0.15 & $u$ & ND &.- \\
\hline Sigma Error $(+/-)$ & 0.04 & $\ldots$ & 0.04 & $\ldots$ & -7. & $\ldots$ & & $\ldots$ & 0.02 & $\ldots$ & 0.01 & $\ldots$ & & $\ldots$ & 0.01 & $\ldots$ & 0.02 & $\ldots$ & &.- \\
\hline MDA" & 0.02 & --- & 0.02 & $\ldots$ & 0.01 & $\mathrm{u}$ & 0.02 & $u$ & 0.01 & $\ldots$ & 0.01 & $\ldots$ & 0.02 & $u$ & 0.02 & $\ldots$ & 0.02 & $\ldots$ & 0.02 & U \\
\hline Uranium 238 & 1.30 & $u$ & 1.37 & $u$ & 0.63 & U & ND & $\ldots$ & 0.67 & u & ND & $\ldots$ & ND & $\ldots$ & 0.48 & $u$ & 0.09 & $u$ & 1.13 & U \\
\hline Sigma Error (+/-) & 0.23 & $\ldots$ & 0.22 & $\ldots$ & 0.10 & $-{ }_{-1}$ & & $\ldots$ & 0.13 & $\ldots$ & & $\ldots$ & & $\ldots$ & 0.16 & $\ldots$ & 0.16 & $\ldots$ & 0.17 &.- \\
\hline $\mathrm{MDA}^{*}$ & 0.39 & - & 0.36 & - & 0.16 & $\ldots$ & 0.36 & u & 0.02 & \begin{tabular}{|l|}
$-\ldots$ \\
\end{tabular} & 0.36 & $u$ & 0.27 & u & 0.28 & $\ldots$ & 0.28 & $\ldots$ & 0.30 & $\ldots$ \\
\hline Lead 210 & 1.62 & - & - & - & 1.72 & - & & -1 & 0.65 & $u$ & & -1 & & - & & - & 1.44 & $u$ & 1.36 & $\ldots$ \\
\hline Sigma Error $(+/-)$ & 0.46 & $\ldots$ & - & -1 & 0.21 & - & & - & 0.20 & $\ldots$ & & - & - & - & -7 & - & 0.33 & $\ldots$ & 0.36 & -- \\
\hline MDA* & 0.90 & - & -1 & -1 & 0.21 & $-\infty$ & 7 & -1 & 0.23 & $\ldots$ & & -1 & & -1 & & 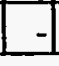 & 0.61 & - & 0.72 & $\ldots$ \\
\hline
\end{tabular}

- Minimum Detectable Activity. "* Data Validation. 


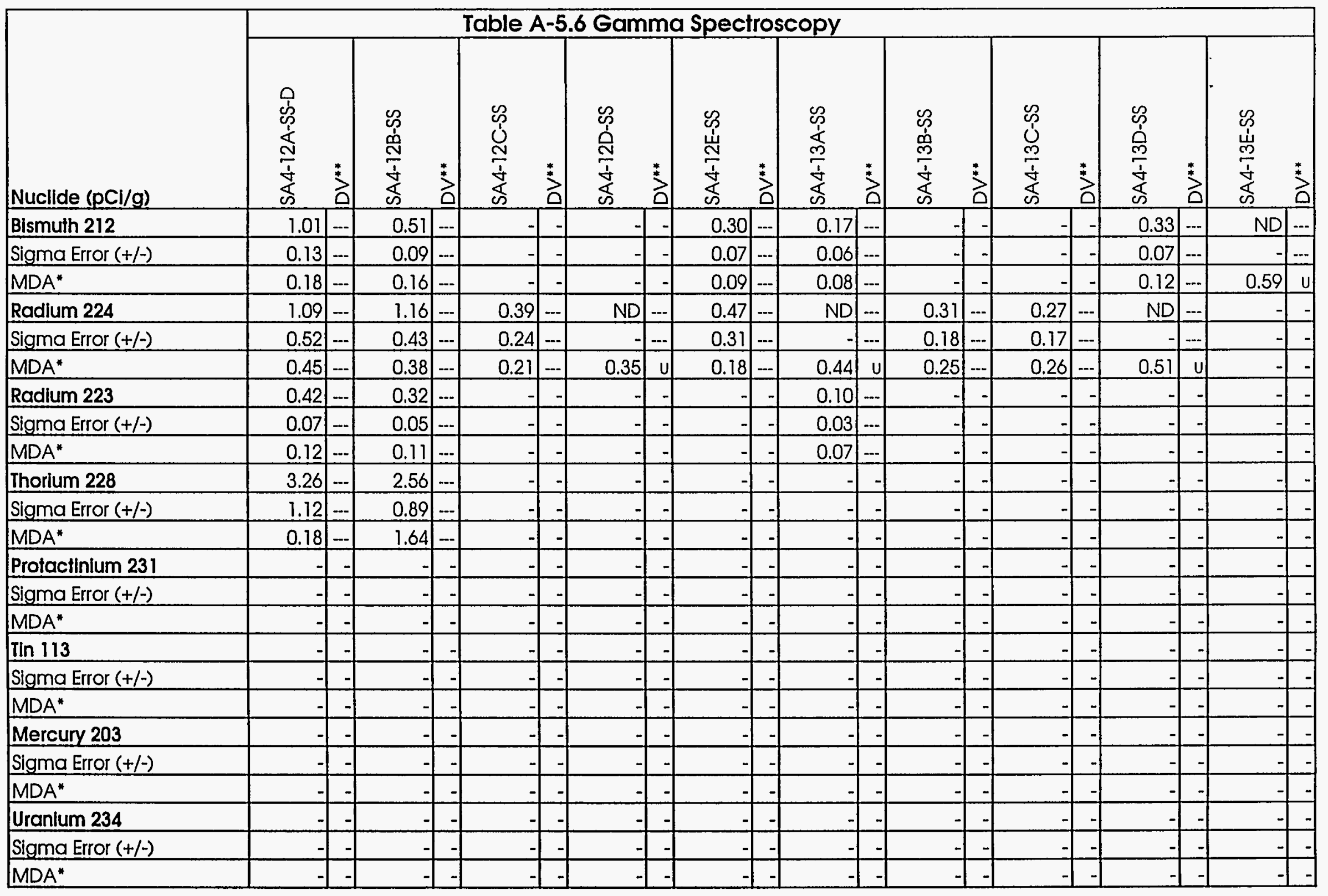




\begin{tabular}{|c|c|c|c|c|c|c|c|c|c|c|c|c|c|c|c|c|c|c|c|c|c|}
\hline \multirow[b]{2}{*}{ Nuclide $(\mathrm{pCl} / \mathrm{g})$} & \multicolumn{21}{|c|}{ Table A-5.6 Gamma Spectroscopy } \\
\hline & 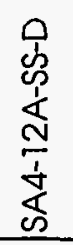 & 艾 & 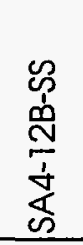 & $\stackrel{*}{*}$ & & 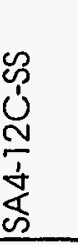 & 菅 & 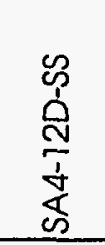 & 草 & 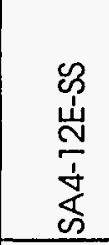 & 艾 & 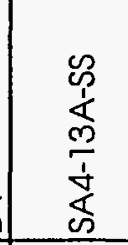 & a & 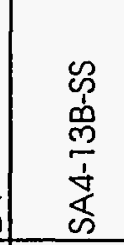 & 草 & 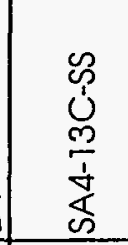 & 艾 & 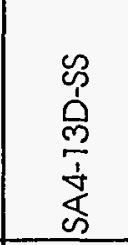 & 莒 & 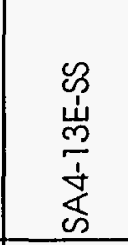 & $\stackrel{*}{*}$ \\
\hline Uranium 235 & & & & & & & & & & & & & -1 & & -1 & & $-1-$ & 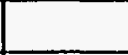 & $-1-1$ & & $-1-$ \\
\hline Sigma Error $(t /-)$ & & & & & & & & & 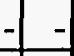 & & - & & -1 & & -1 & & - & & $-1-1$ & & - \\
\hline $\mathrm{MDA}^{*}$ & & & & & & & - & & -1 & & - & & -1 & & -1 & & - & & -1 & & -5 \\
\hline Bismuth 214 & & & & & & & -1 & & - & & - & & - & & - & & - & & - & & \\
\hline Sigma Error $(+1-)$ & & & & & & & - & & - & & - & & - & & -1 & & - & & -1 & & \\
\hline $\mathrm{MDA}^{*}$ & & & & & & & -1 & & - & & - & & - & & -1 & &.- & & -1 & & - \\
\hline Protactinium 234 & & & & & & & & & 7 & & & & & & 7 & & - & & 1 & & - \\
\hline Sigma Error $(+/-)$ & & & & & & & & & & & & & & & -1 & & - & & - & & - \\
\hline $\mathrm{MDA}^{*}$ & & & & & & & & & - & & & & -1 & & -1 & & - & & -1 & & t. \\
\hline Ihorium 234 & & & & & & & & & - & & & & -1 & & -1 & & - & & 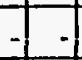 & & 4 \\
\hline Sigma Error $(+/-)$ & & - & & & & & $=$ & & - & & $\Gamma$ & & -1 & & -1 & & $=$ & & - & & - \\
\hline $\mathrm{MDA}^{*}$ & & - & & & & & - & & - & & - & & -1 & & 4 & & - & & - & & - \\
\hline
\end{tabular}




\begin{tabular}{|c|c|c|c|c|c|c|c|c|c|c|c|c|c|c|c|c|c|c|c|c|}
\hline \multirow[b]{2}{*}{ Nuclide $(\mathrm{pCl} / \mathrm{g})$} & \multicolumn{20}{|c|}{ Table A-5.6 Gamma Spectroscopy } \\
\hline & 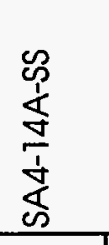 & 艾 & 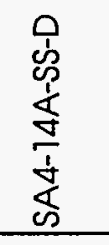 & $\stackrel{*}{3}$ & 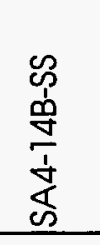 & 兘 & 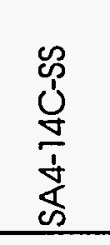 & 3 & 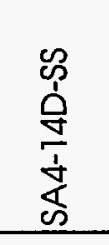 & 范 & 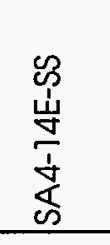 & 满 & 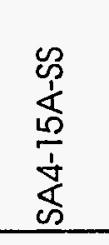 & 满 & 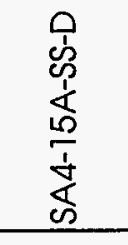 & 点 & 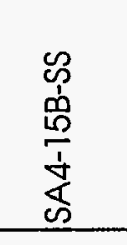 & 草 & 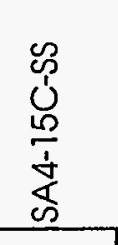 & 艾 \\
\hline Cesium 137 & 0.09 & $\ldots$ & 0.15 & $\ldots$ & ND & $\ldots$ & 0.06 & $\ldots$ & 0.14 & $\ldots$ & 0.03 & -- & 0.05 & $\ldots$ & 0.05 & $\ldots$ & 0.89 & 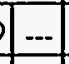 & $\mathrm{ND}$ & $-\infty$ \\
\hline Sigma Error $(+/-)$ & 0.02 & $\ldots$ & 0.02 & $\ldots$ & & $\ldots$ & 0.01 & $\ldots$ & 0.0 & $\ldots$ & 0.01 & $\ldots$ & 0.01 & $\ldots$ & 0.01 & $\ldots$ & 0.08 & $\ldots$ & & $\ldots$ \\
\hline $\mathrm{MDA}^{*}$ & 0.02 & -.. & 0.01 & - & 0.02 & $u$ & 0.01 & -... & 0.0 & $\ldots$ & 0.02 & -- & 0.02 & -- & 0.01 & -- & 0.01 & --. & 0.02 & $u$ \\
\hline Potassium 40 & 0.93 & $u$ & 1.84 & 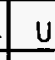 & 2.02 & 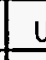 & 0.46 & $u$ & 0.45 & $u$ & 0.60 & $u$ & 3.46 & $u$ & 2.81 & $u$ & 2.90 & $u$ & 0.39 & $\mathrm{u}$ \\
\hline Sigma Error $(t /-)$ & 0.16 & -.. & 0.25 & 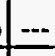 & 0.27 & $=$ & 0.09 & -... & 0.05 & $\ldots$ & 0.10 & - & 0.42 & 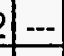 & 0.30 & -- & 0.33 & 3 & 0.27 & -- \\
\hline MDA* & 0.24 & $\ldots$ & 0.08 & $\ldots$ & 0.62 & - & 0.23 & $\ldots$ & 0.17 & -.. & 0.22 & --- & 0.73 & 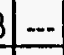 & 0.17 & $\ldots$ & 0.18 & 3 & 0.18 & $\ldots$ \\
\hline Lead 212 & 0.34 & $u$ & 0.67 & $\ldots$ & 0.72 & - & 0.32 & $u$ & & - & 0.25 & $\mathrm{u}$ & 0.89 & $\ldots$ & 0.82 & $\ldots$ & 0.81 & $\ldots$ & 0.94 & $\ldots$ \\
\hline Sigma Error $(+1-)$ & 0.03 & $\ldots$ & 0.05 & $\ldots$ & 0.05 & = & 0.03 & $\ldots$ & & - & 0.04 & - & 0.08 & $\ldots$ & 0.05 & $-\cdots$ & 0.05 & - & 0.06 & -- \\
\hline $\mathrm{MDA}^{*}$ & 0.03 & - & 0.03 & - & 0.03 & - & 0.03 & $\ldots$ & & - & 0.03 & -- & 0.02 & $\ldots$ & 0.02 & $\ldots$ & 0.02 & 2 & 0.02 & -- \\
\hline Radium 226 & 0.25 & $u$ & 0.51 & $u$ & 0.48 & $u$ & 0.31 & $u$ & 0.28 & $\mathrm{u}$ & 0.26 & $u$ & 0.77 & $-=$ & 0.71 & - & 0.74 & $4--$ & 0.73 & - \\
\hline Sigma Error $(t /-)$ & 0.03 & - & 0.03 & - & 0.03 & $=$ & 0.02 & $2-\ldots$ & 0.0 & - & 0.02 & $-\ldots$ & 0.05 & - & 0.04 & $\ldots$ & 0.04 & $4=$ & 0.04 & -- \\
\hline MDA* & 0.03 & $\ldots$ & 0.03 & $-\ldots$ & 0.03 & - & 0.02 & 2. & 0.02 & $-\ldots$ & 0.03 & -.. & 0.02 & $2 \ldots$ & 0.02 & $\ldots$ & 0.03 & $3-$ & 0.02 & - \\
\hline Radium 228 & 0.34 & -.- & 0.53 & $=$ & 0.68 & $=$ & 0.29 & -.. & 0.18 & $=$ & 0.29 & $\ldots$ & 0.79 & ... & 0.68 & $-\ldots$ & 0.64 & $-\ldots$ & 0.89 & - \\
\hline Sigma Error $(+/-)$ & 0.03 & $-\ldots$ & 0.05 & $\ldots$ & 0.05 & $\ldots$ & 0.03 & $\ldots$ & 0.02 & $\ldots$ & 0.03 & $\ldots$ & 0.06 & $\ldots$ & 0.05 & $\ldots$ & 0.05 & - & 0.06 & - \\
\hline MDA* & 0.06 & -.. & 0.09 & -.. & 0.0 & $\ldots$ & 0.0 & 4]-.. & 0.0 & $\ldots$ & 0.05 & ... & 0.03 & 3 & 0.05 & $\ldots$ & 0.05 & -..- & 0.05 & $-\cdot$ \\
\hline Thallium 208 & $N D$ & $\ldots$ & 0.18 & $\ldots$ & 0.20 & - & ND & - & $\mathrm{NL}$ & - & 0.10 & $u$ & 0.23 & $\mathrm{u}$ & 0.22 & $u$ & 0.23 & $u$ & 0.26 & $\ldots$ \\
\hline Sigma Error $(+/-)$ & & - & 0.02 & $\ldots$ & 0.0 & - & & - & & - & 0.01 & $\ldots$ & 0.02 & $2--$ & 0.02 & - & 0.02 & $-\cdots$ & 0.02 & -- \\
\hline MDA* & 0.02 & $u$ & 0.02 &..- & 0.02 & - & 0.02 & $2 \mathrm{u}$ & 0.0 & $u$ & 0.01 & $\ldots$ & 0.01 & $1+=$ & 0.01 & $\ldots$ & 0.02 & $\ldots$ & 0.01 & $\cdots$ \\
\hline Uranium 238 & ND & - & 0.66 & $u$ & 0.6 & 1 & 0.3 & $u$ & 0.3 & $u$ & ND & ... & 1.0 & 10 & 0.86 & $u$ & 0.91 & $u$ & 1.00 & $u$ \\
\hline Sigma Error $(+/-)$ & & - & 0.16 & $\ldots$ & 0.17 & -.. & 0.1 & 1... & 0.0 & $\ldots$ & & $\ldots$ & 0.17 & 7) -- & 0.12 & $\ldots$ & 0.16 & -.. & 0.15 & $\ldots$ \\
\hline MDA* & 0.29 & $u$ & 0.28 & $\ldots$ & 0.3 & - & 0.2 & 6 & 0.1 & $\mid-$ & 0.36 & $\underline{u}$ & 0.18 & 8|-- & 0.17 & - & 0.17 & $\mid-$. & 0.17 & $\ldots$ \\
\hline Lead 210 & & & & T. & & & & & 0.7 & 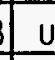 & & & 0.88 & 8 & 0.71 & - & 2.04 & $\ldots$ & 0.81 & $\ldots$ \\
\hline Sigma Error $(+/-)$ & & & & & & & & & 0.11 & $\ldots$ & & & 0.15 & 9.-- & 0.14 & - & 0.25 & -... & 0.12 & $\ldots$ \\
\hline MDA* & & $=$ & & -1. & & & & & 0.1 & - & & & 0.26 & 6]-- & 0.22 & - & 0.24 & 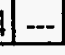 & 0.21 & |-.. \\
\hline
\end{tabular}

"Minimum Detectable Activity. " Data Validation. 


\begin{tabular}{|c|c|c|c|c|c|c|c|c|c|c|c|c|c|c|c|c|c|c|c|c|}
\hline \multirow[b]{2}{*}{ Nuclide $(\mathrm{pCl} / \mathrm{g})$} & \multicolumn{20}{|c|}{ Table A-5.6 Gamma Spectroscopy } \\
\hline & 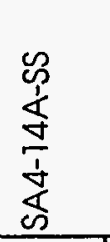 & 方 & 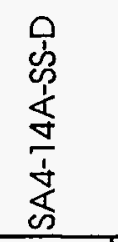 & $\stackrel{*}{3}$ & 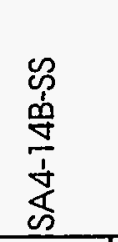 & $\stackrel{*}{*}$ & 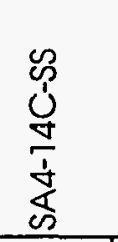 & 莒 & 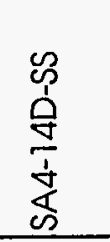 & 苛 & 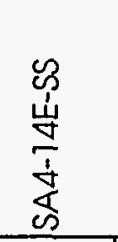 & 茥 & 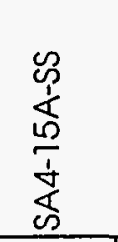 & 苦 & 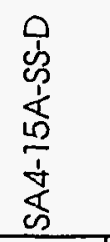 & 3 & 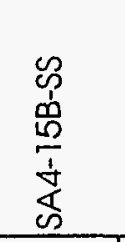 & $\stackrel{*}{2}$ & 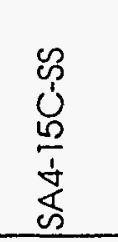 & $\stackrel{3}{0}^{*}$ \\
\hline Bismuth 212 & - & -1 & 0.42 & $\ldots$ & 0.40 & $\ldots$ & -1 & $-\ldots$ & 0.11 & $\ldots$ & 0.21 & $\ldots$ & 0.41 & $\ldots$ & 0.44 &.- & 0.44 & $-\ldots$ & 0.53 & $\ldots$ \\
\hline Sigma Error $(+/-)$ & -1 & - & 0.09 & $\ldots$ & 0.09 & $\ldots$ & - & $\ldots$ & 0.03 & $-\cdots$ & 0.08 & $\ldots$ & 0.07 & $\ldots$ & 0.07 & $\ldots$ & 0.07 & $-\ldots$ & 0.08 & $-\ldots$ \\
\hline $\mathrm{MDA}^{*}$ & & -1 & 0.11 & - & 0.12 & $-\ldots$ & & $\ldots$ & 0.08 & $\ldots$ & 0.11 & $\ldots$ & 0.17 & $\ldots$ & 0.11 & $\ldots$ & 0.09 & \begin{tabular}{|l|}
$\ldots$ \\
\end{tabular} & 0.11 & $\ldots$ \\
\hline Radium 224 & 0.42 & $\ldots$ & ND & $\ldots$ & 0.31 & $\ldots$ & $\mathrm{ND}$ & - & & - & ND & $\ldots$ & ND & $\ldots$ & ND & $\ldots$ & - & - & ND & - \\
\hline Sigma Error $(+/-)$ & 0.22 & $\ldots$ & & $\ldots$ & 0.23 & $\ldots$ & & $\ldots$ & & -7 & - & $\ldots$ & & $\ldots$ & - & $\ldots$ & -1 & - & & $\ldots$ \\
\hline $\mathrm{MDA}^{*}$ & 0.26 & $\ldots$ & 0.29 & $u$ & 0.31 & $\ldots$ & 0.39 & $u$ & & - & 0.43 & $u$ & 0.44 & u & 0.24 & $u$ & -1 & - & 0.25 & $u$ \\
\hline Radium 223 & & - & & - & - & - & 0.08 & - & & -1 & & - & & -1 & 0.22 & $\ldots$ & 0.17 & $\ldots$ & & - \\
\hline Sigma Error $(+/-)$ & & - & & - & - & - & 0.04 & $-\ldots$ & & -1 & - & - & & -1 & 0.04 & $\ldots$ & 0.03 & $\ldots$ & & - \\
\hline $\mathrm{MDA}^{*}$ & & - & & - & - & - & 0.07 & $\ldots$ & & -1 & - & -1 & & -1 & 0.07 & $\ldots$ & 0.07 & $\ldots$ & & - \\
\hline Thorlum 228 & & - & -1 & - & 1.27 & $\ldots$ & -1 & -1 & - & -1 & -1 & -1 & & -1 & 2.06 & $\ldots$ & 1.65 & $\ldots$ & & - \\
\hline Sigma Error $(+1-)$ & & - & -1 & - & 0.65 & $\ldots$ & -1 & -1 & - & -1 & - & - & & -1 & 0.08 & $\ldots$ & 0.80 & $\ldots$ & & - \\
\hline $\mathrm{MDA}^{*}$ & - & - & - & - & 1.25 & $\ldots$ & -1 & -1 & - & - & - & - & & -1 & 0.68 & $\ldots$ & 0.05 & $\ldots$ & & - \\
\hline Protactinlum 231 & - & - & - & - & - & - & - & - & - & -1 & - & - & - & -1 & - & - & - & - & 0.61 & $\ldots$ \\
\hline Sigma Error $(+/-)$ & & -1 & -1 & - & - & - & - & - & - & -1 & - & - & 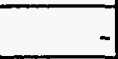 & - & - & - & -1 & - & 0.23 & $\ldots$ \\
\hline MDA* & -1 & - & -1 & - & - & - & - & - & - & -1 & - & - & & -1 & - & - & - & - & 0.38 & $\ldots$ \\
\hline $\operatorname{Tin} 113$ & & - & -1 & - & - & - & - & -1 & - & - & -1 & - & & - & - & - & - & - & & - \\
\hline Sigma Error $(+/-)$ & - & - & -1 & - & - & - & -1 & - & - & -1 & - & - & -1 & -1 & - & - & - & - & & $=$ \\
\hline MDA* & 7 & - & - & - & -1 & - & -1 & - & - & -1 & - & - & & -1 & - & - & - & - & - & - \\
\hline Mercury 203 & & -7 & & - & - & - & - & - & - & $4-7$ & & $\because$ & & -7 & - & - & & -1 & - & - \\
\hline Sigma Error (+/-) & & -1 & & & & - & & - & - & 7 & & - & & -1 & & - & - & - & & - \\
\hline MDA* & & 4 & & -1 & - & - & - & 4 & $=$ & -1 & & - & & - & -1 & - & & -1 & & $=$ \\
\hline Uranium 234 & & - & & - & -1 & - & - & -1 & 3.19 & (... & & - & & -1 & - & - & - & -1 & & - \\
\hline Sigma Error (+/-) & & -7 & & - & & - & & -7 & 2.44 & $4 \ldots$ & & - & & - & - & - & & - & & - \\
\hline MDA* & & -1 & & - & & -1 & - & - & 4.95 & \begin{tabular}{|c|}
5 \\
\end{tabular} & & - & & - & & 1. & -1 & -1 & & $\perp$ \\
\hline
\end{tabular}




\begin{tabular}{|c|c|c|c|c|c|c|c|c|c|c|c|c|c|c|c|c|c|c|c|c|c|}
\hline \multirow[b]{2}{*}{ Nuclide $(\mathrm{pCl} / \mathrm{g})$} & \multicolumn{21}{|c|}{ Table A-5.6 Gamma Spectroscopy } \\
\hline & 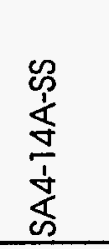 & 굴 & 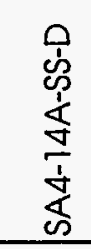 & $\stackrel{3}{*}$ & & 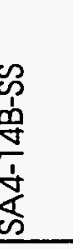 & 苛 & 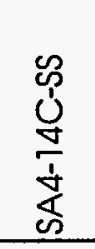 & 3 & 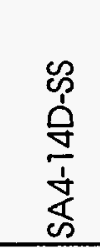 & $3^{*}$ & 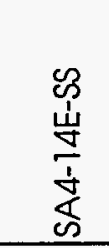 & 3 & 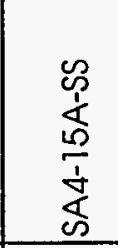 & $3^{*}$ & 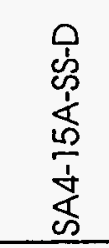 & 莒 & 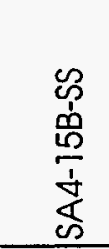 & 莡 & 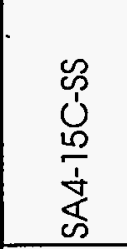 & 3 \\
\hline Uranium 235 & & & & & & & -1 & & - & & - & & - & & - & & $-1-$ & & -1 & & \\
\hline Sigma Error (+/-) & & 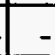 & & & & & - & & - & & - & & - & & - & & -1. & & - & & \\
\hline $\mathrm{MDA}^{*}$ & & $=$ & & & & & -1 & & & & - & & - & & - & & -1. & & - & & L \\
\hline Bismuth 214 & 0.05 & $\ldots$ & & & & & - & & & & . & & - & & 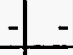 & & -1 & & - & & \\
\hline Sigma Error $(+/-)$ & 0.04 & $\ldots$ & & & & & . & & & & 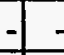 & & - & & & & 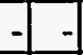 & & Le & & \\
\hline $\mathrm{MDA}^{*}$ & 0.03 & $-\ldots$ & & & & & - & & & & - & & - & & - & & $-1-1$ & & - & & \\
\hline Protactinlum 234 & & 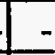 & & & & & - & & - & & E & & - & & - & & $-1-$ & & -1 & & \\
\hline Sigma Error (+/-) & & 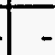 & & & & & 1 & & 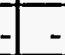 & & - & & - & & - & & 4 & & - & & \\
\hline MDA* & & - & & & & & - & & - & & - & & - & & - & & $-1-1$ & & L. & & L \\
\hline Thorlum 234 & & & & & & & - & & - & & & & $-x^{-}$ & & - & & -1 & & L & & 4 \\
\hline Sigma Error $(+/-)$ & & - & & & & & & & - & & & & & & & & & & & & - \\
\hline MDA* & & $1-$ & & & & & $1-$ & & & & & & - & & & & $-1-$ & & -1 & & - - - \\
\hline
\end{tabular}




\begin{tabular}{|c|c|c|c|c|c|c|c|c|c|c|c|c|c|c|c|c|c|c|c|c|}
\hline \multirow[b]{2}{*}{ Nuclide $(\mathrm{pCl} / \mathrm{g})$} & \multicolumn{20}{|c|}{ Table A-5.6 Gamma Spectroscopy } \\
\hline & 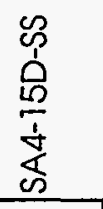 & 3 & 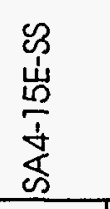 & $3^{*}$ & 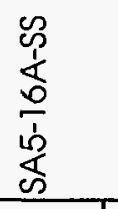 & ${ }^{*}$ & 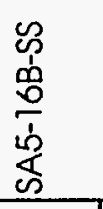 & 莒 & 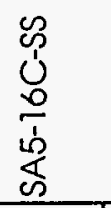 & 3 & 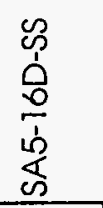 & $\stackrel{*}{3}$ & 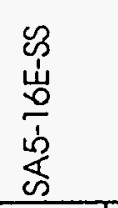 & $3_{0}^{*}$ & 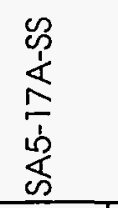 & $3^{*}$ & 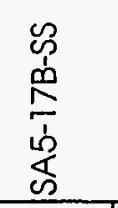 & $\stackrel{2}{0}^{*}$ & 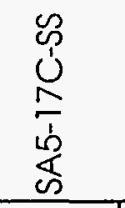 & $\stackrel{*}{0}^{*}$ \\
\hline Cesium 137 & 0.22 & $\ldots$ & 0.18 & -- & 0.07 & $\ldots$ & 0.23 & $-\ldots$ & 0.04 & $\ldots$ & 0.11 & $\ldots$ & 0.24 & $-\ldots$ & 0.92 & $\ldots$ & 0.21 & - & 0.08 & -- \\
\hline Sigma Error (+/-) & 0.03 & $\ldots$ & 0.03 & -- & 0.01 & $-\infty$ & 0.03 & $\ldots$ & 0.01 & $\ldots$ & 0.01 & $\ldots$ & 0.03 & $\ldots$ & 0.08 & $\ldots$ & 0.04 & $\ldots$ & 0.01 & $-\ldots$ \\
\hline $\mathrm{MDA}^{*}$ & 0.01 &.-- & 0.01 & $\ldots$ & 0.02 & $\ldots$ & 0.01 & $\ldots$ & 0.01 & $\ldots$ & 0.01 & $\ldots$ & 0.02 & $\ldots$ & 0.01 & -- & 0.04 &.- & 0.01 & -- \\
\hline Potassium 40 & 3.74 & - & 3.21 & $\mathrm{u}$ & 3.43 & $\ldots$ & 1.47 & $u$ & 1.36 & $u$ & 0.86 & 4 & 3.03 & $\ldots$ & 4.30 & $\ldots$ & 3.88 & $\ldots$ & 3.51 & -- \\
\hline Sigma Error $(+/-)$ & 0.44 & $\ldots$ & 0.42 & $\ldots$ & 0.42 & $\ldots$ & 0.21 &.- & 0.20 & $\ldots$ & 0.17 & $\ldots$ & 0.34 & $\ldots$ & 0.46 & $\ldots$ & 0.71 & $\ldots$ & 0.40 & $-\ldots$ \\
\hline $\mathrm{MDA}^{*}$ & 0.02 & - & 0.21 & $\ldots$ & 0.24 & $-\cdots$ & 0.18 & - & 0.20 & $\ldots$ & 0.21 & $\ldots$ & 0.25 & $\ldots$ & 0.87 & $\ldots$ & 3.24 & $\ldots$ & 0.16 & - \\
\hline Lead 212 & 1.07 & $\ldots$ & 1.23 & $\ldots$ & ND & $\ldots$ & 0.33 & $u$ & 0.53 & $-\cdots$ & 0.45 & $U$ & 0.63 & $\ldots$ & 0.72 & $\ldots$ & 0.70 & $\ldots$ & 0.63 & $\ldots$ \\
\hline Sigma Error (+/-) & 0.08 & $-\ldots$ & 0.09 & $\ldots$ & & $\ldots$ & 0.02 & -- & 0.05 & $\ldots$ & 0.04 & $\ldots$ & 0.04 & $\ldots$ & 0.04 & $\ldots$ & 0.08 & $\ldots$ & 0.04 & $\ldots$ \\
\hline $\mathrm{MDA}^{*}$ & 0.02 & - & 0.02 & $\ldots$ & 0.03 & 4 & 0.02 & - & 0.02 & $\ldots$ & 0.02 & $\ldots$ & 0.03 & $\ldots$ & 0.03 & $\ldots$ & 0.07 & - & 0.02 & $\ldots$ \\
\hline Raudium 220́ & 0.96 & $\ldots$ & 0.91 & $\ldots$ & 0.48 & 4 & 0.32 & 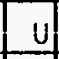 & 0.44 & $u$ & 0.34 & $u$ & 0.64 & $u$ & 0.76 & 4 & 0.54 & u & 0.54 & u \\
\hline Sigma Error $(+/-)$ & 0.06 & -- & 0.06 & -- & 0.03 & $\ldots$ & 0.02 &.- & 0.03 & $\ldots$ & 0.03 & $\ldots$ & 0.04 & $\ldots$ & 0.04 & $\ldots$ & 0.07 & $\ldots$ & 0.03 & $\ldots$ \\
\hline $\mathrm{MDA}^{*}$ & 0.02 & $\ldots$ & 0.02 & $\ldots$ & 0.04 & $\ldots$ & 0.02 & $\ldots$ & 0.02 & $\ldots$ & 0.02 & $\ldots$ & 0.04 & $\ldots$ & 0.03 & $\ldots$ & 0.08 & $\ldots$ & 0.02 & $\ldots$ \\
\hline Radium 228 & 0.91 & $\ldots$ & 1.10 & $\ldots$ & 0.46 & - & 0.28 & $\ldots$ & 0.52 & $\ldots$ & 0.33 & $\ldots$ & 0.57 & $\ldots$ & 0.57 & $\ldots$ & ND & - & 0.55 & $\ldots$ \\
\hline Sigma Error ( $+/-)$ & 0.06 & $\ldots$ & 0.09 & $\ldots$ & 0.05 & $\ldots$ & 0.03 & $\ldots$ & 0.04 & $\ldots$ & 0.04 & $\ldots$ & 0.05 & $\ldots$ & 0.05 & $\ldots$ & & $\ldots$ & 0.04 & $\ldots$ \\
\hline $\mathrm{MDA}^{*}$ & 0.03 & - & 0.04 & - & 0.06 & -- & 0.05 & -- & 0.03 & -- & 0.03 & $\ldots$ & 0.06 & -- & 0.05 & -- & 0.17 & $u$ & 0.05 & $\ldots$ \\
\hline Thallium 208 & 0.28 & -- & 0.33 & $\ldots$ & 0.15 & $\ldots$ & ND &.-- & 0.14 & $u$ & ND & $\ldots$ & ND & $\ldots$ & 0.20 & $\ldots$ & 0.17 & -- & 0.17 & -- \\
\hline Sigma Error $(+/-)$ & 0.03 & - & 0.03 & - & 0.02 & $-\infty$ & & $-\ldots$ & 0.02 & $\ldots$ & & $\ldots$ & & $\ldots$ & 0.02 & -- & 0.03 & $\ldots$ & 0.02 & $\ldots$ \\
\hline MDA* & 0.01 & $\ldots$ & 0.01 & - & 0.02 & -- & 0.01 & $u$ & 0.01 & $\ldots$ & 0.01 & 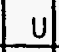 & 0.02 & $u$ & 0.02 & - & 0.04 & -- & 0.01 & $-\cdots$ \\
\hline Uranium 238 & 1.27 & $u$ & 1.33 & $u$ & 0.55 & 4 & 0.38 & $u$ & 0.67 & $\mathrm{u}$ & 0.58 & $U$ & ND & $\ldots$ & 0.76 & $u$ & ND & $\ldots$ & 0.49 & u \\
\hline Sigma Error $(+/-)$ & 0.23 & $\ldots$ & 0.17 & $\ldots$ & 0.15 & $\ldots$ & 0.08 & $\ldots$ & 0.12 & $\ldots$ & 0.11 & $\ldots$ & & $\ldots$ & 0.17 & $\ldots$ & & $-\ldots$ & 0.09 & $\ldots$ \\
\hline MDA* & 0.20 & $\ldots$ & 0.20 & -- & 0.33 & - & 0.14 & $\ldots$ & 0.17 & $\ldots$ & 0.15 & -- & 0.37 & $u$ & 0.31 & $\ldots$ & 0.84 & $u$ & 0.16 & $\ldots$ \\
\hline Lead 210 & 1.12 & - & 1.45 & - & - & - & 0.65 & $\ldots$ & 0.69 & $\ldots$ & 0.87 & $\ldots$ & - & - & 1.60 &.-- & 1.36 & - & 0.80 & u \\
\hline Sigma Error $(+/-)$ & 0.24 & $\ldots$ & 0.30 & $\ldots$ & & - & 0.10 & $\ldots$ & 0.18 & $\ldots$ & 0.21 & $\ldots$ & & - & 0.43 & - & 0.38 & - & 0.11 & $\ldots$ \\
\hline MDA* & 0.27 & - & 0.28 & - & & -1 & 0.17 & - & 0.21 & $\ldots$ & 0.17 & $\ldots$ & & -1 & 0.74 & ]... & 0.69 & $\ldots$ & 0.19 & $\ldots$ \\
\hline
\end{tabular}




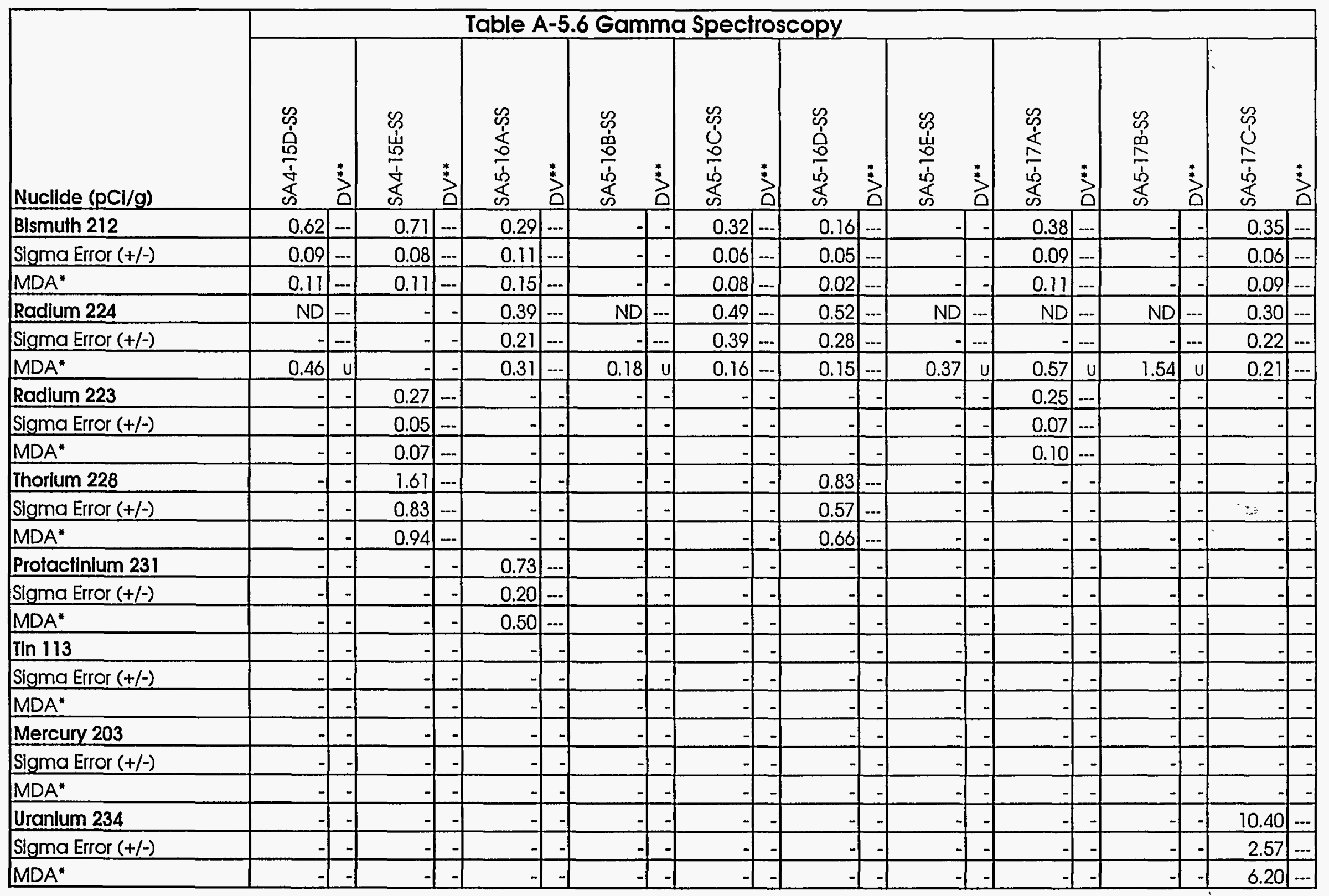




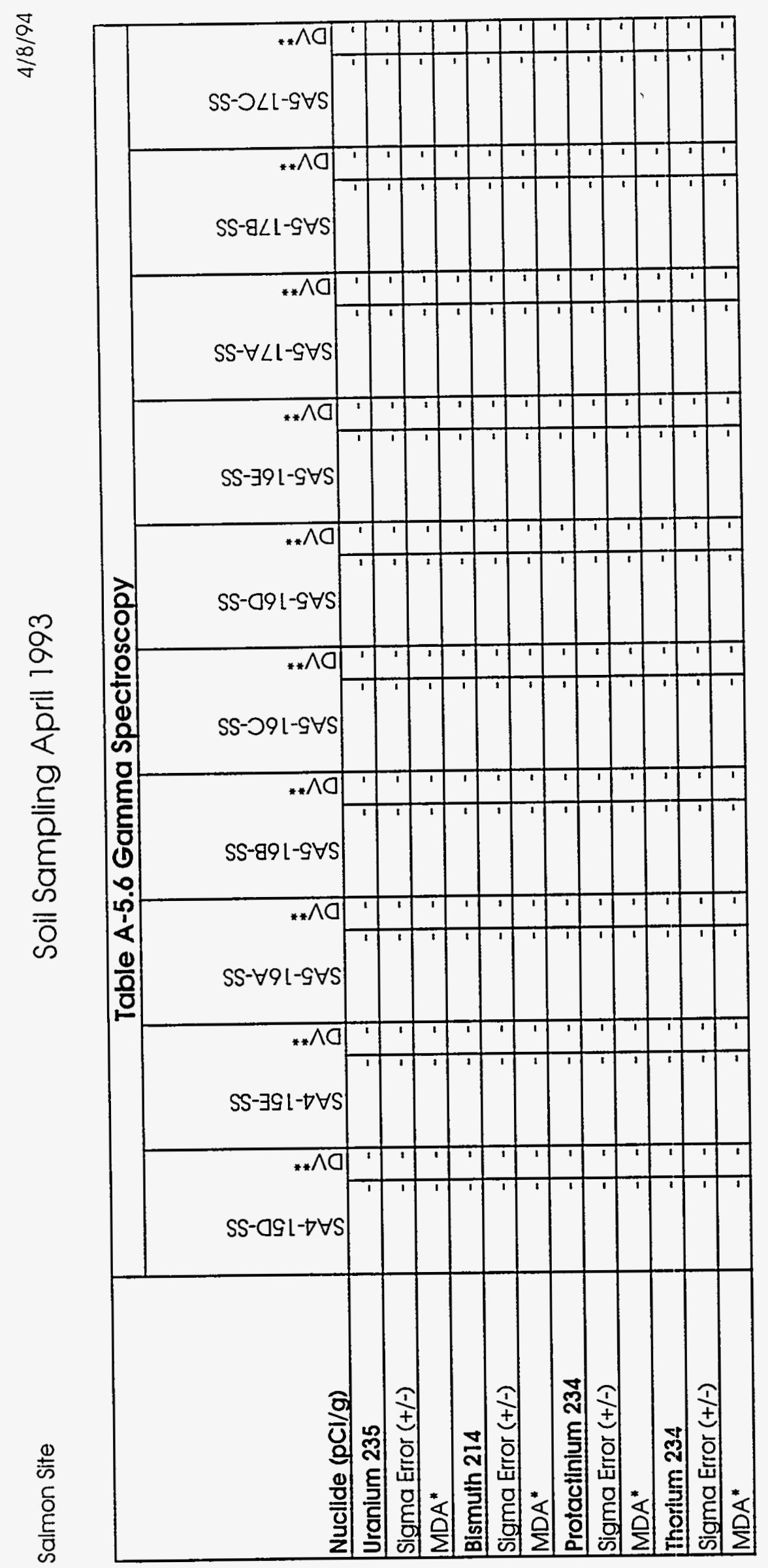




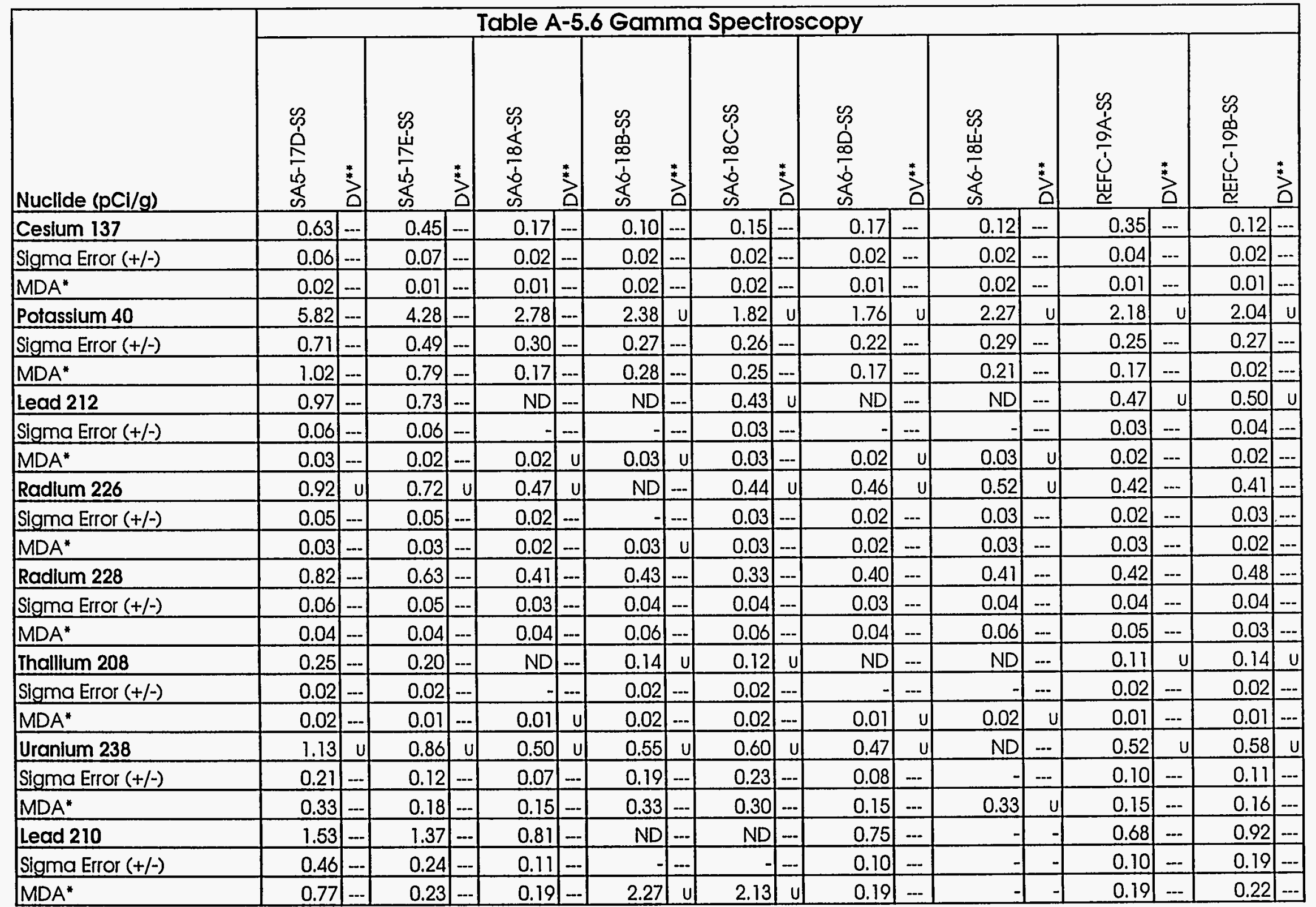




\begin{tabular}{|c|c|c|c|c|c|c|c|c|c|c|c|c|c|c|c|c|c|c|}
\hline \multirow[b]{2}{*}{ Nuclide $(\mathrm{pcl} / \mathrm{g})$} & \multicolumn{18}{|c|}{ Table A-5.6 Gamma Spectroscopy } \\
\hline & 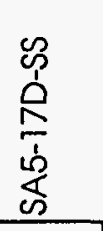 & 草 & 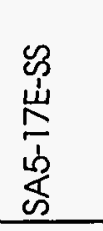 & 兌 & 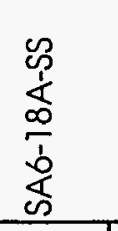 & 艾 & $\begin{array}{l}\mathscr{p} \\
\infty \\
\infty \\
\vdots \\
\dot{b} \\
\infty \\
\infty\end{array}$ & 莒 & 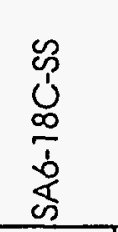 & 艾 & 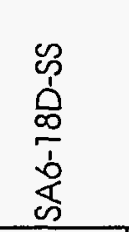 & $3^{*}$ & 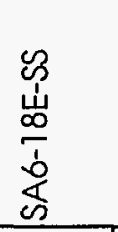 & $\stackrel{*}{\circ}$ & 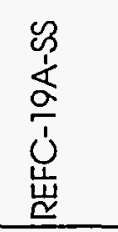 & 茄 & 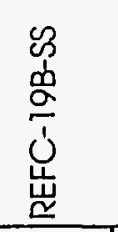 & 艾 \\
\hline Bismuth 212 & 0.44 & $\ldots$ & 0.42 & --- & 0.24 & $\ldots$ & ND & $\ldots$ & ND & $\ldots$ & & - & 0.26 & $\ldots$ & $\mathrm{ND}$ & $\ldots$ & 0.24 & $\ldots$ \\
\hline Sigma Error ( $+/-)$ & 0.10 & $\ldots$ & 0.08 & - & 0.06 & $\ldots$ & & $\ldots$ & -1 & $\ldots$ & -1 & -1 & 0.09 & $\ldots$ & & $\ldots$ & 0.06 & $\ldots$ \\
\hline MDA* & 0.14 & - & 0.09 & --. & 0.09 & $\ldots$ & 0.21 & $u$ & 0.23 & $u$ & - & - & 0.11 & $\ldots$ & 0.18 & $u$ & 0.10 & $\ldots$ \\
\hline Radlum 224 & ND & - & ND & - & ND & $\ldots$ & 1.46 & $-\infty$ & ND & $\ldots$ & ND & $\ldots$ & ND & $\ldots$ & 0.26 & $\ldots$ & & $1=$ \\
\hline Sigma Error $(+/-)$ & & $\ldots$ & - & $\ldots$ & & $\ldots$ & 0.22 & $\ldots$ & - & $\ldots$ & - & $\ldots$ & - & $\ldots$ & 0.18 & $\ldots$ & - & . \\
\hline MDA* & 0.63 & $\underline{U}$ & 0.40 & $\mathrm{u}$ & 0.21 & $u$ & 0.33 & $\ldots$ & 0.48 & $u$ & 0.19 & u & 0.03 & $u$ & 0.20 & U & -1 & - \\
\hline Radlum 223 & & - & 0.19 & $\ldots$ & -1 & - & - & -1 & -1 & - & - & -1 & 0.15 & $\ldots$ & 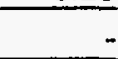 & - & 0.16 & $\ldots$ \\
\hline Sigma Error $(+/-)$ & & $=$ & 0.03 & - & & - & -1 & -1 & - & -1 & - & -1 & 0.04 & $\ldots$ & - & - & 0.03 & $\ldots$ \\
\hline $\mathrm{MDA}^{*}$ & & - & 0.07 & $\ldots$ & -1 & - & - & - & -1 & - & - & -1 & 0.09 & $\ldots$ & - & - & 0.05 & $\ldots$ \\
\hline Ihoilum 228 & & - & & - & -1 & - & - & - & - & - & -1 & -1 & -1 & - & - & - & $N D^{\prime}$ & 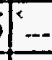 \\
\hline Sigma Error $(+/-)$ & & - & - & - & - & - & - & -1 & - & - & - & -1 & - & - & - & - & 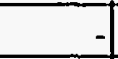 & $\ldots$ \\
\hline $\mathrm{MDA}^{*}$ & & - & - & - & - & - & -1 & - & - & -1 & 7 & -1 & - & - & - & - & 0.76 & $u$ \\
\hline Protactinlum 231 & & - & - & - & -1 & - & -1 & - & - & - & & -1 & - & - & - & - & -1 & . \\
\hline Sigma Error $(+/-)$ & & - & - & - & -7 & - & -1 & 4 & -1 & -1 & & -1 & - & - & - & - & & - \\
\hline $\mathrm{MDA}^{*}$ & & - & - & - & -1 & - & - & - & - & - & & -1 & - & - & - & - & & - \\
\hline $\operatorname{Tin} 113$ & & - & - & - & -1 & - & - & - & - & - & & -1 & - & $\rightarrow$ & & - & & - \\
\hline Sigma Error ( $+1-)$ & & - & - & - & -1 & - & - & -1 & - & - & & -1 & - & - & & - & & - \\
\hline MDA* & & - & - & - & -1 & - & - & - & & -1 & & - & - & & & - & & - \\
\hline Mercury 203 & & - & - & - & -1 & - & - & - & - & -1 & & - & - & - & - & - & - & - \\
\hline Sigma Error $(+/-)$ & & & - & - & & - & - & - & & - & & -1 & - & - & - & - & - & - \\
\hline MDA* & & - & - & - & - & - & - & - & - & - & - & - & - & - & - & - & - & . \\
\hline Uranium 234 & & - & - & - & & - & -1 & - & & - & & -1 & -1 & & - & - & - & - \\
\hline Sigma Error $(+/-)$ & & - & - & - & & - & - & - & -1 & - & & -1 & -1 & - & - & - & 4 & 7 \\
\hline MDA* & - & $=$ & $=$ & - & - & - & - & - & & -1 & & - & - & & & - & 7 & t \\
\hline
\end{tabular}




\begin{tabular}{|c|c|c|c|c|c|c|c|c|c|c|c|c|c|c|c|c|c|c|c|}
\hline \multirow[b]{2}{*}{ Nuclide $(\mathrm{pCl} / \mathrm{g})$} & \multicolumn{19}{|c|}{ Table A-5.6 Gamma Spectroscopy } \\
\hline & 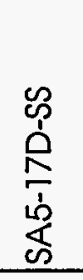 & 莡 & 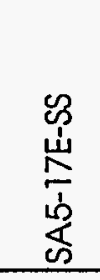 & $\stackrel{3}{*}$ & 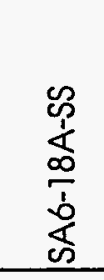 & 芝 & & 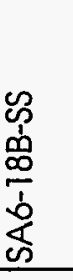 & 3 & 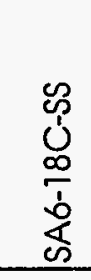 & 3 & 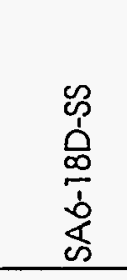 & 3 & $\begin{array}{l}\mathscr{c} \\
\dot{w} \\
\infty \\
\dot{b} \\
\dot{b} \\
\end{array}$ & 를 & 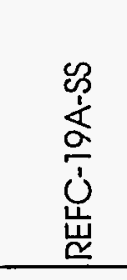 & 莒 & 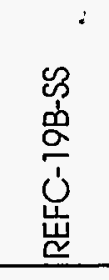 & 草 \\
\hline Uranlum 235 & & & 0.0 & 9. & & - & & & -1 & & $-1-1$ & & - & & - & & -1 & & $\theta$ \\
\hline Sigma Error $(+/-)$ & & & 0.0 & 3] & & - & & & -1 & & $-1-1$ & & - & & - & & - & & $F$ \\
\hline $\mathrm{MDA}^{*}$ & & & 0.0 & 7.-. & & . & & & - & & -1 & & - & & - & & - & & . \\
\hline Bismuth 214 & & & & -1 & & - & & & & & $-1-$ & & - & & - & & - & & -1 \\
\hline Sigma Error (t/-) & & & & 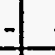 & & - & & & & & 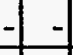 & & - & & - & & 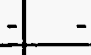 & & -1. \\
\hline MDA* & & & & & & - & & & & & - & & - & & - & & - & & $=$ \\
\hline Protactinlum 234 & & & & & & - & & & - & & - & & - & & - & & - & & - \\
\hline Sigma Error $(+/-)$ & & & & 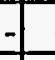 & & - & & & -1 & & - & & - & & - & & - & & . \\
\hline $\mathrm{MDA}^{*}$ & & & & 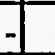 & & - & & & 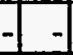 & & -1. & & - & & - & & - & & $t$ \\
\hline Thorlum 234 & & $=$ & & _. & & - & & & & & $-1-$ & & - & & - & & - & & $-1-$ \\
\hline Sigma Error $(+/-)$ & & & & & & & & & & & 1. & & - & & - & & 至 & & $-1:-$ \\
\hline $\mathrm{MDA}^{*}$ & & - & & 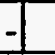 & & & & & & & 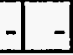 & & - & & . & & 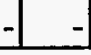 & & $-1-$ \\
\hline
\end{tabular}




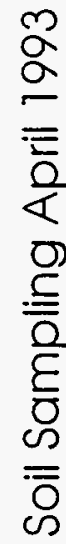

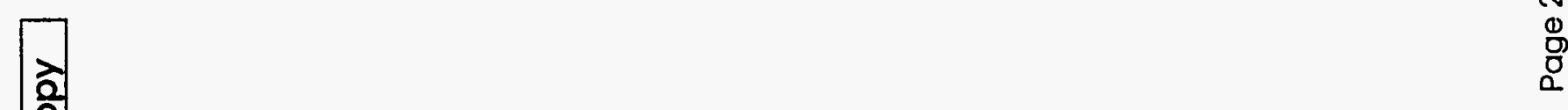

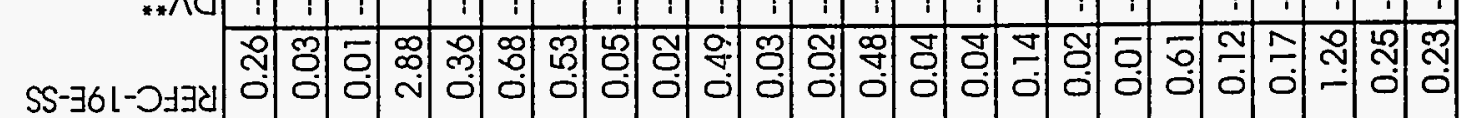
$\wedge 0$ 


\begin{tabular}{|c|c|c|c|c|c|c|}
\hline \multirow[b]{2}{*}{ Nuclide $(\mathrm{pCl} / \mathrm{q})$} & \multicolumn{6}{|c|}{ Table A-5.6 Gamma Spectrc } \\
\hline & 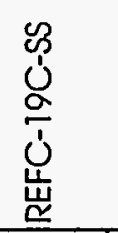 & 艾 & 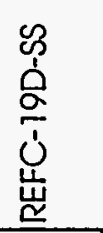 & \ & 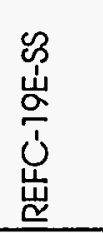 & 草 \\
\hline Bismuth 212 & 0.46 & - & 0.17 & $\ldots$ & 0.41 & $\ldots$ \\
\hline Sigma Error $(+/-)$ & 0.09 & $\ldots$ & 0.07 & $\ldots$ & 0.08 & $\ldots$ \\
\hline MDA* & 0.10 & -- & 0.09 & $\ldots$ & 0.08 & $\ldots$ \\
\hline Radium 224 & 0.59 & - & ND & - & ND & $\ldots$ \\
\hline Sigma Error $(+/-)$ & 0.48 & - & & $\ldots$ & & $\ldots$ \\
\hline MDA* & 0.26 & -- & 0.38 & u & 0.16 & $u$ \\
\hline \multicolumn{7}{|l|}{ Radium 223} \\
\hline \multicolumn{7}{|l|}{ Sigma Error $(+/-)$} \\
\hline \multicolumn{7}{|l|}{ MDA* } \\
\hline \multicolumn{7}{|l|}{ Thorlum 228} \\
\hline \multicolumn{7}{|l|}{ Sigma Error $(+/-)$} \\
\hline \multicolumn{7}{|l|}{ MDA* } \\
\hline \multicolumn{7}{|l|}{ Protactinium 231} \\
\hline \multicolumn{7}{|l|}{ Sigma Error $(+/-)$} \\
\hline \multicolumn{7}{|l|}{$\mathrm{MDA}^{*}$} \\
\hline \multicolumn{7}{|l|}{$\operatorname{Iin} 113$} \\
\hline \multicolumn{7}{|l|}{ Sigma Error $(+/-)$} \\
\hline \multicolumn{7}{|l|}{$\mathrm{MDA}^{*}$} \\
\hline \multicolumn{7}{|l|}{ Mercury 203} \\
\hline \multicolumn{7}{|l|}{ Sigma Error $(t /-)$} \\
\hline \multicolumn{6}{|l|}{ MDA* } & - \\
\hline \multicolumn{7}{|l|}{ Uranlum 234} \\
\hline \multicolumn{7}{|l|}{ Sigma Error $(+/-)$} \\
\hline MDA* & & - & & . & & $1-$ \\
\hline
\end{tabular}





\begin{tabular}{|c|c|c|c|c|c|c|c|c|c|c|c|c|c|c|c|c|c|c|c|}
\hline \begin{tabular}{|l|l}
$m$ & \\
$m$
\end{tabular} & & $\varepsilon 1^{\circ} 0$ & rn & & $\varepsilon L^{\prime} 0$ & Inn & & El'o & $m \mid n$ & $210^{\circ}$ & m & & $\varepsilon L^{\prime} 0$ & rn & & $\varepsilon I^{\prime} 0$ & $m n$ & $\varepsilon 1^{\prime} 0$ & өp!ud $/ 0$ \\
\hline \begin{tabular}{l|l}
$r$ & $\mid$
\end{tabular} & & 1.22 & \begin{tabular}{r|r} 
\\
\end{tabular} & & 961 & I & $\exists$ & $Z^{\prime} \varepsilon L$ & \begin{tabular}{|l|l|} 
& 3 \\
\end{tabular} & $9^{\prime} 62$ & Ir & 9 & $D^{\prime} 02$ & r & $\exists$ & $9^{\prime} 81$ & $r \quad 3$ & $\varepsilon \varepsilon^{\prime} Z Z$ & ou!z \\
\hline \begin{tabular}{|l|l|l|}
$n$ & $E$ \\
\end{tabular} & & 78.0 & $\ln \mid \varepsilon$ & & $18^{\prime} 0$ & -1 & & $2 \nabla^{\circ} 0$ & 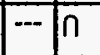 & $2 \nabla^{\prime} 0$ & -1 & n & $20^{\circ} 0$ & -1 & $\bar{n}$ & $2 \sigma^{\prime} 0$ & $-n$ & $20^{\circ} 0$ & Un!pDuD $\wedge$ \\
\hline$m \pi$ & $\overline{M n T C}$ & 020 & $m n \pi$ & $\overline{\mathrm{Mn}}$ & $0 Z^{\prime} 0$ & $m$ & $\overline{\mathrm{Mn}}$ & $10 z^{\prime} 0$ & \begin{tabular}{|l|l|}
$M$ & $M n$ \\
\end{tabular} & 1020 & $m$ & $\overline{\mathrm{Mn}}$ & $0 Z^{\prime} 0$ & r & $\overline{M n}$ & $0 Z^{\prime} 0$ & \begin{tabular}{|l|l|}
$\operatorname{Mn}$ \\
\end{tabular} & $10 z^{\prime} 0$ & wn|||Dपा \\
\hline \begin{tabular}{|l|l}
$r$ & $E$ \\
\end{tabular} & & $9 \cdot 15$ & \begin{tabular}{l|l|l}
$r$ & $t a$ \\
\end{tabular} & - & $D^{\prime} 80$ & r te & 8 & 199 & \begin{tabular}{|l|l|}
$\Gamma$ & $\theta$ \\
\end{tabular} & $\angle 2 t$ & r & 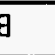 & $\angle S D$ & \begin{tabular}{l|l}
$r$ & $\varepsilon$ \\
\end{tabular} & $\overline{8}$ & 289 & \begin{tabular}{l|l}
$r$ & $\theta$ \\
\end{tabular} & 8.80 & Un!pos \\
\hline$-a-1$ & & $0 \angle 0$ & $-\cdots \mid$ & ก & $O L^{\prime} O$ & - & & $0 \angle O$ & \begin{tabular}{|l|l|}
- & $n$ \\
\end{tabular} & $0 \angle L^{\prime} 0$ & -1 & n & $0 L^{\circ} 0$ & $\cdots$ & $n$ & $0 \angle L^{\prime} 0$ & $-\pi$ & $0 \angle L^{\circ}$ & IəA\|S \\
\hline$--\mid$ & & $0 \nabla$ & $\cdots+1$ & & $0 \%$ & 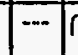 & & $0^{\prime} t$ & \begin{tabular}{|l|l|}
$\cdots$ & $n$ \\
\end{tabular} & $0^{\prime} t$ & -1 & n & $0^{\prime} t$ & ---1 & n & $0^{\prime} t$ & $--\mid n$ & $0^{\prime} t$ & unı̣uə|əs \\
\hline \begin{tabular}{l|l|l}
$r$ & $E$
\end{tabular} & & $\angle D Q$ & $\begin{array}{ll}r \\
\end{array}$ & $\overline{8}$ & $\overline{016}$ & ir $E$ & $\bar{\theta}$ & $9 \angle 9$ & $\cdots n$ & $\angle 69$ & is & 8 & 291 & -- & & 0811 & -- & 1060l & WnissDiOd \\
\hline$--\mid r$ & 1 & 27 & ---1 & ก & $Z^{\prime} t$ & --1 & & $2 \nabla$ & $\cdots n$ & 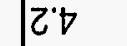 & -1 & n & 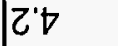 & $-\cdots \mid$ & n & $Z^{\prime} \nabla$ & $\cdots n$ & $Z^{\prime} t$ & 1әXग!N \\
\hline$m n$ & 7 is & $90^{\circ} 0$ & 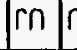 & n & $90^{\circ} 0$ & mn r & & $90^{\circ} 0$ & $m n$ & $90^{\circ} 0$ & m & n & $90^{\circ} 0$ & $-\cdots$ & n & $90^{\prime} 0$ & $\min \mid \pi$ & $90^{\circ} 0$ & LInOJOW \\
\hline$-\cdots$ & & $0 \angle L Z$ & $\cdots-$ & & 0061 & $\cdots$ & & 0.001 & - & O'sDl & --1 & & O'SGL & $\cdots$ & & 0.901 & - & $\angle ' \varepsilon 9$ & əsəubচutow \\
\hline \begin{tabular}{|l|l}
$\Gamma$ & $\varepsilon$ \\
\end{tabular} & 3 & $8 \varepsilon Z$ & 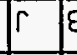 & e & $98 \varepsilon$ & ]$^{\top}[\varepsilon$ & 8 & $8 Z \varepsilon$ & r 18 & 062 & r & g & $80 \varepsilon$ & is & g & 782 & r $\begin{array}{l}\mathrm{a} \\
\end{array}$ & OZE & un!səuD̂pw \\
\hline-- & & $0 \varepsilon^{\prime} \varepsilon$ & -- & & $09^{\circ} \mathrm{L}$ & $\cdots$ & & $O L^{\prime} \varepsilon$ & $\cdots$ & 092 & - & & $0 \varepsilon^{\prime} \mathrm{L}$ & n & $\theta$ & $9 \varepsilon^{\prime} 0$ & $\cdots$ & $00 \mathrm{z}$ & $\mathrm{pD} 27$ \\
\hline \begin{tabular}{r|r} 
& $E$ \\
\end{tabular} & & $\sigma^{\prime} \varepsilon 1$ & $=$ & & $\angle \circ 8$ & $\cdots$ & & $\varepsilon .92$ & \begin{tabular}{l|l} 
& $g$ \\
\end{tabular} & 91 & 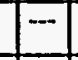 & & $l^{\prime}, 0 z$ & $r$ & 8 & 8.61 & $\cdots$ & $\varepsilon^{\prime} \angle \varepsilon$ & UO.11 \\
\hline$n$ & a & $0^{\circ} \varepsilon$ & -- & & $\angle 9$ & n $\varepsilon$ & & 82 & n 18 & $2 z$ & n & $g$ & 82 & $n$ & 8 & $\varepsilon \varepsilon^{\prime} \varepsilon$ & n 18 & $\nabla^{\prime} \varepsilon$ & 1əddoJ \\
\hline$-\cdots 1$ & & $68^{\circ} 0$ & --1 & n & $\nabla 8^{\circ} 0$ & --1 & & $\$ 8^{\circ} 0$ & $\begin{array}{ll}- & n \\
\end{array}$ & $188^{\prime} 0$ & $\cdots$ & $n$ & $D 8^{\circ} 0$ & $-\cdots$ & $n$ & $188^{\prime} 0$ & $-n$ & $78^{\circ} 0$ & \#Dq03 \\
\hline $\begin{array}{ll}-\cdots & 1 \\
\end{array}$ & & $266^{\circ} 0$ & -1 & & 06.9 & $\cdots$ & & $26^{\circ} 0$ & $-\cdots$ & 260 & $\cdots$ & $n$ & $26^{\circ} 0$ & $-\cdots$ & $n$ & $260^{\circ} 0$ & $--n$ & $266^{\circ}$ & un!wo140 \\
\hline$r \mid \varepsilon$ & & $\varepsilon 26$ & -- & & 0922 & $\cdots$ & & 0122 & -- & $09 \angle 1$ & $\cdots$ & & 0191 & $\cdots$ & & $0 \nabla Z 2$ & -1 & $0 \varepsilon \nabla z$ & un!?|이 \\
\hline--1 & & $29^{\circ} 0$ & $-\cdots$ & $n$ & $29^{\circ} 0$ & $\cdots i$ & & $29^{\circ} 0$ & $n$ & 0.1 & $n$ & & $0 L^{\prime} \mathrm{L}$ & $n$ & $g$ & $\varepsilon 8^{\circ} 0$ & $n$ & $\varepsilon 8^{\circ} 0$ & un!̣pD \\
\hline$-x$ i & & $90^{\circ} 0$ & -- & n & 90.0 & $\cdots$ & & $90^{\circ} 0$ & $\cdots-n$ & 900 & -- & $n$ & $90^{\circ} 0$ & $-\cdots$ & $n$ & $90^{\circ} 0$ & $n$ & 61.0 & un!!|Kag \\
\hline r & 3 & 1.2 & Ir & a & 79 & Ir & & 9.91 & $r^{8} \mathrm{~g}^{\mathrm{s}}$ & $9.0 \mathrm{l}$ & $r$ & 8 & $600 \mathrm{l}$ & a & 8 & $9 . \mathrm{L}$ & r 8 & 82 & unjugg \\
\hline in 1 & un & 020 & an & $\mathrm{Mn}$ & 020 & mn & Mn & $0 Z 0$ & m & 1020 & in & Mn & $02 \%$ & rn & $\mathrm{Mn}$ & $02 \%$ & rn $19 n$ & 020 & ગüssty \\
\hline \begin{tabular}{|ll}
--1 & \\
\end{tabular} & & $\angle \mathrm{L}$ & $-\cdots$ & & $\angle 11$ & \begin{tabular}{|l|l}
--1 & 4 \\
\end{tabular} & & $\angle 11$ & \begin{tabular}{|l|l|} 
& $n$ \\
\end{tabular} & $\angle 11$ & $\cdots$ & n & $\angle 11$ & $=1$ & $n$ & L'L & $\cdots n$ & 211 & Ruow!tuy \\
\hline- & & $0.9 l 1$ & $\cdot 1$ & & $0 \_881$ & $\cdots$ & & 0.691 & $\cdots$ & 10621 & $\cdots$ & & 6.08 & $\cdots$ & & 9.16 & $\cdots$ & 919 & unų̣un| \\
\hline & $\mathbb{D}$ & 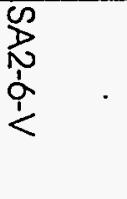 & 穴 & & $\begin{array}{l}\text { 罣 } \\
\text { 少 } \\
<\end{array}$ & 奇 & & 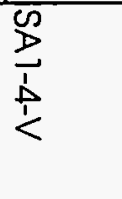 & 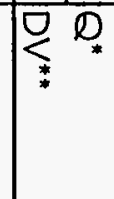 & 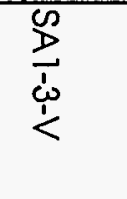 & 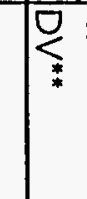 & & $\begin{array}{l}\frac{D}{2} \\
\frac{1}{\hat{N}} \\
\dot{1}\end{array}$ & 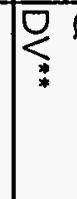 & & 隻 & $\overbrace{*}$ & $\frac{\text { Do }}{\frac{D}{1}}$ & (Бत्र/бW) punoduos \\
\hline
\end{tabular}




\begin{tabular}{|c|c|c|c|c|c|c|c|c|c|c|c|c|c|c|c|c|c|c|c|c|c|}
\hline \multirow[b]{2}{*}{ Compound $(\mathrm{mg} / \mathrm{Kg})$} & \multicolumn{21}{|c|}{ Table A-6.1 Metals/Cyanide } \\
\hline & 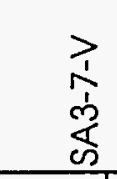 & $\stackrel{*}{Q}$ & & 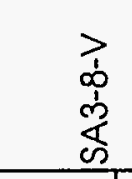 & $\stackrel{*}{Q}$ & & 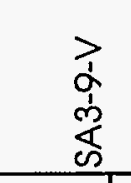 & & & 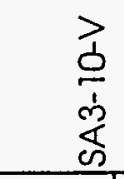 & & & 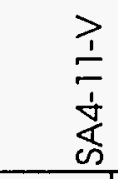 & & & 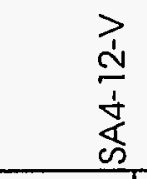 & $\stackrel{*}{\emptyset}$ & 草 & 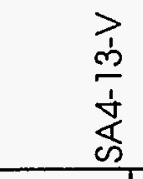 & & 草 \\
\hline Aluminum & 99.9 & & $\ldots$ & 115.0 & & --- & 87.6 & & $\ldots$ & 97.7 & & $\ldots$ & 47.6 & & $-\ldots$ & 108.0 & & \begin{tabular}{|l|l|l|}
- & 0 \\
\end{tabular} & 117.0 & & $\ldots$ \\
\hline Antimony & 11.7 & $u$ & $\ldots$ & 11.7 & $\mathrm{U}$ & - & 11.7 & $u$ & $\ldots$ & 11.7 & $u$ & $\ldots$ & 11.7 & $u$ & $\ldots$ & 11.7 & U. & $\ldots$ & 11.7 & $u$ & $\ldots$ \\
\hline Arsenic & 0.20 & uW & UJ & 0.20 & uW & UJ & 0.20 & $\mathrm{uW}$ & UJ & 0.20 & uW & UJ & 0.20 & UW & Uu & 0.20 & uW & UJ & 0.20 & uW & UJ \\
\hline Barium & 6.2 & $B$ & $\mathrm{~J}$ & 7.6 & $B$ & J & 7.5 & B & $\mathrm{J}$ & 6.7 & $\mathrm{~B}$ & $\mathrm{~J}$ & 3.4 & $B$ & $J$ & 7.3 & $\mathrm{~B}$ & $\mathrm{~J}$ & 3.9 & $B$ & $\mathrm{~J}$ \\
\hline Beryllium & 0.06 & $\mathrm{U}$ & $-\ldots$ & 0.06 & $U$ & $\ldots$ & 0.06 & $u$ & $\ldots$ & 0.06 & $\mathrm{U}$ & $\ldots$ & 0.06 & $\mathrm{u}$ & - & 0.06 & 4 & $\ldots$ & 0.06 & 4 & $\ldots$ \\
\hline Cadmium & 0.62 & $\mathrm{U}$ & $\ldots$ & 0.62 & $\mathrm{U}$ & $\ldots$ & 0.62 & 4 & $\ldots$ & 0.75 & $\mathrm{~B}$ & $u$ & 0.70 & $\mathrm{~B}$ & 4 & 0.62 & 0 & $\ldots$ & 0.83 & $\mathrm{~B}$ & $\mathrm{u}$ \\
\hline Calcium & 1440 & & $\ldots$ & 2050 & & $\ldots$ & 2270 & & $\ldots$ & 1260 & & $-\infty$ & 2180 & & $-\ldots$ & 1470 & & $\ldots$ & 3280 & & $\ldots$ \\
\hline Chromium & 0.92 & 4 & -- & 0.92 & $\mathrm{u}$ & - & 0.92 & $u$ & $\ldots$ & 0.92 & $u$ & $\ldots$ & 0.92 & $\mathrm{U}$ & $\ldots$ & 0.92 & 4 & $-\ldots$ & 0.92 & $u$ & $\ldots$ \\
\hline Cobalt & 0.84 & $u$ & $\ldots$ & 0.84 & $u$ & $\ldots$ & 0.84 & $u$ & $\ldots$ & 0.84 & 4 & $\ldots$ & 0.84 & $u$ & $\ldots$ & 0.84 & 4 & $-\cdots$ & 0.84 & $\mathrm{U}$ & - \\
\hline Copper & 2.8 & $B$ & 4 & 2.6 & $B$ & $u$ & 3.2 & $\mathrm{~B}$ & $u$ & 2.ó & $B$ & U & 2.6 & $B$ & 4 & 2.6 & 8 & 4 & 3.6 & 8 & 1 \\
\hline Iron & 23.6 & & $\ldots$ & 20.9 & & $\ldots$ & 25.8 & & $\ldots$ & 16.3 & $\mathrm{~B}$ & J & 22.7 & & -- & 13.2 & 8 & $\mathrm{~J}$ & 29.8 & & $\ldots$ \\
\hline Lead & 14.30 & & $\ldots$ & 2.90 & $s$ & - & 1.60 & & $\ldots$ & 13.00 & & $-\ldots$ & 4.30 & $\mathrm{~s}$ & $\ldots$ & 0.57 & B & US & 0.48 & $\mathrm{~B}$ & $u$ \\
\hline Magnesium & 240 & B & $\mathrm{J}$ & 251 & $B$ & $\mathrm{~J}$ & 281 & $\mathrm{~B}$ & $\mathrm{~J}$ & 225 & $B$ & $\mathrm{~J}$ & 277 & $\mathrm{~B}$ & $\mathrm{~J}$ & 217 & $B$ & J & 341 & $B$ & $\mathrm{~J}$ \\
\hline Manganese & 157.0 & & $\ldots$ & 168.0 & & $\ldots$ & 87.9 & & - & 115.0 & & $\ldots$ & 33.4 & & -- & 115.0 & & $\ldots$ & 88.1 & & -- \\
\hline Mercury & 0.05 & $\mathrm{U}$ & -- & 0.05 & $U$ & UJ & 0.05 & $\mathrm{U}$ & UJ & 0.05 & 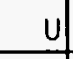 & US & 0.05 & $\mathrm{U}$ & UJ & 0.05 & 4 & U. & 0.05 & $\mathrm{u}$ & UJ \\
\hline Nickel & 4.2 & $u$ & $\ldots$ & 4.2 & $\mathrm{U}$ & -.. & 4.2 & $\mathrm{U}$ & - & 4.2 & $\mathrm{u}$ & $\ldots$ & 4.2 & $\mathrm{U}$ & $\ldots$ & 4.2 & u & $\ldots$ & 4.2 & $\mathrm{U}$ & - \\
\hline Potassium & 597 & $u$ & -- & 597 & $\mathrm{U}$ & $\ldots$ & 606 & $\mathrm{~B}$ & $J$ & 754 & $\mathrm{~B}$ & $\mathrm{~J}$ & 1000 & $\mathrm{~B}$ & $\mathrm{~J}$ & 623 & $B$ & $\mathrm{~J}$ & 688 & $\mathrm{~B}$ & J \\
\hline Selenium & 4.0 & $\mathrm{u}$ & -- & 4.0 & $\mathrm{u}$ & - & 4.0 & $u$ & - & 4.0 & $\mathrm{U}$ & $\ldots$ & 4.0 & $u$ & $-\ldots$ & 4.0 & 4 & $\ldots$ & 4.0 & $\mathrm{u}$ & $\ldots$ \\
\hline Silver & 0.70 & 4 & - & 0.70 & $U$ & - & 0.70 & $\mathrm{u}$ & - & 0.70 & $u$ & $\ldots$ & 0.70 & $U$ & -- & 0.70 & $U$ & $\ldots$ & 0.70 & $\mathrm{U}$ & ... \\
\hline Sodium & 61.3 & $\mathrm{~B}$ & $\mathrm{~J}$ & 60.0 & $B$ & $\mathrm{~J}$ & 53.2 & $B$ & $\mathrm{~J}$ & 37.1 & $\mathrm{~B}$ & $\mathrm{~J}$ & 53.2 & $\mathrm{~B}$ & $\mathrm{~J}$ & 50.8 & $\mathrm{~B}$ & $\mathrm{~J}$ & 63.7 & $\mathrm{~B}$ & J \\
\hline Thallium & 0.20 & UW & UJ & 0.20 & uW & $u_{J}$ & 0.20 & uw & $\mathrm{UJ}$ & 0.20 & uW & UJ & 0.20 & UW & us & 0.20 & $u$ & --- & 0.20 & $\mathrm{U}$ &.- \\
\hline Vanadium & 0.42 & $u$ & $-\infty$ & 0.83 & $B$ & $u$ & 0.42 & $\mathrm{u}$ & - & 0.43 & $B$ & $u$ & 0.42 & $\mathrm{U}$ & - & 0.42 & $u$ & $\ldots$ & 0.42 & 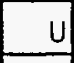 & -.. \\
\hline Zinc & 16.5 & $E$ & $\mathrm{~J}$ & 11.8 & $\mathrm{E}$ & s & 11.7 & $\mathrm{E}$ & 1 & 8.4 & $\mathrm{E}$ & $\mathrm{J}$ & 12.5 & $\mathrm{E}$ & $\mathrm{J}$ & 8.6 & $\mathrm{E}$ & $\mathrm{J}$ & 17.5 & $E$ & $=1 \mathrm{~J}$ \\
\hline Cyanide & 0.13 & $u$ & $\mathrm{UJ}$ & 0.13 & $\mathrm{U}$ & $u$ & 0.12 & $u$ & UJ & 0.13 & $\mathrm{u}$ & UJ & 0.13 & $u$ & $\mathrm{UJ}$ & 0.13 & u) & UJ & 0.13 & $\mathrm{U}$ & UJ \\
\hline
\end{tabular}




\begin{tabular}{|c|c|c|c|c|c|c|c|c|c|c|c|c|c|c|c|c|}
\hline 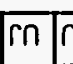 & & 11.0 & $m n$ & $\varepsilon \varepsilon^{\prime} 0$ & m & & $\varepsilon 1^{\circ} 0$ & $\min$ & & $\varepsilon \iota^{\prime \prime} 0$ & $m$ & & $\varepsilon 1^{\prime} 0$ & \begin{tabular}{|l|l|}
$m$ & $n$ \\
\end{tabular} & $\varepsilon L^{\prime} 0$ & әр|uि久O \\
\hline \begin{tabular}{l|l|l}
$r$ & 3 \\
\end{tabular} & & $\mathrm{ZZl}$ & I & $g^{\prime} E t$ & r & 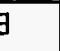 & 0.11 & I 13 & & O'ZOL & Tr & 百 & O'sा & \begin{tabular}{l|l} 
& 1 \\
\end{tabular} & 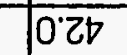 & ou!z \\
\hline$-\pi$ & & $2 \sigma^{\circ} 0$ & \begin{tabular}{l|l}
$n$ & 1 \\
\end{tabular} & $9 L^{\prime} 0$ & -- & & $2 \sigma^{\circ} 0$ & $-1 n$ & & $2 \sigma^{\circ} 0$ & - & & $2 \sigma^{\prime} 0$ & $--\mid n$ & $20^{\circ} 0$ & Wn!pDUD $\wedge$ \\
\hline$m \pi$ & Mn & 020 & $\Gamma n \mid M r$ & ก & $m$ & $\mathrm{Mn}$ & $02 \%$ & $\ln \pi$ & $\mathrm{Mn}$ & $0 Z^{\prime} 0$ & $m$ & $M \cap$ & 020 & 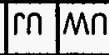 & 1020 & un॥||Dपा \\
\hline \begin{tabular}{l|l}
$r$ & 8 \\
\end{tabular} & & $28 \varepsilon$ & \begin{tabular}{l|l}
$r$ & 8 \\
\end{tabular} & $g^{\prime} 29$ & $r$ & 8 & 629 & ir & & 9.80 & $r$ & & $2+9$ & 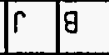 & 198 & wn!pos \\
\hline$\cdots$ & & $0 \angle 0$ & $-\infty n$ & $0 \angle L^{\prime} 0$ & $\cdots$ & n & $0 \angle O$ & $\cdots+1$ & & $0 \angle L^{\prime} 0$ & $\cdots$ & n & $0 \angle O$ & $-{ }^{n}$ & $O \angle O O$ & $\overline{1 \theta \wedge ! ! S}$ \\
\hline 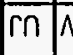 & Mn & $0 \%$ & $\cdots \sqrt{n}$ & 0 & $m$ & $\overline{\mathrm{Mn}}$ & $\overline{0} \theta$ & -1 & & 0 & $\cdots$ & n & 0 & 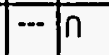 & $0^{\prime} t$ & unjuə|əs \\
\hline-- & & 0101 & \begin{tabular}{|l|l|l}
5 & 8
\end{tabular} & $\overline{\varepsilon Z 9}$ & ri & a & 028 & $\begin{array}{ll}6 \\
\end{array}$ & & 102 & $\pi$ & - & $\angle \angle 8$ & \begin{tabular}{|l|l|}
$r$ & $\theta$ \\
\end{tabular} & 699 & Wn!ssotod \\
\hline$-\overline{1}$ & & $2 t$ & \begin{tabular}{|c|}
$n$ \\
\end{tabular} & 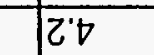 & -- & & $Z^{\prime} t$ & $-\infty$ & & Z't & --- & $n$ & $2 \overline{0}$ & $-\cdots n$ & 27 & |ि्YणाN \\
\hline \begin{tabular}{|l|l}
$\ln$ \\
\end{tabular} & & $90^{\circ} 0$ & \begin{tabular}{|l|l|l}
$m$ & $n$ \\
\end{tabular} & $90^{\prime} 0$ & $m$ & & $90^{\prime} 0$ & mn & & 90 & $m$ & $\pi$ & $90 \%$ & \begin{tabular}{|l|l|}
$r n$ & $n$ \\
\end{tabular} & $90^{\circ} 0$ & KunJeW \\
\hline-- & & 6.89 & $\cdots$ & $0^{\circ} 00 \varepsilon$ & --- & & $0,8 \angle 1$ & -1 & & O'ZOL & $\cdots$ & & O'sLl & $\cdots$ & O'Sll & әsəuDbudW \\
\hline \begin{tabular}{|l|l|l|l}
$\Gamma$ & $E$
\end{tabular} & & 682 & \begin{tabular}{l|l}
$r$ & 8
\end{tabular} & $O L L$ & $r$ & $\overline{8}$ & $\nabla 6 \varepsilon$ & r & & Zsष & 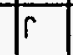 & $\overline{8}$ & $\angle Z Z$ & \begin{tabular}{|l|l|l}
$r$ & 8 \\
\end{tabular} & 692 & ய"n!səuదিow \\
\hline \begin{tabular}{|l|l}
$n$ & $E$ \\
\end{tabular} & & 620 & $\cdots$ & $0 \angle 2$ & $\cdots$ & & $06^{\prime} 1$ & $n_{0}$ & & $8 Z^{\circ} 0$ & $n$ & g & $\varepsilon \nabla^{\prime} 0$ & \begin{tabular}{l|l}
$n$ & $a$
\end{tabular} & $O Z^{\prime} 0$ & pDo \\
\hline- & & 6.82 & $\cdots$ & 991 & $\cdots$ & & 1982 & -- & & $\angle O O Z$ & $\cdots$ & & $\overline{2} 12$ & \begin{tabular}{l|l}
$r$ & 8 \\
\end{tabular} & $\varepsilon$ & UOإ \\
\hline \begin{tabular}{|l|l|l|l}
$\Gamma$ & $E$ \\
\end{tabular} & & 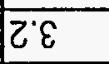 & + & 89 & $n$ & 9 & 8 & $\begin{array}{ll}n \\
\end{array}$ & 9 & 8 & $n$ & & $\varepsilon$ & \begin{tabular}{l|l}
$n$ & 8 \\
\end{tabular} & $\overline{2} \varepsilon$ & Ieddo \\
\hline 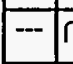 & $n$ & 08.0 & \begin{tabular}{|c|}
$-\infty$ \\
\end{tabular} & 080 & -- & $n$ & 1080 & -7 & $n$ & $788^{\circ} 0$ & - & $n$ & $08^{\circ} 0$ & $--n$ & $\$ 8.0$ & 110900 \\
\hline--1 & & 260 & \begin{tabular}{l|l}
5 & $\theta$ \\
\end{tabular} & $66^{\circ} 0$ & $\cdots$ & $n$ & 260 & -1 & $\bar{n}$ & $26^{\circ} 0$ & $\cdots$ & $n$ & $266^{\circ} 0$ & $--n$ & 26.0 & un!modyo \\
\hline-- & & 0991 & $=$ & 0080 & $-\infty$ & & $00 \angle 2$ & -- & & $0 \varepsilon \varepsilon Z$ & $-\cdots$ & & $0 \angle 02$ & $=$ & $09 \angle 1$ & un!o|DJ \\
\hline \begin{tabular}{|l|l|l}
$n$ & $E$ \\
\end{tabular} & & 99.0 & $\cdots / n$ & $29^{\circ} 0$ & n & a & 960 & $\cdots 1$ & & $29^{\circ} 0$ & - & $n$ & $29^{\circ} 0$ & $--n$ & $29^{\circ} 0$ & un!wpDo \\
\hline$-\infty$ & & $90^{\circ} 0$ & \begin{tabular}{l|l|}
$-\cdots$ & $n$ \\
\end{tabular} & $90^{\circ} 0$ & $\cdots$ & $n$ & $90^{\circ}$ & $-\infty$ & $n$ & $90^{\prime} 0$ & $-\infty$ & $n$ & $90^{\circ} 0$ & \begin{tabular}{|c|c|}
$-\cdots$ \\
\end{tabular} & $90^{\circ} 0$ & 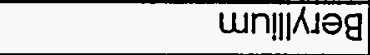 \\
\hline \begin{tabular}{|l|l|l|l} 
& $E$
\end{tabular} & & 0.8 & -- & 0.691 & $r$ & 8 & $2<1$ & $r \quad \varepsilon$ & 8 & 0.8 & $\pi$ & 8 & 9 & \begin{tabular}{r|r|} 
& $\theta$ \\
\end{tabular} & 06 & un!̣og \\
\hline $\min \sqrt{1}$ & $\mathrm{Mn}$ & $0 Z^{\prime} 0$ & $m \mid M r$ & \begin{tabular}{l|l}
$n$ & $0 Z 0$ \\
\end{tabular} & $m$ & $\mathrm{Mn}$ & 020 & min & Mn & 020 & m & Mn & OZ'0 & \begin{tabular}{|l|l|l}
$m$ & $M n$ \\
\end{tabular} & 1020 & ग!UəS $\forall$ \\
\hline$-T^{-1}$ & & $\angle O L$ & $-\cdots$ & $\angle I L$ & -- & $\bar{n}$ & L'LI & -1 & $\bar{n}$ & $\angle ' L$ & $-\cdots$ & n & $\angle I L$ & $\cdots$ & $\angle 11$ & रUOW!!U \\
\hline$\cdots$ & & $0 . \angle 0 Z$ & $\cdots$ & $D^{\prime} 8 \varepsilon Z$ & $\cdots$ & & $0^{\prime} \not \nabla z$ & $\cdots$ & & 0.691 & $\cdots$ & & $O^{\prime}|\varepsilon|$ & - & $0<\angle 6$ & unบ!lun| \\
\hline 兑 & $\Phi_{*}$ & 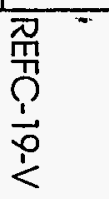 & $\underset{\vdots}{\Phi}$ & 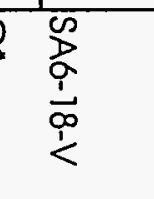 & $\underset{*}{\stackrel{0}{*}}$ & & 要 & $\bar{s}$ & & 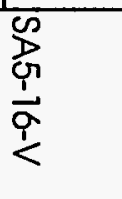 & ${ }_{\sharp}$ & & 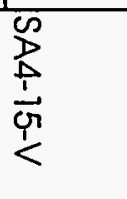 & $\sum_{*}$ & $\begin{array}{l}\frac{D}{D} \\
\frac{D}{+} \\
\frac{1}{2}\end{array}$ & 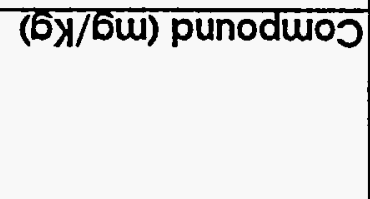 \\
\hline & & & & & & & & & & & & & & & & \\
\hline
\end{tabular}




\begin{tabular}{|c|c|c|c|c|c|c|c|c|c|c|c|c|c|c|c|c|c|c|c|c|c|}
\hline \multirow[b]{2}{*}{ Compound (ug/Kg) } & \multicolumn{21}{|c|}{ Table A-6.2 Pesticides/PCB's } \\
\hline & $\frac{7}{\frac{1}{1}}$ & $\stackrel{*}{6}$ & & $\begin{array}{l}\frac{0}{3} \\
\frac{1}{1} \\
\frac{1}{4} \\
0 \\
0\end{array}$ & & $\stackrel{3}{0}^{*}$ & 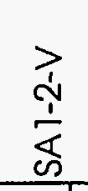 & & & $\frac{>}{9}$ & & $3^{*}$ & 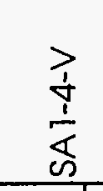 & & $3^{*}$ & $\begin{array}{l}\text { 常 } \\
\text { ஸे } \\
\text { ஸे } \\
\text { c) }\end{array}$ & $\stackrel{*}{\square}$ & 茥 & 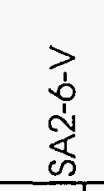 & & $3^{*}$ \\
\hline Alpha-BHC & 16 & 4 & UJ & 16 & 4 & UJ & 16 & 4 & UJ & 16 & 0 & UJ & 16 & U] & UJ & 16 & U & UJ & 16 & 4 & $\mathrm{UJ}$ \\
\hline Beta-BHC & 16 & 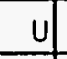 & UJ & 16 & $u$ & UJ & 16 & 0 & UJ. & 16 & 4 & UJ & 16 & $\mathrm{u}$ & UJ & 16 & 4 & UJ & 16 & $u$ & UJ \\
\hline Delta-BHC & 16 & 4 & UJ & 16 & 4 & UJ & 16 & $u$ & UJ & 16 & 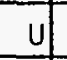 & UJ & 16 & $u$ & UJ & 16 & 4 & UJ & 16 & 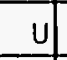 & UJ \\
\hline Gamma-BHC & 16 & 4 & UJ & 16 & 4 & UJ & 16 & 41 & UJ & 16 & 4 & UJ & 16 & U1 & UJ & 16 & 4 & UJ & 16 & 4 & UJ \\
\hline Heptachlor & 16 & u & UJ & 16 & $u$ & UJ & 16 & 41 & UJ & 16 & u & UJ & 16 & U) & UJ & 16 & 4 & UJ & 16 & 4 & UJ \\
\hline Aldrin & 16 & 4 & UJ & 16 & 4 & UJ & 16 & U. & UJ & 16 & u & UJ & 16 & u & UJ & 16 & 4 & UJ & 16 & $u$ & UJ \\
\hline Heptachlor epoxide & 16 & U & UJ & 16 & 4 & UJ & 16 & U] & UJ & 16 & 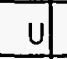 & UJ & 16 & $\mathrm{U}$ & UJ & 16 & 4 & UJ & 16 & 4 & UJ \\
\hline Endosulfan I & 16 & 4 & Uu & 16 & u & UJ & 16 & 4 & UJ & 16 & 4 & UJ & 16 & U. & UJ & 16 & 4 & U.J & 16 & 4 & $\mathrm{UJ}$ \\
\hline Dieldrin & 32 & 4 & Uu & 32 & 4 & UJ & 32 & 4 & UJ & 32 & 4 & Uu & 32 & U) & UJ & 32 & 4 & Us & 32 & 4 & UJ \\
\hline 4,4'-DDE & 32 & 4 & UJ & 32 & 4 & UJ & 32 & 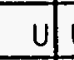 & UJ & 32 & 4 & UJ & 32 & 4 & UJ & 32 & 4 & UJ & 32 & $u$ & $\mathrm{UJ}$ \\
\hline Endrin & 32 & 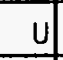 & UJ & 32 & 4 & uJ & 32 & u) & UJ & 32 & 4 & UJ & 32 & Uf & UJ & 32 & 4 & UJ & 32 & 4 & UJ \\
\hline Endosulfan II & 32 & 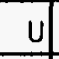 & UJ & 32 & 4 & UJ & 32 & 4 & uJ & 32 & 4 & UJ & 32 & 4 & UJ & 32 & 4 & UJ & 32 & 4 & UJ \\
\hline 4,4'-DDD & 32 & 4 & uJ & 32 & 4 & UJ & 50 & $x$ & J & 32 & 4 & UJ & 32 & 4 & UJ & 32 & 4 & $\mathrm{UJ}$ & 32 & $u$ & UJ \\
\hline Endosulfan sulfate & 32 & 4 & UJ & 32 & 4 & UJ & 32 & u) & UJ & 32 & 4 & UJ & 32 & 4 & UJ & 42 & & J) & 32 & 4 & UJ \\
\hline 4,4'-DDT & 32 & U & UJ & 32 & $\mathrm{U}$ & UJ & 32 & 4 & U. & 32 & 4 & UJ & 32 & u & UJ & 32 & 4 & UJ & 32 & 4 & UJ \\
\hline Methoxychlor & 160 & $\mathrm{u}$ & UJ & 160 & $u$ & UJ & 160 & 4 & UJ & 160 & 4 & UJ & 160 & 4 & UJ & 160 & $u$ & UJ & 160 & u & U. \\
\hline Endrin ketone & 32 & U & UJ & 32 & $u$ & UJ & 32 & 4 & US & 32 & U) & UJ & 32 & 4 & UJ & 32 & 4 & UJ & 32 & U) & UJ \\
\hline Alpha-chlordane & 160 & $u$ & UJ & 160 & 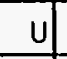 & UJ & 160 & u & UJ & 160 & $u$ & UJ & 160 & $u$ & UJ & 160 & U & UJ & 160 & $u$ & UJ \\
\hline Gamma-chlordane & 160 & $u$ & UJ & 160 & 4 & UJ & 160 & $u$ & UJ & 160 & 4 & UJ & 160 & 4 & UJ & 160 & 4 & UJ & 160 & 4 & UJ \\
\hline Toxaphene & 320 & $\mathrm{u}$ & UJ & 320 & $u$ & UJ & 320 & 4 & UJ & 320 & $u$ & UJ & 320 & 0 & UJ & 320 & 4 & UJ & 320 & $u$ & $\mathrm{UJ}$ \\
\hline Aroclor-1016 & 160 & $\mathrm{U}$ & UJ & 160 & U & UJ & 160 & 4 & UJ & 160 & 4 & UJ & 160 & 4 & UJ & 160 & U & UJ & 160 & uf & UJ \\
\hline Aroclor- 1221 & 160 & 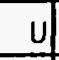 & UJ & 160 & 4 & UJ & 160 & 4 & $\mathrm{uJ}$ & 160 & 4 & UJ & 160 & 4 & UJ & 160 & 4 & UJ & 160 & 4 & UJ \\
\hline Aroclor- 1232 & 160 & 4 & $\mathrm{UJ}$ & 160 & $\mathrm{u}$ & UN & 160 & $u$ & UJ & 160 & $u$ & $\mathrm{UJ}$ & 160 & 4 & UJ & 160 & 4 & UJ & 160 & 4 & UJ \\
\hline Aroclor- 1242 & 160 & $u$ & UJ & 160 & U) & $\mathrm{UJ}$ & 160 & u. & UJ & 160 & 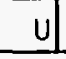 & UJ & 160 & U] & UJ & 160 & U) & UJ & 160 & & UJ \\
\hline
\end{tabular}

"Data Qualifier. " Data Validation. 


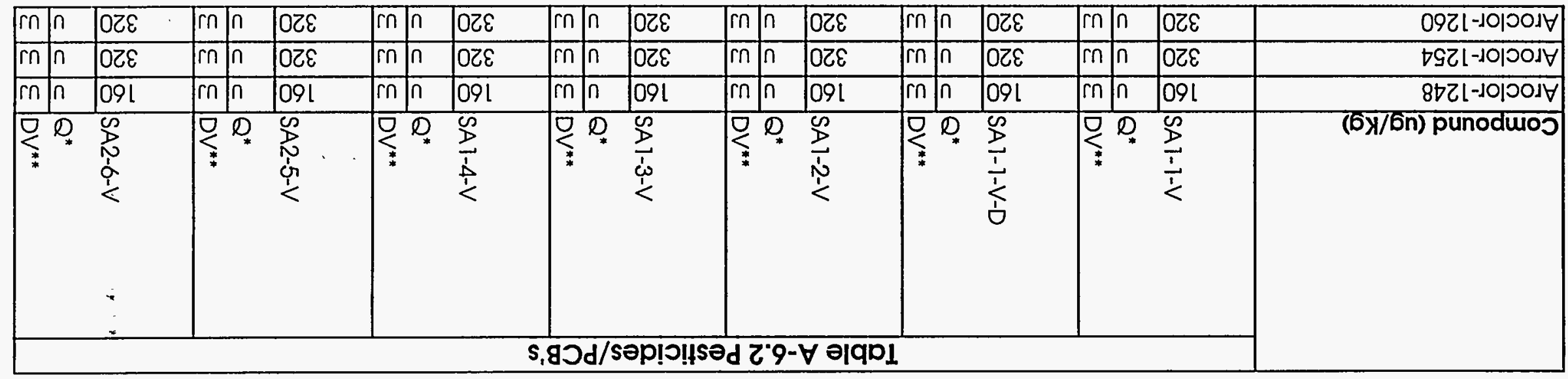




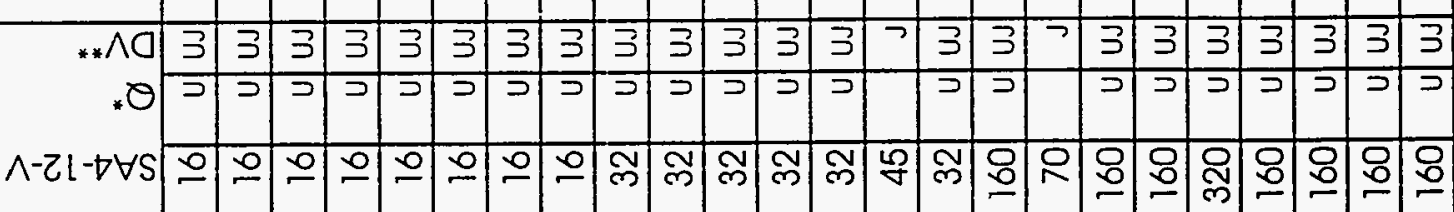

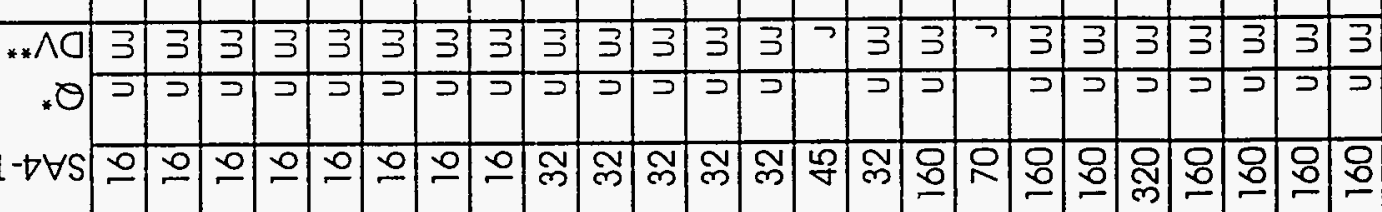

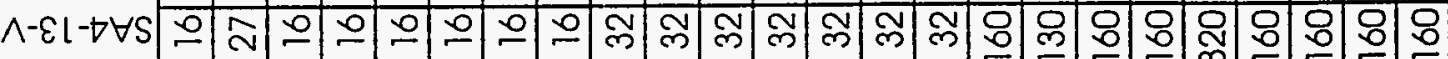

$* * 10$ З

. $\theta$ J

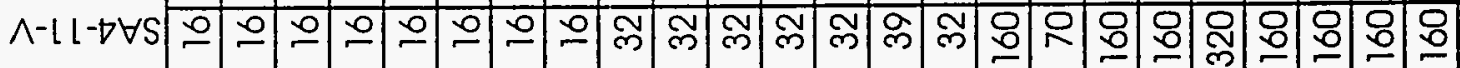

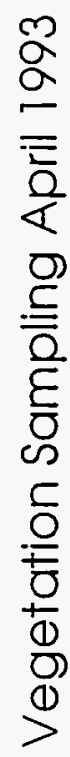

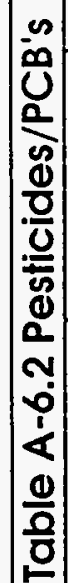

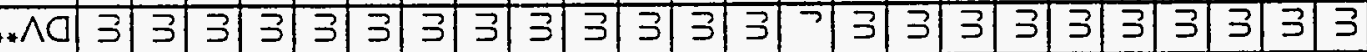

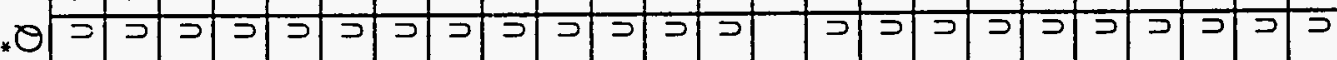

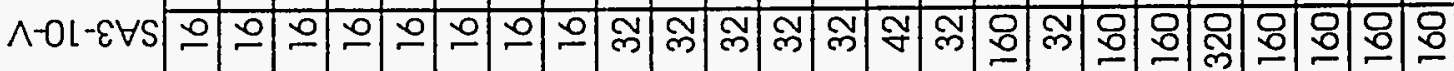

$* \wedge 0$ (3 *

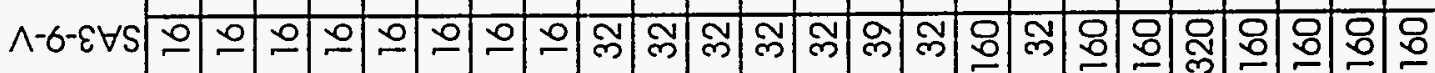
ปे
0
0
0
0

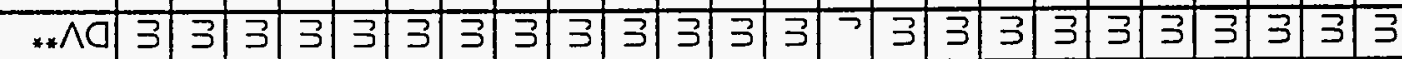
*

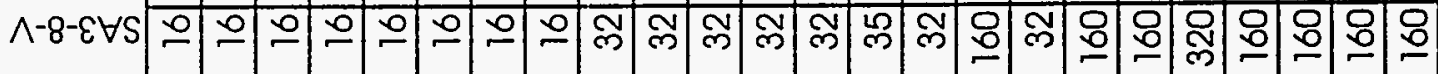

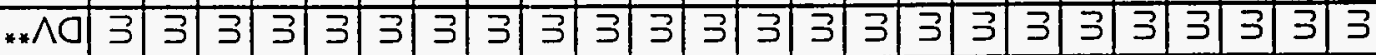
* 0 כ ב

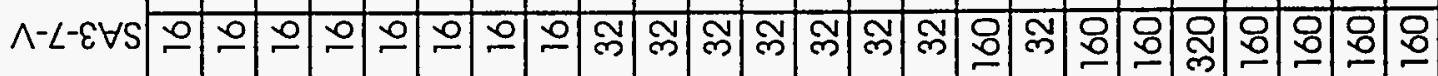




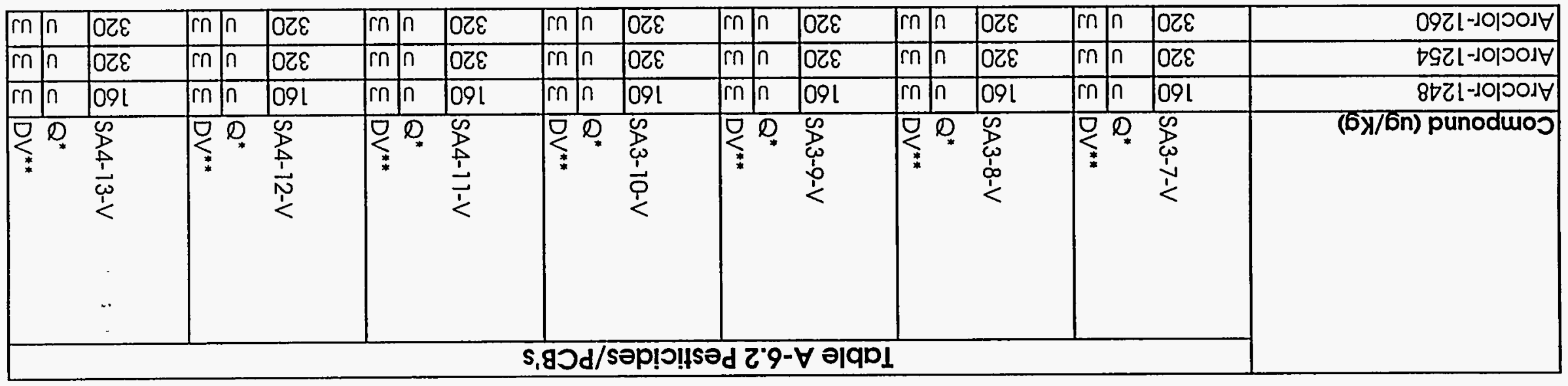


*^0 * כ כ כ כ

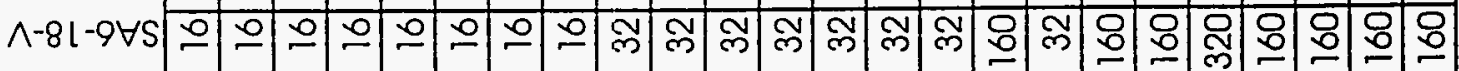

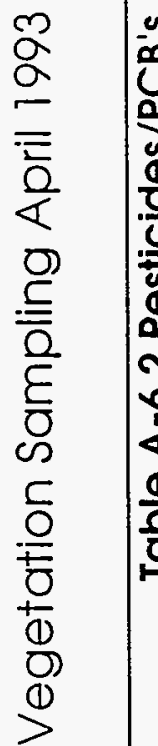

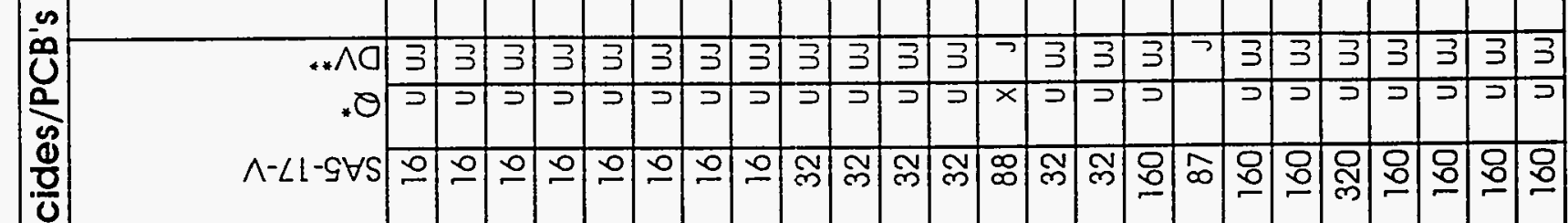

$$
\text { ( }
$$

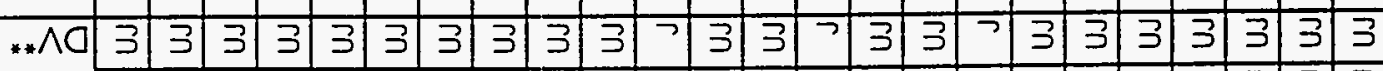
*

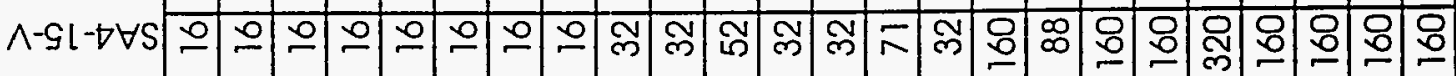

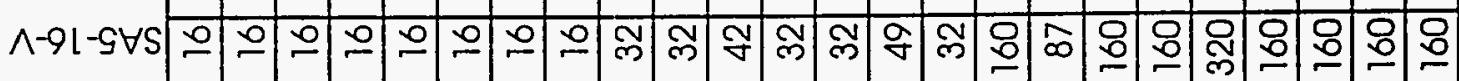
Э

3

$3 \equiv$

v

4

$\frac{0}{0}$

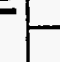

( 


\begin{tabular}{|c|c|c|c|c|c|c|c|c|c|c|c|c|}
\hline \multirow[b]{2}{*}{ Compound (ug/Kg) } & \multicolumn{12}{|c|}{ Table A-6.2 Pesticides/PCB's } \\
\hline & $\begin{array}{l}\frac{3}{+} \\
\stackrel{+}{+} \\
\text { con }\end{array}$ & ${ }^{*} \stackrel{*}{*}$ & 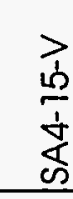 & $\stackrel{\circ}{\circ}$ & 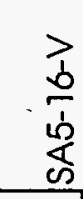 & $\stackrel{*}{0}$ & $\begin{array}{l}\frac{1}{\Delta} \\
\frac{1}{\alpha} \\
\text { co }\end{array}$ & $\underbrace{*}$ & 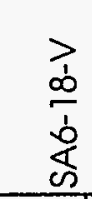 & 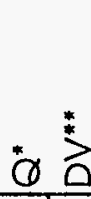 & $\frac{\vec{d}}{\frac{\dot{d}}{\dot{u}}}$ & ${ }^{*} \stackrel{*}{*}$ \\
\hline Aroclor- 1248 & 160 & $0[\mathrm{U}$ & 160 & $0[\mathrm{us}$ & 160 & $0[\mathrm{Us}$ & 160 & 00 & 160 & U]Us & 160 & $40 \mathrm{us}$ \\
\hline Aroclor-1254 & 320 & $\mathrm{u} / \mathrm{u}$ & 320 & $\mathrm{u}[\mathrm{U}$ & 320 & $u \mid u_{s}$ & 320 & $0]$ & 320 & $0 / \mathrm{UJ}$ & 320 & u $[\mathrm{UJ}$ \\
\hline Aroclor-1260 & 320 & u us & 320 & u u & 320 & $u \mid u s$ & 320 & บิ & 320 & U|us & 320 & U U U \\
\hline
\end{tabular}




\begin{tabular}{|c|c|c|c|c|c|c|c|c|c|c|c|c|c|c|c|c|c|c|c|c|c|}
\hline \multirow[b]{2}{*}{ Compound (ug/Kg) } & \multicolumn{21}{|c|}{ Table A-6.3 Semi-Volatiles } \\
\hline & $\frac{7}{\frac{1}{1}}$ & & & $\begin{array}{l}0 \\
\frac{1}{1} \\
\frac{1}{1} \\
\frac{1}{6} \\
0\end{array}$ & & $3^{*}$ & $\begin{array}{l}> \\
\stackrel{1}{1} \\
\frac{1}{4} \\
\text { c) }\end{array}$ & & & $\begin{array}{l}> \\
1 \\
1 \\
\frac{1}{4} \\
\text { c) }\end{array}$ & & $\stackrel{*}{*}$ & 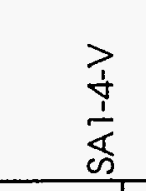 & & 莡 & 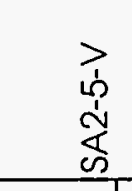 & & $\stackrel{2}{*}^{*}$ & $\begin{array}{l}> \\
\dot{1} \\
\dot{c} \\
\dot{c} \\
\dot{c} \\
\text { co }\end{array}$ & & $\stackrel{3}{0}^{*}$ \\
\hline Phenol & 6600 & $U$ & $\mathrm{j}$ & 6600 & $\mathrm{U}$ & UJ & 6600 & $u$ & UJ & 6600 & 4 & UJ & 6600 & $u$ & UJ & 6600 & 4 & U. & 6600 & 0 & UJ \\
\hline bis (2-Cloroethyl)Ether & 6600 & 4 & $\mathrm{~s}$ & 6600 & 4 & UJ & 6600 & $u$ & UJ & 6600 & $\mathrm{u}$ & UJ & 6600 & $\mathrm{U}$ & UJ & 6600 & 4 & UJ & 6600 & $u$ & UJ \\
\hline 2-Chlorophenol & 6600 & $u$ & $\mathrm{~J}$ & 6600 & $\mathrm{U}$ & UJ & 6600 & 4 & UJ & 6600 & 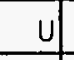 & UJ & 6600 & u & UJ & 6600 & 4 & $\mathrm{UJ}$ & 6600 & U & UJ \\
\hline 1,3-Dichlorobenzene & 6600 & $u$ & $\mathrm{~J}$ & 6600 & $u$ & $\mathrm{UJ}$ & 6600 & $u$ & UJ & 6600 & $u$ & UJ & 6600 & $\mathrm{u}$ & UJ & 6600 & 4 & UJ & 6600 & $\mathrm{U}$ & UJ \\
\hline 1,4-Dichlorobenzene & 6600 & $\mathrm{U}$ & $\mathrm{J}$ & 6600 & $\mathrm{u}$ & UJ & 6600 & $u$ & UJ & 6600 & $u$ & UJ & 6600 & $u$ & $\mathrm{UJ}$ & 6600 & 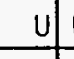 & UJ & 6600 & 4 & UJ \\
\hline Benzyl Alcohol & 6600 & u & $\mathrm{J}$ & 6600 & $\mathrm{U}$ & UJ & 6600 & $\mathrm{U}$ & UJ & 6600 & $u$ & UJ & 6600 & 4 & $\mathrm{uJ}$ & 6600 & $u$ & UJ & 6600 & 4 & UJ \\
\hline 1,2-Dichlorobenzene & 6600 & 4 & $\mathrm{~J}$ & 6600 & 4 & Uu & 6600 & 4 & Uu & 6600 & 4 & UJ & 6600 & $u$ & UJ & 6600 & U & $\mathrm{UJ}$ & 6600 & 4 & UJ \\
\hline 2-Methylphenol & 6600 & $\mathrm{U}$ & $\mathrm{J}$ & 6600 & $\mathrm{u}$ & $\mathrm{UJ}$ & 6600 & U & UJ & 6600 & $u$ & UJ & 6600 & U & UJ & 6600 & $U$ & UJ & 6600 & 4 & $\mathrm{UJ}$ \\
\hline bis (2-Chloroisopropyl)Ether & 6600 & $\mathrm{u}$ & J) & 6600 & $\mathrm{u}$ & $\mathrm{UJ}$ & 6600 & U & UJ & 6600 & U & UJ & 6600 & $\mathrm{u}$ & UJ & 6600 & 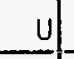 & UJ & 6600 & 4 & UJ \\
\hline 4-Methylphenol & 6600 & 4 & $\mathrm{~J}$ & 6600 & 4 & UJ & 6600 & $u$ & UJ & 6600 & 4 & UJ & 6600 & $\mathrm{u}$ & UJ & 6600 & 4 & UJ & 6600 & u) & UJ \\
\hline N-Nitroso-Di-n-Propylamine & 6600 & $u$ & $\mathrm{~J}$ & 6600 & 4 & UJ & 6600 & 4 & UJ & 6600 & $\mathrm{U}$ & UJ & 6600 & $\mathrm{u}$ & U.J & 6600 & 4 & UJ & 6600 & 4 & $u J$ \\
\hline Hexachloroethane & 6600 & $\mathrm{U}$ & $\mathrm{J}$ & 6600 & $u$ & UJ & 6600 & U & UJ & 6600 & 4 & Uu & 6600 & $u$ & UJ & 6600 & 4 & Uu & 6600 & $\mathrm{u}$ & $u$ \\
\hline Nitrobenzene & 6600 & 4 & 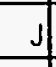 & 6600 & 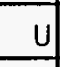 & UJ & 6600 & 4 & UI & 6600 & 4 & UJ & 6600 & $u$ & UJ & 6600 & 1. & !!1 & 6600 & 4 & UJ \\
\hline Isophorone & 6600 & $u$ & $\mathrm{~J}$ & 6600 & $U$ & $\mathrm{UJ}$ & 6600 & 4 & UJ & 6600 & 4 & UJ & 6600 & $u$ & UJ & 6600 & 4 & UJ & 6600 & $\mathrm{U}$ & UJ \\
\hline 2-Nitrophenol & 6600 & U & $\mathrm{J}$ & 6600 & U & $\mathrm{UJ}$ & 6600 & $\mathrm{U}$ & UJ & 6600 & 4 & UJ & 6600 & 4 & UJ & 6600 & 4 & UJ & 6600 & $u$ & UJ \\
\hline 2,4-Dimethylphenol & 6600 & $u$ & $\mathrm{~J}$ & 6600 & $u$ & UJ & 6600 & $\mathrm{u}$ & UJ & 6600 & u) & UJ & 6600 & $\mathrm{U}$ & UJ & 6600 & $\mathrm{U}$ & $\mathrm{uJ}$ & 6600 & $\mathrm{U}$ & U.J \\
\hline Benzolc Acid & 32000 & $\mathrm{U}$ & $\mathrm{J}$ & 32000 & $\mathrm{U}$ & UJ & 32000 & $u$ & UJ & 32000 & U) & UJ & 32000 & 4 & UJ & 32000 & 4 & UJ & 32000 & $\mathrm{u}$ & UJ \\
\hline bis (2-Chloroethoxy)Methane & 6600 & $u$ & $\mathrm{~J}$ & 6600 & $\mathrm{U}$ & UJ & 6600 & $\mathrm{U}$ & UJ & 6600 & u. & UJ & 6600 & $\mathrm{U}$ & UJ & 6600 & $\mathrm{u}$ & $\mu \mathrm{J}$ & 6600 & 4 & UJ \\
\hline 2,4-Dichlorophenol & 6600 & 4 & J & 6600 & $\mathrm{U}$ & UJ & 6600 & $\mathrm{u}$ & UJ & 6600 & 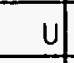 & UJ & 6600 & $u$ & UJ & 6600 & 4 & UJ & 6600 & 0 & UJ \\
\hline 1,2,4-Trichlorobenzene & 6600 & 4 & J & 6600 & $\mathrm{u}$ & UJ & 6600 & $\mathrm{U}$ & U. & 6600 & $u$ & UJ & 6600 & 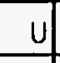 & UJ & 6600 & 4 & UJ & 6600 & 4 & UJ \\
\hline Naphthalene & 6600 & $\mathrm{u}$ & $\mathrm{J}$ & 6600 & $\mathrm{U}$ & UJ & 6600 & $\mathrm{U}$ & UJ & 6600 & $u$ & UJ & 6600 & $\mathrm{U}$ & UJ & 6600 & 4 & UJ & 6600 & $\mathrm{U}$ & UJ \\
\hline 4-Chloroaniline & 6600 & 4 & J & 6600 & $u$ & uJ & 6600 & $\mathrm{U}$ & UJ & 6600 & 4 & UJ & 6600 & 4 & UJ & 6600 & 4 & UJ & 6600 & 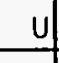 & UJ \\
\hline Hexachlorobutadiene & 6600 & $u$ & 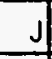 & 6600 & $\mathrm{U}$ & UJ & 6600 & $u$ & UJ & 6600 & u) & UJ & 6600 & $u$ & UJ & 6600 & U & UJ & 6600 & $\mathrm{U}$ & UJ \\
\hline 4-Chloro-3-Methylphenol & 6600 & $\mathrm{u}$ & 7 & 6600 & $u$ & UJ & 6600 & $u$ & $\mathrm{UJ}$ & 6600 & $\mathrm{u}$ & UJ & 6600 & U & Uu & 6600 & U) & UJ & 6600 & $u$ & UJ \\
\hline
\end{tabular}


$* \wedge$ * * ^-૧-乙৮

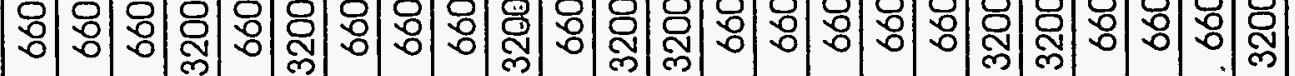

$* \wedge 0$ (3

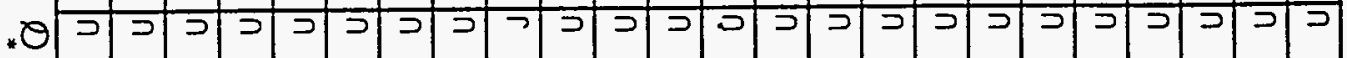

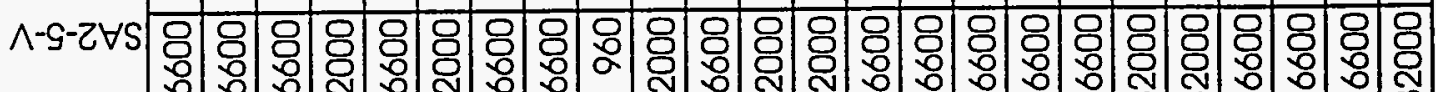

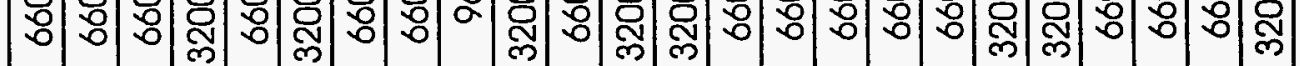

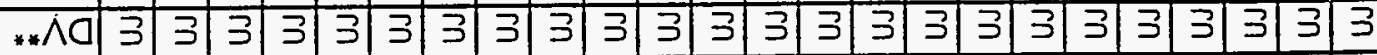
.$\theta 0$ ^-৮-1*s

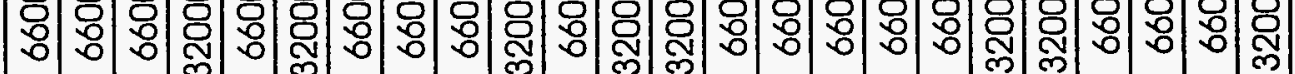

$*_{*} \wedge$ (

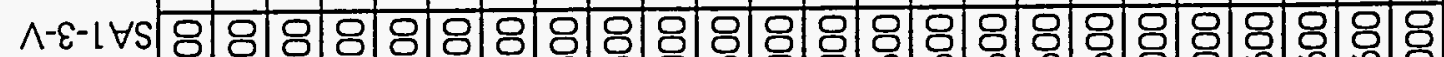

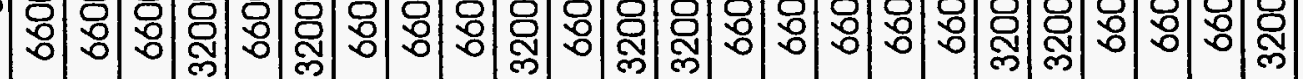

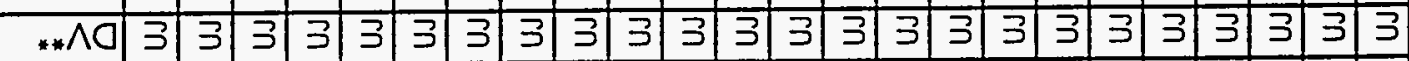

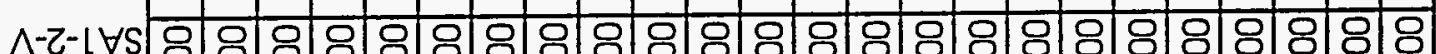

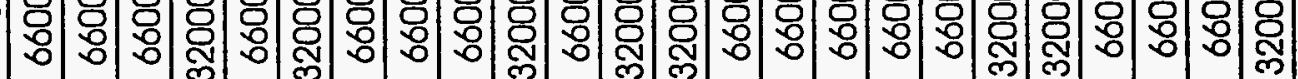

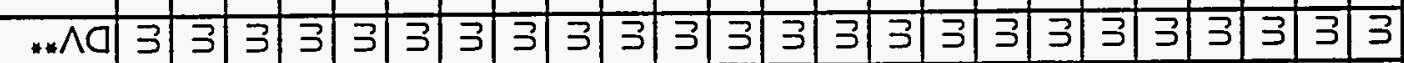

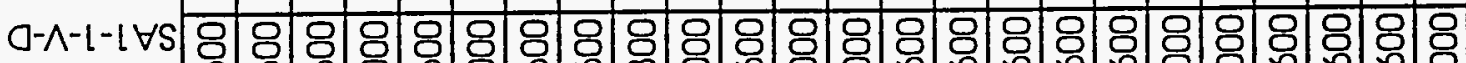

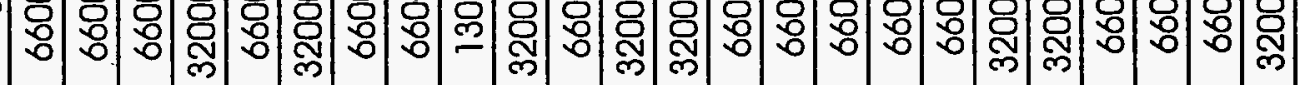

$* * \wedge 0$

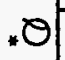

ヘ-1-L4S ర্ঠ

$\frac{D}{5}$
$\frac{5}{0}$
$\frac{E}{D}$
क

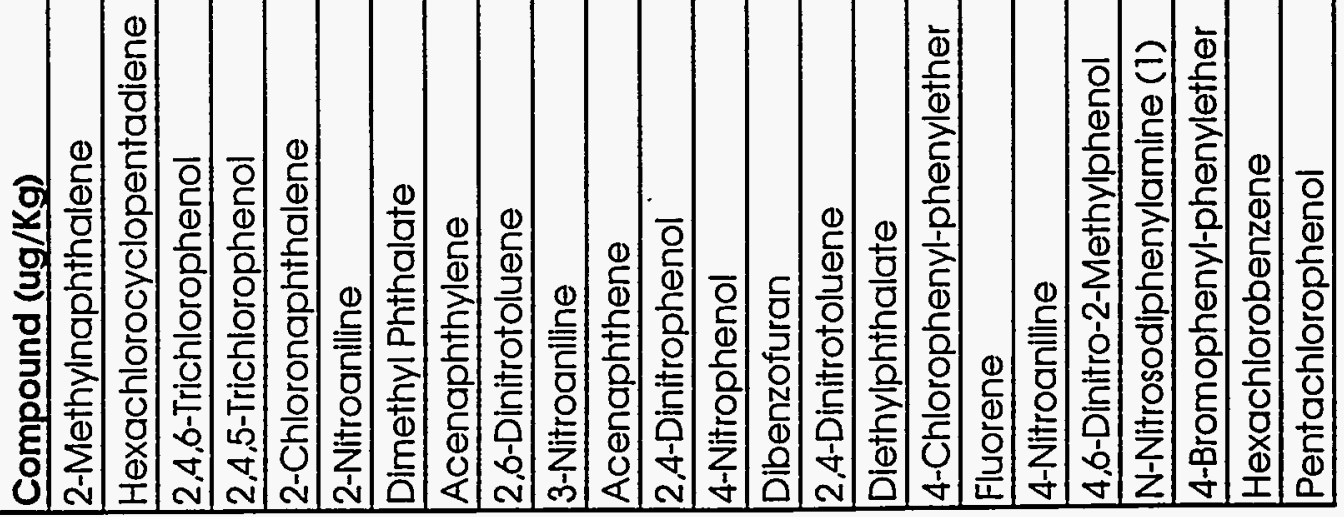




\begin{tabular}{|c|c|c|c|c|c|c|c|c|c|c|c|c|c|c|c|c|c|c|c|c|c|}
\hline \multirow[b]{2}{*}{ Compound (ug/Kg) } & \multicolumn{21}{|c|}{ Table A-6.3 Semi-Volatiles } \\
\hline & $\frac{1}{\frac{1}{1}}$ & & & $\frac{9}{\frac{1}{1}} \frac{1}{\frac{1}{4}}$ & & & \begin{tabular}{l}
$>$ \\
\multirow{1}{*}{} \\
$\frac{1}{4}$ \\
心
\end{tabular} & 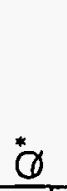 & 艾 & $\begin{array}{l}\vec{r} \\
\dot{p} \\
\frac{1}{\alpha} \\
\text { cs }\end{array}$ & & 己 & 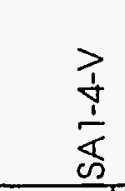 & & 莒 & 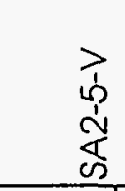 & & $\stackrel{*}{*}$ & 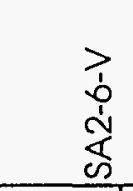 & $\ddot{\theta}$ & $2^{*}$ \\
\hline Phenanthrene & 6600 & u & $\mathrm{J}$ & 6600 & $u$ & UJ & 6600 & 4 & UJ & 6600 & U & $\mathrm{Uu}$ & 6600 & $u$ & UJ & 6600 & $u$ & UJ & 6600 & $0]$ & UJ \\
\hline Anthracene & 6600 & 4 & $\mathrm{~J}$ & 6600 & 4 & UJ & 6600 & $u$ & UJ & 6600 & $\mathrm{U}$ & UJ & 6600 & $u$ & UJ & 6600 & $u$ & U.1. & 6600 & 01 & Uu \\
\hline Di-n-Butylphthalate & 6600 & 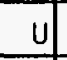 & $\mathrm{J}$ & 6600 & $\mathrm{U}$ & UJ & 6600 & $\mathrm{u}$ & UJ & 6600 & $u$ & UJ & 6600 & $\mathrm{u}$ & UJ & 6600 & $\mathrm{u}$ & UJ & 6600 & 41 & $\mathrm{UJ}$ \\
\hline Fluoranthene & 6600 & 4 & J & 6600 & 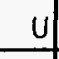 & US & 6600 & 4 & UJ & 6600 & 4 & UJ & 6600 & 4 & UJ & 6600 & $u$ & UJ & 6600 & 4 & UJ \\
\hline Pyrene & 6600 & 4 & J & 6600 & $\mathrm{U}$ & UJ & 6600 & U] & UJ & 6600 & U) & UJ & 6600 & 4 & UJ & 6600 & 4 & UJ & 6600 & $0)$ & UJ \\
\hline Butylbenzylphthalate & 6600 & $u$ & $\mathrm{~J}$ & 6600 & $u$ & UJ & 6600 & 4 & UJ & 6600 & 4 & UJ & 6600 & $u$ & UJ & 6600 & 4 & UJ & 6600 & $4 \longdiv { 1 }$ & UJ \\
\hline 3,3'-Dichlorbenzidine & 13000 & U] & $\mathrm{J}$ & 13000 & 4 & UJ & 13000 & U & UJ & 13000 & $u$ & UJ & 13000 & 4 & UJ & 13000 & 4 & UJ & 13000 & 41 & UJ \\
\hline Benzo(a)Anthracene & 6600 & 4 & $\mathrm{~J}$ & 6600 & 4 & UJ & 6600 & 4 & UJ & 6600 & 4 & UJ & 6600 & 4 & UJ & 6600 & U) & UJ & 6600 & 41 & UJ \\
\hline Chrysene & 6600 & U & $\mathrm{J}$ & 6600 & 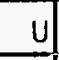 & uJ & 6600 & $u$ & $\mathrm{UJ}$ & 6600 & $u$ & UJ & 6600 & $\mathrm{u}$ & UJ & 6600 & 4 & UJ & 6600 & U & UJ \\
\hline Bis (2-Ethylhexyl)Phthalate & 6600 & 4 & J & 6600 & 4 & UJ & 6600 & $u$ & UJ & 6600 & 4 & UJ & 6600 & 4 & UJ & 6600 & u & UJ & 6600 & 4 & UJ \\
\hline Di-n-Octyl Phthalate & 6600 & 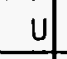 & $\mathrm{J}$ & 6600 & $\mathrm{U}$ & UJ & 6600 & $\mathrm{U}$ & UJ & 6600 & $u$ & UJ & 6600 & $\mathrm{U}$ & UJ & 6600 & 4 & UJ & 6600 & 0 & UJ \\
\hline Benzo(b)Fluoranthene & 6600 & 4 & $\mathrm{~J}$ & 6600 & 4 & UJ & 6600 & $u$ & uJ & 6600 & 4 & UJ & 6600 & 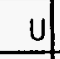 & UJ & 6600 & 4 & UJ & 6600 & 01 & UJ \\
\hline Benzo(k)Fluoranthene & 6600 & 4 & J & 6600 & $\mathrm{u}$ & UJ & 6600 & 4 & UJ & 6600 & $u$ & UJ & 6600 & $u$ & UJ & 6600 & 4 & Uu & 6600 & 41 & UJ \\
\hline Benzo(a)Pyrene & 6600 & 4 & $\mathrm{~J}$ & 6600 & $u$ & uJ & 6600 & $\mathrm{U}$ & UJ & 6600 & 4 & UJ & 6600 & $\mathrm{u}$ & UJ & 6600 & u. & UJ & 6600 & 01 & UJ \\
\hline Indeno(1,2,3-cd)Pyrene & 6600 & 4 & J & 6600 & 4 & UJ & 6600 & u & $\mathrm{uJ}$ & 6600 & $u$ & US & 6600 & 4 & UJ & 6600 & 4 & Uu & 6600 & 41 & UJ \\
\hline Dibenz $(a, h)$ Anthracene & 6600 & $u$ & $\mathrm{~J}$ & 6600 & $\mathrm{U}$ & UJ & 6600 & $u$ & UJ & 6600 & 4 & UJ & 6600 & 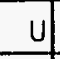 & UJ & 6600 & 4 & UJ & 6600 & 0.1 & uJ \\
\hline Benzo(g,h,i)Perylene & 6600 & U) & J) & 6600 & $u$ & UJ & 6600 & 4 & UJ & 6600 & U. & uJ & 6600 & $u$ & Uu) & 6600 & U) & (J) & 6600 & 1. 1 & U.J. \\
\hline
\end{tabular}




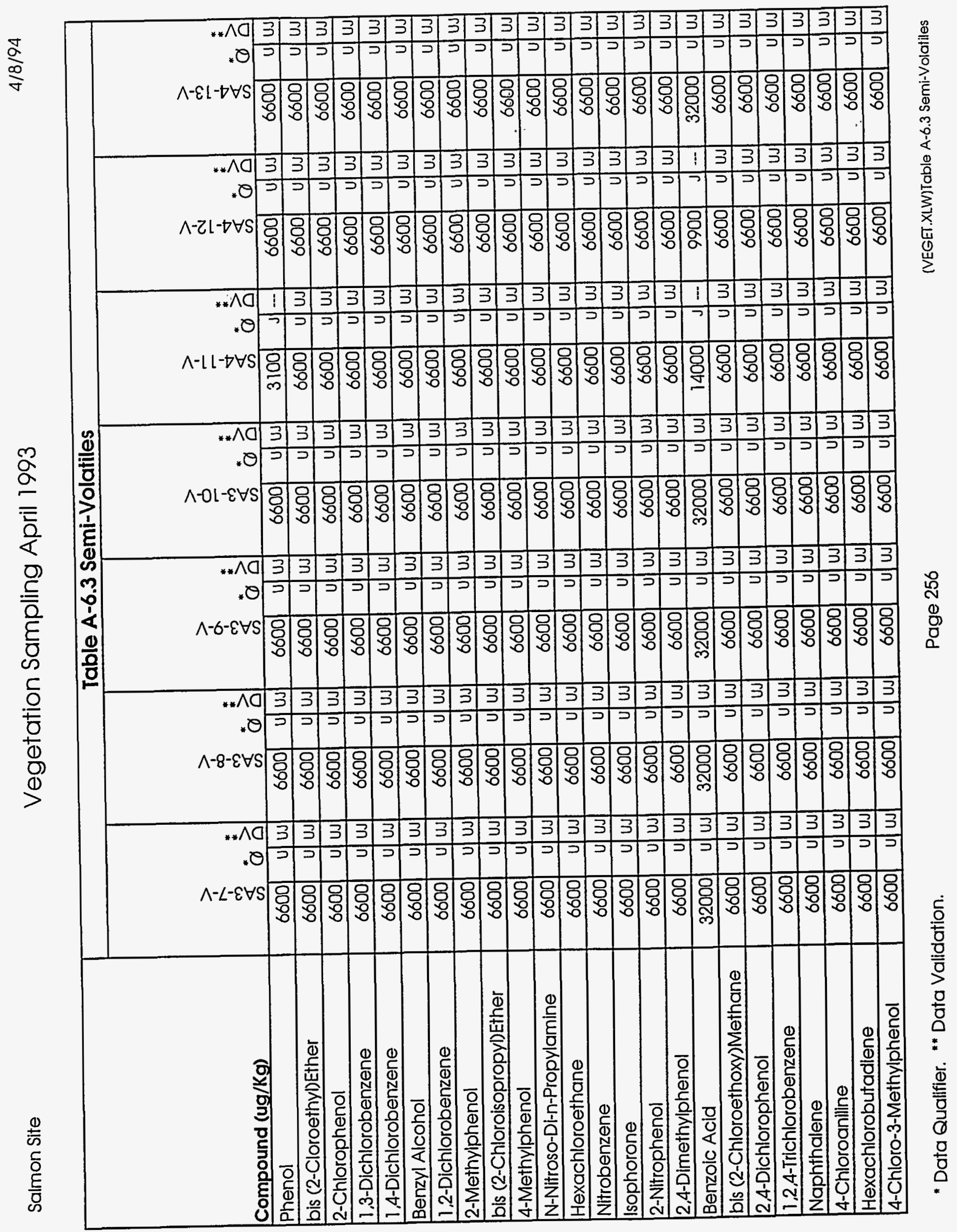




\begin{tabular}{|c|c|c|c|c|c|c|c|c|c|c|c|c|c|c|c|c|c|c|c|c|c|}
\hline \multirow[b]{2}{*}{ Compound (ug/Kg) } & \multicolumn{21}{|c|}{ Table A-6.3 Semi-Volatiles } \\
\hline & 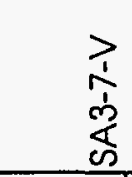 & $\stackrel{*}{\varnothing}$ & & 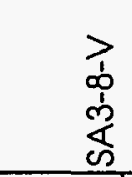 & $\ddot{\theta}$ & & 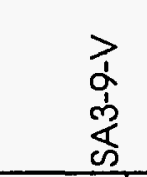 & $\stackrel{*}{\emptyset}$ & & 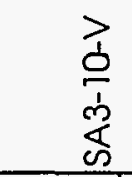 & ¿ & & $\begin{array}{l}\frac{1}{1} \\
\frac{1}{\dot{d}} \\
\frac{1}{5}\end{array}$ & $\stackrel{*}{\varnothing}$ & & 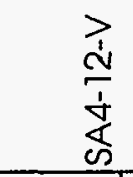 & $\stackrel{0}{0}$ & 它 & 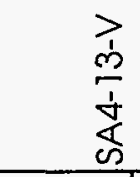 & & $\stackrel{2}{*}^{*}$ \\
\hline 2-Methyinaphthalene & 6600 & $\mathrm{u}$ & UJ & 6600 & $u$ & UJ & 6600 & $u$ & UJ & 6600 & $\mathrm{u}$ & UJ & 6600 & U & $\mathrm{UJ}$ & 6600 & $\mathrm{U}$ & UJ & 6600 & u & $\mathrm{UJ}$ \\
\hline Hexachlorocyclopentadiene & 6600 & $u$ & $\mathrm{UJ}$ & 6600 & $u$ & US & 6600 & $\mathrm{u}$ & UJ & 6600 & $u$ & UJ & 6600 & $u$ & UJ & 6600 & $u$ & UJ & 6600 & $u$ & $\mathrm{UJ}$ \\
\hline 2,4,6-Trichlorophenol & 6600 & $u$ & UJ & 6600 & 4 & UJ & 6600 & $\mathrm{U}$ & UJ & 6600 & $\mathrm{u}$ & UJ & 6600 & 4 & UJ & 6600 & $u$ & UJ & 6600 & u) & UJ \\
\hline 2,4.5-Trichlorophenol & 32000 & 4 & UJ & 32000 & u & $u_{1}$ & 32000 & $u$ & UJ & 32000 & $u$ & UJ & 32000 & 4 & UJ & 32000 & $u$ & UJ & 32000 & U) & UJ \\
\hline 2-Chloronaphthalene & 6600 & 4 & UJ & 6600 & 4 & Uu & 6600 & $\mathrm{u}$ & UJ & 6600 & $\mathrm{u}$ & $u J$ & 6600 & 4 & $\mathrm{UJ}$ & 6600 & $u$ & UJ & 6600 & $\mathrm{u}$ & $U \mathrm{~J}$ \\
\hline 2-Nitroaniline & 32000 & $u$ & UJ & 32000 & $\mathrm{u}$ & UJ & 32000 & $u$ & UJ & 32000 & $\mathrm{u}$ & UJ & 32000 & 4 & UJ & 32000 & $u$ & UJ & 32000 & $u$ & UJ \\
\hline Dimethyl Phthalate & 6600 & U & UJ & 6600 & u & UJ & 6600 & 4 & UJ & 6600 & 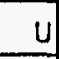 & UJ & 6600 & $u$ & UJ & 6600 & $\mathrm{U}$ & UJ & 6600 & 4 & UJ \\
\hline Acenaphthylene & 6600 & u) & UJ & 6600 & 4 & w & 6600 & $u$ & UU & 6600 & $\mathrm{U}$ & UJ & 6600 & u) & UJ & 6600 & $u$ & UJ & 6600 & u) & UJ \\
\hline 2,6-Dinitrotoluene & 6600 & 4 & UJ & 6600 & $u$ & UJ & 6600 & $\mathrm{u}$ & UJ & 6600 & $\mathrm{u}$ & UJ & 6600 & U & UJ & 6600 & $u$ & UJ & 6600 & 4 & UJ \\
\hline 3-Nitroaniline & 32000 & 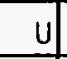 & UJ & 32000 & U & UJ & 32000 & $\mathrm{U}$ & US & 32000 & $u$ & UJ & 32000 & U & UJ & 32000 & $\mathrm{U}$ & UJ & 32000 & 4 & UJ \\
\hline Acenaphthene & 6600 & 4 & UJ & 6600 & $u$ & Wu & 6600 & $\mathrm{U}$ & UJ & 6600 & $\mathrm{U}$ & UJ & 6600 & 4 & UJ & 6600 & $U$ & UJ & 6600 & U & $\mathrm{UJ}$ \\
\hline 2,4-Dinitrophenol & 32000 & $u$ & UJ & 32000 & $\mathrm{u}$ & UJ & 32000 & $\mathrm{u}$ & UJ & 32000 & $u$ & UJ & 32000 & $u$ & UJ & 32000 & $\mathrm{u}$ & UJ & 32000 & u & $\mathrm{UJ}$ \\
\hline 4-Nitrophenol & 32000 & $u$ & UU & 32000 & $u$ & Uu & 32000 & $\mathrm{u}$ & UU & 32000 & $U$ & UJ & 32000 & $u$ & UJ & 32000 & $u$ & UJ & 32000 & u & $\mathrm{UJ}$ \\
\hline Dibenzofuran & 6600 & 4 & UJ & 6600 & U. & UJ & 6600 & $u$ & U. & 6600 & $\mathrm{U}$ & UJ & 6600 & $u$ & UJ & 6600 & $\mathrm{U}$ & US & 6600 & U & $\mathrm{UJ}$ \\
\hline 2,4-Dinitrotoluene & 6600 & 4 & UJ & 6600 & $\mathrm{u}$ & UJ & 6600 & $u$ & UJ & 6600 & $\mathrm{U}$ & Uu & 6600 & $\mathrm{U}$ & UJ & 6600 & $u$ & UJ & 6600 & $u$ & UJ \\
\hline Diethylphthalate & 6600 & $u$ & UJ & 6600 & 4 & US & 6600 & $\mathrm{u}$ & UJ & 6600 & $\mathrm{u}$ & UJ & 6600 & $u$ & UJ & 6600 & $u$ & UJ & 6600 & $u$ & US \\
\hline 4-Chlorophenyl-phenylether & 6600 & $u$ & U. & 6600 & U & Us & 6600 & $u$ & UJ & 6600 & $\mathrm{U}$ & UJ & 6600 & $\mathrm{U}$ & U. & 6600 & $\mathrm{u}$ & UJ & 6600 & $\mathrm{u}$ & $\mathrm{UJ}$ \\
\hline Fluorene & 6600 & 4 & US & 6600 & u) & US & 6600 & $u$ & UJ & 6600 & $u$ & U. & 6600 & U & UJ & 6600 & 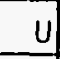 & UJ & 6600 & 4 & US \\
\hline 4-Nitroaniline & 32000 & $u$ & UJ & 32000 & $u$ & UJ & 32000 & $\mathrm{u}$ & UJ & 32000 & $\vec{U}$ & Uu & 32000 & $u$ & UJ & 32000 & $u$ & UJ & 32000 & $u$ & UJ \\
\hline 4,6-Dinitro-2-Methylphenol & 32000 & $\mathrm{U}$ & UJ & 32000 & $\mathrm{U}$ & UJ & 32000 & $U$ & UJ & 32000 & U & Uu & 32000 & $\mathrm{U}$ & UJ & 32000 & $\mathrm{u}$ & UJ & 32000 & U & UJ \\
\hline $\mathrm{N}$-Nitrosodiphenylamine (1) & 6600 & $u$ & UJ & 6600 & 4 & US & 6600 & $u$ & UJ & 6600 & $\underline{U}$ & us & 6600 & $u$ & UJ & 6600 & $u$ & UJ & 6600 & $u$ & UJ \\
\hline 4-Bromophenyl-phenylether & 6600 & 4 & UJ & 6600 & $\mathrm{U}$ & UJ & 6600 & 4 & UJ & 6600 & $\mathrm{U}$ & UJ & 6600 & $u$ & US & 6600 & $u$ & UJ & 6600 & 4 & UJ \\
\hline Hexachlorobenzene & 6600 & $\mathrm{u}$ & UJ & 6600 & $u$ & UJ & 6600 & $u$ & UJ & 6600 & $\mathrm{U}$ & Us & 6600 & 4 & Uu & 6600 & $u$ & UJ & 6600 & 4 & UJ \\
\hline Pentachlorophenol & 32000 & $u$ & UJ & 32000 & $u$ & $\mathrm{UJ}$ & 32000 & $u$ & $\mathrm{uJ}$ & 32000 & $u$ & Uu & 32000 & $\mathrm{u}$ & UJ & 32000 & $u$ & UJ & 32000 & $\mathrm{u}$ & $\mathrm{uJ}$ \\
\hline
\end{tabular}

- Data Qualifier. "“ Data Validation. 


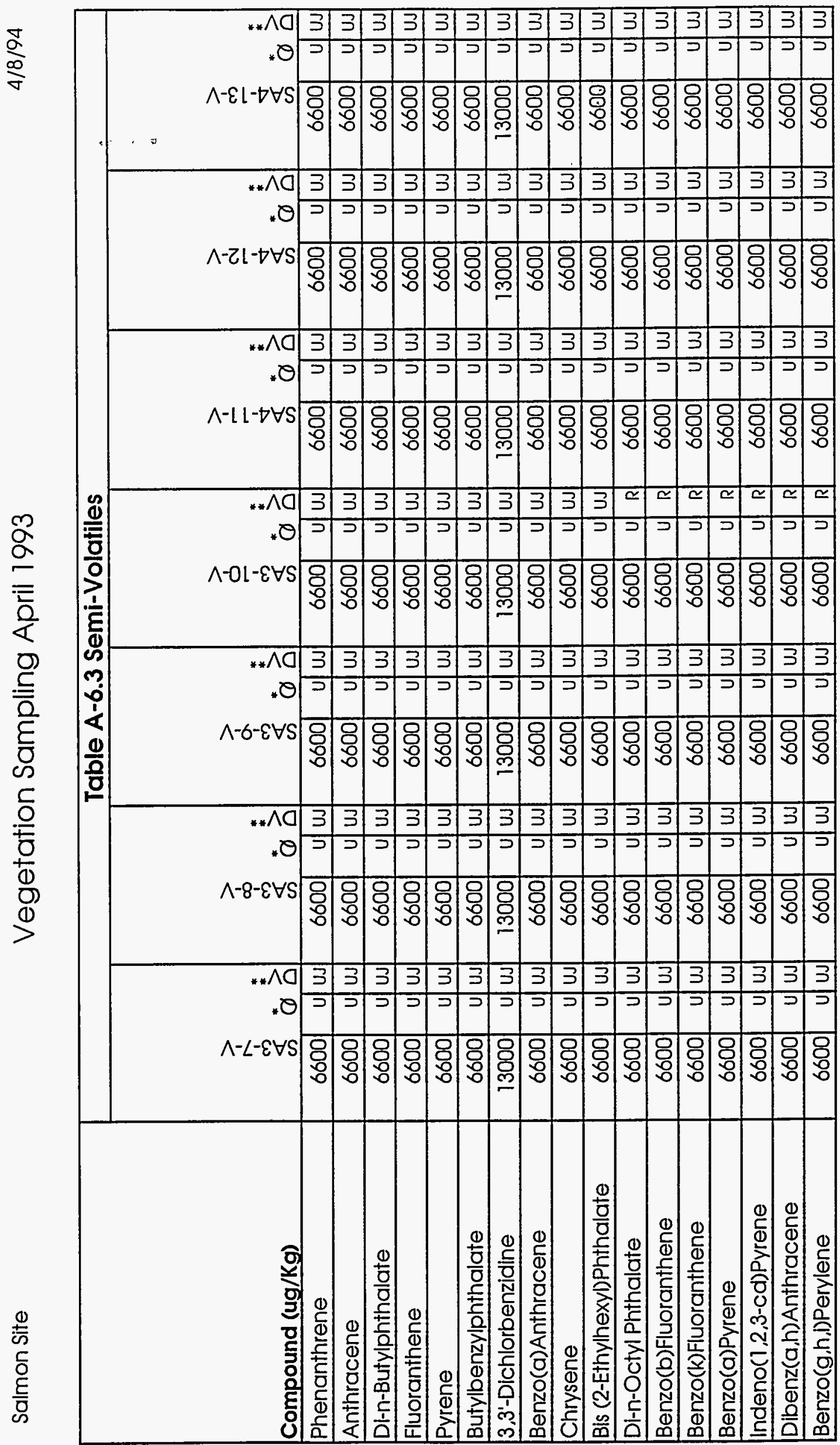

$\infty$
0
0
0
0
0
0 


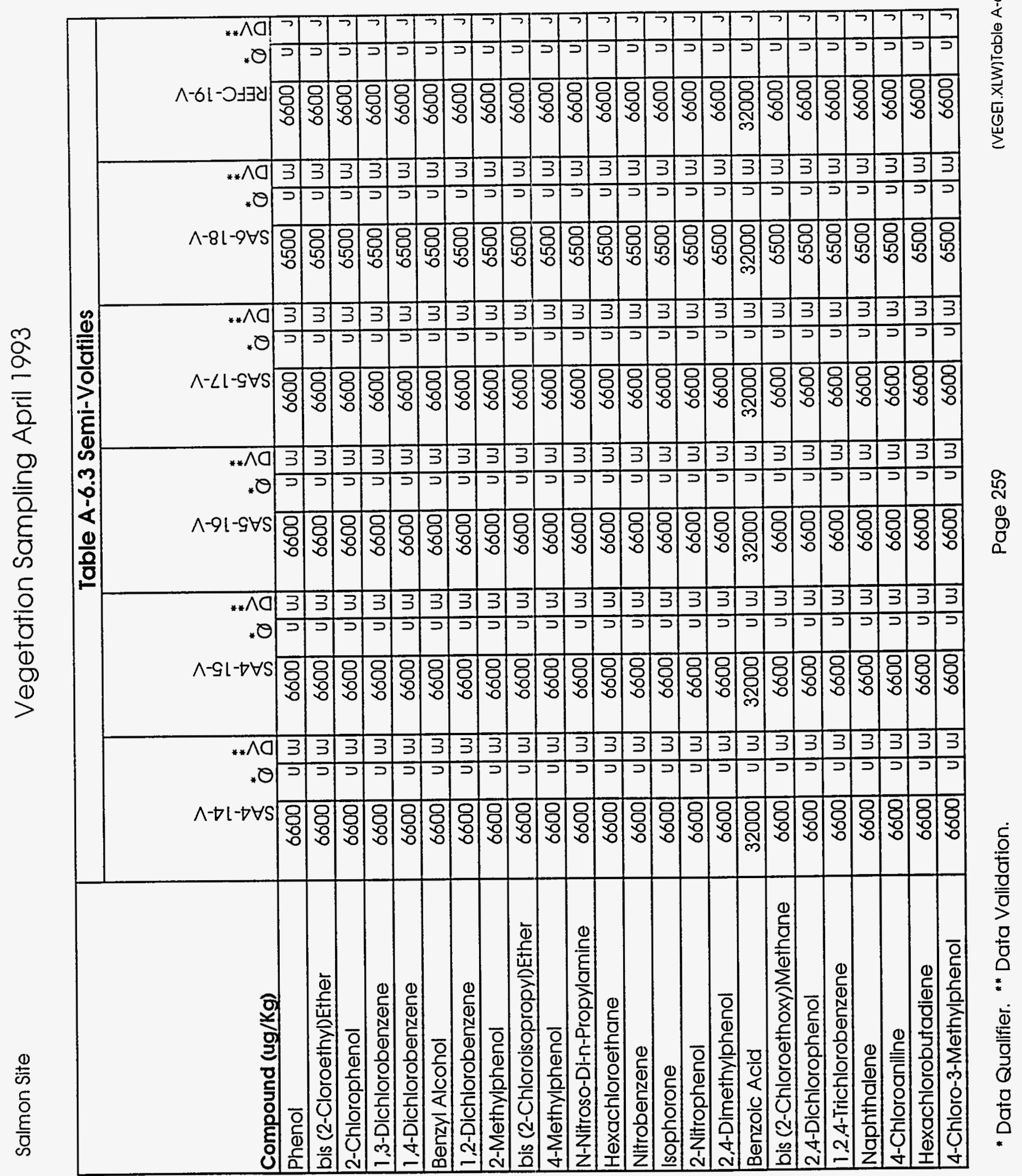




\begin{tabular}{|c|c|c|c|c|c|c|c|c|c|c|c|c|c|c|c|c|c|c|}
\hline \multirow[b]{2}{*}{ Compound (ug/Kg) } & \multicolumn{18}{|c|}{ Table A-6.3 Semi-Volatiles } \\
\hline & 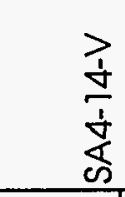 & & $\stackrel{2}{0}^{*}$ & 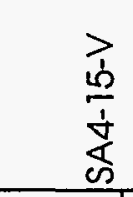 & & $\stackrel{2}{0}^{*}$ & 孛 & $\stackrel{\sigma}{\varnothing}$ & & 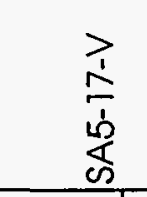 & & & 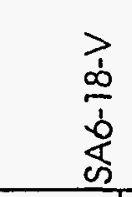 & & $2^{*}$ & 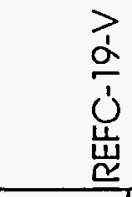 & & \\
\hline 2-Methylnaphthalene & 6600 & $\mathrm{u}$ & UJ & 6600 & $\bar{u}$ & UJ & 6600 & $\mathrm{u}$ & $\mathrm{UJ}$ & 6600 & $u$ & UJ & 6500 & $\bar{u}$ & UJ & 6600 & $u$ & \\
\hline Hexachlorocyclopentadiene & 6600 & $u$ & $\mathrm{UJ}$ & 6600 & $\bar{u}$ & UJ & 6600 & $u$ & UJ & 6600 & $\mathrm{u}$ & UJ & 6500 & $\bar{u}$ & UJ & 6600 & $u$ & \\
\hline 2,4,6-Trichlorophenol & 6600 & $u$ & Uu & 6600 & $\bar{U}$ & UJ & 6600 & $\mathrm{u}$ & UJ & 6600 & $\mathrm{u}$ & UJ & 6500 & $\mathrm{U}$ & UJ & 6600 & $\mathrm{u}$ & \\
\hline 2,4,5-Trichlorophenol & 32000 & $u$ & UJ & 32000 & $\mathrm{U}$ & UJ & 32000 & $\mathrm{u}$ & UJ & 32000 & 4 & UJ) & 32000 & 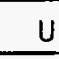 & $\mathrm{UJ}$ & 32000 & u & J \\
\hline 2-Chloronaphthalene & 6600 & $u$ & $\mathrm{UJ}$ & 6600 & $u$ & UJ & 6600 & $u$ & UJ & 6600 & u. & UJ & 6500 & $u$ & UJ & 6600 & $u$ & \\
\hline 2-Nitroaniline & 32000 & 4 & UJ & 32000 & 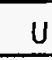 & UJ & 32000 & 4 & $U \mathrm{~J}$ & 32000 & $\mathrm{U}$ & UJ & 32000 & $u$ & UJ & 32000 & 0 & \\
\hline Dimethyl Phthalate & 6600 & $\mathrm{u}$ & UJ & 6600 & $\mathrm{U}$ & uJ & 6600 & $\mathrm{U}$ & $\mathrm{UJ}$ & 6600 & $\mathrm{U}$ & us & 6500 & $u$ & $\mathrm{UJ}$ & 6600 & u & J \\
\hline Acenaphthylene & 6600 & 4 & UJ & 6600 & $U$ & UJ & 6600 & $u$ & UJ & 6600 & $u$ & UJ & 6500 & $\mathrm{U}$ & UJ & 6600 & U & \\
\hline 2,6-Dinitrotoluene & 6600 & 4 & UJ & 6600 & $\mathrm{U}$ & UJ & 6600 & $u$ & $\mathrm{UJ}$ & 6600 & $u$ & UJ & 6500 & $u$ & UJ & 6600 & $U$ & \\
\hline 3-Nitroaniline & 32000 & $\mathrm{U}$ & UJ & 32000 & 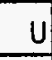 & $\mathrm{UJ}$ & 32000 & $\mathrm{u}$ & $\mathrm{UJ}$ & 32000 & $\mathrm{U}$ & UJ & 32000 & $\mathrm{U}$ & $\mathrm{UJ}$ & 32000 & $\mathrm{u}$ & \\
\hline Acenaphthene & 6600 & 4 & UJ & 6600 & U & UJ & 6600 & 4 & UJ & 6600 & 4 & UJ & 6500 & $\mathrm{U}$ & UJ & 6600 & u) & \\
\hline 2,4-Dinitrophenol & 32000 & $u$ & UJ & 32000 & $U$ & UJ & 32000 & $u$ & UJ & 32000 & 4 & UJ & 32000 & $u$ & UJ & 32000 & $\mathrm{U}$ & \\
\hline 4-Nitrophenol & 32000 & $u$ & UJ & 32000 & $\mathrm{U}$ & UJ & 32000 & $\mathrm{U}$ & UJ & 32000 & $u$ & UJ & 32000 & $\mathrm{U}$ & UJ & 32000 & U & \\
\hline Dibenzofuran & 6600 & 4 & $\mathrm{UJ}$ & 6600 & $\mathrm{U}$ & UJ & 6600 & 4 & UJ & 6600 & $U$ & UJ & 6500 & $\underline{u}$ & UJ & 6600 & $u$ & \\
\hline 2,4-Dinitrotoluene & 6600 & $u$ & $\mathrm{UJ}$ & 6600 & 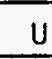 & UJ & 6600 & $u$ & UJ & 6600 & $u$ & UJ & 6500 & $u$ & UJ & 6600 & $u$ & \\
\hline Diethylphthalate & 6600 & 4 & UJ & 6600 & U & UJ & 6600 & $u$ & uJ & 6600 & $u$ & US & 6500 & $u$ & US & 6600 & $u$ & J \\
\hline 4-Chlorophenyl-phenylether & 6600 & $u$ & UJ & 6600 & $\underline{u}$ & UJ & 6600 & $u$ & UJ & 6600 & 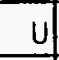 & UJ & 6500 & $\underline{u}$ & UJ & 6600 & u & J \\
\hline Fluorene & 6600 & $u$ & UJ & 6600 & $u$ & UJ & 6600 & $u$ & $\mathrm{UJ}$ & 6600 & $u$ & UJ & 6500 & $\underline{u}$ & $\mathrm{UJ}$ & 6600 & $u$ & \\
\hline 4-Nitroaniline & 32000 & 4 & $\mathrm{UJ}$ & 32000 & $\bar{U}$ & UJ & 32000 & $u$ & UJ & 32000 & 4 & UJ & 32000 & $u$ & US & 32000 & $u$ & J \\
\hline 4,6-Dinitro-2-Methylphenol & 32000 & $\mathrm{u}$ & $\mathrm{UJ}$ & 32000 & $\underline{u}$ & UJ & 32000 & $\mathrm{u}$ & UJ & 32000 & 4 & UJ & 32000 & $\underline{U}$ & UJ & 32000 & $u$ & J \\
\hline N-Nitrosodiphenylamine (1) & 6600 & $\mathrm{u}$ & Uu & 6600 & $\underline{u}$ & US & 6600 & $u$ & UJ & 6600 & $u$ & UJ & 6500 & $\mathrm{U}$ & UJ & 6600 & $\mathrm{u}$ & \\
\hline 4-Bromophenyl-phenylether & 6600 & 4 & UJ & 6600 & $\underline{u}$ & UJ & 6600 & $u$ & UJ & 6600 & $u$ & UJ & 6500 & $U$ & UJ & 6600 & U) & \\
\hline Hexachlorobenzene & 6600 & $\mathrm{u}$ & UJ & 6600 & $\underline{u}$ & UJ & 6600 & $\mathrm{U}$ & UJ & 6600 & $u$ & UJ & 6500 & $\underline{u}$ & UJ & 6600 & $u$ & \\
\hline Pentachlorophenol & 32000 & $u$ & $\mathrm{UJ}$ & 32000 & $\underline{u}$ & UJ & 32000 & 4 & UJ & 32000 & $u$ & UJ & 32000 & $\bar{u}$ & UJ & 32000 & $\mathrm{U}$ & \\
\hline
\end{tabular}

- Data Qualifier. " Data Validation.

Page 260 


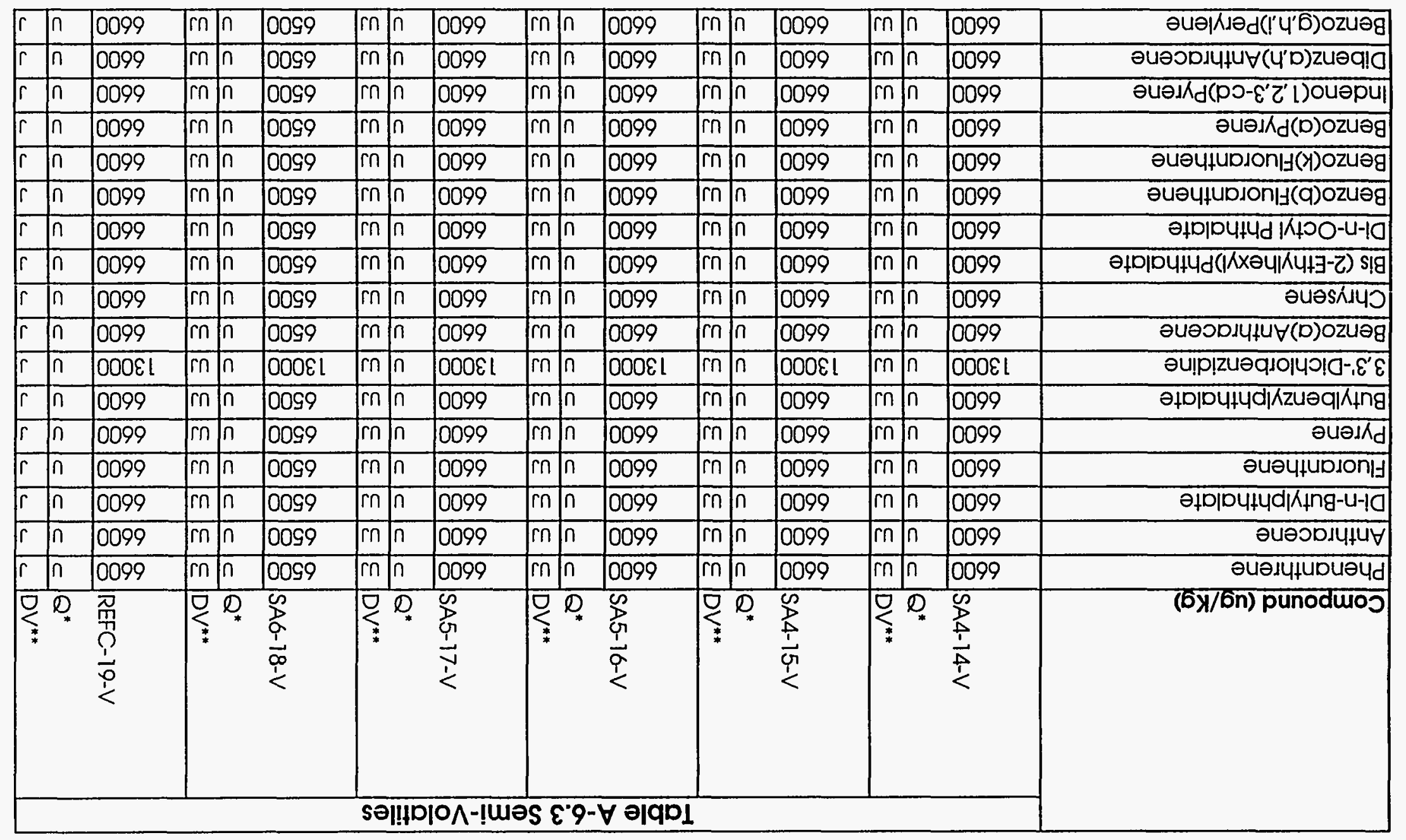




\begin{tabular}{|c|c|c|c|c|c|c|c|c|c|c|c|c|c|c|c|c|c|c|}
\hline \multirow[b]{2}{*}{ Parameter $(\mathrm{pCi} / \mathrm{g})$} & \multicolumn{18}{|c|}{ Table A-6.4 Gross Alpha/Beta } \\
\hline & $\frac{7}{\frac{1}{1}}$ & ${ }_{2}^{*}$ & $\frac{0}{\frac{1}{1}}$ & $\stackrel{2}{0}^{*}$ & 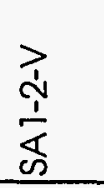 & 兌 & $\begin{array}{l}> \\
\dot{1} \\
\frac{1}{\alpha}\end{array}$ & $\stackrel{2}{2}$ & 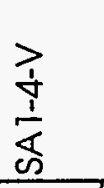 & $\stackrel{2}{2}$ & 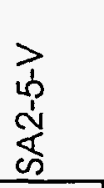 & 足 & 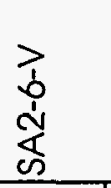 & $\stackrel{*}{*}$ & 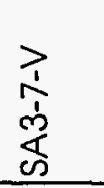 & $\stackrel{2}{0}^{*}$ & 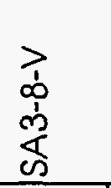 & $\stackrel{*}{2}$ \\
\hline Alpha & 0.33 & - & 0.29 & $\ldots$ & 0.42 & $\ldots$ & ND & $\ldots$ & 0.29 & $\ldots$ & 0.40 & $-\infty$ & 0.26 & $\ldots$ & 0.28 & $\ldots$ & 0.42 & $\ldots$ \\
\hline Sigma Error $(+/-)$ & 1.22 & -- & 0.34 & $\ldots$ & 0.32 & $\ldots$ & & $\ldots$ & 0.39 & $\ldots$ & 3.50 & $-\infty$ & 0.36 & $\ldots$ & 0.25 & $\ldots$ & 1.64 & $\ldots$ \\
\hline $\mathrm{MDA}^{*}$ & 0.24 & - & 0.26 & $\ldots$ & 0.26 & $\ldots$ & 0.24 & $\mathrm{u}$ & 0.23 & - & 0.21 & $-\ldots$ & 0.21 & $\ldots$ & 0.24 & $\ldots$ & 0.21 & $\ldots$ \\
\hline Beta & 0.41 & - & 0.22 & $\ldots$ & 0.47 & $\ldots$ & 0.54 & $\ldots$ & 0.28 & $\ldots$ & 0.54 & -1 & 0.31 & $\ldots$ & 0.40 & $\ldots$ & 0.37 & $\ldots$ \\
\hline Sigma Error $(+/-)$ & 0.06 & $\ldots$ & 0.03 & $\ldots$ & 0.07 & $\ldots$ & 0.08 & $\ldots$ & 0.04 & $\ldots$ & 0.08 & $\ldots$ & 0.05 & $\ldots$ & 0.06 & $\ldots$ & 0.06 & $\ldots$ \\
\hline $\mathrm{MDA}^{*}$ & 0.20 & $-\infty$ & 0.20 & $\ldots$ & 0.20 & $\ldots$ & 0.19 & $\ldots$ & 0.20 & - & 0.19 & -1 & 0.18 & $\ldots$ & 0.19 & $\ldots$ & 0.18 & \\
\hline
\end{tabular}




\begin{tabular}{|c|c|c|c|c|c|c|c|c|c|c|c|c|c|c|c|c|c|c|}
\hline \multirow[b]{2}{*}{ Parameter $(\mathrm{pCi} / \mathrm{g})$} & \multicolumn{18}{|c|}{ Table A-6.4 Gross Alpha/Beta } \\
\hline & 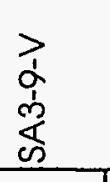 & $\stackrel{2}{2}$ & 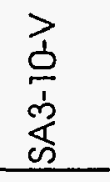 & 竞 & $\begin{array}{l}\frac{1}{1} \\
\frac{1}{\dot{j}} \\
\text { 童 }\end{array}$ & 号 & 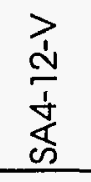 & 主 & 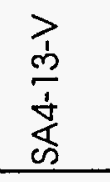 & 莡 & $\begin{array}{l}\frac{3}{d} \\
\frac{1}{d} \\
\frac{5}{5} \\
0\end{array}$ & 足 & $\begin{array}{l}\text { 耍 } \\
\text { 妾 } \\
\text { ch }\end{array}$ & 雚 & 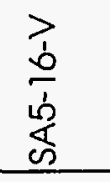 & 总 & 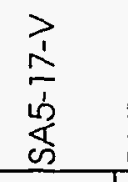 & 莡 \\
\hline Alpha & 0.28 & $\ldots$ & 0.36 & $\ldots$ & ND & $\ldots$ & 0.3 & $\ldots$ & ND & $\ldots$ & 3.89 & $\ldots$ & 0.36 & $\ldots$ & 0.36 & $\ldots$ & $\mathrm{ND}$ & $\ldots$ \\
\hline Sigma Error $(+/-)$ & 0.49 & - & 0.56 & -.. & & $\ldots$ & 0.4 & $\ldots$ & & $\ldots$ & 1.35 & $\ldots$ & 0.27 & $\ldots$ & 0.72 & $\ldots$ & & $\ldots$ \\
\hline $\mathrm{MDA}^{*}$ & 0.24 & - & 0.23 & - & 0.31 & $u$ & 0.2 & 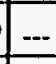 & 0.42 & $u$ & 0.46 & $\ldots$ & 0.31 & $\ldots$ & 0.16 & $\ldots$ & 0.33 & $u$ \\
\hline Beta & $\mathrm{ND}$ & - & 0.64 & $=$ & 0.37 & $=$ & 0.4 & $\ldots$ & ND & $\ldots$ & 0.89 & $\ldots$ & 0.65 & - & 0.30 & $\ldots$ & 0.45 & $\ldots$ \\
\hline Sigma Error (+/-) & & $\ldots$ & 0.11 & - & 0.05 & $\ldots$ & 0.0 & $\ldots$ & & $\ldots$ & 0.17 & $\ldots$ & 0.12 & - & 0.04 & $\ldots$ & 0.06 & \\
\hline MDA* & 0.25 & $\mathrm{u}$ & 0.21 & $\ldots$ & 0.21 & $\ldots$ & 0.2 & $\ldots$ & 0.23 & $u$ & 0.22 & $\ldots$ & 0.21 & -... & 0.19 & $\ldots$ & 0.21 & \\
\hline
\end{tabular}




\begin{tabular}{|c|c|c|c|c|}
\hline \multirow[b]{2}{*}{ Parameler $(\mathrm{pCi} / \mathrm{g})$} & \multicolumn{4}{|c|}{ Table A-6.4 Gross Alk } \\
\hline & 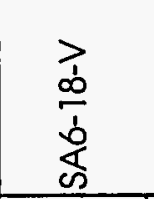 & 0 & 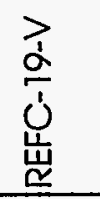 & 草 \\
\hline Alpha & 2.06 & - & 0.28 & 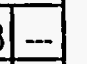 \\
\hline Sigma Error $(+/-)$ & 2.03 & - & 0.32 & - \\
\hline $\mathrm{MDA}^{*}$ & 0.58 & - & 0.25 & ... \\
\hline Beta & 2.56 & $\ldots$ & 1.04 & - \\
\hline Sigma Error $(+/-)$ & 0.59 & $\ldots$ & 0.19 & - \\
\hline $\mathrm{MDA}^{*}$ & 0.40 & $\ldots$ & 0.21 & 1. \\
\hline
\end{tabular}




\begin{tabular}{|c|c|c|c|c|c|c|c|c|c|c|c|c|c|c|c|c|c|c|}
\hline \multirow[b]{2}{*}{ Nuclide (pCi/g) } & \multicolumn{18}{|c|}{ Table A-6.5 Gamma Spectroscopy } \\
\hline & $\frac{7}{\frac{1}{4}}$ & $\stackrel{2}{0}^{*}$ & $\begin{array}{l}0 \\
\frac{1}{1} \\
\frac{1}{1} \\
\frac{1}{4} \\
0\end{array}$ & ${ }^{*}$ & $\begin{array}{l}> \\
\frac{1}{1} \\
\frac{1}{\infty}\end{array}$ & 莡 & $\begin{array}{l}\overrightarrow{1} \\
\frac{1}{6} \\
\frac{8}{\infty}\end{array}$ & $\stackrel{*}{2}$ & $\frac{7}{\frac{1}{4}}$ & $\stackrel{\text { D }}{ }^{*}$ & 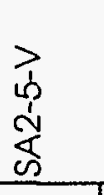 & $\stackrel{*}{\partial}$ & 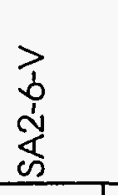 & $\stackrel{*}{2}$ & $\begin{array}{l}> \\
\frac{1}{1} \\
\frac{1}{\infty} \\
\frac{1}{\infty}\end{array}$ & $\stackrel{*}{2}$ & $\begin{array}{l}> \\
0 \\
0 \\
0 \\
0 \\
0\end{array}$ & $\stackrel{*}{\text { * }}$ \\
\hline Cesium 137 & ND & $\ldots$ & ND & $\ldots$ & ND & $\ldots$ & ND & $\ldots$ & ND & $\ldots$ & ND & $\ldots$ & ND & $\ldots$ & ND & $\ldots$ & ND & $\ldots$ \\
\hline Sigma Error (+/-) & & $\ldots$ & -1 & $\ldots$ & & $\ldots$ & & $\ldots$ & & $\ldots$ & - & $\ldots$ & - & $\ldots$ & & $\ldots$ & & $\ldots$ \\
\hline MDA* & 0.21 & $\mathrm{u}$ & 0.22 & $\mathrm{U}$ & 0.20 & $u$ & 0.27 & $u$ & 0.14 & $u$ & 0.19 & $u$ & 0.21 & $u$ & 0.21 & $\mathrm{U}$ & 0.19 & $u$ \\
\hline Potassium 40 & ND & $\ldots$ & 15.40 & $\ldots$ & ND & - & 6.26 & -- & 6.44 & - & 8.58 & -- & ND & -- & ND & -- & ND & -- \\
\hline Sigma Error $(+/-)$ & & $\ldots$ & 1.15 & $\ldots$ & - & $\ldots$ & 1.96 & $\ldots$ & 1.08 & - & 1.31 & $\ldots$ & - & $\ldots$ & -1 & $\ldots$ & - & $\ldots$ \\
\hline MDA" & 3.62 & $\mathrm{u}$ & -1 & $\ldots$ & 3.09 & $\underline{u}$ & 4.06 & $-\ldots$ & 1.41 & $\ldots$ & 1.33 & $\ldots$ & 3.12 & $\mathrm{u}$ & 3.25 & $u$ & 2.79 & U \\
\hline Lead 212 & $\mathrm{ND}$ & $\ldots$ & ND. & - & ND & $\ldots$ & ND & $-\ldots$ & ND. &.- & $\mathrm{ND}$ & $\ldots$ & ND & - & $\mathrm{ND}$ & $\ldots$ & $\mathrm{ND}$ & $\ldots$ \\
\hline Sigma Error $(+1-)$ & & $\ldots$ & -1. & -- & -1 & $\ldots$ & - & -1 & -1 & - & - & \begin{tabular}{|l|}
$\ldots$ \\
\end{tabular} & -1 & $\ldots$ & - & $\ldots$ & -1 & - \\
\hline $\mathrm{MDA}^{*}$ & 0.32 & $u$ & 0.33 & $u$ & 0.22 & $\mathrm{U}$ & 0.37 & $\mathrm{u}$ & 0.23 & $\mathrm{U}$ & 0.19 & $u$ & 0.21 & $u$ & 0.28 & $\mathrm{U}$ & 0.24 & $\mathrm{u}$ \\
\hline Thailium 208 & NDD & $\ldots 1$ & ND. & $\ldots$ & ND & $\ldots$ & $\mathrm{ND}$ & $\ldots$ & ND & $\ldots$ & ND & $\ldots$ & ND & $\ldots$ & ND & $\ldots$ & ND & $\ldots$ \\
\hline Sigma Error (+/-) & & - & & - & & $\ldots$ & & -- & & - & - & $\ldots$ & - & -- & -1 & -- & - & - \\
\hline MDA* & 0.19 & $\mathrm{U}$ & 0.22 & $u$ & 0.17 & $\mathrm{U}$ & 0.23 & $u$ & 0.18 & $\mathrm{u}$ & 0.17 & $\mathrm{u}$ & 0.18 & $u$ & 0.21 & $\mathrm{u}$ & 0.16 & $\mathrm{u}$ \\
\hline Uranium 238 & ND & - & $\mathrm{ND}$. & - & ND & - & ND & -- & $\mathrm{ND}$ & $\ldots$ & $\mathrm{ND}$ & $\ldots$ & $\mathrm{ND}$ & $\ldots$ & $\mathrm{ND}$ & - & ND & - \\
\hline Sigma Error $(+/-)$ & & - & & - & - & $=$ & - & $\ldots$ & - & $\ldots$ & - & $\ldots$ & -1 & $\ldots$ & - &.- & -1 & $\ldots$ \\
\hline MDA* & 1.93 & 4 & 2.18 & $\mathrm{u}$ & 1.77 & $u$ & 2.26 & $u$ & 1.49 & $\mathrm{u}$ & 1.56 & $u$ & 1.66 & $u$ & 2.56 & $u$ & 2.27 & $\mathrm{u}$ \\
\hline Lead 210 & 2.29 & - & $\mathrm{ND}$. & -- & $\mathrm{ND}$ & $\ldots$ & 3.52 & $\ldots$ & & - & ND & $-{ }_{-1}$ & ND & $-\ldots$ & ND & $\ldots$ & ND & -- \\
\hline Sigma Error $(+/-)$ & 0.80 & - & & - & - & - & 1.09 & -- & - & - & - & $\ldots$ & -1 & $-\infty$ & -1 & $\ldots$ & -1 & $\ldots$ \\
\hline MDA* & 1.81 & - & 2.16 & $\mathrm{u}$ & 1.82 & $\mathrm{U}$ & 2.24 & $\ldots$ & & - & 1.54 & $\mathrm{u}$ & 1.63 & $u$ & 20.40 & $\mathrm{U}$ & 18.10 & $\underline{u}$ \\
\hline Beryllium 7 & 3.16 & - & 4.35 . & - & & - & 3.47 & - & 3.00 & $\ldots$ & 2.36 & $\ldots$ & & - & 1.92 & $\ldots$ & -1 & - \\
\hline Sigma Error $(+/-)$ & 0.86 & - & 0.97 & - & - & - & 0.89 & $\ldots$ & 0.78 & $\ldots$ & 0.39 & $\ldots$ & - & -1 & 0.56 & - & & - \\
\hline MDA* & 1.19 & - & -1. & - & -1 & - & 1.39 & $\ldots$ & 0.80 & $\ldots$ & 0.89 & -1 & -1 & -1 & 1.19 & $\ldots$ & -1 & 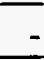 \\
\hline Bismuth 214 & ND & - & ND. & - & ND & - & ND & - & ND. & $\ldots$ & $\mathrm{ND}$ & - & $\mathrm{ND}$. & -- & $\mathrm{ND}$ & $\ldots$ & ND & $\ldots$ \\
\hline Sigma Error $(+/-)$ & & - & & - & + & - & & - & - & $\ldots$ & - & - & & - & -1 & - & -1 & - \\
\hline MDA* & 0.36 & 4 & 0.51 & $\mathrm{u}$ & 0.48 & $\mathrm{U}$ & 0.50 & $\mathrm{u}$ & 0.36 & $\mathrm{u}$ & 0.41 & $u$ & 0.41 & $u$ & 0.39 & $\mathrm{u}$ & 0.29 & $\underline{U}$ \\
\hline Cerium 139 & & 1 & & $\mathrm{~T}$ & 2,1 & - & & $T$ & & & & -1 & & -1 & & & & \\
\hline
\end{tabular}




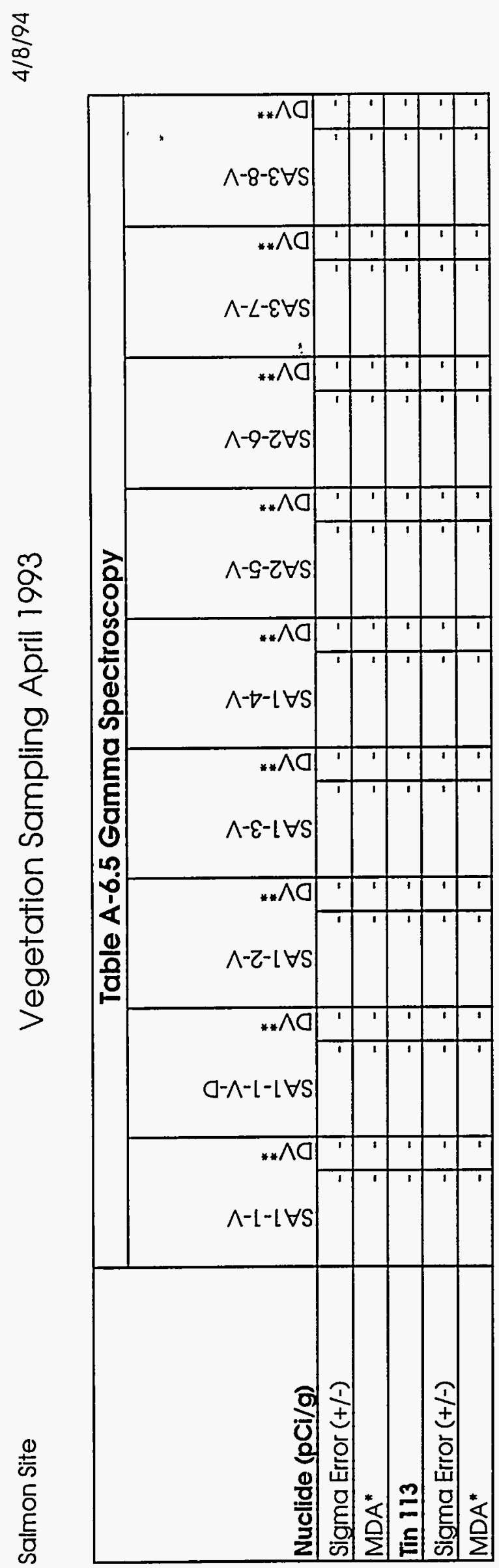




\begin{tabular}{|c|c|c|c|c|c|c|c|c|c|c|c|c|c|c|c|c|c|c|}
\hline \multirow[b]{2}{*}{ Nuclide (pCi/g) } & \multicolumn{18}{|c|}{ Table A-6.5 Gamma Spectroscopy } \\
\hline & 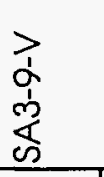 & 苛 & 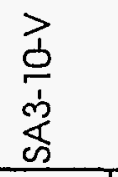 & ${ }^{*}$ & 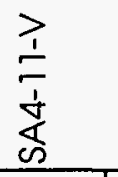 & $\stackrel{2}{0}^{*}$ & 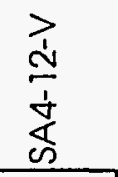 & $\stackrel{2}{0}^{*}$ & 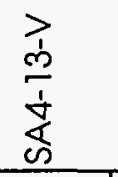 & $\stackrel{*}{2}$ & 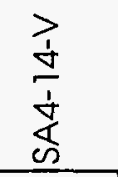 & ${ }_{3}^{*}$ & 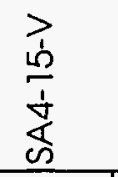 & ${ }_{0}^{*}$ & 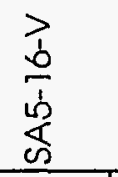 & 3 & $\frac{7}{1}$ & ? $^{*}$ \\
\hline Cesium 137 & ND & $\ldots$ & ND & $\ldots$ & ND & $\ldots$ & ND & $\ldots$ & ND & $\ldots$ & ND & $\ldots$ & ND & $\ldots$ & 0.21 & $\ldots$ & ND & $\ldots$ \\
\hline Sigma Error $(+/-)$ & & $-\ldots$ & & -- & & $\ldots$ & & - & - & $\ldots$ & & $\ldots$ & - & $\ldots$ & 0.10 & $\ldots$ & - & $\ldots$ \\
\hline MDA* & 0.19 & u & 0.14 & $u$ & 0.20 & $u$ & 0.21 & U & 0.22 & $u$ & 0.31 & $\mathrm{u}$ & 0.23 & $\mathrm{u}$ & 0.18 & $\ldots$ & 0.15 & $\mathrm{U}$ \\
\hline Potassium 40 & $\mathrm{ND}$ & $-\infty$ & $\mathrm{ND}$ & $-\infty$ & ND & $\ldots$ & ND & - & ND & $-\ldots$ & 21.30 & $\ldots$ & ND & $\ldots$ & ND & $\ldots$ & ND & $-\cdots$ \\
\hline Sigma Error $(+/-)$ & & $\ldots$ & & $\ldots$ & & $-\ldots$ & - & - & - & $\ldots$ & 3.12 & $\ldots$ & - & $\ldots$ & - & $\ldots$ & - & $\ldots$ \\
\hline MDA* & 2.72 & $u$ & 5.56 & $u$ & 2.83 & $u$ & 3.16 & U & 3.96 & $u$ & 8.23 & $\ldots$ & 4.25 & $u$ & 3.13 & $\mathrm{u}$ & 2.48 & u \\
\hline Lead 212 & ND & -- & $\mathrm{ND}$ & $\ldots$ & ND & $\ldots$ & ND & - & ND & $-\ldots$ & ND & -- & ND & -- & $\mathrm{ND}$ & $\ldots$ & $\mathrm{ND}$ & - \\
\hline Sigma Error $(+/-)$ & & $\ldots$ & & $\ldots$ & & $\ldots$ & - & $-\ldots$ & - & $\ldots$ & - & $\ldots$ & - & $\ldots$ & - & $\ldots$ & - & $\ldots$ \\
\hline MDA* & 0.18 & u & 0.26 & $u$ & 0.21 & $\mathrm{u}$ & 0.24 & $\mathrm{u}$ & 0.35 & $\mathrm{u}$ & 0.46 & $\mathrm{U}$ & 0.38 & $\mathrm{u}$ & 0.25 & $u$ & 0.17 & $u$ \\
\hline Thallium 208 & ND & -1 & ND & $\ldots$ & ND & $\ldots$ & NDD & - & ND & $\ldots$ & ND & $\ldots$ & ND & $\ldots$ & ND & $\ldots$ & ND & $\ldots$ \\
\hline Sigma Error (+1-) & - & $\ldots$ & & $\ldots$ & & -- & & - & -1 & $\ldots$ & & $\ldots$ & & $-\infty$ & & $\ldots$ & $\rightarrow$ & $\ldots$ \\
\hline MDA* & 0.14 & $\mathrm{U}$ & 0.14 & $u$ & 0.19 & $\mathrm{U}$ & 0.22 & $\mathrm{U}$ & 0.22 & U & 0.30 & $u$ & 0.30 & 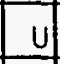 & 0.21 & U & 0.14 & U \\
\hline Uranium 238 & ND & $\ldots$ & ND & -- & ND & $\ldots$ & ND & -- & ND & $\ldots$ & ND & $\ldots$ & ND & $-\infty$ & ND & $\ldots$ & ND & $\ldots$ \\
\hline Sigma Error $(+/-)$ & - & - & & - & & - & & -- & 4 & $\ldots$ & & $\ldots$ & - & $\ldots$ & - & $\ldots$ & - & $\ldots$ \\
\hline $\mathrm{MDA}^{*}$ & 1.50 & $u$ & 1.47 & $u$ & 1.60 & $u$ & 1.84 & $\mathrm{U}$ & 2.69 & $u$ & 3.02 & $\mathrm{u}$ & 2.32 & 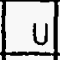 & 2.44 & $\mathrm{u}$ & 1.35 & $\mathrm{u}$ \\
\hline Lead 210 & 1.46 & -- & ND & - & ND & $-\ldots$ & 2.21 & - & ND & $\ldots$ & $\mathrm{ND}$ & $\ldots$ & 4.15 & $\ldots$ & ND & $\ldots$ & 2.10 & $\ldots$ \\
\hline Sigma Error $(+/-)$ & 0.44 & - & & $\ldots$ & & -- & 0.91 & - & - & - & - & $-\ldots$ & 1.05 & - & & $\ldots$ & 0.51 & $\ldots$ \\
\hline MDA & 1.50 & -- & 1.43 & $u$ & 1.54 & $u$ & 1.84 & $\ldots$ & 24.30 & $\mathrm{U}$ & 2.99 & $u$ & 2.15 & $\ldots$ & 19.00 & $u$ & 1.33 & $\ldots$ \\
\hline Beryllium 7 & & - & & - & & - & & - & & - & 5.78 & $\ldots$ & & - & 2.83 & -- & 3.57 & $\ldots$ \\
\hline Sigma Error $(+/-)$ & & - & - & -1 & - & - & - & - & - & -1 & 1.28 & $\ldots$ & -1 & - & 0.62 & $\ldots$ & 0.72 & $\ldots$ \\
\hline MDA* & - & -1 & & - & & - & - & - & - & - & 1.68 & $\ldots$ & - & - & 1.00 & $\ldots$ & 0.78 & $\ldots$ \\
\hline Bismuth 214 & ND & - & ND & - & ND & - & ND & - & ND & - & ND & - & ND & - & $\mathrm{ND}$ & - & $\mathrm{ND}$ & - \\
\hline Sigma Error $(+/-)$ & & -1 & & - & & - & & - & - & - & & - & & - & & - & - & - \\
\hline MDA* & 0.44 & $u$ & 0.33 & $u$ & 0.33 & $\mathrm{u}$ & 0.46 & $\mathrm{u}$ & 0.47 & $\mathrm{u}$ & 0.71 & $u$ & 0.53 & $\mathrm{U}$ & 0.30 & $u$ & 0.29 & 4 \\
\hline Cerium 139 & & -1 & & -1 & -1 & -1 & & $=$ & & 7 & & $\rightarrow$ & & 7 & & 1 & & \\
\hline
\end{tabular}

* Minimum Detectable Activity. ${ }^{\star \star}$ Data Validation. 


\begin{tabular}{|c|c|c|c|c|c|c|c|c|c|c|c|c|c|c|c|c|c|c|c|}
\hline \multirow[b]{2}{*}{ Nuclide (pCi/g) } & \multicolumn{19}{|c|}{ Table A-6.5 Gamma Spectroscopy } \\
\hline & 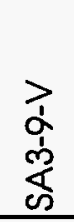 & $\stackrel{*}{*}$ & 旁 & $\stackrel{*}{*}$ & $\frac{⿱}{\frac{1}{5}}$ & $3_{0}^{*}$ & 离 & $\stackrel{*}{2}$ & 离 & 茓 & & $\frac{\text { 辛 }}{\frac{1}{\dot{3}}}$ & 3 & 离 & b & 它 & $3_{0}^{*}$ & 章 & $3^{*}$ \\
\hline Sigma Error $(+/-)$ & & & & & & - & & 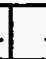 & & $\Gamma$ & & & - - & & $-E$ & & E- & & - \\
\hline MDA* & & & & . & & 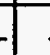 & & 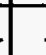 & & & & & - & & $-1-$ & & - & & -1 \\
\hline $\operatorname{Tin} 113$ & & & & 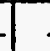 & & 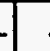 & & . & & & & & - & & -1 & & - & & -1 \\
\hline Sigma Error $(+/-)$ & & & & & & . & & ste & & & & & - & & - & & - & & $-1-$ \\
\hline MDA* & & 1 & & & & & & & & & & & - & & $-1-$ & & - & & - \\
\hline
\end{tabular}




\begin{tabular}{|c|c|c|c|c|}
\hline \multirow[b]{2}{*}{ Nuclide (pCi/g) } & \multicolumn{4}{|c|}{ Table A-6.5 Gamma } \\
\hline & $\begin{array}{l}> \\
\text { ó } \\
\frac{1}{1} \\
\frac{1}{6} \\
0\end{array}$ & ${ }^{*}$ & 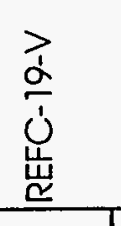 & $\stackrel{*}{*}$ \\
\hline Cesium 137 & ND & -- & ND & - \\
\hline Sigma Error $(+/-)$ & & $-\ldots$ & 7 & $-\ldots$ \\
\hline MDA" & 0.27 & $\mathrm{U}$ & 0.20 & $u$ \\
\hline Potassium 40 & ND & $\ldots$ & ND & - \\
\hline Sigma Error (+/-) & - & -- & - & - \\
\hline MDA* & 5.22 & $\mathrm{u}$ & 3.71 & $u$ \\
\hline Lead 212 & 0.53 & $\ldots$ & ND & $\ldots$ \\
\hline Sigma Error $(+1-)$ & 0.23 & - & - & $\ldots$ \\
\hline MDA* & 0.33 & $-\ldots$ & 0.26 & $\mathrm{u}$ \\
\hline Thallium 208 & ND & -- & ND & -- \\
\hline Sigma Error $(+/-)$ & -1 &.- & 1 & $\ldots$ \\
\hline $\mathrm{MDA}^{*}$ & 0.23 & $u$ & 0.18 & $u$ \\
\hline Uranium 238 & $\mathrm{ND}$ & - & ND & - \\
\hline Sigma Error $(+/-)$ & - & - & -1 & $\ldots$ \\
\hline MDA* & 2.09 & $u$ & 1.56 & $u$ \\
\hline Lead 210 & 7.61 & - & 2.33 & $\ldots$ \\
\hline Sigma Error (+/-) & 1.19 & -- & 1.04 & $\ldots$ \\
\hline MDA* & 2.03 & $\ldots$ & 1.47 & $\ldots$ \\
\hline Beryllium 7 & 25.50 & - & - & - \\
\hline Sigma Error $(+/-)$ & 2.78 & - & & - \\
\hline $\mathrm{MDA}^{*}$ & 1.25 & - & 7 & - \\
\hline Bismuth 214 & 0.68 & - & ND & - \\
\hline Sigma Error $(+/-)$ & 0.23 & $=$ & & - \\
\hline MDA" & 0.49 & - & 0.33 & 0 \\
\hline Cerium 139 & 0.15 & - & & - \\
\hline
\end{tabular}

- Minimum Detectable Activity. ** Data Validation. 
$\frac{\sqrt[J]{\alpha}}{\frac{\sigma}{\sigma}}$

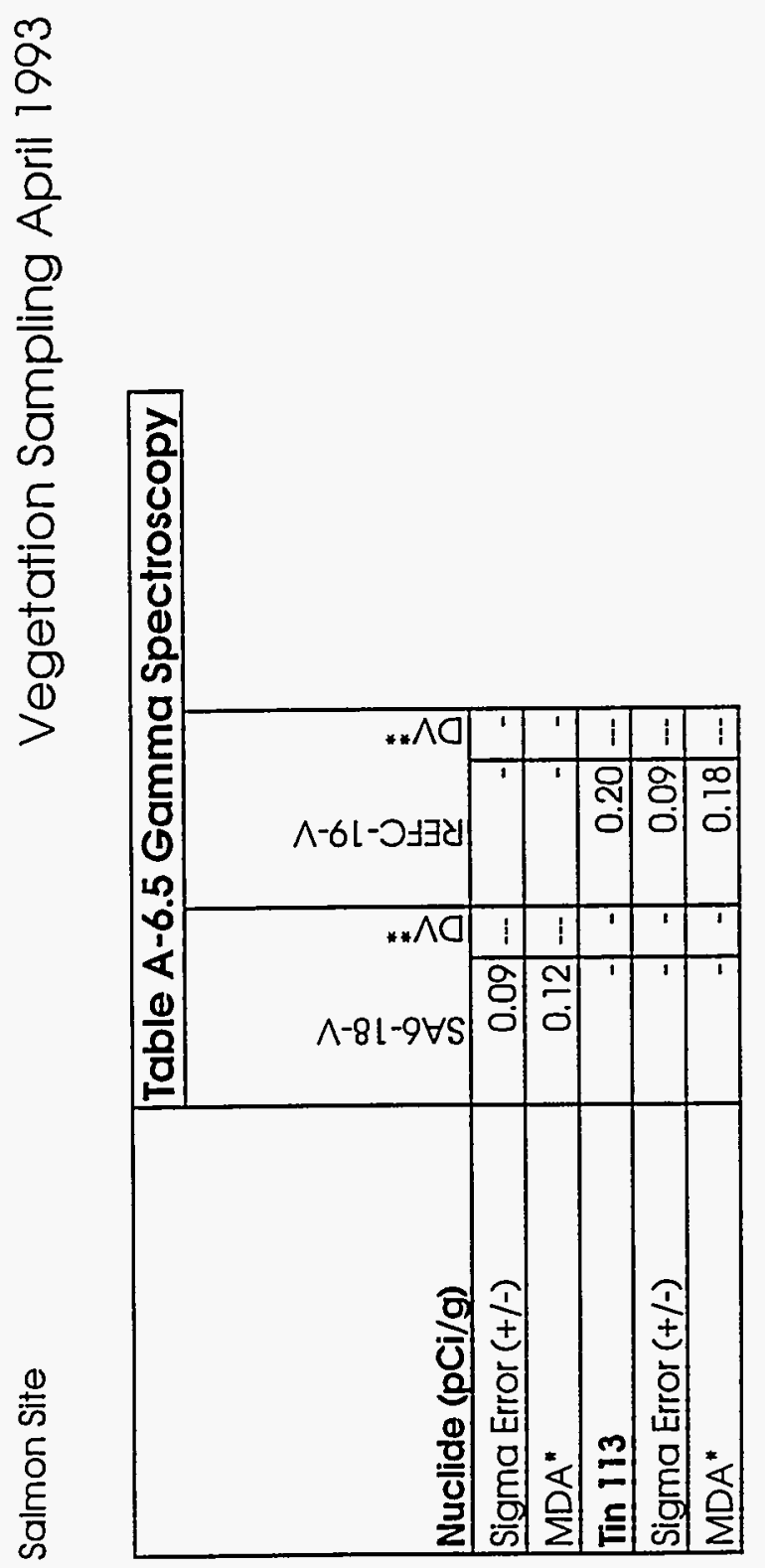

은
0
0
0
0

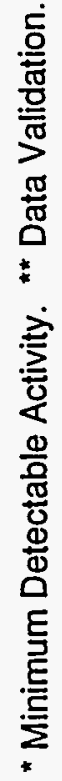





\begin{tabular}{|c|c|c|c|c|c|c|c|c|c|c|c|c|c|c|c|c|c|c|c|c|c|}
\hline \multirow[b]{2}{*}{ Compound $(\mathrm{mg} / \mathrm{Kg})$} & \multicolumn{21}{|c|}{ Table A-7.1 Metals } \\
\hline & 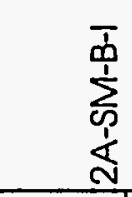 & $\stackrel{*}{Q}$ & & 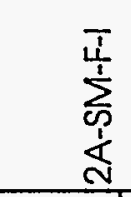 & & & 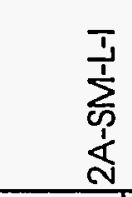 & $\stackrel{*}{\emptyset}$ & 0́ & 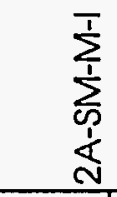 & & 莡 & 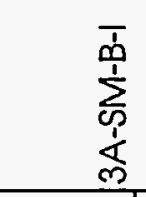 & & $\stackrel{*}{*}$ & $\sum_{\substack{1 \\
\frac{1}{1}}}^{T}$ & & $\stackrel{2}{0}$ & $\begin{array}{l}\bar{U} \\
\sum_{\infty}^{1} \\
\frac{1}{+}\end{array}$ & & 몸 \\
\hline Aluminum & 5.90 & $B$ & $\mathrm{~J}$ & 5.10 & B & $\mathrm{J}$ & 1.00 & $B$ & $\mathrm{~J}$ & 1.80 & $B$ & $\mathrm{~J}$ & 7.60 & $B$ & $\mathrm{~J}$ & 2.80 & $B$ & $\mathrm{~J}$ & 10.70 & & $\ldots$ \\
\hline Antimony & 2.6 & U) & $\ldots$ & 2.5 & $u$ & $\ldots$ & 2.4 & U & $\ldots$ & 2.5 & $u$ & $-\ldots$ & 2.3 & $u$ & $\ldots$ & 2.5 & $u$ & - & 2.2 & $u$ & $\ldots$ \\
\hline Arsenic & 0.42 & uW & UJ & 0.40 & $u$ & - & 0.41 & $u$ & - & 0.37 & $u$ & - & 0.46 & uW & UJ & 0.47 & $\mathrm{U}$ & - & 0.43 & $u$ & -- \\
\hline Barium & 56.90 & & - & 0.30 & B & $\mathrm{J}$ & 0.14 & $\mathrm{~B}$ & $\mathrm{~J}$ & 0.16 & $\mathrm{~B}$ & $\mathrm{~J}$ & 32.10 & & $\ldots$ & 0.30 & $\mathrm{~B}$ & $\mathrm{~J}$ & 14.90 & & $\cdots$ \\
\hline Beryllium & 0.05 & $\mathrm{~B}$ & $\mathrm{U}$ & 0.04 & 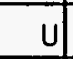 & $\ldots$ & 0.04 & 4 & $\ldots$ & 0.04 & $u$ & $\ldots$ & 0.04 & $\mathrm{u}$ & $\ldots$ & 0.04 & $\mathrm{U}$ & $\ldots$ & 0.04 & $B$ & $\mathrm{U}$ \\
\hline Cadmium & 0.13 & $\mathrm{u}$ & $\ldots$ & 0.12 & $\mathrm{U}$ & $-\ldots$ & 0.12 & u) & $\ldots$ & 0.12 & $\mathrm{u}$ & $\ldots$ & 0.11 & $\mathrm{u}$ & $\ldots$ & 0.12 & $\mathrm{u}$ & $\ldots$ & 0.11 & $u$ & $\ldots$ \\
\hline Calcium & 98000 & & - & 251 & & - & 139 & $\mathrm{~B}$ & $\mathrm{~J}$ & 158 & $\mathrm{~B}$ & $\mathrm{~J}$ & 98500 & & $\ldots$ & 291 & & $\ldots$ & 7960 & & $\cdots$ \\
\hline Chromium & 1.40 & & - & 0.39 & $B$ & $U$ & 0.15 & u & - & 0.35 & 8 & $\mathrm{~J}$ & 3.40 & & $\ldots$ & 0.36 & $B$ & $\mathrm{~J}$ & 0.31 & $B$ & $\mathrm{U}$ \\
\hline Cobalt & 0.28 & $u$ & - & 0.27 & $u$ & -- & 0.26 & $u$ & $\ldots$ & 0.27 & 4 & - & 0.24 & $\mathrm{u}$ & $\ldots$ & 0.27 & $\mathrm{U}$ & $\ldots$ & 0.24 & $u$ & $\ldots$ \\
\hline Copper & 11.10 & & - & 5.30 & & - & 6.80 & & - & 1.90 & & $\ldots$ & 0.81 & $B$ & $\mathrm{U}$ & 2.20 & & $\ldots$ & 3.50 & & - \\
\hline Iron & 76.2 & $E$ & $J$ & 30.8 & $\mathrm{E}$ & $\mathrm{J}$ & 579.0 & $E$ & $\mathrm{~J}$ & 41.8 & $E$ & $\mathrm{~J}$ & 51.9 & $E$ & $J$ & 23.4 & $\mathrm{E}$ & $\mathrm{J}$ & 67.5 & $E$ & $\mathrm{~J}$ \\
\hline Lead & 0.37 & & $\ldots$ & 0.10 & B & $\mathrm{J}$ & 0.11 & $B$ & $J$ & 0.14 & $w$ & $\mathrm{~J}$ & 0.39 & & $\ldots$ & 0.05 & $u$ & -- & 0.28 & & - \\
\hline Magnesium & 1480.0 & & - & 57.3 & B & $\mathrm{J}$ & 162.0 & $B$ & $\mathrm{~J}$ & 251.0 & & - & 1530.0 & & $\ldots$ & 250.0 & & - & 375.0 & & $\ldots$ \\
\hline Manganese & 0.38 & $\mathrm{~B}$ & $\mathrm{~J}$ & 0.23 & $\mathrm{~B}$ & $\mathrm{~J}$ & 2.70 & & -- & 0.21 & $\mathrm{~B}$ & $\mathrm{~J}$ & 0.70 & & $\ldots$ & 0.25 & $\mathrm{~B}$ & $\mathrm{~J}$ & 27.30 & & -- \\
\hline Mercury & 0.08 & & $u$ & 0.07 & $\mathrm{~B}$ & $\mathrm{U}$ & 0.64 & & $\ldots$ & 0.16 & & $u$ & 0.06 & B & $u$ & 0.12 & & $u$ & 0.06 & $\mathrm{~B}$ & $\mathrm{U}$ \\
\hline Nickel & 8.20 & & $\ldots$ & 0.90 & $u$ & -- & 0.86 & $u$ & $\ldots$ & 0.89 & $u$ & $\ldots$ & 0.82 & $\mathrm{U}$ & $\ldots$ & 0.89 & $\mathrm{u}$ & $\ldots$ & 0.80 & $u$ & $\ldots$ \\
\hline Potassium & 1340 & & $\ldots$ & 352 & & $\ldots$ & 1780 & &.- & 3450 & &.-- & 1780 & & $\ldots$ & 3210 & & -- & 2470 & & $\cdots$ \\
\hline Selenium & 0.42 & $u$ & $\ldots$ & 0.40 & $u$ & - & 0.41 & $u$ & -- & 0.37 & 4 & $\ldots$ & 0.46 & $u$ & $\ldots$ & 0.47 & $u$ & $\ldots$ & 0.43 & $u$ & $\ldots$ \\
\hline Silver & 0.16 & $u$ & - & 0.16 & $u$ & $\ldots$ & 0.15 & $u$ & $\ldots$ & 0.16 & $u$ & $\ldots$ & 0.14 & $u$ & $\ldots$ & 0.16 & $\mathrm{U}$ & $\ldots$ & 0.14 & $u$ & - \\
\hline Sodium & 3080.0 & & - & 759.0 & & - & 1500.0 & & $\ldots$ & 542.0 & & $\ldots$ & 2650.0 & & $\ldots$ & 680.0 & & - & 1150.0 & & - \\
\hline Thallium & 0.04 & uW & UJ & 0.04 & uW & UJ & 0.04 & uw & $\mathrm{UJ}$ & 0.04 & uw & UJ & 0.05 & uW & $\mathrm{UJ}$ & 0.23 & UW & UJ & 0.04 & uW & UJ \\
\hline Vanadium & 0.17 & $u$ & $\ldots$ & 0.16 & $u$ & $\ldots$ & 0.28 & $\mathrm{~B}$ & $\ldots$ & 0.16 & $u$ & $\ldots$ & 0.15 & $u$ & -- & 0.16 & $u$ & - & 0.14 & $u$ & - \\
\hline Zinc & 80.0 & & $\ldots$ & 5.1 & & - & 25.1 & & - & 39.4 & & - & 57.2 & & $\ldots$ & 32.5 & & $\ldots$ & 23.4 & & - \\
\hline
\end{tabular}




\begin{tabular}{|c|c|c|c|c|c|c|c|c|c|c|c|c|c|c|c|c|c|c|c|c|c|}
\hline \multirow[b]{2}{*}{ Compound $(\mathrm{mg} / \mathrm{Kg})$} & \multicolumn{21}{|c|}{ Table A-7.1 Metals } \\
\hline & 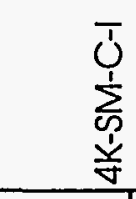 & $\stackrel{*}{\emptyset}$ & & $\begin{array}{l}\bar{j} \\
\sum_{\infty}^{1} \\
\dot{1} \\
\end{array}$ & & & $\begin{array}{l}\bar{d} \\
\sum_{0}^{1} \\
\frac{1}{1} \\
0 \\
0\end{array}$ & $\stackrel{*}{\emptyset}$ & 莡 & 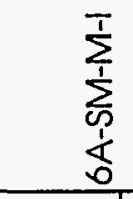 & $\stackrel{*}{Q}$ & 兌 & $\begin{array}{l}\overline{1} \\
\sum_{c}^{1} \\
0 \\
0 \\
0\end{array}$ & ๑ & $\stackrel{2}{0}^{*}$ & 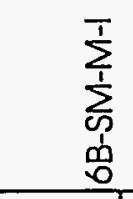 & $\stackrel{*}{\varnothing}$ & 艾 & $\begin{array}{l}\sum_{0}^{\infty} \\
0 \\
0 \\
0\end{array}$ & & 艾 \\
\hline Aluminum & 17.90 & & -- & 4.00 & $\mathrm{~B}$ & $\mathrm{~J}$ & 8.00 & $\mathrm{~B}$ & $\mathrm{~J}$ & 2.10 & $\mathrm{~B}$ & $\mathrm{~J}$ & 3.10 & $\mathrm{~B}$ & $\mathrm{~J}$ & 2.40 & $\mathrm{~B}$ & $\mathrm{~J}$ & 3.00 & B & $\mathrm{J}$ \\
\hline Antimony & 2.7 & 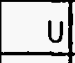 & $\ldots$ & 2.3 & 4 & -- & 2.6 & 4 & $-\ldots$ & 2.7 & 4 & $\ldots$ & 2.5 & 0 & $\ldots$ & 2.6 & 0 & $\ldots$ & 2.7 & 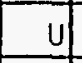 & $\ldots$ \\
\hline Arsenic & 0.45 & $\mathrm{u}$ & $-\ldots$ & 0.37 & $\mathrm{u}$ & $\ldots$ & 0.49 & UW & US & 0.47 & $u$ & $\ldots$ & 0.75 & $B W$ & $\mathrm{~J}$ & 0.45 & $u$ & $\ldots$ & 0.49 & uW & UJ \\
\hline Barium & 9.40 & $\mathrm{~B}$ & J & 0.97 & 8 & $\mathrm{~J}$ & 262.00 & & -- & 0.29 & 8 & $\mathrm{u}$ & 77.40 & & $\ldots$ & 0.34 & $B$ & $\mathrm{~J}$ & 59.40 & &.- \\
\hline Beryllium & 0.05 & B & 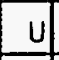 & 0.04 & $u$ & - & 0.04 & 4 & -- & 0.04 & $u$ & $\ldots$ & 0.04 & 4 & - & 0.04 & 4 & $\ldots$ & 0.04 & $\mathrm{U}$ & $\ldots$ \\
\hline Cadmium & 0.13 & $u$ & $-\infty$ & 0.11 & 4 & - & 0.13 & U & $-\ldots$ & 0.13 & $u$ & $\ldots$ & 0.12 & 4 & $\ldots$ & 0.13 & $u$ & $\ldots$ & 0.13 & 4 & $\ldots$ \\
\hline Calcium & 8290 & & $-\ldots$ & 2860 & & - & 61600 & & $-\ldots$ & 184 & $\mathrm{~B}$ & $\mathrm{~J}$ & 29000 & & $\ldots$ & 199 & $B$ & $\mathrm{~J}$ & 22500 & & $\ldots$ \\
\hline Chromium & 0.40 & $B$ & $u$ & 0.30 & 目 & $U$ & 1.20 & & $\ldots$ & 0.28 & $B$ & $\mathrm{~J}$ & 0.65 & & - & 0.20 & $B$ & $\mathrm{~J}$ & 0.33 & B & 1 \\
\hline Cobalt & 0.29 & $u$ & $-\ldots$ & 0.25 & 4 & $\ldots$ & 0.28 & $u$ & $\ldots$ & 0.29 & U) & - & 0.27 & u) & $\ldots$ & 0.29 & 4 & $\ldots$ & 0.29 & 4 & $\ldots$ \\
\hline Copper & 5.20 & & $\ldots$ & 1.50 & & $\ldots$ & 1.50 & & $-\infty$ & 1.90 & & $\ldots$ & 1.50 & & $\ldots$ & 1.70 & & $\ldots$ & 1.20 & $B$ & $\mathrm{~J}$ \\
\hline Iron & 61.8 & $E$ & $\mathrm{~J}$ & 43.1 & $E$ & $\mathrm{~J}$ & 222.0 & & - & 20.4 & & -- & 32.5 & &.- & 15.7 & & $\ldots$ & 30.8 & & $-\ldots$ \\
\hline Lead & 0.36 & & $\ldots$ & 0.07 & $B W$ & $J$ & 0.69 & $\mathrm{~s}$ & $\ldots$ & 0.08 & $B W$ & $\mathrm{~J}$ & 391.00 & & $\ldots$ & 0.15 & $w$ & $\mathrm{~J}$ & 0.33 & & $\ldots$ \\
\hline Magnesium & 355.0 & & $\ldots$ & 218.0 & & - & 1260.0 & & $\ldots$ & 302.0 & & - & 678.0 & & $\ldots$ & 318.0 & & $\ldots$ & 673.0 & & $\ldots$ \\
\hline Manganese & 25.40 & & - & 2.50 & & - & 2.60 & & $\ldots$ & 0.26 & $\mathrm{~B}$ & $\mathrm{~J}$ & 1.00 & & $\ldots$ & 0.31 & $\mathrm{~B}$ & $\mathrm{~J}$ & 4.40 & & $\ldots$ \\
\hline Mercury & 0.07 & $B$ & 4 & 0.04 & B & $U$ & 0.04 & 4 & -- & 0.05 & $u$ & - & 0.04 & 4 & - & 0.05 & 4 & -- & 0.05 & 4 & $\ldots$ \\
\hline Nickel & 0.98 & 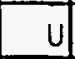 & -- & 0.82 & 4 & - & 0.93 & 4 & - & 0.97 & $u$ & $\ldots$ & 0.91 & $u$ & -- & 0.95 & $u$ & $-\ldots$ & 0.98 & $\mathrm{u}$ & $\ldots$ \\
\hline Potassium & 3060 & & - & 2260 & & - & 1990 & & -- & 3700 & & -- & 2860 & & - & 3780 & &.- & 2870 & & $\ldots$ \\
\hline Selenium & 0.45 & $u$ & - & 0.37 & u. & - & 0.05 & uW & UJ & 0.47 & $u$ & - & 0.48 & 4 & -- & 0.45 & 4 &.- & 0.49 & 4 & $\ldots$ \\
\hline Silver & 0.17 & $u$ & - & 0.14 & $\mathrm{u}$ &.- & 0.16 & $\mathrm{u}$ & $-\ldots$ & 0.17 & $\mathrm{u}$ & $\ldots$ & 0.16 & $\mathrm{u}$ & $\ldots$ & 0.17 & $\mathrm{u}$ & $\ldots$ & 0.17 & $\mathrm{u}$ & $\ldots$ \\
\hline Sodium & 1270.0 & & - & 869.0 & & - & 1870.0 & & - & 465.0 & & $\ldots$ & 1110.0 & & - & 435.0 & & $\ldots$ & 1060.0 & & - \\
\hline Thallium & 0.04 & uW & UJ & 0.04 & UW & UJ & 0.05 & UW & UJ & 0.05 & UW & UJ & 0.05 & uW & UJ & 0.04 & UW & $\mathrm{UJ}$ & 0.05 & UW & UJ \\
\hline Vanadium & 0.18 & $u$ & - & 0.15 & $u$ & - & 0.17 & U) & - & 0.18 & $\mathrm{u}$ & - & 0.16 & u) & - & 0.17 & $\mathrm{u}$ & - & 0.18 & $\mathrm{u}$ & - \\
\hline Zinc & 25.7 & & - & 18.8 & & - & 53.0 & E & $\mathrm{J}$ & 13.1 & $E$ & $\mathrm{~J}$ & 57.1 & $E$ & $\mathrm{~J}$ & 67.0 & $E$ & $\mathrm{~J}$ & 38.9 & $\mathrm{E}$ & $\mathrm{J}$ \\
\hline
\end{tabular}




\begin{tabular}{|c|c|c|c|c|c|c|c|c|c|c|c|c|c|c|c|c|c|c|c|c|}
\hline 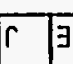 & & 1.02 & r & $\exists$ & 8.96 & Tr 13 & & $\longdiv { 1 . 1 1 }$ & Tr & & 006 & Tr & & $E^{\prime \prime L}$ & r & & 8.60 & Ir 3 & .8 .22 & ouाZ \\
\hline$-\infty n$ & & $\angle 1^{\prime} 0$ & - & $n$ & $\angle L^{\prime} O$ & $1-1$ & & $\angle 1^{\prime} 0$ & - & $n$ & $\angle 1^{\prime} 0$ & $\cdots$ & & $\angle l^{\prime} 0$ & -1 & $n$ & $\angle 1.0$ & $-\pi n$ & $91^{\circ} 0$ & Un!pDuD \\
\hline \begin{tabular}{l|l}
$m \pi n$ \\
$n$
\end{tabular} & un & $50^{\prime} 0$ & $m$ & $M n$ & $90^{\prime} 0$ & $m \pi$ & Mn & $60^{\circ} 0$ & in & $\mathrm{Mn}$ & $90^{\circ} 0$ & mn & $\mathrm{Mn}$ & $90^{\prime} 0$ & $-n$ & $n$ & $90^{\circ} 0$ & mn & $90^{\circ} 0$ & un!||DU1 \\
\hline-- & & 0.820 & - & & $0^{\prime} 0 z \mathrm{DL}$ & 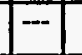 & & $D^{\prime} \varepsilon 9 \varepsilon$ & - & & $0^{\circ} 0021$ & - & & 0.120 & - & & $0^{\prime} 00 \varepsilon$ & - & $0^{\prime} 280$ & unipos \\
\hline$-\infty n$ & & 91.0 & -- & $n$ & 910 & $-\pi$ & & $91 \%$ & $-\infty$ & $n$ & $91^{\circ} 0$ & $\cdots$ & $n$ & $91^{\circ} 0$ & -7 & $n$ & 91.0 & $--\mid n$ & $91^{\circ} 0$ & $1 \nexists \wedge \| S$ \\
\hline \begin{tabular}{l|l}
- & $n$ \\
\end{tabular} & & $2 \nabla^{\prime} 0$ & $\theta$ & $n$ & $\angle \nabla^{\prime} 0$ & $-\cdots n$ & & $9 \sigma^{\prime} 0$ & - & & $60^{\circ} 0$ & -- & $n$ & $60^{\circ} 0$ & $r \sqrt{r}$ & $M B$ & $\angle 0^{\circ} 0$ & $-\pi$ & $80^{\circ} 0$ & un!uə|əS \\
\hline- & & $086 \varepsilon$ & - & & $09 \angle 2$ & -1 & & $0 Z 9 \varepsilon$ & 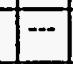 & & $0 \angle 82$ & -1 & & $0 \varepsilon 8 \varepsilon$ & -1 & & 0891 & - & O6DE & wn|SSD łOd \\
\hline$-\cdots n$ & & 060 & $\cdots$ & $n$ & 260 & $\cdots 1$ & & $86^{\circ} 0$ & - & $n$ & $266^{\circ} 0$ & $\cdots$ & $n$ & $86^{\circ} 0$ & $=1$ & $n$ & $86^{\circ} 0$ & -7 & $68^{\prime} 0$ & |QXगIN \\
\hline$-\cdots n$ & & $50^{\prime} 0$ & + & $n$ & $60^{\prime} 0$ & $\pi$ & & $90^{\circ} 0$ & -- & $n$ & $\$ 0^{\circ} 0$ & -- & $n$ & $50^{\circ} 0$ & n & 8 & $80^{\circ} 0$ & n 8 & $70^{\prime} 0$ & KAnOJəW \\
\hline \begin{tabular}{|l|l|l} 
& $\bar{a}$ \\
\end{tabular} & & $60^{\circ} 0$ & - & & $0 \varepsilon^{\prime} Z$ & $r \quad 8$ & & $62^{\prime} 0$ & - & & 09.1 & $r$ & 8 & $6 \varepsilon^{\prime} 0$ & -1 & & $00^{\prime} 2$ & - & $00^{\prime} 2$ & әsəuDSuDW \\
\hline-- & & $0.61 \varepsilon$ & $\cdots$ & & $0^{\prime} \varepsilon \varepsilon 6$ & $\cdots$ & & 0.662 & - & & $0^{\prime} 818$ & - & & 010 & $-\infty$ & & O'ObOl & -- & 0 's82 & Un!ıəuదb \\
\hline$r \sqrt{r}$ & $\bar{n}$ & $\varepsilon Z^{\prime} 0$ & $r$ & $M$ & $9 Z^{\prime} 0$ & $\cdots$ & & 01.0 & $-\cdots$ & & $0 \angle 60$ & $\cdots$ & & $\angle \varepsilon^{\circ} 0$ & -1 & & 09.9 & 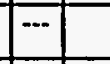 & $G L^{\circ} 0$ & pDə7 \\
\hline-- & & 0.12 & $\cdots$ & & $\nabla^{\circ} \angle \varepsilon$ & $\cdots$ & & 8.91 & - & & $29 \varepsilon$ & - & & 9.91 & -- & & $0<\angle I 1$ & - & 271 & प011 \\
\hline-- & & $00^{\circ} \mathrm{L}$ & $\cdots$ & & $09^{\prime} 6$ & + & & $00^{\circ} 1$ & $\cdots$ & & $0 Z^{\prime} 9$ & $r$ & 8 & 01.1 & $\cdots$ & & $O L^{\prime} L$ & -- & 09.1 & Iəddoj \\
\hline$\cdots$ & & $82^{\prime} 0$ & $\cdots$ & $n$ & $82^{\prime} 0$ & $=1$ & $n$ & $82^{\prime} 0$ & - & $n$ & $82^{\circ} 0$ & - & $n$ & $82 \%$ & -- & $n$ & $8 Z^{\prime} 0$ & $--\mid n$ & $\angle Z O 0$ & \#10905 \\
\hline$\cdots$ & & 61.0 & $\cdots$ & & $96^{\circ} 0$ & is 8 & 8 & $\varepsilon Z^{\prime} 0$ & $\cdots$ & & 280 & is & 8 & 920 & $-\infty$ & & $78^{\circ} 0$ & \begin{tabular}{l|l|l|}
$r$ & $\theta$ \\
\end{tabular} & 220 & 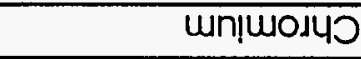 \\
\hline$-\bar{\theta}$ & & 861 & - & & 00280 & r 5 & 8 & 991 & -- & & $00 \angle 9 \varepsilon$ & $r$ & 8 & 161 & -1 & & $00 \angle 99$ & \begin{tabular}{l|l}
$r$ & 8
\end{tabular} & $\nabla<L$ & un|ग|DJ \\
\hline$\cdots$ & & $\varepsilon 1.0$ & - & $n$ & $210^{\circ}$ & -1 & & $81{ }^{\prime} 0$ & $\cdots$ & & $21{ }^{\circ}$ & $\cdots$ & & $\varepsilon 1{ }^{\prime} 0$ & -1 & $n$ & $\varepsilon 1.0$ & $-\cdots$ & 21.0 & un!wpD \\
\hline$\cdots \pi$ & & $80^{\circ} 0$ & $\cdots$ & $n$ & $00^{\prime} 0$ & -1 & & $50^{\circ} 0$ & $\cdots$ & $n$ & $50^{\prime} 0$ & $\cdots$ & $n$ & $50^{\circ} 0$ & -1 & $n$ & $00^{\circ} 0$ & $--1 n$ & 000 & un!!ारdeg \\
\hline \begin{tabular}{|l|l|l}
$n$ & 8 \\
\end{tabular} & & $0 \varepsilon^{\prime} 0$ & - & & $O L E S$ & $n$ & & $0 \varepsilon^{\circ} 0$ & $\cdots$ & & $00^{\circ} \varepsilon 11$ & $n$ & 8 & $\varepsilon \varepsilon^{\circ} 0$ & -- & & 00.891 & -18 & $D \& 0$ & wn!!10g \\
\hline 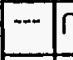 & & 200 & m & mn & $\angle D^{\circ} 0$ & $\cdots 1$ & & $9 \sigma^{\circ} 0$ & $\cdots$ & & $60^{\circ} 0$ & $\cdots$ & $n$ & $60^{\circ} 0$ & $m$ & $M n$ & $80^{\prime} 0$ & $\cdots$ & $80^{\circ} 0$ & गIUESIV \\
\hline $\begin{array}{lll}-1 & 1 \\
\end{array}$ & & 9.2 & + & & $9 \cdot 2$ & -1 & & 972 & $\cdots$ & & 9.2 & $-\cdots$ & & 92 & -- & $n$ & 927 & $-\cdots$ & $g^{\prime} 2$ & Ruou!!!Ut \\
\hline 58 & & $09^{\prime} \mathrm{L}$ & $r$ & & $0 \varepsilon^{\prime} \varepsilon$ & $=1$ & & $\angle 6^{\circ} 0$ & $r$ & & $0 \angle \mathcal{1} \varepsilon$ & $r$ & 8 & OE'L & $r$ & 8 & $0 g^{\prime} \varepsilon$ & $r 19$ & 108.1 & wnulunity \\
\hline & & 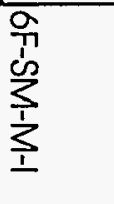 & 吝 & & 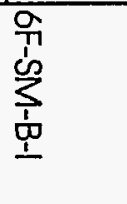 & $\left.\right|_{i}$ & & 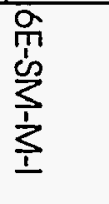 & T) & & 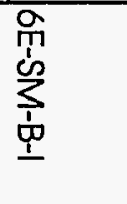 & 䒺 & & 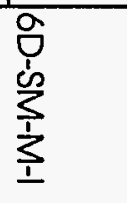 & & & 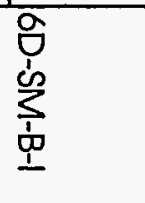 & $P_{i}$ & 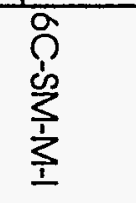 & (бत्र/6w) punodwoJ \\
\hline \multicolumn{20}{|c|}{ s|p|W $I^{\circ} L-\forall$ ә } & \\
\hline
\end{tabular}




\begin{tabular}{|c|c|c|c|c|c|c|}
\hline \multirow[b]{2}{*}{ Compound $(\mathrm{mg} / \mathrm{Kg})$} & \multicolumn{6}{|c|}{ Table A-7.1 Metals } \\
\hline & $\begin{array}{l}\bar{n} \\
\sum_{0}^{1} \\
b \\
b\end{array}$ & $\stackrel{*}{0}$ & $\stackrel{2}{0}^{*}$ & $\begin{array}{l}\sum_{1}^{T} \\
\sum_{0}^{1} \\
b \\
0\end{array}$ & & $\stackrel{*}{*}$ \\
\hline Aluminum & 2.80 & $B$ & J & 1.50 & $B$ & 3 \\
\hline Antimony & 2.5 & 4 & -- & 2.7 & & ........ \\
\hline Arsenic & 0.45 & uW & UJ & 0.45 & & J... \\
\hline Barium & 225.00 & & -- & 0.47 & $B$ & 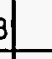 \\
\hline Beryllium & 0.04 & $u$ & -- & 0.04 & & J... \\
\hline Cadmium & 0.12 & $u$ & - & 0.13 & $\mathrm{U}$ & $\ldots$ \\
\hline Calcium & 66200 & & -- & 226 & $B$ & 3. \\
\hline Chromium & 5.10 & & - & 0.18 & $B$ & 3. \\
\hline Cobalt & 0.27 & $\mathrm{U}$ & -- & 0.29 & $\mathrm{U}$ & $\ldots$ \\
\hline Copper & 0.78 & 8 & $U$ & 1.30 & & - \\
\hline Iron & 56.4 & $E$ & J & 55.2 & & - \\
\hline Lead & 43.70 & & - & 19.30 & & $\ldots$ \\
\hline Magnesium & 1300.0 & & -- & 288.0 & & $\ldots$ \\
\hline Manganese & 4.60 & & -- & 0.22 & $B$ & 3 \\
\hline Mercury & 0.05 & B & U & 0.04 & $\underline{U}$ & 1. \\
\hline Nickel & 2.40 & & $\ldots$ & 0.96 & $\mathrm{U}$ & J.- \\
\hline Potassium & 2210 & & - & 3700 & & $\ldots$ \\
\hline Selenium & 0.04 & uW & US & 0.45 & $\underline{U}$ & 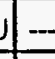 \\
\hline Silver & 0.16 & U & - & 0.17 & $\mathrm{U}$ & - \\
\hline Sodium & 1550.0 & & - & 577.0 & & $\ldots$ \\
\hline Thallium & 0.04 & UW & UJ & 0.05 & UW & $\mathrm{Vu}$ \\
\hline Vanadium & 0.16 & 4 & - & 0.17 & $\mathrm{U}$ & J- \\
\hline Zinc & 51.1 & & - & 9.3 & & E U. \\
\hline
\end{tabular}




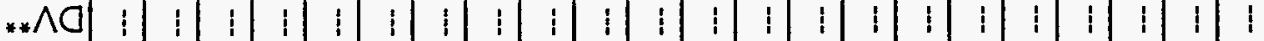

$* 0$

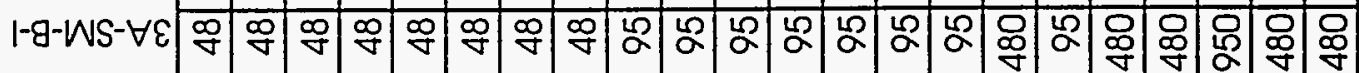

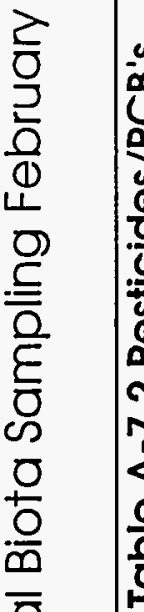

$$
\begin{aligned}
& 0 \\
& 0 \\
& 0 \\
& 0 \\
& \frac{0}{0} \\
& 0 \\
& \vdots \\
& \vdots \\
& 0 \\
& 0 \\
& 0
\end{aligned}
$$

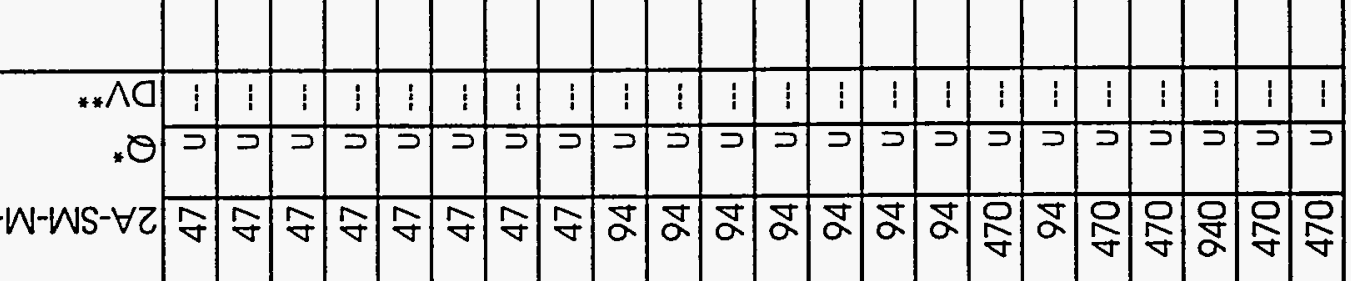

$$
\text { 1-W-WS- } \forall \zeta \text { 当 }
$$

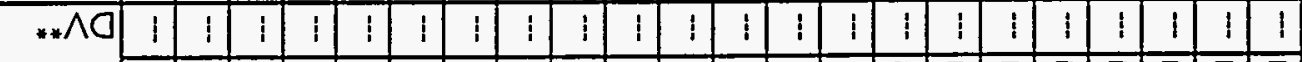

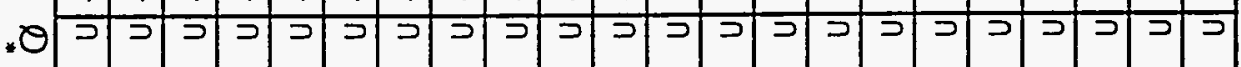

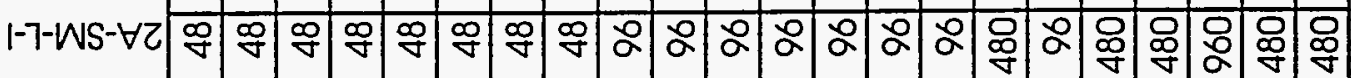

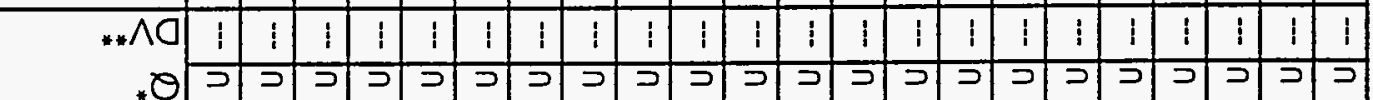

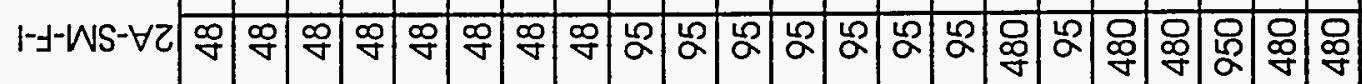




\begin{tabular}{|c|c|c|c|c|c|c|c|c|c|c|c|c|c|c|c|c|c|c|c|c|c|}
\hline \multirow[b]{2}{*}{ Compound (ug/Kg) } & \multicolumn{21}{|c|}{ Table A-7.2 Pesticides/PCB's } \\
\hline & 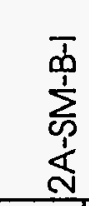 & 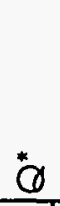 & & 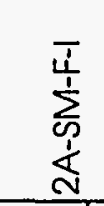 & & ${ }^{*}$ & 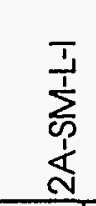 & & 莒 & 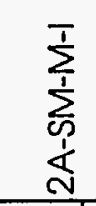 & & $\stackrel{*}{2}$ & 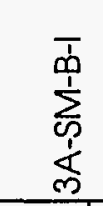 & & $\stackrel{*}{2}$ & 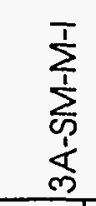 & & $\stackrel{2}{0}^{*}$ & $\begin{array}{l}\bar{J} \\
\sum_{\infty}^{1} \\
1 \\
\frac{1}{+} \\
\end{array}$ & & $\stackrel{*}{2}$ \\
\hline Aroclor-1232 & 470 & $U$ & $\ldots$ & 480 & $u$ & $\ldots$ & 480 & u & $\ldots$ & 470 & U. & $\ldots$ & 480 & & $-\ldots$ & 470 & 4 & $\ldots$ & 470 & & $\ldots$ \\
\hline Aroclor- 1242 & 470 & $\mathrm{U}$ & $-\ldots$ & 480 & $\mathrm{U}$ & $\ldots$ & 480 & $u$ & $-\ldots$ & 470 & $u$ & $\ldots$ & 480 & & -- & 470 & & $\ldots$ & 470 & &.- \\
\hline Aroclor- 1248 & 470 & $u$ & - & 480 & $u$ & $\ldots$ & 480 & $u$ & - & 470 & u. & $\ldots$ & 480 & $\mathrm{u}$ & $\ldots$ & 470 & $\mathrm{U}$ & $\ldots$ & 470 & $\mathrm{u}$ & $\ldots$ \\
\hline Aroclor- 1254 & 940 & $u$ & - & 950 & $\mathrm{u}$ & $\ldots$ & 960 & $u$ & - & 940 & $\mathrm{U}$ & $\ldots$ & 950 & & $\ldots$ & 950 & $u$ & -+ & 940 & $\mathrm{U}$ & $\ldots$ \\
\hline Aroclor- 1260 & 940 & 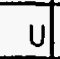 & $-\cdots$ & 950 & $\mathrm{U}$ & $\ldots$ & 960 & $u$ & $-{ }_{-1}$ & 940 & & -- & 950 & & $\ldots$ & 950 & & $\ldots$ & 940 & & $\ldots$ \\
\hline
\end{tabular}




\begin{tabular}{|c|c|c|c|c|c|c|c|c|c|c|c|c|c|c|c|c|c|c|c|c|c|}
\hline \multirow[b]{2}{*}{ Compound (ug/Kg) } & \multicolumn{21}{|c|}{ Table A-7.2 Pesticides/PCB's } \\
\hline & 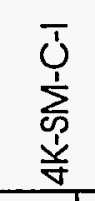 & & & $\begin{array}{l}\bar{U} \\
\sum_{\infty}^{1} \\
\stackrel{1}{\vec{\gamma}} \\
\end{array}$ & & & $\begin{array}{l}\bar{\phi} \\
\sum_{\substack{1 \\
1}}^{1} \\
\delta \\
\end{array}$ & & 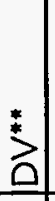 & 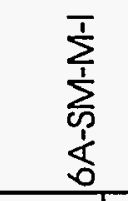 & & ${ }^{*}$ & $\begin{array}{l}\overline{1} \\
\sum_{0}^{1} \\
0 \\
0 \\
0\end{array}$ & & $\stackrel{*}{2}$ & 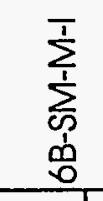 & & $\stackrel{*}{2}$ & $\begin{array}{l}\bar{c} \\
\sum_{\infty}^{\infty} \\
0 \\
0 \\
0\end{array}$ & & $\sum_{0}^{*}$ \\
\hline Alpha-BHC & 47 & $u$ & -- & 46 & $\mathrm{u}$ & \begin{tabular}{|c|}
-- \\
\end{tabular} & 47 & $\mathrm{U}$ & $\ldots$ & 47 & $u$. & $\ldots$ & 47 & $u$ & -- & 47 & U & $-{ }_{-1}$ & 46 & 4 & - \\
\hline Beta-BHC & 47 & 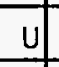 & $\ldots$ & 46 & $\mathrm{U}$ & - & 47 & U & - & 47 & u. &.- & 47 & 4 & $\ldots$ & 47 & 4 & $\ldots$ & 46 & $u$ & $\ldots$ \\
\hline Delta-BHC & 47 & 4 & -- & 46 & $u$ & $\ldots$ & 47 & 4 & -- & 47 & 4. & - & 47 & 4 & -- & 47 & 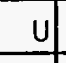 & -- & 46 & $u$ & -- \\
\hline Gamma-BHC & 47 & 4 & - & 46 & 4 & -- & 47 & $u$ & -- & 47 & 4 & - & 47 & 4 & $\cdots$ & 47 & $\mathrm{u}$ & -- & 46 & 4 & -- \\
\hline Heptachlor & 47 & $u$ & $\ldots$ & 46 & $\mathrm{U}$ & $-\ldots$ & 47 & $\mathrm{u}$ & $\ldots$ & 47 & $\mathrm{u}$ & -- & 47 & 4 & -- & 47 & 4 & -- & 46 & 0 & $\ldots$ \\
\hline Aldrin & 47 & $\mathrm{U}$ & -- & 46 & $u$ & $\ldots$ & 47 & $u$ &.- & 47 & $\mathrm{u}$ & -- & 47 & 4 & $\ldots$ & 47 & 4 & $\ldots$ & 46 & $u$ & $\cdots$ \\
\hline Heptachlor epoxide & 47 & $\mathrm{u}$ & -1 & 46 & $u$ & -- & 47 & 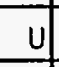 & - & 47 & 4 & - & 47 & 4 & $\ldots$ & 47 & u & -- & 46 & 4 & - \\
\hline Endosulfan I & 47 & 4 & $-\infty$ & 46 & 4 & $-\cdots$ & 47 & 4 & - & 47 & $u$ & $\ldots$ & 47 & 4 & -- & 47 & 4 & \begin{tabular}{|c|}
-- \\
-1
\end{tabular} & 46 & 4 & -- \\
\hline Dieldrin & 94 & $u$ & $\ldots$ & 92 & $u$ & $-\infty$ & 95 & 4 & - & 94 & 4 & -- & 93 & 4 & $\ldots$ & 95 & 4 & $\ldots$ & 93 & 4 & $\ldots$ \\
\hline 4,4'-DDE & 94 & 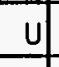 & -- & 92 & 4 & -- & 95 & 4 & -- & 94 & 4 & $\ldots$ & 93 & 4 & $-\infty$ & 95 & 4 & -- & 93 & 4 & $\ldots$ \\
\hline Endrin & 94 & 4 & -- & 92 & 4 & - & 95 & $u$ & -- & 94 & $\mathrm{u}$ & $\ldots$ & 93 & 4 & -- & 95 & 4 & $\cdots$ & 93 & 4 & $\ldots$ \\
\hline Endosulfan II & 94 & 4 & - & 92 & 4 & - & 95 & 4 & -- & 94 & 4 & -- & 93 & 4 & $\ldots$ & 95 & 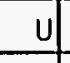 & $\ldots$ & 93 & 4 & $\ldots$ \\
\hline 4.4'-DDD & 94 & 4 & $\ldots$ & 92 & 4 & $-\infty$ & 95 & 4 & $\ldots$ & 94 & $\mathrm{u}$ & $\ldots$ & 93 & 4 & $-{ }_{-1}$ & 95 & 4 & $\ldots$ & 93 & 4 & - \\
\hline Endosulfan sulfate & 94 & U & -+ & 92 & $u$ & -- & 95 & $\mathrm{U}$ & - & 94 & 4 & $\ldots$ & 93 & u & $\ldots$ & 95 & 4 & $\ldots$ & 93 & 4 & - \\
\hline 4,4'-DDT & 94 & 4 & - & 92 & $\mathrm{U}$ & -- & 95 & $\mathrm{u}$ & - & 94 & 4 & $\ldots$ & 93 & 4 & $\ldots$ & 95 & U & -- & 93 & 4 & - \\
\hline Methoxychlor & 470 & $u$ & -- & 460 & $u$ & $-\infty$ & 470 & $\mathrm{U}$ & - & 470 & U & $\ldots$ & 470 & 4 & $\ldots$ & 470 & 4 & $\ldots$ & 460 & $\mathrm{u}$ & -- \\
\hline Endrin ketone & 94 & 4 & $\ldots$ & 92 & $\mathrm{u}$ & $\ldots$ & 95 & 4 & -- & 94 & 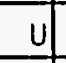 & -- & 93 & 4 & - & 95 & 4 & $\cdots$ & 93 & 4 &.- \\
\hline Alpha-chlordane & 470 & $\mathrm{U}$ & - & 460 & $\mathrm{U}$ & $\ldots$ & 470 & 4 & $-\ldots$ & 470 & U & $\ldots$ & 470 & $u$ & -- & 470 & 4 & -- & 460 & $u$ & - \\
\hline Gamma-chlordane & 470 & 4 & - & 460 & U & $\ldots$ & 470 & 4 & - & 470 & 4 & $\ldots$ & 470 & 4 & - & 470 & U) & -- & 460 & 4 & -- \\
\hline Toxaphene & 940 & 4 & - & 920 & $\mathrm{U}$ & - & 950 & 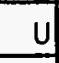 & - & 940 & 4 & - & 930 & 4 & - & 950 & 4 & - & 930 & 4 & -- \\
\hline Aroclor-1016 & 470 & $\mathrm{U}$ & - & 460 & $u$ & - & 470 & $u$ & $\ldots$ & 470 & $\mathrm{u}$ & - & 470 & 4 & - & 470 & 4 & -- & 460 & 4 & - \\
\hline Aroclor-1221 & 470 & $\mathrm{U}$ & - & 460 & $\mathrm{U}$ & - & 470 & $U$ & - & 470 & U) & - & 470 & U] & - & 470 & UI & $\ldots$ & 460 & & $\ldots$ \\
\hline
\end{tabular}




\begin{tabular}{|c|c|c|c|c|c|c|c|c|c|c|c|c|c|c|}
\hline \multirow[b]{2}{*}{ Compound (ug/Kg) } & \multicolumn{14}{|c|}{ Table A-7.2 Pesticides/PCB's } \\
\hline & 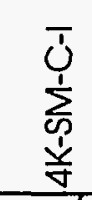 & $\ddot{\theta}$ & 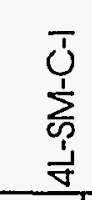 & $\stackrel{0}{*}$ & $\begin{array}{l}\bar{T} \\
\sum_{0}^{\infty} \\
\frac{1}{1} \\
0\end{array}$ & ${ }^{*} \stackrel{*}{*}$ & 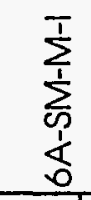 & ${ }^{*} \stackrel{*}{*}$ & $\begin{array}{l}\bar{\phi} \\
\sum_{\infty}^{1} \\
\dot{1} \\
0 \\
0\end{array}$ & $\stackrel{*}{*}$ & 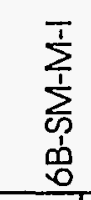 & $\stackrel{*}{*}$ & 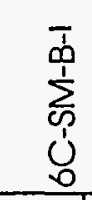 & $0^{*}$ \\
\hline Aroclor-1232 & 470 & U. & 460 & 0. & 470 & U. & 470 & $01 \ldots$ & 470 & $4 . .$. & 470 & $\begin{array}{lll}4 \\
\end{array}$ & 460 & 0. \\
\hline Aroclor-1242 & 470 & $4 \mid-\ldots$ & 460 & $0 \mid$ & 470 & v & 470 & \begin{tabular}{c|c} 
& $\ldots$
\end{tabular} & 470 & \begin{tabular}{l|l|l}
0 & $\ldots$ \\
\end{tabular} & 470 & \begin{tabular}{l|l|}
$U$ & $\ldots$ \\
\end{tabular} & 460 & \begin{tabular}{l|l}
0 & $\ldots$ \\
\end{tabular} \\
\hline Aroclor- 1248 & 470 & 4 & 460 & $4[-$ & 470 & U) & 470 & $\begin{array}{ll}4-\ldots \\
-\ldots\end{array}$ & 470 & U) & 470 & $\begin{array}{lll} & \ldots & \\
\end{array}$ & 460 & \begin{tabular}{l|l|l}
0 & $\ldots$ \\
\end{tabular} \\
\hline Aroclor-1254 & 940 & $4-$ & 920 & 0 & 950 & v- & 940 & U & 930 & $\begin{array}{lll}4 & \ldots \\
\end{array}$ & 950 & \begin{tabular}{l|l|}
4 & $\ldots$ \\
\end{tabular} & 930 & \begin{tabular}{c|c|}
4 & $\ldots$ \\
\end{tabular} \\
\hline Aroclor-1260 & 940 & $4]$ & 920 & U. & 950 & ט. & 940 & U & 930 & \begin{tabular}{l|l|}
0 & $\ldots$ \\
\end{tabular} & 950 & \begin{tabular}{l|l|} 
& $-\ldots$ \\
\end{tabular} & 930 & $\begin{array}{lll} & 0 & \ldots \\
\end{array}$ \\
\hline
\end{tabular}


l-8-WS-J9

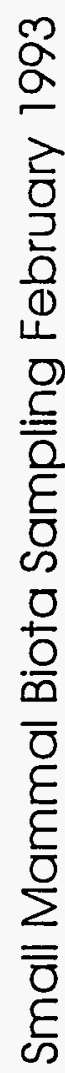

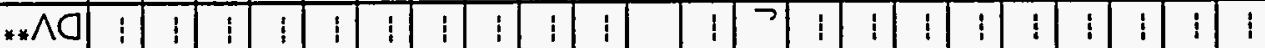

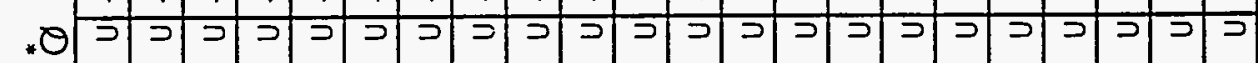
I-W-WS-39 क्ष $\frac{\sigma}{\sigma}$ क

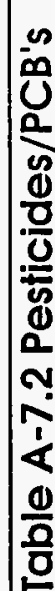

$* * \wedge 0$

.$\theta$

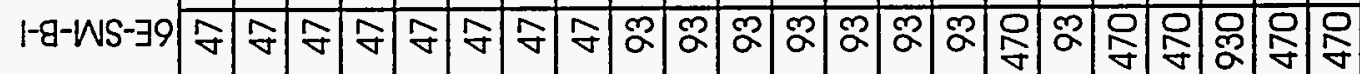

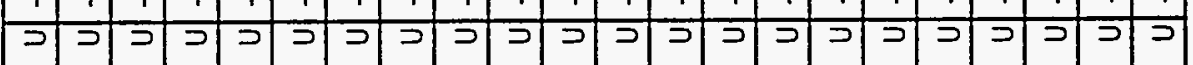

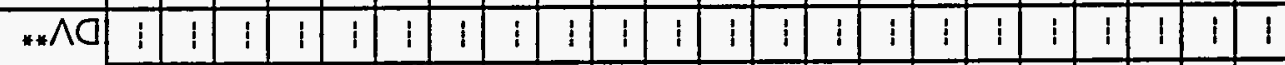

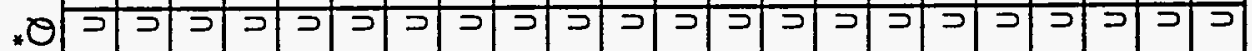

I-W-WL-

ลे
0
0
0
0

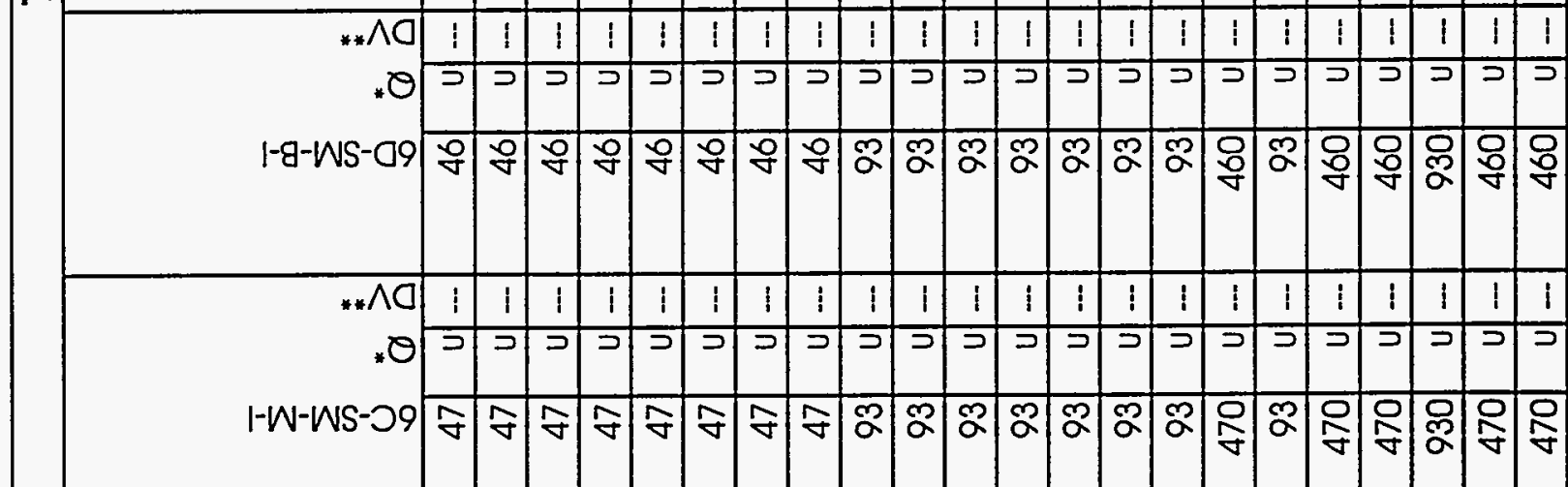




\begin{tabular}{|c|c|c|c|c|c|c|c|c|c|c|c|c|c|c|}
\hline \multirow[b]{2}{*}{ Compound (ug/Kg) } & \multicolumn{14}{|c|}{ Table A-7.2 Pesłicides/PCB's } \\
\hline & $\begin{array}{l}\sum_{0,1}^{T} \\
\sum_{0}^{1} \\
0\end{array}$ & : & $\begin{array}{l}\bar{\phi} \\
\text { 离 } \\
\text { o } \\
\text { ô }\end{array}$ & ${ }^{*}$ & $\begin{array}{l}\sum_{1}^{T} \\
\sum_{0,}^{1} \\
0 \\
0\end{array}$ & ¿ & 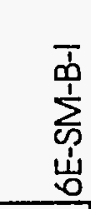 & 胥 & $\begin{array}{l}\sum_{1}^{T} \\
\sum_{0=}^{1} \\
u \\
0\end{array}$ & $\stackrel{0}{\circ}$ & $\begin{array}{l}\bar{\phi} \\
\sum_{0,0}^{1} \\
\dot{1} \\
0\end{array}$ & $\theta^{\circ}$ & $\begin{array}{l}\sum_{i=1}^{T} \\
\sum_{0}^{1} \\
0 \\
0\end{array}$ & 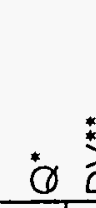 \\
\hline \begin{tabular}{|l|} 
Aroclor- 1232 \\
\end{tabular} & 470 & $0 \mid \ldots$ & 460 & U. & 470 & $0 \ldots$ & 470 & $4 \ldots$ & 480 & $4 \mid-$ & 470 & $0 \mid-\ldots$ & 470 & 4. - \\
\hline Aroclor-1242 & 470 & 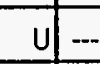 & 460 & v [... & 470 & 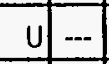 & 470 & \begin{tabular}{l|l} 
& $\ldots$ \\
\end{tabular} & 480 & u. & 470 & \begin{tabular}{c|c} 
& $\ldots$ \\
\end{tabular} & 470 & u. \\
\hline \begin{tabular}{|l|} 
Aroclor-1248 \\
\end{tabular} & 470 & U] & 460 & U. & 470 & \begin{tabular}{l|l|}
0 & $\ldots$ \\
\end{tabular} & 470 & \begin{tabular}{l|l}
$0 .$. \\
\end{tabular} & 480 & u| & 470 & 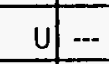 & 470 & u. - \\
\hline Aroclor-1254 & 930 & U. & 930 & u. & 940 & \begin{tabular}{l|l|}
0 & $\ldots$ \\
\end{tabular} & 930 & \begin{tabular}{c|c} 
\\
$0 . .$.
\end{tabular} & 960 & 0 & 930 & $0 \mid-\ldots$ & 940 & u. \\
\hline Aroclor-1260 & 930 & $4 \mid$ & 930 & u & 940 & $\begin{array}{lll}0 & -\ldots \\
\end{array}$ & 930 & U. & 960 & v] & 930 & u| ... & 940 & U. \\
\hline
\end{tabular}




\begin{tabular}{|c|c|c|c|c|c|c|}
\hline \multirow[b]{2}{*}{ Compound (ug/Kg) } & \multicolumn{6}{|c|}{ Table A-7.2 Pesticides/PCB's } \\
\hline & 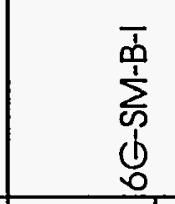 & ¿ & 兌 & $\begin{array}{l}\sum_{i=1}^{T} \\
j \\
0 \\
0\end{array}$ & ${ }^{*}$ & 主 \\
\hline Alpha-BHC & 48 & $\mathrm{U}$ & $\ldots$ & 47 & $\mathrm{U}$ & -- \\
\hline Beta-BHC & 48 & $\mathrm{U}$ & $\ldots$ & 47 & $\mathrm{u}$ & - \\
\hline Delta-BHC & 48 & $\mathrm{U}$ & $\ldots$ & 47 & $\mathrm{u}$ & - \\
\hline Gamma-BHC & 48 & $u$ & -- & 47 & $u$ & - \\
\hline Heptachlor & 48 & $\mathrm{U}$ & -- & 47 & $u$ & -- \\
\hline Aldrin & 48 & $\mathrm{U}$ & $\cdots$ & 47 & $\mathrm{U}$ & - \\
\hline Heptachlor epoxide & 48 & $U$ &.- & 47 & $\mathrm{u}$ & - \\
\hline Endosulfan I & 48 & $\mathrm{U}$ & -- & 47 & $u$ & $\ldots$ \\
\hline Dieldrin & 95 & $\mathrm{U}$ & -- & 94 & $\mathrm{U}$ &.- \\
\hline 4,4'-DDE & 95 & $\mathrm{U}$ & - & 94 & $\mathrm{u}$ &.- \\
\hline Endrin & 95 & $\mathrm{U}$ & - & 94 & $\mathrm{U}$ & - \\
\hline Endosulfan II & 95 & $\mathrm{U}$ & -- & 94 & $\mathrm{U}$ & $\ldots$ \\
\hline 4,4'-DDD & 95 & $\mathrm{U}$ & -- & 94 & $\mathrm{U}$ & - \\
\hline Endosulfan sulfate & 95 & $u$ & - & 94 & 4 & -- \\
\hline 4,4'-DDT & 95 & $\mathrm{U}$ & - & 94 & $\mathrm{U}$ & - \\
\hline Methoxychlor & 480 & $u$ & - & 470 & $\mathrm{U}$ & $\cdots$ \\
\hline Endrin ketone & 95 & $\mathrm{u}$ & -- & 94 & $u$ & - \\
\hline Alpha-chlordane & 480 & $U$ & -- & 470 & $\mathrm{U}$ & - \\
\hline Gamma-chlordane & 480 & $\mathrm{U}$ & $\ldots$ & 470 & $\mathrm{U}$ & - \\
\hline Toxaphene & 950 & $\mathrm{U}$ & - & 940 & $\mathrm{U}$ & - \\
\hline Aroclor-1016 & 480 & 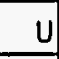 & - & 470 & $u$ & - \\
\hline Aroclor- 1221 & 480 & $\mathrm{U}$ & - & 470 & & - \\
\hline
\end{tabular}




\begin{tabular}{|c|c|c|c|c|}
\hline \multirow[b]{2}{*}{ Compound (ug/Kg) } & \multicolumn{4}{|c|}{ Table A-7.2 Pesticides/PCB's } \\
\hline & $\begin{array}{l}\bar{\alpha} \\
\sum_{0=}^{1} \\
b \\
b\end{array}$ & & $\sum_{\substack{i \\
b}}^{\sum_{0}^{T}}$ & $\left.\dot{0}^{*}\right)^{*}$ \\
\hline Aroclor-1232 & 480 & U) & 470 & U. \\
\hline Aroclor-1242 & 480 & v) - & 470 & $0 \mid-$ \\
\hline Aroclor-1248 & 480 & U] & 470 & U) -.. \\
\hline Aroclor-1254 & 950 & v] & 940 & U. \\
\hline Aroclor-1260 & 950 & 4] & 940 & U. - \\
\hline
\end{tabular}




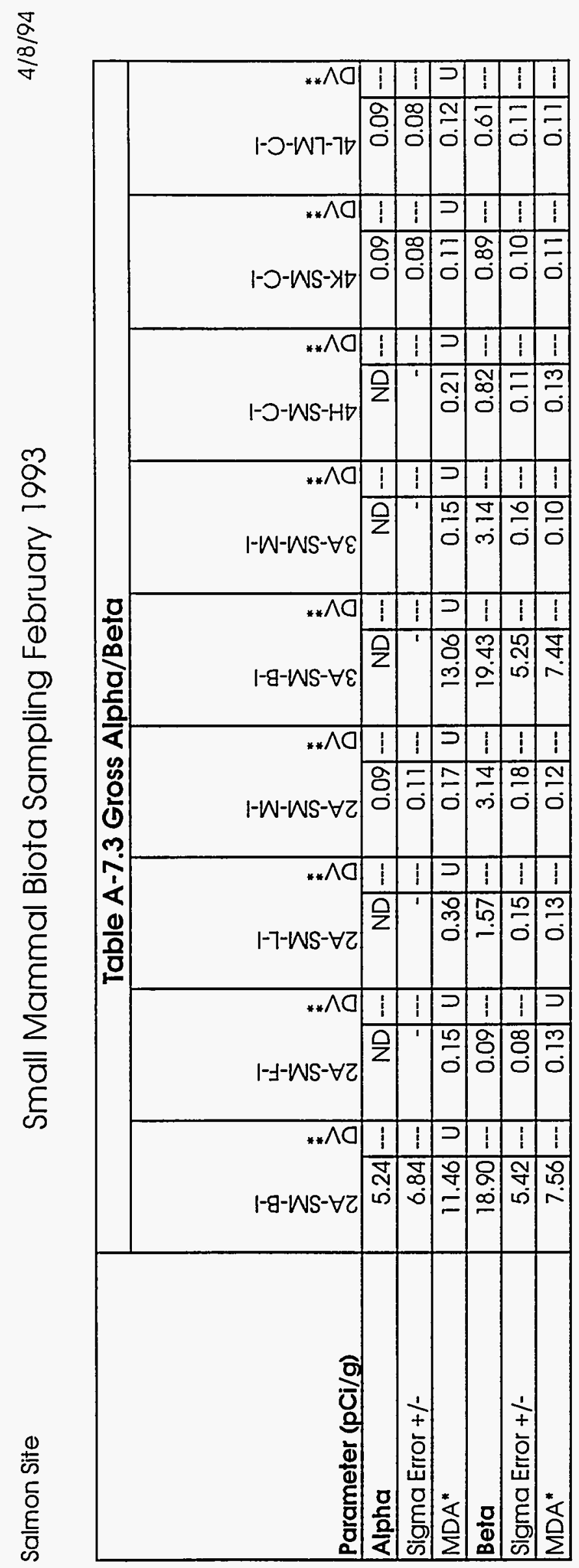




\begin{tabular}{|c|c|c|c|c|c|c|c|c|c|c|c|c|c|c|c|c|c|c|}
\hline \multirow[b]{2}{*}{ Parameter $(\mathrm{pCi} / \mathrm{g})$} & \multicolumn{18}{|c|}{ Table A-7.3 Gross Alpha/Beta } \\
\hline & $\begin{array}{l}\overline{0} \\
\sum_{\infty}^{1} \\
\frac{1}{1} \\
0\end{array}$ & $3_{0}^{*}$ & 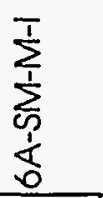 & 艾 & $\begin{array}{l}\overline{1} \\
\sum_{0}^{1} \\
0 \\
0 \\
0 \\
0\end{array}$ & 芳 & 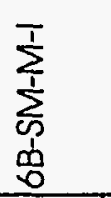 & ${ }_{2}^{*}$ & $\begin{array}{l}\bar{\phi} \\
\sum_{0}^{1} \\
0 \\
0\end{array}$ & $\stackrel{*}{*}$ & $\begin{array}{l}\sum_{\substack{1 \\
0}}^{1} \\
0 \\
0\end{array}$ & $\stackrel{3}{0}^{*}$ & $\begin{array}{l}\bar{\Phi} \\
\sum_{0}^{1} \\
\dot{1} \\
0 \\
0\end{array}$ & $\stackrel{*}{2}$ & 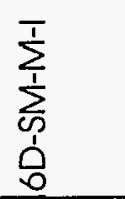 & $\stackrel{*}{3}$ & 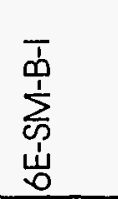 & $\stackrel{*}{2}$ \\
\hline Sigma Error $+1-$ & 5.35 & $\ldots$ & & $-\cdots$ & 7.86 & -- & 0.37 & $\ldots$ & & $\cdots$ & 0.58 & $-\ldots$ & 5.61 & -- & 0.13 & --- & 7 & - \\
\hline $\mathrm{MDA}^{*}$ & 7.97 & UJ & 0.31 & $\mathrm{U}$ & 10.06 & $-\cdots$ & 0.24 & $\ldots$ & 11.38 & UJ & 0.16 & $-\infty$ & 9.30 & UJ & 0.19 & $-\cdots$ & 9.84 & $\mathrm{U}$ \\
\hline Beta & 52.10 & -- & 2.92 & U & 107.27 & - & 3.28 & $\mathrm{U}$ & 85.70 & $-\ldots$ & 3.11 & U & 57.22 & - & 2.83 & U & 71.91 & -- \\
\hline Sigma Error $+1-$ & 5.78 & $-\ldots$ & 0.19 & -- & 8.78 & -- & 0.10 & -- & 7.77 & $-\infty$ & 0.18 & -- & 7.11 & $-\cdots$ & 0.17 & $\ldots$ & 7.08 & - \\
\hline $\mathrm{MDA}^{*}$ & 5.70 & -- & 0.13 & -- & 7.03 & -- & 0.12 & $\ldots$ & 7.35 & -- & 0.12 & -- & 7.47 & $-\cdots$ & 0.13 & -- & 6.73 & $\ldots$ \\
\hline
\end{tabular}




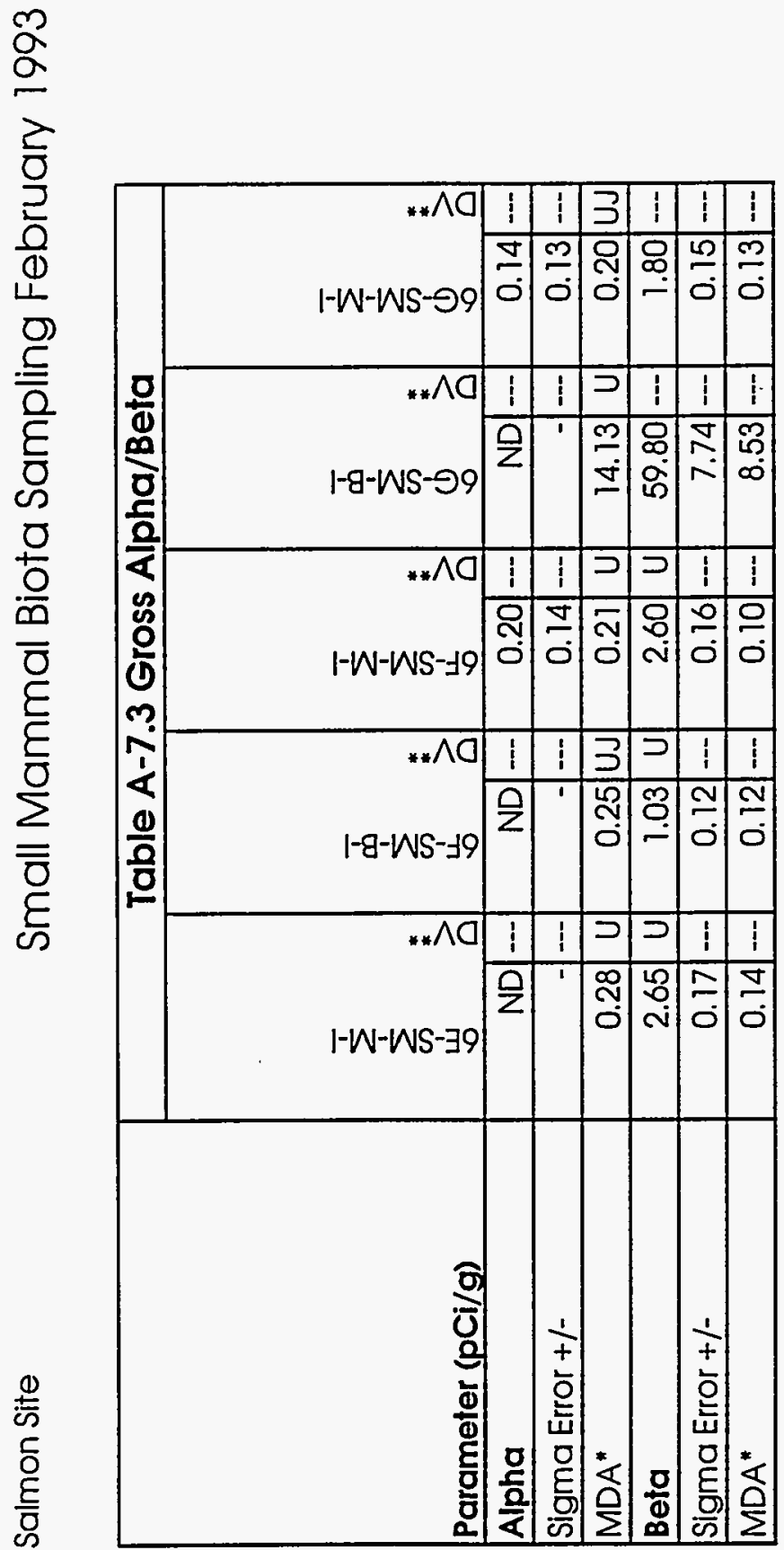

$L$
:
0
0
0
0 


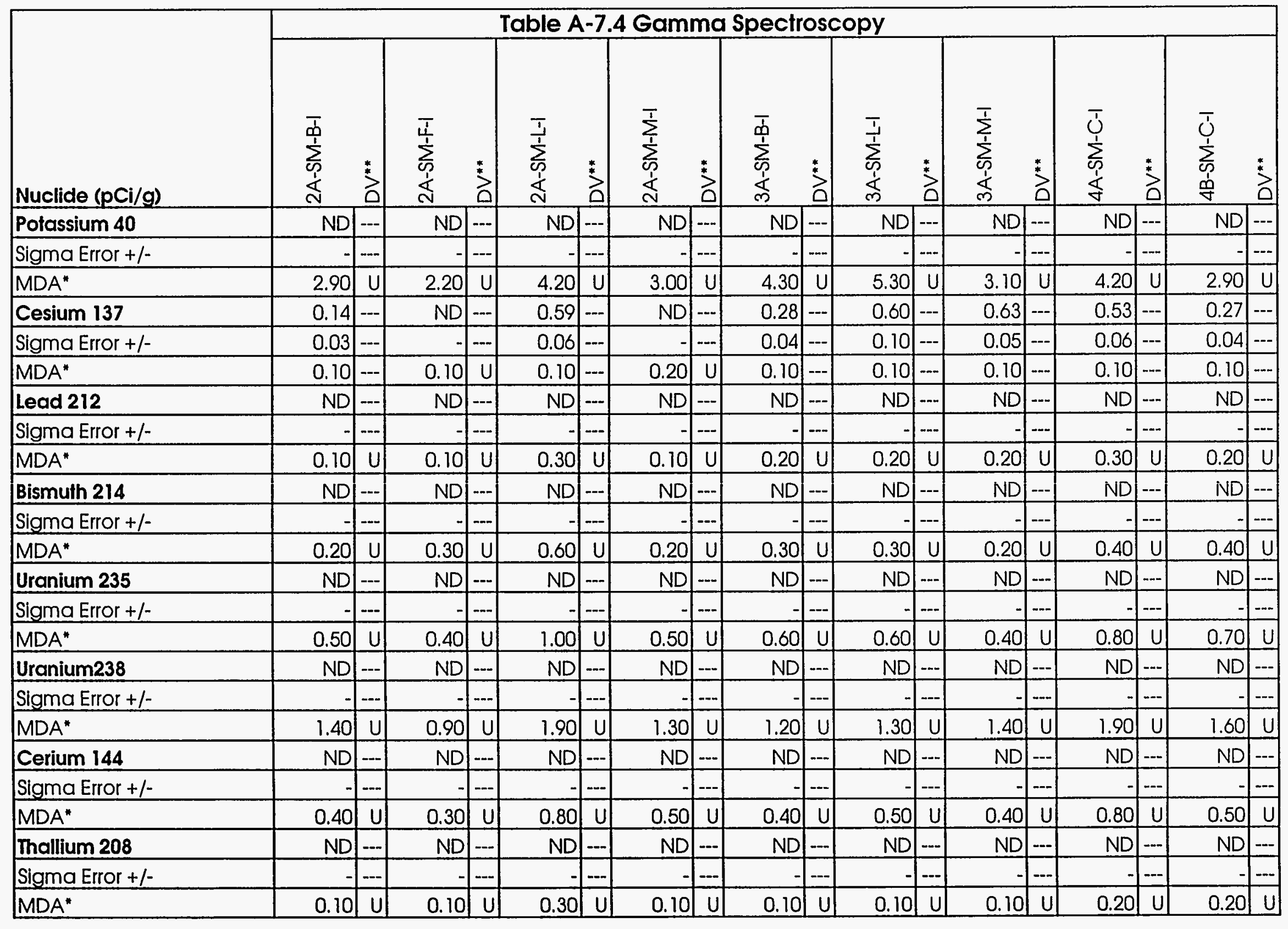




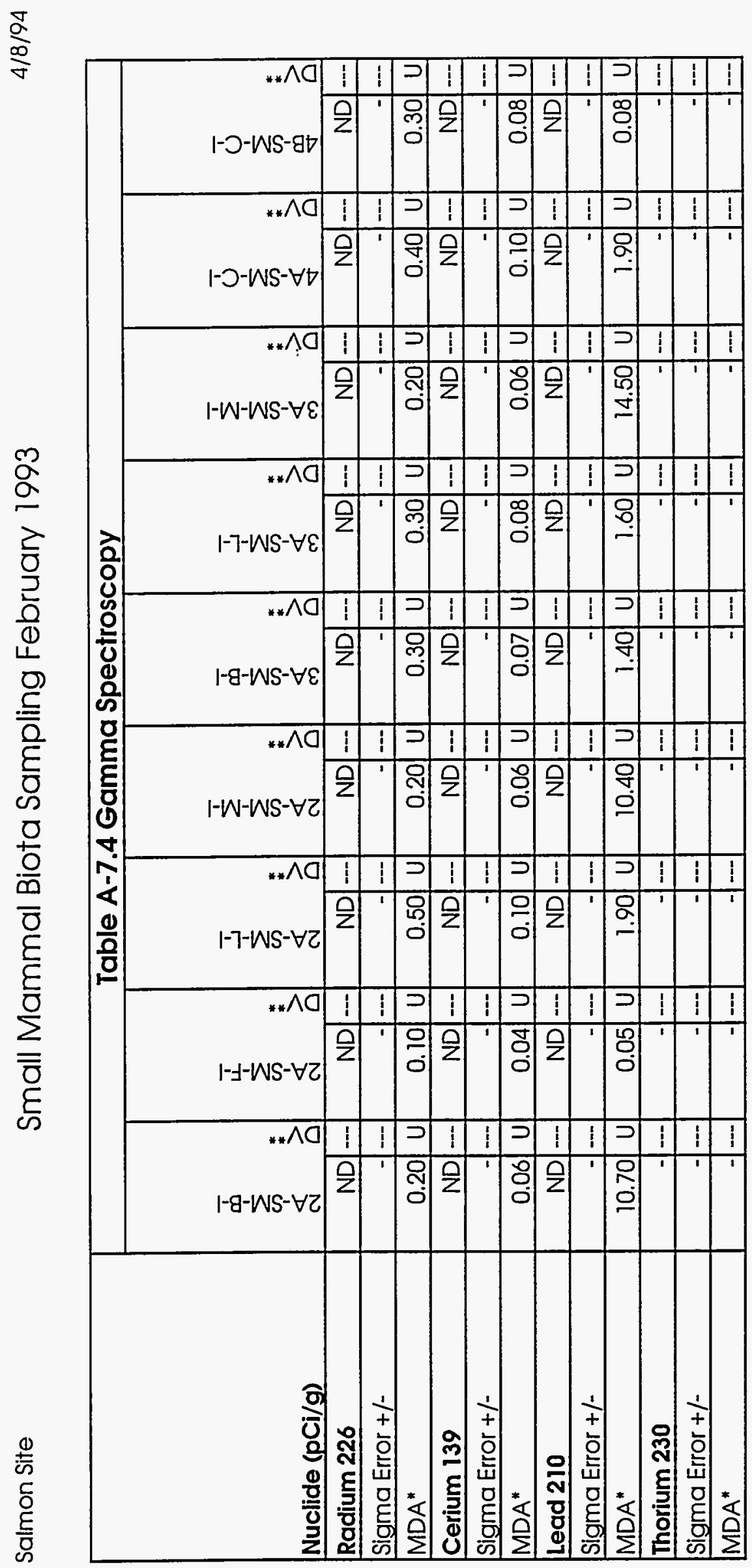

$\infty$
ป
0
0
0
0

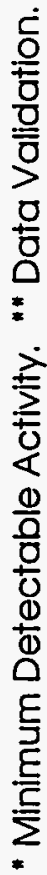




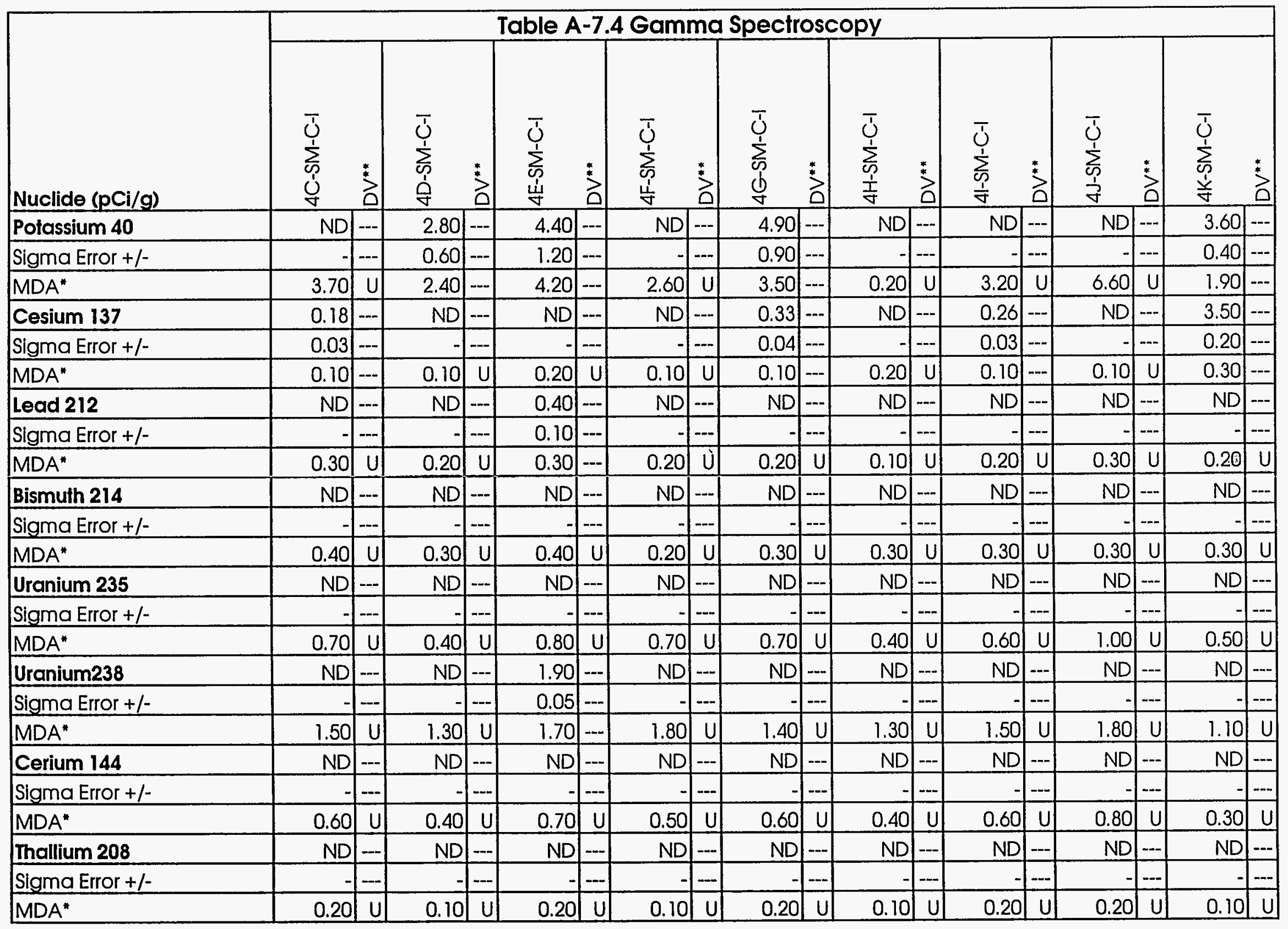

"Minimum Detectable Activity. " " Data Validation. 


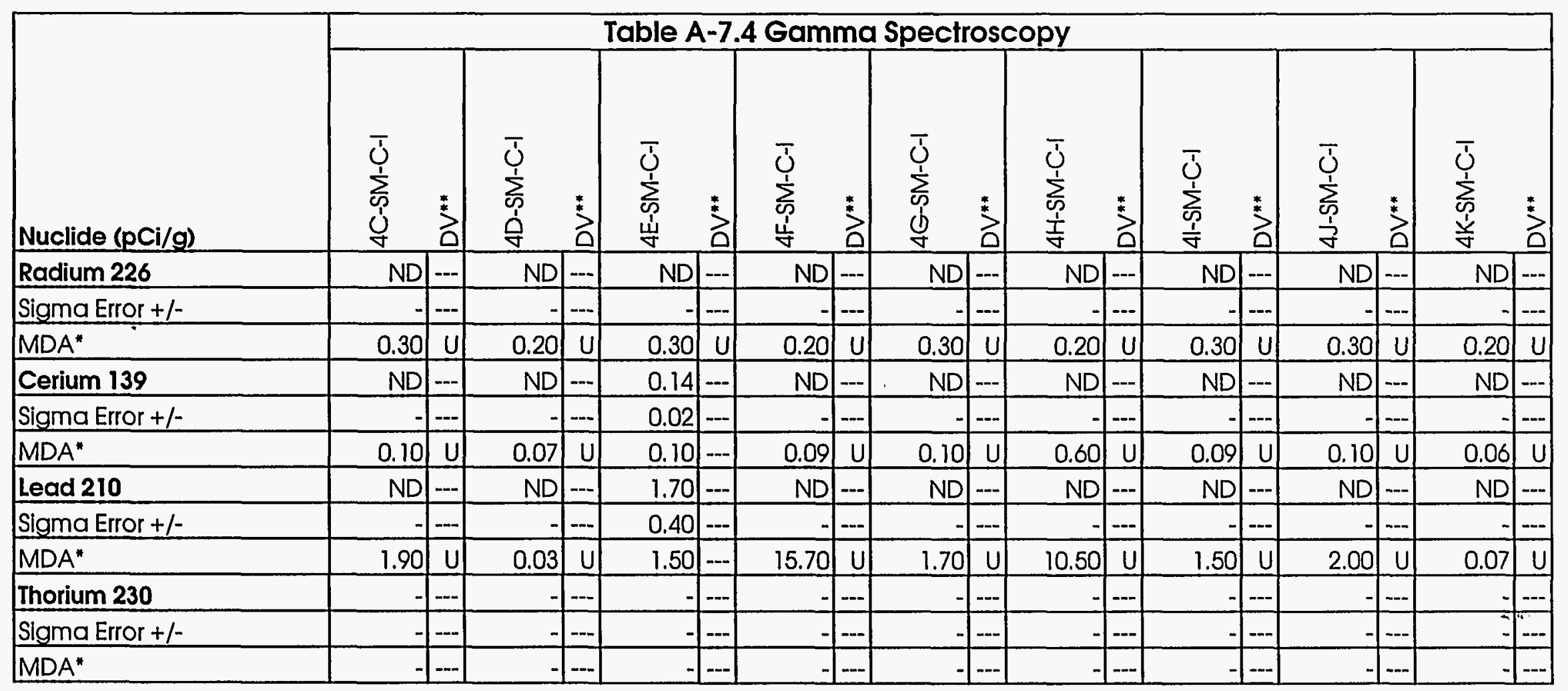




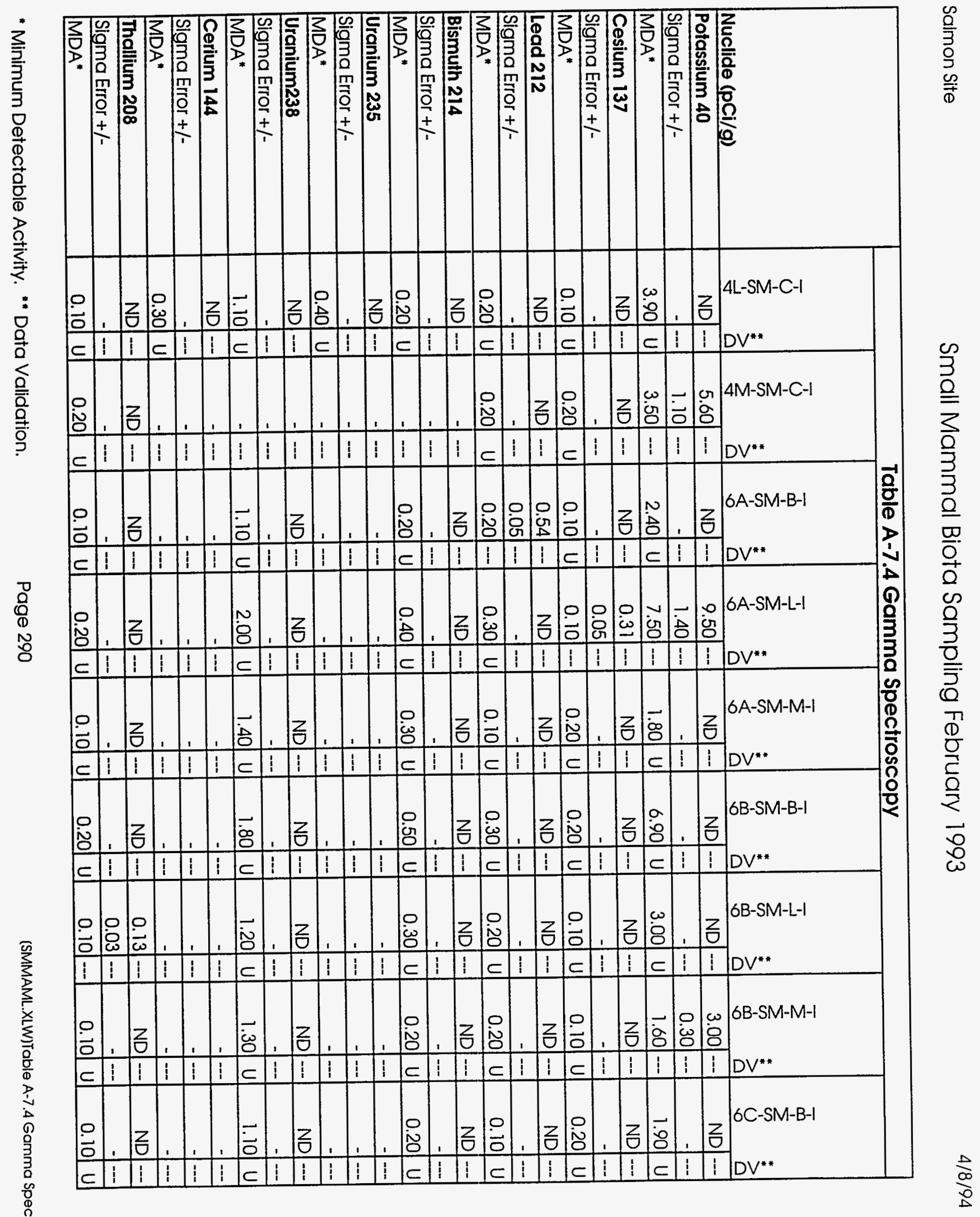




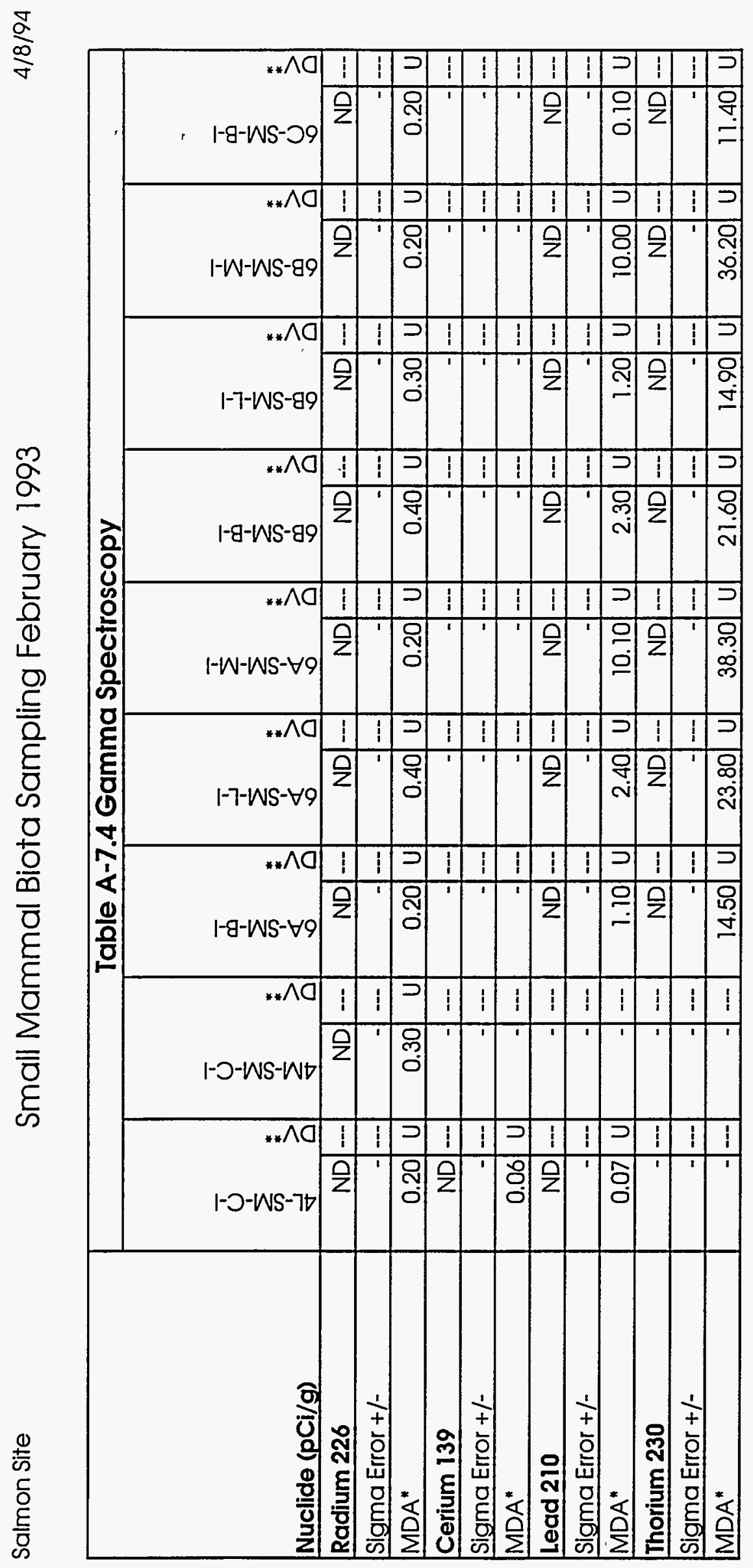




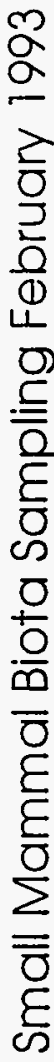

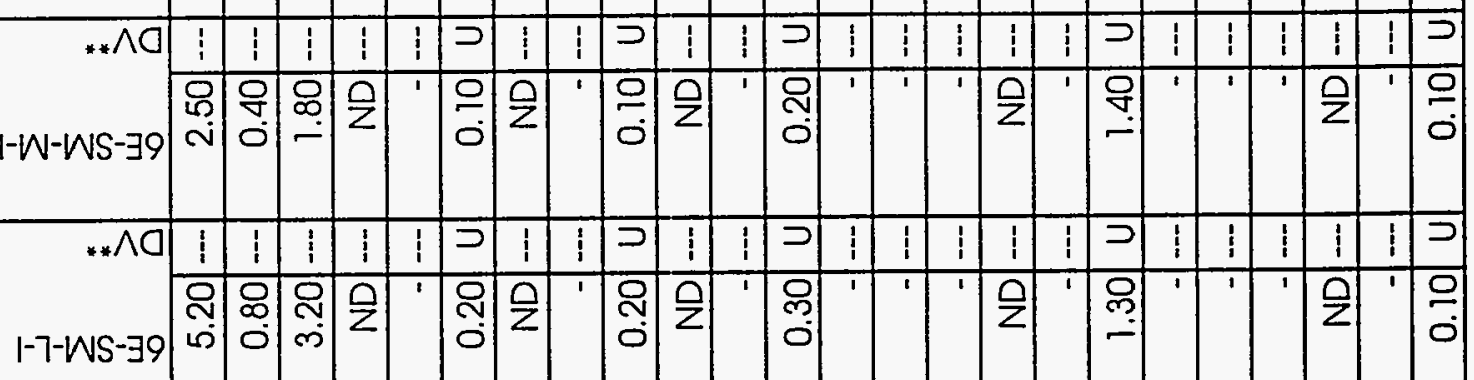

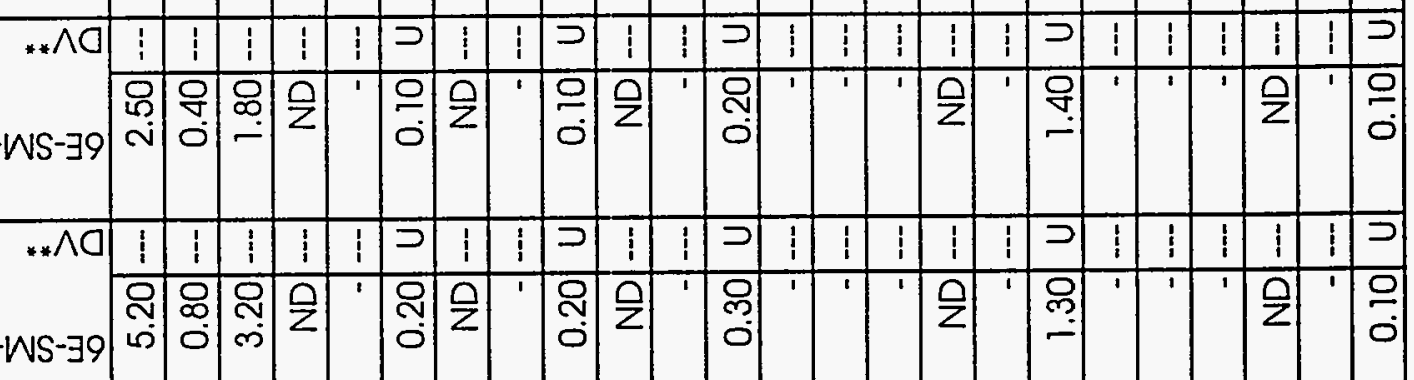

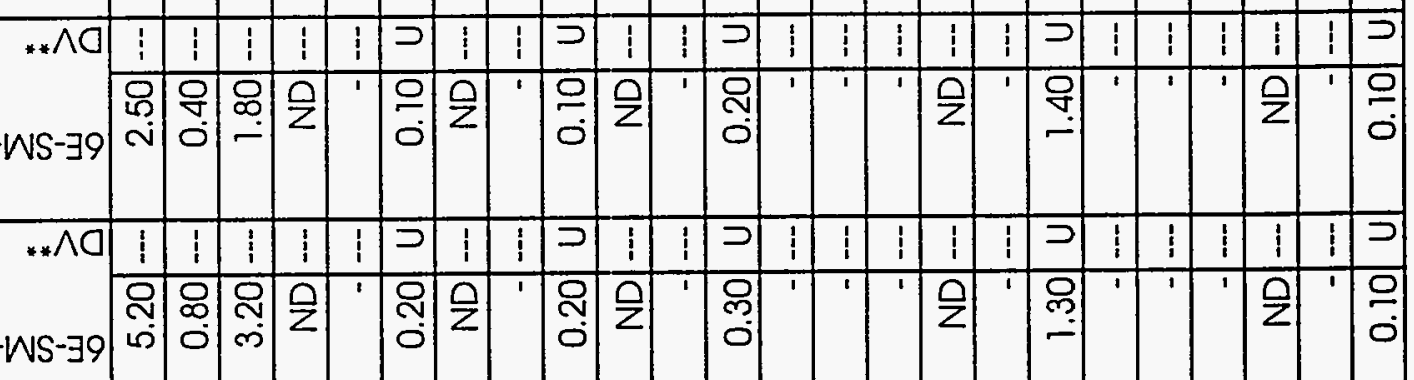

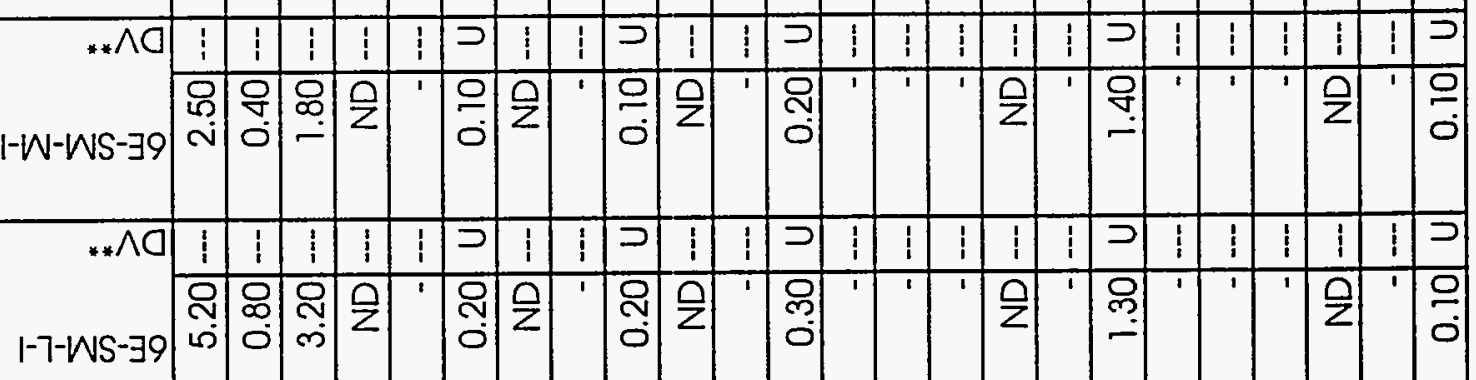

1-g-WS-19

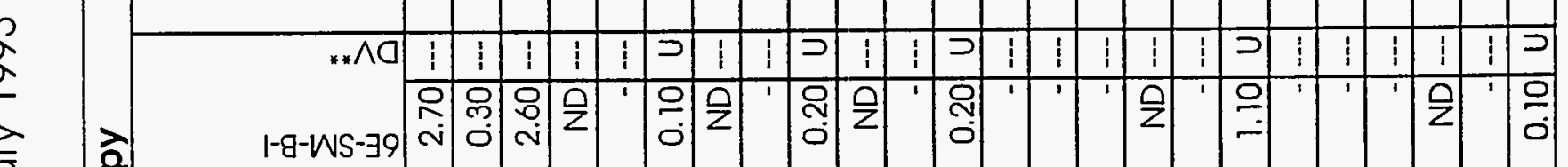

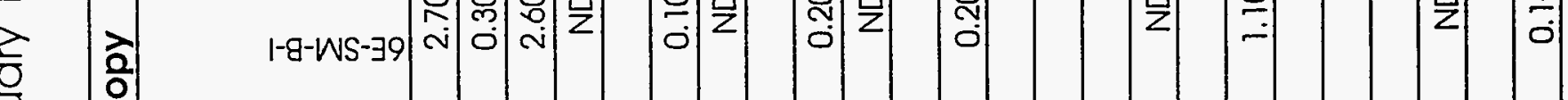

0

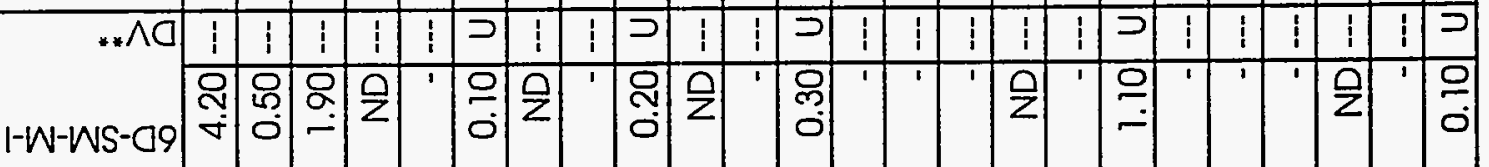
I-W-WS-

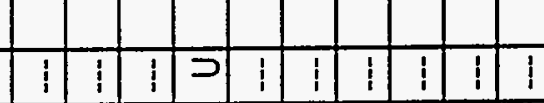

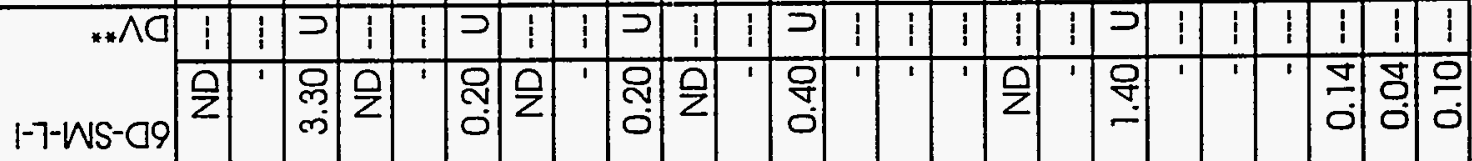

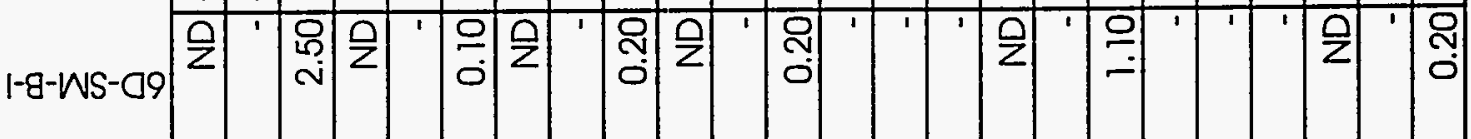

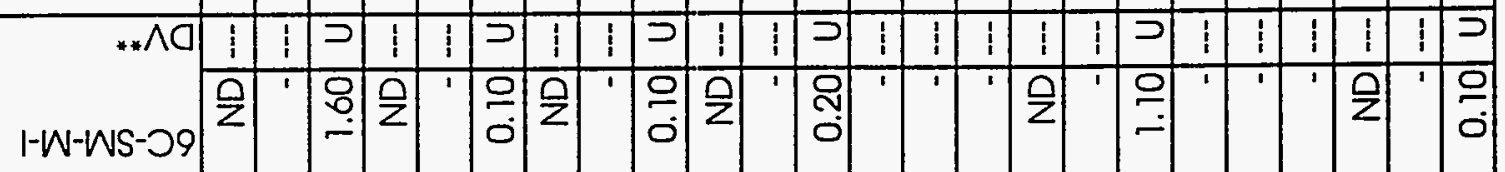

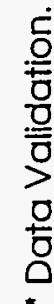

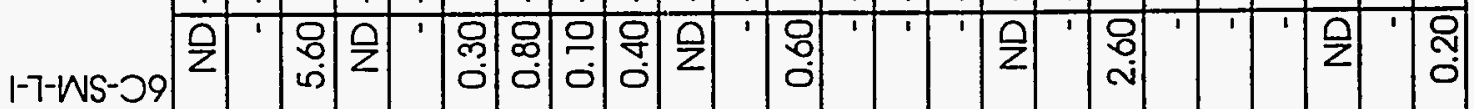

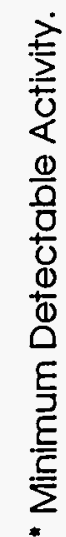




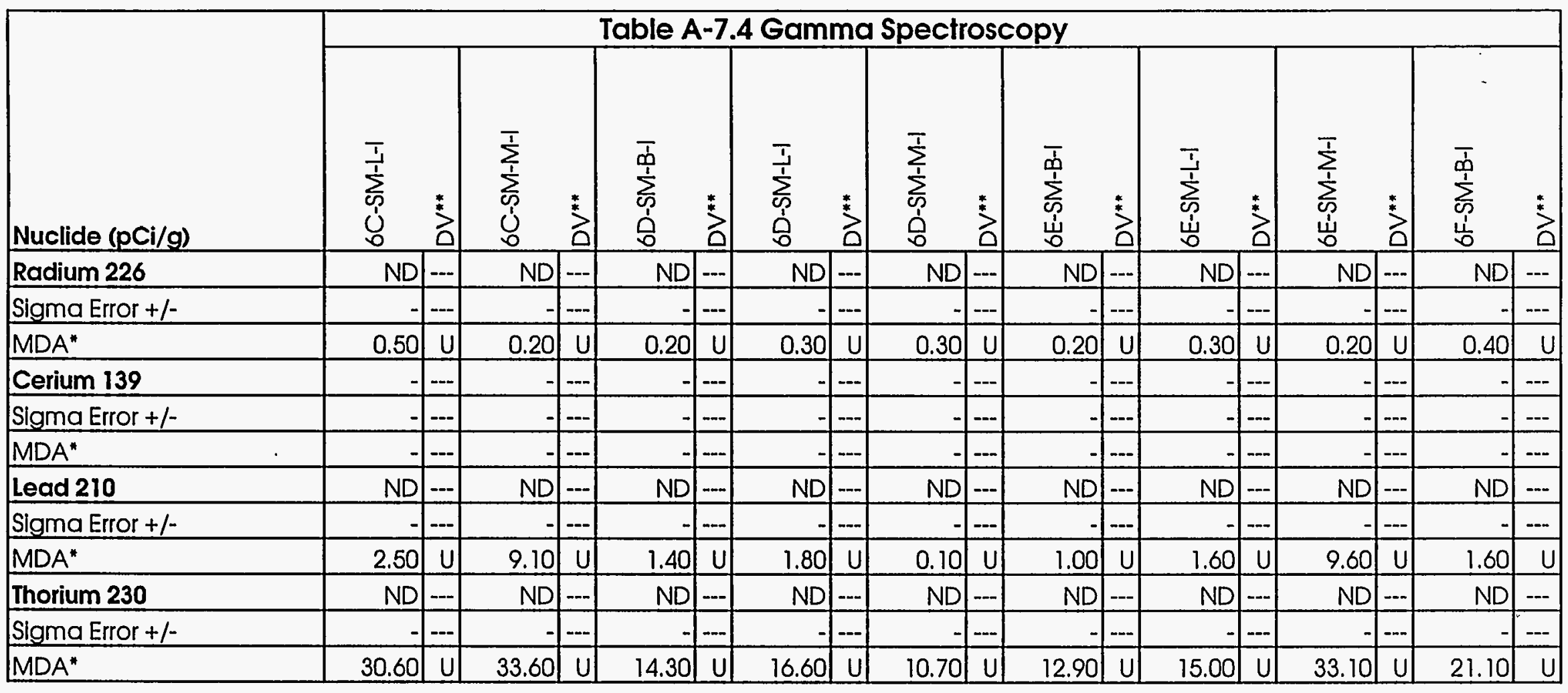




\begin{tabular}{|c|c|c|c|c|c|c|c|c|c|c|}
\hline \multirow[b]{2}{*}{ Nuclide (pCi/g) } & \multicolumn{10}{|c|}{ Table A-7.4 Gamma Spectroscopy } \\
\hline & 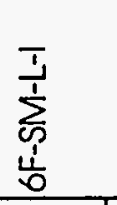 & $\stackrel{3}{*}^{*}$ & $\begin{array}{l}\sum_{i}^{T} \\
\sum_{0}^{1} \\
1 \\
0\end{array}$ & 艾 & $\begin{array}{l}\bar{\phi} \\
\sum_{\infty}^{1} \\
\phi \\
0\end{array}$ & ${ }^{*}$ & $\begin{array}{l}\overline{1} \\
\sum_{0}^{1} \\
b \\
0\end{array}$ & 莡 & 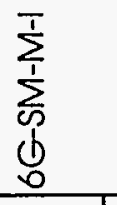 & $\stackrel{*}{*}$ \\
\hline Potassium 40 & 9.80 & -- & 3.10 & -- & ND & --- & 1.90 & --- & 3.90 & --- \\
\hline Sigma Error $+1-$ & 1.20 & $-\cdots$ & 0.40 & -- & - & --- & 0.40 & $\cdots$ & 0.40 & --- \\
\hline $\mathrm{MDA}^{*}$ & 7.70 & $-\cdots$ & 1.80 & $-\cdots$ & 6.50 & $U$ & 1.68 & --- & 1.70 & --- \\
\hline Cesium 137 & ND & --- & ND & -- & ND & $-\cdots$ & ND & $\cdots$ & ND & $-\cdots$ \\
\hline Sigma Error $+1-$ & & $\ldots$ & & \begin{tabular}{|l|}
- \\
\end{tabular} & - & $-\ldots$ & - & \begin{tabular}{|l|}
-- \\
\end{tabular} & - & -- \\
\hline $\mathrm{MDA}^{*}$ & 0.20 & $\mathrm{U}$ & 0.10 & U & 0.20 & $U$ & 0.10 & 4 & 0.10 & $\mathrm{U}$ \\
\hline Lead 212 & ND & $-\cdots$ & ND & \begin{tabular}{|l|}
-- \\
\end{tabular} & ND & -- & ND & $-\cdots$ & ND & -- \\
\hline Sigma Error + - & -1 & --- & - & -- & - & $-\cdots$ & - & $-\cdots$ & - & -- \\
\hline $\mathrm{MDA}^{*}$ & 0.40 & $\mathrm{U}$ & 0.20 & $u$ & 0.30 & 4 & 0.10 & $U$ & 0.20 & $U$ \\
\hline Bismuth 214 & ND & $\ldots$ & ND & $\ldots$ & ND & $\ldots$ & ND & -- & ND & $--\cdot$ \\
\hline Sigma Error + /- & & $-\cdots$ & -1 & $\cdots$ & - & -- & - & -- & - & $-\cdots$ \\
\hline $\mathrm{MDA}^{*}$ & 0.40 & $\mathrm{U}$ & 0.20 & $\mathrm{U}$ & 0.50 & $\mathrm{U}$ & 0.20 & $U$ & 0.20 & $\mathrm{U}$ \\
\hline Uranium 235 & - & $\ldots$ & - & $\ldots$ & ND & $\ldots$ & - & --- & - & --- \\
\hline Sigma Error + $/$ - & - & $\ldots$ & - & -- & - & -- & -1 & -- & - & $-\cdots$ \\
\hline MDA* & -1 & -- & - & -- & 0.10 & U & - & $\ldots$ & - & $\ldots$ \\
\hline Uranium238 & $\mathrm{ND}$ & --- & $\mathrm{ND}$ & -- & ND & $-\cdots$ & $\mathrm{ND}$ & $\ldots$ & $\mathrm{ND}$ & $-\cdots$ \\
\hline Sigma Error + /- & & -- & - & -- & - & --- & - & --- & 1 & --- \\
\hline MDA" & 2.20 & $U$ & 1.10 & U & 1.80 & U & 1.00 & $\mathrm{U}$ & 1.40 & U \\
\hline Cerium 144 & -1 & $-\cdots$ & - & $\ldots$ & ND & -- & - & $-\cdots$ & - & $-\cdots$ \\
\hline Sigma Error +1- & - & $-\cdots$ & - & $-\cdots$ & & $-\cdots$ & - & $-\cdots$ & - & $-\cdots$ \\
\hline $\mathrm{MDA}^{*}$ & & - & - & -- & 0.90 & $U$ & - & $\ldots$ & 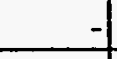 & $-\cdots$ \\
\hline Thallium 208 & ND & --- & $\mathrm{ND}$ & $-\ldots$ & ND & -- & ND & $-\cdots$ & ND & $\ldots$ \\
\hline Sigma Error $+1-$ & -1 & -- & - & $-\cdots$ & & $-\cdots$ & - & $\ldots$ & -1 & - \\
\hline MDA* & 0.20 & $\mathrm{U}$ & 0.10 & $u$ & 0.20 & 4 & 0.10 & $U$ & 0.10 & $U$ \\
\hline
\end{tabular}




\begin{tabular}{|c|c|c|c|c|c|c|c|c|c|c|}
\hline \multirow[b]{2}{*}{ Nuclide (pCi/g) } & \multicolumn{10}{|c|}{ Table A-7.4 Gamma Spectroscopy } \\
\hline & $\begin{array}{l}\frac{T}{1} \\
\sum_{0}^{1} \\
1 \\
0 \\
0\end{array}$ & $\stackrel{*}{0}^{*}$ & 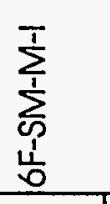 & ${ }_{0}^{*}$ & $\begin{array}{l}\bar{\phi} \\
\sum_{\infty}^{1} \\
\phi \\
0 \\
0\end{array}$ & $\stackrel{*}{*}$ & 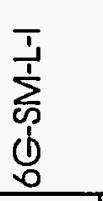 & $3_{0}^{*}$ & $\begin{array}{l}\sum_{i}^{T} \\
\sum_{\infty}^{1} \\
0 \\
0 \\
0\end{array}$ & $\stackrel{*}{3}$ \\
\hline Radium 226 & ND & -- & ND & -- & $\mathrm{ND}$ & $-\infty$ & ND & $\ldots$ & ND & $\ldots$ \\
\hline Sigma Error +1- & & $-\cdots$ & & -- & - & $-\infty$ & - & $-\cdots$ & - & $-\cdots$ \\
\hline MDA* & 0.40 & $\mathrm{U}$ & 0.20 & 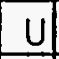 & 0.40 & $\mathrm{U}$ & 0.20 & $\mathrm{U}$ & 0.20 & $\mathrm{U}$ \\
\hline Cerium 139 & & -- & & - & ND & $-\infty$ & - & $\cdots$ & - & $\ldots$ \\
\hline Sigma Error +1- & - & -- & - & -- & - & $-\cdots$ & -1 & $\cdots$ & - & -- \\
\hline MDA" & - & -- & - & $-\cdots$ & 0.10 & U & - & -- & - & -- \\
\hline Lead 210 & ND & $\cdots$ & ND & -- & $\mathrm{ND}$ & $-\infty$ & $\mathrm{ND}$ & $\cdots$ & ND & $-\cdots$ \\
\hline Sigma Error +1- & 7 & -- & & -- & & -- & - & -- & - & -- \\
\hline MDA* & 2.00 & 4 & 10.40 & U & 2.20 & U & 0.03 & $U$ & 9.70 & $\mathrm{U}$ \\
\hline Thorium 230 & 22.80 & $\ldots$ & ND & -- & & $-\cdots$ & ND & -- & ND & --- \\
\hline Sigma Error +1- & 4.40 & $\cdots$ & & -- & & -- & - & $\ldots$ & - & -- \\
\hline $\mathrm{MDA}^{*}$ & 18.90 & -- & 36.00 & U & & $-\cdots$ & 9.30 & $\mathrm{U}$ & 36.00 & $\mathrm{U}$ \\
\hline
\end{tabular}




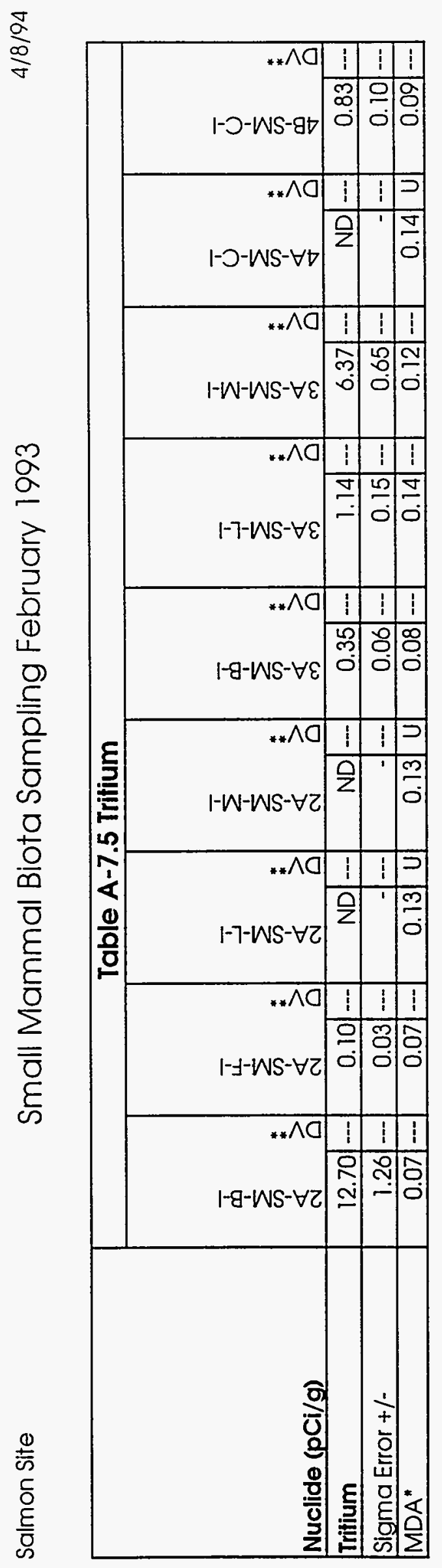

$\stackrel{2}{8}$
0
0
0
0

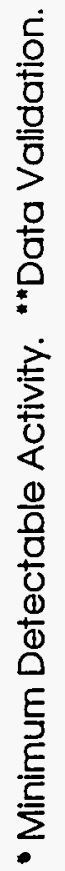




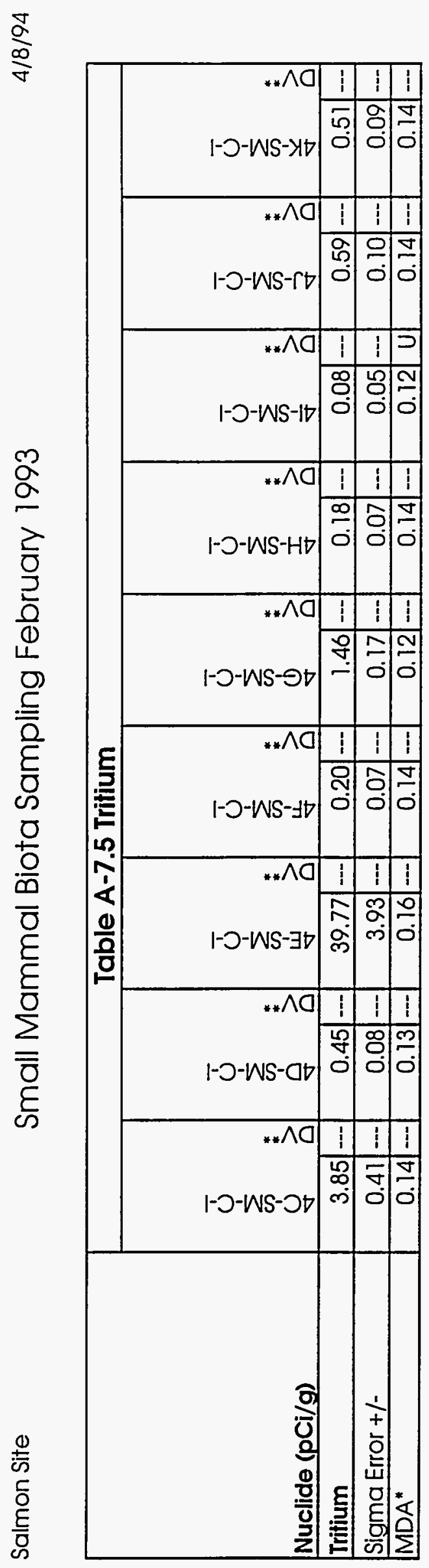

$\widehat{a}$
o
d
$\alpha$

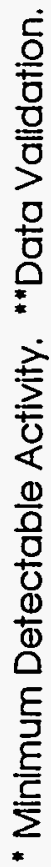




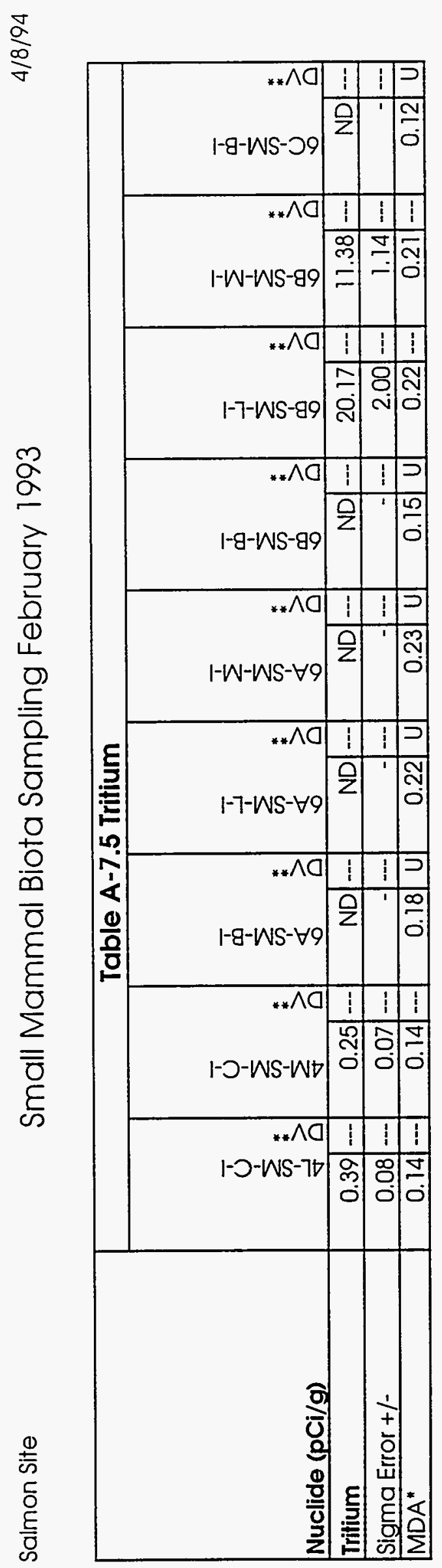

$\stackrel{8}{0}$
d
g
0

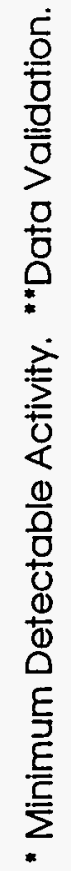




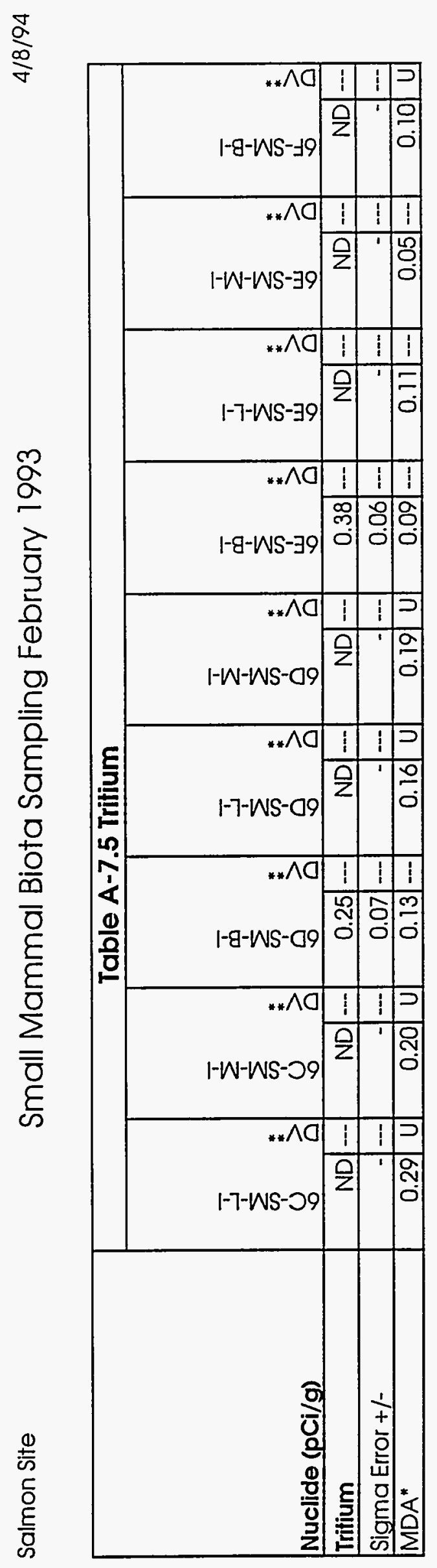

$\stackrel{2}{\alpha}$
$\stackrel{0}{0}$
$\stackrel{0}{0}$
0
0

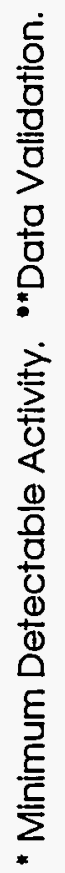




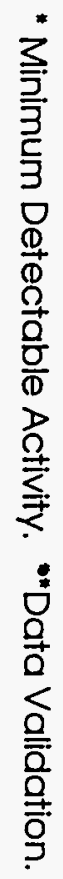

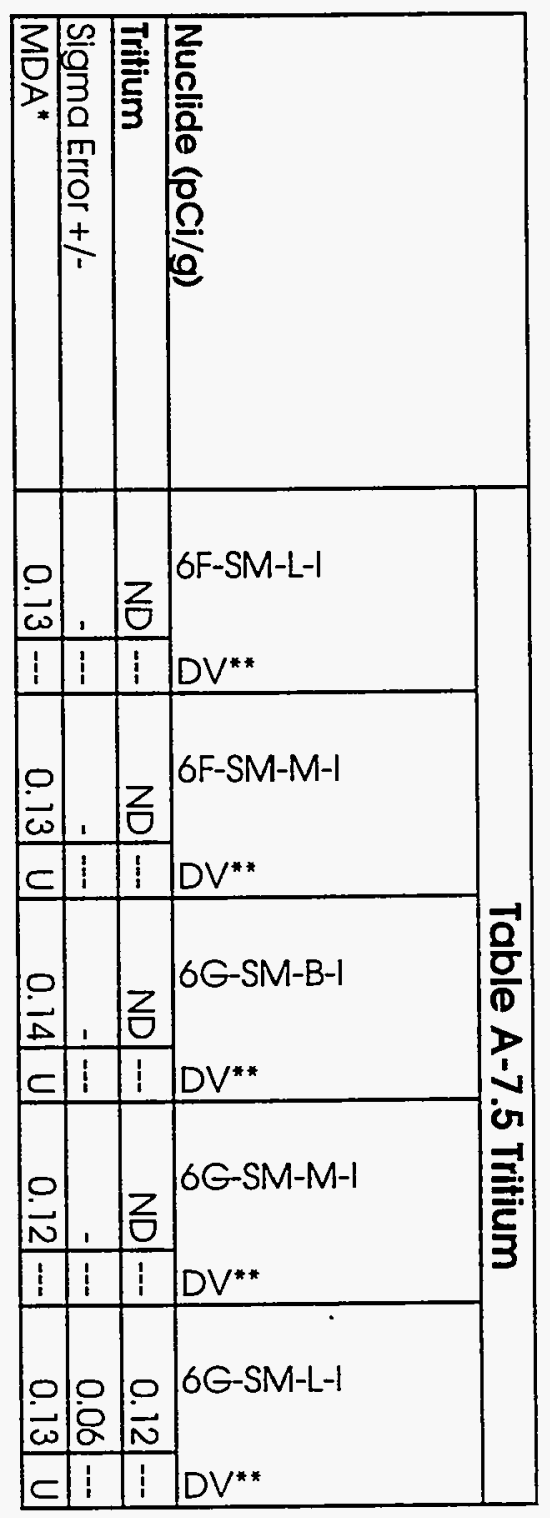

$\infty$
0
3
0
$\frac{0}{3}$
$\stackrel{\infty}{7}$
$\overline{1}$

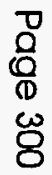

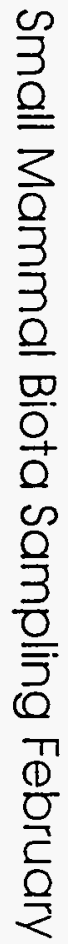

డి 


\begin{tabular}{|c|c|c|c|c|c|c|c|c|c|c|c|c|c|c|c|c|c|c|c|c|c|}
\hline \multirow[b]{2}{*}{ Compound (mg/Kg) } & \multicolumn{21}{|c|}{ Table A-8.1 Metals } \\
\hline & $\frac{\bar{d}}{\frac{1}{\vdots}}$ & & & $\sum_{\substack{\dot{1} \\
\dot{1}}}^{\frac{T}{1}}$ & & & $\begin{array}{l}\sum_{j}^{T} \\
\frac{1}{\alpha} \\
\end{array}$ & & $\stackrel{2}{0}^{*}$ & 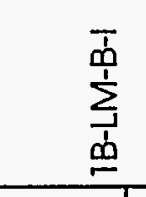 & & 艾 & $\frac{\sum_{j}^{T}}{\dot{1}}$ & & $\stackrel{*}{*}$ & $\frac{\prod_{1}^{T}}{\sum_{1}^{1}}$ & & $\stackrel{*}{2}$ & 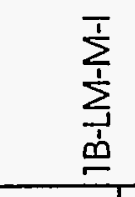 & & 草 \\
\hline Aluminum & 7.4 & $\mathrm{~B}$ & $\mathrm{~J}$ & 2.5 & $\mathrm{~B}$ & 4 & 1.5 & $\mathrm{~B}$ & U & 5.8 & $\mathrm{~B}$ & $\mathrm{u}$ & 2.1 & $B$ & $\mathrm{U}$ & 1.8 & B & $\mathrm{u}$ & 1.9 & $B$ & $\mathrm{U}$ \\
\hline Antimony & 2.6 & U & $-{ }_{-1}$ & 4.7 & $\mathrm{u}$ & - & 2.4 & $u$. & $\ldots$ & 2.6 & 4 & -- & 2.7 & $u$ & $\ldots$ & 4.5 & $\mathrm{u}$. & $-\cdots$ & 2.5 & $u$ & $\ldots$ \\
\hline Arsenic & 0.48 & UW & UJ & 0.07 & 4 & - & \begin{tabular}{l|l}
0.05 & 1 \\
\end{tabular} & uw & uJ & 0.46 & UW & UJ & 0.05 & uW & UJ & 0.07 & 4. & $\ldots$ & 0.04 & uW & UJ \\
\hline Barium & 370.00 & & $\therefore$ & 0.94 & $\mathrm{~B}$ & $\mathrm{~J}$ & 0.39 & $\mathrm{~B}$ & $\mathrm{~J}$ & 345.00 & & -- & 0.80 & $\mathrm{~B}$ & $\mathrm{~J}$ & 0.61 & B & $\mathrm{J}$ & 0.28 & $\mathrm{~B}$ & $\mathrm{~J}$ \\
\hline Beryllium & 0.04 & $u$ & $\ldots$ & 0.08 & $u$ & $-{ }_{-1}$ & 0.04 & $u$ & $\ldots$ & 0.04 & 4 & $\ldots$ & 0.04 & $u$. & $\ldots$ & 0.07 & U. & $\ldots$ & 0.04 & 4. & $\ldots$ \\
\hline Cadmium & 0.13 & 4 & -- & 0.23 & 4 & -- & 0.12 & 4 & $\ldots$ & 0.15 & B & $\mathrm{J}$ & 0.13 & 4. & $\ldots$ & 0.22 & 4. & $-\ldots$ & 0.12 & 4. & - \\
\hline Calcium & 209000 & & $-\ldots$ & 440 & & $\cdots$ & 163 & $\mathrm{~B}$ & $\mathrm{~J}$ & 199000 & & $-\ldots$ & 380 & & -- & 355 & B & $\mathrm{J}$ & 185 & B & $\mathrm{J}$ \\
\hline Chromium & 3.40 & & $\ldots$ & 0.58 & $\mathrm{~B}$ & $\mathrm{~J}$ & 0.22 & 8 & $\mathrm{~J}$ & 3.20 & & $-\ldots$ & 0.61 & & $\ldots$ & 0.39 & $\mathrm{~B}$ & $\mathrm{~J}$ & 0.47 & & $\ldots$ \\
\hline Cobalt & 0.28 & 4 & $-\ldots$ & 0.50 & $U$ & $\ldots$ & 0.26 & 4 & $\ldots$ & 0.28 & 4 & $\ldots$ & 0.29 & 4. & $\ldots$ & 0.48 & 4. & $\ldots$ & 0.27 & 4. & $\cdots$ \\
\hline Copper & 0.28 & $B$ & $u$ & 62.60 & & $\ldots$ & 1.50 & & -- & 0.17 & 4 & - & 3.00 & & $\ldots$ & 33.50 & & -- & 1.70 & & -- \\
\hline Iron & 10.4 & & - & 146.0 & & -- & 24.0 & & $\ldots$ & 2.8 & $B$ & $\mathrm{~J}$ & 35.8 & & -- & 213.0 & & -- & 29.9 & & $\ldots$ \\
\hline Lead & 13.90 & & $\ldots$ & 0.05 & $\mathrm{~B}$ & $\mathrm{~J}$ & 0.04 & $U$ & -- & 0.38 & & - & 0.27 & & $\ldots$ & 0.05 & uW & UJ & 0.06 & $u$ & UJ \\
\hline Magnesium & 3350.0 & & - & 184.0 & $B$ & $\mathrm{~J}$ & 256.0 & & $\ldots$ & 3100.0 & & $\ldots$ & 71.7 & $B$ & $\mathrm{~J}$ & 199.0 & $B$ & $\mathrm{~J}$ & 270.0 & & $\ldots$ \\
\hline Manganese & 1.20 & & -- & 6.30 & & -1 & 4.20 & & $\ldots$ & 1.30 & & - & 2.60 & & $-\ldots$ & 5.20 & & $\ldots$ & 3.30 & & $\ldots$ \\
\hline Mercury & 0.04 & 4 & -- & 0.04 & $B$ & $\mathrm{~J}$ & 0.07 & & $\ldots$ & 0.03 & U & $\ldots$ & 0.04 & 4 & $\ldots$ & 0.06 & $B$ & $\mathrm{~J}$ & 0.19 & & -- \\
\hline Nickel & 0.94 & $\mathrm{U}$ & -- & 1.70 & 0 & -- & 0.88 & 4 & $\ldots$ & 0.94 & U & -- & 0.97 & 4 & $\ldots$ & 1.60 & $\mathrm{U}$ & $\ldots$ & 0.91 & 4 & -- \\
\hline Potassium & 356 & & $u$ & 2620 & & - & 3380 & & -- & 368 & & 4 & 821 & & $\ldots$ & 3200 & & $\ldots$ & 3410 & & -- \\
\hline Selenium & 0.48 & 4 & $\cdots$ & 0.73 & 4 & - & 0.45 & 4 & $\ldots$ & 0.46 & 4 & - & 0.47 & 4 & $\ldots$ & 0.70 & 4 & -- & 0.43 & 4 & -- \\
\hline Silver & 0.16 & 4 & $-\infty$ & 0.29 & 4 & - & 0.15 & 4 & - & 0.16 & 4 & $\ldots$ & 0.17 & 4 & -- & 0.28 & $U$ & -- & 0.16 & U & - \\
\hline Sodium & 5190.0 & & $\ldots$ & 925.0 & & $\ldots$ & 735.0 & & $\ldots$ & 5220.0 & & $\ldots$ & 527.0 & & $\ldots$ & 906.0 & & $\ldots$ & 635.0 & & 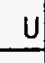 \\
\hline Thallium & 0.05 & UW & UJ & 0.07 & $u w$ & UJ & 0.05 & UW & UJ & 0.05 & 4 & $-\ldots$ & 0.05 & UW & UJ & 0.07 & uW & UJ & 0.04 & uw & UJ \\
\hline \begin{tabular}{|l} 
Vanadium \\
\end{tabular} & 0.17 & $u$ & - & 0.30 & $u$ & - & 0.16 & 4 & - & 0.17 & 4 & $\ldots$ & 0.17 & 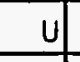 & -- & 0.29 & 4 & $\ldots$ & 0.16 & 4 & $\ldots$ \\
\hline Zinc & 99.1 & & $\ldots$ & 32.2 & & - & 31.3 & & $-\infty$ & 70.4 & & $\ldots$ & 7.6 & & $\ldots$ & 39.8 & & $\ldots$ & 43.7 & & - \\
\hline
\end{tabular}




\begin{tabular}{|c|c|c|c|c|c|c|c|c|c|c|c|c|c|c|c|c|c|}
\hline$\cdots$ & & | & $1-1$ & | & -1 & & $\mid 8.9 \varepsilon$ & - & げ & - & & $\overline{\varepsilon^{\prime}} \varepsilon$ & -1 & D'\&s & - & 9.19 & ou!z \\
\hline$-\infty n$ & n & 910 & $-\pi$ & $82^{\prime} 0$ & -3 & $n$ & $82^{\circ} 0$ & $\cdots n$ & $\angle L^{\circ} O$ & $-n$ & n & $\angle 10$ & $--n$ & 01.0 & $-n$ & $E 1^{\circ} 0$ & un!pous $\wedge$ \\
\hline 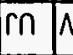 & $\mathrm{Mn}$ & $90^{\circ} 0$ & $-\cdots \mid n$ & $60^{\circ} 0$ & $m$ & $M n$ & $90^{\circ} 0$ & $\cdots \mid n$ & $50^{\circ} 0$ & $n \sqrt{M}$ & $M \cap S$ & $50^{\prime} 0$ & \begin{tabular}{|l|l|}
$--n$ \\
\end{tabular} & $90^{\circ} 0$ & $-\ln$ & $50^{\circ} 0$ & Un!||Dบ1 \\
\hline$n$ & & 0.899 & $-\cdots$ & 00811 & -1 & & $00^{\prime} 0921$ & $\cdots$ & 0.110 & \begin{tabular}{l|l}
$r$ & 9 \\
\end{tabular} & 0 & $\overline{0} 812$ & - & 0.0699 & - & $0.0 Z \angle S$ & wn!pos \\
\hline \begin{tabular}{|l|r|}
$-\cdots$ & $n$ \\
\end{tabular} & & $91^{\circ} 0$ & \begin{tabular}{|l|l|}
$-\cdots$ & $n$ \\
\end{tabular} & $\angle Z^{\prime} O$ & -1 & $\bar{n}$ & $\angle Z^{\prime} O$ & $-\cdots$ & $\angle 10^{\prime}$ & \begin{tabular}{|l|l|}
- & $n$ \\
\end{tabular} & $n$ & 910 & \begin{tabular}{|l|l|}
- & $n$ \\
\end{tabular} & $\varepsilon 1^{\circ} 0$ & $-1 n$ & $\varepsilon L^{\circ} 0$ & 1əA\|S \\
\hline$-\cdots$ & $\bar{n}$ & $60^{\circ} 0$ & $\cdots$ & $88^{\circ} 0$ & $-\theta$ & $n$ & $69^{\prime} 0$ & \begin{tabular}{|l|l|}
$\cdots$ & $n$ \\
\end{tabular} & $90^{\circ} 0$ & $\cdots$ & ก & $\angle D^{\circ} 0$ & \begin{tabular}{|l|l|}
$-\cdots$ & $n$ \\
\end{tabular} & $80^{\circ} 0$ & $-\cdots$ & $80^{\prime} 0$ & Un!uə|əS \\
\hline$-\cdots$ & & 0682 & -- & $08 \varepsilon Z$ & -- & & $0 \angle D Z$ & $\cdots$ & 969 & $n$ & & $\nabla \varepsilon t$ & - & $\Phi \varepsilon \varepsilon$ & $\pi$ & $60 \varepsilon$ & un!sSDIOd \\
\hline $\begin{array}{ll}-\cdots \\
\end{array}$ & & 060 & $\begin{array}{ll}-\infty & n \\
\end{array}$ & $O Q^{\prime} 1$ & $-\infty$ & $n$ & 091 & $\begin{array}{ll}\cdots \\
\end{array}$ & $96^{\circ} 0$ & 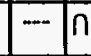 & n & $860^{\circ} 0$ & \begin{tabular}{|l|l|}
- & $n$ \\
\end{tabular} & $\angle L^{\circ} O$ & 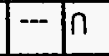 & $G L^{\prime} 0$ & |OYO!N \\
\hline--1 & & $00^{\prime} 0$ & --18 & $50^{\circ} 0$ & I & $\theta$ & 900 & \begin{tabular}{|l|l|} 
& $n$ \\
\end{tabular} & $00^{\circ} 0$ & $\cdots$ & ก & $90^{\circ} 0$ & \begin{tabular}{l|l}
- & $n$ \\
\end{tabular} & $80^{\circ} 0$ & \begin{tabular}{|l|l|}
- & $n$ \\
\end{tabular} & $\varepsilon 0^{\circ} 0$ & KมnวdəW \\
\hline \begin{tabular}{l|l}
$r$ & $\theta$ \\
\end{tabular} & 8 & $\angle Z^{\prime} O$ & -- & 0816 & $\cdots$ & & OL'S & \begin{tabular}{|l|l|l}
$-\cdots$ & 8 \\
\end{tabular} & $0 g^{\prime} 0$ & -- & & $\overline{O Z^{\prime} \varepsilon}$ & - & 001 & --- & $O \sigma^{\prime} 1$ & อsəuDEUDW \\
\hline- & & $0^{\prime} \angle \varepsilon Z$ & $-\cdots$ & $0.0 \angle L$ & $r$ & 8 & 0081 & \begin{tabular}{|l|l|}
-- & 8 \\
\end{tabular} & $\varepsilon^{\prime} 09$ & I 19 & 8 & $\varepsilon^{\prime} 6 \varepsilon$ & - & D.00ZE & -- & 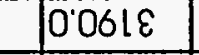 & un!seubow \\
\hline 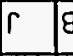 & $g$ & $60^{\circ} 0$ & -- & $0 \varepsilon^{\prime} Z$ & $\cdots$ & $\bar{s}$ & $0 L^{\prime} 9$ & $-\rightarrow$ & $00^{\circ} 02$ & 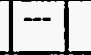 & & $0 Z^{\prime} 88$ & --5 & uny toN & -1 & uny ton & pDə7 \\
\hline-- & & $8^{\circ} 02$ & - & $0 \angle L L$ & -- & & 0.961 & $\cdots$ & $\angle \circ 6 \varepsilon$ & $\cdots$ & & 211 & -18 & 72 & I 18 & $G^{\prime} \varepsilon$ & UOd \\
\hline-- & & $09^{\circ} 1$ & - & 0029 & $\cdots$ & & $09 \cdot 29$ & --1 & $9 L^{\circ} 0$ & - & & $09^{2} \mathrm{Z}$ & $--\operatorname{no}$ & 010 & $--n$ & 01.0 & ləddoJ \\
\hline \begin{tabular}{l|l}
$--\mid$ & 4 \\
1
\end{tabular} & $n$ & $\angle Z^{\prime} O$ & \begin{tabular}{|l|l|}
-- & $n$ \\
\end{tabular} & $90^{\prime} 0$ & r & 8 & $69^{\prime} 0$ & $\begin{array}{ll}-\cdots & n \\
\end{array}$ & 620 & $\cdots n$ & $n$ & $82^{\circ} 0$ & \begin{tabular}{|l|l|}
-- & $n$ \\
\end{tabular} & $\varepsilon Z^{\prime} 0$ & $--n$ & $2 Z^{\prime} 0$ & HipqoJ \\
\hline$\Gamma E$ & & $E \varepsilon^{\circ} 0$ & $-\cdots 8$ & $20^{\circ} 0$ & ir & 8 & $1 \varepsilon^{\prime} 0$ & --10 & $2 \nabla^{\prime} 0$ & $-\cdots$ & & $09^{\circ} 0$ & - & $09^{\prime} \varepsilon$ & - & $09 \varepsilon$ & un!mod40 \\
\hline \begin{tabular}{l|l}
$r$ & $\varepsilon$ \\
\end{tabular} & & Doz2 & \begin{tabular}{|l|l|l}
$\cdots$ & 8 \\
\end{tabular} & 902 & ir & 8 & 981 & - & $88 \varepsilon$ & I 5 a & 日 & $0<1$ & - & $0001 \varepsilon 2$ & -- & 000922 & un!?ㅣㅇㅣ \\
\hline $\begin{array}{lll}-\cdots & 5 \\
\end{array}$ & n & $210^{\circ}$ & --18 & $Z Z^{\circ} 0$ & $\cdots$ & $n$ & $1 Z^{\circ} 0$ & $--n$ & $\varepsilon L^{\circ} 0$ & $--n$ & $n$ & $810^{\circ}$ & 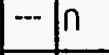 & ol 0 & $--n$ & 010 & wn!upd \\
\hline $\begin{array}{lll}-\infty & 1 & \\
\end{array}$ & & $00^{\circ} 0$ & $-\cdots n$ & $\angle 0^{\circ} 0$ & $\cdots$ & $n$ & $\angle 0^{\circ} 0$ & $\begin{array}{ll}-\infty \\
\end{array}$ & $50^{\prime} 0$ & \begin{tabular}{|l|l}
- & $n$ \\
\end{tabular} & $n$ & $50^{\circ} 0$ & $-n^{n}$ & $80^{\circ} 0$ & $-n$ & $80^{\circ} 0$ & un!ाוKıg \\
\hline \begin{tabular}{l|ll}
$\Gamma$ & $\varepsilon$ &
\end{tabular} & & $\nabla \varepsilon^{\prime} 0$ & \begin{tabular}{|l|l|}
$-\cdots$ & 8 \\
\end{tabular} & $0 \theta^{\prime} 0$ & i & 8 & $90^{\circ} 0$ & \begin{tabular}{|l|l}
--1 \\
\end{tabular} & $28^{\circ} 0$ & \begin{tabular}{|l|l|l} 
& 8 \\
\end{tabular} & 8 & $29^{\circ} 0$ & -- & Do'sob & - & 00 slb & un!ling \\
\hline$m \sqrt{n \pi}$ & $\overline{\mathrm{Mn}}$ & $50^{\circ} 0$ & $\begin{array}{ll}\cdots & n \\
\end{array}$ & $60^{\circ} 0$ & $\cdots$ & & $90^{\circ} 0$ & $--n$ & $90^{\prime} 0$ & $-\cdots n$ & $n$ & 900 & \begin{tabular}{|l|l|}
-- & $n$ \\
\end{tabular} & $80^{\circ} 0$ & m $3 n$ & 8 & O!UӨS৯ \\
\hline$-\cdots$ i & & $\Phi z$ & \begin{tabular}{|l|l|}
$\cdots$ & $n$ \\
\end{tabular} & $2 " t$ & $\cdots$ & & $\varepsilon \circ$ & --18 & 62 & $-\cdots n$ & $n$ & 92 & $-\cdots, n$ & 12 & $--n$ & 112 & Nuou!!uy \\
\hline \begin{tabular}{l|l}
$n$ & $\varepsilon$ \\
\end{tabular} & & 6.1 & \begin{tabular}{|l|l|}
$\cdots$ & $n$ \\
\end{tabular} & 9.1 & n & 8 & 6.1 & \begin{tabular}{|l|l}
$-\cdots$ & 8 \\
\end{tabular} & 12 & $\begin{array}{ll}n & 8 \\
\end{array}$ & $\theta$ & $1 . \varepsilon$ & \begin{tabular}{|c|c|c|}
$-\cdots$ & 8 \\
\end{tabular} & $g^{\prime} t$ & \begin{tabular}{l|l}
$n$ & 8 \\
\end{tabular} & 1.9 & unu!̣unity \\
\hline & & $\begin{array}{l}\vec{O} \\
\frac{1}{3} \\
\frac{1}{3} \\
\frac{1}{1}\end{array}$ & $\sum_{*}^{0}$ & 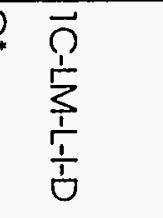 & 穴 & & $\begin{array}{l}\overrightarrow{0} \\
\frac{1}{3} \\
\frac{1}{1} \\
\underline{1}\end{array}$ & $\sum_{3}$ & $\begin{array}{l}\overrightarrow{0} \\
\overrightarrow{1} \\
\frac{1}{3} \\
\frac{1}{1} \\
\frac{1}{0}\end{array}$ & $P_{*}^{\infty}$ & $D_{*}$ & $\begin{array}{l}\overrightarrow{0} \\
\substack{1 \\
+1 \\
\underline{1}}\end{array}$ & $\sum_{*}^{\infty}$ & $\begin{array}{l}\overrightarrow{0} \\
\frac{1}{3} \\
\frac{1}{\dot{\phi}} \\
\frac{1}{0}\end{array}$ & $\underset{\$}{\square}$ & 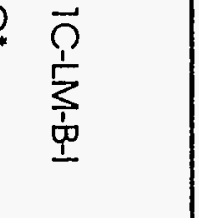 & (6y/6u) punoduoJ \\
\hline \multicolumn{17}{|c|}{ (EW I.8- $\forall$ ә|c } & \\
\hline
\end{tabular}




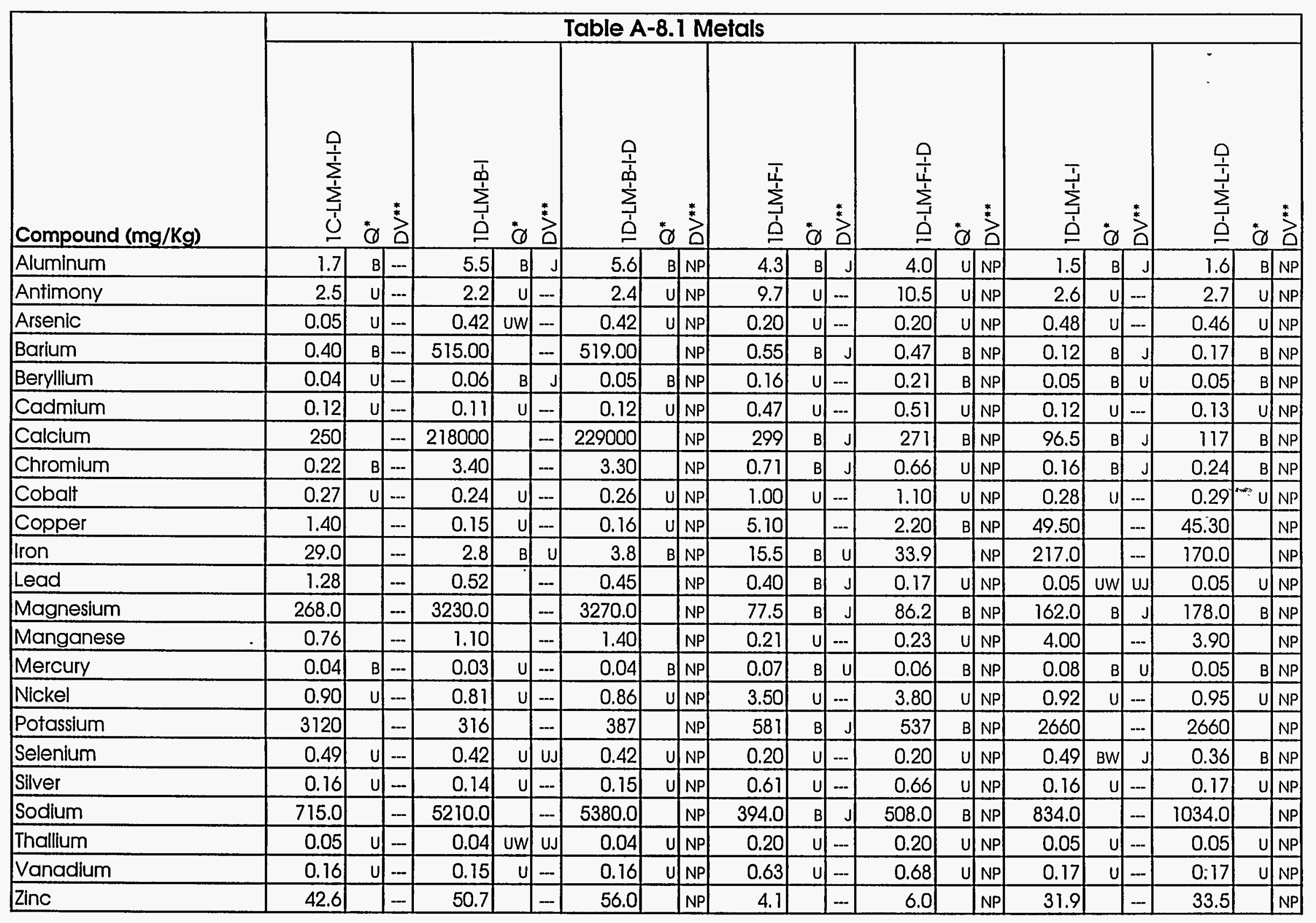




\begin{tabular}{|c|c|c|c|c|c|c|c|c|c|c|c|c|c|c|c|c|c|c|c|c|}
\hline-1 & & 1.02 & --1 & & $9.0 \varepsilon$ & -1 & & 9.98 & - & & 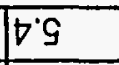 & -- & & $\nabla 0 L$ & $\mathrm{dN}$ & 9.92 & - & & $9^{\circ} \varepsilon \varepsilon$ & $50 ! z$ \\
\hline$-\pi$ & & 81.0 & --1 & $n$ & 910 & -1 & & 910 & - & n & $Z L^{\prime} 0$ & -1 & & 81.0 & $d N \mid n$ & $\angle 10^{\circ}$ & & $n$ & $\angle 10$ & wn!poud $\wedge$ \\
\hline$\pi \sqrt{n}$ & Mn & $60^{\circ} 0$ & -- & n & $60^{\circ} 0$ & -1 & & $90^{\circ} 0$ & - & n & 61.0 & $m$ & Mn & $90^{\circ} 0$ & $d N \mid \pi$ & $90^{\circ} 0$ & -1 & $\bar{n}$ & 500 & un||ाDपा \\
\hline- & & 0.0699 & -- & & $0 \angle O O S$ & -1 & & 0.0901 & $r$ & 8 & $0.11 L$ & -1 & & 0.0929 & $\mathrm{dN}$ & O'SOS & - & & $00^{\prime} \varepsilon \angle G$ & un!̣pos \\
\hline$-\pi$ & n & $\angle 10$ & $-\infty$ & n & 910 & -1 & & $91^{\circ} 0$ & -- & $\pi$ & $0 \angle L^{\circ}$ & -- & $\bar{n}$ & $\angle 10$ & $d N \mid n$ & $\angle 1^{\circ} 0$ & m & n & 91.0 & 1әN\|S \\
\hline \begin{tabular}{r|r}
$r$ & $\Lambda$ \\
\end{tabular} & ME & $\angle Q^{\prime} 0$ & min & $\mathrm{Mn}$ & $0 Z^{\prime} 0$ & r & ng & $2 \nabla^{\prime} 0$ & $m$ & $M n$ & 610 & r & 38 & $99^{\circ} 0$ & \begin{tabular}{l|l|l}
$d N$ & $n$
\end{tabular} & $\varepsilon Z^{\circ} 0$ & - & $\mathrm{Mn}$ & $\nabla Z^{\prime} 0$ & 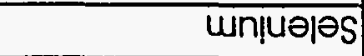 \\
\hline$n$ & & $\nabla \angle Z$ & $\cdots$ & & $O L \angle \varepsilon$ & -- & & $08 \varepsilon Z$ & $\Gamma$ & 8 & $0 \angle 8$ & $-\cdots$ & & $98 \varepsilon$ & $\mathrm{dN}$ & 10092 & $\cdots$ & & $099 \varepsilon$ & unissolod \\
\hline \begin{tabular}{l|l}
-1 & 1 \\
\end{tabular} & n & 860 & $\cdots$ & ก & $98^{\circ} 0$ & $-\infty$ & 5 & $98^{\circ} 0$ & -- & $\pi$ & $00^{\circ} t$ & -- & $n$ & 001 & dN & $96^{\circ} 0$ & - & $n$ & 860 & PXOIN \\
\hline$\cdots$ & $\pi$ & 600 & $n$ & 8 & $90^{\circ} 0$ & $n$ & & $0 Z^{\prime} 0$ & $\cdots$ & $n$ & $90^{\circ} 0$ & $\pi$ & 8 & $50^{\prime} 0$ & $\mathrm{dN} / \mathrm{g}$ & $100^{\circ} 0$ & $n$ & 8 & $90^{\circ} 0$ & KınOIOW \\
\hline$\cdots$ & & $09^{\prime} \mathrm{L}$ & r & 8 & 81.0 & $\cdots$ & & $0 \theta^{\prime} t$ & $-\cdots$ & $n$ & $\nabla Z^{\circ} 0$ & $\cdots$ & & $O \sigma^{\prime} L$ & $\mathrm{dN} / \mathrm{a}$ & 120 & r & 8 & $\angle 1^{\circ} 0$ & әsəuDб̄uDW \\
\hline$\cdots$ & & $0.090 \varepsilon$ & -- & & $0^{\prime} \varepsilon 8 \mathrm{Z}$ & $r^{2}$ & 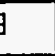 & $0^{\prime} 891$ & r & 8 & 6.16 & $\cdots$ & & $0^{\circ} 0 \varepsilon Z \varepsilon$ & $\mathrm{dN} / \mathrm{\theta}$ & 0.661 & - & & $0^{\circ} \angle L Z$ & wn!səubow \\
\hline$\cdots$ & & 960 & --1 & n & $60^{\circ} 0$ & $\cdots$ & † & $90^{\circ} 0$ & $-\cdots$ & $n$ & 61.0 & $\cdots$ & & $2 \varepsilon^{\prime} 0$ & \begin{tabular}{l|l|l}
$d N$ & $n$ \\
\end{tabular} & $50^{\circ} 0$ & r & ME & $01^{\circ} 0$ & pDo7 \\
\hline$r$ & 8 & $E t$ & $\pi$ & & 292 & -- & & 0.602 & $n$ & & $\angle 12$ & ir & 8 & $s^{\prime} t$ & $\mathrm{dN}$ & 922 & $n$ & & $6 . \mathrm{LZ}$ & पODा \\
\hline$-\cdots-1$ & n & 81.0 & -- & & $09^{\prime} \mathrm{I}$ & -- & & $0 \varepsilon^{\circ} 0 \sigma^{2}$ & $r$ & $\theta$ & $0 \nabla^{\circ} \varepsilon$ & - & $n$ & $8 L^{\prime} 0$ & $\mathrm{dN}$ & 09.1 & -- & & $0 L^{\prime} 2$ & laddoJ \\
\hline \begin{tabular}{r|r}
$r$ & 8 \\
\end{tabular} & a & 620 & -1 & $n$ & $9 Z^{\circ} 0$ & $\cdots$ & & $9 Z^{\prime} 0$ & -- & $n$ & 021 & -- & $n$ & $0 \varepsilon^{\prime} 0$ & $\mathrm{dN} n$ & 620 & & $n$ & $8 Z^{\prime} 0$ & H1Dq00 \\
\hline$\cdots$ & & pé & -1 & & $9 l^{\prime} 0$ & --1 & & $91^{\prime} 0$ & -- & In & $0 \angle 0$ & $\cdots$ & & $0 \varepsilon^{\prime} \varepsilon$ & $\mathrm{dN} / \mathrm{B}$ & $D Z^{\prime} 0$ & -- & $n$ & $91^{\circ} 0$ & un! wo140 \\
\hline$\cdots$ & & $000 \angle 02$ & -- & & $9 \varepsilon \varepsilon$ & $r$ & & $2 \varepsilon 1$ & $r$ & 8 & $8 \varepsilon \varepsilon$ & -- & & $000 \angle Z Z$ & $\mathrm{dN} / \mathrm{g}$ & $\angle G !$ & r & 8 & $\varepsilon \varepsilon 1$ & Un!oip \\
\hline$-\infty$ & n & $E 1.0$ & --1 & & 210 & -- & & $6 \varepsilon^{\circ} 0$ & - & $n$ & $\nabla 9^{\circ} 0$ & $\cdots$ & $n$ & $E l^{\prime} 0$ & $\mathrm{dN} n$ & $E L^{\circ} 0$ & -- & $n$ & $E l^{\circ} 0$ & un!̣pDo \\
\hline$-\cdots-1$ & & 500 & n & $\theta$ & $90^{\circ} 0$ & -- & & $50^{\prime} 0$ & -- & $a$ & 220 & is & $\theta$ & $90^{\circ} 0$ & $\mathrm{dN} / \mathrm{g}$ & $90^{\circ} 0$ & $\cdots$ & $n$ & $50^{\prime} 0$ & un!!ा/1әg \\
\hline$-\cdots$ & & $00 ' 999$ & r & $\theta$ & $2 \angle 0$ & is & & 120 & $n$ & 8 & $9 \angle 0$ & $\cdots$ & & 00.079 & dN $\mathrm{g}$ & $62^{\circ} 0$ & r & 8 & 120 & wnjugg \\
\hline$r$ & $\overline{M B}$ & $001 \mathrm{~L}$ & -- & & $00^{\prime} 0$ & $\cdots$ & & $60^{\circ} 0$ & r & $n$ & 610 & $\cdots$ & $M n$ & $09^{\prime} 0$ & $\mathrm{dN} / \mathrm{n}$ & $90^{\circ} 0$ & -- & $n$ & $\angle \nabla^{\prime} 0$ & ग!บəSภ \\
\hline \begin{tabular}{|lll}
$\cdots$ & 1 & \\
\end{tabular} & & $\angle 2$ & $\cdots$ & & $\nabla 2$ & $\cdots$ & & 52 & $\cdots$ & $n$ & 1.11 & - & & $\varepsilon^{\prime} \varepsilon$ & $\mathrm{dN} n$ & $\angle 2$ & -- & $n$ & 9.2 & Nuou!ı $\forall$ \\
\hline & 8 & 9.9 & $r$ & 8 & 112 & $r$ & & $S^{\prime}$ & $r$ & 8 & 8.9 & 5 & 8 & 9.9 & $\mathrm{dN} / \mathrm{g}$ & 8.1 & r & 8 & $\nabla^{\circ}$ & unu!̣un| \\
\hline & & 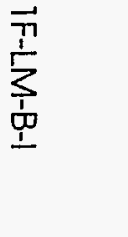 & 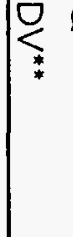 & & 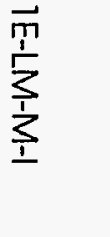 & $\underset{Z}{\mathbb{Q}}$ & & $\begin{array}{l}\vec{T} \\
\frac{\vec{T}}{\mathbf{T}} \\
\frac{1}{\underline{\underline{T}}}\end{array}$ & 䒺 & $\emptyset_{*}$ & 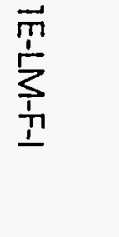 & $\underset{z}{q}$ & & 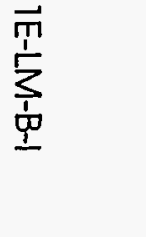 & $\overbrace{*}^{Q}$ & $\begin{array}{l}\overrightarrow{0} \\
\frac{1}{3} \\
\frac{3}{3} \\
\frac{1}{1} \\
\frac{1}{0}\end{array}$ & & & $\begin{array}{l}\vec{\gamma} \\
\frac{1}{5} \\
\frac{1}{3} \\
\frac{1}{1}\end{array}$ & ( $(5, / 6 u)$ punoduos \\
\hline \multicolumn{20}{|c|}{ S|DIOW $[\cdot 8-\forall$ ә|वD। } & \\
\hline
\end{tabular}




\begin{tabular}{|c|c|c|c|c|c|c|c|c|c|c|c|c|c|c|c|c|c|c|c|c|c|}
\hline \multirow[b]{2}{*}{ Compound $(\mathrm{mg} / \mathrm{Kg})$} & \multicolumn{21}{|c|}{ Table A-8.1 Metals } \\
\hline & 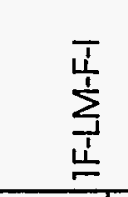 & $\stackrel{*}{0}$ & 艾 & $\frac{\sum_{j}^{1}}{\sum_{1}^{1}}$ & $\stackrel{*}{\emptyset}$ & $\stackrel{*}{*}$ & $\begin{array}{l}\sum_{\substack{1 \\
1}}^{T} \\
\qquad \\
\end{array}$ & $\stackrel{*}{\emptyset}$ & $\stackrel{*}{2}$ & $\sum_{\substack{1 \\
1}}^{1}$ & 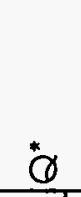 & $\stackrel{\text { : }}{*}$ & $\underset{\substack{1 \\
\dot{1}}}{\frac{1}{1}}$ & & $\stackrel{2}{0}^{*}$ & $\sum_{\substack{1 \\
1}}^{T}$ & & 莡 & $\sum_{i}^{T}$ & $\stackrel{*}{\square}$ & 芝 \\
\hline Aluminum & 2.1 & $\mathrm{~B}$ & u & 3.7 & $B$ & $\mathrm{u}$ & 1.8 & $\mathrm{~B}$ & u & 5.1 & $B$ & $\mathrm{u}$ & 4.9 & $B$ & $\mathrm{U}$ & 3.6 & $B$ & $u$ & 1.4 & $\mathrm{~B}$ & - \\
\hline Antimony & 2.7 & $u$. & -- & 4.2 & $u$ & $\ldots$ & 2.6 & U & -- & 2.7 & 4 & $-\ldots$ & 2.6 & $\mathrm{u}$ & $\ldots$ & 5.5 & $\mathrm{U}$ & -- & 2.1 & u & $\ldots$ \\
\hline Arsenic & 0.05 & $u$. & - & 0.07 & $\mathrm{u}$ & - & 0.05 & $\mathrm{u}$ & $-\cdots$ & 0.62 & $\mathrm{BW}$ & $\mathrm{J}$ & 0.05 & UW & UJ & 0.10 & 4 & -- & 0.05 & UW & $\ldots$ \\
\hline Barium & 0.63 & $\mathrm{~B}$ & $\mathrm{~J}$ & 0.44 & $\mathrm{~B}$ & $\mathrm{~J}$ & 0.32 & $\mathrm{~B}$ & $\mathrm{~J}$ & 560.00 & & $\ldots$ & 1.80 & $\mathrm{~B}$ & $J$ & 0.41 & $\mathrm{~B}$ & $\mathrm{~J}$ & 0.37 & 8 & . \\
\hline Beryllium & 0.04 & 4 & $-\ldots$ & 0.07 & 4 & $\ldots$ & 0.04 & 4 & $\ldots$ & 0.04 & $u$ &.-- & 0.04 & 4 &.- & 0.09 & u & -- & 0.03 & $\mathrm{u}$ & $\ldots$ \\
\hline Cadmium & 0.13 & $u$ & -1 & 0.20 & 4 & $\ldots$ & 0.13 & $\mathrm{u}$ & $\ldots$ & 0.13 & 4 & $\ldots$ & 0.12 & 4 & -- & 0.27 & $\mathrm{u}$ & - & 0.10 & $u$ & $\ldots$ \\
\hline Calcium & 326 & & -- & 271 & $\mathrm{~B}$ & $\mathrm{~J}$ & 169 & $\mathrm{~B}$ & $\mathrm{~J}$ & 204000 & & $\ldots$ & 665 & & - & 192 & $\mathrm{~B}$ & $\mathrm{~J}$ & 221 & & $\ldots$ \\
\hline Chromium & 0.28 & 8 & $\mathrm{~J}$ & 0.32 & B & $\mathrm{J}$ & 0.55 & &.- & 2.90 & & $\ldots$ & 0.26 & $B$ & $\mathrm{~J}$ & 0.77 & 8 & $\mathrm{~J}$ & 0.39 & & - \\
\hline Cobalt & 0.29 & $u$. & - & 0.45 & U & -- & 0.29 & 4 &.- & 0.29 & U & -- & 0.28 & 4 & $\ldots$ & 0.60 & $u$ & -- & 0.22 & $\therefore u$ & $\ldots$ \\
\hline Copper & 0.28 & $\mathrm{~B}$ & $\mathrm{~J}$ & 64.80 & & $\ldots$ & 2.20 & & $\ldots$ & 0.18 & 4 & - & 0.85 & $B$ & $\mathrm{u}$ & 55.30 & & -- & 2.00 & & $\ldots$ \\
\hline Iron & 4.0 & $\mathrm{~B}$ & $\mathrm{~J}$ & 137.0 & & $\ldots$ & 34.5 & & $\ldots$ & 3.7 & $B$ & $\mathrm{~J}$ & 22.3 & & 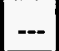 & 258.0 & &.-- & 35.9 & & $\ldots$ \\
\hline Lead & 0.05 & $\mathrm{u}$. & -- & 0.06 & uW & UJ & 0.05 & $\mathrm{~B}$ & UJ & 1.80 & & -- & 0.12 & $\mathrm{~B}$ & $U$ & 0.12 & $\mathrm{BW}$ & UJ & 0.08 & $B$ & U \\
\hline Magnesium & 25.4 & $\mathrm{~B}$ & $\mathrm{~J}$ & 204.0 & $\mathrm{~B}$ & $\mathrm{~J}$ & 244.0 & & $-\ldots$ & 3190.0 & & $\ldots$ & 73.8 & $B$ & $\mathrm{~J}$ & 182.0 & $B$ & $\mathrm{~J}$ & 275.0 & & - \\
\hline Manganese & 0.09 & 8 & $J$ & 5.90 & & $-\infty$ & 0.29 & $B$ & $\mathrm{~J}$ & 1.60 & & -- & 0.73 & & $\ldots$ & 5.40 & & $\ldots$ & 0.59 & & $\ldots$ \\
\hline Mercury & 0.05 & 4. & $\ldots$ & 0.04 & $\mathrm{~B}$ & $\mathrm{~J}$ & 0.03 & $u$ & $\ldots$ & 0.03 & $u$ & - & 0.05 & u & -- & 0.19 & & -- & 0.03 & U) & $\ldots$ \\
\hline Nickel & 0.97 & $\mathrm{U}$ & $-\ldots$ & 1.50 & $u$ & $\ldots$ & 0.95 & 4 & $-\ldots$ & 0.98 & $u$ & $\ldots$ & 0.92 & u & -- & 2.00 & U & -- & 0.75 & u & $\ldots$ \\
\hline Potassium & 182 & $B$ & 4 & 2580 & & $\ldots$ & 2880 & & $\ldots$ & 180 & $\mathrm{~B}$ & $\mathrm{U}$ & 718 & & $\mathrm{U}$ & 2800 & & $\ldots$ & 3570 & & $\ldots$ \\
\hline Selenium & 0.48 & $u$ & $\ldots$ & 0.77 & $\mathrm{~B}$ & $\mathrm{~J}$ & 0.46 & uW & UJ & 0.43 & U) & -- & 0.46 & u & $\ldots$ & 0.99 & 4 & $\ldots$ & 0.48 & uW & U. \\
\hline Silver & 0.17 & $\mathrm{u}$ & $\ldots$ & 0.26 & 4 & - & 0.17 & u & - & 0.17 & U & -- & 0.16 & 0 & - & 0.35 & 4 & $\ldots$ & 0.13 & 4 & $\ldots$ \\
\hline Sodium & 161.0 & $B$ & $\mathrm{~J}$ & 807.0 & & - & 619.0 & & - & 5230.0 & & - & 1050.0 & & -- & 1010.0 & & -- & 548.0 & & $\ldots$ \\
\hline Thallium & 0.05 & $u$ & $\ldots$ & 0.07 & $\mathrm{u}$ & - & 0.05 & 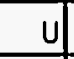 & - & 0.04 & 4 & - & 0.05 & $u$ & - & 0.10 & $u$ & -- & 0.05 & U & - \\
\hline Vanadium & 0.17 & $u$ & -- & 0.27 & $u$ & - & 0.17 & 4 & - & 0.18 & 4 & -- & 0.17 & u & $\ldots$ & 0.36 & $u$ & $\ldots$ & 0.13 & $\mathrm{U}$ & - \\
\hline Zinc & 2.4 & & -1 & 47.7 & & $\ldots$ & 39.8 & & - & 67.4 & & $\ldots$ & 6.7 & & - & 43.0 & & $\ldots$ & 37.5 & & $\ldots$ \\
\hline
\end{tabular}




\begin{tabular}{|c|c|c|c|c|c|c|c|c|c|c|c|c|c|c|c|c|c|c|c|c|c|}
\hline \multirow[b]{2}{*}{ Compound (ug/Kg) } & \multicolumn{21}{|c|}{ Table A-8.2 Pesticides/PCB's } \\
\hline & $\frac{\sum_{1}^{\infty}}{\dot{1}}$ & $\stackrel{*}{Q}$ & 艾 & $\frac{⿱ 亠 \top}{\sum_{3}^{\prime}}$ & $\stackrel{*}{\varnothing}$ & 草 & 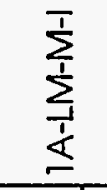 & & 草 & 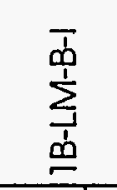 & & & 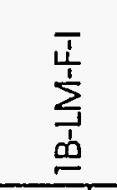 & & 草 & 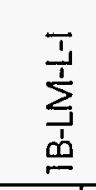 & & 艾 & 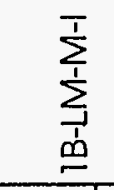 & & 莒 \\
\hline Alpha-BHC & 46 & U. & $\ldots$ & 48 & u. & $\ldots$ & 46 & U. & $\ldots$ & 46 & U. & $\ldots$ & 48 & U. & $\ldots$ & 48 & U. & $\ldots$ & 48 & $\mathrm{U}$ & $\ldots$ \\
\hline Beta-BHC & 46 & $u$. & $\ldots$ & 48 & U. & $\ldots$ & 46 & $U$. & $\ldots$ & 46 & u. & - & 48 & 4. & $\ldots$ & 48 & $\mathrm{U}$. & $\ldots$ & 48 & $u$ & $\ldots$ \\
\hline Delta-BHC & 46 & $U$ & $\ldots$ & 48 & 4. & $\ldots$ & 46 & 0. & $\ldots$ & 46 & $u$. & $\ldots$ & 48 & $4=$ & $\ldots$ & 48 & $\mathrm{U}$. & $\ldots$ & 48 & $u$ & $\ldots$ \\
\hline Gamma-BHC & 46 & $U$. & $\ldots$ & 48 & $\mathrm{u}$. & - & 46 & $\mathrm{U}$. & -- & 46 & u. & $\ldots$ & 48 & U... & $\ldots$ & 48 & $u$. & $\ldots$ & 48 & $\mathrm{U}$ & $\ldots$ \\
\hline Heptachlor & 46 & $u$ & $\ldots$ & 48 & $\mathrm{u}$. & $\ldots$ & 46 & 4. & - & 46 & u. & $\ldots$ & 48 & U. & $\ldots$ & 48 & $u$. & $\ldots$ & 48 & $u$ & $\ldots$ \\
\hline Aldrin & 46 & 4. & -1 & 48 & $U$. & -1 & 46 & U. & $\ldots$ & 46 & $\mathrm{u}$. & $\ldots$ & 48 & $v-$ & $\ldots$ & 48 & 4. & $\ldots$ & 48 & $u$ & $\ldots$ \\
\hline Heptachlor epoxide & 46 & 4. & - & 48 & $\mathrm{u}$ & -1 & 46 & $u$. & $\ldots$ & 46 & 4. & $\ldots$ & 48 & $4=$ & $\ldots$ & 48 & 4. & $\ldots$ & 48 & $\mathrm{u}$ &.- \\
\hline Endosulfan I & 46 & 4. & - & 48 & $u$. & $\ldots$ & 46 & $\mathrm{U}$. & $\ldots$ & 46 & 0. & $\ldots$ & 48 & $4=$ & $\ldots$ & 48 & u. & $\ldots$ & 48 & $\mathrm{u}$ & $\ldots$ \\
\hline Dieldrin & 93 & $u$ & $\ldots$ & 96 & $\mathrm{u}$. & $\ldots$ & 92 & U. & $\ldots$ & 92 & U. & $\ldots$ & 95 & U. . & $\ldots$ & 95 & 4. & $\ldots$ & 95 & $u$ & $\ldots$ \\
\hline 4,4'-DDE & 93 & $u$. & $\ldots$ & 96 & $\mathrm{u}$. & $\ldots$ & 92 & $u$. & $\ldots$ & 92 & $u-$ & $\ldots$ & 95 & U. & $\ldots$ & 95 & u. & $\ldots$ & 95 & u. & $\ldots$ \\
\hline Endrin & 93 & 4. & $\ldots$ & 96 & u. & $\ldots$ & 92 & $\mathrm{U}$. & $\ldots$ & 92 & 0. & $\ldots$ & 95 & $u=$ & $\ldots$ & 95 & $u$. & $\ldots$ & 95 & $\mathrm{U}$ & $\ldots$ \\
\hline Endosulfan II & 93 & 4. & - & 96 & 0. & - & 92 & $u$. & $\ldots-1$ & 92 & 4. & -- & 95 & U. & $\ldots$ & 95 & 4. & $\ldots$ & 95 & $\mathrm{U}$ & -- \\
\hline 4,4'-DDD & 93 & $\mathrm{U}$. & $\ldots$ & 96 & $\mathrm{u}$. & -- & 92 & 4. & -- & 92 & U. & $\ldots$ & 95 & 4. & $\ldots$ & 95 & $u$. & $\ldots$ & 95 & $u$ & $\ldots$ \\
\hline Endosulfan sulfate & 93 & 4. & - & 96 & 0. & - & 92 & 4. & $\ldots$ & 92 & U. & $\ldots$ & 95 & U. & $\ldots$. & 95 & U. & $\ldots$ & 95 & 4 & $\ldots$ \\
\hline 4.4'-DDT & 93 & 4. & - & 96 & $u$. & - & 92 & u. & $\ldots$ & 92 & 4. & $\ldots$ & 95 & U. & $\ldots$ & 95 & $\mathrm{U}$ & $\ldots$ & 95 & $\mathrm{U}$ & $\ldots$ \\
\hline Methoxychlor & 460 & $u$. & $\ldots$ & 480 & $u$. & -1 & 460 & U. & $\ldots$ & 460 & 0. & $\ldots$ & 480 & U. & $\ldots$ & 480 & $u$ & $\ldots$ & 480 & $\mathrm{U}$ & $\ldots$ \\
\hline Endrin ketone & 93 & $u$ & $\ldots$ & 96 & $\mathrm{u}$. & $\ldots$ & 92 & $\mathrm{u}$. & $\ldots$ & 92 & 0. & $\ldots$ & 95 & $\mathrm{U}$. & $\ldots$ & 95 & $\mathrm{U}$ & $\ldots$ & 95 & $u$ & $\ldots$ \\
\hline Alpha-chlordane & 460 & $\mathrm{U}$. & $\ldots-$ & 480 & $u$. & $\ldots$ & 460 & 4. & - & 460 & $u$. & $\ldots$ & 480 & $u$. & $\ldots$ & 480 & u. & $\ldots$ & 480 & 4 & $\ldots$ \\
\hline Gamma-chlordane & 460 & $u$ & $\ldots$ & 480 & $u$. & - & 460 & u. & $\ldots$ & 460 & U. & $\ldots$ & 480 & U. & $\ldots$ & 480 & 4. & $\ldots$ & 480 & 4 & - \\
\hline Toxaphene & 930 & 4 & -- & 960 & 4. & - & 920 & $\mathrm{u}$. & - & 920 & U. & $\ldots$ & 950 & $\mathrm{U}$. & $\ldots$ & 950 & $\mathrm{u}$ & $\ldots$ & 950 & $u$ &.-- \\
\hline Aroclor-1016 & 460 & $\mathrm{u}$ & - & 480 & 4. & - & 460 & 4. & $\ldots$ & 460 & U. & -1 & 480 & U. & $\ldots$ & 480 & $u$ & $-\ldots$ & 480 & 4 &.- \\
\hline Aroclor-1221 & 460 & $\mathrm{u}$ & -1 & 480 & $u$. & -1 & 460 & $\mathrm{U}$. & -1 & 460 & & $\ldots$ & 480 & 4. & -1 & 480 & 4. & -1 & 480 & 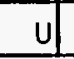 & $\ldots$ \\
\hline
\end{tabular}




\begin{tabular}{|c|c|c|c|c|c|c|c|c|c|c|c|c|c|c|c|c|c|c|c|c|c|}
\hline \multirow[b]{2}{*}{ Compound (ug/Kg) } & \multicolumn{18}{|c|}{ Table A-8.2 Pesticides/PCB's } & \multicolumn{3}{|l|}{$\therefore$} \\
\hline & $\sum_{\frac{1}{\dot{1}}}^{\bar{\phi}}$ & $\stackrel{*}{Q}$ & & 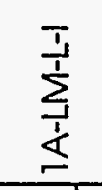 & & 莡 & $\begin{array}{l}\sum_{i}^{T} \\
\frac{1}{1} \\
\leq \\
\end{array}$ & $\stackrel{*}{Q} \stackrel{*}{*}$ & 草 & 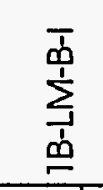 & $\stackrel{*}{0}$ & 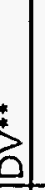 & 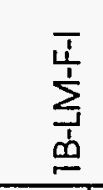 & ¿ृ & 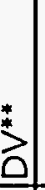 & 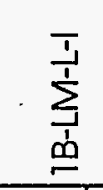 & & 艾 & 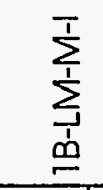 & & 莡 \\
\hline Aroclor-1232 & 460 & & $\ldots$ & 480 & & - & 460 & U. & - & 460 & U. & 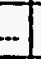 & 480 & U. & - & 480 & U. & - & 480 & & $\ldots$ \\
\hline Aroclor-1242 & 460 & 4 & - & 480 & $\mathrm{U}$ & -1 & 460 & & - & 460 & & - & 480 & & $\ldots$ & 480 & $u$. & $\ldots$ & 480 & & $\ldots$ \\
\hline Aroclor-1248 & 460 & 4 & $\ldots$ & 480 & $\mathrm{U}$ & - & 460 & & $\ldots$ & 460 & $4-$ & - & 480 & &.. & 480 & & $\ldots$ & 480 & 4 & $\ldots$ \\
\hline Aroclor-1254 & 930 & $\mathrm{u}$ & $\ldots$ & 960 & & $\ldots$ & 920 & U. & $\ldots$ & 920 & U. & -1 & 950 & & $\ldots$ & 950 & & $\ldots$ & 950 & u) & $\ldots$ \\
\hline Aroclor-1260 & 930 & $\mathrm{u}$ & $\ldots$ & 960 & $\mathrm{u}$ & $\ldots$ & 920 & U.... & $\ldots$ & 920 & U. & $\ldots$ & 950 & U]... & $\ldots$ & 950 & & $\ldots$ & 950 & $\mathrm{U}$ & $\ldots$ \\
\hline
\end{tabular}




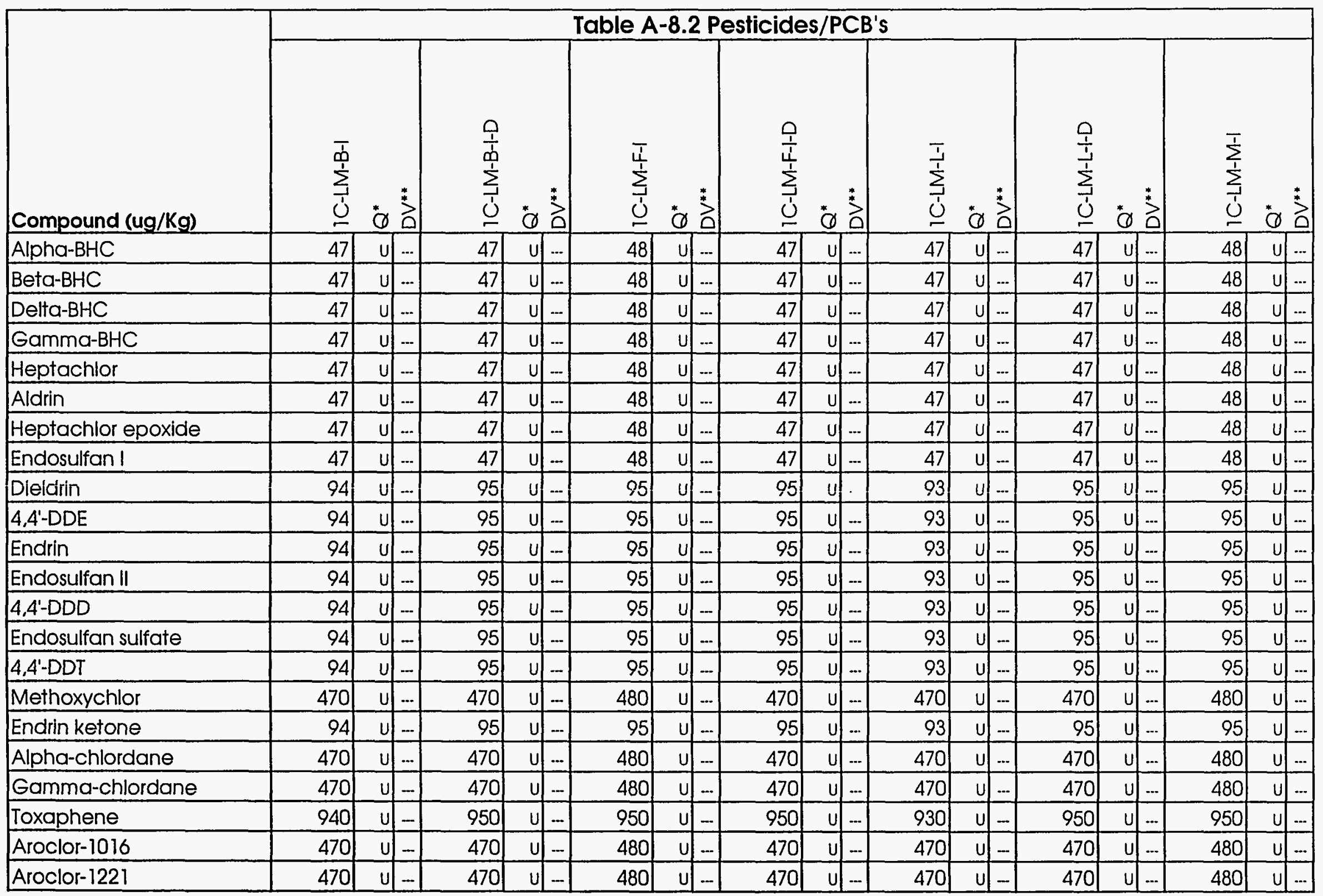




\begin{tabular}{|c|c|c|c|c|c|c|c|c|c|c|c|c|c|c|c|c|c|c|c|c|c|}
\hline Compound (ug/Kg) & \multicolumn{21}{|c|}{ Table A-8.2 Pesticides/PCB's } \\
\hline Aroclor- 1242 & 470 & & - & 470 & 4 & - & 480 & 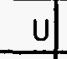 & - & 470 & & - & 470 & 4 & - & 470 & $\mathrm{u}$. & $\ldots$ & 480 & & $\ldots$ \\
\hline Aroclor- 1248 & 470 & $U$ & $\ldots$ & 470 & 4 & - & 480 & 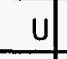 & $\ldots$ & 470 & & $\ldots$ & 470 & $u$ & $\ldots$ & 470 & $\mathrm{u}$ & $\ldots$ & 480 & & $\ldots$ \\
\hline Aroclor- 1254 & 940 & & $\ldots$ & 950 & U & $\ldots$ & 950 & u & - & 950 & & $\ldots$ & 930 & $\mathrm{U}$ & $\ldots$ & 950 & $\mathrm{u}$ & $\ldots$ & 950 & & $\ldots$ \\
\hline Aroclor- 1260 & 940 & & -1 & 950 & U1 & $\ldots$ & 950 & & $\ldots$ & 950 & & $\ldots$ & 930 & U] & $\ldots$ & 950 & & $\ldots$ & 950 & & $\ldots$ \\
\hline
\end{tabular}




\begin{tabular}{|c|c|c|c|c|c|c|c|c|c|c|c|c|c|c|c|c|c|c|c|c|c|}
\hline \multirow[b]{2}{*}{ Compound (ug/Kg) } & \multicolumn{21}{|c|}{ Table A-8.2 Pesticides/PCB's } \\
\hline & $\frac{O}{\sum_{1}^{+}}$ & $\stackrel{*}{Q}$ & & 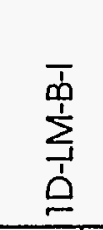 & & & $\begin{array}{l}\frac{0}{1} \\
\frac{1}{1} \\
\frac{1}{1} \\
0\end{array}$ & $\stackrel{*}{\varnothing}$ & & 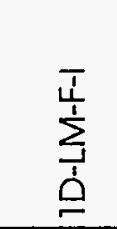 & & & $\begin{array}{l}\frac{Q}{1} \\
\frac{1}{\dot{1}} \\
\frac{1}{1} \\
0 \\
0\end{array}$ & ¿ & ${ }^{*}$ & $\begin{array}{l}\sum_{1}^{\frac{T}{1}} \\
\vdots \\
0\end{array}$ & & $\begin{array}{l}* \\
\text { 己 }\end{array}$ & 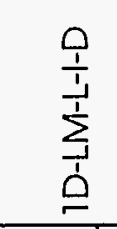 & $\stackrel{*}{Q}$ & $\stackrel{*}{\stackrel{*}{0}}$ \\
\hline Alpha-BHC & 48 & $u$ & $\ldots$ & 47) & u & $\ldots$ & 48 & $\mathrm{u}$ & $\ldots$ & 48 & 4 & $\ldots$ & 47 & $u$ & $\ldots$ & 46 & $u$ & $\ldots$ & 48 & $\mathrm{U}$ & $\ldots$ \\
\hline Beta-BHC & 48 & $\mathrm{U}$ & $\ldots$ & 47 & $u$ & $\ldots$ & 48 & $\mathrm{u}$ & $\ldots$ & 48 & 4 & $\ldots$ & 47 & 4 & $\ldots$ & 46 & $u$ & $\ldots$ & 48 & $\mathrm{u}$ & $\ldots$ \\
\hline Delta-BHC & 48 & $u$ & $\ldots$ & 47 & $u$ & $\ldots$ & 48 & $u$ & $\ldots$ & 48 & $\mathrm{U}$ & $\ldots$ & 47 & $\mathrm{u}$ & $\ldots$ & 46 & $u$ & $\ldots$ & 48 & 4 & $\ldots$ \\
\hline Gamma-BHC & 48 & $u$ & $\ldots$ & 47 & 4 & $\ldots$ & 48 & $u$ & $\ldots$ & 48 & $\mathrm{U}$ & \begin{tabular}{|l|}
$\ldots$ \\
\end{tabular} & 47 & $\mathrm{u}$ & $\ldots$ & 46 & $\mathrm{u}$ & $\ldots$ & 48 & 4 & $\ldots$ \\
\hline Heptachlor & 48 & 4 & $\ldots$ & 47 & $u$ & $\ldots$ & 48 & $\mathrm{U}$ & $\ldots$ & 48 & $u$ & $\ldots$ & 47 & $\mathrm{U}$ & $\ldots$ & 46 & U & $\ldots$ & 48 & 4 & $\ldots$ \\
\hline Aldrin & 48 & $\mathrm{u}$ & $\ldots$ & 47 & $u$ & $\ldots$ & 48 & $u$ &.- & 48 & $u$ & $\ldots$ & 47 & $\mathrm{U}$ & $\ldots$ & 46 & $u$ & $\ldots$ & 48 & 4 & $\ldots$ \\
\hline Heptachlor epoxide & 48 & 4 & $\ldots$ & 47 & 4 & $\ldots$ & 48 & $u$ & $\ldots$ & 48 & U. & $\ldots$ & 47 & $\mathrm{u}$ & $\ldots$ & 46 & $\mathrm{u}$ & $\ldots$ & 48 & U & $\ldots$ \\
\hline Endosulfan 1 & 48 & 4 & $\ldots$ & 47 & 4 & $\ldots$ & 48 & $u$ & $\ldots$ & 180 & $u x$ & $\ldots$ & 47 & $\mathrm{U}$ & $\ldots$ & 46 & 4 & $\ldots$ & 48 & 4 & $\ldots$ \\
\hline Dieldrin & 95 & 4 & $\ldots$ & 93 & 4 & $\ldots$ & 95 & 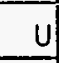 & $\ldots$ & 95 & 4 & $\ldots$ & 93 & $\mathrm{U}$ & $\ldots$ & 91 & 4 & $\ldots$ & 95 & 4 & $\ldots$ \\
\hline $4,4^{\prime}-\mathrm{DDE}$ & 95 & $\mathrm{u}$ & $\ldots$ & 93 & $\mathrm{u}$ & $\ldots$ & 95 & $u$ & $\ldots$ & 95 & $\mathrm{U}$ & $\ldots$ & 93 & $u$ & $\ldots$ & 91 & 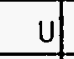 & $\ldots$ & 95 & $u$ & $\ldots$ \\
\hline Endrin & 95 & 4 & $\ldots$ & 93 & 4 & $\ldots$ & 95 & $u$ & $\ldots$ & 95 & 4 & $\ldots$ & 93 & $\mathrm{u}$ & $\ldots$ & 91 & $\mathrm{u}$ & $\ldots$ & 95 & 4 & $\ldots$ \\
\hline Endosulfan II & 95 & $\mathrm{u}$ & $\ldots$ & 93 & $u$ & $\ldots$ & 95 & $\mathrm{U}$ & $\ldots$ & 95 & $\mathrm{u}$ & $\ldots$ & 93 & $u$ & $\ldots$ & 91 & $u$ & $\ldots$ & 95 & 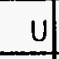 & $\ldots$ \\
\hline 4,4'-DDD & 95 & 4 & $\ldots$ & 93 & $\mathrm{u}$ & $\ldots$ & 95 & $\mathrm{U}$ & $\ldots$ & 95 & $\mathrm{u}$ & $\ldots$ & 93 & $\mathrm{U}$ & - & 91 & U & $\ldots$ & 95 & $\mathrm{U}$ & $\ldots$ \\
\hline Endosulfan sulfate & 95 & $\mathrm{U}$ & $\ldots$ & 93 & $\mathrm{u}$ & -- & 95 & $U$ & $\ldots$ & 95 & u) & $\ldots$ & 93 & $\mathrm{u}$ & $\ldots$ & 91 & U & $\ldots$ & 95 & 4 & $\ldots$ \\
\hline $4,4^{\prime}-$ DDT & 95 & $u$ & $\ldots$ & 93 & $u$ & $\ldots$ & 95 & $U$ & - & 95 & $u$ & $\ldots$ & 93 & $\mathrm{U}$ & - & 91 & $u$ & $\ldots$ & 95 & $u$ & $\ldots$ \\
\hline Methoxychlor & 480 & $u$ & $\ldots$ & 470 & 4 & $\ldots$ & 480 & $U$ & $\ldots$ & 480 & $u$ &.- & 470 & $\mathrm{U}$ & - & 460 & U) & $\ldots$ & 480 & 4 & $\ldots$ \\
\hline Endrin ketone & 95 & $u$ & $\ldots$ & 93 & $u$ & $\ldots$ & 95 & $\mathrm{U}$ & $\ldots$ & 95 & $\mathrm{u}$ & $\ldots$ & 93 & $u$ & $\ldots$ & 91 & $u$ & $\ldots$ & 95 & $\mathrm{U}$ & $\ldots$ \\
\hline Alpha-chlordane & 480 & 4 & $\ldots$ & 470 & $\mathrm{u}$ & $\ldots$ & 480 & $\mathrm{U}$ & $\ldots$ & 480 & $u$ & $\ldots$ & 470 & $U$ & $\ldots$ & 460 & $\mathrm{U}$ & $\ldots$ & 480 & 4 & $\ldots$ \\
\hline Gamma-chlordane & 480 & $\mathrm{u}$ & $\ldots$ & 470 & $\mathrm{u}$ & $\ldots$ & 480 & $u$ & $\ldots$ & 480 & $\mathrm{u}$ & $\ldots$ & 470 & $u$ & $\ldots$ & 460 & u & - & 480 & $\mathrm{u}$ & $\ldots$ \\
\hline Toxaphene & 950 & 4 & - & 930 & $u$ & - & 950 & $u$ & $\ldots$ & 950 & $\mathrm{u}$ & - & 930 & $\mathrm{u}$ & - & 910 & $u$ & - & 950 & 4 & $\ldots$ \\
\hline Aroclor-1016 & 480 & 4 & - & 470 & 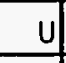 & - & 480 & $\mathrm{U}$ & - & 480 & $\mathrm{u}$ & - & 470 & $\mathrm{U}$ & - & 460 & $\mathrm{U}$ & $\ldots$ & 480 & $u$ & $\ldots$ \\
\hline Aroclor-1221 & 480 & $\mathrm{u}$ & - & 470 & $u$ & $\ldots$ & 480 & & $\ldots$ & 480 & $\mathrm{u}$ & - & 470 & $u$ & - & 460 & U) & $\ldots$ & 480 & $u$ & - \\
\hline
\end{tabular}




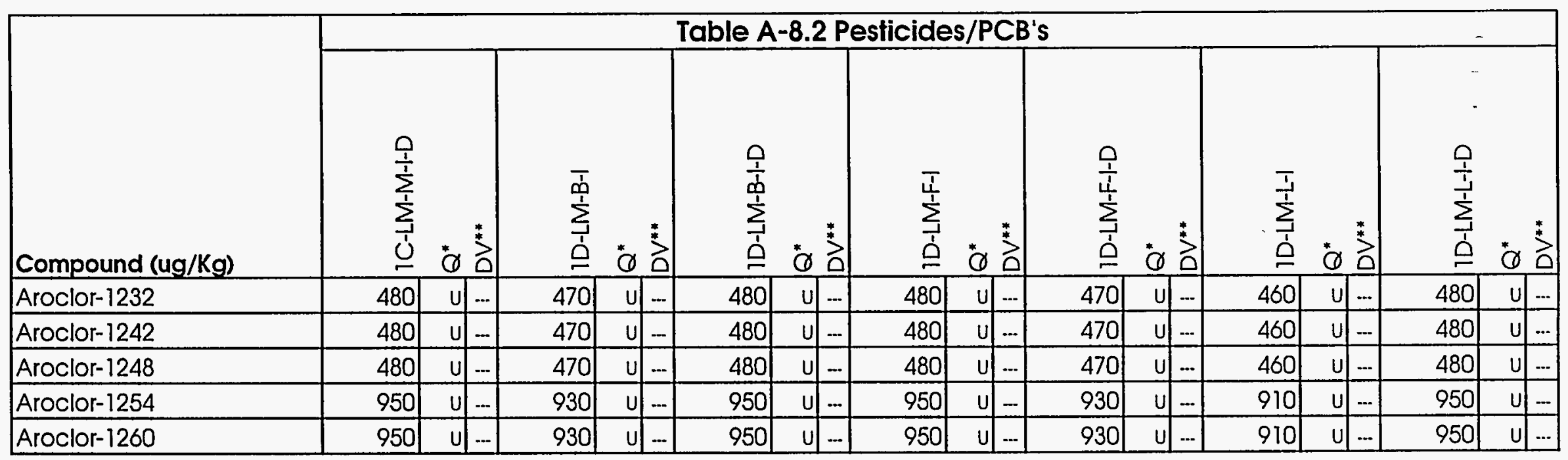




\begin{tabular}{|c|c|c|c|c|c|c|c|c|c|c|c|c|c|c|c|c|c|c|c|c|c|}
\hline Compound (ug/Kg) & \multicolumn{21}{|c|}{ Table A-8.2 Pesticides/PCB's } \\
\hline Beta-BHC & 48 & $u$. & $\ldots$ & 47 & $\mathrm{U}$ & $\ldots$ & 47 & 4 & $\mathrm{~J}$ & 47 & $u$. & $\ldots$ & 46 & $u$ & $\ldots$ & 47 & 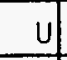 & $\ldots$ & 46 & 4 & $\ldots$ \\
\hline Delta-BHC & 90 & $u x$ &.- & 47 & $u$ & $\ldots$ & 47 & $\mathrm{u}$ & $\mathrm{J}$ & 47 & $u$ & $\ldots$ & 46 & U & $\ldots$ & 47 & $u$ & $\ldots$ & 46 & u & $\ldots$ \\
\hline Gamma-BHC & 48 & $u$ & $\ldots$ & 47 & $u$ & $\ldots$ & 47 & $u$ & J & 47 & $u$ & $\ldots$ & 46 & $u$ & $\ldots$ & 47 & $u$ & $\ldots$ & 46 & 4 & $\ldots$ \\
\hline Heptachlor & 48 & $u$ & -- & 47 & $\mathrm{u}$ & - & 47 & 4 & $\mathrm{~J}$ & 47 & 4 & $\ldots$ & 46 & $u$ & $\ldots$ & 47 & $\mathrm{u}$ & $\ldots$ & 46 & 4 & $\ldots$ \\
\hline Aldrin & 48 & $u$ &.- & 47 & 4 & $\ldots$ & 47 & $\mathrm{u}$ & $\mathrm{J}$ & 47 & $\mathrm{u}$ & $\ldots$ & 46 & 0 &.- & 47 & $\mathrm{u}$ & $\ldots$ & 46 & U & $\ldots$ \\
\hline Endrin & 95 & $u$. & $\ldots$ & 93 & 4 & $\ldots$ & 95 & U & J & 95 & u. & - & 92 & $u$ & $\ldots$ & 93 & 0 & $\ldots$ & 92 & $u$ & $\ldots$ \\
\hline Endosulfan II & 95 & 4. & $\ldots$ & 93 & 4 & $\ldots$ & 95 & $u$ & $\mathrm{~J}$ & 95 & 0. & $\ldots$ & 92 & 4 & $\ldots$ & 93 & U & $\ldots$ & 92 & 4 & $\ldots$ \\
\hline 4,4'-DDD & 95 & 4. & $-\ldots$ & 93 & 4 & - & 95 & 4 & J & 95 & 4. & $\ldots$ & 92 & 4 & $\ldots$ & 93 & 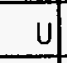 & $\ldots$ & 92 & 4 & $\ldots$ \\
\hline Endosulfan sulfate & 95 & $U$. & $\ldots$ & 93 & 4 & - & 95 & 4 & J & 95 & 4. & $\ldots$ & 92 & 4 & $\ldots$ & 93 & 4 & $\ldots$ & 92 & u) & $\ldots$ \\
\hline 4.4'-DDT & 95 & 4. & - & 93 & U & - & 95 & $\mathrm{u}$ & J & 95 & 4. & $\ldots$ & 92 & U & $\ldots$ & 93 & 4 & $\ldots$ & 92 & 4 & $\ldots$ \\
\hline Methoxychlor & 480 & 4. & $\ldots$ & 470 & 4 & - & 470 & 4 & J & 470 & $\mathrm{u}$. & $\ldots$ & 460 & U) & $\ldots$ & 470 & U & & 460 & U & $\ldots$ \\
\hline Endrin ketone & 95 & 4. & $\ldots$ & 93 & $u$ & - & 95 & 4 & J & 95 & $\mathrm{u}$. & $\ldots$ & 92 & 4 & $\ldots$ & 93 & $u$ & $\ldots$ & 92 & $4)$ & $\ldots$ \\
\hline Alpha-chlordane & 480 & $u$. & $\ldots$ & 470 & 4 & - & 470 & $u$ & $\mathrm{~J}$ & 470 & $u$. & $\ldots$ & 460 & $\mathrm{U}$ & $-\ldots$ & 470 & $u$ & $\ldots$ & 460 & $u$ & $\ldots$ \\
\hline Gamma-chlordane & 480 & 4 & $\ldots$ & 470 & 4 & - & 470 & 4 & $\mathrm{~J}$ & 470 & 4. & $\ldots$ & 460 & $u$ & $\ldots$ & 470 & $u$ & $\ldots$ & 460 & U & $\ldots$ \\
\hline Toxaphene & 950 & 4 & $-\ldots$ & 930 & $\mathrm{U}$ & - & 950 & $u$ & J & 950 & $u$ & $\ldots$ & 920 & $\mathrm{u}$ & $\ldots$ & 930 & $\mathrm{u}$ & $\ldots$ & 920 & 4 & $\ldots$ \\
\hline Aroclor-1016 & 480 & $\mathrm{u}$ & - & 470 & U & - & 470 & u & $\mathrm{J}$ & 470 & $u$. & - & 460 & U) & $\ldots$ & 470 & $\mathrm{U}$ & - & 460 & 4 & $\ldots$ \\
\hline
\end{tabular}




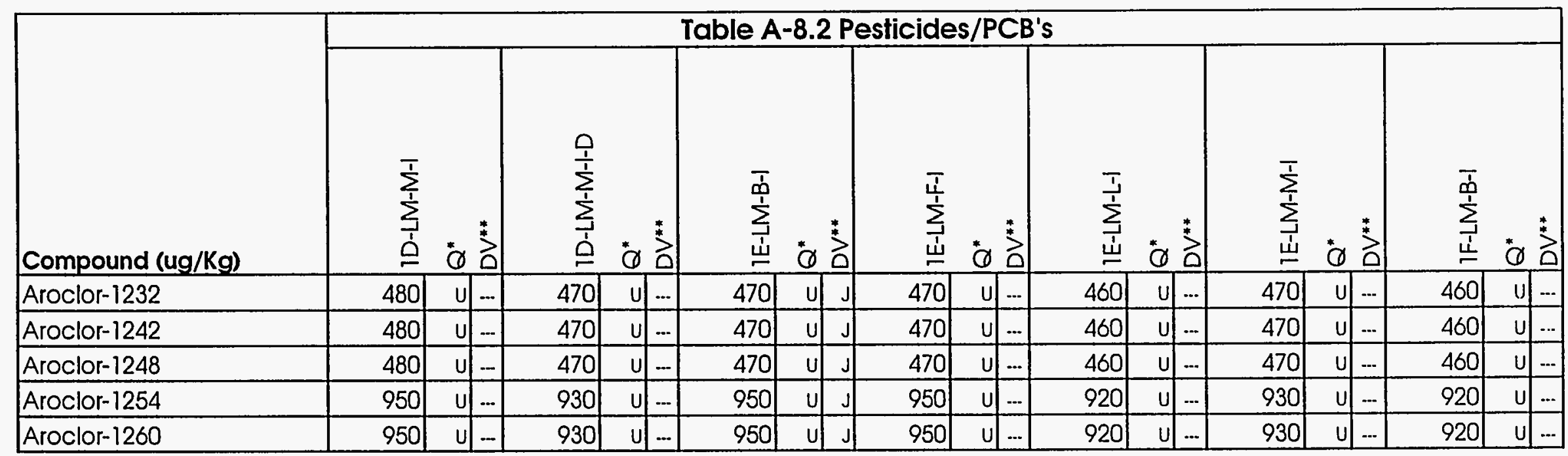




\begin{tabular}{|c|c|c|c|c|c|c|c|c|c|c|c|c|c|c|c|c|c|c|c|c|c|}
\hline \multirow[b]{2}{*}{ Compound (ug/Kg) } & \multicolumn{21}{|c|}{ Table A-8.2 Pesticides/PCB's } \\
\hline & 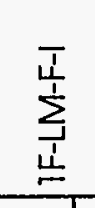 & $\stackrel{*}{\varnothing}$ & & 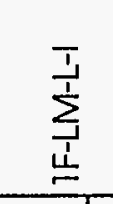 & $\stackrel{*}{\square}$ & & 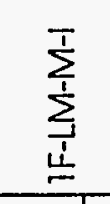 & & & $\begin{array}{l}\bar{\phi} \\
\sum_{1}^{1} \\
\underline{0} \\
\end{array}$ & ${ }^{*} \stackrel{*}{*}^{*}$ & 草 & 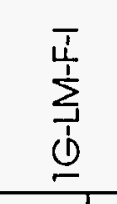 & $\stackrel{\square}{\square}$ & & $\underbrace{\top 1}_{\substack{1 \\
1}}$ & & $\stackrel{2}{*}^{*}$ & $\sum_{\substack{1\\
}}^{T}$ & & $\stackrel{3}{0}^{*}$ \\
\hline Alpha-BHC & 48 & U. & $\ldots$. & 47 & $\mathrm{u}$ & $\ldots$ & 46 & $\mathrm{U}$. & $\ldots$ & 47 & U. & $\ldots$ & 48 & u. &.- & 47 & U. & $\ldots$ & 47 & 0. & $\ldots$ \\
\hline Beta-BHC & 48 & $u$. & $\ldots$ & 47 & $\mathrm{u}$ & $\ldots$ & 46 & 4. & $\ldots$ & 47 & 4. & $\ldots$ & 48 & 4. & $\ldots$ & 47 & 4. & $\ldots$ & 47 & 4. & $\ldots$ \\
\hline Delta-BHC & 48 & 4. & $\ldots$ & 47 & $\mathrm{u}$ & $\ldots$ & 46 & 4. & $\ldots$ & 47 & 4. & $\ldots$ & 48 & 4. & $\ldots$ & 47 & 4. & $\ldots$ & 47 & u. & $\ldots$ \\
\hline Gamma-BHC & 48 & 4. & $\ldots$ & 47 & $\mathrm{u}$ & $\ldots$ & 46 & 4. & $\ldots$ & 47 & 4 & - & 48 & 4. & $\ldots$ & 47 & $u$. & $\ldots$ & 47 & 4. & $\ldots$ \\
\hline Heptachlor & 48 & U. & $\ldots$ & 47 & $\mathrm{u}$ & $\ldots$ & 46 & u. & $\ldots$ & 47 & 4. & - & 48 & 4. & $\ldots$ & 47 & 4. & $\ldots$ & 47 & $u$. & $\ldots$ \\
\hline Aldrin & 48 & U. & $\ldots$ & 47 & 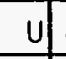 & $\ldots$ & 46 & $U$. & $\ldots$ & 47 & U... & $\ldots$ & 48 & 4. & $\ldots$ & 47 & 4. & $\ldots$ & 47 & 4. & $\ldots$ \\
\hline Heptachlor epoxide & 48 & $\mathrm{U}$. & $\ldots$ & 47 & $U$ & $\ldots$ & 46 & U. & $\ldots$ & 47 & $\mathrm{U}$. & $\ldots$ & 48 & 4. & $\ldots$ & 47 & $\mathrm{U}$. & $\ldots$ & 47 & $\mathrm{u}$. & $\ldots$ \\
\hline Endosulfan I & 48 & $\mathrm{u}$. & $\ldots$ & 47 & $u$ & $\ldots$ & 46 & U. & $\ldots$ & 47 & 4 &.- & 48 & 4. & $\ldots$ & 47 & 4. & $\ldots$ & 47 & 4. & $\ldots$ \\
\hline Dieidrin & 95 & 4. & $\ldots$ & 94 & 4 & $\ldots$ & 91 & $\mathrm{U}$. & $\ldots$ & 93 & 4. & $\ldots$ & 95 & 4. & $\ldots$ & 95 & 4. & $\ldots$ & 94 & 4. & $\ldots$ \\
\hline 4,4'-DDE & 95 & $\mathrm{u}$. & - & 94 & 4 & $\ldots$ & 91 & $\mathrm{U}$. & $\ldots$ & 93 & 4. & $\ldots$ & 95 & 4. & $\ldots$ & 95 & 4. & $\ldots$ & 94 & 4. & $\ldots$ \\
\hline Endrin & 95 & $u$. & - & 94 & $u$ & $\ldots$ & 91 & u. & $\ldots$ & 93 & 4. & $\ldots$ & 95 & U. & $\ldots$ & 95 & u. & $\ldots$ & 94 & u. & $\ldots$ \\
\hline Endosulfan II & 95 & 4. & - & 94 & U) & $\ldots$ & 91 & 0. & - & 93 & $\mathrm{U}$ &.- & 95 & 4. & $\ldots$ & 95 & u. & $\ldots-$ & 94 & 4. & $\ldots$ \\
\hline $4,4^{\prime}-\mathrm{DDD}$ & 95 & 4. & - & 94 & 4 & -- & 91 & $\mathrm{U}$. & -- & 93 & u. & $\ldots$ & 95 & U. & $\ldots$ & 95 & $U$. & $\ldots$ & 94 & 4 & $\ldots$ \\
\hline Endosulfan sulfate & 95 & $u$. & - & 94 & $u$ & $\ldots$ & 91 & 4. & $\ldots$ & 93 & U. & $\ldots$ & 95 & $\mathrm{u}$. & $\ldots$ & 95 & 4. & $\ldots$ & 94 & $\mathrm{U}$ & $\ldots$ \\
\hline 4,4'-DDT & 95 & u. & - & 94 & $\mathrm{U}$ & $\ldots$ & 91 & U. & - & 93 & $\mathrm{u}$. & $\ldots$ & 95 & U. & $\ldots$ & 95 & $\mathrm{u}$ & $\ldots$. & 94 & 4. & $\ldots$ \\
\hline Methoxychlor & 480 & $u$. & - & 470 & u & -1 & 460 & 4. & $\ldots$ & 470 & $\mathrm{u}$. & $\ldots$ & 480 & $\mathrm{u}$. & $\ldots$ & 470 & $\mathrm{U}$. & $\ldots$ & 470 & 4. & $\ldots$ \\
\hline Endrin ketone & 95 & $u$. & $\ldots$ & 94 & 4 & $\ldots$ & 91 & U. & - & 93 & 4. & $\ldots$ & 95 & u. & $\ldots$ & 95 & 4. & $\ldots$ & 94 & 4. & $\ldots$ \\
\hline Alpha-chlordane & 480 & 4. & - & 470 & 4 & $\ldots$ & 460 & 4. & $\ldots-$ & 470 & 4. & $\ldots$ & 480 & $u$. & $\ldots$ & 470 & $u$. & $\ldots$ & 470 & 4. & $\ldots$ \\
\hline Gamma-chlordane & 480 & 4. & -1 & 470 & $\mathrm{u}$ & $\ldots$ & 460 & 4. & - & 470 & 4. & $\ldots$ & 480 & 4. & $\ldots$ & 470 & 4 & $\ldots$ & 470 & 4 & $\ldots$ \\
\hline Toxaphene & 950 & $u$. & -1 & 940 & 4 &.- & 910 & $\mathrm{u}$. & - & 930 & $u$. & $\ldots$ & 950 & U. & - & 950 & $u$ & $\ldots$ & 940 & $\mathrm{u}$. & $\ldots$ \\
\hline Aroclor-1016 & 480 & $u$. & -1 & 470 & & - & 460 & U. & - & 470 & 4. & - & 480 & u. & $\ldots$ & 470 & 4. & $\ldots$ & 470 & u. & $\ldots$ \\
\hline Aroclor-1221 & 480 & 4. & -1 & 470 & U & - & 460 & $\mathrm{U}]$. & -1 & 470 & U. & -1 & 480 & $\mathrm{U}$ & - & 470 & $U$ & -1 & 470 & U. & - \\
\hline
\end{tabular}




\begin{tabular}{|c|c|c|c|c|c|c|c|c|c|c|c|c|c|c|}
\hline \multirow[b]{2}{*}{ Compound (ug/Kg) } & \multicolumn{14}{|c|}{ Table A-8.2 Pesticides/PCB's } \\
\hline & 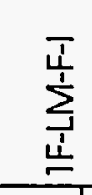 & $\dot{Q}^{*}$ & 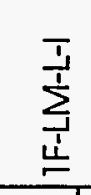 & $\stackrel{*}{*} \stackrel{*}{0}$ & 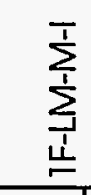 & $\stackrel{\circ}{0}^{*}$ & 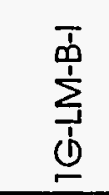 & $\varpi^{*} \stackrel{*}{2}$ & $\begin{array}{l}\sum_{1}^{T} \\
\stackrel{1}{1} \\
\underline{d}\end{array}$ & $\left.\stackrel{0}{0}^{*}\right)^{*}$ & 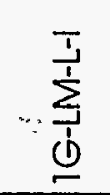 & $\left.{ }^{*}\right)^{*}$ & 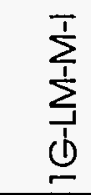 & ${ }^{*}{ }^{*} \stackrel{3}{*}$ \\
\hline Aroclor-1232 & 480 & $0 . .$. & 470 & U. & 460 & 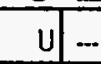 & 470 & U. & 480 & u. & 470 & 0 & 470 & $0 . \ldots$ \\
\hline Aroclor-1242 & 480 & u & 470 & $0 . \ldots$ & 460 & U.... & 470 & u $\ldots$ & 480 & $0 \mid-$ & 470 & U]- & 470 & 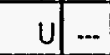 \\
\hline Aroclor-1248 & 480 & U. & 470 & u & 460 & U.... & 470 & u $[\ldots$ & 480 & u[... & 470 & $0[\ldots$ & 470 & U. \\
\hline Aroclor-1254 & 950 & $\mathrm{u}=$ & 940 & $0 \mid \ldots$ & 910 & v. & 930 & U & 950 & u. & 950 & $v[\ldots$ & 940 & U) $\ldots$ \\
\hline Aroclor-1260 & 950 & \begin{tabular}{c|c}
$u$ & $\ldots$ \\
\end{tabular} & 940 & $\mathrm{u}] \ldots$ & 910 & $u \mid \ldots$ & 930 & U] & 950 & U & 950 & $0 \mid \ldots$ & 940 & \begin{tabular}{l|l|} 
& $\ldots$ \\
\end{tabular} \\
\hline
\end{tabular}




\begin{tabular}{|c|c|c|c|c|c|c|c|c|c|c|c|c|c|c|c|c|c|c|}
\hline \multirow[b]{2}{*}{ Parameter $(\mathrm{pCi} / \mathrm{g})$} & \multicolumn{18}{|c|}{ Table A-8.3 Gross Alpha/Beta } \\
\hline & 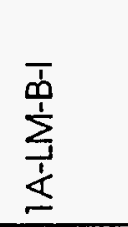 & 莒 & 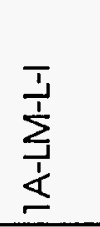 & $\overbrace{0}^{*}$ & $\frac{\sum_{i}^{T}}{\sum_{1}^{1}}$ & 3 & 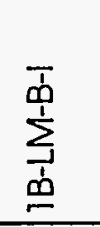 & $3^{*}$ & 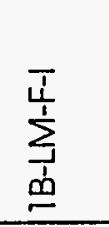 & "े & 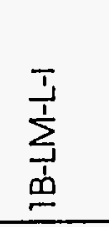 & 草 & 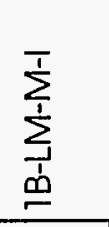 & 莒 & $\begin{array}{l}\bar{\phi} \\
\sum_{1}^{1} \\
\underline{\Delta}\end{array}$ & 草 & 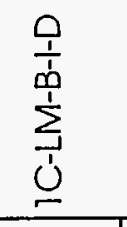 & 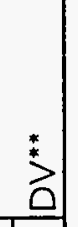 \\
\hline Alpha & 7.80 & $\mathrm{|J}$ & ND & - & $\mathrm{ND}$ & - & ND & - & 0.58 & 0 & 0.22 & 1 & 0.24 & 5 & ND & - & $\mathrm{ND}$ & - \\
\hline Sigma Error +/- & 5.73 & - & & $-\ldots$ & & $-\ldots$ & & -- & 0.13 & - & 0.11 & -- & 0.13 & - & & $-\infty$ & & - \\
\hline MDA" & 7.64 & $-\infty$ & 0.34 & Uus & 0.24 & $4 . \mathrm{UJ}$ & 10.48 & US & 0.10 & -- & 0.10 & - & 0.14 & $\mid-\ldots$ & 9.75 & |uJ & 12.72 & UJ \\
\hline Beta & 30.60 & $-\infty$ & 2.29 & $\ldots$ & 2.13 & - & 21.05 & -- & 0.41 & -- & 2.68 & $-\ldots$ & 2.34 & -- & 28.20 & - & 37.64 & - \\
\hline Sigma Error $+/$ - & 4.92 & - & 0.20 & - & 0.15 & $5-$ & 4.86 & - & 0.08 & - & 0.16 & $-\ldots$ & 0.16 & $\mid--$ & 4.52 & -- & 5.12 & -- \\
\hline MDA* & 5.76 . & - & 0.17 & $-\ldots$ & 0.11 & ] & 6.68 & 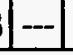 & 0.10 & 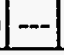 & 0.11 & --- & 0.12 & 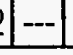 & 5.11 & -1 & 5.46 & \\
\hline
\end{tabular}




\begin{tabular}{|c|c|c|c|c|c|c|c|c|c|c|c|c|c|c|c|c|c|c|}
\hline \multirow[b]{2}{*}{ Parameter $(\mathrm{pCi} / \mathrm{g})$} & \multicolumn{18}{|c|}{ Table A-8.3 Gross Alpha/Beta } \\
\hline & 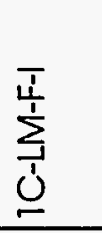 & 艾 & 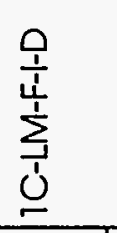 & 草 & $\begin{array}{l}\frac{T}{1} \\
\frac{1}{3} \\
\underline{U} \\
\end{array}$ & 艾 & 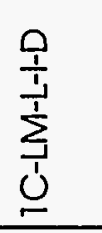 & $\stackrel{*}{2}$ & $\sum_{\substack{1 \\
U}}^{T}$ & $\stackrel{*}{*}$ & $\frac{0}{\sum_{1}^{1}}$ & $\stackrel{2}{0}^{*}$ & 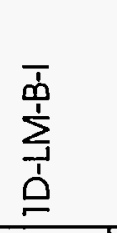 & $\stackrel{*}{3}$ & 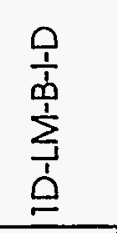 & $\stackrel{*}{2}$ & $\sum_{\substack{1\\
}}^{\frac{T}{1}}$ & $\stackrel{3}{0}^{*}$ \\
\hline Alpha & 0.02 & - & 1.42 & $\mathrm{~J}$ & 0.34 & $\mathrm{~J}$ & ND & $\ldots$ & 0.10 & $\ldots$ & 0.33 & $\mathrm{~J}$ & 7.29 & - & 6.02 & $-\cdots$ & 0.03 & - \\
\hline Sigma Error + $1-$ & 0.03 & - & 0.16 & - & 0.16 & - & & - & 0.11 & - & 0.18 & $-\cdots$ & 5.35 & $-\infty$ & 4.73 & $-\cdots$ & 0.03 & - \\
\hline $\mathrm{MDA}^{*}$ & 0.05 & US & 0.06 & - & 0.17 & - & 0.39 & UJ & 0.17 & UJ & 0.24 & -- & 6.78 & $-\infty$ & 6.22 & $\mathrm{U}$ & 0.05 & $U$ \\
\hline Beta & 0.11 & - & 0.81 & - & 3.06 & - & 2.57 & - & 2.30 & -- & 2.23 & $-\infty$ & 32.82 & $\ldots$ & 32.71 & -- & 0.13 & $-\cdots$ \\
\hline Sigma Error + & 0.06 & - & 0.10 & - & 0.20 & $-\infty$ & 0.18 & -- & 0.16 & $-\infty$ & 0.17 & -- & 5.44 & -- & 5.61 & $-\cdots$ & 0.06 & - \\
\hline $\mathrm{MDA}^{*}$ & 0.10 & -- & 0.11 & $-\cdots$ & 0.13 & $\ldots$ & 0.13 & $-\cdots$ & 0.12 & 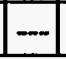 & 0.14 & $\cdots$ & 6.57 & - & 5.89 & $\mid \ldots$ & 0.10 & 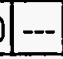 \\
\hline
\end{tabular}




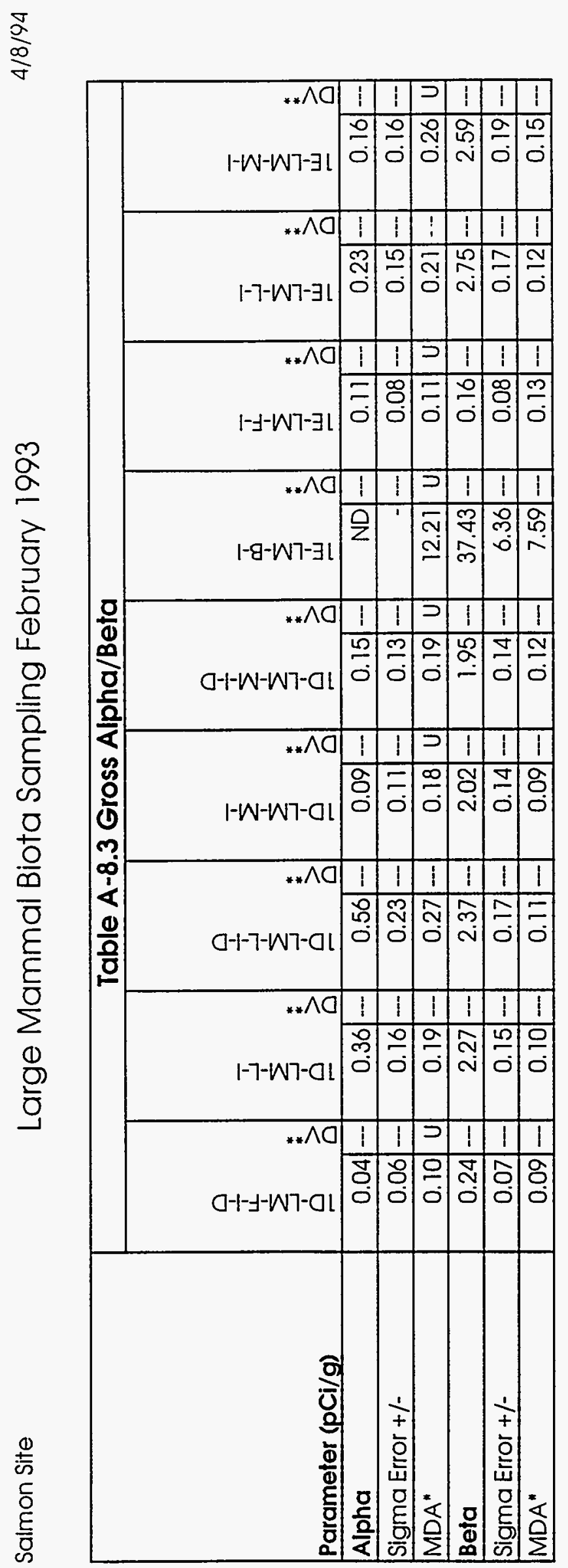

$\infty$
$\frac{\infty}{5}$
0
0
0
0

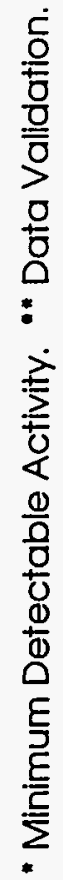




\begin{tabular}{|c|c|c|c|c|c|c|c|c|c|c|c|c|c|c|c|c|}
\hline \multirow[b]{2}{*}{ Parameter $(p \mathrm{Ci} / g)$} & \multicolumn{16}{|c|}{ Table A-8.3 Gross Alpha/Beta } \\
\hline & $\sum_{\substack{1 \\
\underline{1}}}^{\overline{1}}$ & $\stackrel{*}{2}$ & $\sum_{\substack{1 \\
\dot{1}}}^{\bar{i}}$ & $\stackrel{*}{2}$ & 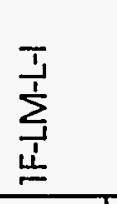 & 茥 & 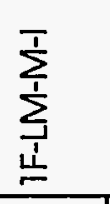 & $\stackrel{*}{2}$ & 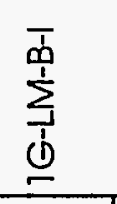 & $\stackrel{*}{2}$ & $\frac{\sum_{i}^{\frac{1}{1}}}{\mathbb{1}}$ & 艾 & $\frac{\sum_{j}^{\top}}{\grave{1}}$ & 莡 & 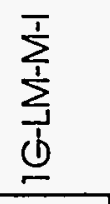 & $\stackrel{*}{2}$ \\
\hline Alpha & ND & - & ND & - & 0.40 & $\mathrm{~J}$ & 0.26 & $\mathrm{~J}$ & ND & - & 0.09 & $-\infty$ & 0.34 & $\mathrm{~J}$ & 0.13 & - \\
\hline Sigma Error $+1-$ & & - & & - & 0.17 & - & 0.14 & -- & - & - & 0.14 & -- & 0.20 & - & 0.11 & - \\
\hline $\mathrm{MDA}^{*}$ & 12.12 & UJ & 0.05 & UJ & 0.19 & - & 0.17 & - & 12.20 & UJ & 0.23 & UJ & 0.29 & - & 0.16 & $\mathrm{UJ}$ \\
\hline Befa & 36.09 & - & $\mathrm{ND}$ & - & 2.67 & -- & 2.46 & $-\infty$ & 29.72 & $-\infty$ & 0.32 & -- & 2.58 & - & 3.07 & - \\
\hline Sigma Error +/- & 6.01 & - & & - & 0.18 & - & 0.17 & $-\cdots$ & 4.78 & - & 0.08 & $-\infty$ & 0.18 & - & 0.19 & - \\
\hline $\mathrm{MDA}^{*}$ & 7.11 & - & 0.10 & 4 & 0.13 & - & 0.11 & $-\cdots$ & 5.48 & $-\infty$ & 0.11 & -- & 0.12 & - & 0.12 & - \\
\hline
\end{tabular}




\begin{tabular}{|c|c|c|c|c|c|c|c|c|c|c|c|c|c|c|c|c|c|c|}
\hline \multirow[b]{2}{*}{ Nuclide (pCi/g) } & \multicolumn{18}{|c|}{ Table A-8.4 Gamma Spectroscopy } \\
\hline & $\sum_{\frac{1}{d}}^{\frac{1}{d}}$ & 苦 & $\frac{\overline{1}}{\sum_{3}^{1}}$ & 艾 & $\frac{T}{\frac{1}{1}}$ & 苦 & $\sum_{\frac{1}{1}}^{T}$ & 莡 & $\frac{\sum_{a}^{\infty}}{\dot{\phi}}$ & 兌 & $\frac{\bar{i}}{\frac{1}{1}}$ & 莡 & 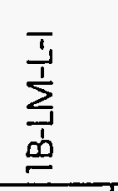 & ${ }^{*}$ & $\sum_{\substack{1 \\
\infty}}^{T}$ & 草 & 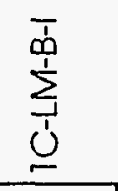 & $\stackrel{3}{0}^{*}$ \\
\hline Cesium 137 & ND & $\ldots$ & ND & $-\ldots$ & ND & $-\ldots$ & ND & $-\ldots$ & $\mathrm{ND}$ & $\ldots$ & ND & $\ldots$ & ND &.- & 0.32 & $\ldots$ & ND & - \\
\hline Sigma Error + /- & - & $\ldots$ & & $\ldots$ & & - & -1 & $\ldots$ & & - & & $\ldots$ & 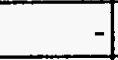 & $\ldots$ & 0.04 & $\ldots$ & - &.- \\
\hline $\mathrm{MDA}^{*}$ & 0.20 & $\mathrm{u}$ & 0.40 & 4 & 0.20 & 4 & 0.20 & 4 & 0.10 & $\mathrm{u}$ & 0.20 & $\mathrm{U}$ & 0.20 & u & 0.10 & $\ldots$ & 0.10 & $u$ \\
\hline Potassium $\mathbf{4 0}$ & ND & $\ldots$ & $\mathrm{ND}$ & - & ND & $\ldots$ & 2.70 & $\ldots$ & ND & $\ldots$ & $\mathrm{ND}$ & $\ldots$ & 10.20 & $\ldots$ & 4.10 & $\ldots$ & ND & $\ldots$ \\
\hline Sigma Error +/- & & $\ldots$ & & $-\cdots$ & -1 & - & 0.40 & $\ldots$ & - & - & - & $\ldots$ & 0.70 & - & 0.50 & $\ldots$ & - &.- \\
\hline $\mathrm{MDA}^{*}$ & 0.50 & 5.00 & 11.10 & 4 & 3.10 & 4 & 2.50 & $\ldots$ & 2.60 & $\mathrm{u}$ & 5.20 & $u$ & 0.80 & $-\ldots$ & 1.90 & $\ldots$ & 1.70 & $\mathrm{u}$ \\
\hline Cadmium 109 & & $\ldots$ & & $\ldots$ & & $\ldots$ & & $-\cdots$ & & $\ldots$ & & $\ldots$ & -1 & $\ldots$ & - & -- & - & $\ldots$ \\
\hline Sigma Error +1- & & $\ldots$ & & - & & -- & & $\ldots$ & & $\ldots$ & - & $\ldots$ & - & - & - & $\ldots$ & - & $\ldots$ \\
\hline $\mathrm{MDA}^{*}$ & & $\ldots$ & & $\ldots$ & -1 & $\ldots$ & & $\ldots$ & -1 & $\ldots$ & - & $\ldots$ & 4 & $-\ldots$ & - & $-\ldots$ & -1 & $\ldots$ \\
\hline Lead 212 & ND & $\ldots$ & ND & $\ldots$ & $\mathrm{ND}$ & $\ldots$ & $\mathrm{ND}$ & $\ldots$ & 0.14 & $\ldots$ & ND & $\ldots$ & ND & $\ldots$ & ND & $\ldots$ & 0.14 & $\ldots$ \\
\hline Sigma Error $+1-$ & & - & & $\ldots$ & & $\ldots$ & & $\ldots$ & 0.03 & - & - & $\ldots$ & & - & & $\ldots$ & 0.04 & $\ldots$ \\
\hline MDA* & 0.30 & $\mathrm{u}$ & 0.60 & 4 & 0.20 & $\mathrm{U}$ & 0.20 & 4 & 0.10 & $\ldots$ & 0.30 & $u$ & 0.30 & u & 0.10 & 4 & 0.10 & $\ldots$ \\
\hline Radium 226 & ND & $\ldots$ & $\mathrm{ND}$ & $\ldots$ & ND & $\ldots$ & ND & $\ldots$ & ND & $\ldots$ & ND & $\ldots$ & ND & - & ND & $\ldots$ & ND & $\ldots$ \\
\hline Sigma Error +1- & & $\ldots$ & & $\ldots$ & & $\ldots$ & & $\ldots$ & & $\ldots$ & & $\ldots$ & & - & & $\ldots$ & & $\ldots$ \\
\hline MDA" & 0.30 & $u$ & 0.70 & 4 & 0.30 & $\mathrm{U}$ & 0.20 & 4 & 0.20 & $\mathrm{U}$ & 0.30 & 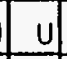 & 0.30 & $u$ & 0.20 & U & 0.20 & $u$ \\
\hline Bismuth 214 & 0.40 & $\ldots$ & ND & $\ldots$ & ND & $\ldots$ & $\mathrm{ND}$ & $\ldots$ & ND &.- & ND & $\ldots$ & ND & - & $\mathrm{ND}$ & $\ldots$ & ND & $\ldots$ \\
\hline Sigma Error + /- & 0.10 & $\ldots$ & & $\ldots$ & & $\ldots$ & & $-\ldots$ & & $\ldots$ & & $\ldots$ & - & -- & - & $\ldots$ & & $\ldots$ \\
\hline MDA" & 0.30 & $\ldots$ & 0.70 & $u$ & 0.40 & u & 0.20 & U & 0.30 & $\mathrm{U}$ & 0.40 & $u$ & 0.40 & u & 0.30 & $u$ & 0.20 & $\mathrm{U}$ \\
\hline Lead 210 & & $\ldots$ & & $\ldots$ & & $\ldots$ & & - & & $\ldots$ & & $\ldots$ & 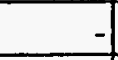 & $\ldots$ & & $\ldots$ & & $\ldots$ \\
\hline Sigma Error $+1-$ & & - & & - & & - & & - & & - & & $\ldots$ & - & $\ldots$ & & $-\ldots$ & & $\ldots$ \\
\hline $\mathrm{MDA}^{*}$ & & - & & -1 & & - & & - & & $\ldots$ & & $\ldots$ & - & $\ldots$ & & $-\cdots$ & & $\ldots$ \\
\hline Uranium 238 & & - & & - & $t$ & - & & - & & - & & $\ldots$ & 7 & -1 & & $\ldots$ & - & $\ldots$ \\
\hline Sigma Error +1- & & - & & - & & - & & - & & - & -1 & $-\ldots$ & - & - & - & - & - & - \\
\hline $\mathrm{MDA}^{*}$ & & - & & - & & -1 & & $\ldots$ & & - & & $\ldots$ & & $\ldots$ & & $\ldots$ & & - \\
\hline
\end{tabular}

- Minimum Detectable Activity. " "Data Validation. 


\begin{tabular}{|c|c|c|c|c|c|c|c|c|c|c|c|c|c|c|c|c|c|c|}
\hline \multirow[b]{2}{*}{ Nuclide $(\mathrm{pCi} / \mathrm{g})$} & \multicolumn{18}{|c|}{ Table A-8.4 Gamma Spectroscopy } \\
\hline & & 3. & $\sum_{\substack{1 \\
\frac{1}{4}}}^{\frac{T}{1}}$ & 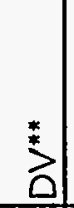 & 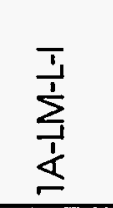 & 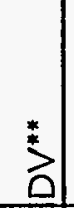 & $\begin{array}{l}\sum_{i}^{T} \\
\leq \\
\leq\end{array}$ & $\vdots$ & 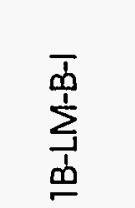 & $\vdots$ & 京 & 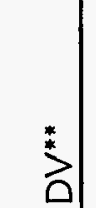 & & 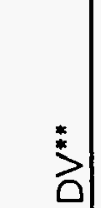 & 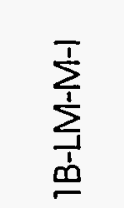 & 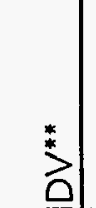 & 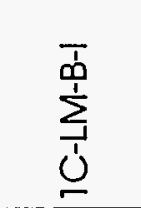 & 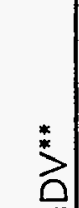 \\
\hline Radium 228 & & - & & $\ldots$ & & $\ldots$ & & $-1 .$. & & -... & & $-\ldots$ & & $\ldots$ & & $\ldots$ & & 11 \\
\hline Sigma Error +/- & & - & & - & & $\ldots$ & & $\ldots$ & & $-\ldots$ & & -... & & $\ldots$ & & $\ldots$ & & \\
\hline $\mathrm{MDA}^{*}$ & & - & & - & & -1 & & $-\ldots$ & & $-\infty$ & & $-\ldots$ & & $\ldots$ & & -1 & & $=$ \\
\hline Thallium 208 & & - & & - & & - & & $-\ldots$ & & $-\ldots$ & & -1 & & - & & $-\ldots$ & & \\
\hline Sigma Error $+1-$ & & - & & $\theta$ & & $\ldots$ & & $-\infty$ & & $-\infty$ & & $-\ldots$ & & $\ldots$ & & $-\ldots$ & & \\
\hline $\mathrm{AA}^{*}$ & & $E$ & & -1 & & 7 & & -1 & & $-\ldots$ & & $\ldots$ & & -1 & & $=$ & & \\
\hline
\end{tabular}


$\frac{\nabla}{\frac{\nabla}{\partial}}$

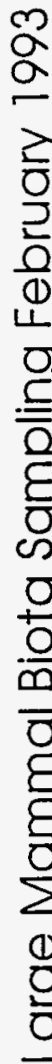

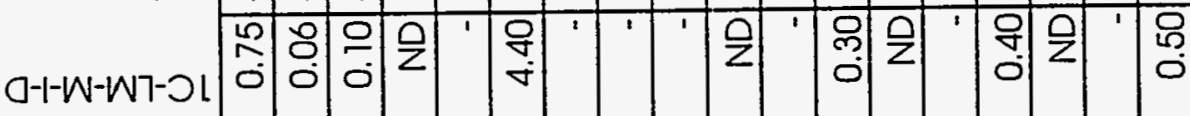

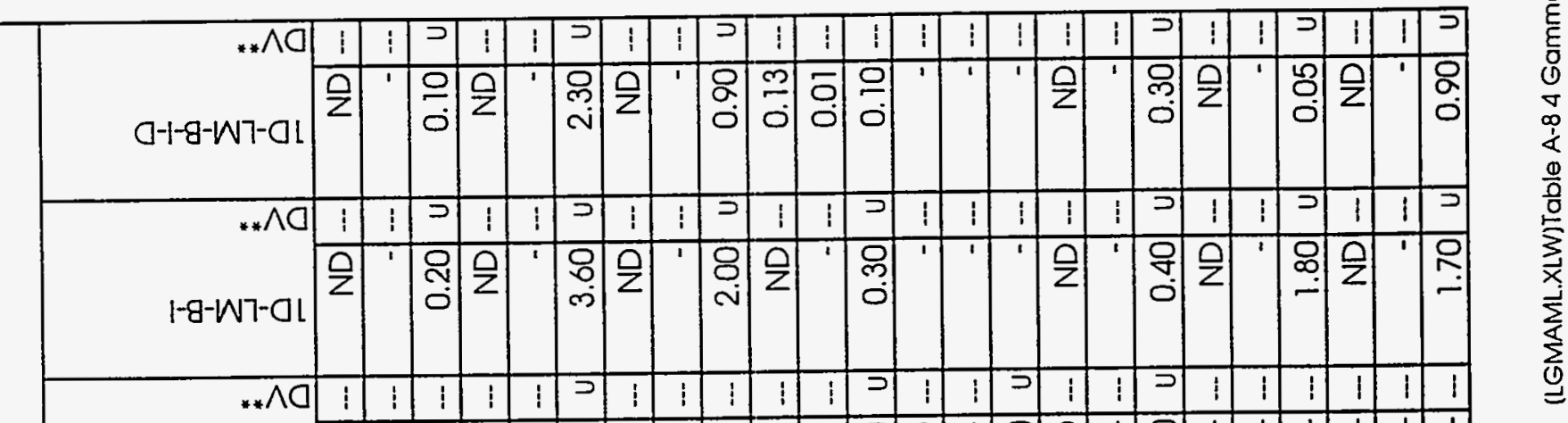

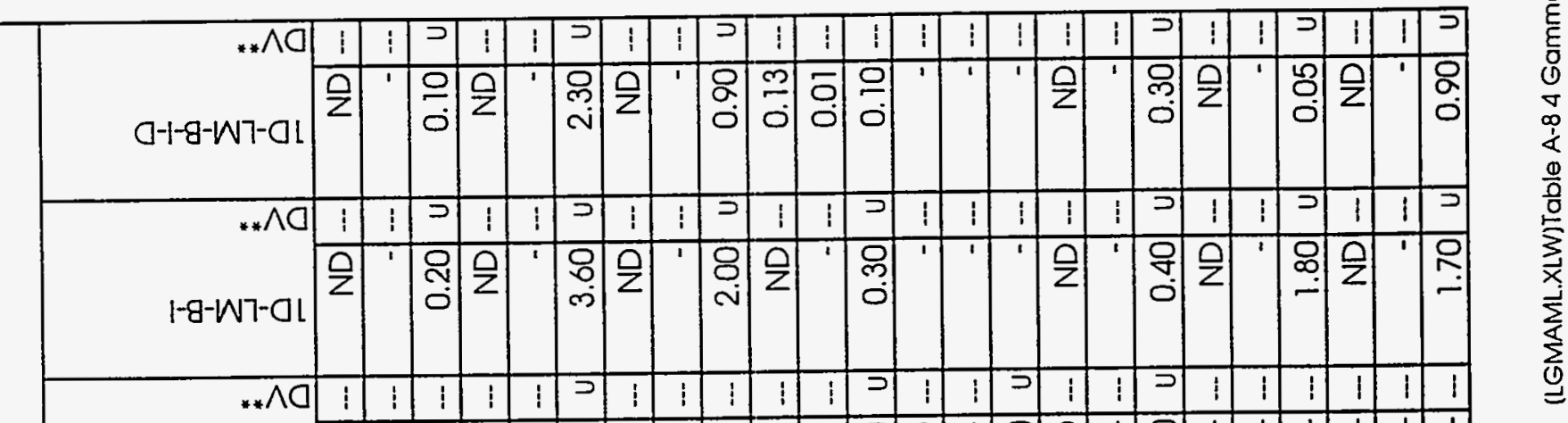

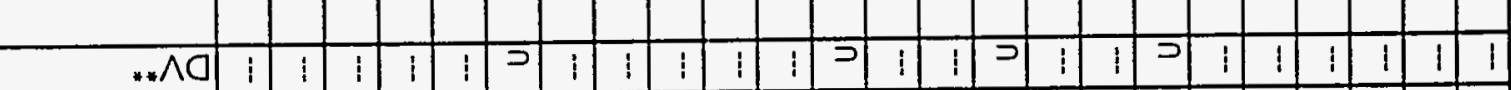

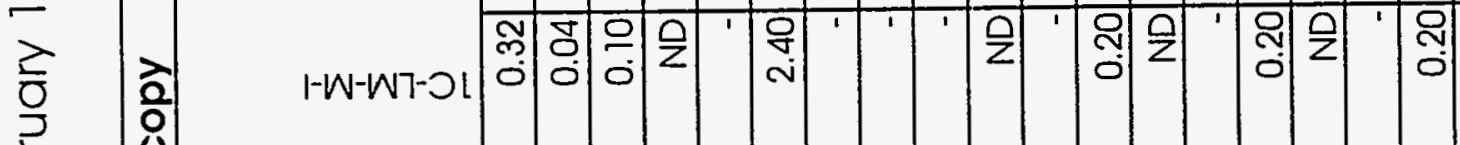

实

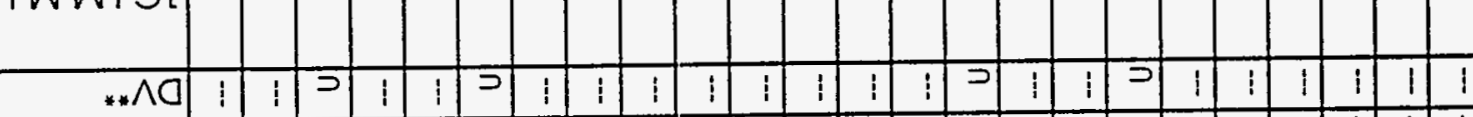

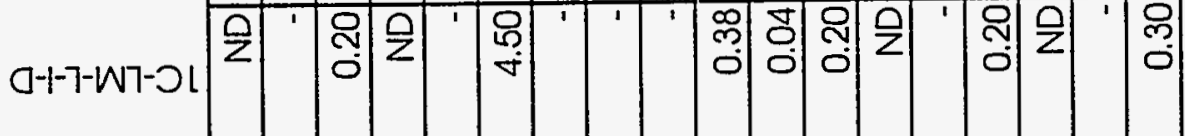

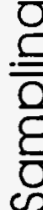

$\frac{0}{\frac{0}{0}}$

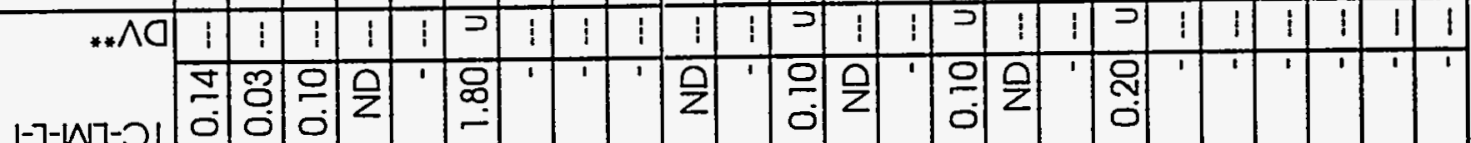

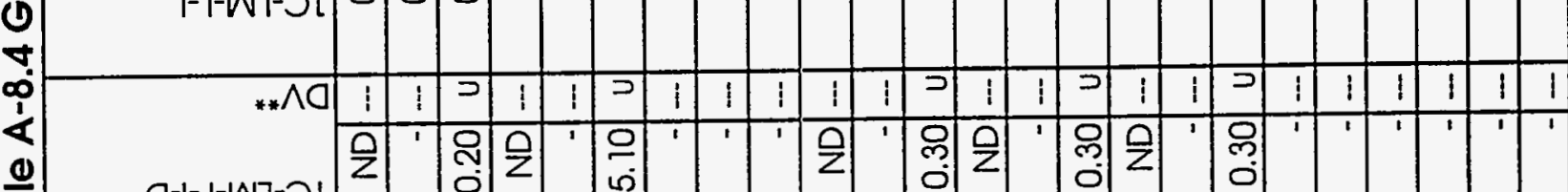

a-1-J-W7-OL $\left.\right|^{2} \quad 0 \quad$ w

은

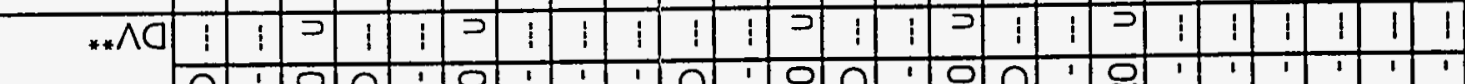

）

ส-1-8-พา-ว!

$\frac{\infty}{\stackrel{5}{5}}$

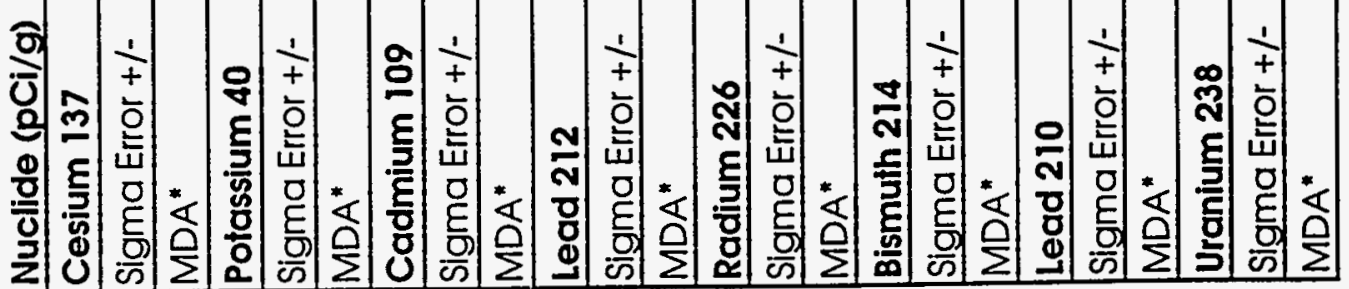




\begin{tabular}{|c|c|c|c|c|c|c|c|c|c|c|c|c|c|c|c|c|c|c|}
\hline \multirow[b]{2}{*}{ Nuclide $(\mathrm{pCi} / \mathrm{g})$} & \multicolumn{18}{|c|}{ Table A-8.4 Gamma Spectroscopy } \\
\hline & 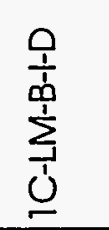 & 素 & 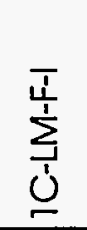 & $3^{*}$ & 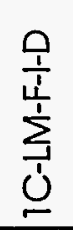 & 艾 & 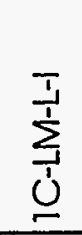 & : & 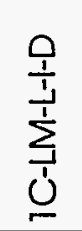 & 莒 & 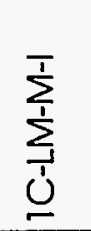 & ? & $\begin{array}{l}\frac{1}{1} \\
\sum_{\substack{1 \\
1}}^{1} \\
\underline{0}\end{array}$ & $3^{*}$ & 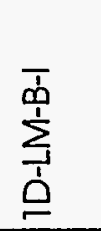 & $\overbrace{}^{*}$ & $\begin{array}{l}\frac{0}{1} \\
\dot{1} \\
\sum_{1}^{1} \\
\underline{1} \\
\underline{0}\end{array}$ & 3 \\
\hline Radium 228 & & $\ldots$ & & $-\ldots$ & & -... & & - & & - & & $-\ldots$ & & $-\ldots$ & 1.40 & F- & ND & $\ldots$ \\
\hline Sigma Error +1- & & - & & - & & $\ldots$ & & - & & - & & $\ldots$ & & $-\ldots$ & 0.20 & ... & & - \\
\hline $\mathrm{MDA}^{*}$ & & $-\ldots$ & & - & & $\ldots$ & & $\ldots$ & & - & & $\ldots$ & & - & 0.80 & -.. & 0.30 & $t$ \\
\hline Thallium 208 & & -. & & $\ldots$ & & $\ldots$ & & $\ldots$ & & -.. & & $\ldots$ & & $-\ldots$ & $\mathrm{ND}$ & $=$ & ND & 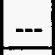 \\
\hline Sigma Error + /- & & $-\ldots$ & & $-\ldots$ & & $\ldots$ & & -.. & & -1 & & -- & & - & & $\ldots$ & & \\
\hline MDA* & & - & & $-\ldots$ & & 1 & & . .. & & .... & & $\ldots$ & & .... & 0.20 & o & 0.10 & \\
\hline
\end{tabular}




\begin{tabular}{|c|c|c|c|c|c|c|c|c|c|c|c|c|c|c|c|c|c|c|}
\hline \multirow[b]{2}{*}{ Nuclide (pCi/g) } & \multicolumn{18}{|c|}{ Table A-8.4 Gamma Spectroscopy } \\
\hline & $\begin{array}{l}\frac{\pi}{1} \\
\vdots \\
0 \\
0\end{array}$ & $3^{*}$ & 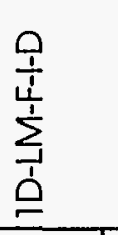 & $\stackrel{*}{*}$ & $\begin{array}{l}\frac{1}{1} \\
\sum_{1}^{1} \\
0\end{array}$ & ${ }^{*}$ & $\begin{array}{l}\frac{0}{1} \\
\frac{1}{1} \\
\underline{1} \\
0 \\
0\end{array}$ & $\stackrel{*}{*}$ & $\begin{array}{l}\sum_{1}^{T} \\
\sum_{1}^{1} \\
\underline{0}\end{array}$ & ${ }^{*}$ & $\begin{array}{l}\frac{0}{1} \\
\sum_{1}^{\frac{1}{1}} \\
0\end{array}$ & $\stackrel{*}{*}$ & 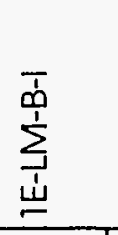 & $\stackrel{*}{2}$ & 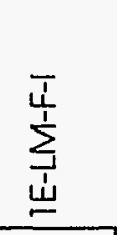 & $\stackrel{*}{2}$ & 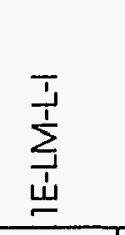 & $\stackrel{3}{0}^{*}$ \\
\hline Cesium 137 & ND & -- & ND & $-\ldots$ & 0.22 &.- & 0.24 & -- & 0.43 & $-\infty$ & 0.32 & $\ldots$ & ND &.- & ND & $\ldots$ & 0.24 & -- \\
\hline Sigma Error $+1-$ & 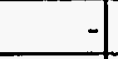 & - & - & -- & 0.03 & -- & 0.03 & -- & 0.04 & $-\ldots$ & 0.03 & -- & -7 & $\ldots$ & & $\ldots$ & 0.04 & $\ldots$ \\
\hline MDA* & 0.10 & $\mathrm{U}$ & 0.10 & 4 & 0.10 & -- & 0.10 & $\ldots$ & 0.10 & -- & 0.10 & -- & 0.10 & $U$ & 0.10 & $\mathrm{u}$ & 0.10 &.- \\
\hline Potassium 40 & ND & -- & ND & -- & ND & $\ldots$ & 4.70 & $-\cdots$ & 3.90 & $\ldots$ & ND & $\ldots$ & ND & $\ldots$ & ND & $-\cdots$ & 3.20 & -- \\
\hline Sigma Error +1- & & $\ldots$ & & $\ldots$ & - & $\ldots$ & 0.40 & $\ldots$ & 0.30 & $\ldots$ & - & $\ldots$ & & - & 7 & $\ldots$ & 0.40 & - \\
\hline MDA* & 1.70 & $U$ & 2.40 & U & 4.60 & 4 & 0.80 & $\ldots$ & 2.50 & -- & 4.70 & $u$ & 2.40 & 4 & 2.90 & 4 & 1.90 & $\ldots$ \\
\hline Cadmium 109 & ND & $-\infty$ & ND. & -- & ND & $\ldots$ & ND & $\ldots$ & ND & $\ldots$ & ND & -- & ND & -- & ND & --- & ND & -- \\
\hline Sigma Error +1- & & -- & & $\ldots$ & & $\ldots$ & & $\ldots$ & & $\ldots$ & 7 &.- & & -- & 4 & $\ldots$ & - &.- \\
\hline $\mathrm{MDA}^{*}$ & 1.80 & $\mathrm{U}$ & 1.00 & $u$ & 1.50 & 4 & 1.00 & 4 & 1.30 & $\mathrm{U}$ & 1.40 & $\mathrm{U}$ & 1.30 & $u$ & 1.10 & u & 1.00 & $\mathrm{U}$ \\
\hline Lead 212 & ND & $\ldots$ & ND & -- & ND & $\ldots$ & ND & -- & ND & $\ldots$ & ND & $\ldots$ & 0.50 &.- & ND & $\ldots$ & ND &.- \\
\hline Sigma Error $+1-$ & & - & & - & - & -- & - & $\ldots$ & - & - & - & $\ldots$ & 0.10 & $\ldots$ & - & $\ldots$ & -1 & $-\ldots$ \\
\hline MDA* & 0.20 & $\mathrm{U}$ & 0.20 & $u$ & 0.20 & 4 & 0.20 & $u$ & 0.20 & 4 & 0.20 & $\mathrm{U}$ & 0.20 & $\ldots$ & 0.20 & $u$ & 0.20 & U \\
\hline Radium 226 & & -- & & -- & -7 & $\ldots$ & & $\ldots$ & & $\ldots$ & & $\ldots$ & -7 & -- & & $\ldots$ & - & $\ldots$ \\
\hline Sigma Error +1- & & $\ldots$ & & -- & & -- & & - & & -- & & -- & - & - & $\rightarrow$ & $\ldots$ & - & - \\
\hline $\mathrm{MDA}^{*}$ & & $-{ }_{-1}$ & . & $\ldots$ & -1 & $\ldots$ & - & $\ldots$ & & $\ldots$ & - & $-\infty$ & 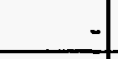 &.- & 1 & $\ldots$ & - & $\ldots$ \\
\hline Bismuth 214 & ND & -- & $\mathrm{ND}$ & $\ldots$ & ND & -- & ND & - & ND & -- & ND & $\ldots$ & ND & -- & ND & -- & ND & - \\
\hline Sigma Error +1- & & $\ldots$ & & - & & - & & $\ldots$ & & $\ldots$ & $\exists$ & $\ldots$ & -1 & $\ldots$ & & $\ldots$ & 4 &.- \\
\hline $\mathrm{MDA}^{*}$ & 0.20 & $\mathrm{U}$ & 0.20 & $u$ & 0.20 & $\mathrm{u}$ & 0.30 & $\mathrm{u}$ & 0.30 & $\mathrm{u}$ & 0.30 & $\mathrm{u}$ & 0.20 & $\mathrm{U}$ & 0.30 & $u$ & 0.30 & $u$ \\
\hline Lead 210 & ND & $\ldots$ & $\mathrm{ND}$ & -- & ND & -- & ND & - & ND & $\ldots$ & ND & $\ldots$ & ND & $\ldots$ & ND & $\ldots$ & ND & -- \\
\hline Sigma Error $+/$ - & & - & & - & 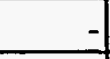 & - & -1 & - & & $\ldots$ & & -- & & $\ldots$ & & $-\ldots$ & -1 & $-\ldots$ \\
\hline MDA* & 1.10 & $\mathrm{U}$ & 1.20 & $u$ & 1.40 & $u$ & 0.10 & $\mathrm{u}$ & 1.00 & $u$ & 1.30 & $\mathrm{u}$ & 1.50 & $\mathrm{u}$ & 0.10 & $\mathrm{u}$ & 0.07 & $u$ \\
\hline Uranium 238 & ND & - & ND & - & ND & - & 3.80 & - & ND & $\ldots$ & ND & - & ND & - & ND & $\ldots$ & ND & - \\
\hline Slgma Error +1- & & $\ldots$ & & - & & - & 0.20 & - & & -- & & $\ldots$ & & $\ldots$ & & $\ldots$ & & $-\ldots$ \\
\hline MDA* & 1.30 & $\mathrm{u}$ & 1.00 & $u$ & 1.20 & $\mathrm{u}$ & 0.70 & - & 1.00 & $\mathrm{u}$ & 1.10 & $u$ & 1.20 & $u$ & 1.10 & $\mathrm{u}$ & 1.10 & $u$ \\
\hline
\end{tabular}

"Minimum Detectable Activity. " " Data Validation. 


\begin{tabular}{|c|c|c|c|c|c|c|c|c|c|c|c|c|c|c|c|c|c|c|}
\hline \multirow[b]{2}{*}{ Nuclide (pCi/g) } & \multicolumn{18}{|c|}{ Table A-8.4 Gamma Spectroscopy } \\
\hline & $\sum_{\substack{1 \\
\dot{1}}}^{\frac{1}{1}}$ & ${ }_{3}^{*}$ & $\begin{array}{l}\frac{0}{1} \\
\frac{1}{4} \\
\stackrel{1}{1} \\
\underline{1} \\
\underline{0}\end{array}$ & 艾 & $\frac{\sum^{\frac{T}{1}}}{\grave{1}}$ & ${ }_{0}^{*}$ & $\begin{array}{l}\frac{0}{1} \\
\stackrel{1}{1} \\
\stackrel{1}{1} \\
\underline{n}\end{array}$ & 光 & $\begin{array}{l}\sum_{i}^{T} \\
\frac{1}{1} \\
0\end{array}$ & 艾 & $\frac{0}{\sum_{1}^{\frac{1}{1}}}$ & $\stackrel{*}{2}$ & $\sum_{\underline{\underline{\omega}}}^{\bar{\phi}}$ & $\stackrel{2}{2}$ & 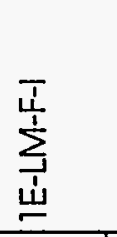 & $\stackrel{*}{2}$ & 京 & $\stackrel{*}{\mathrm{~B}^{\prime}}$ \\
\hline Radium 228 & ND & $\ldots$ & ND & $\ldots$ & ND & - & ND & $\ldots$ & ND & - & ND & $\ldots$ & ND & $\ldots$ & ND & $\ldots$ & $\mathrm{ND}$ & $\ldots$ \\
\hline Sigma Error +1- & & - & & $\ldots$ & & $\ldots$ & & - & - & - & - & $\ldots$ & - & $\ldots$ & - & $\ldots$ & - & -- \\
\hline $\mathrm{MDA}^{*}$ & 0.40 & $u$ & 0.50 & $u$ & 0.50 & $u$ & 0.50 & $u$ & 0.50 & $\mathrm{u}$ & 0.50 & $u$ & 0.70 & $\mathrm{u}$ & 0.60 & $\mathrm{u}$ & 0.50 & $U$ \\
\hline Thallium 208 & ND & $\ldots$ & ND & $\ldots$ & ND & - & ND & - & ND & - & ND & $\ldots$ & ND & $\ldots$ & 0.30 & -- & ND & - \\
\hline Sigma Error +1- & & $\ldots$ & & $\ldots$ & & - & & $\ldots$ & 4 & $\ldots$ & & $\ldots$ & - & $\ldots$ & 0.10 & $\ldots$ & - & $\ldots$ \\
\hline $\mathrm{MDA}^{*}$ & 0.10 & $u$ & 0.10 & $u$ & 0.10 & $\mathrm{u}$ & 0.10 & $\mathrm{u}$ & 0.20 & $\mathrm{u}$ & 0.10 & $u$ & 0.10 & $u$ & 0.10 & $\ldots$ & 0.10 & $\mathrm{U}$ \\
\hline
\end{tabular}




\begin{tabular}{|c|c|c|c|c|c|c|c|c|c|c|c|c|c|c|c|c|c|c|}
\hline \multirow[b]{2}{*}{ Nuclide (pCi/g) } & \multicolumn{18}{|c|}{ Table A-8.4 Gamma Spectroscopy } \\
\hline & 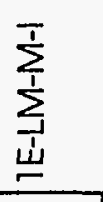 & $\stackrel{2}{0}^{*}$ & 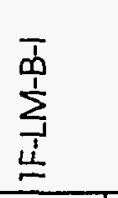 & ${ }^{*}$ & 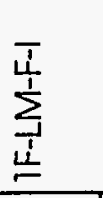 & $\overbrace{}^{*}$ & 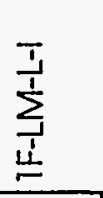 & $\stackrel{*}{2}$ & 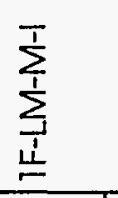 & ${ }^{*}$ & 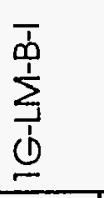 & ${ }^{*}$ & 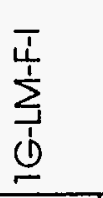 & ${ }^{*}$ & 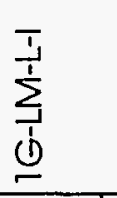 & $\stackrel{*}{*}$ & $\begin{array}{l}\sum_{i}^{T} \\
\stackrel{1}{1} \\
\end{array}$ & : \\
\hline Cesium 137 & ND & -- & ND & $\ldots$ & ND & -- & 0.21 & $-\ldots$ & 0.77 & -- & ND & $\ldots$ & ND & $\ldots$ & ND & $-\infty$ & ND & -- \\
\hline Sigma Error $+/-$ & & - & & $\ldots+$ & & - & 0.02 & --- & 0.07 & -- & & $\ldots$ & - & $\ldots$ & 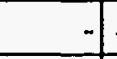 & $\ldots$ & & - \\
\hline MDA" & 0.10 & $u$ & 0.10 & $\mathrm{u}$ & 0.10 & U & 0.10 & $-\cdots$ & 0.10 & - & 0.10 & 4 & 0.20 & $U$ & 0.20 & u & 0.10 & $\mathrm{U}$ \\
\hline Potassium $\mathbf{4 0}$ & ND & $\ldots$ & ND & $\ldots$ & $\mathrm{ND}$ & - & $\mathrm{ND}$ & $\ldots$ & $\mathrm{ND}$ & $\ldots$ & ND & $\ldots$ & $\mathrm{ND}$ & -- & $\mathrm{ND}$ & $\ldots$ & 3.70 & -- \\
\hline Sigma Error +/- & & $\ldots$ & & $\ldots$ & & - & & -- & & $-\cdots$ & & $\ldots$ & - & $\ldots$ & -1 & $\ldots$ & 0.50 &.-- \\
\hline MDA* & 5.20 & $u$ & 2.20 & $u$ & 1.30 & $\mathrm{U}$ & 3.70 & $u$ & 3.70 & $\mathrm{U}$ & 1.80 & $u$ & 5.90 & $\mathrm{u}$ & 6.50 & $u$ & 2.20 & $\ldots$ \\
\hline Cadmium 109 & ND & - & - & -- & & - & - & $\ldots$ & -1 & -- & & $\ldots$ & - & $\ldots$ & - & $\ldots$ & - & -- \\
\hline Sigma Error +/- & & - & & -- & & - & - & $\ldots$ & & $-{ }_{-1}$ & & $\ldots$ & - & $-\infty$ & . & $\ldots$ & - & $-\ldots$ \\
\hline MDA" & 1.50 & $U$ & & -- & - & $\ldots$ & - & $-\cdots$ & - & $\ldots$ & - & $-\cdots$ & - & -- & $L$ & $\ldots$ & - & $\ldots$ \\
\hline Lead 212 & ND & $\ldots$ & 0.20 & $\ldots$ & ND & - & ND & - & ND & $\ldots$ & ND & $\ldots$ & $\mathrm{ND}$ & $\ldots$ & $\mathrm{ND}$ & $\ldots$ & ND & $\ldots$ \\
\hline Sigma Error + /- & & $\ldots$ & 0.03 & -1 & & $\ldots$ & - & $\ldots$ & & $\ldots$ & & $\ldots$ & - & $\ldots$ & -1 & $\ldots$ & - & -- \\
\hline MDA* & 0.20 & $\mathrm{U}$ & 0.10 & $\ldots$ & 0.10 & $\mathrm{U}$ & 0.20 & $u$ & 0.30 & $\mathrm{u}$ & 0.10 & $u$ & 0.40 & U & 0.30 & $u$ & 0.10 & $\mathrm{U}$ \\
\hline Radium 226 & - & $\ldots$ & ND & $\ldots$ & ND & - & ND & $\ldots$ & ND & - & 0.26 & $\ldots$ & ND & $\ldots$ & ND & $\ldots$ & ND & - \\
\hline Sigma Error $+1-$ & - & $\ldots$ & & $\ldots$ & & $\ldots$ & - & $\ldots$ & - & $-\cdots$ & 0.03 & $\ldots$ & - & $\ldots$ & - & - & & $\ldots$ \\
\hline MDA* & - & $\ldots$ & 0.20 & $u$ & 0.10 & u & 0.20 & $u$ & 0.30 & $u$ & 0.20 & $-\ldots$ & 0.40 & $u$ & 0.40 & $u$ & 0.20 & U \\
\hline Bismuth 214 & ND & -- & ND & $\ldots$ & ND & $\cdots$ & $\mathrm{ND}$ & - & ND & - & $\mathrm{ND}$ & $\ldots$ & ND & $\ldots$ & $\mathrm{ND}$ & - & ND & -- \\
\hline Sigma Error $+/-$ & - &.- & & $\ldots$ & & $\ldots$ & - & $\ldots$ & -1 & -- & & $\ldots$ & - & $\ldots$ & & - & & -- \\
\hline MDA" & 0.30 & $u$ & 0.30 & $\mathrm{u}$ & 0.20 & $u$ & 0.20 & $\mathrm{u}$ & 0.40 & U & 0.20 & U & 0.50 & $u$ & 0.50 & $U$ & 0.20 & U \\
\hline Lead 210 & ND & - & & $\ldots$ & & - & & $\ldots$ & & -- & & $-\ldots$ & & $\ldots$ & - & $\ldots$ & & - \\
\hline Sigma Error +1- & & - & & -- & & $=$ & & - & & -- & & - & - & -- & & - & & -- \\
\hline $\mathrm{MDA}^{*}$ & 1.40 & $u$ & & -- & & - & & $\ldots$ & & $-\ldots$ & & $\ldots$ & - & $\ldots$ & & $-\infty$ & - & $\ldots$ \\
\hline Uranium 238 & ND & - & & - & & $=$ & & - & & - & & - & & - & - & $\ldots$ & - & $\ldots$ \\
\hline Sigma Error +1- & & - & & - & & $=$ & & - & & - & & - & & - & & - & & - \\
\hline $\mathrm{MDA}^{*}$ & 1.30 & $\mathrm{U}$ & & -1 & & - & & - & & - & & -1 & & $\ldots$ & & - & & $\ldots$ \\
\hline
\end{tabular}

"Minimum Detectable Activity. "* Data Validation. 


\begin{tabular}{|c|c|c|c|c|c|c|c|c|c|c|c|c|c|c|c|c|c|}
\hline \multirow[b]{2}{*}{ Nuclide $(\mathrm{pC} \mathrm{i} / \mathrm{g})$} & \multicolumn{17}{|c|}{ Table A-8.4 Gamma Spectroscopy } \\
\hline & & 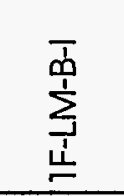 & 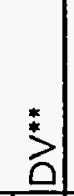 & 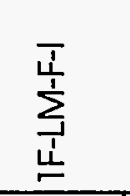 & 3 & 站 & 3 & 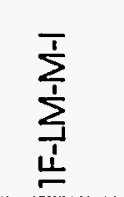 & 3 & 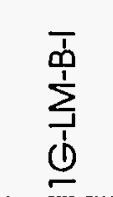 & 3 & 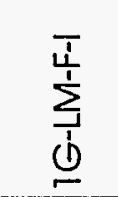 & לे & 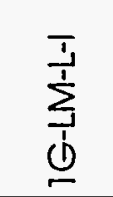 & 3 & 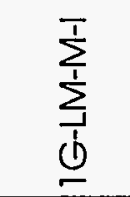 & 辛 \\
\hline Radium 228 & ND. & & $-\ldots$ & & - & & - & & -1 & & -1 & & $-\ldots$ & & $-\ldots$ & & F. \\
\hline Sigma Error $+/$ - & - & & - & & -1 & & $-\ldots$ & & -1 & & $-\ldots$ & & $\ldots$ & & $-\ldots$ & & \\
\hline $\mathrm{MDA}^{*}$ & 0.60 & & a & & - & & -1 & & - & & - & & $\ldots$ & & - & & \\
\hline Thallium 208 & ND. & & -1 & & - & & -1 & & - & & $-\ldots$ & & - & & $\ldots$ & & \\
\hline Sigma Error $+1-$ & & & -a & & - & & 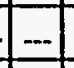 & & - & & - & & - & & 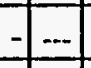 & & \\
\hline 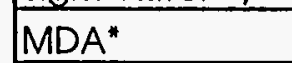 & & & & & & & $\mid \ldots 1$ & & -. & & 7 & & 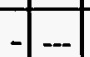 & & $\cdots 1$ & & \\
\hline
\end{tabular}




\begin{tabular}{|c|c|c|c|c|c|c|c|c|c|c|c|c|c|c|c|c|c|c|}
\hline \multirow[b]{2}{*}{ Nuclide (pCi/g) } & \multicolumn{18}{|c|}{ Table A-8.5 Tritium } \\
\hline & $\sum_{\substack{\Phi \\
\Phi}}^{\bar{d}}$ & ${ }^{*}$ & $\frac{\sum_{j}^{\frac{1}{4}}}{\dot{1}}$ & $\stackrel{2}{0}^{*}$ & $\frac{\frac{1}{1}}{\sum_{j}^{1}}$ & ${ }^{*}$ & $\begin{array}{l}\sum_{1}^{T} \\
\sum_{1}^{1} \\
\vdots \\
\end{array}$ & $\stackrel{*}{*}$ & 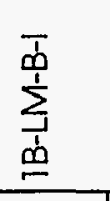 & $\stackrel{*}{*}$ & 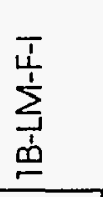 & 艾 & 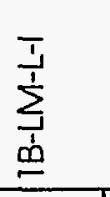 & $\stackrel{*}{2}$ & 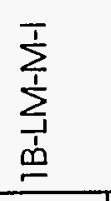 & $\stackrel{2}{*}^{*}$ & $\begin{array}{l}\bar{\phi} \\
\sum_{1}^{1} \\
\underline{u}\end{array}$ & $\stackrel{*}{0}^{*}$ \\
\hline Tritium & ND & -- & 12.88 & -- & 0.10 & -- & ND & $\ldots$ & ND & $-\ldots$ & 0.14 & -- & ND & -- & ND & -- & ND & $-\cdots$ \\
\hline Sigma Error +/- & & $-\infty$ & 1.29 & $\ldots$ & 0.05 & $--\infty$ & & $\ldots$ & & $\ldots$ & 0.03 & -- & & -- & & -- & & $-\cdots$ \\
\hline MDA" & 0.05 & U & 0.13 & -- & 0.11 & $U$ & 0.13 & U & 0.05 & 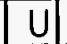 & 0.05 & \begin{tabular}{|l|}
-- \\
\end{tabular} & 0.08 & U & 0.12 & $U$ & 0.05 & $U$ \\
\hline
\end{tabular}




\begin{tabular}{|c|c|c|c|c|c|c|c|c|c|c|c|c|c|c|c|c|c|c|}
\hline \multirow[b]{2}{*}{ Nuclide (pCi/g) } & \multicolumn{18}{|c|}{ Table A-8.5 Tritium } \\
\hline & 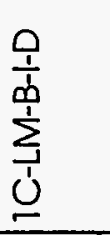 & $\begin{array}{l}* \\
\vdots\end{array}$ & 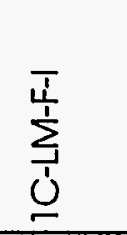 & 莡 & $\begin{array}{l}\frac{0}{1} \\
\frac{1}{4} \\
\stackrel{1}{1} \\
\underline{U} \\
\end{array}$ & 苦 & 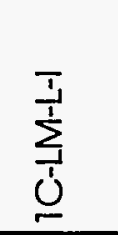 & 莒 & $\sum_{\substack{1\\
}}^{\frac{1}{1}}$ & 莒 & $\begin{array}{l}\sum_{i=1}^{T} \\
\underline{U}\end{array}$ & 莒 & $\begin{array}{l}\frac{0}{1} \\
\sum_{\substack{1 \\
1}} \\
\underline{0} \\
\end{array}$ & 莡 & 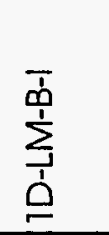 & 苦 & 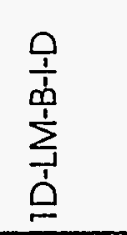 & 辛 \\
\hline Tritium & $\mathrm{ND}$ & - & $\mathrm{ND}$ & $\ldots$ & $\mathrm{ND}$ & $\ldots$ & $N D$ & - & $\mathrm{ND}$ & $\ldots$ & $\mathrm{ND}$ & $\ldots$ & $\mathrm{ND}$ & $\ldots$ & $N D$ & $\ldots$ & 0.54 & $\ldots$ \\
\hline Sigma Error $+1-$ & & |-. & & $\ldots$ & & -.. & & -.. & & $-\ldots$ & & $\ldots$ & & -.- & & $\ldots$ & 0.07 & -.. \\
\hline $\mathrm{MDA}^{*}$ & 0.10 & U & 0.05 & U & 0.05 & u & $\overline{0.06}$ & u & 0.09 & U & 0.13 & U & 0.12 & u & 0.09 & U & 0.09 & $-\ldots$ \\
\hline
\end{tabular}




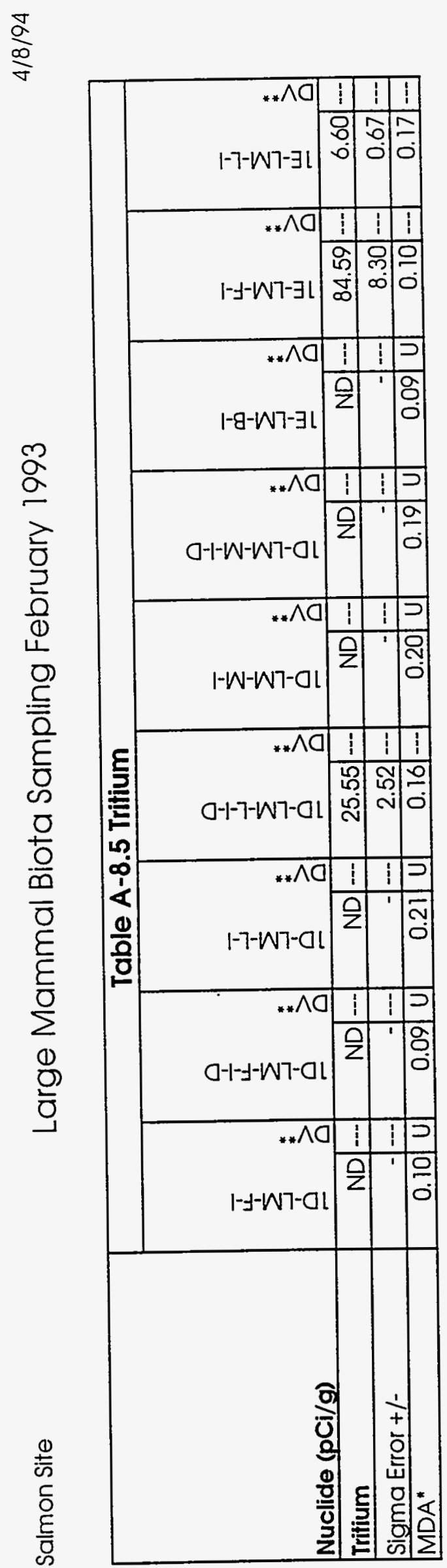




\begin{tabular}{|c|c|c|c|c|c|c|c|c|c|}
\hline$n \mid 110$ & $\ln 2 i^{\circ}$ & \begin{tabular}{|l|l|}
$---80^{\prime} 0$ \\
\end{tabular} & \begin{tabular}{|l|l|l|}
$n$ & $90^{\circ} 0$ \\
\end{tabular} & \begin{tabular}{|l|l|l|l}
$n$ & $\varepsilon L^{\prime} 0$ \\
\end{tabular} & \begin{tabular}{|l|ll} 
& $110^{\circ}$ \\
\end{tabular} & \begin{tabular}{|l|l|l}
$n$ & $90^{\circ}$ \\
\end{tabular} & \begin{tabular}{|l|l|}
$n$ & $90^{\circ} 0$ \\
\end{tabular} & \begin{tabular}{|l|l|l}
-- & $\varepsilon Z^{\circ}$ \\
\end{tabular} & $\forall \forall O W$ \\
\hline$\cdots-$ & -- & $--\overline{08} 2$ & $\cdots$ & $-\cdots$ & $--90^{\prime} 0$ & $-1-$ & $\cdots$ & ---11.0 & $-1+1011]$ DUE!s \\
\hline$--\overline{O N}$ & $-\cdots$ ON & $=10^{\prime} 82$ & $=$ ON & $--O N$ & --110 & $--\mathrm{ON}$ & $-O$ ON & $--9 \varepsilon^{\circ} 0$ & แn!!!!! \\
\hline 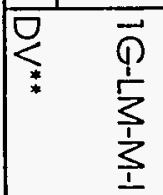 & $\begin{array}{ll}\overbrace{*}^{\nabla} & \overrightarrow{9} \\
& \frac{1}{3} \\
& \frac{1}{1}\end{array}$ & 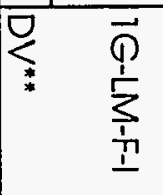 & 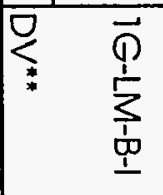 & 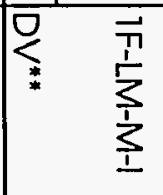 & 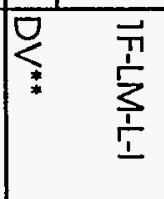 & 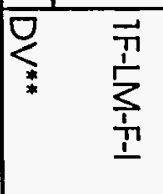 & 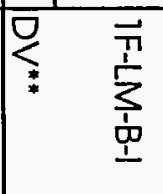 & 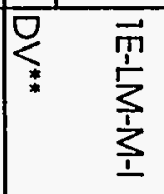 & (ठ/!うd) əp!|गnN \\
\hline \multicolumn{9}{|c|}{ un!!!! $\mathrm{G}^{\prime} 8-\forall$ ә } & \\
\hline
\end{tabular}


Table A-9.1

RBP-I Habitat Assessment Data

\begin{tabular}{|c|c|c|c|c|c|c|c|c|c|}
\hline \multirow{2}{*}{$\begin{array}{c}\text { Habitat Parameter } \\
\text { (RANGE OF VALUES) }\end{array}$} & \multicolumn{9}{|c|}{ TDTS STATION IDENTIFICATIONS } \\
\hline & HMC-11 & HMC-2 & HMC-3 & HMC-4 & HMC-5 & GRC-11 & GRC-2 & $\mathrm{HHC}-1$ & HHC-2 \\
\hline Bottom Substrate $(0-20)$ & 11 & 9 & 9 & 11 & 8 & 10 & 9 & 11 & 6 \\
\hline Stream Flow and/or Stream & & & & & & & & & \\
\hline Velocity $(0-20)$ & 9 & 11 & 11 & 18 & 13 & 16 & 11 & 9 & 2 \\
\hline Channel Aeration (0-15) & 11 & 11 & 11 & 7 & 11 & 9 & 11 & 11) & 15 \\
\hline Bottom Scouring and & & & & & & & & & \\
\hline Deposition $(0-15)$ & 12 & 12 & 12 & 9 & 10 & 9 & 12 & 12 & 7 \\
\hline $\begin{array}{l}\text { Pool/Riffle or Run/Bend } \\
\text { Ration (0-15) }\end{array}$ & 8 & 10 & 11 & 13 & 12 & 12 & 11 | & 8 & 2 \\
\hline Bank Stability $(0-10)$ & 10 & 10 & 10 & 9 & 8 & 9 & 10 & 10 & 10 \\
\hline Bank Vegetative Survey $(0-10)$ & 10 & 9 & 10 & 8 & 10 & 9 & 10 & 10 & 10 \\
\hline Streamside Cover $(0-10)$ & 10 & 10 & 10 & 9 & 10 & 10 & 10 & 10 & 10 \\
\hline Total Score & 81 & 82 & 84 & 84 & 82 & 84 & 84 & 81 & 62 \\
\hline $\begin{array}{l}\text { Percent Comparability to } \\
\text { Reference Station }\end{array}$ & 100 & 101 & 104 & 104 & 101 & 100 & 100 & 100 & 76 \\
\hline
\end{tabular}

\section{Assessment Category}

Comparable to Reference

Supporting

Partially Supporting

Non-Supporting

\section{Percent of Comparability}

$$
\begin{gathered}
\geq 90 \% \\
75-88 \% \\
60-73 \% \\
\leq 58 \%
\end{gathered}
$$

1 Indicates Reference Station for that area NOTE: EPA RBP Habitat Assessment not appropriate for pond stations. 
Table A-9.2

RBP-I Macorbenthos Data

\begin{tabular}{|c|c|c|c|c|c|c|c|c|c|}
\hline \multirow[b]{2}{*}{ Taxon } & \multicolumn{9}{|c|}{ TDTS STATION IDENTIFICATIONS } \\
\hline & HMC-1 & HMC-2 & HMC-3 & HMC-4 & HMC-5 & GRC-1 & GRC-2 & $\mathrm{HHC}-1$ & $\mathrm{HHC}-2$ \\
\hline \multicolumn{10}{|l|}{ Oligochaeta } \\
\hline \multicolumn{10}{|l|}{ Isopoda } \\
\hline \multicolumn{10}{|l|}{ Amphipoda } \\
\hline Decapoda & $\mathrm{C}$ & C & $\mathrm{C}$ & $R$ & & & & $\mathrm{C}$ & $\mathrm{R}$ \\
\hline \multicolumn{10}{|l|}{ Insecta } \\
\hline Anisoptera & $\mathrm{C}$ & $\mathrm{C}$ & $\mathrm{C}$ & $\mathrm{R}$ & $\mathrm{C}$ & $\mathrm{C}$ & $\mathrm{C}$ & $\mathrm{C}$ & $\mathrm{A}$ \\
\hline Zygoptera & $\mathrm{C}$ & & $\mathrm{C}$ & & & & & & \\
\hline \multicolumn{10}{|l|}{ Hemiptera } \\
\hline Coleoptera & $\mathrm{C}$ & & $\mathrm{C}$ & & $\mathrm{C}$ & A & $\bar{A}$ & A & R \\
\hline \multicolumn{10}{|l|}{ Diptera } \\
\hline \multicolumn{10}{|l|}{ Tipulidae } \\
\hline Tabanidae & $\mathrm{R}$ & & & $\mathrm{C}$ & & $\mathrm{R}$ & & $\mathrm{C}$ & \\
\hline Culicidae & & & & & & $\mathrm{C}$ & & & $\mathrm{R}$ \\
\hline Chironomidae & & & & $\mathrm{C}$ & & & & & A \\
\hline Plecoptera & $\mathrm{C}$ & & $\mathrm{C}$ & $\mathrm{A}$ & $\mathrm{C}$ & $\mathrm{C}$ & C & & \\
\hline Ephemeroptera & $\mathrm{C}$ & $C$ & & & & & & & \\
\hline \multicolumn{10}{|l|}{ Tricoptera } \\
\hline Gastropoda & & & $\mathrm{C}$ & & & & & & \\
\hline
\end{tabular}


Table A-9.3

RBP-III Habitat Assessment Data

\begin{tabular}{|c|c|c|c|c|c|c|c|c|c|}
\hline \multirow{2}{*}{$\begin{array}{c}\text { Habitat Parameter } \\
\text { (RANGE OF VALUES) }\end{array}$} & \multicolumn{9}{|c|}{ TDTS STATION IDENTIFICATIONS } \\
\hline & HMC-11 & HMC-2 & HMC-3 & HMC-4 & HMC-5 & GRC-11 & GRC-2 & HHC-1 & HHC-2 \\
\hline Bottom Substrate $(0-10)$ & 10 & 16 & 11 & 14 & 15 & 16 & 15 & 12 & 6 \\
\hline Embeddedness (0-15) & 2 & 2 & 2 & 0 & 2 & 5 & 2 & 2 & 2 \\
\hline Stream Flow and/or Stream & & & & & & & & & \\
\hline Velocity $(0-20)$ & 5 & 11] & 16 & 18 & 16 & 16 & 16 & 4 & 5 \\
\hline Channel Aeration (0-15) & 9 & 11 & 8 & 15 & 11 & 12 & 8 & 11 & 8 \\
\hline $\begin{array}{l}\text { Bottom Scouring and } \\
\text { Deposition }(0-15)\end{array}$ & 12 & 12 & 9 & 12 & 11 | & 12 & 10 & 12 & 7 \\
\hline Pool/Riffle or Run/Bend & & & & & & & & & \\
\hline Ration (0-15) & 8 & 12 & 11 & 12 & 13 & 11 & 10 & 13 & 8 \\
\hline Bank Stability $(0-10)$ & 9 & 9 & 9 & 8 & 10 & 9 & 8 & 9 & 8 \\
\hline Bank Vegetative Survey $(0-10)$ & 8 & 9 & 10 & 10 & 9 & 10 & 9 & 8 & 8 \\
\hline Streamside Cover $(0-10)$ & 5 & 9 & 8 & 8 & 8 & 8 & 8 & 8 & 7 \\
\hline Total Score & 68 & 91 & 84 & 97 & 95 & 99 & 86 & 79 & 59 \\
\hline $\begin{array}{l}\text { Percent Comparability to } \\
\text { Reference Station }\end{array}$ & 100 & 134 & 124 & 143 & 140 & 100 & 87 & 100 & 75 \\
\hline
\end{tabular}

\section{Assessment Category}

Comparable to Reference

Supporting

Partially Supporting

Non-Supporting
Percent of Comparability
$\geq 90 \%$
$75-88 \%$
$60-73 \%$
$\leq 58 \%$

1 Indicates Reference Station for that area NOTE: EPA RBP Habitat Assessment not appropriate for pond stations. 
Table A-9.4

RBP-III Benthos (Riffle/Run) Data

\begin{tabular}{|c|c|c|c|c|c|c|c|c|c|c|c|c|c|c|c|c|c|c|c|c|c|}
\hline & & & & & & & & & & & & Statio & on Identific & cation & & & & & & & \\
\hline Class & Order & Family & Genus & Spocios & GaP-1 & Gap.1a & $\mathrm{GrC}-1$ & GrG-2 & HHC-1 & HHC-2 & HMC-1 & HMC-2 & \begin{tabular}{|l|} 
HMC-3 \\
\end{tabular} & HMC-4 & HMC-4D & HMC-5 & BeP.1 & $\mathrm{BeP}-1 \mathrm{a}$ & BeP-2 & HOP.1 & REP -1 \\
\hline Crustacea & Amphipoda & Gammardao & Gammarus & & & & & & & 3 & & & & & & & & 6 & 17 & & \\
\hline Crustacea & Decapoda & Cembaridae & Oromeolus & & & & & & & 1 & & & & & & & & & & & \\
\hline Crustacea & Decapoda & & & & & & 1 & 1 & 1 & & & 1 & & & & & & & & & \\
\hline Gastropoda & & Physidae & & & & & & & & & & & & & & & & 1 & & & -1 \\
\hline Crustacea & Isopoda & & & & & & & & & 1 & & & & & & & & & & & \\
\hline Crustacea & Isopoda & Asellidae & Caciedoloa & & & & & & & & & & & & & & & 2 & 58 & 1 & \\
\hline Hirudnea & Rhychibdellidae & Glossiphomidaas & Helobdella & stagnails & & & & 1 & & & & & & & & & & & & & \\
\hline Insecta & Coloeplera & Elmidae & & & & & & 1 & & 5 & & & & 8 & 2 & 4 & & 1 & 1 & 3 & \\
\hline Insecta & Coloeptera & Hydrophilldae & Berosus & & & & & & & 1 & & & & & & & & 1 & 1 & & \\
\hline Insecla & Coloeptera & Scirlldae & & & & & & & & & & & & & & & & H & 8 & & \\
\hline Insecta & Diptera & Ceratopegonidae & Palopamoyia & & 1 & 3 & & & & 1 & & & & & & & 16 & 5 & 1 & & \\
\hline Insecta & Diptera & Chironomidae & & & 8 & & & & 2 & & 2 & & & 4. & & & 210 & 8 & 52 . & 12 & 9 \\
\hline Insecta & Diptera & Chironomidae & Polypedallum & & & 1 & & & & 5 & & 2 & & & 2 & & & & & & \\
\hline Insecta & Diptera & Chironomidae & Tribelas & & 2 & 3 & & & & & & & & & & 1 & $\ldots$ & - & 1. & & \\
\hline Insecta & Diptora & Chironomida $\theta$ & Chironomus & & & 1 & & & & & & & 2 & & & & $\ldots$ & $-\ldots$ & - & -7 & \\
\hline Insecta & Diptera & Chironomidae & Xenochironomus & & & & & & & & & & 1 & 1. & i] & & & & & & \\
\hline Insecta & Diptera & Chironomidae & Endochironomus & & & & & & & & & & & & & & & & & 11 & \\
\hline Insecta & Diplera & Chironomidae & Goeldichironomus & & 22 & & & & & & & & & & & & & & & & \\
\hline Insacta & Diptora & Chironominae & Microspectra & & & 10 & & & & & & & & & & & 2 & & & & \\
\hline Insecta & Diptera & Chironomidas & Dicrotandpes & & & & & & & & & & & & & & 2 & & & & \\
\hline Insecta & Diptera & Chironomidae & Glyptepeudipes & & & & & & & & & & & & & & 7 & 111 & -2 & & \\
\hline Insacta & Diptera & Chironomidas & Paratendipes & & & & & & & & & & & & & & $\ldots 41$ & & & & - \\
\hline Insecta & Diptera & Chironomidae & Microtendipes & & & & & & & & & & & & & & & -1 & 3 & & \\
\hline Insecta & Diptera & Chironomidae & Cryptochironomus & & & & & & & & & & & & & & & & & & \\
\hline Insecta & Diptera & Tipulidae & & & & & & & & & 1 & & & 5 & T. & & -1 & & & & \\
\hline Insecta & Diptera & Tauypodas & Procaldus & & & & & & & 16 & & & & & & & & & & & \\
\hline Insecta & Diptera & Orthocladidae & Cricotopus & & & & & & & 12 & & & & & & & & & & & \\
\hline Insecra & Diptera & Simulidae & & & & & & & & 11 & 2 & & & it & 3 & & $-\ldots$ & $\ldots$ & $\ldots$ & & \\
\hline Insecta & Diptera & Tanypedidae & & & & & & & & & & 2 & & & & & & & & & \\
\hline Insecla & Diptera & Tanypedidae & Procladius & & 20 & 65 & & & & & & & & 1 & & & -9 & 2 & 55 & 7 & \\
\hline Insecta & Diptera & Tanypedidae & Dialmeabatista & & & 5 & & & & & & & & & & & & & & & \\
\hline Insecta & Diptera & Chillenydae & & & & & & & & & & & & & & & - & & & & \\
\hline Insecta & Diptera & Tabanidas & & & 1 & & & & & & & & & & & & & 2 & 2 & & \\
\hline Insecta & Ephemoptera & Caenidae & Caenis & & & & & & & & & & & & & & 1 & & & & \\
\hline Insocla & Ephemoplera & Leptophillidao & Brakptophibja & & & & & & & $\underline{2}$ & & & & & & & & & & & \\
\hline Insecta & Ephemoplera & Leptophillidae & Paraleptophidae & & & & & & & & 2 & & & 1 & & & & & & & \\
\hline Insecta & Ephemoptera & Ephemerllidae & Ephemerella & & & & & & & 13 & & & & & & & & & & & \\
\hline Insecta & Ephemop!era & Ephemerillidae & Dannella & & & & & & & & & & & & & & & & 43 & & \\
\hline Insecta & Ephemoplera & Heplagentidae & Slenenora & & & & 1 & 9 & & 1 & 2 & & 2 & 6 & & 1 & & & - & & \\
\hline Insocla & Ephomoplera & Baetldae & & & & & & & & & & & 1 & & & & & & & & \\
\hline Insecta & Ephemoplera & Baolida & Centropilum & & & & & 1 & & 7 & & & & 1 & & & 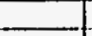 & & 28. & & \\
\hline Insocta & Ephemoptera & & & & & & & & & & & 1 & & & ב & 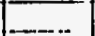 & $\ldots \ldots$ & $\ldots$ & -4 & & \\
\hline Insecta & Hemiptera & Belestonlatidao & Belestoma & & & & & & & & & & & & & & & & 3 & & \\
\hline Insecta & Hemiptera & Gelastocoridae & Nonhra & & & & & & & & & & & & & & & & i & & \\
\hline Insecte & Hemiplera & Corixidae & Palmacorixa & & & & & & & & & & & & & & & & 4. & & \\
\hline Insecta & Megaloptera & Corydalidae & Corydalus & & & & & & & & & 1 & & 1 & & & & & & & \\
\hline Insecla & Odonata & Aeshnidae & Boyaria & & & & & & & & 2 & & & & & & & & & & \\
\hline Insocta & Odonata & Gomphidae & Gomphus & & & & & 1 & & & & it & & & & & & & - & & \\
\hline Insecta & Odonata & Cordulidae & Tetragenenta & & & & & 1 & & & & & & & & & & 1 & 1 & & \\
\hline Insecta & Odonata & Macromildae & Macromia & & & & & 1 & & & & & & & & & & & - & & \\
\hline Insecta & Odonata & Libellulidae & Orthemis & & & & & & & & & & & & & & & & 3 & & \\
\hline Insecta & Odonata & Libellulidae & Leucomhua & & & & & & & & & & & & & & & 2 & 4 & & \\
\hline Insecta & Odonata & Coenagrionidae & Argia & & & & & & & & & & & & & & & & 12 & & 2 \\
\hline Insocta & Odonala & Lestidae & Lestes & & & & & & & & & & & & & & & & 17 & & \\
\hline
\end{tabular}


Table A-9.4

RBP-III Benthos (Riffle/Run) Data

\begin{tabular}{|c|c|c|c|c|c|c|c|c|c|c|c|c|c|c|c|c|c|c|c|c|c|}
\hline \multirow[b]{2}{*}{ Class } & \multirow[b]{2}{*}{ Order } & \multirow[b]{2}{*}{ Family } & \multirow[b]{2}{*}{ Genus } & \multirow[b]{2}{*}{ Species } & \multicolumn{17}{|c|}{ Station Identification } \\
\hline & & & & & GaP-1 & GaP-1a & GrC-1 & GrC-2 & $\mathrm{HHC}-1$ & \begin{tabular}{ll|}
$H H C-2$ \\
\end{tabular} & HMC-1 & HMC-2 & HMC-3 & HMC-4 & HMC-4D & HMC-5 & $\mathrm{BeP}-1$ & BeP-1a & BeP-2 & HOP.1 & REP-1 \\
\hline Insecta & Plocoptera & Perlidae & Bebneuria & & & & & & & & & & & 4 & & & & & & & \\
\hline Insecta & Plecoplera & Perlidas & Eccoptura & & & & & & & & & & & 2 & 2 & & & & & & \\
\hline Insecta & Plecoptera & Perlidae & Phasganephora & & & & & 2 & & & & 1 & & & & & & & & & \\
\hline Insecta & Placoptera & Perlidas & Perinella & & & & & & & & & & & & 1 & & & & & & \\
\hline Insecte & Plecoptera & Perlidae & Perlesta & & & & 1 & 1 & & 8 & 2 & & & & & & & & & & \\
\hline Insecta & Trichoptera & & & & & & & & & & 2 & & & & 1 & & & & & & \\
\hline Insecta & Trichoptera & Philopalamidae & Cymarra & & & & 1 & & & 2 & & & 1 & 3 & & & & & & & \\
\hline Insecta & Trichoplera & Hydropsychidae & Macrostenium & & & & & & & & & & & & 1 & & & & & & \\
\hline Insecta & Trichoptera & Hydropsychidae & Hydropsyche & & & & & & 3. & & & 1 & & & & & & & & & \\
\hline Insecta & Trichoptera & Limnephilidae & & & & & & & 1 & & & 1 & & & & & & & & & \\
\hline Insecta & Trichoptera & Limnephilldae & Pseudostenophylax & & & & & & 1 & & & & & & & & & & & & $\ldots$ \\
\hline Ollgochaola & Tubicilida & Tubicifidae & & & & 4 & & & 3 & 3 & & & & & & & 7. & 11 & 2 & 5 & \\
\hline Tubellaria & Trichadidae & Planclidas & Dugesia & & & & & & & & & & & & & & & & & & 57) \\
\hline & & & & Number of Organisms & 54 & 95 & 4 & 20 & 13 & 92 & 15 & 11 & 8 & 38 & 12 & 6 & 298 & 54 & 415 & 50 & 75 \\
\hline
\end{tabular}


Table A-9.5

RBP-III Benthos (CPOM) Data

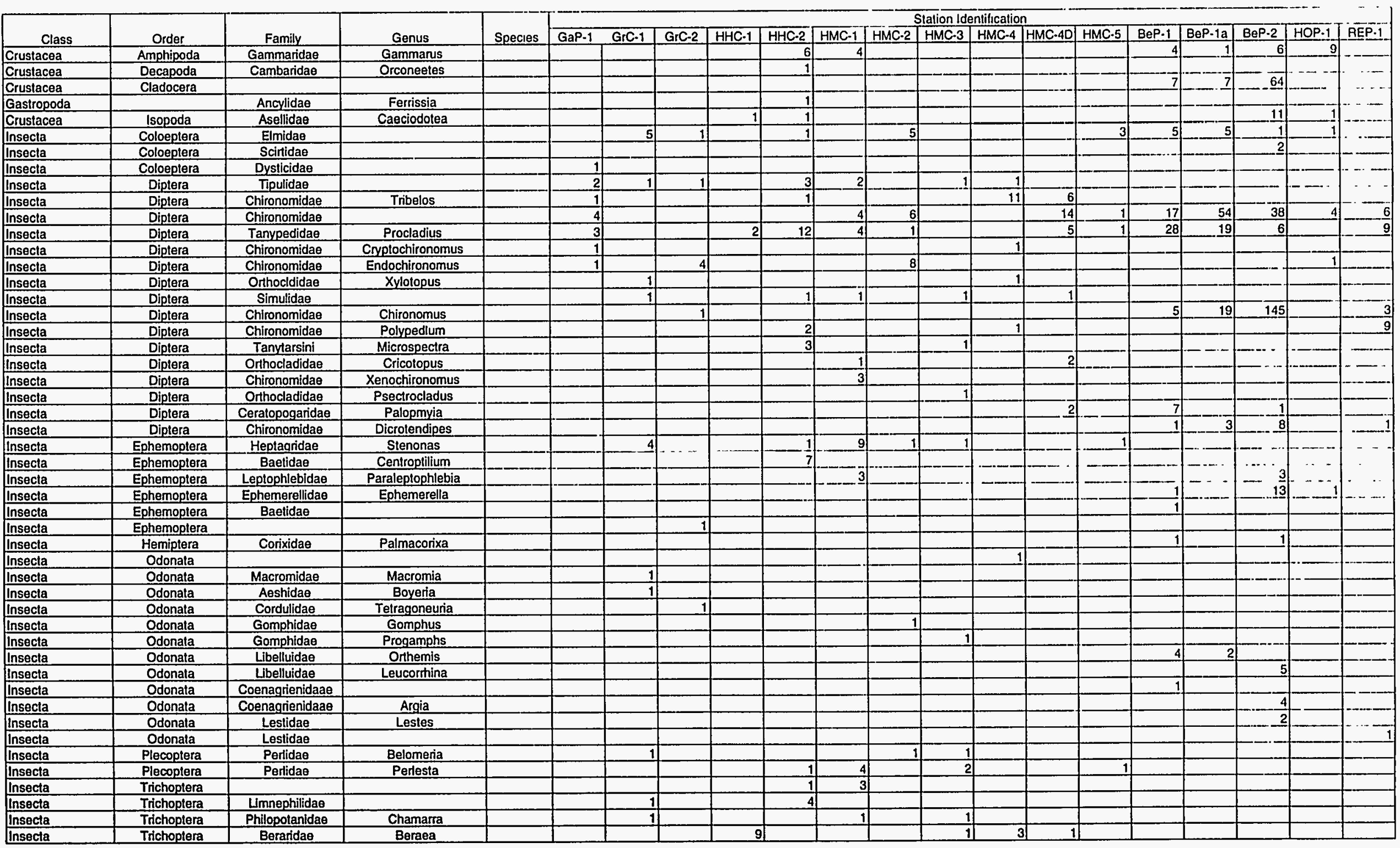




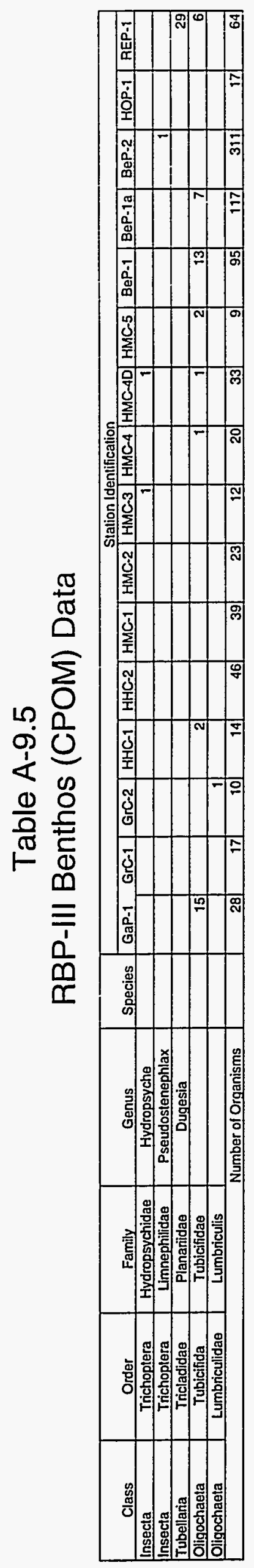

愛 


\section{Distribution List}

\section{Copies}

Robert Bell

Mississippi Department of Health

Division of Radiological Health

P.O. Box 1700

Jackson, Mississippi 39215-1700

Bill Bishop

48 Pennington Loop

Purvis Mississippi 39457

Roxanne Danz

DOE/Nevada Operations Office

P.O. Box 98518

Las Vegas, Nevada 89193-8518

Dr. Fred Howell

Department of Biological Sciences

University of Southern Mississippi

P.O. Box 5018

Hattiesburg, Mississippi 39406

IT Corporation

4330 S. Valley View, Suite 114

Las Vegas, Nevada 89023-0345

David S. Shafer

U.S. Department of Energy Headquarters

656 Quince Orchard Road

Gaithersburg, Maryland 20585

Anita Mullen

U.S. Environmental Protection Agency

Environmental Monitoring Systems Laboratory

P.O. Box 93478

Las Vegas, Nevada 89193-3478

Purvis Library

Purvis, Mississippi 39475

Paul Tatum

Tatum Lumber Company

P.O. Box 15547

Hattiesburg, Mississippi 39404 


\section{Distribution List}

\section{Copies}

U.S. Department of Energy

Nevada Operations Office

Technical Information Resource Center

P.O. Box 98518

Las Vegas, Nevada $89193-8518$

U.S. Department of Energy

Office of Scientific and Technical Information

175 Oak Ridge Turnpike

P.O. Box 62

Oak Ridge, Tennessee 37831

Phillip Weathersby

Mississippi Department of Environmental Quality

Office of Pollution Control

P.O. Box 10385

Jackson, Mississippi 39289-0385 